


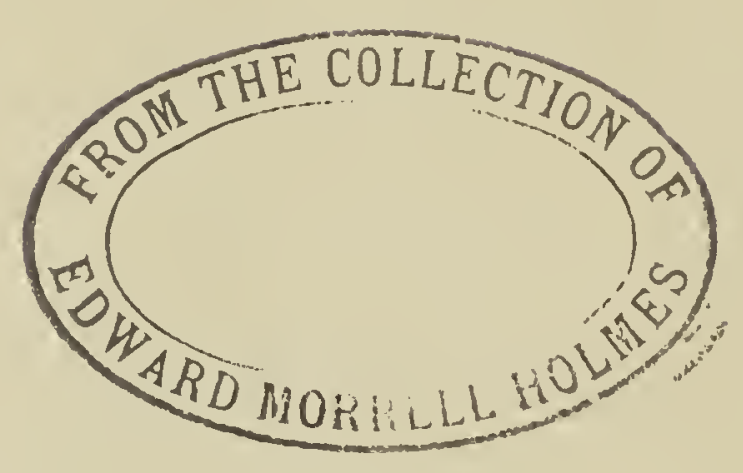




$$
\begin{gathered}
\text { Med } \\
\text { K4504 }
\end{gathered}
$$



MALAYAN FERNS. 



\section{MALAYAN FERNS.}

\section{HANDBOOK}

TO THE DETERMINATION

$\mathrm{OF}$

THE FERNS

OF

\section{THE MAIAYAN ISLANDS}

(INCL. THOSE OF THE MALAY PENINSULA, THE PHILIPPINES AND NEW GUINEA).

BY

Capt. C. R. W. K. van alderWerelt van ROSENBURGH.

PUBLISHED BY

THE DEPARTMENT OF AGRICITI URE

NETHERLANDS INDIA. 
862889

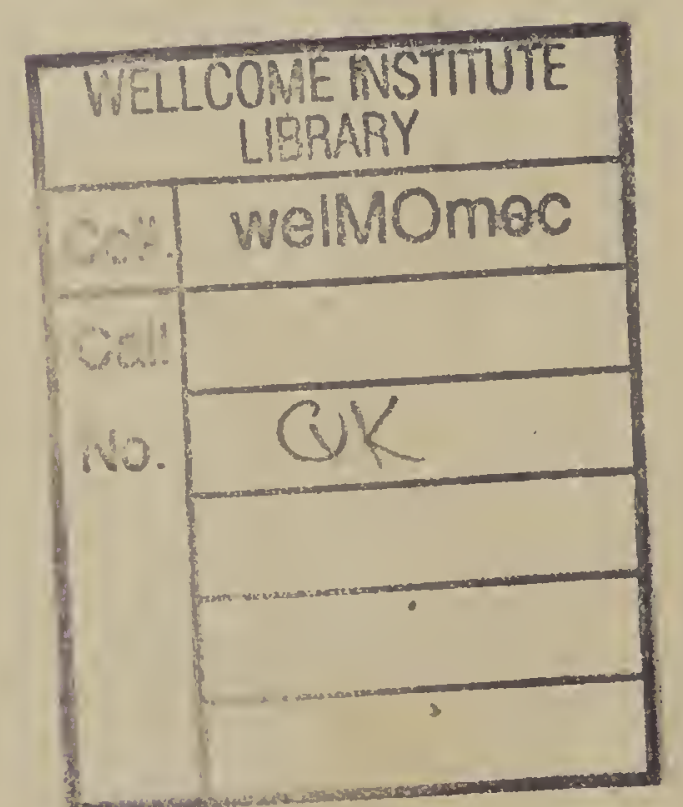




\section{PREFACE.}

Haudboolis are like watches: the worst is better than none, and the best cannot be expected to go quite true.

Dr. JoHnson. - (Variant).

When acting for some few years as an Assistant Curator at the Buitenzorg Herbarium I was directed to elaborate the non-determined fern-material of the Malay Archipelago. Malayan Ferns have much been written about in handbooks and periodicals, but seeing no work exists treating with them more particularly I resolved to collect all available descriptions in one volume. Originally my intention was to do so for my private use, but it occurred to me that publication of this compilation might prove to be of some value to those interested in the Malayan Ferns. Moreover the Director of the Agricultural Department in Netherlands India, Prof. Dr. M. Treus, desired the work to be printed.

The descriptions are taken from various sources and have been compared with living or dried material if on hand in the Buitenzorg Botanical Gardens or in the Herbarium. Those thus controlled and more or less modified if necessary are marked with an asterisk. I used in the first place Raciborsk's Die Pleridophyten der Flora von Buitenzorg and in the second Hooker \& Baken's Synopsis Filicum, the works my studies in pteridology are founded upon and only in cases where these books could not provide me with such information as required I had recourse to other sources, principally Curnst's Die Farnkräuter der Erde, Beddone's Ilandbook to the Ferns of British India and Copeland's The Polypodiaceae of the Philippine Isländs. Thence specific names and synonyms are not followed by an exhaustive and somewhat unnecessary list of old sources, but in most cases only by one or at the utmost two of the newer sources consulted. Likewise enumeration of synonyms has been limited as much as possible. Those desirous to have further particulars on the subject should consult Christensen's Index Filicum.

A definite time being fixed for the completion of the work, I saw myself 
PREFACE.

compelled to discontinue the proper compilation-work just when the last part of the Index Filicum appeared, the remainder of my term of office to be spared for revising, comparing and classifying the various genera and species. Therefore no diagnoses published after January 1st, 1907 are to be found in this work, except those which can be inserted while printing, but as a matter of fact I have not been able to do much more than enumerating as synonyms the new names given to well-known species in consequence of changed conceptions.

I regret that owing to the want of several books in the Buitenzorg Library I am not in a position to give diagnoses of some few species of ferns, a lack however which may be considered of but little importance seeing the ferns in question belong to species which are rather rare. Nevertheless I intend to procure their descriptions and publish them later on in an appendix or other supplementary work, together with the other new species that have still been discovered since the date above quoted.

In giving the diagnoses of the various species I have endeavoured to stick to facts only and to avoid any speculative opinion even when my conception or error's in other author's' work may have tempted me to alter specific names. Of course I do not claim completeness or entire correctness and shall be pleased to have the no doubt many errors and omissions pointed out to me in order to correct them in a supplement.

As to the limitation and the nomenclature of the genera and species I have chiefly followed the Index Filicum, which with a few exceptions agrees with Diels' ferm-system in Engler \& Prantl's Die natürlichen Pflanzenfamilien, Vol. I, part 4. In both works however a nalural syslem has been adopted, but as the object of this book is delerminalion only, I have deemed it more practical to adopt for my purpose an arlificial arrangemerl. Consequently some clashing between system and arrangement could not be avoided, the same as some few modifications in Curistensen's limitation of the genera. So, for instance, I have kept the truly indusiate ferns separate from those which have no indusium or only a spurious one. Accordingly my arrangement is of no systematic value, but only a guide to those studying Malayan Pteridology. Therefore I have quoted under each species the name given in the Index Filicum wherever I followed my own conception. Where I, for convenience' sake, refer to Diels, in Engl. \& Prantr, Nat. Pfl.Fam., I ${ }^{4}$, one should bear in mind that Diess' fern-system is meant, for the articles on the Hymenophyllaceae are written by SADEBEck and those on the Marattiaceae and Ophioglossaceae by Bitter. 
The reason why the ferns found in Malacca (the Malay Peninsula), the Philippines and New Guinea are inserted in this work on the ferns of the Malay Archipelago is that in botany no strict limits may be expected to exist, and fern-species growing closely outside geographical boundaries may reasonably be expected to be found inside these boundaries as well.

In giving habitats I have confined myself to regions and not merely to the places where the species are reported to have been found. By Malaya is understood the entire territory this work is dealing with. The smaller islands, if not treated of separately, are included in the nearest larger territory to which they geographically belong. It will however not be advisable to adhere too closely to the habitats given, seeing it is not at all impossible that species, up till now found in one place only, may also be discovered elsewhere far away from the present known place of origin.

For this work the English language was chosen only in behalf of the foreigners who visit these regions, seeing a book written in Dutch would be useless to them.

In conclusion I beg to tender my best thanks to all who assisted me to render the completion of this work possible and especially to Mrs. H. Gude-Murray, who kindly undertook the grammatical correction of the work. Buitenzorg, January 1908. v. A. v. R. 



\section{A BBREVIATIONS.}

Abh. Nat. Ver. Brem.

A. Br.

A. Cunn.

Adans.

Agardh. (Ag).

Ait.

Amann

Anal.

Ann. Btz.

Ann. Mus. Bot. L. B.

Ann. Nat. Hist.

Ann. of Bot.

Bail.

Balf.

Bau. \& Hk.

Becc.

Bedd.

Beech. Voy.

Bél.

Berk.

Berl. Mag.

Bernh.

Bitt.

Bk. (Bak.)

Bl.

Bory

Bot. Centralbl.
= Naturwissenschaftlicher Verein zu Bremen; Abhandlungen.

$=$ A. Braun.

$=$ Allan Cunningham.

$=$ M. Adanson.

$=$ J. G. Agardh.

$=\mathrm{W}$. Aiton.

$=$ J. Amann (? Kurz).

$=$ Analecta pteridographica, etc. (Kze, 1857).

= Annales du Jardin botanique de Buitenzorg.

$=$ Annales Musei Botanici Lugduno-Batavi. (Miq., 1867_'69).

$=$ Annals of Natural History.

$=$ Annals of Botany.

$=$ F. M. Bailey.

$=\mathrm{J}$. Baylay Balfour.

= F. Bauer \& W. J. Hooker.

$=0$. Beccari.

$=$ R. H. Beddome.

$=$ The botany of Captain Beechey's Voyage. (Hk. \& Arll., 1830-'41).

$=$ Bélanger.

$=$ Berkeley.

$=$ Der Gesellschaft Naturforschender Freunde zu Berlin Magazin etc. (1807-'18).

$=$ J. J. Bernhardi.

$=$ G. Bitter.

$=$ J. G. Baker.

= C. L. Blume.

$=$ Bory de Saint-Vincent.

$=$ Botanisches Centralblatt. 
Bot. Jahrb.

Bot. Misc.

Bot. Voy. Herald.

Bot. Zeil.

Brack.

Br. Ferns

Brong.

Bull. Ac. Crac.

Bull. Ac. Int. Bot.

Bull. Dép. Agrr. I. N.

Bull. Herb. Boiss.

Bull. Soc. Bot. Belg.

Bull. Soc. Bot. Fr.

Bull. Torr. Cl.

Burck

Burm.

Carr.

Cav.

$2^{\text {nd }}$ Cent. of Ferns.

C. Chr.

Ces.

Christ

Clarke

Colen.

Copel.

Dec.

Descr.

Desv.
$=$ Botanische Jahrbücher für Systematik, Pflanzengeschichte und Pflanzengeographie. (Engl.).

= Botanical Miscellany.

= Botany of the Voyage of H. M. S. Herald. (Seemann, 1854-’ร7).

= Bolanische Zeitung. (Mohl \& Schlechtendal).

$=$ Brackenridge.

$=$ The British Ferns, or coloured figures and descriptions, etc. (Hk., 1861).

$=$ A. Brongniart.

$=$ Bulletin international de l'Académie des Sciences de Cracovie.

$=$ Bulletin de l'Académie internationale de géographie botanique.

$=$ Bulletin du Département de l'Agriculture aux Indes Néerlandaises.

$=$ Bulletin de l'Herbier Boissier.

= Bulletin de la Société botanique de Belgique.

= Bulletin de la Société botanique de France.

$=$ Bulletin of the Torrey Botanical Club.

$=$ W. Burck.

$=$ N. L. Burmann.

$=$ W. Carruthers.

= A. J. Cavanilles.

$=\mathrm{A}$ second Century of Ferns. (Hk., 1861).

$=\mathrm{C}$. Christensen.

$=\mathrm{V}$. Cesati.

$=$ H. Christ.

= C. B. Clarke.

= W. Colenso.

= E. B. Copeland.

$=$ M. J. Decaisne.

$=$ Descripcion de las Plantas que D. Antonio Josef Cavanilles demostró en las lecciones publicas del año 1801. (Cav., 1802).

$=$ A. N. Desvaux. 
de $\mathrm{Vr}$.

de $\mathrm{Vr}$. \& Teysm.

Dict. d' Hor't.

llicls

Dissert.

Hon

Dry.

Eat.

Endl.

Lingl.

Engl. Jahrl.

Engl. \& Prantl

Enum.

Enum. Fil.

Epim.

Exot. Flor.

Expl. Exp.

Farng.

Farnkr.

Farnkr. d. Erde

lied.

Fée

Fel. Becc. Polin.
$=\mathrm{W}$. H. de Vriese.

$=$ de Vriese \& Teysmann.

$=$ Dictionnaire d'Horticulture et de Jardinage. (Nich.).

$=\mathrm{L}$. Diels.

$=$ Dissertatio inauguralis medico-botanica de duabus novis Trichomanarum speciebus de earum nec non aliarum huius generis plantarum structura. (Taschn., 1845).

$=$ D. Don.

= J. Dryander.

= D. C. Eaton.

$=\mathrm{S}$. L. Endlicher.

$=$ A. Engler.

$=$ Botanische Jahrbücher für Systematik, Pflanzengeschichte und Pflanzengeographie, ed. A. Engler.

$=$ A. Engler \& K. Prantl.

$=$ Enumeratio Plantarum Javae et Insularum adjacentium. (Bl., 1828).

$=$ Enumeratio Filicum, etc. (Klf., 1824).

= Epimeliae botanicae. (Pr., 1849).

= Exotic Flora. (Hk., 1823-'27).

$=$ U.S. Exploration Expedition, XVI. (Wilk., 1854).

= Uber einige Farngattungen. (Mett.); I, Polypodium (1857); II, Plagiogyria (1858); III, Pteris (1858); IV, Phegopteris \& Aspidium (1858); V, Cheilanthes (1859); VI, Asplenium (1859).

$=$ Die Farnkräuter in kolorirten Abbildungen, etc. (Kze, 1840-'b1).

$=$ Die Farnkräuter der Erde. (Christ, 1897).

$=$ F. Fedde.

$=$ A. L. A. Fée.

$=$ Prospetto delle Felci raccolte dal Signor 0 . Beccari nella Polinesia, etc. - Rend. Acad. Napoli, XVI. - (Ces., 1877). 
Fel. di Bor.

Ferns Br.I.

Ferns S.I.

Ferns S.Br.I., Suppl.

Fil. Exot.

Fil. Gen. \& Spec.

Fil. Lechl.

Fil. Saras.

Fisch.

Flor. Btz.

Flor. deut. Sch.geb.

Flor. Filip.

Flor. Jav., II.

Flor. Kais. Wilhl.

Flor. Trist. d'Ac.

Forb.

Forschr. Gaz., IV, Farne.

Forsk.

Forst.

Fragm.
$=$ Felci e specie nei gruppi affini raccolte a Borneo dal Signor 0. Beccari. - Atti Acad. Sci. fis. e mat. Napoli. - (Ces., 1876).

$=$ The Ferns of British India. (Bedd., 1865-'70).

$=$ The Ferns of Southern India (Bedd., 1863'64).

$=$ Supplement to the Ferns of Southern India and British India. (Bedd., 1876).

$=$ Filices Exoticae or Figures and Descriptions of exotic Ferns, etc. (Hk., 1857-'59).

$=$ Filicum Genera et Species recentiori Methodo accomodatae analytice descriptae. (Hedw., 1799-1803).

$=$ Filices Lechlerianae. (Mett., 1856-’59).

$=$ Filices Sarasinianae, in "Verhandlungen der Naturforschenden Gesellschaft in Basel, XI." - (Christ, 1895).

$=$ Fischer.

$=$ Dic Pteridophyten der Flora von Buitenzorg (Band I der Flora von Buitenzorg; Rac., 1898).

= Die Flora der deutschen Schutzgebiete in der Südsee. (Schum. \& Laut., 1901! - Suppl. (1905).

= Nlora de Filipinas, etc. (Blanco, 1857).

= Flora Javae nec non Insularum adjacentium. Filices. (Bl. 1828-'29).

$=$ Die Flora von Kaiser Wilhelmsland. (Schum. \& Hollr., 1889).

$=$ Esquisse de la Flore de Tristan d'Acugna. (Thouars, 1804?).

$=$ H. 0. Forbes.

= Farne und bärlappartige Gewächse in ,Die Forschungsreise S. M. S. Gazelle." (187476).

= P. Forskål.

$=\mathrm{G}$. Forster.

= Fragmenta Phytographiae Australiae. (Muell., 1864 -'81). 
Fragm. Philipp.

Freyc.

Gard. Chron.

N. S.

Gard. Ferns

Gardn.

Gaud.

Gen.

Gen. Fil.

Gen. Fil.

Ges. Nat. Fr.

Gies.

Gled.

Grev.

Grev. \& Hk.

Griff.

Gris.

Hance

Handb. Ind. Ferns.

" $\quad$, Suppl

\section{Harr.}

Hassk.

Hedw.

Herb. Berol.

Herb. Bog.

Hier.

Hist. Fil.

Hk. (Hook.)

Hk. \& Arn.

Hk. Bk.

Hk. \& Grev.

Hoffm.

hort.

Hort. Bog.
$=$ Fragmenta Florae Philippinae. (Perk., 1905).

$=$ Freycinet.

$=$ The Gardener's Ghronicle.

$="$ " $"$ New Series.

= Garden Ferns. (Hk., 1862).

$=$ G. Gardner.

= C. Gaudichaud Beaupré.

$=$ Genera Filicum. (5e Mémoire sur la famille des Fougères; Fée, 1850-'52).

$=$ Genera Filicum. (Schott, 1834).

= Genera Filicum. (Bau. \& Hk., 1842).

$=$ Gesellschaft Naturforschender Freunde, Berlin.

$=\mathbf{K}$. Giesenhagen.

$=$ J. G. Gleditsch.

$=\mathrm{R}$. K. Greville.

$=$ R. K. Greville \& W. J. Hooker.

$=\mathrm{W}$. Griffith.

= A. Grisebach.

$=\mathrm{H}$. F. Hance.

$=$ Handbook to the Ferns of British India, Ceylon and the Malay Peninsula. (Bedd., 1885 .

$=$ Handbook to the Ferns of British India, Ceylon and the Malay Peninsula, Supplement. (Bedd., 1892).

$=$ M. V. Harrington.

= J. K. Hasskarl.

$=$ J. Hedwig.

$=$ Herbarium Beroliense (Berlin).

= Herharium Bogoriense (Buitenzorg).

$=\mathrm{G}$. Hieronymus.

$=$ Historia Filicum. (J. Sm., 1875).

= W. J. Hooker.

$=$ W. J. Hooker \& G. A. Walker-Arnott.

$=$ W. J. Hooker \& J. G. Baker.

= W. J. Hooker \& R. K. Greville.

$=$ G. F. Hoffmann.

$=$ hortus.

$=$ Hortus Bogoriensis. 
Houtt.

Huds.

Humb. \& Bonpl.

Hym.

Hymen. Jav.

Ic. Fil.

Icon. Pl.

Ind.

Ind.' Ferns

Ind. Fil.

Journ. of Bot.

Journ. of Linn. Soc., Bot.

J. Sm.

Karst.

Kell.

Kew Bull.

Keys.

Kl.

KIf. (Kaulf.)

K. Müll.

K ön.

Kuhn

Kurz

Kze

L. (Linné)

Lab.

Lam.

l.c.

Leafl.

L. f.

L. \& F.

l' Hérit.

link.

Linn.

List.
$=$ M. Houttuyn.

$=$ W. Hudson

$=$ A. von Hunboldt \& A. Bonpland.

= Hymenophyllaceae. (Pr., 1845).

= Hymenophyllaceae Javanicae elc. (V. D. B., 1861).

$=$ Icones Filicum. (Hk. \& Grev., 1827--’31)

$=$ Icones plantarum. (Hk).

$=$ Index Filicum. (Moore, 1857-'62).

$=$ Handb. Ind. Ferns.

$=$ Index Filicum. (C. Chr., 1905-'06).

= The Journal of Botany, British and Foreign

$=$ Journal of the Linnaean Sociely: Botany.

= John Smith.

$=\mathrm{G}$. Karsten.

$=$ A. Kellogg.

$=$ Royal Gardens Kew Bulletin of miscellane ous information

$=$ A. Keyserling.

$=$ J. F. Klotzsch.

$=$ G. F. Kaulfuss.

$=\mathrm{K}$. Müller.

$=\mathrm{l}$. König.

$=$ Max. Kuhn.

$=\mathrm{S}$. Kurz.

$=\mathrm{G}$. Kunze.

$=$ Linnaeus (C. von Limné).

$=$ de Labillardière.

= J. B. A. P. Honel de Lamarck

$=$ loco citalo.

= Leaflets on Philippine Botany.

= C. von Limné, fil.

$=$ G. H. Langsdorff \& F. Fischer.

= L' Héritier de Brutelle.

$=$ H. F. Link.

$=$ Limnaea, Ein Journal für die Botanik, u.s.w.

$=\mathrm{A}$ numerical List of dried specimens of plants, etc. (Wall., 1828-29). 
Lond. Journ. of Bot.

Luer'ss.

Mal.

Mann

Masters

Mém.

Mett.

Michx

Meyen

Milde

Miq.

Mon. Maratt.

Mons.

Moore

Morph. d. Gefässcr.

MS.

Muell.

Muell. \& Bk.

Nat. Geneesk. Arch.

Nat. Pfl.Fam., I ${ }^{4}$.

Nat. Tydschr. Ned. Ind.

Ned. Kruidk. Arch.

Nees

Nees \& Bl.

Nich.

Niph.

Nouv. Ann. Mus.

Nova Acta
$=$ The London Journal of Botany.

$=\mathrm{C}$. Luerssen.

$=$ Malesia. (Becc., 1886).

$=$ H. Mann.

$=$ Maxwell Tylden Masters.

$=$ Mémoires sur la famille des Fougères. (Fée, 1844 -'66).

$=\mathrm{G}$. Mettenius.

$=$ A. Michaux.

= F. J. F. Meyen.

$=\mathrm{J}$. Milde.

= F. A. V. Miquel.

$=$ Monographie des Marattiacées. (de Vr., 185̄ $\mathbf{3}$ ).

$=$ Monsunia. (Warb., 1901).

$=\mathrm{T}$. Moore.

$=$ Untersuchungen zur Morphologie der Gefässcryptogamen. (Prantl); I, Hymen. (= Die Hymenophyllaceen, 1875); II, Schiz. (= Die Schizaeaceen, 1881).

$=$ Manuscript.

$=\mathrm{F}$. von Mueller.

= F. von Mueller \& J. G. Baker.

= Natuur- en Geneeskundig Archinf voor Nederlandsch-Indir.

$=$ Die natürlichen Pllanzenfamilien, T'eil I, Abteilung 4. Pteridophyta. (Engl. \& Prantl, 1902).

$=$ Natuurkundig Tijdschrift voor NederlandschIndië.

$=$ Nederlandsch kruidkundig Archief.

$=$ Nees ab Esenbeck.

$=$ Nees ab Esenbeck \& Blume.

$=$ G. Nicholson.

$=$ Die Farngattung Niphobolus. (Gies., 1901).

= Nouvelles annales du Musée d'Histoire naturelle.

= Nova Acta Physico-Medica Academiae Caesareae Leopoldino-Carolinae Naturae curiosorum. 
Nov. Holl.

Obs. Fil. Jav.

0 . Ktze

Ophiogl.

Pap. Pl.

Par.

Perk.

Philipp. Journ.

Pl. escul.

Poir.

Pol. Cyath. Bung.

Polypod. Philipp.

p. p.

Pr.

Pr. Amer. Ac.

Prantl

Prod.

Prod. Flor. Nepal.

Prod. N.H.

Queensl. Agr. Journ.

Rac.

Raddi

Rb. (Roxb.)

R. Br.
$=$ Novae Hollandiae plantarum specimen. (Lab., 1806).

$=$ Observationes Botanicae, etc., in "Verhandelingen der Natuurkundige Vereeniging in Nederlandsch-Indië."

$=0$. Kuntze.

$=$ Beiträge zur Systematik der Ophioglosseen (Prantl), in "Jahrbuch des Kgl. botanischen Gartens, etc. zu Berlin, III." (1884).

$=$ Descriptive notes on Papuan Plants. (Muell., 1875 -'85).

$=$ Parish.

$=\mathrm{J}$. Perkins.

$=$ The Philippine Journal of Science. ( I + Suppl.; II', Bot.; III ${ }^{c}$, Bot.).

$=$ De plantis esculentis insularum oceani australis, \&c. (Forst. 1786).

$=$ J. L. M. Poiret.

= Polypodiaceae \& Cyatheaceae Herbarii Bungeani. (Keys., 1873).

$=$ The Polypodiaceae of the Philippine Islands. (Copel., 1905).

$=$ pro parte.

$=$ C. B. Presl.

$=$ Proceedings of the American Academy of Arts and Science.

$=\mathrm{K}$. Prantl.

$=$ Prodome de la famille des fougères, in "Mèmoires de la Soc. Linnéenne, VI." (Desv., 1827).

= Prodomus Florae Nepalensis. (Don, 1825).

$=$ Prodomus Florae Novae-Hollandiae et Insulae Van Diemen. (R. Br., 1803).

$=$ The Queensland Agricultural Journal.

$=$ M. Raciborski.

$=$ J. Raddi.

$=\mathrm{W}$. Roxburgh.

$=\mathrm{R}$. Brown. 
Rec.

Reinw. (Rw.)

Rel. Haenk.

Rep.

Rich.

Ridl.

Rev. Gen. Pl.

Roth

Rst. (Rosenst.)

Rud.

Sadeb.

Schk.

Schl.

Schott

Schrad.

Schroet.

Schum. \& Hollr.

Schum. \& Laut.

Scort.

Scott

Sieb.

Sm.

Spec.

Spec. Fil.

Spr.

Sw.

St. Hil.

Syn.

Syn. Fil.

Syst.

Syst. Verz.

'Taschn.
$=$ Recensio specierum generis Pteridis. (Ag., 1839).

$=$ G. G. C. Reinwardt.

= Pteridophyta,. in "Reliquiae Haenkeanae." (Pr., 1825).

$=$ Repertorium novarum speciorum regni vegetabilis. (Fed.).

$=$ L. Richard.

$=$ H. N. Ridley.

$=$ Revisio generum plantarum, elc. (0. Ktze, 1891).

$=$ A. W. Roth.

$=\mathrm{E}$. Rosenstock.

$=$ Rudolphi.

$=$ R. Sadebeck.

$=$ C. Schkuhr.

$=$ J. F. L. von Schlechtendal.

$=$ H. Schott.

= H. A. Schrader.

$=\mathrm{C}$. Schroeter.

$=$ K. Schumann \& M. Hollrung.

$=$ K. Schumann \& K. Lauterbach.

$=$ Revd Father Scortechini.

$=$ J. Scott.

= C. von Siebold.

$=$ J. E. Smith.

= Caroli à Liné. Species plantarum. (Willd., 1810).

$=$ Species Filicum. (Hk., 1846_'64).

= C. Sprengl.

$=0$. Swartz.

$=$ St. Hilaire.

= Synopsis Filicum. (Sw., 1806).

= Synopsis Filicum. (Hk. Bk., 1874, 1883).

= Carolini Linnaei. Systema Vegetabilum ed. XVI curante Curtio Sprengl. (1827).

= Systematisches Verzeichnis, etc. (Zoll., 1854).

= C. F. Taschner.

Filices. 
Tasm. Journ.

T. \& B.

Tent. Pterid.

Thb. (Thunb.)

Thouars

Thw.

Trans. Linn. Soc., Bot.

Trev.

Tijdschr. N. Gesch. Phys.

Und.

Urb.

V. D. B.

Verh. Zool. Bot. Ges.

Voy. Bot.

Voy. Ur. Phys., Bot.

Wall.

Warlo.

Wawra

Wilk.

Willd.

Zeill.

Zenk.

Zipp.

\%oll.

Zoll. \& Mor.
ABBREVIATIONS.

= Tasmanian Journal of Natural Science.

= Teysmann \& Binnendijk.

$=$ Tentamen Pteridographiae, etc. (Pr., 1836).

$=$ K. P. Thunberg.

$=$ Aubert du Petit-Thouars.

$=$ G. H. K. Thwaites.

$=$ The Transaction of the Linnaean Society of London ; Botany.

$=\mathrm{V}$. Trevisan.

$=$ Tijdschrift voor Nat. Geschiedenis en Physiologie.

$=$ L. Underwood.

$=$ J. Urban.

$=$ R. van den Bosch.

= Verhandlungen der K.K. Zoologischen-botanischen Gesellschaft in Wien.

= Voyage aux Indes orientales; Botanique. (Bél., 1833).

= Voyage autour du monde, etc. sur l'Uranie et la Physicienne; Botanique. (Freyc., 1826 - 29.

$=\mathrm{N}$. Wallich.

$=0$. Warburg.

$=$ H. Wawla.

= Ch. Wilkes.

$=\mathrm{K}$. L. Willdenow.

$=$ Zeiller.

= J. C. Zenker.

$=$ Zippelius.

$=$ H. Zollinger.

$=\mathrm{H}$. \%ollinger \& $\mathrm{A}$. Moritz. 


\section{COMPENDIUM}

\section{OF THE FAMILIES, TRIBES AND GENERA AS FOLLOWED IN THIS WORK.}

\section{ORDER FILICALES}

Green plants with 2 distinct generations, a pro-embryonal and an embryonal, the pro-embryonal consisting of a minute, tuberous, flat or filiform, green or white, simple, entire, incised or branched thalloid plant (prothallium) with hair-like roots and bearing one or more, $\sigma^{7}$ and (or) $q$, tuherculiform protuberances (antheridia, archegonia). The embryonal generation, i. e. the normal, cormophytical plint with a solid, short or elongate, rarely tuberous stem (rhizome or caudex) and true roots, stalks (stipes) and leaves (fronds), traversed by one or more fihro-vascular bundles and producing capsules (sporangia) with spores, developes when a ripe archegonium (q) is fecundated by the spiral-shaped spermatozoids of a ripe antheridium $\left(\sigma^{7}\right)$. Fronds seriate or circinate, rarely placed in whorls but then not connected, commonly more strongly developed than the stems, the fertile ones whether or not contracted, rarely metamorphosed. (*)

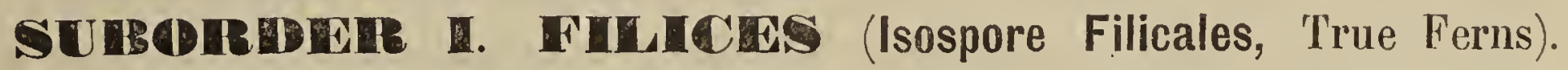
Spores uniform, producing independent prothallia on which are developed

(*) The other fern-allies being also green plants with 2 gencrations and fibro-vascular bundles are realily distinguished from the Fllicales in having the fronds commonly less strongly developed than the stems and by the following principal characters:

Drder Equisetales. Fronds very small, in whorls, connected so as to form distinct, toother, longitudinally ribbed, tubular, ochrea-like organs enclosing the bases of the internodations of the stems. Stems elongate, hollow. Sporangia placed on the under side of metamorphosed, scale-like, peltate, stalked sporophylla forming terminal spikes. Spores uniform. (1 Family).

Drder Lycopodiales. Fronds various, seriate, circinate or in whorls, not connected. Stems tuberous or elongate, solid. Sporangia solitary at the base of the fronds on the rpper side, superficial or imbedded. Sporophylla forming close or lax terminal spikes on an elongated stem or placed with the barren fronds in a dense rosette surrounding a tubcrous stem. Spores uniform or dimorphous. ( 4 Families). 
antheridia and archegonia. Sporangia dorsal (on the under surface) or marginal on leafy fronds, rarely in spikes or panicles. (10 Families).

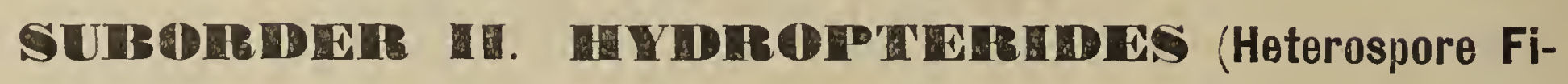
licales, Water-ferns). Spores dimorphous, macrospores and microspores, both developing more or less rudimentary prothallia, those of the macrospores bearing archegonia and those of the microspores antheridia. Sporangia enclosed in metamorphosed fronds forming 1-4-celled, globose or ellipsoidal sporocarpia. (2 Families; not treated with in this work).

\section{FILICES.}

Capsules (sporangia) 1-celled, sessile or stalked, usually membranaceous, dorsal or marginal, encircled by a complete or incomplete, \pm vertical or horizontal, jointed, elastic ring (annulus) and opening by a stomium at right angles to the ring, collected in clusters (sori) of a definite but varied form with or without a covering (indusium), or crowded densely over the parenchyma, sometimes scattered, spicate or paniculate; or the capsules have the ring obsolete, or none, or the ring is confined to the apex of the capsule, where it forms a longitudinally striated crown bursting vertically; or the capsules are sunk in many-celled, fleshy or corky receptacles of varied forms, openirig by pores or clefts on the upper or inner side. Spores minute, various in form, mostly ellipsoidal, bilateral, tetrahedral or globose, and in intermediate forms.

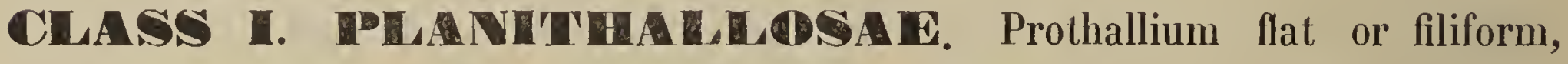
green, entire or variously incised or branched.

Series 1. Annulatac. Sporangia with a complete or incomplete ring consisting of a close or open row or a group of thickened cells.

FAMILY I. CYATHEACEAE. Ring complete, subvertical. Indusium wanting or present, but then neither umbrella-shaped nor linear. Caudex arborescent in the full-grown plants. 
Tribe I. Cyatheae. Ring nol depressed at the place of the stomium. Sori globose, dorsal on the veins.

GENUS 1. CYATHEA. Indusium globose, at least when young, at length cup-shaped, entire, laciniate or evanished.

$\checkmark$ GENUS 2. HEMITELIA. Indusium consisting of a rather large, convex, inferior scale attached at the inner side of the sorus.

GENUS 3. ALSOPHILA. Indusium wanting, or consisting of a minute, inferior scale or a whorl of hairs or fibres.

Tribe II. Dicksonieae. Ring depressed at the place of the stomium. Sori roundish or suboblong, terminal on the veins.

GENUS 4. DICKSONIA. Indusium cucullate, 2-valved, the outer valve consisting of a small lobe of the frond.

$\checkmark$ GENUS 5. CIBOTTUM. Indusium subcucullate, 2-valved, the outer valve differentiated from the margin of the frond.

FAMILY II. MATONIACEAE. Ring complete, subvertical. Sori round. Indusium umbrella-shaped. Caudex not arborescent.

GENUS 6. MATONIA. Characters of the family.

FAMILY III. GLEICHENIACEAE. Ring complete, horizontal, surrounding the sporangium like a belt. Sori roundish, dorsal on the veins. Indusium wanting.

GENUS 7. GLEICHENIA. Characters of the family.

FAMILY IV. HYMENOPHYLLACEAE. Ring complete, \pm horizontal, surrounding the compressed sporangium like a belt. Sori terminal on the veins. Indusium present. 
GENUS 8. HYMENOPHYLLUM. Indusium more or less deeply 2-valved. Surface of the sporangium divided into many, uniform cells.

GENUS 9. TRICHOMANES. Indusium tubular or funnel-shaped, the mouth entire or 2-lipped. Surface of the sporangium divided into few, unequal cells.

FAMILY V. SCHIZAEACEAE. Ring complete, horizontal, crowning the apex of the sporangium like an operculum. Inderesen, wantis g

GENUS 10. LYGODIUM. Sori consisting of 1-2 sporangia placed in the axils of 2 rows of clasping. imbricating indusia. Fronds long and twining.

2 GENUS 11. SCHIZAEA. Sori linear, consisting of $2-4$ lows of sporangia. Indusium wanting. Fronds small and erect.

FAMILY VI. POLYPODIACEAE. Ring incomplete, vertical, the extremities sometimes separated by the stalk of the sporangium only. Sori definite or indefinite, but then closely crowded over the parenchyma. (Ring sometimes as in Family I, but then the sori and indusia linear and the caudex not arborescent).

Indusiatae. Indusium present.

Tribe I. Woodsieae. Sori roundish or linear-oblong. Indusium globose, cupuliform or sausage-shaped, fastened all round the receptacle or apparently so in genus 13 .

GENUS 12. DIACALPE. Indusium globose, bursting down irregularly. Veins free.

GENUS 13. DIPLAZIOPSIS. Indusium sausage-shaped, bursting down irregularly. Veins anastomosing.

GENUS 14. DENNSTAEDTIA. Indusium cup-shaped, open at the top. 
Tribe II. Aspidieae. Sori roundish or oblong. Indusium superior, reniform, round or oblong, if reniform atlached at the top of a more or less deep sinus, if round peltate, if oblong attached by its longitudinal axis, all opening all round the edge or nearly so.

GENUS 15. OLEANDRA. Indusium reniform. Frouds simple, articulate to the rhizome; veins free.

GENUS 16. ARTHROPTERIS. Indusium reniform. Fronds pinnate, articulate to the rhizome; pinnac articulate to the rachis; veins free.

GENUS 17. NEPHROLLPIS. Like genus 16, but the fronds not articulate to the rhizome.

GENUS 18. GYCLOPELTIS. Like genus 17 , but the indusium round.

GENUS 19. POLYSTICHUM. Indusium round or reniform. Fronds divided, not articulate to the rhizome. Leaflets subrhomboidal, not articulate to the rachis; upper base broadly, lower narrowly cuneate; veins free.

GENUS 20. DIJYMOCHLAENA. Like genus 19, but the indusium oblong. Leaflets deciduous.

GENUS 21. PLEOCNEMIA. Indusium reniform, rarely round. Fronds divided, not articulate to the rhizome; veins anastomosing in costal and costular arches.

GENUS 22. DRYOPTERIS. Indusium reniform, rarely round. Fronds divided, not articulate to the rhizome; veins free, but then the leaflets not as in genus 19, or the lower veius anastomosing and forming costal rows of regular, \pm deltoid areolae.

GENUS 25. MESOCHLAENA. Like genus 22, but the veins not free. Indusium oblong. 
GENUS 24. LUERSSENIA. Indusium oblong, $\pm 3 \times$ as long as broad. Fronds simple, not articulate to the rhizome; veins anastomosing copiously.

GENUS 25. ASPIDIUII. Indusium round or reniform, rarely nearly $2 \times$ as long as broad. Fronds simple or divided, not articulate to the rhizome; veins anastomosing copiously; included free veinlets wanting or present, but then not as in genus 26 , if excurrent then solitary in the areolae.

GENUS 26. CYRTOMIUM. Indusium round. Fronds as in genus 25 , but only simply pinnate: included free veinlets excurrent, $2-3$ to each areola.

Tribe III. Davallieae. Sori roundish, oblong or linear, if roundish or longitudinally elongated then solitary and terminal on the veins (dorsal in genus 27), if transversally oblong or linear then uniting the apices of $2 \mathrm{or}^{\circ}$ more veinlets. Indusium \pm of the same shape, attached at the inner side of the sorus, opening outwardly.

GENUS 27. CYSTOPTERIS. Sori roundish, dorsal on the veins.

GENUS 28. ODONTOSORIA. Sori roundish or transversally oblong, terminal on the cuneate, ultimate segments.

GENUS 29. LINDSAYA. Sori roundish, transversally oblong or linear, submarginal. Fronds divided; leaflets dimidiate, i.e. the half on the lower side of the midrib cut away.

GENUS 30. SCHIZOLOMA. Sori transversally oblong or linear, submarginal. Fronds simple or divided; leaflets not dimidiate.

GENUS 51a. SACCOLOMA. Sori roundish, submarginal, immersed in conspicuously cucullate lobes, covered 
by a roundish indusium fixed by a broad base, or placed in submarginal depressions-covered by a cuneate indusium. Indusium with the outer edge \pm entire. Fronds divided, not articulate to the rhizome.

GENUS 31b. LEPTOLEPIA. Sori roundish, submarginal or on marginal, recurved, lobe-like outgrowths. Indusium roundish or transversally oblong, fixed by the apex of the veinlet only, for the rest free, the outer edge lacerato-lobate. Fronds divided, not articulate to the rhizome.

GENUS 32. HUMATA. Sori roundish, submarginal, superficial. Indusium fixed by a broad base, the sides and apex free, \pm entire. Fronds simple or divided, scattered or subapproximate, articulate to the rhizome.

GENUS 53. ACROPHORUS. Like genus 32, but the fronds copiously divided, tufted, not articulate to the rhizome.

GENUS 34. DAVALLIA. Sori roundish or longitudinally elongated, submarginal. Indusium attached at the base and sides, the apex free. Fronds divided, scattered, articulate to the rhizome. Rhizome scaly, the scales not minute, not fibril-like.

GENUS 55. MICROLEPIA. Sori roundish, submarginal. Indusium as in genus 34. Fronds divided, rather scattered, not articulate to the rhizome. Rhizome hairy or fibrillose. Ultimate segments unequal-sided at the base. Receptacle distinct.

GENUS 36. TAPEINIDIUM. Like genus 55 , but the rhizome fibrillose or minutely scaly and the fronds rather approximate. Ultimate segments rather equalsided at the base. Receptacle indistinct. 
Tribe IV. Pterideae. Sori roundish, oblong or linear, if roundish or longitudinally elongated then solitary and terminal on the veins, but not rarely laterally confluent into a submarginal line, if transversally oblong or linear then uniting the apices of several veinlets. Indusium \pm of the sanı shape, marginal, i.e. consisting of the rellexed, modified margin of the frond, opening inwardly.

GENUS 37. ADIANTUM. Differs from the following genera by the indusium bearing the capsules on its inner surface.

GENUS 38. HYPOLEPIS. Sori roundish, distant, confined to the tops (angles) of the ultimate sinuses, 1 to each sinus. Indusium roundish, small, hardly covering the sorus at full maturity.

GENUS 39. CHEILANTHES. Sori roundish or oblong, solitary and terminal on the veins, soon confluent into a submarginal line. Indusium roundish, transversally oblong or linear. Vein tips thickened. Stipes not as in genus 40. Fronds uniform.

GENUS 40. PLAGIOGYRIA Sori as in genus 39. Indusium linear. Vein tips not or hardly thickened. Stipes abruptly thickened at the base and generally purveyed there with $\pm 2-12$ spongy glands or tubercles on the outer side. Fronds dimorphous, the fertile segments contracted, narrowly linear.

GENUS 41. PELLAEA. Sori linear, or round to oblong, but then soon confluent into a submarginal line. Indusium linear. Fronds divided, the leaflets \pm stalked, articulate at the base.

GENUS 42a. DORYOPTERIS. Sori and indusia as in 
genus 41. Fronds simple or incised, the segments adnate, confluent, not articulate at the base.

GENUS 42b. SCHIZOSTEGE. Sori and indusia terminal on the veins, marginal, solitary on $T$-shaped expansions or uniting the fork branches of the veins. Fronds divided; segments not articulate.

GENUS 43. HISTIOPTERIS. Sori and indusia oblong or linear. Fronds compoundly divided; lowest pinnulae short, close to the main rachis, stipule-like; leaflets not articulate at the base.

GENUS 44. ONYCHIUM. Sori and indusia as in genus 43. Fronds finely dissected; ultimate segments narrow, with the sori and indusia (which are occupying both sides of the segments) reaching nearly or quite to the midrib; leaflets not articulate at the base. Spores globose to tetrahedral.

GENUS 45a. PTERIS. Like genus 44, but the fronds nof finely dissected, the ultimate segments broader with the sori and indusia not reaching the midrib. Stipes with a single $V$ - or $\bigcup$-shaped vascular strand.

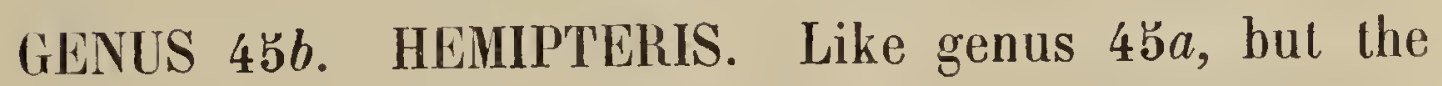
sori occupying only the posterior edge of the ultimate segments, the anterior side destitute of sori.

GENUS 46. PAESIA. Like genus 45a, but the indusia 2-valved and the spores 2-lateral.

GENUS 47. PTERIDIUM. Like genus 46, but the imner valve of the indusium sometimes obsolete, the spores as in genus 44. Stipes with many, irregularly placed vascular strands. 
GENUS 48. LOMARIA. Sori and indusia linear, uniting the vein tips or running them transversely. Fronds simple or pinnate, dimorphous, the fertile fronds or segments narrowly linear. Stipes with 3 to many vascular strands placed in a circle.

Tribe V. Blechneae. Sori transversally oblong or linear, distant from the margin, parallel to the midribs of the fronds or their segments. Indusium of the same shape as the sorus, not marginal, attached at the outer side of the sorus, opening inwardly.

GENUS 49. BLECHNUM. Sori long, linear, some times interrupted, \pm close to the midribs. Veins of fertile fronds united near the base by subcostal strands bearing the sori.

GENUS 50. SADLERIA. Like genus 49, but the veins of both barren and fertile fronds united near the base.

GENUS 51. DO0DIA. Sori oblong, superficial, in one or more rows on each side, not \pm close to the midribs.

GENUS 52. WOODWARDIA. Like genus sori in 1 row, immersed in cavities.

Tribe VI. Asplenieae. Sori oblong or linear, attached to the sides of the veins which unite the midribs or main veins with the margin, therefore mostly oblique to the midribs, rarely placed between the veins. Indusia of the same shape, springing from the veins on the same side as the sori.

GENUS 53. DIPLAZIUM. Stipes with $2 \pm$ flattened vascular strands mostly uniting towards the apex of the stipe (or higher) into a single diarchous one $(\backslash /, \vee, \backslash /, L, \cup)$. Sori linear or linear-oblong, the lower of each group of veins mostly double. 
GENUS 54. ATHYRIUM. Like genus 53, but the sori oblong, the higher never, the lower rarely double, but not rarely hippocrepiform, hamato-recurvate or subreniform.

GENUS ๖ъ. ASPLENIUM. Stipes with 1, or $2 \pm$ concave vascular strands mostly uniting towards the apex of the stipe (or higher) into a single tetrarchous one [)$(),()-,(,>\prec, X, \underline{V}$, $\searrow /$. Sori and indusia not in pairs; indusia opening towards the midribs, occasionally towards the margin.

GENUS ๖6. PHYLLITIS. Like genus ๖̆, but the sori and indusia in opposite pairs, the indusia of each pair opening towards each other.

GENUS 57. TRIPHLEBIA. Like genus 56 , but the sori medial between the veins, i. e. 1 sorus to each pair of indusia.

Exindusiata $\mathrm{e}$. Indusium wanting, but the sori sometimes covered by the unaltered, recurved margin or placed in dorsal or \pm marginal cavities or indusium-like depressions.

Tribe VII. Phegopterideae. Sori punctiform, round or oblong, rarely more than $2 \times$ as long as broad, medial or terminal on the veins and then sometimes runining into a submarginal line, if medial on the veins then sometimes confluent in pairs. Stipes not articulate to the rhizome.

GENUS 58. NOTHOLAENA. Veins free. Sori round or oblong, terminal, not rarely running into a submarginal line. Fronds hairy or fibrillose. Spores globoso-tetrahedral.

GENUS 59. MONACHOSORUM. Veins free. Sori oblong, 
terminal, always distant. Fronds naked. Spores 5-lobaio-tetrahedral.

GENUS 60a. PHEGOPTERIS. Veins anastomosing as in Nephrodium (Dryopteris $\$$ ), or free but then the spores 2-lateral. Fronds naked or hairy. Sori round or oblong, rarely linear-oblong, medial or terminal.

GENUS 60h. DICTYOPTERIS. Veins anastomosing more or less copiously, but not as in genus $60 a$. Fronds simple or divided, but not as in genus 61. Sori \pm round.

GENUS 61. DIPTERIS. Veins anastomosing copiously and irregularly. Fronds flabellato-dichotomous Sori round or punctiform.

Tribe VIII. Gymnogrammeae. Sori linear or linear-oblong, more than $2 \times$ as long as broad, several on each side of the costae, mostly oblique, rarely subparallel to the latter and the margin, free or reticulate. Fronds not articulate to the rhizome.

GENUS 62. CONIOGRAMME. Veins free quite to the margin. Under surface of the fronds not powdery.

GENUS 63. CEROPTERIS. Veins free quite to the margin. Under surface of the fronds white- or yellow-powdery.

GENUS 64 ANTROPHYUM. Veins anastomosing copiously. Sori longitudinal, running along the veins, irregular. Costa wanting, or present in the lower half of the fronds only.

GENUS 65. LOXOGRAMME Veins anastomosing copiously. Sori parallel, \pm oblique to the costa and margin. Costa distinct; veins invisible. 
GENUS 66. SYNGRAMMA. Veins mostly uniting $1-5 \times$ at or near the margin, sometimes anastomosing copiously, but then the veins distinctly visible like the costa. Sori with paraphyses.

GENUS 67. HEMIONITIS. Veins anastomosing copiously, distinctly visible like the costa. Sori without parpahyses.

Tribe IX. Grammitideae. Sori linear, short or long, 1 on each side of the costa, parallel to the latter or the margin. Fronds not articulate to the rhizome.

GENUS 68. MONOGRAMMA. Sori costal, often protected by a lateral, raised outgrowth of leaf-tissue. Fronds simple, grass-like; lateral veins mostly wanting.

GENUS 69. VITTARIA. Sori deeply immersed in marginal or submarginal grooves. Fronds simple or forked, mostly grass-like; lateral veins present, free.

GENUS 70. TAENITIS. Sori not deeply immersed, medial or submarginal. Fronds pinnate or simple, but then not grass-like; lateral veins present, anastomosing.

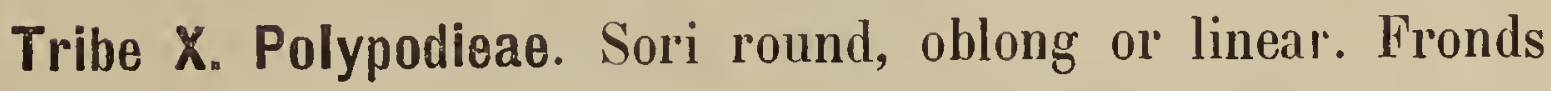
articulate to the rhizome.

GENUS 71. POLYPODIUM. Sori round, oblong or linear, several to numerous on each side, the oblong ones parallel or oblique to the costa, the linear ones oblique. Fronds uniform or dimorphous, simple or divided, the barren ones never oakleaf-like; surfaces naked, scaly or hairy, if hairy the hails not stellately branched.

GENUS 72. GYGLOPHORUS. Sori round or oblong. several to numerous. Fronds as in genus 71, 
but simple; at least the under surface always more or less hairy, the hairs stellately branched.

GENUS 75. DRYNARIA. Sori round, many or numerous. Fronds dimorphous. Barren fronds (cupleaves) oakleaf-like, sessile, humus-collecting, fertile ones pinnatifid or pinnate, stipitate.

GENUS 74. DRYOSTACHYUM. Sori oblong or subquadrangular, many. Fronds pinnatifid, the higher segments fertile, much contracted. Barren fronds not oakleaf-like.

GENUS 75. DRYMOGLOSSUM. Sori linear, 1 on each side, parallel to the costa or the margin. Barren fronds roundish or oblong, fertile ones linear or linear-oblong.

GENUS 76. CHRISTOP'TERIS. Sori linear, 1 on each side, parallel to the costa. Barren fronds sagittate, fertile ones 5-partite.

Tribe XI. Acrosticheze. Sori indefinite, i.e. quite covering portions of the under surface or occasionally both surfaces of the fertile segments at full maturity, but apparently linear in the forms with much contracted fertile segınents.

GENUS 77. PLATYCERIUM. Distinguished from the following genera by the dichotomously branched fertile fronds. Barren (basal) fronds adpressed to the substratum, humus-collecting.

GENUS 78. ELAPHOGLOSSUM. Veins free, the apices not rarely united by a \pm marginal, cartilagineous or decoloured line. Fronds simple.

GENUS 79. STENOCHLAENA. Veins free, those of the fertile fronds united at the base by a \pm 
costal strand. Fronds pimnate, Lomaria-like. Rhizome high-scandent.

GENUS 80. POLYBOTRYA. Veins free, not united at the base in the fertile fronds. Fronds pimnately divided, not Lomaria-like. Rhizome erect or widecreeping, not high-scandent. Sori often occupying the apices of the veins only when young.

GENUS 81. STENOSEMIA. Veins anastomosing, forming costal and costular arches, otherwise free. Barren fronds ternate or pinnate, fertile ones conspicuously contracted, branched.

GENUS 82. HYMENOLEPIS. Veins anastomosing copiously. Fronds simple, the soriferous apex narrowly linear or spoon-shaped.

GENUS 85. ACROSTICHUM. Veins anastomosing copiously. Fronds pinnate; pinnae not articulate to the rachis, the higher ons fertile, rarely much contrated.

GENUS 84. PHOTINOPTERIS. Veins anastomosing copiously. Fronds pinnatifid or pinnate; segments articulate to the rachis, the higher ones fertile, always much contracted.

GENUS 85. CHEIROPLLURIA. Veins anastomosing copiously. Fronds dimorphous, the barren ones simple or more commonly 2-fid, with the segments sometimes 2-fid again, each segment with 2 or more stout, longitudinal ribs. Fertile fronds simple, narrowly linear.

GENUS 86a. LEPTOCHILUS. Veins anastomosing copiously. Fronds dimorphous, simple, 5-fid or pinnate, each segments with a single, central rib. Spores oblong, ovate or bilateral. 
COMPENDIUM.

GENUS $86 b$. PLATYTAENIA. Like genus $86 a$, but the fronds pinnate and the spores globoso-tetrahedral.

FAMILY VII. PARKERIACEAE. Ring incomplete, vertical. Sori indefinite, consisting of numerous : sporangia scattered irregularly along the few, longitudinal veins, covered by the unaltered, recurved margin of the frond when young.

GENUS 87. CERATOPTERIS. Characters of the family.

FAMILY VIII. OSMUNDACEAE. Ring incomplete, short and horizontal or consisting of a lateral group of thickened cells only. Indusium wanting.

GENUS 88. OSMUNDA. Sori globose, placed in opposite, marginal clusters. Segments articulate to the rachis, the fertile ones more or less contracted.

GENUS 89. LEPTOPTERIS. Sori flat, dorsal. Segments not articulate to the rachis, the fertile ones not contracted.

Series II. Exannulatae. 'Sporangia without a ring.

FAMILY IX. MARATTIACEAE. Fronds mostly large, the stipes flanked by 2 stipulaeform appendages at the base. Indusium wanting or inconspicuous.

GENUS 90. ANGIOPTERIS. Sporangia in 2 opposite, close rows, not concrete. Fronds large, compound.

GENUS 91. MARATTIA. Sporangia concrete in 2valved synangia, the valves opposite, boat-shaped. Fronds large, compound.

GENUS 92. CHRISTENSENIA. Sporangia concrete in 
circular synangia. Fronds small, ternate or quinate.

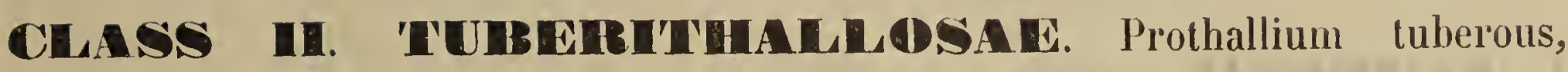
white.

FAMILY X. OPHIOGLOSSACEAE. Sporangia without a ring, sessile, placed on much contracted, spicate or paniculate fertile segments opposite to and springing from the base, the centre or the margin of the normal, frondose, barren segment. Indusium wanting.

GENUS 93. OPHIOGLOSSUM. Fertile segment spicate, with the sporangia in 2 opposite, lateral rows. Barren segment simple; veins anastomosing.

GENUS 94. HELMINTOSTACHYS. Fertile segment spicate, with the sporangia in numerous crested clusters spreading in all directions. Barren segment divided; veins free.

GENUS 95. BOTRYCHIUM. Fertile segment paniculate, with the sporangia placed in 2 rows on the inner face of the branches. Barren segment divided; veins free.

\section{Abbreviated natural arrangement of the FAMILIES, TRIBES AND GENERA as construed in this work.}

I. CYATHEAcEAE. (Diels, in Engl. \& Prantl, Nat. Pfl. l'am., I4, 115).

I. Cyatheae. (Diels, 1.c., 123).

1 Cyathea,

2 Hemitelia,

3 Alsophila. 
II. Dicksonieae. (Diels, I. c., 119).

4 Dicksonia,

丂 Gibotium.

II. MATONIACEAE. (Diels, I. c., 345).

6 Matonia.

III. GLEICHENIACEAE. (Diels, l. c., 350).

7 Gleichenia.

IV. HYMENOPhYLLACEAE. (Sadeb., in Engl. \& Prantl, Nat. Pfl. Fam., I , 91).

8 Hymenophyllum,

9 Trichomanes.

V. SCHIZAEACEAE. (Diels, l. c., 356).

10 Lygodium,

11 Schizaea.

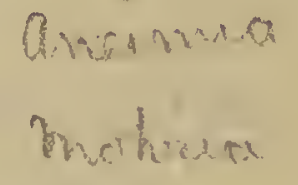

VI. POLYPODIACEAE. (Diels, 1. c., 159).

I. Woodsieae. (Diels, 1. c., 159).

I. W 00 D S I I N A E.

12 Diacalpe,

27 Cystopteris,

55 Acrophorus.

II. 0 N 0 C L E I N A E.

II. Aspidieae. (Diels, 1. c., 166).

I. A S P I D I I N A E.

1. INDUSIATAE.

22 Dryopteris (Nephrodium), excl. Phegopteris,

24 Luerssenia,

23 Mesochlaena,

20 Didymochlaena,

18 Cyclopeltis,

25 Aspidium, excl. Pleocnemia \& Diclyopleris.

21 Pleocnemia,

19 Polystichum, excl. Cyrlomium,

26 Cyrtomium.

2. EXINDUSIATAE.

60 a Phegopteris, 
$60 b$ Dictyopteris,

80 Polybotrya,

o. Stenosemia,

86a Leptochilus (Gymnopteris).

II. D I P T E R I D I N A E.

61 Dipteris.

lla. Oleandrelae. (Diels, l. c., 203).

15 Oleandra.

III. Davallieae. (Diels, l. c., 204).

1. INDUSIATAE.

16 Arthropteris,

17 Nephrolepis,

32 Humata,

$31 a$ Saccoloma,

$31 b$ Leptolepia,

54 Davallia, xxcl. Prosaptia,

35 Microlepia,

28 Odontosoria,

36 Tapeinidium (Wibilia),

14 Dennstaedtia,

30 Schizoloma,

29 Lindsaya.

2. EXINDUSIATAE.

59 Monachosorum.

IV. Pterideae. (Diels, l. c., 254).

I. G Y N 0 GR A M M I N A E.

66 Syngramma,

62 Coniogramme,

67 Hemionitis,

63 Ceropteris (Neurogramme).

II. C H E I L A N T H I N A E.

1. INDUSIATAE.

41 Pellaea,

42a Doryopteris,

39 Cheilanthes,

38 Hypolepis,

44 Onychium (Cryptogramme $\$$ ),

40. Plagiogyria. 
2. EXINDUSIATAE.

๖8 Notholaena (Nothochlaena).

III. A D I A N T I N A E.

37 Adiantum.

IV. P T E R I D I N A E.

45 a Pteris, excl. Schizostege,

$42 b$ Schizostege,

$45 b$ Hemipteris,

43 Histiopteris,

47 Pteridium,

46 Paesia.

V. Blechneae.

VI. Asplenieae. (Diels, 1. c., 222).

I A S P L E N I I A E.

๖4 Athyrium,

53 Diplazium,

13 Diplaziopsis (Allantodi ),

57 Triphlebia,

э6 Phyllitis (Scolopendrium),

55 Asplenium.

II B L E C H N N A E.

1. INDUSIA'I'AE.

49 3lechnum, excl. Lomaria,

48 Lomaria,

50 Sadleria,

๖2 Woodwardia,

51 Doodia.

2. EXINDUSIATAE.

79 Stenochlaena.

VII. Phegopterideae.

VIII. Gymnogrammeae.

IX. Grammitideae (Vittarieae, Diels, 1. c., 297).

I. V I T T A R I I N A E.

68 Monogramma,

69 Vittaria.

II. A N T R O P H I I N A E.

64 Antrophyum.

X. Polypodieae. (Diels, 1. c., 302). 
I. T A E N I T I D I N A E.

1. ARTICULATAE.

75' Drymoglossum,

76 Christopteris,

s6b Platytaenia,

82 Hymenolepis.

2. INARTICULATAE.

65 Loxogramme,

70 Taenitis.

II. P O L Y P O I I I N A E.

71 Polypodium, excl. Loxogramme; incl. Prosaplia: \& Lecanopteris,

72 Cyclophorus (Niphobolus),

74 Dryostachyum,

84 Photinopteris,

75 Drynaria.

XI. Acrosticheae. (Diels, l.c., 330).

I. A G R O T I G H I N A E.

78 Elaphoglossum,

83 Acrostichum.

II. P L A T Y G E R I I N A E.

85 Cheiroplęuria,

77 Platycerium.

VII. PARKERIACEAE. (Diels, l. c. 339).

87 Ceratopteris.

VIII. OSMUNDACEAE. (Diels, l. c., 372).

89 Leptopteris,

88 Osmunda.

IX. MARAtTIACEAE. (Bitt., in Engl. \& Prantl., Nat. Pfl.Fam., I' ${ }^{4}$ 422).

90 Angiopteris,

91 Marattia,

92 Christensenia (Kaulfussia).

X. OPHiOgLossaceae. (Bitt., I. c. 449).

93 Ophioglossum; 95 Botrychium; 94 Helmintostachys. 
Following pages contain besides descriptions keys to the determination of the families, tribes, genera and species.

If one supposes to have found in the keys the name sought after, he should not omit reading the diagnosis itself, seeing the plants are determined by more characteristics than those few admitted in the keys These are mere expedients, no. infallible guides; they chiefly had to be extracted from the aviilable diagnoses since I did not set eyes on a great part of the plants. Furthermore it would have heen like looking for a needle in a haystack to insert all deviations from the normal forms. Consequently the use of the keys may be sometimes the cause of going wrong.

In comparing the collected plants with the descriptions given in this and other works one should bear in mind that dillerent authors are not always unanimous in using botanical terms. So, for instance, the word ovate is not rarely used for oval or even deltoid or another term, spreading for horizontal, erecto-patent for more or less oblique, conspicuous and inconspicuous for distinct and indislinct, costa for rachis, costula for main vein, vein for veinlel, pinna for lobe or lacinia, medial for medial on the veins or medial between the costae (costulae) and edge, excurrent for direcled towards the margin, forling for fork branch, \&c. 


\section{FILICES.}





\section{FILICES (Ferns).}

\section{Arrangement of the families.}

a. CLASS I. PIANITIEAILOSAE. Prothallium green, flat or filiform, entire, incised or branched, epigeous or epiphytical, adpressed to the substratum. Diels, in Engl. \& Prantl, Nat. Pfl. Fam., Í ${ }^{4}$ fig. 11.

6. SERIES I. ANNULATAE. Sporangia with a ring consisting of a close or broken row or a group of conspicuously prominent, thickened cells.

FAMILY I. Cyatreaceac. Ring complete, oblique, subvertical, sometimes interrupted by a group of depressed, transversally oblong cells, which are however distinclly differentiated from the other cells of the sporangium. Sori globose or oblong, consisting of numerous, densely crowded sporangia; indusium wanting or present, but then neither umbrella-shaped nor linear. Arborescent ferns. Diels l. c., fig. 82, D; Hk. Bk., Syn. Fil., tab. I, fig. 4-6.

FAMILY II. Matomiaceace. Ring as in Cyatheaceae but never interrupted. Sori consisting of 4-8 sporangia placed in a whorl; indusium umbrella-shaped. No arborescent ferns. Diels, l. c., fig. $181 \&$ 182, B; Hk. Bk., l. c., fig. 8 .

FAMILY III. Mleichenioceac. Ring complete, \pm horizontal, surrounding the sporangium like a belt. Sori dorsal, consisting of $2-12$ sporangia, mostly placed in a whorl; indusium wanting; receptacle dot-like. Diels, 1. c, fig. 186 ; Hk. Bk., 1. c., fig. 2.

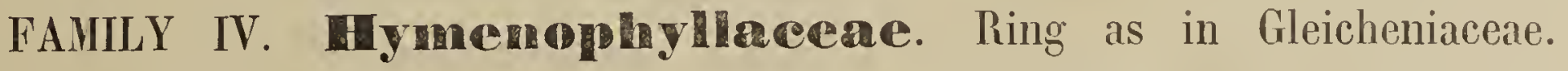
Sori marginal, consisting of numerous sporangia crowded around an erected, oblong, cuneate, capitate, malleiform or columnar-filiform receptacle; indusium present. Diels, l. c., fig. $72 \& 75$, D; Hk. Bk., l. c., tab. II, lig. 16-17. 
FAMILY V. Schimacaceae. Ring operculiform, crowning the apex of the sporangium. Sporangia eilher 1-2, placed in the axils of imbricate, clasping, scale-like indusia or numerous, but then placed in 2-4 regular, naked rows. Diels, l. c., fig. 192; Hk. Bk., l. c., tab. VIII, fig. 64, tab. IX, fig. 68 .

FAMILY VI. Polypodiacere. Ring incomplete, vertical, the extremities sometimes separated by the stalk of the sporangium only. Sori definite or indefinite and then the sporangia densely crowded over the parenchyma; indusium wanling or present. (Ring sometimes as in Cyatheaceae, but then the indusium linear and the ferns not arborescent). Diels, l. c., fig. $57 \& 87$, D \& H; Hk. Bk., l. c., tab. I, fig. 7, d.

FAMILY VII. indefinite, consisting of many sporangia scattered irregularly along the few, longitudinal veins, protected by the much recurved margin of the frond when young. Diels, l. c., fig. 178-179; Hk. Bk., l. c., tab. III, fig. 32.

FAMILY VIII. Bsmundaceae. Ring incomplete, short and horizontal or consisting of a roundish, lateral group of thickened cells. Indusium wanting. Diels, l. c., fig. 205; Hk. Bk., l. c., tab. VIII, fig. 62, c, \& 65, b \& d.

\subsection{SERIES II. EXANNULATAE. Sporangia without ring.}

FAVILY IX. Marattiaceac. Sori consisting of 8-24 sporangia. Sporangia free, placed in 2 close, short rows or joined into 2-valved or circular synangia. Diels, l. c., fig. 259; Hk. Bk., l. c., tab. IX, fig. $69,70 \& 72$.

w.*. Class II. TUEBRITHALILOSAE. Prothallium white, tuberous, hypogeous or immersed in the substratum.

FAMLY X. Dplhioglossaceac. Sporangia without ring, rather large, not gathered into sori but placed on much contracted, spicate or paniculate segments, originating from the base, the centre or the margin of the bar'en, normal-shaped segment of the frond. Diels, l. c., fig. $259, \mathbf{A}-\mathbf{B} \&$ 260 ; Hk. Bk., l. c., fig. 73-75. 
Key to the families.

a. Sporangia with a ring.

b. Ring complete.

c. Ring oblique, subvertical.

d. Ferns arborescent. Indusium wanting or present, but then neither linear nor umbrella-shaped.

I. Cyathenceac.

a.d. Ferns not arborescent. Indusium linear or umbrellashaped.

e. Indusium umbrella-shaped. II. Matoniaceac. e.e. Indusium linear.

VI. Polyporlidecae, No. 40, Plagiogyria t in!

c.c. Ring \pm horizontal, surrounding the sporangium like a belt.

i. Receptacle inconspicuous, dot-like. Indusium wanting.

III. Aleicheniacere.

i.i. Receptacle conspicuous, erect, oblong to columnar-filiform. 'Indusium present. IV. Hymenopihyllaceae.

c.c.c. Ring operculiform, crowning the apex of the sporangium.

V. Selhimacaceac.

b.b. Ring incomplete.

x. Ring vertical, long, the extremities sometimes separated by the stalk of the sporangium only.

$\therefore \quad$ Sori indefinite. Sporangia scattered irregularly on the few, longitudinal veins. VII. Fralkerioceac.

$\therefore$ Sori definite or indefinite, but then the sporangia densely crowded over the parenchyma.

VI. Polypodiacene.

x.x. Ring horizontal, short or consisting of a lateral group of thickened cells only.

VIII. Dsmundaceae.

a.a. Sporangia without ring.

* Sori on the under surface of normal fronds.

IX. Margttiaceac.

*.*. Sporangia not gathered into sori, placed on much contracted, spicate or paniculate segments originating from the base, the centre or the margin of the leafy, barren segment.

\section{$\mathrm{X}$. Dphioglossaceae.}



FAMILY I. CYATHEACEAE. 



\section{CYATHEACEAE (*).}

Sori globose or ellipsoid, dorsal or terminal on the veins; sporangia numerous, sessile or stalked, furnished with a complete, oblique (subvertical) ring, which is sometimes interrupted at the place of the stomium by a row of depressed, transversally oblong cells; stomium opening at right angles to the ring; receptacle often elevated. Indusium wanting or more generally present and then scale-like, 2-valved, subcupuliform or globose, but then afterwards evanishing or becoming cup-shaped, sometimes consisting of a whorl of hairs or fibres, always fastened beneath the sorus.

Caudex arborescent, sometimes subarborescent. Fronds often very large, mostly compoundly divided; veins free or the costal ones sometimes anastomosing in Hemitelia.

Tropical and subtropical.

Arrangement of the tribes.

$\$$ 1. CYATHEAE. Sori dorsal, placed on the back or at the forking of a vein. Annulus not interrupted by a row of depressed cells.

S 2. DICKSONIEAE. Sori terminal on the veins. Annulus interrupted by a row of depressed cells at the place of the stomium.

Key to the tribes and genera.

t. Sori on the back or at the forking of a vein.'

CYATHEAE.

a. Sori indusiate.

b. Indusium distinct, globose, quite enclosing the sorus when young, bursting down irregularly, afterwards evanishing or becoming \pm cup-shaped. Receptacle central.

No. 1. Cyathea.

b.b. Indusium distinct, squamiform, convex, placed at the inner side of the receptacle.

No. 2. Femitelia.

$\left(^{\star}\right)$ The species of this family are difficult of determination unless the whole stipe and the lowest pinnae besides the central pinna and a portion of the main rachis are present. 
b.b.b. Indusium spurious, consisting of a minute scale placed at the inner side of the receptacle or of a circular, entire or lobed scale or a wholl of fibres with the receptacle in the centre.

a.a. Sori exindusiate.

№. 3. Alsophila.

No. 5. Isprbilize.

t. Sori terminal on the veins. DICKSONIEAE.

* Indusium 2-valved, the outer valve consisting of an unmodified, cucullate lobe of the frond, forming with the inner valve a saccate involucre to the sorus.

No. 4. Dicksonia.

**. Indusium 2-valved, the outer valve like the inner one, distinctly differentiated from the margin of the frond, both forming a saccate involucre to the sorus.

No. ร. Civotium. 
TRIBE I. CYATHEAE. 



\section{OYATHEA, Smith.}

Sori globose, dorsal on a vein or veinlet or in the axil of a veinlet; receptacle elevated, globose or shortly columnar. Indusium inferior, membranaceous or somewhat horny, globose, at first quite enclosing the sorus, afterwards evanishing or breaking down and becoming cupshaped, with an entire or more or less irregularly lobed or laciniated margin.

Caudex arborescent, often beautifully marked with the scors of fallen fronds. Fronds mostly large and divided, rarely simple (not in malayan material); veins free, simple or forked. Hk. Bk., Syn. Fil., tab. I, fig. 4.

Tropical and extra-tropical in the southern hemisphere.

a. Fronds simply pinnate.

(1) C. moluccana.

a.x. Fronds 2-pinnatifid to 2-pinnate.

b. Main rachis densely scaly.

(2) C. philippinensis.

b.b. Main rachis naked or nearly so.

c. Pinnae pinnatifid throughout.

(5) C. aneitensis.

c.c. Pinnae pinnate, at least at the base.

d. Pinnae pinnate near the base.

e. Pinnae $\pm 2^{1} / 2$ c.M. broad. Secondary segments \pm 5 m.M. broad.

(4) C. dulitensis.

e.e. Pinnae 3-8 c.M. broad. Segments 上 10 m.M. broad.

(5) C. alternans.

d.d. Pinnac pinnate nearly throughout.

(6) C. sarawakensis.

a.a.a. Fronds 3-pinnatifid to 3-pinnate.

1. Tertiary segments very small, roundish, not more than $\pm 2^{1} / 2$ m.M. long.

(7) C. Macgregorii.

1.1. Tertiary segments oblong to linear, much more than $2^{1 / 2}$ m.M. long.

2. Pinnulae pinnatifid, sometimes pinnate at the base.

3. Main rachis not priclily, naked.

4. Tertiary segments entire or slightly crenate.

* Veins 7-8 on each side of the costulae, deeply forked.

(8) C. polypoda.

*.*.* Veins \pm 12 on each side of the costulae, $2-3 \times$ forked.

(9) C. leucotricha. 
1.1. Tertiary segments \pm toothed.

5. Veins 5-6 on each side of the costulae.

(10) C. suluensis.

5.5. Veins 9-12 on each side.

c. Texture papyraceous. Sori in $\pm 4-5$ pairs to a lobe.

(11) C. saccata.

6.6. Texture coriaceous. Sori in \pm 8 pairs to a lobe.

(12) C. cyclodonta.

3.3. Main rachis not prickly, but scaly, hairy or tomentose, at least on the upper side.

a. Texture membranaceous to papyraceous.

ß. Main rachis hairy or tomentose.

$\gamma$. Ultimate segments obscurely crenate, slightly scaly beneath.

(15) C. fusca.

\%.\%. Ultimate segments serrate, naked beneath.

(14) C. integra.

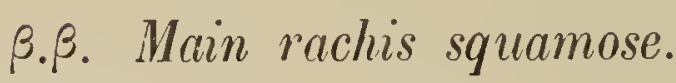

(13) C. assimilis.

๙. . Texture chartaceous to coriaceous.

$\beta^{\prime}$. Main rachis purveyed with large glands on the upper side near the base of the pimnae. (16) C. Zollingeriana. $\beta^{\prime} . \beta^{\prime}$. Main rachis without glands.

$\gamma^{\prime}$. Main rachis hairy or tomentose, not scaly.

$\delta^{\prime}$. Sori costular.

$\varepsilon^{\prime}$. Lobes entire or crenate, indusium rupturing irregularly.

* Secondary rachises lirsute above, slightly scaly beneath.

(17) C. Korthalsii.

*.*.* Secondary rachises tomentose above.

(18) C. crenulata.

$\varepsilon^{\prime} . \varepsilon^{\prime}$. Lobes serrate. Indusium at length regularly cup-shaped. (19) C. orientalis. $\delta^{\prime \prime} . \delta^{\prime}$. Sori medial on the veins.

(20) C. runensis.

$\gamma^{\prime} \cdot \gamma^{\prime}$. Main rachis scaly, or scaly and hairy.

\$. Pinnae under 20 c.M. long; veins $\pm 4-5$ on each side of the costulae.

(21) C. Havilandii. 
\$.\$. Pinnae more than 20 c.M. long; veins \pm 7-10 on each side.

* Lower sori divaricating. Indusium at length regularly cup-shaped.

(22) C. javanica.

*.*. Lower sori not divaricaling. Indusium deciduous or breaking down irregularly. +. Sori costular. (25) C. sumatrana. +.+. Sori rather medial.

(24) C. inquinans.

3.3.3. Main rachis \pm prickly.

4. Upper surface whitish when dry.

(25) C. leucophaës.

4.4. Upper surface not whitish when dry.

5. Sori distant from the costulae.

(26) C. strigosa.

5.5. Sori costular.

6. Rachises tomentose above. Pinnulae $6-71 / 2$ c.M. long. Sori few to a lobe. (27) C. hymenodes.

6.6. Rachises not tomentose. Pinnulae 8-12 c.M. long. Sori many to a lohe. (28) C. spinulosa.

2.2. Pinnulae pinnate \pm throughout.

\$. Main rachis not prickly, naked.

(29) C. Muelleri.

\$.\$. Main rachis nol prickly, but scaly, hairy or tomentose.

* Edges crenate; each crenation corresponding with a bullate vault, prominent on the upper surface. (30) C. oinops.

*.*. Edges entire or crenulate; prominent, bullate vaults wanting.

(51) C. schizochlamys.

\$.\$.\$. Main rachis prickly and tomentose or \pm furfuraceous.

+ Tertiary segments adnate to the rachis. Under surface cobwebby.

(52) C. arachnoidea.

+.+. Lower tertiary segments slightly stalked. Under surface naked or inconspicuously scaly.

(55) C. celebica.

* (1) C. moluccama, Re. Her., Desv., Prod., 522; C.brunonis, Wall., Hk. Bk., Syn. Fil., 16, Schizocaena brunonis, J. Sm., Bau. \& Hk., Gen. Fil., tab. II.

Stipes 50-100 c.M. long, the base slightly rough and furnished with brown scales. Fronds large, \pm 100 c.M. long, simply pinnate. Pinnae nu- 
merous, distant, lanceolate, $\pm 15-50$ c.M. long, $21 / 2-4$ c.M. broad, the edge repando-crenate, or slightly and irregularly undulate, the base subcuneate or rounded, the apex acuminate, crenate-dentate. Texture thinly coriaceous; surfaces naked or the upper one hairy on the costa near the base like the rachis; costae and veins distinct; veins parallel, several times branched. Sori in \pm 2 , often very irregular rows on each side of the costa; indusium thin, breaking down irregularly.

Malaya.

(2) C. philippinensis, Bk., Ann. of Bot., V, 186.

Trunk short, slender; the scales large, linear, pale-brown. Fronds bipinnate, oblong-rhomboid, \pm 90 c.M. long, $\pm \mathbf{5}$ U c.ll. broad, narrowed from the middle to the base; rachises of frond and pinnae densely scaly. Pinnae lanceolate, central largest, $15-18$ c.M. long, $\pm 3^{1} / 2-4$ c.M. broad. Pinnules ligulate, crowded, sessile, $6-7 \mathrm{~m}$. M. broad, entire or crenate, with forked veins and a single row of sori between the midrib and the edge; indusium moderately firm, but breaking up into pieces.

Philippines.

(3) C. aneitensis, Hk., Hk. Bk., Syn. Fil., 26.

Pinnae oblong, 50-45 c.M. long, 10-15 c.M. broad, sessile or nearly so, short-acuminate, pinnatifid nearly to the costa. Lobes rather distant, oblong, acute, subserrate. Texture coriaceo-membranaceous; rachis smooth, purple or ebeneous; costae and costulae scaly with hair-like scales; veins forked. Sori copious, intermediate between the costulae and the margin; indusium thinmembranaceous, persistent, soon breaking down and generally opening at the back so as to form a large, lax, almost transparent, 2-lobed and ragged cup, often again irregularly lacerated.

Ternate; Aneitum.

(4) C. Aulitensis, \#k., Kew Bull., 1896, 40.

Caudex short. Stipes densely tufted, \pm 15 c.M. long, brown, naked above, the base covered with large, spreading, linear-subulate, membranaceous scales. Fronds oblong-lanceolate, \pm 50 c.M. long, $12-15$ c.M. broad, 2-pinnate. Pinnae lanceolate, $\pm 21 / 2$ c.M. broad, pinnate at the base, the lower ones short-stalked, the lowest reduced, deflexed. Segments linear-oblong, \pm 5 m.M. broad, nearly entire, the margin revolute. Texture thick, rigid, coriaceous; surfaces naked, rachis nearly so, brown; veins obscure, immersed, 
erecto-patent, forked. Sori in 1 row on each side of the costa, medial; indusium campanulate, fragile, breaking down irregularly, persistent.

Borneo.

* (5) C. alternans, Pr. (not H/.), Christ, Farnkr. d. Erde, 327; Alsophila allernans, Hk., Hk. Bk., Syn. Fil., 41; Bedd., Ferns Br.I., II, tab. CCXXXVI; Amphicosmia allernans, Moore, Bedd., Handb. Ind. Ferns, 10; Hemitelia altemans, Hk., Icon. Pl., VII, tab. DCXXII; - var. Lobbiana; C. Lobbiana, Hk., Hk. Bk., l. c., 24.

Fronds large, sub-2-pinnate. Pinnae short-stalked, remote, 20-35 c.M. long, 4 - 8 c.M. broad, linear-oblong, acuminate, deeply pimnatifid, but pinnate at the base. Segments linear-oblong, acute, subfalcate, spreading, remote or slightly so, \pm alternate, \pm 1 c.M. broad, the edge entire or serrate, the lowest ones sessile with a broad base. The extremity of the frond suddenly pinnate with oblong, undivided, sessile pinnulae, serrate at the margin. Texture subcoriaceous; rachis and surfaces naked or the rachis tomentose above; veins approximate, $1-2 \times$ forked. Sori 2-seriate on each pinnula or lobe, close, mixed with rather copious, jointed hairs; indusium at length a hemispherical cup, completely surrounding the base of the sorus.

Var. Hobbiama: Pinnae strongly acuminate nearly to the costa; segments obtuse. Indusium very thin, breaking down irregularly.

Penang; - var. Lobbiana: Borneo.

(6) C. sarawakensis, Hr., Hk. Bk., Syn. Fil., 25; (? G. alternans, Pr., C. Chr., Ind. Fil.).

Fronds large, 2-pinnate. Pinnae distant, stalked, to 50 c.M. long or longer, \pm 1 c.M. broad, oblong, pinnatifid only at the acuminate apex, pinnate towards the base. Pinnulae numerous, approximate, horizontal, sessile, 10-15 m.M. broad, linear, acuminate, crenato-serrate, obliquely cuneate at the base. Texture subcoriaceous; surfaces and rachises naked; veins approximate, 2-3-furcate. Sori dorsal, rarely in the axils of the veins; indusium thin, fragile, breaking down into irregular lobes.

Borneo.

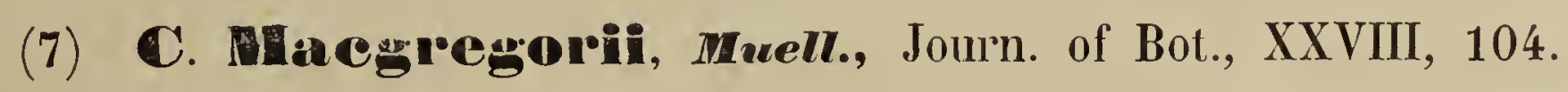

Caudex short, under 60 c.M. long. Fronds 5-pinnatifid; rachises more or less clothed with an intertangled coat of brown scales. Pinnae \pm 10 c.M. long, $\pm 2 \frac{1}{2}$ c.II broad. Pinnulae lanceolate, $4-\breve{~ m . M . ~ b r o a d . ~ S e g m e n t s ~}$ 
round or oblong, bullate, rigid, with the edges much recurved. Texture rigid; surfaces copiously scaly when young. Sori 1-2 to each ultimate segment, quite covering its under surface; indusium globose, fragile.

New Guinea.

(8) C. polypoda, Bh., Trans. Linn. Soc., Bot., $2 d$ Series, IV, 250.

Fronds large, 5-pinnatifid; main rachis naked. Pinnae lanceolate-oblong, \pm 45 c.M. long, $10-15$ c.M. broad. Pinnulae lanceolate, the lower stalked, \pm 15 m.M. broad, pinnatifid nearly to the costa. Lobes oblong, obtuse, entire, $3^{1} / 2-5$ m.M. broad. Texture moderately firm; under surface covered witl numerous white, ovate scales, especially on the costae; veins 7-8 on each side, deeply forked. Sori medial between the costulae and the margin; indusium cupuliform, small, naked.

Borneo.

* (9) C. Iencotricha, Christ, Ann. Btz., XX, 15 5.

Fronds large, tripinnatifid, subtripinnate; main rachis naked, glossy, reddislbrown. Pinnae stalked, approximate, to 50 c.M. long, \pm 18 c.M. hroad, acuminate, \pm 30 on each side below the pinnatifid apex. Pinnulae \pm sessile, \pm 9 c.M. long, \pm 18 m.M. broad, acuminate, the hase slightly narrowed, the edge cut down nearly to the costa; lowest pinnulae not the largest. Ultimate segments pectinate, bluntish or subacute, falcate, \pm 23 on each side below the pinnatifid apex, $\pm 2 \frac{1}{2}$ m.M. broad, linear-oblong, entire or slightly crenate towards the apex, the margin hardly reflexed. Texture coriaceous; under surface not glaucous; costae, costulae and secondary rachises covered beneath with pale, \pm adpressed, firm hairs like the costae above; veins \pm 12 on each side, oblique, $2-5 \times$ forked. Sori medial on the lower veins, $4-5$ on each side of the costulae; indusium thin, hyaline, globose.

Borneo.

C. suluensis, Bk., Journ. of Bot., XVII, 65.

Fronds large, 5-pinnatifid or subtripinnate; main rachis pale-hrown, naked. Pinnae sessile, oblong-lanceolate, 50 c.M. or more long, 12-15 c.M. broad. Pinnulae lanceolate, sessile, 1-2 c.M. broad, cut down nearly (or occasionally at the base quite) to the costa into ligulate-oblong, toothed segments $\mathbf{\pm}$ m.M. broad. Texture moderately firm; rachises naked, pale-hrown; under surface covered with many small, white, bullate scales on the midribs of the pinnulae add ultimate segments; veins 5 -6-jugate, erecto-patent, dis- 
tinct, deeply forked. Sori rather small, placed at the forkings of the lower veins; indusium persistent, semiglobose, entire or slightly. broken up as it matures.

Sulu Islands.

C. saccata, Christ., Ann. Btz., XIX, 42.

Dwarftree. Stipes glossy, sulcate below, convex above, yellow-brown, covered with minute warts and prickles, \pm 25 c.M. long. Fronds \pm 115 c.M. long, \pm 80 c.M. broad, ovate, acuminate, narrowed towards the base, 3-pinnatifid. Pinnae distant, stalked, \pm 12 c.M. broad, ovate, acuminate, caudate, narrowed at the base. Pinnulae distant, $2-21 / 2$ c.M. apart, $\pm 1 \frac{1}{2}$ c.M. broad, the lower ones shorter, stalked, lanceolate, the apex serrate, the edge pinnatifid. Segments 13-14 on each side, ligulate, $\pm 21 / 2$ m.M. broad, obtuse, toothed. Texture papyraceous; upper surface dark-green, under one paler; rachis reddish, those of the pinnae brown or ebeneous; upper surface furfuraceous on the costae, the scales brown; veins distinct, 9-12 on each side, forkêd. Sori $4-5$ on each side, medial; indusium membranaceous, afterwards saccate with the margin entire.

Celebes.

* (12) C. Cyclodonta, v. A. v. R.; Alsophila cyclodonta, Christ, Ann. Btz., XX, 137.

Main rachis naked, glossy, brownish-green. Pinnae \pm 60 c.M. long, 20-25 c.M. broad, acuminate, the base not or harly narrowed, on stalks 1-6 c.M. long, the rachis hairy above. Pinnulae subsessile, spreading, close, $2-2 \frac{1}{2}$ c.M. broad, numerous, the base not narrowed, the apex acuminate, subcaudate, toothed, the costa covered above with adpressed, pale-coloured hairs, clothed beneath with longer, spreading, subulate setae. Tertiary segments linear, falcate, obtuse, $\pm 21 / 2 \mathrm{~m}$. M. broad, the higher ones confluent, the others sessile, $2-3 \mathrm{~m}$.M. apart, united by a narrow wing, decurrent with a rounded, adnate lobe, the lowest subsessile, with a truncate base, the margin dentate-crenate, the crenations semiorbicular, \pm 12 on each side. Texture coriaceous; under surface hairy on the costulae; veins fine, \pm 12 on each side. Sori \pm 8 on each side, contiguous, \pm medial, not occupying the higher veins, 1 to each crenation; indusium at length a shallow, deeply and irregularly lobed, membranaceous, persistent, brown cup.

Borneo.

(13) C. Tusca, Bzi., Becc., Mal., III, 31.

Fronds läge, 5-pinnatifid; main rachis brownish-pubescent Pinnae oblong- 
lanceolate. Pinnulae sessile, lanceolate. Ultimate segments oblong, obscurely crenate. Texture moderately firm; under surface covered with small scales on the veins; veins distinct, erecto-patent, $5-6$ on each side, mostly forked. Sori medial on the veins; indusium firm, persistent, naked, the opening broad, entire or cut down to the receptacle.

New Guinea.

(14) C. integra, J. Sm., Hk. Bk., Syn. Fil., 23; Hk., Icon., Pl., VII, tab. DCXXXVIII; - var. petiolata; C. peliolala, J. Sm., Hk., l. c., fig. 2.

Fronds 5-pinnatifid; main rachis \pm short-hairy or tomentose above (conf. Hooker's drawing). Pinnae large, \pm 4 \pm 15 on each side below the pinnatifid apex, $\pm 71 / 2-12^{1 / 2}$ c.M. long, the apex acuminate, toothed, the base \pm truncate, $\pm 1 \frac{1}{2}$ c.M. broad, the edge cut $1 / 2-2 / 3$-way down to the costa into broad, oblong, subfalcate, serrate lobes. Texture firm-membranaceous; upper surface brownish-green, under one paler, both surfaces naked. Sori in 1 row on each side, medial between the costulae and the margin, occupying the lower veins; indusium pale, membranaceous, breaking down into a persistent, lobed cup.

Var. peciolaca : Pinnulae often stalked.

Amboyna, Philippines.

(15) C. assimilios, Hk., Hk. Bk., Syn. Fil., 24; C. Beccariana, Ces., Fel. di Bor., 5 .

Stipes bright-chestnut-brown, slightly muricate and fringed on one side with long, ferrugineous scales. Fronds large, 5-pinnatifid; superior rachis \pm squamose like the underside of the costae. Pinnae nearly 50 c.M. long, $7 \frac{1}{2}-10$ c.M. broad, acuminate, petiolate. Pinnulae and superior pinnae deeply pinnatifid almost to the costa. Lobes oblong, obtuse, subfalcate, coarsely toothed, the lowest inferior lobe always the smallest. Texlure thinly herbaceous to rigidly membranaceous; veins simple or $1-2 \times$ forked. Sori dorsal on the veins or in the axils of the forks; indusium very thin and filmy, breaking down into irregular lobes.

Borneo, Celebes.

C. Rollingenoma, Mett., Ann. Mus. Bot. L. B., I, 57.

Stipe and rachis blackish-purpureous; stipes rough, nodose below, furfuraceous; rachis rough in the lower part, slightly scaly, densely hirsute above, purveyed with prominent, tuberculiform glands at the base of the pinnae. Fronds 
3-pinnatifid. Pinnae lanceolate, short-stalked. Pinnulae sessile, \pm 7 c M. long, \pm 17 m.M. broad, linear-oblong, the apex narrowed, obscurely serrate. Lobes close, linear-oblong, slightly falcate, entire, serrate at the obtuse apex. Texture coriaceous; upper surface hirsute or furfuraceous on the costae, under one scaly on the costulae; veins fine, forked. Sori close to the costae, 1 on each side of the costulae; indusium firm, membranaceous, cupuliform, the mouth constricted, \pm repand, afterwards cut down irregularly.

Java.

(17) C. Morthalsii, Mett., Hk. Bk., Syn. Fil., 25 ; Mett., Ann. Mus. Bot. L. B., I, 57.

Fronds 5-pinnatifid, main rachis hardly nodulose, short-ferrugineo-tomentose above. Pinnae 50-45 c.M. long, subsessile, elongate-oblong. Pinnulae 5 - 8 c.I. long, 1-2 c.M. broad, sessile, oblong, acuminate, the point bluntish, the edge deeply pinnatifid. Lobes oblong, approximate, subfalcate, subentire, obtuse, narrow. 'Texture firm, chartaceous; colour deep-green above, paler beneatlı; rachises slightly scaly beneath, \pm hirsute above; upper surface ferrugineo-hirsute on the costae, under one sparingly bullato-paleaceous; veins visible, slender, oblique, the lower forked. Sori more or less copious, close to the costulae, chiefly in the lower part of the lobes; indusiun firm-membranaceous, falling away in fragments.

Sumatra, Java, Celebes.

* (18) C. Cremulata, Bt., Rac., Flor. Btz, I, 56; C. excelsa, Kze (not Sw.), Bot. Zeit., 1848, 284.

Fronds 5-pinnatifid; main rachis ferrugineo-tomentose above like the secon-

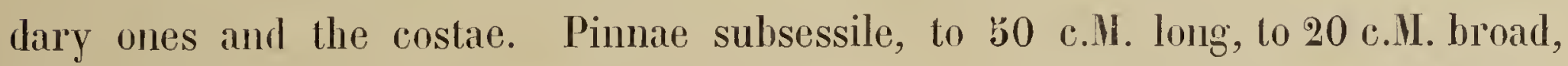
oblong, acuminate. Pinnulae oblong-lanceolate, short-acuminate, b-10 c.H. long, to 2 c.ll. broad. Lobes approximate, oblong, subacute, subfalcate, $\pm 5 \mathrm{~m} . \mathbf{l l}$. broad, slightly crenate, subdistinct. Texture subcoriaceous; colour dark-green, paler beneath; veins to \pm 10 on each side of the costulae, forked. Sori close to the costulae, occupying the lower $1-5$ veins; indusium membranaceous, firm, soon breaking into very irregular lobes. Under surface sparingly scaly on the costulae.

Java.

* (19) C. or Dentalis, Moore, Rac., Flor. Btz., I, 37 ; C. arborea, Sm., var. pallida, Hassk., Obs. Fil. Jav., I, 15.

Fronds large, ovate-lanceolate, to $2 \frac{1}{2}$ M. long, to $1 \frac{1}{2}$ M. broad, 5 -pinnatilid; 
main rachis yellowish, punctato-muricate, tomentose above. Pinnae to 60 c.M. long, on stalks $2-4$ c.M. long. Pinnulae $71 / 2-10$ c.M. long, $1 \frac{1}{2}-2$ c.M. broad, sessile, oblong-lanceolate, câdato-acuminate, the point serrate, the edge deeply pinnatifid nearly to the costa. Lobes linear-oblong, approximate, subfalcate, the margin serrate and rather recurved. Texture coriaceous; colour blackgreen, paler beneath; rachises and costae \pm tomentose above; costae and costulae furfuraceous beneath, the hairs and scales brownish; veins 8-12 on each side of the costulae, mostly forked. Sori 4-9-on each side, close to the costulae which they conceal; indusium firm, persistent, becoming subglobose, the mouth a little contracted, entire.

Java, Celebes.

\section{* (20) C. runensis, v. A. v. R.}

Fronds large, 3-pinnatifid; main rachis setose above like the secondary ones and the costae; the setae subulate, \pm adpressed, reddish-brown. Pinnae \pm 55 c.I. long, $22-25$ c.M. broad. Pinnulae sessile, spreading, $2-21 / 2$ c.II. broad at the base, the apex acuminate, toothed or crenate, the edge cut \pm $4 / 5$-way down to the costa into numerous $( \pm 15)$, oblong, bluntish, subfalcate lobes with a narrow space between them, the margin crenate, recurved, the lowest anterior lobes spreading, $5 \mathrm{~m}$.M. broad, the lowest posterior \pm erecto-patent; lowest pinnulae not the longest. Texture coriaceous; under surface paler than the upper one; veins distinct, \pm 8 on each side of the costulae, the lower $1-3$ forked. Sori medial on the veins, occupying nearly all the veins, except the highest ones, filling up the whole space between the costulae and the margin; indusium thin, hyaline, breaking down irregularly, the lower part persistent.

Pulu Run, (Teysmann).

(21) C. Hailandir, Bk., Trans. Linn. Soc., Bot., 2d Series, IV, 249.

Stipes strong; the scales copious, lanceolate, brown, crisped. Fronds oblong-lanceolate, 5-pinnatifid, \pm 60 c.M. long, 20-50 c.M. broad; main rachis paleaceous. Pimnae sessile, oblong-lanceolate, \pm 5 c.M. broad, the lowest not reduced. Pinnulae numerous, close, lanceolate, sessile, the lower ones deeply pinnatifid. Lobes linear-ohlong, erecto-patent. Texture subcoriaceous; under surface densely scaly on the costae; veins simple, 4-b on each side of the costulae, erecto-patent. Sori in 1 row on each side of the costae; indusium firm, cupuliform, naked, persistent.

Borneo. 
* (22) C. javanica, BI., Rac., Flor. Btz., I, 35.

Fronds large, 5-pinnatifid; main rachis unarmed but not rarely rough, paleaceo-tomentose like the secondary ones. Pinnae to 60 c.M. long, on stalks to 2 c.Mr. long, linear-lanceolate, acuminate. Pinnulae lanceolate, to $1 \frac{1}{2}$ c.M. broad, deeply pinnatifid. Lobes linear, subfalcate, entire or obtuso-crenulate. Texture subcoriaceous; under surface bullato-squamulose on the costae; veins 8-10 on each side of the costulae, the lower forked. Sori $2-6$ on each side of the costulae, the lower divaricating; indusium thin, breaking down irregularly, the base persistent, cupuliform, firmer.

Java, Sumatra.

* (25) C. sumatrana, Bh., Journ. of Bot., XVIII, 209.

Fronds large, 5-pinnatifid to subtripinnate; rachises tomentose, especially on the upper side and clothed with long, linear, acuminate, scattered, brown scales, which make the rachises rough when they fall. Pinnae $\pm \mathbf{5 0}$ c.M. long, with the opposite pinnulae of contiguous pinnae overlapping. Pinnulae numerous, spreading, $\pm 6-8$ c.ll. long, $\pm 1 \frac{1}{2}-2$ c.M. broad, oblong, suddenly acuminate at the narrow, mostly linear, broadly crenate apex, the point blunt, the edges parallel, cut down nearly to the costa, pinnate at the very base. Segments linear-oblong, \pm 5 m.M. broad, falcate, blunt, entire or crenate, not conspicuously recurved at the edge, the lowest $1-2$ free, mostly bluntly toothed; lowest pinnulae not the largest. 'T'exture coriaceous; costae roughhairy above; upper surface dark, the under one paler, covered with pale, bullate scales on the costae and the lower part of the costules; veins 8-10 on each side, forked, the higher simple. Sori close to the costules, occupying the lower $1-4$ veins; indusium membranaceous, thin, breaking down irregularly.

Sumatra, Java.

(24) C. inquinans, Chroist, Ann. Btz., XV, 85, tah. XIII, fig. 5, a-g.

Fronds 5-pinnatifid. Stipes and rachises more or less densely scaly and hairy, the scales to $1 \frac{1}{2}$ c.M. long, pale-ferrugineous, the hairs crisped, ferrugineous, joined into groups. Pinnae 27-50 c.M. long, imbricate, sessile, oblong, bluntish, slightly narrowed at the base. Pinnulae sessile, close, to 6 c.M. long, to $1 \frac{1}{2}$ c.M. liroad, bluntish, cul down nearly to the costa into short-acuminate, subfalcate, crenulate to toothed lobes. Texture coriaceous, under surface hairy between the sori; colour dark-green, paler beneath; veins inconspicuous, forked at the base. Sori large, $6-8$ to each lobe; indusium large, flaceid, yellowish, soon deciduous.

Celebes. 
* (25) C. levcophaës, Massti., Journ. of Bot., VII, 323.

Stipe and rachis muricate. Pinnae linear-lapceolate, $\pm 10-12$ c.M. broad at the base, short-stalked, the apex acuminate. Pinnulae linear-lanceolate, acuminate, the lowest longest, $\pm 1-1 \frac{1}{2}$ c.M. broad at the base, the edge deeply pimnatifid. Lobes linear-oblong, acute, falcate, $\pm 1 \frac{1}{2}-2$ m.M. hroad at the base, the lowest \pm free, the edge recurved, crenato-serrate towards the point. Texture coriaceous; surfaces naked, the upper one nearly white when dry; veins forked. Sori globose; indusium membranaceous, lucid, soon breaking down irregularly, at length evanished.

Java.

(26) C. strigosa, Christ, Ann. Btz., XV, 84, tab. XIII, fig. 6, a-c.

Stipes \pm 45 c.ll. long, angular, orange-brown, covered with small, furfuraceous scales and strong, cylindric, glossy, blackish-red prickles. Fronds \pm 65 c.II. long, \pm 40 c.M. broad, deltoid; main rachis prickly. Pinnae 10-12, \pm 20 c.II. long, $\pm \&$ c.II. broad, ovate, short-acuminate, sessile, the apex pinnatifid, the lowest not shorter. Pimnulae 15-18 on each side, sessile, linear-lanceolate, acute, pimnatifid nearly to the costa. Lobes falcate, deltoid, the edge entire, revolute. Texture coriaceous, firm hut flexible; upper surface naked or sparingly hairy, under surface opaque-glaucous; veins covered with subulate hair's and white, ovate-bullate scales. Sori small, nearer the edge than the costulae; indusium afterwards flat and orbicular.

Celebes.

(27) C. hymenodles, Mett., Hk. Bk., Syn. Fil., 24.

Stipes \pm 17 c.ll. long, dark-brown, densely short-aculeolāte, with few, black-brown, lanceolate scales. Fronds large, 5-pinnatifid; rachis tomentose above, the base subasperous or muricate. Central pimmae elongate-lanceolate to \pm 60 c.M. long, $12-15$ c.II. broad; rachis densely tomentose above. Pinnulae 2-21/2 c.II. broad, elongate-oblong, acuminate, slightly narrowed towards the base, sessile, the apex crenate, the edge deeply pinnatifid nearly to the costa. Lohes compact, $4-5 \mathrm{~m}$.M. broad, oblong, faleate, obtuse, entire or rarely crenate. Texture subcoriaceous; costa hirsute above, sparingly covered beneath with minute, pale, bullate scales; veins \pm 9 on each side, obliqne, forked. Sori few, close to the costulae, occupying the lower 1-2 veins; indusium thin, membranaceous, soon breaking down and falling away. Mettenius describes the texture as membranaceous.

Sumatra. 
* (28) C. spimulosa, Walt., Hk. Bk., Syn. Fil., 23; Hk., Spec. Fil., I, tab. XII, C; — var. muriculata, Hassk., Jomrn. of Bol., VII, 322.

Stipe and rachis strongly prickly, often dark-purple. Fronds large, to 3 M. long, 3-pinnatifid. Pinnulae oblong, moderately long-acuminate, \pm 8-12 c.M. long, \pm 2 c.M. broad, pimnatifid nearly to the costa. Lobes numerous, very close, lanceolate-oblong, acute, subfalcate, serrulate. Texture rather flaccid; surfaces naked, except that the costulae are covered beneath with small, bullate scales; veins forked. Sori small, numerous, close to the costulae, not occupying the higher veins; indusium thin, membranaceous, fragile, soon breaking down irregularly.

Var. muriculata: Stipe and rachis muriculate, not spinulose.

Malaya; Formosa, Japan, Soulh. China, North. India.

\section{Munelleri, Bri., Journ. of Bot., XXVIII, 104.}

Fronds large, 5-pinnate; main rachis naked. Lowest pinnae oblong, \pm 50 c.M. long. Pinnulae lanceolate, to $2 \frac{1}{2}$ c.M. broad. Tertiary divisions linearoblong, \pm 5-4 m.M. broad, adnate to the rachis, the edge not recurved, deeply crenate. Texture moderately lirm; surfaces naked, except the midribs of the pinnules above; colour dark-green, paler beneath; veins forked in the lower laciniae of the ultimate divisions. Sori $8-10$ to the largest leaflets; indusium cup-shaped, entire, persistent.

New Guinea.

* (30) C. Dimops, Hassk., Journ. of Bot., VII, 322; C. sinops, Rac. (not Hassli.), Flor. Btz., I, 56.

Stipes to 50 c.II. long, clothed with very deciduous scales. Fronds oblong, to 150 c.M. long, to 70 c.M. broad, 5-pinnate; main rachis tomentose above. Pinnae not or hardly narrowed at the base, to 24 c.Il. broad, on stalks to 2-5 c.M. long. Pinnulae sessile, linear, to $22 \mathrm{~m}$.M. liroad, acuminate, pinnate. Tertiary divisions, \pm close, hlunlish, subfalcate, to $2 \%$, m. M. Mroad, crenate, each crenation corresponding with a small vault. Texture subcoriaceous; colour dark-green, paler beneath; costac densely scaly, with $8-12$ forked veins on each side. Sori occupying the lower 5-7 veins; indusium thin, breaking down irregularly.

Java.

(51) C. selnizochlamns, Br., Journ. of Bot., XVIII, 209.

Fronds large, 5-pinnate; main rachis thinly tomentose and clothed with 
small, acuminate scales. Pinnae oblong-lanceolate, \pm 45 c.M. long, 12-15 c.M. hroad. Pinnulae lanceolate, $1 \frac{1}{2}-2$ c.M. broad, narrowed from the middle to the apex, cut down to the rachis into linear, entire or rarely crenulated divisions $\pm 21 / 2$ m.M. broad, with a distinct space between them. Texture firm, subrigid; both surfaces green; rachises and under surface densely covered with small, ovate-lanceolate, cuspidate scales on the midribs; veins $9-10$ on each side, distinct, forked from the base. Sori close to the midribs; indusium fragile, membranaceous, soon breaking down to the base.

\section{Sumatra.}

* (32) C. arachnoidea, H1., Hk. Bk., Syn. Fil., 24.

Fronds 5-pinnate; rachises all dark-coloured, opaque, clothed with rusty tomentum and muricate with short, black, sharp spines. Pinnulae 10-12 c.M. long, 1-2 c.M. hroad, oblong, pinnate, pinnatifid only near the narrow, acuminate point. Tertiary divisions scarcely $7 \frac{1}{2}$ m.M. long, linear from a hroad base, acute, subfalcate. Texture coriaceous; under surface cobwebhy; veins immersed, inconspicuous. Sori near the middle of the pinnulae, occupying the whole space hetween the midribs of the ultimate divisions and the recurved margin; indusium thin-nembranaceous, whitish, breaking down into variously lobed and laciniated segments. The javan plant (Leg. Schefler) has the ultimate segments crenate, \pm 1 c.M. long.

Ternate, Java; Queensland.

\section{* (53) C. celebica, v. A. v. IR.}

Fronds large, 5-pinnate; main rachis prickly and furfuraceous like the secondary ones; the prickles blackish, strong, sharp; the tomentum ferrugineous. Pinnae 50-60 c.M. long, \pm 20 c.M. broad, on stalks \pm 5 c.M. long. Pinnulae sessile, the lower ones stalked, \pm 2 c.M. broad, the apex short-acuminate, crenate; lowest pinnulae distant, \pm 5 c.M. apart. 'Tertiary divisions linear, the highest sessile, subfalcate, crenate, blunt, the lowest \pm longest, \pm 2 m.M. broad, spreading, subpetiolate, lobed towards the base, with the lowest segments free, the lowest anterior segments often larger than the other ones. Texture coriaceous but not firm; tertiary rachises tomentose above; surfaces naked or the under surface sparingly and minutely scaly on the veins; veins distinct, \pm 8 on each side, mostly forked. Sori filling up the space between thie costae and the edge, occupying all the veins except the simple highest and the $\mathbf{2}-\mathbf{5} \times$ forked lowest ones; indusium thin, gradually evanishing.

Celebes, (Teysmann, No. 13681). 


\section{HEMITELIA, R. Brown.}

Characters of Cyathea, but the indusium consisting of a lateral, mostly semiorbicular, convex scale, attached at the inner side of the receptacle, too small to cover the sorus permanently. Fronds never simple and the veins sometimes anastomosing near the costae. Hk. Bk., Syn. Fil., tab. I, fig. b้ ; Diels, in Eng. \& Prantl., Nat. Pfl.Fam., I', lig. 82, A-C.

Tropical and subtropical.

Arrangement of the sections.

$\$$ 1. EUHEMITELIA. Costal veins anastomosing. (Not in Malaya).

$\$$ 2. AMPHICOSMIA. Veins all free.

\section{S 2. AMPHICOSMIA.}

\$. Stipes not prickly.

*. Ultimate segments entire or crenulate.

*.*. Ultimate segments strongly serrate.

\$.\$. Stipes prickly, at least at the base.

+. Main rachis smooth.

+.+. Main rachis prickly.
(1) H. crenulata.

(2) H. capensis.

(3) H. Junghuhniana.

(4) H. sumatrana.

* (1) H. Crenulata, Mett., Rac., Flor. Btz., I, 58; Alsophila cremulata, Melt., Hk. Bk., Syn. Fil., 44.

Stipes different in length, often bearing at the base some contracted or reduced pinnae. Fronds to 1 b0 c.M. long, to 70 c.M. broad, oblong-elliptic, narrowed towards both ends, 3-pinnate. Pinnae lanceolate, to 10 c.M. broad, on stalks to 1 c.M. long. Pinnulae sessile, to $15 \mathrm{~m}$. M. broad. Ulimate segments linear, bluntish, the edge entire or slightly crenate. Texture herbaceous; rachises villose above or beneath; under surface scaly on the costae. Sori 2-6 on each side of the costae, near te base.

Sumatra, Java, Philippines.

(2) H. capensis, Tr. Ir*., Hk Bk, Syn. Fil., 29; Bau. \& Hk., Gen. Fil, tab. XLII, A ; Cyathea capensis, Sm., Christ, Farnkr. d. Erde, 322, lig. 1025; Amphicosmia riparia, Gardn., Lond. Journ. of Bot. I, tab. XII.

Stipes scaly at the base, often bearing anomalous pinnae, which are 丂 -10 c.M. long, compoundly and pinnately divided with a rigid rachis and 
linear-filiform segments. Fronds ample, 2-5-pinnate. Pinnae petiolate, ovateoblong. Pinnulae subsessile, acuminate, deeply pinnatifid or pimnate again. Ultimate segments linear-oblong, acute, strongly serrate. T'exture membranaceo-papyraceous; rachises and costae clothed beneath with scattered, deciduous, bullate scales; veins simple, 1 to each serrature. Sori frequently solitary at the base of the ultimate segments, rarely 5-4; receptacle large, prominent; indusium lorown, fimbriate.

Java, South. Africa, Brasilia.

* (3) H. Junghulanians, Mett., Rac., Flor. Btz., I, 58; Alsophila Junghuhniana, Kze, Bot. Zeit., 1848, 284; — var dissoluta, Rac., I. c.

Stipes aculeate at the base. Fronds 3 -pinnatifid or 5-pinnate; main rachis deciduously tomentose. Pinnae lanceolate-oblong, to \pm 60 c.ll. long. Pinnulae sessile or subsessile, $\breve{b}-10$ c.M. long, $\pm 1 \frac{1}{2}$ c M. broad, linearlanceolate, acuminate. Ultimate segments free or slightly joined at the base, 2--5 m.M. broad, linear-oblong, straight or subfalcate, bluntish, the edge crenate, toothed or lobod. Texture membranaceous to chartaceous; secondary rachises tomentose; colour deep-green above, paler beneath; under surface \pm hairy or scaly on the costae and costulae, the scales mostly deciduous; upper. surface naked or hairy on the costae; veins $6-9$ on each side, forked, the highest simple. Sori $1-4$ on each side, occupying the lower veins, \pm costular.

Var. dissoluta: Ultimate segments $1-5 \mathrm{~m} . M$. apart.

Java, Sumatra.

\section{(4) IT. Summtraina, v. A. v. R.}

Fronds 5-pinnatifid, sub-5-pinnate; main and secondary rachises muricate with numerous, short, sharp, dark-tipped warts, densely but rather deciduously furfuraceo-tomentose and purveyed with many, deciduous, linear, spreading scales, the main one rough between the warts. Pinnae \pm b̆ c M. long, stalked. Pinnulae linear-lanceolate, short-acuminate, $8-12$ c.M. long, \pm 2 c.M. broad, deeply pinnatifid, pimnate at the base: Ultimate segments linearoblong, subacute, $\pm 2_{2}^{1}$ m.M. broad, the lower ones free, the edge \pm crenatodentate. Texture chartaceous, fragile when dry; colour dark above, paler beneath; upper surface piloso-tomentose on the costae (tertiary rachises), under one densely scaly on the costae and costulae; veins $1-2 \times$ forked. Sori 1-4 on each side, subcostular, occupying the lower veins, densly mixed with the limbriated scales; indusium brown.

Sumatra, (Teysmann, No. 2456). 


\section{ALSOEHILA, R. Brown.}

Sori globose, dorsal on a vein or veinlet or in the forking of a vein; receptacle elevated, rarely punctiform. Indusium wanting or spurious and minute and then consisting of a semiorbicular, inferior, lateral scale placed at the inner side or of a circular, entire or lobed scale or a whorl of fibres with the receptacle in the centre.

Caudex arborescent. Fronds mostly large, divided; veins simple or forked, free or very rarely joining towards the margin. Hk. Bk., Syn. Fil., tab. I, fig. 6 ; Diels, in Engl. \& Prantl, Nat. Pfl.Fam., I ${ }^{4}$, fig. 85.

Tropical, and extra-tropical in the southern hemisphere.

\section{coaresely serrate. 4. oberima, S. p. $\$ 4$.}

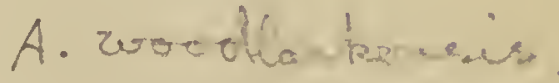

a. Pinnulae entire, crenate or lobed to $1 / 3$-way down to the costa. (1) A. dubia. a.a. Pinmulae lobed or pinnatifid $\pm 1 / 3-2 / 3$-way down to the costa.

b. Main rachis naked, but sometimes rough.

s. Sori divaricating, the higher ones nearer the main veins than the lower ones, so as to form a $\mathbf{\Lambda}$.

(2) A. glabra.

\$.S. Sori not divaricating, medial.

(5) A. Ridleyi.

b.b. Main rachis more or less scaly, hairy or tomentose.

c. Texture \pm herbaceous.

*. Main rachis very densely scaly and long-hairy. (4) A Burbidgei.

*.*. Main rachis not densely scaly or hairy.

+. Main rachis short-hairy above, otherwise nalied or paleaceous.

(5) A. squamulata.

+*. Main rachis moderately long-hairy above, the hairs articulate, mixed with long, linear scales. (6) A. Margarethae.

c.c. Texture chartaceous to coriaceous.

d. Stipes bearing 3-5 long, branched spines at the base.

d.d. Stipes without branched spines at the base.

(7) A. ramispina.

e. Lobes entire. Capsules intermixed with fine hairs.

(8) A. obscura.

e.e. Lobes crenate. Capsules intermixed with paraphyses, which are clavate at the apex.

(9) A. commutata.

a.a.a. Pinnulae deeply pinnatifid, often nearly to the costa, sometimes pinnate at the base.

1. Stipes unarmed, but sometimes scabrous with minute, more or less acute warts. 
2. Slipe or rachis scabrous.

*. Veins 7-8 on each side of the costulae. Sori medial.

(10) A. trichodesma.

*.*. Veins 12-14 on each side. Sori subcostular. (11) A. scaberula.

2.2. Stipe and rachis not scabrous.

3. Pinnulae or tertiary segments \pm dimorphous.

5. Barren pinnulae slightly lobed, ferlile ones deeply pinnatifid.

(12) A. dimorpha.

\$.\$. Both barren and fertile pinnulae deeply pinnaifid but the ferlile lobes much smaller than the barren ones.

$$
\text { (13) A. Selplectuleiri. S. p } 61
$$

3.3. Pinnulae and tertiary segments uniform.

4. Under surface densely hairy.

(13) A. Kingi.

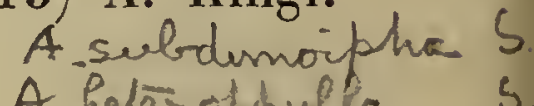

(14) A. Wallacéi.

4.4. Under surface naked or \pm scaly.

5. Main rachis at best pubescent.

+. Lobes entire. Pinnulae not caudate.

(15) A. modesta.

†.+ Lobes serrate. Pinnulae caudate.

5.5. Main rachis pubescent and scaly.

(16) A caudata.
c. Surfaces naked.
(17)
A. sangirensis. Arsubde
6.6. Surfaces scaly on the costulae.

(18) A. lepidoclada.

1.1. Stipes aculeate or muricate.

2. Main rachis smooth, rough or slightly prickly neâr the base.

3'. Receptacle with a minute, spurious indusium at the inner side.

(19) A. latebrosa.

$\mathbf{3}^{\prime} \cdot \mathbf{3}$. Spurious indusium wanting or consisting of a minule, orbicular scale with the receptacle in the centre.

4'. Main rachis furfuraceous, hairy or scaly, at least on the upper side.

5'. Spurious indusium present. is A beurbliolata 5'.5'. Spurious indusium (most probably) A anting.

6'. Main rachis furfuraceous. (21) A. fuliginosa.

6'.6'. Main rachis hairy and slightly scaly.

(22) A. lepifera.

4'. Main rachis nalied or nearly so; spurious indusium (probably) wanting. 
. Sori medial.

(23) A. batjanensis.

:.?. Sori \pm costular

*. Lobes obscurely crenato-serrate.

*.*. Lobes distinctly serrate.

2'.2'. Main rachis conspicuously muricate.

+. Spurious indusium wanting. 26.A. wengiensis (26) A. crinita.

+. Spurious indusium present, consisting of a minute, inferior, 26) A. Heeren orbicular, entire or lobed scale or a worl of fibres, with the receptacle in the centre. Under surface glaucous. (27) A. glauca.

a.a.a.a. Pimulae pinnate; the segments free or sometimes slighily joined at S.poy. $+y$ the base.

b. Texture membranaceous to papyraceous.

c. Pinnae under 15 c.M. broad.

d. Main rachis rough and strigulose. Pinnae \pm 8 c.M. broad. Spirious indusium wanting.

(28) A. Ghristii.

d.d. Main rachis muricate and furfuraceo-tomentose. Pinnae \pm 10-12 c.M. broad. Spurious indusium present.

(29) A. truncata.

c.c. Pinnae 15-20 c.M. broad.

*. Tertiary segments $\pm 2^{1 / 2}$ m.M. broad, crenulate at the apex.

(50) A. celebica.

*.*. Tertiary segments $\pm 5 \mathrm{~m} . M$. broad, disinctly crenate.

(31) A. polyphlebia.

b.h. Texture \pm coriaceous.

c'. Main rachis prickly.

d'. Costae densely paleaceous beneath with ragged, tomentose scales.

(52) A. tomentosa.

$\boldsymbol{d}^{\prime} \cdot \boldsymbol{d}$. Costae naked or not densely scaly beneath. (35) A. extensa.

$\boldsymbol{c}^{\prime} \cdot \boldsymbol{c}^{\prime}$. Main rachis not prickly.

*. Pinnulae $\pm 1-1 \frac{1}{2}$ c.M. broad, the coslae densely scaly.

*.*. Pinnulae \pm 4 c.M. broad, the costae fibrillose.

(34) A. Iurida.

S.p. $71-73$. (35) A. mindanensis.

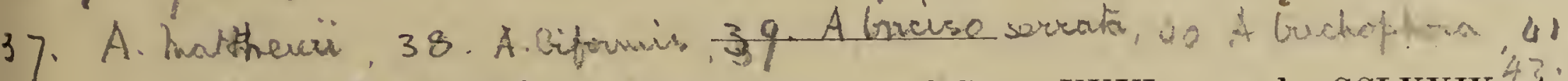

* (1) A. dubia, Bedd., Journ. of Bot., XXVI, 1, tab. CCLXXIX, A:

A. Teysmanniana, Rac., MS. in Herb. Bog.

Fronds large, 2-piunate; rachises brown, naked and glossy beneath, to- 
mentose above, the tomentum dark-reddish-brown. Pinnae \pm crecto-patent, stalked, 40-60 c.M. long, with a terminal segment, which is pinnatifid at the base, toothed towards the acuminate point. Pinnulae spreading, shortstalked, \pm 23 on each side, distant, the lowest longest or sometimes somewhat shorter than the next higher ones, $\pm 7-10$ c.M. long, 10-15 m.M. broad, with the apex acuminate, toothed, the base truncate, the edge broadly crenate or lobed to $1 / 3$-way down, the lobes or crenations entire, crenate or denticulate. Texture coriaceous; colour dark above, paler beneath; surfaces naked; costae and veins distinct, dark-coloured; main veins pinnate, veins simple. Sori large in 1 row medial between the costa and the margin or in 2 rows rather near the costa, on the lower $1-2$ veins, sometimes in $5-4$ rows, not divaricating.

Malacca, Banca, Java, Borneo.

* (2) A. glabrat, Ink., Rac., Flor. Btz., I, 34; Bedd., Ferns S.I., tab. LX; A. gigantea, Wall., (not Hk.), Hk., Spec. Fil., I, 55; A. vexans, Ces., Rudey Fel. di Bor., 4.

Stipe more or less rough, scaly at the base, and as well as the main rachis reddish-black, polished. Fronds oblong-lanceolate, hardly narrowed at the base, 5-pimnatifid, to 5 M. long. Pinnae stalked, 45-60 c.M. long or longer, the apex acuminate and pinnatifid. Pinnulae linear, acuminate, (upper ones sessile, lower ones petiolate), 7--15 c.M. long, 12-24 m.M. broad, the base truncate, the edge pinnatifid $\pm 1 / 3-1 / 2$-way down to the costa. Lobes triangular or rounded, crenate or serrate. 'Texture firm, but not coriaceous; rachises often scaly or tomentose above; surfaces naked; veins simple, 5-6 on each side of the costulae. Sori dorsal on the veins, mostly arranged in the shape of a $\Lambda$, not extending to the apices of the lobes.

Trop. Asia.

(3) A. Meidleyi, Bk., Ann. of Bot., VIII, 122.

Fronds large, deltoid, 3-pinnatifid; main rachis naked, black-brown, unarmed. Pinnae oblong-lanceolate, the lowest \pm 50 c.M. long; rachis brown, hairy above. Pinnulae sessile, linear, subobtuse, $3 \frac{1}{2}-5$ c.M. long, $10-15$ m.M broad, the base truncate, the lower ones pinnatifid $\pm 1 / 2$-way down to the costa. Lobes oblong, entire. Texture rigid; surfaces naked; main veins pinnate in the lobes; veins 4-6-jugate, conspicuous, curved, ascending, simple or the lower ones forked. Sori medial.

Singapore. 
* (4) A. Burldidgei, Rk., Journ. of Bot., XVII, 38.

Fronds ample, 5-pinnatifid. Stipe and rachis densely covered with long, linear, acuminate, yellow-brown, membranaceous scales to 2 c.M. long and with very fine, long and soft, brownish hairs to $8 \mathrm{~m}$.M. long. Pinnae oblonglanceolate, 50 c.ll. or more long, acuminate, \pm 10 c.M. broad at the base, the rachis hairy like the main one. Pinnulae sessile or subsessile, $4-7$ c.M. long, $1-1 \frac{1}{2}$ c.II. broad, cut $1 / 2-2 / 3$-way down into oblong, blunt, subentire lobes $\pm 3 \mathrm{~m} . \mathrm{M}$. broad. Texture herbaceous, but firm; colour dark above, paler beneath; costae hairy and the veins slightly so beneath; veins 4 jugate, simple or forked. Sori medial, occupying the lower veins. - The description is taken from a specimen gathered by Hallier, determined by Christ (Ann. Btz., XX, 158).

Borneo.

* (5) A. Squamulata, Hr. (not Mell.), Rac., Flor. Btz., I, 55;A A. comosa, Wall., Hk. Bk., Syn. Fil., 41; Hk., Spec. Fil., I, tab. XX, A; Bedd., Ferns Br.I, I, tab. LXXXIV.

Stipes to 50 c.M. long, rough, paleaceous with light-brown, linear-subulate scales $\pm 21 / 2$ c.M. long. Fronds ovate, narrowed towards both ends, to 180 c.M. long: main rachis setose or tawny-villous above, the rest naked or paleaceous. Pinnae $\mathbf{3} \breve{b}-50$ c.M. long, lanceolate, stalked, slightly narrowed towards the base. Pinnulae close, sessile or short-stalked, linear, acuminate, $15-20$ c.M. long, $10-15$ m.M. broad, the base truncate, the edge cut $.1 / 2-2 / 3$-way down to the costa with narrow sinusses. Lobes close, \pm crenulate, to $4 \mathrm{~m}$.II. broad, oblong, bluntish, slightly falcate. Texture herbaceous; surfaces glabrous; colour yellowish-green; secondary rachises like the main one; costulae pinnate in the lobes, naked or slightly scaly beneath; veins simple or forked. Sori medial, $1-5$ or rarely more on each side of the costulae, occupying the lower veins.

\section{Malaya.}

* (6) A. Maroganethae, Schroet., Ann. Btz., XX, 156.

Main rachis unarmed, rough, hairy above, the hairs castaneous, not short, intermixed with long, pale-coloured scales. Pinnae short-stalked, \pm 40 c.M. long, \pm 15 c.M. broad, ovate-oblong, acuminate. Pinnulae sessile, \pm 25 on each side below the pinnatifid apex, $\pm 10-11 \mathrm{~m} . M$. broad, close, lobed \pm $1 / 2$-way down to the costa. Lobes pectinate, nearly imbricate, \pm 4 m.M.long, 
rhomboid-oblong, \pm rectangular, the apex truncate, the margin entire. Texture herbaceous; upper surface naked, the under one and the margin covered with scattered, long, white hairs and few, minute scales; veins prominent, forked. Sori medial, not confluent, mixed with hairs; receptacle small, elevated, pale-coloured.

Borneo.

* (7) A. ramispina, mk., Hk. Bk., Syn. Fil., 42.

Stipes subasperous, tomentose above, ebeneous or dark-brown like the rachises, slightly paleaceous at the base and bearing there $5-5$ subsecund, black spines $21_{2}-4$ c.M. long, with many sharp, divaricating branches. Fronds 5-pinnatifid; rachises tomentose above. Pinnae \pm 30 c.M. long or longer, gradually narrowed at the pinnatifid apex. Pinnulae $4-71 / 2$ c.M. long, 1-2 c.M. broad, oblong-lanceolate, sessile or short-stalked, the apex acuminate, the point bluntish, the base truncate, the edge pinnatifid $\pm 1 / 2-2 / 3$ of the way to the costa. Lobes oblong, subfalcate, obtuse, crenate or serrate towards the apex. Texture subcoriaceous; colour dark-green above, paler beneath where the costae and costulae are \pm scaly; veins mostly simple. Sori small, of few sporangia, nearer the costulae than the edge, not reaching the apices of the lobes.

Borneo.

* (8) Aloscurn, Scort., Journ. of Bot., XXV, 321, tab. CCLXXVIII, fig. 2.

Stipes 30-60 c.M. long, densely clothed near the base with long, linearlanceolate, acuminate, sharply serrated scales. Fronds $1-1 \frac{1}{2}$ M. long, \pm 60-80 c.I. broad, 5-pinnatifid, the rachis scaly or tomentose above, naked beneath. Central pinnae $\pm 30-40$ c.I. long, 7-15 c.I. broad, the base a little narrower, the apex pinnatifid, acuminate, the rachis often hairy above. Pinnulae linear-oblong, $\pm 1-1 \frac{1}{2}$ c.M. broad, the base truncate, the apex bluntish, toothed, the edge cut $\pm 1 / 2$-way down into broad, obtuse, entire segments. Texture \pm coriaceous; costae hairy above; costules naked or \pm scaly beneath, pinnate in the lobes; veins simple or forked, $4-5$ on each side. Sori medial on the lower veins, not occupying the lobes; capsules densely intermixed with long, filiform hairs.

Malacca.

* (9) A. commutata, Mett., Hk. Bk., Syn. Fil., 45; A. squamulata, 
Bedd., Ferns Br.I., II, tab. CCXXXV; Gymnosphaera squamulata, J. Sm. (not Bl.), Bau. \& Hk., Gen. Fil., tab. C.

Stipes paleaceous, the base tuberculate-asperous. Fronds 3-pinnatifid, the main rachis dark-purple-ebeneous like the stipe and slightly squamose, (tomentose above?). Pinnae \pm 45 c.M. long, 15-20 c.M. broad, stalked. Pinnulae rather distant, stalked, linear, acuminate, the point serrulate, the base truncate, the edge cut $\pm 1 / 2$-way down to the costa. Segments oblong, obtuse, rotundatoserrate; the margin slightly thickened or recurved. Texture coriaceous; costulae with a few deciduous, bullate scales; veins simple or forked. Sori mostly confined to the lower part of the lobes, the higher ones close to the costulae, the lower slightly divaricating; capsules mixed with paraphyses, which are clavate at the apex.

Malacca, Batjan.

A. trichodesma, Scort., Journ. of Bot., XXV, 321.

Stipes scaly at the base. Fronds 120-180 c.M. long, 3-pinnatifid, the main rachis scabrid above, clothed with adpressed, spreading, semi-viscous, copious, jointed hairs. Pinnae short-stalked, narrow-lanceolate, 60-75 c.M. long, 1b-20 c.M. broad, the rachis stramineous, hairy like the main one. Pinnulae linearlanceolate, \pm 2 c.M. broad, cut down nearly to the costa into linear, obtuse, crenulate, rather distant segments. Texture thinly herbaceous; surfaces hairy like the main rachis, principally on the veins; costulae pinnate; veins forked, $7-8$ on each side. Sori medial, $5-6$ on each side of the costulae.

Malacca.

(11) A. scaberula, Christ, Schum. \& Laut., Flor. deut. Sch.geb., 110.

Stipes yellowish-brown, covered with short, often glanduligerous hairs and with numerous minute, acute warts. Fronds large, \pm 2 M. long, 3-pinnatifid. Pinnae sessile, \pm 45 c.M. long, lanceolate; rachis clothed with narrow, short scales. Pinnulae \pm 8 c.M. long, broadly lanceolate, short-acuminate, not caudate, alternate, distant, \pm 2 c.M. broad, sessile, cut down nearly to the costa into \pm close, falcate, broadly ligulate, obtuse lobes, which are regularly serrato-crenate. Texture thin, lierbaceous, flaccid; veins conspicuous, forked, 12-14 on each side; surfaces naked, but the costae bullato-squamose beneath. Sori occupying the lower portions of the lobes, nearly close to the costulae; receptacle globose.

New Guinea. 
(12) A. dimonphat, Christ, Ann. Btz., XIX, 41.

Stipe and rachis unarmed, castaneous, angular, covered with dark, furfuraceous scales. Fronds large, \pm 2 M. long, \pm 40 c.M. broad, 2-pinnate in the barren, 5 -pinnatifid in the fertile portions. Lower and higher pinnae sterile and shorter, central fertile and longer. Barren pinnae \pm 20 c.M. long, \pm 7 c.M. broad, distant, acuminate, stalked; the pinnulae stalked, with the base cordate, hardly 1 c.ll. broad, narrowed gradually to the point, the apex acuminate, the edge slightly lobed into close, not deep, roundish or acute, crenulate lobes. Texture coriaceous; upper surface dark-green, under one paler, scaly at or near the costae. Fertile pinnulae $\pm 1 / 2$ c.ll. broad, pinnatifid nearly to the costa, the lobes not close, $\pm 3 \mathrm{~m}$.M. hroad, obtuse, deltoid. Sori large, $5-6$ to a lobe, occupying its whole under surface.

Celebes.

* (15) Dángi, Claurlse, Bedd., Handb. Ind. Ferns, 47\%.

Fronds 5-pinnalifid: rachises tomentose above, naked, brown, somewhat glaucous beneath. Pinnae $50-60$ c.M. long, the apex pinnatifid, toothed at the point. Pinnulae distant, short-stalked, the lowest largest or a little shorter, $\pm 6-8$ c.I. long, $\pm 1-1 \frac{1}{2}$ c.I. broad, the apex acuminate and bluntly crenate, the edge cut down nearly to the costa into not very close, oblong, subfalcate, blunt, slightly crenate lobes, the lowest lobes \pm largest. Texture coriaceous; surfaces naked, of a bluish-glaucous tint; costae \pm scaly beneath, hairy above, very prominent especially in the fertile pinnulae, which have the soriferous segments mostly much smaller than the barren segments; veins forked or sometimes simple. Sori in 1 row on each side of the costulae, filling up the whole under surface of the fertile segments, which have the edges recurved.

Malacca.

(14) A. Wallacei, Mett., Hk. Bk., Syn. Fil., $4: 9$.

Fronds large, 5-pinnatifid; rachises stramineous, densely pubescent. Pinnae oblong-lanceolate, 50-40 c.M. long. Pinnulae ligulate, distinctly stalked, 3 -5 c.I. long, \pm 1 c.II. broad, cut down to a narrow wing. Segments close, ligulate, blunt, obscurely toothed, $\pm 21 / 2$ m.M. broad. Texture subcoriaceous; surfaces green, the under one densely pilose, with a few bullate scales on the ribs: veins 4-5-jugate, simple. Sori costular.

Borneo. 
(15) A. modlestan, Bki., Journ. of Bot., XVIII, 210.

Stipes to 30 c.M. long; the scales glossy, dark-brown, linear, to $1 \frac{1}{2}$ c.M. long. Fronds 63 -90 c.M. long, rhomboid, 5-pinnatifid, the rachis pubescent, unarmed. Pinnae oblong-lanceolate, the central ones the largest, $20-30$ c.M. long, $6^{1} / 2-7^{1} / 2$ c.I. broad, short-stalked, the lower smaller, decidedly petiolate. Pinnulae lanceolate, sessile, $1-1 \frac{1}{2}$ c.M. broad, cut down in the lower part to the rachis and in the upper to a narrow wing into close, ligulate, entire, obtuse segments to $\pm 2 \frac{1}{2}$ m.M. broad. Texture moderately firm; surfaces green and nearly naked except a few lanceolate scales on the midribs of the pinnulae beneath; veins distinct, 6-7-jugate, simple or forked. Sori costular, not reaching the margin.

Sumatra.

* (16) C. caudata, J. Sm., Hk. Bk., Syn. Fil., 42; Hk., Spec. Fil., I, tab. XX, B.

Fronds 5-pinnatifid; rachises tomentose or pubescent above (after Hooker's drawing). Pinnulae sessile, oblong-lanceolate, $\pm 6-S$ c.M. long, $\pm 1 \frac{1}{2}$ c.M. broad, broadest at the base, the apex suddenly contracted into a long, nar'row, serrate or toother, tail-like acumen, the edge cut down nearly to the costa into close, oblong, slightly falcate, rather obtuse, \pm serrate lobes \pm 4 m.M. broad. T'exture semicoriaceous, firm; surfaces naked; veins simple or forked. Sori close to the costulae, occupying the lower half of the ultimate segments.

\section{Luzon.}

(17) S. S morrensis, Christ, Warb., Mons., I, 90.

Stipe stramineous, angular, unarmed, but covered like the main rachis with minute, filiform and subulate scales. Fronds \pm 70 c.M. long, broadly ovate-deltoid, 5-pinnatifid. Pinnae 10-15, distant, ovate, the rachis strigosopilose. Pinnulae \pm 4 c.M. long, \pm 1 c.II. broad, deeply incised. Lobes separated by rounded sinusses, ovate, rounded, crenulate. Surfaces naked, the under one paler than the upper one; veins simple. Sori close, \pm 4 on each side of the costulae; receptacle not elevated. - Fronds with the aspect of Dryopteris setigera, 0 . Ktze, but firmer.

Sanggir Islands.

(18) A. Iepidocladan, Christ, Schum. \& Laut., Flor. deut. Sch. geb., Suppl., 37.

Stipes unarmed, fusco-stramineous, castaneous at the base, hardly 10 c.M. 
long, covered with ovate-acuminate, scariose, ochreous scales $\pm 1 / 2$ c.M. long. Fronds \pm 60 c.I. long, \pm 28 c.M. broad, ovate-elongate, acuminate, narrowed towards the base. Pinnae sessile, close, spreading, \pm 50 on each side below the pinnatifid apex, the central ones the longest, bluntish, \pm 5 c.I. broad. Pinnulae close, \pm 25 on each side, sessile, ovate-elongate, obtuse, $\pm 1 / 2$ c.M. broad, cut down nearly to the costa, the segments ovate, \pm 7 on each side, apiculate or obtuse, $\pm 1 \frac{1}{2} \mathrm{~m}$.M. broad. Texture herbaceous; upper surface dark-green, the under one paler, not glaucous; rachis ochreo-stramineous, short-hairy, covered like the costae with scariose, whitish, lanceolate, acute scales, the costulae covered with broadly ovate scales; veins conspicuous, 3-4-jugate. Sori minute, 3-4 to each ultimate segment, placed at the bases of the veins; receptacle punctiform or hardly elevated; indusium none.

New Guinea.

* (19) A. Iatebrosa, Wall. (not Hk.), Hk. Bk., Syn. Fil., 45 ; Bedd., J. J. Fts. Ferns S.I., tab. LVIII; Hemitelia latebrosa, Mett., Rac., Flor. Btz., I, 39.p.125 1920.

Stipes dark-brown, aculeate towards the base, muricate upwards; main tarain rachis muricate towards the base. Fronds 3-pinnatifid, to 2 M. long, to 1 M. broad; rachises often covered with long, linear, fine, brown, deciduous scales on the upper side. Pinnae lanceolate-oblong, acuminate, stalked, 30-60 c.M. long, 12-20 c.M. broad, the rachis \pm tomentose above. Pinnulae linearlanceolate, acuminate, subsessile, $\pm 1 \frac{1}{2}-2$ c.ll. broad, the base subtruncate, the edge deeply pinnatifid into linear-oblong, blunt, subfalcate, crenate or slightly toothed lobes \pm 2 m.M. broad. Texture firm-herbaceous; surfaces naked or the under one slightly hairy, under surface not glaucous; costae and costulae more or less scaly beneath with \pm bullate scales; veins forked. Sori on the 1-7 lower veins, nearly costular; receptacle often with a minute, spurious indusium at the inner side.

Malaya; North. India.

* (20) A. Saparuensis, v. A. v. R.

Stipes aculeate; main rachis slightly so towards the base; secondary rachises somewhat rough towards the base with few, scatlered, minute warts and covered like the main one with copious, very fine, \pm deciduous, crisped, yellowish or brownish, fibril-like hairs. Central pinnae \pm 45 c.M. long, $12-16$ c.M. broad, lanceolate, acuminate. Pinnulae sessile or subsessile, the lower ones spreading, smaller than the central ones, which are $\pm 11 / 2$ c.M. broad, cut down nearly to the costa. Lobes \pm close, oblong, blunt, crenate 
or toothed especially towards the apex, the lowest lobes a little smaller and somewhat narrowed at the base. Texture firm but not rigid; veins distinct, forked, 8-10 on each side; costae and costulae hairy like the rachises, especially beneath. Sori occupying nearly all the veins except the higher ones, medial; receptacle liairy, with a distinct, flat, brown, subentire, orbicular, spurious indusium. - Under surface paler than the upper one, but not glaucous.

Saparua, (Teysmann), Buru.

(21) A. fuliginosa, Christ, Bull. Herb. Boiss., VI, 158.

Stipes blackish-brown, the base covered with aculeate, rough tubercles and long, erect, curved, rigid, dark-coloured bristles. Fronds broadly ovate, \pm 100 c.M. long, \pm 40 c.M. broad, 5-pinnatifid, narrowed towards the base; main rachis yellowish, rough, furfuraceous. Pinnae close, broadly ovate, \pm 8 c.II. broad, sessile, short-acuminate, the rachis clothed above like the costae with large scales, some of which are dark-coloured and lanceolate and the others bullate or cupuliform and greyish with a black centre. Pinnulae ligulate, short-acuminate, $\pm 5 \mathbf{m}$.M. broad, \pm 22 on each side below the pinnatifid apex, the lower ones shorter, cut down nearly to the costa into erectopatent, pectinate, falcate, subacute, slightly crenate lobes, with the margin revolute; veins conspicuous, $4-5$ on each side, naked or scaly. Sori minute, numerous; indusium not seen.

Philippines.

(22) A. Lepifera, J. Sm., Hk., Spec. Fil., I, b4; (? A. tomentosa, Hk., C. Chr., Ind. Fil.); - var. congesta, Christ, Bull. Herb. Boiss., VI, 37.

Stipe furfuraceous at the base and covered like the lower portion of the main rachis with small, prominent, aculeate tubercles with dark-red or blackish points; upper portion of the rachis clothed with long, moderately firm, coarsish, brown hairs and with few, slender, yellowish, ovate, crinite scales like the stipe. Fronds 3-pinnatifid, sub-3-pinnate. Pinnulae sessile, broadest at the hase, narrow, lanceolate, deeply pinnatifid, the point slender, subulate. Segments linear-oblong, distant, falcate, \pm obtuse, the lower ones free. Texture herbaceous; under surface slightly glaucous and covered with flattish, whitish scales on the costae; veins forked. Sori occupying the whole under surface of the segments.

Var. congesta: Segments close or imbricating, the lower ones overlapping the rachis.

Philippines. 
(25) A. batjanensis, Christ, Warb., Mons., I, 90.

Caudex \pm 5 M. high. Stipes very aculeate, the prickles short, conical; rachis rough, less prickly, yellowish-brown. Fronds deltoid, 5-pinnatifid, 100 c.II. and more long. Pinnae 8-10, very distant, petiolate, deltoid-ovate, 8-10 c.ll. long, \pm 6 c.li. broad, short-acuminate. Pinnulae distant, deeply incised; segments obtuse, ligulate-ovate, $6-8$ m.I. long, \pm 5 m.II. broad, serrate. Texture coriaceous; surfaces naked, the under one not glaucous; veins simple, conspicuous. Sori small, not close, medial.

Batjan.

* (24) A. melanopus, Irassks, Journ. of Bot., VII, 52 b.

Stipe very aculeate and densely scaly at the base, the rest rough like the rachis, the scales large, blackish, deciduous. Fronds 3-pinnatifid, ovateoblong, acute. Pinnae elongate-oblong and acute, or lanceolate-oblong and acuminate. Pinnulae linear-oblong, deeply pinnatifid. Ultimate segments linearoblong, obtuse or subacute, subfalcate, obscurely crenato-serrate. T'exture membranaceous; under surface slightly glaucous; costulae clothed with minute, deciduous scales. Sori near the costulae, at length confluent.

Java.

(25) A. ormata, Scott, Hk. Bk., Syn. Fil., 460; Bedd., Ferins Br.I., II, tab. CGCXLII; - var. sikkimensis, Bedd., Journ. of Bot., XXXI, 225 ; A. sikkimensis, Clarke \& Bk., Journ. of Linn. Soc., Bot., XXIV, 409.

Stipe paleaceous at the base, slightly muricate and as well as the main rachis glossy, purplish-hrown. Fronds 5-pinnatifid. Pimnae oblong-lanceolate, rather abruptly contracted into a short, deeply pinnatifid apex. Pinnulae nearly all petiolate, lanceolate-oblong, acuminate, deeply cut down nearly to the costa. Ultimate segments ovate in the sterile, narrow-oblong in the fertile pinnulae, serrate, slightly falcate. Texture herbaceo-membranaceous; costae slightly hairy above and scaly below; veins forked, or a few 3-branched. Sori subcostular, occupying the lower half of the lobes (conf. Beddome's drawing).

Var. sikkimensis: Stipe and main rachis more prominently muricate.

Sikkim; - var. sikkimensis: Malacca; Sikkim.

* (26) A. croinita, Hk., Hk. Bk., Syn. Fil., 42; Hk., Icon. Pl., VII, tab. DCLXXI; Bedd., Ferns S.I., tab. LIX.

Stipe and main rachis strongly muricate, stramineous-brown, long-hispido- 
paleaceous; spines short, tipped with a black gland. Fronds large, 5-pinnatifid. Pinnae \pm 60 c.ll. long, \pm 25 c.ll. broad. Pinnulae oblong, acuminate, pinnatifid - nearly to the costa. Lobes narrow, oblong, subobtuse, subfalcate, the margin recurved, serrate. T'exture subcoriaceous; rachises pilose above; densely paleaceo-crinite beneath; costae and veins often pilose, or scaly below; veins $1 \times$ forked. Sori subcostal (conf. Hooker's drawing), mixed with crinite scales, of ten covering the whole underside of the lobes.

Java; Ceylon, South. India.

* (27) A. glauca, J. Sme, Journ. of Bot., III, 419; A. contaminans, Wall., Rac., Flor. Btz., I, $\mathbf{3} 5$; Hk., Spec. Fil., I, tab. XVIII ; A. Brunoniana, Bedd., Ferns Br.I., I, tab. LXXXVI; Gnoophora glauca, Bl., (oldest name); - var. celebica, Christ in Ann. Btz., XV, 79; - var. longepaleata, Christ, l. c., XIX, 42; - var. squamulata, densa \& setulosa, Hassk. in Journ. of Bot., VII, 324 .

Stipe and main and secondary rachises more or less aculeate with short prickles and whether or not tomentose above. Fronds large, to $5 \mathrm{H}$. long, to $1 \frac{1}{2}$ M. broad, 3-pinnatifid to sub-3-pinnate. Pimnae $\pm 12-24$ c.ll. broad, lanceolate-oblong, acuminate, more or less stalked. Pinnulae linear- or oblonglanceolate, $1 \frac{1}{2}-5$ c.M. broad, cut down nearly to the costa or even pinnate at the base into numerous, linear-oblong, blunt, acute or'acuminate, subfalcate, obscurely crenate to serrate segments, the fertile segments not rarely narrower than the barren ones, the margin subrevolute. Texture more or less coriaceous; under surface glaucous; veins $\pm 8-12$ on each side, mostly $1-2 \times$ forked. Sori commonly nearer the costulae than the margin; receptacle surrounded by a spurious indusium, consistiug of a flat, orbicular, entire or lobed, minute scale or a whorl of fibres. - A variable species. - The typical form (var. robusla, Hassk.) has the rachis and the stipe reddish, often glaucous, the stipe densely clothed at the base with long, pale-coloured scales; the costae and costulae naked or covered beneath with few, small, deciduous, bullate scales.

Var. celebica: Pinnae and pinnulae short and broad; ultimate segments not numerous, 2-3 m.M. apart; veins 5 -furcate.

Var: Iongepaleata: Rachis yellowish-ochraceous, covered with short, dark-coloured prickles and long, brown, linear-subulate, spreading scales. Texture less coriaceous, less glaucous.

Var. squamulata: Costae and costulae densely scaly beneath.

Var. densa: Sori dense, confluent, at length covering the whole under surface of the lobes. 
Var. setulosa: Costae and costulae clothed beneath with moderately long, whitish, subulate bristles especially in the barren portions.

Trop. Asia. - The varieties in Malaya, chiefly Celebes or Java.

(28) A. Christii, v. A. v. R.; A. comosa, Christ (not Wall.), Ann. Btz., XV, 80.

Stipes strong, \pm 2 c.M. thick, pale-brown, rough with numerous, minute, acute warts, not scaly. Fronds large; main rachis slightly rough and strigulose. Pinnae sessile, \pm 40 c.M. long, \pm 8 c.M. broad, lanceolate. Pinnulae spreading, acuminate, $\pm 3 / 4$ c.M. broad, pinnate. Ultimate divisions (leaflets) lanceolatefalcate, obtuse, $\pm 5 \mathrm{~m}$. . . broad, the apex rounded, crenate. Texture herbaceous; costae clothed above with short, whitish hairs and covered beneath with scattered, brown, bullate scales; veins forked. Sori large, yellowishbrown, 6-8 on each side, not reaching to the apex of the ultimate segments.

Celebes.

* (29) A. Iruncenta, Brack., Hk. Bk., Syn. Fil., 59 ; Hemitelia truncata, Christ, Ann. Btz., XV, 81, tab. XIII, fig. 4. - var. nivea, Christ in Schum. \& Laut, Flor. deut. Sch.geb., Suppl., 36.

Main \& second. rachises dark-purple or brownish, glossy, muricate, deciduously furfuraceo-tomentose as well as the costae and costulae beneath. Fronds 5-pinnate. Pinnae 25-45 c.M. long, 10-12 c.M. broad, oblong, acuminate. Pinnulae to $7 \frac{1}{2}$ c.M. long, to $1 \frac{1}{2}$ c.M. broad, sessile, lanceolate, acuminate, numerous (25-30 on each side), pinnate, the short apex pinnatifid. Ultimate segments to $12 \mathrm{~m} . \mathrm{M}$. Iong, to $3 \mathrm{~m} . \mathrm{M}$. broad, herbaceous, firm, the lower ones \pm petiolate, the base subauriculate or hastate, the margin roundly crenate, recurved. Costules thick and prominent, bullato-squamulose; veins simple or forked; colour bright-green above, paler beneath. Sori small, dark-orange, lax, near the costulae; indusium consisting of a narrow, flat, thin, orbicular scale.

Var. nivea : Fronds $2-21 / 2$ M. long, $\pm 1 \frac{1}{2}$ M. broad; under surface covered with adpressed, white-tomentum.

Celebes, Baljan, New Guinea; Fiji, Samoa; - var. nivea: New Guinea.

(30) ? A. celebica, Mett., Ann. Mus. Bot. L. B., I, 53; ? Cyathea celebica, Bl., Enum., 24 כ.

Fronds \pm tripinnatisect; main rachis ferrugineo-hirsute in the upper portion, subfurfuraceous, scaly and slightly aculeate or rough in the lower portion. Pinnae \pm 30 c.M. long or longer. Pinnulae approximate, \pm 10 
c.M. long, $1 \frac{1}{2}-2$ c.M. broad, linear-oblong, acuminate, inciso-serrate at the apex. Tertiary divisions numerous, linear-oblong, subfalcate, obtuse, sessile, $\pm 21 / 2$ m.M. broad, the apex crenulate. Texture membranaceous; veins fine, pellucid, forked at the base. Sori?

Celebes, Ternate, Batjan.

(31) A. polyphlebia, zk., Journ. of Linn. Soc., Bot., XII, 104.

Trunk to $7 \frac{1}{2}$ M. high. Fronds ample, tripinnate. Rachis of pinnae palebrown, slightly furfuraceous and rough with raised points. Pinnae oblonglanceolate, \pm 60 c.M. long, $15-20$ c.M. broad. Pinnulae sessile, lanceolateligulate, $\pm 2 \%$ c.M. broad, cut down to the rachis into close, blunt, distinctly crenate, tertiary segments $\pm b$ m.M. broad. Texture thin, but firm; surfaces naked, the under one with a few bullate scales on the midribs of the tertiary segments; veins 12-14-jugate, close, fine, distinct, forked, the lowest sometimes bifurcate. Sori placed close to the costae, with a distinct space between each, sometimes 12-15 to a segment, absent from the upper $1 / 3$ of the segments.

Aru Islands.

* (32) A. tomentosa, Hk., Rac., Flor. Btz., I, 32.

Stipes densely covered with light-brown scales $2-5$ c.M. long, muricate like the more or less densely scaly rachises; the spines short, often black-tipped. Fronds large, to $2^{1} / 2$. M. long, ovate-lanceolate, 3-pinnate. Pinnae to $4 \breve{b}$ c.M. long or longer, \pm 15 c.M. broad, stalked. Pinnulae sessile, \pm $1 \frac{1}{2}$ c.M. broad, linear-lanceolate, acuminate. Tertiary segments sessile, free or slightly joined at the base, $\pm 2^{1} / 2$ m.M. broad, entire, blunt, slightly convex. Texture coriaceous; upper surface naked or slightly hairy on the costae; under surface densely covered with pale-brown-yellowish hairs and tomentose, ragged scales on the costae and tertiary rachises; veins $8-\mathbf{1 2}$ on each side, mostly forked. Sori close to the central ribs of the ultimate segments, hidden between the scales.

Java.

*'(33) A. extemsa, Spr., Syst., IV, 124; A. lunulala, R. Br., Hk. Bk., Syn. Fil., 41; A. Haenkei, Pr., Rel. Haenk., I, 68; Polypodium extensum, Forst., (oldest name); - var. intermedia; A. intermedia, Mett., Hk. Bk., l. c.

Fronds large, 3-pinnate; the rachises yellowish or pale-brown, \pm densely muricate, naked below, often hairy above. Pinnae oblong-lanceolate, 45-60 c.M. long. Pinnulae close or approximate, ligulate, sessile, 10-15 c.I. long, 
$1 \frac{1}{2}-21 / 2$ c.M. broad. Segments close, free or slightly joined at the base, ligulate, falcate, blunt, $\pm 21 / 2$ m.M. broad, obscurely crenulate. Texture subcoriaceous; surfaces naked; midribs below naked or furfuraceous; veins crowded, \pm 10-12-jugate, forked. Sori minute, subcostular; receptacle pilose.

Var. intermedia: Ultimate segments broader; veins and sori more distant.

Java \& Celebes to Polynesia; - var. intermedia: New Guinea; New Caledonia.

* (34) Iurida, mk., Hk. Bk., Syn. Fil., 45.

Stipes smooth; rachis slightly scabrous and scaly below, densely tomentose and scaly above. Fronds broadly lanceolate. Pinnae to \pm .30 c.M. long and to 10 c.M. or more broad. Pinnulae more than 5 c.M. long, more than 1 c.M. broad, cut down to the rachis into linear-oblong, subfalcate, nearly entire leaflets. Texture subcoriaceous; upper surface dark-green, naked, under surface densely furnished with linear scales on the rachis and costae.

Java, Celebes.

(55) mindanensis, Christ, Warb., Mons., I, 90.

Rachis stramineous, unarmed, covered with a woolly, brown tomentum and long, reddish-brown, fine, fibrillose scales. Pimnae \pm 40 c.M. long, ovate, subsessile. Pinnulae numerous, $20-50$, ligulate-lanceolate, \pm 8 c.II. long, short-acuminate, the lower ones pinnatifid quite to the costa. Segments of the sterile pinnae \pm 2 c.I. long, close, $\pm 6 \mathrm{~m}$.M. broad, deeply incised, with the lobes ovate, bluntish, crenate; those of the fertile pinnae, smaller, narrower, rather distant, ligulate, entire or slightly crenulate. Texture very coriaceous; costae fibrillose like the rachis; veins numerous, forked. Sori minute, close to the central veins of the segments, not reaching the apex.

Philippines.

Species of an indefinite systematical place.

(36) ? xantholepis, Christ, Diels, in Engl. \& Prantl, Nat. Pfl. Fam., I I 138.

Fronds somewhat larger than in A. tristis, Bl. (which is Cystopteris tristis, Mell.), becoming black when dried.

Batjan. 
TRIBE II. DICKSONIEAE. 



\section{DICKSONIA, v'Méritier.}

Sori roundish or transversally suboblong, terminal on the veins, submarginal. Indusium 2-valved, the outer valve consisting of a conspicuously cucullate, small lobe of the frond, forming with the inner valve a saccate involucre to the sorus, the inner valve being of another texture than the outer one.

Caudex arborescent. Fronds compound, \pm elongate as are the segments; veins free. Diels, in Engl. \& Prantl, Nat. Pfl.Fam., I ${ }^{4}$, fig. 78, B-D.

Tropical and subtropical.

* D. HIumei, Moore, C. Chr., Ind. Fil.; D. chrysotricha, Moore, Rac., Flor. Btz., I, 121; Balantium Blumei, Kze, (oldest name).

Caudex arborescent. Stipes to 80 c.M. leng, densely pilose like the rachises and costae, the base covered with long, yellowish or brownish hairs to $51 / 2$ c.M. long. Fronds 3-pinnatifid to 5-pinnate, to $5 \mathrm{M}$. long, narrowed towards both ends. Pinnae $50-75$ c.M. long, 15 - 5 c.M. broad, erectopatent, on stalks to $1 \frac{1}{2}$ c.M. long, oblong-lanceolate, acuminate. Pinnulae \pm sessile, approximate, linear-lanceolate, acuminate, the lowest not the longest, $15-20 \mathrm{~m}$. I. broad at the base. Tertiary segments erecto-patent, linear-oblong, obtuse, 5-4 m.M. broad, free or slightly joined at the base; the barren ones decurrent, toothed, the teeth acute, entire or slightly denticulate; the fertile ones deeply incised, the lobes rounded, cucullate, forming the outer valve of the indusium. Texture coriaceous; surfaces naked, except on the costae or costulae beneath; veins simple or forked. Sori numerous, 1 to each lobe, transversally suboblong; inner valve of the indusium \pm cucullate, brown, firm-membranaceous, at length reflexed.

Java, Celebes.

\section{CIBOTIUM, Kaulfuss.}

Sori roundish or oblong, terminal on the veins, submarginal. Indusium 2-valved, the outer valve similar to the inner one, distincly differentiated from the margin of the frond, forming with the inner one a saccate involucre to the sorus. 
Caudex often, but not invariably arborescent. Fronds compound; segments linear or oblong; veins free. Diels, in Engl. \& Prantl, Nat. Pfl.Fam., $I^{4}$, fig. 78, E-F; Christ, Farnkr. d. Erde, fig. 1001.

Trop. Asia, China, Sandwich Islands, Centr. America.

\section{Barainctis. $(s+1.4 y)$}

* C. Donermetz, গ. Sm. (not Link), Christ, Farnkr. d. Erde, 315; C. assamicum, Hk., Spec. Fil., I, tab. XXIX, B; C. glaucescens, Kze, Farnkr., I, tab. XXXI; Dicksonia Barometz, Link, Hk. Bk., Syn. Fil., 49.

Caudex słhort, strong. Stipes firm, the base densely covered with very long, yelow, hair-like scales. Fronds ovate-oblong, to 2 M. or more long. Lower pinnae ovate-lanceolate, \pm 50-60 c.M. long. Pinnulae linear-lanceolate, acuminate, cut nearly and sometimes quite down (in the lower part) to the costa into oblong, narrow, subfalcate, approximate segments. Texture subcoriaceous; surfaces \pm naked, shining, the under one glaucous, sometimes furfuraceous; veins commonly simple. Sori $2-12$, rarely 1 to a segment; indusium brownish, transversely oblong.

Malaya; Assam, South. China. 
FAMILY II. MATONIACEAE.

Filiaes. 



\section{I. MATONI ACEAF.}

Sori round, consisting of few $(4-10)$ decumbent capsules placed in a whorl. Capsules as in Cyatheae. Receptacle columnar, hearing a superior, umbrella-shaped, obscurely lobed indusium.

Rhizome creeping. Fronds either erect and pedato-flabellate or pendulous and pinnate, the pinnae simple or 1-2 $\times$ forked; veins free or those around the sori reticulate.

Malayan.

No. 6. Matonia.

\section{MATONIA, R. Brovn.}

Characters of the family.

*. Fronds penduluus, pinnate, not pedato-flabellate.

(1) M. sormentosa. *.*. Fronds erecl, pedato-flabellate, nol pinnale.

(2) M. pectinata.

(1) M. sarmentosa, \#k., Christ, Farnkr. d. Erde, 536 ; Diels, in Engl \& Prantl, Nat. Pfl.Fam., fig. 183; Ann. of Bot., V, tab. XIV.

Rhizome short, creeping, scaly. Stipes slender. Fronds pendulous, to \pm 1 M. long, not fan-shaped, pinnate or irregularly branched and the branches pinnate again. Leaflets simple or once or more times forked, the ulitimate segments linear, $\breve{b}-13$ c.M. long, 4-10 m.M. broad, the apex blunt, the edge entire. Texture flaccido-coriaceous; surfaces naked; colour pale; costae stout; veins immersed, simple or forked. Sori terminal on short veinlets, placed \pm midway between the costae and the margin, consisting of $\pm 8-10$ sporangia.

Borneo.

* (2) M. pectinata, R. Br., Christ, Farnkr. d. Erde, 535, fig. 1064 ; Diels, in Engl. \& Prantl, Nat. Pfl.Fam., I ${ }^{4}$, fig. 182: Bedd., Ferns Br.I., II, tab. CLXXXVI; Bau. \& Hk., Gen. Fil., tab. XLIII.

Rhizome creeping, hairy. Stipes stout, erect, to \pm 2 M. long. Fronds fan-shaped, conjugato-pedatisect, 40-60 c.ll. broad, forked. Forkings spreading or divaricating, each pinnate with many pinnulae on the upper side below 
6. MATONIA.

the pinnatifid apex, the lower side destitute of pinnulae. Piunulae linear, the lowest largest, to 4 b c.M. long, cut down nearly to the costa into linear or linear-oblong, erecto-patent, subfalcate lobes. Lobes pectinate, linear-lanceolate, acute, to 2 c.M. long and $\mathbf{5}$ m.M. broad, dilated at the base. Texture very coriaceous; costae distinct; veins simple or forked, free or those around the sori reticulate. Sori solitary at the base of the lobes or in 1 row on each side of the costulae.

Malacca, Lingga Islands, Borneo, Amboyna. 
FAMILY III. GLEICHENIACEAE. 



\section{GLEICHENIACEAE.}

Sori dorsal, consisting of few (2-12) capsules. Capsules commonly decumbent and placed in a whorl, with the receptacle in the centre, sessile or short-stalked, surrounded by a horizontal or subhorizontal, complete ring, bursting vertically. Receptacle punctiform. Indusium wanting.

Rhizome mostly creeping. Fronds rarely unbranched, generally dichotomously forked or pinnate and if pinnate the pinnae or pinnulae dichotomous, frequently bearing axillary buds; the leafy portion of the branches commonly pectinate; veins always free.

Tropical and extra-tropical in the southern hemisphere.

\section{№. 7. Gleichenia.}

\section{GLEICHENIA, Smith.}

Sori consisting of few, commonly $2-5$, rarely $6-12$ sessile sporangia, placed mostly in a whorl. No indusium.

Rhizome creeping, rarely erect. Stipes mostly scattered, not articulate to the rhizome. Fronds mostly forked, rarely pinnate, the primary branchings pinnate or once or more times forked again, or pinnate and forked. The dichotomous forms are often purveyed with axillary buds, which not rarely grow out to fully developed branches, which give the fronds the appearance of pinnate or 2-pinnate fronds with dichotomous branches of a higher order. The thus formed spuriously pinnate fronds are often to be recognized by the presence of mostly divided stipulae or a mass of densely crowded scales placed in the axils of the principal branchings and wanting in the truly pinnate forms. Ultimate segments (lobes or leaflets) semiorbicular and contiguous or linear and pectinate; veins free, simple or forked, often immersed or obsolete.

Tropical and extra-tropical in the southern hemisphere.

\section{Arrangement of the sections.}

\$1. PLATYzoma. Fronds unbranched, simply pinnate; leaflets roundish or ovate, cucullate, to 2 m.M. long. Hk. Bk., Syn. Fil., tab. I, fig. 1, a-c; Diels, in Engl. \& Prantl, Nat. Pfl.Fam., I ${ }^{4}$, fig. 189, C. (Not in Malaya). 
\$2. EUGLEICHENIA. Fronds branched; ultimate segments roundish, $1-\mathbf{3} \mathrm{m} . \mathbf{M}$. long. Diels, l.c., fig. 189, B; Christ, Farnkr. d. Erde, fig. 1068.

S5. MERTENSIA. Fronds branched; ultimate segments oblong to linear, $1-10$ c.M. long. Christ, l.c., fig. 1074, 1077, 1081, 1082.

a. Diceranoptenis. Fronds forked; forkings variously branched again.

b. Protogleichenia. Fronds pinnate; pinnae variously branched again.

\section{\$ 2. EUGLEICHENIA.}

*. Leaflets slightly recurved at the edge. Rachises naked or clolhed with chaffy pubescence.

*.*. Leaflets subhemispherical. Rachises scaly or woolly.

(1). G. circinata. (2). G. vulcanica.

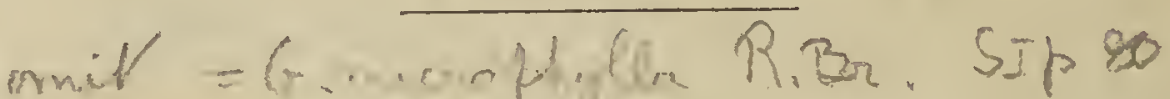

* (1) C. Cimeinata, Sw., Hk. Bk., Syn. Fil., 11; G. semivestita, Lah., Hk., Spec. Fil., I, tab. II, A; G. microphylla, R. Br., Hk, l.c., 3.

Stipes to \pm 50 c.M. long, slender, wiry, flexuose, naked or \pm villose. Fronds to \pm 1 II. broad, dichotomously branched, the branches and internodations with numerous spreading pinnulae \pm 与 c.M. long. Leaflets roundish, \pm 1 m.M. each way, the edges slightly recurved. Texture firm; under surface glaucous; branches and rachises naked or more or less clothed with chaffy pubescence. Capsulès 3-4, superficial.

Malaya; Australia, Tasmania, New Zealand, New Caledonia.

* (2) G. vulcanica, Bt., Rac., Flor. Btz., I, 10; G. dicarpa, R. Br., var. alpina, Hk. Bk., Syn. Fil., 12; G. hecistophylla, A. Cunn., Hk., Spec. Fil., I, tab. II, B.

Fronds 20-80 c.M. long, dichotomously branched, the branches and internodations with spreading, linear pinnulae \pm 3 c.M. long, $1 \frac{1}{2}-3 \mathrm{~m} . \mathrm{M}$. broad. Leaflets loundish, subhemispherical, \pm as long as broad, the edges much recurved. Texture coriaceous; rachises covered with brown scales or ferrugineous, furfuraceous tomentum. Capsules $2-3$, concealed within the almost slipper-shaped leaflets.

Malaya. 


\section{\$ 3. MERTENSIA. a. Dieranopteris.}

a. Fronds forked; branches pinnale; secondary branches (pinnulac) whelher or not branched again, (Diplopterygium, Diels, in Engl. \& Pranll, Nat. P/l. Fam., I4, fig. 188, A).

b. Pinnulae not branched:

c. Pinnulae distant. (3c) G. converued di p 81

(3) G. Norrisii.

c.c. Pinnulae close.

a. Under surface naked or sparingly scaly.

a.d. Under surface densely tomentose with ciliale or fombriale

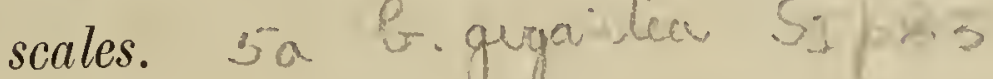

(b) G. araehnoidea

b.b. Pinnulae dicholomously branched.

(6) G. Warburgii.

a.a. Fronds forked; branches dicholomously forked again.

1. The ullimale branches only leafy. The forlings whelher or nol purveyed with a pair of deflexed, opposile, leafy, accessory branches, (Acropterygium \& Heteropterygium, Diels, l. c., fig. 188, C-D).

(7) G. linearis.

1.1. All the branchings leafy litie the ultimate ones, but the 1-3 lower ones not ravely nudate, (Holopterygium, Diels, l. c., fig. 188, B).

2. Ultimate segments (lobes or leaflets) horizonlally spreading.

(8) G. laevigata.

2.2. Ultimale segmenls (lobes or leaflels) more or less ereclo-patenl.

3. Lobes or leaflets (not the' rachises) naked beneath.

*. Texture coriaceous; under surface glaucous.

9) G. oceanica.

*.*. Texture membranaceous; under surface not glaucous.

(10) G. flabellata.

3.3. Lobes or leaflets hairy, scaly or tomentose beneath, al least on the central ribs.

1. Rachises hairy, scaly and white-powdery.

(11). G. Koordersii.

1.1. Rachises hairy or scaly, but not while-powdery.

5. Lobes or leaflets loolhed al the apex. (12) G. hirta. SJ t. as 5.5. Lobes or leaftels not toolhed at the apex.

6. Rachises long-hairy beneath.

(13) G. hispida.

6.6. Rachises densely scaly beneath. (14) G. vestita. 
* (3) C. Norrisii, Mett., Hk. Bk., Syn. Fil., 449 ; Bedd., Ferns S.Br.I., Suppl., tab. CCCXLVI.

Fronds forked. Branches oblong-lanceolate, 60-100 c.M. long, pinnate. Pinnulae lanceolate, distant, alternate, the lowest stalked, 15-25 c.M. long, cut down to a narrow wing into \pm close, ligulate, spreading, blunt segments, the higher ones growing gradually smaller. Texture coriaceous; surfaces naked, the under one green or glaucous; veins once forked. Sori medial, 12 -20 to a segment.

\section{Malacca.}

* (4) G. Glauca, Mk., Christ, Farnkr. d. Erde, 340; Hk., Spec. Fịl., I, tab. III, B ; G. longissima, Bl., Rac., Flor. Btz., I, 10; G. giganlea, Wall., Bedd., JFM.S Ferns Br.I., I, tab. XXX; Hk., l. c., tab. III, A; Polypodium glaucum, Thb., (oldest name).

Fronds large, forked. Branches to 6 M. or more long, bearing numerous closely placed pinnulae. Pinnulae as long, 10-25 c.M. long, 2-5 c.I. broad, cut down nearly or quite to the costa into numerous segments. Segments linear-lanceolate or oblong, acute or rounded, pale or more or less glaucous heneath, to $\boldsymbol{5} \cdot \mathrm{m}$. I. broad. Under surface naked or sparingly covered with small, ciliate scales. Capsules $\mathbf{3}-\breve{b}$, often mixed with hairs.

Malaya; Japan, China, Trop. Asia, Australia and Polynesia.

IfMS Ved nith (5) C. arachnoidea, Mett., Rac., Flor. Btz., I, 11; G. longissima, Bl., var. rigida, Bl., Enum., 2b1; G. longissima, Bl., var. arachnoides, Hk. Bk., Syn. Fil., 12 ; G. glauca, Hk., var., C. Chr., Ind. Fil.

Like G. glauca, Hk., but the stipes and rachises densely tomentose with ferrugineous, membranaceous, crisped, ciliate or fimbriate scales leaving the rachises \pm rough when they fall. Under surface densely tomentose with the same scales. Capsules immersed between the tomentum.

Malayan Islands.

* (6) C. Warburgii, Christ, Ann. Btz., XV, 78.

Fronds forked. Branches flexuose, pinnate, bifurcate at the apex, \pm 50 c.M. long. Pinnulae distant, alternate, spreading, dichotomously forked. The $1-3$ lowest branchings nudate, the other ones leafy, with the rachises naked or covered with deciduous, reddish tomentum. Ultimate branches $5-15$ c.M. long, $2-4$ c.M. broad, acuminate. Lohes or leaflets spreading, $15-50$ on each side, linear, $2-\tilde{z} \mathrm{~m}$. .M. broad, free or joined at the base, the apex blunt; higher lobes abbreviated, reduced. Texture \pm herbaceous to semi- 
coriaceous; surfaces naked or the under one tomentose on the costulae like the rachises. - The description is taken from specimens gathered in Amboyna by Boerlage, determined by Christ.

Borneo, Celebes, Batjan, Amboyna. Luzon (\$>05)

* (7) G. Linearis, Clarke, Trans. Linn. Soc., Bot., 2d Series, I, 42S; G. dichotoma, Hk., Rac., Flor. Btz., I, 15; Redd., Ferns S.I., tab. LXXIV; G. Hermanni, R. Br., B1., Enum., 248; Polypodium lineare, Burm., (oldest name); var. rigida, Rac., l. c.; - var. normalis, Rac., l. c.; - var. ferruginea, Rac., l. c.; G. ferruginea, Bl., Enum., 249; - var. emarginata, Christ, Ann. Btz., XV, 77; - var. malayana, Christ, l. c.

Fronds large, $\pm 3-4 \times$ dichotomous, each forking bearing a pair of deflexed, unbranched branches at the base on the outer side, except the terminal forkings, which are commonly without accessory lateral branches. Ultimate branches mostly with numerous \pm spreading segments on each side. -

Forma typica: Texture subcoriaceous; surfaces naked, not glaucous. Ultimate segments under 4 c.M. long.

Var. rigidla : Texture rigidly coriaceous.

Var. normalis: Under surface glaucous.

Var. ferruginea: Under surface clothed with l'errugineous, furfuraceous tomentum, at least on the costae.

Var. emarginata: Texture very rigid; under surface clothed troughout with ferrugineous hairs.

Var. malayana: Very large; branches much elongated, with the ultimate segments $4-6$ c.M. long or longer.

Tropical and extra-tropical.

* (8) C. Laevigata, Hi., Rac., Flor. Btz., I, 11; G. bifurcata, Bl., Enum., 250; ? G. flagellaris, Spr., Christ, Farnkr. d. Erde, 342.

Stipes terete or nearly so, often narrowly marginate. Fronds large, repeatedly dichotomous; the lowest forkings divaricating or rectangularly spreading, not rarely nudate. Ultimate segments linear, to 5 c.M. long, to $21 / 2$ m.M. broad, horizontally spreading, obtuse or retuse. Texture \pm herbaceous; upper surface bright-green, under one paler, naked, or the costae cobwebby or tomentose with ciliate, ferrugineous scales. Sporangia $\pm 3-4 .-$ G. flagellaris, Spr., which has the under surface very glaucous, is probably another species very near our plant, but not malayan.

Malaya. 
(9) Cr. Deeanica, Trhn, Hk. Bk., Syn. Fil., 449.

Fronds repeatedly dichotomous, above 50 c.M. long. Terminal branches $10-12 \frac{1}{2}$ c M. long, acuminate. Ultimate segments close, to $2^{1 / 2} \mathrm{~m} . \mathrm{M}$. broad, acuminate, erecto-patent, subfalcate. Texture subcoriaceous; under surface glaucous; rachises densely clothed with ferrugineous, lanceolate, fimbriate scales.

Celebes; Polynesia.

(10) C. Aabellata, R. Br., Hk. Bk., Syn. Fil., 12; Hk., Fil. Exot., tab. LXXI.

Stipes firm, polished, dark-brown. Fronds repeatedly dichotomous; flabelliform, to 1 II long, more broad than long. Terminal branches 10-20 c.M. long, $2 \frac{1}{2}$-5 c.M. broad, acuminate. Ultimate segments close, linear, acute. Texture membranaceous; surfaces naked, not glaucous beneath. Sporangia $1-6$, mostly 4 .

New Guinea; Australia, Tasmania, New Zealand, New Caledonia.

(11) C. Koonelenesii, Cherist, Ann. Btz., XV, 76, tab. XIII, fig., 1, $\mathrm{a}-\mathrm{b}$.

Ultimate segments numerous ( $0 \pm 70$ on each side of the terminal branches of the fronds), $\pm 1^{1 / 2}$ m.M. broad, linear, falcate, the margin revolute. Texture coriaceous, under surface hairy; rachises covered with deciduous, fibrillose, woolly, reddish-brown hairs besides linear, flaccid, tortuose, ciliate scales and a white powder. Sori consisting of 4 - 5 sporangia.

Celebes, Luzon.

* (12) C. Inirta, Bt., Rac., Flor. Btz., I, 12.

Fronds dichotomous, to \pm 1 M. long, the rachises, costae and small axillary buds furnished with copious, ferrugineous, lanceolate to subulate, ciliato-dentate, deciduous scales. Primary branches $\mathbf{3}-4 \times$ forked. Lowest internodatons $1 \frac{1}{2}-21 / 2$ c.M. long, nudate, the secondary ones $2-4$ c.II. long, subnudate. Terminal branches $7 \frac{1}{2}-25$ c.M. long, linear, narrowed gradually towards the apex. Ultimate segments $3 / 4-2$ c.M. long, 2-4 m.M. broad, linear, obtuse, subfalcate, the margin entire, revolute, the apex denticulate, those of the lower forkings gradually becoming shorter, the lowest segments semidecurrent. Texture membranaceo-chartaceous; under surface caeruleopruinose; rachises and costae glaucous.

\section{Malaya.}


* (13) C. Iispida, Mlett., Rac., Flor. Btz., I, 12.

Fronds to \pm 50 c.M. long, forked. Forkings $1-5 \times$ forked again. Ultimate segments erecto-patent, linear, entire, close or \pm distant, to 2 c.M. long, \pm 2 m.M. broad, the edges recurved. Texture coriaceous; stipes, rachises and under surface more or less densely covered with a tomentum of long, ferrugineous hairs, the younger portions of the fronds very densely tomentose. Specimens in the Buitenzorg herbarium have the fronds with the axillary buds copiously developed and without stipulae, as in Protogleichenia.

Java, Celebes, Ternate.

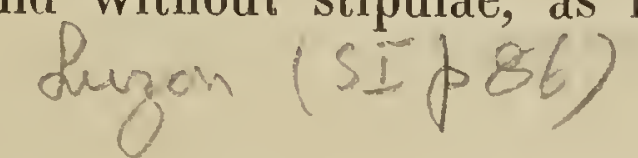

* (14) C. vestita, Bt., Rac., Flor. Btz., I, 11; - var. paleacea, Bk. in Journ. of Bot., XVII, 38.

Frons forked, $1 / 2-1$ M. long. Forkings $1-5 \times$ forked again, the lowest internodations 2 - 5 c.M. long, leafy. Terminal lranches $10-25$ c.M long. Ultimate segments approximate, oblong to triangular-oblong, $71 / 2-121 / 2 \mathrm{~m} . \mathrm{II}$. long, $21 / 2-6{ }^{1 / 2}$ m.M. broad, entire, obtuse, \pm erecto-patent Texture chartaceous to coriaceous; under surface glaucous; rachises and costae densely covered with yellow or ferrugineous, fimbriate scales. Capsules $\mathbf{3}$ -

Var. paleacea: Scales of the rachises linear-subulate Malaya.

\section{S 3. MERTENSIA, b. Protogleichenia ( $\left.{ }^{*}\right)$.}

a. Lowest pinnae forked, the forkings unbranched or once or more times forked again. Texture herbaceous.

(15) G. Hallieri.

a.a. Lowest pinnae pinnate, the pinnulae variously branched. Texlure \pm coriaceous.

b. Pinnulae dichotomously forked like the apex of the frond.

(16) G. amboinensis. $p>96$

b.b. Pinnulae pinnate, the tertiary divisions pseudo-dichotomous like the apex of the frond.

(17) G.-dolosa.onit

* (15) C. Hallieri, Christ, Ann. Btz., XX, 138.

Fronds pinnate, the rachis castaneous, nearly glossy, covered with scattered, subulate, brown hairs. Pinnae flabellate, repeatedly dichotomous, \pm 20 c.M. long, \pm 30 c.M. broad, the internodations \pm 5 c.M. long. Ultimate branches

(') See also G. hispida, Mett. 
\pm 15 c.M. long, \pm 2 c.M. broad, linear-lanceolate, acuminate. Segments of the last internodes but one, abbreviate, deciduous, those of the ultimate branches pectinate, erecto-patent, not imbricate, linear-lanceolate, \pm 1 c.M. long, \pm 2 m.M. broad, bluntish, entire. Texture thinly herbaceous, weak; veins inconspicuous, forked; surfaces covered with few, scattered hairs, nearly naked, Sori fugacious.

Borneo.

\section{* (16) T. amboinonsis, v. A. v. R.}

Fronds pinnate, \pm 50-100 c.M. long, the main and secondary rachises deciduously tomentose or furfuraceous, at length naked, the apex of the frond 3-4 $\times$ dichotomous. Pinnae 2-3-jugate. Lowest pinnae erecto-patent, once pinnate again, the apex dichotomously forked as are the pinnulae. Highest pinnae $2-3 \times$ dichotomous. All the forkings (not the pinniform primary branchings) leafy and clothed beneath with 2 opposite rows of spreading, triangular, elongate, ciliate, pale-yellow-brown scales, which are roundish or cordate at the base. Ultimate segments subspreading, linear-oblong, $1-2$ c.M. long, $\pm 2 \mathrm{~m}$.M. broad, the apex bluntish and crenate, in \pm 20 -50 pairs on the ultimate forkings which are gradually narrowed towards the acuminate, broadly toothed apex. Leaflets of the lower forkings often reduced and \pm orbicular. T'exture subcoriaceous; under surface of the leaflets deciduously tomentose especially on the midribs, not rarely glaucous.

Amboyna (Teysmann, Boerlage No. 488), Buru (Binnendijk No. 155).

(17) C. Hosa, C. Chr., Ind. Fil.; Dicranopleris dolosa, Copel., Perk., Fragm. Philipp., 193, tab. IV, fig. C.

Rhizome creeping: the scales lanceolate-subulate, squarrose, dirty-brown. Stipes erect, $\pm 1-2$ M. long, terete, firm, black-brown, scaly near the base. Fronds \pm 1 M. long, deltoid, pinnate, subdichotomous at the apex. Pinnae 5-5-jugate, the lower ones 2-pinnate again. Highest pinnae and tertiary branches in the lowest part of the frond repeatedly pseudo-dichotomous, the forkings leafy, cut down nearly or quite to the rachis. Ultimate segments 10-12 m.M. long, \pm 2 m.M. broad, close, entire, obtuse, 50-80 on each side of the ultimate forkings. Texture coriaceous, surfaces naked or nearly so; under surface bluish-glaucous; rachises clothed with distant, spreading, brown or whitish scales. Capsules fugacious, $5-5$ to a sorus.

Philippines. 
FAMILY IV. HYMENOPHYLLACEAE. 



\section{HIYMENOPHTITACOEAT.}

Sori marginal, terminal on the veins, exserted or immersed in the substance of the frond. Receptacle erect, oblong, capitate, malleiform, clavate or columnar-filiform, included or exserted. Sporangia dense, imbricate, compressed, surrounded by a broad, horizontal or subhorizontal, complete ring, opening vertically. Indusium inferior, 2-valved or \pm tubular to obconical with the mouth truncate, dilated or \pm 2-lipped, mostly of the same texture as the frond, opening outwardly.

Rhizome frequently creeping. Fronds often small and membranaceous, rarely subcoriaceous; veins free.

Tropical and subtropical, rarely inhabiting cooler climates.

Key to the genera.

*. Indusium more or less deeply 2-valved; receptacle mostly included; surface of the sporangia divided into many, uniform cells.

\section{No. 8. Hymenoplinyllum.}

*.*. Indusium tubular or funnel-shaped, the mouth sometimes 2-lipped; receptacle mostly exserted; surface of the sporangia divided into few, unequal cells.

No. 9. Trichomanes.

\section{HXVENOPIIYITUUM, Smäth.}

Sori marginal, terminal on the veins. Indusium more or lese deeply 2-valved, of the same texture as the frond, exserted or more or less immersed in the margin. Receptacle mostly short and included, rarely elongated and prominent beyond the sporangia. Surface of the sporangia divided into many, uniform cells.

Rhizome mostly creeping, often filiform. Fronds generally small, delicately membranaceous, more or less compoundly divided, with mostly linear or linearoblong ultimate segments. Hk. Bk., Syn. Fil., tab. II, fig. 16; Diels, in Engl. \& Prantl, Nat. Pfl.Fam., I ${ }^{4}$, lig. 74.

Tropical, and extra-tropical in the southern, rarely in the northern hemisphere.

Filiaes. 
Arrangement of the sections.

$\mathbb{S}$ 1. EUHYMENOPHYLLUM. Ultimate segments of the fronds entire.

S 2. LEPTOCIONIUM. Ultimate segments spinuloso-denticulate.

\section{$\$ 1$. EUHYMENOPHYLLUM.}

c. Fronds naked.

b. Main rachis not winged, or winged towards the apex only.

c. Fronds under 5 c.M. long.

c.c. Fronds more than 5 c.M. long.

d. Ultimate segments crisped or complicate.

d.d. Ultimate segments flattened.

e. Pinnae rather distant.

e.e. Pinnae rather imbricating.

f. Ultimate segments emarginate at the apex. Valve's of the indusium slightly repand. (4) H. modestum.

f.f. Ultimate segments entire as are the valves of the indusium.

(马) H. flabellatum.

b.b. Main rachis winged throughout.

1. Valves of the indusium more or less toothed at the outer edge.
5. Edges crisped.
(6) H. australe.

\$.\$. Edges not crisped.

*. Main rachis slightly winged.

(7) H. demissum.

(8) H. subdemissum.

*.*. Main rachis broadly winged.

1.1. Valves of the indusium 'entire, or rarely crenate at the apex.

2. Fronds mostly 2-5 c.M. long.

* Sori numerous on the higher pinnae. Receptacle included.

(10) H. paniculiflorum.

+. Sori solitary on the higher pinnae. Receptacle exserled.

(11) H. ringens.

2.2. Fully developed fronds mostly 5-15 c.M. long. H. pifosusis 5. fag

3. Edges crisped.

(12) H. thuidium.

3.3. Edges not crisped.

4. Stipes winged \pm throughout. (15) H. salakense.

4.4. Slipes nol winged, or winged towards the apex only. 
8. HYMENOPHYLLUM. $\$ 1$. EUHYMENOPHYLLUM.

5. Indusium obovate, narrowed at the apex.

(14) A. Blumeanum.

5.5. Indusium oblong, the apex bluntly rounded or subtruncate.

6. Pinnae $\pm 4-5$ on each side. Indusium exserted, deeply 2-valved. (15) H. Treubii.

6.6. Pinnae $\pm 6-8$ on each side. Indusium immersed, cut 1/2-way down. (16) H. rarum.

2.2.2. Fully developed fronds more than 15 c.M. long.

+. Ultimate segments 1-11/2 m.M. broad. Receptacle globosocapitate.

$+\div$ Ultimate segmenls $11 / 2-2$ m.M. broad. Receptacle mallei-

$$
\text { form. }
$$

a.a. Fronds hairy or ciliate, at least on the central veins.

(18) H. Junghuhnii.

6'. Central ribs of the segments purveyed with 2 wing-like, crisped crests.

+. Ribs slightly crested. Fronds rather long. (19) H. Zollingerianum.

+. . Ribs broadly crested. Fronds rather short.

$\boldsymbol{b}^{\prime} . \boldsymbol{b}^{\prime}$. Central ribs not crested.

(20) H. fuscum.

$$
\text { H. Cameviation S /2 q }
$$

c'. Fronds under 5 c.M. long, \pm 1 c.M. broad. (21) H. borneense.

$\boldsymbol{c}^{\prime} . \boldsymbol{c}^{\prime}$. Fully developed fronds mostly 5-10 c.M. long, 1-5 c.M. broad.

$\boldsymbol{d}^{\prime}$. Fronds under 2 c.M. broad. Indusium free, cleft nearly to the base.

$\boldsymbol{a}^{\prime} \cdot \boldsymbol{d}^{\prime}$. Fronds more than 2 c.M. broad. Indusium rather slightly immersed, cleft $\pm 1 / 2$-way down.

$\boldsymbol{c}^{\prime} \cdot \boldsymbol{c}^{\prime} \cdot \boldsymbol{c}^{\prime}$. Fully developed fronds more than 10

broad.

(25) H. obtusum.

(24) H. pachydernicum. 
naked, $10-15$ c.M. long, to $21 / 2$ c.M. broad; rachis filiform. Pinnae very numerous, lanceolate, erecto-patent, the central ones the largest, usually simply pinnate, rarely 2-pinnate. Ultimate divisions obovate, obtuse, 1-nerved, emarginate, crowded, \pm 2 m.M. long, more or less crisped or complicate. Sori small, terminal on the ultimate divisions; indusium immersed at the base, the valves cuneate, with the outer edge rounded.

New Guinea.

* (3) H. eximium, Kae, V. D. B., Hymen. Jav., 57, tab. XLVI; H. dilatatum, Sw., Rac., Flor. Btz., I, 17, p.p.; C. Chr., Ind. Fil.

Rhizome creeping, naked. Stipes 7-10 c.M: long, firm, terete, not winged. Fronds $\pm 10-13$ c.M. long, $5-8$ c.M. broad, ovate or deltoid-oblong; main rachis narrowly winged towards the apex, terete, angular or marginate in the lower part. Pinnae rather distant, ovate, acuminate to caudate, cut down to a winged rachis, short-stalked. Pinnulae erecto-patent, cut down to a winged rachis into linear, simple, forked or branched segments 2-10 m.M. long, $\pm 1-1 \frac{1}{2}$ m.M. broad. Sori small, terminal on short segments, $2-12$ to a pinna; receptacle clavate-oblong; indusium deeply 2-valved, the valves obovate, with the outer edge minutely and obscurely eroso-denticulate.

Java, Sumatra. Luzon, mindero, hagres

(4) N. modestam, W. D. B., Ned. Kruidk. Arch., V ${ }^{3}, 163$.

Rhizome creeping. Stipes terete, fiexuose, $5-7$ c.M. long. Fronds \pm 10 c.M. long, 4-5 c.M. broad, oblong, narrowed at the base, pimnate, the apex pinnatifid. Pinnae oblong, broadly cuneate at the base, spreading or divaricating, the lowest remote, the rest contiguous, imbricate, slightly decurrent on the rachis, sub-2-pinnatifid. Segments obcuneate, contiguous, erectopatent, the lower ones pimatifid, the other ones 1-3-furcate; lacinulae short, nearly straight, slightly undulate, emarginate at the apex. Texture membranaceous; colour olivaceo-fuscous, subopaque; main rachis flexuose; veins straight, slender. Sori terminal on the lacinulae; indusium oblong, conical at the base, 2-valved $\pm 3 / 4$-way down, the valves narrowly rounded, slightly repand; receptacle cylindrical.

Philippines.

"(5) H. Mabellatum, Lab., Hk. Bk., Syn. Fil., 61; H. nitens, R. Br., Hk. \& Grev., Ic. Fil., tab. CXCVII.

Rhizome creeping. Stipes $b-1 B$ c.M. long, firm, erect. Fronds $10-30$ 
c.M. long, $2 \frac{1}{2}-\cdots 10$ c.M. broad, ovate, acuminate; main rachis winged above. Pinnae rather imbricating; the lower ones distant, broadly rhomboidal-acuminate, subflabellate, erecto-patent or subspreading, divided down to a broadly winged rachis into several cuneate-based pinnulae which are forked or pinnatifid with several simple or forked to pinnatifid segments on each side. Texture flaccid; surfaces somewhat glossy. Sori $6-20$ to a pinna, terminal on the segments; indusium divided more than $1 / 2$-way down, the valves entire, rounded, the base cuneate; receptacle columnar-oblong. - Ultimate segments not emarginate at the apex, entire.

? Sumatra,? New Guinea, Batjan; Australia, New Zealand, Samoa.

spr. ${ }^{*}$ (6) H. australe, willd., Christ, Farnkr. d. Erde, 17; Diels, in Engl. \& Prantl, Nat. Pfl.Fam., I', fig. 74, C; H. javanicum, Spr., Rac., Flor. Btz., I, 17; V. D. B., Hymen. Jav., tah. XL; II. micranthum, V. D. B., H. erosum, Bl., H. fimbriatum, J. Sm., V. D. B., l. c., tab. XLI, XLIII \& XLIV; - var. atrovirens; II. atrovirens, Colen., Tasm. Journ., II, 186; H.tasmanicum, V. D. B., Ned. Kruidk. Arch., IV, 399.

Rhizome wide-creeping, slender, naked or nearly so. Stipes 3-7 c.M. long, erect, margined with a broad, crisped wing, except at the base. Fronds 5-20 c.M. long, 5-10 c.M. broad, ovate to deltoid, 3-4-pinnatifid, main \& secondary rachises provided with a \pm broad wing. Lower pinnae oblong or deltoid-obovate, erecto-patent. Pinnulae oblong, cut down to a crisped wing into simple or bifid segments, which are naked, entire, crisped, \pm 1 m.M. broad. Sori $\pm 6-20$ to a pinna, terminal on the ultimate segments; indusium to $1 \mathrm{~m}$.M. broad, divided down nearly to the hase, the valves roundish or oblong, with the outer edge denticulate; receptacle \pm filiform, included.

Var. atrovirems: Segments nearly plane.

Malaya; North. India, Australia, New Zealand, Antarct. Isles.

* (7) H. Iemissum, Sw., Hk. Bk., Syn. Fil., 61; II.productum, Kze, Rac., Flor. Btz., I, 17; V. D. B., Hymen. Jav., tab. XLV.

Rhizome filiform, creeping, naked. Stipes b̆-15 c.M. long, erect, firm, wingless or narrowly winged above. Fronds ovate-triangular to elongate, 6-50 c.M. long, $\mathbf{3} \frac{1}{2}-10$ c.M. broad, 5- or 4-pinnatifid; main rachis slightly winged. Lower pinnae $2.1 / 2-71 / 2$ c.11. long, triangular-rhomboidal, divided down very nearly to the rachis into numerous pinnulae on each side, which are again divided down nearly to the rachis into pinnatifid segments. Ultimate lobes $2 \frac{1}{2}$-5 m.M. long, $\pm 1 \frac{1}{2}$ m.M. broad. Sori very numerous, 
20-50 to a pinna, on both sides and terminal on the segments; indusium divided down nearly to the base, the valves ovate to lanceolate, the outer edge denticulate (in malayan material).

Malaya; P'olynesia, New Zealand.

$$
\text { onit = H. pyencearfiun. }
$$

(8) H. subriemissum, Christ, Bull. Herb. Boiss., VI, 140.

Like H. demissum, Sw. but the dimensions $1 / 2 X$ as long; stipes and rachises tender, flexuose, filiform; the segments short, narrowed, less numerous, distant; the valves of the indusium minute.

Philippines.

(9) H. Dndium, Im. Grev., Hk. Bk., Syn Fil., 60; Hk. \& Grev., Ic. Fil., tab. LXXVI; Bedd., Ferns Br.I., II, tab. CGLXXXII; H. javanicum, Spr., var. badium., Bedd., Handb. Ind. Ferus, 53.

Stipes $5-7 \frac{1}{2}$ c.II. long, slender, winged above. Fronds $10-50$ c.M. long, $5-71 / 2$ c.ll. broad, oblong or ovate-lanceolate, acuminate, 5-pinnatifid; main rachis broadly winged. Iower pinnae lanceolate-rhomboidal, divided down to a broadly winged rachis into several pinnules on each side, the lowest of which are a few times deeply incised. Ultimate divisions broadly linear. Sori 2-12 to a pinna, on hoth sides and terminal on the segments; indusium nearly $2 \frac{1}{2}$ m.Ml. broad, divided down nearly to the hase, the valves rounded, nearly $2 X$ as broad as long, the outer edge loothed; receptacle very short.

Malacea; Himalaya.

" (10) H. paniculiflorum, Pr., Rac., Flor. BL., I, 16; V. D. B., Hymen. Jav., tah. XXXIX.

Rhizome filiform, sparingly hairy, Stipes naked, slender, 1-马̆ c.M. long, naked, winged above. Fronds ovate to lanceolate-oblong, 2-b̆ c.M. long, 1$21 / 2$ c.M. broad, cut down to a narrowly winged rachis. Pinnae spreading or erecto-patent, ovate or suhorbicular, deeply pimnatifid. Pimulae simple, forked or pimnatifid again. Ultimate segments to $5 \mathrm{~m}$.M. long, $\pm 1 / 2 \mathrm{~m}$. M. broad. Colour reddish or hrownish. Sori numerous, confined to the uppermost pinnae, very close as to form a panicle; indusium large, reddish, elliptical or hroadly hovate, $\pm 2 \mathrm{~m} . \mathrm{Y}$. long, $\pm 1 \mathrm{~m}$. M. broad, joined in the lower half, the valves entire; receptacle schort-columnar, included.

Malaya; Japan.

(11) H. ringens Christ, Ann. Btz., XIX, 54.

Rhizome filiform. Stipes slender, $\pm 1 \frac{1}{2}$ c.ll. long. Fronds ovate-elongate, 
$\pm \quad 3$ c.M. long, $1_{12}^{1}-2$ c M. broad, cut down to a winged rachis into $4-7$ segments on each side, the base narrowed and decurrent. Segments ovate, obtuse, deeply incised. Lobes linear, obtuse, entire, 2-4 on each side, \pm 1 m.II. broad. Texture firm; colour dark-brown; both surfaces nearly naked. Sori solitary on the superior primary segments, exserted, often short-stalked; indusium campanulate, deeply 2-valved; valves triangular, entire, acute, at length reflexed; receptacle $5 \mathrm{~m}$. H. long, broad, exserted.

Celebes.

(12) H. thuidinum, Harr., Journ. of Linn. Soc., Bot., XVI, 25.

Stipes slender, $21 / 2-7 \%$ c.II. 'long, winged. Fronds $5-121 / 2$ c.M. long, $21 / 2$ - 5 c.M. broad, ovate to oblong, 3-4-pinnate, erect; rachis and branches winged like the slipe. Pinnae to $\pm 21 / 2$ c.M. long, deltoid; wings and ultimate divisions finely crisped throughout. Surfaces naked. Sori few to many in the upper part of the frond, on the ends of the ultimate divisions, large; indusium divided nearly to the base; valves large, ovate, crisped.

Philippines.

* (15) H. salakense, Rac., Flor. Btz., I, 18.

Rhizome wide-creeping, slender, sparingly pilose. Stipes distant, $4-8$ c.M. long, winged throughout or nearly so. Fronds lanceolate or ofovate, 5-15 c.M. long, 5-10 c.H. broad, sometimes subdeltoid; main rachis broadly winged. Pinnae erecto-patent, cut down to a broadly winged rachis into simple, forked or $2 \times$ forked pinnulae. Ultimate segments $5-15 \mathrm{~m}$.ll. long, 2-5 m.M. broad, linear or oblong, bluntly rounded or emarginate at the apex. Surfaces naked; a single central rib in each segment. Sori terminal on the segments; indusium deeply 2-valved; valves roundish or transversely oblong, entire, broader than the segments, to $5 \frac{1}{2}$ m.M. broad; receptacle malleiform. Java.

* (14) H. BHanmeanum, Spr., Rac., Flor. Btz., I, 16; V. D. B., Hymen. Jav., tab. XXXVI; Bedd., Ferns S.I., tab. CGLXVI; H. pycnocarpum \& integrum, V. D. B., l. c., tab. XXXVII-XXXVIII; H. polyanthos, Sw., Hk. Bk., Syn Fil., 60, p. p.

Rhizome filiform, creeping. Stipes slender, 1-4 c.M. long, not rarely marginate, not winged, or winged in the upper half only. Fronds offovate to lanceolate or even linear, $\breve{5}-15$ c.M. long, $\pm 1-7$ c.II. broad; main rachis narrowly winged. Central pinnae the longest, oblong or lanceolate, deltoid or rlom- 
boidal, cut down to a winged rachis into simple or once or more times divided segments on each side. Ultimate lobes $\pm 2-4 \mathrm{~m} . M$. long, $1 / 2-1 \mathrm{~m} . M$. broad, entire, each with a single central rib. Surfaces naked. Sori on the higher

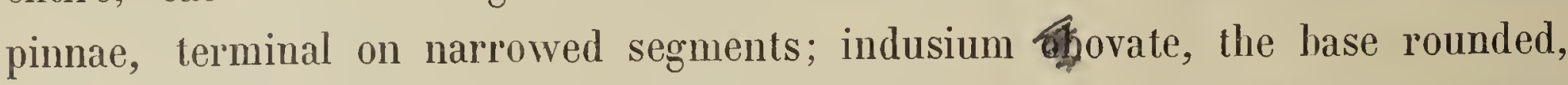
the valves entire, narrowed towards the apex; receptacle linear, not exserted. Trop. Asia.

* (15) Wr. 'Treubii, Rac., Flor. Btz., I, 15; Nat. Tijdschr. Ned. Ind., LIX, tab. III.

Rhizome slender, wide-creeping, sparingly hairy. Stipes filiform, distant, $2-3$ c.M. long, sligthly winged towards the frond. Fronds \pm ovate in general outline, $\breve{3}-8$ c.M. long, $\bar{\jmath}-\breve{y}$ c.II. broad; main rachis flexuose, narrowly winged. Pinnae erecto-patent, to $4-5$ on each side, cut down to a winged rachis into $\pm 5-5$ simple, forked or pinnatifid pinnulae. Ultimate segments oblong or linear, $2-15 \mathrm{~m} . \mathrm{H}$. long, $\pm 2 \mathrm{~m} . \mathrm{M}$. broad, the apex often emarginate. Surfaces naked; a single central rib in each segment. Sori terminal on short segments; indusium deeply 2-valved; valves suboblong, the apex rounded or subtruncate, entire, or slightly and irregularly erose; receptacle erect-oblong.

Java.

(16) H. rarum, $\boldsymbol{R}$. Br., Hk. Bk., Syn. Fil., 58; Kze, Farnkr., I, tab. XCVI, fig. 1 ; H. semibivalve, H/. \& Grev., Ic. Fil., tab. LXXXIII.

Stipes very slender, $21 / 2-8$ c.I. long. Fronds flaccid, pendent, $\breve{b}-1 \breve{b}$ c.M. long, $21 / 2--$ b c.M. hroad, linear-oblong, 2-pinnatifid, the main rachis winged throughout. Pinnae simple, linear, or forked to pinnatifid with $2-5$ deeply cut segments on each side, which are $1 / 2-11 / 2$ c.M. long, $\pm 21 / 2$ m.I. broad. Sori large, terminal on the segments of the upper pinnae, often $2 \frac{1}{2} \mathrm{~m}$. I: broad; indusium divided $1 / 2$-way down or more, the base cuneate, the valves rounded; receptacle erect-oblong.

? Malacca; Tasmania, New Zealand.

* (17) CI. formosum, Bracks, V. D. B., Hymen. Jav., 59, tab. XLVII-XLVIII; H. dilatatum. Sw., Rac., Flor. Btz., I, 17, p. p.; G. Chr., Ind. Fil.

Rhizome creeping, hairy. Stipes $\mathfrak{b}-10$ c.M. long, mostly narrowly winged. Fronds $13-30$ c.M. long, or to 40 c.M. long, \pm b-10 c.M. broad; main rachis winged throughout. Pinnae erecto-patent, cut down to a winged rachis, short-stalked. Pinnulae erecto-patenț, deeply pinnatifid again into linear, simple, 
forked or branched ultimate segments $2-10 \mathrm{~m} . \mathrm{M}$. long, $\pm 1-1 \frac{1}{2} \mathrm{~m}$.M. broad. Sori terminal on short lobes, $2-12$ to a pinna; receptacle globosocapitate; indusium deeply 2-valved, the valves orbicular or oblong-ovate, entire or slightly emarginate at the apex.

Malaya; Polynesia, Trop. Australia, New Zealand.

* (18) H. Dunghulenii, V. D. B., Rac., Flor. Btz.; I, 18; V. D. B., Hymen. Jav., tah. XLIX; H. dilatatum, Bl., Enum., 221.

Rhizome wide-creeping, sparingly hairy. Stipes $5-12$ c.M. long, furnished at the base with few, short, brown, spreading, deciduous hairs, narrowly and shortly winged ahove. Fronds 3-4-pinnatifid, linear-ovate, 15-25 c.M. long, sometimes shorter, 4-10 c.M. broad; rachises more or less broadly winged. Pinnae erecto-patent, to \pm 10 c.M. long and to \pm 2 c.M. broad. Pinnulae erecto-patent; to $\pm 11 / 2$ c.l. long, to $\pm 5 \mathrm{~m}$.M. broad, cut down into $1-3$ simple or bifid, erecto-patent ultimate segments $3-12 \mathrm{~m}$.M. long, $1 \frac{1}{2}-2$ m.M. broad. Sori terminal on lateral segments; indusium roundish, transversely oblong or reniform, $1 \frac{1}{2}-21 / 2$ m.M. long, $2-3 \mathrm{~m} . M$. broad, the outer edge rounded, entire; receptacle malleiform.

Sumatra, Java to Polynesia.

* (19) H. Zollingerianum, Kze, Hk. Bk., Syn. Fil., 62; V. D. B., Hym. Jav., tab. L.; (H. fuscuin, V. D. B., Rac., Flor. Btz., I, 19, p. p.).

Rhizome creeping, \pm hairy. Stipes $5-10$ c.M. long, deciduously hairy. Fronds lanceolate and 10-20 c.M. long or linear and 20-40 c.M. long, acuminate. Pinnae rather distant, $1-21 / 2$ c.M. long, 7-15 m.M. broad, the lower ones triangular or oblong, acute or rounded at the apex, divided more than $1 / 2$-way down into oblong, erecto-patent, deeply pinnatifid segments. Ultimate lobes linear-oblong, $\pm 1 \mathrm{~m}$.M. broad. Rachis narrowly winged, often slightly hairy; a singl central vein in each ultimate segment; veins \pm hairy and slightly crested like the rachises. Sori $2-8$ to a pinna, large, terminal on lateral segments; indusium ovate, divided $\pm 1 / 2$-way down, the mouth rounded, entire; receptacle mostly short.- An abnormal form has the upper pinnae much elongated.

Java.

* (20) H. fuscum, W. D. B., Rac., Flor. Btz., I, 19, p. p.; V. D. B., Hymen. Jav., 62, tab. LI-LII.

Rhizome filiform, creeping, hairy. Stipes $3-7$ c.M. long, hairy. 
Fronds deltoid-Govate or triangular-lanceolate, with a broadly winged rachis, 6-16 c.M. long, 4-5 c.M. broad, 3-pinnatifid. Pinnae moderately close, 1-2 c.M. broad, lowest largest, with a winged rachis, ovate-oblong in outline. Pinnulae close or imbricating, pinnatifid. Segments simple or forked, with a single central vein in each ultimate segment. Veins hairy and purveyed with long and broad, undulate and crisped, entire crests like the rachises. Sori terminal on lateral segments, 1 or more to a pinna; indusium ovate, divided about $1 / 2$-way down; valves entire; receptacle exserted, filiform.

Malaya.

(21) DE. Dormeense, H\%., Hk. Bk., Syn. Fil., 62.

Stipes $\pm 2 \frac{1}{2}$ c.M. long, very slender. Fronds square or fan-shaped in general outline, $\pm 1-2$ c.M. long, \pm 1 c.M. broad, divided down like a fan nearly to the base, the divisions linear, dichotomously branched. Ultimate segments $2^{1} / 2-71 / 2$ m.M. long, $\pm 1 \mathrm{~m}$. . . broad; the surface hairy and the margin ciliate with branched, rufous hairs. Sori terminal, solitary, orbicular, the cuneate base sunk in the frond; valves ciliate.

Borneo.

(22) H. pedicularifolinm, ces., Fel. Becc. Polin., 2 \& 6.

Fronds subsessile, b́-10 c.M. long, $1-1 \frac{1}{2}$ c.M. broad, pendulous, oblong in general outline, pinnatifid to within a short distance of the costa. Lower lobes rhomboidal-cuneate, cleft on both sides, or on one side only; upper lobes simple, linear-oblong, the margin undulate or crisped, the costulae beneath covered with reddish hairs. Sori terminal on the segments of the lobes; indusium free, cleft nearly to the base.

New Guinea.

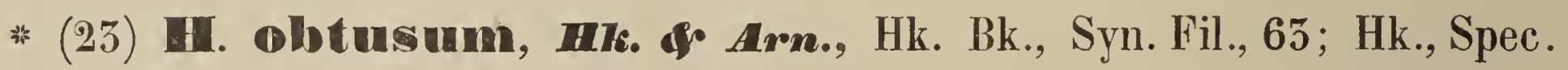
Fil., I, tab. XXXIII, D.

Stipes filiform, to 5 c.II. long, ciliate. Fronds $5-10$ c.II. long, $21 / 2-\breve{z}$ c.M. broad, oblong or lanceolate-oblong; main rachis winged troughtout, but sometimes nudate in the lower part. Pinnae lanceolate, oblong or cuneateoblong, deeply pinnatifiid into few or several simple, or forked segments on each side. Ultimate lobes linear or oblong, bluntly rounded. Texture very thin; margin and central ribs as well as the rachises densely clothed with stalked, stellately branched hairs. Sori $2-6$ to a pinna, terminal on the 
lateral segments; indusium as broad as the segments, divided $\pm 1 / 2$-way down; valves rounded, strongly ciliated, the base \pm cuneate, immersed.

Borneo, Philippines, New Guinea; Hawaii.

(24) H. pachydermicum, Ces., Fel. di Bor., 8.

Rhizome slender, intricate, covered with brown bristles. Stipes slender, \pm setulose, $1-5$ c.I. long. Barren fronds short, subflabellate, as broad as long; fertile ones oblong or lanceolate, \pm 20 c.II. long, 10-15 c.Mr. broad. Primary segments obtuse or truncate, obovato-linear. Lobes $\mathbf{5}-5$ to a segment, densely barbate at the apex in the barren bronds. Under surface covered with short, brown hairs, especially on the veins. Sori immersed; valves of the indusium ovate, acute; receptacle filiform, exserted.

Borneo.

\section{\$) 2. LEPTOCIONIUM.}

a. Fronds 3-partite, subflabellate.

(25) H. subflabellatum.

a.x. Fronds pinnately divided.

b. Edges not crisped.

c. Main rachis narrowly marginate.

(26) H. edulentum.

c.c. Main rachis distinclly winged troughout or nearly so.

d. Sori terminal on the main or higher secondary rachises.

e. Valves of the indusium hardly toothed. (27) H. Kurzii.

e.e. Valves of the indusium subulate-dentate. (28) H. Lobbii.

d.d. Sori axillary on the anterior side of the pinnae.

*. Indusium without crests at the base.

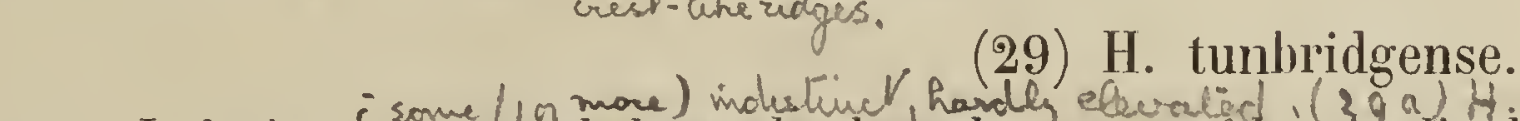

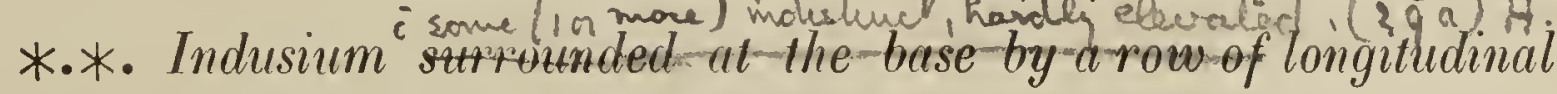

$$
\text { cresta like ridges ot the Base }
$$

(30) H. holochilum.

mhinulation $x$ c.c.c. Main rachis not winged, or winged in the upper half only.

d'. Valves of the indusium toothed.

$\boldsymbol{d}^{\prime} \cdot \boldsymbol{d}^{\prime}$. Valves of the indusium entire.

e. Fronds under 5 c.M. long.

(32) H. praetervisum.

$\boldsymbol{e}^{\prime} \cdot \boldsymbol{e}^{\prime}$. Fully developed fronds 5-20 c.M. long.

$f^{\prime}$. Veins paleaceo-hirsute.

(35) H. violaceum.

$\boldsymbol{f}^{\prime \prime} \cdot \boldsymbol{f}^{\prime}$. Veins naked.
(51) H. blandum.

H herrula $p>95$

$\boldsymbol{g}^{\prime}$. Indusium short-2-lipped, the lips rounded.

(34) H. multifidum. 
$\boldsymbol{g}^{\prime} \cdot \boldsymbol{g}^{\prime}$. Indusium divided $1 / 2$-way down, the lips narrowed at te apex.

(5ら) H. serrulatum.

b.t. Edges crisped.

1. Indusium quite naked on the back.

2. Fronds under 8 c.M long; valves of the indusium elliptical.

(56) H. fraternum.

2.2. Fronds more than 8 c.M. long; valves of the indusium \pm orbicular.

3. Edges blunlly dentate, the teeth not deep.

(37) H. Reinwardtii.

3.3. Edges aculeate-dentate, the teeth deep.

1.1. Indusium spinulose on the back. Throughout

(58) H. physocarpum.

*. Edges of the segments deeply toothed nearly to the midribs.

(59) H. sabinifolium.

*.*. Edges not deeply toolhed.

1.1.1. Indusium surrounded by irregularly spinoso-dentate, transversal crests. apposasiagse, on the back at the base.

2'. Valves of the indusium serrate or dentale.

3'. Fronds 5-8 c.M. long. Indusium divided $\pm 2 / 3-w a y$ down. values retive. denticielate (41) H. denticulatum.

3'.3'. Fronds $2^{1 / 2}-5$ c.M. long. Indusium divided $\pm 1 / 3$-way down. valves shorply torothed. (42) H. aculeatum.

2'.2'. Valves of the indusium entire. (4.5) H. bismarckianum. 1.1.1. 1. Indusium surstorded by a now-of rather close, longitudinal crests at the base.

(44) H. brachyglossum.

(25) 4h. subflabellatum, Ces., Fel. di Bor., 8.

Rhizome creeping, branched, laairy. Stipes slender, $5-10$ m.M. long, not winged. Fronds $\breve{5}-\mathbf{1 0}$ m.M. long, 5-partite, nearly flabellate. Primary segments \pm pinnatifid. Lobes linear, obtuse, distant, spinuloso-denticulate. Sori terminal on the lohes; indusium ovate, with the edges of the valves spinuloso-ciliate; receptacle exserted.

Borneo.

(26) H. edulentum, C. Chr., Ind. Fil.; Leptocionium edulentum, V. D. B., Ned. Kruidk. Arch., V ${ }^{3}, 148$. 
Rhizome creeping, nearly naked, filiform. Stipes filiform, terete, $1 \frac{1}{2}-21 / 2$ c.M. long. Fronds 4-bै c.M. long, 2-21/2 c.M. broad, ovate or ovate-oblong, broadly rounded at the base, narrowed towards the apex, the main rachis narrowly marginate, subterete below. Pinnae spreading, (the lower divaricating), subcontiguous, suboblong, the apex adscendent. Pinnulae spreading, subremote, simple or dichotomous, the lowest pinnatifid. Lacinulae linear, olongate, approximate, flat, the apex entire, the margin subentire ${ }^{\circ}$ denticulate, the teeth small, remote. Texture membranaceous, diaphanous, firm; colour olivaceofuscous; main rachis flexuose; veins straight, blackish-brown. Sori on the lacinulae; indusium moderately immersed, elliptical, turgid, 2-valved $\pm 1 / 2$-way down, the valves entire or obscurely denticulate; receptacle setiform.

Borneo; Assam.

* (27) W. KEn

Main rachis narrowly winged, the wing entire, not toothed. Ultimate segments toothed. Sori terminal on the main and higher secondary rachises, the valves of the indusium hardly toothed. - If this plant is the same as lately found by the Ladies von Grävenitz and Stein, the description will be: Rhizome creeping, filiform, sparingly hairy. Stipes distant, more than \pm 1 c.M. apart, sparingly hairy, 1-2 c.II. long, narrowly winged (rather marginate) towards the frond. Fronds lanceolate-oblong to subdeltoid-6tovate, $4-5$ c.M. long, $1 \frac{1}{2}-21 / 2$ c.M. broad; main rachis narrowly winged, the wing entire, not toothed. Pinnae cut down to a winged, not toothed rachis into linear, simple or forked segments, which are blunt at the apex, toothed at the margin. Texture thin, hyaline; under surface covered with scattered, spinelike hairs on the costae. Sori terminal on the main and higher secondary rachises and some anterior segments of the higher pinnulae; indusium oblong, the laise conical, covered with spine-like hairs on the under side, the valves subacute, slightly toothed at the point; receptacle linear, slightly exserted.

Java.

(28) H. Lobloii, Moore, V. D. B., Ned. Kruidk. Arch., V', 176.

Rhizome filiform, branched, hirsute with deciduous, yellowish hairs. Stipes filiform, terete, flexuose, $10-15$ m.M. long. Fronds 3-4 c.M. long, 6-8 m.M. broad; main rachis narrowly winged by the decurrent pinnae, filiform, flexuose. Pinnae narrow, spreading, slightly incurved, contiguous, obcuneate, eilher 1-2-furcate, or pinnatifid with a single lacinula on each 
side. Lacinulae subfastigiate, narrow, linear, flat, the margin serrate, the teeth remote, subulate, elongate. Texture membranaceous, rather firm; colour reddish-brown, subopaque. Sori small, terminal on the frond; indusium tubular, compressed, 2 -fid \pm to the base, the valves truncate-rotundate and unequally subulate-dentate at the outer edge; receptacle setiform, thick.

Malaya; Assam.

(29) H. Cumbridgense, Sm., Hk. Bk., Syn. Fil., 67; Hk., Br. Ferns, tab. XLIII; Bedd., Ferns S.I., tab. CCLXV; Bau. \& Hk., Gen. Fil., tab. XXXII.

Stipes 1-4 c.M. long, winged in the upper part. Fronds oblong-lanceolate, $21 / 2-8$ c.M. long, $1-21 / 2$ c.M. broad; main rachis winged throughout. Pinnae distichous, subllabellato-pinnatifid, the lobes $21 / 2-71 / 2 \mathrm{~m} . \mathrm{M}$. long, and (as well as the usually, solitary, axillary, suborbicular indusia) spinuloso-serrate.

In the temperate etmetes and the cool, alpine regions of the tropics.

* (50) H. holochilam, C. Cher., Ind. Fil.; H. affine, Rac. (not Haffew V. D. B.), Flor. Btz., I, 20; H. Smithii, Hk., Hk. Bk., Syn. Fil., 69, p. p.; F F S. Leptocionium holochilum \& affine, V. D. B., Hymen. Jav., tab. XXXIV-XXXV. Rhizome slender, filiform, sparingly hairy. Stipes filiform, $2-5$ c.M. long. Fronds oblong to lanceolate-oblong, 4-10 c.M. long, $1 \frac{1}{2}-5^{1 / 2}$ c.M. broad; main rachis winged throughout or in the upper half only. Pinnae cut down to a winged rachis into $1-4$ simple or forked pinnulae. Ultimate segments \pm 2 m.M. broad, the margin toothed. Sori $1-4$ to a pinna, terminal on short lobes, occupying the anterior side of the higher pimnae; previded urth sauc (162 more) moles indusium Govate-oblong, the base \pm obconical, surrounded by a row of longitudinal crests the valves blunt, more or less distinctly denticulate, or quite entire.

Java.

* (31) M. Wlandum, Fac., Flor. Btz., I, 20.

Rhizome filiform, sparingly hairy. Stipes $1 \frac{1}{2}-21 / 2$ c.M. long, filiform, very slender. Fronds irregularly bovate, 2-4 c.M. long, 1-2 c.M. broad, simply pinnate or 2-pinnatifid, the rachis at best winged above. Lower pinnae short-stalked, often forked or pinnatifid, the higher ones commonly undivided, sessile with a narrowed base. Ultimate segments from $1-10 \mathrm{~m} . \mathrm{M}$. long. Sori terminal on the segments; indusium oblong, the valves with the apex blunt and toothed.

Java. 
(32) H. praetervisum, Christ, Farnkr. d. Erde, 21, fig. 26; Ts Trichomanes denticulatum, Bk., Hk. Bk., Syn. Fil., 82.

Rhizome slender, creeping. Stipes slender, naked, \pm b-12 m.M. long. Fronds $2 \frac{1}{2}-4$ c.M. long, to $1 \frac{1}{2}$ c.M. broad, ovate or oblong, 2-pinnatifid; main rachis winged above, nudate below. Pinnae pinnatifid down to a narrowly winged rachis. Ultimate segments linear, serrate, about 5 m.M. long, 1-2 m.M. broad; a single costa only in each segment. Sori 1 to a pinna, terminal on the lowest segments on the upperside; tube exerted, the mouth deeply 2-valved, the valves entire.

Borneo.

(35) H. violaceum, Meyen, MS. in Herb. Berol.; Leplocionium violaceum, V. D. B., Ned. Kruidk. Arch., V $3,147$.

Stipes flexuouse, terete, hirsute, 6-8 c.M. long. Fronds 8-10 c.M. long, 4-41/2 c.M. broad, oblong, acuminate. Pinnae spreading, oblong. Pinnulae erecto-patent, broad-oblong or obcuneate, rather remote or subdistant. Lacinulae straight, parallel, elongate, the margin minutely and irregularly denticulate. Texture firm; colour red-brownish, opaque; main rachis broadly winged above, the wing entire, flat; veins flexuose, all paleaceo-hirsute. Sori axillary, at length turned back on the frond (resupinate); indusium immersed, 2-valved $2 / 3-3 / 4$-way down, the tube cuneate, the valves broadly oblong, entire.

Philippines.

* (54) H. Inultifidum, Sw., Hk. Bk., Syn. Fil., 69; Hk. \& Grev., Ic. Fil., tab. CLXVII; H. llabatense, Christ, Fil. Saras., I, 4; II. polyanthos, Sw., var. dentatum, Ces., Fel. Becc. Polin., 2.

Stipes 5-10 c.M. long, wiry, naked. Fronds broadly ovate-lanceolate, 5-20 c.II. long, $21 / 2-121 / 2$ c.M. broad; main rachis naked or scaly, winged above. Pinnae and pinnulae rhomboidal-lanceolate, the rachises winged, \pm wavy. Ultimate segments linear, to $7 \frac{1}{2} \mathrm{~m} . \mathrm{M}$. long, to $1 \mathrm{~m} . \mathrm{M}$. broad, con-. spiculously dentate with short or less short teeth. Sori 2-12 to a pinna, terminal on the ultimate segments; indusium oblong, tubular below, the valves short, entire; receptacle sometimes exserted.

Philippines and Celebes to Polynesia; New Zealand, New South Wales.

(55) H. serrulatum, C. Chr., Ind. Fil.; H. Smithii, Hk., Hk. Bk., Syn. Fil., 69, p. p.; Hk., Spec. Fil., I, tab. XXXV, B; Bedd., Ferns Br.I., II, tab. CCLXX VII. 
Stipes $2 \frac{1}{2}-5 \quad$ c.M. long, wiry, naked or slightly tomentose. Fronds $7 \frac{1}{2}-20$ c.Ir. long, $5-71 / 2$ c.I. broad, oblong, acuminate, winged in the upper half, hairy below. Pinnae lanceolate-oblong, acuminate, cut down to a winged rachis into $\pm 8-10$ pinnulae. Highest pimulae simple, the lower ones to $4 \times$ forked. Ultimate segments linear or oblong, \pm 2 m.M. broad, the edges toothed. Sori $1-6$ to a pinna, occupying the anterior side of the pinnulae, terminal on short lobes; indusium oblong, divided $\pm 1 / 2$-way down, the valves entire.

New Guinea, Philippines, Malacca.

(36) H. fraternum, Harr., Journ. of Linn. Soc., Bot., XVI, 26; H. Steerei, C. Chr., Ind. Fil.

Stipes slender, \pm 5 c.I. long, winged. Fronds $\pm 6 \frac{1}{2}$ c.M. long, \pm $3^{1}{ }_{12}-4$ c.M. broad, oblong, erect, 5-pinnatifid; rachis and branches winged. Pinnae ovate, \pm 2 c.M. long or less; ultimate divisions linear. Edges of wings and segments crisped, denticulate. Sori terminal, sessile, scattered over the frond; indusium the width of the ultimate divisions, cleft to the base; valves elliptical, laciniate at the apex, elsewhere entire and crisped.

Philippines.

(37) HI. Reinwarolliii, $\boldsymbol{V}$. D. B., Hymen. Jav., 52, tab. XLII.

Rhizome creeping, branched, covered with long, reddish-brown hairs. Stipes $5-8$ c.M. long, firm, broadly winged, nudate at the base. Fronds $8-12$ c.M. long, $2^{1} / 2-4$ c.M. broad, membranaceous, thin, lanceolate or long-acuminate, 5-pinnatifid. Pinnae contiguous, often erecto-patent, the higher fertile ones more distant, ovate or lanceolate, cut down to a crisped wing into several, slightly crisped pinnulae on each side. Pinnulae deeply pinnatifid again. Lobes linear or oblong, simple or 2-fid. Margins of the lobes and wings irregularly and minutely sinuato-denticulate; the apices of the lobes rounded or trucate. Sori terminal on the lobes, $2-12$ or more to a pinna; indusium broad, deeply 2-valved; valves orbicular, with the edge minutely and obtusely denticulate.

Java, Sumatra.

(38) H. physocarpum, Christ, Schum. \& Laut., Flor., deut. Sch. geb., Suppl., 55, tab. I, fig. A, a-b.

Near H. sabinifolium, Bk., but longer. Fronds lanceolate, not triangular,

\pm 12 c.II. long, \pm 5 c.M. broad. Pinnae short, ovate, rather distant, nu- 
merous. Pinnulae short. Segments and rachises aculeato-dentate, crisped, filiform. Sori large, terminal, roundish, $\pm 11 / 2 \mathrm{m.M}$. broad; indusium bullate, globose, scariose, the valves finely denticulate, not spinose on the back.

New Guinea

(59) H. Sabinifolium, Bk., Hk. Bk., Syn. Fil., 71; H. aculealum, Bedd. (not V. D. B.), Handb. Ind. Ferns, Suppl., 8, p. p.

Stipes $21 / 2-5$ c.M. long, naked or slightly winged. Fronds broadly ovate, triangular, deeply 5-pinnatifid, $21 / 2-5$ c.M. long, more than $21 / 2$ c.Mr. broad below; rachis margined throughout with a wing which is thickly beset with aristate teeth. Pinnae crisped, the lower ones flabellato-pinnatifid nearly down to the midrib. Ultimate segments very narrow, $5-8 \mathrm{~m} . \mathrm{M}$. long, deeply cut up nearly to the midrib by numerous, strong, aristate teeth. Sori solitary, supra-axillary; indusium spinose on the back, divided 1/2-way down with ovate, spinoso-serrate valves.

Java, Sumalra.

* (40) H. Neesii, Hr., Hk. Bk., Syn. Fil., 71; Bedd., Fern Br.I., II, tab. CCLXXIX; (H. denticulatum, Sw., Rac., Flor. Btz., I, 21, p. p.; C. Chr. Ind. Fil.; H. aculeatum, Rac., l. c., p. p.; C. Chr., l. c.); Leptocionium Neesï \& acanthoides, V. D. B., Hymen. Jav., tab. XXX \& XXXII.

Rhizome creeping, filiform, nearly naked. Stipes 2-כ̌ c.M. long, winged throughout or towards the apex only. Fronds deltoid or oblong $21 / 2$-5 c.M. long, $1-5$ c.M. broad, the main rachis winged throughout. Pinnae cut down to a winged rachis into simple, pinnatifid to 2-pinnatifid or once to more times forked pinnulae. Ultimate segments $\pm 1-5 \mathrm{~m}$.M. long or longer, $\pm 1 / 2-1$ m.M. broad. Sori $1-\mathbf{z}$ to a pinna; indusium divided $\pm 1 / 2$-way down or deeper, the valves toothed, the outer surface covered with scattered, sharp prickles.

\section{Malaya; Cèylon.}

* (41) H. denticulatam, Sw., Hk. Bk., Syn. Fil., 71 ; Rac., Flor. Btz., I, 21, p. p.; Bedd., Ferns Br.I., II, tab. CCLXXVIII; Leplocionium denticulatum, V. D. B., Hymen. Jav., tab. XXIX.

Rhizome filiform, sparingly hairy. Stipes $2-5$ c.M. long, nudate, or narrowly winged towards the apex. Fronds ovate-triangular, 5-8 c.M. long, $2 \frac{1}{2}-5$ c.M. broad at the base; main rachis margined throughout with a narrow, slightly undulated wing. Pinnae slightly crisped, the lower ones

Filices. 
oblong, deeply cleft with linear, flabellate or pinnatifid pinnulae. Ultimate segments toothed and crisped. Sori $\pm 1-2$ to a pinna, occupying the anterior pinnulae, terminal on short lobes; indusium ovate, divided about $2 / 3$ of the way down, surrrounded at the háse by broad, déeply and/irregularly spirioso-dentate transversal crests, the valves toothed or serrate towards the apex.

Trop. Asia. the bave proveded with dephy veregularly spinos

* (42) II. aculeatum, Rac., (not Sm.), Flor. Btz., I, 21, p. p., H. aculealum, Bedd. (not V. D. B.), Handb. Ind. Ferns, Suppl., 8, p. p. Leptocionium aculeatum, V. D. B., Hymen. Jav., tab. XXXI.

Like H. denticulatum, $S w$., but smaller. Fronds $2 \frac{1}{2}-5$ c.M. long, \pm $21 / 2$ c.M. broad, the indusium not so deeply divided ( $\pm 1 / 3$ of the way down), the lips with the outer edge sharply toothed.

Malaya; Ceylon.

(43) II. bismarckianum, Christ, Schum. \& Laut., Flor. deut. Sch. geb., Suppl., 34 .

Near H. denticulatum, Sw., but $3 \times$ larger. Sori not axillary but terminal on the segments, roundish, minute, blackish-brown; valves of the indusium entire, not spinose.

New Guinea.

(44) H. brachyglossum, A. Br., Kze, Bot. Zeit., 1847, 227; Leptocionium Braunii, V. D. B., Hymen. Jav., 43, tab. XXXIII.

Rhizome creeping, filiform, nearly naked. Stipes scattered, filiform, naked, 2-4 c.M. long. Fronds lanceolate or lanceolate-oblong, 3-6 c.M. long, 1-2 c.M. broad; main rachis winged throughout. Pinnae slightly crisped, cut down to a winged rachis into simple or sometimes forked pinnulae. Ultimate segments linear, toothed and \pm crisped. Sori $1-2$ to a pinna, occupying mostly the anterior side of the higher pinnae; indusium oblong, divided \pm $1 / 3$-way down, the base surpounded $b y=a r$ row of rather close, repand, longitudinal crests, the valves \pm truncate or rounded and toothed at the apex.

Java, Borneo.

\section{TRIOHOMLNES, Limné.}

Sori marginal, terminal on the veins. Indusium tubular, cupuliform, obconical or turbinate, of the same texture as the frond, exserted or more or 
less immersed in the margin, the mouth truncate, dilate or 2-lipped. Receptacle mostly long and exserted, prominent beyond the sporangia. Surfaces of the sporangia divided into few, unequal cells.

Rhizome creeping or erect. Fronds simple or divided, varying from delicately membranaceous to (rarely) \pm coriaceous; ultimate segments mostly linear or oblong, rarely ovate or rhomboidal, sometimes capillary. Hk. Bk., Syn. Fil., tab. II, fig. 17; Diels, in Engl. \& Prantl, Nat. Pfl.Fam., 14, fig. 75. Tropical, rarely extra-tropical.

Arrangement of the sections and groups.

$\$$ 1. FÉEA. Fronds dimorphous, the fertile ones spicate. Diels, in Engl. \& Prantl, Nat. Pfl.Fam., I ${ }^{4}$, fig. 73, D. (Not in Malaya).

\$ 2. EUTRICHOMANES. Fronds uniform, the fertile ones not spicate. Ultimate segments flattened, often narrowly linear, but not capillary. Diels, I. c., fig. 75, A-G; Christ, Farnkr. d. Erde, fig. 54--54, 75.

a. Cardiomanes. Fronds simple, reniform; veins flabellate; spurious veins wanting. Sori pantotactous ( ${ }^{1}$ ). (Not in Malaya).

b. Hemiphlebium. Fronds simple or slightly lobed, not reniform; spurious veins present. Sori epitactous ( $\left.{ }^{2}\right)$.

c. Fonocormus. Fronds digitato-subdichotomous $\left({ }^{4}\right)$; sori paratactous $\left({ }^{3}\right)$.

d. Ptilophyllum. Fronds pinnately divided, the main rachis winged throughtout or towards the base only. Cells of the texture roundish, oblong, quadrangular or subhexagonal, not placed as in $e$. Sori epitactous or paratactous.

e. Abrodietyum. Fronds pinnately divided, the main rachis whether or not winged. Cells of the texture transversally oblong, placed in obliquely longitudinal rows. Sori paratactous. (V. D. B., Hymen. Jav., tab. XII, Habrodictyon).

f. Lacostea. Fronds pinnately divided, the main rachis not winged or winged towards the apex only, but often narrowly marginate. Cells of the texture as in $d$. Sori paratactous.

(1) Prantl, Morph. d. Gefïsscr., I, Hymen., 7.

(2) Prantl. l. c., 11.

(3) Prantl, l. c., 8.

$\left({ }^{4}\right)$ Fronds digitate, the segments simple or once or more times forked, the central segment not rarely elongate and pinnatifid with simple or divided secondary segments. 
*. Cephalomanes. Fronds simply pinnate; pinnae \pm oblate, rathe broad, the base cuneate or rounded.

*.*. Trichomanopsis. Fronds at least 2-pinnatifid; ultimate segments linear or oblong, narrow, the base neither cuneate nor rounded.

5. LEPTOMANES. Fronds uniform, the fertile ones not spicate. Ultimate segments capillary, whether or not narrowly marginate (not visible except under magnifying power). Christ, l. c., fig. 68.

Key to the malayan sections and groups.

(Fronds uniform).

1. Ultimate segments flattened, often narrowly linear but not capillary.

2. EUTRICHOMANES.

2. Fronds simple or slightly lobed. $\quad \mathbb{2} 2, \mathrm{~b}$. Hemiphilebium.

2.2. Fronds divided.

3. Fronds flabellato-digitate; segments simple or once or more times forked, the central segment not rarely elongate and pinnatifid.

$\$ 2$, c. Honocormus.

3.3. Fronds pinnately divided.

4. Cells of the texture transversally oblong, placed in obliquely

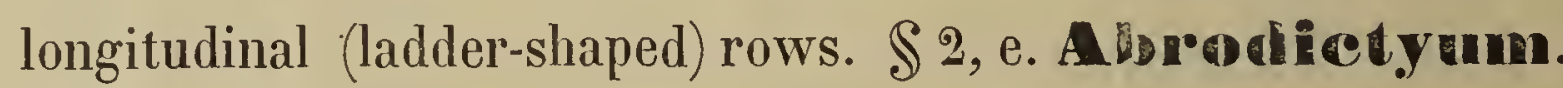

1.4. Cells of the texture roundish, oblong, quadrangular, subhexagonal, \&c, but not as in 4 .

5. Main rachis winged throughout or towards the base only. $\quad \$ 2$ d. Ptilophyllum.

5.5. Main rachis not winged, or winged towards the apex only. $\quad \$ 2$, f. Lacostea. 6. Fronds simply pinnate; pinnae \pm ofate, rather broad, the base cumeate or rounded.

S $2, f^{*}$. Cephalomanes.

6.6. Fronds at least 2-pinnatifid; ultimate segments linear or oblong, narrow, the base neither cuneate nor rounded. $\quad \mathbb{2} 2, f^{* *}$. Triehomanopsis.

1.1. Ultimate segments capillary, whether or not narrowly marginate.

$\$$ 3. LEPTOMANES. 


\section{\& 2. EUTRICHOMANES. b. Tlimiphlebium.}

a. Veins flabellate or radiate. Fronds small, 5-15 m.M. long.
b. Fronds pellate; veins radiate.
(1) T. peltatum.

b.b. Fronds not peltate; veins flabellate.

c. Fronds cordate-orbicular.

d. Indusium funnel-shaped, the mouth entive.

(2) T. Motleyi.

d.d. Indusium subcylindrical, the mouth 2-lipped. (5) T. pannosum.

c.c. Fronds oblong or linear-oblong.

(4) T. Beccarianum.

a.a. Veins pinniform. Fronds $1-71 / 2$ c.M. long.

*. Fronds small, $\pm 1-11 / 2$ c.M. long, $\pm 2^{1} / 2-5$ m.M. broad. Indusium with the mouth conspicuously 2-lipped.

*.*. Fronds larger, $\pm 1 \frac{1}{2}-7 \frac{1}{2}$ c.M. long, $\pm 1-27$ c.M. broad. Indusium with the mouth not or obscurely 2-lipped. (6) T. sublimbatum.

T. vaspedoneurum

* (1) N. peltatum, Bk., Hk. Bk., Syn. Fil., 73; Journ. of Linn. Soc., Bot., IX, tab. VIII, C; T. omphalodes, C. Chr., Ind. Fil.

Rhizome wiry, slender, wide-creeping, tomentose. Fronds quite sessile, attached to the rhizome near its centre or towards the base, suborbicular in general outline, 1-5 c.M. each way, the margin undulate, not thickened, sometimes irregularly, more or less deeply cleft. Texture delicately membranaceous; veins close, radiant, regularly dichotomous, with numerous interrupted. spurious venules between them near the margin and towards the centre, Sori 1-3, scattered; indusium more or less exserted, with a much dilated, spreading, slightly toothed, 2-lipped mouth.

Trop. Asia, Polynesia \& Australia, Liu-Kiu.

*(2) T. Motleyi, V. D. R., Hk. Bk., Syn. Fil., 73; T. Henzaiense, Bedd., Ferns Br.I., II, tab. CLXXXIII; Microgonium Motleyi, V. D. B., Hymen. Jav., tab. I.

Rhizome filiform. Fronds copious, sessile, \pm 6 m.M. long, \pm 4 m.M. broad, cordate-orbicular, nearly entire. 'Texture very thin; bar'en fronds without costa; veins flabellate, with spurious veins; fertile fronds with a distinct costa terminating in a \pm deep sinus, the edge with a marginal vein bordering the frond, slightly denticulate or entire. Sorus terminal on the costa, stalked; indusium funnel-shaped, the mouth entire, much dilated.

Trop. Asia, Queensland, Melanesia. 
(3) T. pannosum, Ces., Fel. Becc. Polin., 2 \& 6; T. Morleyi, V. D. B., var., C. Chr., Ind. Fil.

Near T. Motleyi, V. D. B. Fronds 10-13 m.M. each way, lohed, nigropannose beneath. Sorus not exserted; indusium subcylindrical, the mouth distinctly 2-lipped.

New Guinea.

(4) T. Heccarianum, Ces., Fel. di Bor., 8, tab. I, fig. 2; (? T. Motleyi, V. D. B., C. Chr. Ind. Fil.).

Like T. Motleyi, V. D. B., but the fronds ovate, oblong or linear-oblong, not cordate-orhicular, less pellucid; veins close, divaricating. Sorus solitary, terminal, short; indusium short, the mouth dilated, spreading.

Borneo.

(5) T. bimarginatum, $\boldsymbol{V}$. D. B., Ned. Kruidk. Arch., V', 143; T. neilgherrense, Bedd., Hk. Bk., Syn. Fil., 74; Bedd., Ferns S.I., tab. VI; Microgonium bimarginatum, V. D. B. (oldest name).

Stipes $21 / 2-5$ c.M. long. Fronds $1-1 \frac{1}{2}$ c.M. long, $21 / 2-5$ m.M. broad, oblong-lanceolate, not lobed, sometimes bifid at the apex; spurious venules numerous. Sori 1-2, terminal; indusium more or less sunk in the frond, the mouth exserted, with 2 large, rounded lips.

Malaya to Polynesia, Formosa, South. India, Ceylon, Australia.

* (6) T. sublimbatum, K. Mïll., Rac., Flor. Btz., I, 25; T. muscoides, Bk. (not Sw.), Hk. Bk., Syn. Fil., 75; Microgonium sublimbatum, V.D.B., Hymen. Jav., tab. II.

Rhizome creeping, filiform, hairy at the apex. Stipes, filiform, naked, 1-10 m.M. long, $1-3$ c.M. apart. Fronds $1 \frac{1}{2}-7 \frac{1}{2}$ c.Il. long, $\pm 1-2$ c.M. broad, varying in shape from linear to oblong or suborbicular, entire to bluntly lobed, especially above. Texture very thin; hoth surfaces naked; costa pinnate; veins simple or forked; spurious venules faint but copious. Sori $1-8$, terminal on the lobes; indusium sunk in the frond; the mouth free, dilated, often obscurely 2-lipped.

Malaya; Khasia. 


\section{EUTRICHOMANES. c. Gonocormus.}

1. Fronds not proliferous.

2. Edges not ciliate.

3. Margin not bounded by a thickened line, nor purveyed with a submarginal spurious vein.

4. Spurious veins wanting throughout.

5. Fronds very small, suborbicular-flabellate, 5-71/2 m.M. each way. Segments rather numerous. (7) T. saxifragoides.

5.5. Fronds somewhat larger, $10-20$ m.M. long. Segments not numerous.

6. Slipes short, 1-4 m.M. long. Fronds cuneateflabellate, sometimes simple and oblong.

(8) T. Aswijkii.

6.6. Stipes longer, 10-30 m.M. long. Fronds roundish in general outline.

1.4. Spurious veins present.

(9) T. nitidulum.

s.p 102

(10) T. parvulum.

3.3. Margin bounded by a thickened line or purveyed with a submarginal spurious vein.

*. Marginal line (spurious vein) continuous.

(11) T. nanum.

*.*. Submarginal spurious vein interrupled.

(12) T. rupicolum.

2.2. Edges ciliate.

S. Ciliae tooth-like, distant. Veins naked.

(13) T. digitatum.

\$.\$. Ciliae capillary, approximate. Veins hairy. (14) T. palmatifidum.

1.1. Fronds proliferous, $i . e$. the stipe, rachis or costa bearing 1 or more sessile or stalked secondary frondiculae, which gives the whole frond the appearance of a very irregularly and pinnately divided single frond, besides which there often are also not-proliferous ones.

*. Frondiculae few.

S. Fronds and frondiculae ternate or quinale. (15) T. diffusum.

\$.\$. Fronds and frondiculae with more numerous segments.

(16) T. minutum.

*.*. Frondiculae many.

+ Rhizome hairy. Ultimate segments complicate. (17) T. proliferum.

+.+. Rhizome nearly naked. Ultimate segments not complicate.

(18) T. 'Teysmanni. 
(7) T. saxifraggides, Pr., Hk. Bk., Syn. Fil., 75.

Stipes $\pm 6 \mathrm{~m}$.M. long, slender, tomentose below. Fronds $5-71 / 2 \mathrm{~m} . \mathrm{M}$. each way, flabellato-suborbicular in general outline, cut from the margin in the direction of the apex of the stipe into numerous linear, acute segments, the deepest divisions reaching scarcely $1 / 2$-way down. Veins close, prominent, irregular. Sori 2-4, terminal; indusium sunk, the mouth dilated, spreading, scarcely 2-lipped.

Java, Philippines.

* (8) Tr. Aswijkil (Asnyliii), Rac., Natuurk. Tijdschr. N. I., LIX, 238, tab. II, fig. 6 .

Rhizome creeping, short-hairy, much branched. Stipes 5-12 m.M. apart, filiform, 1-4 m.M. long. Fronds simple or more commonly $1-3 \times$ forked, naked, entire. Undivided fronds linear $1 \frac{1}{2}-2$ c.M. long, $21 / 2-5 \mathrm{~m} . \mathrm{M}$. broad, the apex blunt, emarginate when barren, the base narrowed. Texture thin; a single central vein only carried into each segment. Sori terminal on the segments; indusium cylindrical-infundibuliform, sunk in the margin, the mouth dilated, round or slightly 2-valved; receptacle filiform, exserted.

Java.

* (9) 'T. nitidulum, T. D. B., Rac., Flor. Btz., I, 25; V. D. B., Hymen. Jav., tab. XV.

Rhizome filiform, creeping, branched, sparingly hirsute. Stipes capillary, $11 / 2-3$ c.M. long, sparingly covered with scattered, short hairs. Fronds roundish in general outline, $\pm 1-2$ c.M. each way, the base broadly rotundatocuneate, digitato-dichotomous (digitate, the segments once or more times forked); ultimate segments linear, different in length, to $1 \frac{1}{2}$ c.M. long, $1 \frac{1}{2}-21 / 2 \mathrm{~m} . \mathrm{M}$. broad, the edge entire, the apex blunt, emarginate. Texture thin, hyaline; surfaces naked, slightly hairy when young; veins 1 in each ultimate segment. Sori terminal on the segments; indusium sunk, funnel-shaped, the mouth dilated, naked.

Java, Riouw, Borneo.

(10) 'T. Danvulum, Poir., Hk. Bk., Syn. Fil., 75; Hk., Spec. Fil., I, tab. XXXIX, A; Bedd., Ferns Br.I., II, tab. CLXXIX.

Rhizome wide-creeping, interlaced. Stipes $\pm 21 / 2$ c.M. long, wiry, slender, tomentose below. Fronds $1 / 2-1 \frac{1}{2}$ c.M. each way, orbicular in general outline, cuneate or truncate at the base, flabellately cut about half-way down 
from the outer edge in the direction of the base into narrow, irregular segments. Veins close, prominent (so that the frond when dry appears channeled), dichotomous at a very small angle; spurious venules numerous. Sori 4-6, terminal on the central segments; indusium sunk, the mouth dilated at the sides.

Trop. \& temp. Asia, Australia. Polynesia, East African Islands.

(11) 'T. namum, V. D. . ., Hk. Bk., Syn. Fil., 77; T. Kurzii, Bedd., Ferns. Br.I., II, tab. CCLXXXVI; G. Chr., Ind. Fil.

Rhizome slender, wide-creeping. Stipes very short. Fronds not more than $1 \frac{1}{2}$ c.M. each way, cuneate below, the outer margin rounded; central portion not more than $1 \frac{1}{2}$ c.II. broad, divisions simple or once branched. Ultimate segments $5 \phi_{2}-5 \mathrm{~m} . \mathrm{M}$. long and $\pm 1 / 2 \mathrm{~m} . \mathrm{M}$. broad. Texture thick but not rigid; surface somewhat undulate, margin bounded by a thickened line; a central vein only in each segment. Sori $\mathbf{1 - 2}$ to a frond, subterminal; indusium turbinate, not at all exserted, the mouth dilated, undulated in irregular plications.

Trop. Asia.

* (12) T. rupicolum, Rac., Flor. Btz., I, 24.

Rhizome creeping, densely covered with spreading hairs. Stipes filiform, 1-3 c.M. long, nearly naked. Fronds commonly cuneate-flabellate, \pm 1 c.M. each way, the base cuneate or slightly rounded, the outer edge palmatifid into 5 - 3 segments; central segments $1-2 \times$ forked, the lateral ones simple or bifid; ultimate lobes $\pm 2 \mathrm{~m}$.M. broad, the apex blunt, the edge entire and with a submarginal, interrupted spurious vein. Texture thin, hyaline; veins 1 in each ultimate lobe, sparingly covered with short, acute scales. Sori terminal and solitary on the lobes; indusium funnel-shaped, sunk, the mouth dilated, spreading.

Java.

(15) T. digetatum, Sw., Hk. Bk., Syn. Fil., 76; T. flabellatum, V. D. B., Hymen. Jav., 19, tab. XIII; T. corlicola, Bedd., Ferns S. I., tab. CGLXIV.

Rhizome slender, creeping, nearly naked, intricate. Stipes scattered, $1 / 2$-2 c.M. long, capillary, naked. Fronds $1-5$ c.M. long, 1-21/2 c.M. broad, irregular in general outline, 3-partite, the central portion produced, 3 -fid or 1-3-furcate, the lateral segments shorter, simple or 2-fid. Ultimate segments linear, to 1 m.M. broad or hardly broader, the apex retuse or forked, the margin ciliate. Texture membranaceous, opaque, brownish; surfaces naked; veins 1 in each ultimate segment. Sori $2-6$, terminal and solitary on the 
ultimate segments; indusium sunk, cup-shaped, the mouth dilated, slightly 2-lipped, naked.

Trop. Asia, New Soulh Wales, Mascarenes.

* (14) T. palmatifidum, K. Miill., V. D. B., Hijmen. Jav., 20, tab. XIV; T. digitalum, Sw., var. palmatifidum, Hk. Bk., Syn. Fil., 76.

Rhizome slender, creeping, branched, intricate. Stipes scattered, capillary, pubescent, $1-5$ c.M. long. Fronds $1-1 \frac{1}{2}$ c.M. long, $1-2$ c.M. broad, digitatodichotomous, the base cuneate or rounded. Ultimate segments linear, very unequal in length, $1 \frac{1}{2}-2$ m.M. broad, the apex rounded, obtuse, retuse, the margin minutely denticulate, each projection purveyed with a group of short, flexuose ciliae. Texture thin, hyaline; veins 1 in each segment, ciliate, nearly reaching the apex of the segments. Sori terminal on the segments; indusium sunk, obconical or cupuliform, the surface and the margin ciliate.

Java. Borneo.

* (15) 'T. diffuswm, Bl., Enum., 225; Gonocormus diffusus, V. D. B., Hymen. Jav., 9, tab. IV.

Near. T. minutum, $B l$., but the fronds and frondiculae mostly ternate or rarely quinate, oblong or obovate, the base \pm cuneate, the edges conduplicate, undulate, the indusium short-funnel-shaped with the mouth suddenly much dilated, spreading and undulate.

Java. Luzon, mandenao. Amboina.

* (16) 'T. minutum, Bt., Rac., Flor. Btz., I, 25; Gonocormus minutus, V. D. B., Hymen. Jav., tab. III.

Rhizome creeping, branched, intricate, hairy. Stipes filiform, villose at least at the base, $\breve{b}-20 \mathrm{~m}$.M. long. Fronds and frondiculae conform, roundish in general outline, to \pm 1 c.M. each way, subtruncate to cordate at the base, palmatifid into many linear segments $\pm 1 / 2$ m.M. broad. Segments simple or $1-2 \times$ forked, the ultimate lobes to $4 \mathrm{~m}$.M. long, the apex blunt, rounded or slightly emarginate; the medial segments often elongate and subpinnatifid. Texture membranaceous, diaphanous. Sori terminal and solitary on the lobes; indusium sunk, funnel-shaped, but the mouth not very much dilated.

Java, Borneo, New Guinea.

* (17) T. proliferum, Bt., Hk. Bk., Syn. Fil., 76; Gonocormus palmalus, V. D. B., Hymen. Jav., 11, tab. VI. 
Rhizome wide-creeping, branched, hairy, densely interlaced. Stipes $21 / 2$ b c.M. long, slender, naked, flexuose, repeatedly proliferous. Fronds and frondiculae varying from ovate-lanceolate to roundish, to $21 / 2$ c.M. each way, digitately divided. Segments narrow, complicate or concavo-convolute, divided down nearly to the base into forked or dichotomous lobes, the central lobes often elongate and subpinnatifid. Texture membranaceous, subopaque. Sori terminal; indusium funnel-shaped, marginate (or winged in the lower part), the mouth dilated, undulate, obscurely 2-lipped.

Trop. Asia.

* (18) 'T. Teysmanni, W. D. B., Ned. Kruidk. Arch., V², 142; Gonocormus Teysmanni, V. D. B., Hymen. Jav., 10, tab. V.

Near T. proliferum, $B l$, , but the rhizome nearly naked, the frondiculae ovate-lanceolate to linear-lanceolate, the segments deeply pinnatifid, the lobes erecto-patent, 2-3-fid, not complicate, the edges slightly undulate.

Sumatra, Java.

\section{\$2. EUTRICHOMANES. d. Ptilophyllum.}

a. Main rachis winged towards the base only.

(19) T. microchilum.

a.a. Main rachis winged throughout.

b. Fronds pruinose. Central ribs flanked on each side by a broad stripe consisting of numerous darker coloured cells.

(20) T. pallidum.

b.b. Fronds not pruinose. Central ribs not flanked by darker coloured cells.

c. Marginal or submarginal spurious veins present.

d. Spurious veins quite marginal or appearantly so.

*. Fronds $\pm 1-1 \frac{1}{2}$ c.M. long, simply pinnatifid.

(21) T. Nymani.

*.*. Fronds $\pm 1 \frac{1}{2}-5$ c.M. long, 2-3-pinnatifid.

(22) T. humile.

d.d. Spurious veins not quile marginal.

e. Accessory spurious veins (between the submarginal one and the midrib) many.

(25) T. bilabiatum.

e.e. Accessory spurious veins few or wanting.

f. Submarginal spurious vein not or slightly interrupled.

Lips of the indusium triangular. 
g. Fronds $21 / 2-10$ c.M. long. Stipes $11 / 2-5$ c.M. long.

(24) T. bipunctatum.

g.g. Fronds smaller. Stipes short or nearly wanling.

(25) T. filiculoides.

f.f. Submarginal spurious vein copiously intervupted. Lips of the indusium semiorbicular.

(26) T. capillatum.

c.c. Submarginal spurious vein wanting.

1. Segments with the margin serrate or dentate.

*. Fronds small, under 11/2 c.M. long, membranaceous.

(27) T. serrulatum.

*.*. Fronds middle-sized, 15-30 c.M. long, semicoriaceous.

(28) T. auriculatum.

1.1. Segments with the margin entire.

2. Surfaces or edges hairy or ciliate.

\$. Edges ciliate with short, distant brislles.

(29) T. dichotomum.

\$.\$. Surfaces hairy, especially on the costae.

(50) T. vestitum.

2.2. Surfaces and edges naked.

3. Stipes \pm ufted.

+. Fronds at best 2-pinnatifid.

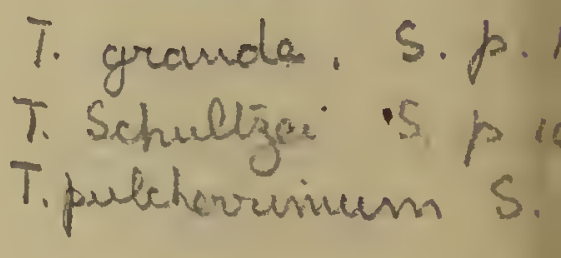

*. Fronds to \pm 15 c.M. long.

(31) T. Warburgii.

*.*. Fronds $10 \pm 30$ c.M. long.

(32) T. ignobile.

+. Fronds 4-pinnatifid.

(33) T. hispidulum.

3.3. Stipes scattered.

4. Fronds small, under 15 c.M. long.

5. Fronds 2-pinnatifid. (34) T. Lauterbachii.

5.5. Fronds 3-pinnatifid, at least at the base.

6. Indusium with the mouth 2-valved.

(35) T. Hosei.

6.6. Indusium with the mouth not or scarcely 2-valved.

8. Fronds small, \pm 3 c.M. long; 7-10 m.M. broad.

(56) T. gracile 
9. trichomanes. $\$$ 2. eutrichomanes. d. ptilophyllum.

8.\%. Fronds larger, \pm 3-15 c.M. long, 25-45 m.M. broad.

(37) T. pyxidiferum.

4.4. Fronds larger, more than 15 C.M. Tong when fully developed.

*. Rhizome lomenlose; fronds membranaceous, 15-30 c.M. long. (38) T. speciosum. *.*. Rhizome \pm naked; fronds subcoriaceous, 30-75 c.M. long. (39) T. maximum.

(19) T. microclnilum, BBk., Trans. Linn. Soc., Bot., $2^{\mathrm{d}}$ Series, IV, 250.

Rhizome wide-creeping, filiform. Stipes slender, naked, erect, 51/2-5 c.M. long, narrowly winged towards the apex. Fronds oblong-lanceolate, naked, decompound, 7-10 c.M. long; rachis narrowly winged at the base. Pinnae sessile, the lower lanceolate, $\pm 21 / 2$ c.M. long, the lower base cuneate. Lower pinnulae not deltoid; ultimate segments erecto-patent, narrow, linear, entire, 1-nerved. Sori few, terminal, sessile; indusium oblong, the mouth 2-lipped, the lips small, ovate, entire, erect.

Borneo.

* (20) T. pallidum, IBI., Rac., Flor. Btz., I, 29; T. glauco-/uscum, Hk., Spec. Fil., I, tab. XL, A; Bedd., Ferns S.I., tab. CCLXIII; Craspeiloneuron allum \& pallidum, V. D. B., Hymen. Jav., lab. VII-VIII; - Var. Braunii; C. Braunii, V. D. B., l. c., tab. IX.

Rhizome creeping, slender, filiform, covered with scattered hairs. Stipes rather distant, 3-7 c.M. long, hairy or naked. Fronds deltoid, abovate or lanceolate, 2-15 c.M. long, 1-4 c.M. broad; main rachis winged throughout. Pinnae erecto-patent, oblong or linear-oblong to rhomboidal, cut down to a winged rachis into simple, linear, bifid or more compoundly divided pinnulae. Texture thin, hyaline; surfaces glaucous or ceraceo-pruinose and covered with long, jointed, or short, not-jointed brownish hairs; the edge bounded by a \pm marginal, spurious vein; veins $1-2$ in each segment, flanked on each side by a very broad, distinctly visible stripe of darker coloured cells. Sori 1-4 to a pinna, terminal on short lobes between the barren, longer ones; indusium subconical, the mouth \pm dilated or truncate.

Var. Freaumii: Surfaces not hairy.

Trop. Asia, Polynesia 
(21) T. Nymani, Christ, Schum. \& Laut., Flor. deut. Sch.geb., Suppl., 36.

Rhizome creeping, rather woody, slender but not filiform, sparingly covered with short, brown hairs. Fronds subsessile, subtufted, erect, $1-1 \frac{1}{2}$ c.M. long, $\pm 1 / 2$ c.M. broad, ovate, subcuneate at the base, simply pinnatifid, the rachis narrowly winged. Segments 3-4 on each side, linear, 2-3 m.M. long, $\pm 1 / 3$ m.M. broad, acute, \pm mucronulate, the higher ones shorter, rarely produced, \pm radiating. Texture thin, diaphanous; rachis and veins blackish; the margin of the pinnae hounded by a blackish, thickened line; veins 1 in each segment. Sori minute, 1-2, terminal on the higher segments; indusium campanulate, winged, the mouth 2-lipped; receptacle short but exserted.

New Guinea.

* (22) T. Inwmile, Forst., Rac., Flor. Btz., I, 28; Hk. \& Grev., Ic. Fil., tab. LXXXV; Crepidomanes humile, V. D. B., Hymen. Jav., tab. XI.

Rhizome creeping, tomentose. Stipes $\mathbf{5}-15 \mathrm{~m} \mathrm{M}$. long, slender, winged above. Fronds lanceolatec.M. broad, 2-pinnatifid; main rachis narrowly winged. Ultimate segments linear, simple or forked. Texture membranaceous; surfaces naked but the veins often covered with distant, short scales; a central vein in each segment; no spurious veinlets, but the frond bounded by an indistinct, \pm marginal line uniting the apices of the veins. Sori solitary on the upper side of the segments, at the base; tube slightly winged, the mouth spreading, 2-lipped.

Java, New Guinea, Ternale; Formosa, Polynesia, Australia, New Zealand. malay a

* (23) T. bilabiatum, Nees of BI., Nova Acta, XI, 123; T. brevipes, Bk., Hk. Bk., Syn. Fil., 84 p. p.; T. Filicula, Bory, Rac., Flor. Btz., I, 28, p. p.; Didymoglossum laxum, V. D. B.. Hymen. Jav., tab. XXVII.

Rhizome creeping, densely tomentose. Stipes short, $\breve{b}-10 \mathrm{~m}$. M. long, narrowly winged towards the apex. Fronds deltoid-oblong, $\mathbf{5}-\mathbf{7 1} / 2$ c.M. long, $21 / 2-4^{1} / 2$ c.M. broad; main rachis narrowly winged. Pinnae spreading, oblong, cut down to a narrowly winged rachis. Lowest pinnulae again deeply pinnatifid with narrow, linear, simple or 2 -fid lobes to $2 \frac{1}{2} \mathrm{~m}$.M. long, $\pm 1 / 2$ m.M. broad, yellow-green, purveyed with a submarginal, flexuose, slightly interrupted spurious vein and many short, flexuose, longitudinal ones between the latter and the single costa. Sori $2-8$ to a pinna, the tube winged, with the mouth 2-lipped, the lips bluntish or rounded.

Malaya; Melanesia. 
* (24) T. bipunctatum, Poir., Christ, Farnkr. d. Erde, 32 (oldest name); T. Filicula, Bory, Rac., Flor. Btz., I, 28, p. p.; Bedd., Ferns Br.I., II, tab. CGLXXXIII; Didymoglossum Filicula, Desv., V. D. B., Hymen. Jav, tab. XXVI; - var. late-alatum; D. late-alatum, V. D. B.

Rhizome creeping, filiform, densely covered with black, hair-like scales. Stipes rather distant, $1 \frac{1}{2}-5$ c.M. long, naked, slightly winged above or throughout. Fronds deltoid to lanceolate- ${ }^{-}$ovate, $\pm 21 / 2-10$ c.M. long, $2-5$ c.M. broad, 3-pinnatifid; main rachis winged. Pinnae ovate-lanceolate to rhomboidal, pinnatifid down to a winged rachis, the lower pinnulae again deeply pinnatifid. Ultimate segments linear, blunt. Texture membranaceous, hyaline, bright-green $0 r^{\circ}$ olivaceous; a central vein in each ultimate segment, besides this a continuous or slightly interrupted, flexuose, submarginal spurious one. Sori $1-4$ to a pinna; indusium winged, the mouth 2-lipped, the lips triangular, rather acute.

Var. Iate-alatum: Ultimate segments acute and very narrow; wing of the rachis somewhat crisped; spurious veins more distinct. Fronds sessile.

Trop. Asia \& Australia, Polynesia, Japan, West. \& South. Africa.

* (25) T. filiculdides, Christ, Schum. \& Laut., Flor. deut. Sch. geb., 108; T. bipunctatum, Poir., var. nana-subflabellata, Christ, MS. in Herb. Bog.

Like T. bipunctatum, Poir., but the fronds smaller, under $21 / 4$ c.M. each way, subflabellate, subdigitato-pinnatifid. Rhizome wide-creeping, filiform, at length naked; stipes distant, short or nearly wanting.

New 'Guinea.

(26) T. capillatum, Taschn., Dissert., 34, tab. I, fig. 2; T. Filicula, Bory, Rac., Flor. Btz., I, 28, p. p.; T. bipunctatum, Poir., var., C. Chr., Ind. Fil.; Didymoglossum capillatum, Pr., V. D. B., Hymen. Jav., tab. XXVIII.

Like T. bipunctatum, Poir., but the colour dark-green, the submarginal spurious vein copiously interrupted, the indusium with the lips semiorbicular. Java; North. India. duzon.

(27) T. serrulatum, Bk., Hk. Bk., Syn. Fil., 80.

Rhizome slender, wide-creeping. Stipes slender, naked, about $1 / 2-11 / 2$ c.M. long. Fronds to $15 \mathrm{~m} . \mathrm{M}$. long, about $6 \mathrm{~m} . \mathrm{M}$. broad, oblong or subrhomboidal in general outline, pinnatifid down to a narrowly winged rachis. Segments erecto-patent, in $2-6$ pairs, linear, simple or forked, $\pm 6 \mathrm{~m} . \mathrm{M}$. long and to $1 \frac{1}{2}$ m.M. broad, toothed at the margin. Texture membranaceous; 
a central vein only in each segment; spurious veinlets none. Sori 1-2, terminal on the segments; indusium exserted or stipitate, the mouth slightly 2-lipped, deeply ciliated with sharp, linear teeth.

Borneo.

* (28) T. auriculatum, Bt., Rac., Flor. Btz., I, 26; Cephalomanes auriculatum, V. D. B., Hym. Jav., tab. XXV; T. dissectum, J. Sm., Bedd., Ferns Br.I., II, tab. CLXXXII.

Rhizome strong, wide-creeping or climbing, the apex clothed with brown hairs. Stipes 3-10 m.M. long. Fronds linear-lanceolate, $13-30$ c.M. long, 2-6 c.M. broad, pinnate, acuminate; rachis narrowly winged, not hairy. Pinnae short-stalked, the upper ones sessile with a narrowed base, the lower ones $2 X$ as long as broad, the apex rounded, the barren ones toothed, incisodentate or -crenate or irregularly pinnatifid $1 / 2$-way down or more, the stalks winged, the base obliquely cuneate, the lowest anterior lobe often prolonged; central ribs pinnate. Fertile pinnae more deeply pinnatifid, sometimes contracted. Texture semicoriaceous; venation subdichotomous. Sori $2-12$ to a pinna; indusium nearly or quite exserted, the mouth truncate.

Trop. Asia, China \& Japan.

* (29) 'T'. dichotonum, Fae, Rac., Flor. Btz., I, 26; V. D. B., Hymen. Jav., tab. XVI.

Rhizome filiform, sparingly clothed with spreading hairs. Stipes filiform, brown, 5-6 c.I. long, covered with short hairs. Fronds $6-15$ c.M. long, $1-21 / 2$ c.M. broad, 雨ovate-oblong, cut down to a winged rachis. Segments erecto-patent, $\pm 5-10$ c.I. long, to \pm 2 c.M. broad, simple, forked or pinnatifid. Lobes erecto-patent, to \pm 3 c.M. long, $1 \frac{1}{2}-2 \mathrm{~m}$. II. broad, simple or divided again, the apices of the ultimate segments bluntish or rounded. Texture thin; surfaces naked, but the margin of the segments sparingly ciliate with short bristles. Sori terminal; indusium obconical, sunk, the mouth furnished with deciduous hairs.

Java; Society Islands.

(30) 'T. vestituma, Bks., Kew Bull., 1894, 7.

Rhizome filiform, wide-creeping. Stipes short, distant, covered with few, subulate scales. Fronds ovate, $15-30$ m.M. long, $10-15$ m.II. droad, deeply pinnatifid, the base cuneate; both surfaces (especially the costa) covered with firm hairs. Lobes paucijugate, central ones 5-b-lobed. Sori few, sessile, 
placed on the upper edge of the lobes; indusium subcylindrical, the mouth spreading, hardly lobed; receptacle included.

Borneo.

(51) T. Warburgii, Christ, Warb., Mons., I, ğ5.

Rhizome short, strong. Stipes densely tufted, filiform, not winged, brownish. Fronds to \pm 15 c.M. long, the rachis broadly winged. Segments caudatoelongate, acute and long-acuminate, undulate, simple or with few lobes. Texture hyaline, pale-coloured. Sori commonly solitary or with 2 on a pinna in the lower sinusses of the segments; indusium stalked, cylindrico-campanulate, the valves dilated; receptacle included.

\section{Mindanao.}

(32) T. ignobile, Ces., Fel. di Bor., 9.

Rhizome fasciculate, fibrillose, short-strigose. Stipes caespitose, to 20 c.M. long, complanate, squamulose, at length naked, passing into the fronds. Fronds $\pm \quad 30$ c.M. long, nearly as broad, ovate, deeply 2-pinnatipartite. Segments subflabellate, the lobes fastigiate, linear, obtuse, crisped when dry. Surfaces naked; colour dark-greenish. - The description being not very complete, I don't know whether this plant has been classified here in the proper way.

Borneo.

(53) T. hispidulum, Mett., Hk. Bk., Syn. Fil., 466.

Rhizome woody, suberect, the scales minute, subulate, brown. Stipes 7-15 c.M. long, winged, and slightly crinite upwards. Fronds $15-30$ c.M. long, deltoid, 4-pinnatifid, the rachis narrowly winged throughout. Pinnae close, deltoid, lowest much the largest, 4-8 c.II. broad, produced on the lower side. Pinnulae close, lower deltoid, cuneate-truncate on lower side at base. Uliimate lobes distant, \pm 1 m.M. broad, 3-6 m.M. long. Texture rather thick; colour dark-olive-green; surfaces naked. Sori copious, placed on upper side of ultimate lobes; indusium minute, free, funnel-shaped, with a ciliated, entire mouth and a long receptacle.

Borneo, Malacca.

(34) T. Lauterbachii, Christ, Schum. \& Laut., Flor. deut. Sch. geb., 108.

Rhizome creeping, tomentose. Stipes winged, varying from very short to 2 c.M. long. Fronds \pm 2 c.M. long, $\pm 1 \frac{1}{2}$ c.M. broad, broadly obovate, the rachis broadly winged. Segments obovate, \pm 4 on each side, cut down Firices. 
to a broadly winged rachis, the lobes incised again. Ultimate segments obtuse, \pm 2 m.I. long, \pm .1 m.M. broad, with an acute sinus. Texture thin; veins very conspicuous, 1 in each ultimate segment. Sori $6-8$ to each frond, placed on the lower lobes of the higher pinnae, $1-2$ to a pinna, deeply inmersed; indusium lanceolato-cylindrical; receptacle included.

New Guinea.

(55) T. Mosei, Bk., Journ. of Linn. Soc., Bot., XXII, 225, tab. XII. Rhizome filiform, wide-creeping. Stipes $1-1 \frac{1}{2}$ c.M. long, erect, distant, naked, not winged. Fronds ovate-rhomboidal, $\pm 5 \frac{1}{2}-4$ c.M. Iong, 3-pinnatifid. Lowest pinnae largest, deltoid, with the lower base cuneate-truncate. Uhimate divisions linear, $5-5$ m.M. long, \pm 1 m.M. broad, 1-nerved, entire, erecto-patent. Sori terminal, solitary; indusium infundibuliform, narrowly winged on both sides nearly or quite to the top of the tube, the mouth 2lipped, the lips small, semi-orhicular; receptacle shortly exserted.

Borneo.

(56) T. groncile, W. ID. B., Ned. Kruidk. Arch., V', 157.

Stipes filiform, 6-8 m.M. long. Fronds \pm 5 c.M. long, 7-10 m.M. broad, oblong or obovate, narrowed at the base, pinnate. Pinnae erect, distant, the lower ones approximate, subopposite, oblong, subpinnatisect, plicate; the segments recurvo-patulous, short, simply forked, with a blunt sinus, the lobes narrow, emarginate at the apex. Wing of the rachis narrow, marginate. Sori terminal on the ultimate segments, small, immersed; indusium short, ventricose, the base narrowed, the mouth dilated, spreading, undulate. - Rhizome unknown, perhaps creeping as in many of the species with small fronds.

Java.

* (37) T. Pyxidifermum, E., Hk. Bk., Syn. Fil., 81; Hk. \& Grev., Ic. Fil., tah. CGVI; T. Filicula, Bedd., Ferns S.I., tab. VII.

Rhizome wide-creeping, rather filiform, tomentose. Stipes $2^{1}{ }_{2}-\breve{b}$ c.M. long, naked, or winged above. Fronds $2 \frac{1}{2}-15$ c.M long, $21 / 2-41 / 2$ c.M. hroad, ovate-oblong or subflabellate, 5-pinnatifid; main rachis narrowly winged. Pinnae pinnatifid down to a narrowly winged rachis, the lower pinnulae again deeply pinnatifid. Ultimate segments more or less numerous, linear, often emarginate at the apex, whether or not purveyed with more or less distinct spurious veins. Texture membranaceous; a central vein only in each ultimate segment. Sori $1-4$ to a pinna, the tuhe more or less winged, the 
mouth broadly dilated, scarcely 2-lipped; receptacle filiform, more or less exserted. - A very variable species.

Pantropical.

"58) 'T. speciosum, Willa, Christ, Farnkr. d. Erde, 50; T. radicans, Sw., Hk. Bk., Syn. Fil., 81, p. p.; Bedd., Ferns Br.I., II, tab. CLXXXI; C. Chr. Ind. Fil.

Rhizome wide-creeping, firm, tomentose. Stipes scattered, long, narrowly winged towards the apex. Fronds lanceolate or deltoid-oblong,

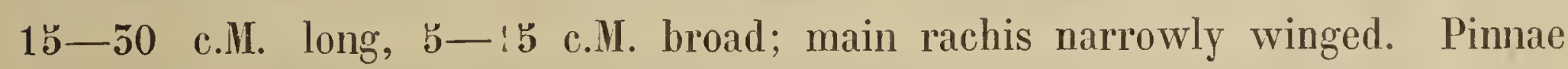
$2^{1} / 2-10$ c.M. long, mostly erecto-patent, ovate-rhomboidal or lanceolate-triangular, the rachis narrowly winged. Pinnulae rhomboid-oblong, cut down to a winged rachis into linear or oblong, simple, bifid or pinnatifid segments. Texture firm-membranaceous; colour blackish-green; ultimate lobes 1-nerved. Sori lateral, $1-4$ to a pinnula; indusium narrow-campanulate, the mouth slightly 2-lipped.

Scatlered throughout warm-temperate regions of both hemispheres.

(59) T. maximume, Bt., Rac., Flor. Btz., I, 29; V. D. B., Hym. Jav., tab. XVIII; T. anceps, Hk., var. $\beta$, Hk., Spec. Fil., I, tab. XL, fig. C, $\mathbf{3}$; T. millefolium, Pr., V. D. B., 1. c., tab. XX. or taveulós

Rhizome stout, creeping, nearly naked. Stipes strong, erect, $1-3$ c.M. apart, naked or slightly hairy at the base, \pm succulent, winged upwards, $71 / 2-40$ c.M. long. Fronds $50-75$ c.M. long, $\mathbf{1 5}-\mathbf{5 0}$ c.M. broad, ovatelanceolate, 4-ら-pinnatifid, \pm succulent, naked. Pimnae erecto-patent, the lowest not much shorter than the next in order, or as long, ovate-lanceolate, acuminate. Pinnulae lanceolate, cut down into segments which are pinnate again with $1-4$ divisions on each side. Ultimate divisions linear, $\pm \mathbf{3}-\vec{b} \mathrm{~m}$. II. long, \pm 1 m.M. broad, simple and truncate, emarginate or bifid, straight, falcate or curved. Texture subcoriaceous; rachises more or less narrowly winged. Sori $2-8$ to a pinnula; indusium cylindrical, the mouth dilated, not 2-lipped.

Malaya; Polynesia, Queensland.

\section{EUTRICHOMANES. e. Alododicty am.}

(40) T. Cumingii, C. Cher., Ind. Fil.; T. Smithii, Hk., Hk. Bk., Syn. Fil., 84; Hk., Icon. Pl., VIII, tab. DCCIV; Habrodictyon Cumingii, V. D. B., Hymen. Jav., tah. XII; Abrodiclyum Cumingü, Pr., (oldest name), Hym., tab. VII. 
Rhizome short-creeping or ascending, densely hirsute. Stipes approximate or subtufted, $2^{1} / 2-7^{1} / 2$ c.M. long, slender, erect, naked, sparingly hairy at the base. Fronds 5-20 c.M. long, $1 \frac{1}{2}-4$ c.M. broad, lanceolate or oblong; main rachis whether or not winged. Pinnae oblong, erecto-patent, the central ones the largest, pinnatifid to a narrowly winged rachis. Pinnulae linear, usually simple, occasionally forked. Ultimate segments $1 / 2-1 \frac{1}{2}$ c.M. long, $\pm 1 / 2-1$ m.M. broad. Texture rather flaccid, the cells transversally elongated, arranged in obliquely longitudinal (ladder-shaped) rows. Sori $1-4$ to a pinna, terminal on short lobes; indusium winged, the mouth dilated. Quite different from all the other species of Trichomanes, which have all \pm roundish, quadrangular, hexagonal or longitudinally oblong cells.

Philippines, Moluccas.

\section{S 2. EUTRICHOMANES. f. Hacostea. *. Cephalomanes.}

*. Sori on the uper edge of the pinnae. Receptacle much exserted.

S.p. $100^{4.2}$.T. sungotracianum S. p. 108.

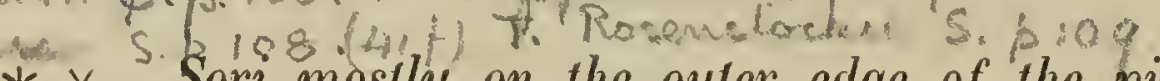

(41) T. javanicum. *.*. Sori mosily on the outer edge of the pinnae. Receptacle noì exserted.

(42) T. asplenioides.

T. sumabranum $p . \varepsilon$

$T$ acrosecurn S.p

T. Kingii \$.p 110

T. Forestivi 5 p.110

* (41) T. javanicum, Bt., Rac., Flor. Btz., I, 27; Hk., Gard. J Fri Ferns, tab. XXXVII; Bedd., Ferns Br.I., II, tab. CLXXX; Cephalomanes javani-p 126 cum, Pr., V. D. B., Hymen. Jav., tab. XXII; C. Zollingeri \& rhomboideum, Ta an V. D. B., l. c., tab. XXIII \& XXIV.

Rhizome erect. Stipes tufted, $1 \frac{1}{2}-15$ c.M. long, erect, naked or villose. Fronds 5 -25 c.M. long, $1 \frac{1}{2}$-5 c.M. broad, lanceolate-oblong; main rachis hairy. Pinnae short-stalked or sessile with a narrowed base, oblong, unequalsided, the apex blunt or rounded, the margin finely toothed or ciliate $\left({ }^{1}\right)$, the base obliquely cuneate. T'exture firm; veins numerous, close, parallel. Sori $1-4$ to a pinna, placed on the upper edge; indusium free, the mouth truncate or dilate; receptacle much exserted.

Trop. Asia, Polynesia \& Australia, Liu-Kiu.

(') If ciliate, the ciliae consisting of the often very much produced veins of the pinnae. 
9. trichomanes. $\mathbb{S}$ 2. eutrichomanes. f*. Gephalomanes.

(42) T. asplenioides, Pr., Kze, Farnkr., I, 218, tab. LXXXIX; T. javanicum, Bl., var., C. Chr., Ind. Fil.; Cephalomanes asplenioides, Pr., Hym., 15 \& 37.

Rhizome covered with small, subulate, black scales. Stipes tufted, flexuose, scaly. Fronds linear-lanceolate, $\pm 10-14$ c.M. long, $21 / 2-3^{1 / 2}$ c.M. broad, narrowed gradually towards both ends. Pinnae \pm 20 on each side, the central ones the largest, linear-oblong, to $18 \mathrm{~m} . \mathrm{M}$. long, \pm b-8 m.M. broad, the apex rounded, the margin finely toothed, the base obliquely cuneate, with the upper side more or less auricled; lower pinnae \pm deflexed, the higher ones erecto-patent, confluent, soliferous. Texture rigid; surfaces naked; rachis villose and scaly, marginate by the decurrent pinnae. Sori $\pm 3-7$ to a pinna, often only terminal; tube not quite free, the mouth obscurely dilated; receptacle not exserted.

Luzon.

\section{S 2. EUTRICHOMANES. f. Hacostea. **. Trichomanopsis:}

a. Stipes naked, or hairy below.

b. Stipes \pm fasciculate.

c. Fronds small, membranaceous, 7-9 c.M. long. (45) T. racemulosum.

c.c. Fronds larger, rather rigid, $10-20$ c.M. long. (44) T. rigidum.

b.Ђ. Stipes scattered.

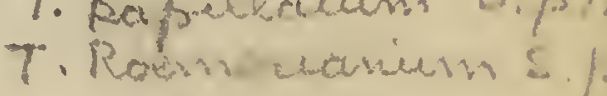

*. Rhizome densely tomentose. Fronds $\pm 71 / 2$ c.M. long. Indusium 2-lipped.

*.*. Rhizome naked, brislly at the extremity. Fronds $T_{ \pm} 40$ c.M. long. Indusium with the mouth much dilated. (46) T. aphlebioides.

a.a. Stipes hairy throughout.

1. Rhizome wide-creeping.

(47) T. giganteum.

1.1. Rhizome short-creeping or erect.

2. Fronds small, to 20 c.M. long.

T. christir p. 800 T. Californiom 5 p 112 Trecedews s.b 112

3. Stipes tufted. Ultimate segments short and broad.

(48) T. saxatile.

3.3. Stipes approximate. Ultimale segments short, often tooth-like.

(49) T. cupressoides.

2.2. Fully developed fronds more than 20 c.M. long.-Segments narrow- 150 linear.

(50) T. Bauerianum. 
(43) T'. racennulosumn, $\boldsymbol{T}$. I. B., Ned. Kruidk. Arch.; V ${ }^{3}, 210$.

Rhizome short, adscendent: Stipes fasciculate, terete, the base hirsute, thickened, 2-5 c.M. long. Fronds 7-9 c.M. long, 2-3 c.M. broad, ovatelanceolate, acuminate; main rachis straight, compressed, firm, narrowly winged, marginate, below. Pinnae erect $0 \mathrm{r}^{\circ}$ erecto-patent, (the lowest largest, divaricating), \pm distant, linear-lanceolate, pinnatifid, broadly cuneate at the base. Pinnulae erect, distant, simple or forked, (the lowest rarely pinnatifid). Lacinulae straight, short, the apex entire, circinate-convolute when dry. Texture membranaceous, thin, opaque; veins flexuose. Sori seriate on the pinnae, immersed in abbreviated pinnulae or lacinulae, small, afterwards curved back ; indusium short, marginate, conical-cupuliform, the mouth straight or subspreading; receptacle filiform.

Borneo.

(44) T. rigidum, Sw., Christ, Farnkr. d. Erde, 30; Hk. Bk., Syn. Fil., 86, p. p.

Rhizome short, firm. Stipes firm, naked, tufted, 10-20 c.M. long. Fronds deltoid-ovate, $10-20$ c.M. long, 5-4-pinnatifid; main rachis slightly winged towards the apex. Pinnulae deeply pinnatifid into deeply and irregularly forked, lanceolate segments. Ultimate lobes linear, acute. Texture rather firm and rigid; surfaces naked. Sori small, between the segments, hardly immersed, often free; indusium slightly dilated at the mouth.

Pantropical.

(45) T. bilingue, ink., Journ. of Bot., III, 417; T. melanorhizon, Hk., Icon. Pl., VIII, tab. DCGV; T. brevipes, Bk., Hk. Bk., Syn. Fil., 84, p. p.; T. bilabiatum, Nees \& Bl., var., C. Chr., Ind. Fil.

Rhizome creeping, densely tomentose. Stipes short, under $1 \frac{1}{2}$ c.M.'long. Fronds $\pm 71 / 2$ c.M. long, oblong; main rachis terete. Pinnae rather distant, 2-pinnatifid, slightly decurrent. Ultimate segments narrow. Sori confined to 5-4 on the ultimate segments: indusium long, conical-tubular, marginate, the mouth slightly dilated, 2-lipped, the lips broadly rounded; receptacle filiform.

Luzon.

* (46) 21. mplalebioides, Christ, C. Chr., Ind. Fil.; T. tenuissimum, Christ, Schum. \& Laut., Flor. deut. Sch.geh., 106.

Rhizome wide-creeping, scandent, flexuose, naked, the extremity sparingly clothed with blackish bristles. Stipes scattered, 1 b-20 c.M. long, firm, erect, 
blackish-green, sparingly pubescent below. Fronds \pm 40 c.M. long, \pm 20 c.M. broad, broadly deltoid-ovate, 4-b̆-pinnate. Pinnae distant, the lower ones shorter, stalked, narrowing from a broad base to an acuminate apex. Pinnulae regularly ovate-deltoid. Tertiary segments cut down into regular segments, the lowest of which are divided again. Ultimate segments \pm 5 m.M. long, $\pm 1 / 3$ m.M. broad, with only a central vein. Sori at the base of the superior tertiary segments; indusium hispid, stalked, hypocrateriform, often incurved, the margin conspicuously dilated; receptacle moderately exserted. Texture thin; segments covered with scattered, adpressed, minute bristles. The plant has often abnormal fronds, which are \pm 6 c.M. long, oblong-lanceolate, short-stalked, irregulary 2-pinnate with capillary divisions.

New Guinea.

(47) T1. giganteum, Bory, Hk. Bk., Syn. Fil., 87; Hk., Icon. Pl., VIII, tab. DCCII.

Rhizome wide-creeping, tomentose. Stipes 10-15 c.M. long, strong, erect, hairy. Fronds $30-45$ c.M. long, $15-25$ c.M. broad, ovate, 4-pinnatifid; main rachis hardly winged above. Lower pinnae ovate-lanceolate, 15 -20 c.M. long, cut down to the rachis. Pinnulae $2 \%$ c.M. long, cut down very nearly to the rachis, the divisions again deeply pinnatifid. Ult. segments linear, flat, $2^{1} / 2$ m.M. long, $1 / 2-1$ m.M. broad. Colour dark-green. Surfaces naked, schining; texture semicoriaceous; a central costa only in each segment. Sori $2-20$ to a pinnula; tube more or less exserted, the mouth \pm dilated, not 2-lipped.

Malaya; Fiji, Comores, Mascarenes.

(48) T. Saxatile, Moore, Nich., Dict. d'Hort., V, 324.

Stipes erect, hairy, tufted. Fronds triangular-ovate. Higher pinnae decurrent, lower ones bipinnatifid. Pinnulae ovate, more or less decurved, \pm undulate. Ultimate segments broad, short, obtuse. Indusium tubuliform, slightly 2-lipped. - Plants small.

Borneo.

* (49) M. cimpressoides, Desv., (oldest name), C. Chr., Ind. Fil.; T. T. obscurum, Bl., Rac., Flor. Btz., I, 30; V. D. B., Hymen. Jav., tab. XVII, F M.s V 10 T. rigidum, Sw., Hk. Bk., Syn. Fil., 86, p. p.; Bedd., Ferns S.I., tab. VIII.

Rhizome short-creeping, scaly throughout or at the extremity only. Stipes approximate, $5-20$ c.M. long, slightly covered with brownish hairs. Fronds 
5-20 c.M. long, $21 / 2-15$ c.M. broad, deltoid, ovate or lanceolate, acuminate, 3-4-pinnatifid, the main rachis mostly slightly winged towards the apex and submarginate below. Pinnae erecto-patent, $1 \frac{1 / 2}{2}-2$ c.ll. broad, lanceolateoblong, cut down nearly or quite to the rachis. Pinnulae deeply pinnatifid, with linear, simple or pinnatifid lobes. Ultimate segments short and often tooth-like. Texture \pm coriaceous; margin often slightly crisped. Sori 2-12 to a pinnula, small; indusium more or less exserted, the mouth slightly dilated.

Trop. Asia, Madagascar, Mascarenes, Comores, Seychelles.

* (50) T. Bauerianum, Endl., C. Chr., Ind. Fil.; T. apiifolium, Pr., Rac., Flor. Btz., I, 31; V. D. B., Hymen. Jav., tab. XIX; T. meifolium, Bl., Enum., 227; - var. polyanthos; T. polyanthos Hk., Spec. Fil., I, 158; Icon. Pl., VIII, tab. DCCIII.

Rhizome erect, clothed with long, brownish hairs. Stipes tufted, 10-20 c.M. long, strong, erect, densely clothed with long, spreading, reddish hairs. Fronds 20-50 c.II. long, 10-20 c.I. broad, ovate, acuminate, 3-4-pinnate; rachis hairy, slightly and narrowly winged towards the apex. Longest pinnae 5-15 c.M. long, $1 \frac{1}{2}-4$ c.M. broad, spreading or erecto-patent, lanceolateacuminate. Pinnulae several, cut down into flattened, linear, simple, bifid or pinnate segments, the ultimate ones to $4 \mathrm{~m}$.M. long, $\pm 1 / 2 \mathrm{~m}$.M. broad. Texture subcoriaceous, surfaces naked; a single costa in each ultimate segment. Sori $2-12$ to a pinnula; indusium small, turbinate, the mouth \pm dillated, entire or slightly 2-lipped.

Var. polyanthos: Sori larger; indusium campanulate, the mouth distinctly 2-lipped. Stipe and rachis \pm hispid.

Malaya; Polynesia; - var. polyanthos: East. Malaya; Polynesia.

\section{\$ 3. LEPTOMANES.}

a. Rhizome wide-creeping.

†. Ulimale segments not spreading into various directions. (51) T. gemmatum. +. U. Ulimate segments spreading into various directions. (52) T. meifolium. a.a. Rhizome short-creeping or erect.

b. Ultimate segments as in a, + . (53) T. parviflorum.

b.b. Ultimale segments as in $\boldsymbol{a},+\%$

c. Pinnae 12-15-jugate. Sori mumerous.

(54) T. trichophyllum.

c.c. Pinnae 20-30-jugate. Sori few. (ち5) T. pluma. 
(51) T. gemunatum, J. Sm., Hk. Bk., Syn. Fil., 87; T. foenicula. ceum, Bory, Hk., Spec. Fil., I, 155, p. p.; T. cellulosum, Kl., Hk., 2d Cent. of Ferns, tab. LXIII.

Rhizome strong, wiry, tomentose, beset with numerous, black wiry fibres. Stipes $2 \frac{1}{2}-71 / 2$ c.M. long, naked, wiry, winged above. Fronds $5-15$ c.M. long, $21 / 2$ - 5 c.M. broad, erect, ovate-oblong; main rachis narrowly winged. Pinnae erecto-patent, cut down to a narrowly winged rachis. Lower pinnulae deeply forked with linear-filiform segments $\mathbf{4 - \mathbf { 5 }}$ m.M. long. Texture subrigid; cellules large. Sori $1-8$ to a pinna, minute, axillary; the tube turbinate, stalked, the mouth nearly truncate.

Malacca, Java, Philippines, New Guinea; Trop. South. America.

* (52) Tr. meifolium, Bory, Willd., Spec., V, 509; T. ericoides, Hedw., Rac., Flor. Btz., I, 30; T. longisenum, Bory, V. D. B., Hymen. Jav., tab. XXI; - var. alatum. .

Rhizome strong, wiry, wide-creeping, densely covered with brown, hair-like scales. Stipes scattered, $2 \frac{1}{2}-10$ c.M. long, erect, wiry, more or less covered with brownish, hair-like scales, more densely towards the base, whether or not marginate. Fronds $5-20$ c.M. long, $2-6$ c.M. broad, erect, deltoid to lanceolate; main rachis nudate, but not rarely marginate. Pinnae spieading or erecto-patent, 1-弓 c.M. long. Pinnulae more or less copiously divided into capillary segments $2-\breve{3}$ m.M. long, spreading into various directions. 'Texture firm; surfaces naker; colour dark-brown or blackish when dry; all the divisions narowly marginate. Sori mostly $1-6$ to a pinna, minute, stalked; indusium \pm truncate.

Var. alatum: Stipe and rachis rather broadly winged.

Malaya; Polynesia, Réunion.

* (53) T. parviflorum, Poir., C. Chr., Ind. Fil.; T. foeniculaceum, Bory, Hk. Bk., Syn. Fil., 88; Hk., Spec. Fil., I, 135, p. p.

Stipes nearly turfted, erect, wiry, $5-10$ c M. long, naked or tomentose. Fronds $10-20$ c.M. long, $2-71 / 2 \quad$ c.M. broad, erect, rigid, ovate-lanceolate; main rachis naked, slightly winged above. "Lower pinnae spreading or erectopatent, $2 \frac{1}{2}-4$ c.M. long, cut down quite or very nearly to the rachis. Pinnulae regularly pinnatifid, with simple or forked, linear-filiform, bifarious segments $2-4$ m.M. long. Texture subcoriaceous, colour dark-green. Sori 2-12 to a pinna, minute, the mouth rather spreading, but not 2-lipped.

Borneo, Malacca; Australia, Madagacar, Mascarenes. 
(34) 'T. triehophyllum, Moore, Hk. Bk., Syn. Fil., 466.

Stipes densely tufted, wiry, terete, $21 / 2-5$ c.M. long. Fronds $5-10$ c.M. long, oblong, decompound, $21 / 2-4$ c.ll. broad. Rachis stiff, terete. Pinnae much imbricated, $12-1$-jugate, many deltoid, $1-1^{1 / 2}$ c.II. broad. Lower pinnulae copiously pimnatifid. Ultimate divisions bristle-like, 5-7 m.M. long, spreading in all directions. Sori copious, free, $\pm 1 \mathrm{~m}$.M. deep, placed near the base of the pinnulae on the upper side; indusium with a funnel-shaped tube and truncate mouth.

Borneo, New Guinea; New Caledonia.

(马5) 'I. pluma, Mk., Hk. Bk., Syn. Hil., 466; Hk., Icon. Pl., X, J F tab. CMXCVII; Christ, Farnkr. d. Erde, fig. 68.

Rhizome short-creeping, the scales dense, minute, fibrillose, brown. Stipes 5-10 c.M. long, terete, wiry. Fronds lanceolate, $10-15$ c.M. long, $21 / 2-51 / 2$ c.M. broad, decompound; rachis stiff, terete. Pinnae crowded, 20-30-jugate, spreading, under $1 \frac{1}{2}$ c.M. broad. Lower pinnulae sparsely pimnatifid, cut into bristle-like, dichotomously forked lobes $\mathbf{3}-7 \mathrm{~m}$.M. long, spreading in all directions. Sori few, placed near the base of the upper pinnae; indusium $\pm 1 \mathrm{~m}$. M. long, stalked; tube funnel-shaped, the mouth truncate; receptacle very long.

Malaya; Samoa, New Caledonia. 
FAMILY V. SCHIZAEACEAE. 



\section{SCHIZAEACEAE.}

Capsules either few (1-2), placed in the axils of imbricating, clasping indusia, which form spikes along the margin of the fertile segments or numerous, ranged in 2-4 regular, close rows, which cover one side of close, distichous spikes at the apex of the fertile fronds or segments $\left({ }^{1}\right)$. Ring complete, operculiform, crowning the apex of the capsule. Stomium vertical.

Rhizome creeping or erect. Fronds small and erect or long and twining.

Tropical and extra-tropical.

\section{Key to the genera.}

*. Capsules 1-2; indusium present. Fronds very long and twining.

No. 10. Lygodium.

*.*. Capsules numerous, in $2-4$ rows; indusium wanting. Fronds small and erect.

No. 11. Schizáea.

\section{LYGODIUM, Swart:}

Sporangia 1-2, placed in the axils of imbricating, clasping, scale-like indusia, which form spikes either on separate, contracted segments or in lax rows along the edge of normal segments.

Rhizome creeping. Fronds very long, twining, pinnate. Pinnae $\left({ }^{2}\right)$ stalked, opposite, the pairs placed on very short, alternate, primary petioles which are often inconspicuous and sometimes quite wanting; veins free or anastomosing. Hk. Bk., Syn. Fil., tab. IX, fig. 68; Diels, in Engl. \& Prantl, Nat. Pfl.Fam., $I^{4}$, fig. 195 .

Tropical and extra-tropical.

Arrangement of the sections.

$\$ 1$. EULYGoDIUM. Veins free.

\$2. HYDROGLOSSUM. Veins anastomosing. (Not in Malaya).

\section{(13) L. herruller}
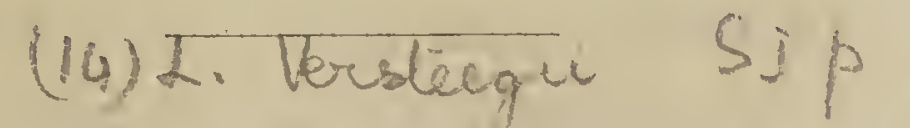

( $\left.{ }^{2}\right)$ The characters of the african and american genera are not mentioned here.

$\left({ }^{2}\right)$ The segments indicated here as pinnae are properly the branches of forked pinnae, the very short stalks of which are forming the so-called primary petioles. 


\section{S 1. EULYGODIUM. see SI $p 114$}

a. Barren pinnae forled or more commonly digilate or dichotomous.

1. Fertile segments not or hardly narrowed.

+. Pinnae once forked.

(1) L. semihastatum. SIp /

+. . Pinnae at least $2 \times$ forked.

1.1. Fertile segments conspicuously narrowed or contracted.

(2) L. Teysmannii.

2. Spiles \pm close, in continuous, short or long rows along the margin of the segments.

3. Ultimate segments bordered by a marginal strand; the gemmiform apex of the rachis clothed with brownish hairs. Spores verruculose.

(5) L. circinatum.

3.3. Ultimate segments without marginal strand; the hairs of the SI por gemmiform apex blackish. Spores coarsely tuberculale.

(4) L. digitatum.

2.2. Spikes in groups of 3-6 on the lobes of the segments. (5)L. trifurcatum. a.a. Barren pinnae pinnale, the pinnulae simple or variously divided.

b. All the pinnulae regularly pectinato-pinnatifid throughout.

(6) L. polystachyum.

b.b. Pinnulae simple, or the lower ones forked, hastate, subpalmate or pinnate.

c. Pinnulae articulate at the base, or the ultimate petioles distinctly nodose at the apex.

+Pinnulae oblong, simple, 2-31/2 c.M. long. Spores reticulate.

(7) L. scandens. p8302

+*. Pinnulae linear-oblong or lanceolate, $3{ }_{2}-11$ c.M. Yong, the lower ferlule ones simple or pimaile. Spores verruculose.

(8) L. salicifolium.

c.c. Pinnulae' not articulate, nor the ultimate petioles distinctly nodose at the apex.

d. Pinnulae 1-2-jugate; the lower ones simple. (9) L. altum. d.d. Pinnulae 2-7-jugate, the lower ones moslly hastate, subpalmate or pinnate.

e. Barren pinnae rather long, the segments serrulate. Fertile segments often narrower, but not contracted. (10) L. flexuosum.

e.e. Barren pinnae rather short, the segments coarsely crenate. Fertile segments contracted and deeply incised.

(11) L. japonicum. 
* (1) C. semihastatum, Desv., Hk. Bk., Syn. Fil., 437; ( ? L. flexuosum, Sw., C. Chr., Ind. Fil.; Prantl, Morph. d. Gefässcr., II, Schiz., 73).

Primary petioles nearly or quite obsolete; secondary ones 2 c.M. or more long. Pinnae ónce forked; each division short-stalked, not articulate, simple, ligulate or lanceolate, 1 ב̆-20 c.M. long, nearly $21 / 2$ c.M. broad, the bases \pm unequal, sometimes very cordate at one side. Texture papyraceous to coriaceous; surfaces naked. Spikes $5-8 \mathrm{~m}$. .M. long, in close rows along the edge of the leaflets. Spores verruculose (in the Borneo-plant which I examined).

Borneo, Philippines; Marianne Islands.

\section{* (2) I. 'Teysumannii, v. A. v. R.}

Primary petioles very short; secondary ones 2-3 c.M. long. Pinnae forked, subpinnate. Pinnulae stalked, not articulate, the lower one spreading, $1-2 \times$ forked again, the stalk $\pm 5-10 \mathrm{~m}$.II. long; the higher one $2 \times$ forked again, the stalk $1-21 / 2$ c.II. long, nearly straight with the secondary petiole. Ultimate segments lanceolate, 8-12 c.M. long, $1-1 \frac{1}{2}$ c.M. broad, free or joined into pairs, the apex narrowed, \pm acute, the edge serrate, the base subcordate or truncate or often cuneate at the inner side when the segments are free. Texture subcoriaceous; surfaces naked or slightly covered with scattered hairs on the costae; upper surface \pm glossy, under one opaque, rachis pale-brown (when dry), slender, slightly hairy and narrowly marginate as are the stalks; costae not or slightly nodulose at the hase. Fertile pinnulae similar to the barren, not or slightly narrowed. Spikes $1-4$ m.M. long, contiguous. (The capsules of the 2 specimens were all unripe, and only 2 reticulated spores are seen among the numerous examined undeveloped ones).

Pulu Pisang (Teysmann Nos. 1597 \& 2304).

* (3) L. Circinatum, Swo, Christ, Farnkr. d. Erde, 353; Prantl, Morph. d. Gefässcr., II, Schiz., 64; L. dichotomum. Sw., Rac., Flor. Btz., I, 8, p. p.; Bedd., Ferns S.I., tab. LXII; - var. monstruosum, Hort. Bog.; var. denticulatum, Prantl, l. c., 65; - - var. cristatum.

Primary petioles very short or wanting, secondary ones $2-5$ c.M. long, semiterete, marginate. Pinnae digitate with $5-6$ lobes reaching down nearly to the cuneate or truncate base or 2-partite with the forkings digitate. Ultimate segments $10-50$ c.Mr. long, $1-4$ c.M. broad, not articulate, lanceolate or linear, subacuminate, the margin bordered by a hypodermical strand (marginal vein). Texture firm-membranaceous to coriaceous; surfaces naked or \pm hairy on the costae, upper surface glossy, under one opaque; main rachis stramineous, the gemmiform apex clothed with pale-fuscous hairs. Fertile segments 
often numerous, not rarely subpinnate, conspicuously narrowed or contracted, 1-10 m.M. broad. Spikes 2-10 m.M. long. Spores verruculose. -

Forma typica: Spores without crests. Laciniae entire, not dichotomous at the apex.

Var. monstruosum: Spores without crests. Laciniae dichotomous at the apex.

Viro denticulatum: Spores without crests. Laciniae denticulate, not dichotomous at the apex.

Var. Cristatum: Like var. denticulatum, but the spores purveyed with 6 joining crests. Laciniae $\pm 1 / 2-1$ c.M. broad. Sumatra (Burck).

Trop. Asia, Queensland.

(4) L. digitatum, Pr., Prantl, Morph. d. Gefässcr., II, Schiz., 66 ; L. dichotomum, Sw., Rac., Flor. Btz., I, 8, p. p.

Primary petioles nearly wanting; secondary ones $1 \frac{1}{2}-2$ c.M. long, semiterete, marginate. Pinnae 2-partite or subpinnate. Pinnulae short-stalked, not articulate, digitate with 5-6 laciniae 7-10 c.M. long, \pm 1 c.M. broad, the apex acute, the margin serrulate, not bordered by a hypodermical strand. Texture subcoriaceous; surfaces naked, upper surface glossy, the under one opaque; rachis reddish-stramineous, the hairs of the gemmiform apex blackish. Fertile pinnae 2-partite, each segment with \pm 5 laciniae to $\mathbf{5} 5$ c.M.long, \pm 5 m.M. broad. Spikes to 6 m.M. long. Spores rather large, coarsely tuberculate. Trop. Asia.

* (๖) D. troifur cartums, \#t., Hk. Bk., Syn. Fil, 457 ; Prantl, Morph. d. Gefässcr., II, Schiz., 67; L. circinalum, Sw., var. mifurcatum, Christ, in Warb., Mons., I, 93.

Primary petioles very short or obsolete, secondary ones $21 / 2-4$ c.M. long. Pinnae forked, 5-furcate or $2 \times$ forked and each division 2-partite nearly to the base. Ultimate barren segments $10-15$ c.M. long, $\pm 2-2^{1} / 2$ c.M. broad, not articulate, the point acute or bluntish, the edge crenulate. Texture subcoriaceous; rachis and surfaces naked. Fertile pinnae varying from dichotomous to b-pinnate, the divisions contracted and often cut down nearly or quite to the costa with the short spikes in groups of $\mathbf{5}-\mathbf{6}$ upon the lobes. Spores coarsely verrucose. - The Banca plant (leg. Berkhout) has the spikes rather long, in groups of $1-3$, and the spores verruculose and crested. Probahly an intermediate form between this species and L. circinatum, $S w$.

Banca, Celebes, Amboyna, New Guinea; Polynesia, Melanesia. 
(6) D. Dolystachyoum, Wall., Hk. Bk., Syn. Fil., 458; Hk., 2d J.FMS Cent. of Ferns, tab. LXXVI; Bedd., Ferns Br.I., II tab. CGG; L. pinnatifidum, Prantl (not Sw.), Morph. d. Gefässcr., II, Schiz., 83.

Primary petioles short or obsolete, secondary ones $1 / 2-11 / 2$ c.M. long. Pinnae 20-50 c.M. long, 10-15 c.M. broad. Pinnulae uniform, 9-12 on each side, $5-71 / 2$ c.M. long, to $2^{1 / 2}$ c.M. broad, articulate at the base, pinnatifid throughout more than half-way down to the costa into close, entire, blunt lobes \pm 5 m.M. broad; upper pinnulae sessile, lower ones short-stalked. Texture subcoriaceous; rachis and surfaces pubescent. The fruit in the fertile pinnulae occupying the back of the scarcely modified lobes. Spores verruculose.

Malacca; Tenasserim.

* (7) L. scandens, Sw., Rac., Flor. Btz., I, 8; Prantl, Morph. d. Gefässcr., II, Schiz., 81; Bedd., Ferns S.I., tab. LXI ; L. microphyllum, R. Br., Bedd., Handb. Ind. Ferns, 455.

Primary petioles very short, secondary ones $1-21 / 2$ c.M. long. Pinnae $7 \frac{1}{2}-20$ c.M. long, with a terminal, simple or bifid pinnula and 4-6 lateral ones on each side. Pinnulae alternate, stalked, articulate at the base, $2-51 / 2$ c.M. long, $\pm 1 \frac{1}{2}$ c.M. broad, subtriangular or oblong, blunt, simple, entire or rarely slightly lobed, the base rounded, truncate, cordate or bluntly hastate. Texture thin but firm. Fertile pinnulae commonly shorter, subdeltoid, with a mostly rounded apex. Spikes $21 / 2-71 / 2$ m.M. long, in close rows. Spores reticulate.

Trop. Africa, Asia, Australia, Polynesia.

* (8) C. Salliẹffollium, Pr., Prantl, Morph. d. Gefässcr., II, Schiz., 79; L. pinnatifidum, Sw., Rac., Flor. Btz., I, 7, p. p.

Primary petioles short or wanting. Pinnae pinnate, 12-50 c.M. long, 7-22 c.ll. broad, the rachis \pm straight and narrowly marginate, with 4-7 pinnulae on each side below the terminal one. Pinnulae stalked, linear-lanceolate, acute or bluntish, the edge serrulate, the base cordate, truncate or rounded, the stalks nodose \& spuriously articulate at the apex. Lowest pinnulae sometimes pinnate with $1-5$ leaflets on each side below the terminal one; lateral leaflets small, subrhomboidal, the base cordate on the lower and cuneate on the upper side; terminal leaflets with the base cuneate on both sides. Texture \pm coriaceous; upper surface glossy, naked or slightly hairy on the costae; under surface opaque; rachises rather slightly hairy. Fertile pinnulae similar to the barren ones. Spikes to $\pm 4 \mathrm{~m}$.M. long. Spores verruculose. Trop. Asia.

Filices. 
(9) R. altum, v. A.v. M.; L. Mexuosum, Sw., var. alta, Clarke, Journ. of Linn. Soc., Bot., XXV, 101, tab. XXIV; Bedd., Ind. Ferns, Suppl., 108.

Scandent, the branches pendant, to 9 M. long, pinnate. Pinnae pinnate again. Pinnulae (both sterile and fertile) \pm 20 c.M. long, \pm 2 c.M. broad, the lateral ones $1-2$ on each side, simple, on stalks $1-1 \frac{1}{2}$ c.II. long, the edges parallel, entire, the base truncate or auriculate, the terminal ones simple or forked at the base. - Baker esteems this a species.

Malacca; Munipore.

* (10) L. Nexumosum, Sw., Prantl, Morph. d. Gefässcr., II, Schiz., 72 ; Bedd., Ferns S.I., tab. LXIII; L. pinnatifidum, Sw., Rac., Flor. Btz., I, 7, p. p.

Primary petioles short or wanting, secondary ones to 5 c.M. long. Pimnae $1 \breve{-50}$ c.M. long, $15-30$ c.H. broad, the rachis \pm flexuose, narrowly marginate, with $2-7$ pinnulae on each side below the terminal one. Pinnulae stalked, the terminal and higher ones free or joined, the base.cordate, often hastato-auriculate or palmatifid, the edge serrulate, the apex acuminate, acute or blunt; central pinnulae subpalmatifid at the base, the lateral lobes similar to the central one but much shorter; lowest pinnulae similar to the central ones but the basal segments mostly free. Texture herbaceous; surfaces more or less densely hairy, rarely subglabrous; rachises hairy or nearly naked, costae rarely subnodose at the base. Fertile pinnulae similar to the barren ones but shorter, 3-5 c.M. long, the lowest nearly always pinnate with \pm 1-3 leaflets on each side similar to the terminal one but smaller. Spikes 2-10 m.M. long. Spores verruculose.

Trop. \& temp. Asia, Australia.

(11) L. joenponicum, Sw., Rac., Flor. Btz., I, 8; Prantl, Morph. d. Gefässcr., II, Schiz., 68, tab. I, fig. 10 ; Bedd., Ferns .S.I., tab. LXIV; Christ, Farnkr. d. Erde, fig. 1122.

Primary petioles short, to 1 c.M. long, secondary ones $1-21 / 2$ c.M. long. Pinnae 10-20 c.M. long, nearly as broad or narrower, \pm deltoid in outline, pinnate, the rachis \pm flexuose, marginate (nar'rowly winged) especially towards the apex. Pinnulae $\pm 2-5$ on each side below the terminal one, not articulate, the higher and terminal ones simple, free or confluent, elongate, linear-lanceolate, the base cuneate or subcordate, the apex bluntish, the edge coarsely crenate or toothed and crenate, or lobed in the lower part; central pinnulae hastate or subpalmatifid, the lowest ones pinnate or 2-pinnate, the rachis marginate, the segments similar to the higher or central pinnulae but 
smaller. Texture herbaceous; rachises and surfaces hairy; costae subflexuose, not nodose at the base. Fertile pinnulae like the barren ones but smaller, more deeply incised and commonly so contracted that there is a little or no lamina present. Spikes to $\breve{b}$ or rarely to $10 \mathrm{~m}$.II. long. Spores verruculose. Trop. and temp. Asia.

\section{SCHIZAEA, Smith.}

Sori linear, consisting of 2 or 4 regular or nearly regular rows of sessile sporangia, covering the inner side of the \pm close branches of the pinnate or digitate, fertile apices of the fronds (or segments of the fronds). Indusium wanting, but the young sori \pm covered by the incurved edges of the fertile segments.

Rhizome creeping or erect. Fronds simple or dichotomous, erect. Small plants, very distinct in habit. Hk. Bk., Syn. Fil., tab. VIII, fig. 64; Diels, in Engl. \& Prantl, Nat. Pfl.Fam., I ${ }^{4}$, fig. 195.

Tropical and extra-tropical.

\section{Arrangement of the sections.}

$\$$ 1. EUSCHIZAEA. Fertile portion pinnate, barren simple, linear. Sporangia 2-serial.

\$2. LOPHIDIUM. Fertile portion pinnate, barren dichotomous. Sporangia 2-serial.

S3. ACTINOSTACHYS. Fertile portion \pm digitate, barren simple, linear. Sporangia appearantly 4-serial.

\section{S 1 . EUSCHIZAEA.}

*. Fertile spikes 3-6-jugate, the lowest ones 5-7 m.M.long. (1) S. malaccana. *.*. Fertile spikes 10-20-jugate, the lowest ones \pm 3 m.M. long.

(2) S. fistulosa. 
(1) S. mnalaccana, Rki., Hk. Bk., Syn. Fil., 428; Bedd., Ferns Br. I., II, tab. CGLV; S. fistulosa, Lab., var. malaccana, Prantl, Morph. d. Gefässcr., II, Schiz., 136.

Stipes dense, not distinguishable from the fronds, which are $10-20$ c.M. long, weak, flexuose, subterete, simply channelled in frònt, not more than $1 / 2$ m.M. thick, the barren and fertile ones similar. Fertile portion erect, 8-10 m.M. long, with 3-6 slender, spreading pinnae (spikes) on each side, the lowest $\mathfrak{b}-7$ m.M. long.

Malaya; Burmah.

(2) S. fistulosa, Lab., Hk. Bk., Sỵ. Fil., 4.29; Lab., Nov. Holl., tab. CCL, fig. 5.

Stipes dense, chestnut-brown, passing gradually into the fronds, which are 10-50 c.M. long, rigid, rush-like, subterete, simply channelled in front. Fertile portion suberect, unilateral, $1-21 / 2$ c.M. long, with $10-20$ close, slender, erecto-patent spikes on each side, the lowest \pm 5 m.M. long.

Borneo; Australia, Tasmania, New Zealand, New Caledonia, Fiji, Chili, Madagascar.

\section{\$2. LOPHIDIUM.}

* (3) S. dichotonna, Sm., Rac., Flor. Btz., I, 6; Bedd. Ferns S.I., J. r tab. LXV; Hk. \& Grev., Ic. Fil., tab. XVII; S. Forsteri, Spr., Muell., Pap. Pl., Vol v IV, 75 .

Rhizome erect, densely covered with lanceolate scales. Stipes dense, 1 b-45 c.M. long, firm, erect, glossy, channelled on the face above. Fronds fan-like in general outline, $71 / 2-221 / 2$ c.M. each way, many times dichotomously Koh $P$ forked; ultimate divisions flattened, $1 \frac{1}{2}-71 / 2 \mathrm{~m} . \mathrm{M}$. broad, with the fertile portion Puid pinnate, 4-12 m.M. long, the rachis often curved, with 3-10 close, spreading, hairy pinnae (spikes) on each side.

Trop. Asia, Australia \& Polynesia, Madagascar, Mascarenes.

$$
\text { P. Sirm }
$$

\section{\$3. ACTINOSTACHYS.}

* (4) S. Iigitata, Sw., Rac., Flor. Btz., I, 7; Bedd., Ferns S.I., tab. CGLXVIII; Hk., Gard. Ferns, tab. IL.

Rhizome creeping or erect. Stipes dense, $21 / 2-5$ c.M. long, brownish, 
subterete, passing gradually into the fronds, which are 20 -35 c.M. or more long, 2-5 m.M. broad, flattened, coriaceous, entire, narrowed towards the apex, the midrib prominent beneath, crowned at the apex with $\mathbf{5}-15$ subtriquetrous, digitate, linear spikes, which are $2-5$ c.M. long, naked beneath, with the edges inflexed.

Trop. Asia \& Polynesia. 

FAMILY VI. POLYPODIACEAE. 



\section{POLYPODIACEAE.}

Sori definite, marginal, submarginal or dorsal, various in shape, punctiform, round, oblong, reniform : or linear, often indefinite and consisting of numerous capsules crowded densely over the under surface or portions of the under surface, occasionally extending \pm on both surfaces of the fronds. Capsules usually stalked, provided with a longitudinal, incomplete annulus, interrupted by the stalk (except in Plagiogyria, which has the capsules of Cyatheae), opening : by a transversal stomium. Indusium wanting or present, various in shape, and size.

Rhizome creeping or erect, rarely arborescent. Fronds various in shape, size and appearance; veins free or anastomosing variously.

A most extensive family inhabiting almost every part of the world.

Arrangement of the tribes.

A. Indusiatae. Indusium present.

$\$ 1$. WOODSIEAE. Sori globose, oblong or linear, situated on the back or apex of a vein or veinlet. Indusium inferior, cupuliform, globose or sausage-shaped, fastened all round the receptacle, open at the top or rupturing down irregularly. Stipes not articulate to the rhizome.

\$2. ASPIDIEAE. Sori oblong, round or reniform, medial or terminal on the veins. Indusium superior, of the same shape as the sorus, fastened by a longitudinal axis, a central point or at the top of a \pm deep sinus, opening all round the edge or nearly so. Stipes in most of the genera not articulate to the rhizome.

S3. DAVALLIEAE. Sori roundish, oblong or linear, rarely medial on the veins but more generally submarginal and then solitary and terminal on the vein tips or uniting the apices of 2 or more veins $0 r^{\circ}$ veinlets. Indusium \pm of the same shape, attached at the inner side of the sorus, opening outwardly. Stipes whether or not articulate to the rhizome.

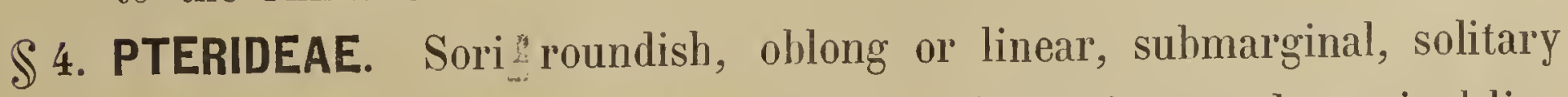
and terminal on the vein tips, often confluent into a submarginal line 
or more commonly uniting the apices of several veins. Indusium marginal, i. e. consisting of the recurved or reflexed, modified edge of the frond or portions of the edge, opening inwardly. Stipes not articulate to the rhizome.

S b. BLECHNEAE. Sori oblong or linear, distant from the margin, parallel to the central ribs of the free or joined ultimate segments. Indusium of the same shape, not marginal, attached at the outer side of the sorus, opening inwardly. Stipes not articulate to the rhizome.

\$6. ASPLENIEAE. Sori oblong or linear, straight or more or less recurved, rarely horseshoe-shaped, springing from the sides of the veins like the indusia, mostly oblique to the costa, rarely placed between the veins or occupying the single central vein of narrow, ultimate segments. Indusium of the same shape, opening towards the costa or sometimes towards the margin, if double opening towards opposite directions. Stipes not articulate to the rhizome.

B. Exindusiatae. Indusium wanting.

\$ 7. PHEGOPTERIDEAE. Sori punctiform, round or oblong, rarely more than $2 \times$ as long as broad, medial or terminal on the veins, if medial the opposite pairs somentimes confluent, if terminal sometimes running into a submarginal line or more or less covered by recurved, not modified margin of the frond. Stipes not articulate to the rhizome

S8. GYMNOGRAMMEAE. Sori linear or linear-oblong, more than $2 \times$ as long as broad, several on each side of the costa, mostly oblique to the latter, or rumning longitudinally and irregularly along the veins, free, joining or \pm reticulate. Stipes not articulate to the rhizome.

$\$ 9$. GRAMMITIDEAE. Sori linear, one on each side of the costa, parallel to the latter or the margin, continuous or interrupted. Stipes not articulate to the rhizome.

$\$ 10$. POLYPODIEAE. Sori punctiform, round, oblong or linear and then either oblique $0 r^{\circ}$ parallel to the costa or the margin. Stipes articulate to the rhizome.

$\$ 11$ ACROSTICHEAE. Sori indefinite, the sporangia densely crowded over the under surface of the fronds or portions of the under surface or occasionally extending \pm on both sides of the fronds or segments, not rarely becoming narrowly linear when the fertile segments are much contracted. Stipes whether or not articulate to the rhizome. 
Keys to the tribes and genera.

1. Indusium present, free from the margin or consisting of the reflexed or recurved, modified margin or portions of the margin.

2. Indusium cupuliform, globose or sausage-shaped, fastened beneath the sorus on all sides, open at the top or bursting down irregularly.

$\$ 1$. Woodsieae.

2.2. Indusium oblong, round or reniform, fastened above the sorus, attached by a longitudinal axis, a central point or at the top of a \pm deep sinus, opening all round the edge or nearly so. $\mathbb{2} 2$. Aspidieace.

2.2.2. Indusium roundish, oblong or linear, fastened mostly at 1 side of the sorus, opening at the opposite, free edge.

3. Indusium marginal, consisting of the reflexed or recurved margin or portions of the margin, opening inwardly. $\$ 4$. Prenideae.

3.3. Indusium not marginal, but often reaching the margin with one of the free edges.

4. Sori either roundish and solitary (dorsal or terminal) on the veins, or oblong to linear and uniting the apices of 2 or more veins. Indusium attached at least at the inner side of the sorus, opening outwardly.

$\$ 5$. Daa vallieae.

4.4. Sori linear or oblong, strictly parallel to the central ribs of the ultimate segments. Indusium atlached at the outer side of the sorus, opening inwardly. $\$ 5$. IBlechnese.

1.1.1. Sori linear or oblong, sometimes much recurved or horseshoe-shaped, springing from the sides of the veins, rarely placed between the veins, oblique to the costa, sometimes subparallel to the latter or occupying the single central vein of narrow, ultimate segments. Indusia springing from the same side as the sori, mostly opening obliquely towards the costa.

S 6. Asplenieac.

1.1. Indusium wanting. Sori sometimes covered by the recurved, not modified margin or portions of the margin, often more or less deeply sunk in marginal or dorsal grooves or pit-like, saccate or indusium-shaped cavities or depressions of the frond.

a. Sori indefinite, the sporangia crowded over the under surface or portions of the under surface, not rarely becoming narrowly linear or sometimes extending on both surfaces of the fronds in the often much contracted fertile segments.

\& 11. Acrostichene. 
a.a. Sori definite. Sporangia gathered into sori, which are sometimes contiguous or confluent, but always distinct when young.

b. Fronds articulate to the rhizome. Sori punctiform, round, oblong or linear.

$\$ 10$. Polypdieae.

b.b. Fronds not articulate to the rhizome.

c. Sori punctiform, round or oblong, not more than $2 \times$ as long as broad, sometimes running into a submarginal line if terminal on the veins. $\$$. Phegopterideac.

c.c. Sori linear or linear-oblong, more than $2 X$ as long as broad, continuous or interrupted, free or reticulate.

d. Sori parallel to the costa or the margin, in 1 line on' each side, free.

S 9. Crammitideae.

d.d. Sori more or less oblique to the costa and the margin, many on each side, free or reticulate.

S 8. Aymmogrammeae.

\section{S 1. WOODSIEAE.}

1. Indusium globose or sausage-shaped, bursting down irregularly.

2. Indusium globose; veins free.

No. 12. Diacalpe.

2.2. Indusium sausage-shaped; veins anastomosing.

No. 13. Diplaziopsis.

1.1. Indusium cup-shaped, open at the top. No. 14. Demnstaedtia.

\section{\$2. ASPIDIEAE.}

a. Stipes articulate to the rhizome. Indusium reniform, attached at the top of the sinus.

+. Fronds simple.

No. 15. Dleandrea.

+. Fronds pimnate; pinmae articulate to the rachis.

No. 16. Anthropteris.

a.a. Stipes not articulate to the rhizome. Indusium oblong, round or reniform; if oblong fastened by its longitudinal axis, if round peltate, fastened by a central point, if reniform attached at the top of its sinus, with the lobes sometimes meeting or overlapping and then appearantly orbicular. 
b. Veins free.

c. Leaflets very unequal-sided, the upper base broadly cuneate or subtruncate, the lower obliquely cut away.

+. Indusium oblong, terminal on the veins; leaflets articulate to the rachis.

No. 20. Didtymochlanema.

**. Indusium round, rarely reniform; leaflets not articulate to the rachis.

No. 19. Polystionnm.

c.c. Leaflets \pm equal-sided and if unequal-sided the lower base not or slightly cut away.

d. Fronds pinnate; pinnae articulate to the rachis; main veins simple or forked. Indusium round or reniform.

e. Indusium round, peltate, without a sinus.

No. 18. Cyclopeltis.

e.e. Indusium reniform, sinus present, the lobes sometimes meeting or overlapping and then the indusium becoming lound and subpieltate.

No. 17. Nephrolepis.

d.d. Fronds generally variously divided; leaflets not articulate; main veins pinnate. Indusium reniform, rarely round.

No. 22. Dryopteris, $\$$ Lastraea.

b.b. Veins more or less anastomosing.

1. Lowest veins of contiguous groups forming a costal row of regular, \pm deltoid areolae on each side, the tops of which with an excurrent veinlet, which is either free or joining in the angles of the superior pairs of veins, which often form 1 or more rows of regular, \pm rhomboidal areolae between the costal ones and the margin.

+. Indusium reniform, rarely round.

No. 22. Pryoperis, $\mathbb{S}$ Nephrodium. $\%$ Indusium oblong, $\pm 5 \times$ as long as broad.

No. 25. Hespelniaena.

1.1. Veins not anastomosing as in 1.

2. Lower veins forming $1-2$ rows of irregular costal areolae, the rest free or slightly anastomosing near the main veins. Indusium reniform.

No. 21. Pleocmemia.

2.2. Veins anastomosing copiously and mostly irregularly.

3. Sori alternate, in 5-4 rows on each side of the midrib. Indusium oblong, $\pm 5 \times$ as long as broad. Fronds simple.

No. 24. Huenessenia. 
3.3. Sori scattered irregulary or placed in 2 rows between the main veins. Indusium round or reniform, and if oblong then at hest $2 \times$ as long as broad and the fronds not simple.

4. Excurrent soriferous free veinlets $2-5$ to each areola. Sori not compital. Indusium round.

No. 26. Cyrotominn.

4.4. Excurrent soriferous free veinlets wanting or 1 to each areola, or the soriferous veinlets spreading into various direčtions. Sori often compital. Indusium round or reniform. No. 2b. Aspidium.

\section{\$ 5. DAVALLIEAE.}

a. Sori roundish, dorsal on the veins. No. 27. Cystopteris.

a.a. Sori roundish, oblong or linear, submarginal, terminal on the veins (or veinlets, which are sometimes very shorl and inconspicuous), or uniting the apices of 2 or more veins or veinlets.

b. Fronds divided; leaflets (not the lobes) dimidiate, i. e. the half on the lower side of the midrib cut away.

\section{No. 29. Lindsaya.}

3.t. Fronds simple or divided, if divided the leaflets not dimidiate.

c. Sori roundish or transversally oblong, occupying the truncate apex of the cuneate, ultimate segments.

\section{No. 28. Dellontosoria.}

c.c. Sori occupying the sides, very rarely the apex of not cuneate, ultimate segments.

d. Sori transversally oblong or linear, uniting the apices of 2 or more veins or veinlets.

+. Fronds simple or divided, if divided the leaflets not articulate to the rachis. No. 50. Selnizoloma.

*.+. Fronds pinnate, leaflets articulate to the rachis. Indusium sometimes 2-valved.

(No. 17. Nephromolepis, $\mathbb{S}$ Lindsayopsis).

d.d. Sori roundish or oblong, solitary on the vein tips, some of them sometimes confluent. 
c. Indusium fastened at the base, open at the sides and the outer edge.

1. Sori placed in conspicuously cucullate, marginal outgrowths, wich are closed by the \pm flattened, transversally oblong indusia.

No. 51. Accolouna (sorbifolium).

1.1. Sori not on marginal outgrowths.

2. Rhizome creeping; stipes scattered, articulate to the rhizome. No. 32. Homat

2.2. Rhizome erect; stipes tufted, not articulate.

No. 55. Al cordingrus.

e.e. Indusium fastened at the base and sides, open at the outer edge.

f. Rhizome scaly, the scales often hair-pointed at the apex, not minute.

g. Stipes articulate to the rhizome, scattered.

No. 54. Davalliak.

y.g. Stipes not articulate to the rhizome.

r. Sori 1 to each ultimate segment. Indusium half-cupshaped.

(No. 55. Aspleniom, $\mathbb{S}$ Loxoscaphe).

r.h. Sori many to each ultimate segment. Indusium cuneate.

No. 51. Sacolorima (moluccanum).

f.f: Rhizome hairy, fibrillose $01^{\circ}$ minutely scaly, creeping. Stipes not articulate to the rhizome.

*. Ultimate divisions unequal-sided, rhomboidal or linear-triangular and then gradually narrowed towards the apex. Receptacle distinct. No. 55. NFiremolepia.

*.*. Ultimate divisions linear-lanceolate or divided into \pm linear segments, with the broadest part in the centre. Receptacle indistinct.

No. 36. Tapeinndium. 


\section{\$ 4. PTERIDEAE.}

1. Indusia bearing and covering the sori. No. 37. Adiantum.

R.1. Indusia not bearing, only covering the sori.

2. Sori submarginal, roundish, distant, terminal on the veins, confined to the tops of the sinusses, 1 to each sinus. Indusium roundish, small, hardly covering the sorus at full maturity.

No. 38. Hypolepis.

2.2. Sori submarginal, either roundish $\cdot 0 r$ oblong, close, soon running into a submarginal line or linear, uniting the apices of the veins, not confined to the tops of the sinusses. Indusia transversally oblong, approximate, contiguous, confluent or linear.

3. Sori terminal on the veins, free, roundish or oblong, soon confluent into a submarginal line.

1. Base of the stipe abruptly tickened, bearing $\pm 3-6$ spongy projections on the outer side. Ring oblique, complete, as in Cyatheae. Fertile pinnae narrowly linear.

No. 40. Plagiogyria.

1.4. Base of the stipe not abruptly thickened, without projections. Ring vertical, incomplete.

5. Vein tips thickened.

No. 59. Cheilantes.

5.5. Vein tips not or hardly thickened.

C. Fronds divided; leaflets \pm stalked, not adnate to the rachis, more or less distinctly articulate at the base. No. 41. Pellaea, $\mathbb{S}$ Platyloma.

6.6. Fronds simple or divided; segments adnate or joined, not stalked, not articulate.

No. 42. Donyopteris, $\mathbb{S}$ Doryopteridastrum.

3.3. Sori linear or linear-oblong, the receptacle uniting the tips of the veins, sometimes running them transversally.

a. Stipes with 1-2, free or joining vascular strands.

b. Fronds compoundly divided; lowest pinnulae (secondary pinnae) short, close to the rachis, stipule-like.

No. 43. Histiopteris.

\$.b. Fronds simple or divided, if divided the lowest pinnulae (secondary pinnae) not stipule-like.

c. Fronds divided; leaflets articulate to the rachis.

No. 41. Pellmen, $\mathbb{S}$ Pleridella. 
c.c. Fronds mostly divided; leaflets not articulate to the rachis.

d. Veins free.

e. Spores bilateral, \pm bean-shaped; indusium mostly double. No. 46. Paesia.

e.e. Spores globose to teluahedral; indusium always single.

f. Fronds finely dissected. Sori and indusia \pm meeting against the midribs of the very small and narrow ultimate segments.

No. 44. Dnychium.

f.f. Fronds not finely dissected. Sori and indusia not meeting. Ultimate segments not very small.

No. 45. Ptemis.

d.d. Veins anastomosing more or less copiously.

*. Stipes black.

No. 42. Doryopteris, $\mathbb{S}$ Eudoryopteris. *.*. Stipes not black. No. 45. Pteris. a.a. Stipes with 3 or more, free vascular strands.

$\therefore \quad$ Stipes with 2 stout and 1 to several finer strands placed altogether in a circle. Fronds dimorphous, at utmost 2-pinnatifid.

No. 48. Homaria.

... Stipes with many (12-24) irregularly placed strands. Fronds uniform, at least 2-pinnate at the base.

No. 47. Pteridium.

\section{S. 5. BLECHNEAE.}

1. Sori superficial.

2. Sori long, linear, 1 on each side of and \pm close to the midribs of the ultimate segments, continuous or interrupted.

3. Fronds dimorphous; fertile pinnae much contracted and the sori filling up nearly the whole space between the margin and the costa. Indusium submarginal. (No. 48. Lomaria).

3.3. Fronds not dimorphous; fertile pinnae not contracted; sori distant from the margin like the indusia.

Filices. 
4. Veins of sterile fronds free, those of the fertile ones united near the base by subcostal strands bearing the sori.

No. 49. FBlechnum.

4. R. Veins of both sterile and fertile fronds united near the base.

No. ๖0. Siandlleria.

2.2. Sori oblong, in 1 or more rows on each side of the midribs, not \pm close to the latter.

No. b1. Modilian.

1.1. Sori immersed in cavilies, oblong, in 1 row on each side of the midribs of the ultimate segments.

No. 52. Wood waredian.

\section{$\$ 6$. ASPLENIEAE.}

a. Sori between the veins; indusia 2 to each sorus, springing from the inner side of the 2 contiguous veins, opening towards one another.

No. ร7. Trouphlebia.

a. $\boldsymbol{x}$. Sori springing from the sides of the veins like the indusia; indusia 1 to each sorus.

Ђ. Stipes with $2 \pm$ flattened vascular strands mostly uniting towards the apex (of the stipe) or higher into a single diarchous one $(\backslash /, \vee, \backslash \ldots /, \sqcup, \cup)$. Scales of the rhizome finely cancellate, the areolae mostly dark-coloured.

c. Sori and indusia mostly long and straight; the lower sori and indusia of the "same group of veins often, the higher ones rarely double, i. e. 2 opposite sori and indusia to a single vein.

No. 55. Diplarivim.

c.c. Sori and indusia mostly short, often curved, sometimes hamate or horseshoe-shaped, the higher ones never, the lower rarely double.

No. 弓้4. Atlleyrianm.

b.b. Stipes with $2 \pm$ concave vascular strands mostly uniting towards the apex (of the stipe) or higher into a single tetrarchous one [)$(, x)-,(,>-<, X, \underline{\vee}, \perp]$. Scales of the rhizome coarsely cancellate, the areolae mostly decoloured.

*. Sori in opposite pairs; indusia opening towards one another.

No. b้6. Phyllidis

*.*. Sori not in pairs; indusia opening towards the costa or occasionally towards the margin. No. 弓丂. Asplenium. 


\section{\$ 7. PHEgOPTERIDEAE.}

1. Fronds flabellato-dichotomous. Sori round or punctiform. Veins anastomosing copiously.

No. 61. Dipteris.

1.1. Fronds variously divided, but not flabellato-dichotomous. Sor'i round or oblong, if terminal on the veins sometimes rumning into a submarginal line.

2. Veins free.

3. Sori lerminal on the veins.

1. Fertile segments much contracted. Sori at length covering \pm the whole under surface of the segments.

(No. 80. Polybotrya).

1.4. Fertile segments not contracted.

5. Spores bilateral.

No. 60a. Phegopteris, SS Euphegopleris \& Leptogramme.

5.5. Spores not bilateral.

6. Fronds hairy, fibrillose or scaly, at utmost 5-pinnatifid. Sori not rarely contiguous and confluent into a submarginal line, often more or less covered by the \pm recurved, hardly modificd margin of the frond. Spores globoso-tetrahedral.

\section{No. ร8. Notholaena.}

6.6. Fronds naked, at least 3-pinnale. Sori distant, never confluent, nor covered by the always flattener margin of the frond. Spores 5-lobato-tetrahedral.

\section{No. 59. Momachosorum.}

3.3. Sori medial or lower on the veins.

No. 60a. Phegopteris, SS Euphegopleris \& Leplogramme.

2.2. Veins anastomosing.

*. Lower veins of contiguous groups uniting as in Nephrodium.

No. 60a. Phegopteris, S.S Goniopteris, Stegnogramme \& Meniscium.

*.*. Veins anastomosing more or less copiously and irregularly.

No. 60h. HDictyopteris, $\mathbb{S}$ Arcypleris. 


\section{S 8. GYMNOGRAMMEAE.}

a. Veins free.

b. Fronds not powdery beneath.

c. Pinnae or pinnulae entire or denticulate; main veins close, simple or forked.

No. 62. Coniogramme.

c.c. Pinnae or pinnulae more or less deeply pinnatifid; main veins pinnate in the lobes. (No. 60a. Plespopteris, \& Leptogramme).

b.b. At least the fertile fronds coated beneath with a white or yellow powder.

No. 63. Ceropteris.

a.a. Veins uniting $1-5 \times$ at or near the margin.

No. 66. Symgramme, SS Toxopteris of Callogramme. a.a.a. Main veins and the lower ones of the same group uniting as in Pleocnemia.

a.a.c.a. Veins anastomosing otherwise.

(No. 60b. Dictyopteris, $\mathbb{S}$ Digrammaria).

1. Lower veins of contiguous groups uniling as in Nephrodium. Sori free or joining in pairs.

(No. 60a. Plegopteris, SS Slegnogramme \& Meniscium).

1.1. Veins anastomosing more copiously and commonly irregularly. Sori free or \pm reticulate.

2. Sori irregularly longitudinal or subflabellate, running along the veins. Costa wanting, or present in the lower half of the frond only.

No. 64. Antroplnyum.

2.2. Sori oblique or sometimes subparallel to the costa. Costa distinct quite to the apex.

3. Fronds thick, veins all invisible. Sori free, parallel, transversing the areolae.

No. 65. Hoxigramme.

3.3. Fronds thinner, at least the main veins visible. Sori free or reticulate, running along the veins.

4. Sori with paraphyses.

No. 66. Symgranmme, $\mathbb{S}$ Dictyogramme.

1.1. Sori without paraphyses. No. 67. Hemionitis.

\section{$\$ 9$. GRAMMITIDEAE.}

1. Fronds simple, rarely forked or subdichotomous, mostly grass-like. (Vittanieae). 
2. Sori on or close to the costa, often protected by a lateral, raised oulgrowth of leaf tissue.

No. $6 \dot{S}$. NHInogramme.

2.2. Sori marginal or submarginal.

3. Sori \pm deeply immersed in mostly 2-lipped, marginal or submarginal grooves or with the margins rolled back over them when young. Midrib present, veins free. No. 69. Vittaria.

3.3. Sori not protected as in 3 . Midrib wanting, veins anastomosing.

(No. 64. Antrophyoum, p. p.).

1.1. Fronds pinnate, rarely simple, but then not grass-like. Veins anastomosing. (Taenitideae).

No. 70. 'Taenitis.

\section{$\$ 10$. POLYPODIEAE.}

$\boldsymbol{x}$. Sori punctiform, roundish or oblong, not more than $\pm 5 \times$ as. long as broad, many on each side of the costae, sometimes solitary and terminal on the segments.

b. At least the under surface covered with scatlered or more or less densely crowded stellately branched hairs. No. 72. Cyclophorus.

b.b. Fronds naked or scaly, not rarely hairy, but then the hairs simple, not stellate.

c. Fronds dimorphous. Barren fronds sessile, oakleaf-like, afterwards brown and rigid, fertile ones stipitate, pinnatifid or pinnate.

No. 73. Drymaria.

c.c. Fronds uniform or dimorphous, if dimorphous the barren fronds not as in $\boldsymbol{c}$.

d. Fronds deeply pinnatifid. Sori restricted to the higher, much contracted segments.

e. Sori oblong or subquadràngular, closely placed in 1 row on each side of and parallel to the costae.

\section{No. 74. Dryostachyum.}

e.e. Sori round, placed on distant, semiorbicular lobes, 1 to each lobe.

No. 71. Polypodium (Mcyenianum).

d.d. Fronds simple or divided. Sori dorsal, marginal or on marginal outgrowths, but not on conspicuously contracted upper segments of divided fronds. No. 71. Polypodium. 
a.a. Sori linear or linear-oblong, more than $5 \times$ as long as broad, continuous or interrupted.

*. Sori more or less oblique to the costa and the margin, many on each side of the costa. No. 71. Polypopioun, $\$$ Selligueá. *.*. Sori parallel to the costa or the margin, 1 on each. side.

\$. Fertile fronds simple as are the barren ones. No. 75. Drymoglossum.

\$.S. Fertile fronds 5-partite, barren ones sagitlate.

No. 76. Christopteris.

\section{$\$$ 11. ACROSTICHEAE.}

1. Fronds dimorphous, the fertile ones dichotomously branched, the barren ones adpressed to the substratum.

No. 77. Platycerium.

1.1. Fronds uniform or dimorphous, the fertile ones not dichotomous, whether or not contracted, the barren ones not as in 1 .

2. Veins free, or sometimes the apices or bases of the veins united by \pm marginal or \pm costal lines.

3. Fronds simple, often more or less dimorphous.

No. 78. Elaphoglossum.

3.3. Fronds divided, the fertile ones contracted.

1. Rhizome high-scandent, cable-like. Fertile fronds Lomarialike, with the veins united at the base by costal lines or spurious veins. No. 79. Stendehlaema.

1. Rhizome erect or creeping, neither high-scandent nor cablelike. Fertile fronds not Lomaria-like, without costal lines or spurious veins.

No. 80. Polybotrya.

2.2. Veins forming 1-2 rows of areolae against the costae and costulae (as in Pleocnemia), otherwise free. No. 81. Stenosemia.

2.2.2. Veins anastomosing more copiously, and generally irregularly.

a. Fertile region restricted to the linear or spoon-shaped apex of simple fronds. No. 82. Hymenolepis.

a.a. Fertile region restricted to the higher segments of pinnatifid or pinnate fronds.

b. Pimnae free, not articulate $10^{\circ}$ the rachis, \pm uniform or the fertile ones rarely linear. No. 83. Acrostichum. 
VI. polypodiageae. $\mathbb{1 1}$. agrostigheae.

b.b. Pinnae free or joining at the base, articulate to the rachis, dimorphous, the fertile ones linear.

No. 84. Photinopteris.

a.c.u. Fertile region not restricted as in a. or $\boldsymbol{\alpha} . \boldsymbol{\alpha}$. Fronds dimorphous, barren and fertile ones separate.

\$. Barren fronds simple or more commonly 2-fid, the lobes divaricating, sometimes 2-fid again. Each segment with 2 or more, stout, longitudinal ribs springing from the base of the frond.

No. 85. Cheinopleuria.

\$.\$. Barren fronds simple or pinnate. Each segment with a single costa.

*. Spores oblong, ovate or 2-lateral.

No. 86a. Leptochilus. ***. Spores globoso-tetrahedral. No. $86 b$. Platytaenia. 



\section{TRIBE I. WOODSIEAE.}





\section{DIA CALPE, HInme.}

Sori globose, dorsal on a vein or veinlet, arising from a small, scarcely elevated receptacle. Indusium inferior, globose, sessile, at first entire and enclosing the whole sorus, at length bursting irregularly at the summit. Capsules numerous, nearly sessile.

Rhizome erect. Stipes not articulate to the rhizome. Fronds much divided; veins free. Sori usually 1 to each ultimate segment, on the lowest acropetal veinlet. Hk. Bk., Syn. Fil., tab. I, fig. 7; Diels, in Engl. \& Prant, Nat. Pfl.lFam. I ${ }^{4}$, fig. 87, A-D.

Tropical Asia.

* D. aspidioides, $\boldsymbol{B r}$., Rac., Flor. Btz., I, 119; Bedd., Ferns S. I., tab. CCLVII; Bau. \& Hk., Gen. Fil., tab. IC; D. pseudo-caenopleris, Kze, Bot. Zeit., 1846, 457; - var. membranulosa, Christ.

Rhizome erect, covered with desiccated stipes and brownish scales. Stipes

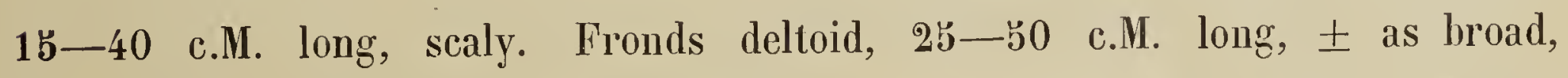
3-4-pinnate. Pinnae not quite opposite, deltoid-lanceolate, stalked, to 10 c.II. broad at the base. Ultimate segments obovate, $\mathbf{b}-8$ m.M. long, 2-5 m.M. broad, sessile, the base narrowed, \pm decurrent, the edge crenate or toothed throughout or at the apex only. Texture submembranaceous; surfaces nearly naked, or sparsely chaffy on the veins; colour disposed to blacken in drying. Sori solitary at the base of the ultimate segments; indusium firm.

Var. membronumlosa: Fronds smaller; pinnae close; segments contiguous; indusium weak.

Trop. Asia.

\section{DIPLAZIOPSIS, christeresen.}

Sori dorsal, linear or oblong, ruming from near the costa to the first areola; indusium sausage-shaped, fastened all round the receptacle, quite enclosing the sorus when young, rupturing irregularly when the spores mature. 
Rhizome short. Stipes not articulate to the rhizome. Fronds simply pinnate; veins anastomosing, forming $2-3$ rows of \pm hexagonal areolae near the margin. Hk. Bk., Syn. Fil., tab. IV, fig. 39; Diels, in Engl. \& Prantl. Nat. Pfl.Fam., Í , fig. 121, E. (Allanlodia).

Paleotropical.

* D. javamica, C. Chr., Ind. Fil.; Allanlodia javanica, Trev. (not Bl.), Rac., Flor. Btz., I, 232; A. Brunoniana, Wall., Bedd., Ferns S.I., tab. CLIX; Bau. \& Hk., Gen. Fil., tab. CXX; Asplenium javanicum, Bl. 'oldest name).

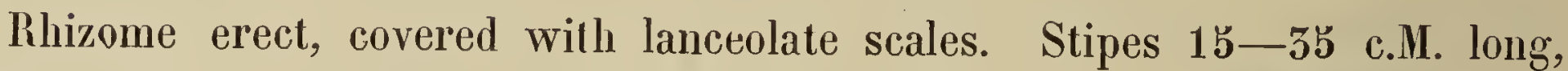
slightly scaly at the base. Fronds oblong-lanceolate, $50-100$ c.M.long, 18-55 c.M. broad, pinnate. Pinnae sessile or short-stalked, linear, the apex acuminate, the base truncate, the longest ones 10-15 c.M. long, 2-4 c M. broad, the margin entire or irregularly crenate. Texture membranaceo-herbaceous; surfaces naked; veins anastomosing, forming several rows of long and shor', nearly hexagonal areolae near the margin. Sori confined to the anterior veinlets of the primary forkings.

North. India, Australasia, Polynesia.

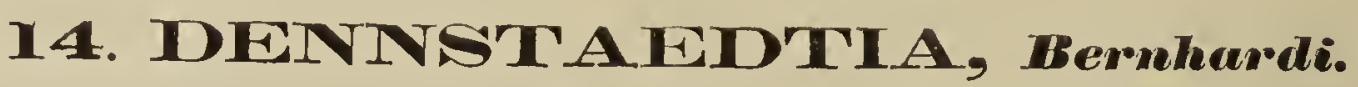

Sori submarginat, terminal on the veins, \pm globose; indusium inferior, united with the margin of the frond to form a distinctly cup-shaped, membranaceous involucre to the sorus, the top open, somelimes slightly 2-lipped or 2-valved.

Rhizome mostly creeping, often hairy, rarely erect or arborescent. Stipes not articulate to the rhizome or the caudex. Fronds rather large, at least 2-pinnate, superficially resembling Dicksonia; veins free. Itk. Bk., Syn. Fil., tab. II, fig. 15, c (as Palania); Diels, in Engl. \& Prantl, Nat. Pfl.Fam., I ${ }^{4}$, fig. 117, C-E.

Pantropical. 
a. Fronds neilher scandent nor lwining.

b. Fronds 2-pinnale or 3-pinnalifid.

\$. Pinnulae rhomboidal, entire or lobed.

(1) D. rhombifolia.

\$.\$. Pinmulae lanceolate, pinnatifid.

(2) I. resinifera.

b.b. Fronds 3-pimnale.

*. Rachis naked; surfaces glaucous.

(3) D. erythrorachis.

*.*. Rachis pubescen/; surfaces nalied.

(4) D. ampla.

*.*.*. Rachis and under surface tomentoso-glandulin.

(马) D. Smithii.

b.b.b. Fronds at least 4-pinnalifid.

c. Rachis more or less hairy.

d. Rhizome creeping. Fronds 4-pinnalifid.

e. Ullimale lobes entir.

(6) D. scabra.

e.e. Ullimate lobes crenaln-pinnalifid.

(7) D. samoensis.

d.d. Caudex arborescenl. Fronds 4-pinnalifid. Lobes loothed.

(8) D. javanica.

c.e. Rachis nalied.

1. Fronds to 90 c.M. broad.

2. Texlure herbaceous.

3. Rachis orange-coloured, slighlly scalrous.

(9) D. remota.

3.3. Richis stramineous, smooth.

(10) D. cuncata.

2.2. Texhure coriaceous.

(11) D. Kingii.

1.1. Fronds more than 90 c.M. brond.

s. Texlure herbaceous.

(12) D. Ilaccida.

\$.\$. Texture coriaceous.

*. Slipes ebeneous, muricale.

(15) D. glabrata.

*.*. Siipes brownish, smoolh.

(14) D. sumatrana.

a.d. Fronds scandent or twining.

+ Rachis aculeale. Texture ralher papyraceous.

(15) D. scandens.

+* Rachis aculeate. Texhure coriaceous.

+. +\%. Rachis smoolh.

(16) D. moluccana.

(17) D. gomphophylla.

(1) D. rhombifolia, C. Cher., Ind. Fil.; Dicksonia rhombifolia, Bk., Journ. of Bot., XXVIII, 105.

Stipe and rachis slender, naked, castaneous. Fronds oblong-lanceolate, 2-pinnate, to 30 c.M. long. Pinnae sessile, lanceolate, cut down to the rachis 
into oblong-rhomboidal pinnulae 6-9 m.M. long, 4-5 m.M. broad, which are truncale at the base on the lower side. Both surfaces naked; veins subflabellate. Sori solitary at the upper margin. of the pinnulae; indusium cupshaped, firm.

New Guinea.

(2)? D. resinifera, Mett., Ann. Mus. Bot. L. B., IV, 290. Cheilanthes resinifera, Bl., Enum., 158; Hypolepis resinifera, Hk.,.Spec. Fil., II, 65 .

Stipes rough. Fronds 2-pinnatifid towards the apex, 3-pinnatifid at the base. Pinnulae sessile, lanceolate, acuminate, deeply pinnatifid, the higher ones confluent. Segments oblong, obtuse, inciso-crenate, subauriculate at the upper base. Texture subcoriaceous; main rachis tomentose above; under surface resinoso-punctate. Sori solitary at the inner edge of the crenulations; indusium dentiform.

Java.

(3) D. erythrorachis, Diels, in Engl. \& Prantl, Nat. Pfl.Fam., I", 218; Dicksonia erythrorachis, Chrisl, Ann. Btz., XV, 86, tab. XIII, fig. 7, a-b.

Stipes erect, polished like the rachises, slightly aculeate or muricate below. Fronds large, deltoid-ovate. Pinnae spreading, straight, the lower ones to \pm 50 c.M. long. Pinnulae linear-lanceolate, acuminate, sessile, to \pm 6 c.M. long and to \pm 2 c.M. broad, rather approximate, the lower part cut down to the rachis into $\breve{b}-8$ close ultimate leallets, the apex pinnatifid. Leaflets ovate-rhomboidal, erecto-patent, slightly lobed, bearing the sori in the sinuses. Texture rigid; surfaces glaucous, the under one paler coloured than the upper one. Sori small, 1-3 to a leaflel; indusium brownish, glossy, subglobose.

Celebes, New Guinea.

(4) D. ampla, Bead., Journ. of Bot., XXXI, 227; Diclisonia ampla, Bk. Journ. of Linn. Soc., Bot., XXII, 225.

Rhizome creeping, clothed with dark-coloured scales. Fronds \pm 120 c.M. long or longer, deltoid, 5-pinnate. Pinnae oblong-lanceolate, the lowest ones 60-90 c.M. long, \pm 50 c.M. broad. Pinnulae lanceolate, multijugate, cut down nearly or quite to the costa into oblong, parallel, adnate, close ultimate segments 4-b̆ m.M. broad. Texlure moderately firm; rachis brown, unarmed, pubescent, canaliculale; surfaces naked; costulae pinnate; veins $6-8$ on each 
side, the lower ones forked, the upper ones simple. Sori small; the outer side of the indusium large, naked, semiorbicular.

Malacca, Borneo.

(5) ID. Smithii, Moore, Ind., 308; Dicksonia Smithii, Ilk., Hk. Bk., Syn. Fil., 54; Hk., Spec. Fil., I, tab. XXVIII, D.

Lower pinnae 18-30 c.M. long, 7-10 c.M. broad. Pinnulae linear, acuminate, cut down to the rachis throughout into several or more numerous, narrow, ovate or oblong segments. Lower segments (leaflets) $\pm 12 \frac{1}{2} \mathrm{mr}$.M. long, \pm 5 m.M. broad, the base more or less obliquely cuneate, the edges slightly inciso-pinnatifid. Rachis and under surface tomentoso-glandular; texture \pm coriaceous. Sori $2-8$ to a leaflet; indusium subglobose: cup-shaped. Celebes, Philippines.

* (6) D. Scabra, Moore, Christ, Farnkr. d. Erde, 312; D. delloidea, Moore Bedd., Ferns S.I., tab. CGLVIII; Dicksonia scabra, Wall., Hk. Bk., Syn. Fil., 54; Hk., Spec. Fil., I, tab. XXVIII, B; Dick. deltoidea, Hk., l. c., tab. XXVIII, A; Davallia celebica, Christ, Fil. Saras.; IV, 426.

Rhizome creeping. Stipes scattered, reddish, more or less hairy. Fronds 20-80 c.M. long, deltoid or lanceolate. Pinnae lanceolate, the largest 10-20 c.Mr. or more long. Pinnulae \pm 4 c.M. long, 1-2 c.M. broad, cut down nearly or quite to the rachis into several, pinnatifid, oblong or lanceolaterhomboidal segments. Texture herbaceous; rachis and under surface more or less hairy. Sori small, 2-6 or more to a segment, terminal on the lobes. Malaya; India, Ceylon, China, Japan, Formosa.

(7) D. sampensis, Moore, Ind., 307; Dicksonia samoensis, Bk., Hk. Bk., Syn. Fil., 462; Dick. delicata, Muell., Pap. Pl., IV., 77.

Fronds ample, 4-pinnatifid; rachises thinly pilose. Lower pinnae 30 c.M. or more long, lanceolate-deltoid. Pinnulae and segments close, lanceolatedeltoid, distinctly stalked, cuneate-truncate on lower side at the base, quaternary lobes close, oblong, blunt, 1-21/2 m.I. broad, crenato-pinnatifid. Texture membranaceous; ribs beneath hairy. Sori minute, placed at the base of the ultimate sinuses; valves of the indusium equal, hemispherical, glabrous. Rhizome creeping?

New Guinea; Polynesia.

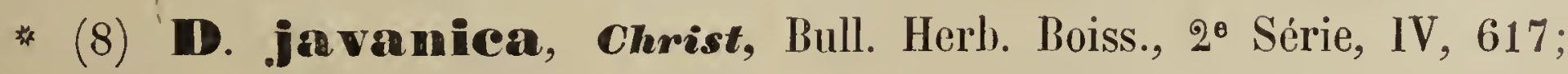
Dicksonia javanica, Bl., Rac., Flor. Btz., I, 120; C. Chr., Ind. Fil. 
Caudex arborescent. Stipe and rachis densely covered with short, adpressed hairs. Fronds lanceolate-oblong, to $1 \frac{1}{2}$ M. long, to 60 c.M. broad. Pinnae lanceolate, stalked, erecto-patent, $\pm 10-121 / 2$ c.II. broad, the stalks $1-1 \%$ c.M. long. Pinnulae short-stalked, linear-lanceolate, $\pm 2-3$ c.M. broad at the base, the apex acuminate. Tertiary divisions sessile or subsessile, the lowest anterior largest, linear-oblong, $1 \frac{1}{2}-2$ c.M. long, to \pm 5 m.M. broad, the apex blunt, toothed, the edge cul down nearly or quite to the costa into oblong, blunt, inciso-dentate ultimate segments, the lowest anterior segiments the largest. Texture herbaceous; upper surface nearly naked, the under one densely hairy like the secondary and tertiary rachises. Sori small, near the ultimate sinuses; annulus long, the extremities separated by a whorl of radiating, slightly thickened cells with the stalk of the sporangium placed in the centre.

Java.

(9) D. remota, Diels, in Engl. \& Prantl, Nat. Pfl.Fam., I I, 218 ; Dicksonia remola, Christ, Ann. Btz., XV, 86, tab. XIV, fig. 8, a-b.

Fronds 3-pinnate to 4-pinnatifid. Pimnae to \pm 45 c.M. long and 15 c.M. broad, stalked. Pinnulae lanceolate, acuminate, alternate, $\pm \mathbf{5}$ c.M. apart, short-stalked, \pm 2 c.II. broad at the base. Ultimate divisions oblong-ovate, short-stalked, the lower ones rather distant, \pm 5 m.M. apart, cuneate at the base, pinnatifid from $1 / 2$-way down to quite to the costa, the upper ones more close and less deeply lobed, or even entire. Texture herbaceous but firm; rachis naked, orange-coloured, slightly scabrous. Sori intramarginal, lateral on the lobes, 1-6 to a pinnula, transversally oblong; indusium broadly ovate. Veins conspicuous, pinnate in the lobes.

Celebes.

* (10) D. cumeata, Moore (not Christ), Copel., Polypod. Philipp., 57; Dicksonia cuneala, Hk., Hk. Bk., Syn. Fil., 462; Hk., Spec. Fil., I, tab. XXVIII, C.

Fronds ample, subdeltoid, 4-pinnatifid; rachis stramineous, naked. Pinnae lanceolate, $15-55$ c.M. long. Pinnulae close, short-stalked, lanceolate, $1-11 / 2$ c.M. broad. Tertiary divisions oblong-rhomboidal, $21 / 2-5 \mathrm{~m} . M$. broad, sessile, the base cuneate, more or less cut away on lower side, the edge inciso-pinnatifid. Texture moderately firm; both surfaces naked; veins subflabellate. Sori at the tops of the ultimate sinuses; indusium cup-shaped, naked. - Perhaps this may be the description of a single pimna regarded 
by Hooker as a complete frond. A specimen gathered by Mr. Whitford has the fronds 5-pinnatifid, the pinnulae \pm 25 (15-35?) c.Ir. long, etc., the ultimate rachises marginate or rather narrowly winged.

Philippines, Baljan.

(11) D. Kingi, Bedd., Journ. of Bol., XXXI, 227; Dicksonia Kingi, Bedd., Handb. Ind. Ferns, Suppl., 6.

Stipes stout, erect, \pm 45 c.M. long. Fronds 90-120 c.M. long, deltoidlanceolate, 4-pinnatifid. Pinnae 20-25 c.M. long, the lower ones deltoid-lanceolate, lanceolate to linear-lanceolate upwards. Lower pinnulae $\pm 6-7$ c.II. long, the others $\pm 2 \%$ c.M., cut down nearly or quite to the rachis into olilong, broadly toothed lobes. 'Texture coriaceous; surfaces naked. Sori terminal on thickened veins and exserted beyond the margin.

\section{Malacca.}

* (12) D. Maceida, Remnte. (not Moore), Diels, in Engl. \& Prantl, Nat. Pfl.Fam., I*, 218; Dicksonia /laccida, Sw., Rac., Flor. Btz., I, 121.

Rhizome creeping. Stipes 1-2 M. long. Fronds 3-4-pinnate, ovaledeltoid, to $2 \frac{1}{2}$ M. long, to $\pm 1 \frac{1}{2}$ M. broad. Pinnae linear, opposite, shortstalked or nearly sessile, lanceolate-acuminate, scarcely narrowed towards the base. Pinnulae sessile, to 8 c.M. long, to 2 c.M. broad, the base \pm truncate. Tertiary divisions close, unequal-sided, to 1 c.M. long, to $4 \mathrm{M}$.M. broad, pinnatifid $1 / 2-3 / 4$-way down to the costa, the apex toothed, the base decurrent, the lobes crenate or toothed. Texture herbaceous; both surfaces naked. Sori at the tops of the sinuses; indusium subglohose when young, cup-shaped at full maturity.

Java, Sumalra; Polynesia.

(15) D. glabrata, C. Chr., Ind. Fil.; Diclssonia glabrala, Ces., Fel. Becc. Polin., $2 \& 6$.

Rhizome tortuose, the scales linear, fibrillose, brown, crisped. Stipe \pm 40 c.M. long, rigid, polished, ebeneous like the rachis, the base densely muricate, the upper part rarely so, the prickles conical, recurved. Fronds \pm 150 c.M. long, 3-pinnate. Pinnae spreading, the lower ones \pm 60 c.M. long, divided as in D. flaccida, Bernh. The lower lobes with the margin often undivided. Texture coriaceous; upper surface dark-green, the under one paler.

New Guinea.

FILIGES. 
* (14) D. Summatrama, v. A. v. R.

Fronds large, 3-pinnate; stipe and rachis stout, brownish, naked. Pinnae erecto-patent, 85 c.II. long or longer, \pm 15 c.M. broad at the base. Pinnulae linear-lanceolate, acuminate, \pm 2 c.M. broad at the base, the apex pinnatifid, the rachis very narrowly winged. Terliary divisions oblong, bluntly rounded, \pm spreading, $\pm 5 \mathrm{~m}$.M. broad, the margin cut $1 / 3-2 / 3$-way down, the upper base truncate, slightly auricled, the lower cuneate and decurrent, the lobes close, bluntish or rounded. Texture coriaceous; surfaces naked; veins rather visible. Sori marginal, 1 at the top of each sinus; indusium distinctly cupuliform. - This plant was determined by Baker as a variely of Davallia Speluncae, Bl., (Journ. of Bot., XVIII, 210).

Sumatra (Beccari, No. 436).

(15) D. scandens, Moore, Diels, in Engl. \& Prantl, Nat. Pfl. Fam., I4, 218; Diclisonia scandens, Bl., Rac., Flor. Btz., I, 122; Dick. Zippeliana, Kze, Bot. Zeit., 1845, 858 .

Rhizome creeping. Fronds to 8 M. long, distant, at least 3-pinnate, scandent or twining; main rachis aculeate. Pinnae opposite, distant, to $1 \mathrm{M}$. long or longer, scandent, the rachis aculeate. Pinnulae \pm sessile, lanceolate or oblong, acuminate or bluntish, cut down to the rachis into deltoid-oblong or unequally ovate leaflets \pm 2 c.ll. long, blunt, the base narrowed, \pm decurrent, the edge more or less deeply pinnatifid into several roundish, blunt, entire or crenate lobes. Texture semicoriaceous or membranaceous, rather flaccid; surfaces naked, or slightly hairy on the veins. Sori small, roundish, near the sinuses; indusium cupuliform.

Malaya; Samoa.

(16) D. moluccana, Moore, Diels, in Engl. \& Prantl, Nat. Pfl.Fam., I", 218; Diclisonia moluccana, Bl., Hk. Bk., Syn. Fil., 53.

Near I). scandens, Moore, but firmer. Ultimate leaflets less deeply lobed, the lobes deltoid-oblong. T'exture coriaccous. Indusium sulgglobose.

Malaya; Kormosa, Fiji.

(17) D. gompleophylla, C. Chr., Ind. Fil; Dicksonia gomphophylla, Bh., Journ. of Linn. Soc., Bol., XXII, 223.

Fronds large, naked, deltoid, decompount; rachises unarmed. Lowest pinnae largest, 45-60 c.II. long, \pm 50 c.M. broad, deltoid, inequilateral. Pimnulae oblong-lanceolale. Tertiary divisions mullijugate, oblong, quater- 
nary ones multijugate, subsessile, to $3 / 4$ c.II. long, with the upper base parallel to the rachis, the lower cut away, obtuse, deeply pinnatifid. Veins subflabellate. Sori small, placed at the tops of the sinuses of the ultimate lobes: the outer valve of the indusium large, semiorbicular. - Habit of D. scandens \& moluccana, Moore.

Borneo. 



\section{TRIBE II. ASPIDIEAE ( $\left(^{*}\right)$}

(*) The genera Dryopteris and Aspidium have the indusia not rarely rudimentary or caducous and then it is difficult to distinguish the species from Plegopteris and Dietyopteris. 



\section{OILA NDIRA, Cuvumilles.}

Sori on the back of the veins, rarely \pm medial, generally near the costa. Indusium reniform, firm, fixed by the sinus.

Rhizome creeping, scandent or erect, branched. Fronds simple, articulate to the rhizome; veins free, compact. IIk. Bk., Syn. Fil., Lab. V, fig. 46; J)icks, in Engl. \& Prantl, Nat. Pll.Fam., I', fig. $109\left({ }^{1}\right)$.

Pantropical.

1. Rhizome scandent or erect $\left(^{2}\right)$.

2. Sori medial on the voins.

(1) 0. cuspidata.

2.2. Sori near the costa.

3. Rhizome scales ciliate, the ciliae cobwebby.

(2) 0 . ciliata.

3.3. Rhizome scales at best ciliate when young, the ciliae short.

1. Stipes articulate at the apex, the joint close to the base of the lamina.

(5) 0 . colubrina.

1.1. Stipes articulate below the apex or towards the base, the joint not close to the base of the lanina. (4) 0. neriiformis.

1.1. Rhizome creeping.

a. Costa naked or hairy beneath.

b. Stipes articulate at the base.

c. Sori somewhat distant from the costa.

(b) 0. musifolia.

c.c. Sori close to the costa.

(6) 0. Wallichii.

b.b. Stipes articulate above the base or towards the apex.

\$. Rhizome scales \pm adpressed. Stipes arliculate belseen the base and the apex.

(7) 0. Cumingii.

\$.\$. Rhizome scales spreading. Stipes arliculate at the summit.

(8) 0. tricholepis.

a.a. Costa scaly beneath.

(9) 0. Whilmeci.

( $\left.{ }^{1}\right)$ Most of the species are more or less variable and so closely allied that they might be considered as varieties of 1 or 2 species united by several intermediate forms, wich are often difficult of determination.

${ }^{2}$ ) Sec also D. musifolia, $\operatorname{Pr}$. 
(1) (1. cuspidata, IBk., Becc., Mal., III, 44.

Rhizome stout, woody, copiously branched, densely clothed with small, adpressed, castaneous, ovate, firm scales, which are pale-coloured at the maroin. Stipes short, articulate at the summit. Fronds ligulate, cuspidate, 10-15 c.M. long, narrowed gradually from the middle to the base. Texture rigid; surfaces naked; veins conspicuous. Sori in 1 row on each side of the costa, not below the middle of the veins; indusium small, firm, reniform, persistent.

New Guinea.

(2) D. ciliata, Ku., Linn., XXXVI, 126.

Rhizome scandent; the scales ovate and adpressed at the base, the point subulate, spreading, the edge finely ciliate, the ciliae cobwebby. Stipes 8-15

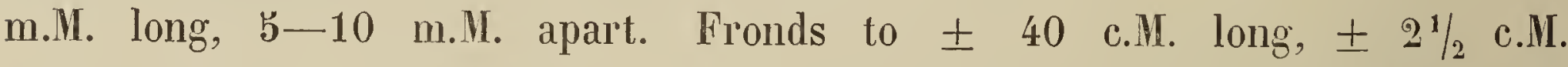
broad, acuminate, narrowed gradually at the base. Texture membranaceous or subchartaceous; upper surface naked, \pm glossy, under one covered with scattered hairs. Sori not contiguous, in 1 row on each side near the costa; indusium reniform, both sides unequally rounded, coriaceous, reddish-brown. Amboyna; New Hebrides, Pinorum Island.

* (5) D. Colubroina, Copet., Polypod. Philipp., 48; Blechnum colubrinum, Blanco, Flor. Filip., 834; - var. brachypus; O. neriiformis, Cav., var. brachypus, Hk., Spec. Fil., IV, 156.

Rhizome woody, stout, erect or suberect; the scales dense, adpressed, the base obovate, peltate, dark-coloured, the margin brown, \pm ciliate when young, the apex acuminate, erect or spreading, deciduous or persistent. Stipes mostly clustered, articulate immediately below the lamina. Fronds \pm 15-20 c.M. long, $\pm 2-5$ c.M. broad, widening towards the upper part, then narrowed and caudate or acuminate, narrowed gradually towards the base, the edge ciliate with whitish or brownish hairs. Texture papyraceous to coriaceous; costa and surfaces \pm conspicuously clothed with rather long, soft, slightly crisped hairs. Sori in 1 irregular row on each side near the costa.

Var. Draclnypus : Costa and surfaces pubescent or sparingly villose. Philippines, Borneo, Java.

* (4) D. neroiformis, Cav., Hk. Bk., Syn. Fil., 302; Bedd., Ferns of Br.I., II, tab. CCLXIV; O. neriffolia, Pr. (not Cav.), Rac., Flor. Btz., I, 203, p. p. ; - var. mollis; 0. mollis, Pr., Epim., 41; 0. hirtella, Miq., Kze, Farnkr., II, tab. CXXIX; O. pilosa, Hk., Bau. \& Hk., Gen. Fil., tab. XLV, B. 
Rhizome erect or climbing; the scales dense, adpressed, the base obovate, peltate, dark-coloured, the margin brown, \pm ciliate when young, the apex acuminate, erect $0 r^{\circ}$ spreading, deciduous or persistent. Stipes scattered or placed in opposite pairs or distant whorls, $\pm 1-4$ c.M. long, naked, articulate between the apex and the base, often below the middle, the joint in every case remote from the base of the lamina. Fronds $15-40$ c.M. long, 1-4 c.M. broad, linear-lanceolate, acuminate or subcaudate, nar'owed gradually towards both ends. Texture papyraceous to coriaceous; surfaces naked or partially villous or pubescent on the costa and veins. Sori in 1 mostly irregular row on each side near the costa; indusium oblique, entire or ciliate.

Var. mnllis: Fronds more villous with soft, fine hairs.

Malaya; Polynesia, South. America, West. Africa.

* (5) 1. musifolia, Pr. (not Kze), Hk. Bk., Syn. Fil., 302; 0. neriiformis, Bedd. (not Cav.), Ferns S.I., tab. XCI; Hk., Fil. Exot., tab. LVIII; 0. neriifolia, Pr. (not Cav.), Rac., Flor. Btz., I, 205, p. p.

Shoots firm, creeping, scandent or intertwined, clothed with lanceolatesubulate, ciliate, yellow scales, which are dark-coloured and peltate at the base. Stipes scattered, generally single, rarely in whorls or in tufts, \pm $21 / 2$-5 c.M. long, naked, jointed close to the base. Fronds elongate-lanceolate, acuminate, $20-50$ c.M. long, to \pm 5 c.M. broad. Texture thin-membranaceous to firm-papyraceous; surfaces naked or hairy on the veins and midrib. Sori in 1 irregular row on each side near the midrib.

Malaya; Ceylon.

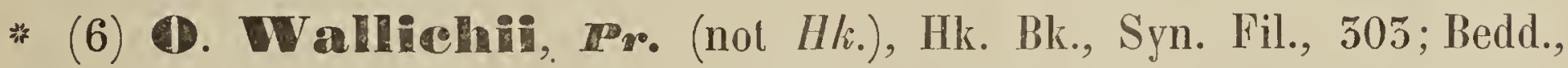
Ferns Br.I., Il, tab. CGLXV; Aspidium Wallichii, Hk., Exol. Flor., I, tab. V.

Rhizome creeping, densely clothed with subulate, ferrugineous, often reflexed scales. Stipes distant or sometimes more close, $1-8$ c.M. long, sometimes paleaceous, articulate at the base. Fronds 1 b-40 c.M. long, subelliptical-oblong, the sides parallel, the base often obtuse or rounded, the apex shortly and sharply acuminate. Texture soft, membranaceous; surfaces more or less hairy. Sori compact, almost imbricate, in a continuous line on each side and close to the costa; indusium reniform. - Costa naked or scaly.

Malacca; North. India.

* (7) D. Camnimair, J. Sm., Hk. Bk., Syn. Fil., 305; Bedd., Ferns Br.I., I, lab. CXXXV; - var. Sibaldii, Hk. Bk, l. c.; O. Sibaldii, Grev., Ann. Nat. Hist., [I $^{1}, 527$. 
Rhizome horizontally creeping, clothed with \pm adpressed, subulate, ciliate scales. Stipes close or scattered, 2\%-20 c.M long, articulate within $1-7$ c.M. from the base. Fronds 20-45 c.M. long, narrowed gradually towards both ends. Texture herbaceous or membranaceous; midrib and both surfaces slightly hairy. Sori in regular rows very near the midrib; indusium firm, oblique.

Var. Sibaldi: Texture thinner; surfaces more hairy; sori in very irregular, wavy lines, rather distant from the midrib.

Mılaya; South. India, Assam, Centr. China, - var. Sibaldii: Sumalra, Java, Timor ; Tahiti.

(8) D. tricholepis, Kae, Bot. Zeit., 1851, 349.

Rhizome creeping, the scales spreading, subulate, reddish-brown, large. Stipes placed in distant lufts, elongate, slender, articulate with the fronds. Fronds cuneate at the base, slightly hairy. Sori unknown.

Borneo.

* (9) D. Whitmeei, Bk., Journ. of Bot., XIV, 11; Eingl., Bot. Jahrb., XXIII, lab. V, fig. 2-4; O. ornala, Chrisl, Fil. Saras., III, 240.

Rhizome wide-creeping, densely clothed with yellow, spreading, subulate scales. Stipes naked, brown, articulate about the middle. Fronds to \pm 30 c.M. long, 4-5 c.M. hroad, narlowed gradually towards the base, the apex finely acmminate. Texture thin, the edge thickened, finely ciliate; upper surface pubescent especially on the midrib; under side of the nuidrib regularly clothed with 2 opposite rows of spreading, yellow, subulate scales. Sori close, placed in 1 wavy row on each side near the midrib, sometimes in 2 close, irregular rows; indusium pale-yellowish, often subpeltate.

Celebes, Philipines; Samoa.

\section{ATRTHIROPTERIS, J. Smith.}

Sori roundish, terminal on the anterior veinlets of the once forked veins. Indusium roundish-reniform, fixed by the sinus.

Rhizome creeping or scandent. Stipes articulate to the rhizome. Fronds pinnate; pinnae articulate to the rachis.

A small genus, very near Nephrolepis, distinguished from this by the articulated stipes.

Paleotropical. 
*. Surfaces \pm hairy. Indusium fugacious.

*.*. Surfaces naked. Indusium persistenl.
(1) $\Lambda$. obliterata.

(2) A. glabra.

* (1) A. obliterata, ש. Sm., C. Chr., Ind. Fil.; A. ramosa, Mell. (nol J. Sm.), Copel., Polypod. Philipp., 46; Nephrolepis ramosa, Moore, Rac., Flor. Btz., I, 201; N. obliterata, J. Sm., Journ. of Bot., IV, 197; Bedd., Ferns S.I., tab. CGLI; Nephrodium oblitcratum, R. Br., (oldest name).

Rhizone wide-creeping, slender, branched, scaly. Stipes scattered, short, \pm 2 c.M. long. Fronds $15-45$ c.M. long, $21 / 2-8$ c.M. hroad, gradually but slightly narrowed towards both ends; rachis slightly flexuose. Pimnae \pm 12-20 on each side, \pm sessile, $1-2$ c.M. broad, obliquely rhomboidal, the apex bluntish or subacute, sometimes rounded, the edges entire or more or less distinctly crenate especially in the fertile pinnac, the upper base truncate and auricled, the lower base obliquely narrowed. Texture thin or more or less coriaceous; rachis and hoth surfaces hairy, somelimes scaly. Sori 1 to each crenation, at a distance of $1-2$ m.M. from the edge; indusium roundish or subcordate, fugacious.

Palcotropical.

(2) A. Glabra, Copel., Polypod. Philipp., 46.

Rhizome wiry, climbing \pm 5 M. high, sparsely clothed will black, adpressed scales. Stipes $\pm 5 \mathrm{~m} . M$. long, articulate $1-2 \mathrm{~m}$. Il. beyond the base. Fronds $20-50$ c.M. long, $5-7$ c.ll. broad, pinnate, with a terminal pinna rather larger than the others. Lateral pinnae \pm 8 m.II. hroad, obtuse or the higher ones subacute, obscurely crenate, slightly auricled, the upper base abruptly truncate, the lower very oblique. Texture papyraceous; surfaces naked; remaining green when dried. Sori roundish, \pm medial, nearer the margin than the costa; indusium fixed by a very narrow sinus, persistent.

Philippines.

\section{NGPHIROLEPIS, Schot.}

Sori cilher round or reniform, submarginal or medial, in 1 row on each side of the costa, terminal on the anterior veinlets of the once forked veins or transversally oblong to linear, marginal, uniting the apices of 2 or inore veins. 
Indusia of the former sori reniform, attached by the sinus, the lobes sometimes meeting or overlapping and then the indusia becoming round and \pm peltate, opening all round the edge or nearly so, those of the latter ones 2-valved \& marginal or transversally oblong to linear \& submarginal, attached at the inner side of the sori, opening outwardly, as in Lindsaya.

Rhizome erect, creeping or scandent. Stipes adherent to the rhizome. Fronds pinnate; pinnae articulate to the. rachis.

Tropical and subtropical.

Arrangement of the sections.

$\$ 1$ LINDSAYOPSIS. Sori transversally oblong or linear, marginal or submarginal, uniting the apices of 2 or more veins. Indusium 2 -valved \& marginal or transversally oblong to linear \& submarginal, attached at the inner side of the sorus, opening outwardly, as in Lindsaya.

$\$$ 2. EUNEPHROLEPIS. Sori round or reniform, intramarginal. Indusium reniform, attached by the sinus, opening all round the edge or nearly so. Hk. Bk., Syn. Fil., tab. V, fig. 45; Diels, in Engl. \& Prantl, Nat. Pfl. Fam., I ${ }^{4}$, fig. 111.

\section{\$ 1 . LINDSAYOPSIS.}

\$. Fertile pinnae lobed, the lobes small, transversally oblong, forming with the equal-shaped indusia 2-valved involucres to the sori.

5.5. Fertile pinnae entire or broadly crenate. Indusia quite as in in Lindsayar. *. Sori and indusia continuous along the margin of the pinnae.

(2) N. acutifolia. *.*. Sori and indusia interrupted especially towards the apex of the pinnae.

(3) N. lindsayae. (36.) N. Schlechteri

(1) N. dicksonioides, Christ, Fil. Saras., III, 241; Farnkr. d. Erde, fig. 907, n, o, p \& q; Dicksonia nephrolepioides, Christ, l. c.

Fronds pinnate, 1-2 M. long, $\pm 20-25$ c.M. broad. Pinnae linear, sessile, acuminate, \pm spreading, $\pm 1 \frac{1}{2}$ c.M. broad, the base rounded, truncate or slightly cordate; the higher and lower pinnae commonly sterile, entire, the 
central ones fertile, longer and narrower than the barren ones, with the edges shortly and regularly undulate or lobed, the apices of the lobes, which are broader than deep, dilated. Texture \pm coriaceous; veins of the barren pinnae nearly straight, parallel, close, simple or forked, those of the fertile ones oblique, curved, branched in the lobes. Sori marginal, 1 to each lobe, uniting the $2-5$ branches of each vein; indusia 2 valved, firm-membranaceous, the outer valves consisting of the lobes of the pinnae.

Celebes. hew Guina

(2) N. acutifolia, Christ, Farnkr. d. Erde, 291, fig. 907, r, s \& y; Isoloma lanuginosum, J. Sm., Bau. \& Hk., Gen. Fil., tab. CII ; Lindsaya lanuginosa, Hik., Hk. Bk., Syn. Fil., 109; Hk., Spec. Fil., I, tab. LXIX, B; Bedd., Ferns Br.I., I, tab. CXL; L. aculifolia, Desv., (oldest name).

Rhizome stout, creeping, clothed with fibrillose scales. Stipes erect, stout, 10-15 c.M. long. Fronds 50-60 c.M. long, 7-10 c.M. broad. Pinnae linear-oblong, nearly equilateral, $1-1 \frac{1}{2}$ c.M. broad, the base truncate, slightly auricled above, slightly rounded below, the edge entire or slightly toothed towards the apex, wich is acute in the fertile, \pm blunt in the barren pinnae. Texture coriaceous; rachis pubescent. Sori and indusia in cotinuous lines along the edges, as in Lindsaya.

Malaya; Burmah, Australia, Trop. Africa.

* N. Lindisayae, Christ, Bull. Herb. Boiss., VI, 857.

Rhizome nodose. Stipes tufted, clothed like the rachis with soft, crisped, filiform scales. Pinnae numerous, close, straight or falcate, unequal-sided, 4 or more c.M. long, \pm 1 c.M. broad, the younger ones slightly tomentose, the sterile ones entire, the fortile ones broadly crenate; the upper base truncate, auricled, the apex ' \pm gradually narrowed, bluntish or acuminate. Veins numerous, close. Sori $6-8$ on each side, often forming a continuous line interrupted towards the apex of the pinna; indusia of the same shape, submarginal, as in Lindsaya.

Sumatra, Halmaheira.

\section{S 2. EUNEPHROLEPIS.}

a. Pinnae very small, roundish or flabelliform.

(4) N. Duffi.

usa. Pinnae not very small, varying from oblong to linear, entire or crenale, rarely lobed, pinnalifid or dicholomous. 
b. Pinnae (at least the fertile ones) cuneale at the base $\left(^{*}\right)$.

*. Ferlile pinnae crenate.

(5) N. floccigera.

*.*. Ferille pinnae more or less deeply and copiously lobed.

(6) N. acuminata.

b.Ђ. Pinnae cordate, truncale, subtruncale or rounded at the base.

c. Pinnae auriculale at the base on the lower side.

(7) N. celebica.

c.c. Pinnae not auriculate at the base, or auriculate on the upper or on both sides.

d. Surfaces and especially the rachis densely clothed with fim-

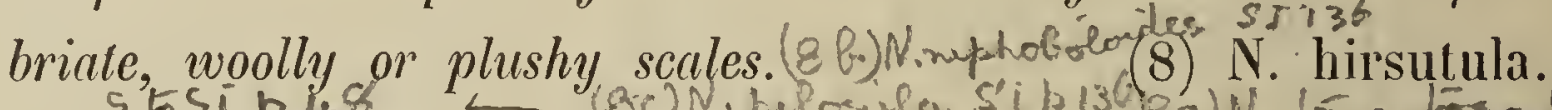

d.d. Surfaces ind rachis nalied or nol copiously scaly.

e. Fully developed fronds mostly under 8 c.M. broad. Pinnae blunt or bluntish.

f. Fronds to \pm 20 c.M. long; pinnae \pm 3 m.M. broad; indusium subpeltale. (9) N. Lauterbachii.

f.f. Fronds more than 20 c.M. long; pinnae $5-15$ m.M. hroad; indusium reniform, with a distinct sinus.

g. Rhizome \pm erect, short, the roots often bearing tubers. Fronds densely lufted; pinnae imbricating with a cordate base. (10) N. cordifolia.

g.g. Rhizome wide-scandent, bearing distant tuifts of few fronds; roots wilhoul tubers. Pinnae \pm rounded or subtruncate at the base.

(11) N. radicans.

e.e. Fully developed fronds 8 c.M. broad or "Qtroader. Pinnate acute or acuminale.

\$. Sori submarginal; pinnae to $\pm 7 \frac{1}{2}$ c.M. long, disinclly auricled.

*. Indusium orbicular, the lobes overlapping.

(12) N. barbata.

*.*. Indusium reniform, with a distinct sinus.

(15) N. exaltata.

\$.S. Sori rather distant from the margin; pinnae mostly more than $7^{1 / 1} / 2$ c.M. long, not or slighlly auricled.

(14) N. biserrata. 
* (4) N. Duffi, Moore, Nich., Dict. d'Hort., III, 461, fig. 632.

Stipes tufted, erect, chaffy like the rachis, 10-20 c.M. long. Fronds $\pm 2 \breve{-5} 5$ c.M. long, linear, $1-1 \frac{1}{2}$ c.M. broad, narrowed gradually towards the base, the apex once or more times forked. Pinnae numerous, the lower ones reduced, distant, the central ones approximate, each consisting of 2 oblong or flabellato-orbicular, strongly imbricated leaflets, which are joined at the very base, with the edges entire or irregularly crenate to slightly lobed. Texture herbaceous; under surface clothed with few, scattered, minute, chaffy scales; veins of each leaflet flabellate in the orbicular, pinnate in the oblong forms.

Malaya; North. Australia.

* (5) N. Ioceigera, Moore, Hk. Bk., Syn. Fil., 502 ; Christ, Farnkr. d. Erde, fig. 907, h \& i; - var. monstruosa, hort.

Stipes furfuraceous. Fronds $60-90$ c.M. long, 1 b-50 c.M. broad. Pinnae $11-2$ c.M. broad, the apex acuminate, the edge crenate to a depth of \pm $1 \frac{1}{2}$ m.M., the base slightly unequal, \pm cuneate. Texture subcoriaceous; rachis and under surface furfuraceous. Sori submarginal, 1 to each crenation; indusium firm, reniform.

Var. monstruosa: A much cullivated form, with the pinnae very broad, deeply and irregularly divided into numerous, close, imbricate, linear segments with entire or toothed edges.

Java, Celebes, Amboyna.

* (6) N. acuminata, Kuhn, Ann. Mus. Bot. L. B., IV, 2S6; N. N. darablec davalloides, Kze, Rac., Flor. Btz., I, 202; Hk., Fil. Exot., tab. LX; Ophioglossum acuminatum, Hoult., (oldest name).

Caudex short, stoloniferous, densely clothed with black-brown, lanceolate scales. Stipes tufted, \pm 30 c.M. long, \pm scaly at the base. Fronds \pm $60-100$ c.M. long, $\pm 20-55$ c.M. broad, hardly narrowed towards the base, sterile in the, lower part. Barren pinnae narrow-lanceolate, $\mathbf{1 - 3}$ c.M. broad, the base slightly unequal, the edge crenate, the point acute; fertile pinnae mostly narrower, the highest ones often very narrow, linear, the base \pm cuneate, the edge more or less deeply lobed sometimes nearly to the costa, the sinuses \pm rounded, the lobes blunt. Texture coriaceous; rachis \pm furfuraceous; surfaces \pm naked; veins forked at the base, the barren branch the shortest, often very short. Sori terminal on the lobes, 1 to each lobe.

Malaya. 
(7) N. celebica, Zou., Syst. Verz., 44, 49.

Pinnae linear-lanceolate, ensiform, sessile, obtuse, the edge obscurely repand, the base cordate, reniform-auriculate below; the lower pinnae growing shorter. Surfaces naked; colour dark-green; rachis short-hairy. Sori minute.

Celebes.

* (8) N. Hires Wawra (not Pr.), Copel., Polypod. Philipp., 47; N. acula, Pr., var. rufescens, Christ, Ann. Btz., XV, 140.

Rhizome erect, stout, densely clothed with dark-coloured, small, adpressed scales, stoloniferous. Stipes tufted, \pm 1 -60 c.M. long, firm, glabrescent, the base \pm scaly like the rhizome. Fronds 50-120 c.M. long, 8-25 c.M. broad. Pinnae more or less close, not imbricate, $1-1 \frac{1}{2}$ c.M. broad, fertile linear, \pm acute, generally serrate or crenato-dentate, often with a minute tooth in the sinuses of the crenations, rounded at the base on lower side, the upper base usually prominently auricled; slerile pinnae shorter than the fertile ones and less acule. Texture herbaceous or subcoriaceous; surfaces (and especially the rachis densely) clothed with \pm deciduous, fimbriate, woolly or plushy, pale-brown or reddish scales. Sori submarginal or intramarginal; indusium often becoming orbicular. - N. rufescens, Wawra, is the broadest form with the sori distant from the margin, united by numerous intermediates with the type, which is the narrowest form with the sori submarginal.

Panlropical.

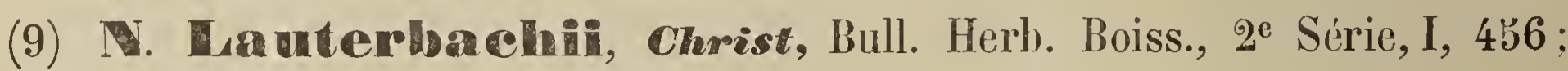
N. cordifolia, Pr., var. Laulerbachii, Christ, in Schum. \& Laut., Flor. deut. Sch.geh., 118.

Near N. cordifolia, $P r$. but the pinnae shorter, narrowly lanceolate, \pm 5 m.M. broad, serrulate or denticulato-crenate. Fronds hardly 20 c.M. long. Sori submarginal; indusium \pm peltate.

New Guinea. Luzon, Mindora \$. 799

* (10) N. condifolia, IP*., Hk. Bk., Syn. Fil., 500; N.tuberosa, Pr., N.c. Rac., Flor. Btz., I, 199; Bedd., Ferns S.I., tab. XCII; Polypodium cordifolium, L., (oldest name).

Rhizome densely clothed with hyaline, yellow-brown, lanceolate scales; the roots often bearing tubers. Stipes tufted, wiry, $21 / 2-29$ c.M. long, glossy, more or less densely scaly. Fronds linear-lanceolate, $2 \breve{b-100}$ c.M. long, 
3-8 c.M. broad. Pinnae numerous, often imbricated, $1 / 2-1 \frac{1}{2}$ c.M. broad, the hase cordate, or rounded on the lower side, more or less auricled on the upper side, the edge entire or more or less crenated chiefly in the fertile pimnae, the apex \pm narrowed, bluntish. Texture subcoriaceous; rachis yellowish, glossy, slightly scaly; surfaces nearly naked, the upper one often with a row of submarginal, cretaceous dots, the under one sometimes densely villose. Sori submedial, nearer the edge than the midrib; indusium firm, reniform, persistent, often very oblique.

Pantropical, New Zealand, Japan.

" (11) N. radicans, Troten, Ain. Mus. Bot., L. B., IV, 285; N. volubilis, J. Sm., Christ, Farnkr. d. Erde, 288; Clarke, Trans. Linn. Soc., Bot., 2d Series., I, tab. LXXVIII ; Polypodium radicans, Burm., (oldest name).

Rhizome scandent, indefinite, naked, wiry, bearing distant tufts of \pm 2 -3 fronds at the ends of short, scaly branches. Stipes \pm 10 c.M. long, firm, naked or nearly so. Fronds $25-50$ c.M. long, $\pm 3-6$ c.M. broad; rachis firm, scarcely chaffy. Pinnae $\pm 5-8$ m.M. broad, very obtusely rounded; nearly entire, the upper base slightly auricled, the lower rounded. Texture coriaceous, surfaces naked or the costa minutely scaly ahove. Sori near the margin; indusium reniform, wilh a deep sinus.

Trop. Asia.

(12) V. arloatar, Copel., Polypod. Philipp., 48.

Rhizome short, suberect. Stipes approximate, suberect, strong, 10-15 c.M. long, sparsely scaly at the base, the scales lanceolate, reddish-brown, with a hyaline margin. Fronds linear, b0 c.M. or more long, \pm 8 c.M. broad, pinnate; rachis brown, glossy, clothed in the lower part with minute, scattered, spreading scales. Sterile pinnae $\pm .3^{1 / 2}$ c.M. long, \pm 1 c.M. broad, acute, entire, fertile ones \pm 5 c.M. long, \pm 7 m.M. broad, acuminate, often serrate towards the apex, subfalcate; the lower base rounded, the upper one acutely auricled; lower pinnae reduced, roundish. Texture subcoriaceous; surfaces naked. Sori submarginal; indusium orbicular, hlack, with a brown margin, the lobes overlapping.

\section{Philippines.}

* (15) N. exditata, Schott, Rac., Flor. Btz., I, 200; Schott, Gen. Fil., tab. III; Bedd., Ferns S.I, tab. XCIII; - var. monstruosa, hort.

Rhizome creeping, bearing distant, short branches with densely tufted Filiaes. 
fronds. Stipes 10-15 c.M. long, naked, or slightly scaly, the base clothed with narrow, adpressed, linear-lanceolate scales like the rhizome. Fronds 20-80 c.M. long, 8-15 c.M. broad. Pinnae close or the lower ones rather distant, not imbricate, bluntish or subacute, the upper base auricled, the lower rounded or auricled, the edge entire, crenate or serrulate; fertile pimnae linear, acute, often \pm falcate and longer than the" barren ones. Texture subcoriaceous; surfaces naked or nearly so. Sori submarginal; indusium reniform, with a deep sinus.

Var. monstruosa is a much cultivated form with $1-3 \times$ forked pinnae.

Pantropical. Luzañ jenomdeñaio.

* (14) N. bisermata, Schott, C. Chr., Ind. Fil.; N. acuta, Pr., Rac., Flor. Btz., I, 202; Bedd., Ferns S.I., tab. XCIV; Aspidium acutum, Schk., Muell., Pap. Pl., IV, 79; N. acuminala, Pr., Tent. Pterid., 79; N. punclulala, Pr., l. c.; Aspidium biserratum, Sw., (oldest name); - var. laurifolia, Christ, Farnkr. d. Erde, 289, fig. 907, d \& e.

Caudex short, erect, stoloniferous, densely clothed with lanceolate, brown, entire or more or less irregularly ciliate scales. Stipes tufted, 10-50 c.M. long, scaly at the base, glabrescent above. Fronds 30-400 c.M. long, 15-40 c.M. broad, pendulous if epiphytical. Pinnae linear-lanceolate, short-stalked or sessile, 1-3 c.M. broad, separated by less than their own breadtl, the point acute, the edge entire when barren, crenate, toothed or repand when fertile, the hase suddenly narrowed or truncate, not or slightly auricled on the upper on both sides, the lower base sometimes rounded. Texture herbaceous or subcoriaceous; rachis and costae naked or slightly scaly; surfaces naked or nearly so. Sori generally distant from the margin; indusium subreniform, rather becoming orbicular by the meeting of the 2 broad, basal lobes.

Var. lauroifolia: Pinnae broad, ovate-oblong or broadly linear-lanceolate, the edges subentire or sometimes irregularly inciso-lobate towards the base, the base truncate, rounded or broadly cuneate. Sori medial between the midrib and the margin.

Pantropical; - var. laurifolia: in a few malayan islands. 


\section{CYOLOPELTIS, J. Smith.}

Sori round, placed in $1-4$ rows on each side of the midrib. Indusium peltate.

Rhizome oblique, decumbent. Stipes not articulate to the rhizome. Fronds pinnate; pinnae articulate to the rachis; veins free, erecto-patent, forked or branched, bearing the sori dorsal or sometimes terminal. Diels, in Engl. \& Prantl, Nat. Pfl.Fam., I I , fig. 96, A-B.

Tropical Asia and America.

*. Pinnae with the lower base not hamalo-recurvale.

(1) C. semicordala. *.*. Pinnae with the lower base hamalo-recurvale.

(2) C. Presliana.

- (1) C. semicordata, J. Sm., Diels, in Engl. \& Prantl, Nat. Pft.Fam., $\mathrm{I}^{4}$, 183, fig. 96, A; Aspidium semicordalum, Sw., Hk. Bk., Syn. Fil., 249; Polystichum semicordatum, Moore, Bedd., Ferns Br.I., I, tab. XXXV; - var. crenata, Hk., Spec. Fil., IV, 17 ; - var. subdimorpha, Christ, in Warl., Mons., I, 76; - var. Kingii, Christ in Ann. Btz., XV, 126; A. Kingü, Hance.

Rhizome strong; the scales subulate, dense. Stipes approximate or scattered, $10-50$ c.M. long, fibrillose at the hase. Fronds 60-100 c.M. long, 20 - 50 c.M. broad, oblong, acuminate, simply pinnate. Pinnae close, articulate, not rarely contiguous, sessile or subsessile, $1-2$ c.Mr. broad, \pm falcate, acute or acuminate, the edge nearly entire, the hase truncate or cordate. Texture papyraceo-herbaceous or subcoriaceous; surfaces naked; rachis more or less scaly; veins pinnate, the lower ones ending short from the margin. Sori in 1-4 rows on each side, the inner row the most constant and regular, often close to the midrib or nearly so.

Var. cremata: Superior base of the pinnae broadly cuneate, lower one variable.

Var. subalimurphos: Pinnae of fertile fronds distant, very narrow.

Var. Kingii: Small form. Pinnae blunt, the base bluntly rounded. Sori in! 1 row.

Malacca; Burmah, Trop. America; - var. crenata: Borneo; - var. subdimorpha: Celebes; - var. Kingii: Celebes; Caroline Islands. 
* (2) C. Presliana, Berlk., C. Chr., Ind. Fil.; Aspidium Pre.lianum, Melt., Farng., IV, Phegop. \& Aspid., 56; Polystichum Preslianum, Moore, Copel., Polypod. Philipp., 16; - var. biauriculata.

Like C. semicordata, J. Sm., but: Stipes clothed with long, spreading scales, which are brown and subulate. Pinnae numerous, distant or approximate, spreading, the edge entire, crenato-sinuate or subrepand, highest pimnae often confluent with the terminal one, the upper base subcordate or rounded to slightly auricled, the lower base conspicuously auricled with an oblong, rounded, hamato-recurvate lobe which is adpressed on the rachis.

Var. biauriculata: Upper base with a conspicuous; deltoid, \pm deflexed auricle, which has the apex obliquely truncate.

Malaya; Burmah, Tonkin; - var. biauriculata: New Guinea (Peekel).

\section{POLYSTICHUM, Rotr.}

Sori roundish, dorsal or terminal on the veins. Indusium normally round and peltate, exceptionally reniform and attached by the sinus.

Rhizome creeping or erect. Stipes not articulate to the rhizome. Fronds at least pinnate, usually tough or rigid, the leaflets mostly unequal-sided, i. e. the lower side less developed, or the upper base broadly cuneate to truncate and often auricled, the lower one obliquely cut away; the edges commonly mucronate or spinulose; veins free. Hk. Bk., Syn. Fil., tab. V, fig. 43, a-b; Diels, in Engl. \& Prantl, Nat. Pfl.Fam., I I ${ }^{4}$ fig. 99.

Tropical and extra-tropical.

a. Fronds simply pinnate, at best 2-pinnatifid al the base. (1) P. auriculatum. a.a. Fronds at least 2-pinnate at the base.

b. Main rachis densely scaly or fibrillose.

c. Texture membranaceous or herbaceous.

(2) P. diaphanum.

c.c. Texture rather coriaceous.

d. Pinnulae distinct, short-stalked, not joined at the base.

e. Scales of stipe and rachis ferrugineous.

f. Teeth aristate or spinulose.

(3) P. aculeatum.

f.f. Teeth blunt or adpresso-mucronale. (4) P. obtusum. e.e. Principal scales of slipe and rachis \pm black.

(b) P. biaristatum. 
d.d. Pinnulae decurrent, joined at the base.

(6) P. lobatum.

b.b. Main rachis naled, or slightly scaly or fibrillose.

1. Sori submarginal.

(7) P. amabile.

1.1. Sori distant from the margin.

2. Sori costal.

(8) P. platypus.

2.2. Sori \pm medial.

3. Lowest pinnae deeply 2-pinnatifid at the base on the lower side.

(9) P. varium.

3.3. Lowest pinnae at least 2-pinnate at the base on the lower side.

1. Rhizome creeping; the scales hair-like or \pm setiform.

(10) P. aristatum.

4.4. Rhizome erect; the scales long, linear-lanceolate.

(11) P. coniifolium.

(1) Puriculatum, Pr., Tent. Pterid., 85; Aspidium auriculatum, Sw., Hk. Bk., Syn. Fil., 251; - var. nervosum, Christ, in Bull. Herb. Boiss., VI, 192; Phegopteris nervosa, Fée, Mém., VI, tab. II, fig. 4.

Stipes tufted, $10-15$ c.M. long, scaly below or throughout. Fronds $30-$ 45 c.M. long, $5-10$ c.M. broad. Pinnae numerous, subsessile, usually close, $21 / 2$-5 c.M. long, $1-1 \frac{1}{2}$ c.M. broad, ovate-rhomboidal, falcate, the point acute, the edge spinoso-serrate, not lobed; the upper base with a prominent auricle, the lower one truncate. Texture subcoriaceous; rachis stramineous, slightly scaly. Sori in 2 rows.

Var. nervosum: Stipes decumbent; pinnae small, crenate, not aristate; sori scattered, small; indusium hardly present.

Malacca; Ceylon, Br. India; - var. nervosum: Philippines; Formosa.

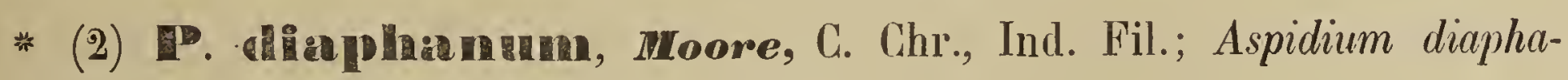
num, Zoll. \& Mor., Rac., Flor. Btz., I, 17 .

Rhizome short, erect, densely clothed with ferrugineous, lanceolate, acuminale, ciliate scales. Stipes 5-6 c.M. long, densely scaly. Fronds $\pm 10-$ 15 c.M. long, $\pm 2 \% \frac{1}{2} \frac{1}{2}$ c.M. broad. Pinnae sessile or the lower ones stalked, oblong-rhomboidal, the base obliquely cuneate, the edge toothed to lohed and toothed. Lowest pinnae pinnate with few, small, obovate pinnulae at the base. Texture thin; rachis densely scaly; the edges and both surfaces hairy; midribs wavy. Sori $1-6$ on each side of the costae.

Java. 
* (3) P. aculeatum, Schott (not Roth), Copel., Polypod. Philipp.; 17; Diels, in Engl. \& Prantl, Nat. Pfl.Fam., Í ${ }^{4}$, fig. 100, A; Aspidium aculea tum, Sw., Hk. Bk., Syn. Fil., 25?; - var. vulcanicum; A. vulcanicum, Bl., Enum., 165; - var. subamoenum, Christ, in Warb., Mons., I, 77; - var. mucronifolium; A. mucronifolium, Bl., Rac., Flor. Btz., I, 172; - var. moluccense; A. moluccense, Bl., l. c., 168; - var. batjanense, Christ, I. c. ; A. batjanense, Christ, Bull. Herb. Boiss., 2e Série, VI, 926; P. horizontale, Copel., 1. c., 18.

Rhizome erect or suberect, strong, scaly. Stipes tufted, scaly, 10-100 c.II. long; the scales of 2 forms, the smaller ones slender, ressembling hairs or fibrils, the larger ones ovate-lanceolate, thin, both ferrugineous. Fronds 50-80 c.M. long, $18-40$ c.M. broad, 2-pinnate, sometimes 5-pinnate, ovatelanceolate to deltoid, acuminate. Pinnae close, numerous, 土 linear-lanceolate, the lowest commonly the longest, 2-4 c.M. broad near the base. Pinnulae subrhomboidal, close, regular, the upper base truncate, \pm auricled, the lower base cuneate, the margin toothed, the apex and the teeth mucronate or aristate. Texture \pm coriaceous; rachis densely, \pm deciduously scaly, the scales linear-lanceolate, ferlugineous, acuminate, often mixed with white or reddish, \pm hair-like smaller ones; under surface naked or slightly fibrillose. Sori in 1 row on each side, \pm medial or subcostal. - A variable species. -

a. Pinnulae at best pinnalifid, the auricle not free.

b. Pinnulae not pinnatifid.

Forma typica: Pinnulae aristate. Sori \pm medial or subcostal, not soliLary. - Cosmopolitan.

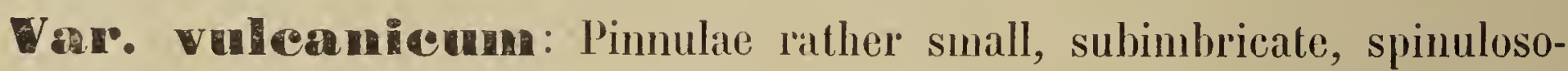
dentate, obscurely auricled. Sori-solitary. -- Java, Sumalra.

b.b. Pinnulae incised.

Var. subamoenum: Philippines.

a.c. P nmulae more or less divided, at least the auricle \pm free.

van. mucromifolinan: Under surface slightly paleaceo-pilose; pinnulae small, at best once pinnate. - Malaya; Br. India.

Var. malaccense: Under surface sparingly furfuraceous; pinnulae once pinnate. - Moluccas, Philippines.

Var. Dadionense: The whole plant densely clothed with cinnamoncoloured scales; pinnulae large, \pm 5 c.M. long, the lowest pinnate or 2pinnatifid. - Batjan, Philippines.

* (4) D. Dusum, J. Sm. (not Pr.), Copel., Polypod. Philipp., 17; Aspidium obtusum, Kze (not Mell.), Hk. Bk., Syn. Fil., 252, Mett., Farng., IV, 
Phegop. \& Aspid., b1; Hk., Spec. Fil., IV, tab. CCXXI; A. aculealum, Sw., var. oblusum, Christ, Bull. Herb. Boiss., VI, 192; - var. densum; A. densum, Zipp., MS. in Herb. Bog.

Stipes 10-15 c.M. long, scaly; the scales copious, ferrugineous, ovate, long-pointed, soft, mixed with narrow, subulate ones which continue upon the rachis, becoming there more or less fibril-like, both forms ciliate. Fronds $\pm 20-50$ c.M. long, ovate-lanceolate, acuminate. Lower pinnae distant, subspreading, $\breve{b-15}$ c.M. long, $1 \frac{1}{2}-2 \frac{1}{2}$ c.M. broad. Pinnulae rhomboid-ovate, oblusely auriculate, obtuse, the teeth blunt or adpresso-mucronate. Texture coriaceo-membranaceous; rachis densely \& deciduously scaly or fibrillose; under surface more $0 r^{\prime}$ less scaly, the scales small, partially filiform, partially stellato-fimbriate. Sori \pm medial; indusium peltate, thin, fringed at the margin. Very near P. aculeatum, Scholl.

Var. demsum: Fronds longer and broader, copiously 2-pinnate. Luzon; — var. densum: ..........? (Zippelius).

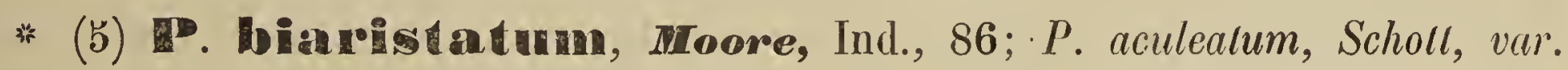
biaristalum, Bedd., Handb. Ind. Ferns, 209; C. Chr., Ind. Fil.; Aspidium biaristaum, Bl., Enum., 164; Hk., Spec. Fil., IV, 29; A. amabile, Rac. (not Bl.), Flor. Btz., I, $17^{2}$.

Stipes tufted, 20-40 c.M. long, very paleaceous below with long, subulate, cilate, castaneous scales (sometimes having a black, central line) mixed with large, broad-lanceolate, intensely black ones, which are brown at the margin, the rest of the stipe and the rachis clothed with more or less deciduous and copious, black-brown, crinite scales, at length often glabrous. Fronds 30-60 c.M. long, from a broad hase ovate-oblong, suddenly acuminate at the apex. Pinnae sessile or subsessile, 10-20 c.M. long, acuminate, serrate towards the apex, ${ }^{1} 1 / 2-4$ c.II. broad at the base. Pinnulae subrhomboidal, acute, serrate, obsoletely-auriculate, the serratures mucronato-spinose. Texlure coriaceous; under surface paleaceo-pilose. Sori medial or \pm submarginal; indusium rather small, peltate. - ? Different from P. vestitum, Pr. (A. vestilum, Sw., Melt. Farng. IV, Phegop. \& Aspid, 45).

Malaya; Br. India.

(6) Imbatum, Tront. Tent. Pterid., 83; Bau. \& Ilk., Gen. Fil., Lah. XLVIII, C; Aspidium lobalum, Sw., Christ, Farnkr. d. Erde, 238; - var. discretum, Christ, in Ann. Btz., XV, 125; A. discrenu, Don, Prod. Flor. Nepal., 4; P. discrelum, Diels in Engl. \& Prantl, Nat. Pfl.Fam., I ${ }^{4}, 191$. 
Like P. aculeatum, Schotl, but the pinnulae decurrent, confluent at the base. Fronds lanceolate, narrowed towards both ends.

Var discererum: Fronds deltoid or triangular. Pinnae cut down to $1 / 3$-way to the costa in the outer half.

Europe and South. Africa to Japan; Hawaii; - var. discretum: Malaya; North. India, Japan.

\# (7) P. amabile, J. Sm., Diels, in Engl. \& Prantl, Nat. Pfl.Fam., I $^{4}$, 195; Aspidium amabile, Bl., Hk. Bk., Syn. Fil., 254; Hk., Spec. Fil., IV, tab. CCXXV; Lastraea amabilis, Moore, Bedd., Ferns S.I., tab. CIX.

Rhizome creeping, the scales linear-lanceolate, ferrugineous. Stipes scattered, $\mathbf{1 5}-\mathbf{5 0}$ c.II. long, slightly scaly below, slender, glossy. Fronds $\pm \mathbf{5 0}$ c.M. long, $15 \mathbf{b}-25$ c.M. broad, with a long terminal pinna and $2-6$ similar lateral ones on each side. Pinnae erecto-patent, the lower ones 10-20 c.M. long, 2-4 c.M. broad, sometimes slightly compound at the base. Pinnulae subrhomboidal, $1-21 / 2$ c.M. long, $1 / 2-1$ c.II. broad, the upper and outer edge cut $1 / 3-1 / 2$-way down to the costa into rounded lobes which terminate into a long bristle or a narrow, sharp tooth; the upper base subtruncate, the lower one obliquely cut away. Texture subcoriaceous; rachis and surfaces naked. Sori submarginal; indusium sometimes reniform.

Malaya; North. India, South. China, Japan.

(8) D. Dlatypus, Diels, in Engl. \& Prantl, Nat. Pfl.Fam., I I, $193_{\mathrm{i}}$; Nephrodium platypus, Hk., Hk. Bk., Syn. Fil., 286; P. aristatum, Pr., val', G. Chr., Ind. Fil.

Stipes 30-90 c.M. or more long, smooth, glossy, with a dense tuft of bright-coloured scales at the base. Fronds $45-60$ c.M. long, 50 c.M. and more broad, deltoid. Lower pinnae 15-2马 c.M. long, 7-10 c.M. broad. Pinnulae deltoid, obliquely truncate at the lower base. Lower segments often free, $1 / 2-11 / 2$ cll. broad, ovate-oblong, the teeth mucronate. Texture sub-coriaceous; rachis and both surfaces naked and glossy. Sori large, copious, in rows close to the midribs; indusium reniform.

Java; Moulmein, Khasia.

(9) D. vaurium, Pr., Copel., Polypod, Philipp., 19; Aspidium varum, Sw., Hk. Bk., Syn Fil., 234; Hk., Spec. Fil., IV, tab CCXXVI.

Rhizome short, subrepent. Stipes 50-60 c.M. long, densely fibrillose below. Fronds $30-50$ c.M. long, 20-30 c.M. broad, lanceolate-deltoid. Lowest pin- 
nae much the largest, subdeltoid, unequal-sided, 7-10 c.M. broad. Pinnulae lanceolate, imbricate, those at the lower base larger than the others, the lowest deeply pinnatifid. Segments oblong, blunt, faintly toothed, the teeth not awned. Texture subcoriaceous; both surfaces naked; rachis and midribs slightly fibrillose. Sori principally medial; indusium peltate or reniform.

Philippines; Assam, China, Korea, Japan.

* (10) P. Aristatum, Pr., Diels, in Engl. \& Prantl, Nat. Pfl.Fam., I ${ }^{4}$ 195; Aspidium aristalum, Sw., Christ, Farnkr. d. Erde, 240; Lastraea aristata, Moore, Bedd., Ferns S.I., tab. CI; - Var. Hamiltonii, Spr., Syst., IV́, 108.

Rhizome creeping, densely clothed with short, setiform or hair-like scales. Stipes scattered, 30-70 c.M. long, fihrillose or scaly at least near the base. Fronds 30-70 c.M. long, deltoid, 20-50 c.M. broad, with a long, pinnate apex and below this \pm b-6 pinnate pinnae on each side. Lowest pinnae 2-pinnate to 5-pinnatifid at the base, the lower basal pinnulae the longest. Leaflets subrhomboidal, the upper base \pm truncate and auricled, the lower hase cuneate, the edges more or less lobed with the lobes copiously toothed, the teeth aristate. 'T'exture \pm coriaceous; surfaces naked; rachis nearly so. Sori néarer the midrib than the edge; indusium peltale or reniform.

Var. Mramilionir: Largest form; ultimate segments large, ovatedeltoid, slightly lobed. -

The rhizome of the type is figured in Bedd., Handb. Ind. Ferns, fig. 118, A.

Malaya; Natal, India, China, Japan, Polynesia; - Var. Hamiltonii: ? Malacca; Nepal, Khasia, Ceylon.

(11) D. Coniliforium, Pr., Copel., Polypod. Philipp., 18; P. carvifolium, C. Chr., Ind. Fil.; Aspidium curvifolium, Kze., Bot. Zeit., 1848, 285; A. carvifolium, Kze, Linn., XXIV, 292; A. coniifolium, Wall., Christ, Farnkr, d. Erde, 240; A. aristatum, Sw., var. coniifolium, Hk. Bk., Syn Fil., 2马5; Lastraea coniifolia, Moore, Bedd., Ferns Br.I., II, tab. CCLXI; -- var. Sarasinorum; A. aristatum, Sw., var Sarasinorum, Christ, Ann. Btz., XV, 124.

Near P. aristatum, $P r$, but the rhizome erect, the scales long, linearlanceolate, Stipes tufted, the base clothed with narrow, blackish scales. Fronds large, 60-90 c.M. long, (50-50 c M. long, conf. Copel.), 4-5-pinnate. Ultimate pinnules and segments small, less coriaceous, ovate or rhomboidal, aristate. Sori large or small; indusium peltate, sometimes reniform. - The creeping rhizome figured in the lead of the mentioned table is that of $\mathrm{P}$. aristatum, $\mathrm{Pr}$. 
Var. Sianasinorum: Small form. Fronds \pm 20 c.ll. long: segments short, deeply incised, huntish or short-acuminate, not aristate.

Malaya; Polynesia, Australia, Japan, China, North. India, Natal; - var. Sarasinorum: Celebes.

\section{O. DHDYMOCHLAENA, Desvarx.}

Sori oblong, terminal on the veins, but not marginal. Indusium the; same shape of the sorus, fixed by its longitudinal axis, opening on all sides

Rhizome erect. Stipes not articulate to the rhizome. Fronds 2-pinnate. Leallets unequal-sided, subdimidiate, the basiscope half being obliquely cut away; veins free. Hk. Bk, Syn Fil., tab, IV, fig. 42; Diels, in Engl ct Prantl., Nat. Pfl.Fam., I', fig. 95.

Pantroprical.

* D. Inumuldata, Desv., Rac., Flor. Btz., I, 197; Bedd., Ferns Br.I., I, tab. XV; Hk., Gard. Ferns, tab. XVII; D. sinuosa, Desv., Bau. \& Hk., Gen Fil., tab. VIII; D. truncalula, J. Sm., Journ. of Bot., IV, 196; G. Chr., Ind. Fil; Adiantun hunulatum, Houtt., (ollest name).

Caudex erect, subarborescent. Stipes densely tufted, several d.M. long, paleaceous. Fronds 60-180 c.M. long, 50-60 c.M. broad, 2-pinnate, oblong to lanceolate. Pinnae numerous, sessile or short-stalked, erecto-patent, linear, acuminate, 2-4 c.M. or more broad. Pinnulae numerous, close, articulate, subrhomboidal, about half as hroad as long, the upper base broadly and the lower narrowly cuneate, the edge entire or slightly sinuate. Texture subcoriaceous; main rachis scaly, the scales narrow, fimbriate; secondary rachises slightly scaly, sometimes hairy; upper surface slightly covered with subulate bristles. Sori $2-6$ to a pinnula.

Pantropical.

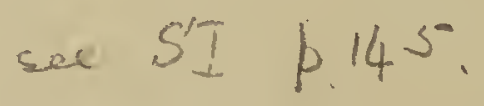

\section{PLEOCNEMIA, Hest.}

Sori roundish, medial or terminal on the free veins or veinlets, rarely on the netted veins. Indusium reniform, attached by the sinus, rarely round and peltate.

Rhizome generally erect. Stipes not articulate to the rhizome. Fronds often ample and compound; lower veins of contiguous groups united and those 
of the same group slightly so, forming 1 -2 rows of irregular areolae near the costae and costulae without included free veinlets, the rest free. Diels, in Engl. \& Prantl, Nat. Pfl.Fam., I ${ }^{4}$, fig. 97, D. (Aspidium, p.p., C. Chr., Ind. Fil). Tropical Asia, Polynesia.

a. Fronds simple, lobed or pinnalifid.

(1) P. heterophylla.

a.a. Fronds at least 2-pinnatifid.

b. Texlure ralher coriaceous.

1. Lower pinnae pinnalifid.

2. Surfaces slighlly hairy on the veins.

(2) P. excellens.

2.2. Surfaces naked, or the upper one slighuly scaly.

1.1. Lower pinnae pinnale, at least on the lower side.

(5) l'. megalocarpa.

b.b. Texure rather herbaceous or membranaceous.

c. Lower pinnae pinnalifid.

(4) P. Leuzeana.

c.c. Lower pinnae pinnatifid with the lowest basiscopical segment pinnatifid again.

(6) P. membranifolia.

c.c.c. Lowest pinnae pimnate at the base, the lowest basiscopical segment pinnatifid or pinnale at the base.

d. Indusium cordalo-reniform.

(7) P. Bakeri.

d.d. Indusium pellate.

(8) P. devexa.

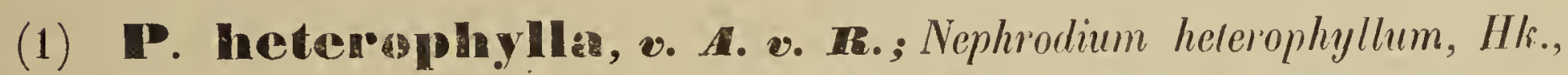
Hk. Bk., Syn. Fil., 295; Aspidium helerophyllum, Mell., Copel., Polypod. Philipp., 59., Hk., Icon. Pl., X, tah. GMXX; Dryopleris canescens, C. Chr., var., C. Chr., Ind. Fil.

Rhizome creeping. Stipes 5-10 c.M. long, densely villose, scaly towards the base. Fronds $12-15$ c.M. long, $\pm 21 / 2$ c.II: broad, simple, acuminate, the erge lobed $1 / 4-1 / 3$-way down into numerous, oblong, blunt, slightly falcate lobes. Texture coriaceous; surfaces villose especially on the edges and the midribs beneath; main veins pinnate in the lobes, those of the barren fronds forming 1-2 rows of costal and constular areolae, those in the fertile fronds anastomosing \pm as in Nephrodium, $5-6$ on each side. Sori medial on the veins; indusium small, fugacious.

Philippines.

(2) P. excellens, v. A. v. IR.; Nephrodium excellens, Hi., Hk. Bk., Syn. Fil., 293 ; Aspidium excellens, Bl., Ĺnum., 160; C. Chr., Ind. Fil. 
Stipes naked, greyish. Fronds large. Lower pinnae to 50 c.ll. long, 7-10 c.M. broad, deeply pinnatifid into oblong-lanceolate, acuminate, entire or distantly crenate lobes. Texture subcoriaceous; rachis, veins and margins slightly hairy on both sides; veins of the lobes slightly pinnate, and mostly forming costal arches. Sori small, copious, principally in irregular rows near the costulae.

Java.

(5) P. megallocarma, Hedd., Handb. Ind. Ferns, Suppl, 48; Polypodium megalocarpum, IIl., Hk. Bk, Syn. Fil., 318; Nephrodium oligodictyon, Bk., Ann. of Bot., V, 328, Aspidium megalocarpum, C. Chr., Ind. Fil.

Rhizome erect, scaly at the crown. Stipes stout, $40-60$ c.M. long, scaly towards the base. Fronds oblong-deltoid, 60-90 c.M. long, the upper part deeply pinnatifid with lanceolate, pinnatifid lobes. Pinnae in \pm 6 pairs; the lowest largest, equilateral, $15-2 b$ |c.M. long, $5-9$ c.M. broad, cut more than $1 / 2$-way down to the costa into narrow, oblong, crenated segments to $\pm 3 / 2$ c.M. long, \pm 5-8 m.M. broad. Texture subcoriaceous, opaque; surfaces naked or the upper one furnished with scattered, small, jointed, transparent scales; venation pinnate in the lobes, forming areolae near the costae only. Sori medial or nearly so, in 2 rows on each side of the costa along the wing and in a single row on each side of the costulae; indusium fugacious.

Java, Malacca.

* (4) P. Leuzeana, Pr., Rac., Flor. Btz., I, 194; Bedd., Ferns Br.I., I, tab. CXXXIV; Nephrodium Leuzeanum, Hl., Hk. Bk., Syn Fil., 295 ; Aspidium Leuzeanum, Kze., Copel., Polypod. Philipp., 39; C. Chr., Ind. Fil. var. hemiteliiformis, Rac., l. c.; - var. digitata.

Caudex erect, short, to \pm 12 c.M. high, or subarborescent and to \pm 1 M. high, the apex clothed with long, linear-lanceolate, ciliate, woolly, brown seales. Stipes 50-100 c.M. long, often striated, scaly at the base. Fronds subdeltoid, 2-3-pinnalifid, \pm 1-2 M. long, 30-90 c.M. broad. Pinnae numerous, close, pinnatifid, or at least the lowest pinnate on the lower side, shorl-stalked. Pinnulae sessile or short-stalked, to \pm 25 c.M. long, to \pm 8 c.Mr. broad, the lowest $1-2 \times$ pinnatifid. Lobes numerous, separated by narrow sinuses with roundish tops, oblnng, bluntish, subfalcate, entire, toothed or sinuated. Texture coriaceous; surfaces naked. Sori usually in 1 row on each side, nearer the edge than the costulae; indusium early fugacious, (often wanting?). 
Var. hemiteliformis: Pinnulae $6-9$ c.M. long, 8-12 m.M. broad; edges ciliate; sori close.

Var. digigitata: Fronds digitate.

Malaya; Polynesia, South. China, North. India; - var. hemiteliiformis: Java; - var. digitata: Celebes.

"(5) IP. gigantea, Pr., Rac., Nlor, Btz., I, 193; P. Trimeni, Bedd., Handb. Ind. Ferns, 225; Sagenia gigantea, Moore, Bedd., Ferns S.I., tab. LXXX; Aspidium giganteum, Bl., Enum., 159 ; C.Chr., Ind. Fil., p.p.

Caudex erect, to \pm 8 c.M. high, clothed with ovate-lanceolate, rigid, entire scales. Stipes to $50-60$ c.M. long, scaly at the base. Fronds $50-90$ c.M. long, to 4 b c.M. broad, 2-pinnatifid. Pinnae sessile or short-stalked, lanceolate to linear, the edge cut to $2 / 3-5 / 6$-way down into erecto-patent, subfalcate, entire, crenate or sinuate lobes. Lowest pinnae to 12 c.M. broad, the apex acuminate, the base obliquely truncate or cuneate, medial pinnae to $\mathrm{b}$ c.M. broad, the higher ones decurrent. Texture herbaceous to submembranaceous; veins forming about 3-4 rows of costal areolae and about 1 row of costular ones. Sori numerous, in 1 or rarely 2 rows on each side of the costulae.

Malaya; Ceylon, South. India.

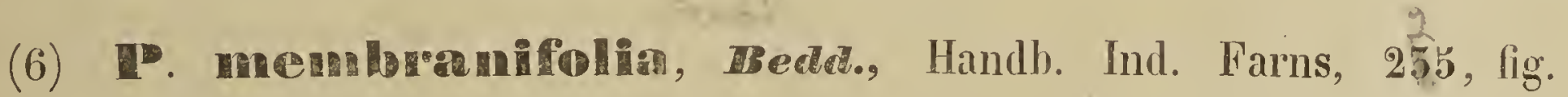
115; Nephrodium membranifolium, Pr., Hk., Spec. Fil., IV, tab. CCLXI; Aspidium membranifolium, Kze. (not Pr.), Diels, in Engl. \& Prantl, Nat. Pfl. Fam., Iㄴ, 188 ; C. Chr., Ind. Fil.

Stipes tufted, clothed with black, linear, subulate scales, but more copiously towards the base, \pm 50 c.Mr. long. Fronds to 50 c.M. or more long, deltoid to ovate, pinnate, the apex pinnatifid. Lateral pinnae in few pairs, \pm opposite, b-10 c.M. long, 3-4 c.M. broad, more or less deeply pinnatifid, the segments rounded, nearly entire; lowest pair of pinnae largest, deltoid, pinnatifid or subpinnate, with the lower basal segments elongate and pinnatifid. Rachis and surfaces \pm softly hairy; texture softly herbaceous. Fertile fronds similar to the barren ones or \pm contracted. Sori generally terminal on free veinlest, in 1 row on each side of the costulae; indusium reniform.

Malacca, (? Malaya).

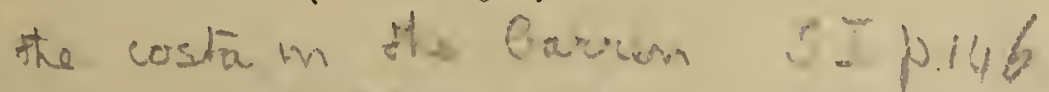

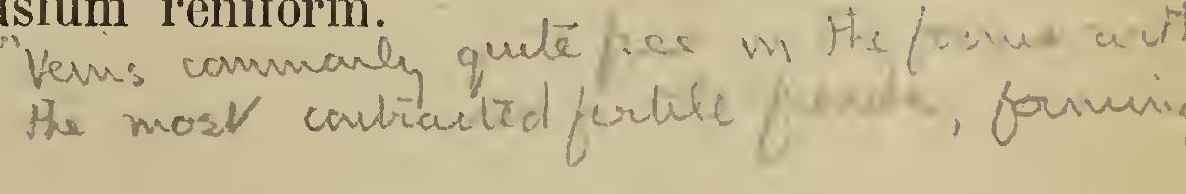

* (7) Hakeni, v. A. v. R.; Nephrodium giganteum, Bk., Hk. Bk., Syn Fil., 505; Aspidium giganteum, Copel. (not Bl.), Polypod. Philipp., 58; (? Bl., G. Chr., Ind. Fil., p.p.). 
Stipes 50-60 c.M. long, brown, glossy. Fronds 30-60 c.M. long, broadly deltoid, with a pinnalifid apex and $\pm 4-5$ pairs of pinnae on each side, the higher ones decurrent, the lower stalked. Lowest pinnae largest, deltoid, the pinnulae on the lower side prolonged, deeply pinnatifid; highest pinnae bluntly lobed. Texture moderately firm; surfaces nearly naked; veins anastomosing at least near the costae. Indusium subcordate. - A plant, gathered in Borneo and cullivated in the Buitenzorg gardens, which may be a form of this species has the fronds under 50 c.M. long, the ullimate lobes linear, gradually narrowed towards the apex, entire or broadly toothed and the sori submarginal.

Philippines, ? Borneo.

* (8) R. devexa, v. A. v. R.; P. membranacea, Bedd., Handb. Ind. Ferus, 225; Aspidium membranaceum, Hk., Hk. Bk., Syn. Fil., 259; A. devexum, Kze., (oldest name), Bot. Zeit., 1848, 259; C. Chr., Ind. Fil.; - var minor ; A. giganteum, Bl., var. minor, Hk., Spec. Fil., IV, כ0; Sagenia gigantea, Bedd., var minor., Bedd., Ferns S.I., tab. CCXLIII.

Stipes tufted, to about 50 c.M. long, nearly naked, with a few spreading, linear scales below. Fronds to $45-60$ c.M. long, \pm 50 c.M. or more broad. Lower pinnae much the largest, subdeltoid, 15 -20 c.I. long, 7-10 c.M. broad. Pinuulae on lowest side much larger than the others, pinnatifid (pinnate at the base) with lanceolate, pinnatifid segments, with small, oblong, sinuated lobes. Texture thinly herbaceous; colour pale-green; veins anastomosing principally in costal arches, but sometimes also as in Aspidium. Sori copious, terminal on the veins or veinlets; indusium peltate.

ar. minor: A less divided form; pinnae pinnatifid, the lowest ones pinnate at the base; pinnulae pinnatifid, the edges of the lobes entire or \pm slightly lobed.

Malaya; Formosa, Soulh. China, Ceylon.

\section{DRYOPTERIS, Adanson.}

Sori roundish, commonly \pm medial on the veins. Indusium reniform, attached by the sinus, rarely peltate and round or cordate.

Rhizome creeping or erect. Stipes not articulate to the rhizome. Fronds commonly pinnate or sometimes more compoundly divided; veins free or the lower ones of adjacent groups anastomosing and then forming on each side of the midribs 1 row of regular, deltoid, costal areolae with an excurrent 
veinlet springing from the top, free or joined in the angle of the next superior anastomosing veins, which often form 1 or more rows of regular, rhomboidal areolae between the costal ones and the margin. Segments mostly equal-sided or nearly so; surfaces often \pm hairy; texture commonly herhaceous. - The species are difficult of determination unless the whole slipe and the rhizome are present; the frond only is of little value.

Tropical and extra-tropical.

Arrangement of the sections.

\$1. LASTRAEA. Veins free. Indusium reniform. Hk. Bk., Syn. Fil., tab. V, fig. 44, c-d.

S 2. NEPHRODIUM. Veins anastomosing. Indusium reniform. Hk. Bk., l. c., fig. $44, a-b$.

$\$ 3$. CYCLOSORUS. Like $\$ 2$, but the indusium peltate, and round or cordate.

\section{S 1. LASTRAEA:}

a. Fronds pinnate. Pinnae cutire or lobed less than $1 / 3$-warty down to the costa. *. Fronds subsessile. Pinnae entive or slighlly crenale. (1) D. Warhurgii. *.*. Fronds moderalely long-slallied. Pimae lobed $1 / 4-1 / 3$-way down.

(2) D. hirlipes.

a.c. Fronds pimale. Pinnac cut more than $1 / 3$-vay down to quite to the cosict. Secondary seqments entive or crenale to repand ( $\left.{ }^{1}\right)$.

1. Central ribs of the lobes pimule; veins simple.

2. Lower pimas slighlly, if al all, reduced, nol dwindling down into more auricles.

3. Fronds small, under 10 c.M. long $\left({ }^{2}\right)$. (5) D. grammitoides.

3.3. Fronds more than 10 c.M. long.

1. Texlure \pm chartaccous or coriaccous.

5. Fronds under 75 c.M. long.

6. Surfaces nated, at best pubescent on the costac.

\%. Rachis naked $\left({ }^{3}\right)$.

(') See also phegopteroidea, C. Chr.

$\left(^{2}\right)$ See also D. diversifolia, $v . A . v, R$.

$\left(^{3}\right)$ See also D. pectinala, $v . A, v . R$. 
8. Fronds \pm 15 c.M. long; veins \pm 8 on each side in the secondary segments.

\section{(4) D. Koordersii.}

8.8. Fronds more than 50 c.M. long; veins $\pm 4-5$ on a side.

(5) D. phaeostigma.

-. Rachis pubescent or villose.

†. Pinnae under 6 c.M. long, cut down to the costa.

(6) D. gymnopoda. +. Longest pinnae more than 6 c.M. long, cut to $2 / 3$-way down to the costa.

(7) D. crassifolia.

6.6. Under surface pubescent.

$\therefore \quad$ Stipes scaly, at length scabrous. Fionds 7 D Dersquane
scabrous. Four conds
. (8) D. echinata. ... Stipes naked or pubescenl. Fronds under 20 c.M. broad.

*. Stipes pubescent, subtufled. Pinncte close, not dotted with white above.

(9) D. Teuscheri. *.*. Stipes naked, scattered. Pinnae subremote, dotted with white above.

(10) D. pectinata. 5.5. Fully developed fronds more than 75 c.M. long.

5. Rachis pubescent or scaly, under surface pubescent on the veins.

*. Stipes naked, grey.

(11) D. ligulata.

*.*. Stipes hairy and scaly, brown.

\$.\$. Rachis naked.

(12) D. Hallieri.

* Under surface glandular. (15) D. attenuata.

+. Under surface naked. (14) D. Beccariana.

1.4. Texture \pm membranaceous or herbaceous.

a. Sori medial, or lower on the veins.

B. Fronds mostly under 60 c.M. long.

$\gamma$. Stipes naked.

ঠ. Lower secondary segments not very small.

(15) D. Greaghii. 


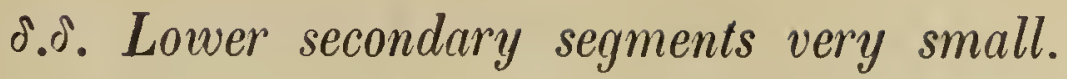
(16) D. vulcanica.

$\gamma \cdot \gamma$. Stipes more or less finely villose or pubescent, at least on the upper side $\left({ }^{1}\right)$.

. Under surface villous.

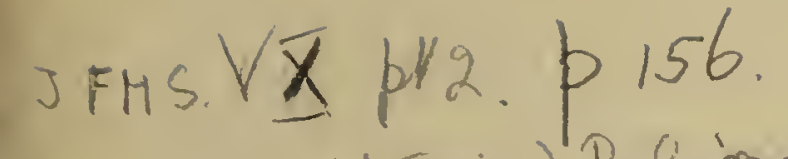

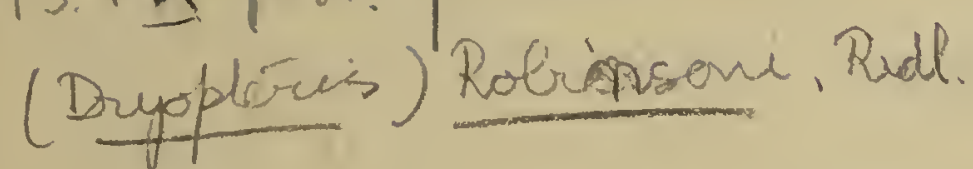

(17) D. calcarata.

... Under surface naked or glandular. +Densely glandular.

(18) D. viscosa. +. . Naked or slightly glandular.

(19) D. gracilescens.

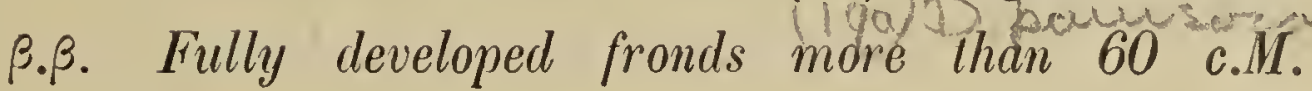
long.

$\therefore \quad$ Stipes densely hairy. Secondary segments with a single tooth in the sinus on the anterior side.

(20) D. monodonta. 21b) D. dwergors Sip N\}.... Stipes scaly. Secondary segments

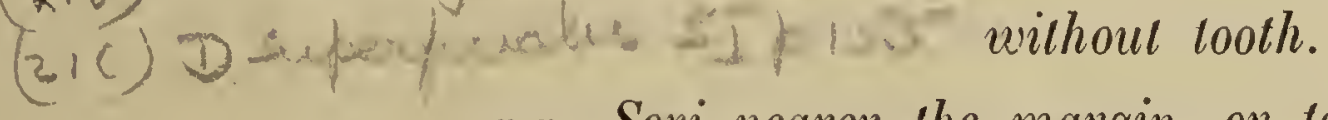

a. . Sori nearer the margin, or terminal on the veins $\left({ }^{2}\right)$.

$\beta^{\prime}$. Sori immersed.

$\beta^{\prime} . \beta^{\prime}$. Sori superficial.

(22) D. immersa. 24a) D bepiniala

$\gamma^{\prime}$. Lowest pinnae with the lowest anterior segment toothed or pinnatifid, the other segments entire.

(23) D. Peekeli.

$\gamma^{\prime} \cdot \gamma^{\prime}$. All the secondary segments similar, entire or crenate.

$\delta^{\prime}$. Surfaces naked.

$\delta^{\prime \prime} . \delta^{\prime}$. Surfaces more or less villous.

(24a) D. Dayi.

$\varepsilon^{\prime}$. Fronds \pm small. (24b) D. diversifolia.

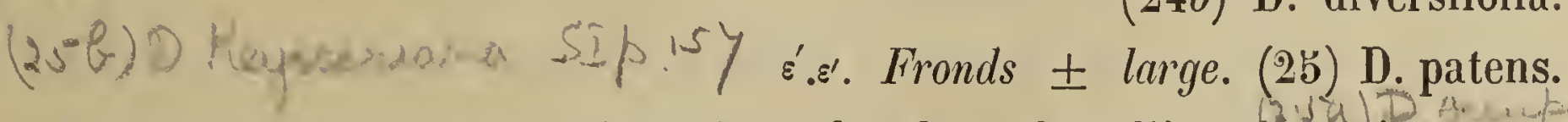

2.2. Lower pinnae conspicuously reduced or dwindling down into mere auricles.

3'. Sori medial, or lower on the veins.

(') See also under D. hispidula, $O$. Ktze.

$\left({ }^{2}\right)$ See also D. gracilescens, $O$. Klze.

Flliaks. 
1'. Pinnae cut $\pm 1 / 2$-way down to the costa $\left({ }^{*}\right)$.

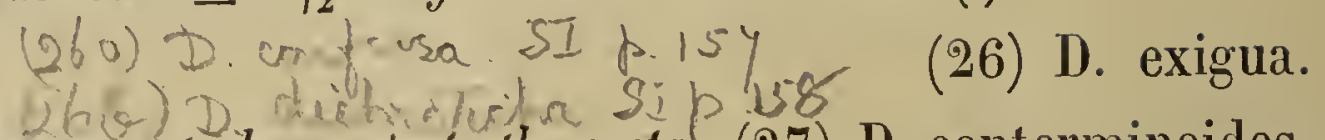

4.4. Pinnae cut down \pm lo the costa. (27) D. conterminoides. 3'.3'. Sori near the margin, or terminal on the veins. Foci $p 814$

+. Rhizome short. Veins 8-12 on a side. Fronds rather large.

+. Rhizome wide-creeping. Veins 4-5 on a side. Fronds (28) D. Luerssenii. rather small.

1.1. Central ribs pinnate, lateral veins forked.

(29) D. Beddomei.

$\therefore \quad$ Rachis scaly.

:.. Rachis naked, hairy or fibrillose.

(50) D. adnata.

* Fronds under 75 c.M. long.

?. Stipes dark-coloured. Surfaces naked. Rachis naked.

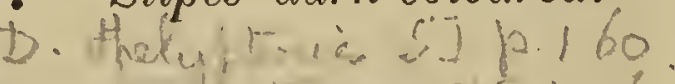

(उ C) D. Stipes grey. Surfaces finely pubescent. Rachis pubescent

(31) D. sagenioides.

(32) D. singalanensis.

+.+. Fronds more than 75 c.M. long when fully developed. Rachis fibrillose.

(55) D. Wigmanii.

1.1.1. Central ribs pinnate, lower lateral veins subpinnate. (34) D. filix mas. a.a.a. Fronds pinnate. Pinnae cut down nearly or quite to the costa. Secondary segments toothed or lobed.

b. Secondary segments toothed.

.. Sinuses wuth a tooth in the top, just between each pair of lobes.

(55) D. syrmatica.

..5. Sinuses without tooth in the top. Indusia red when young.

3s a) hellomana

(36) D. erythrosora.

Ђ.b. Secondary segments lobed, not pinnatifid.

c. Fronds under 75 c.M. long.

(3la D medir sipils

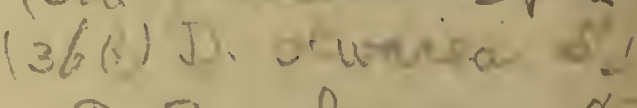

D Bannfar cana SI t

d. Under surface naked. Texture \pm chartaceous or coriaceous.

e. Ultimate lobes entire, with \pm 6 pairs of veins. Sori subcostular.

(57) D. Preslii.

e.e. Ultimate lobes crenate or toothed, with $\pm 3-4$ pairs of veins. Sori medial on the lower veins.

(58) D. chaerophyllifolia.

d.d. Under surface fibrillose on the main veins. Texture herbaceous. Sori costal.

(59) D. ediłenta. cunt edentiva

(*) See also D. hispidula, $0 . K t z e$. 
d.d.d. Under surface villous. Texure herbaceous. Sori medial.

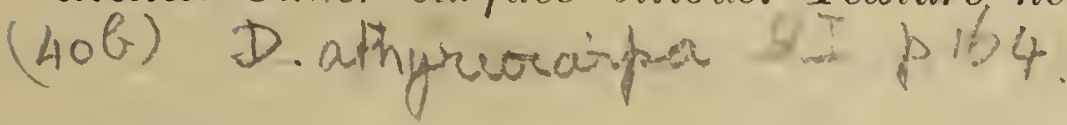

c.c. Fronds more than 75 c.M. long.

b.b.b. Secondary segments pinnatifid.

(40) D. flaccida.

(41a) D. splendens.

(41b) D. phegopteroidea:

a.a.d.a. Fronds at least deeply 3-pinnatifid at the base. (41a) D. Plav-cureeins

b'. Tertiary segments entire, crenulate or slightly toothed.

$\boldsymbol{c}^{\prime}$ Rachis naked or nearly so.

. Tertiary segments entire or cremulate.

?. Texture herbaceous. Lobes cremulale.

?.?. Texture subcoriaceous. Lobes entire.

(42) D. dissecta.

(45) D. papuana.

… Terliary segments slighlly \& \pm sparingly loolhed. (44) D. sparsa.

$\boldsymbol{c}^{\prime} \cdot \boldsymbol{c}^{\prime}$. Rachis more or less pubescent or pilose.

d'. Sori nearer the edge than the costulae.

*. Ulimate segments separaled by an intermediale vein, which unites the costa with the top of the sinus.

(45) D. Raeiborskii.

*.*.Intermediate veins wanting.

(46) D. recedens.

$\boldsymbol{d} \cdot \boldsymbol{d}$. Sori medial, or lower on the veins.

$\boldsymbol{e}^{\prime}$. Rhizome wide-creeping.

(47) D. borneensis.

$\boldsymbol{e}^{\prime} \cdot \boldsymbol{e}^{\prime}$. Rhizome short-creeping or erect.

$f^{\prime}$. Sori close to the costulae.

(48) D. Millettii.

f".f". Sori medial.

(49) D. padangensis.

$\boldsymbol{c}^{\prime} \cdot \boldsymbol{c}^{\prime} \cdot \boldsymbol{c}^{\prime}$. Rachis scaly.

s. Texhire coriaceous. Sori occupying nearly the whole under surface of the small ullimate segments.

(50) D. vilis.

\$.\$. Texture herbaccous or moderately firm Sori medial, or lower on the veins.

$\therefore$ Fronds al ulmost \pm 15 c.M. broad.

+. Rhizome short-creeping.

+. Caudex erecl.

$\therefore$ Fully developed fronds more than \pm 20 c.M. broad.

*. Ultimate segments to 1 c.M. long. (55) D. pulvinulifera.

+. Ultimale segments 2-21/2 c. it. long.

D. aciculata.

b'.b'. Tertiary segments at least conspicuously toothed (*).

1. Rachis naked, or slighlly scaly.

(*) See also ID. sparsa, 0. Ktze \& Raciborskii, $v . A . v \cdot R$. 
S. Tertiary segments toothed. Sori subcostular. (๖5) D. Boryana.

S.S. Tertiary segments at least pinnatifid. Sori \pm medial.

(כ,6) D. purpurascens.

1.1. Rachis hairy or fibrillose, at least on the upper side.

2. Surfaces densely hairy like the rachis.

2.2. Under surface slightly hairy or scaly on the veins.

(57) D. crenata.

3. Rachis slightly fibrillose, the fibrils deciduous.

\section{6) D. deer persita SI p.l6f (58) D. rhodolepis.}

3.3. Rachis pubescent on the upper side.

(59) D. setigera.

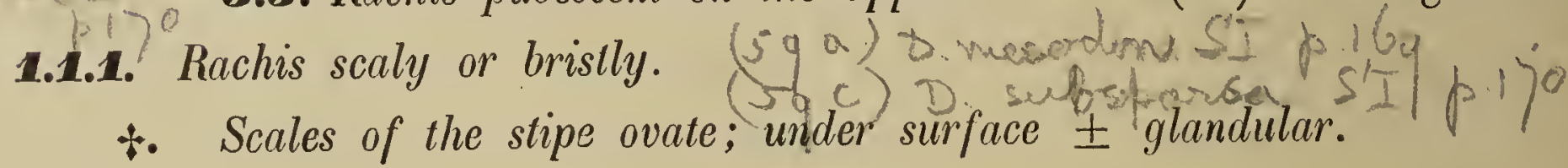

+. Scales of the stipe ovate; under surface \pm glandular.
(60) D. zeylanica.

+. Scales of the stipe bristle-like; under surface naked or hairy.

$+* *$ Scales of the stipe subulate; under surface scaly.

(61) D. multiseta.

(62) D. subarborea.

(6rd) D. tabaucuma

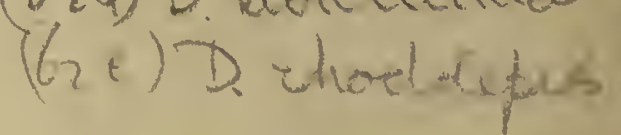

(1) D. Warburgii, C. Chr., Ind. Fil.,; Aspidium Warburyii, Kuhn \& Christ, Warb., Mons., I, 81; - var. reticulata, Christ, 1. c.

Stipes tufted, very short, nearly wanting. Fronds \pm 10 c.M. long, \pm 2 c.M. broad; rachis hairy. Pinnae ligulate, bluntish, the upper base truncate, the lower one cuneate, the margin entire or slightly crenate. Veins simple or forked. Sori minute, medial, in 1 row on each side of the midribs, $8-10$ to a row; indusium small, fugacious.

Var. reticulata: Pinnae ovate; veins \pm anastomosing.

New Guinea.

* (2) D. Inirtipes, C. Cher., Ind. Fil.; Aspidium hirtipes, Bl., Rac., Lustron. Flor. Btz., I, 168; A. atratum, Wall., Mett., Farng., IV, Phegop. \& Aspid., how Fis No. 126; Lastraea hirtipes, Moore, Bedd., Ferns S.I.; tab. XCVI; Nephrodium hirtipes, Hk., Hk. Bk., Syn. Fil., 261.

Rhizome short-creeping; the scales dense, long, lanceolate-subulate, darkcoloured. Stipes subtufted, $15-35$ c.M. long, scaly; the scales black-brown, the lower ones large, lanceolate-subulate, the higher ones linear-subulate or filiform. Fronds $15-60$ c.M. long, 8-3弓̆ c.M. broad, pinnate, the apex pinnatifid. Pinnae $1 \frac{1}{2}-2 \frac{1}{2}$ c.M. broad, short-stalked, the highest sessile, the lowest longest, linear-lanceolate, the base truncate, the edge lobed from 
$1 / 4-1 / 3$ on the way down to the costa, the point long-acuminate, toothed. Texture herbaceous to semicoriaceous; rachis fibrillose with black, filiform scales; surfaces naked, or the midribs slightly scaly; main veins pinnate in the lobes; lower veins not reaching the edge. Sori medial on the veins. - This resembles D. filix mas, Schott in general habit (Bk.).

Malaya; Polynesia, South. China, North. India.

(3) ID. grommmitoides, C. Cher., Ind. Fil.; Aspidium grammitoides, Christ, Bull. Herb. Boiss., VI, 195; Nephrodium grammiloides, Copel., Polypod. Philipp., 21.

Rhizome short-creeping, scaly. Stipes weak, 3-4 c.M. long, stramineous, clothed like the whole plant, and especially the costae and veins, with short, rigid, whitish hairs. Fronds $5-7$ c.M. long, $1 \frac{1}{2}-2$ c.M. broad, broadly oblong, narrowing from the base to the caudate, pinnatifid apex. Pinnae \pm 6 on each side, lowest largest, distant, sessile, deltoid, acuminate, cut down to the costa at the base, the upper portion pinnatifid. Lobes $\pm 4 \mathrm{~m}$.M. long, deltoid, crenate. Main veins pinnate in the lobes. Sori minute, $\mathbf{3}-\mathbf{4}$ on each side of the main veins; indusium small and villose, or suppressed.

Luzon.

(4) D. Koorden'sii, C. Chr., Ind. Fil.; Aspidium Koordersii, Christ, Ann. Btz., XV, 128, tab. XV, fig. 17, a-b.

Rhizome short, erect, woody, clothed with blackish, acuminate scales. Stipes tufted, polished, rufo-stramineous, partially spotted, firm, \pm 15 c.M. long. Fronds \pm 15 c... long, \pm 10 c.M. lroad, ovate-deltoid, 2-pinnate. Pinnae \pm 8 on each side, erecto-patent, the lower ones not shorter, ovate towards the base, subsessile, the apex caudate to acuminate, the rachis narrowly winged. Secondary segments $\pm 1 \frac{1}{2}$ c.M. long, distant, linear-lanceolate, acute, slightly crenate, narrowed at the base. Texture thinly coriaceous; colour dark-green; rachis and both surfaces naked; veins black, erecto-patent, simple, \pm 8 on each side. Sori small, medial on the veins; capsules few; indusium laterally fixed, crustaceous, convex, brown, glossy, the margin decurved.

Celebes.

(5) D. Dhacostigma, C. Chr., Ind. Fil.; Aspidium phacostigma, Ces., Fel. Becc. Polin., 4 \& 7.

Slipes erect or suberect, 60-75 c.M. long, the base densely clothed with long, linear-subulate, brown scales, the rest naked. Fronds 4 b-60 c.M. long, $\pm 20-25$ c.M. broad, lanceolate, pinnate. Pinnae spreading, pinnatifid 
quite to the costa. Segments linear, falcate, confluent at the base, hardly repand, subacute. Surfaces naked, opaque; veins $4-\breve{5}$ on each side. Sori solitary on the veins; indusium coriaceous, moderately large, at length deciduous.

Now Guinea.

(6) D. symnopoda, C. Chr., Ind. Fil.; Nephrodium gymnopodum, Bk., Trans. Linn. Soc., Bot., 2d Series, IV, $22^{2} 2$.

Stipes slender, naked, glossy, reddish-brown, 10-15 c.M. long. Fronds oblong-lanceolate, 2-pinnate, \pm 15 c.M. long. Pinnae \pm 20 -jugate, the lowest largest, deflexed, lanceolate, $5 \frac{1}{2}-4 \frac{1}{2}$ c.M. long, \pm 1 c.M. broad, cut down to the costa. Segments linear-oblong, enlire, \pm 2 m.M. broad. Texture subcoriaceous; surfaces naked; rachis pubescent; veins distant, simple, erectopatent. Sori solitary at the base of the segments, medial; indusium small.

Borneo.

\# (7) D. crassifolia, O. Kt:e, G. Chr., Ind. Fil.; Aspidium crassifolium, Bl., Rac., Flor. Btz., I, 169 ; Lastraea nephrodioides, Bedd., Ferns Br.I., II, tab. CIC; L. crassifolia, Inomer, Bedd., Handb. Ind. Ferns, 238; Nephrodium crassifolium, Hk., Hk. Bk., Syn. Fil., 266; - var. Motleyanum; A. Motleyanum, Christ, Ann. Btz., XX, 10כ ; N. Motleyanum, Hk., Hk. Bk., l. c.; D. Motleyana, C. Chr., Ind. Fil.

Rhizome creeping, the scales lanceolate. Stipes approximate, scaly below, hairy above, 30-50 c.M. long. Fronds 50-60 c.M. long, 15-50 c.M. broad, deltoid-lanceolate. Pinnae $2-4 \%$ c.M. broad, the fertile commonly narrower than the barren ones and sometimes much contracted, sessile or short-stalked, the lowest stalked, cut $1 / 2-2 / 3$-way down to the costa into blunt or acute, falcate, entire lobes $\breve{b}-8$ m.M. broad, the lowest of which are \pm reduced in size. Texture subcoriaceous; rachises and midribs finely or obscurely hairy; veins 10-12 on each side of the main ones, the lowest sometimes joining or terminating in the tops of the sinuses. Sori commonly 1 to each vein, the higher ones close to the main veins, the lowest often divaricating.

Var. Motleyama: Veins anastomosing in the barren fronds; sori medial. Pinnae less numerous, distant.

Malaya; Burmah; - var. Motleyana: Borneo. Negoos $(\$ 1, p 144)$

* (8) D. eclninata, O. Htwe, C. Chr., Ind. Fil.; Aspidium echinatum, Mett., Ann. Mus. Bot. L. B., I, 230; Nephrodium echinatum, Bk., Hk. Bk., Syn. Fil., 266. 
Stipes \pm 30 c.M. long, clothed with long, spreading, brown, lanceolatesubulate scales, scabrous when they fall. Fronds \pm 30 c.M. long, 20-25 c.M. broad, lanceolate-deltoid. Lowest pinnae stalkerl, $\pm 121 / 2$ c.M. long, $15-20 \mathrm{~m} . M$. broad, cut down to a narrowly winged rachis into close, linearoblong, entire lobes. Texture coriaceous; rachis like the stipe; under surface thinly pubescent and glandular; veins $7-8$ on a side, the lowest sometimes joining. Sori nearer the midrib than the edge.

Sumalra, Borneo, Celebes, New Guinea.

\section{* (9) Menscheri, v. A. v. IR.}

Rhizome scaly; the scales brown, linear-lanceolate, acuminate, ciliate. Stipes subtufted, $\pm \breve{b}-10$ c.II. long and like the rachis greyish or brownish, densely short-hairy. Fronds linear-lanceolate, acuminate, pinnate, $\pm 15-20$ c.M. long, $\pm \tilde{5}-4$ c.ll. broad, with a pinnatifid apex and an elongate, crenate point. Higher pinnae oblong, entire, sessile; following pinnae subsessile; central pinnae close, short-stalked, erecto-patent, falcate, \pm 1 c.M. broad, the base truncate, auricled on the upper side, the edge pinnatifid \pm $1 / 3$ on the way to the costa, but more deeply and nearly to the costa towards the base, the apex oblong, blunt, entire or crenate; lower pinnae shorter, deflexed. Lobes blunt, subentire. Texture semicoriaceous; under surface densely glandular and short-hairy; veins forked, or pinnate in the lobes. Sori medial on the veins, in 1 row on each side of the costulae; indusium densely hairy. - Fronds with the general aspect of D. pilosiuscula, C. Chr., but the pinnae more deeply lobed and the upper surface naked.

Borneo (Teuscher).

(10) D. pectinata, v. A. v. R.; D. orientalis, C. Chr., Ind. Fil.; Aspidium pectinatum, Christ, Farnkr. d. Erde, 250; Nephrodium albo-punctatum, Desv., Hk. Bk., Syn. Fil., 264; Hk., Fil. Exot., tab. LXXXIX; N. pectinalum, Ilier., Engl. Jahrb., XXVIII, 341; N. Webbianum, Hk., Spec. Fil., IV, 85; Polypodium pectinatum, Forsk., (oldest name).

Rhizome wide-creeping, scandent. Stipes naked, greyish-blackish, distant, \pm 10 c.II. long. Fronds $20-3$ J c.M. long, 10-15 c.M. broad, ovate. Pinnae spreading, subdistant, sessile, lanceolate, blunt, $1-1 \frac{1}{2}$ c.M. broad, cut $1 / 2$-way down or more into oblong, entire, subspreading lobes. Texture firm; surfaces and rachis more or less pubescent; upper surface with white cretaceous dots; main veins pinnate, with $3-4$ veins on each side. Sori small, near the edge; indusium hairy. $N$. Webbianum, Hk. has the fronds 
quite naked, the pinnae less deeply lobed, the upper base auriculate and the sori between the main veins and the margin.

Amboyna, New Guinea; Fiji, Mascaren Islands, Trop. Africa.

(11) D. ligulata, o. Kt:e, C. Chr., Ind. Fil.; Aspidium ligulatum, Kze, Mett., Farng., IV, Phegop. \& Aspid., No. 213; Nephrodium ligulatum, Hk., Hk. Bk., Syn. Fil., 264.

Stipes grey, glossy, naked. Fronds $90-120$ c.M. long, 50-45 c.M. broad. Pinnae $15-25$ c.M. long, $\pm 2 / 2$ c.M. broad, cut down very nearly to the costa into linear, blunt, entire, erecto-patent lobes $\pm 21 / 2 \mathrm{~m} . M$. broad and with more than their own space between them, lower pinnae slightly reduced. Texture subcoriaceous; rachis and under surface finely pubescent; veins $\pm 10-12$ on a side. Sori submarginal.

Philippines.

* (12) Hallieri, C. Chr., Ind. Fil.; Aspidium Hallieri, Christ, Ann. Btz., XX, 106.

Stipes thick, brown, opaque, clothed like the rachis with short hairs and like the base of the rachis with lanceolate-subulate, spreading, brown scales. Fronds ovate-lanceolate, \pm 100 c.II. long or longer, $\pm \mathbf{5 5}$ c.M. broad, acuminate, hardly narrowed at the base. Pinnae of the barren fronds close, sessile, spreading, caudate-acuminate, the margin incised $3 / 4$-way down to the costa, the base \pm 5 c.M. broad. Segments pectinate, close, \pm 35 below the serrate apex, \pm 1 c.M. long, $\pm 4-5$ m.M. broad, falcate, lanceolate, bluntish, the margin subentire or subcrenulate, short-ciliate, slightly inflexed. Costae, costulae and veins pubescent; veins $12-15$ on each side, very prominent. Fertile pinnae 2-21/2 c.M. broad, the lower ones distant; segments $2-51 / 2$ m.M. broad. Sori minute, medial or subcostular, \pm 13 on each side; indusium small or wanting (suppressed ?).

Borneo.

* (15) D. attenuata, O. Kt:e, Rev. Gen. Pl., II, 812; D. stenobasis, C. Chr., Ind. Fil.; Aspidium attenuatum, Kze, Mett., Farng., IV, Phegop. \& Aspid., 96; Nephrodium altenuatum, Fée (not Bk.), Hk. Bk., Syn. Fil., 263.

Stipes 50 c.M. or more long, firm, glossy, naked. Fronds $90-120$ c.M. long, \pm 50-60 c.M. broad. Pinnae \pm 2 c.M. broad, acuminate to caudate at the. apex, the lower ones short-stalked, the edge cut $1 / 2-3 / 4$ of the way down into entire, spreading, blunt lobes $21 / 2-4$ m.M. broad, the basal lobes 
reduced. Texture subcoriaceous; rachis naked; under surface \pm glandular; veins numerous. Sori in close rows near the midribs of the lobes. General habit of Mesochlaena polycarpa, Bedd. (Bk.).

Philippines, Celebes, Amboyna, Now Guinea.

(14) D. Beccariana, C. Chr., Ind. Fil.; Nephrodium Beccarianum, Ces., Fel. di Bor., 23.

Near D. attenuata, 0 . Klze. Especially the lower pinnae moderately longstalked, long-acuminate, divaricating. - Stipes lucid, the base clothed with linear-subulate, brown, entire, lucid scales. Surfaces naked. Sori less numerous; indusium coriaceous.

Borneo.

(15) D. Creaghii, C. Chr., Ind. Fil.; Nephrodium Creaghii, Bk., Kew Bull., 1898, 230.

Stipes stramineous, naked, $35-40$ c.M. long. Fronds oblong-lanceolate, 2-pinnatifid, \pm 45 c.M. long, \pm 15 c.M. broad at the middle. Pinnae multijugate, sessile, lanceolate, deeply pinnatifid, $2-2^{1} / 2$ c.M. broad, the lower ones not reduced. Lobes linear-oblong, entire, obtuse, $\pm 21 / 2 \mathrm{~m} . \mathrm{M}$. broad. Texture moderately firm; upper surface naked, under one obscurely pubescent; veins simple, erecto-patent, 7-R-jugate. Sori small, medial; indusium naked, persistent.

Borneo.

(16) D. vulcanica, C. Cher., Ind. Fil.; Nephrodium vulcanicnm, Bk. Ann. of Bot., VIII, 127.

Stipes naked, slender. Fronds oblong-lanceolate, \pm 4 b c.M. long, deeply 2-pinnatifid. Pinnae sessile, multijugate, lanceolate, acuminate, cut down nearly to the costa, the lower ones $61 / 2-71 / 2$ c.M. long, $1 \frac{1}{2}-2$ c.M. broad, not reduced. Lobes linear-oblong, $\pm 21 / 2$ m.M. broad, entire, the lower ones very small. Rachis slender; surfaces naked except on the costae; main veins pinnate; veins 6--8-jugate, simple, immersed, obscure. Sori small, medial; indusium naked, persistent, reniform, with a deep sinus.

Java.

* (17) D. calcarata, O. Ktae, C. Chr., Ind. Fil.; Aspidium calcaralum, Bl., Rac., Flor. Btz., I, 170; Lastraea calcarala, Moore, Bedd., Ferns S.I., tab. CCXLVI; L. falciloba, Hk., Bedd., I. c., tab. CV; Nephrodium falcilobum, 
Hlk., Spec., Fil., IV, 108; N. calcaralum Hk., Hk. Bk., Syn. Fil., 264; - var. serecia; L. calcarala, Moore, var. sericea, Bedd., Handb. Ind. Ferns. 257; L. sericea, Scholl, Bedd., Ferns Br.I., II, tab. CCCVIII.

Rhizome erect, clothed with few, broad, lanceolate scales. Stipes tufted, 4-:0 c.ll. long, hairy on the upper side, deciduously scaly near the base. Fronds $10-60$ c.M. long, 5 -20 c.M. broad, ovate, the apex acuminate, pinnatifid with linear-oblong, suberect lobes. Pimnae spreading or erecto-patent, sessile or stalked, 1-2 c.Mr. broad, the lower ones hardly shorter, the apex acute or acuminate, the base cuneate to truncate, the edge cut down $2 / 3$ or more to the costa into oblong, acute or bluntish, falcate or suberect lobes 1-5 m.M. broad, the lowest lobe on the anterior side not rarely elongate, \pm parallel to the rachis. Texture herbaceous but firm; rachis and surfaces villous; veins simple, $3-8$ on a side. Sori medial; indusium hairy or naked, persistent. - A well-marked plant by the often nearly erected lobes. N. falcilobum, Hk. is a form with broader pinnae and deeper and more spreading lobes than usual.

Van . sericea: Pinnae short, oblong, $2 \frac{1}{2}-5$ c.M. long, $1-2$ c.M. broad, obtuse at the apex or ending in a sudden point, never cordate. Indusium naked.

Malaya; Br. India, South. China, Samoa, - var sericea:Malacca, North.\&. South. India.

* (18) D. vilscosa., O. Ktae, C. Chr., Ind. Fil., Nephrodium viscosum, Bk., Hk. Bk., Syn. Fil., 264; Lastrace viscosa, J. Sm., Bedd., Ferns Br.I., II, tab. CCCXXXIV.

Stipes 1 c.Y. or more long, firm, erect, reddish-brown, slightly scaly, finely villose. Fronds $20-50$ c.M. long, $10-1$ b.M. broad, oblong-lanceolate. Pinnae close, $5-8$ c.M. long, $1-1 \frac{1}{2}$ c.I. broad, cut nearly to the costa into close, spreading, linear-oblong lobes under $21 / 2 \mathrm{~m}$. .. broad. Texture herbaceous; rachises villose; at least the under surface densely glandular; veins $b-6$ on a side. Sori medial. - Lower pinnae a little shorter and deflexed.

Malacca, Sumatra, Borneo, Philippines.

* (19) Dracilescens, O. Ktee, C. Chr., Ind. Fil.; Aspidium gracilescens, Bl., Rac, Flor. Btz., I, 170., Lastraea gracilescens, Moore, Bedd., Ferns Br.I., II, tab. CCLIII; Nephrodium gracilescens, Hlk., Hk. Bk., Syn. Fil., 262 ; - var. decipiens, Bedd., Handlı. Ind. Ferns, Suppl., 51; var. glanduligera, Bedd., 1. c.; A. glanduligerum, Kze., Mett., Farng., IV, Phegop. \& Aspid., No. 207. 
Rhizome short-creeping; the scales few, linear-lanceolate, entire. Stipes approximate, 15 - 40 c.M. long, slender, slightly scaly and short-hairy. Fronds lanceolate-oblong, $15-40$ c.M. long, 8-24 c.M. broad, acuminate. P'innae sessile, spreading, straight or falcate, acuministe, $\pm 7 \frac{1}{2}-15 \mathrm{~m}$. I. broad, deeply pinnatifid nearly to the costa, the lowest rather distant, not or not much shorter, \pm deflexed. Lobes ohlong, blunl, straight or subfalcate, approximate, to $\pm 5 \mathrm{~m}$.M. broad. Texture thin; rachis naked, or hairy above; surfaces naked, or glandular beneath, sometimes setulose on the veins; costulae pinnate in the lobes; veins $4-6$ on a side. Sori in 1 row on each side of the costulae, medial or submarginal; indusium naked or minutely pilose.

Var. decipiens: Fronds shorter, deltoid; pinnae ralher hroader.

Var. glanduligeren: lihome wide-creeping; stipes distant.

Malaya; Br. India; - var. decipiens: Mulacea; Br. India; - var. glanduligera: Malacca; Br. India, China, Japan.

(20) D. monodonta, C. Chr., Ind. Fil.; Lastraea unidentata, Bedd., Handb. Ind. Ferms, Suppl., 55

Stipes, nearly 60 c.M. long, densely villose, as is the rachis, with fine hair-like, jointed scales. Fronds $6+1-90$ c.M. long, pinnate. Pinnae $17 \frac{1}{2}$ c.M. long, $\pm 2 \frac{1}{2}-51 / 2$ c.M. broad, cut down nearly to the costa into narrowoblong segments, which are entire or nearly so except a large tooth-like lobe on one side at the base near the sinus (most prominent in the lower pinnae), lower pinnae not smaller, deflexed. Texture herbaceous to subcoriaceous; costae densely strigose above, furnished beneath with long, white, weak hairs; costulae slightly hairy on both sides; under surface covered with glandular dots; veins in 10-12 pairs, simple or the lower forked. Sori medial on the veins; indusium persistent.

\section{Malacca.}

* (21) D. polyericha, v. A. v. I.; D. trichopod", C. Chr., Ind. Fil.; Nephrudium polylrichum, Ble, Journ. of Bot., XXIX, 107; - var. Hallieri. Stipes stout, 4b-60 c.M. long, densely clothed with large, spreading, lanceolate-acuminate, brown scales. Fronds lanceolate-oblong, 2-pinuatifid, 90-12() c M. long, \pm 60 c.M. broad. Pinnae lanceolate, sessile, spreading, the lowest the largest, $\pm 3 \frac{1}{2}-4$ c.M. broad, cut down to a narrow wing into entire, linear-oblong segments \pm 4 m.M. hroad. Texture moderately firm; under surface pubescent; rachis destitute of scales except a fer in the lower part; veins simple, 15-20-jugale, distinct, arcuate. Sori nearer the midrib than the edge; indusium small, fugacious. 
Var. Hallieri: Fronds smaller; pinnae narrower, the lower ones narrowed towards the base; rachis diduously scaly like the stipe; pimnae pubescent on the costa and slightly so at the margin; sori superficial, the lower ones divaricating. (Hallier No. 248 , determined by Burck as Aspidium immersum, $B l$. .).

Borneo.

* (22) D. immer'sa, o. Ktes, C. Chr , Ind. Fil.; Aspidium immersum, Bl., Rac., Flor. Btz., I, 169; Lastraea immersa, Moore, Bedd., Handlb. Ind. Ferns, 234; Nephrodium immersum, Hk., Hk. Bk., Sỳn. Fil., 263.

Rhizome short-creeping. Stipes approximate, $70-120$ c.M. long, glossy, slightly scaly at the base. Fronds $80-200$ c.M. long, 30-70 c.II. broad, ovate-oblong. Pinnae sessile, $2-4$ c.M broad, almost horizontal, acuminate or nearly caudate, cut down nearly to the costa into \pm close, spreading or nearly spreading, straight or subfalcate, subacute, linear lobes $2-5$ m.M. broad. Texture herbaceous; upper surface naked or provided with distant, inconspicuous hairs; under surface and rachis provided with minute, yellow, glandular dots or stiff, white hairs. Sori near the margin, 1 to each vein, much immersed as to project on the upper surface; indusium persistent, reniform, the basal lobes overlapping.

Malaya. Luzon

\section{* (23) D. Peekeli, v. A. v. Th.}

Stipes \pm 10 c.M. long, naked or slightly glanduloso-pilose. Fronds lanceolate or obovate, $\pm 30-40$ c.M. long, $15-20$ c.ll. broad. Pinnae 18-22 on each side below the deeply pinnatilid apex, linear-lanceolate, the central ones the largest, rather spreading, acuminate, $1-1 \frac{1}{2}$ c.II. broad, sessile or shortstalked, cut down nearly to the costa into linear-oblong, erecto-patent or subspreading, entire, bluntish segments $1 \frac{1}{2}-2 \mathrm{~m}$.M. broad, the lowest lobes not or hardly shorter. Lowest pinnae shorter, deflexed, with the lowest segments free and only those on the upper base broader and deeply toothed or pinnatifid. Texture thin; rachis and surfaces finely short-hairy; veins 8-10-jugate, simple. Sori submarginal, solitary at the base of the lobes or numerous along the edges; indusium villose.

New Guinea (Peekel, No. 44).

(24a) D. Dayi, C. Cles., Ind. Fil.; Aspidium Dayi, Bedd., Journ. of Bot., XXVI, 4 ; Lastraea Dayi, Bedd., Handb. Ind. Ferns, Suppl., 54; Nephrodum Dayi, Bedd., Journ. of Bot., XXV, 325. 
Stipes 30-60 c.M. long, stramineous, naked, or with a few hair-like scales towards the base. Fronds $45-60$ c.M. long. Pinnae 12-15 c.M. long, $2-21 / 2$ c.M. broad, the lower ones scarcely shorter, cut down nearly to the costa into linear-oblong lobes $\mathbf{3}^{1 / 1}-4 \mathrm{~m}$. I. broad. Texture papyraceo-herbaceous, surfaces naked exept the costa, which is fincly puberulous above; veins $6-8$ on each side, simple, not reaching the margin. Sori terminal on the veins; indusium persistent.

\section{Malacca.}

\section{* (24b) D. aliversifolia, v. A. v. IR.}

Rhizome erect or ascending. Stipes tufted or approximate, $5-6$ c.M. long, pale-hrown, copiously pubescent with more or less, short, whitish, spreading hairs, scaly at the base, the scales brown, subulate, ciliale. Fronds acuminate, $\pm 6-12$ c.M. long, $\pm 4-9$ c.M. broad, triangular with the lowest pinnae longest or obovate-lanceoate with the central pinnae longest and then the lower pinnae deflexed and gradually growing shorter (dwarfed but not reduced into mere auricles). Pinnae in $\pm 6-10$ pairs below the pinnatifid apex, close or imbricating, the longest spreading, linear-oblong, 7-12 m.M. broad, the apex entire, blunt, the edge pinnatifid $\pm 3 / 4$-way down or more, or even pinnate at the very base. Secondary segments oblong, close or slightly imbricating, blunt, entire, the lowest ones not rarely free and subdistant. Texture herbaceous; rachis pubescent like the stipe; surfaces hairy on the veins and costae and minutely so between the veins beneath; costulae pinnate in the lobes; veins simple. Sori small, confined to the lobes, in 1 row on each side nearer the margin than the costulae; indusium minutely pubescent, the margin beset with globose, yellow glands, or the surface and the margin covered with yellow glands and powder.

Batu Islands (Raap, No 27).

(25) Datens, o. Ktze, G. Chr., Ind. Fil.; Aspidnum patens, Sw., Christ, Farnkr. d. Erde, 251; A. deversum, Kze, Mett., Farng., IV, Phegop. \& Aspid., No. 209; Nephrodium polytrichum, Schrad., Gött. Anz., 869; N. patens, Desv., Hk. Bk., Syn. Fil., 262.

Rhizome oblique, slightly creeping. Stipes 50 c.M. or more long, naked or slightly hairy, pale-coloured. Fronds $60-100$ c.Mr. long, $20-50$ c.M. broad, linear-oblong. Pinnae close, spreading, sessile with a broad base, 1-2 c.M. broad, finely acuminate, cut down $\pm 3 / 4$ of the space to the costa. Lobes linearoblong, subfalcate, bluntish, entire or slightly crenate. Lowest pinnae not 
reduced. Texture herbaceous; colour pale-green; rachis and surfaces more or less villose; veins simple, $6-12$ on a side. Sori nearer the edge than the midrib ; indusium reniform, persistent, hairy. - General aspect of D. parasitica, O. Kize, but much larger.

New-Guinea; Polynesia, Japan, China, Trop. Africa, Trop. \& Subtrop. America.

(26) D. exiguan, o. Ktwe, Rev. Gen. Pl., II, 812; D. philippina, C. Chr., Ind. Fil.; Aspidium cxiguum, Kze, Mett., Farng., IV, Phegop. \& Aspid., No. 180 ; Nephrodium exiguum, IIk, Hk. Bk., Syn. Fil., 267.

Stipes tufted or approximate, 12-25 c.M. long, slender, grey, villosotomentose with short hairs like the rachis. Fronds $20-25$ c.M. long, $\mathbf{3} 11_{2}-5$ c.M. broad. Pinnae numerous, approximate, ovate-falcate, $1 / 2-1$ c.M. broad, blunt, the base cordate, sometimes subauriculate on the upper side, the edge cut $\pm 1 / 2$-way down or more to the costa into close, blunt lobes; lowest pinnae reduced. Texture papyraceo-herbaceous; veins obscure, 2-5 on each side of the main veins (constulae). Sori near the constulae.

Philippines.

(27) D. Conterminoides, C. Chr., Ind. Fil.; Nephrodium simulans, Bk., Journ. of Bot., XXVIII, 106 (not Journ. of Bot., XXVI, 525, nor Hk. Bk., Syn. Fil., 500!

Stipes short, naked. Fronds lanceolate-oblong, 2-pinnate, to 50 c.M. long, $\pm 7 \frac{1}{2}$ c.N. broad at the middle, narrowed gradually to the base. Pinnae lanceolate, $1-1 \frac{1}{2}$ c.II. broad, the central ones $21 / 2-4$ c.M. long, cut down \pm to the costa into linear-oblong segments $\pm 2 \mathrm{~m}$.Í. broad. Texture moderately firm; rachis densely crinite; veins simple, erecto-patent, $\breve{5}-6$-jugate. Sori subcostal; indusium persistent.

New Guinea.

(28) Duenosseni: C. Chr., Ind. Fil.; Aspidium Luerssenii, Christ, Bull. Herb. Boiss., VI, 195 ; Nephrodium Luersenii, Harr., Journ. of Limn. Soc., Bot., XVI, 29.

Stipes clustered, firm, shining, light-purplish. Fronds $45-75$ c.M. long, 13 -25 c.M. broad, oblong. Pinnae $10-20$ c.M. long, $2^{1 / 4}-4$ c.M. broad, lanceolate, acuminate, jointed at the base, cut down nearly or sometimes quite to the costa into numerous linear or oblanceolate lobes $21 / 2-4$ c.II. long, $21 / 2-4$ m.M. broad. Lower pinnae very small. Texture membranaceous; surfaces naked; veins $8-12$ on a side, simple, free, distant. Sori terminal on the veins.

Philippines. 
(29) D. Bedlonnei, O. Ktwe, C. Chr., Ind. Fil.; Aspidium Beddomei, Pranll, Verh. Zool. Bot. Ges., XXXI, 119 ; Nephrodium Beddomei, Bk., Hk. Bk., Syn. Fil., 267; Lastruea gracilescens, Bedd., Ferns S.I., tab. CX.

Rhizome slender, wide-creeping. Stipes $15-25$ c.M. long, slender, glossy. Fronds 1 b-50 c.M. long, 7-10 c.M. broad; oblong-lanceolate. Central pinnae the longest, $5^{1 / 2}-5$ c.M. long, \pm 1 c.M. broad, \pm spreading, cut down to the costa into close, rather acute, entire lobes under $2 \frac{1}{2}$ m.M. hroad. Lower pinnae distant, dwindling down gradually. Texture firm; main veins villous beneath; veins $4-5$ on a side. Sori close to the incurved margin.

Java, Philippines; South. China, South. India, Ceylon.

* (50) D. admata, v. A. v. R.; D. filix mas, Scholt., var., C. Chr., Ind. Fil.; Aspidium paleaceum, Rac. (not Bl.), Flor. Btz., I, 171; A. adnatum, Bl., Enum., 162.

Rhizome suberect, densely clothed with very long, yellow-brown, thin, lanceolate, entire scales. Stipes $2.3-5 \breve{b}$ c.M. long, the lower half scaly like the rhizome, the upper half like the rachis. Fronds linear-lanceolate, $55-100$ c.M. long, 15-50 c.M. broad. Pinnae sessile, linear, $1 \frac{1}{2}-21 / 2$ c.M. broad, the apex acuminate, toothed, the edge cut down nearly to the costa; lower pinnae shorter, but not reduced. Lobes linear-oblong, close, blunt, toothed at the apex, $3 \frac{1}{2}-5 \mathrm{~m}$.M. broad, the edge entire or slightly crenate. Texture coriaceous; rachis scaly; veins forked, bearing the sori at the base of the anterior branches, in 1 row on each side of the costulae.

Java.

(51) D. sagenioides, D. Htze, C. Chr., Ind. Fil.; Aspidiun sagenioides, Mell., Christ, Farnkr. d. Erde, 255; Lastraea fuscipes, Moore, Bedd., Handb. Ind. Ferns, 243; L. melanopus, Bedd., Ferns Br.I., I, tab. XXXVIII; Nephrodium melanopus, Hk., Spec. Fil., IV, 110; N. sagenioides, Bk., Hk. Bk., Syn. Fil., 271.

Rhizome short, erect. Stipes tufted, slender, 1 ๖̌-50 c.M. Jong, darkcoloured, polished, scaly at the base. Fronds 50-60 c.M. long, $1.5-50$ c.M. broad, oblong-lanceolate. Pinnae $\pm 8-10$ on each side below the pinnatifid apex, $\pm 5-4$ c.M. broad, the base subtruncate, the apex short-acuminate, the edge cut down nearly to the midrib into linear-oblong, crenate or entire lobes; the lowest ones deflexed, rather shorter than the others with some of the lobes on the lower side sometimes prolonged. Texture papyraceo-herbaceous; surfaces naked; rachis polished; veins $6-10$ on a side, forked, or 
the higher ones simple. Sori \pm terminal on the acropetal veinlets, \pm medial between the costulae and the edge.

Malaya; Burmah.

(32) D. singalanensis, C. Chr., Ind. Fil.; Lastraea singalanensis, Bedd., Handb. Ind. Ferns, Suppl., 54; Nephrodium singalanense, Bk., Journ. of Bot., XVIII, 212.

Stipes densely tufted, grey, slender, to \pm 30 c.M. long, with a few small, linear, brown scales near the base. Fronds lanceolate-oblong, 2-pinnate, 45-65 c.M. long, $13-50$ c.M. broad. Pinnae lanceolate, sessile, the central ones $61 / 2-17$ c.M. long, $2-21 / 2$ c.M. broad, the lower a little reduced, cut down nearly to the costa into lanceolate, entire or crenate lobes 2-4 m.M. broad. Texture rather thin; rachis sulstramineous and minutely pubescent; surfaces finely pubescent; veins 8-10-jugate, distinct, chiefly forked. Sori small, medial. Sumalra, Malacca.

* (55) D. Wigmanii, C. Chr., Ind. Fil.; Aspidium Wigmanii, Rac., Bull. Ac. Crac., 1902, 61; Nephrodium Wigmanii, Rac., ViS. in Herb. Bog.

Caudex erect, clothed like the lower part of the stipes with castaneous, lanceolate-subulate, deflexed scales. Stipes \pm 50 c.M. long, canaliculate, densely clothed like the whole frond (costae, veins and parenchyma) with erected or spreading, pale-coloured 0r whitish, glutinose fibrils. Fronds $100-130$ c.M. long, 30-40 c.M. broad. Pinnae numerous, rather approximate, opposite, linear-lanceolate, acuminate, sessile or stalked, erecto-patent, to 25 c M. long, the lower deflexed, $21 / 2-41 / 2$ c.M. broad in the barren, $51 / 2-71 / 2$ c.M. broad in the fertile fronds, deeply pinnatifid. Lobes close, $4-5 \mathrm{~m} . \mathrm{M}$. broad, crenate or serrate, linear-oblong, the base often slightly narrowed. Texture herbaceous; main veins pinnate with $4-8$ pairs of mostly forked veins. The lowest posterior lobe mostly shorter than the lowest anterior one. - Fertile fronds with the lobes deeper, narrower, more distant, repando-crenate. Sori numerous, 1 -2 to a crenation; indusium reniform.

Aru Islands.

* D. Cilix mas, schott, G. Chr., Ind. Fil.; Aspidium Filix-mas, Sw., Christ, Farnkr. d. Erde, 256; Lastraea Filix-mas. Pr., Bedd., Handb. Ind. Ferns, 248; L. odontoloma, Moore, Bedd., Ferns S.I., tab. CXIV; Nephrodium Filix-mas, Rich., Hk. Bk., Syn. Fil., 272; - var. parallelogramma; var. fibrillosa, Christ, in Ann. Btz., XV, 127; A parallelogrammum, Kze, Linn., XIII, 146;- 
var. cochleata, Bedd., Handb. Ind. Ferns, 250; L. cochleata, Moore, Bedd., Ferns S.I., tab. CXV; D. cochleata, C. Chr., Ind. Fil.

Rhizome oblique, stout, densely clothed with pale-brown, broadly lanceolate scales. Stipes tufted, $\pm 15-20$ c.M. long, scaly like the rachis, the scales lanceolate. Fronds $30-100$ c.I. or more long, $20-50$ c.I. broad, ovate-lanceolate. Pinnae lanceolate, acuminate, 2-4 c.M. broad, cut down nearly or quite to the rachis into numerous, blunt, close, entire, crenate or serrulate segments 5-5 m.II. broad; lower pinnae rather shorter than the others and more distant. Texture herbaceous; surfaces naked; lower veins subpinnate. Sori large, numerous, in 1 row on each side, nearer the costulae than the margin; indusium reniform, \pm convex, naked, often persistent.

Varo. parallelogramma nate; rachis scaly, the scales linear, black-brown.

Jan. cochleata: Fronds dimorphous, barren ones subdeltoid, 2pinnatifid, fertile ones linear, pinnate, with the pinnae oblong, simple, toothed, blunt. Sori very large, completely covering the under surface of the fertile fronds.

Inhabiting almost all the temperate climates of the world except Australia; var. parallelogramma: Celebes; South. India, Columbia, Mexico; - var. cochleata: Malacca; Br. India.

* (35) D. syrmaticen, o. Ktre, C. Chr., Ind. Fil.; Aspidium syrmaticum, Willd., Rac., Flor. Btz., I, 171; Lastraea syrmatica, Moore, Bedd., Handb. Ind. Ferns, 243; L. spectabilis, J. Sm., Bedd., Ferns S.I., tab. CVIII; Nephrodium spectabile, Hk., Spec. Fil., IV, 115; N. syrmaticum, Desv., Hk. Bk., Syn. Fil., 272.

Rhizome erect, densely clothed with entire, lanceolate scales. Stipes tufted, 50-60 c.I. long, scaly at the base. Fronds 50-150 c.ll. long, ovateoblong. Pinnae $\pm 10-50$ c.II. long, 2-4 c.M. broad, linear-lanceolate, cut $3 / 4-4 / 5$-way down to a broadly winged rachis into ovate, bluntish, slightly falcate, toothed lobes 4-8 m.M. broad, the sinuses rounded, with a small tooth in the top. Lower pinnae not much smaller, short-stalked. Texture subcoriaceous, slightly pellucid; surfaces naked; veins 7-15 on a side, nearly all forked. Sori small, medial on the anterior veinlets, nearer the edge than the costulae:

Malaya; North. India.

(36) 1D. erythrosond, O. Ke:e, G. Ghr., Ind. Fil.; Nephrodium erythrosorum, Hk., Hk. Bk., Syn. Fil., 273; N. prolificum, Diels, in Engl. \& Prantl, Nat. Pfl.Fam., I I 173.

Filices. 
Stipes tufted, 15-25 c.M. long, more or less densly clothed with long, lanceolate and linear scales. Fronds 50-45 c.M. long, 20-50 c.M. broad, ovate-lanceolate. Pinnae lanceolate, the lowest the largest, 15-15 c.M. long, $\pm 5 \frac{1}{2}-4$ c.M. broad, cut down quite to the rachis below into oblong, bluntish pinnulae $\breve{b}-8$ m.M. broad, the edge slightly (sometimes spinosely) toothed. Texture herbaceous, but firm; surfaces naked; rachis slightly scaly. Sori in rows of $6-9$ to a pinnula, near the midribs; indusium red when young.

Philippines; China, Japan.

(57) D. Preslioi, O. Ftwe, C. Chr., Ind. Fil.; Neprhodium Preslii, Blk, Hk. Bk., Syn. Fil., 272.

Stipes 15 -25 c.M. long, slender, deciduously fibrillose. Fronds 15-25 c.M. long, 10-15 c.M. broad, lanceolate-deltoid. Upper pinnae lanceolate, close, lowest pair deltoid. Upper pinnulae \pm 5 m.M. broad, blunt, entire, lower ones pinnatifid with similar lobes to a broad, uncut centre. Texture subcoriaceous; rachis fibrillose; both surfaces naked. Sori about 6 to the * lower lobes, dorsal on the veins, nearer the midribs than the edge.

Philippines.

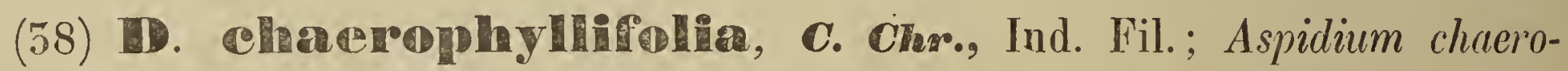
phyllacfolium, Zipp., Ann. Mus. Bot. L. B., I, 228.

Caudex oblique, clothed like the base of the stipes with large, ferrugineous scales. Stipes \pm 50 c.M. long. Fronds to \pm 45 c.M. long, ovate, acuminate. Pinnae subopposite, short-stalked, \pm 1 c.M. long, ovate-oblong, acuminate, the lower ones spreading. Pinnulae spreading, $\pm 5 \% \frac{1}{4}-4$ c.M. long, \pm 2 c.M. broad, approximate, the higher ones confluent, the lower ones short-stalked, ovate-lanceolate, the apex obtuse, serrate, the base truncate on the upper, subcordate on the lower side. Lobes not deep, with a distinct, sharp sinus, oblong, subtruncate, crenate or toothed. Texture thinly chartaceous; rachis yellowish or reddish, furnished with minute, reddish-brown, lanceolate or subulate, scattered scales; surfaces naked, the upper one opaque, the under one yellowish; main veins pinnate in the lobes with 5-4 pairs of simple veins. Sori medial on the lower veins.

Java; Aneitum.

(59) D. calulemta, O. Kt:e, C. Chr., Ind. Fil.; Aspidium edulentum, Kze, Bot. Zeit., 1846, 474; Nephrodium edulentum, Bk., Hk. Bk., Syn. Fil., 279.

Stipes stramineous. Fronds oblong, acute, 50 c.M. or more long and 
nearly as broad. Lower pinnae 10-15 c.M. long, more than 5 c.M. hroad, lanceolate-oblong, acuminate, erecto-patent. Pinnulae rather distant, spreading, connected at the base, oblong, obtuse, \pm 5 c.M. long, with oblong, obtuse, entire lobes. Texture thinly herbaceous; colour deep-green; under surface fibrillose on the main veins, the rest naked; veins 1 to each lobe. Sori close to the costae, 1-2 to a lobe; indusium thin, glabrous, persistent.

Java.

* (40) D. Maccidla, O. Ktae, C. Chr., Ind. Fil.; Aspidium flaccidum, Bl., Rac., Flor. Btz., I, 176; Nephrodium flaccidum, Hk., Hk. Bk., Syn. Fil., 274.

Rhizome erect, densely clothed with linear-lanceolate scales. Stipes tufted, 13 -50 c.M. or more long, slender, stramineous, slightly scaly below, naked or villose above. Fronds linear-lanceolate, slightly narrowed towards the base,, $\pm 50-43$ c.M. long, 13 - 20 c.M. broad. Pinnae sessile, linear-lanceolate, $21 / 2-4$ c.M. broad, cut down nearly to the rachis with a narrow, distinct, straight wing into linear-oblong lobes $\pm 5 \mathrm{~m}$.II. broad. Lobes lobed again $\pm 1 / 2$-way down or more to the costa. Ultimate segments entire, bluntish or acute, the edge \pm hairy. Lowest pinnae distant and often deflexed. Texture herbaceous; rachis and both surfaces villose, the under surface commonly copiously; veins forked, or subpinnate in the lower lobes. Sori about midway between the edge and the midribs.

Malacca, Java, Philippines; South. China, North. India, Ceylon.

(41a) D. Splendens, O. Kt:e, C. Chr., Ind. Fil.; Aspidium splendens, Christ, Farnkr. d. Erde, 259; Lastraea splendens, Bedd., Ferns Br.I., I, tab. XLII; Nephrodium splendens, Hk., Hk. Bk., Syn. Fil., 282,

Very large. Rhizome creeping (?). Stipes 60-100 c.Mi. long, stout, slightly scaly, polished, dark-brown or nearly black like the rachises. Fronds 90-120 c.M. long, $45-60$ c.M. broad. Lowest pimae stalked, to \pm 50 c.M. long, $\pm b-6$ c.ll. broad, numerous, elongate-lanceolate. Pinnulae numerous, unequal-sided, oblong, blunt, the lowest short-stalked, the base dilated and slightly auricled, the edge lobed, the lobes blunt, often toothed. Texture subcoriaceous; rachis naked like both surfaces; veins forked. Sori large, near the midribs; indusium coriaceous, brown.

Malacca; North. India, South. China.

(41b) D. phegopterdidea, C. Chr., Ind. Fil.; Iypodematium phegopteroideum, Kuhn, Forschr. Gaz., IV, Farne, 8. 
Stipes to 11 c.M. long, stramineous like the rachis, the base clothed with scaltered, cystopteroid, lanceolate, ferrugineous, acuminate scales to $5 \mathrm{~m} . \mathrm{M}$. long. Fronds 7-10 c.M. long, 6-7 c.M. broad, triangular-ovate, acuminate, 2-pinnatisect. Pinnae erecto-patent, petiolate, the lowest subopposite, triangular-ovate. Secondary segments oblong with a broad base, obtuse, entire or pinnatifid, the apex obscurely crenate. Texture membranaceous, thin; colour bright-green; both surfaces densely pilose; veins free, forked, reaching the sinuses of the crenations. Sori roundish, in 2 rows on the ultimate segments indusium membranaceous, pale-coloured, setose and ciliate; sporangia naked; spores globose or ovate, smooth.

Timor.

* (42) D. Missectr, O. It:e, C. Chr., Ind. Fil.; Aspidium dissectum, Christ, Ann. Btz., XV, 136; Lastraea dissecta, Carr., Bedd., Handb. Ind. Ferns, 260 ; L. membranifolia, Bedd., Ferns S.I., tab. CII ; Nephrodium dissectum, Desv., Hk. Bk., Syn. Fil., 282, p.p.; N. conjugaum, T. \& B., MS. in He, b. Bog.

Rhizome erect. Stipes to 50 c.M. long or longer, \pm scaly at the base. Fronds deltoid to ovate, $30-150$ c.M. long, $15-90$ c.M. broad, pinnate. Higher pinnae 15 - 25 c.M. long by $5^{1} / 2$ c.M. broad, pinnatifid $2 / 3$ towards the costa; lower pinnae pinnate, some of the lower basal pinnulae stalked, much elongated, deeply pinnatifid, and similar to some of the upper primary pinnae. Ultimate segments crenulate. Texture herbaceous; upper surface hairy with scale-like hairs, under one naked or also hairy; veins forked. Sori terminal on the anterior veinlets, forming a single row on each side near the margin; indusium reniform, naked. - Fertile portions of the fronds not rarely more or less contracted.

Malaya; Polynesia, Trop. Australia, North. India, Madagascar.

(43) D. Derparama, C. Chr., Ind. Fil.; Nephrodium dissitifolium, Bl., Kew Bull., 1899, 120.

Stipes naked, glossy, pale-brown. Fronds lanceolate-oblong, 5-pinnate 45-60 c.M. long. Pinnae lanceolate, the lowest largest, short-stalked, 10-15 c.M. long. Pinnulae ovate-oblong, sessile, obtuse, the base cuneate, pinnatifid or pinnate. Segments obtuse, erecto-patent. Texture subcoriaceous; rachis naked, slender, pale-brown; veins pinnate. Sori in 1 row on each side of the costae, not contiguous; indusium naked, fugacious.

New Guinea. 
* (44) D. Spren'se, O. It:e, C. Chr., Ind. Fil.; Aspidium sparsum, Spr., Rac., Flor. Btz., I, 175; Lastraea sparsa, Moore, Bedd., Ferns S.I., tab. CIII ; Nephrodium sparsum, Don, Hk. Bk., Syn. Fil., 276, p.p.; - var. Raapii.

Rhizome suberect; the scales dense, light-brown, entire, thin, oblong. Stipes $15-40$ c.M. long, \pm scaly. Fronds 50-60 c.M. long, $10-50$ c.M. broad, 5-4-pinnatifid at the base. Pinnae distant, short-stalked, $51 / 2-10$ c.M. broad, acuminate. Highest pinnae simple, oblong, blunt, obliquely cuneate at the base. Lowest pinnulae largest, short-stalked, blunt or acute, $1-2 X$ pinnalifid at the base, those on the lower side prolonged. Ultimate free segments obliquely cuneate at the base, the apex mostly blunt; ultimate lobes oblong, blunt, the margin toothed with few, distant, sharp, small teeth, the teeth not rarely solitary, on the anterior side of the larger lobes. Texture firm, membranaceous to papyraceous; rachis stramineous or brownish like the stipe, naked like both surfaces. Sori \pm near the costae, often 1 to each ittimate lobe.

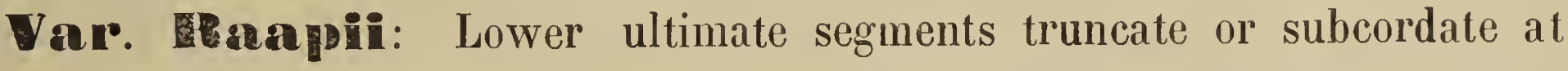
the base. Each lobe with a single, small tooth on the upper side, often nearly in the top of the sinus. $\left(^{*}\right)$.

Malaya; South. China, Norlh. India, Ceylon, Mauritius; - var. Raapii : Tioblong (Raap, No. 3).

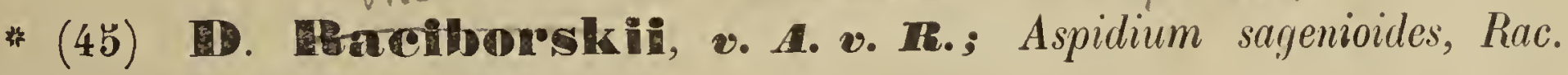
(not Melt.), Flor. Btz., I, 178.

Stipes long, clothed with lanceolate scales and gland-like hairs. Fronds deltoid-lanceolate, to 100 c.M. long, to 60 c.M. broad. Pinnae large, distinctly stalked, deltoid, the stalks to \pm 4 c.M. long. Pinnulae lanceolate or lanceolate-oblong, short-stalked, the lowest posterior ones the longest, the higher ones oblong, sessile, decurrent at the base, the highest ones united at the base by short, intermedial lobes, the longest to 18 c.M. long, to 8 c.M. broad, deeply pinnatifid or rarely subpinnate at the base. Tetriary segments to 4 c.M. long, $1-1 \frac{1}{2}$ c.M. broad, bluntish or acute, the smaller ones entire, the larger ones toothed or not deeply lobed. Texture herbaceous; rachises finely short-hairy; both surfaces sparingly fibrilloso-pilose; main veins (and veins forked or pinnate in the ultimate lobes; between each 2 lowest veins of conliguous groups is a free, simple, forked or pinnate vein which unites the midril, with the top of the sinus. Sori nearer the edge than the main veins.

Java.

$\left(^{\star}\right)$ See also purpurascens, $v$. A. v. R. 
* (46) D. recedens, O. Kt:e, G. Chr. Ind. Fil.; Lastraea recedens, J. Sm., Bedd., Ferns S.I., tah. XGVIII: Nephrodium recedens, Hk., Hk. Bk., Syn. Fil., 281.

Rhizome wide-creeping. Stipes about 30 c.M. long, erect, villose, clothed at the base with squarrose, linear scales. Fronds $45-60$ c.M. long, 50 c.M. or more hroad, deltoid. Lower pinnae much the largest, $7-15$ c.M. broad. Pinnulae of the lowest side the largest, often $12 \frac{1}{2}$ c.M. long, to 5 c.M. broad, with distinct, lanceolate segments. Segments decurrent, with close, entire or slightly toothed, acute, linear-oblong lobes. 'Texture firm; rachises villose; under surface naked or villose. Sori small, 6-8 round the edge of the larger lobes.

Java, Philippines; Ceylon, Soulh. India.

(47) ? D. Donmeensis, O. Ktze, C. Chr., Ind. Fil.; Lastraea borneensis, IIk., Icon. Pl., X, tab. XMIII; Nephrodium borneense, IIk., Hk. Bk., Syn. Fil., 275; Davallia borneensis, J. Sm., Mett., Ann. Mus. Bot. L. B., IV, 286.

Rhizome wide-creeping, stout, densely fibrillose. Stipes \pm 1 c..M. long, lirm, erect, brown, naked. Fronds 30-45 c.M. long, 10-15 c.M. broad, lancecolate. Pinnae $5-8$ c.M. long, $2-2{ }^{1}{ }_{2}$ c.M. broad, cut down to a broadly winged rachis into linear-oblong, deeply pinnatifid lobes. Texture subcoriaceous; rachis and veins beneath finely villose; veins about 6 on a side. Sori \pm midway on the veins; indusium coriaceous, persistent. - Habit of D. flaccida, 0 . Ktze, but different in texture and mode of growth, in which it approximates Davallia (Bk.).

Borneo.

(48) D. Willettin, C. Chr., Ind. Fil.; D. setosa, O. Ktze, Rev. Gen. Pl., II, 815; Nephrodium setosum, Bk., Hk. Bk., Syn. Fil., 274.

Stipes tufted, 10-15 c.M. long, densely clothed with fibrillose scales. Fronds 50-45 c.M. long, $15-25$ c.M. broad. Lowest pinnae largest, deltoid, 5-8 c.M. broad. Pinnulae lanceolate, $5 \frac{1}{2}-5$ c.M. long, cut down to the rachis below into erecto-patent, entire, linear segments. Texture herbaceous; rachises densely fibrillose; both surfaces naked; veins of the segments b-6 on a side, the lower ones forked. Sori in a line close to the costulae.

Java.

(49) D. Dadiangensis, C. Chr., Ind. Fil.; Lastraea padangensts, Bedd., Handb. Ind. Ferns, Suppl., 60. 
Rhizome erect. Stipes 20-25 c.M. long, furnished with long, hair-like scales as are the rachises, costae and costulae. Fronds $30-60$ c.M. long, narrowly deltoid-lanceolate. Lower pinnae largest, deltoid, with the lower pinnulae considerably elongated; upper pinnae $7 \frac{1}{2}-10$ c.M. long, pinnulae $1 \frac{1}{4}-2$ c.M. long, the lower ones cut down nearly to the costa into lanceolate, entire or slightly crenated lobes. Texture firm-herbaceous; surfaces sparingly covered with minute hairs; costulae of ultimate segments wavy; veins distant, simple or forked, not reaching the margin. Sori medial; indusium ?

\section{Malacca.}

* (弓0). D. vilis, o. Kt:e, C. Chr., Ind. Hil.; Aspidium vile, Kze, Rac., Flor. Btz., I, 173; Nephrodium vile, Bk., Hk. Bk., Syn. Fil., 499.

Rhizome suberect, densely clothed with rigid, pale, linear-lanceolate, ciliate scales. Stipes 10-4y c.M. long, clothed like the rachis with subulate; blackish, brownish or pale, spreading scales, which become shorter towards the apex of the frond. Fronds ovate-deltoid, 5-pimnatifid (rarely 2-pimmate), 25-60 c.M. long, 15 - -40 c.M. broad. Pinnae lanceolate-deltoid, short-stalked, lowest largest. Pinnulae oblong to lanceolate, lowest sessile or subsessile, to $5 \frac{1}{2}$ c.M. long, to 1 c.M. broad, deeply pimnatifid. Segments close, oblongdeltoid, the margin recurved and crenated. Texture coriaceous; under surface villose. Sori numerous, occupying nearly the whole under surface of the small lobes; iudusium minute, hairy.

Java.

* (b1) D. intermedia, o. Irtae, Rev. Gen. Pl., II, 815; ( ? D. rhodolepis, C. Chr., Ind. Fil.); Aspidium intermedium, Bl., Rac., Flor. Btz., I, 176.

Rhizome short-creeping, clothed with linear-lanceolate, pale-brown, entire scales. Stipes 3-15 c.M. long, furnished with broadly obovate, suddenly acuminated, blackish-brown, spreading scales. Fronds 2-5.pinnatipartite, obovate-lanceolate, $5-55$ c.M. long, 5-15 c.M. broad. Lower pinnae shortstalked, lanceolate or deltoid, unecrual-sided (the lower side produced), to 3 c.M. broad; higher pinnae sessile. Lobes $2-5 \mathrm{~m}$. M. broad, the lowest ones entire or pinnatipartite. Texture herbaceous; rachis scaly like the stipe; main veins naked or slightly scaly beneath; veins simple. Sori medial on the veins, $1-5$ on each side of the main veins (or costae). - See the information in Rac., Flor. Btz., I, 177.

Malaya. 
(52) D. Gara พvakerisi̊s, v. A. v. R.; D. rhodolepis, C. Chr., var., C. Chr., Ind. Fil.; Nephrodium sarawakense, Bli., Journ. of Linn. Soc., Bot., XXII, 225.

Caudex erect. Stipes lufted, \pm 15 c.M. long, clothed throughout with small, squarrose, rigid, dark-brown scales like the rachis. Fronds ovatelanceolate, nearly 30 c.M. long, 8-10 c.M. broad at the base, 5-pinnale. Lowest pinnae largest, deltoid, opposite, short-stalked, the lower side produced, the other ones alternate, sessile, oblong-lanceolate. Pinnulae multijugate, oblonglanceolate, the lower ones pinnate. Tertiary divisions $6-7$ m.M. long, $3-3 \frac{1}{2}$ m.M. broad, adnate, contiguous, entire, with the central rilss pinnate. Texture thin, obscurely pubescent on the rachises and main veins; veins erecto-patent, \pm 4 on a side, the lower ones forked. Sori small, fugacious.

Borneo.

* (55) D. Dorlvinali feroa, O. Kt:e, C. Chr., Ind. Fil.; Aspidium pulvinuliferum, Rac. (not Bedd.), Flor. Btz., I, 177; Lastraca pulvinulifera, Bedd., Ferns Br.I., II, tab. CCGXXXIII; Nephrodium pulvinuliferum, Bli., Hk. Bk., Syn. Fil., 500 .

Caudex erect, densely clothed, with linear-lanceolate, entire, yellowish or reddish-brown scales. Stipes $15-75$ c.M. long, stramineous to brownish, the base scaly like the rhizome, the rest scaly like the rachises. Fronds $30-90$ c.M. long, 20-40 c.M. broad, 5-4-pinnatifid, deltoid. Lowest pinnae largest, subdeltoid, stalked, \pm produced on the lower side. Pinnulae lanceolate, lower ones stalked, higher ones decurrent at the base. Ultimate lobes ligulate-oblong, the largest ones to $8 \mathrm{~m}$.M. long, $3 \frac{1}{2}$ - $5 \mathrm{~m}$.M. broad. Texture herbaceous or moderately firm; rachises scaly, the scales becoming shorter towards the apices of the fronds and segments, broad at the base and suddenly narrowed into a long, bristle-like, firm, spreading, dark-brown or blackish point; surfaces naked; veins pinnate in the lobes. Sori medial or subcostal, $3-5$ on each side of the costulae, terminal on short veinlets. - iesembling D. sparsa, 0 . $K t z e$, but the rachises scaly.

Java; Sikkim.

(54) D. Coicullata, C. Cher., Ind. Fil.; Nephrodium aciculahm, Bli., Journ. of Linn. Soc., Bot., XXII, 226.

Stipes 50-45 c.M. long, densely clothed throughout like the rachises with squarrose or spreading, subulate, brown scales. Fronds oblong-deltoid, 
\pm 60 c.M. long and \pm 50 c.M. broad, 5-pinnate. Lowest pinnae largest, deltoid, with the pinnulae on the lower side produced. Pinnulae multijugate, lanceolate, deeply pinnatifid, or pinnate at the base. Ultimate segments oblong, obtuse, entire, contiguous, $2-21 / 2$ c.M. long, $4-4 \frac{1}{2} \mathrm{~m} .1 \mathrm{l}$. broad. Texture morlerately firm; surfaces naked; central veins of the segnents pinnate, with 6-8 erecto-patent, obscure, hidden veins on each side. Sori small, many to a segment, subcostular; indusium small, membranaceous, fugacious.

Borneo.

* (55) D. Deryoma, C. Cher., Ind. Fil.; Aspidium Boryamun, Willd., Rac., Flor. Bı.z., I, 178; Lastraca Boryana, Moore, Bedd., Handb. Ind. Ferns, 266 ; L. divisa, Moore, Bedd., Ferns S.I., Lab. XCVII ; Nephrodium divisum, IIle., Copel., Polypod. Philipp., 26; N. Boryanum, Bk., Hk. Bk., Syn. Fil., 284.

Caudex \pm erect, clothed with thin, ovate-lanceolate scales. Stipes 60-100 c.M. long, stramineous or brownish, sometimes blackish, the hase winged or dilated, deciduously scaly. Fronds lanceolate to deltoid, $120-300$ c.M. long, 60-100 c.M. broad. Lower pinnae longest, $\pm 10-15$ c.M. broad, on stalks to 3 c.M long. Pinnulae lanceolate, sessile, cut down to a narrowly winged rachis into blunt, spreading, sharply toothed lobes $5-15 \mathrm{~m}$. M. long, 2-4 m.M. broad, which are sometimes lobed and toothed again. Texture herbaceous; rachis and surfaces naked; veins simple or forked. Sori in rows of 3 -4 near the midribs of the ultimate segments; indusium fugacious.

Malaya; Japan, South. China, North. India, Reunion.

* (56) D. pureunascens, v. H. v. R.; D. sparsa, O. Ktze., var., C. Chr., Ind. Fil.; Aspidium purpurascens, Bl., Rac., Flor. Btz., I, 174; Nephro-. dium purpurascens, Hk., Spec. Fil., IV, 152, p. p.

Rhizome erect, densely clothed with thin, entire, long, linear-lanceolate scales. Stipes tufted, to 100 c M. long, the base densely scaly, the rest slightly so. Fronds deltoid-ovate, acuminate, $60-120$ c.M. long, to 80 c.M. broad, 4-pinnatifid, or rarely 5 -pinnatifid at the base. Pinnae stalked, linear-oblong, the apex acuminate, inciso-serrate. Pinnulae spreading, oblong, acuminate, short-stalked, \pm 5-6 c.M. long, $\pm 2-5$ c.M. broad or broader at the base. Tertiary divisions trapezio-oblong, $\pm 5-\breve{b}$ m.M. broad or broader, the higher decurrent and confluent, the lower sessile, with the base obliquely subtruncate, pinnatifid especially in the lower half with oblong, blunt, enirie or slightly emarginate lobes, the superior basal one mostly larger than the others. Texture herbaceous to semicoriaceous; main rachis nearly naked, 
reddish- or blackish-hrown; surfaces naked; secondary rachises slightly scaly beneath: veins $4-6$ on each side. Sori \pm medial, mostly 1 to each lobe. Resembling D. sparsa. O. Kıze, but larger and more divided.

Malaya.

* (57) D. cremata, o. Ktze, C. Chr., Ind. Fil.; Aspidium crenalum, Kuhn, Christ, Farnkr. d. Erde, 262; Lastraea crenala, Bedd., Handb. Ind. Ferns, 258 ; L. eriocarpa, Pr., Bedd., Ferns S.I., tab. XCX; Nephrodium crenalum, Bl., Diels, in Engl. \& Prantl, Nat. Pfl.Fam., I ${ }^{4}, 175$; N. odoralum, Bli., Hk. Bk., Syn. Fil., 280; Polypodium crenatum, Forsk., (oldest name).

Rhizome erect, stout, short; the scales dense, bright-brown, lanceolatesubulate, \pm 5 c.M. long. Stipes tufted, 20 - 50 c.M. long, pale-coloured, glossy, the base scaly like the rhizome Fronds $20-40$ c.M. long, deltoid. Lowest pinnae much the longest, $\pm 10-25$ c.M. long, 5-10 c.M. broad. Pinnulae lancrolate, often imbricate. Tertiary divisions oblong, decurent, pinnatifid, the lobes rounded. T'exture herbaceous; colour pale-green; rachis and surfaces densely furnished with greyish hairs. Sori copious; indusium large, pale-grey, hairy.

Malacea, Philppines; Cape Verde Islames to China.

* (58) D. nhorlotepis, C. Chs"., Ind. Fil.; Aspidium inlermedium, Christ (not Bl.), Farnkr. d. Erde, 265; Lastrace Blumei, Moore, Bedd., Ferns S.I., tab. CGIL; Nephrodium Blumei, IIl., Spec. Fil., IV, 155, p.p.; $N$. inlermedium, Bk., Hk Bk., Syn. Fil., 285; N. rhodolcpis, Clarlic, Trans. Linn. Soc., Bot., 2d Series, I, tab. LXXII.

Stipes 50-60 c.M. long, stout, erect, densely clothed at the base with long, bright-brown, silky fibrils. Fronds 60-100 c.M. long, 50-5i) c.Mr. broad, subdeltoid. Lower pinnae lanceolate, often 50 c.M. long, $10-15$ c.M. broad. Pinnulae close, lanceolate, with distinct, oblong-lanceolate segments, with small, ligulate, subentire lobes to about $2^{1} / 2 \mathrm{~m}$. II. broad. Texture herbaceous, firm ; rachises slightly fibrillose like the stipe; under surface slightly hairy or scaly on the midribs. Sori small, copious, medial or nearer the midribs than the edge; indusium thin, fugacious.

Trop. Asia; China, Japan.

* (59) D. setigeng, o. Irtae, C. Chr., Ind. Fil.; Aspidium seligerun, Kuhn, Rac., Flor. Btz., I, 178; Lastraen tenericaulis, Moore, Bedd., Handb. Ind. Ferns, 266; Nephrodium lenericaule, IH/., Spec. Fil., IV, tab. CGLXIX; N. seligerum, Bk., Hk. Bk., Syn. Fil., 284; - var. pallida; Polypodium pallidum. Brack., Hk. Bk., l. c.; D. ornata, C. Chr., var., C. Chr., Ind. Fil. 
Rhizome erect or suberect. Stipes tufted or approximate, 25-60 c.II. long, often glaucous, scaly throughout or at the base only. Fronds deltoidlanceolate, 30-100 c.M. long. Lower pinnae largest, often 20-30 c.M. long, 10-15 c.II. broad, sessile or short-stalked, linear-lanceolate, with the rachis often narrowly winged above. Pinnulae close, ovate- to linear-lanceolate, $1 / 2-1 \frac{1}{2}$ c II. broad, cut down nearly or quite to the rachis into close, pinnatilid lobes $1 \frac{1}{2}-21 / 2 \quad$ m.M. broad. Texture herbaceous; main rachis hairy on the upper side; rachises and under surface finely villose, the hairs whitish, scattered. Sori minute, copious, $4-6$ on each side of the costulae; indusium fugacious.

Gar. Dallida: Indusium suppressed and undeveloper, visible only by ъ0-100 X magnifying power, soon hidden between the much larger capsules. Br. India across China and Japan, Polynesia and Trop. Australia.

* (60) D. zeylinicea, v. A. v. Te.; D. obtusiloba, O. Kize (not C. Chr.), Rev. Gen. Pl., II, 815; D. peranemiformis, C. Chr., var., C. Chr., Ind. Fil.; Aspridium olıusilobum, Pranll (not B/.), Christ, Ann. Btz., XV, 150; Lastraea ollusiluba, Bedd., Ferns Br.I., II, tab. CCXCVI; Nephrodium oblusilobum, Bl., Hk. Bk., Syn Fil., 284.

Stipes 30-60 c.M. long, firm, erect, densely clothed with large, ovate scales. Fronds $90-120$ c M. long, 4b-60 c.M. broad. Lower pinnae longest, to 15 c.M. broad. Pinnulae lanceolate; most of the segments of the lower pinnae distinct, ovate, oblong, cut down to the rachis into oblong-rhomboidal, \pm entire lobes, the largest to $3-6 \mathrm{~m}$. Mr. long, to $2 \frac{1}{2}-3 \mathrm{~m}$.M. broad. Texture herbaceous; rachises more $0 \mathrm{r}^{\circ}$ less scaly, the upper ones, and especially the under surface more or less glandular; lower veins of the lobes forked. Sori medial.

Celebes; Ceylon.

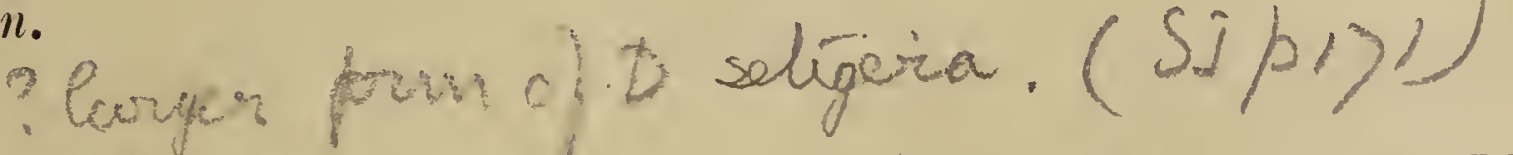

* (61) D. maltissedat, C. Chr., Ind. Fil.; Nephrodium mullisehum, Bk., Journ. of Linn. Soc., Bot., XXII, 226.

Stipes tufted, long, pale, densely clothed like the rachises with long, spreading $0 \mathrm{l}^{\circ}$ squarrose, rigid, subulate, castaneous bristles. Fronds deltoid, decompound, \pm 120 c.M. long. Lower pinnae oblong-lanceolate, $50-45$ c II. long, 10-15 c.M. broad. Pinnulae multijugate, lanceolate, 1-2 c.M. broad, the largest with 12-15 adnate, distinct, pinnatifid divisions on each side below the pimnatifid apex. Tertiary divisions linear-oblong, \pm 2 m.M. broad; the lobes small, deltoid. 'Texture herbaceous; veins forked in the largest 
lobes. Sori small, medial, $1-2$ to a final segment; indusium membranaceous, fugacious.

Borneo.

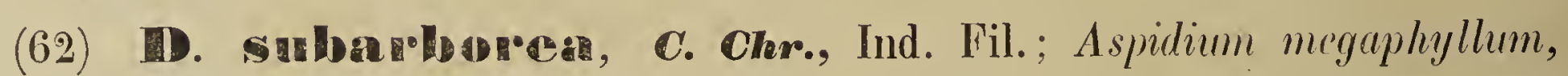
Chrisl, Bull. Herb. Boiss., VI, 194; A. Filix-Mas, Sw., var. megaphyllum, Christ, Ann. Btz., XV, 127; Polypodium subarboreum, Bl., Journ. of Linn. Soc., Bot., XXIV, 259; Nephrodium megaphyllum, Bk., I. c., XXII, 227; - var. Warburgii, Christ, in Warb, Mons., I, 81; Alsophila Warburgii, Christ, Ann. Biz, XV, 80, tab. XIIl, fig. 5, a-e.

An ennrmous fern. Stipes rough, clothed wilh adpressed, subulate, brown scales like the rachis. Fronds large, deltoid, 4-pinnate. Pinnae 4 b-75 c.II. long, \pm 15 c.M. broad, stalked, acuminate, oblong-lanceolate. Pinnulae ovateohlong, remote, sessile, alternate. Tertiary divisions oblong, \pm sessile, 2-5 c.ll. long, the rachis narrowly winged. Ultimate segments $\pm 4 \mathrm{~m}$.II. long, toothed. Texture herbaceous; surfaces furfuraceous. Sori single at the base of the ultimate lobes; indusium membranaceous, fugacious.

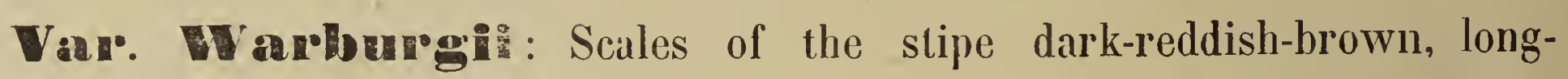
acuminate from a hroad base, the higher ones obliterate, mixed with rough, short prickles. Stipes brown, rachis furfuraceous, polished; secondary rachises densely clothed with reddish-hrown, ovate scales like the veins beneath.

Malaya; - var. Warburgii: Baljan, Celebes.

\section{\$ 2. NEPHRODIUM.}

1. Fronds simple or pinnale, the terminal pinna much excecding the lateral

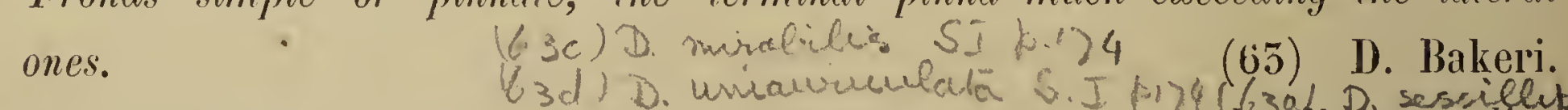

1.1. Fronds pinnale or 2-pinnalifid; lhe lerminal pinna not or hardly exceeding the largest lateral ones.

2. Rhizome wide-creeping $\left({ }^{1}\right)$.

3. Lower pinnae slighlly, if at all, reduced; the fronds occasionally with a single pair of dwarfed or reduced pinnac at the base $\left({ }^{2}\right)$.

1. Texhure \pm herbaceous.

5. Pinnae entire, or cut less than $1 / 2$-way down tho the costa.

(') See also parasitica, $0 . K l z e$.

${ }^{2}$ ) See also D. invisa, 0 . Klzc. 
6. Pinnae cntire or crenate.

6.6. Pinnae lobed.

\%. Sori 土.marginal.

\%. Sori nol marginal.
(64) D. lineata. (6ua) D distaria.

(65) D. pteroides.

(66) D. otaria.

5.5. Pinnac cul more than $1 / 2$-way down 10 the costa.

x. Rachis \pm scaly and hairy.

(67) D. alatella.

x.x. Rachis naked or \pm hairy, hul nol scaly.

$\beta$. Sori \pm terminal on the veins.

(48) D. extensa.

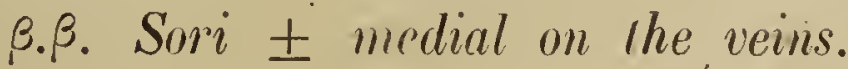

\%. Pinnae $\pm 1 \frac{1}{2}$ c.M. broad, cul down nearly to the costa.

(69) D. procurrens.

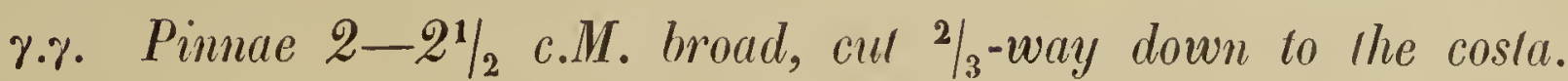

(70) D. longipes.

4. Texture \pm coriaceous.

(71) D gongylodes.

3.3. Lower pinnae conspicuously reduced or dwindling down into mere auricles.

p. Pinnae cut to $\pm 1 / 3$-way down 10 the costa.

q. Lower pinnae conspicuously dwarfed only. (*)

(72) I). invisa.

q.q. Lower pinnae reduced into mere auricles.

- Sori \pm medial on the veins; veins resinous benealh; lower pinnae \pm gradually reduced.

(75) D. arida.

r.x. Sori sublerminal on the veins; under surface glandular; lower pinnae suddenly reduced.

(74) D. cucullata.

p.p. Pinnae cut $1 / 3-1 / 2$-way down 10 the costa.

*. Fronds generally under 50 c.M. long. Under surface glandular.

(75) D. appendiculata.

*.*. Fully developed fronds more than 50 c.M. long.

+. Sori \pm terminal on the veins. Under surface pubescent.

(76) D. Haenkeana.

+.+. Sori \pm medial on the veins.

$\therefore \quad$ Stipes nalied. Under surface pilose on the ribs. (77) D. eminens.

... Slipes villose: Under surfuce glandular.

(78) D hirsuta.

p.p.p. Pinnac cul more than 1/2-way down to the costa. Surfaces nalicd.

(79) D. ochtodes.

2.2 Rhizome short-creeping or erect.

a. Pinnae cntire, crenate, loolhed or slighlly lobed.

( ${ }^{\star}$ See also under $\mathbf{3}$. 
6. Lower pinnae slightly, if at all, reduced, not dwindling down into mere auricles ( $\left.{ }^{1}\right)$; the fronds occasionally with a single pair of dwarfed or reduced pinnae at the base.

c. Fronds under 30 c.M. long. Under surface glandular and \pm hairy. $\quad$ (S0) D. pilosiuscula.

c.c. Fully developed fronds more than 30 c.M. long.

d. Fronds rather dimorphous; fertile pinnae distinctly narrower than the barren ones. Under surface short-hairy and glandular.

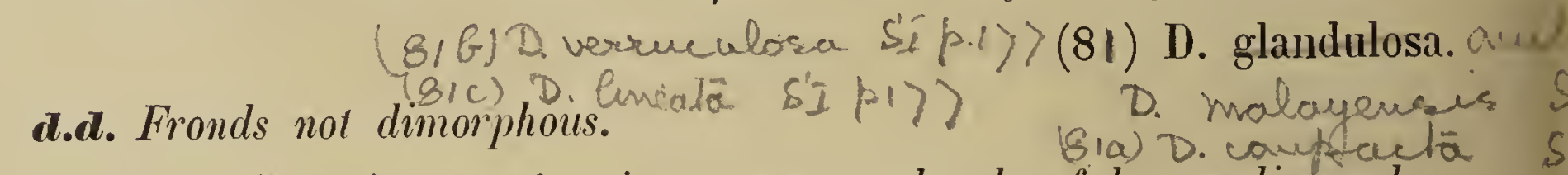

e. Sori contiguous, forming transverse bands of brown lines close
to the main veins.
(82) D. cyatheoides.

e.e. Sori not contiguous, rather distant from the main veins.

f. Veins 8-14 on each side of the main veins.

(836) D. poucijuga SI P I 88

(85) D. urophylla.

f.f. Veins 15-20 on-each side of the main veins.

(84) D. moulmeinensis.

b.3. Lower pinnae conspicuously reduced or dwindling down into mere auricles.

c'. Surfaces naked.

d'. Veins 3-5 on each side of the main veins.

(85a) D. Reener vaina

$\boldsymbol{d}^{\prime} \cdot \boldsymbol{d}$. Veins $6-8$ on each side of the main veins.

(85) D. latipinna.

$\boldsymbol{c}^{\prime} \cdot \boldsymbol{c}^{\prime}$. Under surface \pm hairy, at least on the veins.

\$. Lower pinnae suddenly reduced.

(87) D. megaphylla

\$.\$. Lower pinnae gradually reduced.

+. The 2-3 lower veins anastomosing.

*. Fronds $10-20$ c.M. broad.

*.*. Fronds 20-30 c.M. broad.

+.+. The 5-6 lower veins anastomosing.

(88) D. arbuscula.

(89) D. amboinensis

(9)) D. multilineata.

a.a. Pinnae cut from $1 / 4-2 / 3-$ way down to the costa.

b'. Texture \pm coriaccous.

c'. Lower pinnae slightly, if at all, reduced; the fronds occasionally with a single pair of dwarfed or reduced pinnae at the base $\left(^{2}\right)$.

d'. Stipe and rachis purveyed-with large, distant glands, those of the rachis placed on the under side at the base of the pinnae.

(91) D. callosa.

(') See also D. Iineata, C. Chr.

$\left(^{2}\right)$ See also D. crassifolia \& echinata, 0 . Ktze. 
22. DRyopteris. $\$ 2$. NePHRODIUM.

d'a'. Stipe and rachis without glands.

$\boldsymbol{e}^{\prime}$. Stipes naled.

$f^{\prime}$. Veins \pm 7 on each side of the main veins. (92) D. laevis.

$f^{\prime} \cdot f^{\prime}$. Veins 10-15 on each side of the main veins.

(93) D. brachyodus.

$\boldsymbol{e}^{\prime} \cdot \boldsymbol{e}^{\prime}$. Stipes hairy or bristly.

(94) D. felox.

$\boldsymbol{c}^{\prime} \cdot \boldsymbol{c}^{\prime}$. Lower pinnae conspicuously reduced or dwindling down into mere auricles.

\$. Sori submarginal.

(95) D. Loheriana.

\$.\$. Sori \pm medial.

*. Costae with a large gland at the base beneath.

(96) D. latebrosa.

*.*.Costae without gland at the base beneath.

+ Reduced pinnae few, distant. Surfaces rather naked.

*.+. Reduced pinnae numerous, close. Surfaces conspicuously hairy.

J). sagittifolia.

$\boldsymbol{b}^{\prime} \cdot \mathbf{b}$. Texture herbaceous to firm-papyraceous.

a. Lower pinnae hardly, if at all, reduced; the fronds occasionally with a single pair of dwarfed or reduced pinnae at the base.

$\beta$. Pinnae cut less than $\pm 1 / 2$-way down to the costa.

$\gamma$. Sori medial on the veins.

o. Surfaces nalied.

990)D. Easelares

ס.o. Surfaces hairy, at least on the ribs beneath.

$\varepsilon$. Lowest pinnae sharply deflexed.

(100) D. simillima.

$\varepsilon . \varepsilon$. Lowest pinnae not sharply deftexed.

* Lowest 1-2 pairs of veins anastomosing.

*. Pinnae cut ${ }_{14}^{1 /}-1 / 3$-way down to the costa. The 2 lower veins anastomosing. (101) I. pseudoreptans. *.*. Pinnae cul $\pm 1 / 2$-way down to the costa. Only the lowest veins anaslomosing. (102) D. parasitied.

$+\cdot+$ Lower $5-8$ pairs of veins anastomosing.

(103) 0. indica.

$\% \cdot \%$ Sori near the main veins. Upper surface \pm hairy, the under one \pm glandular.

(104) D. sakayensis.

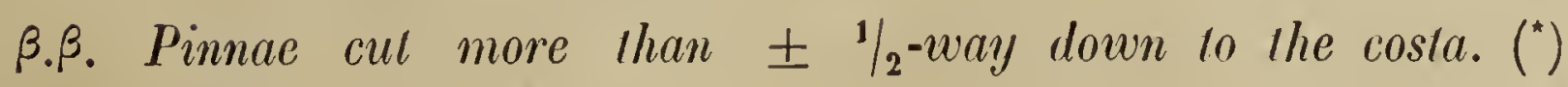

$\left({ }^{*}\right)$ See also D. parasitica, $0 . K t z e$. 
+. Sori submarginal, or terminal on the veins.

*. Pinnae \pm 6 c.M. long, cut $1 / 2-{ }^{2} / 3$-way down.

(105) D. Benoiliaua.

*.*. Pinnac $\pm 7 \frac{1}{2}-9$ c.M. long, cut ${ }_{13}^{2 / 2}$-way down or more.

(106). D. didymosora.

+ Sori medial, or lower on the veins.

(107) D. microchlamys.

a.a. Lower pimnae conspicuously reduced or dwindling down into mere auricles.

$\beta^{\prime} \quad$ Lower pinnae gradually reduced.

*. Stipe and rachis glaucous.

(108) D. glaucostipes.

*.*. Stipe and rachis not glaucous.

+. Fronds under 40 c.M. long.

(loge) D. psendo-arbuscula

(109) D. perakensis.

*.*. Fully developed fronds more than 100 (0.1\%). Pongerpelefora

$\beta^{\prime} . \beta^{\prime}$. Lower pinnae suddenly reduced.

(110) D. sumatrana.

(110a) D. anguelifies SI

$\gamma^{\prime}$. Pinnae cut less than $1 / 2$-way down to the costa $\left(^{*}\right)$

8'. The lowest veins anastomosing. Pinnae provided with a (11ic) D balacoum 5 . short, thick gland at the base beneath. (111) D. stipellata.

'ঠ' The 2-3 lower veins anastomosing. Pinnae without gland.

(112G) D. paphyucica. SI P186

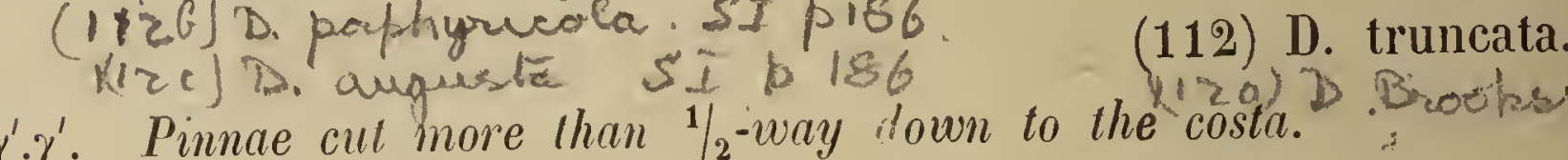

$\gamma^{\prime} \cdot \gamma^{\prime}$. Pinnae cul more than -way down to the costa. Brosksi Si

*. Veins 3-4 on each side of the costulae.

*.*. Veins 6-10 on each side of the costultie.

(115) D. hispidula.

(113a) D. heipradifolia

$\times$. Stipe and rachis hairy.

(114) D. heterocarpa.

$\times \cdot \times$. Stipe and rachis scaly.

(115) D. crinipes.

(63). D. Tratrent, Copet., Philipp. Journ., II, 405; D. canescens, C. Chr., var., C. Chr., Ind. Fil.; Aspidium canescens, Christ, Ann. Btz., XV, 150, p.p.; Nephrodium Balieri, Harr., Copel., Polypod. Philipp., 27; Hk., Icon. Pl., XVII, tab. MDCLXIV.

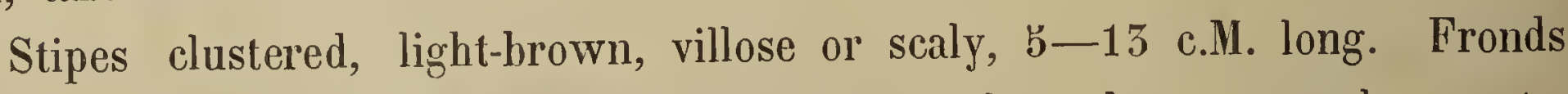
7-15 c.M. long, $1-21 / 2$ c.M. broad, oblong-oblanceolate, obtuse, coarsely crenate, the segments extending about $1 / 3$ the distance to the midrib, with usually 2-4 distant, oblong-ovate, sessile pinnae at the base, rather smaller than the

(*) See also D. abortiva 0. Ktze, \& megaphylla, C. Chr. 
lobes. Texture papyraceous; surfaces villose throughout. Veins usually $\pm 6-8$ on each side, of which $\pm 4-5$ unite with the opposite veins of adjacent lobes. Sori small, medial on the veins; indusium hairy, often absent.

Philippines.

*64) D. Iimeata, C. Chr., Ind. Fil.; Nephrodium linealum, Pr., Rac., Flor. Btz., I, 186; N. glandulosum, J. Sm., Hk. Bk., Syn. Fil., 291, p. p.; Aspidium lineatum, Bl., Enum., 144.

Rhizome creeping, bearing on regular distances groups of tufted or approximate fronds, the scales brown, narrow-lanceolate. Stipes $13-50$ c.M. long, those of the fertile fronds much elongated. Fronds $\pm 25-45$ c.M. long, lanceolate. Pinnae in $\pm 12-14$ pairs, the barren ones $5 \frac{1}{2}-7$ c.M. long, 1-2 c.M. broad, sessile, opposite or alternate, sometimes very close and overlapping, lanceolate, acute, erecto-patent, the base truncate, auricled on the upper side and sometimes on the lower side at the base, the margin entire or more $0 r^{\circ}$ less crenate particularly towards the apex, the lower pinnae not rarely deflexed; fertile pinnae shorter and generally contracted, distant. Texture firm-herbaceous; rachis strigose; surfaces nearly naked but verruculose; veins $5-5$ on each side, all anastomosing. Sori terminal on the veins, elongated, soon confluent and becoming meniscioid; indusium villose or glandular, at length deciduous.

Malaya.

* (65) ID. Dteroidos, o. Kt:e, C. Chr., Ind. Fil.; Nephrodium pleroides, J. Sm., Rac., Flor. Btz., I, 185 ; N.terminans, J. Sm., Bedd., Ferns S.I., tab. XC; Aspidium pteroides, Sw., Christ, Farnkr. d. Erde, 247.

Rhizome creeping, the scales narrow, lanceolate. Stipes distant, stramineous or greyish, 50-60 c.M. long, scaly at the base. Fronds 50-120 c.M. long, 20-40 c.II. broad, 'deltoid-oblong. Pinnae 6 to many on each side, spreading or erecto-patent, the lowest largest, short-stalked, $1-21 / 2$ c.M. broad, acumnate, the edges cut $1 / 3-1 / 2$-way down. Lobes oblong or subdeltoid, straight or subfalcate, to $\pm 7 \mathrm{~m}$.II. long, 4-弓 m.M. broad. Texture \pm herbaceous; rachis and both surfaces nearly naked except on the \pm villose costae and veins; main veins pinnate in the lobes with $5-12$ veins on each side, the 2 -3 lower veins anastomosing. Sori submarginal, nearly confined to the lobes. Malaya; China, Burmah, Queensland, Polynesia.

(66) D. otaria, O. It 2 e, C. Chr., Ind. Fil.; Nephrodium olaria, Bk., Hk. Bk., Syn. Fil., 288; N. aristalum, Hli., Spec. Fil., IV, tab. CCXXXVIII; Fllices. 
Pleocnemia aristata, Bedd., Ferns S.I., tab. LXXXIII; Aspidium otaria, Kze, Christ, Farnkr. d. Erde, 249.

Rhizome creeping. Stipes to 15 - 50 c.M. long, substramineous. Fronds 15 - 50 c.M. or more long, with a linear-oblong, terminal pinna $5-15$ c.M. long, 2-4 c.Yl. broad, the apex acuminate, the margin with finely serrated. lanceolate lobes $4-8$ m.M. long. Below this 5-6 distant, spreading, similar pinnae on each side, the lower ones stalked. Texture thinly herbaceous; rachis and both surfaces naked; main veins pinnate in the lobes; veins 4-8 on each side, with sometimes a sorus on each.

Philippines; Assam, South. India, Ceylon.

(67) D. Iatellat, C. Cher., Ind. Fil.; Nephrodium alalellum, Christ, Schum. \& Laul., Flor. deut. Sch. geb., 112; Aspidium alatellum, Christ, Bull. Herb. Boiss., $2^{\circ}$ Série, I, $454^{4}$

Rhizome not very wide-creeping. Stipes \pm 60 c.M. long, dark-yellow, smooth, clothed near the base with ovate, acuminate, broad, brown scales, the rest sparingly scaly and hairy like the rachis. Fronds $55-40$ c M. long, ovate-oblong, $\pm 1,5$ c.M. hroad, not narrowed towards the base. Pinnae erectopatent, $20-25$ on each side, sessile, not adnate, $10-25$ c.M. long, $\pm 11 / 2$ c.M. broad, linear-lanceolate, caudate-acuminate, the point nearly entire, the margin cut $2 / 3$-way down to the costa into numerous ( \pm 50 on each side), truncate, coarsely crenate lohes $\pm 5 \mathrm{~m}$.M. broad. Texture flaccido-herhaceous; costae and main veins naked ol slightly hairy: main veins pinnate in the lobes; veins simple, the lower ones anastomosing. Sori medial on the veins; indusium rudimentary, thin, fugacious, not rarely wanting.

New Guinea.

(68) D. extensm, O. Wter, C. Chr., Ind. Fil.; Nephrodium extensum, Noore (not IIk.), Hk. Bk., Syn. Fil., 289; N. punctanum, Bedd., Ferns Br.I., I, tab. CXXXI; Aspidium extensum, Bl., Christ, Farnkr. d. Erde, 247; A. conioneuron, Fice, Mett., Farng., IV, Phegop. \& Aspid., No. 245.

Rhizome creeping. Stipes 50-60 c.M. long, naked or slightly puhescent. Fronds $45-120$ c.M. long, $20-30$ c.M. hroad. Pinnae $1-2$ c M. broad, cut down $\pm 2 / 3$ on the way to the costa into linear-oblong, falcate or straight, slightly crenulate lobes: lower pinnae scarcely shorter than the others. Texture papyraceo-herbaceous; rachis nearly naked; upper surface naked or with a few distant hairs; under surface hairy, and glandular with minute glands between or on the veins; main veins pinnate in the lobes; veins $6-12$ on 
each side, often only the lowest united. Sori nearly terminal on the veins, present on all the veins, or on all except the 1-2 lower ones, not rarely immersed and visible as punctiform dots on the upper surface.

Malaya; Ceylon, South. India, Burmah.

(69) W. Drocturens, O. Ktae, C. Chr., Ind. Fil.; Nephrodium procurrens, Bk., Hk. Bk., Syn. Fil., 290; Aspidium procurrens, Mett., Ann. Hus. Bot. L. B., I, 251.

Rhizome wide-creeping, clothed sparingly with deciduous, linear scales. Stipes approximate, up to $4 \breve{b}-60$ c.M. long, slightly and deciduously scaly towards the base. Fronds deltoid to deltoid-lanceolate, 45 c.M. or more long, nearly 30 c.M. broad; rachis more or less hairy or nearly glabrous. Pinnae $12-50$ on each side, patent, the lowest sometimes a little smaller and deflexed, narrow-linear, acuminate, $\pm 1 / 2$ c.M. broad, cut down nearly to the costa into narrow, oblong, entire lobes, the lowest of which often suddenly reduced in size. Texture papyraceo-membranaceous, more or less hairy or nearly glabrous, often furnished beneath with golden pubescence in the way of close, pressed hairs or oblong dots more on the paranchyma than on the veins; veins in 6-12 pairs, all simple, the lowest pair only anastomosing. Sori medial on the veins; indusium naked or hairy. - Very like D. parasitica, 0. Kt:se, (Bk.).

Java, Borneo, Celebes; North. India.

* (70) D. Ionginges, D. Irtee, C. Chr., Ind. Fil.; Nephrodium longipes, Moore, Rac., Flor. Btz., I, 182; Aspidium longipes, Bl., Christ, Ann. Btz., XV. 133.

Rhizome creeping, the extremity clothed with few, small scales. Stipes 1-8 c.M. apart, 80-120 c.M. long, livid, naked, glossy. Fronds linearlanceolate, to 100 c.M. long, 20-45 c.M. broad. Pinnae numerous (20-35 on each side), $2-21 / 2$ c.M. broad, sessile, slightly narrowed towards the base, linear-lanceolate, acuminate, the edge cut down $2 / 3$ of the way to the costa into oblique, oblong, bluntish or acute lobes. Lobes straight or subfalcate, 10-14 m.M. long, \pm 4 m.M. broad, with a distinct sinus between them. Texture herbaceous; the edges and both surfaces more or less hairy on the costae and veins; veins $8-16$ on a side, often only the lowest ones anastomosing. Sori $\pm 6-9$ on each side of the main veins, medial, not occupying the higher veins.

Java, Celebes. 
* (71) D. gongylodes, o. Hee, C. Chr., Ind. Fil.: Nephrodium unilum, R. Br., Rac., Flor. Biz., I, 182; N. gongylodes, Scholl, Gen. Fil., tab. X; Aspidium unitum, Mell. (not Sw.), Christ, Farnkr. d. Erde, 246; A. gongylodes (goggilodes), Schk., (oldest name); - var. propinqua; N. propinquum, R. Br., Hk., Spec. Fil., IV, 79; Bedd., Ferns S.I., tab. LXXXIX.

Rhizome wide-creeping, the extremity clothed with ovatedeltoid scales. Stipes $20-50$ c M. long, brownish, naked. Fronds 50-60 c.M. or more long $\pm 10-20$ c.M. broad. Pinnae numerous, erecto-patent, $5-121 / 2$ c.M. long, $\pm 1 / 2-11 / 2$ c.ll broad, the edges cut $1 / 4-1 / 2$-way down into \pm erecto-patent, triangular, acute, entire or toothed lobes; lower pinnae not or a little smaller than the others. Texture cnriaceous; veins $\breve{b-8}$ on each side of the main veins, the 1-2 lowest ones anastomosing; rachis and surfaces naked. Sori nearly terminal on the veins, at length confluent and forming a zigzag line along the margin; indusium small.

War. propoinctua: Rachis and under surface hairy.

Pantropical.

* (72) D. Invisa, O. Ftae, C. Chr., Ind. Fil.; Nephrodum invisum, Carr., Hk. Bk., Syn. Fil., 290; Aspidium dissectum, Mell., Ann. Ilus. Bot. L. B., I, 252; A. invisum, Chrisl, Engl. Jahrb., XXIII, 550.

Rhizome stout, creeping. Stipes $25-50$ c.M. long or longer, stout, brownish, villose. Fronds 40-60 c.I. long, $\pm 20-50$ c.II. broad. Pinnae numerous, $\pm 1-1 \frac{1}{2}$ c.N. broad, cut $\pm 1 / 3$-way down to the costa into sharp, triangular, \pm falcate lobes; lower pinnae dwarfed, distant. Texture rather coriaceous; rachis and under surface villose, upper surface \pm short-pubescent; main veins pimnate in the lobes; veins $6-8$ on each side. Sori in 1 row on each - side, \pm close to the midribs or more numerous and then in pairs close to the intermedial veins: sporangia setose. - Fronds with the aspect of D. cucullata, Christ, but the lower pinnae conspicuously dwarfed only, not reduced into mere auricles.

Philippines, New Guinea; Polynesia.

* (73) D. an aida, O. Ktze, C. Chr., Ind. Fil.; Nephrodium obscurum, Moore, Rac., Flor. Btz., I, 183; N. aridum, J. Sm. (not Bk.), Hk., Bk., Syn. Fil., 291: Bedd., Ferns Br.I., II, tab. CGXCVII; Aspidium aridum, Don, (oldest name), Christ, Farnkr. d. Erde, 247.

Rhizome creeping. Stipes 13 -50 c.M. long or longer, erect, naked or pubescent. Fronds $40-120$ c.M. long, $20-45$ c.M. broad, deltoid-lanceolate. 
Pinnae $\pm 1-2 \frac{1}{2}$ c.ll. broad, linear, the base \pm truncate, the edges cut \pm $1 / 4-1 / 3$-way down to the costa, the apex acuminate. Lobes numerous, subtriangular, \pm acute, slightly recurved at the edge. Lower pinnae more or less gradually reduced into mere auricles. Texture firm; rachis naked or pubessent; surfaces pubescent or pilose on the costae and veins; veins \pm $8-11$ on each side of the main veins, resinous beneath, the secretions minute, oblong, brown or semetimes yellow, pellucid, the $5-6$ lower veins anastomosing. Sori small, \pm medial on the veins; indusium slightly hairy, \pm fugacious; sporangia naked.

Malaya; North. India.

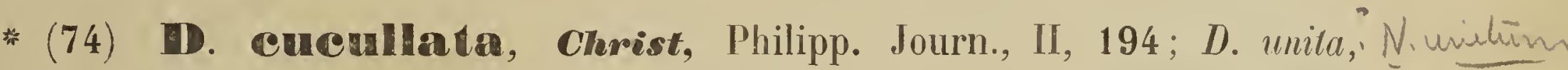
0. Ktze, C. Chr., Ind. Fil.; Nephrodium cucullatum, Bk., Rac., Flor. Btz., I, , :N, 184; N. unilum, Bory, Bél., Voy. Bot., II, 61; Bedd., Ferns S.I., tah. LXXXVIII; Aspidium cucullalum, Bl., Christ, Farnkr. d. Erde, 247; A.unitum, Sicb., Nelt., Farng., IV, Phegop. \& Aspid., No. 257.

\section{N uncullation BC}

Rhizome creeping. Stipes distant, 10-53 c M. long, strong, erect, brownish, more or less villose like the rachis, scaly at the base. Fronds ovatelanceolate, $55-80$ c.M. long, $18-50$ c.M. broad. Pinnae rather close, \pm 1-2 c.M. broad, linear, erecto-patent, the base \pm truncale, the edges cut $\pm{ }_{1}$ - -way down to the costa, the apex acuminate. Lobes triangular or oblong, bluntish or caute, subfalcate, the margin slightly recurved. Lower pinnae dwindling down suddenly into mere auricles. Texture coriaceous; costae hairy; under surface hairy on the veins, glandular between or on the veins, the glands minute, glohose, brown or more commonly yellow or pale-yellow, impellucid: veins $7-10$ on each side of the main veins, the 5-5 lower ones anastomosing. Sori subterminal on the veins; indusium naked.

Malaya; Polynesia, Ceylon, South. India, Mascarenes, Seychelles.

* (75) D. appendicalada, C. Cher., Ind. Fil.; Nephrodium appendiculanm, Rac., Flor. Btz., I, 186: Gymnogramme appendiculala, Bl., Flor. Jav., II, tab. XXXIX.

Rhizome creeping, clothed at the extremity with narrow, lanceolate, ciliated scales. Stipes $15--18$ c.M. long, densely villose. Fronds oblong-lanceolate, 20 -40 c.M. long, $10-16$ c.M. broad. Pinnae linear-lanceolate, sessile, to 15 m.ll. broad, commonly cut $\pm 1 / 2$-way down into entire, oblong, subfalcate, bluntish or acute lobes $10 \pm 5 \mathrm{~m} . \mathrm{II}$. long and $5^{1 / 2} \mathrm{~m} . \mathrm{M}$. hroad. The lower, not-reduced pimae deflexed, the reduced ones \pm 2 c II. ipart,

avideci 0,31 . (1) or gente cre heare $c$ 
22. DRYOPTERIS. \$2. NEPHRODIUM.

occupying nearly the whole stipe. Texture subcoriaceous; under surface slightly villose on the veins and covered with globose glands, upper one clothed with adpressed hairs, the edges hairy; veins $\breve{b}-9$ on a side, the lowest ones only anastomosing. Sori $5-6$ on a side, medial on the veins; indusium hairy, fugacious; capsules hairy.

Java.

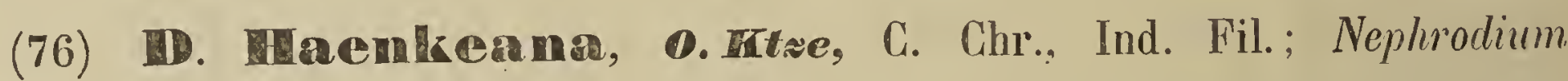
Haenlieanum, Pr., Hk. Bk., Syn. Fil., 290; N. multilinealum, Pr., Tent. Pterid., 81.

Rhizome creeping. Stipes scattered, 30-60 c.M. long, strong, erect, slightly pubescent. Fronds 90-120 c.H. long, 30-40 c.H. broad. Pinnae \pm 2 c.M. broad, cut $1 / 3-1 / 2$-way down to the costa into acute, subfalcate lobes. Texture subcoriaceous; rachis and under surface finely pubescent; veins $10-12$ on a side. Sori subterminal on the veins; indusium very fugacious.

Malaya; Polynesia.

(77) E. emninems, C. Chr., Ind. Fil.; Nephrodium eminens, Bli. Journ. of Bot., XVIII, 213.

Rhizome creeping. Stipes stout, naked, \pm 120 c.M. long or longer, the, upper half occupied by the much reduced pinnise. Fronds 2-pinnatifid, 75-90 c.M. long in the normal portion, half as broad. Normal pinnae distinctly stalked, the central ones lanceolate, $15-50$ c.M. long, $\pm 2 \%$ c.II. broad, cut $\pm 1 / 2$-way down to the costa into oblong, obtuse, contiguous.

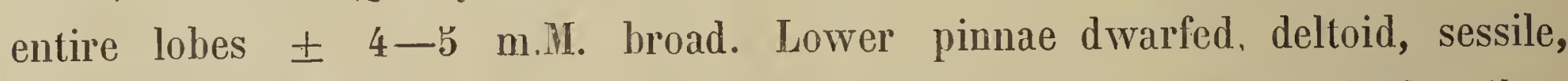
the lowest changed into glands. Texture subcoriaceous; surfaces finely pilose on the ribs; veins distinct, 10-12-jugate, several lower ones anastomosing. Sori small, medial; indusium minute, fugacious.

Sumatra, Malacca.

(78) D. Hionesunta, O. Irae, Rev. Gen. Pl., II, 815; D. adenophora, C. Chr., Ind. Fil.; Nephrodium hirsulum, J. Sm., Hk. Bk., Syn. Wil., 291 ; Hk., Spec. Fil., IV, tab. CCXL, B; Aspidium hirsulum, Kze (not Melı.), Christ, Ann. Btz., XV, 154.

Rhizome creeping. Stipes 30 c.M. long or longer, grey, villose. Fronds 90-120 c.i. long, \pm 4 c.M. broad. Pinnae very close and numerous, spreading or more or less erecto-patent, the largest $\pm 2 b$ c.M. long, \pm 2 c.M. broad, cut 
down $1 / 2$-way to the costa into very numerous, entire, limear-oblong, subfalcate lobes. Lower pinnae with a distinct gland beneath at the base. Texture subcoriaceous; rachis densely clothed with soft, spreading hairs; under surface glandular; veins $6-8$ on a side, generally the 5 lower anastomosing. Sori medial on the veins.

Celebes, Philippines.

(79) D. Delntates, C. Cher., Ind. Fil.; Nephrodium mulijugum, Bli., Hk. Bk., Syn. Fil., 291; N. ochtodes, Hk., Spec. Fil., IV, 109; Aspidium multijugum, Christ (not Wall.), Ann. Btz., XV, 155; A. ochtodes, Kze, (oldest name).

Rhizome creeping. Stipes 30-60 c.H. long, subglabrous, strong, erect. Fronds $90-120$ c.M. long, 50-45 c.M. hroad. Pinnae $\pm 2-21 / 2$ c.M. broad, cut down $\pm 2 / 3$ of the way to the costa into close, acute, subfalcate lobes $21 / 2-51 / 2$ m.M. broad. Texture subcoriaceous; rachis and both surfaces \pm naked; veins $10-12$ on a side. Sori nearer the main veins than the edge. Malacca, New Guinea, Celebes; Japan, South. China, Br. India.

* (80) D. poilosionseuna, C. Cher., Ind. Fil.; Nephrodium pilosiusculum, Zipp., Rac., Flor. Btz., I, 189.

Rhizome short-creeping or suberect, the extremity clothed with lanceolate, cilate scales. Stipes approximate, $12-28$ c.M. long, densely pubescent above, polished helow. Fronds ovate-lanceolate, long-acuminate, 1 b-20 c.M. long, 4-7 c.M. broad. Pinnae close, lanceolate, erecto-patent or falcate, sessile, the base truncate, the edge slightly crenate, the apex blunt, the lower base rounded, the upper slighlly auricled. Texture semicoriaceous; rachis pubescent; upper surface densely clothed with adpressed hairs, under one covered with numerous, globose glands, hairy on the veins; veins $4-5$ on a side, the 2 lower ones commonly anastomosing. Sori $2-5$ on a side; indusium fugacious, densely villose.

Java.

\section{owil = D malousensis C. Cin}

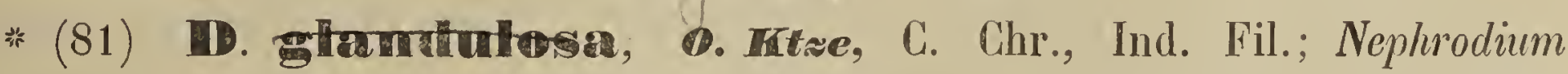
glandulosum, Moore (not Sm.), Rac., Flor. Btz., 1, 185; Hk. Bk., Syn. Fil., 291, p.p.; Aspidium glandulosum, Bl., Christ, Farnkr. d. Erde, 24 b̆.

Rhizome short-creeping or erect, slightly clothed with lanceolate, shortciliated hairs. Stipes \pm tufted, 10-60 c.M. long, naked or pubescent, scaly at the base. Fronds 50 c.M. or more long, 10-15 c.Mr. broad or rarely broader, with $\pm 2-10$ pairs of spreading pinnae on each side below the 
terminal one. Pinnae sessile or short-stalked, more or less close or the largest ones distant, the barren ones the largest, $1 \frac{1}{2}-5$ c.M. broad, the apex acute or short-acuminate, the margin entire or slightly lobed, the base \pm truncate, not rarely $上$ auricled above; fertile pinnae generally considerably contracted, but sometimes the larger uncontracted pinnae soriferous. 'Texture papyraceo-herbaceous; surfaces \pm short-hairy, the under one glandular with numerous, dol-like, yellowish glands; veins to 12 pairs in the larger pinnae, 4-8 in the narrower ones, nearly all anastomosing except the highest ones. Sori medial on the veins, eventually elongating, meeting, and covering the whole of the veins so as to become meniscioid; indusium fugacious, ciliate. Malaya.

* (82) D. cyadhedides, O. Kt:e, C. Chr., Ind. Fil.; Nephrodium cyatheoides, Pr. (not Klf.), Hk. Bk., Syn. Fil., 295 ; Hk., Spec. Fil., IV, tab. CCXLI, A; Aspidium cyatheoides, Klf., Enum. Fil., 254.

Rhizome erect or suberect. Stipes 30-60 c.M. long, strong, naked, glossy, greyish. Fronds $60-90$ c.M. long, 50-60 c.Nl. broad. Pinnae \pm close, spreading or \pm oblique, 2-4 c.M. broad, the apex acuminate, the edge irregular, furnished with acute, forward pointing teeth or loles to a depth 2-y m.M., the lowest pimnae not shorter than the next. Texture papyraceous, herbaceous or subcoriaceous; rachis and both surfaces naked; main veins pinnate wilh $10-12$ veins on a side. Sori contiguous, close to the main veins, the lower ones close to the costae.

Sumatra, New Guinea; Hawaii.

* D. Inoplnylla, C. Chex., Ind. Fil.; Nephrodium urophyllum, Keys.h urof (not Bedd.), Rac., Flor. Btz., I, 184; N. linealum, Bedd., Ferns Br.I., I. tab.J.FM.S CXXXIII; Aspidium urophyllum, Christ (not Bedd.), Farnkr. d. Erde, 248; thv Polypodium wrophyllum, Wall., Hk. Bk., Syn. Fil., 314; - var. Pinwillei, p 13 Bedd., Handb. Ind. Ferns, Suppl., 72.

Rhizome short-creeping or erect, clothed with small, ovate-lanceolate scales at the extremity. Stipes approximate, 2)-60 c.M. long, naked or shorthairy, stout, erect. Fronds \pm 4 b̆-120 c.ll. long, $25-45$ c.M. hroad, with a terminal pinna and below this 2-7 lateral ones on each side. Pinnae 2-5 c.M. broad or broader, sessile or short-stalked, the base truncate or narrowed, the edge entire, crenate, serrate or sharply toothed, the apex acuminate. Texture thinly coriaceous; rachis and both surfaces naked or nearly so, surfaces verruculose; veins conspicuous, $\pm 8-14$ on each side of the main 
ones, nearly all anastomosing. Sori medial on the veins; indusium fugacious or undeveloped.

Var. Pindover: Pinnae very broad in the middle, considerably attenuated at both enls, often long-caudate at the apex.

Malaya; North. India, South. China, Trop. Australin, Polynesia; - var. Pinwillei: Malacca.

* (84) D. Mnoulaneinensis, C. Cher., Ind. Fil; Nephrodium moulmeinense, Bedil.; Handb. Ind. Ferns, 275 ; Polypodium mullilineatum, Wall., Hk. Bk., Syn. Fil., 516; Aspidium mulilineanum, Christ, Farnkr. d. Erde, 249 ; A. moulmeinense, Christ, Ann. Btz., XIX, 59; Goniopteris lineala, Bedd., Ferns Br.I., I, tab. III; G. mullilineata, Berld., 1. c., II, tab. CGXXXI.

Rhizome short-creeping. Stipes erect, 60-120 c.M. long, naked. Fronds 60-120 c.M. long, 40-60 c.M. broal. Pinnae broadly linear, usually more than 6 on each side, $20-40$ c.M. long, $\pm 3-4 \%$ c.M. broad, the apex acuminale to subeaudate, the edges subparallel, entire, crenate or with sharp, falcate teeth reaching about $2-5 \mathrm{~m} . \mathrm{K}$. deep, the base broadly cuneate or subtruncate. Texture coriaceous or subcoriaceous: rachis and surfaces naked or nearly so, \pm verruculose; veins prominent, $\pm 15-20$ on each side of the main veins, nearly all anastomosing. Sori medial on the veins; indusium fugacious.

Celebes, Philippines; Fiji, China, Br. India.

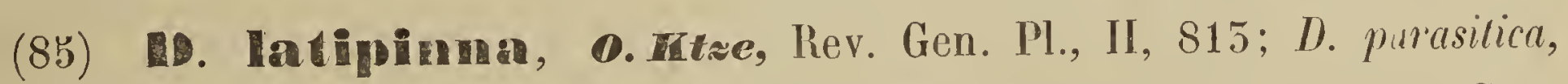
0. Ktze, var., C. Chr., Ind. Fil.; Nephrodium latipinna, Ml., Hk. Bk., Syn. Fil., 292; Aspidium latipmna, Hance, Journ. of Linn. Soc., Bot., XIII, 141.

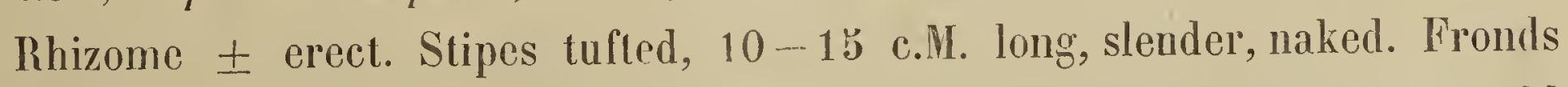
20-50 c.M. long, 7-15 c.M. broad, the upper $1 / 2$ or $1 / 3$ lanceolate, pinnatifid with broad, oblong lobes. Below this several pinnae on each side, the largest 5-7 c.M. long, 1-2 c.M. broad, cut to $\pm 1 / 4$ of the way down into broad, oblong. subfalcate lobes. Lower pinnae much reduced and distant. Texture papyraceo-herbaceous; rachis and hoth surfaces naked; main veins pinnate in the lobes with 5-5 distant veins on each side. Sori medial on the veins. Hardly different from D. parasitica, 0. Klze.

Java, Philippines; Hongliong.

(86). D. abordiva, o. Kt:e, C. Chr., Ind. Fil.; Nephrodinm abortivum, J. Sm., Hk. Bk., Syn. Fil., 292; N. pemigumum, Moore, Bedd., Handl). 
Ind. Ferns, 277, p. p.; Aspidium aborlivum, Bl., Enum., 154; - var. puberula \& tomentosa; var. $B \& C$, Bl., 1. c.

Rhizome \pm erect. Stipes tufted, $15-50$ c.M. long, firm, erect, naked. Fronds $30-60$ c.M. long or longer, $15-50$ c.M. hroad. Central pinnae 7-15 c M. long, $1 \frac{1}{2}-2$ c.Y. broad, acuminate, cut to $\pm 1 / 3$ of the way down into close, truncate lobes; lobes oblong, entire, or crenulate at the apex, the lower ones sub-abbreviate, $\pm 1 / 4-1 / 3$ c.M. broad. Lower pinnae distant, reduced suddenly into mere auricles. Texture firm-herbaceous; rachis naked, or puberous on the upper side; costae puberous above; veins $\pm 6-8$ on each side of the main veins. Sori medial.

Var. paberoulde Pinnae long-acuminate. Rachis puberulous throughout.

War. Tomentosen: Pinnae short and narrow. Rachis tomentose and sparingly paleaceous above.

Malaya.

* (87) Degandillan, C. Cher., Ind Fil.; Nephrodum pennigerum, Moore (not Hk.), Rac., Flor. Btz., I, 190; N. abruptum, Bedd., Ferns S.I., tab. LXXXVI; Aspidium pennigerum, Bl., Christ, Farnkr. d. Erde, 248; A. megaphyllum, Mell., (oldest name), Ann. Mus. Bot. L. B., I, 253.

Rhizome short-creeping or suberect, clothed with firm, blackish-brown, lanceolate, entire scales. Stipes approximate, stout, $15-100$ c.M. long, finely or minutely villose, scaly at the base. Fronds 50-120 c.M. long, 20-60 c.M. broad, linear-lanceolate or oblong. Pinnae numerous, oblique, $1-4$ c.M. broad, the apex acuminate, the edge cut $1 / 6-1 / 4$ or rarely to $1 / 3$ of the way down to the midrib into oblong, falcate lobes, the base broadly cuneate; lower pinnae suddenly dwarfed, dislant, occupying \pm the upper $1 / 2-2 / 3$ of the stipe. Texture herbaceous to papyraceous; rachis and under, surface villose, or the under surface slightly hairy on the costae and veins only; veins $6-10$ on each side, the $5-4$ lower anastomosing. Sori medial on the veins, s-7 to a row; sporangia often setose.

Malaya; North. India, Ceylon, Comores, South. Africa.

* (88) D. andousender, O. Hetee, C. Chr., Ind. Fil.; Nophrodium Arbuscula, Desv., Rac., Flor. Btz., I, 189; Bedd., Ferns S.I., tab. LXXXVII ; Aspidium Hookeri, Wall., Hk., Icon. Pl., X, tab. CMXXII; A. Arbuscula, Willd., Christ, Farnkr. d. Erde, 249.

Rhizome short-creeping or erect, clothed with narrow, lanceolate scales. 
Stipes approximate or tufted, 10-25 c.M. long, naked or slightly pubescent. Fronds lanceolate, narrowing towards both extremities, $30-65$ c.ll. long, 10-- 20 c.M. broud. Pinnae often close and numerous, linear-lanceolate, acuminate, the base truncate, slightly cordate or broadly cuncate, the edge cut down $1 / 4$ or less into blunt lobes; 2-10 lower pairs distant, gradually reduced. Texture herbaceous; rachis pubescent or naked; under surface short-hairy; veins pubescent above and beneath, $5-6$ on a side, the $2-5$ lower ones commonly anastumosing. Sori inedial or terminal, on the veins, forming close rows; indusium often naked, persistent.

Malaya - Polynesia; Br. India, Mascarenes.

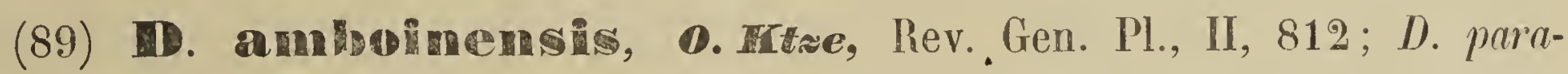
sitica, 0. Ktze, var., G. Chr. Ind. Fil.; Nephrodium amboinense, Pr., Hk. Bk., Syn. Fil., 292; N. molle, R. Br., var. amboinense, Bedd., Handb. Ind. Ferns, 278; N. extensum, Moore, var. minor, Bedd., Ferns Br.I., II, tab. CGI.

Rhizome short-creeping or erect. Stipes tufted, to 20 c.M. long, greyish, nearly naked. Fronds 60 c.M. or more long, 20-30 c.M. broad. Pinnac spreading, 7-25, alternate or opposite, the longest $1-2$ c.M. broad, sometimes caudate, the edge entire, slightly crenate or shallowly lobed, the lobes blunt; lower pinnae gradually reducel into mere auricles, often sagittate or butterfly-shaped, rather distant, the normal ones rather clove. Texture thinly lierbaceous to papyraceous; rachis and under surface slightly pubescent; veins 4-6 rarely $7-8$ on a side, the $2-3$ lower pairs anastomosing. Sori medial on the 1-5 lower veins, the lowest often close to the midribs.

Malaya; Br. India.

(90) H. Hnullimimeats, D. Hoe, Rev. Gen. Pl., II, 811; (? D. megaphylla, C. Chr., Ind. Fil.); Nephrodium mulitinealum, Bedd., Handb. Ind. Ferns, Suppl., 80.

Rhizome erect. Stipes furnished with a few lanceolate scales at the base. Fronds 90 c.M. or more long, \pm 4 c.M. broad, pinnate, gradually dwindling down nearly to the base into small, rounded auricles. Pinnae sessile or shortstalked, $\pm 2^{1} / 2$ c.M. broad, the apex very acuminate, the edge cut down only about $1 / 6$ - $1 / 5$ towards the costa into rounded lobes, the hase truncate. Texture herbaceous to papyraceous; under surface finely villose on the costae and veins; veins \pm 7 on each side, the $b-6$ lower anastomosing. Sori medial; indusium persistent.

Malacca. 
* (91) ID. callosa, C. Chr., Ind. Fil.; Nephrodium callosum, Keys., N.ral Rac., Flor. Btz., I, 192; - var. sumatrana.

Rhizome erect, to 10 c.M. long, mucous at the apex. Stipes naked, glossy, to 100 c.M. long, provided with large, distant glands sometimes 1 c.M. long and subulate. Fronds lanceolate, acuminate, $100-200$ c M. long, $40-80$ c.M. broad. Pinnae linear, sessile, to 2 c.ll. broad, the hase \pm truncate, the edge cut $\pm 1 / 4-1 / 3$-way down to the costa. Lobes $5-5 \mathrm{~m}$.M. long, to $5 \mathrm{~m}$.M. broad, falcate, entire, crenate or toothed. Texture coriaceous; surfaces naked, not rarely minutely verruculose; rachis hairy above, provided on the under side (at the bases of the pinnae) with glands similar to those of the stipe; veins pale-coloured, $8-14$ on each side of the main veins, the $5-6$ lower anastomosing. Sori close, $8-13$ an a side, divaricating from the apices of the lobes towards the costa.

Var. Sumatroana : Fronds small; $\pm 20-2$ a c.M. long, $\pm \breve{b}-7$ c.M. broad, on stipes to 15 c.M. long. Pinnae cut $\pm 1 / 4$-way down to the costa, the lower ones gradually dwarfed; veins not pale-coloured, $6-8$ on each side, the 5 lower ones anastomosing. Sori confluent.

Java, Sumatra; - var. sumatrana: Sumatra (Burck).

(92) D. Iaevis, C. Chr., Ind. Fil.; Aspidium laeve, Kze, Melt., Farng. IV, Phegop. \& Aspid., 104.

Stipes stramineous, naked. Fronds \pm 90 c.I. long, ovate, the base abruptly narrowed, pinnate. Pinnae \pm 22 c.M. long, $15-18$ m.M. broad, sessile, linear, pinnatifid caudato-acuminate, the base truncate, the apex serrate; lower pinnae shorter, the lowest \pm 10 c.M. long, oblong, remote. Lobes ovate, acute, repando-denticulate, those on the upper base the largest. Texture subcoriaceous; surfaces glossy, scabrous; costae thinly pubescent; veins \pm 7 on each side, the $1-2$ lowest anastomosing. Sori medial; indusium naked.

Luzon.

(95) D. Iorgelhyoulus, O. Ktae, C. Chr., Ind. Fil.; Nephrodium brachyodom, Hk., Hk. Bk., Syn. Fil., 295; Aspidium brachyodus, Gris,, Christ, Farnkr. d. Erde, 248.

Rhizome \pm erect. Stipes tufted, 50-60 c,M. long, greyish, naked. Fronds 60-90 c.M. long, 30-45 c.H. hroad. Pinnae 51/2-4 c.M. broad, cut from $1 / 3-1 / 2$ the way down into blunt, oblong, slightly falcate lobes; lower pinnae not much smaller than the others. Texture coriaceous; rans and both surfaces \pm naked; costae and costulae slightly hairy; main veins 
pinnate in the lobes with $10-15$ veins on a side, with a sorus on each about midway between the main veins and the edge; indusium small, fugacious.

Malaya; Galapagos Islands, Trop. America.

* (9') D. ferox, o. Htae, C. Chr. Ind. Fil.; Nephroltium ferox, Moore, Rac., Flor. Btz., I, 192; Redd., Ferns Br.I., I, lab. CXXIX; Aspidium ferox, Bl., Christ, Farnkr. d. Erde, 247; Poiypodium barbatum, Hl.., Sepc. Fil., V, 11; Phegopleris barbata, Melt., Farng., IV, Phegop. \& Aspid., No. 48.

Caudex to $10-20$ or sometimes to 100 c. H. high Stipes tufted, 50-150 c.M. long, clothed like the rachis with long, subulate, reddish or blackish, spreading bristles leaving the stipes rough when they fall. Fronds 90-500 c.M. long, to 60-100 c.M. broad, lanceolate-oblong. Pinnae rather close, linear-lanceolate, $17-50 \mathrm{~m}$. .I. broad, the apex acuminate, the edge cut \pm $1 / 3$-way down into numerous, entire, deltoid-oblong, straight or falcate lobes, the base truncate, on stalks to $\pm 1 \mathrm{~m}$.M. long or longer. Texture subcoriaceous; surfaces glossy: midribs villose beneath; main veins pinnate in the lobes; veins $\pm 10-15$ on each side, the $5-7$ lower anastomosing. Sori often numerous, close to the main veins, the lower close to the midribs; indusium fugacious.

Malaya.

(95) D. Lohereiana, C. Chr., Ind. Fil. ; Nephrodium Loherianum, Copel., Polypod. Philipp., כ0; Aspidium Loheriamum, Christ, Bull. Herb. Boiss., VI, 191.

Rhizome short-creeping. Stipes approximate, the base clothed with few, ovate, brown scales, the rest short-haired like the rachis, costae and veins, dark-stramineous, firm, \pm 50 c.ll. long, the upper part bearing distant, reduced, auriculiform pinnae. Fronds short-haired, deltoid-ovate, \pm 30 c.r. long, $18-20$ c.M. broad, acuminate. Lowest not-reduced pinnae the longest, \pm 2 c.M. broad, lanceolate, patent, acuminate, sessile, cut down to a distance of $\pm 5 \mathrm{~m}$.I. from the costa into falcate, oblong, pectinate, obtuse, entire lobes $\pm 5 \mathrm{~m}$. I. broad. Texture subcoriaceous; veins \pm 12-jugate. Sori submarginal, close, small; indusium villose.

Philippines.

(96) ID. Intehrosa, C. Cher., Ind. Fil.; Aspidium latehrosum, Kze, Mett., Farng., IV, Phegop. \& Aspid., 104.

Stipes nodulose below. fironds \pm 90 c.M. long, linear-lanceolate, pimnate. 
Pinnae \pm 9 c.M. long, \pm 2 c.M. broad, sessile, elongate-oblong the base hroadly truncate, narrowed gradually towards the acuminate apex, the margin deeply pinnatifid; lower pinnae gradually reduced, obtuse, pinnatifid, the lowest abortive, reaching nearly the base of the stipe. Lobes ovate-oblong, subfalcate, obtuse, the lowest ones the largest. Texture rigid; upper surface clothed with adpressed bristles, under surface covered with minute, sessile, scattered glands; costae with a large tubercular gland beneath at the base; veins \pm 8 on each side, the $1-2$ lowest anastomnsing. Sori \pm 8 on a side, medial or nearer the margin than the midrib; indusium subcoriaceous, naked.

Java, Sumalra.

* (97) TD. Dilleso-squamata, v. A. v. Fe. Hort. Bog.

Rhizome short, clothed with linear-lanceolate, brown, acuminate, haircovered sciles. Stipes approximate, \pm b5 c.M. long, stout, erect, firm, green, inconspicuously short-hairy, scaly towards the hase. Fronds ovate-lanceolate, \pm 50 c.M. long, \pm 50 c.II. broad. Pinnae sessile, linear-lanceolate, 2-2 $1 / 2$ c.M. broad, acuminate, the edge cut $\pm 1 / 3-1 / 2$-way down to the costa into oblong, rounded or subtruncate, subentire lobes $\pm 21 / 2$ m.II. broad, the base truncate or subtruncate, the lowest not reduced pinnae the longest, deflexed; below this $\pm 4-5$ distant, much reduced, deflexed auricles, occupying the upper half of the stipe. Texture \pm coriaceous, rachis inconspicuously hairy; surfaces minutely hairy on the costae and costulae, rather naked; veins 8-10 on each side of the main veins, the $\tilde{z}-5$ lower anastomosing. Sori numerous, medial on the veins, afterwards becoming subconfluent and densely covering the under surface of the pinnae; indusium reniform, with the surface covered with very short hairs and yellow, globose glands. - The description is taken from a specimen cultivated in the Buitenzorg gardens.

Skroe (New Guinea).

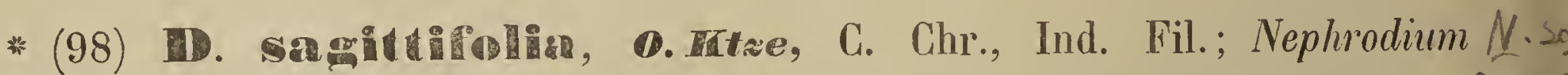
saillaefolium, Monre, Rac., Flor. Btz., I, 191; Aspidium sagillaefolium, Bl., woon Enum., 155

Rhizome erect or suberect, the extremity sparingly clothed with delioid scales. Stipes tufted, 50-60 c.M, long, stout, densely villose, scaly at the base. Fronds $90-120$ c.M. long, 50 c.M. or more broad. Pinnae numerous, spreading, straight or falcate, \pm 2 c.ll. broad, the apex acuminate, the base truncate and often auricled on the upper side, the edge cut $1 / 3-1 / 2$-way down into oblong-falcate lobes; lower pinnae suddenly dwarfed and deflexed, close, 
occupying nearly the whole stipe. Texlure subcoriaceous; rachis and under surface densely villose; main veins pinnate in the lobes with 7 - 10 veins on a side, the 2-3 lower anastomosing. Sori midway on the veins, $6-7$ on a side; capsules setose or naked; indusium densely villose.

Malacca, Java. Borneo. hew Gerinaa

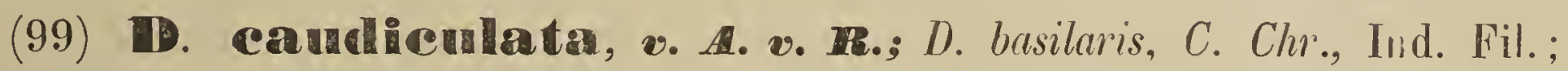
Nephrodium philippinense, Bl., Copel., Polypod. Philipp., 51; N. basilare, Pr., Epim., 258, N. caudiculatum, J. Sm., (oldest name).

Rhizome erect. Fronds oblong-lanceolate, 2-pinnatifid, 60-90 c.V. long, $50-45$ c.M. broad. Pinnae lanceolate, acuminate, 20-25 c.M. long, $1-11 / 2$ c.M. broad, cut less than $1 / 2$-way down to the costa into oblong, erecto-patent lobes $5-3^{1} / 2$ m.M. broad. Lower pinnae not reduced. Texture moderately firm; rachis and surfaces naked; veins simple, 8-9-jugate. Sori medial; indusium firm, naked, persistent.

Philippines.

(100) S. Simininima, C. Cher., Ind. Fil ; Nephrodium simulans, Bli., Journ. of Bot., XXVI, 325 (not Hk. Bk., Syn. Fil., 500, nor Journ. of Bot. XXVIII, 106).

Rhizome erect, Stipes tufted, naked, nearly 50 c.M. long. Fronds oblonglanceolate, 2-pinnatifid, 50-45 c.NI. long, 5-8 c.M. broad. Pinnae sessile, linear-oblong, obtuse, shallowly pinnatifid, $\pm 1-1 \frac{1}{2}$ c.M. broad, the lower ones sharply duflexed. Texture moderately firm; hoth surfaces finely pubescent; main veins pinnate; veins 4-b̆-jugate. Sor'i medial on all the veins; indusium obscure, minute, fugacious.

Borneo.

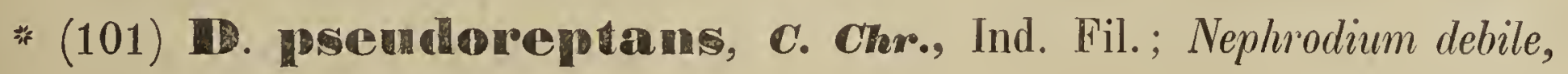
Bli., Journ. of Bot., XVIII, 212.

Rhizome short-creeping. Stipes approximate, slender, grey, naked, 20-50 c.M. long. Froods lanceolate, $20-30$ c.II. long, 5-7 c.M. broad. Pinnae sessile, oblong-lanceolate, $21 / 2-4$ c.M. long, $1-11 / 2$ c.M. broad, cut $1 / 4-1 / 3$ of the space down to the costa into ohlong, obtuse lobes. Lower pinnae slightly reduced or dwarfed. Texture moderately firm; upper surface strigillose, under one pubescent on the ribs; veins 4-6-jugate, the 2 lower joining. Sori small, medial; indusium persistent.

Sumalra. 


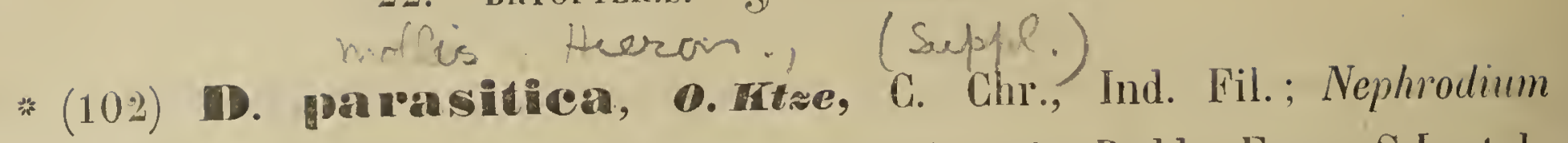
molle, R. Br., (not Desv.), Rac., Flor. Btz., I, 188; Bedd., Ferns S.I., tab. LXXXIV; N. parasiticum, Desv. (not Bk.), Copel., Polypod. Philipp., $52 ;$ Aspidium parasilicum, Sw. (not Mell.), Christ, Farnkr. d. Erde, 245; Polypodium parasilicum, L., (oldest name).

Rhizome erect or suberect, clothed with dark-brown, entire, lanceolate scales. Stipes tufted or subremote, $15-30$ c.M. or more long, slender, densely and deciduously hairy; hairs short. Fronds ovate-lanceolate, to $50-60$ c.M. long, $121 / 2-50$ c.M. broad. Pinnae spreading, approximate, $1 / 2-21 / 2$ c.M. broad, cut $\pm 1 / 2$-way down to the midrib into scarcely falcate, blunt or acute lobes, the base not narrowed, the apex acuminate. Lower pinnae distant, not rarely shorter than the next in order, the lowest sometimes slightly dwarfed. Texture herbaceous, rachis and surfaces finely hairy; main veins pimnate in the lobes with 6-9 veins on each side, only the lowest anastomosing. Sori medial on the veins; capsules naked; indusium villose. A form found in Borneo (forma caudala) has the fronds caudate and subglabrous, and a form gathered in Sumatra (forma repens; has the rhizome wide-creeping.

Tropical and subtropical regions all round the world. Wargen I

* (103) D. indiea, v. A. v. R.; N. pennigerum, Bedd., Handb. Ind. Ferns, Suppl., 73 ; - var. malayensis, Bedd., l. c., 74.

Rhizome erect or short-creeping. Stipes hairy or nearly naked, to 120 c.M. long. Pinnae numerous, spreading, $20-25$ c.ll. long, $21 / 2-4$ c.ll. broarl, the fertile sometimes much contracted, the apex acuminate, the edge cut down only $\pm 1 / 4$ towards the costa into oblong, falcate lobes; lowest pinnae not reduced. Texture herbaceous; rachis hairy; upper surface strigose on the costae, otherwise naked or more or less strigose particularly near the eilges, under surface hairy on the veins; veins $8-12$ pair, $5-8$ pair anastomosing except in contracter, fertile pinnae. Sori medial on the veins; indusium generally persistent.

Var. malayensis: Pinnae rather deeply cut; surfaces rather densely clothed with short hairs; only $2-5$ lower pairs of veins anastomosing. Burmah, Br. India, Ceylon; - var. malayensis: Malacca, Tenasserim.

(104) ID. sakayensis, C. Cher., Ind. Fil.; Nephrodium sakayense, Zeill., Bull. Soc. Bot. Fr., XXXII, 75.

Rhizome erect. Fronds densely tufted, bipinnatifid, 100-120 c.M. long, 
25-30 c.M. broad, ovate-lanceolate, with a long, terminal, pinnatifid pinna. Pinnae erecto-patent, alternate, $\pm 21 / 2-3$ c.II. apart, linear-lanceolate; $15-20$ c.M. long, 15-20 m.M. broad, the apex narrowed to an acute point, the margin cut $1 / 3-2 / 5$-way down into subacute (rather bluntish), slightly falcate lobes, obscurely crenate at the apex. Texture papyraceous; rachis dark-reddishbrown, slightly canaliculate and hairy and scaly. on the upper side, the scales large, pale-brown; upper surface covered with pale or whitish hairs on the costae and rarely on the costulae and veins; under surface finely glandular; veins $\pm 8-10$ on each side, only the 5 lowest ones anastomosing. Sori costular, confined to the 4 -5 lowest veins; indusium very fugacious.

Malacca.

(105) D. Benoidianse, v. A. v. IR.; Nephrodium Benoitianum, Pr., Tent. Pterid., 81; C. Chr., Ind. Fil.; Polystichum Benoitianum, Gaud., Freyc., Voy. Ur. Phys. Bot., 351; Aspidium Benoitianum, Gaud., Freyc., I. c., sub tab. XI.

Rhizome \pm erect. Stipes tufted, to \pm 20 c.M. long, short-hairy, scaly at the base. Fronds ovate-lanceolate, acuminate, \pm 35 c.M. long, \pm 12 c.M. broad, with \pm 12 pair's of lateral pinnae below the deeply pinnatifid apex. Highest pinnae erecto-patent, central ones largest, lanceolate, slightly acuminate, the point bluntish, the edge cut $1 / 2-2 /{ }_{3}$-way down into oblong, rounded, \pm erecto-patent lobes, the base truncate or broadly cuneate, not much narrower than the centre, which is $\pm 1 \frac{1}{2}$ c.M. broad, lowest pinnae shorter, deflexed. Rachis and veins densely short-hairy beneath; veins \pm 7 on each side, only the lowest ones anastomosing. Sori 3-6 on a side, submarginal; indusium short-hairy.

Moluccas.

(106) D. didymosorm, C. Cter., Ind. Fil.; Nephrodium didymosorum, Par., Bedd., Ferns Br.I., II, tab. CG; N. tectum, Bedd., Handb. Ind. Ferns, Suppl., 79.

Rhizome strong, erect. Stipes densely tufted, a span or more long. Fronds deltoid or somewhat lanceolate, 30-40 c.M. long, 15-18 c.M. broad. Pinnae cut down $2 / 3$ or more towards the costa into entire, slightly falcate lobes, lowest pinnae not or slightly reduced, deflexed. Texture firm-herbaceous; rachis, midribs and lamina on hoth sides rather densely covered with long, white, needle-like hairs; veins $7-8$ pair, only the lowest anastomosing. Sori terminal, on nearly all the veins or not rarely confined to the lowest Filices. 
pair; indusium often very hairy. - Some specimens have the lowest pinnae suddenly reduced and much deflexed, but not distant from the others.

Malacca.

(107) D. microchlamns, v. A. v. Re.; Nephrodium microchlamys, Bk., Journ. of Linn. Soc., Bot., XV, 107; Mesochlaena polycarpa, Bedd., var., C. Chr., Ind. Fil.

Rhizome \pm erect. Stipes \pm 15 c.M. long, pale-brown, scaleless, finely pilose. Fronds oblong-lanceolate, 60-90 c.M. long, 50-40 c.M. broad, 2-pinnatifid. Pinnae in \pm 40 pairs below the small, entire, terminal one, sessile, linear-ligulate, the largest, $20-221 / 2 \mathrm{~m}$. M. broad, the lower not reduced, cut down to a broad wing into close, blunt, entire, rather ascending lobes \pm $3-3^{1} / 2$ m.M. broad, the lowest anterior lobe slightly elongated. Texture membranaceous; surfaces finely villose and densely covered with minute, pale-brown glands; veins 12-16-jugate, the lowest anastomosing, the next meeting at the sinus. Sori round, minute, in regular rows nearer the main veins than the edge.

Kei Islands.

(108) D. glaucostipes, C. Chr., Ind. Fil.; Nephrodium glaucostipes, Bedd., Handb. Ind. Ferns, Suppl., 80.

Rhizome erect or suberect. Stipes scaly at the base, glaucous as is the main rachis. Fronds $90-120$ c.M. long, pinnate. Central pinnae 12-15 c.M. long, 2-21/2 c.Mr. broad, cut down $1 / 2$-way into oblong, rounded lobes, lower pinnae very gradually reduced in size, becoming at first small and hastate or semihastate, and at length mere auricles down to almost the base of the stipe. Texture rather papyraceous; surfaces naked but the costae minutely villose above; veins in \pm 10 pairs, the 2 lower ones anastomosing, all soriferous. Sori medial.

Malacca.

(109) Derakensis, C. Chr., Ind. Fil.; Nephrodium perakense, Bk., Ann. of Bot., V, 519; Aspidium perakense, Bedd., Journ. of Bot., XXVI, 4. Rhizome small, erect. Stipes slender, villous. Fronds pinnate, 30-35 c.M. long, מ-15 c.M. broad, oblong-lanceolate, the lower pinnae gradually reduced. Central pinnae largest, $1-1 \frac{1}{2}$ c.M. broad, cut $\pm 1 / 2$-way down to the costa into close, rather acute lobes. Texture softly herbaceous; rachis and surfaces copiously furnished with long, white, soft hairs; veins $\mathbf{4 - 5}$ on 
each side of the main veins, the lowest pair anastomosing. Sori subterminal on the veins.

Malacca.

(110) D. summatrama, v. A. v. R.; N. molle, R. Br., var. major, Bedd., Handb. Ind. Ferns, Suppl., 76.

Rhizome erect or somewhat creeping. Fronds large, often 120-150 c.M. long, $20-50$ c.M. broad. Pinnae very numerous, cut down $1 / 3-1 / 2$-way towards the costa, the lower ones gradually reduced to butterfly-like auricles down the base of the stipe. Texture herbaceous; rachis and surfaces not very hairy, often quite glabrous except the costae above; veins $7-8$ pair, the 2-3 lower pair anastomosing. Sori medial, generally on all the veins except the $1-2$ highest ones.

Sumatra, Malacca; Ceylon, Br. India.

* (111) D. stipellata, o. Kt:e, G. Chr., Ind. Fil; Nephrodium stipellatum, Moore (not Hk.), Rac., Flor. Btz., I, 188; Aspidium stipellatum, Bl., Enum., 152.

Rhizome short-creeping or erect. Stipes tufted, 30-100 c.M. long, hairy above, naked below. Fronds linear-lanceolate, 60-100 c.M. long, 12̆-25 c.M. broad. Pinnae sessile, linear-lanceolate, the apex acuminate, the base truncate or broadly cuneate, 1-2 c.M. broad, provided with a short, thick gland beneath, the edge cut about $1 / 3-1 / 2$-way down into oblong, subfalcate lobes; reduced pinnae numerous, often occupying nearly the whole stipe. Texture herbaceous to semicoriaceous; rachis, midribs and apices of the veins villose beneath; main veins pinnate in the lobes; veins $6-9$ on a side, only the lowest ones anastomosing. Sori in rows, medial or nearer the main veins than the edge.

Sumatra, Java, Celebes.

* 112) D. truncata, o. Irtwe, G. Chr., Ind. Fil.; Nephrodium truncatum, Pr., Rac., Flor. Btz., I, 190; N. eusorum, Bedd., Ferns Br.I., I, tab. CXXX ; N. abruptum, J. Sm., Hk., Spec. Fil., IV, tab. CGXLI, B ; Aspidium truncatum, Gaud. (not Pr.), Christ, Farnkr. d. Erde, 248.

Rhizome erect or suberect. Stipes tufted, stout, erect, $60-80$ c.M. long, greyish, naked, or slightly villose above. Fronds 60-120 c.M. long, 30-45 c.M. broad or broader, lanceolate-oblong. Pinnae sessile, 2-3 c.Mr. broad, linear-lanceolate, the apex acuminate, the base more or less broadly cuneate 
to subtruncate, the edge cut $1 / 3-1 / 2$-way down into blunt or subtruncate, spreading or suberecto-patent lobes \pm 5 m.M. broad, subentire, or crenate or toothed at the apex, lower pinnae \pm narrowed at the base; reduced pinnae few, distant. Texture papyraceo-herbaceous; under surface naked or nearly so, verruculose; rachis slightly villose; main veins pinnate in the lobes; veins $6-11$ on each side, the $2-3$ lower ones anastomosing. Sori medial or lower on the veins, to \pm 6 on a side.

Malaya; Polynesia, Trop. Australia, Br. India, Madagascar, Mascarenes.

* (115) D. Inispidula, o. Itze, C. Chr., Ind. Fil.; Nephrodium hispidulum, Bk., Hk. Bk., Syn. Fil., 295; N. angustifolium, Pr., Hk., Spec. Fil., IV, 69; Aspidium hispidulum, Dec., Nouv. Ann. Mus., III, 346.

Rhizome \pm erect. Stipes tufted, $15-45$ c.M. long, villose at least on the inner side. Fronds $20-45$ c.M. long, 8-25 c.M. broad. Pinnae distant, spreading, $5-15$ c.M. long, b-15 m.M. broad, the apex acuminate, the edge cut $\pm 1 / 2$-way down into oblong, more or less bluntish, slightly falcate lobes, the base obtuse, lower pinnae reduced to mere auricles. Rachis villose; texture herbaceous to semicoriaceous; under surface finely villose; main veins pinnate in the lobes; veins $5-4$ on a side, the lowest pair anastomosing. Sori nearly terminal or medial on the veins. - A plant gathered in Borneo by Dr. Nieuwenhuis and determined by Dr. Christ (Ann. Btz., XX, 107) has the pinnae erecto-patent, with the base cuneate, the surfaces deciduously hispid especially on the costae and edges, the lowest veins joining at or a little below the tops of the sinuses, the lobes strongly erect as in D. calcarata, 0 . Ktze, but less deep and the rhizome short-creeping.

Malaya; Samoa.

* (114) D. Ineterdearopa, O. Kt:e, C. Chr., Ind. Fil.; Nephrodium heterocarpon, Moore, Rac., Flor. Btz., I, 187; Aspidium heterocarpon, Bl., Christ, Ann. Btz., XV, 133.

Rhizome short-creeping or suberect, clothed with ovate-lanceolate, brown scales. Stipes \pm tufted, 30-60 c.M. long, densely (deciduously?) villose, the base glossy and scaly. Fronds ovate-lanceolate, 50-90 c.M. long, 20-40 c.M. broad. Pinnae linear-lanceolate, sessile, acuminate, more or less narrowed towards the base, $1-2$ c.M. broad, the edge cut $1 / 2-3 / 4$ down into linearoblong, subfalcate lobes to 4 m.M. broad, lower not-reduced pinnae deflexed; below this several distant, abruptly dwarfed pinnae occupying the upper half of the stipe, sometimes changed into glands. Texture herbaceous, firm, rachis 
and under surface hairy especially on the veins; under surface densely covered with globose, yellow glands; main veins pinnate in the lobes; veins $8-10$ on a side, only the lowest anastomosing. Sori few or to 6-9 on a side, the lowest close tho the midribs; indusium hairy or naked; capsules naked.

Malaya.

* (115) D. crinipes, o. Htze, C. Chr., Ind. Fil.; Nephrodium crinipes, Hk., Hk. Bk., Syn. Fil., 294 ; Bedd., Ferns Br.I., II, tab. CGLXIII.

Rhizome \pm erect. Stipes 30 -45 c.M. long, stout, erect, densely clothed thairy with lanceolate-linear, brown scales. Fronds $\pm 60-90$ c.M. long, \pm 20 - 35 c.M. broad. Pinnae horizontal, $\pm 10-171 / 2$ c.M. long, $1-2$ c.M. broad, cut down $1 / 2-3 / 4$-way to the costa into oblong, scarcely acute lobes, the upper basal one often somewhat enlarged; lower pinnae dwarfed into auricles. Texture herbaceous; rachis scaly like the stipe, the scales \pm deciduous; costae, costulae and veins sparingly hairy above; veins $6-8$ on each side of the main veins, minutely hairy beneath, the lowest pair anastomosing. Sori medial on the veins, but a little nearer the apex than the base; indusium persistent.

Celebes, Malacca; North India.

Species of an indefinite systematical place (*).

(116) D. penangiana, C. Chr., Ind. Fil.; Nephrodium costahum, Bedd., Handb. Ind. Ferns, 275; Ferns Br.I., II, tab. CGXX; Polypodium linealum, Colebr., Hk. Bk., Syn., Fil., 316; P. penangianum, Hk., Spec. Fil., V, 13., Goniopleris penangiana, Bedd., l.c., II, tab. CCXXXII.

Rhizome indefinite. Stipes \pm 45 c.M. long or longer, rather stout, scaleless, glossy and as well as the rachis strongly tinged with red, or rarely stramineous. Fronds broad-oblong or -lanceolate, 30-90 c.M. long, pinnate. Pinnae numerous, rather distant, spreading, sessile, 12-20 c.M. long, 1-2 $1 / 2$ c.M. broad, the lower ones wether or not subpetiolate; lanceolate or elongateoblong, finely acuminate, the edge coarsely and sharply submucronate-serrate, the base obliquely cuneate. Texture coriaceo-submembranaceous; surfaces naked, or slightly hairy on the veins; costae prominent beneath, generally reddish; veins $\pm 6-8$-jugate, the $3-6$ lower anastomosing. Sori in 2

(*) Rhizome unknown or indefinite.

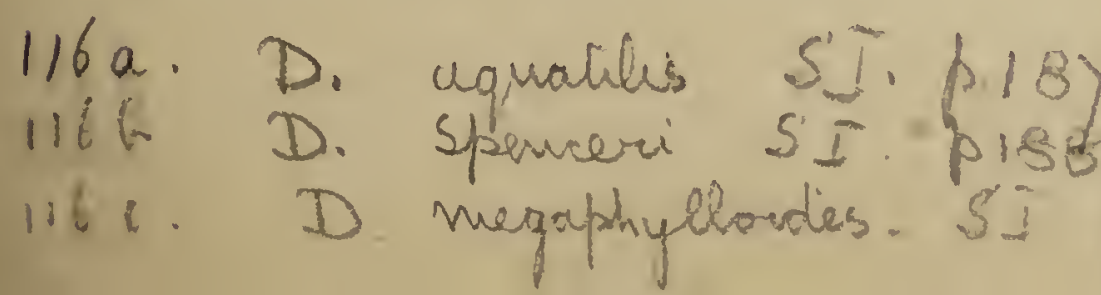


rows between the main veins, generally near the base of the veins; indusiun very fugacious or undeveloped, only to be detected on very young fronds.

Penang; North India, China.

(117) D. Dosora, C. Chr., Ind. Fil.; Nephrodium oosorum, Bk., Kew Bull., 1896, 41.

Rhizome unknown. Stipes \pm 30 c.M. long, grey, slightly puhescent. Fronds oblong-lanceolate, $45-60$ c.M. long, $15-20$ c.M. broad, 2-pinnatifid. Pinnae multijugate, $1 \frac{1}{2}-2$ c.M. broad, pinnatifid $1 / 2$-way down to the costa, the lower ones not reduced. Lobes ovate-lanceolate, crenulate, slightly falcate. Texture subcoriaceous; rachis pubescent; both surfaces naked; veins simple, erecto-patent, conspicuous, 10-12-jugate. Sori oblong, medial; indusium membranaceous, pubescent, persistent.

11) a. Borneo. dichroficicha SI pisq.

* (118) D. Riedleana, v.A. v. R.; Nephrodium Riedlianum, Moore, Ind., 102; Polystichum Riedleanum, Gaud., Freyc., Voy. Ur. Phys. Bot., 327 ; C. Chr., Ind. Fil.; Aspidium Riedleanum, Gaud., Freyc., l. c., 326.

Rhizome unknown. Stipe and rachis dark-red, nearly black, (brown when dry?), pubescent. Fronds pinnate. Pinnae lanceolate, pinnatifid, subacuminate, the base truncato-cuneate, lower pinnae gradually reduced, distant. Lobes ovate, obtuse, subfalcate, the lowest subauriculiform. Surfaces hairy. - Different from D. parasitica, 0 . Ktze by the rather gradually reduced lower pimnae.

Timor.

(119) D. producta, C. Chr., Ind. Fil.; Nephrodium produchum, Klf., Mett., Farng., IV, Phegop. \& Aspid., 109.

Rhizome unknown. Stipes hirsute. Fronds 30-60 c.M. long, oblong, acuminate, the base suddenly narrowed. Pinnae sessile, 7-15 c.M. long, 1-2 c.M. broad, linear-lanceolate, acuminate with a long, entire point, the edge pinnatifid, the base truncate, lowest pinnae suddenly reduced, distant, $\pm 1 \frac{1}{2}$ c.M. long, semiorbicular, obtuse, 3-fid. Texture rigid; rachis canaliculate and pubescent on the upper side; surfaces covered with inconspicuous hairs on the costae and veins; veins $6-7$ on each side, the $2-3$ lowest anastomosing, all soriferous. Sori medial on the veins; indusium persistent. Luzon.

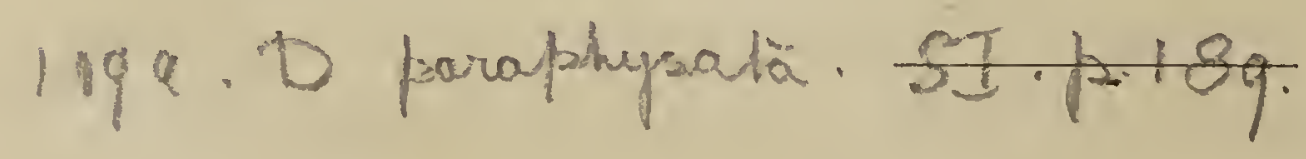




\section{\$ 3. CYCLOSORUS.}

*. Fronds 10-30 c.M. long. Rachis havy. (120) D. Blumei. *.*. Fronds 60-90 c.M. long. Rachis naked.

(121) D. nephrodioides.

(120) D. Blumei, v. A. v. R.; D. canescens, C. Chr., Ind. Fil., p.p.; Nephrodium Blumei, J. Sm., Journ. of Bot., III, 411; N. subdimorphum, Christ, Fil. Saras., I, 16; N. canescens, Christ, Copel., Polypod. Philipp., 27, p. p.; Aspidium canescens, Christ, forma nephrodiiformis, Christ, Ann. Btz., XV, 150-131.

Rhizome short-creeping or erect, nearly naked. Stipes 5 -20 c.II. long, scaly at the base, \pm hairy above. Fronds $10-50$ c.M. long, with a long, acuminate, terminal pinna $5-10$ c.I. long, cut to $\pm 1 / 2$-way down into blunt lobes. Lateral pinnae few or to 14 on each side, alternate, $2-6$ c.M. long, 1-5 c.M. broad, the apex blunt, the edge slightly lobed, the base \pm adnate to the rachis; lower pinnae deflexed, sometimes much reduced. Texture papyraceous to herbaceous; surfaces naked, or hairy on the veins; rachis hairy; only the lowest veins anastomosing. Fertile fronds often on the longest stipes, with the pinnae sometimes shorter and narrower than in the barren ones. Sori near the main veins or \pm medial on the veins.

Celebes, Philippines; Fiji.

(121) D. nephrodioides, o. Ktae, Rev. Gen. Pl., II, 811; D. orbicularis, C. Chr., Ind. Fil.; Aspidium Hookeri, Bk., Hk. Bk., Syn. Fil., 257; A. nephrodioides, Hk., Spec. Fil., IV, tab. CCXXXV.

Stipes 50 c.M. or more long, naked, erect. Fronds 60-90 c.M. long, \pm 50 c.M. broad. Pinnae $15-20$ c.M. long, $\pm 21 / 2$ c.II. broad, cut down to a broadly winged rachis into nearly close, spreading, entire, linear-oblong lobes $\pm 3^{1 / 2}$ m.M.' broad. Texture herbaceous, rachis naked, substramineous; veins slightly hairy, about 10 on a side, the lowest pair uniting. Sori nearer the edge than the midribs; indusium membranaceous, reddish in the centre, scariose in the outer half.

Malaya.

\section{MESOCHLAENA, R. Brown.}

Sori oblong, medial on the veins. Indusium oblong, fastened by its longitudinal axis, opening all round the edge. 
Rhizome short, \pm erect. Stipes not articulate to the rhizome. Fronds large, 2-pinnatifid; veins anastomosing as in Nephrodium. Diels, in Engl. \& Prantl, Nat. Pfl.Fam., I I , fig. 84; Christ, Farnkr. d. Erde, fig. 793.

Malaya, Polynesia.

*. Pinnae 11/2 - 2 c.M. broad, cut to $1 / 2$-way down to the costa. (1) M. polycarpa. *.*. Pinnae 3-5 c.M. broad, cut to ${ }^{1 / 4}$-way down to the costa. (2) M. larutensis.

* (1) M1. polycarpa, Medd., Hädb. Ind. Ferns, 199 ; M. javanica, J.F.M R. Br:, Bedd., Ferns Br.I., II, tab. CCCXLIV; Didymochlaeña polycarpa, Bk., PV iv D Rac., Flor. Btz., I, 197; Nephrodium javanicum; Hk., Fil. Exot., tab. LXII ; P130 Aspidium polycarpum, Bl., Christ, Farnkr. d: Erde, 249; Sphaerostephanos asplenioides, J. Sm., Bau. \& Hk., Gen. Fil., tab. XXIV.

Rhizome erect, densely clothed with linear-lanceolate, ciliate scales. Stipes tufted. Fronds 60-200 c.M. long, pinnate, acuminate. Pinnae spreading, close, linear-lanceolate, gradually narrowing from the \pm truncate base towards the acuminate apex, the largest $15-25$ c.M. long, $1 \frac{1}{2}-2$ c.M. broad, the edge cut down to $1 / 2$-way or more to the costa into close, bluntish, oblong lobes, lower pinnae reduced into several or numerous mere auricles occupying the largest part of the stipe. Texture herbaceous; rachis and surfaces hairy; main veins pinnate in the lobes; veins numerous, close, the 2-3 lower anastomosing. Sori numerous, medial on the veins, ultimately confluent; indusium villose and glandular.

Malaya; Polynesia.

* (2) N. Innutensis, v. A. v. Re.; Nephrodium larulense, Bedd., Handb. Ind. Ferns, Suppl., 75; Dryopteris larutensis, C. Chr., Ind. Fil.; - var. borneensis.

Stipes 20-50 c.M. long; furnished with very regular auricles (reduced pinnae) below the pinnae, densely villous with short hairs as in the rachis. Fronds $60-90$ c.M. long. Pinnae $25-30$ c.M. long. 3-5 c.M. broad, finely acuminate at the apex, cut down $\pm 1 / 4$ towards the costa into short, subfalcate lobes, the base truncate or broadly cuneate. Texture herbaceous or subcoriaceous; upper surface hairy on the costae, veins and parenchyma, under surface hairy on the costae and veins, the lamina furnished with minute resinous dots; veins \pm 10 pairs, ascending, the $5-6$ lower pairs anastomosing. Sori medial; indusium hairy. 
Var' bornecensis: Upper surface naked exept on the costae; under surface copiously and minutely short-hairy; indusium covered with yellow, minute, globose glands.

Malacca; - var. borneensis: Borneo (Hallier No. 2704).

\section{LUERSSEIVIA, Kuhn.}

Sori oblong, terminal on included, excurrent, free veinlets, alternate, in several rows on each side of the costa. Indusium oblong, attached by its longitudinal axis, opening all round the edge.

Rhizome erect. Stipes not articulate to the rhizome. Fronds simple, slightly dimorphous, the fertile ones a little narrower and longer stalked than the barren ones; veins anastomosing, forming several rows or areolae; areolae with free veinlets, which are more copious in the barren than in the fertile fronds. Sori solitary in the areolae of the fertile fronds. Diels, in Engl. \& Prantl, Nat. Pfi.Fam., I ${ }^{4}$, fig. 93, A-B.

Sumatra.

L. Kehdingiana, Koun, Bot. Centralbl., XI, 77; Diels, in Engl. \& Prantl, Nat. Pfl.Fam., I ${ }^{4}$, fig. 95, A \& B; Aspidium Kehdingiamum, Luerss., Christ, Farnkr. d. Erde, $25 \%$.

Barren fronds \pm 50 c.M. long, \pm 5 c M. broad, lanceolate, the apex acute, acuminate or bluntish, the base gradually narrowed, the stipe.4-5 c.M. long. Texture papyraceous or chartaceous; main veins flexuose, distinct to the edge; areolae with free veinlets. Fertile fronds linear-lanceolate, $\pm 20-25$ c.M. long, \pm 2 c.M. broad, narrowed gradually towards both ends, the base decurrent, the stipe \pm 20 c.II. long; no distinct main veins; areolae numerous, hexagonal. Sori terminal on the excurrent, free veinlets; indusium elliptical or oblong.

Sumatra.

\section{ASPIDIUM, Swart*.}

Sori roundish, rarely oblong, compital (*) or on free veinlets. Indusium round or reniform, attached by a central point or at the apex of a \pm deep

( ${ }^{\star}$ On connected veinlets, 
sinus, very rarely oblong and attached by a short, longitudinal axis, opening all round the edge or nearly so.

Rhizome creeping or erect. Stipes not articulate to the rhizome. Fronds uniform or nearly so, often inclined to a triangular shape, simple or divided, if divided the lowest pinnae often inclined to a stronger development of the basiscopic side; texture often herbaceous; veins anastomosing \pm copiously and irregularly; areolae with or without included, free veinlets.

Pantropical.

Arrangement of the sections.

\$1. TECTARIA (Ev-aspidium). Indusium round, peltate. Hk. Bk., Syn. Fil., tab. V, fig. 43, d; Diels, in Engl. \& Prantl, Nat. Pfl.Fam., I ${ }^{4}$, fig. 96, C-D.

2. SAGENIA. Indusium reniform and attached at the top of the sinus, very rarely oblong and attached by a short, longitudinal axis. Diels, l. c., fig. $97, \mathrm{~A}-\mathrm{C}$.

\section{S 1. TECTARIA ( $\left.{ }^{1}\right)$.}

a. Fronds simple $\left({ }^{2}\right)$.

a.e. Fronds palmately 3-5-fid.

*. Segments lanceolate.

*.*. Segments triangular.
(1) A. singaporianum.

(2) A. tricuspe.

(5) A. platanifolium.

a.a.4x. Fronds ternate, or pinnale to 3-pinnatifid.

b. Sori arranged along the margin of the ultimate segments.

(4) A. calcareum.

b.b. Sori scattered irregularly $\left({ }^{3}\right)$.

S. Stipe and rachis glossy, cheneous.

\$.S. Stipe and rachis minutely pubescent.
(5) A: angulatum.

(6a) A. Kunstleri.

b.b.b. Sort in rows between the main veins or costulae $\left({ }^{3}\right)$.

c. Fronds under 55 c.M. long.

d. Lowest pinnae simple or forked.

e. Sori dorsal on the veinlets.

( ${ }^{1}$ See also under A. coadunatum, Wall.

$\left({ }^{2}\right)$ See also A. angulatum, $J$. Sm.

$\left(^{3}\right)$ See also A. multicaudatum \& polymorphum, Wall., \& A. oligophyllum, Rst. 
25. ASPIDiUn. $\$ 1$. TEctaria.

f. Lateral pinnae in 2 pairs. (6b) A. oligophyllum.

f.f. Lateral pinnae in 4 or more pars.

(7) A. Haenkei.

e.e. Sori terminal on free veinlets.

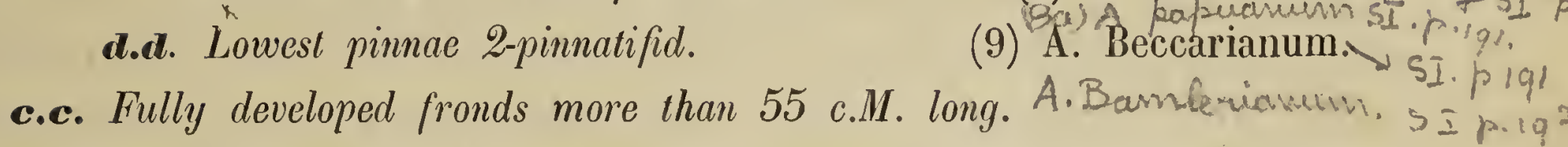

(8) A. ternatense.

(9) Ba) A papuawum SI. + SI P

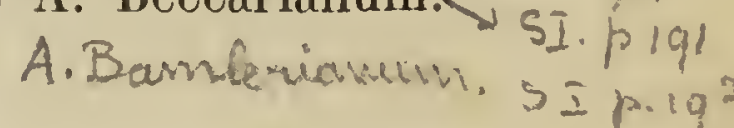

(10) A. repandum.

* (1) A. singaporianum, Wall., Christ, Farnkr. d. Erde, T/ 227; Bedd., Ferns Br.I., II, tab. CLXVIII; Nephrodium singaporianum, Bk., Hk. Bk., Syn. Fil., 296; Hk. \& Grev., Ic. Fil., tab. XXVI.

Rhizome short-creeping or erect. Stipes subtufted, those of the fertile fronds $13-30$ c.M. long in the unwinged part, scaly below. Fronds to 30 c.M. long or longer, $5-10$ c.II. broad, the fertile ones not rarely more or less smaller than the barren ones, oblong, entire, acuminate, narrowed rather suddenly in the lower part and then decurrent at the base so as to form a not very long wing to the highest part of the stipe. Texture papyraceo-herbaceous to subcoriaceous; main veins distinct nearly to the edge; areolae copious, subquadrangular, divided into irregular-shaped smaller ones, with free veinlets. Sori numerous, often ranged in lines which are subparallel to the costa, $4-6$ in a line between the main veins.

Malaya; China.

(2) A. tricuspe, Bedd., Handb: Ind. Ferns, Suppl., 44.

Rhizome stout, erect. Stipes 20-45 c.M. long, naked or nearly so, winged upwards. Fronds $25-50$ c.M. long, $15-20$ c.ll. broad, deeply 3-lobate. Lobes lanceolate, long-acuminate, the lateral ones $12-15$ c.M. long, $4-5$ c.M. broad, the central one \pm 25 c.M. long, $61 / 2-71 / 2$ c.M. broad; margins entire. Texture papyraceo-herbaceous; surfaces slightly pilose on the costae and veins beneath; main veins prominent nearly to the margin, connected by prominent transverse veins, between which are copious small areolae with free veinlets. Sori small, copious; indusium rather persistent.

Malacca. Borneo.

* (3) A. platanifolium, Mett., Hk. Bk., Syn. Fil., 258; A. angulatum, Hk., Spec, Fil., IV, 44.

Rhizome erect, the scales dense, dark-brown, linear-subulate. Stipes tufted, 
15-40 c.M. long, ebeneous, naked or covered with numerous, minute, adpressed, glandlike, brown hairs, scaly at the base. Fronds $10-25$ c.M. each way, palmately and more or less deeply $5-5$-fid, cordate at the base. Terminal lobe \pm triangular, acuminate, lateral ones similar but smaller, the basal ones sometimes blunt. Texture papyraceo-herbaceous to subcoriaceous; each lobe with a prominent midrib; main veins distinct to the edge, connected by copious areolae, with free veinlets. Sori small, scattered, abundant; indusium peltate or reniform, often absent.

Malaya.

(4) A. calcareum, Pr., Hk. Bk., Syn. Fil., 259; Mett., Farng., IV, Phegop. \& Aspid., tab. XVIII, fig. 1-3; Tectaria calcarea, Copel., Philipp. Journ., II, 41 .

Rhizome subrepent. Stipes approximate, naked, 10-15 c.M. long. Fronds 30 c.M. or more long, $15-25$ c.M. broad, with $4-6$ stalked, distant, acuminate pinnae on each side below the pinnatifid apex, the lowest triangular, to 15 c.M. long, 7-10 c.M. broad, cut down to the rachis below in stalked, lanceolate, deeply and bluntly lobed pinnulae, the upper part lobed or more or less pinnatifid. Texture semicoriaceous; areolae very irregular, with free veinlets. Sori submarginal; indusium small, peltate or reniform.

Philippines.

nofereefreg $C . W$.

* (5) A. angulatum, J. Sm., Hk. Bk., Syn. Fil., 258.

Stipes 30-60 c.M. long, glossy, ebeneous, scaly below. Fronds 30-60 c.M. long, sometimes simple, usually with a large, cordate, entire or trifid terminal pinna and $1-2$ lateral ones on each side, the lowest $1 \mathfrak{b}-50$ c.M. long, $5-10$ c.M. broad, often forked at the base with $2-3$ branches, which are often unequal. Texture papyraceo-herbaceous; midribs glossy, ebeneous; main veins distinct to the edge; areolae fine, copious, with free, included veinlets. Sori small, scattered, abundant; indusium minute, fugaceous.

Malaya.

(6a) Kumstleri, Bedd., Handb. Ind. Ferns, Suppl., 44.

Stipe and rachis minutely pubescent. Fronds 30-45 c.M. long, deltoidovate, pinnate. Upper pinnae narrow-lanceolate, $\pm 12{ }^{1} / 2$ c.I. long, $1 \frac{1}{2}-21 / 2$ c.M. broad, entire or with scalloped margins, lowest pair broad-deltoid, the lower side produced towards the base into 5-4 long lobes, the largest lobes 
10-13 c.M. long, the upper side deeply scalloped. Texture rather coriaceous; surfaces naked except the main veins which are zigzag and tolerably prominent nearly to the margin; areolae rarely with free veinlets. Sori very small, numerous, scattered, generally on connected veinlets.

Malacca.

(6b) A. oligophyllam, Rst., Fed., Rep., V, 15.

Stipes tufted, 1 M. long or longer, straight, erect, clothed towards the base with lanceolate, long-acuminate, ferrugineous scales 1 c.M. long. Fronds to 50 c.M. long, 20 c.M. broad, pinnate (quinate). Pinnae simple, elongateovate, the lateral ones erecto-patent, more or less incurved, the base cuneate, the margin entire or obscurely repand, the apex long-cuspidate, lowest pinnae subopposite, \pm 50 c.M. long, \pm 7 c.M. broad, short-stalked, the stalks slightly marginate, highest pinnae sessile, smaller than the lowest ones, the very base decurrent, terminal pinna largest, the base long-decurrent, sometimes joining with the next following ones. Texture membranaceo-chartaceous; rachis naked, livid-brown, glossy, canaliculate above; surfaces naked; costae and veins stramineous, \pm prominent beneath; main veins erecto-patent, nearly straight, upcurved towards the apex; primary areolae subquadrangular, in \pm 9 rows on each side, divided into subhexagonal or irregular smaller ones, with copious included free veiniets. Fertile pinnae narrower than the barren ones. Sori large, numerous, compital, in \pm 18 longitudinal rows, 4-b to a row (in $4-5$ rows between the main veins?); indusium persistent, afterwards corrugate.

Sumatra.

* (7) A. Haenkei, Pr., Mett., Ann. Mus. Bot. L. B., I, 258.

Rhizome? Stipes \pm 15 c.M. long or longer, stramineous like the rachis. Fronds 30 c.M. long or longer, \pm 20 c.M. broad, broadly oblong, pinnate with 4 or more pinnae on each side below the terminal one. Terminal pinna oblong, sinuate or subpinnatifid, the base cuneato-rotundate, lateral pinnae erectopatent, to 15 c.M. long, \pm 3 c.M. broad, lanceolate-oblong, acuminate, falcate, narrowed at the base, or the upper base cuneate or truncato-rotundate and the lower one rounded, higher pinnae adnate to the rachis, the lower ones short-stalked, unequal-sided, sub-2-fid. Texture rigidly membranaceous; surfaces naked, or the upper one short-hairy on the costae only; main veins prominent, erecto-patent, upcurved; areolae in $4-5$ rows on each side of the 
costae, translucent, divided in smaller secondary ones. Sori in 2 rows, 2 or rarely 3 to each primary areola, dorsal on the veinlets; indusium persistent. Timor, (? Malaya); Marianne Islands.

\section{* (8) A. termatemse, v. A. v. IR.}

Stipes 50-45 c.M. long, naked, firm. Fronds \pm 45 c.M. long. Terminal pinna lanceolate, $\pm 10-15$ c.M long, \pm 2 c.M. broad, gradually narrowed towards both ends, the edge entire or irregularly sinuate, the apex acute or acuminate, lateral pinnae $6-8$ on each side, suberect, similar to the terminal one, the highest sessile, decurrent, free or joining with the terminal one, the lower stalked, the lowest forked at the base. Texture herbaceomembranaceous; surfaces naked; main veins fine, erecto-patent; areolae subquadrangular, in 2 rows between the main veins, each with a single, included, excurrent, free veinlet; costae prominent beneath. Sori copious, slightly immersed, 1 to each areola, terminal on the free veinlets, forming 2 regular rows between the main a veins, with $\pm b-7$ sori to a row; indusium persistent. Barren fronds not seen.

Ternate (Teysmann).

(9) A. Beccarixnum, Bki., Becc., Mal., III, 45; A. Cesalianum C. Chr., Ind. Fil.

Rhizome erect, densely clothed with firm, linear, acuminate, brown scales. Stipes tufted, brown, firm, \pm 30 c.M. long, sparingly paleceous above and below the centre. Fronds ohlong-deltoid, \pm 50 c.M. long, 2-3-pinnatifid. - Pinnae in \pm 3 opposite pairs, the lower ones short-stalked, inequilateral, deltoid, produced on the lower side. Lower pimnulae deeply pinnatifid, only adnate at the base. Segments oblong. Texture firm; surfaces naked like the castaneous rachis; main veins straight from the costa to the margin; veins immersed, obscure; areolae copious, hexagonal. Sori in 2 rows, parallel to the main veins; indusium large, glabrous, persistent.

New Guinea.

(10) A. repandum, Willd., Hk. Bk., Syn. Fil., 258; A. platyphyllum, Pr., Epim., 65 ; Sagenia repanda, Moore, Ind., 102; Tectaria crenata, Cav., Copel., Philipp. Journ., II, 414, p. p.

Stipes 50-75 c.M. long, furnished with a few hair-like scales near the base, naked upwards. Fronds 60-90 c.M. long, pimnatifid at the apex. Pinnae 4-8 on each side, $15-30$ c.M. long, 3--5 c.M. broad, linear-oblong, 
acuminate, slightly and bluntly sinuate, the base narrowed, the lowest stalked, 2-partite. Texture subcoriaceous; main veins distinct to the edge; areolae copious, with free veinlets. Sori large, in 2 rows betwen the main veins. Resembling A. pachyphyllum, Kze \& polymorphum, Wall. (Bk.)

Malacca, Borneo, Philippines, New Guinea.

\section{S 2. SAGENIA (*).}

1. Sori scattered irregularly.

2. Fronds pinnatifid.

*. Stipes not winged.

(11) A. Everetti.

*.*. Stipes long-winged.

(12) A. vastum.

2.2. Fronds simple or more generally pinnate, $3-\infty$-foliate.

3. Simple frond or terminal pinna entire or sinuate.

4. Fronds simple or 3-foliate.

\$. Stipes winged nearly to the base. (13) A. pteropodum.

S.S. Stipes not winged, or winged in the upper half only.

+. Rhizome wide-creeping.

(14) A. ternatum.

†. . Rhizome \pm erect.

(15) A. subcaudatum.

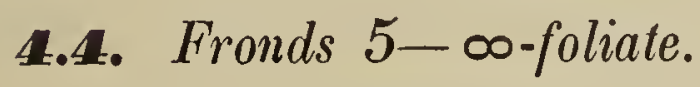

5. Lowest pinnae simple, or forked at the base.

6. Edges entire, crenate or repand.

8. Rhizome erect. (16) A. psilopodum.

8.ซ. Rhizome creeping. (17) A. polymorphum.

6.6. Edges sinuate.

(18) A. menyanthidis.

5.5. Lowest pinnae 3-partite or 3-nate.

*. Lateral pinnae \pm 2 on each side. Texture \pm coriaceous.

(19) A. Lobbii.

*.*. Lateral pinnae \pm 5 on each side. Texture \pm herbaceous. (20) A. semibipinnatum.

3.3. Simple frond or terminal pinna deeply lobed at the base.

a. Rhizome erect or ascending.

b. Stipes black.

c. Fronds mostly under 25 c.M. long.

(21) A. Weinlandii.

(*) See also A. platanifolium, Melt. \& calcareum, $P r$. 
c.c. Fully developed fronds more than 25 c.M. long.

(22) A. melanocaulon.

b.b. Stipes not black.

$\times$. Stipes greyish, finely villose.

(25) A. irriguum.

$\times \cdot \times$. Stipes castaneous, slightly scaly at the base.

(24) A. nebulosum.

a.a. Rhizome creeping.

(25) A. subtriphyllum.

1.1. Sori in 2 rows between the main veins $\left(^{*}\right)$, in 1 row on each side of the costae in No. 29.

a. Fronds palmatifid or pinnatifid.

$\beta$. Stipes winged nearly or quite to the base.

$\gamma$. Fronds $\pm 20-30$ c.M. long, the edges serrate or toothed.

(26) A. heterodon.

$\gamma . \%$. Fronds \pm 60-120 c.M. long, the edges entire, repand or sinuale.

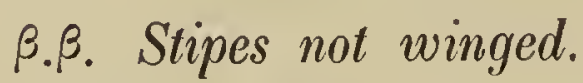

(27) A. decurrens.

(28) A. palmatum.

a.a. Fronds 3-nate, each division 3-partite.

(29) A. stenophyllum.

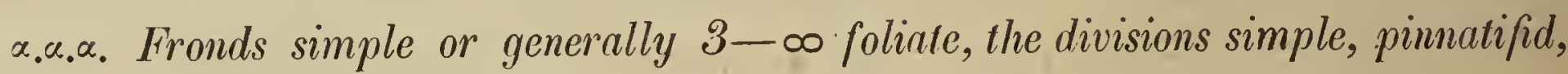
or even pinnate at the base.

$\beta^{\prime}$. Texture herbaceous to papyraceous.

$\gamma^{\prime}$. Stipes more or less densely hairy.

(50) A. Keckii.

$\gamma^{\prime} \cdot \gamma^{\prime}$. Stipes naked, or scaly at the base.

$\delta^{\prime}$. Lateral pinnae in $\pm 1-6$ pairs below the terminal one.

$\varepsilon^{\prime}$. Lowest pinnae pinnatifid or pinnate at the base.

$\times$. Stipes brown or rufous.

*. Central pinnae sinuate or slightly lobed.

(31) A. variolosum.

*.*. Central pinnae pinnatifid.

(52) A. coadunatum.

$\times . \times$. Stipes ebeneous.

(53) A. latifolium.

$\varepsilon^{\prime} . \varepsilon^{\prime}$. Lowest pinnae forled at the base. Fronds 60-90 c.M. long.

(54) A. grande.

$\delta^{\prime} . \delta^{\prime}$. Lateral pinnae in $\pm 9-11$ pairs, the $2-4$ lowest pairs 2-3-furcate.

(55) A. nudum.

$\gamma^{\prime} \cdot \gamma^{\prime} \cdot \gamma^{\prime}$. Stipes more or less scaly throughout.

(56) A. multicaudatum.

(") See also A. polymorphum, Wall. 
25. ASPIDIÚM. $\$ 2$. SAgení.

$\beta^{\prime} . \beta^{\prime}$. Texture generally chartaceous to coriaceous.

\$. Surfaces pubescent. Texture moderately firm.

(37) A. melanorachis.

\$.S. Surfaces naked. Texture \pm coriaceous except in No. 40.

*. Lowest pinnae simple. Sori dense, superficial.

(38) A. persoriferum.

*.*. Lowest pinnae forked, lobed or pinnatifid. Sori superficial.

$\times$. Fronds under 50 c.M. long. Sori in close rows, often confluent, on connecled reins. (59) A. siifolium.

$\times . \times$. Fully developed fronds often more than 50 c.M. long. 'Sori not in close rows, on free veinlets. Texture herbaceous to chartaceous.

(40) A. pachyphyllum.

*.*.*. Lowesl pinnae pinnate. Sori copious, immersed.

(41) A. brachiatum.

(11) Everenti, C. Chr., Ind. Fil.; Nephrodium Everetti, Bk., Kew Bull., 1896, 41.

Stipes slender, 15-20 c.M. long, naked, castaneous. Fronds deltoid, 20 -25 c.M. each way, cut down nearly to the costa. Lobes 2 on each side lanceolate or oblong-lanceolate, acuminate, entire, the lowest largest, $21 / 2 \ldots$ ? c.M. broad. Texture membranaceous; both surfaces naked; primary veins arcuate, reaching the margin; areolae small, copious, with free veinlets. Sori copious, scattered, small, superficial ; indusium membranaceous, persistent.

Natuna Islands.

* 12) vastum, Bt., Christ, Farnkr. d. Erde, 250; A. alatum, Wall., Hk. \& Grev., Ic. Fil., tab. CLXXXIV; Sagenia vasta, Moore, Rac., Flor. Btz., I, 196; S. alala, Bedd., Ferns. Br.I., II, tab. CLXIX ; Tectaria vasta, Copel., Philipp. Journ., II, 411.

Rhizome creeping or erect, clothed with rigid, brown, lanceolate, subentire scales. Stipes scattered or approximate, narrowly winged often nearly or quite to the base, 30-60 c.M. long. Fronds ovate, 30-120 c.M. long, 15-60 c.M. broad, cut down to a broadly winged rachis into entire, distant, linear-oblong segments 7-30 c.M. long, 2-5 c.M. broad, acute or acuminate, about $4-6$ on a side. Texture papyraceo-herbaceous or subcoriaceous; main veins distinct, reaching to $\pm 3 / 4$ of the way or nearly to the edge, Filices. 
connected with copious areolae with included free veinlets. Sori numerous, densely crowded, often confluent; indusium small, persistent.

Malaya; Burmah, North. India.

A. Dtenopolum, Diels, in Engl. \& Pranll, Nat. Pfl.Fam., 14, 183; Nephrodium pteropodum, Bli., Journ. of Bot., XXVI, 325; Sagenia pteropoda, Christ, Ann. Btz., XX, 108; (? Polypodium Scortechinii, Bk., C. Chr., Ind. Fil.).

Rhizome wide-creeping. Stipes with a narrow wing beginning $\pm \mathbf{5}$ c.M. from the base, $\pm 1 / 2-3 / 4$ c.M. broad, 30-45 c.M. above it. Fronds oblong-lanceolate, acuminate, entire, \pm 50 c.M. long, 7-10 c.M. broad, narrowed at the base gradually. Main veins distinct nearly to the edge; areolae with copious free veinlets. Sori minute, scattered irregularly, sometimes confluent; indusium minute, obscure.

Borneo.

* (14) A. tenmatuan, Diels, in Engl. \& Prantl, Nat, Pfl.Fam. I ${ }^{4}$, 184; Nephrodium ternatum, Bl., Hk. Bk., Syn. Fil., 296.

Rhizome wide-creeping, scaly. Stipes 15 -25 c.M. long, slender, stramineous. Fronds sometimes simple, $20-25$ c.M. long, ّ̋-8 c.M. broad, oblong, entire, narrowed gradually to the apex and base, but more usually trifoliate, the lateral pinnae like the terminal one but smaller. Texture papyraceoherbaceous; main veins distinct nearly to the edge; areolae copious, but rather large, with few free veinlets. Sori distant, in 2 distinct rows and others scattered between; indusium distinct.

Borneo.

* (15) : A. subcandaturit, *. A. 2.

Rhizome erect or suberect, the scales linear-lanceolate, \pm acuminate, dark-brown. Stipes \pm tufted, erect, naked, or scaly at the base, 6-12 c.M. long, the upper $1 / 2-1 / 5$ narrowly winged by the decurrent base of the frond except in the truly trifoliate forms. Fronds simple, deeply 5-fid or 3 -foliate, with the central leaflet similar to the simple fronds, lanceolate, $15-25$ c.M. long, 4-5 c.M. broad below the middle, the base cuneate, \pm gradually narrowed, the margin entire or repand, the apex long-acuminate, subcaudate; lateral leaflets similar but smaller and narrower, erecto-patent, slightly upcurved, free or joined at the base with the terminal one. Texture papyraceous; surfaces naked; costae and main veins prominent; main veins 
distinct nearly to the edge, slightly upcurved; areolae distinct, fine, with numerous free veinlets. Sori not copious, scattered irregularly, some of them sometimes confluent; indusium fugacious.

Bornco (Teuscher).

(16) psillopodum, C. Chr., Ind. Fil.; Nephrodium subdigitulum, Bk., Journ. of Linn. Soc., Bot., XXIV, 259; Sagenia subdigitata, Chrisl, Ann. Btz., XX, 100.

Rhizome erect. Stipes densely tufted, 7-10 c.M. long, with a few, spreading, black-brown scales near the base. Fronds small, deltoid, subdigitate. Pinnae $\breve{b}-7$, lanceolate, acuminale, the edge entire or repand, the lower ones usually forked at the base, the terminal one the largest, distinctly stalked, $\pm 7-8$ c.M. long, $1-1 \frac{11}{2} \quad$ c.M. broad at the middle, distinctly repand, narrowed gradually to both ends. Surfaces naked; no distinct main veins; areolae copious. Sori not very small, irregularly scattered; indusium firm, persistent.

Bomeo.

* (17) Dolymorplonen, Ealt., Chrisl, Farnkr. d. Erde, 229; Bedd., Ferns S.I., tab. CXVI; A. grandifolium, Mell., Farng., IV, Phegop. \& Aspid., 124; A. angulaum, Christ (not J. Sm.), Bull. Herb. Boiss., $2^{\mathrm{e}}$ Série, VI, 1003; Neplirodium polymorphum, Bk., Hk. Bk., Syn. Fil., 297; Sagenia polymorpha, Chrisı, Ann. Btz., XX, 108; Tectaria polymorpha, Copel., Philipp. Journ., II, 413; - var. Wightii: N. Wightii, Clarke, Trans. Linn. Soc., Bot., 2d Series, I, 558, tah. LXXVI; - var. subvariegatum, Hor't. Bog.

Rhizome creeping. Stipes seriate, to 30 c.II. long or longer, brown, naked or \pm scaly. Fronds $30-120$ c.M. long, $25-45$ c.M. broad. Terminal pinna lanceolate-oblong; $10-50$ c.Mr. long, $2-8$ c.M. broad, entire, acuminate, \pm rounded at the base; below this $2-6$ similar, lateral pinnae on each side, the higher ones \pm sessile or adnate to the rachis, mostly distinct, rarely joined with the terminal one, the lower ones \pm stalked, often forked at the base on the lower side. Texture papyraceous to coriaceous; rachis brownish, naked or nearly so; surfaces naked; areolae fine, with copious free veinlets. Fertile pinnae not contracted. Sori small, abundant, scattered, placed on the connected veins; indusium mostly present, reniform or peltato-cordate to orbicular, the edge not rarely irregularly fimbriate.

War. Whightii: Fertile pinnae contracted; sori in 2 rows between the main veins. 
Var. subvariegatum: Like var. Wightii but the fronds inconspicuously variegated with green and pale-green.

Malaya; North. India, Burmah, Ceylon.

(18) A. menyanthirlis, Pr., Copel., Polypod. Philipp., 38 ; Nephrodium Menyanthidis, Bk., Hk. Bk., Syn. Fil., 297; Tectaria Menyanthidis, Copel., Philipp. Journ., II, 414.

Rhizome creeping. Stipes $15-30$ c.ll. long, naked, brownish. Fronds 30-60 c.M. long, 30 c.M. or more broad, with an acuminate, oblong-lanceolate, sinuate, terminal pinna $15-30$ c.M. long, $2 \frac{1}{2}-4$ c.M. broad; below this 2-4 similar pimnae on each side, the lowest stalked, sometimes forked. Texture subcoriaceous; main veins close, conspicuous, reaching the edge; areolae fine, with copious free veinlets. Sori small, on the comnected veins.

Philippines, New Guinea; Salomon Islands.

(19) A. Hobbii, Hk., Spec. Fil., IV, 49, tab. CGXXXII; Nephrodium Lobbii, Bk., Hk. Bk., Syn. Fil., 297; Sageniu Lobbii, Christ, Ann. Btz., XX, 100 .

Stipes 15 c.Mr. or more long, naked, substramineous. Fronds \pm 30 c.M. each way, subdeltoid, with an entire terminal pinna 10-15 c.Ir. long, 1-2 c.M. broad, tapering gradually from the middle to each end, and 2 similar lateral ones on each side, the lowest long-stalked and tripartite or ternate. Texture subcoriaceous; veins obscure, the main ones close and very ohlique; areolae without free veinlets. Sori copious.

Borneo.

* (20) A. semibipinnatum, Wall., Hk., Spec. Fil., IV, 59, tab. GCXXXI; Nephrodium semibipinnalum, Bli., Hk. Bk., Syn. Fil., 297.

Stipes 30 c.I. or more long, pale-brown, naked. Fronds $50-45$ c.ll. long, $15-25$ c.M. broad, with a long terminal pinna $15-25$ c.M. long, \pm $21 / 2$ c.M. broad, entire and narrowed towards both ends; below this $\pm 3-6$ lateral pinnae on each side, the lowest $1-2$ pairs tripartite or ternate. Texture papyraceo-herbaceous; veins inconspicuous, the main ones not reaching the edge; areolae fine, close, with free veinlets. Sori minute, confined to the connected veins.

Malacca, Banca, Borneo.

(21) A. Weinlandii, Christ, Bull. Herb. Boiss., 2 Série, I, 450ँ. : 
Rhizome suberect. Stipes subtufted, 10-20 c.M. long, slender. Rachis, main veins (and partially also the veins) blackish. Fronds $\pm 10-20$ c.M. long, 10-15 c.M. broad, ternate. Terminal division long-stalked, cuneate or subcordate, long-acuminate, 3 -lobed, the lobes produced, with the margin broadly lobato-dentate, lateral divisions falcate, short-stalked, lobed, the lowest lobes on the lower side much produced. Texture herbaceous; surfaces naked; veins fine but conspicuous, reaching the margin; areolae with free veinlets. Sori central in the lobes, or scattered, deciduous, minule; indusium fugacious.

\section{New Guinea.}

* 22) A. melanocanter, Bst., Copel., Polypod. Philipp., 57: Sagenia melanocaulon, Moore, Rac., Hlor. Btz., I, 193̈; Nephrodium melanocaulon, Bk., Hk. Bk., Syn. Fil., 296; Tectaria melanocaulon, Copel., Philipp. Journ., II, 416.

Rhizome erect or ascending, clothed with black-brown, lanceolate scales to $10 \mathrm{m.M}$. long. Stipes 50-50 c.M. long, ebeneous, glossy, scaly at the base. Fronds $3 \mathfrak{C}-90$ c.Il. long, 15 - 50 c.M. broad, ovate- or lanceolatedeltoid, with a large, deeply pinnatifid terminal pinna and $1-4$ lateral ones on cach side, the highest ones entire or lobed, the central ones mostly deeply pinnatilid with oblong, acuminate lobes, the lowest stalked, 8-50 c.M. long, to 7-15 c.M. broad, often again pinnate at the base. Texture herbaceopapyraceous; rachises ebeneous, glossy, naked or the upper side pubescent or glandular; both surfaces naked; main veins reaching the edge; areolae numerous, fine, with free veinlets. Sori numerous, minute; indusium small, fimbriate, fugacious.

Malaya; Eası. China, Tonkin.

* (23) A. irorisumm, J. sm., Copel., Polypod. Philipp., 38; Neplirodium irriguum, Bk., Hk. Bk., Syn. Fil., 297; Teclaria irrigua, Copel., Philipp. Journ., II, 415, p. p.

Stipes tufted, $10-15$ c.M. long, greyish, finely villose. Fronds $15-50$ c.M. long, 10-20 c.M. broad, subdeltoid, with a large, oblong, terminal pinna with a pair of deep, lanceolate lobes at the base; below this $1-2$ pairs of slightly sinuate lateral pinnae, the lowest forked at the hase. Texture papyraceo-herbaceous; main veins flexuose; areolae fine, copious, with free veinlets. Sori small, often confluent; indusium small, fugacious.

Philippines, Amboyna. 


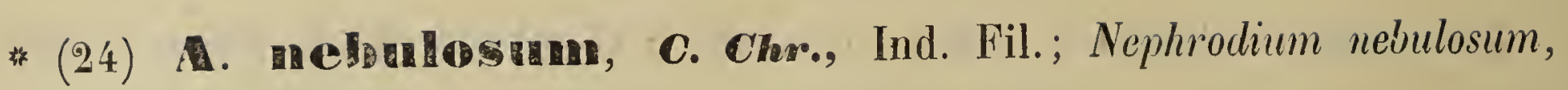
Bk., Jourll. of Bot., XVIII, 213.

Stipes tufted, castaneous, \pm 45 c.M. long, with only a few, small, brown, lanceolate scales at the base. Fronds deltoid, 30-40 c.M. long, rather less broad, with a deeply pinnatifid, large terminal pinna with short, obtuse upper lobes and large, lanceolate lower ones; below this $2-4$ lanceolate, free pimnae, the lowest ones unequal-sided and forked at the base on the lower side. Texture moderately firm; both surfaces naked; main veins distinct to the edge, slender, erecto-patent, with very copious areolae between them, with free veinlets. Sori very abundant, minute; indusium minute, very fugacious.

Sumatra.

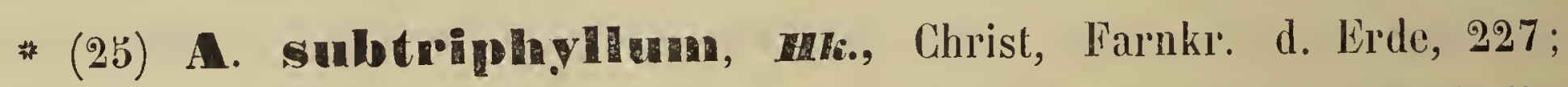
Nephrodium sublriphyllum, Bí,. Hk. Bk., Syn. Fil., 296; Sagenia subtriphylla, Bedd., Ferns Br.I., I, tab. XLVIII; Ferns S.I., tab. CCXLII; Tectaria sublriphylla, Copel., Philipp. Journ., II, 410.

Rhizome creeping. Stipes 50 c.M. long or longer, substramineous or brownish. Fronds 30-90 c.M. long and 20-75 c.M. broad, rarely smaller, subdeltoid, with a large, often deeply pinnatifid apex with entire or broadly toothed, lanceolate lobes; below this $1-2$ pinnae on eacli side, the lowest stalked, distant, forked at the base or pinmatifid, the apex lanceolate. Texture herbaceous to semicoriaceous; surfaces somewhat hairy beneath and on the main veins above; main veins distinct to the edge; areolae fine, with copious free veinlets. Sori often moderately large, confined to the united veins.

Malaya; Polynesia, China, Burmah, Ceylon.

(26) A. Leterodon, Copel., Polypod. Philipp., 56; A. Copelandii, C. Chr., Ind. Fil.; Tectaria decurrens, Copel., Philipp. Journ., II, 412, p. p.

Rhizome erect, woody. Stipes 15-20 c.M. long, naked or nearly so, winged, the wing $\pm 5 \mathrm{~m}$.M. broad on each side, narrowed gradually towards the base. Fronds $20-30$ c.M. long, 3-5-partite. Terminal (or central) segment oblanceolate, 4-5 c.M. broad, acuminate, irregularly serrate or toothed, the teeth $0-1$ c.M. long, lateral segments smaller, erecto-patent, obscurely serrate. Texture herbaceous; surfaces naked; main veins reaching the margin; areolae irregular, with free veinlets. Sori large, in rows near the main veins; indusium persistent.

Philippines. 
* (27) A. Alecurrens, Pr., Christ, Farnkr. d. Erde, 229; A. pleropus, Kze, Bedd., Ferns S.I., tab. LXXXII; Sagenia decurrens, Houlst. (not Moore), Rac, Flor. Btz., I, 196; Nephrodium decurrens, Bk., Hk. Bk., Syn. Fil., 299; Teclaria decurrens, Copel., Philipp. Journ., II, 412, p. p.; - var. mamillosum; A. mamillosum, C. Chr., Ind. Fil.; S. mamillosa, Moore, in Gard. Chron., N. S., XXVI, 330.

Rhizome creeping.or erect, scaly. Stipes 20-30 c.M. long, winged often nearly or quite to the base. Fronds 60-120 c.M. long, 30-60 c.M. broad, cut down to a winged rachis into $5-8$ pairs of entire, repand or sinuate linear-oblong, acuminate laciniae $15-30$ c.M. long, 2-6 c.M. broad, terminal segment similar, the lowest ones often bifurcate. Texture herbaceous or subcoriaceous; surfaces naked; main veins distinct to the edge, connected by copious areolae with free veinlets. Sori rather large, in 2 rows between the main veins; indusium persistent. - Resembling A. vastum, $B l$.

Var. Imomillostrinat: Sori deeply immersed so as to form prominent papilliae on the upper surface of the frond.

Malaya; Norlh. India, Soulh. China, Polynesia; - var. mamillosum: Malaya.

(28) A. palmatum, Mett., Ann. Mus. Bot. L. B., I, 258; Sagenia palmala, Christ, Ann. Btz., XX, 108.

Rhizome short, erect; the scales lanceolate, ciliate or dentate, ferrugineous, nearly glossy. Stipes densely tufted, 50-40 c.M. long, glossy, purpureous. Fronds $15-25$ c.II. long, $20-25$ c.M. broad, palmatipartite, cordate at the base. Central segment ovate-oblong, acuminate, the lateral ones 2 -fid with a large, falcate, erecto-patent, anterior lobe and a smaller, spreading posterior one. 'Texture membranaceous or thinly chartaceous; surfaces naked; costae and veins prominent; primary areolae in 6-8 rows on each side, divided into nearly regular smaller ones. Sori in 2 regular rows between the main veins; indusium rigid, roundish-reniform, subpeltate, with a short-toothed margill.

Sumalra, Borneo.

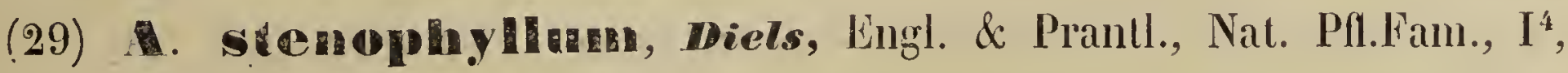
183; A. ILosei, C. Chr., Ind. Til.; Nephrodum IIosei, Bk., Ann: of Bot., V, 550 ; N. stcnophyllum, Bk., Journ. of Linn. Soc., Bot., XXII, 227, tab. XI.

Stipes slender, tufted, naked, castaneous, 10-15 c.M. long. Fronds ternate, 10-13 c.M. each way, the lateral segnients nearly as long as the central one, each made up of 5 linear, entire, acuminate free or joined, secondary 
25. ASPIDIUM. $\$ 2$. SAGENIA.

segments $5-8$ c.M. long and $6-7$ m.M. broad at the middle, tapering gradually to the base. Surfaces naked; veins faint and indistinct; areolae copious, hexagonal. 'Sori in a single, irregular row on each side of the central vein of the segments; indusium large, naked, persistent.

Borneo.

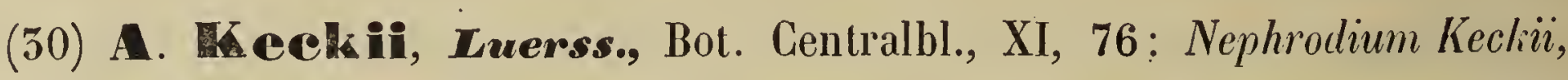
Bk., Ann. of Bot., V, 350 .

Stipes \pm 40 c.M. long, red-brown, \pm densely clothed with small, ferrugineous hairs, \pm rough below, slightly canaliculate. Fronds \pm 48 c.M. each way, deltoid-ovate, 2-pinnatifid. Terminal pinna deeply pinnatifid, the lobes \pm falcate, entire, acuminate, the lowest lobe bluntly lobed; below this 2 pairs of lateral pinnae, which are \pm falcate, acuminate, wilh the lower side more or less deeply lobed, the lobes blunt or acuminate, falcate, lowest pinnae on stalks \pm 5 c.M. long. Texture papyraceous; rachis, costae and main veins hairy like the stipe; main veins distinct nearly or quite to the edge; areolae moderately large, with free veinlets. Sori few, in short, regular rows, large; indusium large, membranaceous, naked, persistent.

Sumatra.

* (31) A. variolosum, Walt., Christ, Farnkr. d. Erde, 228; A. Zollingerianum, Bedd., Ferns Br.I., II, tab. CGLI; Nephrodium variolosum, Bli., Hk. Bk., Syn. Fil., 298.

Stipes to 30 c.M. or more long, naked, or scaly near the base, brownish. Fronds 1 b-4ว c.M. long, $10-50$ c.M. broad, subdeltoid, the apex deeply pinnatifid with lanceolate, acuminate, entire or sinuate lobes; below this \pm 2-3 pairs of lateral, lobed or sinuate pinnae, the lowest much the largest, often cut down nearly or quite to the rachis at the base with more or less deeply pinnatifid pinnulae, the higher ones less divided. Texture papyraceoherbaceous; surfaces naked or somewhat, puberulous; main veins distinct; areolae rather large, with free veinlets. Sori large, in rows near the main veins, terminating free veinlets. - Resembling A. subtriphyllum, H/s.

Malaya; North. India, Burmah.

(32) A. condunatam, Wall., Christ, in Philipp. Journ., II, 187; Mett., Farng., IV, Phegop. \& Aspid., 118, p. p.; Hk. \& Grex., Jc. Fil., tab. C.CII; A. cicularium, Christ, Farnkr. d. Erde, 250, p. p.; (Sw., C. Chr., Ind. 
Fil., p p.); Teclaria Christii, Copel., Philip. Journ., II, 416; Sagenia coadunala, J. Sm., Bedd., Ferns S.I., tab. LXXXI.

Stipes rufous, \pm naked, sparingly scaly at the base, the scales acute, flaccid, brown. Fronds 50-90 c.I. long, pinnate, the rachis naked, smooth, glossy, flavido-rufous. Pinnae pinnatifid, $\pm 1-4$ on each side bolow the deeply pinnatifid terminal one, the lowest largesı, ovate-lanceolate, acute, deeply pinnatifid, the lobes broadly ovate, obtuse or subacute, crenate or lobed. Texture thin, diaphanous; upper surface clothed with short, white pubescence, the margins ciliate; costulae slightly pubescent; veins copiously anastomosing, with copious, included, clavate, free veinlets. Sori in 1 row on each side of the costulae; indusium orbicular-reniform, with a pale margin. - This species was often confounded with the american A. cicutarirum, Sw., which is quite another plant. - Trop. Asia.

Christ describes another form in Philipp. Journ., II, 187: Aspidium malayense, Christ (Teclaria malayensis, Copel., l. c., 416), distinguished from this by the scaly stipes, the naked fronds, the less copiously anastomosing veins, the rather wanting included veinlets and the peltate indusia. - Malacca, Singapore, Luzon.

(33) A. Iatifolium, J. Sm., Journ. of Bot., III, 410; Nephrodium latifolium, Bk., Hk. Bk, Syn. Fil., 298; (? Tectaria melanocaulon or sïfolia Copel., Philipp. Journ., II, 418); T. lalifolia, Copel., I. c., 416.

Stipes 50 c.II. or more long, glossy, ebeneous. Fronds $60-90$ c.M. long, 50-45 c.M. broad, the apex deeply pinnatilid with lanceolate-acuminate lobes, the lower lobes sinuated; below this $\breve{\jmath}-5$ pinnae on each side, the lowest much the largest, 20-30 c.M. long, $15-20$ c.M. broad, deeply pinnatifid above, pinnate at the base, lobes acute. Texture papyraceo-herbaceous; rachis glossy like the stipe; main veins distinct to the edge; areolae fine, with copiuus free veinlets. Sori in irregular rows near the main veins, mainly or entirely on the connected veins.

Celebes, Amboyna, New Guinea; Polynesia.

(34) A. grande, J. Sm., Copel., Polypod. Philipp., 36; A. grandifolium, Pr., C. Chr., Ind. Fil.; Nephrodium grande, Bk.; Ann. of Bot., V, 350 ; Teclaria grandifolia, Copel., Philipp. Journ., II, 413.

Stipes rufescent, shining. Fronds $60-90$ c.M. long, ovate-oblong, pinnate. Lateral pinnae in 5-6 pairs below the deeply 3 -fid apex, \pm 25 c.M. long, $6-61 / 2$ c.M. broad, oblong-lanceolate, caudato-acuminate, slightly sinuate, the 
lowest ones stalked, cuneately rounded at the base, decurrent upon the petiole, unequally 2-partile. Texture membranaceous; surfaces naked; venation as in Drynaria; primary areolae in serveral rows on each side of the costae. Sori in 2 rows between the main veins and approximate to them, 2 in each primary areola; indusium with a short sinus.

Philippines.

A. Indism, Diels, in Schum. \& Laut., Flor. deut. Sch. geb., 116; Nephrodium mudum, Bk., Journ. of Bot., XVII, 41.

Stipes \pm 60 c.M. long, pale-brown, naked Fronds oblong-deltoid, 45-60 c.M. long, $15-50$ c.II. broad. Terminal piuna lanceolate, $15-30$ c.I. long, $2-2 \frac{1}{2}$ c.M. broad, much acuminate, the edge entire, the base gradually narrowed; below this 9--11 distant, sessile, similar but smaller pinnae, the lowest stalked, the 2-4 lower bi- or trifurcate from the base. Texture membranaceous; rachis and surfaces naked; main veins erecto-patent, distinct to the edge; areolae copious, small, irregular, with free veinlets. Sori in regular rows near the main veins; indusium naked, persistent.

Borneo; Bismarcle Islands.

(56) A. multicaudatum, Wall., Bedd., Handb. Ind. Ferus, 222; Nephrodium multicaudahum, Clarke, Trans. Limn. Soc., Bot., 2⿺ Series, I, tab. LXXVII: Sagenia Griffithii, Bcdd., Ferns Br.I., II, tab. CCGXXXVII.

Stipes 30-90 c.II. long, brownish, often densely clothed (nearly ils whole length) with linear-subulate, brown, persistent scales. Fronds $90-120$ c.II. long, pinnate. Terminal pinna large, deeply pinnatifid, the lobes lanceolate-acuminate; below this several lateral pinnae on each side, the lowest deltoid, \pm 30 c.M. or more long and nearly as broad, deeply pinnatifid above and pinnate below. Texture firm, herbaceous; rachises rusty beneath; main veins distinct to the edge; areolae with copious free veinlets. Sori rather large, in 2 rows between the main veins or more numerous and scattered, generally terminal on free veinlets; indusium reniform or peltate.

Malacca; North. India, Burmah.

(37) A. melanorachis, C. Cher., Ind. Fil.; Nephrodium melanorachis, Bli., Journ. of Bot., XXVI, 325.

Stipes black, \pm 46 c.Mr. long, scaly on the lower half, but more densely at the base, the scales linear, spreading, brown. Fronds oblong-deltoid, 2-pinnatifid, $45-60$ c.M. long, \pm 30 c.M. broad. Pinnae \pm 5 on each side, the terminal one pinnatilid, the lowest much the largest, deltoid, produced on the 
lower side, deeply pinnatifid, the lobes lanceolate. Texture moderately firm; both surface sfinely pubescent; main veins distinct to the margin; areolae witl copious free veinlets. Sori 2-serial, approximate to the main veins; indusium small, membranaceous, \pm persistent.

Borneo.

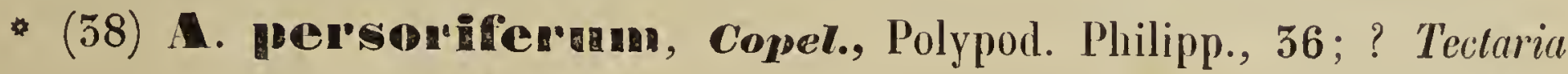
crenala, Cav., Copel., Phillipp. Journ., II, 414, p.p.

Rhizome short, ascending. Stipes 40-60 c.M. long, stramineous or brown, the base clothed with lanceolate, arcuate scales $\pm 12 \mathrm{~m}$.M. long, the rest naked like the rachis. Fronds $50-50$ c.ll. long, ovate, pinnate, the barren ones the largest. Terminal pinna \pm 25 c.M. long, \pm 7 c.M. broad, acuminate, entire or subrepand; below this $\mathbf{3}$-5 lateral pinnae on each side, which are sessile, erecto-patent, straight or subarcuate, lanceolate, 15-20 c.M. long; fertile pimiae smaller, \pm 10 c.M. long, \pm 2 c.M. broad, obscurely crenate, the lowest stalked. Texture subcoriaceous; surfaces naked; main veins almost reaching the margin: areolae irregular, with included, free veinlets. Sori large, in 2 rows between the main veins, ahmost covering the entire lamina; indusium persistent. - $\mathrm{A}$ for'm from Borneo, cultivated in the Buitenzorg gardens has the pinnae of both barren and fertile fronds \pm 2 $X$ as broad as in the philippine plant (forma latipinni).

Mindanao, Borneo.

*59) S. Sillonimu, Metr., Ann. Mus. Bot. L.B., I, 257; A. menisciicarpon, Mell., Farng., IV, Phegop. \& Aspid., No. 287; A. biserialum, Chrisl, Bull. Herb. Boiss., $2^{e}$ Série, VI, 1002; Nephrodium siifolium, Bli., Hk., Bk., Syn. Fil., 299; Teclaria siifolia, Copel., Philipp. Joùrn., II, 414; - var. Teysmannianum, Christ, Amn. Btz., XV, 158; A. Teysmannianum, Hk., Spec. Fil., IV, tab. CCXXXVI; - var. subtrifoliatum, Christ, l. c.

Rhizone oblique, the scales black-brown. Stipẹs few, tufted, $15-4 b$ c.II. long, brownish, naked, or scaly at the base. Fronds 30-45 c.M. long, $13-20$ c.M. broad, with a broad, oblong, acuminate, terminal pimna and 2-4 lateral ones on each side. Lateral pinnae short-stalked or sessile, the lower ones stalked, $7-15$ c.M. long, 4-6 c.ll. broad, bipartite, the margin rather deeply lobed. Texture subcoriaceous; main veins close, distinct to the edge; areolae fine, copions, with free veinlets. Sori large, copious, in 2 close rows, the contiguous pairs often confluent, on connected veins; indusium ciliate. Fertile pinnae $i-10$ c.M. long, lanceolate, acuminate. 
War. Teysmumnianum: Pinnae wavy, broadly crenate or sinuate.

Var. subtrifoliatuma: Barren fronds with a broad, ovate, terminal pinna to \pm 16 c.M. long, to \pm 8 c.M. broad and below this conmonly 1 pair of similar lateral pinnae. Fertile pinnae small, subentire, in $2-5$ pair's.

Malaya; Polynesia; - var. Teysmannianum: Sumatra, Celebes; - var. subtrifoliatum: Celcbes.

* (40) A. pachyphyllum, Tze, Christ, Farnkr.d. Erde, 229; Diels, in Engl. \& Prantl, Nat. Pfl.Fanı., I*, lig. 97, A-C; A. siifolium, Mell., var. pachyphyllum, Christ, Ann. Bt.., XV, 158; Sigenia pachyphylla, Moore, Rac., Flor. Btz., I, 19:3; Nephrodium puchyphyllum, Bk., Hk. Bk., Syn. Fil., 299; Tectaria crenala, Cav., Copel., Philipp. Journ., II, 414, p. p.

Caudex erect, to 10 c.M. high, the scales ovate-lanceolate, dark-brown. Stipes 50-50 c.M. long, naked, brownish, scaly at the base. Fronds 60-100 c.M. long, \pm half as broad, with an oblong-lanceolate, entire or sinuate terminal pinna $10-50$ c.II. long, 2-b c.M. broad, often deeply pinnatifid at the base; below this $2-8$ erecto-patent, entire or repand lateral pinnac on each side, the lowest lobed, forked or pinnatifid on the lower side. Fertile pinnae often narrower, or even \pm contracted. Texlure herbaceous to chartaceous; main veins straight or slightly curved, distinct nearly to the edge; areolae fine, with copious free veinlets. Sori large, in regular rows, distant, on free veinlets; indusium entire.

Malaya; Polynesia.

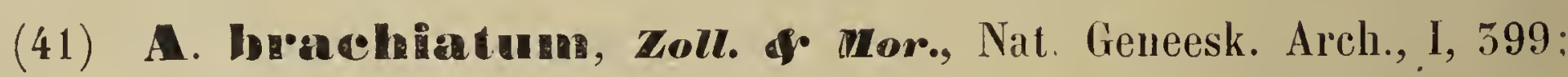
A. Zollingerianum, Kze, Bot. Zeit., 1846, 462; A. imp'essum, Hk., Spec. Fil., IV, b8; Nephrodium Zollingerianum, Bk., Hk. Bk., Syn. Fil., 298.

Stipes $20-50$ c.M. long, naked. Fronds $20-30$ c.M. long, 15-20 c.M. broad, subdeltoid. Terminal pinna deeply pinnatifid; below this $3-4$ lateral pinnae on each side, the lowest largest, long-stalked, deltoid, cut down below into distinctly separated, deeply pinnatifid pinnulae with blunt, linear-oblong lobes. Texture subcoriaceous; veins beneath prominent, anastomosing principally in large costular arches; areolae large, with included free veinlets, depressed so as to form cavities in which on the ends of the free veinlets the large, copious sori are placed.

Java. 


\section{CYRTOMMIUM, Prest.}

Sori round, terminal on the included free veinlets. Indusium round, peltate.

Rhizome erect. Stipes not articulate to the rhizome. Fronds pinnate with the pinnae whether or not \pm auricled at the base, the base \pm rounded; veins pinnate from a central costa, angularly anastomosing, forming \pm hexagonal areolae within which are $1-3$ included, excurrent free veinlets. Bedd., Handb. Ind. Ferns, fig. 206. (Polystichum p. p., C. Chr., Ind. Fil.).

Asia and Africa.

* falcatum, Pr., Bedd., Handb. Ind. Ferns, 211; Aspidium falcatum, Sw., Hk. Bk., Syn. Fil., 257; Hk., Fil. Exot., tab. XCII ; Polystichum falcatum, Diels, in Engl. \& Prantl, Nat. Pfl.Fam., I*4, 194; C. Chr., Ind. Fil.; - var. caryotideum, Bedd., Handb. Ind. Ferns, 211; C. caryotideum, Pr., Tent. Pterid., 86; Bau. \& Hk., Gen. Fil., tab. XLIX, C; Bedd. Ferns S.I., lab. CXIX; A. caryolideum, Wall., Hk., Gard. Ferns, tab. XIII; Hk. \& Grev., Ic. Fil., tab. LXIX.

Rhizome short, erect, clothed like the base of the stipes with large, dark-culoured scales. Stipes tufted, 13-50 c.M. long. Fronds 50-60 c.M. long, 15-25 c.II. broad, ovate. Pinnae \pm 10-12 on each side, ovate-acuminale, subfalcale, \pm erecto-patent, 10-15 c.M. long, $21 / 2-b$ c.M. broad, the point acuminate, the edge entire or slighlly undulate, the upper base suddenly narrowed or broadly rounded, sometimes auricled, the lower base narrower. Texture coriaceous; surfaces naked. Sori copious, scattered.

Var. cotidenn: Pinnae sharply toothed, slightly lobed, sometimes auricled on 1 or on hoth sides at the hase.

Malaya; Ceylon, Br. India, China, Japan, Sandwich Islands, South. Africa, Madagascar. 

TRIBE III, DAVALLIEAE. 



\section{CYSTORTEREIS, Hernhardi.}

Sori roundish, dorsal on a vein or veinlet. Indusium membranaceous, round and cucullate or lanceolate, convex, covering the sorus, but at length more or less reflexed or fugacious, attached at the inner side of the receptacle, opening towards the apex or the margin of the segment.

Rhizome creeping or erect. Stipes not articulate to the rhizome. Fronds bipinnate or more compoundly divided; veins free, forked or pinnate. Diels, in Engl. \& Prantl, Nat. Pfl.Fam., I ${ }^{4}$, fig. 89, B-G.

Ferns inhabiting the temperate zones and the alpine regions of the tropics.

*. Stipes dark-purplebrown. Indusium ligulate, fugacious. (1) G. tristis. *.*. Stipes stramineous. Indusium semiorbicular or transversally oblong.

(2) C. tenuisecta.

* 1) C. tristis, Mett., Ann. Mus. Bot. L. B., I, 241; Davallia tristı, Rac., Flor. Btz., I, 151; Alsophila tristis, Bl., Hk. Bk., Syn. Fil., 44; C. Chr., Ind. Fil.; Aspidium tristis, Bl., Enum., 169.

Rhizome erect, short, densely clothed with entire, lanceolate, brown scales. Stipes $50-90$ c.M long, \pm 7 m.M. thick at the scaly, tuberculato-asperous base, purple-brown, villose towards the rachis. Fronds ovate-lanceolate to deltoid, \pm 45-90 c.M. long, \pm 40-60 c.M. broad, 3-pinnate, Pinnae ovate to lanceolate, acuminate, short-stalked, the largest to 10 c.M. broad. Pinnulae lanceolate, short-stalked. Ultimate segments sessile, narrowed at the base, $5-12 \frac{1}{2}$ m.M. long, to \pm 4 m.M. broad, oblong, obtuse, incised to \pm $1 / 2$-way down to the costa, more or less decurrent. Texture subcoriaceous; rachises and costae pilose or fibrillose especially beneath; veins simple or forked. Sori 1 to each lobule, covered by a small, at length reflexed, fugacious, ligulate indusium; receplacle elevated.

Java.

(2) C. tenuisecta, Mett., Ann. Nus. Bot. L. B. I, 241 ; Alsophila tenuisecta, Bl., Moore, Ind., 58; Aspidium lomisectum, Bl., Enum., 170.

Filices. 
Rhizome short, oblique, clothed like the young fronds with large, membranaceous, ferrugineous, ovate-lanceolate, acuminate scales. Stipes stramineous, to 45 c.M. long, scaly at the base, purveyed like the rachis with articulated hairs and minute tubercles. Fronds to 45 c.II. long, ovate-lanceolate. Pinnae subsessile, subopposite, spreading, subdivaricating, 15-30 c.M. long, oblonglanceolate, the lower ones distant. Pinnulae numerous, approximate, spreading, $\breve{b}-8$ c.M. long, $\mathbf{1 b - 2 5} \mathrm{m}$. M. broad, oblong-lancecolate. Tertiary divisions oblong, obtuse, the lower ones sessile, pinnatifid, the higher ones adnate, shortly toothed or crenate. T'exture membranaceous, flaccid or firm; costae and veins sparingly hairy; under surface glandular; veins fine. Indusium transversely oblong or semiorbicular, with the margin fimbriato-glandular, at length reflexed.

Java.

\section{ODONTTOSURIA, Prest.}

Sori roundish or transversally oblong, terminal or subterminal on the ultimate segments of compoundly divided fronds, solitary on the vein tips or uniting the tips of $\pm 2-5$ veins. Indusium of the same shape, attached at the inner side of the sorus, opening outwardly.

Rhizome short. Stipes not articulate to the rhizome. Fronds compound; ultimate segments more or less narrowly cuneate, the apex \pm trurcate. Diels, in Engl. \& Prantl, Nat. Pfl.Fam., I ${ }^{4}$, fig. 116, D.

Pantropical.

Arrangement of the sections.

$\$$ 1. EU-ODONTOSORIA. Fronds small or middle-sized, erect, not climbing. S2. STENOLOMA. Fronds long, climbing. (Not in Malaya).

\section{$\$ 1$. EU-ODONTOSORIA.}

5. Sori solitary on the vein tips, 1-2 to a lobe.

*. Lower pinnae not caudate al the apex.

(1) 0 . chinensis.

*.*. Lower pinnae caudate at the apex.

(2) 0 . biflora.

5.S. Sori uniting the apices of 2 or more veins or veinlets, occupying the whole breadth of the lobes.

(3) 0. retusa.

4) 0. dieyprimy 
(1) C. Chinensis, J. Sm., Copel., Polypod. Philipp., 57; Davallia Ständ tenuifolia, Sw., Rac., Flor. Btz., I, 156 ; Bedd., Ferns S.I., tab. XVI; Lindsaya tenuifolia, Mell., Christ, Farnkr. d. Erde, 296; L. chinensis, Burck, Ann. Btz., IV, 90; Stenoloma chinensis, Bedd., Handb. Ind. Ferns, 70; Trichomanes Chinense, L., (oldest name).

Rhizome creeping, the scales dense, brown, hair-like. Stipes 2-20 m.M. apart, polished, naked, erect, $\pm 10-50$ c.M. long. Fronds 5-pinnatifid to 4-pinnate, $\pm 10-50$ c.M. long, 4-25 c.M. broad, lanceolate or ovate. Lower pinnae ovate- to deltoid-lanceolate, erecto-patent, $5-15$ c.M. long, $1 \frac{1}{2}-8$ c.M. broad. Pinnulae \pm oblong or lanceolate. Ultimate segments cuneate, the apex \pm truncate, entire or toothed, $1-4$ m.M. broad. Texture subcoriaceous; surfaces naked; veins dichotomous. Sori terminal, roundish, 1-2 to a lobe.

Trop. Asia, Polynesia, Japan, China, Comore \& Mascarene Islands, Madagascar.

(2) D. Diffora, C. Chr., Ind. Fil.; Davallia biflora, Klf., Enum. Fil., 221.

Like 0. chinensis, J. Sin., but the fronds 2-5-pinnate, the apices of the lower pinnae caudate, the ultimate segments cuneate, broader; indusium suborbicular.

Luzon.

* (5) Hetusa, J. Sme., Copel., Polypod. Philipp., 57; Davallia relusa, Cav., Hk., Spec. Fil., I, tab. LII, A; D. decipiens, Ces., Fel. Becc. Polin., 3 \& 7 ; Lindsaya relusa, Mell., Hk. Bk., Syn. Fil., 110; L. cuneifolia, Pr., Hk., l. c., 219.

Rhizome short-creeping, strong. Stipes strong, erect, reddish like the rachises, to \pm 100 c.II. long. Fronds ovate-deltoid, 5-pinnatifid, to \pm 90 c.M. long. Pinnae stalked, the lower ones $20-60$ c.M. long, $10-20$ c.M. broad, deltoid. Pinnulae stalked, lanceolate-deltoid, pinnate or more commonly pinnatifid below, the apex pinnatifid. Segments cuneate, the lower ones to $\pm 1 \frac{1}{2}$ c.ll. long, to \pm 1 c.I. broad, the base cuneate, the outer margin irregularly flabelliform, cut down towards the base into 5-6 cuneate lobes often different in length. $1-6$ m.M. deep, $3-6$ m.M. broad at the apex. Texture herbaceous, slightly fleshy; veins flabellate, several times forked. Sori terminal on the lobes, occupying the whole breadth.

Malaya; Melanesia. 


\section{LINDSA Y A, Drgander.}

Sori submarginal, solitary and terminal on the veins or uniting the apices of 2 or more veins or veinlets, roundish, oblong or linear. Indusium \pm of the same shape as the sorus, attached at its inner side, opening outwardly.

Rhizome short or creeping. Stipes not articulate to the rhizome. Fronds at least simply pinnate. Leaftets dimidiate, i. e. the half on the lower side almost or quite undeveloped, the "midrib" therefore running along the lower margin, which is always destitute of sori; veins free or anastomosing. Hk. Bk., Syn. Fil., tab. II, fig. 20, a; Diels, in Engl. \& Prantl, Nat. Pfl.Fam., I" fig. 119, D, E, G, H; Christ, Farnkr. d. Erde, fig. 926-928.

Tropical and subtropical.

Arrangement of the sections.

$\$ 1$ ODONTOLOMA. Sori solitary on the vein lips, but sometimes contiguous and with a tendence to become confluent. Christ, l. c.

$\$ 2$. EULINDSAYA. Sori uniting the apices of 2 or more veins or veinlets. Veins free. Hk. Bk. \& Diels, l. c.

$\$$ 3. SYNAPHLEBIUM. Sori as in $\mathbb{S} 2$. Veins anastomosing.

\section{$\$ 1$ ODONTOLOMA.}

a. Fronds not branched, i.e. pinnate or 2-pinnatifid..

b. Leaflets (pinnae) entire or crenate.

(1) L. repens.

b.b. Leaflets (pinnae) coarsely toothed or lobed.

c. Fronds to $11 / 2$ c.M. broad.

*. Leaflets toothed or lobed with 2-4 teeth or lobes.

(2) L. gracilis.

*.*. Leaflets 2-fid.

(5) L. blanda.

c.e. Fronds more than $1 \frac{1}{2}$ c.M. broad.

d. Fronds sessile.

(4) L. delicatula.

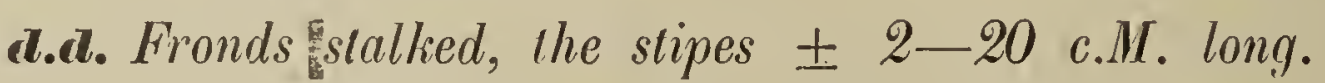

e. Fronds rather short, under 35 c.M. long.

f. Leaflets shallowly lobed.

(๖a) L. adiantoides.

(๖b) L. Havicei. 
f.f. Leafleis rather deeply incised

e.e. Fronds rather long, more than 35 c.M. long. (6a) L. apoensis.

(6b) L. cyathicola.

(7) L. Merilli.

b.b.b. Leaftets deeply pinnatifid or even pinnate, the segments linear-cuneate. *. Lobes truncale at the apex, which is slightly rounded and entire or somewhat erose.

(8) L. hymenophylloides.

*.*. Lobes as in *, but the apex purveyed with $2-3$ distinct teeth.

(9) L. capillacea.

a.a. Fronds branched, i.e. 2-pinnate or 3-pinnatifid.

5. Leaflets (pinnulae) deeply lobed 10 a broad, leafy rachis, the segments broad.

(10) L. tenuifolia.

\$.S. Leaflets (pinnulae) cut down to a filiform rachis, the segments filiform.

(11) L. Blumeana.

* (1) L. repens, Eedd., Handb. Ind. Ferns, 74; Ferns S.I., tab. CCIX; Christ, Farnkl. d. Erde, fig. 926; Davallia repens, Desv., Hk. Bk., Syn. Fil., 93; Odontoloma Boryanum, J. Sm., Bau. \& Hk., Gen. Fil., tab. CXIV, B; - var. hemiptera; D. hemiptera, Bory, Bel., Voy. Bot., II, 73, tab. VII, fig. 2.

Rhizome wide-creeping, climbing, scaly. Fronds simply pinnate, 20-45 c.M. long, $2-4$ c.M. broad. Leaflets $1-2$ c.II. long, \pm half as broad, the lower line often slightly upcurved, the point acule or rounded, the upper edge straight or \pm rounded, subentire or' crenato-lobate. 'T'exture pellucido-herbaceous. Sori submarginal, large, \pm as broad as long, 1 to each crenation, often confluent in the subentire forms when the apices of the veins are joining. - Scarcely different from L. pectinata, $B l$.

Var. Inemipter'se : Barren fronds dimorphous (as in Teratophyllum), the abnormal ones deeply pinnatifid on the upper and outer side, the lobes very fine, narrowly linear, simple or $1-2 \times$ forked.

Trop. Asia, Polynesia, Mauritius.

* (2) L. gracilis, Br., Rac., Flor. Btz., I, 140.

Rhizome creeping, slender, very long, brown, glossy, sparingly provided with lanceolate, spreading scales. Stipes 1-5 c.M. apart, naked, polished, \pm $1-8$ c.M. long. Fronds $15-30$ c.M. long, 8-15 m.M. broad, linear-lanceo- 
late, simply pinnate. Leaflets \pm triangular, erecto-patent, $\pm 3 \mathrm{~m}$.M. broad, close, sessile or short-stalked, the base \pm cuneate, the lower edge often curved upwards, the apex rounded or bluntish, the upper margin toothed or lobed with 2-4 entire, rounded or trunctate teeth or lobes. Texture membranaceous; veins simple or forked, often joining. Sori $1-2$ to each lobe, the pairs often confluent when the veins are joining. (Forma concinna = L. concinna, J. Sm.).

Trop. Asia, New Caledonia.

(3) L. blanda, Mett., Linn., XXXVI, 80.

Rhizome long, slender, branched, clothed with fugacious scales. Stipes \pm 5 c.M. long, slender, stramineous like the rachis. Fronds \pm 15 c.M. long, \pm 15 m.M. broad, linear, acuminate, simply pinnate. Leaflets numerous, imbricate, erecto-patent, sessile, 7-10 m.M. long, cuneate or obovate-cuneate, bifid, the outer lobe commonly the broadest. Texture membranaceous; surfaces naked; veins simple or forked, free or joining at the apex. Indusium reniform or transversally oblong.

Java.

(4) L. Delicatula, Christ, G. Chr., Ind.. Fil.; Davallia delicatula, Christ, Ann. Btz., XV, 79, tab. XIV, fig. 11, a-b.

Rhizome slender, filiform, wide-creeping, densely clothed with yellowbrown scales. Fronds sessile, close, but not tufted, to 12 c.II. long and to $21 / 2$ c.M. broad, lanceolate, simply pinnate, narrowing gradually towards both ends. Leaflets \pm 20 on each side of the rachis, to $\pm 1 \frac{1}{2}$ c.M. long and to \pm 1 c.M. broad, the lower edge straight or slightly curved upwards, the outer edge cut into \pm 5 rounded lobes \pm 4 m.M. deep, the sinuses very sharp. Texture thin, hyaline, flaccid; both surfaces naked; colour brightlight-green. Sori placed in the lobes on a short distance below the apices, blackish; indusium broad, subreniform, reaching to the edgé.

Celebes.

* (5a) L. adliantoides, Katlen, Ann. Mus. Bot. L. B., IV, 278; L. pulchella, Melt., Linn., XXXVI, 81; Davallia pulchella, Hk., Hk. Bk., Syn. Fil., 93; Hk., Spec. Fil., I, tab. LIII, B; Aspidium adianloides, Bl., (oldest name).

Rhizome slender, wide-creeping. Stipes slender, wiry, erect, naked, 5-71/2 c.M. long. Fronds $10-30$ c.M. long, $1 \frac{1}{2}-21 / 2$ c.M. broad, simply pinnate. Leaflets slightly stalked; $7-12 \mathrm{~m} . M$. long, to $\pm 5 \mathrm{~m}$.M. broad, the 
lower margin more or less curved upwards, the upper cut into 2-5 blunt, short lobes. Texture herbaceous; rachis and both surfaces naked. Sori small, placed in the lobes at a short distance from the edge; veins sometimes joining at the apex and then their sori becoming confluent.

Malaya; Fiji, Samoa.

(5b) L. Havicei, Copel., Philipp. Journ., I, Suppl., 149.

Rhizome scandent, slender, fuscous, clothed with caducous, minute scales of the same colour. Stipes distant, 2-4 c.M. long, fuscous, naked. Fronds $12-15$ c.I. long, $\pm 21 / 2$ c.I. broad, acuminate, simply pinnate. Leaflets short-stalked, $\pm 1 \frac{1}{4}-1 \frac{1}{2}$ c.M. long, \pm 4 m.M. broad at the truncate base, falcate, narrowed gradually towards the acuminate apex, the upper edge finely lobed. Texture membranaceous; rachis fine, stramineous; veins free. Sori minute, terminal, more broad than deep.

Mindanao.

(6a) L. apoensis, Copel., Polypod. Philipp., 64; Perk., Fragm. Philipp., tab. IV, A.

Rhizome scandent, ferrugineous, nearly naked. Stipes straight or flexuose, firm, 12-18 c.M. long, reddish-brown near the base, the rest green, nearly naked as is the rachis. Fronds \pm 20 c.M. long, \pm 6 c.M. broad, simply pinnate. Leaflets short-stalked, the largest \pm 4 c.ll. long, $\pm 7 \mathrm{~m}$.M. broad, the lower edge curved, the upper one more or less deeply incised with the higher lobes mostly linear. Texture herbaceous; surfaces naked; veins free or confluent at the apex. Sori small, terminal on the.lobes; indusium suborbicular.

Mindanao.

(6b) L. Cyathicola, Copel., Philipp. Journ., I. Suppl., 149, tab. V. Rhizome scandent, purpureous, glossy, sparingly fulvo-paleaceous. Stipes distant, 4-5 c.M. long, slender, naked, glossy, purpureous below, greenish above like the rachis. Fronds simply pinnate, $15-20$ c.II. long, $1 \frac{1}{2}-2$ c.M. broad, narrowed towards both ends. Leaflets sometimes cuneate, the largest \pm 9 m.M. long, $\pm \cdot 5$ m.M. broad, obtuse, the acroscopical edge cut hardly $1 / 2$-way down into $2-3$ lobes. Texture membranaceous; surfaces naked; veins free except when united by the sori. Sori small, distant from the margin, more broad than deep, simple or confluent.

Luzon. 
* (7) L. Merrilli, Copel., Polypod. Philipp., 61.

Rhizome strong, scandent, reddish-brown, glossy, nearly naked or clothed with spreading, ferrugineous, lanceolate, entire scales. Stipes $\pm 2-5$ c.M. long, strong, slightly scaly, brownish or stramineous. Fronds $40-80$ c.M. long, 3-4 c.Y. broad, simply pinnate, narrowed towards both ends. Leaflets sessile, subsessile or short-stalked, the largest to $22 \mathrm{~m}$.II long, $5-9 \mathrm{~m} . \mathrm{M}$. broad near the rachis, the base cuneate, the lower edge straight or curved especially near the base, the upper edge inciso-crenate, the apex acute or bluntish; crenations \pm acute, the higher ones sometimes suddenly elongated and forked so as to form abnormal, linear, simple or bifid lobes. Texture membranaceous; rachis stramineous and like the surfaces naked; veins free, 1 to each crenation, the apices somelimes uniting. Sori submarginal, the tips of the lobes projecting beyond them, solitary in the crenations or occasionally confluent in pairs.

Philippines.

* (8) L. hymenoplnylloides, Bt., Christ, Farnkr. d. Erde, 294; L. Lapeyrousii, Bk., Hk. Bk., Syn. Fil., 106; Davallia hymenophylloides, Bk., Hk. Bk., l. c., 93; Hk., Icon. Pl., XVII, tab. MIDCXXIII; D. Lapeyrousii, Hk., $2^{d}$ Cent. of Ferns, tab. LVI.

Rhizome slender, wide-creeping, scaly. Stipes short, to $b$ c.ll. long. Fronds simply pinnate, lanceolate, $10-40$ c.M. long, 2-4 c.M. broad. Leaflets close, oblong, \pm 3 -b̆ m.M. broad, the lower edge entire, straight or slightly curved, the upper margin deeply pinualipartite nearly to the lower edge into 5-8 narrow, linear-cuneate, truncate lobes. Texture thinly herbaceous; veins 1 to each lobe, simple or forked; surfaces naked. Sori transversally oblong, subterminal on the lobes, solitary, or rarely double and confluent.

Malaya; Polynesia. hindoro

* (9) C. capillacen, Christ, Bull. Herb. Boiss., VI, 144, tab. IV, fig. 7, a-c; (? L. pectinata, Bl., Christ, 1. c., $2^{\circ}$ Série, VI, 1006).

Rhizome creeping, filiform, intertwined. Stipes filiform, brownish, naked. Fronds \pm 10 c.M. long, \pm 10 m.I. broad, linear-lanceolate, acuminate, simply pinnate. Leaflets alternate, \pm b m.M. long, triangular-oblong, the lower edge entire, the upper edge cut nearly or quite down into 5-4 segments, which are \pm spreading, linear-cuneate, the lower ones forked, the apices of all truncate, 2-5-dentate. Texture thin, weak, flaccid; rachis green, naked; surfaces naked; 1 central vein to each lobe. Sori 
small, subterminal and solitary on the segments, flanked on each side by the acule teeth.

Luzon.

* (10) L. tenuifolia, IBI., Enum., 219; L. triquetra, Melt., Christ, Farnkr. d. Erde, 294; Diels, in Engl. \& Prantl, Nat. Pfl. Fam., I , fig. 119, H; Davallia riquelra, Bk., Hk. Bk., Syn. Fil., 95; D. Blumeana, Ces., Fel. Becc. Polin., 3.

Rhizome creeping, fibrillose. Stipes strong, erect, 10-15 c.M. long. Fronds 2-pinnate, with a terminal branch and $2-7$ pairs of spreading or erectopatent lateral ones, which are 5 -10 c.M. long, to $5 \frac{1}{2}$ c.M. broad, linear or lanceolate. Leaflets oblong, $\pm 1 / 2 \times$ as broad as long, cut down on the upper side into linear or oblong, simple or 2 -fid lohes to a nearly straight, leafy rachis. Texture pellucido-herbaceous; surfaces naked. Sori small, terminal on the segments; indusium suborbicular.

Malaya; Polynesia.

* (11) A. Blumeana, Kuhn, Ann. Mus. Bol. L. B., IV, 277; Davallia Blımeana, IIk., Hk. Bk., Syn. Fil., 93; Hk., Spec. Fil., I, tab. LIV, A.

Rhizome creeping. Stipes strong, erect, 10-50 c.M. long. Fronds $20-30$ c.M. long, branched. Branches rigid, erecto-patent, $7 \frac{1}{2}-15$ c.M. long, to \pm $1 \frac{1}{2}$ c.M. broad, pinnate, acuminate. Leaflets cut down on the upper side to a filiform, decurved rachis into very slender, filiform, simple or forked segments. Texture thinly herhaceous. Sori small, subterminal on the dilated, entire or crenated apices of the segments.

Sumatra, Celebes, Philippines, New Guinea.

\section{\$2. EULINDSAYA.}

1. Fronds unbranched, i.e. pinnale or 2-pinnalifid. ( $)$.

2. Fronds to $1 \frac{1}{2}$ c.M. broad.

a. Leaftels (pinnae) entire, crenate or slighlly lobed.

b. Leaflels 4--5 m.M. long, \pm 3 m.M. broad.

(12) L. gracillima.

b.b. Leaflels 6-7 m.M long, \pm 5 m.M. broad. (15) L. concinna. a.o. Leaflets (pinnae) deeply lobed.

(14) L. Loheriana.

(*) See also L. orbiculata, Mett. \& Iancea, Bedd. 
2.2. Fronds $1 \frac{1}{2}$ c.M. hroad or broader when fully developed ( ${ }^{1}$ ).

3. Fronds to 15 c.M. long.

\$. Indusium continuous, or interrupted, not undulate.

*. Fronds small, 3-6 c.M. long, $\pm 1^{1} / 2$ c.M. hroad.

(15) L. montana.

*.*. Fronds larger, 10-15 c.M. long, $\pm 2-5$ c.M. broad. $\times$. Leaflels blunı. (16a) L. humilis. $\times \cdot \times$. Leaflets acute. (16b) L. falcata.

\$.\$. Indusium contimuous, undulale.

(17) L. crispa.

3.3. Fully developed fronds more than 15 c.M. long.

1. Rhizome short-creeping.

*. Texlure membranaceous.

(18a) L. cultrata.

*.*. Texture coriaceous. (18b) L. crassipes.

1.1. Rhizome firm, scandent.

5. Leaftels crenale; sori interrupted.

5.5. Leaflels entire; sori continuous.

(19) L. pectinata. (20) L. scandens.

1.1. Fronds branched, i.e. 2-pinnale or 3-pinnatifid $\left({ }^{2}\right)$.

2'. Veins flabellate.

*. Leaflels (pinnulae) 5-8 m.M. broad.

(21) L. orbiculata.

*.*. Leaflets (pinnulae) 10-15 m.M. broad.

(22) L. gomphophylla.

$\mathbf{2}^{\prime} \cdot \mathbf{2}^{\prime}$. Veins nol flabellate.

3'. Branches of the fronds mostly under 2 c.M. broad.

5. Leaflets (pimulae) entire, crenate or toolhed.

+. Sori roundish or oblong, lerminal on the leaflels.

(23) L. tricrenata.

+. Sori in a continuous submarginal line. (24) L. borneensis.

\$.\$. Leaflets (pinnulae) bluntly, not deeply lobed.

(25) L. rigida.

$\boldsymbol{3}^{\prime} .3^{\prime}$. Branches mostly 2-4 c.M. broad; leaflels (pinnulae) not entire.

4'. Leaflets dimorphous.

(26) L. impressa.

4'.4'. Leaflets uniform.

5'. Fronds rather small, to \pm 30 c.M. long, the branches \pm 3-4-jugate, to 15 c.M. long.

(27) L. natunae.

$\mathbf{5}^{\prime} . \mathbf{s}^{\prime}$. Fronds rather large, to $\pm 80 \mathrm{c.M}$. long or longer, the branches \pm 5-6-jugale, to 40 c.M. long. (28)L. longissima.

$\mathbf{3}^{\prime} .3^{\prime} \cdot \mathbf{3}^{\prime}$. Branches mostly 4 c.M. broad or broader; leaflets (pinmulae) enlire.

(29) L. lancea.

(') See also L. concinna, J. Sm.

$\left({ }^{2}\right)$ See also L. pectinata, $\mathrm{Bl}$. \& scandens, $H /$. 
* (12) L. gracillinna, Copel., Polypod. Philipp., 61.

Rhizome short. Stipes densely tufted, erect, hrown, nearly naked, \pm 5 c.M. long. Fronds simply pinnate, linear, \pm 52 c.M. long, \pm 1 c.M. broad. Leaflets alternate, petiolate, deltoid or rhomboidal, $\pm 4 \mathrm{~m}$.M. long, $\pm 5 \mathrm{~m} . \mathrm{M}$. broad, the lower ones \pm reduced, the lower edge straight, upper edge rounded, entire, or when sterile crenate. Texture herbaceous; surfaces naked; veins flabellate. Sori continuous or subinterrupted.

Luzon.

* (15) D. Concinma, J. Sm., Hk. Bk., Syn. Fil., 105; Hk., Spec. Fil., I, tab. LXI, B ; L. Lobbiana, Hk., I. c., tab. LXII, C ; (? L. gracilis, Bl., C. Chr., Ind. Fil.).

Rhizome short-creeping. Stipes wiry, flexuose or straight, erect, $5-10$ c M. long. Fronds $15-50$ c.M. long, $\pm 12-15$ m.M. or rarely 2 c.Mr. broad, simply pinnate. Leaflets $\pm 5 \mathrm{~m} . \mathrm{M}$. broad, oblong; the lower edge straight or curved commonly upwards, the upper and outer margin rounded, entire or slightly lobed with shallow, broad, truncate lobes. Texture pellucido-herbaceous. Sori in a continuous line except when interrupted by the lobes.

Malaya.

(14) E. Holneriana, Cherist, Bull. Herb. Boiss.; VI, 144, tah. IV, fig. $6, \mathrm{a}-\mathrm{b}$.

Rhizome short-creeping, firm. Stipes fasciculate or approximate, terete, slender, firm, erect, \pm 2 c.M. long, purple at the base. Fronds \pm 12 c.M. long, \pm 1 c.M. hroarl, linear-lanceolate, acuminate, simply pinnate. Leaflets alternate, triangular-cuneate, on stalks $\pm 2 \mathrm{~m} . \mathrm{M}$ long, the lower edge entire, the upper one deeply lohed with $2-5$ lohes. Lobes cuneate, truncate at the apex. Texture firm; rachis stramineous; veins few, conspicuous, forked in the lobes. Sori subterminal on the lobes, single or double; indusium inflated.

Luzon.

(15) L. montana, Copel., Polypod. Philipp., 62; L. Copelandi, C. Chr., Ind. Fil.; (? L. orbiculata, Mell., p. p., Copel., Philipp. Journ., I, Suppl., 148).

Rhizome short, creeping, the scales ferrugineous. Stipes tufted, $1-\tilde{5}$ c.M. long, slender, flexuose, reddish-brown below, stramineous upwards, nearly naked. Fronds $5-6$ c.M. long, $\pm 1 \%$ c.M. broad, simply pinnale. Leaflets stalked, \pm 9 m.M. long, \pm 6 m.M. broad, semiorbicular, the lower edge deflexo- 
29. Lindsaya. $\$ 2$. Eulindsaya.

arcuate, the upper edge rounded, entire or incised, the higher leaflets erectopatent, the lower much deflexed. Texture membranaceous to coriaceous; rachis nearly naked; veins flabellate. Sori often continuous.

Philippines.

* (16a) L. Intmillis, Fouten, Ann. Mus. Bot. L. B., IV, 278; L. adtantoides, J. Sm., Hk. Bk., Syn Fil., 104; Hk., Spec. Fil, I, tab. LXI, C.

Stipes nearly iufted, often blackish, polished, wiry, $21 / 2$ Fronds $10-15$ c.M. long, $\pm 2 \frac{1}{2}$ c M. broad, simply pinnate. Leaflets to $11 / 2$ c.M. long, to $7 \mathrm{~m}$. .I. broad, the upper ones imbricated, the lower edge straight or slightly curved, the upper rounded and broadly lobed to $\pm 1 / 3$ of the way down. T'exture pellucido-herbaceous. Sori subterminal on the lobes. Java, Celebes, Philippines.

(16b) H. falcata, Dry., Trans. Linn. Soc., Bot., III, 41, tal.. VII, fig. 2; L. trapeziformis, Dry., Hk. Bk., Syn. Fil., 107, p. p.; L. Leprieurii, Hk., Spec. Fil., I, 298, tab. LXII, D.

Rhizome filiform, creeping. Stipes dark-brown, tetragonal, almost black and glossy. Fronds oblong, at utmost $221 / 2$ c.M. long inclus. the stipe, simply pinnate. Leaflets half-ovate, $\pm 21 / 2$ c.H. or more long, acuminate, deflexofalcate, truncate at the base, which is parallel to the obscurely winged rachis, the edge entire, the apex rather acuminate, the termincl pinna formed of $\mathbf{z}$ combined pinnae with a main nerve running through the centre. Texture membranaceous; rachis like the stipe. Sori continuous, distant from the margin, indusium narrow.

Negros; Trop. America.

(17) L. Crispan, IBte., Journ. of Bot., XVII, 59; Hk., Icon. Pl., XVII, tab. MDCXXVII.

Rhizome short-creeping. Stipes wiry, naked, castaneous, ${ }^{1} 1 / 2-25$ c.II. long. Fronds lanceolate, simply pinnate, $\pm 7-15$ c.M. long, $1 \frac{1}{2}-21 / 2$ c.II. broad. Leaflets not crowded, sessile, deltoid, truncate on the inner and spreading or erecto-patent on the lower side, the upper edge irregularly incisocrenate. Texture membranaceous; surfaces naked; colour bright-green; veins distinct, \pm flabellate. Indusium undulate, with 2 distinct, nearly equal, cartilagineous valves.

Borneo. 
* (18a) C. cultrata, Sw., Rac., Flor. Btz., I, 141; Hk., Fil. Exot., tab. LXVII; Bedd., Ferns S.I., tab. XXIII; L. apiculala, Kze, Farnkr., I, tab. LXXXV, fig. 2 ; - var. varia, Copel., Polypod. Philipp., 62.

Rhizome creeping, more or less densely clothed with linear, brown, setiform scales. Stipes approximate, $7-1$ s c.M. long, naked, polished, often reddish, the base clothed with setifor'm scales. Fronds linear-lanceolate, $15-50$ c.M. long, $\pm 2-4$ c.M. broad, simply pinnate. Leaflets to 1 c.M. broad, not imbricate, triangular, the lower margin straight or slightly curved (usually upwards), the upper edge crenate, so that the continuity of the line of fructification is broken, sometimes nearly entire, lower leaflets shortstalked. Texture firm-membranaceous. Sori 1 ginal line, only broken by the crenations, slightly concave.

Var. varia : Fronds shorter and narrower, membranaceous.

Trop. Asia, North. Australia, East. Africa; - var. varia: Philippines.

(18b) H. Crassipes, Rst., lied., Rep., V, 56.

Rhizome short-creeping, branched, the scales minute, linear-lanceolate. Stipes dense, flexuose, black-brown, polished, slender, naked, to nearly 10 c.II. long. Fronds linear-lanceolate, to 18 c.M. long, 102 c.M. broad at the centre, simply pinnate. Leaflets alternate, sulsremote, trapezio-ovate, on stalks $1-1 \frac{1}{2}$ m.M. long, the midial ones nearly 1 c.II. long, 1/2 c.M. broad, narrowed at the apex, with the upper edge 2-crenate, the lower ones smaller, rounded at the apex, 5-"y-crenate, the higher ones gradually growing smaller, entire, narrowed at the apex. Texture coriaceous; surfaces naked, the upper one dark-green, the under one somewhat paler; rachis black-brown, flavidomarginate above; veins slightly visible, dichotomous. Sori interrupted by the crenations.

New Guinea.

* (19) L. pectinata, Bt., Hk. Bk., Syn. Fil.; L. oblongifolia, Reinw., Hk., Spec. Fil., I, tab. IXI, D ; L. repens, Kze, Rac., Flor. Btz., I, 142 , p. p.

Rhizome long, creeping or scandent, densely clothed with short, lanceolate scales. Fronds sessile or short-stalked, $1 / 2-4$ c.M. apart, lanceolateligulate, nårrowed towards both ends, 20-60 c.M. long, 2-5 c.M. broad, simply pinnate, rarely 2-pinnate. Leaflets $7-10$ c.Mr broad, the lower ones reduced, the central ones linear-oblong, closely placed, the lower edge nearly straight, the upper margin rounded, \pm crenate, the apex bluntish to bluntly 
29. Lindsaya. $\$ 2$. EUlindsaya.

rounded. Texture pellucido-herbaceous. Sori in an interrupted submarginal line along the upper edge and the apex.

Tropical Asia.

* (20) Scandens, Wk., Hk. Bk., Syn. Fil., 106; Hk., Spec. Fil., J Fl I, tab. LXIII, B ; L. repens, Kze, Rac., Flor. Btz., I, 142, p. p.

Like L. pectinata, $B l$., but the lower edge of the leaflets slightly decurved the upper and outer edges entire, broadly rounded. Sori in a continuous submarginal line.

Malaya.

* (21) L. orbiculata, Mett., Bedd., Handb. Ind. Ferns, 75; L. flebellulata, Dry., Hk. Bk., Syn. Fil., 107; Dry., Trans. Linn. Soc., Bot., III, tab. VIII, fig. 2; Bedd., Ferns S.I., tab. CCXVI; Adiantum orbiculatum, Lam., (oldest name); - var. polymorpha; L. polymorpha, Wall., Hk. \& Grev., Ic. Fil., tab. LXXV ; - var. gigantea, Hk., Spec. Fil., I, tab. LXIII ; - var. tenera, Bedd., Ferns S.I., tab. XXIV; L. tenera, Dry., l. c., tab. X ; L. striata, Bl., Enum., 220.

Rhizome short-creeping, the scales brown, dense, small, lanceolate-subulate. Stipes \pm approximate, $5-30$ c.M. long, erect, naked, glossy, often black or brown, the fertile fronds on the longest stipes. Fronds 10-25 c.M. long, the fertile ones longer than the barren, simply pinnate, or 2-pinnate with a \pm long, terminal branch and 1 to several, spreading or suberecto-patent branches on each side various in length. Leaflets various in shape, roundish, flabellate, oblong, sub-quadrangular or trapeziform, 7-15 m.M. long, $5-8$ m.M. broad, the lower line nearly straight or decurved, the upper and outer edges bluntish or rounded, entire, crenate or lobed, the lobes entire, blunt or 2-5-dentate in the barren, \pm truncate in the fertile leaflets, which are often the smallest. Texture \pm pellucid, rather rigid; rachis and surfaces naked; veins flabellate, dichotomous. Sori in a continuous line except when interrupted by the lohes. - Variable.

Var. polymorpha: Some of the branches reduced to large, irregularly incised or subdivided leaflets.

Var. gigantea: Some of the leaflets of the central rachis $21 / 2-5$ c.M. long, lengthened to an acute point.

Var. Teneran: Texture thin.

Trop. Asia \& Australia.

* (22) E. gomploophylla, Bks., Ann. of Bot., V, 204. 
Rhizome creeping, the scales lanceolate, acute or acuminate. Stipes naked, castaneous. Fronds 2-pinnate, \pm 1 c.M. long, branched in the lower half, the lowest branches much the longest. Leaflets orbicular-cuneate, $\pm 1-1 \frac{1}{2}$ c.M. broad, the hase cuneate, the upper and outer edge deeply crenate or rather deeply lohed and crenate, the lohes cuneate-flabellate or cuneate-oblong. Texture thin, membranaceous or more rigid; surfaces naked; veins flabellate. Sori interrupted by the lobes and crenations; indusium narrow.

Borneo.

(25) L. tricienata, Mik., Journ. of Bot., XXVIII, 106.

Stipes 10-13 c.M. long, like the rachises slender, naked, castaneous. Fronds deltoid, 2-pinnate. Branches few, 15-20 c.M. long, 8-9 m.M. broad. Leaflets sessile, cuneate, $4-41 / 2$ m.M. broad, crenate on the outer edge. Texture moderately firm; surfaces naked; veins \pm 5 to a pinnula, forked. Sori roundish or oblong, terminal on the pinnulae; indusium narrow, firm.

New Guinea.

* (25) H. Dotrmecmsis, Hk., Hk. Bk., Syn. Fil., 107.

Rhizome short-creeping, paleaceous. Stipes strong, erect, polished, $20-55$ c.M. long. Fronds 2-pinnate, $30-45$ c.M. lung, 20-30 c.M. broad, with a long, terminal branch and 6-10 pair's of lateral ones, which are $15-25$ c.M. long. Leaflelts 7-10 m.M. long, 3-5 m.M. broad, closely placed, often slightly imbricate, the upper edge entire, the apex broadly rounded, entire or finely toothed. Texture pellucido-herbaceous to subcoriaceous; veins prominent. Sori in a continuous, submarginal line.

Borneo, Sumalra, Malacca.

(25) 4. noigida, J. Sm., Hk. Bk., Syn. Fil., 108; Hk., Spec. Fil., I, tab. LXIII, A.; Bedd., Ferns Br.I., II, tab. CLXVI.

Rhizome wide-creeping: Stipes 10-15 c.M. long, rigid, erect, prickly towards the base. Fronds 2-pinnate, with a long terminal branch and $1-4$ pairs of flexuose, lateral ones 10-20 c.M. long. Leaflets 6-10 m.M. long, 4-b m.M. broad, the lower edge often falcate, the upper 5-4 times bluntly, not deeply lobed, placed close together, not imbricate. Texture very thick and coriaceous; veins prominent. Sori subterminal on the lobes. - The colour of the nature frond is sepia-brown and the pale veins stand out from the ground-work in relief $(\mathrm{Bk})$.

Malacca, Baljan, Celebes, New Guinea, Philippines, 
* (26) I. impressa, Christ, Ann. Btz., XX, 132.

Rhizome creeping, brown, the scales subulate, brown. Stipes approximate, $5-20$ c.I. long castaneous, firm, naked. Fronds $1-2 \times$ pinnate, 20-40 c.II. long. Branches 5-5, sessile, erecto-patent, \pm 15 c.M. long, \pm 5 c.II. broad, acuminate. Leaflets approximate, spreading, dimorphous, the barren ones $\pm 15 \mathrm{~m}$.M. long. \pm 6 m.M. hroad, sessile, ovate-oblong, with the apex obtuse, narrowed, the upper and outer edge toothed or nearly lobed; the lobules \pm serrate, the fertile ones smaller, acute, triangular, entire. Texture subcoriaceous, fragile; rachis and surfaces naked; veins blackish, conspicuous, deeply impressed, forked, some of them sometimes anastomosing. Sori narrow, linear, continuous, occupying the upper edge of the fertile leaflets.

\section{Borneo.}

* (27) C. natunae, Br., Kew Bull., 1896, 40.

Rhizome short-creeping. Stipes approximate, elongate, naked, pale-brown, canaliculate. Fronds deltoid, \pm 50 c.M. long, 2-pimnate. Branches \pm 5 -4jugate, $8-121 / 2$ c.I. long, 2-2 $1 / 2$ c.M. broad, lancenlate, subsessile. Leaflets multijugate, close, the central ones the largest, $\pm 5 \mathrm{~m}$.H. broad, sessile, the lower edge straight, the upper one lobed. Texture membranaceous; rachis naked, pale-brown; surfaces naked; veins simple, distant, conspicuous, the lower ones forked. Sori oblong, terminal on the lobes. - A plant found in Lingga by . Mr. Teysmann and which may be a form of this species has the leaflets nearly.close, the veins forked, the sori continuous except when interrupted by some shallow, broad, lohe-like crenations. Branches of the fronds 1-2-jugate.

Natuna Islands,? Lingga Islands.

* (28) L. Iongissima, Christ, Ann, Btz., XX, 151.

Stipes castaneous, slender, nearly glossy, naked, \pm 40 c.M. long. Fronds to 80 c.M. long or longer, 2-pinnate. Branches distant, alternate, sessile, acuminate, arcuato-nutant, $\pm 5-6$ below the terminal one, \pm 60 c.M. long, $2-21 / 2$ c.M. broad, pectinato-pinnate. Leaflets very numerous, close, sessile, rhomboidal, obtuse, \pm g m.M. broad, the base cuneate, the lower edge \pm decurved, the upper and outer edges broadly lobed, the lobes shallow, obtuse, crenate Texture herbaceous, opaque; surfaces naked; veins not conspicuous, forked, some of them sometimes anastomosing. Sori few, submarginal, ter minal on the outer lobes, $2-5$ to. a pinnula; indusium greyish.

Borneo. 
* (29) L. Iancea, Bedd., Handb. Ind. Ferns, 75 ; L. trapeziformis, Dry., Hk. Bk., Syn. Fil., 107, p. p.; Trans. Linn. Soc., Bot., III, 42, tab. 9; Bau. \& Hk., Gen. Fil., tab. LXIII, A ; Adiantum lanceum, L., (oldest name); - var. caudata; L. caudata, Hk., Spec. Fil., I, 215; Bedd., Ferns S.I., tab. CCXVII ; Hk., Icon. Pl., X, tab. CMLVIII.

Rhizome short-creeping, more or less provided with brown, lanceolate scales. Stipes strong, erect, 20-40 c.M. long, dark-coloured. Fronds $20-40$ c.M. long, simply pinnate or more commonly 2-pinnate with a long terminal branch and 1-4 similar, erecto-patent, lateral ones on each side. Leaflets $2-5^{1} / 2$ c.M. long, 7-15 m.M. broad, rarely smaller, oblong, the lower line \pm decurved or nearly straight, the upper and outer edges entire, rounded. Texture pellucido-herbaceous. Sori in a continuous line round the upper margin.

Var. caudata: A large form with more branches than usually.

Malaya; Ceylon, Trop. America.

\section{3. SYNAPHLEBIUM.}

๙. Sori continuous.

(30) L. azurea.

a.a. Sori interrupled.

b. Leaflets entire, toothed or shallowly incised enough to interrupt the line of the sori.

×. Rhizome short-creeping, sparingly scaly. (51a) L. decomposita. $\times \cdot \times$. Rhizome wide-creeping, naked.

(31b) L. Werneri.

b.b. Leaflets lobed $1 / 3-1 / 2-$ way down.

c. Leaflets dimidiate throughout, under 2 c.M. long, lobed $\pm 1 / 3_{3}$-way down.

d. Lobes rounded.

(32) L. davallioides. d.d. Lobes truncate.

(53) L. ambigens.

c.c. Leaflets dimidiate in the lower half only, more than 2 c.M. long, lobed $\pm 1 / 2-w a y$ down.

(34) L. Sarasinorum.

(30) L. azurea, Christ, Ann. Btz., XV, 101, tab. XIV, fig. 12, $\mathrm{a}-\mathrm{b}$.

Stipes rigid, dark-reddish, \pm 50 c.M. long. Fronds 2 -pinnate, with $2-5$ lateral branches on each side below the terminal one. Leaflets $\pm 6 \mathrm{~m}$.M

Filicis. 
long, $4 \pm$ m.M. hroad, the lower edge straight or curved, the upper and outer ones rounded, entire. Texture subcoriaceous; surfaces naked, the upper one with a disticnt, bluish reflexion of light; veins inconspicuous. Sori continuous, occupying the upper snd outer margin.

Celebes.

* (51a) H. Aleconposita, Willa., Spec., V, 425; L. lobata, Poir., Rac., Flor. Btz., I, 142; L. recurvata, Wall., Hk., Spec. Fil., I, 222 ; L. propinqua, Hl., l.c., 225, tab. LXVI, B.; L. nitens, Bl., Enum., 217; Schizoloma lobala, Bedd., Handb. Ind. Ferns, 77; S. recurvala, Bedd., Ferns S.I., Lab. XXVII; Synaphlebium recurvalum, J. Sm. (not Bl.), Bau \& Hk., Gen. Fil., tab. CI.

Rhizome short-creeping, the scales scattered, linear-lanceolate, brown. Stipes approximate, firm, erect, naked, b-25 c.M. long. Fronds simply pinnate or 2-pinnate with a long unbranched apex and 1-6 pairs of lateral branches 7-25 c.M. long. Leaflets $1-2$ c.M. long, \pm half as broad, the lower often strongly decurved principally at the base, the upper and outer margin rounded, entire or shallowly incised enough to interrupt the sori, toothed or double-toothed. Texture thinly herbaceous, pellucid. Sori submarginal.

Trop. Asia \& Australia, Polynesia.

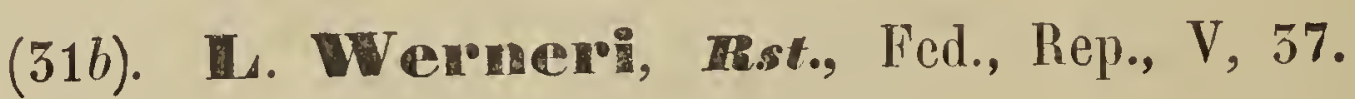

Rhizome wide-creeping, ferrugineous, glossy, rather naked. Stipes distant, subquadrangular, firm, 4-10 c.M. long, stramineous. Fronds linear-lanceolate, to 40 c.M. long, $\pm 6 \frac{1}{2}$ c.M. broad, simply pinnate. Leallets 15 - 25 -jugate, to $3 \frac{1}{2}$ c.M. long, $\pm 1 \frac{1}{4}$ c.M. broad, short-stalked, the lower ones slightly decurved, the rest rather spreading, the inner edge parallel to the rachis, the upper and outer edges irregularly crenate, the apex bluntly rounded or obliquely truncate. Texture membranaceous; surfaces naked. Sori linear, interrupted, occupying the crenations, rather distant from the margin; indusium very narrow, chartaceous, naked.

New Guinea.

* (32.) H. Mavellioides, Bt., Rac., Flor. Btz., I, 145; Hk., J.F Spec. Fil., I, tab. LXVIII, A; Davallia Kunzeana, IIl., 1.c., 177; Schizoloma pes 19 davallioides, Moore, Bedd., Ferns Br.I., I, tab. CXLI.

Rhizome short-creeping, the extremity clothed with short, lanceolate scales. Stipes rather approximate, 6-20 c.M. long, firm, erect. Fronds 2-pinnate, with a long terminal branch and 1 - 5 pairs of spreading, curved, lateral branches 


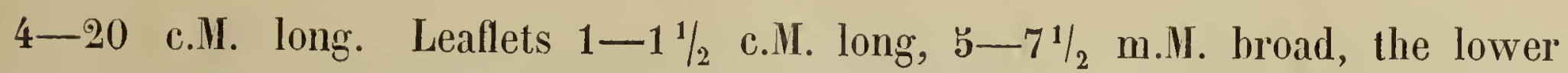
margin straight or slightly curved, the upper with 3-6 regular, oblong, rounded lobes reaching $\pm 1 / 3$-way down, placed close together, but not imbricate. Texture pellucido-herbaceous. Sori terminal on the lobes. - High alpine forms not rarely unbranched.

Malaya.

(55) 耳. ambigens, Ces., Fel. Becc. Polin., 5 \& 7 ; (? L. decomposita, Willd., C. Chr., Ind. Fil.).

Like L. davallioides, $B l$., but the lobes of the leaflets truncate.

New Guinea.

(54) L. Sarasinorum, Christ, Amn. Btz., XV, 101, tab. XIV, fig. 13, a-b.

Rhizome short-creeping. Stipes clustered, reddish-brown, \pm 12 c.M. long, provided like the rachis with scattered, brown scales. Fronds $\pm 8-12$ c.II. long, simply pinnate, or 2-pinnate with a pair of lateral branches below the central one. Leaflets dimidiate near the hase, hecoming \pm equilateral towards the apex, \pm 5 c.M. long, narrowly oval or rhomboidal, strongly bent outwards, the upper and outer edges rounded with 4-5 lobes, which are broad, obtuse, often lobed again; primary lobes, $\pm 1 / 2$ as deep as the breadth of the leaflets. Texture herbaceous; surfaces naked. Sori thick, brown, terminal on the lobes.

Celebes, Philippines.

\section{O. SCHIZOLOMA, Guadichuad.}

Sori linear or linear-oblong, uniting the apices of many veins. Indusium of the same shape, continuous, attached at the inner side of the sorus, opening outwardly.

Rhizome mostly short. Fronds simple or generally pinnate; leaflets equal-sided or unequal-sided, but not dimidiate; veins free or anastomosing. Diels, in Engl. \& Prantl, Nat. Pfl Fam., I ${ }^{4}$, fig. 118.

Tropical and extra-tropical. 
Arrangement of the sections.

\$1. ISOLOMA. Veins free. Fronds always pinnate.

S. EUSCHIZOLOMA. Veins anastomising. Fronds sometimes simple.

\section{S 1. ISOLOMA.}

a. Pinnae roundish or oblong, 5-121/2 m.M. long.

b. Fronds to 20 c.M. long. Pinnae 4-6 m.M. broad.

c. Pinnae \pm equal-sided, cordate or truncate at the base.

(1a) S. jamesonioides.

(1b) S. angustum.

c.c. Pinnae unequal-sided, the upper base truncate, the lower one cuneate or rounded.

(2) S. ovatum

b.tb. Fully developed fronds to 30 c.M. long. Pinnae 7-10 m.M. broad.

(3a) S. induratum.

(3b) S. fuligineum. Sip

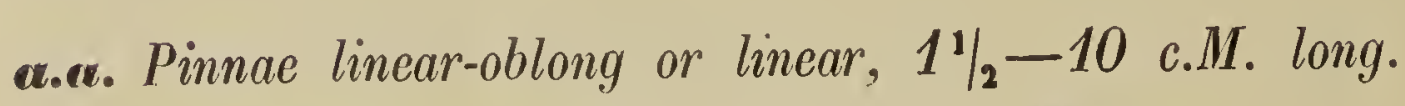

S. Pinnae spreading, $11 / 2-2^{1 / 2}$ c.M. long.

+. Sori not reaching the apex of the pinnae.

(4) S. pellaeiforme.

+.+. Sori continuous along the apex of the pinnae.

(b) S. divergens.

\$.\$. Pinnae erecto-patent, $3{ }_{2}=10$ c.M. long.

(6) S. Walkerac.

(1a) S. jamesomioides, Copel., Philipp. Journ., I, Suppl., 252 ; Lindsaya Jamesonioides, Bk., Journ. of Bot., XVII, 59 ; Hk., Icon. Pl., XVII, tab. MDCXXVI; C. Chr., Ind. Fil.

Rhizome short-creeping, the scales minute subulate, rigid, nearly black. Stipes wiry, nearly black, $21 / 2-15$ c.M. long. Fronds linear, pinnate, 7-20 c.M. long, 1-2 c.M. broad, composed of sessile, contiguous, roundish or oblong, alternate, spreading, deciduous, entire leaflets $4-6 \mathrm{~m} . \mathrm{M}$. broad, with the apex rounded, the base rounded, broadly cuneate or truncate, those of the upper $1 / 3$ of the frond growing gradually smaller. Rachis wiry, dark-brown; texture coriaceous; surfaces naked, the upper one wrinkled; veins hidden. Sori continuous all round the edge or occupying the outer half of the pinnae; indusium broad, chartaceous, persistent.

Borneo, Celebes. 
(1b) \$. angustum, Copel., Philipp. Journ., I, Suppl., 232, tab. I, B.

Rhizome short-creeping, clothed with minute, narrow, castaneous scales. Stipes approximate, 5-8 c.M. long, black-purpureous, sometimes llexuose, sparingly clothed towards the base with scattered hairs of the same colour, the rest naked, glossy, triangular like the rachis. Fronds 10-18 c.M. long, \pm 1 c.MI. broad, simply pinnate. Pinnae sessile, spreading, oblong, slightly convex, \pm ๖ m.M. long, \pm 4 m.M. broad, at length deciduous, the apex rounded, the margin entire, the base truncate or subcordate, often overlapping the rachis, lower pinnae somewhat distant, deflexed. Texture coriaceous; veins hidden, flabellate. Sori broad, continuous. - Near S. ovatum, Copel.

Philippines.

* (2) S. ovatum, copel., Philipp. Journ., I, Suppl., 252; S. Guerinianum, Gaud., var., C. Ghr., Ind. Fil.; Lindsaya ovata, J. Sm.; Hk. Bk., Syn. Fil., 10马; Hk., Spec. Ftl., I, tab. LXIV, A.

Rhizome short-creeping. Stipes $\breve{b-10}$ c.M. long, wiry, flexuose, black. Fronds 10-15 c.M. long, \pm 2 c.M. broad, simply pinnate. Pinnae \pm こ m.M. broad, not imbricate, sessile, the lower ones with their own breadth between them, horizontally oblong, the apex broadly rounded, the lower base rounded or cuneate, the upper one truncate, slightly auricled. Texture \pm coriaceous. Sori in a continuous marginal line.

Philippines, Borneo, Celebes.

(3a) S. induratum, C. Chr., Ind. Fil.; Lindsaya indurata, Bk., Journ. of Bot., XXVI, 324 .

Rhizome creeping, the scales, minute, spreading, linear, brownish-black. Stipes wiry, naked, castaneous, 20-25 c.M. long. Fronds lanceolate, pinnate, \pm 50 c.II. long, $2-2 \frac{1}{2}$ c.M. broad. Pinnae oblong, obtuse, sessile, subequilateral, \pm 8-9 m.M. broad, the edges entire, rather reflexed. Texture firm; surfaces naked; costae distinct; veins immersed, obscure. Sori continuous all round the sides and the apex of the pinnae; indusium narrow.

Borneo.

(5)) S. fuliginemm, Copel., Philipp. Journ., I, Suppl.. 252, tab. I, A. Rhizome short, creeping, clothed with minute, filiform, castaneous scales. Stipes caespitose, 7-10 c.M. long, scaly at the loase, the rest glossy, naked, castaneous like the rachis. Fronds $20-50$ c.M. long, $21 / 2-5$ c.M. broad, narrowed gradually towards the apex. Pinnae subsessile, articulate to the 
rachis, the lowest deflexed, the others spreading, obtuse, entire, $\pm 11_{4}^{1}-1 \frac{1}{2}$ c.M. long, $\pm 7-10 \mathrm{~m}$. M. broad, the upper base truncate, auriculate, the auricle sometimes acute. Texture coriaceous; surfaces naked, the upper onie black-castaneous, the under ove fuligineous; veins free. Suri continuous. About one pinna in ten shows an anastomosis of veinlets.

\section{Mindanao.}

(4) S. pellaeiforme, C. Cher., Ind. Fil.; Lindsaya pellaciformis, Christ, Ann. Btz., XV, 102, tab. XIV, fig. 14, a-b.

Rhizome short, strong, slightly creeping, clothed with black-brown, spreading, subulate scales. Stipes approximate, subtufted, blackish-red, polished, naked or punctate, $10-20$ c.M. long. Fronds ligulate-linear, \pm 30 c.II. long, 5-4 c.M. broad, simply pinnate. Terminal pinna oblong, slightly lobed. Lateral pinnae inequilateral, numerous ( \pm 40 on each side), close, spreading, sessile, the lower ones short-stalked, ovate-rhomboidal, the base truncate \& \pm auricled above, cuneate \& commonly slightly rounded below, the apex blunt, the margin entire or finely crenate. T'exture papyraceous, pellucid, dark-green; veins erecto-patent, simple or forked, the tips thickened. Sori occupying the upper and lower margin, forming a continuous line on each side of the costa.

Celebes.

* (5) S. divergens, Kuhn (not Diels), Copel., Polypod. Philipp., 58; Vittaria divergens, Rb., Wall., List, No. 2191; Lindsaya divergens, Hk. \& Grev. (not Wall.), Hk. Bk., Syn. Fil., 109; Bedd., Ferns Br.I., II, tab. CCL; Hk. \& Grev., Ic. Fil., tab. CGXXVI. - var. auriculata, Christ, MS. in Herb. Bog.

Stipes approximate, wiry, erect, blackish, polished, 5-15 c.M. long. Fronds $10-30$ c.M. long, 3-马 c.Mr. broad, lanceolate, pinnate. Pinnae close, spreading, $3^{1} / 2-7^{1} / 2$ m.M. broad, the apex blunt, the edge entire or nearly so, the upper base truncate, slightly auricled, the lower base rounded or cuneate, lower pinnae \pm reduced, \pm deflexed. Texture subcoriaceous; rachis naked, polished; surfaces naked; veins forked, inconspicuous; costa present. Sori continuous along both sides and the apex.

Var. auriculata: Pinnae distinctly auricled at the base on the upper side.

Malaya.

* (6) S. Walkerae, Kuhn, Diels, in Engl. \& Prantl, Nat. Pfl.Fam. I $^{4}$ 218; Lindsaya Walkerae, Hk., Hk. Bk., Syn. Fil., 109; Hk., Spec. Fil., I, tab. LXIX, A; Bedd., Ferns S.I., tab. CGXV. 
50. SCHIZoLoma. $\$ 1$. isolona.

Rhizome creeping, ferrugineous, with scale-like hairs. Stipes wiry, erect, $15-50$ c.M. long and as well as the rachis dark-coloured, glossy. Fronds $15-50$ c.M. long, with a terminal pinna and $6-9$ pairs of similar lateral ones. Pinnae 5 $1 / 2-10$ c.M. long, $1 / 2-1$ c.M. broad, distant, erecto-patent, gradually narrowing from a cuneate base towards the bluntish or acute apex, the highest ones sometimes confluent with the terminal. Texture coriaceous; rachis naked; veins numerous, very oblique. Sori in a continuous line along both edges.

Borneo, Banca, Sumalra; Ceylon.

\section{\$2. EUSCHIZOLOMA.}

a. Fronds dimorphous, simple, forled or ternate.

*. Barren fronds cordale-oblong, simple.

(7) S. cordatum.

*.*. Barren fronds delloid, 3-partite.

(8) S. trilobatum.

a.a. Fronds uniform, pinnale, rarely simple or $2-3 \times$ pinnale.

b. Pinnac simple, spreading or falcate, 1-2 c.M. long.

(9) S. Guerinianum.

b.b. Pinnae crecto-patent, $3 \frac{1}{2}-15$ c.M. long or longer.

c. Pinnae simple, linear or lanccolate, acuminate.

d. Fronds approximale, thin-herbaceous. (10) S. ensifolium.

d.d. Fronds dislanl, subcoriaccous. (11) S. coriaceum.

c.c. Pinnue varying from simple to irregularly 2upinnate. Leaflets semiorbicular, triangular, trapezoidal or cuncale-obovate, blunt or bluntish.

(12) S. heterophyllum. SI p $2 / 5$

* 7) S. conoliatmin, Gead., Bedd., Handb. Ind. Ferns, 79; Ferns Br.I., II, tab. CGIC; Lindsaya cordala, Gaud., Hk. Bk., Syn. Fil., 111.

Rhizone short-creeping. Stipes 7-20 c.M. long, slender, erect, wiry. Fronds dimorphous. Barren fronds $3^{1} / 2-71 / 2$ c.M. long, $21 / 2-4$ c.M. broad, cordate-oblong, quite entire, fertile ones $7-1$ b.M. long, linear, simple, forked or tripartite. Texture coriaceous. Sori in a continuous line along the margin.

Malaya. 
(8) S. trilobatum, v. A. v. R.; Lindsaya trilobata, Bk., Journ. of Bot., XXIX, 107; L. Hosei, C. Chr., Ind. Fil.

Rhizome short-creeping. Stipes naked, those of the barren fronds slender, ${ }_{2} 1 / 2-10$ c.M. long. Fronds dimorphous, the barren ones deltoid, 5-partite, with an obovate-cuneate terminal lobe slightly repand in the upper half, and 2 shorter side-lobes produced on the lower side. Texture subcoriaceous; surfaces naked; veins immersed, obscure, flabellate, anastomosing. Fertile fronds with the terminal segment lanceolate. Sori running down both sides of the terminal segment, from the apex nearly to the base; indusium coriaceous, narrow.

Borneo.

(9) S. Guerinianum, Gaud., Freyc., Voy. Ur. \& Phys., Bot., 380, tab. XVIII; Lindsaya Gueriniana, Gaud., Hk. Bk., Syn. Fil., 111.

Rhizome creeping, scaly. Stipes $10-15$ c.M. long. Fronds $15-25$ c.M. long, oblong-lanceolate, simply pinnate. Pinnae 1-2 c.M. long, ovate or oblong, nearly entire, horizontal or falcate, slightly auricled at the base on the upper side. Texture subcoriaceous. Sori in a continuous line along hoth margins.

Malaya.

* (10) S. ensifolium, J. Sm., Journ. of Bot., III, 414; Bedd., Ferns S.I., tab. XXV; Lindsaya ensifolia, Sw.; Rac., Flor. Btz., I., 143 ; Hk., Gard. Ferns, tab. LXII; Hk. \& Grev., Ic. Fil., tab. CXI.

Rhizome short-creeping, densely scaly, the scales fibril-like, brown, subadpressed. Stipes 7-25 c.M. long, wiry, flexuose, rather approximate, stramineous or brownish. Fronds $15-50$ c.M. long, $51 / 2-10$ c.M. broad, simply pinnate, the apex long, linear, simple or pinnatifid. Pinnae in $2-12$ pairs, stalked or sessile, $31 / 2-15$ c.M. long, $21 / 2-25$ m.M. broad, linear or lanceolate, acuminate, \pm erecto-patent, equilateral, the base obliquely truncate to cuneate, sterile pinnae toothed, fertile ones rather narrower, entire. Texture thin, herbaceous. Sori in continuous lines along the margins. - The young plants have the fronds simple or ternate, but sterile.

Tropical Asia, Australia and Polynesia.

\section{* (11) S. coriaceum, v. A. v. R.}

Rhizome creeping, the scales dense, subadpressed, brown, small, fibrillike. Stipes rather distant, naked, glossy, dark-brown or purpureous, \pm 8-15 c.M. long or longer. Fronds simple, linear-lanceolate, $10-20$ c.M. 
long, $5-15 \mathrm{~m} . M$. broad, narrowed gradually at both ends, forked, or pinnate with $\pm 1-5$ lateral pinnae on each side similar to the simple fronds, the edges entire, much recurved. Texture firm, subcoriaceous; surfaces naked; rachis like the stipe; veins anastomosing; costa prominent beneath, \pm wavy. Sori long, continuous along the margins; indusium firm. - The description is taken from a specimen determined as Taenitis blechnoides, Sw., (Ann. Btz., $\mathrm{XX}, 128)$.

Borneo (Hallier No. 1934).

* (12) S. heterophyllum, J. Sm., Copel., Polypod. Philipp., 59; Bedd., Ferns S.I., tab. XXVI; Lindsaya helerophylla, Dry., Hk. Bk., Syn. Fil., 112; Bedd., l. c., tab. CCVI; (? L., orbiculata, Mell., p. p., Copel., Philipp. Journ., I, Suppl., 148).

Rhizome short-creeping, the scales fine, brown. Stipes approximate, erect, 5-20 c.I. long, naked. Fronds $10-50$ c.M. long, pinnate and lanceolate or 2-pinnate and deltoid with erecto-patent branches 7-10 c.M. long. Leaflets semiorbicular and fixed by the middle of the straight side with radiate venation and a continuous submarginal indusium around the upper side, or triangular with the indusium along 2 sides, or trapezoidal with the indusium usually continuous along the upper and outer sides, $1-21 / 2$ c.II. long, $1 / 2-1$ c.M. broad, the apex blunt or bluntish, the margin entire or finely toothed. Texture papyraceo-herbaceous; surfaces naked. - A very variable fern.

Trop. Asia, Soulh. China.

\section{1a. SACCOLOMA, Kaulfuss.}

Sori roundish or transversally oblong, submarginal, small, numerous, terminal on the veins, placed in submarginal depressions. Indusium slightly convex, covering the depression, attached at the base or the base and sides, open at the outer edge.

Rhizome short or creeping, scaly. Stipes not articulate to the rhizonte. Fronds divided; veins free.

Malayan, Polynesian and Neotropical. 
Arrangeinent of the sections.

$\$$ 1. CYSTODIUM. Indusium transversally oblong, attached by the broad base, covering a marginal, distinctly cucullate outgrowth. Diels, in Engl. \& Prantl, Nat. Pfl.lant., I ${ }^{4}$, fig. 115 , E.

$\$$ 2. PARASACCOLOMA. Indusium cuneate-oblong, the base acute, covering a half-cupshaped submarginal depression. Hk., Spec. Iil., I, tab. LVIII, A, (as Davallia inequalis, Kze, var. minur).

$\$$ 3. EUSACCOLOMA. Indusium transversally oblong, the base broad, covering an intramarginal depression. Diels, l. c. lig. 113, C. (Not in Malaya).

\section{\$ 1. CYSTODIUM.}

* (1) S. Sorbifolinm, Chroist, Farnkr. d. Erde, 309; Diclisonia sorlufolia, Sin., Hk. Bk., Syn. Fil., 52; Hk., Spec. Fil., I, Lab. XXV, A; Cyslodium sorbifolium, J. S»., Bau. \& Hk., Gen. Fil., tab. XCVI; - var. dentatum.

Stipes tufted, מ0 c.M. or much more long, the base densely clothed with long, fine, silky or woolly, yellowish hairs. Fronds large, 2-pinnate, 60 c.M. or much more long, ovate-lanceolate. Largest pinnae $25-35$ c.M. long, \pm 8 c.M. broad, stalked, the lowest sometimes smaller than the next in order. Pinnulae numerous, the highest sessile with a broarl base, the lowest largest, \pm 7-10 m.M. broad, short-stalked, the base truncate or cordate, whether or not auricled on the upper side, the edge sharply serrate towards the apex. Texture subcoriaceous; rachises and under side of the costae and veins more or less hairy; veins simple or forked. Fertile pinnulae bluntly toothed, bearing the sori on the teeth. Sori numerous, 1 to each tooth; indusium semiglobose, outer valve cucullate, formed by the apex of a toolh, iuner valve smaller, \pm plane.

Van. dentatuan: Lower pinnulae deeply toothed.

Malaya.

\section{S2. PARASACCOLOMA.}

* (2) S. molucerunum, Mett., Diels, in Engl. \& Prantl, Nat Pfl., Fanı., I", 211; Davallia moluccana, Bl., Rac., Flor. Btz., I, 156; D. inequalis, Kze., var. minor., Hk., Spec. Fil., I, tab. LVIII, A; D. asperrima, Ces., Fel. 
Becc. Polin., 5 \& 6 ; Microlepia moluccana, Bedd., Handb. Ind. Ferns, Suppl., 15 ; - var: stenolohum, Christ, Bull. Herh. Boiss, 2e Série, VI, 1005.

Rhizome creeping or suberect, clothed with large, pale-brown, lanceolate scales. Stipes strong, erect, to 40 c.M. long, \pm naked. Fronds deltoid to lanceolate, 3-pinnate to 4-pinnalifid, 60-120 c.M. long, 20-55 c.M. broad. Lower pinnae linear-lanceolate, to $8-15$ c.M. broad, stalked. Pinnulac 10 2 c.M. loroad. Segments elliptical, the base decurrent, toothed or cut down to the costa into toothed, oblong lobes in the lower part. Texture membranous to subcoriaceous; both surfaces \pm naked. Sori $1-6$ to a lobe, small, placed in the leeth near the base; the apices of indusia often produced beyond the margin of the lobes.

Var. stenololoum: Pinnulae mach narrower than in the type.

Malaya; Polynesia; - var. stenolobum: Luzon.

\section{LEPTOLEPIA, Methenies.}

Sori roundish or transversally oblong, submarginal, solitary and termimal on short veinlets, whether or not placed on marginal, recurved outgrowths. Indusium of the same shaje, fixed at the base, but by the apex of the veinlet only, otherwise free, the outer edge lacerato-lobate, opening outwardly.

Rhizome creeping and hairy (as far as known). Stipes not articulate to the rhizome. Fronds copiously divided; veins free. Diels, in Engl. \& Prantl, Nat. Pfl.Fam., I, fig. 115, A-B.

Australia and Papua.

H. novae guineae, v. A. v. Rh.; Davallia Novac Guincae, Rs.., Fed., Rep., $\mathrm{V}, 36$.

Rhizome and stipes unknown. Fronds large, \pm 2 M. long, \pm 1 M. broad, ovate-lanceolate, acuminate, 4-pinnatifid to 4-pinnate. Pinnae on stalks 3-5 c.M. long, subfalcate or erecto-patent, subsymetrical, lanceolate, acuminate, the anterior side a little broader than the posterior orie, the apex scrratopinnatifid. Pinnulae and tertiary segments of the same shape as the pimmae, the former to 20 c.M. long and 8 c.M. broad, the latter to b c.M. long and $\pm 13 / 4$ c.M. broad at the base. Quateruary segments sessile, suberecto-patent, narrowed at the base, decurrent, clongate-ovate, acute, the edge oblusely serratu-dentate, the lowest to 10 m.M. long and 4 m.M. broad. Texture char- 
taceo-herbaceous; surfaces naked; colour olive-green, paler beneath; rachis, costae and costulae furnished beneath with scattered hairs; veins simple or forked, lower veins pinnate, the veinlets simple or forked. Sori subglobose, occupying the apex of the higher anterior veinlets, submarginal, placed on subscariose, recurved, blunt or acute lobules; indusium transversally oblong, fastened by the apex of the veinlet only, whitish-yellowish, scariose, forming with the lobule a 2 -valved involucre to the sorus, the outer edge dilacerate, the lacinulae piloso-fimbriate.

New Guinea.

\section{HUMATA, Cavanilles.}

Sori roundish or oblong, solitary and terminal on the veins or veinlets, submarginal or somewhat remote from the margin. Indusium \pm of the same shape, fixed by a broad base at the immer side of the sorus, free at the sides, opening outwardly $\left(^{\star}\right)$.

Rhizome scaly, creeping. Stipes articulate to the rhizome, scattered. Fronds mostly divided; veins free. Diels, in Engl. \& Prantl, Nat. Pfl.Fam., $I^{4}$, fig. 112 .

Paleotropical.

Arrangement of the sections.

$\$ 1$. EUHUMATA. Indusium thick, coriaceous.

$\$$ 2. LEUCOSTEGIA. Indusium thin, membranaceous (Davallia, p. p., C. Chr., Ind. Fil.).

\section{$\$ 1$. EUHUMATA.}

a. Barren fronds simple, entire, crenate or toothed.

*. Fertile fronds al best loolhed.

(1) H. angustata.

*.*. Fertile fronds decply pinnalifid.

(2) H. heterophylla.

(2a) H. mieroscra

$\left({ }^{*}\right)$ The genera Oleandra, Davallia \& Microlepia have the indusia sometimes more or less resembling those of Humata. 
a.a. Barren fronds varying from pinnatifid to 3-pinnate.

b. Lowest primary segments simple or pinnalifid, not much broader or larger than the higher ones.

5. Rhizome scales adpressed. Stipes \pm 5-10 c.M. long.

(3) H. Gaimardiana.

\$.S. Rhizome scales spreading. Stipes wanting or $70 \pm \pm$ c.M. long.

(4) H. sessilifolia.

b.b. Lowest primary segments at least pinnatifid, distinctly broader or larger than the higher onies.

c. Fronds uniform.

d. All the divisions very narrow, almost filiform, al utmost 1 m.M. broad. Fronds under 5 c.M. long. m.M. broad. Fronds under 5 c.M. long. G (5) H. parvula.
d.d. The divisions not almost filiform, at leasl 3 m.M. broad. Fully developed fronds 5-20 c.M. long.

e. Lobes of the lowest primary segments entire.

f. Primary segments deltoid-lanceolate.

(6) H. pinnatifida.

f.f. Primary segments linear-oblong.

(7) H. pectinata.

e.e. Lobes of the lowest primary segments crenate or lobed.

(8) H. repens.

c.c. Fronds more or less dimorphous; i. e. the fertile segments narrower than the barren ones or the fertile fronds much larger than the barren frouds.

1. Barren fronds small, $\pm 21 / 2-4$ c.lf. long.

*. Fertile fronds \pm as large as the barren ones, with the segments contracted and sharply toothed. (9) H. pusilla. *.*. Fertile fronds much larger than the barren oncs, with the segments not contracted.

(10) H. lepida.

1.1. Bolh barren and fertile fronds 4-20 c.M. long when fully developed.

2. Fertile fronds with the segments not toothed.

(11) H. neoguineensis.

2.2. Fertile fronds with the segments toothed, the teeth often very sharp.

3. Lowest pinnae pinnatifid or pinnate in the barren fronds.

4. Secondary segments entire or crenate in the barren fronds.

(12) H. alpina. 
52. нuмata. $\$ 1$. еunumata.

4.4. Secondary segments blunlly toolhed in the barren fronds.

(15) H. botrychioides.

3.3. Lower pinnae 2-pinnate in the barren fronds.

(14) H. vestita.

Q La) H nibrésa

(ivb) H. obturatía

(14c) H. tenuis

* (1) II. angusta1a, J. Sme, Copel., Polypod. Philipp., 50; Bedd., Ferns Br.I., II, tab. CCXXXVII; II. hererophylla, Desv., var., C. Chr., Ind. Fil.; Davallia angustnia, Wall., Hk. Bk., Syn Fil., 88; Hk. \& Grev., Ic. Fil., tab. CCXXXI.

Rhizome wide-creeping; scales brown, ovate-lanceolate, acuminate, erectopatent to erect, the hase pellate. Fronds subsessile or stalked, linearlanceolate, $7 \frac{1}{2}-20$ c.M. long, $1 / 2-2$ c.M broad, slightly or more distinctly and irregularly crenate to toothed at the margin, sometimes once forked, the stipes varying from short to 6 c.h. long, often slightly winged. Texture coriaceous; surfaces naked. Sori in a row along the edges.

Malaya.

* (2) M. Ineteroplnylla, Desv. (not J. Sm.), Copel., Polypod. Philipp, 50.; Bedd., Ferns Br.I., I, tah. C; Davallia heterophylla, J. Sm., Rac., Flor. Btz., I, 126; Hk., Fil. Exol., tah. XXVII; Hk. \& Grev., tab. CGXXX; var. nervosa.

Rhizome wide-creeping, the scales dense, with an oblong, peltate, adpressed base and a long, linear-subulate, recurved or spreading, shortly ciliate or finely toothed point. Stipes $1-4 \frac{1}{2}$ c.M. long, 1-3 c.M. apart. Fronds dimorphous, the barren ones lanceolate, 6-15 c.M. long, $1 \frac{1}{2}-51 / 2$ c.M. broad, the apex acute, the edge entire or slightly crenate, the base more or less suddenly, narrowed or rounded and then often decurrent so as to form a long, narrow wing to the stipe. Texture coriaceous, rigid; surfaces naked; veins commonly once or more times forked. Fertile fronds narrower, deeply pinnatifid into blunt, entire or broadly toothed lobes $5-4$ m.M. broad. Sori 2-10 to a lobe, often close; indusium transversally oblong.

War. Henvosa: Fronds crisped; veins more conspicuous.

Malaya; Polynesia.

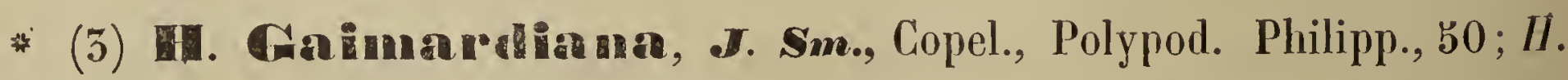
parallela, Brack., Bedd., Ferns Br.I., I, tab. IC; Davallia Gaimardiana, Pr., 
Rac., Flor. Btz., I, 127; D. parallela, Wall., Hk., Spec. Fil., I, tab, XLII, A; Hk. Bk., Syn. Fil., 89; D. intramarginalis, Bl., Hk., 1. c., 154.

Rhizome wide-crceping, densely clothed with adpressed, lanceolate, pellate scales. Stipes $1-\breve{b}$ c.M. apart, $\breve{-10}$ c.M. long, erect, more or less scaly like the rachis. Fronds $10-20$ c.M. long, 3-弓̆ c.M. broad, triangularlanceolate, cut down nearly or quite to the rachis into long, nearly or quite close, parallel, linear-oblong, entire, bluntish or acule segments, the lowest pair often a little shorter and sometimes auricled. Texture coriaceous; surfaces naked; veins forked. Sori oblique, occupying the apices of the anterior veinlets, placed in 1 row on each side of the costulae; indusium with the base slightly excavate.

Malaya; Burmah, Polynesia.

* (4) H. sessillifolia, Dett. (not Sm.), Diels, in Engl. \& Prantl, Nat. Pll.Fam., I", 209; Davallia sessilifolia, Bl., Rac., Flor. Btz., I, 128; var. polypodioides; II. polypodinides, Brack., Wilk., Expl. Exp., XVI, 228, tab. XXXII, fig. 1.

Rhizome wide-creeping, the scales dense, with the base dilated and pellate, the point lanceolate-subulate, spreading. Stipes very short, $101 \frac{1}{2}$ c.M. long. Fronds ovate or ileltoid-lanceolate, acuminate, $5-10$ c.M. long, $21 / 2-4$ c.M. broad, cut down nearly to the costa into linear-oblong, parallel, entire or toothed segments, the lower ones sometimes deeply pinnatifid or auricled at the lower base. Segments $\pm 5-4 \mathrm{~m}$.M. broad. Texture varying from thin to subcoriaceons; surfaces naked; veins forked. Sor'i in 1 row on each side of the costulae, occupying the greater part of the space between the costulac and the edges.

ar. molypodioides: Fronds larger, more acute, on stipes $21 / 2-5$ c.M. long.

Forms reported from Celches had the fronds hoth sessile and stalked on the same rhizome.

Java, Celebes; Fiji.

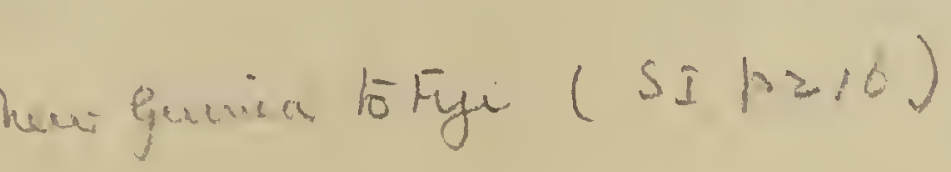

* (5) Er. Danverla, Tret. (not J.Sm.), Dicls, in Engl. \& Pranll, Nat. Pfl.Fam., I', 209; Davallia parvula, Wall., Hk. Bk., Syn. Fil., 92; Hk. \& Grev., Ic. Fil., Lab. CXXXVII; C. Chr", Ind. Fil.

Rhizome wide-creeping, branched, the scales lanceolate, peltate near the base, entire or nearly so, ferrugineous. Stipes scallered, $1-71 / 2$ c.M. long. Fronds $1 \frac{1}{2}-4$ c.M. long, to 5 c.M. Hroad, deltoid-ovate in general outline, 
2-5-pinnate, with all the divisions almost filiform and the ultimate segments sharp at the point. Sori placed at the sinuses of the ultimate forks; indusium coriaceous, broader than the segments.

Malacca, Banca, Borneo, Celebes.

(6) Tr. Dinnatifidat, Bedd., Handb. Ind. Ferns, Suppl., 12; H. intermedia, C. Chr., Ind. Fil.; Davallia pinnatifida, Bk., Journ. of Linn. Soc., Bot., XXIV, 257.

Rhizome slender, firm, wide-creeping, clothed with close-pressed, ovate, peltate scales, glaucous beneath the scales. Stipes distant, firm, erect, stramineous, 5\% -10 c.M. long. Fronds elongate-deltoid, broadest at the base, narrowed gradually towards the apex, $7 \frac{1}{2}-15$ c.M. long, $51 / 2-61 / 2$ c.M. broad at the base, pinnatifid nearly to the costa into numerous, deltoid-lanceolate, entire, crenate or slightly lobed segments 4-7 m.M. broad, the lowest pair much the broadest, deltoid, lobed on the lower side. Texture rigidly coriaceous; veins simple or forked. Sori small, terminal on the veins; indusium rigid, persistent, broader than long.

Borneo, Malacca. Sun abiea

(7) IL. pectinata, Desv., Prod., 325 ; Davallia pectinala, Sm., Hk. Bk., Syn. Fil., 89; Hk. \& Grev., Ic. Fil., tab. CXXXIX.

Rhizome creeping, scaly. Stipes distant, scaly. Fronds $10-20$ c.M. long, 5-8 c.M. broad, elongate-deltoid, cut down nearly or quite to the rachis into many, parallel, oblong or linear-oblong segments. Segments approximate, blunt, the higher ones entire, the lower ones inciso-pinnatifid, the lowest ones a little broader and deeply pinnatifid on the lower side, with the lobes sometimes $1-1 \frac{1}{2}$ c.M. long. Texture coriaceous. Sori oblique, submarginal; indusium transversally oblong, broader than deep, attached at the central part of the base.

Borneo, New Guinea; Polynesia.

* (8) - r. repens, Diels (not J. Sm.), Copel., Polypod. Philipp., 50; II. pedata, J. Sm., Bedd., Handb. Ind. Ferns, 48; Ferns S. I., tab. XII; Davallia pedela, Sm., Rac., Flor. Btz., I, 128; Hk., Spec. Fil., I, tab. XLV, A; Gard. Ferns, tab. VII; Adiantum repens, L., (oldest name).

Rhizome wide-creeping; scales dense, lanceolate, the apex acute, the base peltate, hlunt.' Stipes distant, b-10 c.M. long, sparingly scaly. Fronds 
5-20 c.M. long, 4-10 c.II. broad, deltoid, or ovate-deltoid, cut down nearly or quite to the rachis into few to several, oblong or linear-oblong segments. Segments rather close, blunt, crenate or toothed, the lowest ones broader, sessile or subsessile with a narrowed base, the lower side the broadest, lohed or pinnatifid, with the lobes crenate, toothed or lobed again, the upper side narrow, toothed or lobed. T'exture coriaceous. Sori submarginal, 1 to each crenation or tooth; indusium \pm orhicular, sometimes slightly and transversally oblong, but not much broader than deep.

Trop. Asia \& Australia, Japan, South. China, Mascarenes, Seychelles.

* (9) H. pusilla, Carr. (not Sm.), Diels, in Engl. \& Prantl, Nat. Pfl.Fam., 14, 209; Davallia pusilla, Mett., Hk. Bk., Syn. Fil., 89.

Rhizome creeping, scaly. Stipes to 5 c.M. long. Fronds $21 / 2-4$ c.M. long, $1 \frac{1}{2}-5$ c.M. broad, or the barren fronds not rarely smaller, cordato deltoid in general outline, cut down to a narrowly winged rachis. Upper segments linear-oblong, deeply inciso-dentate in the fully developed fronds, the lower pair deeply inciso-pinnatifid on the lower side, those of the fertile fronds narrower than in the barren ones, with the teeth sharper. Texture coriaceous; veins \pm prominent. Sori small, placed at the base of the small teeth.Plants suggesting H. alpina, Moore, but much smaller, with the harren fronds not rarely very small and the segments nearly undivided.

Borneo, Mindanao, New Guinea; Melanesia.

* (10) H. Iepida, Moore, C. Chr., Ind. Fil.; II. Cumingii, Brack., Copel., Polypod. Philipp., 51; Davallia Cumingii, Hk., Hk. Bk., Syn. Fil., 90; Hk., Spec. Fil., I, tab. XVL, B; D. longula, Kze, Bot. Zeit., 1848, 215 ; D. lepida, Pr., (oldest name).

Rhizome creeping, scaly. Stipe $71 / 2-10$ c.M. long, both it and the rachis rather scaly. Fronds dimorphous. Barren fronds deltoid-cordate \pm $21 / 2$-5 c.ll. each way, cut down nearly to the costa. Upper lobes oblong, blunt, slightly toothed, the lower pair deeply pinnatifid below. Texture coriaceous. Fertile fronds \pm the same shape, but more divided, $10-121 / 2$ c.M. long, 7-8 c.M. broad, pinnate. Upper pinnae toothed to pinnatifid, united at the base by a narrow wing, linear-oblong, lower pinnae cut down nearly or quite to the rachis at the base into toothed lobes or pinnulae. Sori placed in the teeth. - Allied to II. repens, Diels and like this with the fertile segments not contracted.

Philippines.

Fiuces. 


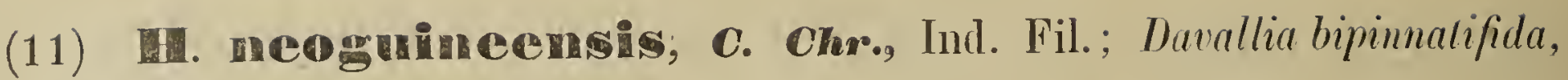
Bk., Kew Bull., 1899, 119.

Rhizome slender, wide-creeping, the scales lanceolate, adpressed, membranaceous, pale-brown. Stipes slender, naked, 7-10 c.M. long. Fronds lanceolate-deltoid, 2 pinnatifid, $12-15$ c.M. long, \pm 5 c.M. broad. Pinnae sessile, the lower largest, the barren ones oblong, obtuse, slightly pinnatifid, cuneate at the base, the fertile ones narrower, deeply pinnatifid, wilh the lobes erecto-patent, the lower lobes oblong, obtuse. Texture coriaceous; surfaces naked like the slender rachis; veins flabellate, conspicuous. Sori solitary on the higher lobes, $2-5$ on the lower ones; indusium semiorbicular, firm. New Guinea.

* (12) WII alpima, Moore (not Sm.), Diels, in Engl. \& Prantl, Nat. Pfl.Fam., I", 209; II. repens, Diels, var., C. Chr., Ind. Fil.; Davallia alpina, Bl., Rac., Flor. Btz., I, 127 ; — var. montana.

Like H. repens, Diels, but dimorphous. Stipes 1-10 c.M. Jong. Fronds 4-10 c.M. long, 3-9 c.M. broad. Barren fronds with, the central pinnae oblong, crenate, toothed or obliquely pinnatifid and the lower pinnae pinnate or 2-pinnatifid. Fertile fronds brown when dry, the central pinnae linear, simple and the lower pinnae pinnate, the laciniae slightly narrowed, the edges toothed, the teeth commonly sharp, upcurved. Sori occupying the upper base of the teeth.

War. Intarnat Fertile fronds more finely divided, blackish when dry, the laciniae much contracted so that the leafy membrane is nearly wanting. Sori occupying the base of the always very sharp, hamate teeth.

Malaya; Polynesia; - var. montana: Java (Forbes), Billiton (Teysmann).

(13) H. Dotrychioides, Brack. (not J. Sm.), Copel., Polypod. 1hilipp., 51; Wilk., Expl. Exp., XVI, tab. XXXII, fig. 1; Diels, in Engl. \& Prantl, Nat. Pfl.Fam., I"4, fig. 112, C-D; Davallia botrychioides, Ble. (not Brack.), Hk. Bk., Syn., Fil., 90.

Rhizome wide-creeping, scaly. Stipes 5-121/2 c.M. long, scaly below. Fronds 6-20 c.M. long, 5-12 $\frac{1}{2}$ c.M. broad, deltoid in outline, dimorphous, the barren ones with a narrowly winged rachis. Lowest pinnae cut down nearly to the rachis with decp, blunlly toothed segments. Fertile pinnae more finely divided; pinnulae of the lower pinnae cut down to a narrow rachis into narrow, sharply toothed segments. Sori in the sinuses of the leeth. Philippines, Celclies; Polynesin. 
* (14) rer. vestita, moore (not J.Sm.), Copel., Polypod. Philipp., 50; Davallia vestita, Bl., Rac., Flor. Btz., I, 126; Hk. Spec. Fil., I, tab. XLI, C; D. bipinnatifida, Bl., Hk., l. c., 156; D. chaerophylla, Ces., Fel. Becc. Polin., 3; D. Bélangeri, Bory, Bél., Voy. Bot., II, tab. VII, fig. 1.

Rhizome wide-creeping, the scales dense, linear-lanceolate, membranaceous, peltate at the base. Stipes rather distant, 71/2-20 c.M. long, sparingly covered with long, thin scales especially near the base. Fronds deltoid to lanceolate-ovate, $10-20$ c.M. long, 7-10 c.M. broad. Barren fronds with the central pinnae pinnate and the lower pinnae 2-pinnate, the segments oblong, crenate (scarcely toothed), united at the base by a narrow wing. Fertile fronds with the segments narrower, sharper toothed. Texture coriaceous. Sori placed on the teeth. - Near H. repens, Diels, and alpina, Maore. Malaya.

\section{\$2. LEUCOSTEGIA.}

a. Fronds small, under 20 c.M. long $\left(^{\star}\right)$.

(15) H. falcinella.

a.๙. Fully developed fronds middle-sized, 20-60 c.M. long.

b. Sori on the dilated tips of the ultimate segments. (16) H. cicutarioides.

b.6. Sori at or near the base of the ultimate segments.

c. Scalcs of the rhizome obtusely rounded, adpressed. (17) H. pulchira. c.c. Scales of the rhizome acule or acuminate.

d. Sori \pm immersed, prominent on the upper surface.

(18) H. immersa.

d.d. Sori not immersed.

e. Rhizome scales with the apex not recurved.

*. Fronds 2-pinnale.

(19) H. Hosei.

*.*. Fronds 4-5-pinnate. (20) H. hymenophylloides.

e.e. Rhizome scales with the apex spreading or recurved.

f. Rachis narrowly winged.

(21) H. Kingii.

f.f. Rachis nol at all winged.

(22) H. viscidula.

u.c.e. Fronds large, 60-90 c.M. long when fully developed.

(25) H. nephrodioides.

(") See also under H. immersa, Mell. 
(15) 1I. Falcinellse, Copel., Polypod. Philipp., 51; Davallia falcinella, Pr., Hk. Bk., Syn. Fil., 91 ; Pr., Rel. Haenk., I, tab. XI, fig. 2; C. Chr., Ind. Fil.

Rhizome wide-creeping, thickly beset with stiff, spreading hairs, ferrugineous, turning toward black. Stipes 5 -10 c.M. long, naked. Fronds $10-1 \mathbf{b}$ c.M. long, 71/2-10 c.M. broad, deltoid, 5-4-pinnatifid; main rachis slightly winged. Lowest pinnae inequilateral. Pinnulae oblong, cut down nearly 10 the rachis into segments which are again deeply toothed. Ultimate segments of the fertile fronds falcate-mucronate, of the barren fronds broader and not so sharp. Texture subcoriaceous; surfaces naked. Sori $2-6$ to a lobe, placed at the base of the teeth. - Ferns with the aspect of Colposoria and the rhizome hairs of Microlepia.

\section{Philippines.}

(16) 1H. cicutanoioides, Diels, in Engl. \& Prantl, Nat. Pfl.Fam., $1^{4}$, 210 ; Davallia cicutarioides, Bk., Journ. of Bot., XXVIII, 106 ; 'C. Chr., Ind. Fil.

Fronds decompound. Lower pinnae ovate-lanceolate, 1 h -20 c.M. long. Ultimate segments linear, 2-4 m.M. long, the sterile ones acute, the fertile ones obtuse. Texture moderately firm; rachises slender, naked, polished, hrown; veins 1 to each ultimate segment. Sori minute, solitary on the dilated tips of the ultimate segments; indusium pale-coloured, suborbicular.

New Guinea.

* (17) Fl. Dulchrea, Diels, in Engl. \& Prantl, Nat. Pfl.Fam., I", 209: Davallia pulchra, Don, Chrisi, Farnkr. d. Erde, 505; C. Chr., Ind. Fil.; D. chaerophylla, Waill., Hik. Bk., Syn. Fil., 92; Leucoslegia pulchra, J. Sm., Bedd., Handb. Ind. Ferns, 52; Acrophorus pulcher, Moore, Bedd., Ferns S.I., tab. X.

Rhizome wide-creeping, clothed with broad, obtuse, adpressed scales. Stipes $10-15$ c.M. long, naked. Fronds $20-40$ c.M. long, 10-50 c.M. broad, lanceolate-deltoid, 3-4-pinnatifid. Lowest pinnulae $2 \frac{1}{2}-5$ c.II. long, $21 / 2$ c.II. broad, cut down to a narrowly winged rachis into deeply pinnatifid segments. Ultimate lobes narrow and acute in the fertile, rather broader in the barren fronds. Texture thinly herbaceous, rather flaccid. Sori copious, placer at the base of the teeth of the segments, wich they about equal in breadth.

New Guinea, Malacca; Ceylon, Nolh. India, Yunnan.

"(18) M. Immer.sa, Mett. (not Diels), Copel., Polypod. Philipp., 31; Davallia immersa, Wall, Rac., Flor. Biz., I, 129; Hk., Fil. Exol., tab. 
LXXIX; C. Chr., Ind. Fil.; Leucostegia immersa, Pr., Bedd., Handb. Ind. Ferns, b้1; Acrophorus immersus, Moore, Bedd., Ferus S.I., tab. XI; — var. amplissima, Christ, Ann. Btz., XV, 90; - var. minuta; - var. nana, Copel., Philipp. Journ., 1, Suppl., 147.

Rhizome wide-creeping, clothed with lanceolate, ferrugineous fibrils. Stipes 10 - 50 c.M. long, firm, erect, naked. Fronds 50-45 c.M. long, 15-25 c.M. broad, triangular, 3-pinnate. Lowest pinuulae lanceolate-triangular, c.M. long, with the ultimate divisions rhomboidal, the base, obliquely cuneate, the upper side broader than the lower one, the edge lobed, with the lobes rounded and crenate above. T'exture herbaceous or flaccido-coriaceous; surfaces naked. Sori commonly large, immersed, \pm prominent on the upper surface, $1-6$ to a leaflet; indusium broader than long, the outher edge semiorbicular, the base straight.

War. annlissimae: Fronds lanceolate, to 75 c.M. long; indusium rẻniform.

Var. minuta : Fronds small, to 10 c.M. long, to bै c.M. broad. Stipes slender.

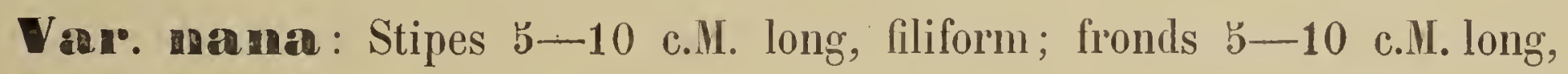
2-pinnate; pinnae obtuse; pinnulae rounded.

Philippines, Java, Malacca; Br. India; - var. amplissima: Celebes; var. minuta: Timor (Forbes, no. 3522); — var. nana: Luzon.

(19) П. Hosei, v. A. v. R.; Davallia Hosei, Bl., Journ. of Bot., XXVI, 325; C. Chr., Ind. Fil.

Rhizome creeping, the scales minute, adpressed, linear, brown. Stipes llaked, brownish, 30-40 c.M. long. Fronds lanceolate-ohlong, 2-pinnate, 45-60 c.M. long, 12-15 c.M. broad. Pinnae distant, lanceolate, erecto-patent, $2-21 / 2$ c.M. broad, cut down to the rachis into unequal-sided, lanceolateoblong, deeply crenate pinnulae $\pm 4-5$ m.M. broad, with the upper base produced and the lower cut away. Texture firm; surfaces naked; veins indistinct, 1 to each lobule. Sori-small, 1 at the base of each lobule; indusium rigid, naked, as broad as long.

Burneo.

* (20) H. Inymemorbylloides, Copet., Polypod. Philipp., b1; Davallia affuis, IIK., Rac., Flor. Btz., I, 129; Hk., Spec. Fil., I, Lab. LII, B; D. hymenophylloides, Kuhu, Ann. Mus. Bot. L.B., IV, 286; (not Bl.), Christ, Farnkr. d. Erde, fig. 957; C. Chr., Ind. Fil.; Acrophorus affinis, Moore, Bedd., 
Ferus S.I., tab. CGLII; Leucoslegia hymenophylloides, Bedd., Handb. Ind. Ferns, 54; Aspidium hymenophylloides, Bl., (oldest name).

Rhizome wide-creeping, the scales \pm dense, ferrugineous, lanceolate, longacuminate, peltate at the base. Stipes scattered, 10-50 c.M. long. Fronds 50-60 c.M. long, 15 -40 c.M. broad, deltoid-lanceolate, 4-ら̌-pinnate. Lowest pinnulae with oblong-rhomboidal divisions, the segments of which are entire or deeply and finely inciso-pinnatifid with sharp teeth. Texture herbaceous; surfaces naked; veins line, blackish, 1 in each ullimate segment. Sori minute, solitary near the base of the segments, $\pm 2-6$ to each tertiary division, terminal on very short veinlets and therefore often appearantly medial on the ultimate veins; indusium broad, semiorbicular or subcordate.

Trop. Asia \& Polynesia.

(21) 11. EK imgingi, Diels, in Engl. \& Prantl, Nat. Pfl.Fam., I4, 210, lig. 112, H; Davallia Kingii, Bk., Hk., Icon. Pl., XVII, tab. MDCXXII ; C. Chr., Ind. Fil.

Rhizome strong, woody, wide-creeping, the scales dense, spreading, subulate, membranaceous, peltate at the base. Stipes erect, straight, naked, \pm 15 c.M. long. Fronds oblong-lanceolate, \pm 45 c.M. long, 20-25 c.M. broad, 3-pinnatifid, sparingly hairy on both surfaces; rachis hairy, narrowly winged. Pinnae lanceolate, the central and lowest longest, subspreading, $\pm \mathbf{5}-4$ c.M. broad. Pinnulae oblong, adnate, decurrent, deeply pinnatifid, the lobes close, oblong, bluntish or acute. Sori solitary at the base of the lobes; indusium subtriangular-oblong. - Hardly diflerent from H. viscidula, v. A. v. R. It is much like Davalia hirsuta, v. A. v. R., but totally different in the structure of the indusium.

Java.

* (22) W. viscoidula, v. A. v. R.; Davallia viscidula, Mell., Rac., D.vi Flor. Btz., I, 131; C. Chr., Ind. Fil. I. FHS We vil Ptiv

Rhizome wide-creeping, densely scaly, the scales with the base rounded, adpressed, reniform, the apex spreading, long-acuminate to filiform. Fronds 3-4-pinnatifid, \pm 3 c.M. long, $10 \pm 22$ c.M. broad, acuminate, the lower pinnae shorter than the following. Pinnae sessile, oblong-lanceolate, acuminate, to \pm 12 c.M. long. Pinnulae close, to $2 \frac{1}{2}$ c.M. long, erecto-patent, lanceolate, bluntish or acute, free and decurrent at the base or more or less confluent, cut down to a \pm winged rachis into toothed or pinnatifid segments to m.M. long and 5 m.M. broad, narrowed at the base, (of the same shape as 
the pimnulae). Texture herbaceous; stipes, rachises and surfaces glandulosopubescent. Sori near the sinuses of the teell; indusium \pm cordate-oblong.

Java.

(23) II. neplnudioides, v. A. v. R.; Davallia nephrodioides, Bli., Journ. of Linn. Soc., Bot., XXIV, 257; C. Chr., Ind. Fil.

Rhizome, wide-creeping, the scales fine, blackish, spreading, hair-like, pellate at the base. Stipes stillly erect, naked, \pm 15 c.M. long. Fronds $60-90$ c.II. long, oblong-lanceolate, $20-25$ c.M. broad at the middle, 2-pinnate, hairy un the costae (rachises), scaleless. Pinnae subpetiolate, lanceolate, the central ones $21 / 2-51 / 2$ c.M. broad, the lower rather smaller, all except the lowest cuneate-truncate on the lower side at the base. Pinnulae multijugate, oblique,

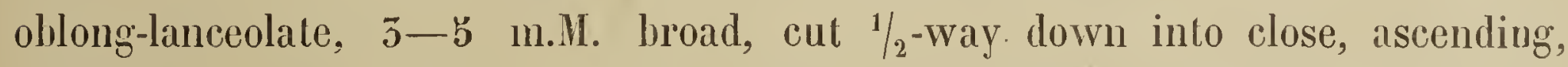
lanceolate lobes. Veins 1 to each final lobe, with a small medial sorus; indusium naked, subreniform, small.

Borneo.

\section{ACREOPHOTEUS, prest.}

Sori roundish, submarginal, terminal on a veinlel, which is springing \pm from the middle of the fertile vein. Indusium broadly ovate, attached at the inner side of the sorus, free at the sides, opening outwardly.

Rhizome erect. Stipes tufted, not articulate to the rhizome. Fronds mucl divided; veins free. Diels, in Engl. \& Prantl., Nat. Pfl.Fam., I ${ }^{4}, 165$, 89, D-F.

Malaya, Northern India.

* A. nodosus, Px., Christ, Farnkr. d. Erde, 285 ; Bedd., Ferns Br.I., I, Lab. XCIII; A. slipellalus, Moore, C. Chrr., Ind. Fil.; Davallia nodosa, Illi., Rac., Flor. Btz., I, 130; - var. alpinus, Christ, Ann. Btz., XV, 89.

Rhizome short, erect, the scales large, ovate or oval, entire, membranitceous. Stipes tufted, 50-100 c.M. long, strong, erect, scaly below. Fronds deltoid-ovate, $6^{\prime \prime-120}$ c.M. long, to 80 c.M. broad, 3-4-pinnate. Pinnae subopposite, sessile or short-stalked, the rachis glandular at the base, lower pinnac $\pm 15-2 \%$ c.M. broad. Pinnulae lanceolate, the rachis glandular 
33. \GRORHORUS.

at the base; lower pinnulae $\pm 2-5$ c.M. broad, with the segments cut down nearly or quite to the rachis into oblong, blunt, entire or toothed lobes \pm 3 m.M. long, $\pm 1^{1} / 2$ m.M. broad, \pm narrowed at the hase. Texture herbaceous; surfaces sparingly hairy; rachises scaly at the base of the divisions. Sori small, solitary and medial in the ultimate lobes.

Var. alpinus: Fronds small, 10-15 c.II. long. Stipes clothed with spreading, acuminate scales.

Malaya; North. India; - var. alpina: Celebes.

\section{DAVALLIA, Smith.}

Sori roundish or oblong, submarginal, solitary and terminal on the veins or veinlets; indusium \pm half-cupshaped or semicylindrical, attached at the hase and sides, opening outwardly.

Rhizome scaly, short or creeping, the scales not minute. Stipes articulate to the rhizome. Fronds variously divided; veins free; soriferous veinlets sometimes very short and then the sori appearantly medial on the veins.

Tropical and subtropical in the old world.

Arrangement of the sections.

$\$ 1$. SCYPHULARIA. Fronds pinnate with $1-4$ linear, undivided pinnae on each side below the terminal one. Diels, in Engl. \& Prantl, Nat. Pfl. Fam., I ${ }^{4}$, fig. 115, J.

\$2. COLPOSORIA. Fronds at least 2-pinnatifid with small, ultimate segments. Diels, l. c., fig. 11\%, K.

\section{\$ 1. SCYPHULARIA.}

*. Fronds 3-foliate.

*.*. Fronds 5-9-foliate.
(1) D. triphylla.

(2) D. pentaphylla. 
(1) D. troiphylla, Mt., Hk. Bk., Syn. Hil., 94; Hk., Spec. Fil., I, tah. XLVI, A; Bedd., lierns Bri.I., I, tab. GV.

Rhizome creeping, stout, densely clothed with chaffy scales. Stipes scattered, 5-10 c.II long, erect, strong. Fronds ternate. Central segment linear, 10-15 c.M. long, 1-2 c.M. broad, obtuse, entire, the very base cuneate, short-stalked, lateral segments similar but shorter, sessile, oblique at the base. T'exture coriaceous; veins copious, crowded, parallel, forked, flat. Sori placed in a close row along the margin; indusia semicylindrical, compressed, contiguous so as to form an uninterrupted marginal line along whole the length of the leaflets.

\section{Malacca.}

* (2) D. pentaphylla, Bt., Rac., Flor. Bt\%., I, 155; Diels, in Engl. T FM S \&. Prantl, Nat. Pfl.Fam., I I , fig. 11b, J; Christ, Farnkr. d. Erde, lị.. 947 ; Hk., Fil. Exot., tab. XXXVII.

Rhizome wide-creeping, the scales dense, rounded, adpressed, peltate at the base, the long, hair-like point spreading. Stipes scattered, strong, erect, b-10 c.M. long. Fronds with $2-5$ pairs of lateral pimnae and a terminal one. Terminal segment 4-13 c.M. long, 1-2 c.I. broad, of the barren frond the broadest and shortest, stalked, linear, bluntish, the base cuneate, the edge-more or less crenate or serrulate, lateral segments similar, but commonly shorter, sometimes sessile, the lowest pair sometimes with 1-2 similar, smaller pinnulae at the base. Texture coriaceous; veins close, forked, parallel, flat. Sori close, numerous, in rows along the margin; indusia semicylindrical, often contiguous.

Malaya.

\section{S2. COLPOSORIA.}

a. Rhizome scales with a small, roundish or oblong, pellate base, the apex suddenly narrowed into a very long, hair-litie point. Rachis and surfaces hairy or fibrillose. (Davallodes).

(5) D. Lirsuta.omit

a.đ. Rhizome scales olherwise. Rachis and surfaces naked or \pm scaly. (Ludavallia).

b. Veins with a terminal, calcareous scale on the upper surface of the frond.

(4) D. Korthatsii.

b.b. Upper surface without calcareous scales.

c. Indusium \pm as broad as long or broader. 
54. mavalua. \$2. Colposoria.

d. Indusium more broad than long, or shorlly allached in the lower half of the sides.

*. Indusium half-cupshaped, shortly altached at the sides nearly as in IIumala.

(5) D. Griflithiana.

*.*. Indusium broader than deep, allached at the sides Ihroughout.

(i) D. Lobbiana.

d.d. Indusium \pm as broad as long, allached al lhe sides ihroughoul.

e. Indusium cuncale.

(7) D. stenololo.

e.e. Indusium half-cupshaped or suburceolute, the apex subrotund.

(8) D. pallida.

e.e.e. Indusium hal'-cupshaped, the apex truncale.

f. Apex of indusium \pm reaching the margin of the segment. Spurious veins more or less distinctly present.

y. Rhizome scales crisped and interlaced, shorlciliale.

(9) D. denticulata.

g.g. Rhizome scales flat, entire. (10) D. epiphylla.

f.f. Apex of indusium at some distance from the margin: of the segment. No spurious veins. (11) D. decurrens.

e.e.e.e. Indusium \pm orbicular or elliptical, the apex rounded or delloid-roundish.

(12) D. clata.

c.e. Indusium generally longer than broad $\left(^{*}\right)$.

(12a) D papuances.

1. Indusium less than $2 \times$ as long as broad.

2. Fronds under 50 c.M. long.

3. Rhizome scales nearly black.

(15) D. Lorrainii.

3.3. Rhizome scales whitish or pale-brown.

4. Edges of the ultimale segments not incised at the inner side of the sori, the teeth therefore not lobe-like.

(14) D. pyxidata.

1.1. Edges of the ultimate segments incised at the inner side of the sori, which gives the tecth the appearance of very small, soriferous lobes.

5. Indusium half-cupshaped lo semicylindrical.

c. Soriferous lecth short and broad.

6.6. Soriferous lecth long and narrow.

(15) D. bullata.

(16) D. fructuosa.

(*) See also D. elata, Spr. 
34. Davalia. \$2. colposoria.

5.5. Indusium urceolale.

(17) D. trichomanoides.

3.3.3. Rhizome scales brown. Rhizome sloul, scandenl.

(18) I). Wagneriana.

2.2. Fully developed frouls more than 50 c.M. long.

(19) D. divaricata.

1.1. Indusium: $\pm 2 \times$ as long as broad.

1gal bae holl

a. Rhizome scales strongly adpressed, which gives the rhizome the appearance to be quite naked.

(20) I). solidia.

\%.๙. Rhizome scales nol strongly adpressed.

$\beta$. Indusium rostrate. (21) D. embolostegia.

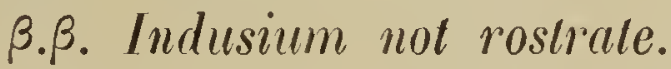

$\% \quad$ Soriferous segments wilhoul horns, bul denticulate at the apex.

(22) D. Veilchii.

$\% \%$ Soriferous segments wilh 1-2 distinct horns.

ঠ. Tips of the ultimale segments ralher hairlike. Slipes winged. (23) D. hrevipes.

$(24 c)=20$ ho is $(24 d) \sec$ holt

D. barbata SI p 2.26 D Puller SI prik

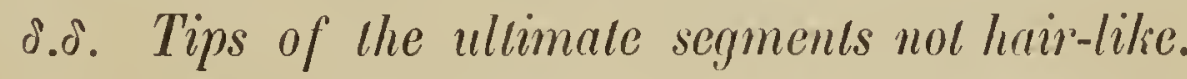
Stipes not winged.

(24) dissectia.

1.1.1. Indusium $\pm 3-4 \times$ as long as broad. (25) D. lijiensis.

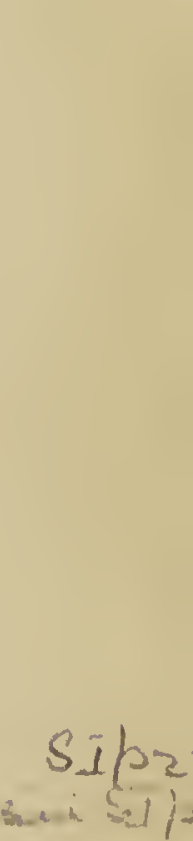

* (3) D. Inirsunta , v. A. v. IE., Hort. Bog.; D. ciliala, IIk., Hk. Bk., Syn. Fil., 98; Hk., Spec. Fil., I, tab. LX, A; Microlepia ciliala, Copel., Polypod. Philipp., 55; M. Lirsula, Pr., Epim., 97 ; C. Chr., Ind. Fil ; Davallodes grammalosorum, hirsulum \& gymnocarpum, Copel., Philipp. Journ., III, 35-34; Leucoslegia hirsula, J. Sm., (oldest name).

Rhizome firm, creeping, scaly, the scales with a bluntish, roundish or oblong, peltate base and a suddenly very long-acuminate, hair-like, erectopatent or spreading apex $\pm 1--1 \frac{1}{2}$ c.M. long. Stipes scattered, $5-10$ c.M. long, pubescent, firm, erect. Fronds $\pm 20-60$ c.M. long, $\pm 71 / 2-25$ c.M. broad, lanceolate, 2-5-pinnatifid. Pinnae spreading, lanceolate, the centrial ones the longest, $1^{1 / 2-4}$ c.M. broad, deeply pinmatifid wilh oblong or linearoblong, entire to pinnatifid, blunt or acute, close segments. Texture thin, flaccid; rachis and under surface and occasionally also the upper surface hairy or fibrillose especially on the costae and veins. Sori 2-12. 10 a segment, very small, semicupuliform or semicylindrical, placed near the centre of the teeth at the base, whether or not ciliate. - Copeland distinguishes 5 forms: 
Davallodes grammalosorum, Copel, 1. c., tah. VI: Indusium narrowly semicylindrical, naked; lower pinnae hardly reduced.

Davallodes hirsulum, Copel.: Indusium' semicupuliform; lower pinnae moderately reduced.

Davallodes gymnocarpum, Copel., l. c., tab. V: Indusium broader than long, attached by the base (as in Humata); lower pinnae gradually much reduced. Philippines, Celcbes, Borneo.

(4) D. Exonthalsii, Mett., Linı., XXXVI, 142.

Rhizome probably creeping. Fronds \pm 45 c.II. long, ovate, acuminate, 4-pinnatipartite; main rachis stramineous, canaliculate at the upper side. Pinnae petiolate, trapezoidal or oblong-lanceolate, the apex curved and caudato-acuminate. Pinnulae short-stalked, traperio-ovate or oblong, the apex short, narrowed, obtuse. Ultimate divisions trapezio-oblong, obluse, pinnatipartite at the base. Lobes spathulate-cuneate, with the upper edge crenate. Texture thinly chartaceous, firm; veins thickened at the apex, covered with a calcareous scale on the upper surface of the frond. Sori unknown.

Sumalra, Singapore.

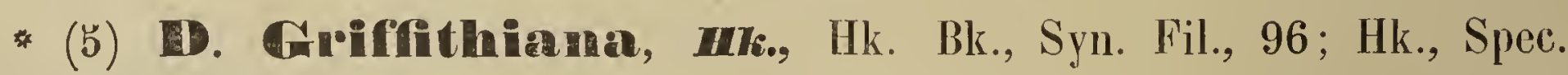
Fil., I, tab. XIIX, B.

Rhizome stout, the scales dense, pale-brown or whitish, linear. Stipes erect, wiry, $10-20$ c.M. long. Fronds $20-50$ c.M. long, $10-20$ c.M. broad, deltoid, 3-4-pinnatifid. Pinnulae of the lower pinnae lanceolate-deltoid, 5$7 \%$ c.M. long, $21_{2}^{1}$ c.M. or mrore broad. Lower segments loothed in the barren fronds, cut down nearly to the rachis in the fertile ones. Texture coriaceous. Sori large; indusium half-cupshaped, \pm as long as broad, very shortly attached on the sides nearly as in Humata, the apex whether or not reaching the margin.

Malacca; Norlh. India, China, Formosa.

(6) D. Lobloiana, Moore, Hk. Bk., Syn. Fil., 94.

Fronds $30-45$ c.I. or more long, 15 - 25 c.M. broad, lanceolate-deltoid, 2-5-pinnatifid; main rachis slightly winged above. Lower pinnae 10-13 c.II. long, \pm 5 c.Ml. broad, lanceolate-deltoid, acuminate, cut down to the rachis in the lower part into linear- or deltoid-oblong, blunt segments, only the lowest of which are deeply toothed. Sori copious, placed obliquely in 2 long rows in the pinnulae near the edge; indusium broader than deep.

Borneo. 
(7) D. Stemoloba, IBk., Becc., Mal, III, 55̆: 1). corniculala, Ces. (not Moore), Fel. Becc. Polin., 5.

Rhizome wide-creeping, stout, the scales minute, lanceolate, castaneous. Stipes slender, brown, naked, \pm 50 c.M. long. Fronds lanceolate-deltoid, 5-pinnatifid, \pm 4 c.M. long. Pinnae subsessile, acuminate, the lowest the longest, lanceolate-deltoid, the highest lanceolate. Lower pinnulae lanceolate, sessile, deeply pectinato-pinnatifid. Lohes distant, erecto-patent, inequilateral, lanceolate. Texlure firm; surfaces maked: rachis sparingly scaly; veins 1 to each lobe. Sori small, subterminal: indusium firm, cuneate, as long as broad. Amboyna.

* (8) D. pallida, Mett., Hk. Bk., Syn. Fil., 469; Hk., Icon. Pl., XVII, tab. MDCXXIV; D. Mooreana, Masters, Gard. Chron., 1869, 964, with figure; D. Beccariana, Ces., Fel. di Bor., 14, Lab. III, fig. 6-6c.

Rhizome thick, wide-creeping, the scales lanceolate, dark-brown. Stipes 30-45 c.M. long, naked, stramineous. Fronds 60-90 c.M. long, subdeltoid, 4-pinnatifid. Pinnae deltoid, lowest largest, 15-20 c.M. broad, produced on the lower side. Pinnulae and tertiary divisions deltoid, stalked, obliquely cuneate at the base; ullimate lobes obovate-cuneate, lolunt, $2 \frac{1}{2}-4 \mathrm{~m} . \mathrm{M}$. broad, hearing the sorus on the upper side at the base. Texture tirm-membranaceous; surfaces naked; veinlets immersed. Sori immersed, prominent on the upper surface; indusium half-cupshaped or suburceolate, submaroginal, the apex subrotınd.

Borneo, Mindanao, New Guinea; Ancium, Samoa.

* (9) D. Lenticulata, Mett., C. Chr., Ind. Fil.; D. clegans, Sw.,

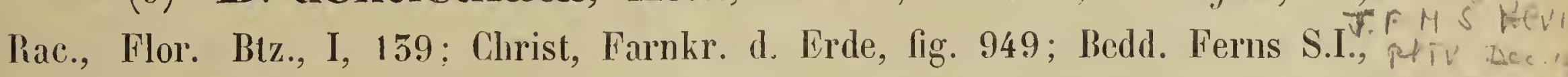
tab. XVIII; Hk., Spec. Fil., I, tab. XLIII, B; Adiantum denticulatum, Bum., p1: (oldest name).

Rhizome stout, creeping; scales dense, lincar-lanceolate, ferrugineous, the base \pm dilated, peltate, the point long, linear-subulate, crisped, interlaced, short-ciliate, giving the rhizome a woolly appearance. Stipes firm, naked, 10-50 c.M. long. Fronds 50-60 c.M.'long, 15-40 c.M. broad, delloid to ovate-lanceolate, 5-4-pinnatifid; main rachis slightly winged towards the apex. Pinnulac of the lower pinnae $\pm 2 \frac{1}{2}$ c.M. broad, deltoid-lanceolate, cut down to the rachis in the lower part with oblong-deltoid, more or less decply toothed segments, wich are obliquely cuneate at the base. 'Texture curiaceuus; surfaces naked; venation prominent, irregular, with spurious veins be- 
Iween the true ones. Sori in the teeth of the \pm narrowed and more deeply toothed fertile segments, several to a segment, with $1-2$ sharp horms projecting beyond them; indusium half-cupschaped, \pm as broad as long, with the apex reaching the margin of the frond.

Trop. Asia, Australia \& Polynesia, Madagascar, Fernando-Po.

* (10) D. eprophylla, \#t., Rac., Flor. Btz., I, 157; D. clegans, Sw., var. pulchra (not bidentala), Hk., Spec. Fil., I, tab. XLIII, A; D. corniculala, Moore, C. Chr., Ind. Fil.

Rhizome wide-creeping; scales linear-lanceolate, the base peltate, the edge entire. Stipes distant, $10-50$ c.M. long, erect firm. Fronds 20-60 c.M. long, 15-40 c.M. broad, deltoid to broad-lanceolate, 5-5-pinnatifid; main rachis hardly at all winged. Pinnulae of the lowest pinnae lanceolate, 1-4 c.M. long, 2-10 m.M. broad. Segments narrow, sharply loothed, mucronate. Texture coriaceous; veins not immersed, $1-5$ carried into each tooth, with spurious veins belween the true ones. Sori small, with the sharp mucro of the tooth extending beyond; indusium half-cupshaped, semiorhicular, \pm as long as broad. - Scarcely different from D. denticulata, Mell.

\section{Malaya.}

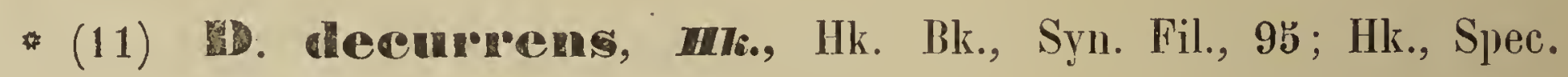
Fil., I, tab. XLIV, B.

Rhizome stout, creeping, densely fibrillose. Stipes 10-15 c.M. long, stout, erect. Fronds 50-65 c.M. long, 15-45 c.M. broad, deltoid, 5-pinmatifid; main rachis hardly at ail winged at the apex. Pinnulae of the lower pinnae lanceolate-acuminate, $71 / 2-10$ c.M. long, $2-5$ c.M. broad, cut down throughout within a short distance of the costulae with broadly toothed, linear-oblong segments. Texture subcoriaceous. Sori 1 to each tooth, the blunt teeth slightly projecting beyond them; indusium half-cupshaped, as long as broad, not reaching the margin.

Sumala, Celebes, Philippines.

* (12) D. elata, Spr. (not Sw.), Hk., Spec. Fil., I, 166, tah. LV, A; D. denticulata, Mell., var., C. Chr., Ind. Fil.

Stipes firm, naked. Fronds \pm 40 c.M. long or longer, deltoid to lanceolate-triangular, 5-4-pinnate. Pinnae erecto-patent, stalked. Ultimate divisions ovate-lanceolate, the edge crenate, inciso-serrate or pinnatifid with entire 
or crenate, oblong lobes. 'Texture coriaceous; main rachis slightly winged towards the apex, secondary and terliary rachises marrowly winged; surfaces more or less distinctly striated or marked with lines or spurious veins hetween the true veins. Sori in the teeth of the mostly narrower fertile segments, several to a segment, with 1-2 horns projecting beyond them; indusium \pm orbicular or elleptical, the both ends rounded or roundish-deltoid, the apex reaching the margin of the segment.

Tropical Asia, Polynesia, Australiu.

(15) D. Lorrainii, Hanee, Hk. Bk., Syn. Fil. 469; Bedd., Ferns S.Br.I., Suppl., tab. CCCLI.

Rlirome thick, clothed with linear-subulate, nearly black, densely greyciliated scales. Stipes 7//2-10 c.M. long, naked, brownish. Fronds $15-30$ c.M. long, deltoid, 4-pimnatifid. Pinnae stalked, deltoid, lowest largest, produced on the lower side, their rachises winged to base. Pinnulae and segments subsessile, crowded, deltoid, \pm reduced on the lower side; final lobes ligulate, $1 / 2-1$ m.M. hroad, with sorus at base of inner side. Texture subcoriaceous, surfaces naked; barren lobes 1-veined. Indusium subcylindrical.

Malacca.

(14) D. Pyxiolata, Cav., Hk. Bk., Syn. Fil., 96; Hk., Spec. Fil., I, tab. LV, C; Bau. \& Hk., Gen., Fil., tab. XXVII.

Rhizome slout, creeping, densely clothed wilh pale-brown, linear scales. Stipes erect, strong, 10-15 c.M. long. Fronds $20-45$ c.M. long, 15-25 c.M. broad, deltoid, 3-4-pinnatifid. Pinnulae of the lower pinnae lanceolate, $5-8$ c.M. long, $\pm 21 / 2$ c.M. broad, with deltoid or oblong segments, the lowest of which are cut down nearly to the rachis. Texture coriaceous. Sori in the teeth, with a broad space outside them, which projects like a horn beyond them; indusium half-cupsliaped.

Kei Islands; Australia.

* (15) D. Wullata, Wall., Hk. Bk., Syn. Fil., 97; Hk., Spec. Fil., I, tab. L, B: Christ, Farnkr. d. Erde, lig. 95丂; Bedd., Fern S.I., tab. XVII.

Rhizome creeping, stout; the scales light-brown or whitish, the base round, peltate, the apex long, filiform, hair-pointed, short-ciliate, \pm recurved. Stipes strong, $71 / 2-121 / 2$ c.M. long, erect. Fronds $15-30$ c.M. long, $10-20$ c.M. hroad, \pm deltoid, 5-4-pinnatifid. Pinnulae of the lower pinnae lanceolate, b-S c.M. long, $\pm 2 \frac{1}{2}$ c.M. broad, wilh deeply inciso-pinnatifid, ollong-rhom- 
hoidal segments. Texture coriaceous; surfaces naked. Sori occupying the greater part of the teeth in which rhey are placed, with usually a large horn or 1-2 teeth projecting beyond: indusimm deeply half-cupshaped, more long than broad, the apex \pm reaching the margin.

Trop. Asin, China, Japan.

* (16) D. fructuosat, Christ, Warh. Mons., I, 86.

Scales of the rhizome filiform, pale-brown, long, spreading. Stipes naked, stramineous, \pm 15 c.M. long. Fronds deltoid, \pm 25 c.M. long, $\pm 18-24$ c.M. broad, 4-pinnalifid. Pinnae 10-12, the lower ones ovate-acuminate, the rachis narrowly winged. Pinnulae deltoid-ovate, spreading, pinnate, with the divisions pinmatifid to the rachis; segments narrow, linear, bearing the sori on the \pm dilated apices. Texture coriaceous. Indusium half-cupshaped to semicylindrical, opaque, slightly emarginate, narrowly winged by the edge of the segments, with a short tooth beyond. - Near D. fijiensis, Hk.

Java.

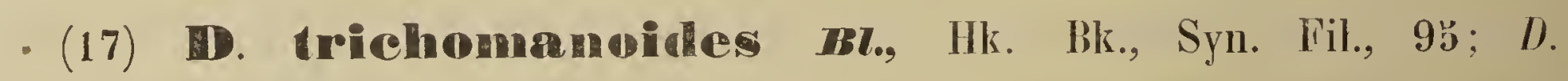
slenomeru, Kze, Bot. Zeit.,. 1848, 216.

Rhizome wide-creeping, the scales linear, squarrose, pale-brown. Stipes b-10 c.M. long, grey-straminenus, naked. Fronds deltoid, 4-pinnatifid, 15-25 r.M. long, acuminate. Pinnae short-stalked, lanceolate, lowest largest, deltoidlanceolate, 5-5 c.M. broad, rachis winged. Pinnulae close, lanceolate. Ultimate segments (teeth) cuneate-ohlong when harren, spathulate when ferlite and forming a narrow wing on each side of the sorus. Texture \pm coriaceous; surfaces naked. Sori terminal on the lobe-like teeth; indusium rather leeper than broad, urceolate, with mostly a horn beyond on both sides.

Malaya.

(18) D. Wagneriana, Copel., Polypod. Philipp., 54.

Rhizome stout, scandent, the scales dense, lanceolate, acuminate, adpressed, hrown. Stipes stout, scaly near the base. Fronds 20-25 c.M. long, 10-15 c.M. broad, 5-pinnatifid at the base only, the fertile narrower than the sterile ones. Lowest pinmae not larger than the succeeding, with a few, distinct, deeply toothed, equal pinnulae at the base of each, followed by lroadly linear, acutely toothed segments. Texture coriaceous; rachis winged, naked like the surfaces. Sori usually a little longer than broad, rarely reaching the margin.

Mindanas. 
* (19) D. divarieata, Bt., Rac., Flor. Btz., I, 138; D. polyantha, Hk., Spec. Fil., I, tab. LIX, A; Bedd., Ferns Br.I., I, tab. GVII.

Rhizome stout, creeping, the scales linear-lanceolate, dense, ferrugineous or pale-brown, with the base truncate, not peltate, the edge entire or beset with short, spreading teeth or ciliae, the apex acuminate or acute, not adpressed, deciduous. Stipes firm, erect, 13 -30 c.M. long, naked. Fronds 60-90 c.I. long, 3-pinnatifid to 4-pinnate. Lower pinnae often 30 c.M. long by 15 c.M. broad. Ultimate segments linear-oblong, toothed. Texture coriaceous; surfaces naked. Sori numerous, 1 to each tooth of the ultimate segments; indusium half-cupshaped, often $\pm 1 \frac{1}{2} X$ as long as broad, the apex at some distance $( \pm 1 / 2-1$ m.M. $)$ from the margin of the segment.

Trop. Asia.

* (20) D. solida, Sw., Rac., Flor. Btz., I, 137; Hk., Spec. Fil., I, tab. XLII; Hk., Fil. Exot., tab. LVII; Bedd., Ferns Br.I., I, tab. CIV; D. elegans, Hedw., Fil. Gen. \& Spec., 1803; - var. caudata; D. caudata, Cav., Descr., 1802, 279; - var. Lindleyi ; D. Lindleyi, Hk., l. c., 163, tab. LVIII, B ; - var. ornata; D. ornata, Wall., List, No. 246.

Rhizome stout, wide-creeping; scales adpressed, black, white when young, the base roundish, peltate, persistent, the apex finely acuminate, the margin beset with spreading, cobwebby, deciduous, adpressed, interlaced fibres altogether forming a dense, flat coat to the rhizome. Stipes distant, strong, erect, 10-20 c.M. long, naked. Fronds ovate-deltoid, $15-60$ c.II. long, $15-$ 40 c.M. broad, 5-pinnatifid to -pinnate, the apex with a moderately broad, undivided centre. Ultimate segments ovate-rhomboidal, $\pm \mathbf{z} \times$ as long as broad, deeply toothed, narrower and sharper in fertile fronds. Texture coriaaceous; surfaces naked. Sori in the teeth, sometimes "with $1-2$ horns beyond; indusium semicylindrical, $\pm 2 \times$ as long as broad, the apex nearly or quite reaching the edge of the frond.

Var. caudata: Ultimate segments acuminate to caudate.

Var. Lindleyi: Pinnulae more divided, with narrower segments.

Var. ornata : Ultimate segments broad, slightly cut.

Malaya; Polynesia, Queensland.

(21) D. embolostegia, Copel., Philipp. Journ., I, Suppl., 147, tab. III.

Rhizome creeping, densely clothed with ferrugineous, brumnescent, linear scales. Stipes distant, 30 - 0 c.M. long, naked, glossy. Fronds deltoid, Fiuices. 
60-100 c.I. long, acuminate, 4-b-pinnatifid. Pinnae and lower pinnulae long-acuminate, deltoid-ovate, the higher ones narrower. Ultimate segments lanceolate or oblong, serrate or incised. Texture hardly coriaceous; surfaces \pm naked; penultimate rachises winged; no spurious veins. Sori flanked mostly by $1-2$ teeth; indusium semicylindrical, conspicuously rostrate. - Fronds resembling D. solida, $S w$. \& divaricata, $B l$.

Luzon, Mindoro. hagrers.

(22) D. Veitselnii, Hh., Journ. of Bot., XVII, 59.

Rhizome wide-creeping, the scales small, shining, linear, acuminate, castaneous. Stipes naked, erect, slender, castaneous, 50-45 c.M. long. Fronds oblong-deltoid, decompound, $50-45$ c.M. long, \pm 15 c.M. broad. Pinnae distant, deltoid, stalked, erecto-patent, many of the lower ones subequal, 10-15 c.M. long by half as broad. Pinnulae and tertiary divisions subpetiolate, rhomboidal, the base cuneately cut away on the lower side. Ultimate lobes subremote, ligulate or rather broader towards the truncate apex, $\pm 1-3 \frac{1}{2} \mathrm{~m}$.M. long, $\pm 1 / 2$ m.M. broad, with only a single central vein, the apex denticulate. Texture subcoriaceous; surfaces naked. Sori small, oblong, usually immersed in the tips of the segments.

Borneo.

(23) D. Drevipes, Copel., Philipp. Journ., I, Suppl., 147, tab. II. Rhizome creeping, densely clothed with fuscous, lanceolate, \pm adpressed scales, which are whitish at the apex and the edge. Stipes remote, $\pm 1 \frac{3}{4}$ c.M. long, naked, narrowly winged. Fronds deltoid, \pm 10 c.M. long, \pm 6 c.M. broad, the rachis furcato-alate on the upper side. Pinnae ascending, \pm straight, narrowly ovate, the lowest largest, broadly ovate, falcate, slightly deflexed. Pinnulae minute, cuneate, cut down to the costa into narrow, longsubulate, rather hair-like segments. Texture coriaceous; surfaces naked; no spurious veins. Sori on the ultimate segments, flanked by a horn on each side; indusium semicylindrical, marginal.

Mindanao.

(24) ID. Missecta, J. Sm., Rac., Flor. Btz., I, 159; Moore, in Gardn. Chron., 1855, 469, with figure.

Rhizome stout, wide-creeping, the scales brown or pale-brown, with the hase roundish, peltate, adpressed, the apex long-acuminate, recurved, spreading, ciliate, at length deciduous, giving the rhizome a woolly appearance when 
young. Stipes 5 - 15 c.M. long, naked. Fronds $12^{1 / 2}-45$ c.M. long, 10-50 c.M. broad, deltoid to lanceolate-triangular, 5-4-pinnatifid. Pinnae lanceolate, the lower deltoid, produced on the lower side. Pinnulae lanceolate-deltoid, subsessile, obliquely cuneate at the base. Segments oblong, cuneate at the base, deeply pinnatifid with erecto-patent, ligulate, simple or 2-fid lobes 3 -b m.M. long, 1-2 m.M. broad, those of the fertile fronds oblong, $1 / 2$ m.M. broad at the base, with a suddenly dilated, cuneate, soriferous apex. Texture \pm coriaceous; surfaces naked. Sori numerous, 1 to each ultimate lobe, commonly with $1-2$ horns beyond; indusium nearly $2 \times$ as long as broad, the apex \pm reaching the margin of the segment.

Java, Sumatra.

(25) D. fijiensis (fejensis), Hk., Hk. Bk., Syn. Fil., 97; Hk., Spec. Fil., I, tab. LV, D; D. solida, Sw., var., C. Chr., Ind. Fil.

Rhizome creeping, densely fibrillose. Stipes 15 - 25 c.M. long, erect, strong. Fronds 50-45 c.M. long, 15-30 c.M. broad, deltoid, 4-pinnatifid. Pinnulae of the lower pinnae deltoid-lanceolate, the lobes of the tertiary segments cut down nearly to the rachis into narrow, linear laciniae. Texture coriaceous. Sori semicylindrical, on the dilated apices of the laciniae, without horns; indusium long, $5-4 \times$ as, long as broad.

New Guinea; Fiji.

\section{MICROLEPIA, Prest.}

Sori roundish or oblong, submarginal, solitary and terminal on the veins. Indusium half-cupshaped or semicylindrical, attached at the base and sides, open at the outer edge., Receptacle distinct.

Rhizome creeping, hairy or fibrillose. 'Stipes 2-seriate, adherent to the rhizome. Fronds variously divided; ultimate free divisions rhomboidal-oblong or linear-triangular, broadest \pm at the base, the upper base rather broadly and the lower rather narrowly cuneate; veins free, simple or branched. Diels, in Engl. \& Prantl, Nat. Pfl.Fam., I ${ }^{4}$, fig. 116, A; Bedd., Handb. Ind. Ferns, fig. $33\left(^{*}\right)$.

Pantropical.

(*) Copeland thinks that Microlepia would better be abandoned as a genus and regarded as a section of Dennstaedtia (Philipp. Journ., II, 126). 
a. Fronds simply pinnate or at best 2-pinnatifid.

t. Rhizome erect. Fronds rather small, naked.

(1) M. firmula.

t.+. Rhizome creeping. Fronds rather large, hairy beneath.

a.a. Fronds at least 2-pinnate at the base.

(2) M. marginalis.

b. Texture membranaceous or herbaceous.

c. Indusium naked.

×. Fronds small, \pm 25 c.M. broad.

$\times \cdot \times$. Fronds large, \pm 90 c.M. broad.

c.c. Indusium hispid, hairy or bristly.

(2a) M. Hooke rianum

d. Receptacle rather small, not exserted.

e. Ultimate lobes entire or crenato-lobate. The hairs of the under surface bulbous at the base. (5) M. trichosticha.

e.e. Ultimate segments toothed or pinnatifid. The hairs of

(3) M.- scaberula.

(4) M. manilensis. the under surface not bulbous at the base.

(6) M. speluncae.

d.d. Receptacle prominent, exserted.

(7) M. exserta.

b.b. Fronds more or less coriaceous.

1. Surfaces naked.

$\times$. Small. Pinnulae crenato-lobate.

(8) M. philippinensis.

X.x. Large. Pinnulae deeply pinnatifid.

(9) M. platyphylla.

1.1. At least the under surface hairy or strigose.

2. Pinnulae crenate or broadly toothed.

(10) M. strigosa. $s_{2}+2$

2.2. Pinnulae (at least the lower ones) \pm deeply pinnatifid.

3. Tertiary segments bluntly serrate.

(11) M. Kurzii. Sipz 3

3.3. Tertiary segments entire or broadly crenate.

4. Stipes naled.

1.4. Stipes pubescent.

2.2.2. Pinnulae (at least the lower ones) pinnate.
(12) M. proxima.

(13) M. trapeziformis.

(14) M. hirta.

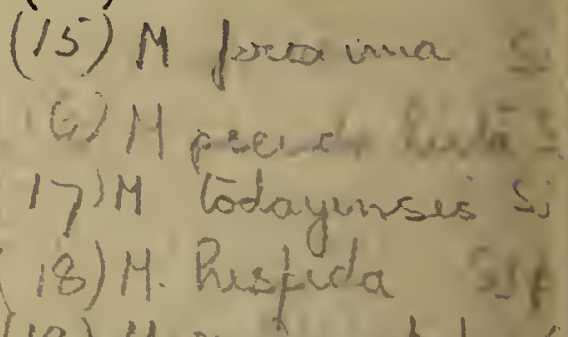

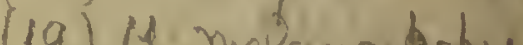

(1) M. firmula, C. Chr., Ind. Fil.; Davallia firmula, Bk., Ann. of Bot., VIII, 123.

Stipes tufted, 20-25 c.M. long, slender, firm, naked above, scaly at the base, stramineous, the scales lanceolate, membranaceous, ferrugineous. Fronds deltoid, 20-25 c.M. each way, simply pinnate. Pinnae sessile, $\infty$-jugate, 
linear, often entire, with the base cuneate, the lower ones $10-15$ c.M. long, $\pm 7 \frac{1}{2}$ in.M. hroad. Texture firm; surfaces naked like the stramineous rachis; veins not close, erecto-patent, deeply forked, not reaching the margin. Sori small, terminal on the veins; indusium semicupuliform, naked, persistent. Sumatra.

(2) M. margimalis, Bedd. (not Hance), Christ, Farnkr. d. Erde, 507 ; M. scabra, J. Sm., Bedd., Ferus Br.I., I, tab. CII; M. marginala, C. Chr., Ind. Fil.; Davallia marginalis, Bk., Hk. Bk., Syn. Fil., 98; D. villosa, Wall., Hk., Spec. Fil., I, tab. XLVIII, A.

Rhizome creeping, villose. Stipes 50-60 c.M. long, erect, strong. Fronds $45-75$ c.M. long, 20-55 c.M. broad, pinnate. Pinnae linear, distant, alternate, slightly stalked, straight or subfalcate, $\pm 2 \%$ c.M. broad at the hase, narrowed gradually towards the apex, the edge cut $\pm 1 / 3-2 / 3$-way down into numerous, close, deltoid-oblong, crenato-dentate lobes, the upper base broadly and the lower rather narrowly cuneate. Texture subcoriaceous; rachis and stipe downy, the latter at length glabrous; under surface hairy. Sori submarginal, $2-8$ to a lobe, 1 to a serrature; indusium broadly half-cupshaped, densely hairy.

New Guinea; Japan, China, Ceylon.

(5) M. scaberula, Mett., Linn., XXVI, 148.

Fronds \pm 30 c.M. long, \pm 25 c.M. broad, deltoid, acuminate, sub- $\mathbf{5}-$ pinnatisect. Pinnae alternate, not close, spreading, short-stalked, acuminate. Pinnulae approximate, spreading, sessile, trapezio-oblong-lanceolate, unequalsided, the upper base truncate, auricled, the lower cuneate. Segments oblong, obtuse, pinnatifid, incised, or crenate with a few teeth at the apex. Texture thinly chartaceous; costae and veins beneath covered with subadpressed, reddish-brown, small, sharp bristles; rachis short-hairy; veins prominent beneath. Sori submarginal, small; indusium naked.

New Guinea.

(4) M. mamilemsis, Pr., Tent. Pterid., 125 ; Davallia manilensis, Hk., Ann. Btz., XV, 95, tab. XIV, fig. 9, a-b; D. Sarasinorum, Christ, Fil. Saras., IV, 7.

Fronds large, to $\pm 2 \mathrm{M}$. long, deltoid, 2-pinnate to 5-pinnatifid. Pinnae 40-50 c.M. long, oblong, $15-18$ c.M. broad at the base, the apex longcaudate. Pinnulae numerous, $25-50$ on each side below the pinnatifid apex 
of the pinnae, alternate, the lower ones 8-10 c.M. long, \pm 3 c.M. broad at the base, caudate, deeply pinnatifid, with the upper base truncate, auricled, the lower cuneate, the auricle sometimes free; higher pinnulae close, cut $1 / 2$-way down to the costa or more into numerous, close, rhomboidal, blunt, crenate lobes. Lobes to 1 c.M. long, with $4-8$ crenations on each side. Texture firm-herbaceous; rachises and surfaces covered with short, brown hairs. Sori numerous, large, immersed, slightly intramarginal below the teeth or crenations; indusium grey.

Java, Celebes, Philippines.

(5) D. Iroichosticha, J. Sm., Journ. of Bot., III, 416; Davallia trichosticha, Hk., Spec. Fil., I, 185; D. Speluncae, Bk., var. trichosticha, Hk. Bk., Syn. Fil., 470.

Fronds large, 2-5-pinnate. Pinnae \pm 50 c.M. long, the rachis winged above. Ultimate segments sessile, obliquely cuneate at the base, lanceolateoblong, acuminate, deeply pinnatifid, with the lowest anterior lobe the largest. Lobes ovate, obtuse, nearly entire or crenato-lobate. Texture submembranaceous; upper surface slightly hairy, under surface densely and minutely pubescent, the hairs bulbous at the base, almost concealing the veins. Sori small, rather distant from the margin; indusium small, semicupuliform, very downy.

Malaya ; Samoa

* (6) spelancere, Moore, Christ, Farnkr.d. Erde, 308; Diels, in Engl. \& Prantl, Nat. Pfl.Fam., Iㄴ, fig. 116, A-C; Davallia Speluncae, Bk., Rac., Flor. Btz., I, 155; D. polypodioides, Don, var. subglabra \& pubescens, Hk., Spec. Fil., I, 182 ; D. flaccida, R. Br., Prod. N.H., 157; - var. immersa.

Rhizome creeping, more or less densely clothed with pale or brownish hairs or fibres. Stipes strong, 20-100 c.M. long, stramineous, brownish or purpureous, minutely hairy or squamulose. Fronds 40-200 c.M. long, 20-100 c.Mr. broad, triangular or ovate-lanceolate, 5-5-pinnatifid. Lower pinnae ovate-lanceolate. Pinnulae lanceolate, cut down to a winged rachis into toothed or pinnatifid lobes, the lowest lobe on the upper side the largest; lobes and teeth \pm rounded. Texture herbaceous, membranaceous or flaccid; rachis and surfaces more or less hairy or setose, or with few or many, long, glistening, flaccid, scale-like hairs; veins conspicuous. Sori at the base of the teeth or lobes, $2-20$ to a segment; indusium half-cupshaped, hispid or hairy, rarely glabrous. 
Var. immerosa: Sori immersed, distinctly prominent on the upper surface.

Tropical and subtropical.

(7) M. exserta, Mett., Linn., XXXVI, 148; Davallia Speluncae, Bk., var. exserta, Hk. Bk., Syn. Fil., 470.

Fronds large, 4-pinnatisect. Pinnae 30 c.M. long or longer, acuminate. Pinnulae short-stalked, 5-8 c.M. long, trapezio-oblong, acuminate, or the apex narrow and obtuse. Ultimate divisions trapezio-oblong, obtuse, unequal-sided, the anterior base the broadest. Lobes contiguous, oblong, oblique, obtuse, the higher ones crenate, the lower pinnatifid. Texture membranaceous; upper surface naked or nearly so, under surface pubescent; main rachis clothed beneath which a dense, pale-brown tomentum. Sori submarginal, subapproximate, 1 or more to a lobe, placed near the sinuses; indusium membranaceous, purveyed with some few bristles; receptacle prominent, exserted.

? Malaya; Fiji.

(8) M. philippinensis, Copel., Polypod. Philipp., 56; Davallia philippinensis, Harr., Journ. of Linn. Soc., Bot., XVI, 27.

Rhizome thickly clothed with narrow, reddish-brown scales. Stipes \pm 15 c.M. long, dark-brown, with a few scales below like those of the rhizome, naked above. Fronds deltoid, 7 -25 c.ll. long, nearly as broad; rachis naked. Lower piunae deltoid, pinnate, the higher ones simple, those at the apex confluent. Pinnulae linear, crenato-lobate, the lobes extending $1 / 2$-way to the costa, lowest pinnulae on the lower side much larger than the other ones. Texture coriaceous; surfaces naked; veins ascending. Indusium intramarginal, broader than deep.

Philippines.

(9) D. platy bluylla, J. Sm., Christ, Farnkr. d. Erde, 507; Bedd., Ferns S.I., tab. XIII; Davallia platyphylla, Don, Hk. Bk., Syn. Fil., $99 ;$ D. lonchitidea, Wall., Hk., Spec. Fil., I, tab. XLVI, B; Fil. Exot., tab. XIX.

Rhizome stout. Stipes firm, erect, $60-90$ c.M. long. Fronds $90-120$ c.II. long, 5-pinnatifid. Lower pinnae 50-40 c.M. long, 15-25 c.M. broad. Pinnulae distant, linear, the higher ones adnate, the lower narrowed gradually from the base towards the apex, the edge cut $\pm 1 / 3-2 / 3$-way down to the costa into many, bluntish, toothed, oblong-deltoid lobes, the upper base broadly, the lower rather narrowly cuneate. Texture subcoriaceous; surfaces naked.

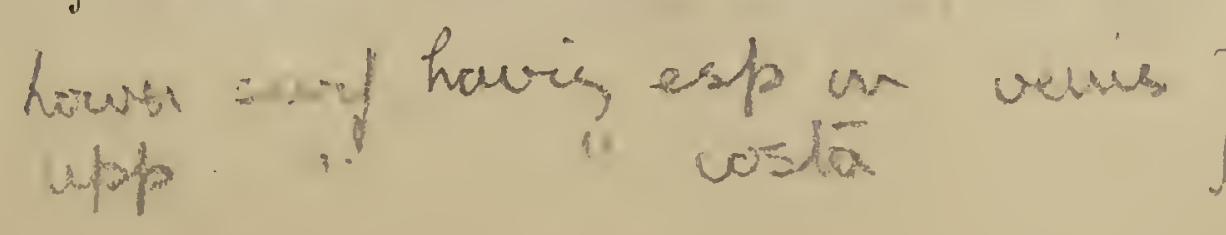


Sori 2-12 to a lobe, 1 to a crenation, a short distance from the edge; indusium naked.

Philippines; Ceylon, North. India.

* (10) MI. Strigosn, Pr., Christ, Farnkr. d. Erde, 508 ; Bedd., Ferns S.I., lab. CCLV; Davallia strigosa, (Sw.) Kze, Rac., Flor. Btz., I, 155.

Rhizome creeping, hairy. Stipe erect, strong, 15-40 c.M. long, both it and the rachis pubescent troughout. Fronds ovate-lanceolate, acuminate, $30-100$ c.M. long, 15-50 c.M. broad, 2-pinnate. Pinnae short-stalked, erecto-patent, linear-lanceolate, acuminate, straight or falcate, the lowest longest, 10-20 c.M. long, \pm 2 c.M. broad, cut down to the rachis with numerous close pinnulae. Pinnulae rhomboidal, obliquely cuneate at the base, the lowest largest, oblong, broadly and rather bluntly toothed or crenated. Texture sul-coriaceous; rachises and veins beneath more or less copiously hairy; veins beneath prominently raised. Sori small, 2-12 to a pinnula, placed near the bases of the crenations at a short distance from the sinuses: indusium halfcupshaped, hairy.

Trop. Asia \& Polynesia, Japan, China.

(11) M. Kurezie, Bedd., Hand. Ind. Ferns, 66; Davalia Kurzii, Clarke, Trans. Linn. Soc., Bot., 2d Series, I, 446.

Fronds large, 5-pinnatifid. Lower pinnae $30-40$ c.M. long, 15-25 c.M. broad, lanceolate, with linear-lanceolate pinnulae, which are cut down to the rachis (which is not wavy, or only slightly so towards the apex) below into triangular, subobtuse or lanceolate-caudate lobes, which are bluntly serrate. Texture more or less coriaceous; under surface pubescent even when adult; venation moderately prominent. Indusium finely ciliated round the margin. Near M. platyphylla, J. Sm.

Malacca; Burmah.

* (12) M. proxima, Pr., C. Chr., Ind. Fil.; Davalia proxima, Bl., Rac., Flor. Btz., I, 154.

Stipes 30 c.M. or more long, naked. Fronds 100 c.M. or more long, $10-80$ c.M. broad, 2-pinnate; rachis rough-hairy. Pinnae stalked, to 40 c.M. long, to 10 c.M. broad, lanceolate, the lower ones shorter than the following, the stalks $1-1 \%$ c.II. long. Pinnulae short-stalked, lanceolate, inequilateral, to 6 c.M. long, to 2 c.M. broad, toothed at the apex, the base deeply pinnatifid. Segments rounded, entire, the lower to 15 m.M. long, to 6 m.M. broad, 
dark-green above, light-green below. Texture subcoriaceous; upper surface short-haired on the veins, the under one covered with pale hairs. Sori on a short distance from the edge; indusium very small, semiorbicular, covering only the base of the sorus when mature, slightly hairy.

Malaya.

(13) M. Trapeziformis, Kuhn, C. Chr., Ind. Fil.; M. thomboidea, Pr., Tent. Pterid., 125; M. polypodioides, Redd., Ferus S.I., Lab. XV; Davallia rhomboidea, Wall., Bot. Zeit., 1850, 158; D. strigosa, Sw., var. rhomboidea, Hk. Bk., Syn. Fil., 99; D. polypodioides, Don, var. hispida \& rhomboidea, Hk., Spec. Fil., I, $182 ; D$. trapeziformis, Rb., (oldest name).

Near M. strigosa, Pr., but rather larger in all parts. Rachis downy or hispid, beneath. Lower pinnulae lanceolate-deltoid, cut down nearly to the rachis into oblong, entire or irregularly inciso-lobate or again pinnatifid, suboblique, very obtuse lohes. Sori rather large, usually solitary on the entire lobes, several on the pinnatifid ones, near the sinuses, within the margin; indusium half-cupshaped, naked or hispid.

Trop. Asia.

* (14) Mr. hirta, Pr., Tent. Pterid., 125; Bedd., Ferns S.I., tab. CCLVI; Davallia hirta, Klf., Hk. Bk., Syn. Fil., 100.

Stipes strong, 30-60 c.M. long, deciduously short-hairy. Fronds 45-180 c.M. long, 30-60 c.M. broad, ovate-deltoid, subcaudate, 3-pinnate. Lower pinnae erecto-patent, 7-10 c.M. broad, triangular-lanceolate. Pinnulae triangular-lanceolate; tertiary segments rhomboidal-oblong, the lowest largest, blunt, broadly toothed or deeply pinnatifid, the base obliquely cuneate, slightly decurrent. Texture coriaceous; rachises and especially the under surface densely pubescent. Sori 2-12 to a tertiary segment, 1 or more to each ultimate tooth or lobe; indusium \pm hairy or covered by the hairs of the veins. - Stature and habit of M. speluncae, Moore, but firmer.

Trop. Asia; Hawaii.

-

\section{TAPEINIDIUM, Chistensen.}

Sori roundish, terminal on the veins, submarginal, single or in \pm confluent pairs. Indusium broadly half-cupshaped, attached at the base and sides, open at the outer edge. Receptacle indistinct. 
Rhizome. creeping, minutely scaly or fibrillose. Stipes 2 -seriate, \pm distant or approximate, adherent ot the rhizome. Fronds variously divided; leaflets narrow, linear-lanceolate or divided into narrow, oblong or linear segments; veins free, simple or forked. Diels, in Engl. \& Prantl, Nat. Pfl.Fam., I ${ }^{4}$, fig. 116, J \& H. (Wibelia).

Malaya, Polynesia.

a. Fronds at best 2-pinnate.

b. Fronds small, under 10 c.M. long.

(1) T. oligophlebium.

b.b. Fronds larger, more than 10 c.M. long.

c. Pinnae slightly crenate or toothed.

c.c. Pinnae deeply toothed, pinnatifid or pinnate.

(2) T. pinnatum. $S_{1}$

(3) T. gracile.

u.a. Fronds at least deeply 3-pinnatifid at the base.

*. Fronds rather small, 3-pinnatifid or 3-pinnate, coriaceous.

(4) T. amboinense.

*.*. Fronds rather large, 4-pinnatifid, herbaceous.

(5) T. Denhami.

* (1) T. oligophlebium,. C. Chr., Ind. Fil.; Davallia oligophlebia, Bk., Journ. of Bot., XXVI, 523; Wibelia oligophlebia, Christ, Ann. Btz., $\mathrm{XX}, 154$.

Rhizome slender, short-creeping, the scales minute, adpressed, linear, brown. Stipes slender, naked, deciduously scaly near the base, $\pm 1 \frac{1}{2}-7^{1 /} / 2$ c.M. long. Fronds triangular, $\pm 5 \cdot-71 / 2$ c.M. long, $4-9$ c.M. broad at the base, pinnate, the lower pinnae \pm spreading, pinnate again, \pm 2 c.M. broad at the base. Ultimate segments oblong to linear, m.Mr. broad, the base cuneate, the edge, crenate or bluntly toothed to lobed, the point narrowed, bluntish. Texture subcoriaceous; rachis and surfaces naked; veins 1 to each tooth or lobe. Sori terminal on the crenations, 1 to each; indusium firm naked, suborbicular, small. - The description is taken from specimens gathered by Hallier, determined by Christ. - Baker's description: "Fronds pinnate, $31 / 2-5$ c.M. long, $8-9$ m.M. broad, with the pinnae rhomboid, obluse, 3-lobed," is probably taken from a young specimen.

Borneo.

* (2) T. pinnatum, C. Chr., Ind. Fil.; Davallia pinnata, Cav., Rac., Flor. Btz., I, 1̋̄j; Christ, Farnkr. d. Erde, fig. 967: D. longipinnula \& 
intramarginalis, Ces., Fel. Becc. Polin., $7 \& 8$; D. Ragellifera, Wall., Hk. \& Grev., Ic. Fil., tab. CCLXXXIII ; Microlepia pinnata, J. Sm. (not. Cav.), Copel., Polypod. Philipp., 55; Bedd., Ferns S.I., tab. XIV; Wibelia pinnata, Fée (not Bernh.), Diels, in Engl. \& Prantl, Nat. Pfl.Fam., I ${ }^{4}$, fig. 116, J \& H.

Rhizome creeping, densely clothed with subulate-lanceolate, fibrillose scales. Stipes erect, strong, $10-30$ c.M. long, scaly towards the base. Fronds oblong, 15 -40 c.M. long, 7 -20 c.M. broad, simply pinnate with 8-20 short-stalked, erecto-patent pinnae on each side below the terminal one. Pinnae linear, 4-20 c.M. long, 3--10 m.M. broad, acuminate, the base cuneate, the edge slightly crenate or toothed. Texture coriaceous; rachis and surfaces naked. Sori 1-2 to each tooth, more broad than long, sometimes confluent.

Malaya; Polynesia.

* (3) T. gracile, v. A.v. R.; T. pinnatum, C. Chr., var., C. Chr., Ind. Fil. ; Davallia gracilis, Bl., Rac., Flor. Blz., I, 154; D. Luzonica, Hlk., Spec. Fil., I, tab. LX, B, fig. 2, $3 \&$ \&; Microlepia pinnala, J. Sm., var.gracilis, Copel., Polypod. Philipp., 55; M. pinnata, J. Sm., var. Luzonica, Bedd., Handb. Ind. Ferns, Suppl., 15; Wibelia gracilis, Christ, Ann. Btz., XX, 154.

Rhizome creeping, densely clothed with small, brown, subulate-lanceolate, fibrillose scales. Stipes $\pm 5-10$ m.M. apart, $10-15$ c.M. long, densely scaly at the base. Fronds oblong-lanceolate, 20-50 c.M. long, to 17 c.M. broad. Texture coriaceous; rachis and surfaces naked. Sori 1-2 to each tooth, the pairs often \pm confluent. - Two forms.

Forma grandidentata: Fronds simply pinnate. Pinnae linear, \pm 5 m.M. broad, deeply toothed or subpinnatifid, the teeth or lobes broad, obliquely deltoid, reaching down nearly to the costa.

Forma dissecta: Fronds pinnate. Pinnae $\pm 2-5$ c.M. broad, deeply pinnatifid nearly to the costa or pinnate again, the segments linear or oblong, entire or obliquely toothed, the base adnate, decurrent or cuneate.

Both forms may be found on the same rhizome.

Malaya.

* (4) T. amboimense, C. Cher., Ind. Fil.; Davallia amboinensis, IIk., Hk. Bk., Syn. Fil., 470; Hk., Spec. Fil., I, tab. LVI, C; D. moluccana, Rb., Wall. List, No. 2219; Wihelia amboinensis, Kuhn, Diels, in Engl. \& Prantl, Nat. Pfl.Fam., I I 216.

Rhizome creeping, the scales lanceolate-subulate, fibrillose, brown. Stipes 
seriate, \pm b-10 m.M. apart, $15-45$ c.M. long, firm, erect, \pm scaly at the base. Fronds lanceolate-ovate, $15-35$ c.M. long, deeply 3-pinnatifid or 5-pinnate at least at the base. Pinnae erecto-patent, the higher ones pinnate, the segments entire, toothed or subpinnatifid, lowest pinnae largest, with the lower pinnulae deeply pinnatifid or pinnate, those on the lower side often much produced. All the teeth and segments erecto-patent or ascending. Texture coriaceous; rachis and surfaces naked. Sori near the base on the inner side of the ultimate segments or teeth, minute, intramarginal.

Moluccas; Sımoa.

(5) T. Denhami, C. Chr., Ind. Fil.; Davallia Denhami, Hk., Hk. Bk., Syn. Fil., 100; Hk., 2d Cent. of Ferns, tab. XLVII; Wibelia Denhami, Kuhn, Diels, in Engl. \& Prantl, Nat. Pfl.Fam. I ${ }^{4}, 217$.

Rhizome creeping, the scales subulate-fibrillose. Stipes slender, erect, 10-20 c.M. long. Fronds 30-60 c.M. long, 15-30 c.M. broad, 4-pinnatifid. Pinnae erecto-patent. Pinnulae of the lower pinnae erecto-patent, lanceolate, $5 \frac{1}{2}-7 \frac{1}{2}$ c.M. long, $\pm 2 \frac{1}{2}$ c.M. broad, cut down to the rachis into oblong, toothed segments, the lower of which $\pm 1 / 2$ c.M. long, $\pm 1 / 4$ c.M. broad. Texture herbaceous; surfaces naked. Sori numerous, intramarginal, very small; indusium obpyriform, the outer edge rounded.

New Guinea; Polynesia. 
TRIBE IV. PTERIDEAE. 



\section{ADIANTUUM, Linné.}

Sori roundish, obreniform, transversally oblong or linear, terminal on the veins, the sporangia springing from the veins only (Eu-adiantum), or placed both on the veins and the spaces between them (Adiantellum). Indusium of the same shape, marginal, consisting of the modified, reflexed margin, bearing the sori on its inner surface.

Rhizome creeping or erect. Stipes often black and polished, not articulate to the rhizome. Fronds erect or climbing (not in malayan material), simple or commonly variously divided; leaflets inclined to be dimidiate, but often cuneato-flabellate, the outer edge not rarely more or less deeply incised, the laciniae generally finely toothed; veins free or sometimes anastomosing. Ferns mostly known and cultivated under the name of nchevelure" or "maiden-hair". Hk. Bk., Syn. Fil., tab. II, fig. 21 ; Diels, in Engl. \& Prantl, Nat. Pfl.Fam., $\mathrm{I}^{4}$, fig. $150\left(^{*}\right)$.

Tropical and subtropical; some species also in the temperate zones.

Arrangement of the sections and groups.

$\$$ 1. EU-ADIANTUM (incl. Adiantellum). Veins free.

a. Heniformiane. Fronds simple.

b. Drigosoriae. Fronds pinnately divided. Leaflets not cuneatoflabellate. Sori linear, in continuous or interrupted lines.

c. Polysoriae. Fronds pinnately divided. Leaflets not cuneatoflabellate. Sori transver'sally oblong, or sometimes obreniform.

1. Cumeatac. Fronds pinnately divided. Leaflets cuneato-flabellate, \pm oblique, the petiole near the centre at the base. Sori obreniform, or sometimes transversally oblong.

e. Perlatae. Fronds pedato-dichotomous, i.e. forked, with the secondary branchings springing from the upper side of the 2 primary ones. S2. HEWARDIA. Veins anastomosing. (Not in Malaya).

$\left(^{*}\right)$ With view on the many beautiful species of this genus, which are much beloved as ornamental plants, I inserted in this work the imported species (not the varieties got by cullivation), which I know are found in our indian gardens. 
Key to the malayan groups.

$(\$ 1 . \quad$ Eu-adianlum).

a. Fronds simple.

S) 1. a. Henifioniane.

a.a. Fronds divided.

b. Fronds forked, the primary branches pinnately branched on the upper (inner) side only.

S 1. e. Pedatae.

b.b. Fronds varying from simply to more copiously pinnate.

c. Sori long, linear, continuous or interrupted. Leaflets dimidiate or unequal-sided.

$\$ 1$. b. Dligosoriae.

c.c. Sori short, transversally oblong or obreniform.

d. Leallets dimidiate or unequal-sided. $\$$ 1. c. Polysoriane.

d.d. Leaflets obliquely cuneato-flahellate, sometimes tending towards orbicular, or traperifor'm- or rhomboidal-dimidiate.

S 1. d. Cuncartae.

\section{$\$$ 1. EU-ADIANTUM. a. Benifonmiae.}

(1) A. Panishii, Mk., Hk. Bk., Syn. Fil., 114; Hk., Spec. Fil., III, tab. CXLII, A; Fil. Exot., tab. LI; Bedd., Ferns Br.I., I, tah. XVI.

Stipes tufted, slender, naked, dark-brown, polished, $1 / 2-1 / 2$ c.M. long. Fronds 1-2\% c.M. each way, suborhicular, slightly undulate, cuneate at the base. Texture papyraceo-herbaceous; veins radiant, not prominent. Sori few, placed in the crenations of the fronds.

Malacca; Burmah.

\section{\$ 1. EU-ADIANTUM. b. Dligosoniac.}

*. Fronds simply pinnate. Leaftels (pinnae) sessile or subsessile, rather opposite.

(2) A. maciophyllum.

*.*. Fronds once or more limes pinnale. Leaflels (pimnae or pinnulae) dislinclly slallied, ralher allernale.

(5) A. platyphyllum. 
37. adiantum. $\$ 1$. eu-adintum. b. oligosoriat.

* (2) A. macrophyllum, Sav., Hk. Bk., Syn. Fil, 121; Hk., Fil. Exot., tab. LV; Hk. \& Grev., Ic. Fil., tab. CXXXII; - var. striatum, Hort. Bog.

Stipes 15-30 c.M. long, firm, erect, polished, naked, blackish. Fronds $20-40$ c.Ml. long, $10-20$ c.M. broad, simply pinnate with $\pm 4-6$ pairs of \pm opposite lateral pinnae below the lerminal one. Lower pinnae (leaflets) of the barren fronds 7-10 c.M. long, \pm b c.M. broad, so broad at the base that the opposite ones frequently overlap; all the pinnae sessile or the lower ones very short-stalked, inequilateral, but not dimidiate, the margin rather distinctly lobed; fertile pinnae narrower than the barren ones. 'Texture flaccido-papyraceous. Sori linear, in long-continuous or interrupted marginal lines. - Occasionally this well-known species becomes 2-pinnate in the lower part. The young fronds are often beautifully tinged with red.

Var. striatum : Beautifully variegated with long or short, broad or narrow, white stripes placed irregularly between or along the veins.

Much cullivated. - Orig. loc.: Trop. America.

(3) A. platyplnyllum, Sw., C. Chr., Ind. Fil.; A. Seemanni, Hi., Hk. Bk., Syn. Fil., 121; Hk., Spec. Fil., II, tab. LXXXI, A.

Stipes $1.2-25$ c.M. long, erect, blackish, polished. Fronds 1 b̆-50 c.M. long, 1-2 X pinnate. Leaflets $7-10$ c.M. long, 51/2-5 c.M. hroad, ovate, acuminate, rather unequal-sided, but not dimidiate, the barren ones fincly serrate, one side usually cordate at the base, the other obliquely truncate; petioles of the lowest leaflets nearly $2^{1} / 2$ c.M. long. Texture subcoriaceous; veins prominent; rachis naked, polished. Sori in long, continuous, marginal lines, often accompanied by roundish or oblong ones. - Resembles A. peruvianum, $K l$. in habit.

In cultivation. - Orig. loc.: Centr. America, Brasilia, Bolivia.

\section{$\$ 1$. EU-ADIANTUM. c. Polysoriac.}

a. Fronds $1-2 \times$ pinnale.

b. Sori few, typically 1-2 to a leaflet.

*. Fronds simply pinnale. Indusium narrow. (4) A. gomphophyllum.

*.*. Fronds 2-pinnate. Indusium broad.

b.b. Sori many, typically 3 or more to a leaflet.

c. Surfaces pilose or strigose at least on the veins.

- (5) A. Hosei.

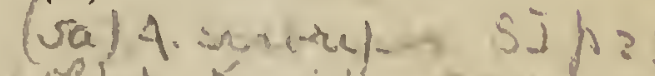
(36) A. Mungi" S.1 fi? 34

S. Texture thinly herbaceous or memlranaceous. (6) A. diaphanum.

\$.S. Texlure charlaceous or coriaceous. 
57. ADinNtum. $\$ 1$. EU-ADiANTUM

*. Rhizome scales hristle-like. Lobes of the leaflets ovate or transversally oblong.

(7) A. Zollingeri.

*.*. Rhizome scales lanceolate. Lobes of the leaflets oblong or linear-ıblong.

(8) A. caudalum.

c.e. Surfaces naked or nearly so.

d. Rachis not winged.

e. Fronds unbranched, often proliferous at the apex.

f. Pinnae (leaflets) rather deeply lobed.

y. Rachis naked. (9a) A. rhizophorum.

g.g. Rachis rather long-hairy. (9b) A. ciliatum.

f.f. Pinnae (leaflets) entire or rather shallowly lobed.

+. Fronds 1-21/2 c.M. broad.

(10a) A. Spencerianum.

+*. Fronds 3-8 c.M. broad. (10b) A. lunulatum.

e.e. Fronds mostly branched, not proliferous at the apex (1). *. Leaflets dimidiate, trapeziform. (11) A. trapeziforme. *.*. Leaflets unequal-sided, rather obliquely ovate.

(12) A. peruvianum.

d.d. Rachis winged.

(13) A. Mettenii.

a.a. Fronds 3-4-pinnale at least at the base $\left({ }^{2}\right)$.

1. Rachises pubescent or tomentose at least on the upper side.

*. Rhizome wide-creeping; leaflets bluntish at the apex.

(14) A. pulchellum.

+.*. Rhizome short-creeping; leaflets bluntly rounded at the apex.

(ise) a.chisitui SI pz3) (15a) A. aculeolatum.

(15b) A. mindanaoense.

1.1. Rachises naked, but often scabrous.

- (isc) A buluherrenucion

2. Leaflels small, 1-2 c.M. long, 3-5 m.M. broad. (16) A. formosum.

2.2. Leaflets larger, 2-3 c M. long, \pm 10 m.M. broad. A hoclundwal S.

(17) A. polyphyllum.

(4) A. gomphophyllum, BBi., Ann. of Bot., VIII, 124.

Stipes tufted, erect, straight, black-brown, nearly naked. Fronds ligulate, 丂 -10 c.M. long, $2-21 / 2 \quad$ c.M. broad, simply pinnate. Leaflets $\breve{b}-6$-jugate, 7-10 m M. each way, short-stalked, deltoid, the sides entire, straight, the

$\left.{ }^{2}\right)$ See also A. diaphanum, $B l$, var. affine \& aculeolatum, $v . A . v . R$.

$\left(^{2}\right)$ See also $A$. peruvianum, $K l$. \& trapeziforme, $L$. 
apex lobed. Lobes rounded, crenulate. Surfaces naked; rachis slender, blackbrown, naked; veins flabellate. Sori often 2 on a pimna, terminal on the lubes; indusium narrow, obreniform, naked, persistent.

Malacca.

(כ) A. Mosei, Bk., Journ. of Bot., XXVI, 324.

Stipes slender, castaneous, $\pm \tilde{\mathbf{z}} 0$ c.M. long, sparingly covered with small, reflexed, linear, brown scales towards the base. Fronds 2-pinnate, rhomboidal in outline. Pinnae lanceolate, $10-25$ c.M. long, $2-2 \frac{1}{2}$ c.M. broad. Leaflets (pinnulae) close, numerous, rhomboidal, dimidiate, obtuse, short-stalked, the central ones $2-2 \frac{1}{2}$ c.M. long, 6-9 m.M. broad, the barren ones minutely crenate. Texture moderately firm; surfaces naked like the castaneous rachis. Sori 1-2, placed on the upper margin of the leaflets, to 4-7 m.M. long; indusium broad, firm. - Pendulous plants.

Borneo.

* (6) A. diaphanum, Bl., Rac., Flor. Btz., I, 145; Hk., Spec. Fil., II, tab. LXXX, G; - var. affine; A. affine, Hk., l. c., 32.

Rhizome short, erect, densely clothed with small, lanceolate scales. Stipes tufted, 6-20 c.M. long, slender, erect, blackish, polished, scaly at the very base. Fronds 10-20 c.M. long, simply pinnate, linear-lanceolate, or with $1-\tilde{\mathbf{z}}$ branches varying from short to nearly as long as the terminal one. Leaflets short-stalked, $1-2$ c.M. long, $1 / 2-1$ c.M. broad, unilateral or sometimes slightly inequilateral, ovate to rhomboidal, the lower line straight or upcurved, the upper one \pm parallel to the lower, crenate or slightly lobed like the rounded outer edge. Texture very thin; rachis naked; upper surface purveyed with few, scattered, brown, subulate bristles especially near the lower edge, the under surface clothed with numerous small, adpressed hairs; veins terminating in the ultimate crenations or serratures. Sori obreniform, placed in nearly circular hollows on the upper and often also the outer edge; capsules springing from the veins and parenchyma. - In habit this shows an approximation towards the pedate group when branched.

Var. affine: Surfaces naked except the subulate bristles on the upper surface, olive-green when dry.

Trop. Asia, Polynesia, Australia, New Zealand.

(7) A. Zollingeri, Mett., Ann. Mus. Bot. L. B., IV, 280.

Rhizome short, clothed like the base of the stipes with reddish-brown, 
bristle-like scales. Stipes dense, $\pm 17-18$ c.M. long, ebeneous and glossy like the rachis. Fronds \pm 45 c.Mr. long, linear, simply pinnate, proliferous, narrowed gradually towards the apex. Leaflets subsessile, spreading, to 2 c.M. long, 5-8 m.M. broad, the upper base obliquely truncate or cuneate, the outer edge obtuse. Lobes ovate or transversally oblong, the lower ones 2-fid, the harren ones obtusely denticulate, the fertile ones retuse. Texture rigidly chartaceous; rachis hairy abore; veins prominent, strigose. Sori solitary on the lobes; indusium coriaceous, transversally oblong.

Java; Angola.

* (8) A. caudatum, L., Rac., Flor. Btz., I, 145 ; Bedd., Ferns S.I., tab. II.

Rhizome short-creeping or erect, clothed with brown, lanceolate scales. Stipes tufted or approximate, $\mathbf{3}-\mathbf{1} \mathbf{3}$ c.M. long, wiry, dark-brown, clothed with a brown tomentum. Fronds simply pinnate, $\mathbf{1 5 - 5 0}$ c.M. long, the apex often nudate, elongate, caudate, rooting at the point. Leaflets dimidiate, \pm sessile with a cuneate base, $1-2$ c.M. long, half as broad, the lower edge straight and entire, the upper and outer more or less broadly cut, often deeply and repeatedly, the outer edge bluntly rounded, lowest leaflets not rarely subflabellate. Lohes linear-oblong or oblong, with the apex rounded or truncate, entire or serrulate. Texture coriaceous; rachis and surfaces more or less densely pilose. Sori roundish or transversally oblong, terminal on the lobes; sporangia springing from the veins only.

Trop. Asia \& Africa; New Hebrides.

(9a) A. Phizophorum, Sw., Hk., Spec. Fil., II, 12, tab. LXXX, A.

Near A. caudatum, $L$. Fronds elongate-lanceolate, simply pinnate, often tapering into a long rooting and proliferous apex bare of pinnae. Leaflets alternate, short-stalked, semiovate, the upper base truncate, parallel to the. rachis, the upper edge lobed, the lobes retuse, soriferous, shining above. Texture chartaceo-coriaceous; rachis ebeneous or reddish-brown like the slightly chaffy stipe, naked, glossy; surfaces $\pm^{\prime}$ naked; veins numerous, compact, fine. Indusium obreniform, thick, coriaceous.

Timor; South. Africa.

* (9b) A. ciliatum, Bt., Enum., 215; A. caudatum, L., var., C. Chr., Ind. Fil.; A. caudalum, L., var. $\beta$ Hk., Spec. Fil., II, 14.

Near A. caudatum, $L$. Fronds elongate-lanceolate, simply pinnate, often 
tapering into a long, rooting and proliferous apex bare of pinnae. Leaflets sessile or subsessile, dimidiate, the base cuneate, the inner edge \pm parallel to the rachis, the upper and outer edge laciniate, the laciniae linear or oblong, \pm 2-fid, the apices denticulate, frequently ciliate. Texture firm, rachis hirsute with moderately long, spreading hairs; surfaces naked or clothed with some scattered hairs. Sori terminal on the lobes; indusium lunulate to obreniform.

Trop. Asia \& Africa.

(10a) A. Spencerianum, Copel., Philipp. Journ., I, Suppl., 154, tab. XI.

Rhizome very short, scaly. Stipes approximate, 2-15 c.M. long, purpleblack, glossy, the base clothed with, small, thin, deciduous scales. Fronds 7-17 c.M. long, or longer and rooting, $1-21 / 2$ c.M. broad, simply pinnate. Leaflets approximate, nearly sessile, sometimes falcate, the base obliquely cuneate, the inner edge excised, the upper edge entire or rarely slightly incised, the apex acute. Texture papyraceous; surfaces naked; veins inconspicuous. Sori continuous or interrupted.

Luzon.

* (10b) A. Iunulatum, Barm., Rac., Flor. Btz., I, 144; Iİk. \& Grev., Ic. Fil., tab. CIV; Bedd., Ferns S.I., tab. I; A philippense, L., Copel., Polypod. Philipp., 95 .

Stipes 5 - 20 c.M. long, tufted, wiry, naked, polished, dark-brown. Fronds 15-30 c.M. long, 5-8 c.M. broad, simply pinnate, often alongated and rooting at the apex. Leaflets $1 \frac{1}{2}-4$ c.M. long, to $1-21 / 2$ c.M. broad, dimidiate or subdimidiate, the base broadly cuneate or truncate (upper and lower base in a continuous, straight or curved line), the lower base in a line or oblique with the petiole, the upper and outer edge rounded, more or less lobed or nearly entire; petioles of the lower leaflets spreading, to $1-1 \frac{1}{2}$ c.M. long. Lobes rounded, $1 / 2-5$ m.M. deep. Texture papyraceo-herbaceous; both surfaces naked. Sori occupying the apices of the lobes, in continuous rows along the edge, sometimes confluent; capsules on the veins only.

Trop. Africa, Asia, Australia \& Polynesia, Centr. America.

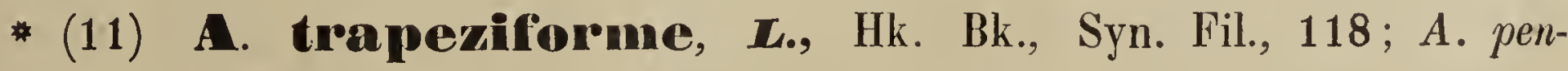
dactylon, L. \& F., Hk. \& Grev., Ic. Fil., tab. XGVIII. 
Stipes 1b-40 c.M. long, firm, erect, naked, blackish, polished. Fronds 2-5-pinnate with a terminal branch 10-20 c.M. long, 5-8 c.M. broad and 2-4 large ones on each side, the lowest of wich are often branched again. Leaflets 5-6 c.M. long, $1-5$ c.M. broad, dimidiate, the apex \pm acute, the upper and lower edges parallel, the lower sometimes decurved, the outer edge oblique, the inner deflexed, the upper and outer edge more or less deeply or shallowly lohed, the lobes blunt: lowest leaflets on stalks $1 / 2-1 \frac{1}{2}$ c.M. long. Texture papyraceo-herbaceous; rachis and both surfaces naked; veins terminating in the ultimate lobes or their crenations or serratures when present. Sori numerous, terminal on the lobes, approximate, transversally oblong; capsules on the veins only, but densely crowded.

Much cullivaled. - Orig. loc.: Trop. America.

* (12) A. pentuvianum, Ku., Hk. Bk., Syn. Fil., 116; Hk. Spec. Fil., II, tab. LXXXI, C.

Stipes 15-25 c.M. long or longer, erect, naked, polished, nearly black, deciduously scaly at the base. Fronds either simply pinnate or 2-pinnate with 1-5 branches at the base $0^{\circ}$ even with some of the latter slightly branched again. Leaflets large, 4-7 c.M. long, 5-5 c.M. broad, unequally ovate or subtrapezoidal, the base broadly cuneate or subtruncate, the edge slightly lobed, the apex varying, from bluntish to acuminate; lowest leaflets on stalks 1-2 c.M. long. Texture papyraceous; veins copious, flabellate, terminating in the ultimate lobes or their crenations or serratures when present: rachis and surfaces naked. Sori many or numerous along the upper and outer edge; capsules springing from the veins only. - Leaflets mostly resembling those of A. platyphyllum, $S w$.

In cultivation. - Orig. loc.: Peru.

* (13). A. Mettenii, Kuhn, Hk. Bk., Syn. Fil., 472; A. lumulatum, Burm., var. Mettenii, Bedd., Handb. Ind. Ferns, 83; Ferns S.Br.I., Suppl., tah. CCCLIV; A. alatum, Copel., Polypod. Philipp., 93.

Rhizome erect, short. Stipes \pm 8-12 c.M. long, blackish-brown, glossy, slightly scaly at the base, more or less narrowly winged throughout like the rachis and the stalks of the pinnae. Fronds $10-50$ c.M. long, $\pm 4-5$ c.M. broad, simply pinnate. Leaflets more or less spreading, the lower often subdeflexed, $1-1 \frac{1}{2}$ c II. broad; the lower side entire, nearly straight, the upper and outer ones rounded, \pm irregularly lobed, the inner one subparallel to the rachis. Texture papyraceous; surfaces naked; veins conspicuous. Sori trans- 


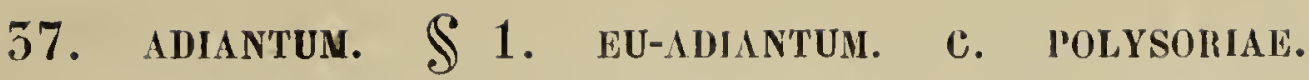

versally oblong, terminal on the lobes, 5-10 to a jinna, straigt or subcurved; capsules on the veins only.

Philippines; Trop. India, West. Africa.

* (14) A. pulchellum, BI., Rac., Flor. Btz., I, 146; A. Lobbianum, II/., Spec. Fil., II, tab. LXXXVI, C.

Rhizome wide-creeping, the scales dense, linear-lanceolate, brown. Stipes remote, 1 -60 c.M. long, polished, blackish, naked, scaly towards the base, the scales linear-subulate, spreading, crisped, leaving the stipes rough when they fall. Fronds $20-40$ c.M. each way, 2-5-pinnate with a terminal branch 15-25 c.M. long, $2-4$ c.M. broad and a few lateral ones on each side, the lower ones branched again with $2-4$ erects-patent secondary branches. Leaflets dimidiate or slightly inequilateral, close, the largest to \pm 2 c.M. long, to \pm 1 c.M. broad, the lower edge upcurved, the upper one nearly straihgt, the apex bluntish, but not rounded. Texture coriaceous; rachises hirsutotomentose on the upper side; surfaces naked; veins terminating in the ultimate serratures. Sori obreniform, small, numerous, placed on the upper and often also on the outer edge in slightly rounded hollows; capsules springing from the veins and parenchyma.

Java.

* (15a) A. aculedatum, v. A. v. R., Hort. Bog.; ( ? A. mindanaoense, Copel.).

Rhizome short, the scales narrow, dense, brown, narrowed gradually from the base towards the acuminate point. Stipes approximate, $\pm 30-40$ c.M. long, polished, dark-purple-brown or nearly hlack, with the lower $1 / 3$ covered with irregularly scattered, spreading, crisped, brown scales, which leave the stipes rough (subaculeate) when they fall. Fronds $\pm 20-35$ c.M. long, $15-30$ c.M. broad, 2-3-pinnate with a terminal branch $12-15$ c.M. long, \pm 3 c.M. broad, and 1-4 lateral branches on each side. Lowest branches largest, erecto-patent, generally branched again at the base, with the secondary branch on the lower side often the longest. Leaflets dimidiate, often close and imbricate, the largest \pm 2 c M. long, \pm 1 c.M. broad, erectopatent, the lower line upcurved, the upper edge \pm straight, the apex rounded, denticulate, the upper edge slightly lobed and denticulate, the base cuneate, the lowest leaflets of each branch \pm flabellate. Texture coriaceous; rachises purple-blackish, rather hirsute-tomentose on the upper side; surfaces naked; veins terminating in the ultimate serratures. Sori transversally oblong or 
37. adiantum. $\$ 1$. eu-adintum. c. polysoriae.

nearly ohreniform, placed in shallow or semiorbicular hollows along the upper edge, solitary on the lobes; sporangia springing from the veins as well as from parenchyma. - The description is laken from a specimcn cultivated in the Buitenzorg gardens.

Amboyna.

A. mindanadense, Copet., Philipp. Journ., I, Suppl., 154, tab. X.

Rhizome short-creeping. Stipes approximate, 25-40 c.M. long, clothed towards the base with glossy, linear-subulate, fuscous scales, otherwise naked, black-fuscous. Fronds deltoid-ovate, $25-40$ c.M. long, $20-50$ c.M. broad, acuminate. 5-pinnate. Leaflets short-stalked, dimidiate, $\pm 1 \frac{1}{2}-1 \frac{3}{4}$ c.M. long, $\pm 3 / 4$ c.M. broad, the outer edge obtuse, denticulate, the upper one slightly lobed, the base truncate on the upper side. Texlure papyraceous; rachis densely furnisched on the upper side with minute hairs; surfaces naked. Sori \pm 6 to a leaflet, solitary on the lobes, suborbicular-reniform, the sporangia springing from the veins and parenchyma.

Mindanao.

* (16) A. formosumm, R. Br., Hk. Bk., Syn. Fil., 119 ; Hk., Spec. Fil., II, tah. LXXXVI, B.

Stipes 50-50 c.M. long, erect, scabrous, strong. Fronds $45-75$ c.ll. loug, 5-4 $\times$ pinnate. Lowest branches 30-40 c.M. long, erecto-patent, $15-25$ c.M. broad, deltoid. Leaflets short-stalked, $1-2$ c.M. long, $\mathbf{3}-5$ m.M. broad, dimidiate, numerous, rhomboidal, the lower edge straight, erecto-patent, the inner one parallel to the rachis, the upper and outer edge lobed and loothed, the teeth often sharp. Texture firm; rachis scabrous or hirsute towards the apex; veins prominent above, terminating in the ultimate serratures. Sori numerous, transversally oblong, slightly obreniform, in slightly rounded hollows of the upper and outer edge; capsules springing from the veins and parenchyma.

In cultivation. - Orig. loc.: Australia, New Zealand.

* (17) A. polyphyllum, Willd., Hk. Bk., Syn. Fil., 118; Hk., Gard. Ferns, Lab. XII ; A. cardiochlaena, Kze, Hk., Spec. Fil., II, tab. LXXXIII.

Stipes 50-45 c.M. long, strong, erect, blackish, polished, deciduously scaly, rather scabrous. Fronds $60-120$ c.M. long, 50-60 c.M. broad, 5-pillnale, with a long, terminal branch and several lateral branches on each side, 
the lower of which are branched again below a long terminal branch. Secondary branches \pm 8 c.M. long or longer. Leaflets dimidiate, rhomboidal (almost a parallelogram), sessile, numerous, close, $2-5$ c.M. long, \pm 1 c.M. broad, the upper and lower sides parallel, the apex bluntly rounded, the upper and outer edge crenate, or lobed and serrate. Texture firm-membranaceous or subcoriaceous; rachises and surfaces naked; veins terminating in the ultimate serratures. Sori numerous, placed in shallow hollows at the apices of the lobes or crenations, 1 to each lobe, along the upper and sometimes also the outer edge; capsules springing from the veins only.

Much cultivated. - Orig. loc.: Venezuela, Peru.

\section{\$) 1. EU-Adiantum. d. Cumeatae.}

a. Ultimate segmen/s (leaflets) articulate at the base; ultimate petioles distinctly nodose at the apex.

(18) A. tenerum. a.a. Ultimate segments (leaflets) not articulate at the base; ultimate petioles not nodose at the apex.

b. Leaflets with the outer edge entire or shallowly lobed.

c. Sori ralher numerous, typically 3-6, sometimes 2 to a leaflet.

d. Leaflets often dimidiate or trapezoidal, the terminal ones cunieate.

(19a) A. neoguineense.

(19b) A. opacum. S. I $p=3$

d.d. Leaflets cuneato-flabellate to suborbicular.

e. Sori in rather half-rounded hollows; sporangia springing from the veins and parenchyma. (20) A. aethiopicum.

e.e. Sori in shallow hollows; sporangia springing from the veins only.

(21) A. suborbiculare.

c.c. Sori few, typically 1-2, sometimes 3 to a leaflel.

(22) A. celebicum.

b.b. Leaftets with the outer edge rather deeply lobed.

(2.2.a)A cubresion

s. Lower leaflets of the pinnae overlapping the main rachis, adpressed to the latler.

t. Pinnae spreading.

(25) A. concinnum.

t+ +. Pinnae erecto-patent.

(24) A. tinctum.

\$.S. Lower leaflets not overlapping the main rachis. 
37. adintum. $\mathbb{S} 1$. eU-adiantum. d. cuneatal.

*. Sori roundish-obneniform. Veins lerminating in the angles lotween the ultimate serralures of the barren leaflets.

(25) A. cuneatum.

*.*. Sori transversally oblong. Veins terminaling in the lops of the ultimate serratures of the barren leaflets.

(26) A. capillus veneris.

(26a) A. Forgeveoni si

* (18) A. Temerom, Sw., Hk. Bk., Syn. Fil., 124; A. nobile, Fisch., hort.

Stipes to 50 c.M. long, erect, naked, blackish, glossy. Fronds $25-90$ c.II. long, $20-45$ c.M. broad, deltoid, ;-4-pinnate. Leaflets cuneate or tending loward rhomboidal-dimidiate in shape, the largest $1 \frac{1}{2}-21 / 2$ c.II. long, $1-2$ c.M. broad, articulate to the nodose apex of the petioles, the upper and outer edge rounded or somewhat angular, broadly and often rather deeply lobed. Texture thin: rachis glossy and naked like the surfaces; veins terminating in the ultimate serratures. Sori placed in roundish or transversally oblong patches in slightly rounded, shallow hollows, terminal on the lobes, the sporangia springing from the veins only.

In cultivation. - Orig. loc.: Bermuda, West. India, Mexico, Juan-Fernandez.

(19a) A. neoguineense, Moore, Ann. of Bot., V, 208.

Stipes naked, castaneous, 1弓̆-20 c.M. long. Fronds deltoid, 5-pinnate, naked, above 50 c.M. long and broad; rachises very slender, naked, nearly black. Terminal leaflets cuneate, lateral trapezoidal, $1-1 \frac{1}{2}$ c.M. long, cuneate. Sori orbicular, 3-4 to a leaflet, placed in deep sinuses. - Intermediate between A. tenerum, $S w$. and A. aethiopicum, $L$.

New Guinea.

(19b) A. opacum, Copel., Philipp. Journ., I, Suppl., 255, tab. 111.

Rhizome short, clothed with narrow, castaneous scales. Stipes approximate, slender, \pm 20 c.M. long, the base furnished with long, scaltered, deciduous hairs, otherwise pubescent like the lower part of the rachis. Fronds 16-20 c.M. long, ovate, 3-pinnate. Leaflets deciduous (? articulate, the stalks persistent), often dimidiate, $\pm 8 \mathrm{~m} . M$. broad, $1-1 / 4$ c.M. long, the margin narrowly cartilagineous, the upper and outer edge rounded, slightly lobed with 2-4 shallow lobes. Texture papyraceous, opaque; surfaces naked, pale- 
colonred. Sori transversally oblong, 1 to each lobe, the sporangia nearly restricted to the veins.

\section{Palawan.}

* (20) A. aethiopicum, L., Hk. Bk, Syn. Fil., 12j; Hk., Spec. Fil., II, tah. LXXVII; Bedd., Ferns S.I., lah. V.

Stipes 15 -25 c.M. long, erect, naked, dark-brown or blackish, polished. Fronds $15-45$ c.M. long, $10-25$ c M. broad, \pm deltoid in outline, 5-4pinnate. Leaflets suborhicular, broadly flabellate, rather equilateral, the base straight, rounded or broadly cuneate, the outer edge rounded, broadly and shallowly lobed. T'exture thinly herbaceous to papyraceous; rachis and surfaces naked; veins terminating in the ultimate crenations or serratures. Sori in several roundish or transversally oblong patches in rather half-rounded hollows; capsules springing from the veins and parenchyma.

Banca, New Guinea; Australia, New Zealand; Soulh. \& Trop. Africa, ? Spain.

$$
\text { malacea ( } 5 \text { I } 23 q \text { ) }
$$

\section{* (21) A. suborbiculare, v. A. v. R.}

Rhizome short, densely clothed with linear-subulate, entire, bright-reddishbrown scales. Stipes approximate, to 20 c.M. long, erect, blackish, polished like the rachises, scaly at the very base. Fronds $\pm 15-20$ c.M. each way, 3-pinnate with several alternate, erecto-patent lateral branches below the terminal one, the lowest largest, branched again in the lower part. Leaflets \pm 1 c.M. long, $1 / 2-1 \frac{1}{2}$ c.M. broad, obliquely flabellate or suborbicular, slalked, the base cuneate, truncate or rounded, the outer edge rounded, often irregularly and shallowly lobed. Texture papyraceous, firm, subpellucid; surfaces naked like the rachises and the stipes; veins terminating in the serratures. Sori 2-6 to a leaflet, roundish or transversally oblong, placed in indistinct or shallow hollows of the outer edge, the sporangia springing from the veins only.

\section{Sumalra (Burck).}

* (22) A. celebicum, Christ, Ann. Bt\%, XV, 10\%, tab. XV, fis. $15, a-c$.

Stipes wiry, black, polished, shorter than the fronds. Fronds $20-50$ c.M. long, 7-15 c.M. broad, 5-pinnate at least at the base; rachises black, naked, polished, erecto-patent. Leaflets $1-2$ c.M. long, $1 / 2-1 / 2$ c.M. broad, the base more or less broadly cuneate, sometimes rounded, whether or not 
ohlique, shallowly and hroadly lobed with 2-5 subentire lobes. 'Texture membranaceous-lierbaceous; surfaces naked, opaque, often bluish. Sori obreniform, 1-2, rarely 3 to a leaflet, placed in orbicular hollows along the outer edge at the tops of the sinuses; indusium adpressed, persistent.

Celebes.

* (23) A. concinmum, \#. B. F., Hk. Bk., Syn. Fil., 123.

Stipes 10-25 c.M. long, hlackish, naked, polished. Fronds 50 - 50 c.ll. long, 15-30 c.M. broad, ovate or ovate-deltoid, 3-pinnate. Branches many, spreading, alternate, the lowest $10-15$ c.M. long, $.5-71 / 2$ c.M. broad at the base. Leaflets $6-20$ m.M. across, broadly flabellate, the outer edge irregularly rounded, deeply lobed, the lobes again crenate, the base hroadly cuneate, truncate or subcordate. Texture papyraceo-herbaceous; main rachis naked, glossy, flexuose, overlapped by the large, adpressed lower leaflets; surfaces naked; veins terminating in the angles of the sinuses between the ultimate serratures. Sori numerous, obreniform, placed in round or semiorbicular hollows, the sporangia springing from the veins and parenchyma.

In cultivation. - Orig. loc.: Trop. America.

* (24) A. tinctum, Moore, Hk. Bk., Syn. Fil., 474; A. Wagneri, Mctl., IIk. Bk., I. c. 475; A. decorum, Moore, Gardn. Chron. 1869, 582.

Stipes 10-20 c.M. long, erect, naked, blackish, glossy. Fronds \pm delLoid, 15-45 c.M. long, 2-4-pinnate. Lower primary and secondary branches erecto-patent, stalked, deltoid. Terminal leaflets obliquely cuneate-flabellate, the lateral ones subrhomboidal, $3 / 4-1 / 2$ c.M. long, the lower edge straight, the inner one \pm touching the rachis or even wrapped over it, upper and outer edge more or less distinctly lobed, the lobes blunt, lowest leaflets equilateral, broadly flabellate, imbricated over the main rachis and adpressed to it. Surfaces naked; texture papyraceous; rachis glossy, naked, slightly zigzag; veins terminating in the tops of the sinuses between the ultimate serratures. Sori round, obreniform, in \pm circular hollows of the upper and outer edge; capsules on and between the veins. - Intermediate between A. concinnum, II. B. K. and A. cuneatum, L. \& F.

In cultivation. - Orig. loc.: Costa Rica, Peru.

* (25) A. cumeatum, L. \& F., Hk. Bk., Syn. Fil., 124; Hk. \& Grev., Ic. Fil., tab. XXX.

Stipes $15-25$ c.M. long, slender, naked, blackish, polished. Fronds 20-40 
c.M. long, 15-25 c.M. broad, deltoid, 3-4-pinnate. Lower branches c.M. broad. Leaflets numerous, $1 / 2-2$ c.M. broad, the base cuneate, the outer edge obliquely rounded, deeply lobed, the lobes whether or not lobed again. 'Texture thin; rachis and surfaces naked; veins terminating in the angles of the sinuses between the ultimate serratures. Sori $\pm 4-6$ to a leaflet, obreniform, placed in distinct semiorbicular or circular hollows, the sporangia springing from the veins and parenchyma. - A variable species with many garden varieties.

In cultivation. - Orig. loc.: Brasilia, Peru, Argentinia.

* (26) A. capilius veneris, $\boldsymbol{x}$. , Hk. Bk., Syn. Fil., 125; Bedd., Ferns S.I., tab. IV; Hk., Spec. Fil., II, tab. LXXIV, B; Bau. \& Hk., Gen. Fil., tab. LXVI, B.

Slipes slender, $10-25$ c.M. long, naked, polished, blackish. Fronds 2pinnate at least at the base, $20-40$ c.M. long, deltoid-oblong. Branches alternate. Leaflets to 5 c.M. long, $1-21 / 2$ c.M. broad, the base cuneate, the outer edge obliquely rounded, deeply lobed from the circumference in the direction of the base, the lobes again bluntly crenate and slightly lobed and whether or not serrulate. Texture pellucido-herbaceous; rachises and surlaces naked; veins terminating in the ultimate crenations or serratures. Sori roundish or Iransversally oblong, slightly curved, placed in slightly rounded, shallow hollows, the sporangia springing from the veins only. - Variable, with several garden varieties.

Paleotropical, Temperate Asia \& Africa, South. Europe.

\section{S 1. EU-Adiantum. e. Pedatae.}

\$. Surfaces hispid.

(27) A. hispidulum.

\$.\$. Surfaces nalied.

*. Leaflets imbricated over the rachises.

(28) A. stenochlamys.

*.*. Leaflets not or hardly imbricated over the rachises. (29) A. flabellulatum.

* (27) A. hispidulum, sw., Rac., Flor. Btz., I, 145; Bedd., Ferns S.I., tab. III.

Rhizome short-creeping or erect, scaly. Stipes strong, erect, polished, dark-brown, 13-35 c.M. long, scabrous and rough-hairy. Fronds irregularly 
broadly ovate, $12-15$ c.M. each way, pedato-subdichotomous with the main divisions flabellately branched. Central branches 1 b-25 c.M. long, $1-21 / 2$ c.M. broad. Leaflets $1 / 2-21 / 4$ c.M. long, 5-10 m.M. broad, dimidiate, subrhomboidal, rather broader on the side nearest the stipe, the outer edge bluntly rounded or oblique, upper and outer margin often crenate, finely toothed; lower leaflets slightly stalked. Texture subcoriaceous; rachises and both surfaces hispid. Sori roundish, contiguous round the upper and outer edge; indusium obreniform, hairy.

Paleotropical.

(28) A. stemochlamys, Bts, Ann. of Bot., V, 209.

Stipes long, naked, wiry, nearly black. Fronds pedate, deltoid, 5-pinnate, $\pm 15-25$ c.M. each way. Terminal leaflets cuneate, 1-2 c.M. broad, shallowly lobed, crenate round the upper edge; lateral leaflets subrhomboidal, short-stalked, little longer than broad, the upper and outer edge shallowly lobed and crenate, the inner edge inflexed so that it is imbricated over the rachis. Texture firm; surfaces naked. Sori $6-8$ to a leaflet; indusium firm, narrow.

Borneo.

* (29) A. Iabellulatum, I., Rac., Flor. Btz., I, 146; Bedd., Ferns S.I., tab. CGXVIII; A. amoenum, H/. \& Grev., Ic. Fil., tab. CIII.

Rhizome erect, short, clothed with narrow, lanceolate scales. Stipes erect, strong, polished, dark, naked, to 25 c.M. long. Fronds irregularly broadly ovate, to \pm 20 c.M. or more long and to \pm 15 c.M. or more broad, pedato-subdichotomous and the branches once or twice branched again. Central branches to 20 c.M. long, to $2 \frac{1}{2}$ c.M. broad. Leaflets to $\pm 10 \mathrm{~m}$.M. broad and to $\pm 7 \%$ m.M. deep, flabellato-cuneate to dimidiate, the base truncate, rounded or cuneate the upper and outer margin rounded, entire or slightly or finely toothed. Texture coriaceous, rachis naked or tomentose above, surfaces naked. Sori in several transversally oblong patches round the upper and outer edge, contiguous, often confluent.

Trop. Asia, China, Japan.

\section{H Y POLEPIS, Bernhardi.}

Sori round, subterminal on the veins on a thickened receptacle, sub- 
marginal, solitary at the tops of the sinuses of the ultimate segments, protected by reflexed, membranaceous, roundish lobes, too small to cover them permanently.

Rhizome whether or not creeping. Stipes not articulate to the rhizome. Fronds variously divided, herhaceous, more or less hairy; veins free. Hk. Bk., Syn. Fil., tab. II, fig. 24; Diels, in Engl. \& Prantl, Nat. Pfl.Fam., I ${ }^{4}$, fig. 147. Pantropical.

\section{Arrangement of the sections.}

$\$$ 1. ASPIDOTIS. Rhizome not creeping; fronds small, tufted. (Not in Malaya). $\$$ 2. EUHYPOLEPIS. Rhizome wide-creeping; fronds large, scattered.

\section{\$2: EUHYPOLEPIS.}

5. Fronds 2-3-pinnale, under 50 c.M. long.

\$.S. Fronds al least 4-pinnatifid, more than 50 c.M. long. *. Surfaces naked except a few hairs on the midribs. *.*. Surfaces sparingly glanduloso-pubescent.

\section{See Sipr40(diff toy)}

(1) H. alpina.

(2) H. punctata.

(5) H. tenuifolia.

* (1) H. Alpima, Ht., Rac., Flor. Btz., I, 149; Cheilanthes alpina, Bl., Enum., 158.

Rhizome branched, densely clothed with reddish-brown, spreading, narrow fibrils. Stipes $\breve{b}-20$ c.Y. long, densely clothed with spreading hairs. Fronds triangular-lanceolate, less than 50 c.M. long, 15 - 30 c.M. broad, 2-5-pinnate. Ultimate segments oblong, blunt, not close, $5-10 \mathrm{~m} . \mathrm{M}$. long, $21 / 2-5$ m.M. broad at the base, adnate to the rachis, very slightly decurrent, often united at the base by a narrow wing $\pm 1 / a$ m.M. broad, the edges crenate or toothed. Texture herbaceous, but firm; rachises and surfaces hairy. Sori $1-8$ to each segment.

Java.

(2) H. punctata, Bedd., Handb. Ind. Ferns, Suppl., 19 ; ( ? Phegopteris punctata, Mell.; Dryopleris punclata, C. Chr., Ind. Fil.).

Rhizome large, wide-creeping. Fronds 120-560 c.M. long, 4-pinnatifid; rachises strigose. Pinnae \pm 60 c.M. long, more than 30 c.M. hroad at the 
base, on petioles $\pm \check{5}$ c.M. long. Pinnulae lanceolate, $15-20$ c.M. long. Tertiary segments $\pm 5 \%$ c.M. long, \pm 1 c.M. broad, cut down to a narrowly winged rachis into 10-12 oblong, obtuse segments on each side, which are bluntly lobed. Texture herbaceous; surfaces naked; tertiary rachises and midribs with a few, longish, white hairs on both sides. Sori in the axils of the 1-2 lower lobes on each side of the segments; indusium distinct, membranaceous.

Malacca.

* (5) H. cenuifolia, Bermh., Rac., Flor. Btz, I, 148; Hk., Spec. Fil., II, tab. LXXXIX, C \& XG, A; II. pallida, H/.., I. c., 64; Cheilanthes pallida, Bl., Enum., 159.

Rhizome densely clothed with short, spreading fibrils. Stipes 20-100 c.M. long, puberulous like the rhizome but less so. Fronds 50-500 c.M. long, 4-5-pinnate. Lower pinnae ovate-lanceolate, 20-100 c.M. long. Ultimate segments linear-oblong, bluntish, free or joining at the base by a very narrow wing, the edges toothed or shallowly pinnatifid. Texture herbaceous; surfaces sparingly glandular-pubescent, the rachises more so. Sori in the ultimale sinuses.

Malaya; Australia, New Zealand, Polynesia, China.

\section{OHELLANTHES, Swartz.}

Sori roundish or oblong, terminal on the veins, at first small and distinct, afterwards more or less laterally confluent into a submarginal line. Indusium semiorbicular or transversally oblong, contiguous or confluent, consisting of the wholly or partially recurved, modified margin of the frond.

Rhizome ascending or creeping, mostly short, scaly. Stipes dark-coloured, not articulate to the rhizome. Fronds divided; veins free, the tips thickened. Hk. Bk., Syn. Fil., tab. III, fig. 25; Diels, in Engl. \& Prantl, Nat. Pfl.Fam., $\mathrm{I}^{4}$, fig. 116.

Arrangement of the sections.

S1. PHYSAPTERIS. Ultimate segments very small, roundish, $\pm 1-2 \mathrm{~m} . \mathrm{M}$. each way. Diels, 1. c., fig. 116, D. 
\$2. ALEURITOPTERIS. Ultimate segments not very small. Fronds coated beneath with a white or yellow powder.

$\$ 5$. EUCHEILANTHES. Like $\mathbb{2}$, but the fronds not powdery beneath.

\section{\& 1. PHYSAPTERIS.}

(1) Ch. Boltoni, Copel., Polypod. Philipp., 95.

Stipes densely tufted, $1 \frac{1}{2}-3$ c.M. long, brown-black, sparsely covered with hairs of the same colour. Fronds linear-oblanceolate, to \pm 16 c.M. long, $1 \frac{1}{2}$ c.M. broad, 2-pinnate, the broadest part $1 / 3$ of the way from the apex. Pinnae almost sessile, remote, the largest to \pm 8 m.M. long, 6 m.M. broad. Pinnulae in $1-5$, pairs, ovate, minute, crenulate, plane when moist, curling up when dry. Texture very thin, but firm when dry; rachis blackish-brown, nearly naked; surfaces naked. Indusium interrupted.

Philippines.

\section{\$ 2. ALEURITOPTERIS.}

a. Primary segments not reaching down to the rachis, i. e. joined at the base.

(2) Ch. argentea. a.d. At least the lowest primary segments reaching down quite to the rachis, $i$. e. free from the next higher ones.

b. Fronds 2-pinnatifid.

(3) Ch. rufa.

b.b. Fronds 3-pinnatifid.

(4) Ch. farinosa.

* (2) Ch. argentea, Kae (not $H k$.), Hk. Bk., Syn. Fil., 142 ; Bedd., Ferns Br.I., I, tab. CXLIII ; Pteris argentea, Gmel., (oldest name).

Stipes densely tufted, 7-15 c.M. long, polished, dark-brown, scaly at the base especially when young. Fronds $7-10$ c.M. long, $5-8$ c.M. broad, 3-pinnatifid at the base, the primary segments not reaching down quite to the rachis. Lowest segments the largest with the lowest basipetal lobe the largest. Costae polished like the stipe; upper surface naked, the under one covered with white, waxy powder. Sori very small, fusing; indusium crenate or fimbriate.

Siberia to Malaya.

Fitices. 
(3) Ch. Iufia, Don (not Desv.), Hk. Bk., Syn. Fil., 141; Hk., Spec. Fil., II, tab. IC, A; Bedd., Ferns Br.I., I, tab. CXLIV.

Stipes tufted, $2 \frac{1}{2}-5$ c.M. long, densely clothed with rusty-brown, woolly tomentum like the rachis. Fronds $8-25$ c.M. long, 4-8 c.M. broad, ovatelanceolate, 2-pinnatifid. Pinnae opposite, the lower ones with 2-5 c.M. space between them, oblong, much shorter than the central ones, with the lowest segments on the lower side produced, the higher ones linear-oblong, regularly lobed or wavy. Texture herbaceous or ftaccido-coriaceous; surfaces somewhat tomentose, under surface more or less coated with white powder. Sori roundish, small, nunterous; indusium brown, ragged or ciliate.

Philippines; North. India.

* (4) Cln. Pandinosa, Irtf., Rac., Flor. Btz., I, 147; Bedd., Ferns S.I., tab. CXCI; Hk. \& Grev., Ic. Fil., tab. CXXXIV; Pleris farinosa, Forsli., (oldest name); - var. chrysophylla; Ch. chrysophylla, Hk., Spec. Fil., II, 115 ; Ch. argentea, Kze, var. chrysophylla, Hk. Bk., Syn. Fil., 142; Hk., Fil. Exot., tab. XCV.

Stipes densely tufted, $10-30$ c.M. long, polished, dark-brown, clothed with scattered, deciduous, linear-lanceolate scales. Fronds $5-30$ c.M. long, 4-15 c.M. broad, 3-pinnatifid. Pinnae in opposite pairs, sessile, the lower ones the largest, remote, reaching to the rachis, with the segments on the lower side longer than the others and deeply lobed, the higer ones confluent at the base so as to form a deeply pinnatifid, acuminate terminal pinna. Texture subcoriaceous; rachis and costae polished, naked, dark-brown; under surface covered with white, waxy powder. Indusia brown, scariose, rounded, conliguous or confluent and then waved or lobed, the margin entire or toothed.

Var. Chrysophylla: Powder yellow.

Trop. Asia, Africa, America, Fiji, China, Japan.

\section{$\$ 3$. EUCHEILANTHES.}

1. Rachis naked.

2. Fronds 2-pinnatifid.

(b) Ch. varians.

2.2. Fronds at least 3-pinnatifid.

3. Indusium transversally oblong, narrow.

(6) Ch. tenuifolia.

3.3. Indusium roundish-obreniform, broad.

(7) Gh. multifida.

1.1. Rachis tomentose. 
*. Fronds 2-pimatifid, herbaceous.

(8) Ch. fragilis.

*.*. Fronds 3-pinnalifid, subcoriaccous.

(9) Ch. hirta.

* (5) Ch. varians, Mk., Hk. Bk., Syn. Fil., 156; Hk., Spec. Fil., II, tab. CIII, A; Bedd., Ferns S.I., tab. CLXXXIX; Ch. Belangeri, C. Chr., Ind. Fil.; Pteris varians, Wall., List, No. 86.

Stipes densely tufted, 5-15 c.M. long, dark-bown, polished, rather slender and brittle; fibrillose below. Fronds $15-25$ c.M. long, $5 \frac{1}{2} / 2-5$ c.M. broad, lanceolate, 2-pinnatifid. Pinnae in numerous pairs, the lower ones opposite, often 51/2-5 c.M. apart, $21 / 2-51 / 2$ c.M. long, \pm 2 c.M. hroad, deltoidacuminate, cut down to the rachis in the lower part into oblong or linear, oblong, entire or slightly toothed lobes. Texture herbaceous; rachis polished like the stipe; both surfaces naked. Sori copious, continuous; indusium narrow, membranaceous.

Trop. Asia.

* (6) Cl. temuifolia swo, Rac., Flor. Btz., I, 148; Hk., Spec. Fil., II, tab. LXXXVII, C; Bedd., Ferns S.I., tab. CLXXXVIII; Ch. hispidula, Kze, Bot. Zeit., 1848, 212; Trichomanes tenuifolium, Burm., (oldest name).

Stipes not tufted, 10-20 c.M. long, wiry, flexuose, naked, dark-brown, polished, slightly fibrillose towards the base. Fronds $10-20$ c.M. long, 7-10 c.M. broad, deltoid to lanceolate, 3-pinnatifid. Pinnae in numerous, opposite, erecto-patent pairs, the lowest 5 -10 c.M. long, 2-5 c.M. broad, deltoid. Pinnulae on the lower side the largest, the lowest $\pm 21 / 2$ c.M. long, cut down to the rachis into oblong, entire or sinuato-pinnatifid segments. Texture subcoriaceous; rachis polished like the stipe; both surfaces naked. Sori roundish or subcontinuous; indusium brownish, narrow, transversally oblong, \pm toothed.

Trop. Asia, Australia, Polynesia, Tasmania, New Zealand.

(7) Ch. multifida, Sw., Hk. Bk., Syn. Fil., 158; Hk., Spec. Fil., II, tab. C, B ; Gard. Ferns, tab. XXXIX.

Stipes tufted, 7-25 c.M. long, strong, erect, dark-chestnut-brown, polished, slightly scaly towards the base. Fronds 7-50 c.M. long, 5-20 c.M. broad, ovate-lanceolate or deltoid, 5-4-pinnatifid. Lower pinnulae opposite, remote, erecto-patent, deltoid, 5 -15 c.M. long. Ultimate divisions linear-oblong, deeply lobed and the margin in the ferlile fronds much recurved. Texture subco- 
riaceous; rachis dark-chestnut-brown, naked and polished; surfaces naked. Sori small, roundish, slightly confluent; indusium roundish-obreniform.

Java; South. Africa, St. Helena.

(8) Ch. fraginis, Hik., Hk. Bk., Syn. Fil. 155; Hk., Fil. Exot., tab. XCVI; Bedd., Ferns Br.I., II, tab. CCXXIII.

Stipes densely tufted, not more than 2-3 c.M. long, strong, tomentose and fibrillose, erect. Fronds $15-30$ c.M. long, 5-10 c.M. broad, ovate-lanceolate, 2-pinnatifid. Pinnae numerous, alternate, the lowest 2-5 c.M. apart, 2-5 c.M. long, $1-1^{1 / 2}$ c M. broad, oblong-lanceolate, cut down to the rachis below into numerous linear-oblong, blunt, sinuato-crenate lobes. Texture herbaceous; rachises bright-brown, tomentose, but the surfaces naked except on the midribs beneath. Sori small, roundish or subcontinuous; indusium pale-brown, membranaceous.

Malacca; Moulmein, Yunnan.

(9) Cly. Whirta, Sw., Hk. Bk., Syn. Fil., 136; Hk., Spec. Fil., II, tab. CI, B; Ch. parviloba, Sw., Syn., 128.

Stipes tufted, 5-10 c.I. long, strong; erect, densely coated with spreading, bright-reddish-brown, woolly hairs. Fronds $10-30$ c.M. long, $5-15$ c.M. broad, ovate-lanceolate, 5-pinnatifid. Pinnae opposite, spreading from the main rachis at right angles, lanceolate, $2^{1} / 2-7^{1 / 2}$ c.M. long, cut down to the rachis into numerous oblong pinnulae, which are scarcely more than $1 / 2$ c.M. long and again inciso-pinnatifid. Texture subcoriaceous; rachis and both surfaces more or less tomentose; margin of the segments much incurved. Sori copious. Ch. parviloba, Sw. has the rachis and surfaces less tomentose, the pinnae shorter and the segments and apex slightly divided and convolute.

Java; Réunion, South. Africa.

\section{PLAGIOG MRIA, Mettenius.}

Sori oblong, on the somewhat thickened ends of the mostly branched veins, soon becoming confluent and quite covering the space between the costae and the edges of the narrowed segments at maturity. Sporangia long-stalked, with an oblique, complete annulus. Indusium long, linear, continuous, consisting of the more or less modified, reflexed or recurved margin of the pinnae. 
Rhizome erect. Stipes clustered, adherent to the rhizome, the base abruptly dilated, bearing on the outer side generally $\pm 2-12$ spongy tubercles or projections. Fronds simply pinnate, dimorphous; barren pinnae linear-lanceolate, fertile ones much contracted, linear. Diels, in Engl. \& Prantl, Nat. Pfl. Fam., I ${ }^{4}$, fig. 149.

Eastern Asia, Tropical America.

a. Pinnae of barren fronds adnate to the rachis by a broad base.

*. Fronds $\pm 20-25$ c.M. long, $\pm 6-71 / 2$ c.M. broad, submembranaceous.

(1) P. stenoptera.

*.*. Fronds $\pm 30-45$ c.M. loing, $\pm 10-15$ c.M. broad, subcoriaceous.

(2) P. adnata.

a.a. At least the lower pinnae of barren fronds not adnate to the rachis.

b. Tubercles wanting on the stipes at the base.

(3) P. Christii.

Ђ.b. Tubercles present.

c. Pinnae of barren fronds glaucous or white-powdery beneath.

(4) P. glauca.

c.c. Pinnae of barren fronds not glaucous, nor powdery beneath.

d. Pinnae of barren fronds \pm truncate at the base.

(5) P. pycnophylla.

d.d. Pinnae of barren fronds narrowed at the base.

e. Barren pinnae serrate throughoul. (6) P. euphlebia.

e.e. Barren pinnae serrate towards the apex only, otherwise entire.

(7) P. tuberculata.

(1) Stemoptera, Diels, Copel., Philipp. Journ., I, Suppl., 154; Blechnum stenopterum, Hance, Journ. of Bot., XXI, 268; Lomaria concinna, Ble., Jonrn. of Bot., XXIII, 103; L. stenoptera, Bk., Ann. of Bot., V, 220.

Rhizome short, erect. Stipes tufted, greenish, nearly naked, 10-25 c.M. long, basal tubercles present, the fertile fronds on the longest stipes. Barren fronds oblong-lanceolate, $20-25$ c.M. long, 6-71/2 c.M. broad. Pinnae \pm 20 on a side, lanceolate, contiguous, adnate by a dilated base, $\pm 71 / 2 \mathrm{~m} . \mathrm{M}$. broad, acute, minutely denticulate. Texture nearly membranaceous; surfaces naked; veins distinct, simple or forked. Fertile fronds with the pinnae less numerous, remote, linear.

Luzon; Formosa, China. 
* (2) P. adriata, Beda., Handb. Ind. Ferns, 127; Ferns Br.L., I, tab. LI ; Lomaria adnata, Bl., Rac., Flor. Btz.', I, 162; Hk., Spec. Fil., III, tab. CXLVII.

Rhizome short, stout. Stipes 15 - 45 c.M. long, firm, erect, naked, basal tubercles present. Fronds ovate-lanceolate, 50-45 c.M. long, 10-15 c.M. broad. Pinnae linear, falcate, the largest $\pm 7 \%$ c.M. long, to $1 \frac{1}{2}$ c.M. broad, the lower ones narrowed at the base below, dilated at the base above, $1-21 / 2$ c.M. apart, the apex narrowed gradually and finely toothed. Texture subcoriaceous; rachis naked; veins conspicuous. Fertile fronds similar, but the pinnae more distant and narrowly linear.

Java, Sumatra, Philippines; Japan, Yunnan, Khasia.

(3) Clmistii, Copel., Philipp. Journ., I, Suppl., 155.

Rhizome short, erect. Stipes approximate, 20-50 c.M. long, naked, castaneous, the base thickened, without tubercles. Fronds pinnate, $40-60$ c.M. long. Barren fronds with \pm 13 pinnae on each side. Pinnae nearly horizontal, \pm 13 c.M. long; $11 / 2-2$ c.M. broad, acuminate, serrulate, the lower ones stalked, the higher ones adnate. Texture herbaceous; surfaces naked; veins simple or forked. Fertile fronds with 12-16 pinnae, the pinnae linear, \pm 10 c.M. long, $2-5$ m.M. broad, stalked, or the higher ones adnate. Fronds with the aspect of Stenochlaena, and the absence of the basal projections of the stipes helps to conceal the real aflinity. However, the oblique annulus and the insertation of the sori establish the place beyond doubt (Copel.).

\section{Mindanao.}

* (4) P. daucea, Mett., Christ, Farnkr. d. Erde, 175 ; Bedd., Ferns Br.I., I, tab. XG; Lomaria glauca, Bl., Rac., Flor. Btz., I, 162 ; - var. philippinensis, Christ, Bull. Herb. Boiss., VI, 1 ๖̌

Rhizome erect. Stipes erect, naked, \pm 30 c.M. or more long, basal tubercles present. Fronds ovate, 50-150 c.M. long, $15-50$ c.M. broad, pinnate, the apex pinnatifid, narrowed. Pimnae contiguous, linear, $11 / 4-2$ c.II. broad, sessile or the lower short-stalked, the apex acuminate, the edge sharply serrulate, but more distinctly towards the point, the base rounded or narrowed, often provided with a large gland beneath. Texture coriaceous; veins fine, copious, compact, simple or forked; under surface glaucous or white-powdery. Fertile fronds with the pinnae distant and narrowly linear.

Vax. phillippoinensis: Pinnae of barren fronds scarcely acuminate, 
minutely serrulate, separated by as much as their own breadth; terminal pinna like the lateral ones.

Malaya; North. India, Yunnan; - var. philippinensis: Luzon.

* (5) D. pyenoplly ylle, Mett., Christ, Farnkr. d. Erde, 175; Bedd., P R Ferns Br.I., I, tab. LII; Lomaria pycnophylla, Kze, Rac., Flor. Btz., I, 161; Hk., Spec. Fil., III, tab. CXLVIII ; - yar. remota, Christ, Bull. Herb. Boiss., VI, 150 ; - var. mixta, Copel., Philipp. Journ., I, Suppl., 1 54.

Rhizome stout, erect, woody. Stipes erect, naked, $15-40$ c.M. long, basal tubercles present. Fronds ovate-lanceolate, $\pm 60-150$ c.M. long, $15-30$ c.M. broad, the apex pinnațifid, narrowed. Pinnae numerous, linear, spreading or nearly so, contiguous, $1-1 \frac{1}{2}$ c.ll. broad, the apex acuminate or subcaudate, the edge finely serrulate, but more strongly towards the point, the base truncate or subtruncate, mostly purveyed beneath with 1-2 conspicuous, prominent glands. Texture coriaceous; veins numerous, close, simple or forked. Fertile pinnae distant and narrowly linear.

Var. remota: Pinnae separated by \pm their own breadth.

Var. mixta: Fertile pinnae often dilated and sterile at the apex.

Malacca, Java, Borneo; Yunnan, Norlh.India; - var. remota: Philippines; - var. mixta: Luzon.

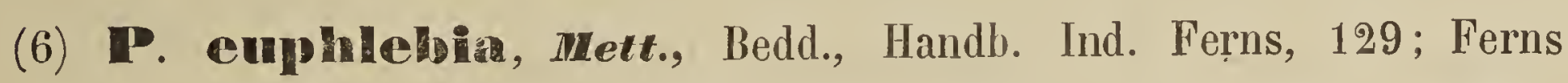
Br.I., II, tab. GLXV; Lomaria euphlebia, Kze, Hk. Bk., Syn. Fil., 185 ; Hk., $2^{d}$ Cent. of Ferns, tab. LXXXIX; L. articulala, Muell., Fragm., V, 174.

Rhizome stout, woody. Stipes 30 c.M. or more long, naked, erect, basal tubercles present. Fronds ovate-lanceolate, 30-60 c.M. long, 15-50 c.M. broad. Pinnae $: 1 / 2$ c.M. or more apart at the base, erecto-patent, linear, serrulate, $10-15$ c.M. long, 1-2 c.M. broad, narrowed at the base on both sides and at the toothed apex. Texture subcoriaceous; veins prominent. Fertile fronds similar, but the pinnae more distant and narrowly linear.

New Guinea, Malacca; China, Japan.

(7) T. Interecullata, Copel., Philipp. Journ., I, Suppl., 153.

Rhizome erect, short. Stipes close, 20-40 c.M. long, the fertile fronds on the longest stipes, the base bearing \pm 12 tubercles. Barren fronds \pm 60 c.M. long, $20-25$ c.M. broad, the apex abruptly acuminate, the rachis quadrangular, naked, glossy, reddish-brown, bearing glands on the under side 
at the base of the pinnae. Pinnae 30-40-jugate, nearly horizontal, the largest $\pm 1 \frac{1}{4}$ c.M. broad, the lase acute, the edge entire, the apex acuminate, serrate; lower pinnae short-stalked, higher adnate, highest confluent. Texture papyraceous; surfaces naked; veins conspicuous, simple or forked. Fertile fronds narrower, the pinnae spreading, \pm 11 c.M. long, $\pm 2-3 \mathrm{~m}$.M. broad. Luzon.

\section{PELLAEA, Linti.}

Sori intramarginal, either dot-like to oblong, solitary and terminal on the veins, but soon runining into a submarginal line or linear, placed on a submarginal receptacle uniting the vein tips. Indusia roundish, contiguous or linear, consisting of the reflexed, modifid margin of the frond.

Rhizome more or less creeping. Stipes seriate, not articulate to the rhizome, with a single, 2-4-archous vascular strand $(V, Y, X)$. Fronds divided; leaflets mostly \pm stalked, more or less distinctly articulate, not adnate at the base; veins free or sometimes anastomosing, the apices not or hardly thickened. Diels, in Engl. \& Prantl, Nat. Pfl.Fam., I ${ }^{4}$, fig. 142.

Trop. Asia, Australia, Polynesia, America, Africa.

Arrangement of the sections.

$\$ 1$ PLATYLOMA Sori terminal on the veins, free, but soon running into a submarginal line. Veins always free. Diels, l. c., fig. 142, B.

$\mathbb{S}$ 2. PTERIDELLA. Sori linear, on a submarginal receptacle uniting the vein tips. Veins free in malayan material. Diels, l. c., fig. 142, F.

\section{S 1. PLATYLOMA.}

+. Fronds simply pinnate.

$\times$. Stipes scaltered. Lower pinnae not or hardly reduced. (1) P. falcata. $\times \cdot \times$. Stipes lufled. Lower pinnae much reduced.

(2) P. Zippelii. +. Fronds more compoundly divided.

(3) P. pteroides. 
* (1) Palcatan, Fée, Hk. Bk., Syn. Fil., 151; Platyloma falcatum, J. Sm., Bedd., Ferns S.I., tab. XXII; Plcris falcala, Burm., (oldest name).

Rhizome wide-creeping, densely scaly; scales linear-lanceolate, with a broad or narrow black line in the centre, the margin brown. Stipes $71 / 2-15$ c.M. long, erect, more or less densely clothed with short (narrow) and longer (linear-lanceolate), ferrugineous scales. Fronds 1 b- 4 bै c.M. long, $21 / 2-$ b c.M. broad, linear-oblong to lanceolate, simply pinnate. Pinnae more or less numerous, nearly sessile, $1-21 / 2$ c.M. long, $1 / 2-11 / 2$ c.M. broad, lanceolate or oblong, blunt or mucronate, often slightly falcate, cuneate or dilated and cordate at the base. Texture coriaceous; rachis densely scaly and tomentose, both surfaces nearly naked. Sori in broad marginal lines, soon hiding the narrow indusium.

Trop. Asia; Australia, Tasmania, New Zealand, New Caledonia.

(2) F. Rippelini, Mk., Hk. Bk., Syn. Fil., 477; Allosurus Zippelii, Miq., Ann. Mus. Bot. L. B., IV, 98.

Stipes short, tufted, scaly. Fronds lanceolate, \pm 4 b. c.M. long, \pm 7 c.M. broad, simply pinnate. Pinnae very numerous, opposite, patent, short-stalked, linear-lanceolate, obtuse, straight or slightly falcate, the central ones $\pm 3 \frac{1}{2}$ c.M. long, with the base $\pm b \mathrm{~m}$.M. broad, the lower ones much reduced. Texture firm, subcoriaceous; rachis clothed with subulate scales; upper surface naked, lower scaly on the midribs; veins simple or 2 -fid, tumid at the tip.

New Guinea.

(3) D. Dterodiales, Prant, Engl. Jahrb., III, 420; Diels, in Engl. \& Prantl, Nat. Pll.Tam., Iㄴ, fig. 142, G-H; Cheilanthes plervides, Sw., Hk. Bk., Syn. Fil., 131; Hk., Spec. Fil., II, tab, CI, A; Adiantum pteroides, L., (oldest name).

Stipes 1丂̆-30 c.ll. long, strong, erect, polished, dark-brown, naked. Fronds 20-40 c.M. long, 15-25 c.M. broad, deltoid, 3-pinnate; upper part simply pinnaty, lower with several opposite pairs of wiry, erecto-patent branches growing gradually larger down, the lowest often again branched. Ultimate segments $\pm 1-21 / 4$ c.M. long, $\pm 1 / 2-1$ c.M. broad, oblong, entire, broadly rounded at both ends, sessile. Texture subcoriaceous; rachis polished; both surfaces naked. Sori small, roundish, distinct but contiguous; indusia oblong, contiguous, numerous.

? Java; South. \& West. Africa. 


\section{S 2. PTERIDELLA.}

* (4) P. timoremsis, v. A. v. M.

Rhizome short, the scales long, linear-subulate, brown, eroso-denticulate. Stipes approximate, 12-20 c.II. long, blackish, polished, flbrilloso-tomentose on the upper (inner) side, deciduously scaly at the base. Fronds lanceolateoblong, $15-25$ c.M. long, 8-12 c.M. broad, simply pinnate. Pinnae $\pm 10-15$ on each side, stalked, \pm spreading, $\pm 1-1 \frac{1}{2}$ c.M. broad, the lower ones longer or smaller than the others, lanceolate, subacute, the edge recurved when dry, crenate throughout when barren, the base rounded or slightly cordate. Texture coriaceous; rachis and stalks of the pinnae blackish, polished, tomentose on the upper side; surfaces naked; midribs conspicuous, black in the lower half; veins rather hidden. Sori on a marginal receptacle uniting the vein tips, soon hiding the indusium. - Probably closely allied to the african P. Doniana, Hk., (Spec. Fil., II, lab. GXXV, A).

Timor (Forbes, No. 3918).

\section{2a. DORYOPTERIS, J. Smith.}

Sori roundish or oblong, either solitary and terminal on the veins, but soon running into a submarginal line, or linear and placed on a submarginal receptacle uniting the vein tips. Indusium linear, continuous, consisting of the reflexed, modified margin of the frond:

Rhizome short, the scales costate. Stipes black or dark-coloured, polished, not articulate to the rhizome, with a single, 2-4-archous vascular strand $(\bigvee, Y, X)$. Fronds simple or divided, if divided the segments adnate or joined, not articulate at the base; veins free or anastomosing, the tips not or hardly thickened. Diels, in Engl. \& Prantl, Nat. Pfl.Fam., I ${ }^{4}$, fig. 143.

Pantropical.

\section{Arrangement of the sections.}

$\$ 1$. DORYOPTERIDASTRUM. Sori solitary and terminal on the veins, but soon running into a submarginal line. Veins free, or anastomosing near or towards the margin. Diels, l. c, fig. 142, B (sub Pellaea).

$\$ 5$ 2. EUDORYOPTERIS. Sori linear, on a submarginal receptacle uniting the vein tips. Veins anastomosing copiously. Diels, l. c., fig. 142, F (sub Pellaea). 


\section{\$ 1. DORYOPTERIDASTRUM.}

* (1) D. concolor', Kuhn, Copel., Polypod. Philipp., 94; Pellaea concolor, Bk., Christ, Farnkr. d. Erde, 157; P. geraniacfolia, Fée, Hk. Bk., Syn. Fil., 146 ; Pleris geraniae/olia, Raddi, Rac., Flor. Btz., I, 146 ; Hk., Icon. Pl., X, tab. GMXV; Bedd., Ferns S.I., tab. XXXVII; Pl. concolor, L. \& F., (oldest name).

Rhizome short-creeping, clothed with short, lanceolate scales. Stipes uumerous, subtufted, 5-20 c M. long, naked, erect, blackish, scaly at the base. Fronds ovate-deltoid, $\breve{b-1} 10$ c.M. each way, cut down nearly or rarely quile to the rachis into $5-5$ pinnae on each side, the lowest pair the largest, with the segments on the lower side produced and deeply lobed with linearoblong lobes, the segments of the ferlile fronds not always deeply lobed. T'exture coriaceous; lateral veins once forked; rachis and costae dark-coloured and polished. Sori in broad, marginal lines.

Pantropical.

\section{S 2. EUDORYOPTERIS.}

(2) D. Hudens, J. Sm. Copel., Polypod. Philipp., 94; Diels, in Engl. \& Prantl, Nat. Pfl.Fam., I' ${ }^{4}$ lig. 145, C; Pcllaea ludens, Prantl, Engl. Jahrb., III, 419; Pleris ludens, Wall., Hk. Bk., Syn. Fil., 166 ; Litolrochia pedala, Bedd., Ferus Br.I., I, tab. XXVI; L. ludens, Berlı., I. c., tab. XXVII.

Rhizome creeping, the scales adpressed, linear, brown, pale at the margin. Stipes polished, blackish, naked, sometimes with a few scales and often with dusky, subtomentose pubescence at the base. Barren fronds on stipes 7-10 c.II. long, triangular or ovate-lanceolate, deeply curdate or auriculate, sometimes with $2-5$ pairs of lobes, acuminate, with an entire or crisped margin. Texture coriaceous, rather flaccid; costa polished, surfaces naked; veins hidden, anastomosing copiously. Fertile fronds on stipes to 30 c.M. long, $10-20$ c.M. each way, cut down into $5-7$ lanceolate or linear-lanceolate lobes, the lowest of which are deeply forked, with the lower segment deflexed. Sori in narrow marginal lines.

Malacca, Fhilippines; Br. India. 


\section{SOHIZOS'TEGE, Hillebrund.}

Sori roundish, submarginal, on terminal T-shaped expansions of the veins or veinlets or uniting the apices of the fork branches of forked veins. Indusium of the same shape, remarkably broad. Spores tetrahedral.

Rhizome erect. Stipes not articulate to the rhizome, with a single $U$ shaped vascular strand. Fronds divided; veins free or joining.

. Hawaii, Mindanao.

$\times$. Pinnae pinnatifid $3 / 4-w a y$ down to the costa, the segments entire.

(1) S. pachysora. $\times \cdot \times$. Pinnae pinnatifid nearly or quite to the costa, the segments crenate or lobed. (2) S. calocarpa.

(1) S. pachysora, Copet., Philipp. Journ., I, Suppl., 155.

Rhizome short, erect, thick, crowned with fuscous, lanceolate scales. Stipes tufted, \pm 50 c.M. long, yellow-fuscous, clothed with scales of the same colour. Fronds \pm 40 c.M. long, \pm 20 c.M. broad, 2-pinnatifid. Lowest pinnae somewhat deflexed, \pm 10 c.M. long, sessile, forked at the base on the lower side, the branches subacute, cut $3 / 4$-way down to the costa into entire, obtuse lobes $\breve{b-10}$ m.M. long, $\breve{-7}$ m.M. broad, central pinnae similarly pinnatifid, decurrent, nearly confluent, the higher ones gradually reduced. Texture carnoso-subcoriaceous; surfaces naked; veins hidden, joining in 1 row of costal areolae, rarely forming a second row of areolae in the segments. Sori solitary on the vein tips, free or confluent.

Mindanao.

(2) S. Calocanpa, Copet., Philipp. Journ., I, Suppl., 155, tab. XII. Like S. pachysora, Copel., but: Fronds 5מ-40 c.M. long, \pm 20 c.M. broad, acute, 2-pinnate or sub-2-pinnate. Lower pinnae oblique, deltoid, the following lanceolate, 10 c.M. long, \pm 3 c.M. broad, acuminate, cut down nearly or quite to the costa. Secondary segments \pm 1 b m.M. long, $\pm 4 \mathrm{~m} . \mathrm{I}$. broad, decurrent, crenale or cut $1 / 2$-way down to the costula. Texture carnosocoriaceous; main rachis cinereous, marginate; veins free. Sori not confluent.

Mindanao. 


\section{HISTIO PRHLES, J. Smith.}

Sori linear, submarginal, on a receptacle connecting the vein tips, commonly continuous around the sinuses. Indusium linear, consisting of the reflexed, modified margin. Spores 2-lateral.

Rhizome wide-creeping; stipes polished, stramineous to purplish, not articulate to the rhizome. Fronds at least 2-pinnate; lowest pinnulae shorter than the next in order, stipule-like, close to the main rachis; veins free or anastomosing. Diels, in Engl. \& Prantl, Nat. Pfl.Fam., I'4, fig. 155, F.

Pantropical and farther south.

\section{(1") H.alle-alpina V. AvR. SIp 510}

(1) H. montana, Copel., Polypod. Philipp., 104.

Rhizome wide-creeping, beset with minute, brown scales. Stipes firm, 10-20 c.M. high, erect, black-brown. Fronds deltoid, 15 -50 c.M. long, often broader than long, 2-5-pinnatifid. Lowest pinnae somewhat larger than the next following ones, pinnate. Pinmulae sinuate or pinnatifid, the lowest close to the rachis. Lobes often deltoid-ovate, obtuse, entire. Texture coriaceous; veins prominent above, anastomosing. Indusium broad; margin everywhere rolled in, giving the segments a lomarioid appearance.

\section{Philippines.}

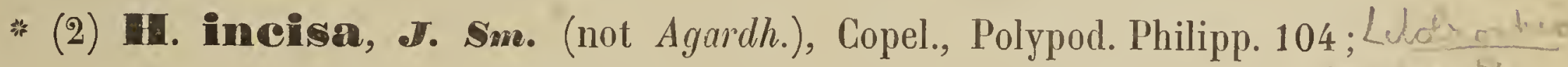
Diels, in Engl. \& Prantl, Nat Pfl.Fam., I', fig. 15̆5, F; Pteris incisa, Thb., Rac., Flor. Btz., I, 159; Pt. Vesperitionis, Lab., Nov. Holl., II, tab. CCXLV; Litobrochia incisa, Pr., Bedd., Handb. Ind. Ferıs, 120 ; - var. aurita; Pt. aurita, Bl., Enum., 213; L. aurita, Pr., Bedd., Fern S.I., Lab. CCXXI ; - var. integrifolia, Bedd., Handb. Ind. Ferns, Suppl., 25.

Rhizome wide-creeping, clothed with narrow, linear-lanceolate scales. Stipes distant, stout, erect, sometimes slightly muricate towards the base, $8-150$ c.M. long. Fronds 10-600 c.M. long, or even longer (!), 2-3-pinnate at the base, often scandent or twining in the largest forms, with long, spreading, rigid branches. Central pinnae opposite, with numerous, lobed or pinnatifid pinnulae $\pm 2 \%-7 \frac{1}{2}$ c.M. long, $\pm 8-20 \mathrm{~m}$. M. broad, the lowest pinnulae shorter, adpressed to the rachis, reduced in size, stipule-like, lowest pinnae more compound. Texture herbaceous to coriaceous; surfaces naked or the under one glaucous; veins free or anastomosing.

Wr. andurita: Stipule-like pinnulae quite entire.

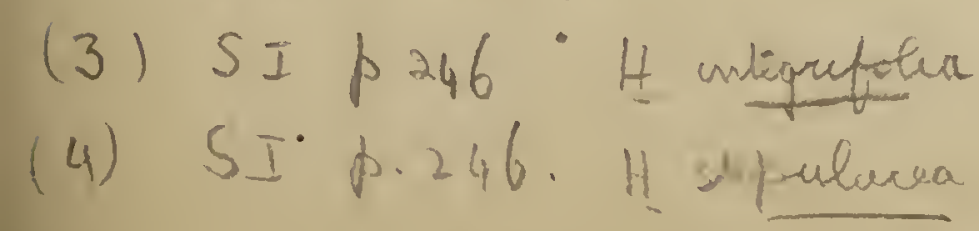


Var. integrifolia: Pinnae petiolate; pinnulae sub-petiolate, long, linear, acuminate, entire, obliquely cordate at the base, the basal pair not auricle-like, distant from the rachis. Sori continuous almost to the finely acuminated apex.

Pantropical and farther south.

\section{ONYCHIUM, Kantfuss.}

Sori linear, submarginal, on a continuous receptacle connecting the vein tips. Indusium consisting of the reflexed, modified margin, broad enough to reach \pm the costa. Spores tetrahedral.

Rhizome creeping. Stipes pale-coloured or brown, with 1-2 vascular strands, not articulate to the rhizome. Fronds finely divided, fertile and sterile divisions \pm unlike; veins free. Hk. Bk., Syn. Fil., tab. III, fig. 27.

Tropical and extra-tropical Asia, Africa \& America.

\$. Sporangia yellow.

*. Fronds 10-15 c.M. long. Indusium whitish.

(1) 0 . tenue.

*.*. Fronds 15-60 c.M. long. Indusium yellow.

(2) 0 . siliculosum.

\$.\$. Sporangia brown.

(3) 0 . japonicum.

(1) D. tenue, Chrost, Bull. Herb. Boiss., 2 e Série, I, 4 b̆1.

Rhizome short, erect. Stipes densely tufted, \pm b c.II. long, slender. Fronds $10-15$ c.M. long, narrowly ovate. Pinnae and pinnulae erect; ultimate segments narrow, cuneate and 5-lobate when sterile, lanceolate and acuminate when fertile. Sori pale-yellow; indusium whitish.

Java, New Guinea, Philippines.

* (2) D. Siliculosum, C. Chr., Ind. Fil.; O. auratum, Klf., Rac., Flor. Btz., I, 163; Bedd., Ferns S.I., tab. XXX; Cryplogramme aurala, Pranll, Diels, in Engl. \& Prantl, Nat. Pfl.Fam., I I , 279; Pleris chrysocarpa (chrysospermân), Hk. \& Grev., Ic. Fil., tab. CVII; Pl. siliculosx, Desv., (oldest name).

Rhizome short, creeping, clothed with subulate-lanceolate, brown, spreading scales. Stipes 10-35 c.M. long, stout, erect, naked, stramineous or pale- 
brown. Fronds 15-60 c.M. long, 7-20 c.M. broad, ovate or lanceolate-deltoid, 5-pinnate to 4-pinnatifid. Lower pimnae subdeltoid, erecto-patent. Pinnulae and segments numerous; ultimate divisions dimorphous, the sterile ones often obovate-cuneate, $\tilde{3}$-fid at the apex, not more than $\breve{b}-10 \mathrm{~m}$.M. long and $1 / 2-1$ m.M. broad, the fertile ones pod-like, $1 / 2-2 \frac{1}{2}$ c.M. long, $1-2 \mathrm{~m} . \mathrm{M}$. broad. Texture coriaceous; rachis and both surfaces naked. Indusium membranaceous and like the sori long, lincar or linear-oblong, of a rich goldenyellow colour.

Trop. Asia.

* (3) 10. japonicum, Kae., Rac., Flor. Blz., I, 164; O. lucidum, Spr., Bedd., Ferns Br.I., I, tab. XXI; Cryptogramme japonica, Pranll, Diels, in Engl. \& Prantl, Nat. Pfl.Fam., I, 279 ; Trichomanes japonicum, Thb., (oldest name).

Rhizome creeping, clothed with narrow, lanceolate scales. Stipes stout, erect, naked, glossy, 10 - 30 c.M. long, stramineous or pale-brown. Fronds ovate-lanceolate, 20-5̆ c.H. long, 7-20 c.M. broad, 5-pinnate or 4-pinnatifid. Lower pinnae lanceolate-deltoid, erecto-patent. Pinnulae and segments numerous, the ultimate divisions uniform or nearly so, 5-lobate, copious, the lobes mucronate, 4-1.0 m.M. long, $1-2 \frac{1}{2}$ m.M. broad. Texture herbaceous to subcoriaceous; rachis and both surfaces naked. Sori short, oblong; indusium pale or brown, membranaceous; capsules hrown or pale-brown.

Jıva, Timor, Philippines; Japan, China, North. India.

\section{5a. PrIRIS, Limné.}

Sori linear, submarginal, on a receptacle uniting the vein tips, occupying both (posterior and anterior) sides of the ultimate segments, generally interrupted at the tops of the sinuses between the ultimate lobes. Indusium of the same shape, consisting of the reflexed, modified margin of the frond. Spores globose to tetrahedral.

Rhizome creeping or erect, scaly. Stipes not articulate to the rhizome, traversed by a single, mostly $V$ - or $\bigcup$-shaped vascular strand. Fronds commonly variously divided, sometimes variegated, i. c. the upper surface provided with broad, whitish or pale-coloured bands running down the costae; veins free or anastomosing. Hk. Bk., Syn. Fil., tab. III, fig. 51, a-c; Diels, in Engl. \& Prantl, Nat. Pfl.Fam. I ${ }^{4}$, lig. 154. 
S 1. EUPTERIS. Veins free.

a. Pinnatifidac. Fronds pinnatifid throughout, at best pinnate at the very base.

b. Pinnatace. Fronds 5-foliate or pinnate, the lowest pinnae simple, or forked with $2-5$ undivided segments in the barren fronds.

c. Compositace. Fronds 3 -foliate or pinnate, the lowest pinnae at least pinnatifid in the barren fronds.

*. Bipinnatifidae. Fronds not 5- or 5-partite; lowest pinnae not much longer than the next higher ones and similarly pinnatifid or pinnate, with the lowest segments on the lower side not rarely elongate and divided again.

*.*. Partitae. Fronds. 5- or 5-partite; lateral branches nearly as long as the central one and similarly 2-pinnatifid, with the lowest segments on the lower side not rarely elongate and divided again.

\$2. CAMPTERIA. Veins slightly anastomosing, forming 1 single row of costal areolae on each side, otherwise free.

55. LITOBROCHIA. Veins anastomosing more copiously.

Key to the sections and groups.

a. Veins free.

\& 1. EUPTERIS.

7. Fronds pinnatifid, at hest pinnate at the very base.

$\$ 1$, a. Pimmatificlae.

W.6. Fronds 3-foliate, pinnate or more compcundly divided.

c. Lower primary segments simple, or forked at the base with 2-3 undivided secondary segments in the barren fronds.

$\$ 1$, b. Pinnatae.

c.c. Lower primary segments at least pinnatifid in the barren fronds

S 1 , c. Compositae.

d. Fronds not 3- or 5-partite, i. e. the lowest pinnae not much longer than and similarly pinnatifid or pinnate as the next higher ones, but not rarely forked at the base with similarly divided branches. $\mathbb{S} 1, \mathrm{c}^{*}$. Bipinnatifidae. a.d. Fronds 3 - or 5 -partite, i. e. the fronds divided into 3 or 
5 branches clustered at the apex of the stipe, the lateral branches often nearly as long and similarly 2-pinnatifid as the central one, not rarely forked near the base with more or less divided secondary branches. $\mathbb{S} 1, c^{* *}$. Partitae. a.a. Veins free except that the central ribs (costulae) of the ultimate segments are more or less connected at the very base by arching veins forming 1 single row of costal areolae on each side. $\mathbb{S}$ 2. CAMPTERIA. a.a.a. Veins anastomosing more copiously than in a.a. \$ 3. LITOBROCHIA.

\section{EUPTERIS. a. Pinnatifidlae.}

* (1) Pt. retucta, Bhis., Journ. of Bot., XVIII, 211; Pt. biaurita, L., var., C. Chr., Ind. Fil.

Stipes tufted, 15-25 c.M. long, erect, naked, the base often dark-coloured and slightly scaly. Fronds $25-55$ c.M. long, $5-7$ c.M. broad, linear-lanceolate, cut down in the upper part. nearly, in the lower nearly or quite to the costa into 50-40 pairs of crowded, linear lobes below the caudate apex. Lobes \pm close or slightly imbricate, rather spreading, subfalcate, 6-9 m.M. broad, the apex bluntly rounded, entire or slightly crenate, the edges parallel, entire, the lower lobes hardly shorter than the others. Texture firm; costules and veins prominent, the latter simple or forked: surfaces naked. Sori not reaching the apex of the lobes; often (but not always) extending to the top of the sinuses; indusium narrow.

Sumatra.

\section{S 1. EUPTERIS. b. IPInnatae.}

a. Fronds dimorphous. Lowest barren pinnae simple, lowest fertile ones often contracted, mostly forked or pinnatifid on the upper side only. (2) $\mathrm{Pt}$. rangiferina. a.a. Fronds uniform. Lowest pinnae simple or 2-3-furcate, the fertile ones sometimes contracted, not divided as in $\boldsymbol{\pi}$.

b. Pinnae cordate, truncate or rounded at the base.

$\leftarrow$ Veins close; lower pinnae \pm sessile.

*. Lowest pinnae \pm largest. Rachis reddish or purpureous, deciduously villose.

(5) Pt. orientalis.

Filices. 
45a. pteris. $\$ 1$. eUpteris. b. PinNatae.

*.*.Central or highest pinnae largest. Rachis yellowish-green, naked or slightly scaly.

(4a) Pt. longifolia.

*. Veins distant; lower pinnae stalled.

(4b) Pt. platysora.

b.J. Pinnae cuneate at the base.

c. Rachis pubescent.

c.c. Rachis naked.

(5) $\mathbf{P t}$ opaca.

a. Largest lateral pinnae of fully developed fronds more than $27^{1} / 2$ c.M. long.

×. Fronds middle-sized. Lowest pinnae 2-3-furcate.

(6) Pt. Treubii.

X.X. Fronds large. Lowest pinnae simple. (7) Pt. moluccana. d.d. Largest lateral pinnae under $27^{1} / 2$ c.M. long.

e. Barren fronds with 3-5 pinnae clustered at the apex of the stipe.

(8) Pt. stenophylla.

e.e. Barren fronds with the pinnae not clustered at the apex of the stipe.

f. Barren pinnae entire or nearly so, at best serrate or toothed towards the apex.

g. Lowest pinnae simple or 2-furcate.

g.g. Lowest pinnae 3-lobate or 3-furcate.

(9) Pty pellucida. SI pru

(10) $\mathrm{Pt}$, papuana.

f.f: Barren pinnae more coprously serrate throughout.

+. Stipes stramineous or pale-brown.

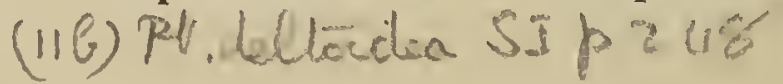

(11) Pt. cretica

+. Stipes black.

(12) Pt. melanocaulon.

* (2) Pt. rangiferina, Pr., Ann. Mus. Bot. L. B., IV, 95; Pt. Dalhousiae, Rac. (not Hk.), Flor. Btz., I, 153; Pt. laevigata, Zipp., MS. in Herb. Bog.

Rhizome erect, thick, densely clothed with brownish, tomentose hairs. Stipes 50-150 c.M. long, erect, naked, the outer side convex, the inner 5sulcate, the base reddish-brown, the rest stramineous. Fronds dimorphous. Barren fronds lanceolate-oblong, 45-250 c.M. long, pinnate with $\pm 8-12$ pairs of stalked, erecto-patent pinnae below the terminal one. Terminal and lateral pinnae similar, lanceolate, $15-50$ c.M. long, $2-4$ c.M. broad, the 
point acuminate, the sides \pm parallel, the base broadly cuneate, often slightly unequal-sided, the edge entire, bordered by a continuous, narrow, \pm pellucid line, the stalks $1-40$ m.M. long. Texture coriaceo-chartaceous when dry; rachis and both surfaces naked; upper surface glossy, lower pale, opaque; veins numerous, simple or forked, the tips dilated and often confluent. Fertile fronds with the pimnae linear, acuminate, $\breve{\partial}-8$ m.II. broad when simple, the base cuneate; higher pinnae simple, the lower with a long, terminal segment and 1-5 distant, linear lobes near the base on the upper side, the lower side undivided or rarely lobed like the upper. Indusium membranaceous. - Besides both barren and fertile fronds there are semi-fertile ones, which have the pinnae broad or narrow, simple or forked at the base with stalked segments, the sori often interrupted into many shorter, oblong ones. - Pt. Dalhousiae, Hk. is quite another plant.

Java.

* (5) Pt. orientalis, v. A. v. IR.

Stipe and rachis reddish or purpureous, deciduously villose, at length naked. Fronds $\pm 40-5$ b c.M. long, \pm 50 c.M. broad in the broadest part. Pinnae in $\pm 20-30$ pairs below the terminal one, simple, linear, erectopatent, sessile, close or imbricate, the lowest largest, or a little smaller than the next higher ones, 15-2. c.M. long, 1-2 c.M. broad near the base, narrowed gradually towards the apex, the point somewhat bluntish, the margin entire or serrate in the barren pinnae, often crispate, the base rounded, the highest pinnae the smallest, membranaceous, pellucid; costae prominent and rounded beneath; veins fine, numerous, close, not very oblique, not rarely nearly horizontal, deciduously and sparingly pilose on both sides, at length naked. Sori long; indusium narrow. - The description is taken from specimens determined as Blechnum orientale, $L$. probably by the resemblance with that species.

Banda Islands (Treub).

* (4a) Pt. Iongifolia, $\mathbb{L}$. , Rac., Flor. Btz., I, 151; Bedd., Ferns S.I., tab. XXXIII; - var. diversifolia, Rac., I. c.; Pt. diversifolia, Sw., Syn., $96,288$.

Rhizome short, the scales yellowish, linear-lanceolate. Stipes clustered, 10-50 c.I. long, erect, pale-green, more or less clothed towards the base with pale scales. Fronds 10-100 c.M. long, 5-20 c.M. broad, simply pinnate, oblong or lanceolate. Pinnae sessile, linear, the central ones the longest, 
acuminate, entire $01^{\circ}$ serrulate when barren, $\pm 5-12$ m.M. broad, truncate or cordate, sometimes slightly auricled at the base; lower pinnae gradually dwarfed. Texture subcoriaceous; rachis naked or slightly scaly; surfaces naked; veins close, mostly once forked. Indusium narrow, membranaceous.

Var. Iiver'sifollax: Fronds narrowed gradually towards the base; the lowest pinnae reduced, roundish or oblong, the highest the longest. United to the type by intermediate forms.

Tropical and subtropical, everywhere.

(4b) Pt. platysorn, Bic., Journ. of Bot., XVIII, 211.

Stipes 60-90 c.M. long, naked, stramineous upwards, castaneous towards the base. Fronds $45-60$ c.M. long, \pm 15 c.M broad, oblong-lanceolate, simply pinnate. Pinnae \pm 25 , simple, linear, erecto-patent, the lower distinctly stalked, $12-15$ c.M. long, 6-9 m.M. broad, entire, $\breve{b}-8$ c.M. apart, the upper sessile, the terminal one like the others. Texture moderately firm; surfaces naked; veins distant, simple or forked. Sori continuous, not reaching the apex of the pinnae; indusium broad and distinct, but hidden when the fruit is fully developed. - Near Pt. longifolia, $L$.

Sumatra.

(5) Fit. olpaca, \. Sm., Hk. Bk., Syn. Fil., 154; Hk., Spec. Fil., II, tab. CXIV, A.

Stipes strong, erect, pale-coloured, finely pubescent like the rachis. Fronds 60-200 c.M. long, oblong. Pinnae in numerous \pm opposite pairs, linear, cuneate at the base, the edge quite entire towards the point, the largest \pm 50 c.M. long, $\pm 1-1 \frac{1}{2}$ c.M. broad. Texture coriaceous; surfaces naked except on the midribs beneath; veins sunk in the frond and only visible as faint striations. Indusium narrow, brownish.

Celebes, Batjan, Philippines.

\section{* (6) F1. The}

Stipes \pm 20 c.M. long, brownish and naked like the rachis. Fronds 30-4y c.M. long, pinnate. Terminal pinna linear, $20-50$ c.M. long, \pm 5 m.M. broad, the base gradually narrowed, the edge entire, the apex acuminate, spinuloso-denticulate. Lateral pinnae $3-4$ on each side, erecto-patent, similar to the terminal one, the highest ones simple or forked at the base, the lowest the longest, to 40 c.M. long, \pm 5 m.M. broad, stalked, 2-5-partite, the stalks $\pm 1 \frac{1}{2}-2$ c.M. long; segments of the divided pinnae as long, 
4与a. Pteris. $\mathbb{S} 1$. eupteris. b. Pinnatae.

sometimes forked again. Texture moderately firm, but thin; surfaces naked; veins obscure, spreading, simple or forked. Sori very long, not reaching the serrate apex of the pinnae; indusium narrow. - Barren fronds not seen.

Ceram (Treub).

(7) Pt. nofuccana, Hit., Hk. Bk., Syn. Fil., 154; Hk., Spec. Fil., II, tab. CXII, B; Pt. indica, Christ (not Lam.), Farnkr. d. Erde, 16 .

Stipes strong, erect, naked, polished, dark-brown. Fronds 60-100 c.M. long, oblong. Pinnae in numerous, nearly opposite pairs, cuneate at the base, spinuloso-serrate towards the apex, the largest $30-45$ c.M. long, $1-3$ c.M. hroad. Texture subcoriaceous; rachis naked; both surfaces shining; veins conspicuous, very close, $\pm 20-25$ to a c.M., usually simple. Indusium narrow, membranaceous.

Malaya; West. Polynesia.

*'(8) Pr. stemophylla, Waul., Hk. \& Grev., Ic. Fil., tab. GXXX; Pt. cretica, L., var. stenophylla, Hk. Bk., Syn. Fil., 134; Pt. pellucida, Pr., var. stenophylla, Bedd., Handb. Ind. Ferns, 107.

Near Pt. pellucida, Pr., but the fronds with $3-5$ pinnae clustered at the apex of the stipe, the central pinna sometimes with a pair of basal segments. Fertile fronds often on the longest stipes, with the pinnae longer and narrower than in the barren ones.

Malacca, Philippines; North. India.

* (9) Pet. pellacida, Po., Rac., Flor. Btz., I, 152; Bedd., Ferns S.I., tab. XXXVIII ; Pt. venusla, Kze, Bot. Zeit., 1848, 195 ; Pt. venulosa, Bl., Enum., 209.

Rhizome erect or short-creeping, the scales linear-lanceolate, blackish. Stipes 20-50 c.M. long, erect, naked, glossy, stramineous or brownish. Fronds $15-60$ c.M. long, ovate-lanceolate or deltoid-ovate, pinnate. Pinnae in 3-6 opposite or alternate pairs below the sometimes very long terminal one, erecto-patent, $10-20$ c.M. long, $1 \frac{1}{2}-21 / 2$ c.M. broad, linear-lanceolate, the base cuneate, the edge entire or repand to undulate, the apex acuminate, entire, serrate or toothed, the point \pm bluntish; higher pinnae \pm decurrent, free or joining with the terminal one, the lowest \pm stalked, simple or forked at the base, the fertile ones whether or not contracted, not rarely $1 / 2 X$ as broad as the barren ones. Texture papyraceous to coriaceous, pellucid; veins 
visible, fine, simple or forked, close, $\pm 10-15$ to a c.M. Sori not reaching the apex. - The young plants have the fronds ternate or quinate.

Malaya; North. India.

(10). P4. Dapuana, Ces., Fel. Becc. Polin., $5 \& 7$.

Near Pt. pellucida, $\mathrm{Pr}$., but much finer. Pinnae more approximate, about $1 / 3$ narrower and $1 / 2$ shorter, entire, the highest ones simple, the following slightly 2-lobed, the lower 3-furcate or 5-lobed, petiolate. Sori long, reaching the apex of the pinnae except on the upper side.

New Guinea.

*(11) Tt. cretion, I., Hk. Bk., Syn. Fil., 154; Bedd. Ferns S.I., tab. XXXIX.

Stipes $15-50$ or even to 60 c.M. long, erect, wiry, naked, stramineous or pale-brown, polished. Fronds $15-40$ c.M. long, $15-25$ c.M. broad, ovate, sometimes subflabellate. Pinnae usually in $2-6$ pairs below the terminal one, the upper ones sometimes more or less decurrent, sessile, ascending, the longest linear-lanceolate, $7-20$ c.M. long, 1/4-2 c.M. broad, the sterile ones not seldom considerably the broadest, acuminate, narrowed towards the base, spinuloso-serrate at the edge, the lower ones stalked, often cleft down nearly or quite to the base into $2-5$ linear segments. Texture coriaceous, but not thick; rachis and surfaces naked; veins fine, close, parallel, simple or forked. Indusium narrow, pale, membranaceous. - Exceedingly variable.

Tropical and extra-tropical all round the world.

* (12) Pt. melandeanion, ree, Copel., Polypod. Philipp., 100; Pt. cretica, L., var. melanocaulon, Hk. Bk., Syn. Fil., 154; C. Chr., Ind. Fil.; Pl. Treacheriana, Bk., Journ. of Bot., XVII, 65.

Rhizome erect, short. Stipes tufted, slender, naked, blackish, polished, fragile, $\pm 10-50$ c.M. long. Fronds ovate-lanceolate, simply pinnate, $\mathbf{1 5 - 5 6}$ c.M. long. Pinnae stalked, linear, arcuate, suberect, 5-2.) c.M. long, 3-5 m.M. broad, narrowed towards the base, serrate or toothed in the barren fronds, crenate and sterile towards the apex in the fertile fronds, the higher ones \pm decurrent, the lowest often with $2-5$ fork branches at the base. Texture rather firm; rachis and surfaces naked, ( \pm glaucous ?); veins generally once forked, sometimes scarcely visible. Indusium mostly broad.

Philippine and Sulu Islands. 
45a. PTERIS.

\section{$\$$ 1. EUPTERIS. c. Compositae. * Hipinnatifidae.}

a. Pinnae with a long, undivided lerminal segment and moslly few, rarely pectinale lateral ones near the base.

b. Fronds dimorphous.

(13) Pt. ensiformis.

b.ъ. Fronds uniform or nearly so.

c. Mains rachis winged by the decurrent bases of the pinnae.

(14) Pt. serrulata.

c.c. Main rachis at best winged towards the apex.

a. Pinnae divided on the lower side only.

*. Lowest pinnae with 2 large segments on the lower side.

(15) Pt. sumatrana.

*.*. Lowest pinnae with more than 2 , not very large segments on the lower side.

(16) semipinnata.

d.d. At least the lower pinnae divided on both sides.

e. Pinnae generally with 1-6 segments on each side below the long terminal one.

f. Lower pinnae with the lateral segments short, close or approximate.

y. Secondary barren segments serrate troughoul.

h. Segments, somewhal distant, decurrent.

(17) Pt. dispar.

h.h. Segments close, not decurrent.

(18) Pt. distans.

y.y. Secondary barren segments entire or al best spinulose serrate al or towards the apex.

(19) Pt. heteromorpha.

f.1. Lower pinnae with the segments long, distant.

(20) Pt. Dalhousiae.

e.e. Pinnae with numerous lateral segments on each side below an often very long terminal one.

(218) Rt low an often very

(21) $\mathrm{Pt}_{\mathrm{t}}$ Beccariana.

a.d. Pinnae pectinalo-pinnatisect throughoul, with a rather short, rarely subcaudale point and \pm inany laleral segments on each side.

1. Lateral pinnae few, 1-2 on each side below the terminal one.

*. Veins indislinct.

(22a) Pt. Grevilleana.

*.*. Veins distincl. (229) ho 1

(22b) Pt. pluricaudata.

1.1. Laleral pinnae more numerous, at least 3 on each side.

2. Fronds moslly under 125 c.M. long. 
45. PTERIS. $\mathbb{S} 1$. EUPTERIS. $c^{*}$ BIPINNATIFIDAE.

3. Pinnae not pinnatifid quite to the base, the lowest segments distinctly decurrent.

×. Veins 2-furcate

$\times \cdot \times$. Veins 4-furcate.

(23) Pt.longipinnula. (24) Pt. torricelliana.

3.3. Pinnae pinnatisect quite to the base, the lowest segments not or hardly decurrent.

4. At best the lowest pinnae forked at the base.

5. Stipes and rachises green, stramineaus or pale-brown.

6. Ultimate segments entire or slightly serrate, herbaceous, papyraceous or coriaceous.

*. Upper surface not bluish.

8. Ultimate segments joined at the base.

(25a) Pt. quadriaurita.

8.8. Ultimate segments generally free at the base.

(25b) Pt. parviloba.

\%.\%. Upper surface bluish.

(25c) Pt. caesia.

6.6. Ultimate segments appresso-serrate, membranaceous.

(26) Pt. amoena.

5.5. Stipes and rachises black or dark-brown.

*. Ironds rather small; ultimate segments erecto-patent, not conspicuously dilated at the base.

(27) Pt. furcans.

+*. Fronds rather large; ullimate segments horizontally spreading, conspicuously dilated at the base.

(28) Pt. decussata.

1.4. Several lower pinnae forked at the base. (29) Pt. Walkeri. 2.2. Fully developed fronds more than 125 c.M. long. (30) Pt. excelsa.

* (13) P1. ensiformis, Ram, Rac., Flor. Btz., I, 154; Pt.crenata, Sw., Hk., Spec. Fil., II, tab. CXXVII, A; Bedd., Ferns S.I., tab. XXXV; var. Victoriae, Bk., Gard. Gron., III ${ }^{7}, 576$; Pt. Victoriae, hort.; - var. permixta, Christ, Philipp. Journ., II, 175.

Rhizome creeping, sparingly clothed with deltoid-lanceolate, slightly adpressed scales. Stipes slender, naked, erect, stramineous. Fronds $10-50$ c.M. long, the barren ones the shortest, $\pm 5-15$ c.M. broad, with a long terminal pinna and $2-7$ pairs of lateral ones. Pinnae of the barren fronds slightly compound, the 
45a. Pteris. $\mathbb{S} 1$. eupteris. $c^{*}$. Bipinnatifidae.

lower ones cut down to the rachis below into $1-3$ pairs of oblong, sharply toothed pinnulae, which are often $1 \frac{1}{2}$ c.M. broad, the higher ones simple, decurrent, often joined. Texture herbaceous to subcoriaceous; rachis and surfaces naked; veins not very conspicuous, often $1-2 \times$ forked. Pinnae of fertile fronds long, linear, narrow, entire or toothed at the apex, erect, simple, forked or pinnate at the base with linear segments. - Exceedingly variable.

Var. Victariae: Fronds with broad, whitish bands running down the costae.

Var. permixta : Apex of fertile fronds elongated into a linear, caudiform appendage much exceeding the plant, furnished with irregular, short, obtuse lobes.

Malaya; Trop. Australia, Polynesia, China, North. India.

* (14) Pt. serrulata, L. f., Hk. Bk., Syn. Fil., 155; Pt. multifida, Poir., C. Chr., Ind. Fil.

Stipes 15-25 c.M. long, erect, wiry, naked, pale or brownish. Fronds 20-45 c.M. long, $15-25$ c.M. broad, ovate, pinnate, the main rachis winged by the decurrent and confluent bases of the pinnae, the wing growing gradually narrower downwards, sometimes wanting between the 2 lowest pinnae, $3^{1} / 2-5$ m.I. broad at the top of the rachis. Pinnae 4 or more on each side, opposite, the upper ones simple, often $10-15$ c.M. long, $3-7$ m.M. broad, acute or acuminate, with the edges \pm parallel, serrate in the barren region, the lower ones with several (rarely 1 or few), long, linear, erecto-patent pinnulae on each side. Texture scarcely coriaceous; rachis and both surfaces naked; veins distinct, simple or forked. Indusium slightly intramarginal, narrow, membranaceous.

In'cultivation. - Orig. loc.: China, Japan.

(15) Pt. Sumatrana, BTi., Journ. of Bot., XIX, 367.

Stipes naked, castaneous like the rachis, \pm 15 c.M. long. Fronds doltoid, 20-25 c.M. long, pinnate. Pinnae $\pm: 3-6$-jugate below the simple terminal one; upper lateral pinnae decurrent to the next lower pair, simple, linear, 7-10 c.M long, 8-12 m.M. broad, the lowest ones with 2 large segments on the lower side, the apices strongly inciso-crenate. Texture sulcoriaceous; surfaces naked; veins obscure, immersed, line, simple or forked. - Near Pt. serrulata, $L . f$.

Sumalra. 
"(16) IPt. semipinnata, I., Rac., Flor. Btz., I, 153; Hk., Gard. Ferns, tab. LIX; Bedd., Ferns S.I., tab. XXXIV; Pl. dimidiala, Willd., Spec., V, 581 ; - var. inaequalis; Pl. inaequalis, Bk., Journ. of Bot., XIII, 199.

Rhizome creeping, clothed with blackish-brown, linear-lanceolate, finely acuminate scales. Stipes 20-50 c.M. long, strong, erect, naked, stramineous, reddish or bright-brown. Fronds 15 - 45 c.M. long, 10-25 c.M. broad, ovatelanceolate, the upper part cut down nearly or quite to the rachis into close, entire, linear or oblong, \pm falcate or straight segments, the lower $2 / 3$ part with 4-8 pairs of opposite, distant pinnae with a \pm long entire point and a broad, undivided, leafy membrane on the upper side, but the lower side with several linear or oblong lobes or pinnulae $2-5$ c.M. long, with the hase \pm decurrent; barren segments finely serrate. Texture subcoriaceous; rachis and surfaces naked; veins simple or forked. Indusium membranaceous.

Van. Inncequalis: Two times as large as the type.

Trop. Asia, China, Japan; - var. inaequalis: Celebes; Hongkong.

(17) Pt. Iispar, Kae, Copel., Polypod. Philipp., 101; Pt. semipinnala, L., var., C. Chr., Ind. Fil.

Like Pt. semipinnata, L., but the pinnae more or less pinnate on the upper side also.

Philippines; China, Japan.

(18) Pt. distans, J. Sm., Hk. Bk., Syn. Fil., 156 ; Hk., Spec. Fil., II, tab. CXXIV, B.

Stipes about 15 c.M. long, slender, erect, naked, pale. Fronds about 50 c.M. long, 10-15 c.M. broad, terminated by a pinna with a long, narrow, sharply serrate, linear apex, below which are $12-20$ pairs of closely placed short lobes to $1 \frac{1}{2} \quad$ c.M. long and $1 / 3$ c.M. broad, the lower $2 / 3$ part of the fronds with $6-9$ pairs of opposite, distantly placed pinnae with a long, linear apex, and at the base a few, short, oblong, close, spreading pinnulae. Texture coriaceous; rachis scabrous; veins conspicuous, simple or forked; barren lobes sharply and finely spinuloso-serrate. Indusium membranaceous. Philippines.

* (19) Pt. Ineteromoroha, Fée, Hk. Bk., Syn. Fil., 156; Hk., Spec. Fil., II, tab. CXXVII, B; Bedd, Ferns Br.I., I, tab. LXXXIX; Pt. cretica, L., var. heleromorpha, Bedd., Handb. Ind. Ferns, 106. 
Stipes $15-45$ c.M. long, naked, erect, pale-coloured. Fronds 30 -6ə⿱ с.M. long, $15-25$ c.M. broad, ovate-lanceolate; pinnate. Terminal pinna with the lower half sinuate and furnished with a few short, linear lobes. Lateral pinnae usually in 4-6 opposite pairs, erecto-patent, the higher ones linearlanceolate, $7 \frac{1}{2}-1$ b c.M. long, \pm 1 c.M. broad, simple or here and there with 1-2 lobes or ears near the base, lower pinnae $5-10$ c.ll. apart, 10-30 c.M. long, cut down nearly to the costa with $\pm 4-6$ oblong or linear-oblong, \pm spreading lobes on each side near the base below the often very long terminal segment, the lateral lobes varying from very short to \pm $2^{1 / 2}$ c.M. long, $1 / 2-1$ c.M. broad, the margin entire or sinuato-subcrenate, the apex provided with $1-5$ minute spines. Texture subcoriaceous; rachis and both surfaces naked; the margin rather slightly crisped; veins conspicuous, usually once forked. Indusium narrow, membranaceous. - Very variable; the lowest pinnae sometimes with 1-12 lateral lobes on each side. The javan plant found by Mr. Buysman has the lobes of the terminal pinna in \pm 9 pairs, linear, to 4 c.M. long.

Java (Pasuruan), Celebes, Philippines; Burmah.

* (20) Pt. Dalhousiae, Hr., Hk. Bk., Syn. Fil, 157; Hk., Spec. Fil., II, 170, tab. CXXI, A.

Rhizome short. Stipes \pm clustered, strong, erect, reddish-brown and naked like the rachis, polished, $\pm 30-40$ c.M. long. Fronds oblong, 30-60 c.M. long, the apex deeply pinnatifid with \pm 5 erecto-patent, distant, linear, acuminate segments below the long terminal one, \pm slightly joined by their suddenly dilated, decurrent bases; below this \pm 4 upcurved, \pm stalked pinnae on each side. Higher pinnae with a long, undivided, acuminate terminal segment, and with the lower side provided with $1-4$ lateral segments similar to those of the apex of the frond, the upper side undivided, ( \pm as in Pt. semipinnata, $L$, but the segments distant), central and lower pinnae similar, but with 4 ones on the upper side near the base ( \pm as in Pt. dispar, Kze), lower pinnae $20-50$ c.M. long, with the lowest segment on the lower side simple, or divided like the upper pinnae. Ultimate segments linear, upcurved, acuminate, the longest $10-15$ c.M. long, $5-8 \mathrm{~m} . \mathrm{M}$. broad in both barren and fertile fronds, the edges finely crente in the barren region. Texture firm; rachis polished; surfaces naked; veins distinct, simple or forked, the apices not thickened.

Java, Sumalra, Penang. 
4马̆a. Pteris. $\mathbb{S} 1$. eupteris. $c^{*}$. BipinNatifidae.

* (21) Pt. Meceanoigma, C. Chr., Ind. Fil., Pl. concinna, Bl. (not Hew.), Becc., Mal., III, 57; Pl. longipinnula, Ces., Fel. Becc. Polin., 5.

Stipes tufted, black-brown, naked, 13-30 c.I. long. Fronds deltoid, 2-pinnate, 15-25 c.M. long, naked; rachis black-brown, naked. Pinnae opposite, paucijugate, lanceolate, often conspicuously caudate, the lowest largest, forked at the base. Segments linear, contiguous, multijugate, entire, arcuateascending, adnate. Sor'i not reaching the apices of the pinnulae; indusium naked, broad, persistent, firm. - Near Pt. Griffithiana, Hk., (Spec. Fil., II, tab. CXXIII, A). - - If this plant is the same as found at the same locality (Andai) by Teysmann, then the segments are very irregular, varying from 1-50 m.M. (mostly \pm 20 m.M.) long, joined at the hase, the edges broadly crenate, the sori lateral on the fully developed segments, but terminal on the reduced ones.

New Guinea.

* (22a) Pe Crevilleama, Wall., Trans. Linn. Soc., Bot., $2^{\text {nd }}$ Series, I, 466, tab. LIV; Pl. quadriaurita, Retz, var. digitala, Bk., Journ. of Bot., XVII, 40; - var. ormata, Hort. Bog.

Stipes tufted, to 16 c.M. long, firm, erect, naked. Fronds pinnate with 1-2 pinnae on each side below the terminal one, the lowest pair forked at the base on the lower side in the fully developed plants. Pinnae and fork branches of the lowest pinnae lanceolate, acuminate, pectinato-pinnatifid, to 15 c.M. long, to 8 c.M broad, the apex crenato-serrate. Lobes linear-oblong, falcate, often broader upwards, erecto-patent, to 4 c.M. long, to 1 c.M. broad, not rarely shorter and narrower in the fertile than in the barren fronds, crenate throughout $0 r^{\circ}$ towards the rounded or bluntish apex only. Texture coriaceous; surfaces naked; veins very obscure, intermixed with numerous, fine, spurious veins. Sori not reaching the apex of the lobes.

Var. ormata: Fronds provided with broad, whitish or pale-grey-green bands running down the centre of the pinnae.

Malacca, Borneo, Philippines; Siam, Norlh. India.

(22b) Pr. plunioradata, Copel., Philipp. Jouln., I, Suppl., 156; Pl. Blumeana, Ag., var. pluricaudala, Christ, Philipp. Journ., II, 175.

Rhizome very short, crowned with lanceolate-setaceous, cinnamon-coloured scales. Stipes close, 10 -23 c.M. long, slender, erect, naked, rubro-stramineous, sparingly scaly at the base. Fronds orbicular-ovate, $\pm 10-15$ c M. long, 5-5-foliate. Pinnae cut down nearly or quite to the costa, the lowest ones 


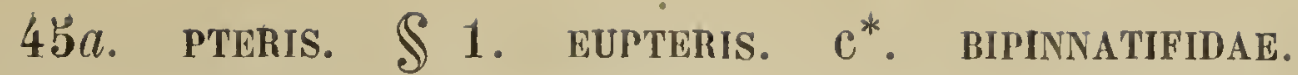

forked. Ultimate segments approximate, linear, $21 / 2-5$ m.M. broad, obtuse, serrulate, the terminal one narrowed, the fertile ones hardly contracted. Texture papyraceous; veins conspicuous, albo-setaceous above; the rest naked. Sori not reaching the apex of the segments. - Probably a local derivative of Pt. quadriaurita, Retz (Copel.).

Mindanao.

* (23) Pt. Iongipinnula, att., Hk. Bk., Syn. Fil., 158; Hk., Spec. Hil., II, tab. CXXXIV, A ; Bedd., Ferns S.I., tab. XLIII; Pt.quadriaurita, Retz, var. longipinnula, Rac., MS. in Herb. Bog., Pl. umbraculifera, Metl., Ann. Mus. Bot. L. B., IV, 97 ; - var'. sumatrana.

Stipes erect, naked, 60-90 c.M. long, yellowish-green, rarely brown. Fronds $30-90$ c.M. long, $50-45$ c.M. hroad, the terminal pinna to 30 c.M. long, $5-8$ c.M. broad, regularly pectinato-pinnatifid with numerous nearly spreading or falcate, entire, crenate or serrate, blunt, linear, close or \pm remote lobes on each side, which are to 5 c.M. long and reach down nearly to the costa, the terminal lobe \pm caudiform. Lateral pinnae several on each side, similar to the terminal one, the lowest \pm 5 c.M. apart, whether or not forked at the base. Texture subcoriaceous; rachis and both surfaces naked; costae not rarely spinulose above; veins once forked. Sori reaching nearly to the apex of the segments. - Hardly different from Pt. quadriaurita, Retz, but the stalks of the pinnae \pm shortly winged by the decurrent bases of the lowest lobes, the lowest anterior lobe generally shorter than the opposite posterior one.

Var. sumatrana: Pinnae irregularly pinnatifid, the lobes different in length, varying from $1 / 2-5$ c.H. deep, the edges crenato-serrate.

Malaya; Samoa, Japan, China, Burmah, North. India; - var. sumatrana: Sumatra (Hagen).

(24) Pt. Ton ricelliana, Cherist, Schum. \& Laut., Flor. deut. Sch. geb., Suppl., 45.

Like Pt. longipinnula, Wall., but the sterile pinnae ovate-oblong, narrowed at the base; pinnulae lanceolate-acuminate, very approximate, the veins 4 -furcate. New Guinea.

* (25a) Pr. Muadrianurita, Reta, Rac., Flor. Btz., I, 156; Hk., Spec. Fil.. II, tab. CXXXIV, B; Bedd., Ferns S.I., tab. XXXI; Pt. biaurita, L. Pl var., C. Chr., Ind. Fil.; - var. setigera, Copel., Polypod. Philipp., 102; Pl. 
asperula, J. Sm., Christ, Bull., Herb. Boiss., VI, 148; Pl. Blumeana, Ag., var. asperula, Christ, Philipp. Journ., II, 172; - var. Blumeana, Bedd., Handb. Ind. Ferns, 112; Pl. Blumeana, Ag., Rec., 22; - var. argentea, Bedd., 1. c., 111; ? Pl. argyraea, Moore; - var. normalis; Pl. normalis, Don, Bl., Enum., 211 ; - var. albido-maculata; Pl. normalis, Don, var. B., Bl., I. c., 211 ; var. nemoralis; Pl. nemoralis, Willd., Bl., 1. c., 210; Bau. \& Hk., Gen. Fil., tab. LXIV; - var. trachyphylla; Pt. trachyphylla, Kze, Bot. Zeit., 1848, 196 ; - var. Whitfordi; Pl. Whitfordi, Copel., Philipp. Journ., I, Suppl., 255.

Stipes $15-60$ c.M. long, erect, strong, naked, or scaly at the base, smooth, green, stramineous or broivn. Fronds 15-100 c.M. long, 10-30 c.M. broad or broader, with a terminal pinna and 5-11 lateral ones on each side. Pinnae erecto-patent, pinuatifid $1 / 3$-way down or more to the costa, 5-50 c.M. long, the lowest ones forked at the base on the lower side with 1-2 similar, but smaller, regularly pinnatifid segments. Lobes several to numerous, rather close, parallel, pectinate, linear or linear-oblong, rather erectopatent or falcate, entire or serrate, blunt or acute, $\pm 1-21 / 2$ c.M. long, \pm $21 / 2-71 / 2$ m.M. broad, the lowest not or hardly decurrent at the base. Texture herbaceous to subcoriaceous; rachis and surfaces naked, smooth, rachis and costae often canaliculate above and purveyed there with distant, spinelike bristles; veins conspicuous, simple or often forked, the lowest posterior ones springing from the base of the costulae (main veins). Sori often continuous along the whole margin of the lobes. - A very variable species.

War. Setigera: Costulae spinulose like the costae.

Va: Hilumeana: Very large; lobes 50-60 to a pinna, not falcate, nearly free at the base, equally wide throughout or broader at the apex, the apex rounded, barren, entire or crenulate.

Var. argentea: Fronds provided with broad, whitish bands running down the centre of the pinnae. Lobes not retuse at the apex.

War. normalis : Lobes subtruncate, retuse at the apex; lowest posterior veins often springing from the costae at some distance from the costulae.

Var. albido-maculata: Like var. normalis, but the fronds variegated like var. argentea.

Var. nemuralis: Lowest posterior veins springing from the costae as in var. normalis, sometimes uniting with the opposite anterior lowest veins and then forming here and there a single costal areola.

Var. trachyplaylla: Stipe, rachis and costae more or less scabrous.

Var. Whitfordin: Lobes conspicuously erecto-patent, nearly close. All warm countries, the varieties scatlered here and there. 
45a. Pteris. $\$ 1$. EUPTERIS. $c^{*}$. BIPINNATIFIdA.

(25b) Pt. Darviloloa, Cherist, Bull. Sci. Fr. \& Belg., XXVIII, 264, tab. XII.

Near Pt. quadriaurita, Retz, but small. Stipes slender, rufo-stramineous, scaberulous. Fronds broadly deltoid, the lowest pinnae produced, sharply deflexed. Ultimate segments close, linear-oblong, short, rather free. Texture rigidly papyraceous; colour pale-ochraceous-green; upper surface often rough with rigid setae; veins distinct beneath. Sori and indusia generally very slender. - This form is often found strongly reduced in and size resembling Pt. Grevilleana, Wall.

\section{Luzon, Palawan.}

(25c) Pt. Caesia, Copel., Philipp. Journ., I, Suppl., 156.

Rhizome short, erect. Stipes tufted, stramineous or brownish, slightly puberulous like the rachis, the base densely clothed with fuscous, filiform scales. Fronds $20-55$ c.M. long, $10-18$ c.M. broad. Pinnae \pm 1 c.M. broad, cut down nearly or quite to the costa, the terminal one the longest, the basal ones forked. Ultimate segments $\pm 1 \frac{1}{2}$ m.M. broad, entire, obtuse, subauriculate, \pm overlapping at the base, the sinuses closed. Texture papyraceous; upper surface bluish, spinulose on the costae and veins, under one pale-green. Sori narrow. - Near Pt. quadriaurita, Retz, distinct enough to constitute a species. Christ points out that this species is near Pt. furcans, Ble. (Copel.).

Mindanao.

(26) Pt. amoena, Bt., Enum., 210; Hk. Bk., Syn. Fil., 479.

Stipes naked. Fronds 2-pinnatifid. Pinnae opposite, short-stalked, lanceolate, narrowed at both ends, pinnatifid, the lowest ones 2-partite. Segments subfalcate-oblong, somewhat acute, the lower ones obtuse, the edges appressoserrate. Texture membranaceous; rachis and surfaces naked. - Baker considers this plant to be a form of Pt. semipinnata, $L$. See the information in Hk., Spec. Fil., II, 205.

Java.

*. (27) Pt. furcans, Bk., Journ. of Bot., XXVI, 324.

Stipes naked, slender, blackish-purple or castaneous, glossy, 12-30 c.M. long. Fronds $15-20$ c.M. long. Pinnae erecto-patent, lanceolate, simply pinnate, $2-21 / 2$ c.M. broad, lowest largest, \pm 15 c.M. long, forked at the base in the fully developed plants. Ultimate segments linear, entire, obtuse, adnate 10 the rachis, free or sometimes slightly joined, $\pm 2-5 \mathrm{~m} . \mathrm{M}$. broad. 
4ว̆a. pteris. $\mathbb{S} 1$. enpteris. $\mathrm{c}^{*}$. Bipinnatifidae.

Texture moderately firm; surfaces naked; rachises dark-coloured; veins copious. Sori nearly reaching the apex of the segments; indusium narrow, naked.

Borneo.

* (28) Pt. Cecussata, J. Sm., Journ. of Bot., III, 405; Pl. patens, Hk., Hk. Bk., Syn. Fil., 165; Hk., Spec. Fil., II, tab. CXXXVII ; Bedd., Ferns S.I., tab. CCV.

Stipes tufted, stout, scaly at the base, glossy, rather dark-brown. Fronds large, 90-120 c.M. long, 60 c.M. broad or broader. Terminal pinna 15-25 c.M. long, $3^{1} / 2-7^{1} / 2$ c.M. broad, with several, \pm horizontally spreading, linear lobes on each side reaching down nearly or quite to the costa, dilated suddenly on both sides at the base, the barren ones slightly serrate or crenate. Lateral pinnae numerous, similar to the terminal on but longer, sometimes 45 c.M. long, to 5 c.M. broad, the lowest forked. Texture thinly coriaceous ; rachis and both. surfaces naked; veins oblique, the lowest sometimes anastomosing (Christ, Farnkr. d. Erde, 168), commonly once forked. Sori continued nearly to the end of the segments. - I am sceptical to the anastomosing of the veins. A plant gathered in Borneo by Hallier and determined by Christ as Pt. pasens, Hk., (Ann. Btz., XX, 150) has the fronds smaller, the veins quite free and the costae purveyed with 2 interrupted, narrow wings on the upper side. (See Bedd., Handb. Ind. Ferns, 114, line 5 from bottom).

Malacca, Borneo, Celebes, Philippines; Ceylon, Samoa, Society-Islands

(29) P1. Walleri, Journ. of Bot., XXVI, 324.

Stipes naked, castaneous, $15-20$ c.M. long. Fronds rhomboidal, irregularly 5-pinnate, \pm 30 c.M. long. Pinnae usually caudate, terminal and higher ones simply pinnate, several lower forked at the base. Ulimate segments obtuse, at utmost \pm 2 c.M. long, \pm 2 m.M. broad. Texture moderately firm; surfaces naked; rachises castaneous; veins copiously pinnate in the ultimate segments; veinlets indistinct. Sori occupying nearly the whole margin of the segments; indusium narrow, naked.

Borneo.

* (30) Pt. excelsa, Gaval., Rac., Flor. Btz., I, 155; Hk., Spec. Fil., II, tab. CXXXVI; Bedd., Ferns Br.I., II, tab. CGXVIII.

Rhizome erect, short, densely clothed with narrow, lanceolate, brown scales. Stipes tufted, naked, erect, stout, reddish, greenish or pale-brown, to 
\pm 170 c.M. long. Fronds $150-200$ c.M. long. Terminal pinna 30 c.M. or more long, 7 c.ll. or more broad, with numerous closely placed, linear, \pm spreading, straight or falcate segments on each side, which are sometimes 5 c.M. long, 1 c.M. broad, dilated at the base and slightly serrate in the barren part. Lateral pinnae several, similar to the terminal one, the lowest distant, to 60 c.M. long and to 20 c.M. broad, whether or not forked at the base. Texture subcoriaceous; rachis channelled and sparingly bristly above: both surfaces naked; veins once forked. Sori not reaching the apex of the segments.

Malaya; Norlh. India, Fiji, Hawaii.

\section{$\$$ 1. EUPTERIS. c. Compositac. **. Partitae.}

*. Fronds 3-parlite.

*.*. Fronds 5-partile.

(31) Pt, longipes.

(32) $\mathrm{Pt}$. radicans. 
branches, \pm 5 c.M. long and 2 c.M. broad, cut down nearly or quite to the costa into ligulate, blunt, slightly crenate segments. Texture thinly herbaceous; both surfaces naked; veins inconspicuous, forked. Sori not reaching the base and the apex of the segments; indusium narrow. - Branches proliferous at the apex.

Celebes.

Species of an indefinite systematical place $\left(^{*}\right)$.

(55) T1. Iigulata, Geaud., Freyc., Voy. Ur. Phys., Bot., 585; Pt. quadriaurita, Retz, var. Lauterbachii, Christ, in Schum. \& Laut., Flor. deut. Sch.geb., 154, p. p.

Stipes tufted, black, glossy, \pm 50-45 c.M. long. Fronds 3-partite. Branches whether or not branched, deeply pinnatifid or pinnate, the apex long-acuminate, the base auricled. Lobes unequal, linear, entire, sinuate, toothed or lobed, the lower sometimes distinct, free, stalked, auricled. Sori irregular, lateral on the fully developed lobes or terminal on the reduced ones. - The scales (of the rhizome?) capillary, reddish, thin, diaphanous.

Borneo, Moluccas, New Guinea.

(34) mixta, Christ, Schum. \& Laut., Flor. deut. Sch.geb., Suppl., 4 ; ; Pt. quadriaurita, Relz, var. Lauterbachii, Christ, p. p.

Rachis blackish-castaneous. Fronds 2-pinnatifid, nearly 5-partite. Pinnae deeply pinnatifid, the apex caudato-elongate, subentire or irregularly incised; lobes pectinate, linear-acuminate. Sori thick, ochraceous; indusium nearly wanting. - Fertile fronds slightly suggesting Pt. ligulata, Gaud. but smaller.

New Guinea.

(35) Dhillippimensis, Fée, Mém., VIII, 114; X, 17, tab. XXXIII, fig. 2.

Fronds ovate-lanceolate, 2-pinnate at the base. Pinnae stalked, lanceolate, the apex caudiform. Segments oblong, toothed. Sori reaching neither the base nor the apex of the segments.

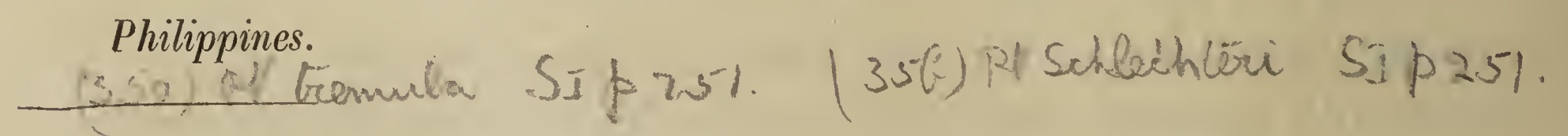

$\left({ }^{*}\right)$ Having not seen the 3 following species and being not able to judge their syste matical place from the descriptions alone, I placed them here. 
45a. PTERIS.

\section{$\$$ 2. CAMPTERIA.}

a. Fronds pinnately divided, not 3-partite; lowest pinnae not much longer than the next higher ones $\left(^{*}\right)$.

b. Fronds small or middle-sized, under 100 c.M. long. (36) Pt. biaurita. b.b. Fronds large, more than 100 c.M. long.

(57) Pt. geminata. a.a. Fronds 3-partite; branches similarly 2-pinnatifid, the lateral ones somelimes nearly as long as the central one, whether or not forked at the base on the lower side, and if so the secondary branches not rarely forked again.

*. Texture herbaceous; barren ultimate segments flat at the edge.

(58) Pt. Wallichiana.

*.*. Texture coriaceous; barren ultimate segments revolute at the edge.

(59) Pt. heterophlebia.

* (36) Dt. biammita, I., Rac., Flor Btz., I, 157; Pt. quadriaurita, Retz., var. biaurita, Christ, Ann. Btz., XV, 110; Campleria biaurila, Hk., Bedd., Ferns S.I., tab. XLIV; Bau. \& Hk., Gen. Fil., tab. LXV, A.

Rhizome erect, short, densely clothed with short, deltoid-lanceolate scales. Stipes 50-70 c.Mr. long, strong, erect, naked, or scaly at the base, the scales very fugacious. Fronds to 90 c.M. iong, with a terminal pinna 7 -30 c.M. long, 2-5 c.M. broad, cut down nearly to the costa into numerous spreading or erecto-patent, linear, straight or falcate, entire lobes on each side, which are to $\pm 1 / 2$ c.M. broad. Lateral pinnae few or several on each side, similar to the terminal one, the lower ones often forked at the base. Texture herbaceous to subcoriaceous; rachis and surfaces naked, under surface sometimes glaucous; veins usually forked. Sori commonly continued to the apex. Differs from Pt. quadriaurita, Relz only in the costulae being united at the base by an arching vein.

Pantropical.

(57) Pt. geminata, Wall., List, No. 2180; Pt. maxima, Bl., Hk. Bk., Syn. Fil., 480; Pt. Kleiniana, Christ (not Pr.), Copel., Polypod. Philipp., 105 ; Campteria Kleiniana, Pr., Bedd., Handb. Ind. Ferns, 116 ; Pr., Tent. Pterid., tab. V, fig. $19 ;$ C. anamallayensis, Bedd., Ferns S:I., tab. XIV.

(*) See also Pt. quadriaurita, Retz, var. nemoralis \& Pt. decussata, J. Sin. 
Large; 120-180 c.M. high. Fronds deltoid-ovate, pinnate. Pinnae subsessile, lanceolate, long-acuminate, deeply pinnatifid, the lowest to \pm 50 c.M. long, with $1-2$ pinnatifid branches on the lower side. Segments erecto-patent, falcate-oblong, sterile ones broadly crenate, 5-4 c.M. long, 7-10 m.M. broad, fertile ones crenate at their barren apices. Texture subcoriaceous: rachis and surfaces naked; veins anastomosing in costal arches. Sori never reaching the base or apex of the segments. - Scarcely more than a variety of Pt. biaurita, $L$.

? Java, Philippines; Japan, China, South. India.

* (38) D1. Wallichiona, Agardh., Rac., Flor. Btz., I, 157; Cam- 5.F pteria Wallichiana, Moore, Bedd., Ferns Br.I., I, tab. XXV; II, tab. CGXVII.

Rhizome erect, clothed with roundish, entire or dentate, soft scales. Stipes 50-180 c.M. long, strong, naked, glossy, green or brown. Fronds 5-partite. Central branch mostly $25-60$ c.M long, $15-50$ c.M. broad, with numerous linear-lanceolate, sessile, opposite pinnulae on each side below the terminal one. Pinnulae $7-15$ c.M. long, to 5 c.M. broad, cut down nearly to the costa into numerous flattened, contiguous, linear-oblong, rounded, finely toothed or crenate lobes. Lateral branches similar to the central one and nearly as long, forked near the base, the lower fork branch sometimes forked again. Texture herbaceous; rachises and both surfaces naked; veins not conspicuous, commonly once forked. Sori constinuous along nearly the whole length of the edge, or occupying the lower half of the lobes only.

Java, Celebes, Philippines; Samoa, North. Indıa.

* (59) Pt. Leteronhllebia, Kae, Bot. Zeit., 1848, 196 ; Campteria heterophlebia, Moore, Ind., XLIII.

Whole plant to $1 \frac{1}{4}$ M. high. Stipes yellowish. Fronds 5-partite; branches to 60 c.M. long, to 25 c.M. broad. Pinnulae approximate, deeply pinnatifid, 10-1弓 c.M. long, to 4 c.M. hroad, short-stalked, spreading, elongate-lanceolate. subacuminale. Lobes falcate, oblong, with a broad base, the apex bluntish, the edge crenato-serrulate, revolute. Texture coriaceous; surfaces naked; rachises, costae and costulae subterete, the upper side flat, reddish-yellowbrown, pubescent; main veins united at the base by arching veins, the other veins free, forked, some of them forming here and there a single costular areola in the lobes.

Java. 


\section{$\$$ 5. LITOBROCHIA.}

1. Lronds simply pinnate; pinnae entire.

(40a) Pt. Warburgii.

(40b) Pt. finisterrae.

1.1. Lronds pinnate; pinnae pinnatifid, the lowest ones not much longer than the next higher ones, whether or not forked at the base.

2. Indusium inconspicuous.

(41) Pt. microdictyon.

2.2. Indusium distinct.

3. Fronds to \pm 60 c.M. long; lowest pinnae nol forked at the base.

(42) Pt. Junghuhnii.

3.3. Fully developed fronds more than 60 c.M. long; lowest pinnac forlied at the base.

(4j) Pt. Milneana.

1.1.1. Fronds 3-partite; branches similarly 2-pinnatifid, the laterul ones sometimes nearly as long as the central one, whether or not forlied at the base on the lower side, and if so the secondary branches not rarely forked again (").

(44) Pt. tripartita.

(40a) Pt. UVarburaid, Christ, Warb., Mons., I, 70.

Stipes 45 c.ll. or more long, canaliculate in the higher part, naked, stramineous. Fronds large, ovate, probably \pm 100 c.M. long or longer, \pm 40 c.M. broad, simply pinnate. Pinnae distant, \pm 4 c.M. apart, ligulatelinear, as long, entire, long-acuminate, adnate at the base, the lower ones free, not reduced, the higher decurrent so as to form a broad wing to the rachis, the longest \pm 24 c.M. long, \pm 2 c.M. broad. Texture herbaceous or mentbranaceous; surfaces naked; costae prominent; no main veins; areolae numerous, hexagonal-oblong, in 5-4 rows; no free veinlets. Sori reaching nearly the apex. - Sterile fronds smaller, with the apex pinnatifid, the pinnae 10 $\pm 3 \%$ c.I. broad.

Moluccas, New Guinea.

(40b) Pt. Cinisterenc, Rst., Fed., Rep., V, 37.

Rhizome and stipes unknown. Fronds elongate-ovate, to $60 \mathrm{c.M}$. long or longer, to 50 \%.M. broad, pinnate at the lase, pinnatifid lowards the apex. Lowest pinnae $\ddot{b}-10$ c.M. apart, sometimes more approximate, short-stalked, forked at the base on the lower side, the $1-3$ following pinnae decurrent,

$\left.{ }^{*}\right)$ See also Pt. heterophlebia, Kze. 
with the upper base free and truncate or joined with the next higher pinnae, the higher pinnae joined at the base by a wing $3 / 4-1 / 2$ c.ll. broad. Lower and central pinnae to 25 c.M. long, to 5 c.l. broad, the fertile ones narrower than the barren, entire, linear, or slightly dilated towards the acuminate apex, the higher ones rather suddenly abbreviated, $\pm 1 / 3 \times$ shorter, the terminal one nearly as long as or longer than the highest ones. Texture membranaceous, pellucid; colour grey-green; surfaces naked; rachis and costae dark-purple beneath, yellowish above; costulae and veins distincl; areolae roundish- or elongate-subhexagonal. Sori continuous along the sides, interrupted at the base and apex of the segments; indusium dark-purple, rigidly membranaceous.

New Guinea.

(41) ? Pr. mierodictyon, Hik. (not Fée), Spec. Fil., II, 228; Lilobrochia mierodictyon, Fée, Gen., 158.

Stipes reddish. Fronds tall, ovate; rachis subtrigonous, channelled. Pinnae shorl-stalked, alternate, acuminate, pinnatifid. Segments lanceolate, falcate, slightly dilated at the base, obtuse, crenate. Indusium narrow, inconspicuous, receptaculiform; the margin thick and black.

Philippines.

* (42) Pt. Junghubnii, Blk., Hk. Bk., Syn. Fil., 170; P/ Iripartita, Sw., var. Junghuhnit, Hk., Spec. Fil., II, 226 ; Campleria Junghuhnii, Remw., MS.

Stipes firm, erect, polished, nearly stramineous. Fronds to 60 c.M. long, with several or numerous pinnae on each side, which are cut down $2 / 3-3 / 4$ of the way to the costa into linear-oblong, falcate, entire lobes $\pm 1 / 2$ c.l. broad at the base; lowest pinnae simple (i.e. not forked at the base), to 25 c.M. long. Texture herbaceous to subcoriaceous; rachis and both surfaces naked; veins fine, anastomosing principally in costal arches (as in Campteria) and in the space between the sinuses and the costae, sometimes also in the lobes. Sori reaching nearly to the apex of the lobes. - Habit of Pt. quadriaurita, Retz \& biaurita, $L$.

Java, Banca.

(45) Pr. Milneama, Bls., Hk. Bk., Syn. Fil., 170; I't.tripartita, Sw., var. Milneana, Hk., Spec. Fil., II, 226, tab. GXXXVIII, B.

Stipes strong, erect, polished, yellowish-brown. Fronds $60-90$ c.ll. long, with numerous pinnae on each side cut down throughout nearly to the costa 
into lineilr-oblong, falcate lobes $1-2$ c.M. long, $\pm b \mathrm{~m}$.M. broad, lowest pimnae 15-2: c.ll. long, $21 / 2-4$ c.M. broad, with a single, similar, but smaller pinnula at the base on the lower side. Texture herbaceous; rachis and surfaces naked; veins anastomosing copiously. Sori not reaching the subentire apices. The form found in Batjan has the veins only slightly anastomosing.

Batjan; Polynesia, Trop. Australia.

* (44) Pt. troipartia, Su., Hk., Spec. Fil., II, 225 (excl. $\beta$ \& 7); P\%. marginala, Bory, Rac., Flor. Btz., I, 158 ; Litobrochina marginala, Pr., Bedd., Ilandb. Ind. Ferns, 122; L. Iripurlita, Pr., Bedd., Ferns S.I., tab. CCXXX.

Stipes 30-150 c.II. long, strong, erect, naked, polished, stramineous or brownish. Fronds deltoid, $\pm 50-150$ c.M. each way. Central branch with a terminal pinnula 7-25 c.Il. long, 8-25 m.M. broad, cut down nearly to the costa into numerous closely placed, linear, straight or falcale, spreading or erecto-patent lohes on each side, which are entire or slightly toothed when barren; below this many closely placed, similar lateral pinnulae on each side. Lateral branches similar to the central one, but a little smaller, unbranched or branched again at the base on the lower side. Texture commonly herbaceous; rachises and surfaces naked; veins fine, anastomosing principally in arches against the midribs and costulae. Sori falling rather short of the apex of the segments.

Paleotropical.

Species of an indefinite syslemalical place.

(45) Tr. mertensidides, Willd., Spec., V, 394.

Fronds 60 c.I. or more long, 2-pinnate. Lowest pinnae $15-171 / 2$ c.M. long, highest 71/.2 c.M. long. Pinnulae linear-lanceolate, sessile, subacute, entire, subconfluent, $1-1 \frac{1}{2}$ c.II. long. Texture thinly membranaceous. Sori narrow. - Pinnae resembling the leafy branches of Mertensia.

Java, Borneo, Amboyna.

\section{5\%. HEMIPTERTHS, Rosenstocli.}

Like Pteris, hut the sori occupying only the posterior edge of the ultimate segments, the anterior side destitute of sori. Fed., Rep., V, 38.

Papuan. 
4. Wer'nenoin, IRst., Fed., Rep., V, 38.

Rhizome and stipes unknown. Fronds (ex sched.) pedate, with the primary segments (of the primary branches?) elongate-ovate, 50 c.M. long or longer, \pm 50 c.M. broad, pinnate like the terminal segments. Secondary segments multijugate, alternate, subcontiguous, linear-lanceolate, erecto-patent, deeply pinnatifid, narrowed lowards the serrate apex, the point entire, the largest ones \pm 25 c.M. long, $\pm \mathbf{3}$ c.M. broad, the higher ones suberect and smaller than the lower ones. Lobe; multijugate, erecto-patent, not very distant, joined at the base by a wing \pm 1 m.M. broad, linear, $1 \%$ c.M. long, $1 / 2$ c.M. broad, the apex obtuse, the margin serratodentate, the teeth slightly crenate. Texture membranaceo-herbaceous; surfaces naked; costae and costulae sparingly clothed with minute, linear or irregularly dilacerate scales, flattened above and provided there with whitish-membranaceous, subinterrupted, unequal wings (the internodes narrow at the base and broad at the apex); veins anastomosing, forming principally costal and custular areolae, the branches free or slightly anastomosing. Sori 4-5 on each side of the lobes, occupying the posterior side of the ultimate lacinulae (i. e. the teeth) from the base to the apex; indusium grey-brown.

New Guinea.

\section{PATSLA, St. Hitaire.}

Sori linear, submarginal, uniting the apices of several veins. Indusium linear, consisting of the reflexed, modified margin of the frond, often 2 -valved, the inner valve attached at the inner side of the sorus. Spores bilateral.

Rhizome creeping. Stipes distant, not articulate to the rhizome, purveyed with a single, \pm semicylindrical vascular strand. Fronds compound; veins free. Diels, in Engl. \& Prantl, Nat. Pfl.Fam., I"4, fig. 156, B-E.

America, Polynesia, Malaya.

* (1) rodula, C. Chx., Ind. Fil.; Pleris Radula, Bk., Journ. of Bot., XVIII, 211.

Rhizome wide-creeping. Stipes distant, brown, naked, 15-50 c.M. long, rough with minute, raised points like the flexuose rachis. Fronds lanceolate, 5-pinnatifid or 5-pinmale, $20-40$ c.M. long, 7-10 c.M. broad. Lower pinnac erecto-patent, often cut away on the lower side at the base, lanceolate-deltoid. 
Pinnulae unequal-sided, \pm deltoid, \pm 2 c.M. long, \pm 1 c.M. broad, cut down nearly to the costa into small, oblong-cuneate, entire or bluntly toothed segments. Upper pinnae rather lanceolate, with nearly simple secondary divisions. Texture firm; surfaces naked; veins free, immersed, obscure. Sori reaching from the base nearly to the apex of the segments; indusium narrow.

Sumatra.

(2) P. rugulosa, Kuten, Copel., Polypod. Philipp., 105; Pteris rugulosa, Lab., Hk. Bk.. Syll. Fil., 480; ? Pt. divaricalissima, Bk., Hk. Bk., I. c., $16 \tilde{3}$.

Rhizome wide-creeping. Stipes and rachises slender, glutinoso-pubescent, canstaneous. Fronds ample, 4-pinnatifid, rhomboidal. Pinnae close, lanceolate, short-stalked, erecto-patent, to 30 c.ll. or more long. Pinnulae lanceolate, close, patent, nearly sessile, 1-2 c.M. broad. Segments lanceolate, cuneatetruncate on lower side at base, lower deeply pinnatifid with oblique, blunt lobes. Texture cartilagineo-coriaceous; rachis zigzag; surfaces glutinose and minutely scaly, especially below; edges of fertile segments revolute, the sori reaching to te midribs.

Philippines; New Caledonia, Tahiti.

\section{PTERIDIUM, Gleditsch.}

Sori linear, on a submarginal strand uniting the vein tips. Indusium linear, consisting of the reflexed, modified margin, often 2-valved with the inner valve attached at the inner side of the sorus.

Rhizome creeping. Stipes distant, seriate, not articulate to the rhizome, purveyed with many $( \pm 12-24)$, irregularly placed vascular strands. Fronds at least 2-pinnate; veins free. Hk. Bk., Syn. Fil., tab. III, fig. 31, d-f (as Pteris, $\$$ Paesia); Diels, in Engl. \& Prantl, Nat. Pfl.Fam., I' ${ }^{4}$ fig. 156, A.

Cosmopolitan.

* Pt. aquilinum, Kuibre, Copel., Polypod. Philipp., 104; Pteris uquilina, L., Rac., Flor. Btz., I, 156; Bedd. Ferns S.I., tab. XLII; - var. lanuginosum, Hk., Spec. Hil., II, 196; Pteris lanuginosa, Spr., Nova Acta, X, 231, tab. XVI, fig. 1-2; - var. esculentum, Hk., l. c., 197; Pteris esculentu, Forst., Pl. escul., 74. 
Rhizome stout, wide-creeping, scaly. Stipes distant, 50-100 c.M. long, strong, erect, naked, stramineous or brownish. Fronds deltoid to broad-lanceolate, $60-200$ e.M. long or longer, 30-60 c.M. or more broad. Uppermost pinnae simple, the next pinnatifid, the following pinnite, the lowest largest, 2-3-pinnatifid. Ultimate segments linear-oblong, 1-21/2 c.M. long, 3-5 m.I. broad, numerous, close. Texture coriaceous; rachis and surfaces naked; veins close, conspicuous, often $1-2 \times$ forked.

War. Ianuginosum : Fronds pubescent or silky-tomentose beneath; pimulae more regulirly pinnatifid.

Var. esculentum: Rhizome fibrillose or hairy; ultimate segments more distant, connected by their suddenly dilated, decurrent bases.

Cosmopolitan, chiefly northern; - var. lanuginosum: chiefly tropical; var. esculentum: Borneo, New Guinea; Australia.

\section{LOMARAA, Willdenow.}

Sori linear, continuous, on a broad receptacle, parallel to the margin, at length filling up the whole space between the midrib and the margin. Indusium linear, consisting of the modified, reflexed margin of the frond ( $\left.{ }^{*}\right)$.

Rhizome or caudex erect. Stipes not articulate, purveyed with 2 stout and 1 to several finer vascular strands placed altogether in a circle, the stout ones abreast at the inner (upper) side. Fronds simple to 2-pinnatifid, dimorphous, the fertile ones with the pinnae narrowly linear; veins free, but united by the receptacle in the fertile segments. Hk. Bk., Syn. Fil., tab: III, fig. 33; Diels, in Engl. \& Prantl, Nat. Pfi.Fam., I ${ }^{4}$, fig. 151 (as Blechnum, $\$$ Lomaria).

Tropical and extra-tropical.

a. Barren fronds simple, pinnalifid or pinnate; lobes or pinnae suddenly dilated and decurrent at the base, adnate to the rachis.

(1) L. Patersoni.

a.u. Barren fronds pinnate; pinnae slightly dilated, but not decurrent at the base, adnate to the rachis.

(2) L. vulcanica.

a.a.a. Barren fronds pinnale; lower pinnae truncate or rounded at the base, not adnate to the rachis. 
b. Barren fronds small, 10-15 c.M. long.

*. Stipes tufled. Pinnae crenate, auricled at the base on boll sides.

(5) L. egenolfivides.

*.*. Stipes scallered. Pinnae finely serrale, not auricled at the base.

(4) I. areolaris.

b.b. Barren fronds larger, 30-200 c.M. long.

c. Stipes nalied, or scaly al the baise.

d. Pinnae 5-7\% c.M. long, 5-71/2 m.M. broad.

(b) L. punctulata.

d.d. Pinnae 7 $1 / 2-30$ c.M. long, $10-25$ m.M. broad. (6) L. capensis.

c.c. Slipes densely scaly.

(7) L. vestita.

a.a.a.a. Barren fronds 2-pinnalifid.

(8) L. Fraseri.

* 1) W. Patersomi, Spr., Hk. Bk., Syn. Fil., 174; Hk., Fil. Exot., tab. IL; L. elongala, Bl., var. Cumingiana, Hl., Spec. Fil., III, tab. CXLHI; Blechnum Palersoni, Mell., Christ, Farnkr. d. Erde, 176, p. p.; C. Chr., Ind. Fil.; Stegania Palersoni, R. Br., (oldest name); - var. elongata; L. elongala, Bl., Rac., Flor. Btz.; I, 160.; B. Palersoni, Mell., var. majus, Copel., Philipp. Journ., I, Suppl., 152.

Rhizome short-creeping or erect, clothed with ovate-lanceolate, brown scales. Stipes $\breve{-S}$ c.MI. long, erect, rather scaly below. Barren fronds simple, \pm 30 c.M. Iong, under $21 / 2$ c.M. broad, broadest $\pm 1 / 3$ of the distance from the top, narrowed gradually downwards, the point acuminate, the margin cartilagineous, wavy. Texture coriaceous: veins inconspicuous. Fertile fronds linear, \pm 5 m.M. broad, simple, or branched with 1 or more segments on 1 or both sides. Sori occupying the whole space between the midrib and the edge.

Var. elongata : Sterile and fertile fronds deeply pinnatifid, 60 c.M. or more long, the harren ones cut down into $\pm 6-10$ segments on each side, which are \pm 15 - 25 c.M. long, $\pm 21 / 2$ c.M. broad, suddenly dilated and decurrent, and free or confluent at the base; fertile pinnae often numerous, erecto-patent, as long as the barren ones, but narrowly linear, mostly connected at the base by a very narrow wing.

Malaya; South. India, Fiji, New Zealand, Australia, Tasmania.

* (2) L. vulcanica, Bt., Rac., Flor. Btz., I, 161; Hk., Icon. PI., X, tab. CMLXIX; Blechrum vulcanicum, Kuhn, Farnkr. d. Erde, 179; C. Chr., Ind. Fil. Rhizome short, erect, clothed with long, linear-lanceolate or subulate 
scales. Stipes 10-50 c.M. long, pale, erect, paleaceous below. Fronds $15-45$ c.M. long, 7-15 c.M. broad, the barren ones ovate-lanceolate, narrowed at the hase or not. Pinnae numerous, close, lancenlate, subfalcate, the point acute or hluntish, $5-10$ c.M. Iong, $1 / 2$-2 c.M broad, the base not decurrent, slightly dilated, lowest pinnae deflexed. Texture coriaceous; veins fine, prominent beneath; surfaces and edges often hairy. Fertile pinnae linear, very narrow, distant, suddenly dilated at the base, $51 / 2-10$ c.M. long.

Java, Celebes \& Luson 10 Polynesiri, Quecnsland, Tasmania, New-Zeeland.

(5) D. egenolioides, HBr., Kew Bull., 1894, 7; Blechnum egenolfioides, C. Chr., Ind. Fil.

Rhizome erect. Stipes densely tufted, $5 \% \frac{1}{2}-15$ c.M. long, the fertile fronds on the longest stipes. Wronds simply pinnate, the baren ones $12-15$ c.M. long, 5-4 c.M. broad at the middle, the stipes slender, brown. Pinnae linear, obtuse, crenate, the base auricled on both sides, lower pinnae deflexed, gradually reduced. Texlure subcoriaceous; surfaces naked; veins distant, erecto-patent, immersed, obscure, simple, the lower forked. Fertile fronds $2-21 / 2$ c.M. broad, with the pimnae narrower, more distant.

Borneo.

(4) L. areolanis, Harr., Journ. of Linn. Soc., Bol., XVI, 28; Blechnum areolare, Copel., Polypod. Philipp., 90; C. Chr., Ind Fil.;Stenochlaena arenlaris, Copel., Philipp. Journ., II, 406.

Rhizome long, slender, naked, lwisted. Stipes of barren fronds \pm 1 b c.M. long. Barren fronds ovate, 10-15 c.M. long, 7-10 c.M. broad, pinnale. Pinnae 7-9, subsessile, linear-lanceolate, 1-2 c.M. broad, acule, finely serrate, the base truncale or rounded. Texture coriaceous; veins forming a series of costal arches with free, simple or forked veins beyond; surfaces naked; costae and veins slightly chaffy below. Fertile fronds on stipes \pm 30 c.M. long, with the pinnae narrowly linear, $5 \frac{1}{2}-5$ c.M. long, rather distant. Indusium narrow.

Philippines.

(b) A. Dennctalata, Hae, Ilk. Bk., Syn. Fil., 179; Blechnum puncIulatum, Sw., Christ, Farnkr. d. Lrde, 178; C. Chr., Ind. Fil.

Rhizome stout, densely paleaceous at the crown. Stipes 7-15 c.M.long, strong, erect. Barren fronds oblong-lanceolate, 30-60 c.M. long, 10-15 c.M. broad. Pinnae very numerous, contiguous, linear, subfalcate, $5-71 / 2$ 
c.M. long, $1 / 2-2 / 3$ c.M. broad, rounded or cordate and auricled at the base, the lower ones deflexed and the lowest reduced to auricles. Texture coriaceous; veins inconspicuous; rachis stout, erect, naked, stramineous. Fertile fronds similar, but the pinnae narrowed, often not more than $21 / 2$ m.M. broad. Indusium not rarely \pm intramarginal.

Java; Soulh. Africa.

* (6) L. capensis, Willd., Spec., V, 291 ; L.procera, Spr., Hk. Bk., Syn. Fil., 179, p. p.; Hk., Icon. Pl., II, tab. CXXVII-GXXVIII; Gard. Ferns, tab. LIII; Blchnum capense, Schl., Christ, Farnkr. d. Erde, 178; C. Chr., Ind. Fil.: Osmunda capensis, L., (oldest name).

Rhizome stout, erect, woody, clothed with large, ovate or lanceolate, acuminate, ferrugineous scales. Stipes 1 -50 c.M. long, stout, erect, scaly below. Barren fronds 30-120 c.M. long, 15-60 c.M. broad. Pinnae numerous, linear, $7 \frac{1}{2}-30$ c.M. long, 1-21/2 c.M. broad, narrowed gradually from the base to the apex, the base unequally cordate, sometimes auricled, the margin serrate, the apex acuminate, lower pinnae sessile or slightly stalked, higher adnate to the rachis, the terminal one free, often very long. 'T'exture coriaceous; rachis stout, slightly scaly, the scales not large; costac \pm chaffy beneath; veins fine and parallel. Fertile fronds with the pinnae narrowly linear, distant, $10-15$ c.M. long, to $1 / 2-2 / 3$ c.M. broad. Indusium broad, membranaceous, occasionally ciliate, sometimes intramarginal.

Malaya; Polynesia, Trop. America, South. Africa.

* (7) E, vestita, Bbt., Rac., Flor. Btz., I, 161; L. procera, Spr., Hk. Bk., Syn. Fil., 179, p. p.; Blcchnum vesilum, Kuhn, Ann. Mus. Bot. L. B., $\left.\bar{F} F\right|_{-}$ IV, 284; C. Chr., Ind. Fil.

Rhizome erect, forming a short, thick caudex, densely clothed with broad, brown, acuminate scales. Stipes \pm 25 c.N. long, thick, densely clothed throughout with large, acuminate, brown or pale-brown scales. Fronds dimorphous. Barren fronds pinnate, 50-200 c.M. long. Pinnae numerous, linear, $12-24$ c.M. long, $1-1 \frac{1}{2}$ c.M. broad at the base, acuminate, the edge serrate, the base truncate or rounded. Texture coriaceous; rachis scaly like the stipe; costae \pm chaffy beneath; veins numerous, fine, parallel. Fertile lronds with the pinnae of the same lenght, erecto-patent, $4--5 \mathrm{~m} . M$. broad.

Malaya.

(8) D. Fraseni, Camn., Hk. Bk., Syn. Fil., 182; Icon. Pl., II, tab. 
CLXXXV; Blechnum Fraseri, Luerss., Christ, Farnkr. d. Erde, 180 ; G. Chr., Ind. Fil.; - var. philippinesis, Christ, Bull. Herb. Boiss., VI, 149, tab. II.

Caudex elongate, stout, suberect, densely clothed with linear, dark-brown scales at the crown. Stipes $10-15$ c.M. long, strong, erect, scaly. Fronds ovate-acuminate, 2-pinnatifid, $30-45$ c.M. long, 10-15 c.M. hroad. Pinnae linear-lanceolate, the lower ones $5-7$ c.M. long, 1--2 c.M. broad, cut down very nearly to the costa into linear-oblong, mucronate, slightly toothed segments, their bases decurrent into a pinnatifid wing to the main rachis, the lobes triangular. Texture herbaceous; veins fine, simple or forked. Fertile fronds similar in size and cutting.

Var. philippinensis: Caudex subarborescent, to $1 \frac{1}{2}$ M. high, the scales lanceolate-ovate to subulate. Stipes $\overline{0}-4$ c.M. long. Fronds $20-$ 25 c.M. broad, long-acuminate, narrowed at the base. Indusium narrow, evanishing.

New Zealand; - var. philippinensis: Philippines. 
TRIBE V. BLECHNEAE. 



\section{HLECHINUM, Linné.}

Sori long, linear, 1 on each side, \pm close to the costa, continuous or sometimes interrupted. Indusium of the same shape, attached at the outer side of the sorus, opening towards the costa.

Caudex mostly erect, sometimes subarborescent. Stipes tufted, not articulate to the caudex. Fronds simple or commonly divided; veins free, but those of the fertile fronds united near the base by a costal strand occupied by the sori. Hk. Bk., Syn. Fil., tab. IV, fig. 34; Diels, in Engl. \& Prantl, Nat. Pfl.Fam., I I , fig. 150.

Tropical and subtropical.

Arrangement of the sections.

$\$ 1$. EUBLECHNUM. Fronds erect.

S2. SALPICHLAENA. Fronds twining. (Not in Malaya).

\section{$\$ 1$. EUBLECHNUM.}

1. Fronds simple.

(1) B. Treubii.

1.1. Fronds pinnatifid.

*. Stipes naled.

(2) B. nitidum.

*.*. Stipes scaly and muricate in the lower part.

(3) B. cartilagineum.

1.1.1. Fronds pinnate.

2. Pinnae entire.

3. Pinnae narrowed at the base.

(4) B. Finlaysonianum.

3.3. Pinnae rounded, truncate or cordate al the base.

4. Pinnae auricled at the base.

1.4. Pinnae not auricled.

2.2. Pinnae serrate or finely incised.

(马) B. Blumei。

(6) B. orientale. Sip 255

*. Pinnae narrow at the base.

(7) B. serrulatum.

*.*. Pinnae broad at the base.

(8) B. egregium.

Finices. 


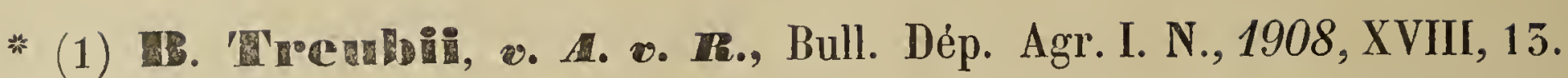

Small. Rhizome short, erect or nearly so, slightly scaly, copiously stoloniferous so as to form a dense mass of low plants. Stipes tufted, clothed with few, scattered scales, but more copiously towards the base, slender, erect, 2-5 c.M. long. Fronds simple, lanceolate, 4-9 c.M. long, 8-12 m.M. broad, narrowed gradually towards both ends, the apex acuminate, but the point bluntish, the margin entire or slightly irregular, the very base not rarely purveyed with 1-2 minute auricles. Texture subcoriaceous; surfaces naked; veins not very close, some of them sometimes anastomosing, mostly forked, sometimes simple or 5-furcate, the apex thickened, not reaching the margin. Sori long, continuous or interrupted, close to the costa, not reaching the base and apex of the fronds. - Very near the brazilian and panaman B. lanceola, Sw. (Hk. Bk., Syn. Fil., $185 ;$ Hk., Icon. Pl., X, tab. CMLXX, right-hand figure), but distinguished from Baker's description and Hooker's drawing by the tufted stipes, the smaller fronds, the mostly once forked and sometimes anastomosing veins. - It bears the name of Prof. Dr. M. Treub, Director of the Agricultural Department in Netherlands India.

Java (Mount Salak).

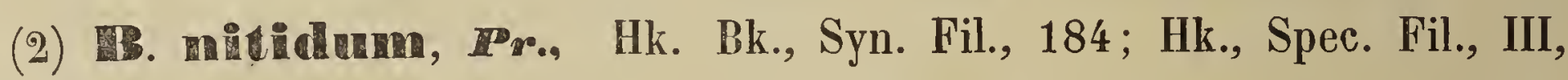
tab. CLV; B. elongatum, Gaud., Freyc., Voy. Ur. Phy̧s., Bot., 595 ; C. Chr., Ind. Fil.

Stipes stout, erect, naked, $7-10$ c.M. long. Fronds oblong-lanceolate, 50 c.M. or more long, 10-15 c.M. broad. Segments numerous, erecto-patent, subfalcate, linear, 7-10 c.M. long, $1 / 2-1 \frac{1}{2}$ c.M. broad, narrowed gradually towards the point, dilated and connected at the base, the edge undulato-dentate; lower segments linear, acute and not much smaller than the rest. Texture coriaceous, rachis and both surfaces naked; veins fine. Sori in a continuous line on each side close to the midrib; indusium conspicuous.

Philippines; Polynesia, Brasilia.

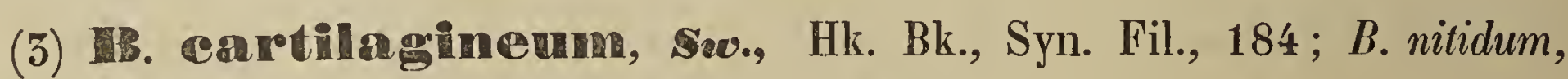
Pr., var. contracta, Hk., Spec. Fil., III, 44, tab. CLVI.

Rhizome oblique, densely clothed at the crown with blackish, fibrillose scales. Stipes strong, erect, 10-15 c.M. long, scaly and muricate in the lower part. Fronds ovate-oblong, 30-60 c.M. long, 15-25 c.M. broad. Segments numerous, erecto-patent, linear, $1 / 2-1 \frac{1}{2}$ c.M. broad, narrowed gradually towards the apex, the margin finely toothed, dilated and connected at the base, the lower ones not much smaller than the others. Texture coriaceous; rachis 
and both surfaces naked; veins fine. Sori in broad lines close to the midribs.

Philippines; Mishmee, Australia,

* (4) R. Tinlaysonianum, Walt., Hk. Bk., Syn. Fil., 187; Hk. \& Grev., Ic. Fil., tab. CCXXV; Bedd., Ferns Br.I., II, tab. CGIL.

Rhizome short. Stipes erect, brown, polished, 30 c.M. long or longer. Fronds $90-120$ c.M. long or longer, with a large terminal pinna and numerous erecto-patent lateral ones on each side. Largest pinnae $20-30$ c. M. long, $21 / 2$ c.M. broad or broader, narrowed at both ends, the apex acuminate, the base \pm obliquely cuneate, the margin entire; upper pinnae decurrent at the base, lower reduced to mere auricles. Texture coriaceous; both surfaces naked. Sori in a continuous line on each side close to the midrib.

Malacca, Borneo, New Guinea. Java. ( 52 P 255)

(5) B. Bunmei, IRoore, Ind., 195; Lomaria auriculata, Bl. (not Desv.), Enum., 202.

Stipes subpaleaceous. Fronds pinnate. Pinnae sessile, approximate, naked. Sterile pinnae linear-lanceolate, obtuse; upper base truncate, auriculate, lower subcordate; fertile pinnae linear, truncate, auriculate.

Java.

* (6) B. orientale, L., Rac., Flor. Btz., I, 163; Hk., Fil. Exot., tab. LXXVII; Bedd., Ferns S.I., tab. XXIX; - var. undulatum, Hk., Spec. Fil., III, 52.

Caudex stout, erect, densely clothed with linear, acuminate, glossy, brown scales. Stipes 10-40 c.M. long, erect, scaly at te base. Fronds $2 \breve{5}-200$ c.M. long, 10-40 c.M. broad, linear-lanceolate or ovate, with very numerous, nearly contiguous pinnae, on each side. Pinnae sessile, the apex acuminate, the upper ones decurrent at the base, the lower ones with the base truncate, rounded or cordate, $5-20$ c.M. long, $1 / 2-2$ c.M. broad, the lowest ones reduced to mere auricles or glands. Texture subcoriaceous; rachis and both surfaces naked; veins fine and close. Sori in a long continuous lines close to the costae.

War. undulatum: Pinnae transversally undulate, the apex finely acuminate.

Trop. Asia, Australia \& Polynesia. 
* (7) B. Serrulatum, Rich., Hk. Bk., Syn. Fil., 186; B. strialum, R. Br., Hk., Spec. Fil., III, tab. CLIX.

Caudex elongate, stout, ascending. Stipes $15-50$ c.M. long, strong, erect, smooth, nearly naked. Fronds oblong-acuminate, 50-60 c.M. long, 15-25 c.M. broad, with $12-24$ pairs of quite distinct, articulate, linear-oblong pinnae on each side, the largest of which are 10-15 c.M. long, 1-2 c.M. broad, narrowed gradually towards the point, and downwards to a narrow base, the margin finely incised. Texture coriaceous; rachis rigid, naked; veins fine and close, not conspicuous. Fertile pinnae narrower. Sori in continuous lines close to the midribs.

Trop. America, Asia \& Australia, New Caledonia.

(8) VB. eg gogium, Copet., Polypod. Philipp., 90.

Stipes clustered in form of a nest, 10-20 c.M. long, stout, browll, black below and densely clothed with long, black scales. Fronds \pm 100 c.M. long, \pm 50 c.M. broad, pimmate, naked, moderately dimorphous. Pinnae acuminate, serrate, the higher ones cofluent, the central ones attached to the rachis by a broad base but free, the lowest reduced into distant auricles; fertile pinnae coriaceous, \pm 15 c.M. long, $1 \frac{1}{2}-2$ c.M. broad at the base, contracted gradually until the sorus occupies very, nearly the whole breadth; barren pinnae thinner but broader. Indusium coriaceous, persistent.

Philippines.

\section{SADLARIA, Hamifuss.}

Sori linear, close to the costa on both sides, continuous or interrupted. Indusium of the same shape as the sorus, attached at its outer side, opening inwardly.

Caudex arborescent. Stipes tufted, not articulate to the caudex. Fronds large, 2-pinnate; veins united near the base by transversal strands, which are occupied by the sori in the fertile segments. Hk. Bk., Syn. Fil., tab. IV, fig. 55; Diels, in Engl. \& Prantl, Nat. Pfl.Fam., I", fig. "132, A-B.

* S. eyatheoides; ruf., Hk. Bk., Syn. Fil., 187; Diels, in Engl. \& Prantl, Nat. Pfl.Farn., I4, fig. 132, A-C.

Stipes strong, erect, $15-45$ c.M. long, densely clothed with long, linear scales at the base, the rest naked. Fronds 100-250 c.M. long, 2-pimnate. 
Pinnae erecto-patent or spreading, 20-40 c.M. long, 1-3 c.M. broad, cut down into very numerous pimnulae. Pinnulae linear, subfalcate, acute or bluntish, sessile with a dilated base, to 4 m.M. hroad, those of the upper pinnae conected at the base, the lower ones free. Texture coriaceous; veins inconspicuous; rachis and both surfaces naked. Sori placed on elevated receptacles.

Sumatra; Hawaii.

\section{DOODIA, R. Hrown.}

Sori oblong, straight or slightly recurved, superficial, placed in 1 or more rows on each side, parallel to the costa. Indusium of the same shape as the sorus, attached at the outer side, opening inwardly.

Rhizome \pm erect. Stipes not articulate to the rhizome. Fronds pinnatifid or pinnate; veins forming 1 or more series of arches between the midrib and edge, on which the sori are placed. Hk, Bk., Syn. Fil., tab. IV, fig. 37; Diels, in Engl. \& Prantl, Nat. Pfl.Fam., I', fig. 134, C-D.

* Fronds pinnatifid, at best pinnate in the lower half, the 1-3 lowest pairs of segments occasionally quite free, rounded and subauriculate at the base.

(1) D. dives.

** Fronds pinnatifid in the upper, pinnate in the lower half, with some of the lower pairs of pinnae cordate or dislinclly auricled, or even hastate at the base.

(2) D. media.

* (1) D. dives, Kae, Rac., Flor. Btz., 1, 164; Kze, Farnkr., II, tab. CV; Bedd., Ferus S.I., tab. CGXXII.

Rhizome \pm erect, densely clothed with dark-brown, lanceolate, acuminate scales. Stipes slender, erect, naked, blackish like the rachis, scaly at the base, $10-30$ c.M. long. Barren fronds ovate-lanceolate, to \pm 50 c.M. long, 7-13 c.M. broad, deeply pinnatifid throughout, at best pinnate in the lower half. Segments several to many, linear or linear-oblong, \pm blunt, subundulate, serrate, dilated at the base, \pm 1 c.ll. broad, the higher ones confluent, the lower ones confluent or contiguous and occasionally the $1-5$ lowest pairs quite free, rounded and subauriculate at the base. Texture coriaceous; surfaces naked. Fertile fronds often longer, with narrower segments; seg- 
51. DOODIA.

ments linear, the central ones $\pm 21 / 2$ c.M. apart, connected by a decurrent wing, the lowest pairs free. Sori oblong, straight or recurved, placed in 2 irregular rows on each side.

Java; Ceylon.

* (2) D. media, R. Rr., Hk. Bk., Syn. Fil., 190; Diels, in Engl. \& Prantl, Nat. Pfl.Fam., I ${ }^{4}$, fig. 154, C-D.

Near D. dives, $K z e$, but the fronds mostly longer, $\pm \mathbf{3 0 - 4 5}$ c.Mr. long, 4-20 c.M. broad, lanceolate or subtriangular-lanceolate, deeply pinnatifid in the upper, but pinnate in the lower half. Segments linear, bluntish or acute, toothed or serrate, the higher ones conflent, the central ones confluent or contiguous and some of the lowest pairs quite free and cordate or distinctly auricled, or even hastate at the base. Texture more or less coriaceous; surfaces naked. Sori oblong, straight or recurved, \pm distant, in 1-2 rows on each side, the inner rows not rarely at some distance from the midrib. Sumbawa, Timor; Australia, New Zealand, Polynesia.

\section{WOODW ARDIA, Smith.}

Sori oblong or linear-oblong, in 1 row on each side, parallel and nearly close to the costa, immersed in cavities occupying the costal areolae. Indusium of the same shape as the sorus, attached at the outer side, covering the cavity like a lid, opening inwardly.

Rhizome erect. Stipes not articulate to the rhizome. Fronds pinnate or 2-pinnatifid; veins anastomosing to form 1 or more rows of areolae between the midrib and the edge. Hk. Bk., Syn. Fil., tab. IV, fig. 36; Diels, in Engl. \& Prantl, Nat. Pfl.Fam., I ${ }^{4}$, fig.. 134, A-B.

Warmer regions, chiefly of the northern hemisphere.

\section{Arrangement of the sections.}

1. EUWOODWARDIA. Fronds uniform. Veins anastomosing between the sori and the margin.

2. ANCHISTEA. Fronds uniform. Veins free between the sori and the margin. (Not in Malaya).

S 3. LORINSERIA. Fronds dimorphous. Veins anastomosing as in $\mathbb{S} 1$. (Not in Malaya). 


\section{$\mathbb{S}$ 1. EUWOODWARDIA.}

* W. radicans, Smo, Hk. Bk., Syn. Fil., 188; Bedd., Ferns Br.I., I, tab. LXXXVIII; Bau. \& Hk., Gen. Fil., tab. XVII; W. auriculata, Bl., Rac., Flor. Btz., I, 165; Blechnum radicans, L., (oldest name); - var. prolifera, Copel., Philipp. Journ., III, 55; W. prolifera, Hk. \& Arn., Beech. Voy., 275, tab. LVI.

Rhizome erect. Stipes strong, erect, naked, scaly at the base. Fronds 1-2 M. long, 30-70 c.M. broad, 2-pimnatifid. Pinnae linear-lanceolate, erectopatent, the lowest to 40 c.M. long, on stalks $0-5$ m.M. long, cut down into linear, subfalcate or nearly straight, acute, serrulate lobes 1-4 c.M. long, the lower lobes often shorter. Texture coriaceous; rachis and under surface naked or covered with long or short, narrow, brown scales or hairs; veins anastomosing, forming 1 row of arches on each side. of the costulae (midribs of the lobes), and 1 row of areolae outside the fruit, the rest free. ( $W$. auriculata, Bl.: Pinnae auricled at the base).

Va: prolifera: Fronds small, membranaceous, proliferous.

Sumatra, Java, Philippines; Formosa, Japan, China, North. India, South. Europe, Atlant. Islands; - var prolifera; Batan Island (Philippines). 

TRIBE VI. ASPLENIEAE 



\section{DIPLAZIUM, Swartw.}

Sori linear or linear-oblong, straight or slightly curved, springing from the sides of the veins, \pm oblique to the costa, the lower veins of each group mostly, the higher ones rarely bearing 2 sori, i.e. with a sorus on each side. Indusia single or double (according to the sori), the single ones opening towards the main veins or the central veins of the ultimate seginents, the double ones in opposite directions.

Rhizome creeping or erect, the scales finely cancellate, with the areolae mostly dark-coloured, i. e. the cells with the side walls thin and the lumina mostly dark-coloured (Sadeb., in Engl. \& Prantl, Nat. Pfl.Fam., I ${ }^{4}$, fig. 40, A). Stipes not articulate to the rhizome, with 2 free, \pm flattened fibro-vascular bundles, which mostly unite towards the lamina (or higher) into a single diarchous one $(\backslash /, \vee, \backslash /, \sqcup, \cup)$. Fronds simple or divided; veins free or anastomosing. Hk. Bk., Syn. Fil., tab. IV, fig. 38, $\mathrm{f}-\mathrm{g}$.

\section{Arrangement of the sections.}

S1. EUDIPLAZIUM. Veins free. Diels, in Engl. \& Prantl, Nat. Pfl.Fam., I ${ }^{4}$, fig. $121, \mathrm{~A}-\mathrm{D}$.

S2. ANISOGONIUM. Veins anastomosing. Bedd., Handb. Ind. Ferns, fig. 92-94.

\section{EUDIPLAZIUM.}

a. Fronds simple, the margin entire, crenate or toothed. a.a. Fronds pinnatifid, at best pinnate at the very base.

(1) D. subserratum. SIp25y (1a) D. lanceum Sap $25 y$

s. Fronds herbaceous. Rhizome creeping.

*. Fronds pinnatifid throughout. Stipes approximate.

(2a) D. Merrilli. *.*. Fronds pinnate at the very base. Stipes rather remote.

(2b) D. zeylanicum.

5.S. Fronds subcoriaceous. Rhizome erect or short-creeping. Stipes \pm tufted.

(3) D. porphyrorachis. a.a.d. Fronds pinnate or 2-pinnalifid, the lower pinnae sometimes pinnate at the base.

b. Pinnae entire, crenate, serrate, toothed or slightly lobed, the lowest sometimes more deeply lobed. 
53. Diplaziun. $\mathbb{S} 1$. eudiplazium.

c. Texlure \pm herbaceous to papyraceous. $\left(^{*}\right)$

d. Under surface densely scaly on the veins. (4) D. chlorophyllum.

d.d. Under surface not densely scaly on the veins.

e. Pinnae truncate, rounded or broadly cuneate at the base.

s. Stipes \pm sialy.

*. Pinnae \pm 6 on each side, not hastate at the base.

(ちa) D. inconspicuum. *.*. Pinnae \pm 8-9 on each side, hastate at the base.

(๖b) D. Weinlandii.

\$.\$. Stipes naked, or scaly at the base.

*. Main veins simple or forked.

(6) D. camarinum.

*.*. Main veins pinnate.

(7) D. silvaticum $282 b$

c.e. Pinnae more narrowly cuneate at the base, or the lower If 2. base obliquely cut away \& narrower than the upper.

f. Stipe and rachis \pm scaly or fibrillose, the scales or fibres persistent or deciduous.

g. Fronds narrow, \pm 3 c.M.broad. Pinnae prominently auricled at the base above.

(8) D. acrotis.

..y. Fronds broader, $\pm 3^{1} 1_{2}-5$ c.M. broad. Pinnae not auricled at the base.

(9) D. biseriale.

f.f: Stipe and rachis naked.

(10) D. aequibasale.

c.c. Texture \pm chartaceous to coriaceous.

$\boldsymbol{d}^{\prime}$. Rachis pubescent, at least on the upper (inner) side.

\$. Pinnae paucijugate, rather broad.

$\times$. Fronds small.

$\times \cdot \times$. Fronds middle-sized.

S.S. Pinnae multijugate, rather narrow. (11a) D. barisanicum.

(11b) D. tabacinum. Sב $p z$

(1) Di crass noffe SI 2 d.'d'. Rachis \pm naked, or sometimes slighlly pubescent. Bamleriamum

$\boldsymbol{e}^{\prime}$. Pinnae unequal-sided at the base, i.e. the upper base \pm broadly, the lower \pm narrowly cuneate.

*. Stipes stramineous. Fronds pale-green.

(13) D. pallidum.

*.*. Stipes bluish-glaucous. Fronds salurate-green.

(14) D. vacillans.

$\left.{ }^{*}\right)$ See also D. bulbiferum, Brack, Williamsi, Copel. \& Grammitoides, $P r$. 
53. DiplaziUM. $\mathbb{S} 1$. EUdiplaziUU.

$\boldsymbol{e}^{\prime} \cdot \boldsymbol{e}^{\prime}$. Pinnae rather equal-sided at the base.

$f^{\prime}$. Pinnae narrowed at the base.

$\boldsymbol{g}^{\prime}$. Sori reaching \pm the margin.

n'. Pinnae in $\pm 1-8$ pairs.

(15) D. bantamense.

$\boldsymbol{h}^{\prime} . \boldsymbol{h}^{\prime}$. Pinnae in \pm 13-25 pairs.

(16) D. xiphophyllum.

$\boldsymbol{g}^{\prime} \cdot \boldsymbol{g}^{\prime} \cdot$ Sori distant from the margin.

(17) D. palauanense. S_p

$\boldsymbol{f}^{\prime} \cdot \boldsymbol{f}^{\prime}$. Pinnae troad at the base. ( $\left.{ }^{*}\right)$

a. Fronds narrow, under 71/2 c.M. broad.

(18) D. larutense.

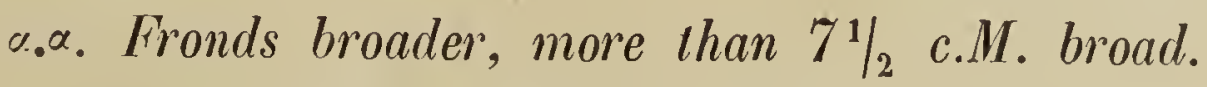

3. Lateral pinnae $\pm 3-5$ on each side below the pinnatifid terminal one.

(19) D. cultratum.

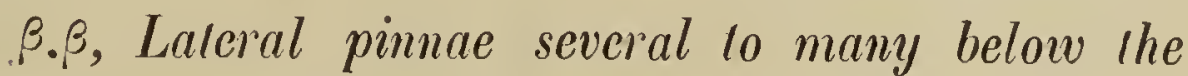
pinnatifid terminal one.

$\%$ Largest pinnae 1-21/2 c.M. broad, auricled or hastate at the base.

ঠ. Pinnae rather close, broadly chneate to truncate at the base.

(20) D. crenato-serratum.

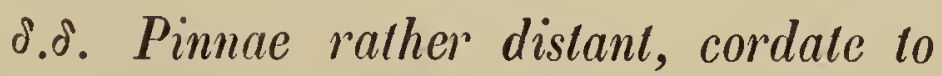
truncate at the base. (21) D. Hosei.

$\% \%$ Largest pimnae 2-4 c.M. broad, not auriclel.

(22) D. Lobbianum.

b.b. Pinnae more decply lobed often to $1 / 2-3 / 4-w a y$ down or more to the costa, sometimes pinnate at the base.

1. Texture \pm herbaccous to papyraceous.

2. Lower pinnae deeply lobed or pinnatifid.

3. Rachis nalied.

1. One or both surfaces slightly hairy. (23) D. japonicum.

4.1. Surfaces nalied or nearly so.

5. Pinnae ralher few. (24) D. shepherdioides.

5.5. Pinnae rather many.

c. Fronds ralher narrow. (25a)D. Williamsi.

(') Sce also under D. bantamense, $\mathrm{Bl}$. 


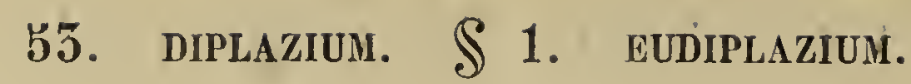

6.6. Fronds ralher broad. (25b) D. acuminatum.

3.3. Rachis more or less scaly or hairy.

S. Pinnae acute at the base.

(26) D. petiolare.

\$.S. Pinnae broadly cuneate to truncate at the base.

+. Pinnae 2-10 c.M. long.

+. Stipes scaly or fibrillose throughout.

$\times$. Pinnae $\pm 2-31 / 2$ c.M. long, $1 / 2-1$

c.M. broad. (27a) D. grammitoides.

$\times \cdot \times$. Pinnae to \pm 10 c.M. long, \pm 2

c.M. broad. , (27b) D. Woodii.

.++ Slipes villose or tomentose, al least on

the upper (inner side), sometimes scaly at the base.

$\times$. Surfaces villose or short-hairy.

(28a) D. Petersenii. SI $p$

$\times \cdot \times$. Surfaces naked, except on the costulae beneath. (28b) D. Burchardi.

+. Pinnae 10-20 c.M. long in the fully developed fronds.

(29a) D. sorzogonense. SI $p$ -

$(29 b)$ D. brachysoroides. SI $p$ -

2.2. Lower pinnae pinnate, at least at the base.

a. Stipes muricate.

(30) D. Prescottianum.

๙. . Stipes not muricate.

B. Rachis \pm naked.

\%. Lower pinnae reduced.

(3id) D. geoflw Lower pinnae reduced.

$\gamma . \%$ Lower pinnae not reduced.

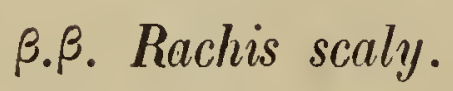

(31a) D. brachypodum. SI : (31b) C. Bolsteri. SI F (32) D. crinitum.

1.1. Texture rather coriaceous.

+. Rachis hairy or tomentose.

(33) D. tomentosum.

+.+. Rachis nalied or \pm scaly.

+. Läteral pinnae commonly \pm 6-10-jugate, lobed.

(34) D. bulbiferum.

+.+. Lateral pinnae commonly $\pm 10^{3}-20$-jugate, pinna. tifid.

$\therefore$ Fronds $\pm 6-15$ c.M. broad.

(35a) D. Whitfordi.

a.. Fronds $\pm 20-35$ c.M. broad.

$(35 b)$. D. speciosum.

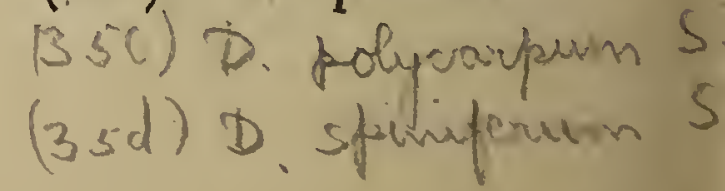


53. Diplazium. $\$ 1$. eudiplaziUm.

a.a.a.a. Fronds copiously 2-pinnate to 3-pinnatifid (*).

b. Pinnulae lobed at best $1 / 2-w a y$ down to the costa.

c. Rachis naked or glabrescent.

d. Fronds herbaceous or membranaceous.

+. Lobes sharply toothed.

+.+. Lobes obscurely denticulate.

(36a) D. cyatheifolium.

(36b) D. davaoense.

d.d. Fronds papyraceous to coriaceous.

e. Stipes smooth. (3) b)D dotutose

e.e. Stipes at length sparingly muricate $(37 b) \mathrm{1}$. dolichosorum.

c.c. Rachis tomentose or scaly.

$\times$. Pinnulae entire to serrate; main rachis scaly.

(38) D. manilense.

$\times \cdot \times$. Pinnulae broadly and shallowly lobed; main rachis tomentose.

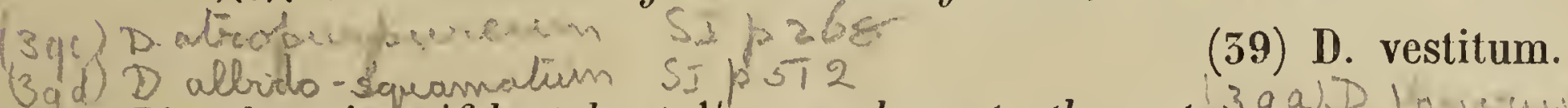

b.b. Pinnulae pinnatifid at least $1 / 2$-way down to the costa.

1. Fully developed fronds under 50 c.M. lonig. (40) D. deltoideum.

1.1. Fully developed fronds more than 50 c.M. long isech $45 \mathrm{ce}$.

2. Main rachis smooth, unarmed.

3. Sori reaching nearly to the edge.

+. Texture thinly coriaceous.

(41a) D. Meyenianum.

+.+. Texture nearly woody.

3.3. Sori not reaching nearly to the edge.

(41b) D. atratum

1. Rachises not ebeneous.

5. Pinnae 30-45 c.M. long; pinnulae $\pm 2^{1 / 2}-3^{1} / 2$

D. sibuyanuse SIpzpo c.M. broad. (42) D. amplissimum.

) D amplifiacs si $y^{0}$ 5.5. Pinnae 20-30 c.M. long; pinnulae $\pm 1-2$ c.M. broad.

6. Pinnae paucijugate. (43a) D. oligosorum. 5 I $p 2)^{\prime}$

6.6. Pinnae multijugate.

$(43 d) D$. funbulegum sipzyz

10.1. Rachises ebeneous.

(43b) D. polypodioides.

(43C) (44) D. ebeneum.

2.2. Main rachis \pm asperous, muricate or aculeate.

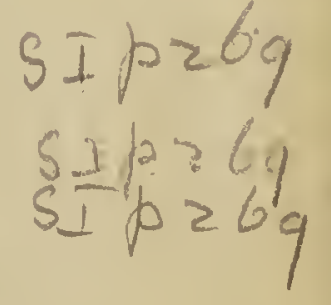

+ Costae and costulae not paleaceo-asperous.

+. Ultimate lobes \pm rounded.

(45a) D. asperum.

+.+. Ultimate lobes truncate.

$(45 b)$ D. fructuosum.

(') See also D. crinitum, C. Chr. 
$+\cdot$ Coslae and costulae paleaceo-asperous.

(46) D. prionophyllum.

a.a.a.a.a. Fronds 3-pinnate to 4-pinnatifid.

* Tertiary divisions crenalo-pinnalifid at the base.

(47) D. ceramicum.

+.+. Terliary divisions deeply pinnalifid.

(48) D. Huttoni. Asu) D ussimai

* (1) D. subserpoatum, Moore, Bedd., Handb. Ind. Ferns, 174 ; Ferns Br.I., II, tab. CCLXXXIX; Asplenium subserratum, Bl., Rac, Flor. BIz., I, 220 ; Hk., Spec. Fil., III, tab. CLXIV, B.

Rhizome short, erect, (after Bedd. creeping \& elongated). Stipes firm, erect, naked, $21 / 2-20$ c M. long. Fronds $20-50$ c.M. long, $1-4$ c.M. broad, narrowed gradually towards both ends or rounded at the base, the apex acuminate, toothed or bluntly crenate. Texture herbaceous or firm-membranaceous; surfaces naked; costa slender, firm, prominent, scaly beneath; main veins pinnate with few veins. Sori linear, occupying $\pm 2 / 3$ of the space between the costa and the edge.

Java, Malacca.

(2a) D. Menrill, Copel., Philipp. Journ.; II, 128, tab. II, A.

Rhizome creeping. Stipes clustered, 2-5 c.M. long, densely clothed with narrow, horizontal, black-brown scales. Fronds 15 -25 c.M. long, narrowed towards both ends, acuminate, deeply pinnatifid, the sinuses narrow or the lobes often imbricated. Lobes oblong, nearly horizontal, the central ones the largest, \pm 1 c.M. broad, the apex rounded, the edge sometimes denticulate. Texture herbaceous; costa densely scaly beneath, but slightly so above; veins forked, minutely scaly beneath; upper surface black-greenish; lower olive-coloured. Sori linear, not reaching the costulae.

Mindoro.

* (2b) D. zeylanicum, Moore, C. Chr., Ind. Fil.; D. Ceylanicum, Christ, Frankr. d Erde, 216, fig. 679; Asplenium zeylanicum, Hk., Hk. Bk., Syn. Fil., 230; Hk., 2nd Cent. of Ferns, tab. XVI.

Rhizome creeping, slightly covered with lanceolate, brownish scales. Stipes erect, firm, scaly, $1 / 2-3$ c.M. apart, to $10-20$ c.M. long. Fronds 1 b- 30 c.M. long, $2 \frac{1}{2}--5$ c.M. broad, lanceolate, the apex acuminate, the upper $1 / 4-$ $1 / 3$ slightly lobed, the lower $2 / 3-3 / 4$ more or less deeply lobed to pinnatifid, the base cut down to the rachis into $1-4$ sessile or subsessile pinnae, with 
the lowest segments shorter than the next in order. Lobes and pinnae bluntly rounded, linear-oblong, to $\pm 1 / 2-1$ c.M. broad. Texture herbaceous; veins forked. Sori reaching nearly from the midribs (costulae) to the edge.

Java (escaped from gardens?); Ceylon.

* (3) D. porphyrorachis, Diels, in Engl. \& Prantl, Nat. Pfl. Fam., I ${ }^{4}, 225$; Asplenium porphyrorachis, Bk., Journ. of Bot., XVII, 40; Hk., Icon. Pl., XVII, tab. VDCL; A. zeylanicum, Ces., Fel. di Bor., 21 ; A. lomariaceum, Christ, Fil. Saras., III, 229; Polypodium subserralum, Hk., Hk. Bk., Syn. Fil., 325.

Rhizome erect or short-creeping, clothed with lanceolate-acuminate, darkbrown scales at the extremity. Stipes \pm tufted, firm, slender, $5-50$ c.M. long, scaly at the base, black-hairy or scaly above, the hairs or scales deciduous. Fronds $15-40$ c.M. long, $21 / 2-61 / 2$ c.M. broad, lanceolate, acuminate, the apex lobed or toothed, the lower $2 / 3-5 / 6$ deeply pinnatifid into many or numerous, close, spreading, subfalcate, linear-oblong, blunt, slightly crenate, serrate or toothed segments $8-15 \mathrm{~m}$. M. broad, which have not seldom the sides entire and only the apex serrate. Lower segments gradually growing smaller, the 1-4 lowest free and deflexed. Texture subcoriaceous; rachis and under surface slightly covered with scattered scales; veins distinct, mostly once forked. Sori oblique, parallel, reaching \pm the edge.

Malacca, Borneo, Celebes.

(4) D. Chlorophyllum, Fedd., Handb. Ind. Ferns, Suppl., 39; Asplenium chlorophyllum, Bk., Journ. of Bot., XXIII, 104.

Stipes tufted, dull-grey-green, pubescent like the rachis, \pm 15 c.M. long. Fronds oblong-lanceolate, simply pinnate, \pm 50 c.M. long, $10-13$ c.M. broad. Pinnae \pm 20 on each side, close, lanceolate, sessile, acute, crenulate towards the apex, conspicuously auricled on the upper side at the base, the central ones $1-1 \frac{1}{2}$ c.M. broad, the lowest strongly deflexed. Texture moderately firm; upper surface minutely paleaceous, under surface densely clothed with minute, linear-subulate scales on the veins; veins distinct, erecto-patent, deeply forked. Sori not quite reaching midrib and margin; indusium crisped, narrow, moderately firm, pale-brown.

Penang; Formosa.

(ba) D. inconspicuum, Chraist, Bull. Herb. Boiss., 2e Série, VI, 1000.

Rhizome suberect, black. Stipes few, \pm 20 c.II. long, the base black, clothed with subulate, black-brown scales, the rest rufo-stramineous like the

Filices. 
rachis, sparingly scaly towards the frond. Fronds oblong, \pm 20 c.M. long, \pm 11 c.M. broad, hardly narrowed at the base. Terminal pinna \pm 11 c.M. long, acuminate, lobed at the base; lateral pinnae \pm 6 on each side, oblong, nearly sessile or short-stalked, rather distant, spreading, \pm b c.M. long, \pm $1 \frac{1}{2}$ c.M. broad, the base subtruncate on the upper, rounded on the lower side, the edges densely 2 -crenulate, the apex obtuse. Texture herbaceous; rachis and surfaces subglabrous; veins dense, forked, subpinnate in the terminal pinna. Sori distant, unequal, linear, not reaching the margin; indusium thin, inconspicuous, greyish.

\section{Luzon.}

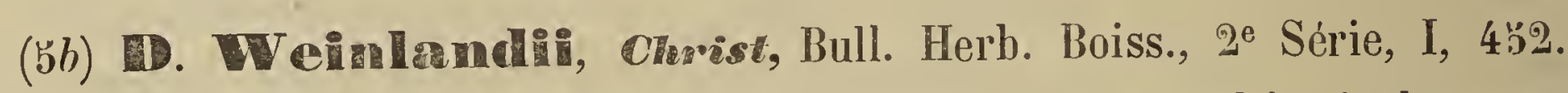

Rhizome oblique, black, decumbent or creeping. Stipes subfasciculate, erect, subflexuose, slender, $10-16$ c.M. long, the base black, the rest green, clothed like the rhizome with few, distani, black, subulate scales. Fronds elongatelanceolate, \pm 15 c.M. long, $4-5$ c.M. broad at the base, pinnate. Pinnae 8-9 on each side, distant, the lower ones short-stalked, obtuse, the base hastate, (the auricles obtuse, rarely deeply incised), the margin broadly, but not deeply incised and crenate, the teeth acute; terminal pinna \pm 6 c.M. long, pinnatifid. Texture herbaceous; surfaces naked; veins oblique, $7-8$ on each side, forked or sometimes 3 -partite. Sori reaching from the midrib to the margin, narrow; indusium thin, grey.

\section{New Guinea.}

(6) D. Camanoingum, Copet. (not Bk.), Polypod. Philipp., 73; Asplenium camarinum, Bk., Hk. Bk., Syn. Fil., 250.

Stipe and rachis dull-brown, naked. Fronds oblong, simply pinnate, 20-45 c.M. long, 15-25 c.M. broad. Pinnae in 8-12 pairs, distant, stalked, linear-ligulate, acute, crenate, $10-15$ c.M. long, \pm 2 c.M. broad, rather reduced on the lower side, rounded on both sides at the base; lowest pinnae not reduced. Texture membranaceous; surfaces naked; colour dull-green; veins distinct, in close, little-ascending pairs, posterior forked, anterior simple. Sori reaching from the costa to the edge; indusium persistent.

South. Camarines.

* (7) D. Silvationnt, Sev., Christ, Farnkr. d. Erde, 217; Bedd., Ferns S.I., tab. CLXI (small); D. acuminatum, Pr., Tent. Pterid., 115; Asplenium sylvalicum, Pr. (not Melı.), Rac., Flor. Btz., I, 225; Callipleris sylvatica, Bory, (oldest name). 
Rhizome erect or decumbent, slightly clothed at the apex with lanceolate scales. Stipes 10-30 c.ll. long, firm, erect, naked, yellowish to brownish, scaly at the base. Fronds $\pm 20-60$ c.M. long, $\pm 10-50$ c.M. broad, ovateto triangular-lanceolate, with many or numerous spreading pinnae. Largest pinnae $5-15$ c.M. long, $1-21 / 2$ c.M. broad, acuminate, or the upper ones blunt or bluntish, the edges crenate and broadly, mostly shallowly lobed (commonly to $2 \frac{1}{2}$ m.M. deep), the base rounded, broadly cuneate or truncate, whether or not auricled on the upper side; lower pinnae stalked, upper sessile; apex of the frond deeply pinnatifid. Texture thin, herbaceous; veins pinnate in the lobes. Sori long, linear.

Pantropical.

(8) D. acrotis, Cherèt, Bull. Herb. Boiss., 2e Série, VI, 1000.

Rhizome oblique, short. Stipes tufted, numerous, 5-4 c.M. long, slender, pale-castaneous like the rachis, crinite with subulate, black-brown scales. Fronds caespitose, 12-14 c.M. long, \pm 3 c.M. broad, pinnate, the rachis slender, nearly filiform, not winged, sparingly furfuraceous. Pinnae \pm 14 on each side below the pinnatifid, acuminate apex, \pm horizontal, stalked, regular, oblong, $\pm 1 \frac{1}{2}$ c.M. long, $\pm 8 \mathrm{~m}$.M. hroad, subfalcate, the base cuneate on the lower, truncate and prominently and acutely auricled on the upper side, the edge coarsely toothed with 5 --6 teeth on each side, the apex bluntish or acute; lower pinnae becoming shorter, higher sessile. Texture herbaceous; veins 1 to each tooth, simple, the lowest anterior one pinnate in the auricle. Sori oblong, oblique, regular, reaching the midrib and the edge, often double.

Luzon.

(9) W. Heำ Linn. Soc., Bot., $2^{\text {nd }}$ Series, IV, 252.

Rhizome short-creeping. Stipes erect, $3^{1 / 2}-5$ c.M. long, clothed above with lanceolate, spreading, brown scales. Fronds oblong-lanceolate, simply pinnate, naked, 10-15 c.M. long, 51/2 -5 c.M. broad; rachis covered with small scales. Pinnae multijugate, sessile, lanceolate, the higher ones entire, the lower $\pm \mathbf{b}$ m.M. broad, deeply crenate, with the lower base reduced; veins obscure, erecto-patent. Sori in 1 row on each side of the costae, linear-oblong, often diplazioid; indusium broad, membranaceous, naked, persistent.

Borneo. 
(10) D. acquilonsale, C. Chr., Ind. Fil.; Asplenium aequibasale, Bk., Journ. of Linn. Soc., Bot., XXII, 225.

Rhizome erect. Stipes tufted, 7-10 c.M. long, with few, black, lanceolate, spreading scales near the base. Fronds oblong, 1 b-20 c.M. long, 10-15 c.M. broad, simply pinnate. Pinnae alternate, 9-11, adnate, distant, lanceolate, acuminate, crenulate, the base narrowed and equal on both sides, the middle $1-1 \frac{1}{2}$ c.M. broad. Texture rather thin; surfaces naked; veins conspicuous, erecto-patent, simple or forked. Sori medial on the veins, parallel; indusium narrow, naked, persistent.

Borneo.

(11a) D. Danoisanicum, C. Cter., Ind. Fil.; Asplenium barisanicum, Bk., Ann. of Bot., VIII, 126.

Stipes \pm 15 c.M. long, slender, green, naked, clothed near the base with linear, brown scales. Fronds deltoid-oblong, 15-20 c.M. long, 12-15 c.M. broad, simply pinnate. Terminal pinna pinnatifid; lateral pinnae paucijugate, lanceolate-oblong, 3-4 c.M. broad, deeply crenate, short-stalked, the lower ones not or hardly shorter. Both surfaces naked; rachis pubescent above; main veins pinnate; veins erecto-patent, simple. Sori occupying the lower portion of the veins; indusium membranaceous, naked, persistent.

Sumatra.

(11b) D. Labacinum, Copel., Philipp. Journ., I, Suppl., 149, tab. VI.

Rhizome erect, clothed with brown, lanceolate-subulate scales. Stipes 50-40 c.M. long, canaliculate, the lower part sparingly scaly, the upper part short-pubescent like the rachis and the stalks of the pinnae. Fronds $30-40$ c.M. long, ovate, pinnate. Pinnae $2-4$ on each side below the terminal one, simple, lanceolate-oblong, the base cuneate-truncate, the edge serrate towards the falcato-acuminate apex; lowest pinnae largest, \pm 15 c.M. long, \pm 5 c.M. broad, the terminal one simple or with a pair of basal lobes. Texture subcoriaceous; surfaces naked; veins 3-4-furcate. Sori linear, reaching nearly the costae and the margin.

Mindanı.

(12) D. confertum, C. Cher., Ind. Fil.; Asplenium confertum, Bl., Ann. of Bot., VIII, $12 \%$.

Stipes \pm 15 c.M. long, scaly at the base, slender, green, the scales 
lanceolate, firm, castaneous. Fronds lanceolate-oblong, 15-25 c.M. long, $61 / 2$ $7 \frac{1}{2}$ c.M. broad, pinnate. Pinnae nultijugate, 15 - 18 m.M. broad, close, sessile, obtuse, crenate, the upper base auricled; lower pinnae not much shorter, deflexed. Texture firm; surfaces naked; rachis pubescent; veins obscure, erecto-patent, forked. Sori linear, reaching from the costae to the margin; indusium naked, narrow, persistent.

Sumatra.

* (15) D. pallidum, Moore (not Bl.), Copel., Polypod. Philipp, 75; Bedd., Ferns Br.I., II, tab. CXCVI; Asplenium pallidum, Bl., Rac., Flor. Btz., I, 222.

Rhizome short, creeping, clothed with black, lanceolate scales. Stipes 15-30 c.M. long, firm, erect, stramineous, naked or scaly at the dark-brown base. Fronds 30-100 c.M. long, wilh numerous nearly horizontal, straight or falcate pinnae on each side. Pinnae 7-15 c.M. long, short-stalked, linearlanceolate, the apex acuminate, 1-2 c.M. broad, the edge often sharply toothed, the upper base truncate, often rounded, the lower cuneate, slightly rounded. Texture coriaceous; veins once or twice forked. Sori in regular lines, reaching from the midribs to the edge or occupying the lower half of the veins.

Malaya; Queensland.

(14) D. vacillams, C. Chr., Ind. Fil.; Asplenium vacillans, Kze, Bot. Zeit., 1848, 172. .

Rhizome short-creeping, clothed with black scales. Stipes $40-45$ c.M. long, bluish-pruinose, the base blackish, scaly like the rhizome. Fronds oblong, \pm 50 c.M. long, $15-20$ c.M. broad, acuminate. Pimnae \pm stalked, spreading, rather distant, linear-oblong, falcate, the apex narrowed, the edge regularly and broadly serrate, the upper base truncate, the lower subcuneate. Texture thinly coriaceous; surfaces naked; costae prominent; veins forked, the higher simple, the lowest once or more times forked, oblique. Sori rather distant, rarely diplazioid, commonly reaching from the midribs to the margin.

Java.

* (15) Dantanense, Chu., Christ, Farnkr. d. Erde, 216; D. fraxinifolium, Bedd., Ferns Br.I., I, tab. LXIX; Asplenium fraxinifolium, Wall., Hk., $2^{\text {nd }}$ Cent. of Ferns, tab. XIX; A. banlamense, Bk., Rac., Flor. Btz., I, 221 ; - var. alternifolium; A allernifolium, Mett., Ann. Mus. Bot. L. B., II, 237 ; D. allernifolium, Bl., Hk., Fil. Exot., tab. XVII. 
Rhizome short, stout, clothed with brown, lanceolate scales. Stipes tufted, 15-30 c.M. long, erect, firm, stramineous, scaly at the base. Fronds \pm 20-100 c.M. long, with a large terminal and $1-8$ pairs of \pm stalked, lateral pinnae. Pinnae $10-20$ c.M. long, $\pm 2-5$ c.M. broad, narrowed at or wer both ends, the point acuminate, the edge serrate or nearly entire; higher pinnae sessile. 'Texture coriaceous but rather thin; surfaces naked; veins \pm $\mathbf{3} \times$ forked. Sori narrow, irregular, the longest reaching nearly from the midrib to the edge.

Var. atcernifolium : Stipes green, passing gradually into brown at the base. Pinnae ovate, broad, $7 \frac{1}{2}-10$ c.M. long, the base rounded or cordate, the edge entire, obscurely sinuate or subcrenato-serrate towards the apex. Texture subcarnoso-coriaceous.

Trop. Asia; - var. alternifolium: Java.

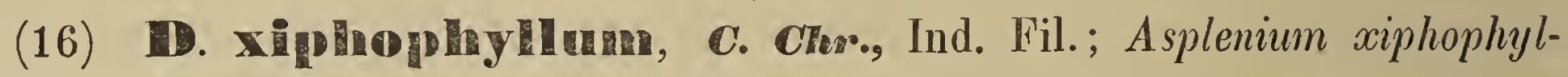
lum, Bk., Journ. of Bot., XVII, 40.

Rhizome suberect. Stipes close, to 30 c.M. long, the base densely clothed with large, brown, linear scales. Fronds oblong-deltoid or deltoid, simply pinnate, $30-45$ c.M. long, with a terminal pinna similar to the lateral ones. Pinnae 13-25, subsessile, lanceolate, 20 - 25 c.M. long, 2-4 c.M. broad, toothed and much acuminate at the point, cuneate at the base. Texture subcoriaceous; surfaces naked; veins in pinnate groups of $3-4$. Sori reaching from the midrib to the edge; indusium narrow, naked, persistent.

Borneo.

(17) D. palmuanense, Comel., Polypod. Philipp., 72.

Stipes firm, 50-40 c.M. long, the base black and covered with black scales, the higher part stramineous. Fronds $30-60$ c.M. long, pinnate. Pinnae alternate, distant, \pm 6-jugate, the largest \pm 30 c.ll. long, $21 / 2-5$ c.M. broad, acute, obscurely serrate, the higher ones sessile, the lower narrowed at the base into a short stipe, both sides nearly equal. Texture coriaceous; rachis naked; surfaces naked; veins $2-3 \times$ forked. Sori linear, distant from the margin.

Philippines.

(18) D. Marutense, Redd., Handb. Ind. Ferns, Suppl., 38.

Rhizome erect. Stipes \pm 50 c.M. long, firm, erect, naked. Fronds narrow, linear-lanceolate, \pm 50 c.I. long, $4-5$ c.M. broad, broadest at the base, gra- 
dually tapering upwards, pinnate, pinnatifid towards the apex; rachis deeply channelled above. Pinnae numerous, horizontal, oblong, with a broad base and rounded apex, \pm 1 c.M. broad, the margin slightly crenate, the upper base slightly lobed. Texture coriaceous; veins simple or the lowest forked. Lowest sori sometimes double, the others always single, reaching from the midrib to the margin.

Malacca.

(19) D. Collo cultralum, Hk. (not Melı.), Hk. Bk., Syn. Fil., 231.

- Stipes tufted, 10-15 c.M. long, grey, naked. Fronds $15-25$ c.M. long, 7 -10 c.M. broad, the apex pinnatifid, the lower $2 / 3$ pinnate with 3 - 5 pinnae on each side. Lower pinnae distinctly stalked, \pm 5 c.M., long, \pm 2 c.M. broad, the point acute, rather falcate, the edge nearly entire, both sides narrowed suddenly at the base, the upper base auricled. Texture subcoriaceous; veins twice forked; sori linear, slender, 'reaching the edge but not the midrib.

Luzon.

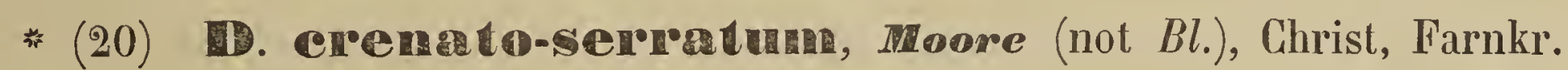
d. Erde, 217; D. porreclum, Pr., Bedd., Handb. Ind. Ferns, 176; Ferns Br.I., II, tab. CCXLV; Asplcnium porrectum, Wall., Hk. Bk., Syn. Fil., 230; A. crenato-serratum, Bl., (oldest name).

Stipes tufted, to 30 c.M. long or longer, brownish. Fronds $20-45$ c.M. long, $10-25$ c.M. broad, deltoid-oblong, with several to numerous horizontal pinnae on each side. Pinnae linear-lanceolate, nearly straight, acute or bluntish, the edge varying from slightly crenate to shallowly lobed or broadly toothed, the base \pm equally and broadly cuneate to truncate and auricled on the upper side; lower pinnae $\pm 1 \frac{1}{2}-2 \frac{1}{2}$ c.M. broad, short-stalked, bluntly lobed, longer than the next in order, sometimes shorter or deflexed; highest pimnae erecto-patent, sessile, adnate to the rachis. Texture more or less distinctly coriaceous; rachis naked or slightly pubescent; surfaces naked; main veins pinnate; veins simple or forked. Sori in regular, parallel rows, extending from the midrib to the edge.

Malaya.

* (21) D. rosei, Christ, Bull. Soc. Bot. Belg., XXXIII ${ }^{2}, 93$.

Stipes long, slightly rough like the rachis. Fronds $\pm 50-45$ c.M. long, $\pm 14-18$ c.M. broad, triangular, pinnatifid at the apex. Pinnae $\pm 12-20$ - 
jugate, spreading, the highest ones the shortest, the lower ones the largest, short-stalked, broadly lanceolate, \pm 3 c.l. apart, \pm 2 c.I. broad, cordate to truncate at the base, the upper base auriculate to hastate, the apex acute to acuminate, the edge regularly but slightly crenate to serrate. Texture firm, chartaceous or subcoriaceous; surfaces naked; costae distinct; veins 2-3-jugate, inconspicuous. Sori \pm 25 on each side of the costa, \pm 1 c.M. long, only double near the margin.

Borneo.

* (22) D. Lobbianum, Moore, C. Chr., Ind. Fil.; Asplenium Lobbianum, Hlk., Spec. Fil., III, $244 ; 2^{\text {nd }}$ Cent. of Ferns, tab. XVII.

Rhizome suberect, clothed with black, subulate scales. Stipes approximate or subtufted, 15-50 c.M. long, scaly at the base. Fronds oblong-ovate, 20-45 c.M. long, with a pinnatifid apex and to 20 or more pinnae on each side. Pinnae subhorizontal, linear-oblong or lanceolate-oblong, 71/2-15 c.M. long, 2-4 c.ll. broad, stalked, subfalcale, acuminate, the edge more or less serrate, the base \pm truncate and subauriculate. Texture thinly coriaceous; surfaces naked; veins $2-3 \times$ forked. Sori nut reaching the margin or the midrib.

Java, Philippines, New Guinea.

* (23) D. japonioum, Bedd., Christ, Farnkr. d. Erde, 218; D. decussatum, Bedd., Ferns Br.I., II, tab. CCXCII; Asplenium japonicum, Thb., Hk. Bk., Syn. Fil., 234.

Rhizome slender, wide-creeping. Stipes $15-30$ c.M. long, stramineous or brownish, slightly scaly towards the base. Fronds $20-35$ c.M. long, 10-13 c.M. broad, ovate-lanceolate to subdeltoid. Terminal pinna pinnatifid, narrowed gradually towards the point; lateral pinnae 8-10 on each side, rather distant, to $2 \frac{1}{2}$ c.M. broad, short-acuminate, cut down in the lower part $2 / 3$ of the way to the costa, the base hroadly cuneate or subtruncate. Lobes oblong, rounded or bluntish, slightly loothed, approximate. Texture herbaceous; surfaces slightly hairy; rachis \pm naked; veins $4-6$ on each side in the lower lobes. Sori short, not reaching the margin.

Trop. Asia, China, Japan.

(24) D. shepherdioides, C. Chr., Ind. lil.; Asplenium shepherdioides, Bk., Ann. of Bot., VIII, 126.

Stipes $20-25$ c.M. long, slender, green, naked. Fronds oblong-lanceolate, 30 c.II. and more long, 2-pinnatifid; surfaces naked; rachis slender, green, 
naked. Pinnae lanceolate, acuminate, $7-13$ c.M. long, $21 / 2-3$ c.M. broad, paucijugate, cut down $1 / 2$-way to the costa, the lower base cuneate; higher pinnae sessile, lower short-stalked, not reduced. Lobes oblong, $5-61 / 2 \mathrm{~m} . \mathrm{M}$. broad, entire. Main veins pinnate; veins 4-6-jugate, erecto-patent, simple. Sori not reaching the apices of the veins; indusium narrow, naked, persistent.

Sumatra.

(25a) D. Wriliamsi, Copet., Philipp. Journ., I, Suppl., 150, tab. VII.

Rhizome erect, short, the scales subulate, blackish-fuscous. Stipes 4-10 c.M. long, erect, the base black, scaly, the upper part green, naked. Fronds 10-20 c.M. long, lanceolate, acuminate, pinnate, the rachis slender, green, naked. Pinnae in \pm 10 pairs below the pinnatifid apex, alternate, serrate or slightly lobed, obtuse or acute, the upper base truncate-auriculate, the lower cuneate; lowest pinnae distant, short-stalked, \pm 2 c.M. long, deltoid-lanceolate, deeply pinnatifid into oblong, obtuse, denticulate lobes. Texture papyraceous; surfaces naked; veins subconspicuous, 2-4-furcate. Sori elongate, often double. - Fruiting fronds are found less than $\boldsymbol{b}$ c.M. long including the stipe, with the lowest pinnae less incised. In size and shape this species resembles $\mathrm{D}$. grammitoides, $P r$.

Mindanao.

(25b) D. acuminntum, $\boldsymbol{B r} .$, Christ, Ann. Btz., XII, 220; D. Chrislii, C. Chr., Ind. Fil.; Asplenium acuminatum, Wall., List, No. 20 s.

Stipes naked, yellowish, \pm 55 c.M. long. Fronds oblong-deltoid, $\pm \mathbf{5 5}$ c.M. long, $\pm 25-30$ c.M. broad. Pinnae \pm 20 on each side, the lowest largest, \pm 2 c.M. broad, distinctly stalked, the base slightly rounded, the edge cut $\pm 1 / 2$-way down to the costa, the apex long, toothed. Segments close, broadly ligulate, blunt, truncate, \pm b m.H. broad, entire or slightly denticulate. Texture herbaceous; surfaces naked. Sori $\pm b$ on each side of the costulae, not reaching the latter, linear; indusium very narrow, inconspicuous.

Malaya.

(26) D. Detiolare, Pr., Copel., Polypod. Philipp., 74.

Stipes brown, smooth. Fronds about 30 c.M. long, pinnate, with a pinnatifid apex. Pinnae \pm 12 c.M. long, the lowest a little shorter, but longer 
stalked, linear, acute, pinnatifid $1 / 2$-way down to the costa, the base equilateral, acute. Texture herbaceous; colour bright-green above, paler heneath; surfaces naked; rachis densely beset with short, spreading hairs; veins free, all bearing sori.

Philippines.

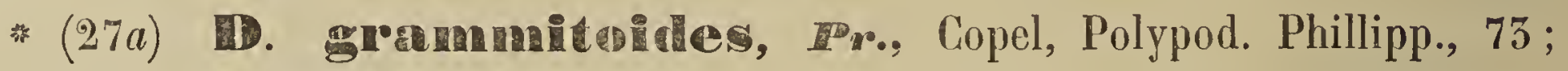
Asplenium grammitoides, Hk., Hk. Bk., Syn. Fil., 491; Hk., Icon. Pl., X, tab. CMXIII.

Rhizome creeping, the scales brown, lanceolate, acuminate. Stipes seriate, approximate, slender, $6-15$ c.M. long, deciduously scaly like the rachis, the scales fibril-like, spreading, crisped. Fronds linear-lanceolate, 10-25 c.M. long, 3-6 c.II. broad, the upper $1 / 3-1 / 2$ deeply pinnatifid, toothed to serrate towards the acuminate point, the lower part pinnate with $6-10$ erecto-patent pinnae on each side. Central pinnae largest, subsessile, lanceolate, subfalcate, blunt or acute, $2-3 \frac{1}{2}$ c.M. long, $1 / 2-1 \quad$ c.M. broad, the edge toothed or lobed and crenate, the base broadly cuneate, distinctly auricled on the upper side; lower pinnae shorter, remote, blunt, \pm stalked, the edge distinctly lobed with short, blunt, subentire or crenate lohes, the lowest anterior lobe the largest. Texture herbaceous but firm; surfaces sparingly setulose; rachis winged in the upper part; veins oblique, once or more times forked. Sori moderately large, the $1-3$ lower of each pinna often double. - Fruiting young specimens often small and with the lowest pinnae less incised. The description is taken from specimens gathered by Raciborski in Central Java and determined as Asplenium pusillum, Bl.

Malaya.

(27b) Domedi: Capelog, Philipp. Journ., II, 129.

Rhizome erect. Slipes close, 20-30 c.M. long, straight, the base greybrown and densely clothed with brown, falcate scales, the upper part stramineous-brown and covered like the rachis with few, short, narrow, castaneous, whether or not deflexed, distand scales. Fronds 40 -50 c.M. long, hardly 20 c.M. broad, acuminate, 2-pinnatifid, the rachis stramineous-brown. Pinnae $\pm 12-17$ on each side, the central ones the largest, horizontal, short-stalked, \pm 2 c.M. broad, acuminate, deeply pinnatifid, the hase truncate, the rachis castaneous. Lobes oblong, $\pm \mathbf{5}$ m.M. broad, subfalcate, serrulate, obliquely truncate, separated hy sinuses $\pm 1 \mathrm{~m}$.M. broad. Texture herbaceous; surfaces naked, upper hlack-green, lower olivaceous; veins simple 5 -6-jugate. 
35. Diplazium. $\mathbb{S} 1$. nudiplazium.

Sori 2-5 m.M. long, oblique, rarely diplazioid, distant from the costulae, not reaching the margin.

Mindoro.

* (28a) D. Pelersenili Chast, Bull. Ac. Int. Bot., 1902, 245; D. Lasiopteris, Kze., Linn., XVII, 568; Bedd., Ferns S.I., tab. CLX; Asplenium lasiopteris, Melt., Rac., Flor. Btz., 1, 226; A. tomentosum, Melt., Farng., VI, Asplen., No. 209; A. Petersenii, Kze, (oldest name).

Rhizome creeping, clothed with short, broad, \pm adpressed scales. Stipes 15-50 c.II. long, erect, villose, scaly at the base, $1-5$ c.M. apart. Fronds 15 -43 c.M. long, $6-20$ c.M. broad, lanceolate, with a toothed to deeply pinnatifid terminal pinna. Lateral pinnae $\pm 8-15$ on each side, \pm horizontal, straight or falcate, bluntish or acute to acuminate, close or \pm distant, the upper ones sessile, the lowest subsessile, sometimes deflexed and shorter than the next in order, the longest $3 / 4-3$ c.M. broad, cut $\pm 1 / 2$-way down to nearly to the costa, the base broadly cuneate, nearly truncate, or sometimes narrowed in the lower pinnae, the edges of the lobes \pm crenate. Texture herbaceous; rachis and at. least the under surface villose or paleaceous; main veins pinnate in the lobes. Sori shiort.

Java, New Guinea; China, Br. India.

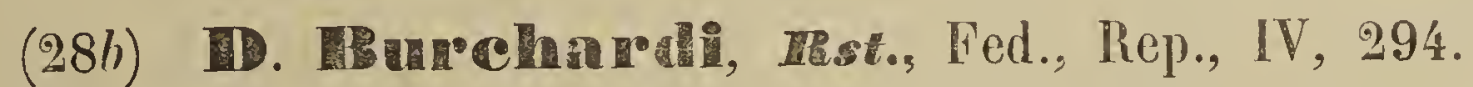

Stipes slender, to 15 c.M. long or longer, the inner side deeply sulcate, the groove tomentose, the rest naked; rachis slightly hirsute. Fronds deltoidlanceolate, long-acuminate, to 27 c.M. long, 16 c.M. broad at the base, pinnate. Pinnae to 20-jugate, subcontiguous, spreading, falcate; lowest pinnae largest, to 8 c.M. long, $21 / 2$ c.M. broad, ovate-elongate, short-acuminate, pinnatifid nearly to the costa, the segments linear, moderately acute, suberect, somewhat falcate, the lowest very abbreviate, the central the largest, $\pm 1 \%$ c.M. long, $4 \mathrm{~m}$.II. broad, the highest rather suddenly diminished into the denticulate apex; next following pinnae similar to the basal ones in the fully developed plants, but similar to the central pinnae in the fronds of the younger plants; central pinnae short-stalked, subfalcate, \pm equally truncate at the base on both sides, auricled on the upper side, linear-lanceolate, short-acuminate, pinnatifid $\pm 1 / 2$-way down to the costa, the segments linear-lanceolate, falcate, the lowest anterior elongate, the lowest posterior slightly reduced or nearly as long as the others, the medial ones $\pm 5 \mathrm{~m}$.M. long, $5 \mathrm{~m}$.M. broad at the base, the higher ones gradually tapering into the crenate apex, the point 
entire; higher pinnae sessile, obliquely serrate at the margin, otherwise similar to the medial ones; highest pinnae gradually passing into the lobes of the terminal pinna. Texture chartaceo-herbaceous; colour blackish when dry; surfaces naked; costulae pinmate, slightly hirsute beneath; veins simple, to 8-jugate in the lower, to 5-jugate in the central pinnae. Sori copious, straight, parallel, reaching \pm from the costulae to the edge; indusium firm, shortly fimbriate, pilose when young. - Near D. sorzogonense, $P r$.

\section{Sumatra.}

* (29a) D. Sorzogonense, Pop., Copel. Polypod. Philipp., 74; Bedd., Ferns Br.I., II, tab. CGXLVI; Asplenium sorzogonense, Pr., Hk. Bk., Syn. Fil., 236 ; - var. major, Bedd., Handb. Ind. Ferns, Suppl., 40.

Stipes tufted, $10-15$ c M. long, densely fibrillose below. Fronds $50-6 \breve{3}$ c.M. long, 20-3 3 c.M. broad, with nurnerous pinnae on each side, the lower ones sessile, $10-18$ c.M. long, $\pm 21 / 2$ c.M. broad, \pm truncate at the base, cut down regularly throughout $2 / 3$ of the way down to the costa into spreading, blunt, subentire lohes $\pm 4-5 \mathrm{~m}$.M. hroad. Texture herbaceous, rachis slightly fibrillose; main veins pinnate in the lobes; veins simple. Sori in regular rows, reaching from the main veins to the edge.

Var. major: Stipes \pm 75 c.II. long. Fronds 120-180 c.M. long. Pinnae \pm 50 c.M. long, $5-7 \frac{1}{2}$ c.M. hroad, the 3 lower pairs much deflexed, cut down nearly to the costa into narrow, slightly crenated segments. Surfaces naked; veins generally forked. - Perhaps a distinct species.

Philippines, Malacca; Himalaya ; - var. major: Malacca.

\section{(296) D. brachysonoides, Congel., Philipp. Journ., II, 127,} tab. I, A.

Stipes $20-40$ c.M. long, black in the lower, dirty-brown in the upper part, sparingly clothed like the rachis with narrow, spreading, flexuosc scales becoming smaller towards the ajex of the frond Fronds $50-60$ c.M. long, \pm 50 c.M. broad, acuminate, hardly 2-pinnate, thie apex pinnatifid. Central pinnae largest, horizontal, acuminate, deeply pinnatifid, the base truncate or subtruncate, with a short, black stalk; lowest pinnae slightly remote and reduced, sometimes deflexed. Lobes oblong, subacute, the largest \pm 3 c.M. long, \pm 1 c.M. broad, sharply serrate towards the apex, connected at the base by a narrow wing, but some of them sometimes free, the lowest lobes of the lowest pinnae reduced. Texture papyraceous; upper surface black- 
53. DiplaziUm. $\$ 1$. endiplaziUn.

green, lower olive-green; veins forked. Sori small, oblong, oblique, \pm costular, hardly 2 m.M. long, the lowest often double, longer.

Mindoro.

(30) D. Prescottianum, Moore, G. Chr., Ind. Fil.; Asplenium Prescollianum, Wall., Hk., Spec, Fil., III, 251.

Stipes $\pm \mathbf{5} \breve{~ c . M . ~ l o n g, ~ s t r a m i n e o u s, ~ m u r i c a t e . ~ F r o n d s ~ t o ~} 80$ c.M. long, ovate-lanceolate, with several to numerous spreading pinnae. Lower pinnae 10 c.M. apart, upper 4 c.M. apart, all petiolate, on stalks to 1 c.M. long except the highest ones, which are sessile; lower pinnae pinnatifid $2 / 3$ on the way down into blunt lobes and the lowest cut down quite to the costa at the base, (the lower segments 2 c.M. long, linear-oblong, blunt at the apex), the base suddenly narrowed or rounded on both sides. Texture thin-herbaceous; rachis naked, smooth or muricate; main veins fine, pinnate in the lobes with the short sori on the branches.

Malaya.

(31a) H. Inrechydodune, Copel., Polypod. Philipp., 7: ; Asplenium brachypodum, Bk., Hk. Bk., Syn. Fil., 490; (? D. grammitoides, $\mathrm{Pr}$, G. Chr., Ind. Fil., 669).

Stipes tufted, slender, $1-21 / 2$ c.M. long, with a few, minute, linear scales. Fronds oblanceolate, acuminate, $10-15$ c.M. long, $\pm 21 / 2$ c.M. broad, 2 -pinnate. Lower pinnae lanceolate-deltoid, $\pm 1 / 2$ c.M. broad, distinctly stalked, square on upper side, cuneate-truncate on lower, cut down to the rachis below; many lower pinnae distant, reduced. Lowest anterior pinnulae much the largest, cuneate-oblong, dentate, 2-4 m.M. broad, the others lanceolate, entire. Texture moderately firm; rachis naked; main veins pinnate in the lower lobes. Sori medial, linear.

Philippines.

(31b) D. EBolsteri, Copel., Philipp. Journ., I, Suppl., 254, tab. II.

Rhizome ascending. Stipes approximate, $5-10$ c.M. long, slender, the base black, clothed with black-rastaneous scales, the upper part dirty-green and nearly naked like the rachis. Fronds $20-25$ c.M. long, $31 / 2-5$ c.M. broad, acuminate, the terminal pinna long, pinnatifid at the base. Lateral pinnae many on each side, falcate, erecto-patent, stalked, dentato-lobate, the base subtruncate, conspicuously and deeply auricled on the upper, obliquely cut away on the lower side, the apex serrate; lower pinnae deflexed, pimna 
tifid, pinnate at the base (the auricle free, serrate or crenate); higher pinnae toothed. Texture papyraceous; surfaces naked; veins distinct, forked, pinnate in the auricles. Sori very oblique; indusium narrow, castaneous-fulvous.

Mindanao.

(32) D. Cormitum, C. Craso, Ind. Fil.; Asplenium crinitum, B/., Journ. of Linn. Soc., Bot., XXIV, 258; A. sorzogonense, Pr., var. majus, Hk., Spec. Fil., III, 252.

Stipes strong, long, clothed like the rachis with lanceolate, castaneous, crisped scales. Fronds oblong-lanceolate, 2-pinnatifid or 2-pinnate. Pinnae lanceolate or the lower ones lanceolate-oblong, \pm 15 c.M. long, with the largest segments \pm b c.M. long, $1-1 \frac{1}{2}$ c.M. broad. Ultimate lobes parallel, oblong, obtuse, $\quad 5-9$ m.M. broad. Texture membranaceous; main veins pinnate; lower veins forked, oblique. Sori confined to the inner half of the segments, neither very close nor so regular.

Borneo.

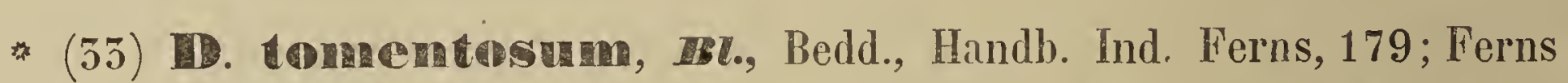
Br.I., II, tab. CXCV; Asplenium tomentosum, Hk. (not Mell.), Rac., Flor. Btz., I, 226.

Rhizome short, the scales dense, lanceolate-acuminate, black or dark-brown. Stipes tufted, dark-brown, fibrillose above, scaly towards the base, $\pm 9-50$ c.M. long. Fronds lanceolate, acuminate, $15-50$ c.M. long; rachis dark-brown, fibrillose or villose; the apex deeply pinnatifid with broadly serrate or crenate, blunt, oblong lobes. Pinnae $\pm 1 b-20$ on each side, the highest oblong, erecto-patent, blunt, sessile with a broad base, slightly auricled above, the edge crenato-serrate; central pinnae sessile or subsessile, spreading, $\pm 3-31 / 2$ c.M. long, 5-8 m.M. broad, blunt or acute, the upper base truncate-auriculate, the lower base truncate, rounded or broadly cuneate, the edge distinctly toothed; lowest pinnae stalked, deflexed, lanceolate, $\pm 4-5$ c.M. long, blunt or acuminate, $\pm 1 \frac{1}{2}$ c.M. broad at the centre, the edge cut down $1 / 2-3 / 4$ on the way to the costa, the segments oblong, blunt, erecto-patent, serrate or crenate, the lowest anterior segment (auricle) free, deflexed. Texture coriaceous; surfaces naked; costae and veins distinct, fibrillose beneath; main veins pinnate in the lobes, $1-2 \times$ forked in the teeth of the central pinnae; veins often \pm hairy. Sori rather few, slightly recurved, reaching \pm the midrib and the margin.

Málaya. 
53. Diplaziun. $\mathbb{S} 1$. eudiplaziún. = selavicion SI p. 264

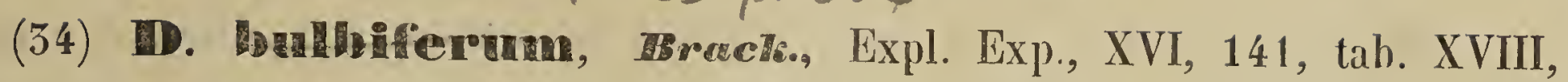
fig. 1; D. Braclienridyei, Diels, Schum. \& Laut., Flor. deut. Sch.geb., 124; Asplenium Brackenridgei, Bk., Hk. Bk., Syn. Fil., 234.

Rhizome thick, oblique. Stipes tufted, 15-25 c.M. long, thě base black, clothed with black, subulate scales, the rest slender, slightly setose with scattered, black bristles. Fronds $20-45$ c.M. long, 8-25 c.M. broad, ovateoblong, acuminate, pinnate, gemmiferous and somelimes viviparous. Pinnae $\pm 6-16$ on each side below the pinnatifid apex, more or less distinctly stalked, \pm horizontal, acute, to \pm 2 c.M. broad, crenate at the base on the lower side, the upper base truncate, auriculate, the edge coarsely crenatolobate, the lobules short, to $3 \mathrm{~m} . \mathrm{M}$. long, $3-5 \mathrm{~m} . \mathrm{M}$. broad, decumbent, subacute, tooth-like; lowest pinnae shorter, deflexed. Texture herbaceous; surfaces and rachis naked; colour blackish-green above, paler beneath; veins pinnate in the lobules Sori on the anterior veinlets, often double, to $7 \mathrm{~m}$.M. long; indusium thin, decoloured, diaphanous. - [T'exture subcoriaceous; pinnae cut $1 / 3$-way down to the costa. (Bk.)].

Luzon, Mindanao; Polynesia.

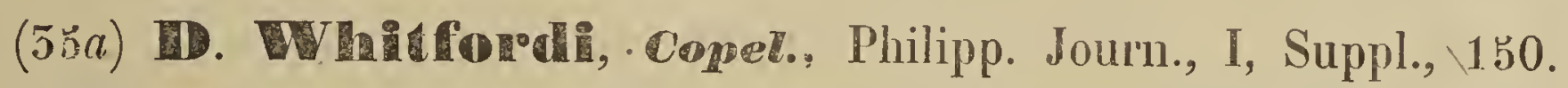

Rhizome short, horizontally creeping. Stipes approximate, $10-20$ c.M. long, the lower part asperous, the base black, clothed with scallered, brown, caducous scales, the upper part smooth, naked, greenish or stramineous. Fronds 20-5y c.M. long, 6-15 c.M. broad, 2-pinnatifid, the rachis naked. Pinuae 10-20-jugate, alternate, the central ones the largest, \pm spreading, broadly lanceolate, acute, cut down nearly to costa; lower pinnae rather distant, somewhat shorter, deflexed. Lobes oblong, 3-4 m.H. broad, serrate towards the apex. Texture chartaceous; surfaces naked; veins rarely forked. Sori $4-5$ on each side of the costulae, occupying the lower part of the veins. Luzon.

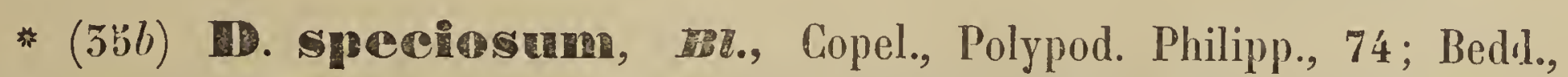
Ferns Br.I., II, tab. CCXC; Asplenium speciosum, Mell., Rac., Flor. Btz, I, 224; (? D. sorzogonense, Pr., C. Chr., Ind. Fil.).

Rhizome or caudex erect or suberect, clothed with lanceolate scales. Stipes tufted, 30-50 c.M. long, firm, erect, stramineous or brownish, the base covered with narrow, lanceolate scales. Fronds 50-150 c.M. long, 20-55 c.M. broad, with $10-20$ pair's of pinnae below the pinnatifid apex, the lower ones often stalked, the stalks $1-4 \mathrm{~m}$.M. long. Largest pinnae to 
17 c.M. long, $2 \frac{1}{2}-4$ c.M. broad, straight or subfalcate, horizontal or nearly erecto-patent, the apex acuminate, the edges pinnatifid to deeply pinnatipartite, the lowest segments generally the longest, \pm spreading and all blunt, entire, crenate or toothed. Texture subcoriaceous; rachis naked or \pm scaly; veins pinnate in the lobes. Sori reaching nearly or quite to the edge.

Malaya.

(36a) D. eyatheifolium, Pr., Copel., Polypod. Philipp., 75 ; Asplenium cyatheifolium, Rich. (not Bory), Hk. Bk., Syn. Fil., 238.

Caudex erect, subarborescent. Stipes erect, firm, dark-brown, nearly naked. Fronds $45-60$ c.M. long, 30-45 c.M. broad. Lower pinnae to $20-25$ c.M. long, $7-8$ c.M. broad, cut down to the rachis in the lower $2 / 3$ into numerous pinnulae on each side, the upper ones inciso-crenate, the lower ones $3 \frac{1}{2}-4$ c.M. long, $\pm 1-1 \%$ c.M. broad, cut down $1 / 3$ of the distance to the costa into oblong, falcate, sharply toothed lobes. Texture herbaceous; rachis dark-brown, naked like the stipe; main veins pinnate with $\mathbf{3}-\mathbf{4}$ veins on each side in the lower lobes. Sori falling short of the edge.

Philippines, New Guinea; Polynesia.

(36b) D. davadense, Copel., Philipp. Journ., I, Suppl., 151.

Stipes lufted, \pm 70 c.M. long, conspicuously sulcate, nearly naked, the lower part asperulous. Fronds ovate, $1-1 \frac{1}{2}$ M. long, the lower part 2-pinnate, the higher part simply pinnate, the terminal part pinnatifid, the apex acuminate, serrate. Pinnae few, spreading, \pm 50 c.M. long, 20-25 c.M. broad, the lower ones hardly reduced. Pinnulae short-stalked, $21 / 2-3$ c.M. broad, the base truncate, the edge cut $\pm 1 / 3$-way down to the costa, the apex acuminate. Lobes falcate, truncate, obscurely denticulate. Texture membranaceous; surfaces naked; veins \pm 6 on each side of the main veins, arcuate, remote, simple. Sori linear. - Near D. cyatheifolium, Pr, \& latifolium, Moore.

\section{Mindanao.}

* (37a) W. Intifoliumm, Hoore (not Don), Christ, Farnkr. d. Erde, 220 ; D. maximum, C. Chr., Ind. Fil.; D. dilatatum, Bl., Bedd., Ferns S.I., tab. CLXII (not quite correct); Asplenium lalifolium, Don, Rac., Flor. Btz., I, 227.

Caudex erect, short or subarborescent, clothed with linear-lanceolate, dark-brown scales. Stipes strong, erect, 50-90 c.M. long, livid, smooth, scaly at the base. Fronds subdeltoid, 90--200 c.M. long, with \pm 12 pinnae on each side, the largest to \pm 50 c.M. or more long. Pinnulae numerous, the 
largest to 18 c.M. long, to \pm 3 c.M. broad at the hase, linear-lauceolate, the point acute or acuminate, the edge lobed, and crenate or loothed, the base truncate or rounded. Texture subcoriaceous; rachis naked; main veins pinnate in the lobes with $b-8$ veins on each side. Sori linear, the lowest much the longest, not reaching the edge. - A variable plant.

Trop. Asia, Polynesia \& Australia, China.

(57b) D. Aolichosonom, Copet., Philipp. Journ., I, Suppl., 151. Rhizome strong, clothed with long, black-brown scales. Stipes close, \pm 35 c.M. long, clothed with fuscous, linear, contorted scales, the upper part subglabrescent, at length sparingly muricate. Fronds ovate, $1-1 \frac{1}{2}$ M. long, 2-pinnate, the apex pinnatifid, the main rachis glabrescent, sometimes asperulous. Pinnae remote, the largest \pm 4 b.M. long, \pm 20 c.M. broad, the lowest shorter. Pinnulae short-stalked, \pm 2 c.II. broad, subfalcate, acuminate, the base truncate, the edges lobed $\pm 1 / 3$-way down in the lower part, the apex serrate. Lobes truncate, denticulate. Texture papyraceous; surfaces naked; veins \pm 6 on each side of the main veins, the lower ones curved. Sori linear.

Mindanao.

(58) D. manilemse, c. Chr., Ind. Fil.; Asplenium serrulatum, Pr., Rel. Haenk., I, 46; A. manilense, Spr., Syst., IV, 89.

Fronds ovate, \pm 45 c.M. long, 2-pinnate; main rachis tetragonal, clothed with small, ovate, fuscous, membranaceous scales. Pinnae distant, alternate, petiolate, pinnate, the apex pinnatifid, acuminate; central pinnae $\pm 12 \%$ long, the rachises scaly like the main one. Pinnulae spreading, sessile, lanceolateoblong, $21 / 2-4$ c.M. long, $1-11 / 4$ c.M. broad, acuminate, the base truncate on both sides, the highest ones entire, the central ones serrate with the serratures 2-denticulate, obtuse, the lowest largest, serrulate. Texture membranaceous; surfaces naked; veins simply branched. Sori long, narrow, double; indusium diaphanous.

Philippines.

(39) D. vestitum, Pr., Copel., Polypod. Philipp., 75 ; Asplenium veslitum, Hk. (not Pr.), Hk. Bk., Syn. Fil., 259; Hk., 2nd Cent. of Ferns, tab. XLVI.

Rhizome erect. Stipes stout, erect, brownish, tomentose, sometimes muricate. Fronds 60-90 c.M. long, 20-45 c.M. broad, with numerous pinnae on each side, the lower ones $10-25$ c.M. long, to 10 c.K. broad, with numerous, distinct, subsessile pinnulae, which are $\pm 21 / 2$ c.M. broad, blunt, bluntly lobed to a depth of $5-6 \mathrm{~m} . \mathrm{M}$., the base narrowed suddenly or even cordate.

Filiaes. 
Texture thinly herbaceous; rachis chaffy like the stipe; main reins pinnate in the lobes; veins $4-5$ on each side. Sori not reaching the margin.

Philippines.

(40) D. deltoideum, Pr., Copel., Polypod. Philipp., 76; Asplenium delloideum, Pr., Hk. Bk., Syn. Fil., 237; Pr., Rel. Haenk., I, tab. VII, fig. 2.

Rhizome erect, black-scaly. Stipes $15-20$ c.M. or more long, black and black-scaly at the base, naked and green above. Fronds 30-40 c.M. long, $20-25$ c.M. broad, deltoid, with a few distant pinnae on each side. Lowest pinnae largest, \pm 6 c.M. broad, bearing numerous subsessile pinnulae. Pinnulae obtuse, $\pm 1-1 \frac{1}{2}$ c.M. broad, cut $\pm 2 / 3$ of the way down to the costa into blunt lobes. Texture herbaceous; surfaces naked; ráchises naked, black or green; main veins pinnate in the lower lobes. Sori reaching the margin.

Celebes, Philippines.

(41a) D. Heyenianum, Pr., Copel., Polypod. Philipp., 76; Asplenium Meyenianum, Metl., Hk. Bk., Syn. Fil., 258.

Fronds probably $\pm 1 \mathrm{M}$. long, ovate-triangular. Largest pinnae 30-40 c.II. long, 20-2s c.M. broad, stalked, alternate, oblong-lanceolate, acuminate. Lower pinnulae $21 / 2-5$ c.Ir. broad, stalked or subsessile, linear-oblong, acuminate, the base subcordate, the edge pinnatifid $\pm{ }^{3} / 4$-way down to the costa; higher pinnulae decurrent with a narrow wing or confluent at the base. Lobes subopposite, ovate-oblong, subfalcate, obtuse, crenate or serrulate, to $\pm 3 / 4^{-}$c.M. broad. Texture thinly coriaceous; surfaces glabrous; rachis brown, channelled above; veins pinnate, the higher forked. Sori copious, reaching from the costulae nearly to the edge.

Philippines.

(41h) D. atratum, Cherist, Philipp. Journ., II, 165.

Stipes 25 c.I. or more long, sulcate, ebeneous or black-purple, the base thick, densely clothed on the inner side with long, subulate. black scales, the rest nearly naked or minutely furfuraceous. Fronds broadly deltoid, 5-pinnatifid, acute, 60 c.M. or more long, the base 45 c.M. or more broad. Pinnae distant, \pm 20 on each side, on stalks $\pm 2-3$ c.M. long, the lowest not reduced, \pm 10 c.ll. broad, horizontally spreading, long-acuminate, narrowed at the base, the higher subsessile. Pinnulae \pm 20 below the incised apex, more than 1 c.I. apart, horizontally spreading, the lowest stalked, broadly lanceolate, acuminate, cut down $1 / 2$-way to the costa; but deeply pinnatifid at 
53. Diplazium. $\$ 1$. eudiplaziun.

the base. Lobes \pm 15 on each side, $\pm 5 \mathrm{~m}$.M. long, porrect, triangularfalcate, acute, the edges serrulate, often reflexed. Texture very rigidly coriaceous, nearly woody; surfaces naked; colour black-brown; veins $\pm 4-7$-jugate, oblique, stout, simple. Sori reaching from the costulae nearly to the edge, very oblique, convex, black-brown, linear, simple; indusium coriaceous, brown, persistent.

Palawan.

(42) D. amplissimum, Diels, in Engl. \& Prantl, Nat. Pft.Fam., I', 227; Asplenium amplissimum, Bk., Ann. of Bot., V, 310.

Fronds ample, 3-pinnatifid. Pinnae oblong-lanceolate, 30-45 c.ly. long. Pinnulae lanceolate, lower short-stalked, $7-10$ c.M. long, $21 / 2-51 / 2$ c.M. broad, cut down to a narrow wing into oblong-lanceolate, crenate tertiary segments. Texture moderately firm; surfaces naked; rachises brown-stramineous, naked or sparsely fibrillose; veins 6-7-jugate, mostly forked. Sori oblong, reaching from the midrib $1 / 2$-way to the edge.

Amboyna.

(43a) D. oligosonum, Copel., Philipp. Journ., II, 128.

Rhizome erect. Stipes close, \pm 40 c.M. long, the base castaneous, swollen, aculeate, slightly scaly, the rest smooth and yellowish-brown like the rachises. Fronds b0-60 c.II. long, 40-50 c.M. broad, acuminate, 3-pinnatifid. Lateral pinnae opposite, \pm 3-jugate, rather equal, \pm 10 c.M. apart, stalked, horizontal, acuminate. Pinnulae subsessile, \pm 7 c.M. long, \pm 2 c.M. broad, caudatoacuminate, the base truncate, the edge cut down nearly to the costa intooblong, obtuse, subfalcate, entire or serrulate segments $4-5$ m.M. broad. Texture thinly coriaceous; surfaces naked, the upper black-green, the lower paler; veins distant, often simple. Sori minute, nearer the edge than the costulae.

Mindoro.

* (43b) D. polypodioides, Hi., Christ, Farnkr. d. Erde, 219; Bedd., Ferns Br.I., II, tab. CCXCIII; Asplenium polypodioides, Mell., Rac., Flor. Btz., I, 227, p. p.

Caudex erect, strong, subarborescent, densely clothed at the crown with long, brown scales. Stipes densely tufted, stout, 30-100 c.ll. or more long. Fronds $90-120$ c.I. long, \pm 50-60 c.II. broad, 2-piniate, with $\pm 8-9$ distant, stalked, divided pinnae on each side below the simple higher ones. 
Pinnulae $10-13$ on each side, approximate, sessile, sharply acuminate, 5 - 10 c.M. long, $\pm 1-2$ c.M. broad at the suddenly narrowed base, the edge cut $1 / 2-3 / 4$ way down to the costa into oblong, entire, crenate or serrate, bluntish, approximate or close lobes. Texture herbaceous; surfaces naked or nearly so; rachis green, \pm naked; main veins pinnate with $5-7$ simple or forked veins on each side. Sori copious, the lower commonly double, commencing at the main vein (costula), generally falling short of the edge.

Malaya; Trop. Australia, North. India.

(44) D. eloeneum, J. Smo, Copel., Polypod. Philipp., 76; (? D. asperum, Bl., G. Chr., Ind. Fil.).

Differs from D. polypodioides, Bl. by its slender, naked, ebeneous rachises, and the ultimate lobes, with but 4 distinct veins in each.

Philippines.

* (4b̆a) D. asperuma, \#t., Christ, Farnkr. d. Erde, 219; D. polypodioides, Bedd., Ferns S.I., tab. CLXIII; Asplenium polypodioides, Mell., Rac., Flor. Btz., I, 227, p. p.; A. asperum, Hk. (not Mett.), Hk., Spec. Fil., III, 258.

Near D. polypodioides, $B l$., but the stipes, main and partial rachises asperous and more or less scaly. Pinuulae and lobes \pm spreading, the lobes rounded or bluntish, not truncate. Texture rather coriaceous; veins 8-12 on each side, commonly simple. Sori short, commonly coufined to the lower half of the veins.

Malacca, Java, Mindoro; North. India.

(4ab) ID. fuctuosam, Copel., Philipp. Journ., I, Suppl., 150, tab. VIII.

Near D. polypodioides, $B l$. Rhizome erect. Stipes \pm 1 M. long, deeply sulcate, the lower part clothed with long, linear, black-brown scales leaving the stipes spinulose when they fall, the upper part glabrescent. Fronds $1 \frac{1}{2}-$ 2 M. long, \pm 1 M. broad, the rachis muricate. Pinnae \pm 15 c.M. broad, nearly spreading, the lower ones hardly reduced, the rachis smooth. Pinnulae subsessile, acuminate, \pm spreading, $\pm 1 \frac{1}{2}$ c.M. broad near the base, the edge hardly cut $1 / 2$-way down to the costa into entire, falcate, truncate lobes. Texture herbaceous; surfaces naked; veins \pm 6 on each side of the main veins. Sori often filling up the whole under surface.

Mindanao.

(46) D. promophyllum, K*e., Bot. Zeit., 1848, 194. 
Fronds large. Pinnae petiolate, falcate, oblong, acuminate, the largest 30-45 c.II. long. Pinnulae short-stalked, spreading, oblong, acuminate, the base cordato-truncate, the edge pinnatifid. Lobes falcate, ovate, bluntish, irregularly inciso-serrulate, the margin revolute. Texture subcoriaceous; surfaces glabrescent; rachis partially aculeolate; costae and costulae paleaceo-asperous, \pm flexuose. Sori numerous, at length confluent.

Java.

(47) D. ceræamicum, C. Cler., Ind. Fil.; Asplenium ceramicum, Miq., Ann. Mus. Bot. L. B., IV, 168.

Main rachis covered with few, deciduous scales; secondary rachises dilated at the base, blackish. Fronds oblong, membranaceous, large, 3-pinnate or 4-pinnatifid. Pinnae and pinnulae alternate. Pinnae short-stalked, lanceolate, acuminate, the lower ones $55-40$ c.M. long. Pimulae 10-13 c.M. long, shortstalked, long-acuminate. Tertiary divisions short-stalked, sligthly falcate, the apex obtuse, serrulate, the lower part crenato-pinnatifid, the base broadly cuneate. Veins 2-fid or the lower ones forked or pinnate, the higher branches soriferous. Sori linear, medial on the veins; indusium membranaceous, entire, brownish.

Ceram.

(48) D. Huttoni, C. Chr., Ind. Fil.; Asplenium Hulloni, Bk., Ann. of Bot., V, 311.

Fronds large, deltoid, decompound. Pinnae oblong-lanceolate, 50 c.M. long or longer. Pinnulae lanceolate. Tertiary segments obtuse, 4broad, deeply. pinnatifid. Lobes oblong, obtuse. Texture moderately firm; surfaces naked; main veins (costulae) pinnate in the lobes; veins erecto-patent, simple. Sori medial, short; indusium firm, naked, persistent.

Malaya.

\section{S2. ANISOGONIUM.}

a. Fronds simple, or wilh 1-6 lateral pinnae on each side.

b. Simple frond or terminal pinna cordate at the base.

c. Fronds simple, or with 1-2 pairs of lateral pinnae.

(49) D. cordifolium.

c.c. Fronds pinnate; pinnae 3-5-jugate.

(50) D. Forbesii. 
6.t. Simple frond or lerminal pinna cuneate or rounded at the base.

*. Stipes scaly throughoul. Fronds with $0-3$ lateral pinnae on eacn side.

(51) D. alismifolium.

*.*. Stipes scaly at the base. Fronds with 1-6 lateral pinnae on sach side.

(52) D. fraxinifolium.

a.a. Fronds pinnate with more than 6 lateral pinnae on each side. aspers:

s. Pinnae entire.

*. Pinnae membranaceous, narrowly cuneate at the base.

(53) D. angustatum.

*.*. Pinnae subcoriaceous, rounded at the base.

(54) D. pariens.

\$.\$. Pinnae toothed, wavy or slighly lobed.

a.a.a. Fronds at least 2-pinnate $\left(^{*}\right)$.

1. Largest pinnae to 25 c.M. long.

2. Pinmulae rounded at the base.

(55) D. proliferum.

(55a) D. Surevizu

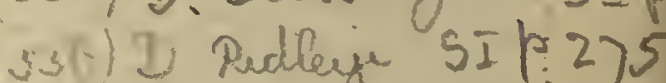

(55c) D Brothere

(56) D. Smithianum.

2.2. Pinnulae truncate at the base.

(57) D. spinulosum.

1.1. Largest pinnae \pm 30 c.M. long or longer in the fully developed fronds.

(58) D. esculentum.

* (49) D. cordifolium, IBt., Christ. Farnkr. d. Erde, 221; Hk., Icon. Pl., X, tab. GMXXXVI; Asplenium cordifolum, Mett., Hk. Bk., Syn. Fil., 243; A. integrifolium, Melt., Rac., Flor. Btz., I, 230, p.p.; Callipteris cordifolia, Copel. (not J. Sm.), Polypod. Philipp., 70; Anisogonium cordifolium, Bedd., Ferns Br. I., II, tab. CCCXXXI.

Rhizome erect, densely clothed with brown, lanceolate scales. Stipes clustered, \pm 20 c.M. long, firm, erect, scaly below. Fronds $\pm 2 \breve{b}-3 \breve{c}$ c.M. long, \pm 10 c.M. broad, undivided, acuminate, the edge entire or subrepand, the base cordate. Below this there are sometimes $1-2$ pairs of lateral pinnae, which are \pm erecto-patent, similar to the simple frond but smaller and narrower, the lowest to \pm 15 c.M. long and $\pm \mathbf{b}-7$ c.M. broad. Texture coriaceous; surfaces naked; veins in groups of 3-4, anastomosing in the outer half of the pagina. Sori reaching from the midrib \pm to the edge.

Africa to Polynesia.

* (๖0) D. Forbesii, C. Cher., Ind. Fil.; Asplenium Forbesii, Bk., Ann. of Bot., V, 312 . 
Stipes naked, 12-15 c.M. long. Fronds deltoid, simply pinnate, \pm 30 c.M. long. Pinnae $\pm \mathbf{3}$-5-jugate, lanceolate, acuminate, entire, sessile, \pm 15 c.M. long, 5-6 $1 / 2$ c.M. broad, cordate at the base. Texture moderately firm; surfaces naked; veins $\mathbf{3}$-b-jugate, anastomosing towards the margin. Sori linear.

Java.

(马1) D. alismifolium, v. A. v. R.; D. Cumingii, C. Chr., Ind. Fil.; Asplenium alismaefolium, Hk., Hk. Bk., Syn, Hil., 243; Calliplerts alismaefolia, J. Sm, Copel., Polypod. Philipp., 70; Anisogonium alismaefolium, Christ, Fil. Saras., III, 255; Oxygonium alismaefolium, J. Sm., (oldest name).

Stipes $5-15$ c.M. long, firm, erect, scaly throughout. Fronds varying in shape from simple, oblong-lanceolate, 15 -2 25 c.M. long, entire, acuminate, to ternate or pinnate with a large terminal and to 5 pairs of lateral pimnae, each like the entire frond of the simple form. Texture coriaceous; veins $\pm \mathbf{5}$ to a group in the inner half, anastomosing copiously, with hexagonal areolae towards the edge.

Celebes, Philippines.

* (52) D. Praxinifoliuim, Pro, Rel. Haenk., I, 49 ; D. elegans, Hk. Icon. Pl., X, tab. CMXXXIX-GMXL; D. lineolatum, Bl., Enum., 191; Asplenium lineolatum, Metl., Hk. Bk., Syn. Fil., 243; Callipleris elegans, J. Sm., Copel., Polypod. Philipp., 70; Anisogonium lineolatum, Bedd., Ferns Br.I., II, tab. CGCXXX ; A. elegans, Pr., Epim., 93.

Rhizome erect, the scales brown, lanceolate. Stipes erect, firm, grey, 15-25 c.M. long, scaly below. Fronds occasionally simple, usually with a terminal pinna and 3-6 pairs of lateral ones, which are $15-30$ c.M. long, 4-ə̌ c.M. or more broad, entire, or serrate towards the often suddenly acumi. nate apex, the base subcuneate or rounded. 'Texture coriaceous; rachis naked; veins 4-8 to a group, uniting slightly towards the margin. - A small form with bluish-green, succulent fronds and $1-3$ lateral pinnae was reported from Celebes (Christ, Ann. Btz., XV, 122).

Malaya; Japan.

(b3) D. angustatum, Mmann, Nat. Tijdschr. Ned. Ind., XXIII, 406. Stipes \pm terete, smooth, reddish-brown, glossy. Fronds \pm ovate, $30-45$ c.M. long (incl. the stipe), pinnate. Pinnae alternate, the higher ones sessile, decurrent, the lower short-stalked, lanceolate or oblong, acuminate, the base 
narrowly cuneate, the edge entire, \pm revolute. Texture membranaceous. Sori reaching from the midrib to the edge, parallel, dichotomous as in D. cordifolium, $B l$.

Banca.

(54) D. paniens, C. Chr., Ind. Fil ; Callipteris parions, Copel., Polypod. Philipp., 70.

Rhizome strong, erect, black, clothed with lanceolate, dark-brown scales. Stipes canaliculate, \pm 55 c.M. long, blackish and slightly scaly at the hase, above green and clothed with minute fibrils like the rachis. Fronds \pm 50 c.M. long, \pm 20 c.M. broad, pinnate. T'erminal pinna ovate, acuminate, entire, rounded at the base; lateral pinnae \pm 11 on each side, similar to the terminal one, those of the lower half of the frond larger, \pm 10 c.M. long, \pm 4 c.M. broad, short-stalked. Texture subcoriaceous; surfaces naked; veins 1-2 $X$ forked, anastomosing: indistinct in the marginal $1 / 3$. Sori linear, straight, occupying the lower $2 / 3$ of the veins.

Philippines.

* (๖5) D. Droliferum, Thouars, Flor. Trist. d'Ac., 35ّ; D. decussatum, Christ, Farnkr. d. Erde, 221; Callipteris prolifera, Bory, Copel., Polypod. Philipp., 70; Asplenium decussatum, Sw., Rac., Flor: Btz., I, 251; A.proliferum, Lam.,"(oldest name); - var. robustum; Digrammaria robusta, Fée, Gen., 218 ; - var. accedens; Dipl. accedens, Bl, Enum., 192 ; A. spinulosum, Mett., Farng., VI, Aspl., 172 (not Ann. Mus. Bot. L. B., II, 257).

Rhizome erect (or creeping after Christ), the scales long, lanceolate. Stipes 50-60 c.M. long, strong, erect, scaly and slightly muricate at the base. Fronds large, $60-250$ c.M. long, the apex pinnatifid, and below this many to numerous sessile pinnae. Pinnae 8-30 c.M. long, 2-6 c.M. broad, the lower ones often stalked, the base truncate or subtruncate, the apex acute or acuminate, the edge toothed, wavy or slightly lobed, the lobes blunt, \pm toothed. Texture herbaceous to subcoriaceous; main veins uniting $\pm 1 / 3$ or less of the distance from the costa to the margin. Sori very regularly running along the veins, reaching \pm the edge, often copiously double.

Var. robustum: Pinnae $30-45$ c.M. long, deeply lobed in the upper part, in the lower cut down to the costa.

Var. accedens. Stipes muricate or spinulose throughout. A frica to Polynesia and Australia. 
53. DiplaziUm. $\$ 2$. ANisogonium.

(56) D. Smithianum, Diels, in Engl. \& Prantl, Nat. Pfl.Fam., I ${ }^{4}$, 228; Asplenium Smithianum, Bk., Hk. Bk., Syn. Fil., 245; Anisogonium Smithianum, Bedd., Handb. Ind. Ferns, 192; Callipteris Smithiana, Bedd., Ferns Br.I., II, tab. CGCXXXII.

Rhizome oblique, decumbent. Stipes thick, \pm 50 c.M. long, slightly scaly below, furfuraceous throughout and rather densely muricate. Fronds 45-60 c.M. long, by nearly as broad, with 4-5 pinnated pinnae and 4-5 that are only pinnatifid below the point on each side, the lowest $7-8$ c.M. apart, $\pm 20-25$ c.M. long, \pm 10 c.M. broad. Pinnulae sessile, long, $1 \frac{1}{4}$ - - 2 c.M. broad, the edge subentire, the point slightly toothed, acuminate, the base rounded on both sides. Texture subcoriaceous; both surfaces and rachis naked, the latter muricate in the lower part; veins in groups of $2-3$ on a side, the groups usually joining half-way across to the edge.

New Guinea, Batjan, Celebes, Luzon; Ceylon.

(57) D. Spinulosum, Bt., Enum., 193; Asplenium spinulosum, Mett., Ann. Mus. Bot. L. B., II, 237 (not Farng., VI, Aspl., 172); A. heteropteron, Mett., Farng. VI, Aspl., 174.

Stipes \pm 15 c.M. or more long, scaly and tomentose-chaffy, the scales membranaceous, blackish-brown, lanceolate, acuminate, thinly ciliate, deciduous. Fronds ovate, the base slightly narrowed. Pinnae stalked, $\pm 20-25$ c.M. long, ovate or lanceolate-oblong, the lower ones distant, pinnate, the ligher pinnatifid. Pinnulae approximate, the lower ones $\pm 7-8$ c.M. $\operatorname{long}, 1 \frac{1}{2}-2$ c.M. broad, subsessile, oblong-acuminate or slightly obtuse, the edge truncatocrenate, the base truncate; higher pimnulae adnate to the rachis, sometimes decurrent, the highest confluent. Lobes of the highest pinnae oblong, \pm bluntish. Texture membranaceous, rigid, opaque; lowest veins anastomosing; rachis deciduously scaly. Sori $2-5$ on each side, the lowest acroscopical double; indusium narrow, membranaceous. - (Stipe and rachis aculeate after Blume, l. c.).

Moluccas, New Guinea.

* (58) D. esculentum, Sw., Christ, Farnkr. d. Erde, 222; Asplenium esculentum, Pr., Rac., Flor. Btz., I, 231; Callipleris esculenta, J. Sm., Copel., Polypod. Philipp., 71; Bedd., Ferns, S. I., tab. CLXIV; Anisogonium esculentum, Pr., Bedd., Handb. Ind. Ferns, 192 ; Gymnogramme edulis, Ces., Fel. di Bor., 28; Hemionilis esculenta, Retz, (oldest name). 
Caudex erect, to 15 c.M. high, densely clothed with narrow, lanceolate scales. Stipes 1 - -60 c.M. long, strong, erect, tufted. Fronds $60-180$ c.M. long or longer, 2-pinnate, deltoid or broadly lanceolate. Lower pinnae 3045 c.M. long, $15-20$ c.M. broad. Pinnulae $7-15$ c.M. long, $1 \frac{1}{2}-2 \frac{1}{2}$ c.M. broad, short-stalked, the point acuminate, the edge crenate to shallowly lobed, the lobes entire or serrate, the base truncate and often auricled on both sides. Texture subcoriaceous; rachis often pubescent; main veins distinct, copiously pinnate with 6-10 veins on each side in each lobe, which are beginning to unite a short distance from the midrib, the higher ones often free. Sori copious, occupying nearly all the veins, reaching \pm the margin. - Lowest pinnae sometimes simple.

Trop. Asia \& Polynesia.

\section{ATHYRIUM, Roth.}

Characters of Diplazium, except that the sori and indusia are oblong, often strongly recurved, sometimes horseshoe-shaped or \pm reniform and then sometimes hardly diflerent from those of Lastraea, the lower of the same group rarely, the ligher never double. Fronds at least simply pinnate; veins free. Hk. Bk, Syn. Fil , tab. IV, fig. 38, e; Diels, in Engl. \& Prantl, Nat. Pfl. Fam., $I^{4}$, fig. 120.

a. Fronds simply pinnale. Pinnae entire or slighlly lobed, at best the lower ones pinnatifid.

\$. Rachis winged throughoul.

(1a) A. nanum. SI $p 27$

\$.S. Rachis not winged, or only winged in the upper half.

t. Fronds herbaceous, $\pm 71 / 2-15$ c.M. long.

*. Fronds $\pm 1-2$ c.M. broad.

(1b) A. pusillum.

*.*. Fronds $\pm 2-21{ }_{2}$ c.M. broad.

(1c) A. Toppingianum. SI $\mathrm{I} 27$

t. +. Fronds coriaceous, $\pm 15-50$ c.M. long.

(2) A. gedeanum. SIPr-

u.e. Fronds more copiously 2-pinnalifid to 3-pinnale.

b. Pinnae pinnatifid, somelimes pinnale al the base.

+. Lower pinnae nol redu ed.

*. Fronds small, $10 \pm 9$ c.M. broad.

$\times$. Indusium reniform.

(3a) A. anisopterum.

(3b) A. benguetense. anvil $=$ 
544. ATHYRIUM.

$\times . \times$. Indusium nol reniform.

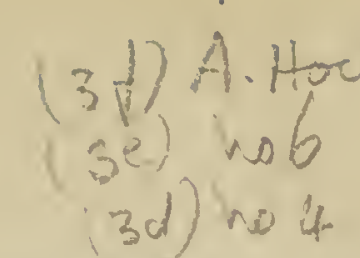

(3c) A. Copelandi.

*.*. Fully developed fronds larger, more than 10 c.M. broad.

+. Lower pinnae reduced.

(4) A. macrocarpum.

(5) A. acrostichoides.

b.b. At least the lower pinnae pinnate to 2-pinnute. ( $\left.{ }^{1}\right)$

c. Fronds small, under 15 c.M. long. $\left({ }^{2}\right)$

\$. Rhizome creeping, often intertwined.

(6) A. hyalostegium.

\$.\$. Rhizome short, erect.

*. Fronds \pm as broad as long.

(7) A. Loheri.

*.*. Fronds $\pm 2 \times$ as long as broad. (8) A. Sarasinorum.

c.c. Fronds larger, more than 15 c.M. long when fully developed.

a. Teeth of the segments finely aristate, retroflexed.

(9) A. aristulatum.

d.d. Teeth whether or not aristate, not retroflexed.

e. Lower or costal sori often horseshoe-shaped or hamato-reniform.

$\times$. Texture herbaceous.

$\times \cdot \times$. Texture coriaceous.

e.e. Largest sori hamalo-recurvate at the apex only.

e.e.e. Sori straight or slighlly curved, the lower sometimes double.

t. Midribs of the leaflets beset with distant, subulate, spine-like appendices on the upper side. Fronds \pm 20-60 c.M. long.

*. Fronds to 30 c.M. long, to 12 c.M. broad. Pinnae spreading. (15) A. gymnogrammoides.
(12) $\dot{A}$. nitidulum.

(10) A. solenopteris.

(11) A. drepanopterum. broader. Pinnae erecto-palent. (14) A. nigripes.

f.f. Appendices wanting or indistincl. Fronds $60-200$ c.M. long in the fully developed plants.

g. Tertiary segments elliptico-rhomboidal, the base narrowed or \pm decurrent. (15) A. umbrosum.

y.y. Tertiary segments linear-oblong, the base not narrowed, not decurrent. (16) A. silvaticum.

(') See also A. macrocarpum, Bedd.

$\left({ }^{2}\right)$ See also aristulatum, Copel.

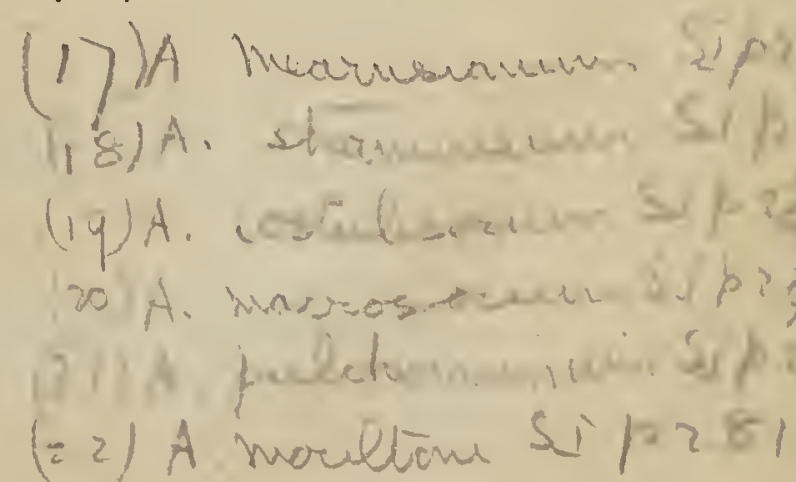


(1a) Manum, Charist," Philipp. Journ., II, 161.

Rhizome oblique, short or nearly creeping. Stipes few, tufted, slender, fuscous, $\pm 1 / 2-1$ c.M. long, pubescent like the rachis and clothed with thin, setulose, reddish-brown, spreading scales. Fronds lanceolate, \pm 6 c.M. long, 7 m.M. broad, pinnate below the much prolonged, pinnatifid apex, the lobes erecto-patent. l'innae in $\pm 5-6$ pairs, erecto-patent, subremote, $21 / 2-5 \mathrm{~m} . \mathrm{M}$. long, the higher equilateral at the base, entire, oblong, the central inequilaleral, auricled on the upper side, subcrenate, the lowest inequilateral, crenatolobate. Texture flaccido-herbaceous; rachis winged; surfaces puberulous; colour bright-green; veins forked, hardly pinnate. Sori $\breve{b-6}$ to a segment, small, hardly $1 \mathrm{~m}$.M. long, ochraceous; indusium lanceolate, rarely aspidioideo-reniform.

\section{Mindanao.}

* (1b) A. pusillum, v. *. R.; Asplenium pusillum, Bl., Rac., Flor. Btz., I, 221 ; G. Chr., Ind. Fil.; A. confluens, Kze, Bot. Zeit., 1848, 174 ; Hk. Bk., Syn. Fil., 490.

Rhizome creeping, flexuose, the scales brown, lanceolate, acuminate, small. Stipes seriate, slender, $\pm 2-6$ c.M. long, deciduously scaly like the rachis, the scales minute, crisped, setiform Fronds linear-lanceolate, $\pm 7^{1} / 2-12^{1} / 2$ c.M. long, $\pm 1-2$ c.M. broad, with \pm b-6 pairs of pinnae below the terminal one. Terminal pinna long, deeply pinnatifid at the base, narrowed gradually towards the toothed or serrate, acuminate point; lateral pinnae erecto-patent, the highest longest, lanceolate-oblong, bluntish, sessile; lowest pinnae smallest, nearly stalked, remote, oblong, \pm b-6 m.M. long, \pm 5 m.M. broad, blunt, the edge \pm repando-denticulate, the base obliquely cuneate, slightly auricled on the upper side. Texture papyraceous; rachis narrowly winged above; surfaces sparingly covered with few, minute, inconspicuous scales on the costae; main veins oblique, simple, the lower forked. Sori few, minute, the lower anterior of the pinnae often elongate-hippocrepiform, but without sinus between the branches. - The scales of the rhizome being finely cancellate and the cells coloured this plant is decidedly no Asplenium. $\left(^{\star}\right)$ - Forbes plant (no. 2894) determined by Raciborski as Asplenium pusillum, $B l$. is a young form of Diplazium grammitoides, $P r$.

Java.

* (1c) A. Toppingianum, Copel., Philipp. Journ., II, 127; As-

(*) Zollinger's No. 2925 is in the Buitenzorg Herbarium 
plenium toppingianum, Copel., Polypod. Philipp., 80; - var. mixtum (mistum), Copel., I. c.; Asp. Toppingii, Copel., MS. in Herb. Bog.

Rhizome creeping, chaffy, the scales lanceolate, pale-brown. Stipes 5-10 c M. long, scattered, the base brown and chaffy, upward becoming green and naked like the rachis. Fronds $10-15$ c.M. long, $2-21 / 2$ c.M. broad, the upper half deeply pinnatifid with several erecto-patent, oblong, blunt lobes, the apex toothed to crenate, acuminate, the lower half simply pinnate with \pm 6 pinnae on each side. Pinnae oblong, blunt, serrato-crenate, auricled at the base on the upper side. Texture herbaceous, rather firm; surfaces naked; main rachis narrowly winged towards the upper half of the frond. Sori short, straight, curved, or some of them horseshoe-shaped, the lower sometimes double.

Var. mixtum: Larger; teeth of the pinnae more rounded; the lowest pair of pinnae more than $2 \times$ the dimensions, deeply incised.

Luzon.

* (2) A. gedeanum, Christ, Journ. de Bol., XIX, 68; Asplenium gedeanum, Rac., Flor. Btz., I, 223.

Rhizome erect or suberect, densely clothed with brown, lanceolate scales. Stipes firm, erect, 10-50 c.M. long, stramineous, glossy, scaly at the base. Fronds oblong- or lanceolate-deltoid, $15-50$ c.M. long, $5-15$ c.M. broad, the apex acuminate, toothed to deeply pinnatifid. Lateral pinnae $10-50$ on each side, linear to lanceolate, the higher ones sessile, the lower ones distant, subsessile, \pm deflexed, often shorter than the next in order, the longest ones spreading, $5-10 \mathrm{~m}$. M. broad, the apex acute or blunt, sometimes acuminate, the upper base truncate or broadly cuneate, often auricled, the lower base cuneate, often slightly auricled, the edge slightly lobed, the lobes sharply toothed. Texture coriaceous; main veins pinnate in the lobes. Sori short, mostly close to the midribs, rarely diplazioid at the apex.

Java; Annam.

(3a) A. anisopterum (anisopteron), Christ, Bull. Herb. Boiss., VI, 962; Philipp. Journ., II, 160; Bull. Ac. Int. Bot., 1907, 135; Aspidium Fauriei, Chrisl, var elatius, Christ, Bull. Herb. Boiss., VI, 193; Nephrodium Fauriei, Christ, var elatius, Copel., Polypod. Philipp., 21.

Rhizome oblique. Stipes tufted, few, slender, to \pm 25 c:M.long, stramineous, naked, the base black-brown, sparingly clothed with brown, subulate scales. Fronds lanceolate-elongate, to \pm 25 c.M. long and 8 c.M. broad, not narrowed at the base. Pinnae alternate, to \pm 18 on each side, spreading, 
moderately approximate, petiolate, the lower distant, rhomboid-ovate, unequalsided, lobed, acute, the lower side cuneately cut away, the upper side auriculate; lowest pinnae $\pm 3^{1 / 2}$ c.M. long, $\pm 21 / 2$ c.M. broad at the base. Lobes oblique, oblong, obtuse, \pm 7 on each side, denticulate, the lower shallowly lobed again, the lowest deeply incised and sometimes free like the auricle. Texture thin; surfaces naked like the rachis; colour dark-green; veins pinnate in the lobes. Sori scattered, numerous, $3-7$ to a lobe, ovate or roundish; indusium reniform.

Luzon; Yunnan.

(3b) A. benguetense, Christ, Philipp, Journ., II, 161.

Rhizome creeping or oblique, slender, black. Stipes approximate, few, slender, stramineous, 25 c.M. or more long, the base clothed with scattered, lanceolate, brown scales. Fronds lanceolate, \pm 30 c.M. long, \pm 9 c.M. broad, 2-pinnatifid, not narrowed at the base. Pinnae sessile, spreading, remote, \pm 25 below the pinnatifid apex, the lowest subdeflexed, \pm 5 c.M. long, $\pm 1 \frac{1}{2}$ c.M. broad, lanceolate, acuminate, pinnatifid nearly to the costa. Lobes subpectinate, \pm 18 on each side, linear-oblong, $\pm 21 / 2$ m.M. broad, bluntish, entire or subcrenate. Texture flaccid; rachis and costae stramineous, puberulous; surfaces naked; colour black-green; veins simple, oblique, \pm . $6-8$ on each side. Sori medial, $6-8$ on each side, roundish, hardly 1 m.M. broad; indusium thin, hyaline, roundish-reniform, indistinctly umbonate, caducous. - By its nephrodioid sori a Dryopteris, but in all other respects a true Athyrium.

Luzon.

(3c) A. Copelandi, Christ, Philipp. Journ., II, 161.

Rhizome branched, short-creeping, blackish. Stipes \pm 9 c.M. long, plumbeo-stramineous, furfuraceo-squamulose like the rachis, the base sparingly clothed with brown, lanceolate-subulate scales. Fronds oblong, \pm 14 c.M. long, \pm 6 c.M. broad, long-acuminate, not narrowed at the base, the rachis winged towards the apex. Pinnae sessile, \pm 15 on each side, falcate, the higher ones adnate, decurrent, the lower remote, coarsely lobed, \pm 3 c.I. long, \pm 1 c.M. broad. Lobes \pm 6 on each side, the lowest anterior largest, triangular-ovate, \pm 4 m.M. long, 3 m.M. broad, subacute, subcrenate. Texture coriaceous; surfaces naked; colour black-green, paler beneath, main veins pinnate in the lobes with $\mathbf{5}-4$ veins on each side, all soriferous. 
Sori oblique, $2-3$ m.M. long, \pm 1 m.M. broad, ovate-lanceolate, slightly curved; indusium greyish, turgid, persistent.

Luzon.

* 4) A. macrocanpum, Beald., Handb. Ind. Ferns, 16ə̆ ; Ferus S.I., tab. CLII-CLIII; Asplenium macrocarpum, Bl., Rac., Flor. Btz., I; 225 ; Aspidium macrocarpon, Bl., Enum., 162.

Rhizome erect or suberect, clothed with lanceolate, brown scales. Stipes \pm tufted, 12-25 c.M. long, firm, erect, stramineous, scaly at the base. Fronds ovate-lanceolate, acuminate, 15-60 c.M. long, 10-25 c.M. broad, pinnate. Pinnae numerous, the lower ones often deflexed, the longest stalked, 1-4 c.M. broad, cut down into several oblong, bluntish, erecto-patent, crenate lobes or even pinnate at the base, the base \pm auricled on the upper side. Secondary segnents sometimes pinnatifid. Texture herbaceous; rachis naked or glanduloso-pubescent. Sori copious, roundish or oblong, the costal ones horseshoe-shaped or hamato-reniform.

Trop. Asia, China, Japan.

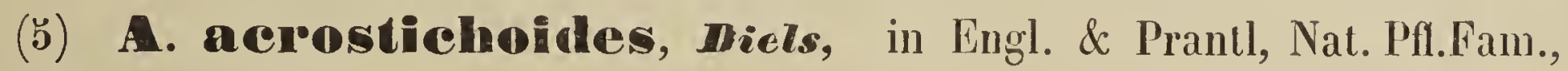
$\mathrm{I}^{4}$, 225, fig. 120, C; A. thelyptheroides, Desv., Bedd., Handb. Ind. Ferns, 164; A. allantodioides, Bedd., Ferns Br.I., II, tab. CCXXI; Asplenium thelypteroides, Mchx., Hk. Bk., Syn. Fil., 226;A. acrostichoides, Sw., (oldest name).

Stipes $15-50$ c.M. long, erect, polished, stramineous, furnished at the base with large, lanceolate, thin, light-coloured scales. Fronds $\pm 50-90$ c.M. long, $15-30$ c.M. broad, lanceolate, pinnate. Pinnae numerous, the lower ones gradually reduced, distant, the largest ones spreading or ereclo-patent, $2-2 \frac{1}{2}$ c.M. broad at or near the base, narrowed gradually towards the apex, the edge deeply cut down into numerous crenate or nearly entire, oblong, blunt, \pm spreading segments. Texture herbaceous; rachis naked or \pm hairy. Sori in close, regular rows, sligbtly curved, reaching nearly from the costulae to the edge, the lower single or double.

Penang; Br. India, China, North. America.

(6) A. hyalostegium, Copel., Philipp. Jouru., I, Suppl. 253.

Rhizome creeping, often intertwined, sparingly clothed with minute, fer rugineous scales. Stipes caespitose, 4-8 c.M. long, filiform, stramineous or greenish, the base brownish, the upper part clothed like the rachis with short, whilish, silky hairs. Fronds $3-7$ c.M. long, $1 \frac{1}{2}-4$ c.M. broad, acu- 
minate, pinnate. Pinnae ovate, obtuse, the lower ones pinnate again, the higher ones simple, joining. Pinnulae (or segments) narrowly oblong, obtuse, often entire. Texture herbaceous; surfaces sparingly pubescent with short, white hairs; veins simple. Indusium thin, setaceous, rarely asplenioid, often curved and nephrodioid.

Luzon.

(7) A. Woheri, Christ, Bull. Herb. Boiss., 2 ${ }^{e}$ Série, VI, 1001.

Rhizome short, stout, sparingly clothed like the stipes with setiform scales. Stipes tufted, slender, erect, \pm 18 c.M. long, green, castaneous at the base. Fronds \pm 13 c.M. each way, deltoid, nearly 3-partite at the base, the rachis winged. Pinnae $\pm \breve{b}$ on each side, the higher ones oblong, subacute, \pm deeply lobed, the lowest ones subdeltoid, rather 2-pinnatipartite, the posterior side produced. Lobes close, subobluse, minutely crenulate. Texture thin, pellucid; colour pale-green; surfaces rather naked or hardly puberulous. .Sori minute, in 1 or more rows, roundish or broadly reniform; indusium thin, greyish, asplenioid or aspidioid (round), fimbriate.

Luzon. hindowo (SI P z) 8 ]

(8) A. Sarasinorum, Cherist, Fil. Saras., IV, 434 ; Ann. Btz., XV, 125, tab. XV, fig. 16, a-b; Asplenium Sarasinorum, Copel., Polypod. Philipp., 87; - var. philippinense, Christ, Bull. Herb. Boiss., VI, 154; Ath. philippinense, Christ, Copel., Philipp. Journ., I, Suppl., 254.

Rhizome short, clothed with long, blackish-brown scales. Stipes tufted, slender, succulent, \pm flaccid, brown, slightly scaly, $10-15$ c.M. long. Fronds \pm 10 c.M. long, \pm 4 c.M. broad, oblong-deltoid, acuminate, 5-pinnatifid to 5-pinnate. Pinnae \pm 10 on each side, the lowest the longest. Pinnulae sessile, the lower ones short-stalked, roundish-ovate, divided again, the lobes roundish, broadly crenate or toothed. Texture herbaceous. Sori $\mathbf{3}-\mathbf{5}$ on the ultimate divisions, solitary on the lobes, oblong, slightly recurved; indusium brownish.

Var. philippinense: Lobes deeply incised, the terminal ones linear-lanceolate, moderately acute, $\pm 1 / 2$ m.M. broad.

Celebes, Philippines.

(9) A. aristulatum, Copet., Philipp. Journ., I, Suppl., 255; var. sphagnicolum, Copel., l. c.

Rhizome erect, densely clothed with lanceolate, acuminate, cinnamon- 
coloured scales like the base of the stipes. Stipes caespitose, \pm 20 c.M. long, slender, the base nigrescent-stramineous, the upper part naked, greenish like the main rachis. Fronds $20-25$ c.M. long, 10-15 c.M. broad, acuminate, 5-pinnate. Pinnae lanceolate-ovate, short-stalked, often acute. Pinnulae oblong, obtuse, the rachis narrowly winged. Tertiary segments oblong, adnate, obtuse or truncate, serrate or dentate, the teeth finely aristate, retrollexed. Texture membranaceous; surfaces naked, the upper blackish-green, the lower paler. Sori costal, short, broad, straight or curved; indusium whitish.

Var. Sphagnicolum: Stipes filiform, 6-12 c.II. long; fronds $\breve{b}-10$ c.M. long, 2-pinnate.

Luzon.

* (10) A. solenopteris (selenopteris), Iroore, Bedd., Handb. Ind. Ferns, 166; A. pectinatum, Bedd., Ferns S. I., tab. CLV; A. nigripes, Bedd., 1. c., tab. CLVII; Asplenium Selenopleris, Mett., Farng., VI, Aspl., 196; Allantodia Solenopleris, Kze, Linn., XXIV, 266; - var. remotum.

Rhizome oblique or erect, the scales rather large, ovate-acuminate, dense. Stipes stramineous, slightly scaly, often $25-30$ c.M. long. Fronds ovate-acuminate $01^{\circ}$ lanceolate, never deltoid, $25-50$ c.M. long. Pinnae distant, erectopatent, $15-20$ c.M. long, stalked, lanceolate-acuminate. Pinnulae to \pm 4 c.M. long, short-stalked, close, bluntish, the edge cut down nearly or quite to the costa, the base more or less obliquely subtruncate. Segments oblong, the lower incised and toothed, the others toothed or serrate. Texture herbaceous, rather flaccid; surfaces naked. Sori oblong, more or less curved, the lower ones not rarely hamate or horseshoe-shaped.

Var. remotum: Pinulae distant, the lower ones to \pm 2 c.M. apart. Texture somewhat firmer.

South. India, Ceylon; -- var. remotum: Java (Zippelius).

(11) A. drepanopteram, A. Hr., C. Chr., Ind. Fil.; A. drepanopteron, Moore, Christ, Philipp. Journ., II, 161;A. oxyphyllum, Moore, Bedd., Ferns Br.I., I, tab. LXVII; Asplenium oxyphyllum, Hk., Hk. Bk., Syn. Fil., 228; Polypodium drepanopteron, Kze, Linn., XXIII, 278, 318.

Stipes firm, erect, $15-50$ c.M. long, stramineous, clothed at the base with large, lanceolate-acuminate, "reddish-brown scales. Fronds 50-60 c.M. long, $15-50$ c.M. broad, lanceolate, with several distant pinnae on each side, which are $10-20$ c.M. long, $2 \frac{1}{2}-$ c.M. broad. Pinnulae lanceolate, some- 
times auricled on the upper side, in the larger forms again pimnatifid, the teeth mucronate. Texture subcoriaceous; rachis firm, naked, stramineous; veins regularly pinnate. Sori in 2 rows on the pinnae or pinnulae, medial; indusium often oblong-reniform.

Luzon; Japan to Yunnan and North. India.

* (12) A. nitislulum, Milde, Bot. Zeit., 1870, 570 ; Asplenium nilidulum, Moore, Rac., Flor. Btz., I, 229; Allantodia nilidula, Kze, Bot. Zeit., 1848, 191.

Rhizome erect or suberect, densely clothed with brown, narrow, lanceolate scales. Stipes to 18 c.M. long, slightly scaly at the base. Fronds deltoid-ovate, $15-50$ c.M. long, nearly as broad, acuminate. Pinnae \pm 12 on each side, pinnate, the lower ones stalked, lanceolate, acuminate, to 4 c.M. broad. Pinnulae to 1 c.M. broad, lanceolate, bluntish, the upper base broadly, the lower narrowly cuneate, the edge cut down $1 / 2-2 / 3$-way to the costa into linear-oblong, nearly close lobes. Lobes erecto-patent, rounded and crenate to toothed at the apex. Texture herbaceous to subcoriaceous; rachis pale-coloured like the stipe; main veins pinnate in the lobes; veins few, simple. Sori short, mostly in 2 regular rows, close to the costae, the largest recurved at the apex.

Java.

* (15) A. gymagogemamoides, Medd., Handb. Ind. Ferns, 168; Ferns S.I., tab. GLVI; Asplenium Filix Femina, Bernh., var., Rac., Flor. Btz., I, 228; A. gymnogrammoides, Kl., Melt., Farng., VI, Aspl., 195, tab. VI, fig. 13-14.

Rhizome erect, slightly scaly, the scales pale-ferrugineous or brown, ovate. Stipes 7-15 c.M. long, stramineous-green, sparingly scaly. Fronds 20-30 c.M. long, to 12 c.M. broad, lanceolate-oblong, narrowed gradually towards the apex. Pinnae spreading, oblong, to $4 \frac{1}{2}$ c.M. long, the lowest not the largest, subremote, oblong, the apex not or hardly acuminate, the rachis marginate (narrowly winged). Pinnulae trapezoid-oblong, to 1 c.M. long, to 7 m.M. broad, the apex mostly rounded or obtuse, duplicato-inciso-dentate, rarely acuminate, the edge lobed or deeply pinnatifid at the base, the base obliquely cuneate, subtruncate and auricled on the upper side, the lobes inciso-dentate. Texture membranaceo-herbaceous; rachis and surfaces naked but the midribs of the pinnulae beset with subulate, spine-like appendices on the upper side. Sori straight or slightly curved. - The ceylonese specimens are larger and commonly $\tilde{3}$-pinnate.

Java; Ceylon. 
* (14) A. nigripes, Moore (not Bedd.), Christ, Farnkr. d. Erde, 224; Asplenium nigripes, Bl., Rac., Flor. Btz., I, 230; Aspidium nigripes \&े costale, Bl., Enum., $162 \& 170$.

Rhizome erect, clothed with dark-brown, lanceolate scales. Stipes tufted, 15-70 c.M. long, stramineous, erect, scaly below. Fronds 50-60 c.M. long, 12 - 0 c.M. broad, ovate-lanceolate to deltoid, with numerous erecto-patent pinnae on each side. Pinnae lanceolate, pinnate, the apex acuminate, pinnatifid. Lowest pinnulae $1 \frac{1}{2}-4$ c.M. long, oblong, cut $1 / 2$-way down or quite to the costa into oblong or ovate, more or less toothed segments. Texture thin, membranaceous or herbaceous; rachis naked, stramineous; upper surface beset with few, distant, subulate, spine-like appendices on the midribs of the segments. Sori oblong or linear-oblong, often slightly curved only, principally in 2 rows near the costae.

Trop. Asia, China, Madagascar. huzon.

* (15) A. umbrosum, Pr., Christ, Farnki. d. Erde, '225; $\Lambda$. australe, Pr., Bedd., Ferns S.I., tab. CLVIII ; Diplazium umbrosum, Bedd., Handb. Ind. Ferns, 188; Asplenium umbrosum, J. Sm., Rac., Flor. Btz., I, 228; Polypodium umbrosum, Ait., (oldest name); - var. muricatum; Asplenium muricatum, Mett., Ann. Mus. Bot. L. B., II, 259.

Caudex erect, to 25 c.M. high, densely covered with the bases of fallen fronds, routs and brown, lanceolate scales. Stipes 50-80 c.M. long, strong, scaly at the base. Fronds $60-160$ c.M. long, 50-120 c.M. broad, ovatelanceolate to deltoid. Pinnae ovate-lanceolate to deltoid-lanceolate, 7-20 c.M. broad. Pinnulae close, cut down nearly or quite to the costa into unequalsided, elliptico-rhomboidal segments $1 / 2-1 \frac{1}{2}$ c.M. long, 2-5 m.M. broad; the apex of the pinnulae lobed. Segments sessile, the apex rounded, the edge toothed or deeply inciso-crenate, the base narrowed or decurrent. Texture herbaceous; surfaces naked; central ribs of the segments pinnate, veins simple or forked. Sori oblong, copious, the lower often double; indusium inflate, slightly curved, entire. - A variable plant.

Var. muricatumn: Stipes muricate.

Trop. Asia \& Australia, New Zealand, A/rica; - var. muricatum: Java.

* (16) A. silvaticum, Milde, Bot. Zeit., 1866, 376; A. woodwardi. oides, Christ, Fil. Saras., III, 235; Asplenium basilare, Moore, Rac., Flor. Btz., I, 229 ; A. woodwardioides, Bk., Hk. Bk., Syn. Fil., 229; Diplazium brevisorum, J. Sm., Journ. of Bot., III, 408; Allantodia sylvalica, Bl., (oldest name). 
Rhizome erect. Stipes firm, erect, naked, dark-brown, to \pm 70 c.ll. long or longer. Fronds subdeltoid, $60-200$ c.M. long, 50-120 c.M. broad. Lower pinnae to 60 c.II. long, $7 \frac{1}{2}-20$ c.M. broad, pinnate. Pinnulae slightly stalked, $1-5$ c.II. broad, narrowed towards the apex, cut down $2 / 3$ or more on the way to the costa into close or nearly close, linear-oblong, blunt. toothed, subfalcate segments, which are to $\pm 1 \frac{1}{2}$ c.II. long, to $\pm 1 / 2$ c.M. broad. Texlure herbaceous; rachis and surfaces naked; main veins pinnate in the lobes; veins simple or forked. Sori oblong, short, close to the costulae, the lower ones often double, close to the midribs, not reaching more than $1 / 2$-way the edge; indusium ciliate or eroso-fimbriate. - Resembles Diplazium polypodioides, $B l$. in habit (Bk.).

Java, Celebes, Philippines.

\section{ASPLENIUM, Timné.}

Sori linear or linear-oblong, straight or slightly recurved, springing from the sides of the veins, oblique to the costa, or occupying the sides of the single central veins of linear ultimate segments, only 1 sorus to a vein. Indusia of the same shape as the sori, springing from the same sides of the veins, opening obliquely towards the costa or occasionally towards the margin.

Rhizome creeping or erect, the scales coarsely cancellate, with the areolae mostly decoloured, i. e. the cells with the side walls conspicuously thickened and mostly brown-coloured, the lumina generally pale or decoloured (Sadeb., in Engl. \& Prantl, Nat. Pfl.Fam., I I ${ }^{4}$, fig. 40, B). Stipes not articulate to the rhizome, with 1 , or 2 free, \pm concave vascular bundles, which mostly unite towards the lamina (or higher) into a single tetrarchous one [)$(),()-,($, $\succ \prec, X, \underline{V}, \perp /$. Fronds simple or divided; veins free or rarely anastomosing. Hk. Bk., Syn, Fil, tab. IV, fig. 38, a-c, h.

Cosmopolitan.

Arrangement of the scctions.

$\$ 1$. THAMNOPTERIS. Vein tips united by a \pm marginal strand or an intramarginal line. Fronds simple. Diels, in Engl. \& Prantl, Nat. Pff.Fam., $\mathrm{I}^{4}$, fig. $125, \mathrm{E}$.

S2. NEOTTOPTERIS. Veins free. Fronds simple. Diels, l.c., fig. 125, F-G. 
S5. EU-ASPLENIUM. Veins free. Fronds divided. Ultimate segments with several to many soriferous veins. Indusium opening mostly towards the costa. Hk. Bk., Syn. Fil., tab. IV, fig. 38, a; Diels, l.c., fig. 126.

\$4. DAREA. Veins free. Fronds divided. Ultimate segments linear or oblong, each with a single, central soriferous vein. Indusium opening towards the margin. Hk. Bk., l.c., tab. IV, fig. 58, b-c; Diels, l.c., fig. 127, F \& H.

$\$ 5$. LOXOSCAPHE. Like $\mathbb{4}$, but sori and indusia much contracted, Davallialike. Hk. Bk., l.c., tab. II, fig. 18, e; Diels, l.c., fig. 127, J-K.

S6. ASPLENIDICTYUM. Veins anastomosing towards the margin. Fronds divided. Hk. Bk., l.c., tab. IV, fig. 38, h (Hemidictyum).

Key to the sections.

a. Veins quite free.

b. Sori and indusia contracted, half-cupshaped or semicylindrical, not running along the veins. Fronds divided.

$\$$ 5. LOXOSCAPHE.

b.b. Sori and indusia not contracted, oblong or linear, running along the veins.

c. Fronds simple.

S. NEOTTOPTERIS.

c.c. Fronds divided.

d. Ultimate segments linear or oblong, each with a single soriferous vein. Indusium opening towards the margin.

$\$$ 4. DAREA.

d.d. Ultimate segments various, each with several to many soriferous veins. Indusium typically and obliquely opening towards the costa or costula.

5. EU-ASPLENIUM.

a.a. Veins united at the apex by a transverse, continuous, \pm marginal or intramarginal line. Fronds simple.

$\$$ 1. THAMNOPTERIS.

a.a.a. Veins anastomosing more copiously towards the margin. Fronds divided.

\section{\$ 6. ASPLENIDICTYUM.}

\section{$\$$ 1. THAMNOPTERIS.}

a. Fronds linear, loriform, $1^{1} / 2-3$ c.M. broad. Indusium black.

(1) A. colubrinum.

a.a. Fronds lanceolate or linear-lanceolate, $\pm 3-35$ c.M. broad. Indusium not black.

b. Fronds conspicuously acuminate, rather rostrate. (2) A. Simonsianum. 
b.7. Fronds obtuse, acule or acuminale, nol rostrate.

c. Texture \pm coriaceous throughout; fronds narrowed lowards the base.

a. Fronds rather obluse.

(3a) A. pachyphyllum.

d.d. Fronds rather acute or short-acuminate.

e. Edges cartilagineous, very prominent. (5b) A. curtisorum.

e.e. Edges not or hardly cartilagineous, not conspicuously prominent.

c.c. Texhre membranaceous or subcoriaceous; base of fronds broad, scariose or chartaceous.

(4) A. cymbifolium.

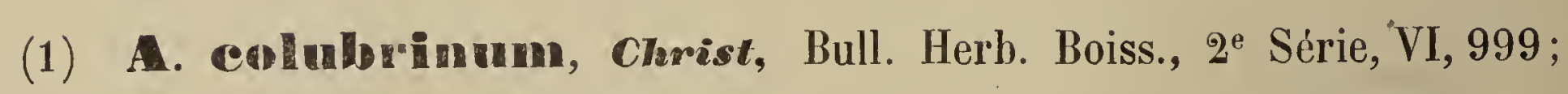
- var. taeniophyllum, Copel., Philipp. Journ., II, 131.

Fronds tufted, linear, loriform, to 85 c.M. long, $1 \frac{1}{2}-5$ c.M. broad, the apex acuminate, the edge entire, the base narrowed into a short stipe. Texture coriaceous, rigid; costa stout, surrounded on each side by black lines (the costa or the frond?), black-fuscous, prominent beneath, sulcato-concave above; under surface furfuraceous with minute, pale scales; veins prominent, black, numerous, nearly spreading, simple or geminate at the base, $\pm 1 \frac{1}{2}$ m.M. apart. Sori numerous, occupying the upper half of the frond, slightly immersed, black-brown, each pair separated by a sterile vein; indusium persistent, cartilagineous, black, with a pale margin.

Was. Lacuionhyllum: Stipes 2-5 c.M. long; fronds narrowed very gradually into the stipe; costa keeled beneath, 2-angular above, concave between the angles at the base; under surface naked; veins inconspicuous; sori often separated by 2 sterile veins.

Luzon; - var. taeniophyllum: Mindoro.

* (2) A. Simmoninmum, Hk., Hk. Bk., Syn. Fil., 191; Hk., Icon. Pl., X, tah CMXXV; A. nidus L., var. Simonsianum, Chrìst, Bull. Herb. Boiss., VI, 151; Thamnopleris Simonsiana, Moore, Bedd., Ferns Br.I., II; Lab. CGXLVIII.

Fronds $30-45$ c.M. long, $21 / 2-4$ c.M. hroad, tapering above into a distinctly acuminate point and very gradually below into a short stipe, the margin nearly entire, the midrib rounded and prominent below. Texture coria- 
ceous; veins erecto-patent. Sori copious, reaching from the midrib to a shor' distance of the edge.

Philippines; North. India.

(5a) A. pachyplnyllum, Kae., Bot. Zeit., 1848, 146; A. nidus, L., var. pachyphyllım?

Stipes tufted, very short, nigro-paleaceous at the base. Fronds linearlanceolate, $\pm 45-50$ c.M. long, 4 rowed towards the base, the margin thickened, reflexed, subrepand, obsoletelyremotely veined. Texture coriaceous, firm, thick; surfaces glossy; veins erecto-patent, often forked. Sori occupying the upper half of the frond distant from each other as well as from the costa and the margin.

Java, New Guinea.

(3b) A. Curtisorum, Cherist, Ann. Btz., XIX, 39.

Rhizome stout, rarely clothed with ovate scales. Fronds sessille or subsessile, nariowed gradually towards the base, \pm 50 c.M. long and 9 c.M. broad, shortly acuminate, the edge entire and cartilagineous, very prominent. Texture coriaccous; surfaces glossy, glaucous-green, naked; costa stoui, prominent beneath; veins conspicuous, numerous, erecto-patent, forked at the base. Sori at the base of the veins, \pm close to the costa, oblique, \pm 10 m.M. long, occupying the upper half of the frond and reaching to \pm 7 c. Y. below the apex, brown; indusium thin, whitish.

\section{Celebes.}

* (3c) A. nidlus, I., Rac., Flor, Btz., I, 209; A. australasicum, Hli. T. midus (not J. Sm.), Fil. Exot., tab. LXXXVIII; A. simplex, Mell. (not Bl.), Farng., VI, Aspl., 86; Thamnopteris Nidus, Pr., Bedd., Ferns Br.I., II, tab. CXCVII ; - var' musifolium; A. musaefolium, Mett, l.c. 86 ; - var. plicatum; A.plccatum, Zipp.

Rhizome short. Fronds 40-120 c.M. long, 5-50 c.M. broad, lanceolate, sessile or tapering gradually into a short stipe, the apex acute or short-acuminate, the edge entire. Texture \pm coriaceous; costa rounded or keeled on the back; veins fine, $3 / 4--2$ m.M. apart. Sori reaching nearly or quite from the costa to $1 / 3-2 / 3$ on the way towards the margin. - A. phyllutidis, Don is the shortest and narrowest form, under 60 c.M. long, under $71 / 2$ c.M. broad.

War. musifolium: Fronds larger, to $2 \frac{1}{2}$ M. long, 1055 c.M. broad, with the sori extending nearly to the edge. 
55. ASPLenium, $\mathbb{S} 1$. ThamNopteris.

Var. plicatum: Fronds obtuse, rigidly coriaceous, plicate, the edge undulate.

Paleotropical.

(4) A. Cymbifolium, Christ, Bull. Herb. Boiss., 2e Série, VI, 999; Copel., Philipp. Journ., II, 130.

Fronds sessile, $55-120$ c.M. long, $15-20$ c.M. broad in the upper part, slightly narrowed below the middle, the base as broad or broader, 12-15 c.M. broad, (cordate after Christ), subscariose (chartaceous after Copel.), the edge entire, the apex subacute or abruptly short-acuminate. Texture membranaceous (subcoriaceous after Copel.), flaccid; costa very prominent, black or castaneous, woody; veins nearly spreading, slender, 1-2 m.M. apart, simple, connected by a distinct intramarginal line. Sori numerous, reaching from the costa to $\% / 10$ on the way to the edge, separated by $1-2$ sterile veins; indusium yellow (brown after Copel.).

Luzon.

\section{\$ 2. NEOTTOPTERIS.}

1. Texture herbaceous to papyraceous.

†. Fronds narrowed below into a rather suddenly truncate or subacute base.

+. Rhizome scales few, scaltered.

t.t. Rhizome scales numerous, dense.

+. Fronds gradually decurrent at the base.

$\times$. Fronds lanceolate, not suddenly narrowed into the lower half.

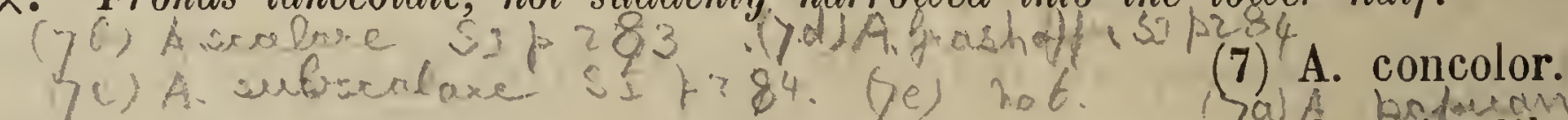

$\times \cdot x$. Fronds spathulate, rather suddenly narrowed into the wing-like lower half.

1.1. Fronds coriaceous or nearly so.

(8) A. spathulatum.

(8a) A sulispothulatum $S$.

2. Stipes naked or nearly so.

a. Margin entire or subentire.

b. Fronds small, under 30 c.M. long.

(9) A. microxiphion.

b.h. Fully developed fronds more than 30 c.M. long.

c. Stipes seriate. Sori erecto-patent.

c.c. Slipes tufled. Sori patent.
(10) A. batuense.

(11) A. Scortechinii. 
5马. ASPLENiUn. $\mathbb{S}$ 2. NEOTtOPTERIS.

a.w. Margin crenate, serrate or toothed.

+. Rhizome erect, scaly. Fronds finely acuminale.

(12) A. Nactierii.

+.t.Rhizome wide-creeping, naked. Frınds acute.

(15) A. vittaeforme.

2.2. Slipes.more or less scaly.

3. Margin quile entire or obscurely repand.

4. Surfaces naked.

(14) A. scolopendrioides.

4.4. Surfaces scaly, at least on the costa beneath.

5. Fronds narrow, 11/2-21/2 c.M. broad; surfaces naked, costa scaly.

5.5. Fronds broader, 3-10 c.M. broad; under surface 4 scaly, at least when young.

6. Fronds $3-31 \frac{1}{2}$ c.M. hroad. (16) A. natunae.

6.6. Fronds $31 / 2-10$ c.M. broad.

8. Fronds not rounded, not abruplly acuminate at the apex.

(17a) A. squamulatum.

8.8. Fronds rounded and abruplly acuminate at the apex.

(17b) A. Werneri.

3.3. Margin crenate, at least lowards the apex of the frond.

+. Fronds rather distant, 25 -35 c.M. long; costa prominent.

(18b.) A-proucuders $51 p 286 \quad$ (18) A. glochidiatum.

1.+. Fronds densely auproximate, 40-50 c.M. Pong : costa depressed.

(19) A. comosum.

(5) A. epiphyticum, Copel., Polypod. Philipp., 79.

Rhizome scandent, clothed with few, small scales. Stipes distant, \pm 8 c.M. long, covered with minute, ferrugineous scales. Fronds simple, 20-30 c.M. long, \pm 4 c.M. broad, acuminate, crenate or serrate, the base obtuse or subacute. Texture membranaceous; surfaces naked; costa firm, scaly; veins conspicuous, often forked, nearly spreading. Sori linear, not reaching the costa and the margin. - The fronds of the young plants are sometimes 2-3-pinnatisect or entire in the upper and divided in the lower part.

Mindanao.

* 6) A. amboinense, Willd., Rac., Flor. Btz., I, 210; A. fejeense, 
Brack., Hk. Bk., Syn. Fil., 192; A. simplex, Bl., Enum., 174; A. tacniosum, Kze, Bot. Zeit., 1848, 145; A. scolopendrioides, Muell., Pap. Pl., IV, 81.

Rhizome \pm creeping or climbing, the scales dense, brown, lanceolate, acuminate. Stipes 1-15 c.M. long, more or less scaly, especially below. Fronds lanceolate, $40-120$ c.M. long, $5^{1 / 2}-7^{1 / 1} / 2$ c.M. broad, with the apex caudate or acuminate, often proliferous, gradually narrowed. below into a rather subtruncate base, the margin entire or nearly so. Texture thin to subcoriaceous; costa slightly scaly below; veins oblique, simple or branched. Sori occupying the lower $2 / 3$ of the veins or reaching nearly to the edge.

Malaya; Polynesia.

* (7) A. concolor', Mr., Hk. Bk., Syn. Fil., 191; Hk., Spec. Fil., III, tab. CLXIV, A; A. diversifolium, Bl., forma concolor, Rac., Flor. Btz., I, 211; A. diversifolium, Bl., forma indivisa, C. Chr., Ind. Fil.

Rhizome creeping, clothed with lanceolate scales. Stipes approximate, 2-5 c.M. long, firm, scaly in the lower part. Fronds $15-25$ c.M. long, $21 / 2$ c.M. or more broad, lanceolate, the point acute, the edge slightly crenatoserrate upwards, the lower part narrowed into the stipe gradually. Texture herbaceous;' veins usually simple. Sori numerous, narrow, extending from the midrib to the margin.

Java, Celebes.

* (8) Apathulatum, Bhe., Ann. of Bot., VIII, 124.

Stipes short, to 5 c.M. long, approximate, slightly scaly, the scales few, small, lanceolate, \pm adpressed, blackish or brownish. Fronds simple, \pm 25-55 c.M. long, 3-9 c.M. broad in the upper half, which is oblong-lanceolate, cuspidate, crenate or repando-crenate but more conspicuously towards the apex; near the middle the frond is rather suddenly narrowed into the wing-like lower half, which is $1-2^{1 / 2}$ c.M. broad and decurrent upon the stipe. Texture membranaceous to papyraceous; surfaces naked; costa prominent and clothed beneath with 2 opposite rows of small, distant, \pm spreading scales; veins parallel, nearly spreading, simple or forked, reaching the margin. Sori narrow, occupying the lower $1 / 2-2 / 3$ of the veins; indusium narrow, membranaceous, pale-coloured when young, at length recurved.

Sumatra, Malacca.

(9) A. microxiphion, \#k., Kew Bull., 1896, 40.

Rhizome erect, the scales dense, lanceolate, membranaceous, dirly-brown. 
Stipes tufted, slender, $2 \frac{1}{2}-5$ c.M. long, naked. Fronds simple, lanceolate, $15-20$ c.M. long, 1--2 c.M. broad, entire, acuminate, narrowed at the base. Texture subcoriaceous; surfaces naked; veins erecto-patent, distant, simple or forked. Sori linear, not reaching the margin; indusium membranaceous.

Natuna Islands.

* (10) A. Watwense, v. A. v. R., Bull. Dép. Agr. I.N., 1908, X VIII, 13.

Rhizome stout, woody, creeping, scaleless. Stipes short, distant, to 1 c.M. long. Frouds lanceolate, 40-75 c.M. long, 4-10 c. M. broad, the apex acute or short-acuminate, often proliferous, the edge entire, the lower part narrowed very gradually towards the bluntish base. Texture papyraceous to coriaceous; costa prominent and \pm quadrangular beneath, marginate there with 2 opposite, very narrow wing-like crests in the angles; veins conspicuous, fine, erectopatent, simple or forked. Sori numerous, occupying nearly the whole frond except the upper $1 / 8$ and the lower wing-like part, not reaching the midrib and the edge, very irregular in length, separated by $0-6$ sterile veins or veinlets; indusium narrow, subcoriaceous, at length distinctly recurved.

Balu Islands (Raap, No. 674).

(11) A. Scortechinir, Bedd., Journ. of Bot., XXV, 322.

Stipes tufted, short, erect. Fronds linear-lauceolate, 60-75 c.M. long, $\pm 2 \frac{1}{2}$ c.M. broad, gradually narrowed below into the stipe, and to the apex into a long, fine point, the uargin entire or subentire. Texture coriaceous; surfaces naked or the under surface slightly scaly. Sori patent, occupying the lower $2 / 3$ of the veins.

Malacca.

\section{A. Mactierii, Bedd., Journ. of Bot., XXVI, 3.}

Rhizome short, erect, scaly, the scales dark-browl, with a paler margin, lanceolate from a broad base, finely acuminate. Stipes $13-2 b$ c.M. long, paleyellow, whitish at the base. Fronds $15-25$ c.M. long, $21 / 2-51 / 2$ c.M. broad, gradually narrowed below, gradually and finely acuminate at the apex, the margin crenate or serrate. 'Texture subcoriaceous; veins distinct, usually once forked near the base, occasionally again forked towards the apex, not quite reaching the margin. Sori occupying the lower $2 / 3$ of the veins; indusium broad, prominent.

Penang. 
* (13) A. vittactorme, Cav., Hk. Bk., Syn. Fil., 192; A. sundense, Bl., Rac., Flor. Btz., I, 209.

Rhizome slender, wide-creeping, naked. Stipes short, erect, naked. Fronds rather distant, lanceolate, $15-45$ c.M. long, $2-71 / 2$ c.M. broad or narrower, the apex acute, the base narrowed gradually into the stipe, the margin crenate or obscurely toothed. Texture coriaceous, veins simple or forked, close. Sori copious, often reaching from the midrib nearly to the edge. - The plant has sometimes also abnormal fronds, which are finely divided like those of Teratophyllum.

Malaya; Polynesia.

(14) A. scolopendrioides, J. Sm., Hk. Bk., Syn. Fil., 192 ; Hk., Icon. Pl., X, tab. CMXXX.

Rhizome clothed with lanceolate, brown, chaffy scales. Stipes $\pm 2-4$ c.M. long, erect. \pm scaly. Fronds lanceolate, $30-50$ c.M. long, 3-4 c.M. broad, the apex \pm suddenly caudate, the base narrowed very gradually, the edge entire. Texture subcoriaceous; veins oblique, commonly simple, rather distant. Sori reaching from the midrib to within $5-7 \mathrm{~m}$. I. of the margin; indusium leaving a distinct, elevated ridge on the frond when it dehisces. - (See also A. glochidiatum, Rac.).

Borneo, Philippines.

A. apoense, Copel., Polypod. Philipp., 79.

Rhizome thick, short, erect. Stipes clustered, $1-5$ c.M. long, firm, scaly. Fronds $20-35$ c.M. long, $1 \frac{1}{2}-21 / 2$ c.M. broad, entire, acute, narrowed gradually into the stipe. Texture coriaceous; surfaces naked; costa firm, scaly; veins inconspicuous, erecto-patent, often forked. Sori linear, occupying the lower $2 / 3$ of the veins.

Mindanno.

A. natumae, Bts., Kew Bull., 1896, 41.

Rhizome erect, woody, the scales dense, lanceolate, membranaceous, dirtybrown. Stipes $10-15$ c.M. long, brown, slightly scaly above. Fronds simple, $30-45$ c.M. long, $3-3^{1 / 1} / 2$ c.M. broad, lanceolate, narrowed at the base. Texture rigidly coriaceous; under surface minutely scaly; veins close, obscure, immersed, $\pm 1 \frac{1}{4} \mathrm{~m} \mathrm{M}$. apart, reaching to the margin. Sori linear, not reaching the margin; indusium persistent.

Naluna Islands. 
* (17a) A. Squamulatum, $\boldsymbol{E t}$., Rac., Flor. Btz., I, 210; Thamnopleris stipitala, Pr., Epim., 68; - var. sessile.

Rhizome short, creeping or erect. Stipes \pm tufted, $5-20$ c.M. long, strong. erect, scaly like the costa, the scales persistent or more or less deciduous. Fronds 50-100 c.M. long, כ-10 c.M. broad, lanceolate, the apex bluntish, acute or acuminate, the edge entire or nearly so, the base narrowed gradually into the stipe. Texture coriaceous; surfaces scaly at least when young, the scales scattered, adpressed, minute; veins not very distinct, simple or $1--2 X$ forked, $\pm 2 \frac{1}{2}$ m.M. apart. Sori reaching from near the midrib to $5-15$ m.M. of the margin; indusium broad, membranaceous, naked.

Var. sessile: Stipes short or wanting. Fronds $20-25$ c.II. long, $\mathbf{3}^{1} \mathrm{~L}_{2}-\mathbf{5}^{1} \mathrm{I}_{2}$ c.M. broad; veins rather close; indusium \pm coriaceous. - United with the type by intermediate forms (e. g. forma calvescens, Christ, in Ann. Btz, XX, 111).

Malaya; - var. sessile: Borneo (Teuscher).

A. Werne ri, Rst., Fed., Rep.. V, 39.

Rhizome short-creeping, at lenghth suberect, densely clothed with lánceolate, fusco-ferrugineous, entire or slightly fimbriate scales. Stipes subfasciculate, firm, 10-20 c.M. long, \pm densely brown-scaly. Fronds ovate-elongate, to 45 c.M. long, to 6 c.M. broad, the apex obtuse and abruptly acuminate, the base nearly rounded or short-decurrent upon the stipe, the edge entire or obscurely repand. Texture chartaceous; upper surface olive-green and slightly scaly, lower lividgreen and copiously scaly; costa prominent, scaly: veins erectu-patent, simple or forked, $\pm 1 \frac{1}{2}$ m.M. apart, parallel. Sori occupying the lower $3 / 4$ of the veins; indusium entire.

\section{New Guinea.}

* (18) glochidiatum, Rac, Bull. Ac. Crac., 1902, 62; A. echinosporum, Rac., MS. in Herb. Bog.

Rhizome creeping, ascending, the scales light-brown, adpressed, lanceolate, acuminate, covered with short hairs near the base. Stipes \pm 1 c.ll. apart, 6-10 m.I. long, black, scaly. Fronds simple, $25-35$ c.M. long, \pm 5 c.M. broad, narrowed gradually towards both ends, but more or less suddenly at the apex into an acuminate point and towards the base into a narrow wing to the costa, the margin crenate, the lower, narrowed part entire. Texture chartaceous, surfaces glossy, naked except in the lower part; costa prominent on both sides, black and scaly at the base, green in the higher part; veins parallel, suboblique, 
slightly prominent beneath, simple or forked. Sori linear, occupying the lower $1 / 2-2 / 3$ of the veins, often separated by $1-2$ sterile veins; indusium thin, entire, pale. - Fronds of the young plants sessile, the lower part gradually narrowed, the base bluntish, the higher part deeply pinnatifid. - The ripe spores are copiously echinate, and the fronds cultivated in the Buitenzorg gardens have the indusia like those of A. scolopendrioides, J.Sm. - Both species are probably identical.

Borneo.

(19) A. comosum, Christ, Schum. \& Laut., Flor. deut. Sch. geb., 127. Rhizome creeping, clothed like the stipes with lanceolate, acuminate, blackbrown scales. Fronds approximate, numerous, erect, 40-50 c.M. long, linearlanceolate, long-acuminate, caudate, undulato-crenate in the upper, entire in the lower part, decurrent. Texture coriaceous, lucid; surfaces naked; costa broad, depressed; veins conspicuous, dense, erecto-patent, simple or forked. Sori numerous, \pm 100 on each side, reaching from the costa to the margin, occupying the whole frond; indusium narrow.

New Guinea.

\section{S5. EU-ASPLENIUM.}

a. Fronds simply pinnate; pinnae entire or incised, but nor deeply pinnatifid.

b. Pinnae short, roundish or oblong, blunt, rarely acute, not more than 2 c.M. long ${ }^{1}$ ).

1. Rachis green, at least in the upper half.

2. Rachis naked.

3. Pinnae in \pm 6 pairs, $1 \frac{1}{2}-2$ c.M. long.

(20) A. subnormale.

3.3. Pinnae in \pm 30 pairs, to $1 \frac{1}{4}$ c.M. long.

(21) A. minus. SIf 2

2.2. Rachis hairy or scaly.

(22a) A. Loheriaıum.

1.1. Rachis dark-coloured throughout, not green.

5. Fronds under 2 c.M. broad ( $\left.{ }^{2}\right)$.

t. Stipe and rachis 3-winged.

(22b) A. Stantoni.

t.+. Stipe and rachis not 3-winged.

(') See also A. heterocarpum, Wall., uniliaterale, Lam. \& filipes, Copel.

(') See also A. normale, Don. 
*. Sori at lenglh confluent.

*.*. Sori not confluent. (25a) A. trichomanes.

(25b) A. exiguum.

\$.\$. Fronds broader, 2-4 c.M. lroad when fully developed.

$\times$. Stipe and rachis naked.

(24) A. normale

$\times \cdot \times$. Stipe and rachis densely fibrillose. (25) A subavenium.

b.b. Pinnae linear or linear-oblong, acute or acuminate, rarely obtuse, more than 2 c.M. long in the fully developed plan's.

c. Pinnae \pm equally cuneate or truncate on both sides al the base.

d. Rachis naked.

e. Pinnae few, not more than \pm 5 on each sile.

bb) A Kingu SI $p_{28} 7 *$. Pinnae cuneate at the base. 6e) A.trifolcatumsips.*.*. Pinnae cordate at the base.

(26) A. salignum.

e.e. Pinnae 6 or more on each sile.

(27) 200 is axa cas

f. Texture \pm herbaceous or membranaceous.

g. Pinnae not deeply toothed.

h. Sori few, distant. (28) A. Labillardierii.

h.h. Sori numerous, close.

(29) A. remotum.

g.y. Pinnae deeply toothed.

(30) A. subaquatile.

f:f. Texture \pm coriaceous.

$\times$. Rachis narrowly winged in the upper part.

(51) A. sumatranum.

$\times \cdot \times$. Rachis not winged.

(52) A. vulcanicum.

d.d. Rachis scaly, chaffy or fibrillose.

\$. Pinnae broadly alnate to the rachs. Rachi, fibrillose.

(53) A. fuliginosum.

\$.S. Pinnae not or narrowly adnate to the rachis. Rachis chaffy or scaly.

+. Pinnae in \pm 9 pairs, cordate at the base.

(54) A. horizontale.

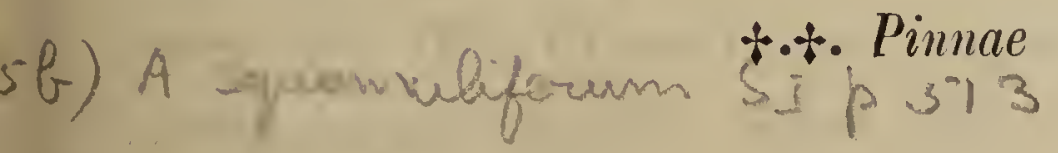

(55) A. longissimum.

c.c. Pinnae unequal-sided at the base, $i$. e. the acroscopical side broadlys cuneale or truncale and the basiscopical \pm narrowly cuneate.

1. Texture \pm herbaceous or membranaceous.

u. Fronds dimorphous, the fertile ones much longer and broader than the barren ones.

(56) A. monotis.

\%.\%. Fronds uniform, the ferlile ones \pm as large as the barren ones.

$\beta$. Pinnae bluntiy rounded or subtruncate at the apex. 
5. ASPLeniUm. $\mathbb{S} 5$. EU-ASPLenium.

*. Lower pinnae gradually reduced.

(37) A. borneense.

*.*. Lower pinnae not reduced. (58) A. tenerum.

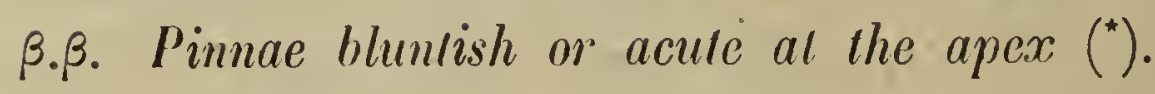

\%. Fronds small or middle-sized, under 50 c.M. long.

§. Fronds narrow, under 10 c.M. broad.

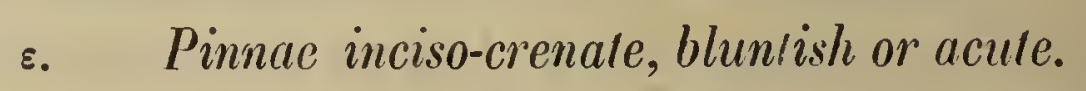

(59) A. lunulatum. SI p

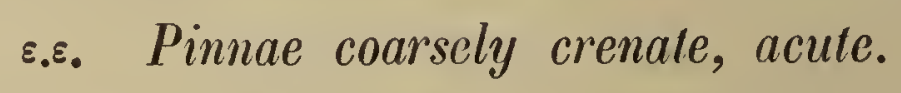

(40a) A. Steerei. SI

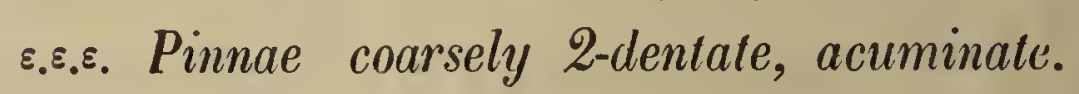

(40b) A. Meyenianum.

§.ঠ. Fronds broader, more than 10 c.M. broad when fully developed. (41) A. prionurus.

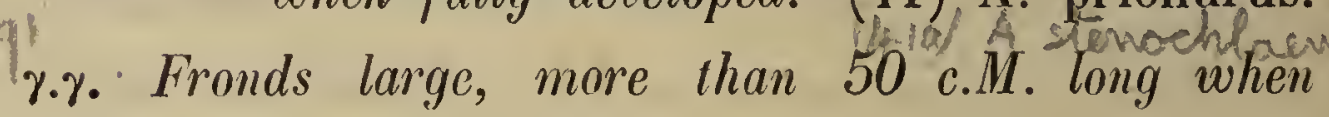
fully developed.

+. Pinnae 2-31/2 c.M. broad; sori occupying the lower half of the veins.

(42) A. griseum.

+.+. Pinnae narrower; sori reaching nearly 10 the edge.

(45) A. persicifolium.

1.1. Texhure charticeous to coriaceous.

2. Higher sori subparallel and nearly close to the costae.

s. Pinnae more or less deeply lobed, the lobes \pm rounded, entire or bluntly crenate, the higher lobes not rarely tooth-like.

†. Fronds small, under 15 c.M. long, under $71 / 2$ c.M. broad. Pinnae bluntish or subacule.

(44) A. Sehoggersii.

$+\div$. Fronds larger, more than 15 c.M. long, more than $71 / 2$ c.M. broad. Pinnae long-acuminale.

(45) A. caudatum.

\$.\$. Pinnae serrate, broadly crenate or \pm decply lobed, the crenations or lobes sharply serrale or toolhed. $\times$. Pinnae 4-71/2 c.M. lony, with the upper base suddenly cuneale. (46) A. contiguum.

(*) See also under A. tenerum, Forst. $a+b$. 


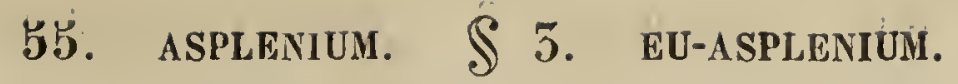

$\times . \times$. Pinnae 10-18 c.M. long, with the upper base rather truncate or rotundato-cuneate.

(47a) A. nigrescens.

(47b) A. militare.

2.2. Higher sori erecto-patent, not subparallel to the costa.

3. Lower pinnae reduced, suborbicular or subcordate.

(48) A. pellucidum.

3.3. Lower pinnae not or hardly reduced.

4. Pinnae suddenly narrowed from a broad base into a narrow point. Stipes \pm black.

(49) A. dimidiatum.

1.4. Pinnae not suddenly narrowed into the point. Stipes mostly green, grey or brown.

5. Pinnae narrow, to $\pm 21 / 2$ c.M. broad.

c. Pinnae varying from crenulate to inciso-crenate.

*. Crenulate. (๖0) A. Cesatianum. \%. Inciso-crenate.

8. Stipe and rachis fibrillose.

(๖1) A. crinicaule.

8.8. Stipe and rachis \pm scaly or nearly naked.

(52) A. acutiusculum.

6.6. Pinnae serrate or toothed.

+. Rachis strigoso-paleaceous.

(53) A. impressum.

†. . Rachis naked or slightly scaly.

+. Pinnae ascending. Sori rather regular, \pm 5-6-jugate.

(54) A. Gardneri.

+.+. Pinnae spreading. Sori rather irregular, more numerous.

(ъ5) A. adiantoides.

5.5. Pinnae broader, $21 / 2-71 / 2$ c.M. broad.

*. Pinnae minutely 2-serrate.

(56) A. Sancti-Christophori.

+.+. Pinnae entire, crenate or irregularly and sharply toothed.

FiLICES. 
$\times$. Veins distinclly visible beneath.

(57) A. macrophyllum. Si $p_{2}$ $\times \cdot \times$. Veins sunt, indistinct beneuth.

(58) A. paradoxum.

c.c.c. Pinnae dimidiate or subdimidiate, $i$. e. at least the lower ${ }^{1}{ }_{3}$ of the lower side cut away along the costa.

d. The lower side of the pinnae quite cut away.

(๖9) A. heterocarpum.

d.d. The lower $1 / 3-2 / 3$ of the lower side cut away.

e. Stipe and rachis purple or black-brown, sometimes grey.

(60a) A. unilaterale.

(60b) A. filipes.

e.e. Stipe and rachis green.

(61) A. ohscurum.

a.a. Fronds pinnate; pinnae deeply pinnaitifd, or pinnate at the base.

1'. Fronds small or middle-sized, under 45 c.M. long.

2'. Secondary segments undivided.

3'. Pinnae ovate, the lobes cuneate-oblong. (62) A. denticulatum.

$\mathbf{3}^{\prime} \cdot \mathbf{3}^{\prime}$. Pinnae linear-lanceolate, the lobes linear-cuneate.

(65) A. Warburgianum.

2'2'. At least the lower secondary segments on the anterior side shallowly or deeply 2-3-fid ( $\left.{ }^{1}\right)$.

+. Lowest anterior segment ralher broader than long, \pm spreading. Sori short, oblong.

+. Lowest anterior segment longer than broad, erecto-patent. Sori long, linear.

(65) A. Hagenii:

1.1'. Fronds large, more than 45 c.M. long when fully developed. $\left({ }^{3}\right)$

(66) A. horridum.

a.a.a. Fronds more copiously 2-4-pinnate $\left({ }^{2}\right)$.

b'. Ultimate segments small, lanceolate-spathulate, acute or incised with 2-3 sharp, entire teeth at the apex.

(67) A. tenuifolium.

$\boldsymbol{b}^{\prime} . \boldsymbol{b}^{\prime}$. Ultimate segments oblong or cuneate-oblong, the outer edge more copiously cremulate to dentale, or incised and crenulate to dentate.

c. Fronds 2-3-pinnate.

d'. Rachis pilose, fibrillose or scaly, at least when young.

( $\left.{ }^{1}\right)$ See also A. stereophyllum, Kze.

${ }^{3}$ ) With regard to the determination of the species a very difficult group and not always clearly distinguished from group a.a.

$\left({ }^{3}\right)$ See also A caudatum, Forst. 
55. asplenium. $\$ 5$. eUd-asplenium.

+. Pinnae ralher shorl, $2^{1} / 2-4$ c.M. long.

$\times$. Pinnae obluse.

(68a) A. stereophyllum.

$\times \cdot \times$. Pinnae acuminate.

(68b) A. Elmeri.

+.+. Pinnae longer, acute or acuminate, 4-8 c.M. long.

A. muaticesern SIP279.

$\boldsymbol{d} \cdot \boldsymbol{d}$. Rachis naked or slighlly scaly.

(69) A. praemorsum.

$\boldsymbol{e}^{\prime}$. Lower pinnulae cuneate-oblong, with the outer edge \pm rounded, more or less incised.

(70) A. cuneatum.

$\boldsymbol{e}^{\prime} \cdot \boldsymbol{e}^{\prime}$. Lower pinnulae lanceolate, rhomboidal or subdeltoid, narrowed towards the apex, the sides more or less incised. f. Texture herbaceous. Venation pinnate.

(71) A. bulbiferum.

$\boldsymbol{f}^{\prime} \cdot \boldsymbol{f}^{\prime}$. Texture subcoriacenus. Venation subflabellate.

$\boldsymbol{g}^{\prime}$. Sori short, radiant.

(72) A. nitidum.

$\boldsymbol{y}^{\prime} \cdot \boldsymbol{g}^{\prime}$. Sori long, linear.

h'. Pinnae long-acuminate, caudate, the apex nearly filiform.

(75) A. setisectum.

$\boldsymbol{h}^{\prime} . \boldsymbol{h}$. Pinnae less conspicuously acuminale.

(74a) A glancopteylluin $S I / 34$ A. affine.
$\boldsymbol{c}^{\prime} \cdot \boldsymbol{c}^{\prime}$. Fronds decoumpound, copiously 3-4-pinnate. (75) A. laserpitiifolium.

(20) A. sulbnormale, Copet., Polypod. Philipp., 80; Perk., Fragm. Philipp., tab. IV, fig. B.

Fronds solitary or few on a short, creeping rhizome. Stipes $\pm 11 / 2-4$ c.M. long, naked towards the frond, slender, dark and polished, but shading into a green rachis, with green, lateral lines. Fronds $4-10$ c.M. long, to 4 c.M. broad, lanceolate-ovate, acute, pinnate. Distinct pinnae \pm 6 pairs, 2 or more pairs indicated by clefts, the lowest whether or not-smaller than the next in order, crenate, commonly trapezoid, irregular in shape, the lower half cut away to the midrib at the base, the upper base parallel to the rachis. Texture membranaceous; surfaces naked. Indusium narrow.

Luzon.

* (21) A. minus, Bt., Rac., Flor. Btz., 1, 211; A. normale, Mett. (not Don), Ann. Mus. Bot. L.B., II, 254.

Rhizome short, erect or creeping, sparingly covered with small, lanceolate scales. Stipes densely crowded, 1-5 c.M. long. Fronds linear-lanceolate, to 
20 c.M. long, to $2 \frac{1}{2}$ c.M. broad. Pinnae numerous ( \pm 50 on each side), sessile, the lower ones \pm obliquely flabellate, truncate at the base, nearly twice as long as broad, the following subrhomboidal, to $12 \frac{1}{2} \mathrm{~m} . M$. long, to $5 \mathrm{~m} . \mathrm{M}$. broad, the upper base truncate and \pm auricled, the lower narrowly cuneate, the upper and outer edge of all crenate or bluntly toothed. Texture thinly herbaceous; rachis naked, becoming reddish towards the base; both surfaces naked; costae wavy; veins simple, the lower ones on the anterior side forked. Sori $\mathbf{1 - 3 - 5}$ to a pinna, oblong; indusium broad. - Lower pinnae sterile.

Java.

A. Holnerianunim, Cherist, Bull. Herb. Boiss., VI, 152.

Rhizome short. Fronds 2-5, short-stalked, \pm 10 c.M. long. Pinnae 12-20 on each side, alternate, very distant, \pm 5 m.M. long, ovate, deeply crenato-dentate, the teeth obtuse. Texture rather fleshy; rachis slender, flexuose, decumbent, purplish or green at the base, clothed with linear scales, proliferous at the apex; veins subflabellate. Sori oblong, oblique, at length covering the whole under surface of the pinnae.

Philippines.

(22b) Stantoni, Copel., Philipp. Journ., I, Suppl., 151.

Rhizome erect, short, scaly. Stipes tufted, \pm 2 c.M. long, naked, fuscous, triangular, the angles acute, winged. Fronds \pm 1 c.M. long, \pm 1 c.M. broad, pinnate, the rachis conspicuously 5 -winged, not green. Pinnae oblong, obtuse, deflexed, the lower ones flabelliform, somewhat remote. Texture coriaceous; surfaces naked. Sori \pm g to a pinna, at length filling up the whole under surface of the pinnae.

Luzon.

* (25a) A. trichomanes, ז., Hk. Bk., Syn. Fil., 196; Bedd., Ferns S.I., tab. CXLVII; - var. densum; A. densum, Brack., Expl. Exp., XVI, 151, tab. XX, fig. 5 .

Stipes densely tufted, 1-10 c.M. long, naked, glossy, chestnut-brown, polished. Fronds 13 -50 c.M. long, $\pm 10-12 \mathrm{~m}$. M. broad, linear-lanceolate, with $15-50$ opposite pairs of sessile, horizontal, \pm orbicular or oblong pinnae, the edges slightly crenate, the 2 sides \pm unequal, the upper side the broadest, the base rounded or broadly cuneate. Texture firm; veins pinnate, inconspicuous; surfaces naked: rachis polished, blackish-brown, slender. Sori linearoblong, at length covering the whole under surface of the pinnae. 
55. ASPLeniun. $\$ 5 . \quad$ EU-ASPlenium.

Var. densum: Smaller and narrower.

In the temperate zones and the cool alpine regions of the tropics.

A. exiogunum, Bedd., Ferns S.I., 49, tab. CXLVI.

Rhizome short, erect, clothed above with numerous subulate, black scales. Stipes numerous, 7-30 c.M. long, blackish-purple, more or less furnished with long, black, subulate scales. Fronds 4-15 c.M. long, 6-20 m.M. broad, the rachis sulcate above, slightly flexuose, more or less extended at the apex into a naked tail and often bearing a young plant. Pinnae numerous, subsessile from a broad base, in the smaller fronds suborbicular and simply crenate, in the larger ones lanceolate-oblong and pinnatifid, cuneato-excised below, the superior and inferior basal auricles 3-4-dentate or crenate, the other lobes 2-dentate or entire; superior pinnae gradually smaller, uppermost ones often very minute but fertile (with $1-2$ sori); inferior pinnae gradually smaller, subrotund or flabelliform, always fertile. Texture membranaceous; surfaces minutely hairy when young, at length naked; veins obscure, the apex thickened. Sori of the larger pinnae arranged in a double row, 1 row of $4-5$ on each side of the costa and approximate to it, superior auricle bearing $1 \pm$ diverging sorus, rarely 2, sometimes none, lower auricle generally barren, rarely bearing $1-2$ sori.

Luzon; Centr. China, South. India.

* (24) A. Honmale, Don., Hk. Bk., Syn. Fil., 197; A. multijugum, Wall., Hk., Spec. Fil., III, tab. CLXXXVIII; Bedd., Ferns S.I., tab. GXXXIII.

Stipes tufted, $10-15$ c.M. long, blackish, polished. Fronds $20-30$ c.M. long, $2 \frac{1}{2}-4$ c.M. broad, pinnate. Pinnae in $12-\infty$ pairs, to 2 c.M. long, the lower ones to $2 / 3$ c.M. broad, deflexed, the apex obtuse, the upper and outer edge inciso-crenate, the upper base truncate and \pm auricled, the lower narrowly cuneate, cut away in a \pm horizontal line which extends nearly the length of the lower margin of the pinna. Texture rather firm-membranaceous to subcoriaceous; rachis glossy, nearly black; veins simple or forked. Sori oblong or linear-oblong, in 2 unequal, opposite, parallel rows. - A philippine form has the stipes $2-6$ c.M. long and the fronds $10-25$ c.M. long, $1-2$ c.M. broad.

Malacca, Sumatra, Celebes, Philippines; China, North. India, Hawaii.

(25) A. Subavenium, ITk., Hk. Bk., Syn. Fil., 198; Hk., Spec. Fil., III, tab. CLXXXI, B; Bedd., Ferns Br.I., II, tab. CCLXXXVIII. 
Stipes tufted, $\breve{5}-8$ c.M. long, wiry, blackish, densely fibrillose. Fronds 20-30 c.M. long, $21 / 2-4$ c.M. broad, with very numerous close-placed, horizontal pinnae on each side, which are $\pm 1 / 2-1$ c.M. broad, blunt at the point, the edge slightly inciso-crenate, the upper side distinctly auricled and narrowed suddenly at the base, the lower narrower below, but nearly equal upwards. Texture coriaceous; veins faint; a distinct midrib only in the lower part of the pinnae; rachis densely fibrillose, especially below. Sori $2-4$ on each side, oblong, oblique. - The Malacca plant is perhaps a form of A. pellucidum, Lam. and different from the Madagascar fern.

Malacca; Madagascar.

* (26) A. salignum, Bt., Enum., 175.

Stipes \pm tufted or approximate, greyish-green, $10-20$ c.M. long, deciduously scaly in the lower half. Fronds lanceolate, $10-15$ c.M. long, $1 \frac{1}{2}-21 / 2$ c.M. broad, narrowed towards both ends, simple or with $1-3$ pairs of similar, distant but smaller pinnae at the base. Pinnae 6-10 c.M. long, 1--2 c.M. broad, stalked, acuminate, the edge entire, crenate or toothed, but more conspicuously towards the point, the base cuneate. Texture coriaceous or subcoriaceous; under surface covered with few, scattered, adpressed, deciduous scales; veins oblique, simple or forked. Sori whether or not reaching the margin and the costa; indusium persistent.

Java.

* (27) A. diversifolium, Bt., Rac., Flor. Btz., I, 211; A. salignum, Hk. (not Bl.), Spec. Fil., III, tab. CLXV; Hk. Bk., Syn. Fil., 199.

Rhizome creeping, clothed with long, lanceolate scales. Stipes approximate, 10-20 c.M. long, slender, slightly scaly below. Fronds $15-50$ c.M. long, 15 -20 c.II. broad, with a long, linear terminal pinna and $1-\breve{b} \pm$ opposite pairs of lateral ones, which are suberecto-patent, straight or sulfalcate, \pm 2 c.M. broad, with the point long-acuminate, the margin faintly crenate or entire, the base cordate. Texture coriaceous; rachis and both surfaces green and naked; veins parallel, \pm distant, obscure. Sori reaching from the midrib nearly to the edge.

Java, New Guinea.

(28) A. Habillardieri, Kze, Mett., Farng., VI, Aspl., 95, tab. IV, fig. 11 .

Stipes livid, narrowly marginate, afterwards naked. Fronds $\pm 30-40$ c.M. 
long, ovate-oblong, pinnate. Pinnae 12-15-jugate, obliquely patent, $10-13$ c.M. long, 2-2 $1 / 2$ c.M. broad, linear-lanceolate or elongate-oblong, acuminate, crenulate-serrulate, the base somewhat obliquely cuneate (somewhat broader and slightly rounded on the upper side). Texture membranaceous, thin; surfaces naked; veins erecto-patent, simple or forked at the base, translucent. Sori distant ( $1-5$ sterile veins between 2 sori), narrow, 10-15 m.M. long, reaching nearly the costa and the margin; indusium thin, narrow.

\section{Buru Island.}

* (29) A. remotum, Moore, G. Chr., Ind. Fil.; A. multilineatum, Hk., Hk. Bk., Syn. Fil., 199; Hk., Spec. Fil., III, tab. CLXXXIII.

Rhizome creeping. Stipes scattered, firm, erect, greyish-green, $\pm 15-20$ c.M long. Fronds oblong-lanceolate, 30-50 c.M. long, $15-20$ c.M. broad, with a long terminal pinna and 8-18 lateral ones on each side. Pinnae stalked, erecto-patent, 10-15 c.M. long, 1-2 c.M. broad, acuminate, the edge faintly toothed, but more acutely towards the point, the base rather broadly cuneate. Texture slightly fleshy: colour dark-green; rachis and surfaces naked; veins mostly simple, rather spreading, close. Sori numerous, close, reaching from the midrib nearly or quite to the edge.

Java, Celebes, Philippines, New Guinea; Polynesia.

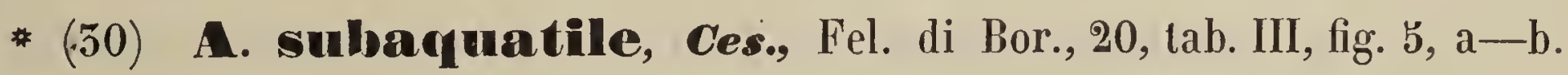

Rhizome short, tomentose. Stipes numerous, erect, slender, greenish or brownish, naked, 2-10 c.M. long. Fronds $15-30$ c.M. long, simply pinnate. Pinnae stalked, alternate or subopposite, erect or erecto-patent, linear, $21 / 2-71 / 2$ c.M. long, $21 / 2-5$ m.Mr. broad, the apex narrow, the edge deeply and obliquely toothed with distant, acute teeth, the base narrowed gradually into the stalk. Texture herbaceous; surfaces naked; rachis often slightly winged in the upper part; costae wavy; veins simple, 1 to each tooth, very oblique. Sori short, 1 to each tooth, subparallel and nearly close to the costae.

Borneo.

A. sumatranum, Mk., Hk., Bk., Syn. Fil., 199; Hk., Spec. Fil., III, tab. CLXVIII.

Stipes $15-25$ c.M. long, firm, erect, grey, naked. Fronds \pm 4 c.M. long, \pm 15 c.M. broad, with a long, narrow, linear terminal pinna and $6-12$ erecto-patent lateral ones on each side, which are \pm 15 c.M. long, \pm 2 c.M. broad, the point acuminate, the lower part obscurely undulate, the upper 
crenate, the base equally cuneate on both sides; upper pinnae connected by a more or less narrow wing. Texture very coriaceous; veins oblique, often once forked. Sori long, reaching nearly from the midrib to the edge.

Sumatra. hablucisa.

* (32) A. vulcanicum, $\boldsymbol{B l}$., Rac., Flor. Btz., I, 215 ; A. heterodon, Mett. (not $B l$.), Hk., Spec. Fil., III, 107; A. Wightianum, Wall., Hk., l. c., tab. CLXVII.

Rhizome creeping or erect, the scales dense, brown, lanceolate. Stipes 15-25 c.M. long, erect, naked or deciduously scaly towards the base. Fronds 30-100 c.M. long, 10-20 c.M. broad, oblong, with a linear terminal pinna or a proliferous apex and 6-12 lateral pinnae on each side. Pinnae erectopatent, to 15 c.M. long, $1-3$ c.M. broad, all or only the lower ones on stalks to $1 \frac{1}{2}$ c.M. long, the apex acute or acuminate, the edge entire or more or less distinctly crenate to denticulate, the base varying from narrowly to broadly cuneate, equal on both sides, or the upper base sometimes a little broader than the lower and with a tendency to become slightly auricled. Texture coriaceous or subcoriaceous; rachis naked; veins simple or forked. Sori regular, linear, in 2 opposite rows, reaching from the midrib nearly or $1 / 2$-way to the edge. - A variable plant.

Malaya; Ceylon, South. India.

A. fuliginosum, Hk., Hk. Bk., Syn. Fil., 203; A. lugubre, Hk., $2^{\text {nd }}$ Cent. of Ferns, tab. III.

Stipes tufted, very short, densely clothed with blackish, fibrillose scales. Fronds $1 \mathfrak{b}-30$ c.M. long, $\breve{b}-7 \frac{1}{2}$ c.M. broad, with $12-24$ broadly adnate, horizontal, subfalcate pinnae on each side. Pinnae $1-1 \frac{1}{2}$ c.Mr. broad, the point acute, the edge slightly toothed, the base a little narrowed on both sides in the lower ones, which are gradually reduced in size. Texture thin; rachis densely fibrillose; veins usually once forked. Sori in 2 regular rows near the point of the pinnae.

Borneo.

(34) A. horizontale, Bki, Ann. of Bot., VIII, 125.

Stipes 20-25 c.M. long, slender, green, clothed with minute scales, the lower of which are larger, dense, lanceolate, acuminate, pale-brown. Fronds oblong, \pm 30 c.M. long, caudate, pinnate. Pinnae \pm 9 , lanceolate, $7-15$ c.M. long, $21 / 2-3$ c.M. broad, acuminate, obscurely crenate, horizontal, sessile, the lowest the largest, cordate at the base, auricled on the upper side. Texture 
55. ASPLENIUM. $\int 5 . \quad$ eU-ASPLENIUN.

membranaceous: rachis green, slender, slightly scaly; surfaces naked; veins nearly spreading, often forked at the base. Sori medial, linear; indusium broad, membranaceous, naked.

\section{Sumatra.}

* (35) Iongissimuan, Hu., Rac., Flor. Btz., I, 212 ; Bedd., Ferns Br.I., I, tab LXIII; Hk., Spec. Fil., III, tab. GXC; A. erecum; Bl. (not Bory), Enum., 178; A. Belangeri, Bory, Bél., Voy. Bot., II, 47.

Rhizome creeping, the scales lanceolate, long-acuminate, brown. Stipes approximate, 5-50 c.M. long, erect, dark-coloured, clothed with ciliate scales. Fronds $50-200$ c.M. long, $4-15$ c.M. broad, lanccolate-elongate, often proliferous at the point, narrowed gradually towards the base. Pinnae numerous, spreading, $1 / 2-1 \frac{1}{2}$ c.M. broad, acuminate or subacute, the edge \pm toothed, the base subtruncate, auricled on one or both sides; higher pinnae not rarely unequalsided at the base. Texture herbaceous to subcoriaceous; rachis dark-coloured, slightly chaffy; veins oblique, the lower however more spreading, forked. Sor'i very oblique, reaching from the midrib to $1 / 2$-way or quile to the margin.

Malaya; North. India, Mauritus, Juan Fernandez.

(36) A. monotis, Christ, Schum. \& Laut., Flor. deut. Sch.geb., Suppl., 43.

Rhizome slender, climbing, yellowish-greenish, naked or sparingly covered with minute, subulate, blackish scales. Stipes distant, 2-8 c.M. long, greenishstramineous, slightly tinged with red like the rachis. Barren fronds to 12 c.M. long, elongate-lanceolate, long-acuminate, pinnate, narrowed gradually towards the base. Pinnae close, short-stalked, 17-25 on each side, broadly cuneate-oblong, the upper base 2-partite with an ovate-cuneate lobe or auricle, the edge crenate or 2-crenate; lower pinnae growing smaller, distant. Texture thinly herbaceous; surfaces naked; veins simple or forked, blackish. Fertile fronds to 30 c.M. long, the pinnae larger, distant, deeply. inciso-dentate, the teeth acute, curved. Sori 1 to each vein, reaching nearly from the costa to the margin; indusium persistent.

New Guinea.

* (37) A. Worneense, Mrk., Hk. Bk., Syn. Fil., 203; Hk., Spec. Fil., III, tah. CLXXXVI.

Rhizome short, the scales lanceolate-subulate, brown. Stipes clustered, 2-10 c.M. long, grevish, slightly fibrillose. Fronds $25-90$ c.M. long, $21 / 2-$ 
$71 / 2$ c.M. broad, with numerous sessile or short-stalked pinnae, the lower ones growing smaller very gradually, the central ones spreading, \pm close, 4-7 m.Y. broad, the point bluntly rounded, the upper and outer edge incisolobate to toothed, the upper base broadly cuneate, \pm auricled, the lower very narrowly cuneate. Texture herbaceous to subchartaceous; rachis firm, greyish, nearly naked; veins oblique, inconspicuous or more distinctly visible, those of the upper base subflabellate. Sori few, those on the lower side nearly parallel to the costa.

Borneo, Malacca.

* (38) A. Tenerum, Forst., Rac., Flor. Btz., I, 215; A. elongatum, J.F.M Sw., ? Bedd., Ferns S.I., tab. CCXXIV; - var. acuminatum, Hk., Spec. Fil., bol UII III, 117; A. Doreyi, Kze, Anal., 23.

Rhizome erect, clothed with lanceolate, brown scales at the apex. Stipes tufted, firm, erect, greyish, nearly naked, $\mathbf{b}-25$ c.M. long. Fronds $15-50$ c II. long, $\pm 3 \frac{1}{2}-10$ c.M. broad, lanceolate-oblong, with 10 to numerous sessile or \pm stalked, horizontal pinnae on each side. Pinnae oblong or linearoblong, $3 / 4-2$ c.M. broad, the sides \pm parallel in the typical form, the apex bluntly rounded or subtruncate, the edge deeply crenato-dentate throughout; the upper base \pm truncate, slightly auricled, the lower cuneate. Texture herbaceous, not rarely firm; rachis naked or slightly scaly; surfaces naked; veins commonly simple. Sori numerous, regular, linear-oblong, parallel, not reaching either the midrib or the edge.

Var. acuminatum : Pinnae acute or nearly acuminate at the point. Trop. Asia.

* (39) A. Innulatum, Sw., Hk. Bk., Syn. Fil., 202; A. erectum, Bory, ? Hk., Fil. Exot., tab. LXXII, (var. proliferum).

Rhizome short, slightly scaly. Stipes tufted, nearly naked, grey or darkcoloured. Fronds $15-4$ c c.M. long, $\pm 3^{1} / 2-4 \frac{1}{2}$ c.M. broad, linear-lanceolate, with 10 to numerous horizontal pinnae on each side. Pinnae close, subtrapezoid-oblong, narrowed towards the bluntish or acute apex in the type, $1 / 2-1$ c.II. broad, the edge inciso-crenate throughout; the upper base truncate, slightly auricled, the lower cuneate. Texture herbaceous; rachis naked like the surfaces; veins mostly simple. Sori short, oblong, falling short of both edge and midrib. - Near A. tenerum, Forst., but diflerent from it by the less blunt pinnae.

Pantropicul. 
(40a) A. Steerei, Marr., Journ. of Linn. Soc., Bot., XVI, '28.

Stipes dark-grey, 12-15 c.M. long, firm, provided with some few small, brown, scattered scales. Fronds $15-25$ c.M. long, $5-6 \frac{1}{2}$ c.M. broad, oblonglanceolate. Pinnae 12-15 on each side, short-stalked, $\mathbf{3} \frac{1}{2}-\breve{b}$ c.M. long, $1-1 \frac{1}{2}$ c.M. broad, the apex acute, the margin coarsely crenate, the upper base abrupt with a more or less distinct, large lobe, the lower base cuneate; lower pinnae slightly deflexed. Texture firm-herbaceous; colnur dark-green above, brownish beneath; veins distant, simple or once forked. Sori $2-8$ in a row on each side of the costa, regular, not reaching midrib and margin.

Philippines.

(40b) A. Meyenianum, Pr., Christ, Bull. Herb. Boiss., 2e Série, VI, 999; A. pellucidum, Lam, C. Chr., Ind. Fil., p.p.

Rhizome firm, erect, clothed with black, fimbriate, subulate scales. Stipes tufted, black-rufous, 8-12 c.M. long, hispid with short scales like the ebeneous rachis. Fronds to 45 c.M. long, 4-6 c.M. broad, linear, acuminate, the base not or moderately narrowed. Pinnae numerous, subremote, $4 \breve{-5}-50$ on each side, sessile, falcato-rhomboidal, acuminate, $21 / 2-3$ c.M. long, the upper base truncate, the lower cuneate, auricled, the edge coarsely 2-dentate; lower pinnae more distant, more blunt. Texture herbaceous, impellucid; upper surface dark-, lower pale-green; veins hidden. Sori very oblique, $\pm \check{b}$ on each side, narrow, reaching the margin and the costae; indusium narrow, brown.

Luzon, Palawan.

(41) A. proonurus, J. Sm., Hk. Bk., Syn. Fil., 202.

Stipes tufted, 15-25 c.M. long, firm, erect, slightly scaly below. Fronds 30-45 c.M. long, $15-25$ c.M. broad, oblong, with 9-18 pinnae on each side, which are \pm 1 c.M. or more broad, very much acuminate at the point, deeply toothed throughout, the base rather unequal, more broadly cuneate on the lower side, with a short petiole on the lower ones. Texture herbaceous; veins usually simple. Sori reaching nearly to the edge.

Philippines.

(42) A. griseunn, Copel., Polypod. Philipp., 82; A. insigne, Copel., Perk., Fragm. Philipp., 185.

Rhizome short, densely clothed with large, brown scales. Stipes firm, slightly chaffy, 40-50 c.M. long, reddish-brown or blackish-green. Fronds 60 c M. and more long, \pm 50 c.M. broad, pinnate. Pinnae 12 or more on 
each side, stalked, \pm 20 c.M. long, $\pm 5^{1} / 2$ c.M. broad, lanceolate, acuminate, subserrate, the upper base broadly and the lower more narrowly cuneate. Texture tough-herbaceous; surfaces naked; veins oblique, often forked, \pm conspicuous. Sori broad, occupying the lower half of the veins, moderately regular.

\section{Mindanao.}

A. Beroficilolium, J. Sm., Hk. Bk., Syn. Fil., 202.

Stipe and rachis grey, with few, scattered, minute, grey scales. Fronds oblong-lanceolate, $60-90$ c.M. long, often proliferous at the apex. Pinae distant, ascending, $15-50$ on each side, subpetiolate, 10-13 c.M. long, linear-ligulate, acuminate, $\pm 1-2$ c.M. broad, distinctly inciso-crenate throughout, obliquely cuneate at the base, the lower base narrower; lower pimnae not reduced. Texture thin but firm; surfaces naked; veins fine, forked, not close. Sori regular, 7-10 m.M. long, reaching nearly to midrib and edge.

Celelies, Borneo, Sulu Islands, Philippines.

$$
\text { curet }=\text { A.caudation Forst. SIp2q2. }
$$

1908, XVIII, 14.

(44) A. Sehrogger'sii, v. A. v. R., Bull. Dép. Agr. I. N.,

Stipes tufted, \pm 4 c.M. long, dark-brown, clothed like the rachis with fine, diciduous scales. Fronds ovate-lanceolate, $8-10$ c.M. long. Pinnae \pm 15 on each side, spreading, the lowest shorter, the central ones \pm 2 c.I. long, $\pm 1 / 2$ c.M. broad, the point acute or bluntish, toothed, the edge lobed $1 / 3-1 / 2$-way down, the lobes truncate or rounded and crenate, oblique like the teeth, the base obliquely truncate-cuneate. Texture coriaceous; under surface provided with few, very minute, deciduous, fimbriate scales; veins few, oblique, simple or forked. Sori very small, subparallel and nearly close to the costa, occupying the base of the veins.

Java (Preanger Regencies, Lieut.' Col. J. C. F. Schoggers).

* (45) A. caudatuman, Forst., Rac., Flor. Btz., I, 218; A. contiguum, Beld., Ferns S.I., tab. CXL; A. truncatilobum, Fée, Christ, Philipp. Journ., II, 164; $A$. arayalense, Christ,. MS.

Rhizome erect, the scales linear-lanceolate, brown. Stipes tufted, firm, erect, densely clothed with fine, fibrillose, brown scales. Fronds $25-100$ c.M. long, 10-25 c.M. broad, with $20-30$ pinnae on each side. Pinnae spreading, $1-2 \frac{1}{2}$ c.M. broad, the apex long-acuminate, toothed, the edge cut to $\pm 1 / 2$-way down or somelimes more at the hase into rounded, entire or crenate, oblique 
lobes, the base broadly cuneate and auricled on the upper and more narrowly cuneate on the lower side. Texture coriaceous; rachis leciduously scaly; veins very oblique, Sori linear, the higher subparallel and nearly close to the costa, occupying the lowest part of the veins. - Hardly different from A. horridum, Klf. in the deeply lobed forms.

Pantropical.

* (46) A. Contigumm, Kuf., Hk. Bk., Syn. Fil., 205; Hk., Spec. Fil., III, tab. CXCIV, fig. 1; - var. lepturus, Hk., l.c., 1ə̆6, tab. CXCIV, lig. ّ̋; A. leplurus, J. Sm., Mett., Farng., VI, Aspl., 152; — var. bipinnatifidum, Christ, Bull. Herb. Boiss., VI, 152; A. laxivenum, Copel., Philipp. Journ., II, 132;? A. insilitium, Brack., Christ, Phllipp. Journ., II, 166.

Rhizome creeping or ascending. Stipes 15-25 c.Il. long, firm, erect, dark-coloured, naked. Fronds lanceolate, acuminate, pinnate, $15-50$ c.M. long, the apex pinnatifid. Pinnae 10-50-jugate, subfalcate, short-stalked, $4-7 \frac{1}{2}$ c.M. long, $\pm 1-1 \frac{1}{2}$ c.M. broad, acute or acuminate, the edge obliquely and broadly serrate, the lower serratures sharply serrate or toothed, the higher sharp, simple or 2-dentate, the upper base cuneate, sometimes \pm auricled, the lower narrowly cuneate in a curve. Texture \pm coriaceous, rachis firm, naked or slightly villose, brown; veins oblique. Sori close, subparallel and nearly close to the costa.

Var. Hepturens: Pinnae longer, 9-121/2 c.M. long, the edge deeply serrate, rather lobed, the lower lobes or serratures sharply serrate, the apex long-acuminate.

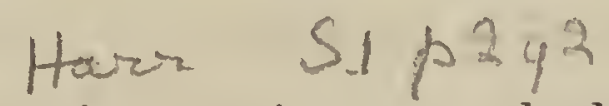

Var. Lipinnatifidunan: Lower pinnae pinnate at the base; pinnulae nearly free, cuneato-rotundate, auricled, deeply toothed.

Java, New Guinea; Hawaï; — var. lepturus \& bipinnatifidum: Philippines.

* (47a) A. nigrescens \#it., Mett., Farng., VI, Aspl., '151; ? Rac., Flor. Btz., I, 217.

Rhizome and stipes? Fronds 50-90 c.M. long, elongate-oblong, pinnate, the apex pinnatifid. Pinnae numerous, spreading, 10-15 c.M. long, linear, short-stalked, acuminate, the edge broadly and shallowly crenate, bul often more deeply lowards the apex, the serratures 2-4-dentate except the higher ones, which are often entire and narrow, the upper base broadly and roundly, the lower narrowly cuneate. Texture chartaceous; rachis naked or paleaceo-villose, dark-coloured; veins repeatedly forked. Sori oblique, subparallel and nearly close to the costa. - Scarcely different from A. contiguum, Klf. except 
in the size of the fronds and the length of the pinnae. The plant found and determined by Raciborski is problaby a young form of the latter.

Java, Moluccas.

(47b) A. militare, Copet., Philipp. Journ., I, Suppl., 254.

Rhizome creeping, densely clothed with lanceolate, murino-fuligineous, acuminate scales. Stipes $40-50$ c.M. long, castaneous, glossy and glabrescent like the rachis. Fronds $60-100$ c.M. long, $25-50$ c.M. broad: Pinnae shortstalked, remote, $15-18$ c.M. long, $2-21 / 2$ c.M. broad, the base obliquely cuneate, or truncate on the upper side, the edge serrate, 2-serrate towards the caudate apex; lower pinnae hardly shorter. Texture chartaceous; surfaces naked, the upper rather fuligineous, the lower olive-green; veins forked, spreading, very oblique at the base. Sori curved, costal.

Mindanao.

* (48) A. pellucidum, Lam., Rac., Flor. Btz., I, 212; A. hirlum, Klf., Christ, Farnkr. d. Erde, 196; Bedd., Ferns Br.I, II, tab. CXCIV; A. approximalum, Bl., Enum., 179; - var. obtusum, Christ, Ann. Btz., XX, 111, - var. repressum, Copel., Polypod. Philipp., 85.

Rhizome erect or suberect, densely clothed with dark-brown, linear, acuminate scales. Stipes varying from short to 10 c.M. long, strong, erect, brownish, deciduously scaly, the scales \pm fibrillose. Fronds 20-100 c.M. long, 4-20 c.M. broad, lanceolate. Pinnae numerous, sessile, spreading, acute or acuminate, the edge serrate or toothed, the teeth sometimes toothed again, the upper base truncate, auricled, the lower cuneate; lower pinnae reduced, suborbicular or subcordate. Texture coriaceous; rachis fibrillose or chaffy, the scales dense, dark-coloured, fimbriate, at length deciduous; veins oblique, inconspicuous. Sori short, in regular rows, oblique, occupying the lower half of the veins.

Vsr. Obtusumen: Pinnae short, obtuse.

Var. repressum; Fronds under 20 c M. long, almost sessile; pinnae obtuse.

Malaya; Polynesia, Madagascar, Mascarenes, Seychelles.

(49) A. dimidiatum, Sav., Hk. Bk., Syn. Fil. 209; ? A. Zamiaefolium, Willd., Kze, Farng., I, tab. XLVIII.

Stipes tufted, $7 \frac{1}{2}-30$ c.M. long, blackish, slightly paleaceous, firm, erect. Fronds 15-4:5 c.M. long, 8-15 c.M. broad, with 6-9 opposite pairs of pinnae. Pinnae $\pm 2-2 \frac{1}{2}$ c.M. broad, the point acuminate, especially the 
outer and upper edge sharply inciso-serrate, the upper base rounded or cuneate, the lower very narrowly cuneate. Rachis dark-coloured, firm, slightly scaly; veins close, flabellate; no midribs. Sori radiant, narrow, long. - Resembles A. adiantoides, $C$. Chr., but the pimnae suddenly narrowed from a broad, unequally auricled base into a narrow point.

New Guinea, Timor, Malacca; Tonkin, West. Africa, Trop. America.

(50) A. Cesatianum, Bk., Becc., Mal., III, 59; A. Wightianum, Ces. (not Wall.), Fel. Becc. Polin., 4.

Stipes $\pm \mathbf{5} 0$ c.M. long, greyish, scaly at the base, the scales few, large, lanceolate-oblong, acuminate, brown. Fronds oblong-lanceolate, simply pinnate, \pm 45 c.M. long. Pinnae multijugate, distant, lanceolate, erecto-patent, crenulate, obscurely stalked, obliquely cuneate at the base, the lower base reduced. Texture firm; surfaces naked; veins conspicuous, erecto-patent, not closely placed, commonly deeply forked. Sori oblong, parallel, medial on the veins; indusium firm, naked, persistent.

New Guinea.

(51) A. crinicaule, Hance, Hk. Bk., Syn. Fil., 208: A. Hancei, Bk., Bot. Zeit., 1869, 130; A. falcalum, Bedd., Ferns S.I., tab. CXLI.

Stipes densely tufted, 7-10 c.M. long, erect, dark-brown, fibrillose. Fronds 15-90 c.M. long, $4-12$ c.M. broad, with 9-25 horizontal pinnae on eacl side, which are 4-10 m.M. broad, the point bluntish, the edges irregularly inciso-crenate, the upper base narrowed suddenly, sometimes auricled, the lower obliquely cuneate, sometimes auricled. Texture subcoriaceous; rachis firm, fibrillose; midribs not distinct; veins subflabellate. Sori few, linear, oblique, regular, not rearhing to the edge.

Philippines; Br. India, Souih. China.

*(52) A. acutiusculum, Bt., Rac., Flor. Btz., I, 217; A. anisodon/um, Pr., Hk. Bk., Syn. Fil., 205.

Rhizome erect, the apex clothed with narrow, lanceolate, brown scales. Stipes tufted, firm, erect, \pm scaly, to 50 c.M. long. Fronds $50-70$ c.M. long, with numerous sessile or stalked, spreading or subfalcate pinnae on each side. Pinnae acute or acuminate, the lowest hardly smaller, rather larger than the next following ones, 4-10 c.M. long, $1 / 4-1 \frac{1}{2}$ c.M. broad near the base, the edges more or less inciso-crenate, the upper base broadly cuneate or subtruncate, \pm auricled or deeply incised, the lower rather 
narrowly cuneate. Texture firm; rachis nearly naked; veins oblique; mostly once forked or the lower acroscopical to $4 \times$ branched. Sori in regular rows, reaching nearly the midrib and the edge.

Java, Borneo, Celebes, Philippines, New Guiner; Samoa.

(53) A. inmpressunn, Christ, C. Chr., Ind. Fil.; A. canaliculalum, Christ, Warb., Mons., I, 73.

Like A. contiguum Klf. but smaller. Rachis densely strigoso-paleaceous, at lenght nearly naked. Pinnae shorter, broader, ovate-cuneate, not 2-auricled, caudato-acuminate, 2-serrate. Veins prominent above, subflabellate. Sori not close to the costae, more spreading, elongate, distant.

Baljan.

(54) A. Crandelneri, \#k., Hk. Bk., Syn. Fil., 485; Bedd., Ferns S. Br.I., Suppl., tab. CCCLV.

Rhizome short-creeping. Stipes grey, $\breve{b-15}$ c.M. long, with a few small, scattered scales. Fronds lanceolate, $\mathbf{1 5 - 3 0}$ c.M. long, 7-15 c.M. broad, often gemmiferous; rachis not winged. Pinnae 8-10-jugate, distant, ascending, lanceolate, subpetiolate, acute, central ones $5-8$ c.M. long, $1-1 \frac{1}{2}$ c.II. broad, toothed, the base obliquely and rather broadly cuneate. Texture thin but firm, supple; surfaces naked; veins erecto-patent, forked, moderately close. Sori regular, parallel, $\mathbf{b}-6$-jugate, nearer the midribs than the edge, 6-12 m.M. long. - Closely allied to A. macrophyllum, Sw.

Sumatra; Ceylon, Khasya.

* (55) A. adiantoides, C. Chr., Ind. Fil.; A. falcalum, Lam., Hk. I Bk., Syn. Fil., 208; Diels, in Engl. \& Prantl, Nat. Pfl. Fam., I ${ }^{4}$, fig. 126, G; A. caudatum, Bedd., Ferns S.I., tab. CXIIIII ; A. zamiaefolium, Pr., Rel. Haenk., I, 43; Trichomanes adiantoides, L., (oldest name).

Stipes tufted, 15-30 c.M. long, erect, grey or brown, naked or slightly scaly. Fronds $15-60$ c.M. long, 10-25 c.M. broad. Pinnae horizontal, 620 on each side, stalked, alternate or opposite, acute or caudate, $1-21 / 2$ c.M. broad, the edge toothed or lobed, the teeth or lobes toothed again, the upper base broadly and the lower narrowly cuneate, the lower sometimes slightly cut away. Texture coriaceous; rachis naked or nearly so; veins very oblique. Sori long, in . 1--2 irregular lines, reaching nearly to the edge. - Distinct enough from A. macrophyllum, $S w$. if typical specimens only are shown but gradually passing into it (Bedd.).

Trop. Asia, Australia, Polynesia; New Zealand, East. A/rica. 
55. ASPLenium. $\mathbb{S} 3$. eUt-asplenium.

(56) A. Samchi-Chroistophori, Christ, Schum. \& Laut., Flor. deut. Sch.geb., 128.

Like A. macrophyllum, $S w$, hut the rachis strigoso-squamulose, the pinmae more numerous, (12-15 on each side), smaller, broadly rhomboidal, inequilateral, auriculate on the upper side, alternate, nearly sessile, growing shorter towards the pimatifid apex of the frond, the margin not incised but copiously and minutely 2 -serrate.

New Guinea.

* (57) A. macropliylum, Sw., Rac., Flor. Btz., I, 216; Hk., Spec. Fil., III, tab. CXCVI-CXCVII; Bedd., Ferns S.I., tab. CXLII ; A. ca. naliculalum, Bl., Enum., 180 ; -- var. minus.

Rhizome short, the extremity clothed with long, narrow scales. Stipes \pm tufted, $15-50$ c.M. long, stout, erect, brownish, nearly naked. Fronds 15 -80 c.M. long, $12-30$ c.M. broad. Pinnae $\pm 6-12$ on each side, $2.1 / 2-71 / 2$ c.M. broad, the terminal one often large, not rarely 5-fid, the point unate of all acute, the edge mostly sharply and irregularly toothed, not or slightly lobed, the base obliquely and broadly cuneate, the lower base narrower than the upper. 'Texture \pm coriaceous; rachis naked or deciduously chaffy, firm; veins oblique, distinct beneath. Sori long, oblique, often reaching from the midrib to the edge. - Near A. adiantoides, C. Chr., and scarcely different from the latter in the smaller forms.

Var. minus: Fronds smaller and narrower; lateral pinnae 1-2jugate.

Malaya; Polynesia, Ceylon, South. India, Comores, Mascarenes; - var. minus: Timor (Forbes, No. 3124a).

* (58) A. Dagradoxam, IB., Rac., Flor. Btz., I, 216; A. zamioides, Hk., Berd., Ferns Br.I., II, tab. CXCIII.

Rhizome short-creeping or ascending, the scales short, broad, deltuid, adpressed. Stipes firm, erect, 1丂̆-2马̆ c.M. long or longer, greyish to brownish, slightly scaly. Fronds 50-100 c.M. long, 15-25 c.M. broad, with a rather large, oblong-rhomboidal, simple or 3 -lid terminal pinna and 8-12 lateral ones on each side, the lowest the largest, subrhomboidal, $21 / 2-5$ c.M. broad, mostly entire, crenate or toothed towards the apex, the upper base suddenly narrowed, broadly cuneate, the lower more narrowly cuneale. 'l'exlure coriaceous; rachis firm, \pm scaly; veins indistinct lieneath, rather very oblique,

Filiges. 
commonly once forked. Sori reaching nearly from the midrib to the edge, sometimes accompanied by smaller ones, which are \pm terminal on the veins, sometimes \pm scolopendrioid. - United with $\Lambda$. macrophyllum, Sw. by intcrmediate forms, but distinguished by the indistinct, hardly visible veins.

Malacca, Sumalra, Java, Borneo.

* (59) Leterocarpunn, Wall., Hk. Bk., Syn. Fil., 210; Hk., Spec. Fil., III, tab. CLXXV; Bedd., Ferns S.I., tab. CXXXI; A. cheilosorum, Kze, Mett., Farng., VI, Aspl., tab. V, fig. 12-13; C. Chr., Ind. Fil.

Rhizome creeping, scaly at the apex. Stipes firm, erect, brown, polished. Fronds $15-40$ c.II. long, $51 / 2-5$ c.M. broad, with numerous closely placed pinnae on each side. Pinnae horizontal, subsessile, $\pm 1 / 2-2 / 3$ c.M. broad, dimidiate, the lower side being entirely cut away, the upper and outer edge deeply incised, the crenations crenate or toothed again, the upper base nearly truncate; lower pinnae hardly shorter and more or less deflexed. Texture pellucido-herbaceous; rachis like the stipe. Sori 1 or rarely 2 together in the teeth.

Malacca, Borneo, Mindoro; Formosa, North. India. Luzon.

* (60a) unilaterale, cum., Bedd., Handb. Ind. Ferns, 152; J FNS A. resectum, Sm., Rac., Flor. Btz., I, 214; Hk. \& Grev., Ic. Fil., tab. CXIV; Bedd., Ferns, S.I., tab. CXXXII; A. amoemum, Pr., Mett., Farng., VI, Aspl., tab. V, fig. 11; - var. delicatulum, Bedd., Handb. Ind. Ferns, 155; Ferns S.Br.I., Suppl., tab. CCGLVIII.

Rhizome slender, wide-creeping, the scales small, nearly linear. Stipes scattered, 1-2 c.M. apart, slender, naked, dark-coloured, \pm black-brown and polished like the rachis, some of them sometimes grey and opaque, 10-20 c.M. long. Fronds $15-60$ c.M. long, 4-10 c.M. broad, rarely narrower, lanceolate-oblong, acute to long-acuminate. Pinnae stalked or subsessile, 10-30 on each side, trapezoid-lanceolate, horizontal or erecto-patent, the apex bluntish or acute, the upper and outer edge inciso-crenate to dentate, the upper base \pm cuneato-subtruncate, $1 / 2-2 / 3$ of the lower side cut away at the base. Texture thinly herbaceous; veins $1-2 \times$ forked. Sori oblong, occupying the base or the centre of the veinlets.

Var. delicatulum: Fronds and pinnae much smaller and nạrrower than in the type, the pinnae less cut away at the base on the lower side.

Trop. Asia, Japan, Polynesia, West. Africa and East African Islands; var. delicatulum: Malacca; Tenasserim. 
(60b) A. filipes, Copel., Philipp. Journ., III, 34; - var. minutum, Copel., l. c., 35.

Rhizome creeping, slender, scaly at the extremity. Stipes seriate, \pm 5 c.M. long, filiform, purple, glossy. Fronds 8-12 c.M. long, acuminate, pinnate. Pinnae \pm 15 on each side, the largest to $1 \frac{1}{2}$ c.M. long, 3-4 m.M. broad, oblique or auriculate, the lower edge straight, the upper serrate; lower pinnae hardly reduced, spreading, the higher ones ascending. Texture membranaceous; surfaces naked. Sori few, short. - Near A. unilaterale, Lam.

Van. minutum: Stipes $1-5$ c.M. long; fronds $4-7$ c.M. Jung, diaphanous; sori 1 or sometimes 2 to each pinna.

Negros Island (Philippines).

* 61) A. Obscunuman, IBI., Rac., Flor. Btz., I, 214; A. serraeforme, Mell., Farng., VI, Aspl., tab. IV, fig. 15.

Phizome long, slender, creeping, the apex clothed with short, lanceolate scales. Stipes distant, to 20 c.M. long, erect, greenish like the rachis, scaly

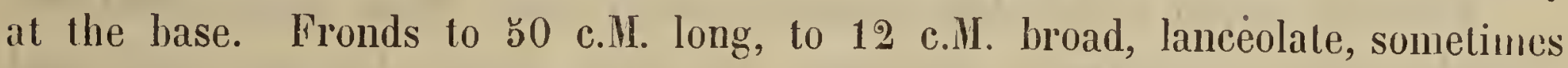
2-pinnate at the base, with $\pm 20-50$ short-stalked pihnae on each side. Pinnae spreading to erecto-patent, the lowest to 6 c.M. long, to 2 c.M. broad, bluntish or acute, the upper and outer edge crenate to toothed, the upper base cuneate, $1 / 3-1 / 2$ of the lower side cut away at the base. Texture thin, \pm hyaline, rachis and both surfaces naked; veins commonly once forked. Sori short, occupying the lower part of the anterior veinlets.

Java.

(62) A. Ienticulatenm, IBt., Enum., 186.

Fronds 2-pinnatifid. Pinnae petiolate, small, ovate in general outline, deeply 5-partite or pinnatifid. Lobes cuneate-oblong, obtuse, the apex obscurely denticulate. Texture coriaceous; rachis and costae beneath \pm fibrillose.

Java.

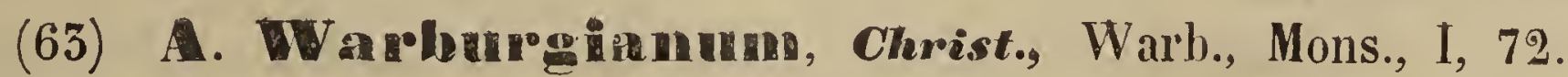

Rhizome short, the scales black, subulate. Stipes tufted, \pm 10 c.ll. long, clothed like the rachis with lanceolate, brown scales. Frouds $\pm 1 b$ c.M. long, \pm 4 c.M. broad, ovate-oblong, pinnate, acuminate, the base not narrowed. Pinnae \pm 5 c.M. long, erecto-patent, linear-lanceolate, deeply pinnatifid with 4-5 linear, cuneate, praemorse segments. Texture coriaceous: surfaces pilose; veins fine, parallel. Sori few, narrow; indusium thin, filiform. Java. 
* (64) A. Iaciniatum, Don., Hk. Bk., Syn. Fil., 211; Hk., Spec. Fil., III, tab. CG, A.; Bedd., Ferns S.I., tah. GXLV.

Rhizome thick, ascending, the scales, dense, blackish, subulate, rigid. Stipes tufted or subtufted, 10-20 c.M. long, grey or brown, partially and deciduously scaly. Fronds $15-50$ c.M. long, $21 / 2-71 / 2$ c.M. broad; main rachis deciduously scaly. Pinnae $\pm 12-20$ on each side, spreading, stalked, \pm 1-2 c.M. hroad, oblong, narrowed towards the apex, cut down often quite to the costa in the lower part, the upper base truncate, the lower narrowly cuneate. Lobes erecto-patent, rhomboidal-oblong or cuneate, $2-5$-fid, the superior basal one (auricle) the largest, broad-flabelliform. Texture \pm coriacous; veins oblique, those of the lower lobes flabellate. Sori few, the higher ones oblique, the lower radiating in the auricle, not reaching either the midrib or the edge.

Celebes; Ceylon, North India, Japan.

\section{mut = A storectiglear Rizo. SI P297}

* (65) A. Mngenii, v. A. v. Re., Bull. Dép. Agr. I.N., 1908, XVIII, 14.

Rhizome, stipes and fronds beneath densely scaly when young; the scales linear-lanceolate, acuminate, caducous, the base dilated, the edge finely and shortly toothed, the point very fine, capillary, those of the rhizome and base of the stipes dark-brown, erecto-patent, the others smaller, spreading, crisped, those of the under surface of the fronds the finest, pale-brown. Stipes \pm 12 c.I. long, erect, firm, dark-brown. Fronds \pm 15 c.M. long or longer, lanceolate-oblong, acuminate. Pinnae subrhomboidal, erecto-patent or nearly horizontal, the lowest mostly the largest, $4-6$ c.M. long, $1 \frac{1}{2}-2$ c.ll. broad, blunt or acute to acuminate, stalked, unequal-sided, deeply pimnatifid or pimnate at the base. Segments 5-4 on each side, oblong or cuneate, erecto-patent, with the outer edge finely toothed, the lower ones \pm flabellate-cuneate, with the outer edge flabellato-5-fid and finely toothed. Texture coriaceous; veins indistinct. Higher sori subparallel to the costa, the lower \pm parallel to the edges of the segments on which they are placed; indusium membranaceous.

Sumatra (Hagen).

* (66) A. horrielum, Mlf., Hk. Bk., Syn. Fil,, 211; Hk., Spec. Fil., III, tab. CXCIII; A. caudalum, Forst., var. horridum, Christ., Fil. Saras., I, 15. Stipes strong, erect, brownish, fibrillose. Fronds $60-90$ c.M. long, 12--50 c.M. broad, with numerous (20-50) spreading to erecto-patent pinnae on each side. Pinnae $\pm 1-2$ c.ll. broad at the base, narrowed gradually to an acuminate toothed point, cut down throughout more than halfway to the costa into \pm uniform, loroad lohes, the lobes with the outher edge more or less crenate "or 
toothed, the upper base broadly cuneate, truncate, cordate or broadly rounded, the lower cuneate in a curve. Texture subcoriaceous; rachis stout, clothed with reddish to blackish, woolly fibres; veins oblique, commonly once forked. Sori nearly parallel and close to the midrib, except lhose on the lobes which are more spreading. - Near A. caudatum, Forst.

Malaya.

* 67) A. Lenuifoliuma, Don., Hk. Bk., Syn. Fil., 220; Hk., $2^{\text {nd }}$ Cent. of Ferns, tab. XXIX; Bedd. Ferns S.I., tah. CXXX.

Stipes tufted, 7-15 c.M. long, slender, naked, slightly ebeneous. Fronds $15-30$ c.M. long, 7-13 c.M. broad, oblong-lanceolate, with numerous pinnae on each side, the lower ones $5-7$ c.M. long, \pm 2 c.M. broad. Lower pinnulae subdeltoid, cut down to a narrowly winged rachis into spathulate segments $\pm \mathbf{3}$ m.M. broad, sharply incised on the outer edge. Rachis green, naked, slender; veins solitary. Sori $1-2$ to each segment.

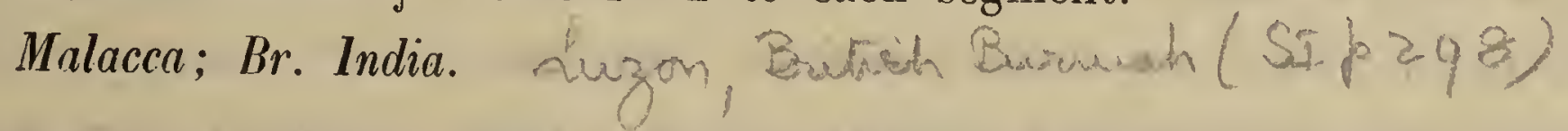

* (68a) A stereophyllum, Kae, Bot. Zeit., 1848, 17\%; Mett. Farng., VI, Aspl., 158.

Stipes 7-15 c.M. long, paleaceo-pilose, fusco-paleaceous at the base, afterwards naked. Fronds $12--30$ c.M. long, $5-7$ c.M. broad, lanceolate-deltoid, acuminate. Pinnae many, short-stalked, trapezio-oblong, mostly obluse, approximate, subspreading, the lowest \pm the largest, the upper base truncate, the lower subdimidiate-cuneate. Pinnulae rather distant, cuneate or spathulatelinear, the apex incised or toothed, obtuse, the lowest \pm 5-partite, spreading, the higher ones erecto-patent, decurrent, confluent. Texture rigidly coriaceous; surfaces sparingly paleaceo-pilose; rachis subflexuose, inconspicuously marginate, opaque.

Java, Sumalra.

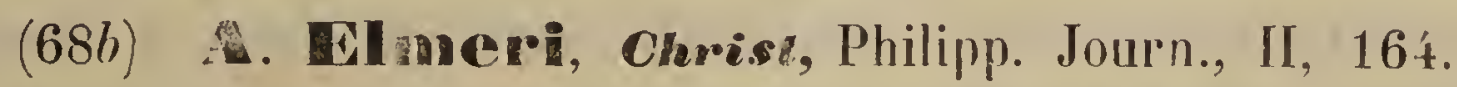

Rhizome short, crowned with castaneous, subulate scales. Slipes fasciculate, 7-12 c.M. long, rather deep-hlack-brown and clothed with spreading, subulate, brown scales like the rachis. Fronds oblong, acuminate, narrowed at the base, \pm 20 c.M. long, $6-8$ c.M. broad, 2-pimnate to 5-pinnatifid. Pinnae short-stalked, horizontal, $\pm 16-20$ on each side, subremote, ovate-elongate, acuminate, the apex coarsely toother, "lanceolate, the rachis short-winged above. Pinnulae few, 2--5 on each side, short-stalked, ovale. 
cuneate, obtuse, coarsely toothed, $2-5$ c.M. long, $\pm 1 \frac{1}{2}$ c.M. Mroad, the teeth $\pm 8 \mathrm{~m}$.M. long, $\pm 5 \mathrm{~m}$.M. broad, the lowest anterior lobe acute, approximate to the rachis. Texture herbaceous; colour black-green; veins flabellato-furcate. Sori $2-5$ to a segment, lanceolate, $\pm 4 \mathrm{~m}$.M. broad; indusium narrow, greyish, persistent.

Luzon.

* 69) A. pracemor:sum, Sw., Christ, Farnkr. d. Erde, 204; A. furcalum, Thb., Rac., Flor. Btz., I, 218; Bedd., Ferns S.I., tab. CXLIV; - var. alpestre, Christ, Ann. Btz., XV, 118; - var. angustissimum, Christ.

Rhizome wide-creeping, densely clothed with polished, lanceolate, brown scales. Stipes 8-25 c.I. apart, 10-20 c.M. long, firm, erect, clothed with deciduous, woolly hairs. Fronds $15-4$ c.M. long, $7-15$ c.M. broad, linearlanceolate, with 12-20 pinnae on each side. Pinnae lanceolate-deltoid, shurtstalked, 4-8 c.M. long, $2-2 \%$ c.M. broad, acute, cut down throughout nearly or quite to the costa into sessile segments Segments linear- or oblong-cuneate, the outer edge rounded and sharply serrate; lower segments often deeply incised. Texture coriaceous; rachis firm, more or less fibrillose like the stipe; veins deep-channelled, \pm flabellate.

Var. alpesre: Stipes and fronds $\pm 12 \mathrm{c:NI}$ long. Ultimate segments \pm ovate, deeply incised, the outer edge slightly crenate-dentate. Scales of the rhizome very acuminate.

Var. angustissianum: Fronds linear-lanceolate; pinnae erect, the lobes with the apices long-acuminate.

Tropical and subtropical.

* 70) A. cunentum, Lam., Rac, Flor. Btz., I, 219; - var. subaffine, Christ, Ann. Btz., XV, 117; - var. oceanicum, Christ, l. c.; -var. tripinnatum, Christ, Philipp. Journ., II, 163.

Rhizome suberect, clothed with brown, lanceolate scales. Stipes tufted, $12-$ a 0 c.Mr. long, scaly at the base. Fronds $15-100$ c.M. long, $\pm 10-25$ c.I. broad or broader, deltoid-lanceolate, with numerous spreading pinnae on each side. Lower pinnae $2 \frac{1}{2}-4$ c.ly. or more broad, lanceolate-deltoid, cul down to the rachis into distinct, oblong-cuneate, more or less rounded pinnulate with the outer edge inciso-dentate and the lower part entire or lobed or cut down nearly or quite to the costa. Texture thinly coriaceous; rachis firm. greyish to brownish, nearly naked; veins fine, visible above. Sori subflabellate, linear. 
55. ASPLENiUm. $\$ 3$. EU-ASPLenium.

Van. Uandine: Ultimate segments obovate, nearly flabellate, $2 \times$ as large.

Wan. Dcennicuna: Texture firmly coriaceous; rachis often darkbrown or black.

Ver. taיpipinmatum: Fronds 5-pinnatifid; segments short, ovatecuneate.

Pantropical; - var. subaffine: Celebes; - var. oceanicum: Malaya; var. tripinnatum: Mindanao.

* (71) A. Wullbifereuran, Forst., Hk. Bk., Syn. Fil., 218; A.bullatum, Wall., Bedd., Ferns Br.I., I, tab. LXV; Hk., Icon. Pl., V, tab. CDXXIII.

Stipes tufted, $15-50$ c.M. long, firm, erect, greyish, scaly at the base. Fronds 50-60 c.M. long, 20-30 c.M. broad, oblong-deltoid, with many pinnae on each side, erect or pendulous. Pinnae horizontal (erecto-patent after Bedlome's drawing), the largest $10-20$ c.M. long, $3 \frac{1}{2}-5$ c.M. broad, the apex acuminate, toothed or subpinnatifid, the rest cut down to a crompressed, winged rachis into many lanceolate-deltoid, unequal-sided pinnulae, which are again cut down into oblong or linear-oblong segments. Segments $1 / 2-1 \frac{1}{2}$ c.M. long, $21 / 2$ — $\mathrm{m}$.M. broad, slightly toothed. Texture herbaceous, slightly fleshy; surfaces naked, the upper side not rarely copiously proliferous; veins fine, pinnate in the tertiary segments, (the apices thickened and pellucid in the controlled specimens). Sori oblong, at length often filling the whole breadth of the segments.

Penang; Br. India, Australia, New Zealand.

* 72) A. Hitiofum, Sw., Rac., Flor. Btz., I, 219; Bedd., Ferns S.I., Lab. CXLVIII, CXLIX; A. laserpiliifolium, Bedd, l. c., tab. CCXXV.

Rhizome suberect, densely clothed with lanceolate, black, glossy scales. Stipes 15--50 c.M. long, firm, erect, greyish to brownish or black, naked. Fronds commonly 60-90 c.M. long, 15-50' c.M. broad, with numerous lanceolate to delloid, acuminate pinnae on each side. Pinnae \pm erecto-patent, the lowest $15-25$ c.M. long, $5-8$ c.M. broad, cut down to the rachis into numerous stalked, subdeltoid or subrhomboidal pinnulae, which are again cut down into flabellate to cuneate segments, which are inciso-serrate round the outer edge or pinnatifid again. Texture subcoriaceous; rachis firm, naked; veins channelled, conspicuous. Sori short, radiant.

Malaya; Norlh. India. 
* (75) A. Setisectuma, Bl., Rac., Flor. Btz., I, 219; A. sulcalum, Mell. (not Lam.), Ann. Mus. Bot. L. B., II, 236.

Near A. praemorsum, $S w$., but larger. Fronds to 60 c.M. long or longer, to 22 c.M. broad. Pinnae numerous, erectu-patent, stalked, lanceolate, to 3 c.M. broad or broader, cut down to the rachis into numerous erecto-patent pinnulae, the apex pinnatifid, long-acuminate, caudate, the point nearly filiform. Pinnulae subsessile, lanceolate, $\mathbf{3}-4 \times$ as long as broad, the base cuneate, the edge incised and serrate-dentate, the apex acute or acuminate, the teeth fine-pointed. Texture subcoriaceuus; rachis polished, naked. Sori linear.

Java.

*(74) A. affine, Sw., Hk. Bk., Syn. Fil., 215; Hk., Spec. Fil., III, tab. CCII; A. spathulinum, J. Sm., Bedd., Ferns S.I., tab. CGXXVI.

Stipes $15-50$ c.M. long, firm, erect, grey, nearly naked. Fronds 50-45 c.M. long, 13-50 c.M. broad, with numerous pinnae on each side, the lower ones lanceolate-triangular, the apex pinnatifid, acute or acuminate. Pinnulae distinct, rhomboidal-triangular, blunt or acute, inciso-serrate or deeply pinnatifid to pinuate again, the hase obliquely cuneate; lowest pinnulae acute, $\pm 5 \frac{1}{2}$ c.M. long, $\pm 1 \frac{1}{2}$ c.M. broad, the largest undivided ones $1 \frac{1}{2}-2$ c.M. long, under 1 c.M. broad, the higher ones and those of the higher pinnae with the outer edge \pm hluntish or \pm rounded to truncate, crenate. Texture subcoriaceous; rachis firm, naked; veins subflabellate. Sori copiuus, linear, the higher ones more oblique than the lower.

Mu'aya; Polynesia, Ceylon, Easl African Islands.

* (75) A. Iaserpitiifolium, Lame, Rac., Flor. Btz., I, 220; Hk., Spec. Fil., III, tab. CCIII; - var. intermedium, Christ; - var. subvenustun, Christ, Philipp. Journ., II, 16 .

Rhizome creeping, short, densely clothed with spreading, hyaline, yellowish scales. Stipes $15-30$ c.M. long, firm, erect, naked, or scaly at the base. Fronds $50-120$ c.M. long, to 45 c.M. broad, with numerous pinnae on each side. Lowest pinnae $5-25$ c.M. long, 2-15 c.M. broad, deltoid-lanceolate, cut down to the rachis into numerous distinct pinnulae, the lowest of which often 2-pimate. Uttimate divisions cuneate-oblong, with the outer edge rounded, lincly toothed and occasionally incised. Texture herbaceous to chartaceous: rachis slender, naked; veins fine, conspicuous. Sori linear-oblong, irregular.

Var. intermedium: Texture thinly herbaceous; segments broadly ovate, ohtuse, coarsely toothed. Sori short, flabellate. 
Var. subvenustum: Reduced form; fronds $50-45$ c.M. long, much divided, on slender stipes. Leaflets \pm 5 m.M. long or sometimes longer, triangular, flabellate. Sori small, $2-3$ to a pinnula (leaflet).

Malaya; - var. subvenustum: Luzon.

\section{\$4. DAREA.}

a. Fronds small, to 10 c.M. long.

b. Ulimale segmenls obluse.

c. Fronds $2^{1}{ }_{2}-4$ c.M. long, rachis and margins besel with deciluous, black brislles.

(76) A. Beccarianum.

c.c. Fronds 6-10 c.M. long, rachis and margins not bristly.

b.b. Ullimale segmenls ralher acute.

(77) A. Lauterbachii.

(78) A. dichotomum

a.a. Fronds larger, 12-60 c.M. long when fully developed.

1. Stipes tufled. Lowest secondary segments simple or forked.

2. Pinnae 6-12 on each side, subdeltoid, the apex narrowed; secondary segmenls few.

(79) A. obtusilobum.

2.2. Pinnae many 10 numerous, linear-oblong, the apex rounded; secondary segments many.

1.1. Stipes scallered. Lowest secondary segments rather copiousty pinnale.

(8ic) A debium. SI p 302

(81) A. scandens.

(81a) A mpirees sevenum

(76) Mecrarianum, Ces., Fel. Becc. Polin., 4 \& 7.

Rhizome wide-creeping. Stipes approximale, placed in distant groups, erect, $\pm 21 / 2$ c.M. long, naked, filiform. Fronds oblong or ovate, $\pm 21 / 2-4$ c.I. long, 2-pinnate. Pinnae $8-10$ on each side, the segments cuneate, obtuse at the apex, the margin entire or indistinctly crenate with few $(1-5)$ crenations, beset with fugacious, black bristles. Texture weak; rachis bristly like the margin of the pinnae when young. Sori 1 to each ultimate segment.

New Guiner.

* (77) Lautenbachii, Cherist, Schum. \& Laut., Flor. deut. Sch.geb., 130.

Rhizome wide-creeping, slender, sparingly scaly, bearing distant groups of fronds. Stipes green, sparingly scaly, $\pm 3-8$ c.M. long. Fronds $\pm 6-10$ c.M. long, $\pm 1 \frac{1}{2}-2$ c.M. broad, lanceolate, acuminate, pinnate. Pinnae 
8-12 on each side, subremote, erecto-patent, the higher ones linear-oblong simple, obtuse, entire, the lowest the largest, $\pm 1-1^{1 / 1} / 2$ c.M. long, $5-6$ m.M. hroad, the base cuneate, the edge more or less deeply lobed with 2-3 lobes. Lobes not short, oblong to linear-oblong, the largest $\pm 5 \mathrm{~m}$.M. long, \pm 1 m.M. broad, the apex rounded. Texture moderately thick; rachis and surfaces naked; veins flabellato-pinnate, not very distinct, 1 to each ultimate lobe. Sori linear, 1 to each lobe; indusium greyish.

New Guinea.

* (78) A. dichotomum, Hk., Hk. Bk., Syn. Fil., 221; Hk., 2nd Cent. of Ferns, tah. XXXIX.

Stipes tufted, $\pm 21 / 2$ c.M. long, erect, greenish, deciduously setoso-paleaceous. Fronds 4-10 c.M. long, oblong, acute, sub-3-pinnate. Pinnae 6-12 on each side, 1-2 c.M. long, the base on the lower side cut away, the edge cut down to a narrow, compressed rachis into $\pm 3-7$ linear segments, the lowest of which are mostly $1-2 \times$ forked. Ultimate segments $3-5$ in.M. long, ${ }_{2}-2$ m.M. broad, acute. Texture herbaceous; main rachis compressed, slighlly winged, greenish, naked; 1 vein and sorus to each ultimate segment.

Borneo.

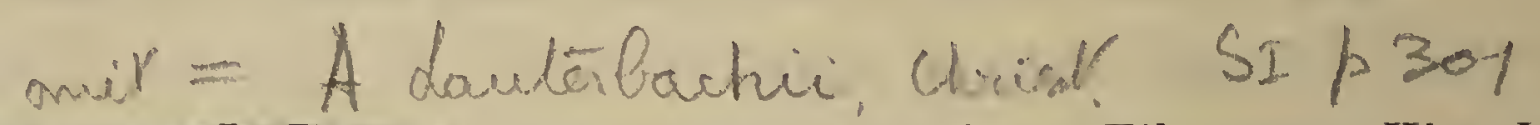

(79) A. obrusilobum, Mk., Hk. Bk., Syn. Fil., 221; Hk., Icon. Pl., X, tab. II ; A. oceanicum, C. Chr., Ind. Fil.

Rhizome short, erect, stoloniferous. Stipes tufted, 5-10 c.M. long, naked, greenish or blackish and polished. Fronds $12-15$ c.M. long, $1 \frac{1}{2}-5$ c.M. broad, often proliferous at the apex. Pinnae 6-12 on each side, subdeltoid, the lower $1 / 3$ of the basiscopical side cut away, the largest $1-21 / 2$ c.M. long, to 2 c.M. broad, \pm flabellately cut into $5-5$ linear, obtuse lobes. Texture thin, herbaceous; rachis green, or black in the lower half; veins 1 to each ultimate segment, covered with scaltered, blackish, stellate hairs like the rachis. Sori 1 to each lobe.

Celebes, New Guinea; Polynesia.

* (81) A. Belangeri, Kze, Hk. Bk., Syn. Fil., 22j; Bedd., Ferns Br.I., II, tab. CCLXXXVII; Hk., Fil. Exot., tab. XLI; A. Ienerum, Fors:., var. Belangeri, Rac., Flor. Btz., I, 215 ; C. Chr., Ind. Fil.; A. decorum, Kze, Bot. Zeit., 1848, 176.

Rhizome erect or suberect, the scales brown, lanceolate. Stipes tufted, 5-20 c.M. long, firm, erect, greenish, naked. Fronds $15-50$ c.M. long, 
4-8 c.M. broad, varying from linear-lanceolate to deltoid-ovate, blunt to caudate, with many to numerous pinnae on each side. Pinnae horizontal, 7 $10 \mathrm{~m} . \mathrm{M}$. broad, the apex rounded, the edge regularly cut down throughout to a narrowly winged rachis into many linear, erecto-patent segments, the base truncate on the upper side, cuneate below. Segments $1-1 \frac{1}{2} \mathrm{~m} . \mathrm{M}$. broad, simple, the lowest anterior usually forked. Texture coriaceous; veins 1 to each segment, naked or provided with some few fimbriate, minute scales. Sori solitary on the segments. - The young plants have the pinnae less deeply lobed, \pm bluntly toothed.

\section{Malaya; Tonkin.}

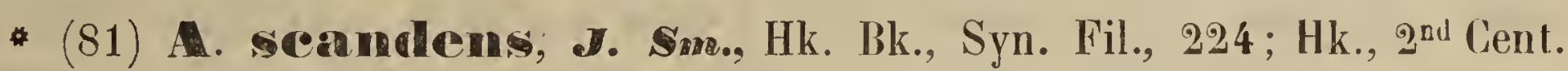
of Ferus, tab. XXXVII; A. myriophyllum, Muell. (not Spr.), Pap. Pl., IV, 82. Stipes scattered, varying from very short to 20 c.M. long. Fronds $3(1-60)$ c M. long, 15-50 c M. broad, with numerous horizontal pinnae on each side. Pinnae \pm 5-4 c.M. broad, cut down to a winged rachis into numerous subdistant, ovate-rhomboidal pinnulae, which are cut down to the rachis throughoul, with the lowest segments forked or pinnatifid again. Ulimale segments narrowly linear. Texture thin, herbaceous; rachis firm, erect; veins 1 to each ultimate segment. Sori solitary on the segments.

Philippines, Borneo, Cerarn, Amboina, New Guinea; Fiji.

\section{\$5. LOXOSCAPHE.}

*. Slipes pale-coloured; fronds small, 2-pinnate. (82a) A. Bikeri. *. .. Slipes darli-coloured; fronds large, 3-4-pinnale.

(82b) A. novo-guineense.

(82, A. Baken, C. Cher., Ind. Hil.; Davallia lanceolala, Bk., Kew Bull., 1899, 119.

Rhizome slender, short-creeping. Stipes short, slender, stramincous, brownish below. Fronds lanceolate, 2-pinnate, b-10 c.M. long, $1 \frac{1}{2}-2$ c.M. broad, naked; rachis naked, stramineous. Pinnae numerous, contiguous flabellato-pinnate. Segments few, narrowly linear, 1-nerved, $21 / 2-4$ m.M. long, the ipex dilated. Sori solitary, terminal; indusium persistent, naked.

New Guinea. 
(82b) A. novo-guineense, Rst., Fed., V, 40.

Rhizome short-creeping, densely clothed with rigid, black, linear-lanceolate, finely acuminate scales. Stipes dense, straight, to 60 c.M. long, terete, naked, black or purple-black, the sides provided with a narrow, pale-coloured stripe. Fronds linear-lanceolate, nearly 1 II. long, \pm 20 c.M. broad, compound. Pinnae suberecto-patent, short-stalked, subremote, linear-lanceolate, to $12 \mathrm{c} \mathrm{M}$. long, to 4 c.M. broad, acuminate, truncate at the base. Pinnulae lanceolate, to $2 \%$ c.II. long, to $1 \frac{1}{2}$ c.M. broad, the base truncate on the upper, cuneale on the lower side, the apex short-acuminate or obtuse, the anterior side produced. Tertiary divisions simple or 2-fid, the laciniae narrowly linear, nearly $3 \mathrm{m.M}$. long, $1 / 2$ m.M. broad, slightly dilated at the apex. Texture thinly herbaceous; surfaces pale-green, nearly naked (clothed here and there with some few blackpurple, spinuloso-subulate hairs on the costulae and the margin); veins 1 in each ultimate segment, forked near the apex. Sori subterminal on the longest veinlets; indusium semiovate, opening towards the shortest veinlet.

New Guinea.

\section{\$6. ASPLENIDICTYUM.}

- (83) A. Finlaysoniamum, Well., Hk. Bk., Syn. Fil., 245 ; Hk., Icon. Pl., X, tab. CMXXXVII; Hemiliclyum Finlaysoniınum, Moore, Bedd., Ferns Br.I., I, tab. LXXII.

Stipes $15-25$ c.M. long, naked or clothed with blackish, subulate-lanceolate scales at the base. Fronds 20 - 73 c.M. long, acuminate, simply pinnate, with an entire or subrepand lerminal pimna, which is often pinnatifid at the base and 1-6 lateral pinnae on each side, the highest of which are smaller than the terminal one Lowest pinnae to 10 c.M. apart, 10 - 20 c.M. long, 5-8 c.M. broad, erecto-patent, acuminate, the base often unequal, narrowed gradually into a distinct petiole, the edge entire or subrepand, sometimes slightly incised near the base. Texture \pm coriaceous; rachis often slightly winged towards the apex; veins erecto-patent, the highest very oblique. Sori scattered irregularly, $1 / 2-5$ c.M. long.

Cclebes, Malacca; Br. India.

\section{PHYLCITIS, Ladwig.}

Characters of Asplenium except that the sori and indusia are arranged in 
opposite pairs, one originating from the anterior side of a vein or veinlet, the other from the posterior side of the next higher vein or veinlet and so the indusia opening towards each other. - Veins free or anastomosing variously. Hk. Bk., Syn. Fil., tab. IV, fig. 41. (Scolopendrium).

A small genus inhabiting different regions and climates.

\section{Arrangement of the sections.}

\$1. SCOLOPENDRIUM (Euscolopendrium). Midrib present; veins free, not flabellate. Diels, in Engl. \& Prantl, Nat. Pfl.Fam., I ${ }^{4}$, fig. 12j, A-B.

$\$ 2$. CAMPTOSORUS. Midrib present; veins anastomosing near the base, not flabellate. Diels, l. c., fig. 123, C-D. (Not in Malaya).

\$5. ANTIGRAMME. Midrib present; veins anastomosing towards the apex, not flabellate. Diels, l. c., fig. 124, E. (Not in Malaya).

$\$ 4$. SCHAFFNERIA. Midrib wanting; veins free, or anastomosing towards the apex, flabellate. Diels, 1. c., fig., 124, F-H. (Not in Malaya).

\section{$\$$ i. SCOLOPENDRIUM.}

\$. Rhizome, stipes and costae quile naked.

(1) $\mathrm{Ph}$. scolopendropsis.

\$.\$. Rhizome, stipes and costae sparingly provided with small or punctiform scales. *. Rhizome wide-creeping.

$\times$. Rhizome pale-olivaceous; edges of the fronds entire or undulatocrenate.

(2) Ph. intermedia.

$x \cdot x$. Rhizome dark-brown; edges of the fronds rather sharply serrate.

(5) $\mathrm{Ph}$. mambare.

*.*. Rhizome short-creeping.

(4) Ph. shizocarpa.

(1) Ph. scolopendropsis, v. A. v. R., Bull. Dép. Agr. I.N., 1908, XXI, 6; Asplenium Scolopendropsis, Muell., Pap. Pl., III, 49; C. Chr., Ind. Fil. Rhizome creeping, quite naked like the știpes and fronds. Fronds simple, elongate, linear-lanceolate, $20-43$ c.M. long, $\pm 21 / 2$ c.M. broad, narrowed very gradually into an acuminate apex and a long, wingless stipe, the margin more or less sinuato-denticulate, the denticulations rather distant. Texture chartaceous or almost membranaceous; costa stout; veins very spreading, simple or forked, almost parallel. Sorj broad, in pairs, traversing the whole width 
56. PHYLLITIS. $\$ 1$. SCOLOPENDRIUM.

of the frond from the costa to the margin, those of each pair separated by an ample, empty interstice; the indusia of each pair touching each other with their edge.

New Guinea.

* (2) Ph. interomediat. v. A. v. R., Bull. Dép. Agr. I. N., 1908, XXI, 6.

Rhizome wide-creeping, angular, pale-olive-brown, rather greenish, covered here and there with very minute, punctiform, dark-brown, scattered scales. Stipes scattered, $\breve{b}-10$ c.M. long, apparently articulate, pale-olive-grecn, angular, 5-10 c.M. long, naked or sparingly covered with dot-like scales like the stout costa. Fronds linear-lanceolate, simple, rarely forked towards the apex, $\pm 25-35$ c.M. long, $1 \frac{1}{2}-2$ c.M. broad, narrowed gradually towards both ends, the apex rather caudate, irregularly crenate, the edge irregularly (but more or less broadly and slightly) undulato-crenate, here and there entire. Texture chartaceous, subpellucid; colour olive-green, but paler between the 2 sori of each pair; surfaces naked; veins simple or forked, not close, subspreading or erecto-patent. Sori lroad, in pairs, reaching from the costa to some distance from the margin, those of each pair separated by an ample, empty, thin-membranaceous, translucent interstice; the indusia of each pair not touching each other with their edge, at length strongly recurved. - This plant seems to be intermediate between $\mathrm{Ph}$. mambare \& scolopendropsis, $v$. A. v. R., and specimens recently received from New Guinea (Leg. Dr. Versteeg) quite agree with this.

New Guinea (Treub).

(5) Ph. mambane, v. A. v. R., 1. c.; Scolopendriun mambare, Bail., in Queensl. Agric. Journ., III' ${ }^{2}, 162$; C. Chr., Ind. Fil.

Rhizome wiry, angular, dark-brown, scaly on the younger portion, the scales few and scattered on the older parts. Fronds erect, linear-lanceolate, sometimes forked at the end, often exceeding 50 c.M. in lenght, not exceeding $21 / 4$ c.II. in width, the edges irregularly sinuate, sometimes the lobes cut down to the costa, all more or less sharply serrate, the apex tapering into an almost filiform cauda and the base into a stipe $\breve{b}-71 / 2$ c.M. long. Stipe and costa slightly and minutely scaly; veins simple or forked, rather close, parallel. Sori reaching from the costa to near or some distance from the margin.

New Guinea. 
(4) Ph. schizocarpa, v. A. v. R., l. c.; Scolopendrium schizocarpum, Copel., Philipp. Journ., I, Suppl., 152, tab. IX.

Rhizome short, creeping, clothed towards the apex with fuscous, adpressed scales. Stipes 2-5 c.M. long, black, sparingly scaly. Fronds simple, oblanceolate, 20-50 c.M. long, $\pm \mathbf{3}$ c.M. broad, caudate-acuminate, entire or undulate, narrowed gradually into the stipe. Texture coriaceous; surfaces naked; veins indistinct, forked. Sori oblique, regular, not reaching either the midrib or edge.

Mindanao.

\section{8. ? TRIPHLEBLA, Bulier.}

Characters of Phyllitis except that the sori (not the indusia) are not placed on but between the two contiguous veins, i. e. 1 sorus to each pair of indusia, which open towards each other. Veins free. Diels, in Engl. \& Prantl, Nat. Pfl Fam., I', fig. 122, C-D. (')

East. Malaya, Philippines and New Guinea.

1. Fronds uniform.

2. Fronds simple.

3. Fronds deeply crenato-repand.

3.3. Fronds entire.

2.2. Fronds pinnate.

1.1. Fronds dimorphous.
(1) T. linza.

(2) T. longifolia. (3) T. pinnata. (4) T. dimorphophylla.

(1) T. linzan, Brk., Becc., Mal., III, 42, tab. V ; Asplenium Linsa, Ces., Fel. Becc. Polin., 4, 7.

Rhizome creeping, naked, slender, grey. Stipes to $\breve{z}-8$ c.M. long, naked, the base dilated, articulate. Fronds lanceolate, naked, \pm 50 c.M. long, the base angustate, the margin deeply and irregularly crenato-repand. Texture

(*) Triphlebia, at least in the case of T. pinnata, $B k$, is not distinguished by any constant character from Scolopendrium (Phyllitis), to which genus the species should be returned (Copel., Philipp. Journ., I, Suppl., 152). 
membranaceous; veins conspicuous, simple or forked. Sori reaching from the costa to the margin; indusium nirrow, naked, persistent; receptacle obscure. $\left({ }^{1}\right)$

New Guinea.

(2) T. Iongifolia, Bk., Copel., Polypod. Philipp., 87; Scolopendrium longifolium, Pr., Rel. Haenk., I, 48, tab. IX, fig. 1.

Differs from $T$. pinnata, $B k$. only in that the fronds are simple and entire, and the limit between the two indusia is marked by a thin, not emphasized line. - Perhaps an undivided form of the young plants of T. pinnati, $B k$.

Bornen, Celebes, Philippines 10 Papua.

(3) 'T. pimmata, Brk., Copel., Polypod. Philipp., 87; Hk., Icon. Pl., XVII, tab. MDCLII; Scolopensriu'n pinnatum, J. Sm., Kze, Farnkr., I, 124, tab. LVI.

Stipes compressed, greyish. Fronds $50-120$ c.M. long, with an entire or finely crenate terminal pinna $10-20$ c.M. long, 5-5 c.M. broad, proliferous at the point; below this $1-6$ lateral pinnae similar in shape to the terminal one. Texture coriaceous; surfaces naked; veins mostly once forked. Sori numerous, oblique, not reaching either the midrib or edge; indusium ridged where the halves meet.

Borneo, Celebes, Philippines to Papua.

(4) T. dimorphophylla, Rls., Becc., mal., III, 42, tab. IV, Diels, in Engl. \& Prantl, Nat. Pfl.Fam., I', fig. 122, C--D; Asplenium subserratum, Ces., (not Bl.), Fel. Becc. Polin., 4; Stenochlaena sorbifolia, J. Sm., var., C. Chr., Ind. Fil.

Rhizome creeping, slender, naked. Stipes short, the base articulate. Fronds dimorphous, both simple and once pinnate. Simple fronds lanccolate, \pm 15 c.M. long, the base acute or very gradually narrowed, the edge irregularly crenato-repand. Pinnae of the other fronds small, paucijugate, \pm obovate, flabellately cut or inciso-crenate. Texture membranaceous; both surfa. ces naked; veins erecto-patent, conspicuous, simple or forked. Sori reaching nearly from the costa to the margin; indusium narrow, naked, persistent. $\left({ }^{2}\right)$ New Guinea.

(') See Schum. \& Laut., Flor. deut. Sch.geb., Suppl., 42, 43.

$\left({ }^{2}\right)$ See Schum. \& Laut., Flor. deut. Sch.geb., Suppl, 43. 
TRIBE VII. PHEGOPTERIDEAE.

filuaes. 



\section{NOTHHOLAENA, R. Hrown.}

Sori roundish, oblong or linear-oblong, terminal on the veins, often coalescing afterwards into a continuous, submarginal line, naked or partially covered by the unaltered, often \pm recurved edge of the frond. Spores globoso-tetrahedral.

Rhizome commonly short-creeping. Stipes not articulate to the rhizome. Fronds rather small, divided, glandular, hairy or scaly, often hardly different from Cheilanthes; veins free. Hk. Bk., Syn. Fil., tab. VI, fig. 50; Diels, in Engl. \& Prantl, Nat. Pfl.Fam., I ${ }^{4}$, fig. 145, B-E. (Nothochlaena).

Tropical and subtropical, but also found in cooler regions, generally inhabiting dry climates.

Arrangement of the sections.

S 1. EUNOTHOLAENA. Fronds not powdery beneath.

$\$$ 2. CINCINALIS. Fronds coated beneath with white or yellow powder. (Not in Malaya).

\section{$\$ 1$. EUNOTHOLAENA.}

*. Under surface more or less hairy or fibrillose.

*.*. Under surface scaly.

(1) N. hirsuta.

(2) N. distans.

* (1) N. hirsuta, Desw., Hk. Bk., Syn. Fil., 372; Cheilanthes hirsula, Mett., Rac., Flor. Btz., I, 147; Pteris hirsula, Poir., (oldest name); — var. densa; N. densa, J. Sm., Copel., Polypod. Philipp., 97; Kze, Farnkr., I, tab. LXIV, fig. 2, a-c.

Rhizome short-creeping, the scales dense, ferrugineous or brown, linearsubulate. Stipes approximate, 3-15 c.M. long, erect, firm, dark-purplishbrown, polished, more or less copiously clothed with whitish or ferrugineous, small, spreading or crisped, subulate, fibrillose scales. Fronds 10-20 c.M. long, 4-8 c.M. broad, ovate-elongate, 5-pimnatifid at the base. Pinnae several on each side below the pinnatifid apex, \pm lanceolate, the lower ones rather 
distant, \pm deltoid-oblong, equalling or smaller than those next ahove, pinnate towards the hase. Pinnulac sessile, to $1 \frac{1}{2}$ c.M. long, to $4 \mathrm{~m}$.M. broad, blunt, crenate, lobed or pinmatilid, the lobes oblong, blunt, small. Texture herba ceous; rachises and lower part of the costae fibrillose; veins sparingly fibrillose, the fibrils whilish or brownish. Sori small, consisting of few or not very numerous capsules, confluent into a rather narrow, more or less interrupted submarginal line, whether or not partially covered by the slightly recurved margin.

Var. Iensa: Fronds narrower, to 5 c.M. hroad, often less divided. Sori broader, extending from the margin nearly or quite to the costules at full maturity.

Trop. Asia, Australia \& Polynesia.

* (2) N. Iistans, Tr. Mr., Hk. Bk., Syn. Fil., 572; Hk., Icon. Pl., X. tab. CMLXXX: Cheilanlhes distans, Metı., Farng., V, Cheil., 25; - var. leontopodium, Christ, Ann. Btz., XV, 169.

Stipes tufted, $21 / 2-71 / 2$ c.M. long, castaneous, wiry, clothed with ferrugineous, linear-lanceolate-subulate scales. Fronds $15-2 b$ c.M. long, $2-5$ c.M. broad, 2-pinnate. Lower pinnae distant, deltoid, cul down to the rachis below into oblong, obtuse, entire or slightly lobed pinnulae. Texture subcoriaceous; upper surface pale-green and slightly villose, rachis and under side more or less densely coated with long, linear-lanceolate, ferrugineous scales. Pinnae often much curled logether and the edge recurved, subindusiform. Sori at length continuous along the margin.

Var. Iedutopodinam: Scales of the under surface very long, white when young.

Philippines; Polynesia, New Zealand, Australia; - var. leontopodium: Celebes.

\section{Species of a dubious syslematical place.}

(3)? N. Dteridiformis, ER., Becc., Mal., III, 49; Gymnogramme pteridiformis, Ces., Fel., Becc., Polin., 5 \& 8.

Rhizome wide-creeping, slender, clothed with brown, fugacious scales. Stipes furfuraceous, fugacious scales. Fronds pinnate, oblong, 20--25 c.M. long. Pinnae 3-6, distant, glossy, naked, erect or moderately spreading; sterile 
pinnae $12-13$ c.M. long, $\pm 2 \frac{11}{2}$ c.M. broad, subfalcate, acute or acuminate, the base obliquely and shortly narrowed, the edge entire; fertile pimnae \pm $1 / 2 X$ as broad as the sterile ones, long-caudate, the margin eroso-dentate. Veins close, parallel, simple or forked, free, reaching the margin, those of the fertile pinnae dilated at the apex, the fertile ones accompanied by yellow, subpellucid lines on each side, which are connected by a submarginal, moderately conspicuous, yellow strand.

New Guinea.

\section{MON ACHOSORUM, Kune.}

Sori oblong, terminal on the veins, without an indusium, never confluent. Spores 3-lobato-tetrahedral.

Rhizome short-creeping. Stipes approximate, not articulate to the rhizome. Fronds large, finely dissected, naked; veins free. Diels, in Engl. \& Prantl, Nat. Pfl.Fam., I ${ }^{4}$, fig. $117, B$ \& F.

Tropical Asia.

* NI. subdigitatum, Kuhn, Christ, Farnkr. d. Erde, 76, fig. 199; Polypodium subdigitatum, Bl., Rac., Flor. Btz., I, 97; Bl., Flor. Jav., II, tab. XCIII; Bedd., Ferns Br.I., II, tab. CCXXIX; P. davalloides, Mell, Hk., Spec. Fil., IV, 256; Phegopteris subdigitala, Bedd., Handb Ind. Ferns, 295; Aspidium subdigitatum, Bl., (oldest name).

Rhizome creeping, clothed with reddish, bristle-like hairs. Stipes approximate, firm, stramineous, brown in the lower part, furfuraceous or nearly naked, 30-50 c.M. long. Fronds 50-100 c.M. long, triangular, 3-4-pinnate. Lower pinnae largest, 15-25 c.M. long, deltoid. Pinnulae lanceolate, 3-6 c.M. long, 2-3 c.M. broad. Tertiary divisions stalked, oblong, divided nearly or quite to the costa into oblique, entire or toothed to incised ultimate segments, which are cuneate at the base, $1 / 2-1$ c.M. long, $1-3 \mathrm{~m} . M$. broad, the teeth bluntish or acute. Texture thinly herbaceous; rachis furfuraceous: surfaces naked; veins 1 to each ultimate tooth, \pm clavate at the apex. Sori copious, terminal on the veins, \pm oblong.

Tropical Asia. 


\section{Oa. PHEGOPTERIS, Fée.}

Sori roundish or oblong: rarely more than $2 X$ as long as broad. Indusium wanting.

Rhizome creeping or erect. Stipes not articulate to the rhizome. Fronds various in size and shape, commonly with the habit and appearance of Dryopteris; main veins pinnate; veins free as in Lastraea or anastomosing as in Nephrodium. (Dryopteris, p. p., C. Chr., Ind. Fil.).

Tropical and subtropical, also found in cooler climates. (*)

\section{Arrangement of the sections.}

S 1. EUPHEGOPTERIS. Veins free. Sori round. Differs from Lastraea by the absence of an indusium. Bedd., Handb. Ind. Ferns, fig. 148-152.

$\$$ 2. LEPTOGRAMMA. Like $\mathbb{1}$, but the sori linear or oblong. Diels, in Engl. \& Prantl, Nat. Pfl.Fam., I ${ }^{4}$, fig. 91, G.

$\$$ 3. GONIOPTERIS. Opposite veins of contiguous groups uniting as in Nephrodium. Sori round, free. Differs from Nephrodium by the absence of of an indusium. Hk. Bk., Syn. Fil., tab. V, fig. 4in, e.

$\mathbb{S}$ 4. STEGNOGRAMMA. Like $\mathbb{3}$, but the sori linear or oblong, the opposite pairs not conlluent. Hk. Bk., l. c., tab. VI, fig. 52, b.

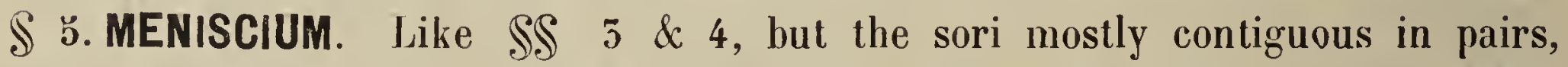
at least the lowe: (sumetimes the higher) pairs confluent and not rarely produced along the excurrent veinlets. Bedd., l. c., fig. 231-234; Diels, l. c., fig. $92, \mathrm{H}$.

Key to the sections.

a. Veins free, as in Lastraea.

*. Sori round.

$\$ 1$. EUPHEGOPTERIS.

*.*. Sori oblong, sometimes linear.

(*) Regarding this genus see the information in "Christ, Farnkr. d. Erde, 266". Its natural place is near Dryopteris, from which it differs by the wanting indusium only. A species of Dryopteris with fallen or obliteratell indusia is not or hardly distinguishable from this genus. 
a.c. Veins uniting as in Nephrodium.

b. Sori free, i. e. the contiguous pairs liever confluent.

c. Sori round.

\$ 3. GONIOPTERIS.

c.c. Sori oblong or sometimes linear.

\& 4. STEGNOGRAMMA.

b.b. At least the lower (sometimes the higher) contiguous pairs of sori confluent and not rarely ruming along the excurrent veinlets. Sori oblong, rarely round.

$\$$ ร. MENISCIUM.

\section{\$ 1 . EUPHEGOPTERIS.}

a. Fronds 1-2 $\times$ pinnate.

b. Pinnae cut down $1 / 2$-way or more to the costa into close, regular, entire or subentire secondary segments.

c. Slipes not tuberculate at the base.

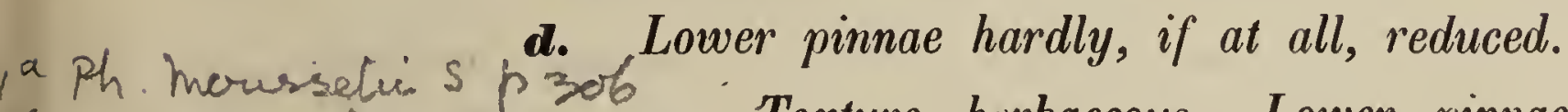

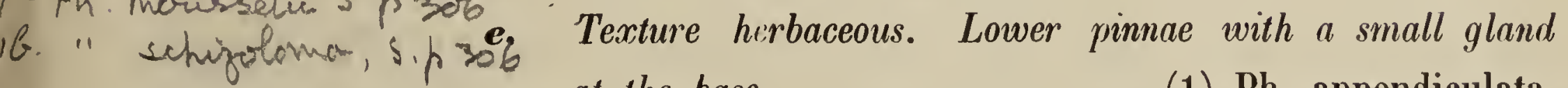
at the hase.

(1) Ph. appendiculata. $\$$ mes

e.e. Texture \pm coriaceous. Pinnae without a gland at the base.

2d. Ph Schlachter s $p 308 \times$. Lowest pinnae with the lowest segments free, incised, produced, stipule-like.

(2a) Ph. guadriaurita. $\times . \times$. Lowest pinnae with the lowest segments otherwise. 3 p $30>$

(2b) $\mathrm{Ph}$. erubescens.

(3a) Ph firislerracad. Lower pinnae gradually reduced. at the base.

(3) Ph. Smithii. Dryeterus

*.*. Sori nearer the costulae than the edge. Pinnae with
a gland at the hase.
(4) Ph. auriculata.

c.c. Stipes tuberculate at the base.

(5) Ph. tuberculata.

b.b. Pinnae cut down nearly or quite to the costa into toothed or lobed secondary segments.

s. Stipes naked, stramineous; secondary segments sharply toothed.

(6) Ph. oxyodus.

\$.S. Stipes \pm bristly or scaly, dark-brown or blackish; at least the lower secondary segments lobed or incised.

*. Fronds narrow, \pm 4 c.M. broad. Pinnae pinnate at the base.

(7) Ph. subobscura. 
*.*. Fronds broader, $12-25$ c.M. broad. Pinnae deeply pinnatifid throughout.

a.a. Fronds at least deeply 3-pinnatifid.

(8) Ph. obscura.

1. Fronds mostly under 45 c.M. long.

2. Main rachis scaly, or scaly and hairy.

*. Lowest pinnae produced on the lower side. Ultimate segments entire.

*.*. Lowest pinnae not produced on the lower side. Plitimale (9a) Ph. hirta. segments toothed.

2.2. Main rachis naked or hairy, not scaly.

(9b) Ph. Copelandi.

3. Rachis and under surface slightly pubescent or tomentose.

(10) $\mathrm{Ph}$. rufescens.

3.3. Rachis and both surfaces nalied.

4. Stipes rather short, castaneous. Lowest pinnae \pm equilateral.

(11) Ph. loxoscaphoides.

4.4. Stipes rather long, green or stramineous. Lowest pinnae with the lower pinnulae on the lower side produced.

5. Sori medial on the veins.

5.5. Sori terminal on the veins.

(12) Ph. Hasseltii. (15) Ph. laserpitiifolia.

1.1. Fronds more than 45 c.M. long when fully developed.

a. Stipes copiously scaly.

*. Texture firm; both surfaces densely setose.

(14) Ph. cheilanthoides.

*.*. Texture thin-herbaceous; costae and veins often hairy.

u. . . Stipes naked, hairy or glandular.

(15) Ph. ornata.

ß. Texture \pm coriaceous ( $\left(^{*}\right)$

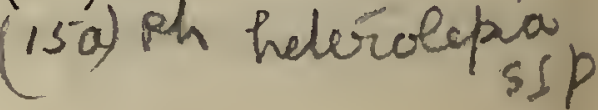

$\beta . \beta$. Texture \pm herbaceous.

(16) Ph. asperula.

$\% \quad$ Sori submarginal.

*. Fronds large, erect, 45-120 c.M. long.

(17) Ph. penotata.

*.*. Fronds very large, subscandent, 360-450 c.M. long.

(18) $\mathrm{Ph}$. Keraudreniana.

\%.\%. Sori \pm medial on the veins.

o. Fronds $\pm 20-50$ c.M. broad. 
60a. Phegopteris. $\mathbb{S} 1$. eUPHEgopteris.

E. Stipe and rachis long-hairy.

(19) Ph. subcomnexa.

ع.s. Slipe and rachis naked or short-pubescent.

(20) Ph. distans.

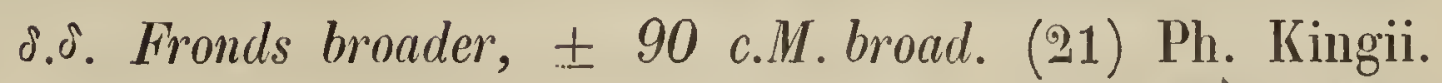

(210) Ph atrorreidis

(1) Wh. appendiculdata, v. A.v. It.; Polypodium appendiculatum, Wall., Hk. Bk., Syn. Fil., 506; (? Dryopteris cana, O. Ktze., C. Chr., Ind. Fil.).

Stipes tufted, \pm 50 c.M. long, deciduously villose. Fronds $45-60$ c.M. long, 20-25 c.M. broad, ovate-lanceolate. Pinnae $7-15$ c.M. long, 2-2 $/ 2$ c.M. broad, narrowed from the base to an acuminate point, cut down nearly to the costa into linear-oblong, falcate lobes; lower pinnae with a small gland a the base, slightly reduced. 'Texture herhaceous; rachis and under surface villose; veins $8-12$ on a side. Sori close to the costulae.

Penang; Easl. Himalaya.

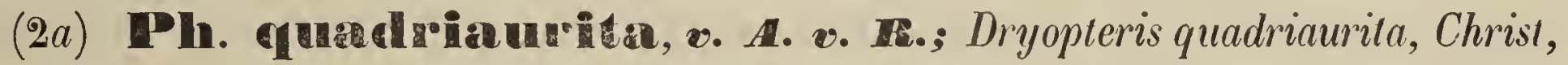
Philipp. Journ., II, 209.

Rhizome probably oblique, the apex crowned with rigid, castaneous, opaque, subulate scales nearly 1 c.M. long. Stipes few or solitary, \pm 35 c.M. long, naked, grey-stramineous, terete. Fronds \pm 35 c.M. long, \pm 24 c.M. broad, deltoid-oblong, hardly narrowed towards the base. Pinnae \pm 15 on each side below the pinnatifid apex, sessile, lower opposite, lowest deflexed or decurved, acuminate, \pm 12 c.M. long, $\pm 2 \%$ c.M. broad, cut down to the costa into subdistant, horizontal segments. Secondary segments linear, acute, entire, with acute sinuses between them, $\pm 1 \%$ c.M. long, $\pm 5 \mathrm{~m} . M$. hroad, lower free, falcate, lowest produced, petiolulate, incised, adpressed to (overlapping?) the rachis, stipule-like. Texture coriaceous, rigid; colour bright-green; costae very short-hairy; veins simple, $\pm 8-10$ on each side, oblique. Sori minute, medial, impressed. - Fronds with the appearance of Pteris quadriaurita, Retz.

Mindanao.

* (2b) Ph. erubescens, J. Sm., Christ, Farkr. d. Erde., 272; Polypodium erubescens, Wall., Hk. Bk., Syn. Fil., 506; Bedd., Ferns Br.I., II, tab. CCXIII; Dryopteris erubescens, C. Chr., Ind. Fil.; Nephrodium erubescens, Diels, in Engl. \& Prantl, Nat. Pfl.Fam., $\mathbb{I}^{4}, 171$; - var. amboinensis, Hk. Bk., I. c. Stipes $30-75$ c.M. long, tufted, angular, \pm reddish like the rachis. Fronds 
50-120 c.M. long, $15-60$ c.M. broad, ovate-acuminate, pinnate. Lower pinnae not abbreviated, 1-4 c.M. hroad, approximate, sessile, the sides parallel for a long way, the apex gradually acuminate, serrate, the edge deeply pinnatifid nearly to the costa into close, hlunt or acute, subfalcate, entire or obscurely serrate segments. Texture rigid, subcoriaceous; rachis, costae (and veins sometimes) beneath sparingly covered with needle-like hairs; veins close, simple, free, soriferous at the very base, the higher ones without sori. Sori in 1 row on each side of the costulae, close to the latter.

War. amboinemsis: Lower pinnae on stalks $2^{1 / 2}$ c.M. long, conspicuously narrowed at the base. Sori not close to the costulae.

Malaya; North. India, South. China; - var. amboinensis: Amboyna.

* (3) Ph. Smithii, v. A. v. R., Bull. Dép. Agr. I. N., 1908, XVIII, 15; Dryopteris Smilhii, v. A. v. R., l.c.

Stipe and rachis naked, stramineous. Fronds $\pm 30-35$ c.M. long, $6-8$ c.M. hroad, lanceolate, acuminate, the apex pinnatifid. Pinnae \pm 50 on each side, spreading, the higher ones sessile with a broad base, the central ones largest, subsessile, the base broadly cuneate, the edge cut down nearly to the costa into numerous, subspreading lohes; lower pinnae gradually reduced to mere auricles. Lobes oblong, blunt, the lowest the largest, \pm 5 m.M. long, \pm 1 m.II. broad, the edge entire or slightly crenate, strongly recurved in dried material. Texture subcoriaceous; upper surface hairy on the costae, lower long-hairy on the costae, costulae and veins; veins distinct, simple. Sori round, distant, terminal on the veins, few, submarginal, covered by the recurved edge of the lobes. -- It bears the name of Mr. J. J. Smith, Assistant Curator of the Buitenzorg Herbarium.

Java (Leg........?, No. 4710).

(4) Ph. auriculata, J. Sm. (not Bedd.), Christ, Farnkr. d. Erde, 271 ; Polypodium auriculatum, Wall., Hk. Bk., Syn. Fil., 506; Bedd., Ferns Br.I., II, tab. CGIII; P. appendiculalum, Wall., var. squamaestipes, Clarke, Trans. Linn. Soc., Bot., $2^{\text {nd }}$ Series, I, tab. LXXIX, fig. 2; Dryopteris squamaestipes, C. Chr., Ind, Fil.; Nephrodium auriculatum, Diels, in Engl. \& Prantl, Nat. Pfl.Fam., $I^{4}, 171$.

Stipes stout, tufted, densely villose with deciduous, white hairs, furnished below with numerous, ovate, blark, shining scales. Fronds ample, 90-120 c.M. long, 30-40 c.M. broad, lanceolate-oblnng, pinnate, acuminate. Pinnae numerous, $\pm 2 \frac{1}{2}$ c.M. broad, sessile, furnished at the base beneath with a pro- 
minent; hooked gland, the edge pinnatifid nearly to the costa; lower pinnae gradually reduced to mere auricles. Lobes broad, oblong, obluse, entire, subfalcate. T'exture firm-membranaceous; surfaces sparingly hairy; costae and veins villose. Sori nearer the costulae than the edge; capsules furnished with few, long, weak hairs.

Java; China, North. India.

(5) Ph. tuberculata, v. A. v. R.; Dryopteris tuberculıta, C. Chr., Ind. Fil.; Nephrodium luberculalum, Ces., Fel. Becc. Polin., 4 \& 7; Polypodium tuberculatum, Bk., Ann. of Bot., V, 456.

Stipes strong, the base provided with conical, rough, obtuse tubercles, the rest naked, deeply canaliculate, \pm 45 c.M. long. Fronds $90-120$ c.M. long, pinnate. Pinnae numerous, $20-25$ c.M. long, more than $2 \%$ down to the rachis into numerous linear, falcate, subobtuse lobes, naked on both sides except the costa. Under surface glandular; veins simple. Sori small, in 1 row on each side of the costae.

New Guinea.

(6) Ph. oxyodus, v. A. v. R.; Polypodium oxyodon, Bk., Journ of Bot., XVII, 66; Dryopteris oxyodus, C. Chr., Ind. Fil.; Nephrodium oxyodon (oxydon), Copel., Polypod. Philipp., 23.

Rhizome short-creeping, the scales small, erect, lanceolate, membranaceous, dark-brown. Stipes approximate, naked, substramineous, $1 \mathfrak{5}-30$ c.M. long, slightly scaly near the base Fronds deltoid-oblong, $15-30$ c.M. long, 2-pinnatifid. Pinnae 9-18, lanceolate, 7-10 c.M. long, $21 / 2-4$ c.M. broad, cut down to a broad wing into lanceolate-oblong, sharply toothed lobes 4 - $5 \mathrm{~m} . \mathrm{M}$, broad; higher pinnae sessile, lower stalked. Texture moderately firm; both surfaces naked; main veins pinnate in the lobes; veins 10-12-jugate, many of them $2-4 \times$ forked. Sori small, round, medial on the anterior fork branches of the veins.

Sulu Islands.

(7) Ph. subobscuma, Christ, Bull. Herb. Boiss., VI, 836; Dryopteris subobscura, C. Chr., Ind. Fil.

Stipes numerous, tufted, \pm 8 c.M. long, tender, and like the rachis blackish-brown and covered with spreading, narrow, acuminate, hispid bristles. Fronds oblong-deltoid, long-acuminate, 10-15 c.M. long, \pm 4 c.M. broad. Lower pinnae deltoid-ovate, short-stalked, deeply pinnatifid towards the blunt- 
ish apex, pinnate at the base, the higher ones ovate, sessile, the terminal one pinnatifid. Lower segments incised, the other ones serrate, falcato-lanceolate, bluntish or short-acuminate. Texlure papyraceo-membranaceous; surfaces naked; veins black, conspicuous, the lower pinnate, the hightr forked. Sori minute, medial, often submarginal, slightly prominent on the upper surface, sometimes with a depressed indusium.

Sumatra; Yunnan.

(8) Ph. Aloseura, Fée, Bull. Herb. Boiss., VI, 196, tab. IV, fig. '3, a-e; Polypodium obscurum, Hk., Hk. Bk., Syn. Fil., 508; Dryopteris sagenioides, O. Ktze, var., C. Chr., Ind. Fil.; D. obscura, O. Ktze, Rev. Gen. Pl., II, 812; Nephrodium obscurum, Diels, Copel., Polypod. Philipp., 25.

Stipes tufted, blackish, polished, 18-30 c.M. long, sparingly scaly, the scales dark-coloured, subulate, spreading. Fronds deltoid-oblong, acuminate, $\pm 18-45$ c.M. long, $\pm 12-25$ c.M. broad. Pinnae close, \pm opposite, in several pairs below the pinnatifid apex, lowest largest, produced on the lower side, deeply pinnatifid. Lobes 1 - $21 / 2$ c.M. long, regularly, shallowly and roundly lobed, the apex bluntish. Texture thinly papyraceo-herbaceous, flaccid; surfaces (especially the margin and veins) covered with soft, hyaline, purple or reddish hairs, not rarely glandular. Sori small, immersed, medial.

Philippines; Annam,

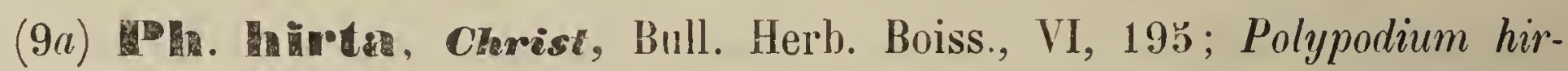
tum, Pr., Ann. of Bot., V, 458: Dryopteris selosa, C. Chr., Ind. Fil.; Nephrodium hirtum, Copel., Polypod. Phillipp., 25.

Fronds deltoid, decompound, \pm 50 c.M. long. Lower pinnae the largest, deltoid, produced on the lower side, the central ones lanceolate-oblong. Ultimate segments oblong, entire, $2-2 \frac{1}{2}$ m.M. broad. Texture moderately firm; surfaces naked; rachises clothed with copious, adpressed, linear, brown scales; veins paucijugate, erecto-patent. Sori medial.

Philippines.

(9b) Ph. Coppelandi, v. A. v. R.; Dryopteris Copelandi, Chrisl, Philipp. Journ., II, 216.

Rhizome propably oblique. Stipes few, rufo-stramineous, \pm 50 c.M. long, clothed like the rachises with minute, setiform, strigillose, reddish-brown paleae besides rather large, ovate, obtuse, diaphanous, pale-brown scales. Fronds deltoid oblong, \pm 40 c.M. long, \pm 50 c.ll. broad, 3 -pinnatisect. Pinnae ovate- 
oblong, \pm 15 on each side, acuminate, distant, the lower short-stalked, hardly narrowed at the base, the lowest \pm 7 c.M appart, hardly produced on the lower side, with the lowest anterior pinnulae shorter. Pinnulae \pm 15 on each side, approximate, \pm 4 c.ll. long, $\pm 1 \frac{1}{2}$ c.M. broad, regularly pinnatifid nearly to the costa. Tertiary segments in \pm 10 pairs, rhomboidal-oblong, obtuse, subdecurrent at the base, \pm 6 m.M. long, \pm 5 m.M. broad, regularly toothed with \pm b subacute teeth on each side. Texture flaccido-herbaceous; surfaces pubescent with numerous whitish hairs; colour bright-green; costulae pinnate, veins forked $\left({ }^{*}\right)$. Sori numerous, \pm 3 on each side of the costulae.

\section{Luzon.}

* (10) Ph. Mufescens, Mett., Christ, Farnkr. d. Erde, 276; Polypodium ru/escens, Bl., Hk. Bk., Syn. Fil., 509; Bl., Flor. Jav., II, tab. XGI; Bedd., Ferns S.I., tab. CGXXXVI; Dryopteris rufescens, C. Chr., Ind. Fil.; Nephrodium rufescens, Diels, in Engl. \& Prantl, Nat. Pfl.Fam., I I, 175 ; Aspidium rufescens, Bl., (oldest name).

Rhizome creeping, commonly slender, scaly. Stipes 20-45 c.M. long, erect, naked, stramineous (conf. Blume's drawing). Fronds 30 -43 c.M. long, 15--50 c.M. broad, subdeltoid. Lowest pinnae largest, erecto-patent, 7-10 c.M. broad, deltoid. Lowest pinnulae lanceolate, stalked, bluntly lobed, deeply pinnatifid or pinnate at the base, those on the lower side the longest, the central ones sessile, decurrent, the highest confluent. Ultimate divisions twice as long as broad or longer, crenate, toothed or lobed. Texture herbaceous to subcoriaceous; rachis and under surface slightly pubescent or tomentose; veins pinnate in the lobes. Sori copious, medial on the veins.

Java; Ceylon, Queensland, New Caledonia.

(11) Plk. Loxoseaphoides, v. w. R.; Polypodium loxoscaphoides, Bk., Journ. of Bot., XXVIII, 107; Dryopteris loxoscaphoides, C. Chr., Ind. Fil.

Stipes short, slender, naked, castaneous. Fronds deltoid-oblong, decompound, \pm 30 c.M. long. Lower pinnae the largest, lanceolate-oblong, subequilateral, $10-15$ c.II. long. Ultimate segments $\pm 2 \mathrm{~m} . M$. long, cuneate with 2 veins, or oblong with a single vein. Texture moderately firm; surfaces naked. Sori solitary and dorsal on the veins, medial in the ultimate segments.

New Guinea.

(*) Christ writes: nervis pinnatis, furcatis. 
(12) Ph. Masseltii, Mett., Farng., IV, Phegop. \& Aspid., 13; $P_{0}$ lypodium Hassellii, Bl., Flor. Jav., II, 195, tab. XGII; Dryopteris Hasseliii, C. Chr., Ind. Fil.

Rhizome oblique. Stipes \pm 20 -25 c.M. long, sparingly scaly, stramineous (green after Blume's drawing). Fronds \pm 30 c.M. long and as broad, deltoid. acuminate. Lowest pinnae largest, subopposite, \pm 10 c.M. broad at the base, unequal-sided, the lowest posterior pinnula much the largest. Pinnulae triangular-oblong, with the lowest divisions deltoid-oblong, obtuse, deeply pinnatilid or pinnate at the base, the ultimate segments oblong, blunt, entire or bluntly toothed. Texture coriaceous; rachis and both surfaces naked. Sori medial on the veins.

Java.

(13) Ph. Inserpitifolia, Bedd., Handb. Ind. Ferns, Suppl., 84 , Polypodium laserpitiifolium, Scort., Journ. of Bot., XXV, 324; Dryopteris laserpitiifolia, C. Chr., Ind. Fil.

Stipes tufted, fine, stramineous, 30-40 c.M. long, scaly below, naked above. Fronds as long, deltoid-ovate, 5-pinnate; rachis naked. Pinnae numerous, b-8 c.M. hroad. Pinnulae $2-21 / 2$ c.M. broad, those on the lower side of the rachis the largest, naked, shining above. Ultimate divisions ovate, oblong, rounded, the base unequal, cuneate on the lower side, the margin broadly lobed; main veins pinnate in the lobès, not reaching the edge. Sori terminal, large, $1-2$ on the lowest anterior veins.

Malacca.

(14) Ph. Cheilanthoides, v. A. v. R.; Polypodium cheilanthoides, Bk., Becc., Mal., III, 45; Cheilanthes gigantea, Ces., Fel. Becc. Polin., 3 \& 7 ; Dryopteris brunneo-villosa, C. Chr., Ind. Fil.

Stipes \pm 90 c.M. long, thick, clothed with copious, lanceolate, pale-brown, hairy scales. Fronds ample, deltoid, derompound. Pinnae lanceolate-oblong. Pinnulae multijugate, sessile, lanceolate. Tertiary segments multijugate, lanceolate, adnate at the base. Ultimale segments small, ovate or semiorbicular, the margin incurved. Texture firm; both surfaces densely setose; veins pinnate. Sori small, occupying the whole under surface of the fertile fronds.

New Guinea.

(15) Pln. ormata, Fée (not Bedd.), Christ, Farnkr. d. Frde, 27i, lig. 876; Polypodium ornalum, Wall., Bedd., Ferns S.I., tab. CLXXI; Dryopteris 
60a. Phegopteris. $\$ 1$. EUPhegopteris.

ornata, C. Chr., Ind. Fil.; Nephrodium tenericaule, Hk., Spec. Fil., IV, tab. CGLXIX (not page 142); N. ornatum, Christ (not Bk.), Copel., Polypod. Philipp., 26; Aspidium ornatum, Christ, Ann. Btz., XV, 130.

Caudex erect, sometimes subarborescent. Stipes, main and lateral rachises clothed with linear-lanceolate scales and muricate or scabrous from their persistent bases, not pilose, viscous or glaucous. Fronds large, to 6 M. long, 5-pinnate, the rachises narrowly winged. Pinnae generally 60 c.M. long or longer, \pm 30 c.M. broad. Pinnulae $2^{1 / 2}-5$ c.M. broad, the rachis scabrous and scaly, and furnished with long, white, subulate hairs. Tertiary segments numerous, parallel, 6-7 m.M. broad, linear-oblong from a sessile, square base, connected by a narrow wing, rather distant, the apex blunt or acute, the edges deeply toothed or lobed. Texture thin-herbaceous; costae and often also the veins hairy; veins simple or forked in the ultimate lobes. Sori near the costulae, 1 to each ultimate tooth or lobe, medial on the lowest anterior veinlet.

Malaya; South. China, North. India, Norlh. Australia, Polynesia.

(16) Ph. asperula, v. A. v. R.; Polypodium asperulum, J. Sm., Hk. Bk., Syn. Fil., 311; Dryopleris asperula, C. Chr., Ind. Fil.; Nephrodium asperulum, Copel., Polypod. Philipp.; 25.

Stipes firm, terete, brownish, pubescent. Fronds 45-60 c.M. long, 30 c.M. or more broad. Lower pinnae $15-25$ c.M. long, $5-8$ c.M. broad. Pinnulae lanceolate, $\pm 1-1 \frac{1}{2}$ : c.ll. broad, unequal-sided, cut down to the rachis below into oblong, pinnatifid, unequal-sided divisions. Texture subcoriaceous; rachis and both surfaces villose; veins immersed. Sori copious, 1 to each ultimate lobe.

\section{Philippines.}

- (17) Ph. pumetata, Mett. (not Bedd.), Christ, Farnkr.' d. Erde, 277; Polypodium punctatum, Thb., Hk. Bk., Syn. Fil,, 312; Hypolepis punctata, Mett., Kuhn, Fil. Afric., 120; Nephrodium punctatum, Diels, in Engl. \& Prantl, Nat. Pfl.Fam., I ${ }^{4}, 177$; Dryopteris punctata, C. Chr., Ind. Fil.; - var. rugulosa; P. rugulosum, Lab., Hk., Spec. Fil., IV, 272 ; Bedd., Ferns S.I., tab. CLXX; H. rugulosa J. Sm., Bot. Mag., LXXII, Comp. 8; N. rugulosum, Copel., Polypod. Philipp., 26.

Rhizome firm, wide-creeping, clothed with reddish hairs or fibrils. Stipes scattered, 30-60 c.M. long, \pm viscous, hairy or fibrillose, at length often naked. Fronds 45-120 c.M. long, 5-4-pinnate. Pinnae lanceolate or deltoid, 
ereclo-patent, lowest largest, $25-50$ c.M. long. Pinnulae close, 10-15 c.M. long. Ultimate divisions numerous, sessile, adnate to the rachis, the apex blunt, the edge crenate, or pinnatifid and crenate. Texture herbaceous; rachis and under surface hairy or fibrillose on the costae and veins. Sori copious, placed near or in the ultimate sinuses, \pm covered by the partially recurved margin as in Hypolepis.

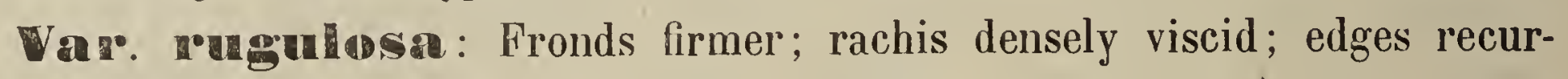
ved \pm as in Cheilanthes.

Nearly pantropical, extending to Japan, New Zealand and the West \& East African Islands; not from continental Africa.

* (18) Ph. CÉ eraudirenianna, Mamm, Pr. Amer. Ac., VII, 218; Polypodium Keraudrenianum, Gaud., Hk. Bk., Syn Fil., 313; Freyc., Voy. Ur. Phys., Bot., tab. VII; Dryopteris Keraudreniana, C. Chr., Ind. Fil.; Nephrodium Keraudrenianum, Diels, in Engl. \& Prantl, Nat. Pfl.Fam., I' 177.

Stipes $100-200$ c.II. long, stramineous or brownish, polished. Fronds 560-450 c.M. long, subscandent. Pinnae distant, the lower ones 50-90 c.M. long, $13-40$ c.M. broad. Pinnulae lanceolate, \pm spreading, pinnatifid $1 / 2$-way down or nearly or quite to the costa into lanceolate-deltoid or oblong, \pm spreading, bluntish, entire, crenate or incised segments. Texture herbaceous, rachises stramineous; both surfaces naked or the under side hairy; veinlets pellucid. Sori submarginal.

Java, Celebes; Hawaii.

* (19) Pli. sulbcommexa, Christ, Warb., Mons., I, 85; Dryopteris subconnexa, C. Chr., Ind. Fil.

Stipes strong, \pm 50 c.M. long, clothed like the rachis with long, greyishbrown hairs. Fronds $\pm 45-50$ c.M. long, broad, deltoid. Pinnae very distant, $6-8$ on each side, to \pm 25 c.M. long, petiolate. Pinnulae deltoid-ovate, the lowest the longest, the higher ones pinnatifid, the lower pinnate at the base. Tertiary divisions $\pm 4 \mathrm{~m}$. II. broad, the higher ones entire, ovate, shortacuminate, the lower coarsely toothed. Texture herbaceous; veins conspicuous, forked. Sori medial, numerous, not close, mixed with white paraphyses. - The whole plant pilose.

Batjan.

* (20) Ph. distans, Mett., Christ, Farnkr. d. Erde, 274; Polypo* dium distans, Don, Rac., Flor. Btz., I, 96 ; P. paludosum, Bl., Flor. Jav., II, 
tab. XG; Bedd., Ferns S.I., tab. CLXVIII; Dryopleris brumea, C. Chr., Ind. Fil.; Nephrodium distans, Diels, Copel., Polypod. Philipp., 21.

Rhizome creeping, scaly at the extrenity. Stipes 45-60 c.M. long, slender, stramineous or brownish, naked or pubescent, the base sparingly clothed with lanceolate scales. Fronds deltoid or ovate, 4b-100 c.ll. long, 20- 00 c.M. broad. Lowest pinnae generally the longest, linear-lanceolate, $3^{1 / 2}-7$ c.M. broad, spreading or sometimes deflexed, cut down nearly or quite to the costa into deeply pinnatifid pinnulae. Pinnulae linear-lanceolate, $1 / 2-1$ c.M. broad, \pm 1 c.M. apart, the bașe broadly adnate, slightly decurrent, the lobes blunt or acute, entire or toothed. Texture herbaceous; rachis naked or villose, stramineous or brown; surfaces more or less hairy on the veins; veins pinnate in the lobes. Sori copious, \pm medial, in 1 row on each side of the costules. Malaya; Formosa, Japan, South. China, North. India.

* (21) Ph. Kingi, Medd., Handb. Ind. Ferns, Suppl., 84; Dryopieris Kingii, C. Chr., Ind. Fil.

Fronds lạge, 5-4-pinnatifid. Pinnae \pm 4 c. c.M. long. Pinnulae \pm 10 c.M. long, $\pm 3-4$ c.M. broad, cut down nearly or quite to the rachis into oblong or ovate-oblong, rather deeply lobed tertiary segments $\pm 7-8 \mathrm{~m}$.M. broad. Texture membraliaceous, rather flaccid; surfaces naked except a few weak setae chiefly on the veins; veins forked. Sori medial, at the forks A form gathered in Java by Mr. Raap differs from Beddome's plant by the tertiary segments being nearly 5 m.M. broad, with the veins forked or pinnate in the ultimate lobes.

Malacca, Java.

\section{S2. LEPTOGRAMMA.}

*. Pinnae pinnatifid $\pm 1 / 2$-way down to the costa, the lowest not the longest. $=$

*.*. Pinnae pinnate, the lowest the longest.

(22) $\mathrm{Ph}$. totta.

(25) Ph. opaca.

* (22) PH. Totta, Mett., Christ, Farnkr. d. Erde, 272; Gymnogramme Totta, Schl., Rac., Flor. Btz., I, 68; G. Lowei, Hk. \& Grev., Ic. Fil., tab. LXXXIX; Leptogramme Totta, J. Sm., Bedd., Handb. Ind. Ferns, 577; Grammitis Totta, Pr., Bedd., Ferns S.I., tab. XLIX; Bau. \& Hk., Gen. Fil., tab. LXXII, FiLices. 
B, fig. 7; Nephrodium Tolta, Diels, in Engl. \& Prantl, Nat. Pfl.Fam., I ${ }^{4}$, fig. 91, G.; Dryopteris africana, C. Chr., Ind. Fil.; Polypodium tottum, Willd., (oldest name).

Rhizome short, creeping or oblique, the scales brown, lanceolate. Stipes subtufted, $10-50$ c.M. long, hairy or setulose, scaly below. Fronds $15-50$ c.M. long, 5-25 c.M. broad, ovate-oblong, the apex pinnatifid. Pinnae numerous, lanceolate, acute, $1 / 2-5$ c.M. broad, the lowest not the longest, short-stalked, cut $\pm 1 / 2$-way down to the costa into regular, blunt, entire lobes $51 / 2-5$ m.M. broad. Texture herbaceous; rachis and surfaces pilose or setulose; main veins pinnate in the lobes with 5-6 veins on each side. Sori irregular, round. ish or more commonly linear-oblong, medial. - Fronds with the aspect of Dryopteris parasitica, $0 . K t z e$.

Malaya; Japan, Korea, China, North. India, South. Africa, Madeira, Azores.

* (23) Ph. Opaca, Mett., Farng., IV, Phegop. \& Aspid., 15; Gymnogramme opaca, Spr., Rac., Flor. Btz., I, 69; Bedd., Ferns Br.I., II, tab. CGXXXVIII; G. obtusata, Bl., Flor. Jav., II, tab. XLIII; Ph. obtusala, Christ (not Melt.), Farnkr. d. Erde, 274; Leplogramme opaca, Bedd., Handb. Ind. Ferns, 379; Dryopleris opaca, C. Chr., Ind. Fil.; Nephrodium oblusalum, Diels (not Bedd.), in Engl. \& Prantl, Nat. Pfl.Fam., I, 171 ; Hemionitis opaca, Don, (oldest name).

Rhizome suberect or ascending, sparingly scaly. Stipes 50-60 c.M. long, strong, stramineous, glossy, naked or slightly scaly. Fronds 50-100 c.II. long: 50-60 c.M. broad, ovate-deltoid, the apex pinnatifid. Highest pinnae pinnatifid, the lobes broadly crenate; lower pinnae longest, pinnate, stalked, 丂-15 c.M. broad. Pinnulae oblong, sessile, decurrent, cut down into rather shallow, slightly toothed or crenated lobes. Texture herbaceous; surfaces naked; rachises and costae commonly slightly hairy; main veins pinnate in the lobes; lower veins soriferous near the base. Sori oblong.

Java; North. India.

\section{GONIOPTERIS.}

1. Fronds simple.

(24) Ph. holophylla.

1.1. Fronds pinnate $\left(^{1}\right)$.

2. Pinnae entire or crenate $\left({ }^{2}\right)$.

3. Pinnae under 5 c.M. long in the fully developed plants.

4. Pinnae not auricled, 1-6 on each side. (25) Ph. simplicifolia.

( $\left.{ }^{1}\right)$ See also Ph. canescens, Mell.

${ }^{2}$ ) See also Ph. prolifera, $K u h n$ \& diversiloba, $v$. A. $v . R$. 


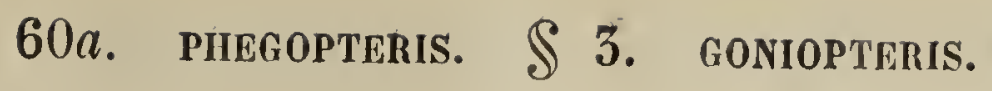

1.1. Pinnae auricled on the upper side at the base.

5. Lateral pinnae \pm 4 on each side.

(26) $\mathrm{Ph}$. borneensis.

5.5. Lateral pinnae many to numerous.

6. Pinnae \pm herbaceous, the lower ones gradually reduced.

(27) Ph. debilis.

6.6. Pinnae \pm coriaceous, the lower ones not reluced.

(28) Ph. aortisora.

3.3. Pinnae more than 5 c.M. long in the fully developed plants.

S. Pinnae paucijugate.

†. Surfaces pubescent.

(29a) Ph. xiphioides.

+. Surfaces naked.

×. Rhizome wide-creeping. Pinnae 7-10 c.M. long.

(29b) Ph. firmula.

$\times \cdot \times$. Rhizome short-creeping. Pinnae 12-15 c.M. long.

(29c) Ph. Ramosii.

\$.\$. Pinnae mullijugale.

*. Stipes naked like the rachis. Fronds middle-sized.

(50) Ph. rubida.

*.*. Stipes scaly, rachis pubescent or furfuraceou: Fronds large.

(51) Ph. arfakiana.

2.2. Pinnae toothed or lobed.

a. Fronds under 100 c.M. long.

b. Pinnae irregularly toothed, or lobed at the very apex.

b.t. Pinnae irregularly lobed.

(52) Ph. granulosa.

b.b.3. Pinnae regularly toothed or lobed.

c. Lower pinnae gradually reduced. (54) Ph. pennigera.

c.c. Lower pinnae hardly, if at all, reduced, but the fronds sometimes with a single pair of reduced pinnae at the base.

d. Lowest pinnae broadest at the base.

*. Texture \pm coriaceous. (55a) Ph. prolifera.

*.*.Texture \pm herbaceous. (55b) Ph. Merrillii.

d.d. Lowest pinnae not broadest at the base.

e. Pinnae rather short, ovate, obovale or rhomboidal.

f: Sori submarginal. (56a) Ph. acromanes.

f.f. Sori nol submarginal.

(56b) Ph. chamaeotaria. 
60a. PHEGOPTERIS. $\$ 5$. GONIOPTERIS.

e.e. Pinnae rather long, linear-acuminate. Sori medial.

(36c) Ph. ceramica.

a.a. Fronds very large, to 250 c.M. long.

(37) Ph. imponens.

(24) Ph. holophylla, v. A. v. R.; Polypodium holophyllum, Bk., Journ. of Bot., XXVI, 525 (not XVII, 43); Dryopteris holophylla, C. Chr., Ind. Fil.

Rhizome erect. Stipes crowded, naked, erect, \pm 15 c.ll. long. Fronds oblong-lanceolate, entire, acuminate, truncate at the base, $15--20$ c.M. long, $31 / 2-5$ c.II. broad. Texture moderately firm; under surface slightly hairy on the midrib; main veins distinct from the midrib to the margin, parallel; crossveins $10-12$, arcuate. Sori 2 to each cross-vein. round, minule, superficial.

Burneo.

(25) Ph. Simplicifolia, v. A. v. R.; Polypodium simplicifolium, Hk., Hk. Bk., Syn. Fil., 315; Aspidium simplicifolium, Hk. (not J. Sm.), Icon. Pl., X, tab. CMXIX; Dryopleris canescens, C. Chr., rar., C. Chr., Ind. Fil.; D. simplicifolia, Christ, Philipp. Journ., II, 206; Nephrodium simplicifolium, I. Sm., Diels, in Engl. \& Prantl, Nat. Pfl.Fam., I ${ }^{4}, 178$.

Stipes approximate, firm, $\breve{-10}$ c.M. long, villose upwards, scaly below. Fronds $15-50$ c.M. long, with a large, lanceolate, acuminate, entire terminal pinna $21 / 2-4$ c.ll. broad and below this $1-6$ very small, blunt, spreading, distant, entire ones on each side. Texture subcoriaceous; midrib beneath hispid and the prominent veins slightly so; main veins \pm 5 m.M. apart; all the veins joining. Sori minute, \pm medial between the main veins, sometimes Meniscium-like.

\section{Philippines.}

(26) Ph. bormeensis, v. A. v. R.; Polypodium borneense, Hk., Hk. Bk., Syn. Fil., 514; Dryopleris labuanensis, C. Chr., Ind. Fil.

Stipes \pm 15 c.M. long, naked, slender, stramineous. Fronds $15-20$ c.H. long, $\pm 7 \%$ c.M. hroad, with an acuminate terminal pinna $\pm 2 \%$ c.M. broad, with shallow, blunt lobes; below this \pm 4 smaller pinnae on each side, $1 \frac{1}{2}-2$ c.M. broad, truncate at the base and auricled on the upper side. Texture subcoriaceous; rachis and both surfaces naked; veins fine, $\mathbf{4 - 5}$ on each side. Sori small, in 2 rows.

Borneo. 
(27) Pl. Mebilis, Mett., Ann. Mus. But. I.. B., I, 225, tab. VI, fig. 1; Polypodium delile, Bk., Hk. Bk., Syn. Fil., 515; Aspidium Warburgii, Christ, var. debile; Dryopteris debllis, C. Chr., Ind. Fil.; Nephrodium debile, Diels, in Engl. \& Prantl., Nat. Pfl.Fam. I 178.

Stipes slender, slightly hairy. Fronds $15-50$ c.M. long, $5-7$ c.M. broad, oblong-lanceolate. Pinnae close, $\pm 15-20$ on each side, the central ones $21 / 2-51 / 2$ c.M. long, $1 / 2-1$ c.M. broad, the point bluntish, the edge slightly crenate, the base truncate, with a distinct, broad, blunt auricle on the upper side; lower pinnae gradually reduced. Texture papyraceo-herbaceous; rachis villose and under surface slightly so; veins $2-5$ on a side. Sori small, medial.

Moluccas, New Guinea.

(28) Ph. aortisoran, v. A. v. R.; Polypodium aortisorum, Harr., Journ. of Linn. Soc., Bot., XVI, 30; Dryopleris aortisura, C. Chr., Ind. Fil.; Nephrodium aorhsorum, Copel., Polypod. Philipp., 28.

Rhizome short, the scales slender, brown. Stipes clustered, $7-15$ c.M. long, slender, grey, slightly pubescent above. Fronds 15-25 c.M. long, $2-4$ c.M. broad, linear-lanceolate. Pinnae short-stalked or sessile, $20-40$ on each side, 7-10 m.M. broad, elliptical, slightly falcate, obtuse, coarsely crenate, auricled on the upper side, the lower ones deflexed. Texture subcoriaceous; rachis and under side of veins pubescent; main veins pinnate; veins $2-5$ on each side, usually the lowest ones only anastomosing. Sporangia scattered, grouping into indefinite sori.

Philippines.

(29a) Ph. xiphioides, v. A. v. R.; Dryopteris xiphioides, Christ, Philipp. Journ., II, 201.

Rhizome oblique, creeping. Stipes fragile, approximate, rather close, \pm 30 c.M. long, rufo-stramineous. Fronds broadly ovate, \pm 20 c.M. long, \pm 11 c.M. broad, pinnate, not or hardly narrowed at the base. Terminal pinna \pm 10 c.M. long, $\pm 1 \frac{1}{4}$ c.M. broad, lanceolate, acuminate, crenate. Lateral pinnae 4 -5, similar 10 the terminal one but shorter, to 7 c M. long, the lowest not reduced, the highest reduced, approximate to or connected with the terminal one. Texture herbaceous; the whole plant grey-pubescent; colour grey-green; veins 3-4 on each side of the main veins, all anastomosing. Sori small, few.

Mindanao.

(29b) Ph. firmula, v. A. v. R.; Polypodium firmulum, Bk., Kew Bull., 1893, 211; Dryopteris firmula, C. Chr., Ind. Fil. 
Rhizome woody, naked, wide-creeping. Stipes naked, \pm 45 c.M. long. Fronds oblong-lanceolate, 30-45 c.M. long, simply pinnate. Pinnae paucijugate, sessile, 7-10 c.M. long, 2-5 c.M. broad, lanceolate, acuminate, subentire, the base truncate or broadly cuneate. Texture firm; rachis pubescent; surfaces naked; main veins erecto-patent, parallel; areolae in 3-4 rows between the costae and margin. Sori small, not close, superficial, in 2 rows between the main veins.

Borneo.

(29c) Ph. Itamosii, v. A. v. R.; Dryopteris Ramosii, Christ, Philipp. Journ., II, 203.

Rhizome short-creeping. Stipes approximate, flexuose, $35-60$ c.M. long, rufostramineous, clothed with some few, short, scattered scales. Fronds $20-\mathbf{3 5}$ c.M. long, oblong, pinnate. Lateral pinnae few, $1-4$ on each side below the terminal one, erecto-patent, nearly sessile, ovate-oblong, $12-15$ c.M. long, \pm 5 c.M. broad, the base cuneate, the edge subentire or repando-crenate, the apex abruptly caudato-acuminate. Texture herbaceous or papyraceous; rachis naked, provided with roundish axillary buds; surfaces naked, upper dark-green, lower paler; main veins fine but distinct; veins 8-10 on each side of the main ones. Sori small, round, $7-8$ on each side near the main veins.

Luzon, Mindoro.

(30) Ph. rubida, v. A. v. R.; Polypodium rubidum, Hk., Hk., Bk., Syn. Fil., 314; Dryopleris rubida, C. Chr., Ind. Fil.; Nephrodium rubidum, Copel. (not Hk.), Polypod Philipp., 27; Goniopteris rubida, J. Sm., (oldest name).

Stipes firm, erect, glossy, naked, reddish-brown. Fronds 50-45 c.M. long. Pinnae numerous, the lowest stalked, $15-20$ c.I. long, $2-2 \frac{1}{2}$. c.I. broad, the apex acuminate, the edge nearly entire. Texture subcoriaceous; rachis and both surfaces naked; veins obscure, $8-10$ on a side. Sori close to the main veins.

Philippines, ? Borneo, ? Java.

(31) Ph. arfakiana, v. A. v. R.; Polypodium arfakianum, Bk., Becc., Mal., III, 45; Dryopleris arfakiana, C. Chr., Ind. Fil.

Rhizome erect. Stipes short, clothed with more or less spreading, lanceolate, brown scales. Fronds lanceolate-oblong, 90-120 c.M. long, simply pinnate, narrowing gradually towards both ends. Pinnae numerous, alternate, sessile, lanceolate, the medial ones sterile, $7-10$ c.M. long, $\pm .21 / 2$ c.M. broid, 
60a. phegorteris. $\mathbb{S}$. goniopteris.

the edge entire or crenate; several lower pinnae gradually becoming smaller, the lowest very small. Rachis brown, rigid, furfuraceous or pubescent; both surfaces naked, green; main veins with $5-6$ veins on each side. Sori semiglobose, occupying the whole under surface of the fertile pinnae.

New Guinea.

(32) Ph. granulosa, v. A. v. R.; Polypodium granulosum, Pr., Rel. Haenk., I, 24, tab. IV, fig. 2; Nephrodium granulosum, J. Sm., Bot. Voy. Herald, 428; Dryopteris granulosa, C. Chr., Ind. Fil; - var. lobata, Pr., l.c.

Stipes $10-15$ c.M. long, clothed like the rachis with a rather rigid, reflexed, dense pubescence, 3 -sulcate above, convex below, the base often \pm naked. Fronds broadly ovate, $\mathbf{5}-8$ d.M. Iong, pinnate. Pinnae alternate, sessile, linear-oblong, narrowed into a long, entire point, the margin obtusely and irregularly dentate, the base cordate, the lower base auriculate, the upper sometimes so; lower pinnae rarely opposite, inclined to become lanceolate, horizontal or deflexed with an upcurved acumen, the medial ones the longest, 7-10 c.M. long, $1 \frac{1}{2}-2$ c.M. broad, horizontal, the highest confluent, the terminal one long, broad, unequally and coarsely toothed. Texture membranaceous; colour deep-green; upper surface naked, lower covered with green tubercles or granules and therefore rough; costae pubescent; veins upcurved. Sori nearly round, small, in 2 rows between the main veins.

Var. Iobata: Highest lateral pinnae with the acumen abbreviate, with the higher teeth elongate and the apex 4-7-fid, the lobes linear-lanceolate, apiculate, the medial lobe the longest. Terminal pinna not modified.

Timor; Philippines.

(53) Ph. diversiloba, v. A. v. R.; Nephrodium diversilobum, Pr., Copel., Polypod. Philipp., 27; Dryopleris diversiloba, Christ, Philipp. Journ., II, 199 ; D. canescens, C. Chr., Ind. Fil., p. p.; - var. acrostichoides, Christ, l. c., 200; Aspidium canescens, Christ, forma acrostichoides, Christ, Ann. Btz., XV, 130-151; Nephrodium acrostichoides, J. Sm., Journ. of Bot., III, 411; - subvar. rhombea \& lanceola, Christ, Philipp. Journ., II, 200.

Rhizome elongate, fragile, \pm creeping or ascending. Stipes \pm approximate, nearly caespitose or subsolitary, flexuose, fragile. Fronds oblong, \pm 10 c.M. long, \pm 7 c.M. broad, pinnate. Pinnae subpetiolate, $\mathbf{5}-7$ on each side, \pm 4 c.II. long, $\pm 21 / 2$ c.M. broad, rhomboidal or broadly ovate, or prolonged into a lanceolate apex, the base narrowed, subhastate or subcordate, cre- 
nate, the edge lobed below the acuminate apex, the lobes very irregular, short or to $2-3$ c.M. long, lanceolate, obtuse, $\pm 2 \frac{1}{2}$ m.M. broad. Apex of the frond often broad, much elongate, lobate. Texture herbaceous; colour pale-grey-green; the whole plant grey-pubescent. Fertile pinnae hardly contracted, often soriferous towards the apex only. Sori minute, numerous, irregular, rarely seriate, often elongate.

Var. acrostichoides: Barren fronds more or less like those of the type, but the fertile fronds very long-stalked with the pinnae much contracted.

Subvar. Thombea: Fronds \pm 7 c.M. long, with the terminal pinna elongate and lobate, acuminate. Lateral pinnae \pm 5 on each side, lanceolate-rhomboidal to linear, subpetiolate, truncate at the base, obtuse, crenulate, 4-8 m.Mr. broad. Sori approximate, seriate or confluent.

Sulbvar. Ianceola: Barren pinnae lanceolate, nearly entire, the apex obtuse or subacute; terminal pinna much elongate, nearly caudate.

Philippines.

(54) Pl. Demnigera, v. A. v. R.; Polypodium pennigerum, Forst., Hk. Bk., Syn. Fil., 317; Dryopteris pennigera, C. Chr., Ind. Fil.; Nephrodium pennigerum, Pr. (not Hk.), Diels, in Engl. \& Prantl, Nat. Pfl.Fam. I ${ }^{4}, 179$.

Stipes tufted, $15-30$ c.M. long, slightly scaly. Fronds $45-60$ c.M. long, 20-50 c.M. broad. Pinnae 2-21/2 c.M. broad, cut $\pm 1 / 2$-way down into blunt, falcate, slightly crenate lobes about 5 m.M. broad; lower pinnae gradually reduced. Texture firm-herbaceous; rachis and both surfaces naked; veins $6-8$ on a side. Sori in rows near the costae.

Philippines, New Guinea; Polynesia, New Zealand.

* (55a) Ph. proliferan, Kuthen, Christ, Farnkr. d Erde, 270, fig. 851; Ph. luxurians, Mett., Farng., IV, Phegop. \& Aspid., No. 31; Polypodium proliferum, Rb. (not Pr.), Hk. Bk., Syn. Fil., 315; Meniscium proliferum, Sw., Hk., $2^{\text {nd }}$ Cent. of Ferns, tab. XV; Dryopteris prolifera, C.Chr., Ind. Fil.; Nephrodium proliferum, Keys., Copel., Polypod. Philipp., 28; Hemionilis prolifera, Retz, (oldest name).

Rhizome stout, creeping. Stipes scattered or approximate, naked, 5-20 c.M. long. Fronds $30-120$ c.M. long or longer, $\pm 15-30$ c.M. broad, erect or decumbent, often elongated and proliferous at the point and from the axils of the pinnae. Pinnae short-stalked, $1-4$ c.M. broad, the base broadest, truncate or cordate, sometimes auricled, the edge coarsely crenate or bluntly lobed 
to $\pm 21 / 2$ m.M. deep, the apex often blunt. Texture subcoriaceous; rachis and under surface naked or slightly pubescent; veins fine, $6-10$ on a side. Sori small, medial on the veins, \pm ovate, the lower ones sometimes confluent. Malaya; Australia, Polynesia, Suuth. China, North. India, Mascarenes, Trop. A frica.

(3らb) Ph. Menrillii, v. A. v. R.; Dryopteris Merrillii, Christ, Philipp. Journ., II, 201.

Rhizome erect, stout. Stipes fasciculate, rufo-stramineous, flexuose, 1820 c.M. long, the base minutely scaly. Fronds ovate-oblong, acuminate, 2030 c.M. long, \pm 12 c.M. broad, pinnate, the apex elongate, lobed. Barren pinnae rather numerous, close, spreading, petiolulate, falcate-lanceolate, acute, \pm 6 c.M. long, $\pm 11_{4}$ c.M. broad, the base truncate not oblique, hastate, with the anterior auricle sometimes elongate, the edge serrato-dentate, the teeth decumbent; lowest pinnae sometimes reduced and deflexed. Texture herbaceous; rachis and surfaces sparingly puberulous; colour bright-green; areolae in $4-5$ rows on each side of the costae. Fertile fronds longer stalked, with the pinnae distant, narrowed or contracted and sometimes only 2 m.M. broad. Sori small, close, 4--5-seriate or confluent. - In some respects resembling Polybotrya appendiculata, J. Sm., but distinguished by the equal bases of the pinnae.

Palawan, Mindanao.

(36a) Ph. aeromanes, v. A. v. R.; Dryopteris acromanes, Christ, Philipp. Journ., II, 200.

Rhizome short, stout. Stipes fasciculate, rufo- or plumbeo-stramineous, slender, $15-50$ c.M. long, nearly naked. Fronds oblong, acuminate, \pm 17 c.M. long, \pm 9 c.M. broad, pinnate. Terminal pinna elongate, lobed; lateral pinnae \pm 7 on each side, petiolate, obovate or elongate-rhomboidal, 4-5 c.M. long, \pm 3 c.M. broad, broadest towards the apex, cut $1 / 2$-way down or more to the costa, the base broadly truncate; lowest pimnae deflexed, not shorter, narrowed at the base. Lobes \pm 8 on each side, ovate, obtusely rounded, the higher ones increasing in length. Texture herbaceous; surfaces thinly pubescent; colour dark-green; veins in \pm 8 pairs, the lowest anastomosing. Sori large, round, submarginal, bordering the lobes in a single series.

Luzon.

(36b) Ph. Chnmacotarin, v. A. v. R.; Dryopteris chamaeotaria, Christ, Philipp. Journ., II, 203. 
Rhizome nearly creeping. Stipes approximate, slender, rufo-stramineous, flexuose, 10-15 c.M. long, sparingly puberulous, and clothed with scattered, pale-fuscous, subulate scales. Fronds ovate, \pm 15 c.M. long, \pm 7 c.M. broad, with a large, ovate, acuminate, coarsely lobed terminal pinna \pm 6 c.M. long, \pm 2 c.Mr. broad. Lateral pinnae $2-5$ on each side, petiolulate, similar to the terminal one or reduced, ovate or obtusely rhomboidal, the highest ones adnate. Texture herbaceous; rachis and surfaces minutely puberulous; colour bright-green; veins anastomosing; areolae \pm 4 on each side of the costae. Sori round, in 2 rows on the lobes, $\pm \check{b}$ to a row.

\section{Luzon.}

* (36c) Plh. ceramica, v. A. v. R., Bull. Dép. Agr. I. N., 1908, XVIII, 1与; Dryopteris ceramica, v. A. v. R., l.c.

Stipe and rachis brownish, naked. Fronds deltoid-oblong, \pm 75 c.M. long, \pm 50 c.M. broad near the base. Pinnae \pm 20 on each side below the terminal one. Terminal pinna \pm 15 c.M. long, $\pm 1 \frac{1}{2}$ c.M. broad at the base, narrowed gradually towards the entire, caudate, acuminate apex, the edge cut $\pm 3 / 4$-way down to the costa into oblong, blunt, subentire, subfalcate lobes; higher and central pinnae similar to the terminal one, sessile, broadest and truncate at the base; lower pinnae longer, broadest at the centre, narrowed gradually towards the base, subpetiolate, the lowest pinnae with the lowest lobes subdecurrent. Texture membranaceo-herbaceous; surfaces naked or the costae inconspicuously villose; main veins pinnate in the lobes; veins \pm 12 on each side in the longest lobes, the lowest pair anastomosing. Sori medial, close, small, occupying nearly all the veins except the highest ones.

Ceram (Treub).

(57) Ph. imponems, v. A. v. R.; Polypodium imponens, Ces., Fel. Becc. Polin., 5 \& 7 ; Dryopteris imponens, C. Chr., Ind. Fil.

Fronds very large, to 240 c.M. long or longer, to 7 ă c.M. broad or broader, the main rachis very strong, canaliculate, densely covered with small, brown, rigid, conical, subacute prickles mixed with capillary, deciduous scales and small, yellow hairs. Pinnae to 4 ว̆ c.M. long, $\pm 2 \frac{1}{2}$ c.M. broad or broader, the lower ones short-stalked, the others sessile, spreading, rather approximate, broadly linear, acute at both ends, deeply crenate (toothed?) to more than $1 / 3$ on the way to the costa. Texture chartaceous; surfaces opaque; veins close, $13-15$ on each side of the main veins. Sori in 1 row on each side, close.

New Guinea. 


\section{\$ 4. STEGNOGRAMMA.}

s. Terminal pinna very much exceeding the lateral ones, the largest of which at best 5 c.M. long $\left({ }^{*}\right)$.

(38) Ph. canescens.

\$.\$. Terminal pinna not or not very much exceeding the lateral ones, the largest of which more than 5 c.M. long.

*. Lower pinnae not reduced to mere auricles. (39a) Ph. stegnogramme. *.*. Lower pinnae dwindling down to mere auricles. (59b) Ph. Spenceri.

(58) Ph. canescens, Mett., Ann. Mus. Bot. L. B., I, 223 (not Farng. IV, Phegop. \& Aspid., 30); Polypodium canescens, Bl., Enum., 153; Gymnogramme canescens, Bl., Flor. Jav., II, 95., tab. XL; Nephrodium canescens, Christ, Fil. Saras., II, 208; Copel., Polypod. Philipp., 27, p. p.; Aspidium canescens, Christ, forma gymnogrammoides, Christ, Ann. Btz., XV, 150-131; Dryopteris canescens, C. Chr., Ind. Fil., p. p: - var. lobata, degener \& subsimplicifolia, Christ, Philipp. Journ., II, 198-199.

Rhizome creeping, nearly woody, brownish, bearing the fronds at the extremity. Stipes $10-50$ c.II. long, hairy above. Fronds $12^{1 / 2}-50$ c.II. long, pinnatifid in the upper, pinnate in the lower half. Terminal pinna to 15 c.M. long, to $21 / 2$ c.M. broad, narrowed gradually from the base towards the acuminate point, the edge deeply pinnatifid. Lateral pinnae $4-5$ or more on each side, sessile, spreading or erecto-patent, \pm oblong, the largest \pm 4 c.M. long, $\pm 1-2$ c.M. broad, the lowest deflexed, sometimes reduced, the edge not deeply lobed. Texture firm, upper surface deep-green, lower \pm greyish-green; both surfaces \pm hairy on the veins. Fertile fronds often with the narrowest pinnae. Sori small, oblong or sometimes roundish, \pm medial on the veins.

Var. Iobata: Pinnae less numerous, broader, the lobes broader, less numerous, deeper; veins flexuose, sometimes irregular; areolae in 1 row on each side. Sori often irregularly elongated. Pubescence grey.

Var. degener : Rhizome nearly creeping. Fronds \pm 20 - 40 c.M. long; texture firmer; colour rather blackish-green. Pinnae ovate, often obovate, narrowed at the base, obtusely crenato-lobate, the terminal one elongate, broad, obtusely lobed; barren pinnae short ( \pm 6 m.M. long), fertile ones often longer (to $21 / 2$ c.M. long), stalked, distant. Sori irregularly scattered, \pm roundish. Pubescence strigose, brown.

(*) See also Ph. diversiloba, $v . A . v$. R. 
Var. subsimplicifolia: Smaller, distinguished from the preceding by its distinct, elongated, nearly entire terminal and very slightly developed and auricle-like lateral pinnae.

Java; - the varieties in Luzon.

* (39a) Ph. stegnogmamme, Mlett., Christ, Farnkr. d. Erde, 268, fig. 846; Gymnogramme aspidioides, Hk., Rac., Flor. Btz., I, 70; Hk., Icon. Pl., X tab. CML.; G. Stegnogramme, Bl., Flor. Jav., II, tab. XLIV; ;istgnogramma aspidioides, Bl., Bedd., Ferns Br.I., I., tab. CXLIX; Dryopteris stegnogramme, C. Chr., Ind. Fil.; Nephrodium Stegnogramme, Diels, in Engl. \& Prantl, Nat. Pfl.Fam., I I 181.

Rhizome erect, the scales dense, lanceolate. Stipes tufted, long, deciduously hairy. Fronds 50-100 c.M. long, $\mathbf{1 5 - 3 0}$ c.M. broad, simply pinnate, the apex pinnatifid. Pinnae, lanceolate, often opposite, the lower ones subsessile, often deflexed, acuminate, with the edge pinnatifid $1 / 4-1 / 3$-way down to the costa, the base truncate or broadly rounded; higher pinnae sessile with a broad base. Texture herbaceous; rachis and surfaces hairy, especially on the veins, main veins pinnate; veins $5-10$ on each side, the $3-6$ lower anastomosing, with an excurrent veinlet reaching to the sinus, all soriferous. Sori linear-oblong, nearly the length of the veins, the lower sometimes produced olong the excurrent veinlets as in Meniscium. - A form found in Malacca has the fertile fronds contractcd.

Java, Malacca; Ceylon, North India.

(39b) Ph. Spenceri, v. A. v. R.; Dryopteris Spenceri, Christ, Philipp. Journ., II, 206; Nephrodium Spenceri, 'Copel., MS.

Rhizome elongate. Stipes $20-30$ c.I. long, rufo-stramineous. Fronds 丂0 c.M. or more long, \pm 12 c.M. broad, oblong, pinnate, with a large, coarsely lobed terminal pinna \pm 12 c.M. long, $\pm 3 \frac{1}{2}$ c.M. broad. Lateral pinnae sessile, oblong, falcate, short-acuminate, \pm crenato-lobate, to \pm 8 c.M. long, \pm 2 c.M. broad, the base unequal-sided, truncate above, semicordate below, overlapping the rachis; lower pinnae dwindling down into mere, triangular auricles ( $4-10$ on each side). Lobes \pm 5 m.M. broad. Texture herbaceous; colour bright-green; the whole plant clothed with scattered, grey hairs; veins distinct, \pm 6 on each side of the main veins, $3-4$ lower anastomosing, the terminal pinna with the veins more numerous and anastomosing more copiously. Sori numerous, $4-10$ on each side near the main veins (costulae), often oblong. Mindanao. 


\section{\$ ๖. MENISCIUM. ( $\left.{ }^{*}\right)$}

a. Fronds simple.

a.a. Fronds pinnate with 1-2 pinnae on each side.
(40) Ph. Beccariana. (41) Ph. triphylla.

a.a.a. Fronds pinnate with 3 or more pinnae on each side.

b. Fronds 10-25 c.M. long. Pinnae truncale at the base.

c. Pinnae \pm 5-20-jugate, the barren ones $\pm 3-4$ c.M. long.

(42) Ph. Hosei.

c.c. Pinnae \pm 20-30-jugate, the barren ones $1-21 / 2$ c.M. long.

(4j) Ph. stenophylla.

b.b. Fronds 30-120 c.M. long. Pinnue cuncate or rounded at the base.

+ Pinnae narrowed very gradually at the base, wuth the areolae in 3-5 rous on each side of the costa.

(44) Ph. salicilolia.

+.+. Pinnae not narrowed very gradually at the base, with the areolae in 6-20 rows on each side of the costa. (45) Ph. cuspidata.

(40) Pl. Heccaniana, v. A. v. R.; Meniscium Beccurianum, Ces., Fel. Becc. Polin., 5 \& 8; Dryopteris Cesatiana, C. Chr, Ind. Fil.

Rhizome creeping, slender, naked, blackish. Stipes angular, dark-brown, strong, slender, 7-15 c M. long. Frouds simple, lanceolate, \pm 50 c.M. long, $\pm \breve{c}$ c.M. broad, the apex broadly, nearly suddenly acuminate, the margin undulate and obscurely crenate, the base gradually narrowed. Texture subcoriaceous; costa and veins beneath covered with adpressed hairs.

New Guinea; Fiji.

* (41) Pl. Moiplnylla, Mett., Christ, Farnkr. d. Erde, 269, fig. 850; Meniscium triphyllum, Sw., Rac., Flor. Btz., I, 66; Bedd., Ferns S.I., tab. LVI; Dryopteris triphylla, C. Chr., Ind. Fil.; Nephrodium triphyllum, Diels, in Engl. \& Prantl, Nat. Pfl.Fam., I ${ }^{4}, 177$.

Rhizome creeping, densely clothed with short, spreading hairs and less densely with narrow, lanceolate, ciliate scales. Stipes 1-b c.M. apart, slender, substramineous, slightly pubescent, those of the barren fronds $\mathbf{6 - 1 5}$ c.M. long, those of the fertile 20-40 c.M. long. Fronds with an oblong-lanceolate terminal pinna $10-15$ c.M. long, $21 / 2-4$ c.M. broad, the point slightly acuminate, the edge entire or repand, the base cuneate or rounded; below this

(*) See also Ph. simplicifolia, $v$. A. $v$. R., prolifera, Christ, stegnogramme, Mett. \& Merrilli, v. A. $v . R$. 
1-2 similar but smaller, short-stalked pinnae on each side, the point acute, the base rounded, the fertile ones smaller than the barren. Texture herbaceous or subcoriaceous; veins beneath slightly pubescent; areolae 6-9 between the midrib and edge.

Malaya; Queensland, South. China, North. India.

* (42) Ph. Hosei, v. A. v. R., Bull. Dép. Agr. I. N., 1908, XXI, 7; Meniscium Hosei, Bk., Journ. of Linn. Soc., Bot., XXII, 250; Dryopteris Hosei, C. Chr., Ind. Fil.; - var. sumbensi v. A. v. R., l. c.

Rhizome short-creeping. Stipes approximate, slender, stramineous, pubescent, $5-15$ c.M. long, those of the fertile fronds much longer. Fronds oblonglanceolate, simply pinnate, to \pm 15 c.M. long. Pinnae $5-10$ on each side, lanceolate, straight, erecto-patent, sessile, entire or obscurely crenate, those of the barren fronds $3-4$ c.M. long, $5-9$ m.M. broad, those of the fertile ones to $21 / 2$ c.Y. long, $4-4 \frac{1}{2}$ m.M. broad, the base truncate and auricled on 1 or both sides. Texture firm-herbaceous; surfaces naked, \pm verruculose; rachis pubescent; veins 2-5-jugate. Sori afterwards conlluent. - Quite agreeing with Hooker's coloured drawing of Meniscium proliferum, Sw. (Ph. prolifera, $K u / h n)$.

Var. sumbensis: Pinnae more numerous, 12-16-jugate, rather falcate, serrato-crenate. Fertile fronds narrowed, $\pm 2 \frac{1}{2}-5$ c.M. broad, with the pinnae rather contracted, $2-5 \mathrm{~m}$. .. broad, strongly falcate, the edges entire, \pm recurved when dry. Sori in 1 row on each side of the costae. - Rhizome not seen. Barren fronds sometimes provided with soriferous, but not contracted pinnae.

Borneo; - var. sumbensis: Sumba Island (Karita, Teysmann No. 10695).

(45) Ph. Stemophylla, v. A. v. R.; Meniscium stenophyllum, Bk., Journ. of Bot., XXIX, 108; Dryopteris brevipinna, C. Chr., Ind. Fil.

Rhizome short-creeping. Stipes slender, naked, 7-10 c.M. long, those of the fertile fronds much longer. Fronds lanceolate, simply pinnate, 2025 c.M. long. Pinnae sessile, 20-50-jugate, oblong, obscurely crenate, those of the barren fronds to $21 / 2$ c.M. long, $5-9$ m.M. broad, with the base truncate and auricled on the upper side, those of the fertile ones smaller, with a considerable space between them. Texture firm; surfaces naked, green; main veins pinnate with $2-5$ distinct, raised veins on each side. Sori semiglobose, soon confluent.

Borneo. 
* (44) Ph. salicifolia, Mett., Fil. Lechl., II, 22; Meniscium salicifolium, Wall., Hk. Bk., Syn. Fil., 591; Bedd., Ferns Br.I., II, tab. CGVII; Hk., Icon. Pl., X, tab. XM ; Dryopteris salicifolia, C. Chr., Ind. Fil.; Nephrodium salicifolium, Diels, in Engl. \& Prantl., Nat. Pft.Fam., I I 178.

Stipes 30 c.I. or more long, stramineous or brownish, glossy. Fronds $50-45$ c.M. long, to 50 c.M. broad. Pinnae numerous, 2-4 c.M. apart; $10-20$ c.M. long, $1 / 2-2$ c.I. broad, narrowed very gradually from the middle to both ends, the edge nearly entire, the lowest the largest. Texture subcoriaceous; rachis and both surfaces naked; main veins oblique; areolae 5-5 between the midrib and edge; excurrent veinlets mostly free. Sori oblong, formed of 2 confluent, rounded ones.

Sumatra, Malacca.

* (45) Ph. Cuspidata, Mrett., Farng., IV, Phegop. \& Aspid., 25; Meniscium cuspidatum, Bl., Rac., Flor. Btz., I, 65; Bl., Flor. Jav., II, tab. XLV; Bedd., Ferns Br.I., II, tab. CCCIX; Nephrodium urophyllum, Keys., Diels, in Engl. \& Prantl, Nat. Pfi.Fam., I ${ }^{4}$, 178, p. p.: Dryopteris urophylla, C.Chr., var., C. Chr., Ind. Fil.; D. cuspidata, Chrisı, Philipp. Journ., II, 20 马.

Rhizome creeping, the scales lanceolate. Stipes 20-60 c.M. long, stout, scaly at the very base, blackish in the lower part, yellowish above. Fronds 50-120 c.ll. long, 15-50 c.M. broad, simply pinnate. Pinnae often shortstalked, $2-7 \frac{1}{2}$ c.M. broad, the point acuminate, the edge entire or toothed, the base cuneate or rounded. Texture subcoriaceous; rachis and both surfaces naked or nearly so, but the upper surface sometimes covered with white, cretaceous dots; areolae $6-20$ between the midrib and edge. Sori round or oblong, in 2 rows between the main veins, the pairs mostly contiguous, at least the lower or higher pairs confluent, the others not rarely free; sporangia setose. - This species is very near Dryopteris urophylla, C. Chr., but must be specifically distinct, even if the genera were united (Copel.).

Malaya; North. India.

\section{0\%. DIC'TYOPTERIS, Prest.}

Sori round or subohlong, very rarely more than $2 X$ as long as liroad. Indusium wanting.

Rhizome creeping or erect. Stipes not articulate to the rhizome, Fronds various, commonly with the habit and appearance of Aspidium; veins anasto- 
mosing more or less copiously, commonly irregularly, but never as in Nephrodium. (Aspidium, p. p., G. Chr., Ind. Fil.). ( $\left.{ }^{*}\right)$

Tropical.

\section{Arrangement of the sections.}

S1. ARCYPTERIS. Sori round or suboblong; veins anastomosing generally as in Aspidium, rarely as in Campteria or Pleocnemia. Hk. Bk., Syn. Fil., tab. V, fig. 48, o (as Dictyopteris).

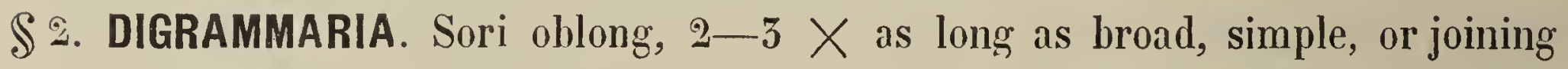
at the base when the veins fork; veins anastomosing as in Pleocnemia. Bau. \& Hk., Gen. Fil., tab. XCIV, fig. 1-4 (as Stenosemia).

\section{S 1. ARCYPTERIS.}

a. Sori marginal or nearly so, or placed in arches within the margin, *. Sori confined to the margins of the lobes. Venation as in Aspidium.

$\begin{array}{ll}(1 b) D \text { henitelifformis SI. } 3321 & \text { (1) D. pteroides. }\end{array}$ *.*. Sori placed in horseshoe-shaped arches. Venation as in Campteria. (2) D. andaiensis.

a.a. Sori placed in rows parallel to the main veins or costulae.

b. Fronds 3-5-fid or pinnate, but then the lowest pinnae forked at the base on the lower side.

c. Stipes winged.

(3) D. Bryanti.

c.c. Stipes not winged.

d. Included free veinlets few or wanting.

(4) D. subdecurrens.

d.d. Included free veinlets copious.

(丂) D. Barberi.

6.6. Fronds deeply pinnatifid or pinnate, but then the lower pinnae pinnatifid or more compoundly divided.

\$. Fronds pinnatifid.

(6) D. Beccariana.

\$.\$. Fronds 2-pinnalifid.

*. Lateral pinnae 5-12 on each side.

(7) D. saxicola.

(*) See the note under Phegopteris. The natural place of this genus is near Pleocnemia and Aspidium, from which it differs by the exindusiate sori only. 
*.*. Lateral pinnae more numerous.

(8) D. macrodonta.

\$.S.S. Fronds at least 2-pinnate. Venation \pm as in Pleocnemia.

(9) D. ferruginea.

a.a.a. Sori scattered irregularly. $\left.{ }^{*}\right)$

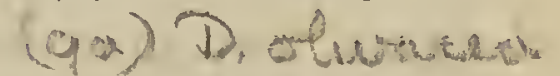

1. Fronds simple, lobed, 3-partite or pinnalifid.

2. Fronds under 30 c.M. long.

3. Under surface densely hairy; fronds simple.

(10) D. vitis.

3.3. Under surface naked; fronds at best ternate.

1. Shipes naked.

4.4. Stipes minutely fibrillose.

(11) D. labrusca. (12) D. lamoensis.

2.2. Fronds more than 30 c.M. long.

5. Fronds ternate.

(13) D. Hancockii.

\$.S. Fronds deeply pinnatifid.

*. Lobes \pm 4-5 c.M. broad.

(14a) D. heterosora.

*.*. Lobes \pm 10 c.M. liroad.

(14b) D. Bolsteri.

1.1. Fronds pinnate; pinnae entire, crenate, lobed or pinnatifid, the lowest pinnatifid or forked at the base.

a. Pinnae paucijugate.

B. Lateral pinnae \pm 2-jugate.

(15) D. pentaphylla.

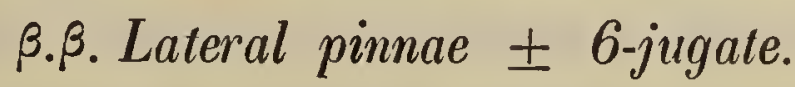

\%. Lowest pinnae 2-partile.

(16) D. Whitfordi.

\%.\%. Lowest pinnae 3-partite.

a.๙. Pinnae multijugate.

(17) D. polycarpa.

(18) D. irregularis.

(1) D. pteroides, Pr., Tent. Pterid., 194, tab. VIII, fig. 6 \& 13; Phegopteris Brongniartii, Mett., Farng., IV, Phegop. \& Aspid., 51; Aspidium Brongniartii, Diels, Copel., Polypod. Philipp., 55; C. Chr., Ind. Fil.; Polypodium Brongniartii, Bory, Hk. Bk., Syn. Fil., 318; Tectaria irregularis, Cupel., var. Brongniartii, Copel., Philipp. Journ., II, 41.7; P. pteroides, Pr., (oldest name).

Fronds $60-90$ c.M. long, $30-45$ c.M. broad, the apex pinnatifid with deep, lanceolate, repand lobes; below this numerous distinct pinnae, the lowest 15 - 25 c.M. long, lanceolate, cut $3 / 4$ of the way down throughout into acute, subentire, lanceolate lobes $1-51 / 2$ c.M. long, $1 / 2-1$ c.M. broad. Texture subcoriaceous; areolae copious, with few free veinlets. Sori rather small and confined to the margin of the lobes.

Malaya.

(*) See also D. Bryanti, $v$. A. $v$. $R$.

Filices. 
(2) BD. amdaiensis, v. A. v. R.; Polypodium andaiense, Bk., Becc.. Mal., III, 45; Aspidium andaiense, C. Chr., Ind. Fil.

Stipes strong, brown, \pm 90 c.M. long, the base densely clothed with linear, elongate, crisped, brown scales. Fronds ample, deltoid, 2-pinnate. Pinnae oblong, lanceolate, the lowest the longest, \pm 30 c.M. long. Pinnulae $21 / 2-4$ c.M. long, lanceolate, adnate at the base, the margin conspicuously crenate. Surfaces naked; venation rather as in Campteria; main veins erecto-patent; higher veins. curved, free, paucijugate. Sori small, semiglobose, placed in horseshoeshaped arches.

New Guinea.

(5) D. Hryanti, v. A. v. R.; Aspidium Bryanti, Copel., Polypod. Philipp., 34; C. Chr., Ind. Fil.; Tectaria Bryanti, Copel., Philipp. Journ., II, 412.

Stipes 20-40 c.M. high, strong, reddish-brown, winged, the scales scattered, spreading, the wing entire, not narrowed, with a truncate base \pm 1 c.M. broad on each side. Fronds 30-50 c.M. long, ovate, 3-fid with the lateral segments approximate, or often b-fid with the lowest. segments distant. Terminal segment $20-30$ c.M. long, \pm 10 c.M. broad, acuminate, entire or subrepand; lateral segments similar, $10-18$ c.M. long, $\mathfrak{b}-7$ c.M. broad. Texture papyraceous; main veins curved, reaching nearly the margin; transversal veins arching, conspicuous; areolae large, regular, divided into irregular smaller ones, with free veinlets. Sori mostly in rows along the main veins.

Philippines.

(4) D. subdecurrens, v. A. v. R.; Phegopteris subdecurrens, Luerss., Bot. Centralbl., XI, 50; Aspidium subdecurrens, C. Chr., Ind. Fil.

Stipes dark-red-brown, opaque, naked like the rachis and costae. Fronds \pm 40 c.M. or more long, \pm 20 c.M. or more broad, elliptic, pinnate. Piunae \pm 5 on each side below the deeply pinnatifid apex, $\pm 4 \frac{1}{2}$ c.M. broad, entire, the lowest pair stalked, deltoid, acuminate, obliquely lanceolate, forked at the base on the lower side. Terminal pinna large, rhomboidal, narrowed gradually at the base, 5-lobate, the lowest lobes large, the central lobe 3-lobate again with a large, ovate central part and 2 small lateral lobes. Costae prominent; main veins slightly curved, distinct nearly to the edge; areolae large, with included smaller areolae, without or rarely with some few free veinlets. Sori in $2-4$ regular rows between the main veins, forming 2 rows on each side of the costae.

Singapore. 
(b) ID. Harberi, Bedd., Handb. Ind. Ferns, 298; Ferns Br.I., II, tab. CCGXXIII; Phegopteris Barberi, Mett., Linn., XXXVI, 125; Aspidium Barberi, C. Chr., Ind. Fil.; Copel., Polypod. Philipp., 34; Polypodium Barberi, Hk., Hk. Bk., Syn. Fil., 317; Tectaria Barberi, Copel., Philipp. Journ., II, 414.

Stipes tufted, $15-30$ c.M. long, slightly scaly at the base. Fronds palmately 5-lobed or simply pinnate with a large, simple or 3-fid terminal segment and 1-4 pairs of lateral pinnae, the upper ones oblong-lanceolate, $10-15$ c.M. long, $\pm 21 / 2$ c.M. broad, nearly entire, the lowest pair with a large, lanceolate lobe at the base on the lower side. Texture subcoriaceous; both surfaces naked; areolae rather large and regular, with copious free veinlets. Sori copious, principally in 2 rows near the main veins.

Malaya.

(6) D. Heceariana, v. A. v. R.; Polypodium Beccarianum, Ces., Fel. Becc. Polin., 5 \& 8; Aspidium Beccarianum, Diels, C. Chr., Ind. Fil.

Stipes paleaceous, strong, the unwinged lower part $21 / 2-5$ c.M. long, the higher part broadly winged, \pm 30 c.M. and more long. Fronds $60-90$ c.M. long, \pm 60 c.M. broad, deeply pinnatifid. Lobes $7-8$ c.M. broad, linear oblong, acuminate, subrepand, the terminal one ovate-lanceolate, 5 -fid at the base, with narrowed lobes. Texture membranaceous; lateral veins of the lobes numerous, distinct to the edge; transversal veinlets arcuate; areolae hexagonal; free veinlets rather numerous. Sori small, in 1 row on each side of the costulae.

New Guinea.

(7) D. Saxicola, v. A. v. R.; D. petrophya, Moore, Ind., 318; Phegopteris petrophya, Mett., Ann. Mus. Bot. L. B., I, 225; Polypodium petrophyum, Bl., Flor. Jav., II, 163, tab. LXXI; Aspidium saxicola, Bl., Enum., 160; C. Chr., Ind. Fil.

Stipes \pm 50 c.M. long, fusco-purpureous, paleaceo-furfuraceous like the rachis, sulcate above, minutely tomentose in the groove. Fronds $30-75$ c.M. long, to \pm 30 c.M. or more broad, ovate, 2-pinnatifid. Terminal pinna ovate, deeply lobed; lobes erecto-patent, falcate, blunt, the lowest again lobed. Pinnae $5-12$ on each side, sessile, \pm 4 c.M. broad, \pm falcate, oblong-lanceolate, acuminate or acute, cut $1 / 3-2 / 3$-way down into oblong, erectopatent, entire, blunt lobes; lowest pinnae 6-12 c.M. broad, with the lobes on the lower side (except the. basal ones) produced, the base sessile, subtruncate or broadly cuneate; higher pinnae slightly decurrent. Texture membranaceous; 
60b. DIGTYOPTERIS. $\$ 1$. ARGYPTERIS.

surfaces nearly naked or slightly furfuraceous or scaly. Sori confined to the lobes, in 1 row on each side of the main veins or costulae.

Java.

(8) D. macrodonta, Pro, Tent. Pterid., 194; Phegopteris macrodonta, Melt., Christ, Farnkr. d. Erde, 266; Polypodium macrodon, Reinw., Hk. Bk., Syn. Fil., 318; P. Cumingianum, Hk., Spec. Fil., V, 105; Aspidıum macrodon, Keys. (not Diels), Copel., Polypod. Philipp., 34; C. Chr., Ind. Fil.; Tectaria irregularis, Copel., var. macrodon, Copel., Philipp. Journ., II, 417.

Rhizome decumbent. Stipes 30 c.M. or more long, slightly scaly below. Fronds 60-100 c.M. long, 30- 0 c.M. broad, the apex deeply pinnatifid; below this numerous lanceolate pinnae, the lowest the largest, $15-20$ c.M. broad, cut down to a narrow wing on the rachis into pinnatifid, close, lanceolate segments. Texture thin; both surfaces naked; areolae copious, without free veinlets. Sori small, in rows near the main veins.

Malaya; Fiji.

* (9) D. Perruginea, v. A. v. IR., Hort. Bog.; Phegopteris ferruginea, Melt., Ann. Mus. Bot. L. B., 224, tab. VI, fig. 2 ; Polypodium ferrugineum, Bk., Hk. Bk., Syn. Fil., 318; Aspidium ferrugineum, Diels, in Engl. \& Prantl, Nat. Pfl.Fam., I ${ }^{4}, 186 ; A$. Zippelianum, C. Chr., Ind. Fil.; Sagenia ferruginea, Christ, MS. in Herb. Bog.

Stipes $\pm 25-45$ c.M. long, clothed densely below, and less so above, with ferrugineous, lanceolate, spreading or deflexed scales. Fronds \pm 30-40 c.M. long, $\pm 20-50$ c.M. broad. Pinnae erecto-patent, the higher ones pinnatifid, the central and lower pinnate. Lowest pinnae largest, deltoid, with the pinnulae on the lower side elongate, again pinnate, the segments pinnatifid. Texture herbaceous; rachises and surfaces fibrillose with sprinkled, ferrugineous or reddish, hair-like scales; lower veins anastomosing, forming costal and costular areolae \pm as in Pleocnemia, otherwise free; areolae without free veinlets. Sori in 1 row on each side of the costulae or main veins of ultimate segments.

New Guinea.

* (10) D. vitis, v. A. v. IR.; Nephrodium Vitis, Rac., Bull. Ac. Grac., 1902, 60; Sagenia Vitis, Christ, Ann. Btz., XX, 108, tab. III, fig. 2; S. rufipubis, Christ, MS. in Herb. Bog.; Aspidium vitis, C. Chr., Ind. Fil.

Rhizome thick, oblique, the scales subulate, brown. Stipes tufted, 20- 
25 c.M. long, slender, flexuose, canaliculate, dark-brown or blackish, hairy or naked, but clothed towards the base with linear, dark-purple scales, which make the stipes rough when they fall. Fronds $\pm 3-10$ c.M. long, $\pm 3-9$ c.M. broad, simple, broadly cordate with a deep sinus, the margin entire or undulate, the basal lobes sometimes meeting or overlapping. Texture subcoriaceous, fragile; upper surface naked or hairy, lower densely clothed with spreading, reddish hairs; main veins 10-12 on each side, conspicuous and prominent like the costa, straight, reaching the margin; veins hidden, forming moderately regular, tetra- or pentagonal areolae with free veinlets. Sori punctiform, scattered irregularly.

Borneo.

* (11) D. Ialorusca, v. A. v. R., Bull. Dép. Agr. I. N., 1908, XVIII, 16; Polypodium Labrusca, Hk., Rac., Flor. Btz., I, 109; Hk., Spec. Fil., V, 73, tab. CCLXXXV, B ; Nephrodium Labrusca, Rac., Bull. Ac. Crac., 1902, 61; Sagenia Labrusca, Christ, Ann. Btz., XX, 108; Aspidium labrusca, Christ, Ann. Btz., XV, 137; C. Chr., Ind. Fil.; Tectaria Labrusca, Copel., Philipp. Journ., II, 410; - var. Boschae, Rac., l. c , 61; - var. ternata, v. A. v. R., l. c.

Rhizome woody, erect, the scales linear- or lanceolate-subulate. Stipes crowded 10-25 c.M. long, firm, naked, erect, glossy, the base dark-coloured and slightly scaly. Fronds 7-18 c.M. long, 6-15 c.M. broad. Texture subcoriaceous; surfaces naked; costae and main veins distinct; areolae fine, visible, copious, with free veinlets. Sori minute, scattered irregularly. -

Forma typica: Fronds simple, cordate with a deep sinus, the edge entire to sinuate, the point acute.

Var. Boschae: Stipes 20-40 c.M. long. Fronds 5-lobed, 10-35 c.M. each way, the base slightly cordate.

Var. termata- Fronds 3-foliate. Terminal segment hastato-3-fid with a broad, sinuate central lobe and 2 narrow, \pm entire lateral ones. Lateral segments free or connected with the terminal one, upcurved, unequal-sided, acuminate, the upper base cuneate, slightly rounded, the lower cordate and broadly rounded, the edges \pm entire.

I think Raciborski's Nusa-Kembangan plant would better be treated as a distinct species.

Borneo, Celebes; - var. Boschae: Borneo; - var. ternata: Nusa-Kembangan (Java).

* (12) D. Iamdensis, v. A. v. R.; Aspidium lamoense, Copel., Polypod. 
Philipp., 35; G. Chr., Ind. Fil., Tectaria irrigua, Copel., Philipp. Journ., II, 413, p. p.

Rhizome ascending. Stipes $\pm 10-25$ c.M. long, erect, minutely fibrillose like the rachis, the base covered with some few small scales. Fronds 15-25 c.M. long, subdeltoid, commonly 3-foliate. Terminal pinna 10-15 c.M. long, simple and lanceolate or more commonly deltoid and deeply 5furcate, the central lobe $2-3$ c.M. broad, narrowed gradually towards the acute or acuminate apex, the edge entire or inconspicuously undulate, the lateral lobes suberect, 6-10 c.M. long. Lateral pinnae erecto-patent, short-stalked, 6-10 c.M. long, forked at the base on the lower side, the terminal lobe \pm acuminate, the lateral one shorter, more or less bluntish. Texture herbaceous; surfaces naked; main veins hardly reaching the margin; areolae with free veinlets. Sori numerous, scattered irregularly, roundish or oblong.

Luzon.

(13) D. Hancockii, v. A. v. R.; Polypodium Hancockii, Bk., Ann. of Bot., VIII, 127 (not Journ. of Bot., XXIII, 106); Aspidium sumatranum, C. Chr., Ind. Fil.

Stipes firm, slender, glossy, naked, brown. Fronds deltoid, ternate, \pm 45 c.M. long. Terminal pinna cordate-ovate, $20-25$ c.M. long, $15-20$ c.M. broad, pinnatifid $1 / 2$-way down. Lateral pinnae petiolate, ovate, $12-15$ c.M. long, the lower side produced, distinctly auricled. Texture membranaceous; surfaces naked; rachis naked, glossy, castaneous; main veins curved; areolae hexagonal, copious, with numerous free veinlets Sori semiglobose, superficial.

Sumatra.

(14a) D. heterosora, Bedd., Handb. Ind. Ferns, 302; Polypodium heterosorum, Bk., Hk. Bk., Syn. Fil., 506; Aspidium vastum, Bl., var., G. Ghr., Ind. Fil.

Stipes short, brown, with spreading, linear scales. Fronds oblong-spathulate, 60-90 c.M. long, deeply pinnatifid, the lowest foot only a narrow wing to the costa; above this $3-4$ pairs of distant, oblong-lanceolate, acuminate lobes $4-b$ c.M. broad at the middle, confluent in a narrow wing, the lowest simple or 2-partite. Texture thin but firm; surfaces naked; ribs naked, brownish; main veins distinct to the edge, with distinct arches.between them, and copious small areolae with free, included veinlets. Sory very abundant, small; irregular, often confluent. - ? An exindusiate form of Aspidium vastum, $B l$.

Malacca. 
60b. DiGTYopteris. $\$ 1$. ARGypteris.

(14b) D. Bolsteri, v. A. v. R.; Aspidium Bolsteri, Copel., Philipp. Journ., I, Suppl., 252; ? Tectaria Bryanti, Copel., l. c. II, 412, p. p.

Rhizome rather ascending, woody, the extremity clothed with rather long, apiculate, castaneous scales. Stipes close, \pm 50 c.M. long, long-winged, the unwinged base \pm 5 c.M. long, the wing $\pm 1 \frac{1}{2}$ c.M. broad. Fronds $60-80$ c.M. long, ovate in outline, pinnatifid. Lobes \pm b-jugate, ovate, spreading, $\pm \mathbf{3 0}$ c.M. long, \pm 10 c.M. broad, acuminate, entire, distinctly narrowed at the base, the costal wing $1 \frac{1}{2}-3$ c.M. broad. Texture coriaceo-papyraceous; surfaces naked; main veins reaching nearly the margin, arcuate; transversing veins inconspicuous in the fertile region. Sori superficial, in 2 rows between the transversing veins, 4-10 to a row, occupying the whole under surface of the fertile segments.

\section{Mindanao.}

* (15) D. pentaphylla, v. A. v. R., Bull. Dép. Agr. I. N., 1908, XVIII, 16; Aspidium pentaphyllum, v. A. v. R., l. c.

Stipes $\pm \mathbf{3} 0$ c.M. long, like the rachis brown or blackish-purpureous, minutely fibrillose and deciduously scaly, the scales few, scattered, lanceolatesubulate, brown or purpureous. Fronds 30-45 c.M. long, 15-25 c.M. broad, with a terminal pinna and 2 lateral ones on each side. T'erminal pinna $15-20$ c.M. long, simple, broadly ovate, acuminate, the edge undulate with rounded or sharp lobes, the base broadly cuneate or rounded, not rarely purveyed with 1-2 lanceolate, bluntly rounded or acuminate, erecto-patent segments. Lateral pinnae erecto-patent, distant, broadly lanceolate, unequalsided, the lower side broader than the upper, the apex acuminate, the edge entire or undulate, the base broadly cuneate to rounded; lower pinnae with an oblong or sublanceolate, blunt or acuminate lobe at the hase on the lower side. Texture subcoriaceous, subpellucid; costae and main veins prominent; veins visible; areolae numerous, with free veinlets; surfaces naked. Sori numerous, scaltered irregularly, often confluent. - According to Copeland's conception of the generic name this plant should be called Tectaria pentaphylla, v. A. v. R.

New Guinea (Treub).

(16) D. Whitfordi, v. A. v. R.; Aspidium Whilfordi, Copel., Polypod. Philipp., 55 ; C. Chr., Ind. Fil.; Teclaria irregularis, Copel., Philipp. Journ., II, 416, p. p.

Rhizome short, suberect, densely scaly at the apex. Stipes $20-50$ c.M. 
long, dark-brown at the base, which is clothed with linear scales, the rest naked, stramineous. Fronds 30-45 c.M. long, deltoid, acuminate, pinnate, the apex pinnatifid with broadly crenate and obscurely serrate lobes. Pinnae \pm 6 on each side, erecto-patent, lanceolate, acuminate, cut $\pm 1 / 2$-way down to the costa into oblong, obtuse, entire or serrate lobes; lowest pinnae stalked, deltoid, with a free, basal pinnula on the lower side resembling one of the upper pinnae. Texture papyraceous; surfaces naked; veins laxly anastomosing, without free veinlets. Sori round or oblong, irregularly scattered but wanting near the costae.

Luzon.

(17) D. polycarpa, Bedd., Handb. Ind. Ferns, 300; Phegopteris; polycarpa, Mett., Linn., XXXVI, 124; Polypodium polycarpum, Bk., Hk. Bk., Syn. Fil., 506; Aspidium Kuhnii, C. Chr., Ind. Fil.

Stipes \pm 15 c.M. long, rubro-stramineous, slightly pilose upwards. Fronds deltoid, 2-pinnatifid, 15-45 c.M. long. Pinnae 6-jugate, lowest largest, deltoid, unequal-sided, stalked, 3-partite, central ligulate, acuminate, crenate. Texture membranaceous; surfaces glabrous; main veins distinct to the edge; areolae with free veinlets. Sori copiously scattered, terminal or compital.

Malacca.

* (18) D. irregularis, Pr., Tent. Pterid., 194, tab. VIII, fig. 7; Bedd., Ferns Br.I., I, tab. LXXVII ; D. difformis, Moore, Bedd., Handb. Ind. Ferns, 300; Phegopteris difformis, Mett., Christ, Farnkr. d. Erde, 267, fig. 843; Ph. irregularis, Mett., Ann. Mus. Bot. L. B., I, 225; Aspidium difforme, Bl., Enum., 160; A. irregulare, C. Chr., Ind. Fil.; Polypodium difforme, Bl., Rac., Flor. Btz., I, 118; Tectaria irregularis, Copel., Philipp. Journ., II, 416, p. p.; P. irregulare, Pr. (oldest name), Bl., Flor. Jav., II, tab. LXXII; - var. eu-irregularis, Copel., l. c.

Rhizome erect or ascending, densely clothed with lanceolate, very longacuminate, brown scales. Stipes tufted, $\pm 50-50$ c.M. long, erect, scaly below. Fronds 50-200 c.M. long, the apex pinnatifid with the lobes crenate or subrepand. Upper pinnae lanceolate, broadly crenate or lobed, the lobes blunt, falcate, reaching $\pm 1 / 4-1 / 2$-way down to the costa; lower pinnae stalked, often deltoid, to $\pm \mathbf{3 0}$ c.M. long, pinnatifid often more than $1 / 2$-way down, the lowest forked at the base on the lower side with the. fork branch deflexed and sometimes free, to 12-15 c.M. long. Texture subcoriaceous; surfaces naked; areolae copious, with few free veinlets. Sori very abundant. 
60b. DICTYOPTERIS. $\mathbb{1} 1$. ARGYPTERIS.

Var. eu-irregularis: Fronds simply pinnate; sori small and very numerous.

Malaya; - var. eu-irregularis: Philippines.

\section{S. DIGRAMMARIA.}

(19) D. ambigua, v. A. v. R.; Digrammaria ambigua, Pr., Tent. Pterid., 117, tab. IV, fig. 12; Phegopteris philippinensis, Mett., var. 1, Mett., Farng., IV, Phegop. \& Aspid., 27; Stenosemia aurita, J. Sm. (not Pr.), Bau. \& Hk., Gen. Fil., tab. XCIV, fig. 1-4; Aspidium ambiguum, Diels, Copel., Polypod. Philipp, 39; C. Chr., Ind. Fil.; Tectaria ambigua, Copel., Philipp. Journ., II, 415, p. p.; Gymnogramme ambigua, Hk., Hk., Bk., Syn. Fil., 378.

Stipes slender, nearly naked. Fronds $45-60$ c.M. long, \pm 30 c.M. broad, oblong-deltoid, 2-pinnatifid. Pinnae lanceolate, 21/2-4 c.M. broad, the lower ones slightly stalked, cut $1 / 2$-way down to the costa or more into linear-oblong lobes, the fertile lobes contracted. Texture thinly herbaceous; colour darkgreen; rachis and both surfaces thinly clothed with long, jointed hairs; veins of the lobes often forked, the lower ones forming costal areolae. Sori oblong, simple, or confluent when the veins fork.

Philippines.

\section{DIPTERRS, Teinvardt.}

Sori punctiform or round, on the back of united veinlets. Indusium wanting.

Rhizome creeping. Stipes scattered, not articulate to the rhizome. Fronds flabellato-dichotomous, i.e. divided nearly or quite to the base in 2 halfs, each half once or more times dichotomously divided again with radiating lobes. Primary ribs radiating, dichotomous; secondary ribs (if present) \pm parallel to the primary ones; veins anastomosing copiously. Diels, in Engl. \& Prant. Nat. Pfl.Fam., I ${ }^{4}$, fig. 108.

Tropical Asia and Polynesia.

a. Sori in 1 row on each side of the costae.

(1) D. Lobbiana.

a.a. Sori scattered irregularly. 
b. Ultimale segments entire.

c. Fronds small, $2-3 \times$ furcate with $6-8$ ultimate segments.

(2) D. Nieuwenhuisii.

c.c. Fronds middle-sized, 4-5 X furcate with 16 or more ultimate segments.

(3) D. quinquefurcata.

b.b. Ultimate segments toothed, fronds rather large.

(4) D. conjugata.

* (1) D. Lobbiama, Moore (not Bedd.), Christ, Farnkr. d. Erde, 125; Bedd., Ferns Br I., II, tah. CCXXXIII; D. bifurcata, Christ (not $B k$.), MS. in Herb. Bog.; Polypodium bifurcatum, Bk., Hk. Bk., Syn. Fil., 562; P. Lobbianum, Hk., Spec. Fil., V, 100 (not IV, 226); Journ. of Bot., V, tab. XI; - var. Ridleyi, Christ, Ann. Btz., XX, 126.

Rhizome creeping, scaly, the scales bristle-like, subulate, blackish, small. Stipes to 50 c.M. long or longer. Fronds $\mathbf{1 5 - 5 0}$ c.M. long, \pm as broad, divided in 2 halfs, which are $5-4 \times$ flabellately dichotomous. Ultimate lobes linear, acute, $\pm 5-8$ m.M. broad, the edges entire. Texture coriaceous, central ribs prominent; areolae fine, in 1 or more rows. Sori small, $1-5$ to each main areola, placed in $1 \pm$ irregular row on each side near the costae of the lobes.

Var. Ridleyi: Fronds 10-15 c.M. long; ultimate lobes 3-4 m.M. broad. Sori punctiform.

Malaya; - var. Ridleyi: Borneo.

* (2) D. Nieuwenhuisii, Christ, Ann. Btz, XX, 124, tab. III; fig. 3 .

Rhizome creeping, blackish-brown, the scales firm, bristle-like, darkbrown, adpressed. Stipes distant, 30 c.M. long or longer, firm, brown, naked. Fronds \pm 14 c.M. long, \pm 22 c.M. broad, flabellate, 2-partite. Each half cuneate at the base, 2-fid, with the inner segment forked and the outer simple or forked again. Ultimate lobes \pm triangular-oblong, acumiuate, \pm $21 / 2$ c.M. broad at the base, entire, 2-costate. Texture rigidly coriaceous; surfaces naked; costae prominent; veins horizontal, connecting the costae as to form quadrangular primary areolae with smaller, included secondary ones. Sori dot-like, scattered irregularly.

Borneo. 
61. DIPTERIS.

* (3) D. quinquefureata, Christ, Farnkr. d. Erde, 125, fig. 550; Polypodium quinquefurcalum, Bk., Journ. of Linn. Soc., Bot., XXIV, 260.

Rhizome creeping, densely scaly, the scales blackish, subulate, bristle-like. Stipes straight, firm, naked, very long. Fronds cuneate-flabellate, 4 - $\mathrm{X} X$ dichotomous with 16 or more linear-lanceolate ultimate segments to 50 c.M. long, 12-20 m.M. broad. Texture rigidly coriaceous; primary veins stout, raised, forming 1 row of large, subcuadrangular primary areolae on each side of the costae of the segments; secondary areolae numerous, fine. Sori near de costae, scattered irregularly, confined to the primary areolae, forming groups of 4-12 to an areola. - Very near D. Lobbiana, Moore.

Borneo, Lingga Islands.

* (4) D. conjugata, Reinov., Christ, Farnkr. d. Erde, 123, fig. 348; D. Horsfieldii, Bedd., Ferns Br.I., II, tab. CCCXXI; D. Dipteris, Chrisl, MS. in Herb. Bog.; Polypodium Dipteris, Bl., Rac., Flor. Btz., I, 108; Bl., Flor. Jav., II, tab. LXXXI; P. Horsfeldii, R.Br., Hk., Spec. Fil., V, 99 ; - var. alpina, Christ, Bull. Herb. Boiss., $2^{\mathrm{e}}$ Série, VI, 991.

Rhizome creeping, densely clothed with blackish, adpressed, subulate scales. Stipes 1-100 c.M. apart, 70-200 c.M. long, firm, naked, glossy, erect. Fronds 30-90 c.M. long, more broad than long, divided quite to the base in 2 halfs, the main lobes of each reaching $\pm 3 / 4$ of the way down, once or twice forked again, with the edges broadly and obliquely toothed. Texture firm, coriaceous; surfaces naked, glossy, the lower often glaucous; primary ribs prominent, dichotomously forked; areolae copious. Sori minute, abundant, scattered irregularly, especially plentiful near the main veins.

Var. alpima: Fronds $3 \times$ smaller; lobes few, obtuse, obscurely toothed.

Trop. Asia \& Polynesia; - var. alpina; Laguna (Philippines). 

TRIBE VIII. GYMNOGRAMMEAE. 



\section{CONIOGRAMME, Fée.}

Sori linear, running along the veins, without paraphyses. No indusium.

Rhizome creeping. Stipes not articulate to the rhizome. Fronds pinnately divided; under surface not powdery; veins free in malayan material, simple or more commonly forked, pinnately arranged. Diels, in Engl. \& Prantl, Nat. Pfl.Fam., I ${ }^{4}$, fig, 138, A-B. - See the information in Philipp. Journ., II, 171, (Christ).

Paleotropical, and extra-tropical in Asia.

* C. fraxinea, Diels (not Fée), Copel., Polypod. Philipp., 66; Diels, in Engl. \& Prantl, Nat. Pfl.Fam., I ${ }^{4}$, fig. 158, A-B; Gymnogramme javanica, Bl., Rac., Flor. Btz., I, 68; G. fraxinea, Bedd. (not Don), Ferns S.Br.I., Suppl., 24; Syngramme fraxinea, Bedd., Handb. Ind. Ferns, 386; Neurogramme fraxinea, Christ, Farnkr. d. Erde, 65; Diplazium fraxineum, Don, (oldest name); - var. serrulata; G. serrulata, Bl., Enum., 113; Bedd., Ferns Br.I., I, tab. LVII \& Ferns S.I., tab. CCXXXII (as G. javanica); (? var. Copelandi, Christ, Philipp. Journ., II, 171).

Rhizome creeping, sparingly clothed with very small, deltoid scales. Stipes firm, naked, glossy, 30-120 c.M. long. Fronds 50-150 c.M. long, varying from simply pinnate to 5-pinnate. Pinnae erecto-patent, 10-50 c.M. long, stalked, the simple ones 2-5 c.M. broad, lanceolate, acuminate, narrowed at the base, the edge entire. Pinnulae of the same shape as the simple pinnae, but smaller. Texture herbaceous; rachis and both surfaces naked or nearly so ; veins distinct, close, simple or once forked. Sori yellow, commonly forked, beginning at the costa, but falling short of the edge.

Var. serrulata: Edges finely toothed.

Trop. Asia, Australia, Polynesia \& Africa, Japan, China, Madagascar.

\section{CEROPTERIS, hints.}

Sori linear or linear-oblong, running along the veins, not quite reaching their tips, without paraphyses. No indusium.

Rhizome commonly short-creeping. Stipes not articulate to the rhizome. Fronds divided, at least the fertile ones coated beneath with white or yellow, 
waxy powder; veins free, generally forked or pinnate. Diels, in Engl. \& Prantl, Nat. Pfl.Fam., I ${ }^{4}$, fig. 159, C. (Neurogramme).

Chiefly neotropical.

+. Both barren and fertile fronds powdery beneath.

+. Fronds 2-pinnatifid.

(1) C. tartarea.

.++ . Fronds 3-pinnatifid.

+. Fertile fronds only powdery beneath.

(2) C. calomelanos.

(5) C. chrysosora.

* (1) C. tartarea, Link, C. Chr., Ind. Fil.; Gymnogramme tartarea, Desv., Hk. Bk., Syn. Fil., 584; Acrostichum tartareum, Cav., (oldest name); var. ochracea; G. ochracea, Pr., Rel. Haenk., I, 17; G. Lartarea, Desv., var. ochracea, Hk. Bk., l. c.

Stipes tufted, firm, 15-50 c.M. long. dark-chestnut-brown, scaly towards the base. Fronds 50-60 c.M. long, $15-50$ c.M. broad, deltoid-oblong, 2-pinnatifid. Pinnae lanceolate, the lowest the largest, sometimes sharply deflexed. Secondary segments oblong, obtuse, entire, united, or the lower free, whether or not toothed. Texture subcoriaceous; under surface powdery; powder dense, white.

Var. ochracea : Segments very regular; powder bright-yellow.

In cultivation. - Orig. loc.: Trop. America.

* (2) C. calomelanos, Und., C. Chr., Ind. Fil.; Gymnogramme calomelanos, Klf., Rac., Flor. Btz., I, 69; Hk., Gard. Ferns, tab. L; Bau.\& Hk. Gen. Fil., tab. XXXVII; G. Boerlageana, Christ, MS. in Herb. Bog.; Neurogramme colomelanos, Diels, in Engl. \& Prantl, Nat. Pfl.Fam., I4, 264; Acrostichum calomelanos, L., (oldest name); - var. chrysophylla; G. chrysophylla, Klf. Enum. Fil., 74; G. calomelanos, Klf., var. chrysophylla, Hk. Bk., Syn. Fil., 385.

Rhizome short, oblique or erect, the scales brown, lanceolate. Stipes tufted, firm, angular, 5 -50 c.M. long, black or brown and polished like the rachis. Fronds 10-90 c.M. long, 5 -50 c.M. broad, deltoid-oblong or lanceolate-triangular, 5-pinatifid. Pinnae close, linear-lanceolate, the lowest mostly the largest, to 2--5. c.M. broad, stalked, the apex pinnatifid. Lower pinnulae lanceolate or deltoid-oblong, the lowest the largest, short-stalked, or sessile with a narrowed base, often deeply pinnatifid into oblong. or deltoid lobes; lobes entire or broadly toothed to serrate, the lowest anterior one often the largest. 
Texture coriaceous; rachis naked; upper surface naked, lower densely coated with white, waxy powder. Sori linear, forked, at length filling up nearly the whole under surface of the lobes, the ripe sporangia visible as blackish points amongst the powder.

Van'. Clneysopliylla : Powder yellow.

Much cultivated, and escaped from gardens: very common now in the neighbourhood of european selllements. - Orig. loc.: Trop. America, West. Africa, Nalal. hargeritá I

(3) C. Chrysosora, v. A. v. R.; Gymnogramme chrysosora, Bk., Journ. of Linn. Soc., Bot. XXIV, 260; C. Chr., Ind. Fil.

Rhizome short-creeping. Stipes approximate, castaneous, naked, $\pm 10-15$ c.M. long, the fertile fronds on the longest stipes. Fronds moderately firm, rather rigid, 7-10 c.M. long. Lowest pinnae much the largest and most compound, ultimate segments obovate-cuneate, $2-5 \frac{1}{2}$ m.M. broad. Both surfaces naked. Ferlile fronds similar, but with the under surface densely coated with golden, waxy powder. Sori at length confluent, covering nearly the whole breadth of the fertile segments, but do not reach the tips. Borneo.

\section{ANTIROPHYUM, Kaulfuss.}

Sori long, linear, carried along the veins, irregularly longitudinal or subflabellate, superficial or more commonly immersed, free or reticulate but often imperfectly. Paraphyses present. No indusium.

Rhizome short-creeping. Fronds simple, stalked or sessile, not articulate to the rhizome; veins copiously anastomosing, forming longitudinally elongated, \pm hexagonal areolae; costa wanting, at least in the upper half of the frond. Christ, Farnkr. d. Erde, fig. $141 \& 142 .\left(^{*}\right)$

Pantropical.

a. Sori marginal or very near the margin, not scattered over the frond.

S. Sori quite marginal, in 1 line on each side.

(1) A. marginale.

\$.S. Sori near the margin, in \pm 3 approximate lines on each side.

(2) A. Clementis.

a.a. Sori not marginal, nor very near the margin, more or less scaltered over Si p 325 the frond.

(*) The species are variable and not always clearly distinguished.

Filuaks. 
b. Paraphyses linear, the apex abruptly thickened, clavate, obpyriform or capitate.

c. Fully developped fronds mostly under 2 c.M. broad.

+. Fronds blunt or rounded at the apex.

(3) A. immersum.

+.*. Fronds acute or acuminate at the apex.

(4) A. parvulum.

c.c. Fully developed fronds 2 c.M. or more broad.

d. Fronds sessile or short-stalked; i.e. the unwinged part of the slipe very short with regard to the length of the whole frond.

e. Costa wanling towards the apex of the frond only.

(5) A. costatum.

e.e. Costa wanting throughout or at best present in the lower half of the frond.

f. Fronds thinly charlaceous. Paraphyses globose at the apex.

(6) A strictum.

f.f. Fronds coriaceous. Paraphyses clavate at the apex.

(7) A. semicostatum. SI 32

d.d. Fronds rather long-stalked, i.e. the unwinged part of the stipe not very short with regard to the length of the whole frond. *. Sori superficial.

(8) A. latifolium.

*.*. Sori immersed.

(Ba) A. Semuletes sip 3 :

$\times$. Texture subcoriaceous, rather thick.

(9) A. plantagineum. SI $p 3$

$\times \cdot \times$. Texture membranaceous, pellucid. (10) A. elongatum.

b.b. Paraphyses linear, the apex not or hardly thickened.

1. Fully developed fronds at best \pm 2 c.M. broad.

*. Sori few, in 2-6 lines.

(11) A. subfalcatum.

*.*. Sori rather copious.

(12) A. coriaceum.

1.1. Fully developed fronds $\pm 21 / 2-10$ c.M. broad.

2. Fronds broadly spathulate, rather small, to \pm 10 c.M. long.

(13) A. ovatum.

2.2. Fronds ligulate, lanceolate or spathulate, mure than 10 c.M. long in the fully developed plants.

3. Sori \pm straight, continuous or inlerrupled, not reticulate.

$\times$. Fronds ligulate-lanceolate. Costa wanting, or only distinct towards the base of the frond.

(14) A. callifolium.

$\times \cdot x$. Fronds spathulate-lanceolate. Costa more distinct in the lower half of the frond.

(15) A. alatum. S $p 3$ 
3.3. Sori mostly flexuose, short or long, reliculate.

4. Costa wanting or present, but then not black.

(16) A. reticulatum.

4.4. Costa present, black.

(17) A. Cumingii.

1.1.1. Fully developed fronds \pm 15 c.M. broad.

(18) A. spathulatum.

(1) A. maromale, Bt., Flor. Jav., II, 80, tab. XXXIV, fig. 1 \& 2 ; (? A. callifolium, Bl., C. Chr. Ind. Fil.).

Rhizome short-creeping, reddish-brown, the scales setiform. Fronds sessile, 4-25 c.M. long, 8-20 m.M. broad, simple, linear-lanceolate, sometimes falcale, narrowed towards both ends, the apex somelimes unecqually 2-fid, the edge entire, or at best undulate in the fertile fronds. Texture coriaceous; no midrib; surfaces naked. Sori marginal, continuous or interrupted, slightly immersed; paraphyses linear.

Java.

(2) Alementis, Christ, Philipp. Journ., II, 175.

Fronds elongate-lanceolate, caudate, \pm 30 c.M. long (incl. the stipe), \pm $2 \%$ c.M. broad at the middle, narrowed gradually towards both ends, the margin bounded by a narrow, hyaline line. Texture diaphanous; costa present in the lower part of the frond, yellow, at best 8 c.M. long; areolae long, verlical, $\pm 2 \frac{1}{2}$ c.M. long, \pm 2 m.M. broad. Sori narrow, filiform, in \pm 5 rows on each side near the margin, irregular, varying from $1 / 2$ to 7 c.M. long, not joining, slightly prominent on the upper surface of the frond. - Colour of the fronds emerald-green.

Mindanao.

* (3) A. immersum, Mett., Rac., Flor. Btz., I, 63; A. pumilum, Klf., Hk. \& Grev., Ic. Fil., tab. XLVI; A. oblusum, Bl. (not Klf.), Flor. Jav., II, 80, tab. XXXIV, fig. 4; Hemionilis immersa, Bory, (oldest name).

Rhizome short, slender, scaly. Fronds dense, $2-6$ or rarely to 10 c.MI: long, \pm 8-15 m.hi. broad, elongate-ohlong to cuneate or spathulate, narrowed gradually from a blunt $0 r^{\circ}$ rounded apex to the base or a stipe to $21 / 2$ c.M long. Texture coriaceous; no distinct midrib. Sori immersed, often forked or joining; paraphyses clavate or capilate at the apex.

Malaya; Mascarenes. 
* (4) A. parvulum, Bt., Flor. Jav., II, 78, tab. XXXIV, fig. 3; Bedd., Ferns Br.I., II, tab. CCLXVII.

Rhizome stinrl-creeping, the scales weak, blackish, subulate or subcapillary, crowded more densely at the base of the younger fronds. Fronds close, erect, sessile or stalked, $21 / 2-10$ or rarely to 20 c.ll. long, $4-10$ or rarely to 20 m.M. broad, ligulate, the apex acute or acuminate, the edge entire, the base narrowed gradually into the stipe. Texture submembranaceous, subpellucid; surfaces naked; costa none, or slightly visible in the lower $1 / 3$ of the frond; areolae longitudinal, oblong to linear. Sori linear, long and subcontinuous, or short and interupted, immersed; paraphyses clavate or obpyriform at the apex.

Java, Penang.

* (马) A. costatum, v. A. v. R., Bull. Dép. Aggr. I. N., 1908, XVIII, 17, tab. II, fig. 2, a-d.

Rhizome short, the scales brown, linear-lanceolate, acuminate, subdenticulate. Fronds dense, sessile, spathulate-euneate, 10-25 c.M. long, 3-5 c.M. broad, the fully developed ones broadest near the blunt apex, narrowed gradually to the base, the silles nearly straight, entire. Texture coriaceous; costa distinct, but lost in the upper $1 / 8-1 / 4$ of the frond. Sori short or long, mostly free, slightly sunk, the edges of the groores slightly raised; paraphyses linear, the apex capitate-clavate.

Borneo (Hallier, No. 5540).

(6) A. strictum, Mrett., AmI. Mus. Bot. L. B., IV, 171, tab. VII, fig. $1-\tilde{5}$.

Rhizome scaly like the base of the stipes, the scales black, denticulate. Fronds spathulate-lanceolite, $1: 3-50$ c.M. long, $2-4 \frac{1}{2}$ c.M. broad, the base narrowed gradually into the winged stipe, the apex short-acuninate. Texture thinly chartaceous but lirm, rigid; colour pale-green; costa visible in the lower half; areolae in 6-8 rows on each side, the central ones moderately elongate, the lateral \pm as broad as long. Suri immersed in the numerous grooves, continuous or interrupted, lrardly reliculate; paraphyses branched, the apices globoso-capitate.

New Guinea.

* (7) A. semicostatum, Bt., Rac., Hlor. Btz., I, 65; Bl., Flor. Jav., II, tab. XXXIII; Christ, Farnkr. d. Erde, fig. 142.

Rhizome creeping, the scales long, linear, narrowed from the base towards 
the apex, thin, spreading, $1-2$ c.M. long. Frunds $15-50$ c..I. long, 2-10 c.M. broad, ligulate, broadest $\pm 1 / 3$ on the way down, acute or acuminate, narrowed gradually to the base or a.short stipe, the edge entire. Texture coriaceous; a distinct, often blackish costa in the lower $1 / 4-1 / 2$ of the frond; areolae large, long. Sori copious, often joiningr; paraphyses minute, the apex clavate.

Malaya; Polynesin, Ceylon.

* (8) A. Iatifoliumn, Ist., Rac., Flor Btz., I, 64; Bedd., Ferus Br.I., II, tab. CLXXVI; A. Boryanum, Bl., Flor. Jav., II, Lab. XXXI.

Rhizome short-creeping, the scales fine, linear-lanceolate, denticulate, blackish-brown, at length deciduous. Stipes approximale, 7 -20 c.M. long, conpressed. Fronds 8-25 c.M. long, 4-12 c.M. hroal, roundish, ovale or obovate, the apex more or less suddenly acuminate with a moderate-long point, the edge entire, slighlly repand or acutely lut not deeply sinuato-luhate lowards the apex, bordered by a narrow, pellucid line, the base cuneate or siddenly narrowed and slightly decurrent. Texture coriaceous; no midrib; areolae longitudinal. Sori mostly copious, not often joining: paraphyses limmear, the apex clavate-capitate.

Malaya; Norlh. India, South. China.

* (9) A. plantaginaum, KIf., Hk. Bk., Syn. Fil., 395; A. reliculatum, Bedu., Ferns S.I., tab. LII ; Hemionitis planlaginea, Cav., (oldest name).

Rhizome shorl; scales inear-lanceolate, acuminate, brown, with the margin beset with sharp, short, spreading, distant teeth. Stipes distinct, approximate, $2 \frac{1}{2}-1$ c.M. long. Fronds spathulate- or ovate-lanceolate, $6-50$ c.M. long, $21 / 2-71 / 2$ c.M. broad, broadest $\pm 1 / 3-{ }^{1}, 2$ of the way down, the point acute or acuminate, the margin entire, often slightly thickened, the base narrowed gradually, or sometimes more suddenly in the smaller forms. Texture more or less coriaceous; no midrib or an indistinct one at the base. Sori short or long, deeply sunk, often forked and anastomosing. the edges of the grooves more or less raised or not raised; paraphyses capitate at the apex.

Malaya; Polynesia, Norlh. India, Ceylon.

(10) A. elongatum, Fée, Hk.. Spec. Fil., V, 168; A. parvulum, Bl., var. elongatum, Bl., Flor. Jav., II, 79.

Stipes 10-15 c.M. long. Fronds elongate-lanceolate, much acuminate, 20-50 c.M. long, $2 \frac{1}{2}-4$ c.M. broad. Texture subnembranaceous, pellucid; 
no midrib; veins very slender; areolae long, narrow. Sori linear, simple, subcontinuous or short and interrupted; paraphyses clavate or obpyriform at the apex.

Java.

* (11) subfalcarum, Brack., Hk. Bk., Syn. Fil. $592 ;$ A. Brookei, H/k, $2^{\text {nd }}$ Cent. of Ferns, tab. LXXIX.

Fronds $15-30$ c.M. long, $1 / 2-1 \frac{1}{2}$ c.M. broad, linear or linear-lanceolate, the point acute, the edge entire, the lower part narrowed very gradually to the base or a short stipe, an indistinct midrib in the lower part. Texture \pm coriaceous; surfaces naked; areolae longitudinal, about $2-5$ on each side, several times longer than broad. Sori moderately immersed, in $2-6$ interrupted lines, hardly uniting; paraphyses linear.

Malaya; Polinesia.

* 12) A. corraceoum, Wall., Hk. Bk., Syn. Fil., 595; A.reticu- ami latum, Bedd., Handb. Ind. Ferns, 401; Ferns S.I., tab. CCXXXI; Hemionilis coriacea, Don, (oldest name).

Fronds $\pm 15-45$ c.M. long, $1-2$ c.M. broad, narrowed gradually from the centre to both ends, the apex acute. Texture very thick, surfaces naked; no midrib; areolae long and narrow; veins raised on the upper surface. Sori rather copious, immersed, sometimes confluent; paraphyses linear.

Malaya; North. India.

* (13) A. ovatum, v. A. v. R., Bull. Dép. Agr. I. N., 1908, XVIII, 17, tab. II, lig. 1, a-e.

Rhizome short, clothed with linear-subulate or -lanceolate, shorlly toothed or entire, brown or black scales. Stipes close, $1-4$ c.M. long, firm, erect. Fronds broadly ovate-spathulate, $\pm 8-10$ c.M. long, the broadest part \pm ovate, 4-6 c.M. broad (at or above the middle), more or less suddenly narrowed into an acuminate point and the lowest \pm cuneate part of the frond, the edge entire, subpellucid. Texture coriaceous; a slender midrib in the lowest part; areolae $1-1 \frac{1}{2}$ c.M. long, to 5 m.M. broad. Sori not copious, slightly sunk, rarely joining, not long, nearer the edge than the central part of the frond, subflabellate; edges of the furrows not raised; paraphyses linear, spirally twisted.

Sumatra (Forbes, No. 2925a). 
64. ANTROPHYUM.

- (14) A. callifolium, Bt., Rac., Flor. Btz., 62; Bl., Flor. Jav., II, tab. XXXV; A. falcatum, Bl., l. c., tab. XXXII.

Rhizome creeping; scales linear-lanceolate, acuminate, the margin sharply serrate or subserrate. Fronds approximate, ligulate-lanceolate, 10-50 c.M. c.M. long, $21 / 2-8$ c.M. broad, broadest $\pm 1 / 3-1 / 2$ of the way down, the apex bluntish, acute or acuminate, the margin bordered by a narrow, yellowish, diaphanous line, the lower part narrowed gradually into the short, flat stipe. Texture fleshy or coriaceous; costa wanting, or only present towards the base. Sori linear, continuous or interrupted, free; paraphyses linear, (tortuose in $A$. falcatum, Bl.).

Malaya; Polynesia.

* (15) A. alatum, Brack., Wilk. Expl. Exp., XVI, 64; A. callaefolium, Bl., var. alatum, Rac., Flor. Btz., I, 65; A. semicostatum, Bl., Hk., Spec. Fil., V, 168, p. p.

Near A. callifolium, $B l$., but the fronds spathulate-lanceolate, relatively shorter and broader, narrowed gradually into the short, winged stipe, with a more distict costa in the lower part; paraphyses linear. - Distinct enough from callifolium if typical specimens only are viewed, but passing into it by intermediate forms, and it is impossible to draw the line between them.

Malaya, Polynesia.

- (16) A. reticulatum, Kt:, Hk. Bk.. Syn. Fil, 393; Christ, Farnkr. d. Erde, fig. 141; Hemionitis reticulala, Forst., (oldest name).

Fronds $15-50$ c.M. long, $21 / 2-8$ c.M. broad, broadest about $1 / 3-1 / 2$ on the way down, the apex blunt, acute or short-acuminate, the margin \pm pellucid, the lower part narrowed gradually to the base or a short stipe. Texture thin-coriaceous: surfaces naked; costa wanting or present, green, usually visible in the lowest $1 / 4-1 / 3$ of the frond; veins distinct. Sori copious, short or long, joining; paraphyses linear. - Very variable, with forms often approaching the other species.

Malaya; Polynesia, Trop. Australia, North India, Madagascar.

(17) A. Cumingii, Fée, Hk. Bk., Syn. Fil., 593; A. Grevillei, Balf., G. Chr., Ind. Fil.

Fronds to \pm 45 c.M. long, $21 / 2-4$ c.M. broad, ligulate, \pm equal in width in the central half, narrowed very gradually to the base and an acute point, with a black midrib in the lower quarter, the central areolae long, 
and not more than $1 \frac{1}{2} \mathrm{~m}$. M. broad. Sori slender, deep-sunk, often joining, the edges of the furrows rather raised; paraphyses linear.

Philippines; Polynesia. Suranatra (S1\&327)

* (18) Apa thulatum, v. A. v. R., Bull. Dép. Agr. I. N., 1908 XVIII, 17.

Rhizome creeping; scales dense, hrown, linear-lanceolate, the margin beset with sharp, short, spreading, subremote teeth. Fronds $45-55$ c.M. long, \pm 13 c.M. hroad, broadest $\pm 1 / 3$ of the way down to the base; upper half obovate, short-acuminate at the point, narrowing gradually below into the linear-cuneate lower half and the short stipe. Texture coriaceous; surfaces naked; the lowest part with a distinct, black, but not prominent midrib; central areolae $1-3$ c.M. long, \pm 4 m.ll. broad. Sori long, very numerous, often joining, deeply sunk; edges of the furrows not raised; paraphyses linear.

Lingga Islands ('Teysmann, No. 16656).

\section{LOXOGRAMME, Prest.}

Sori linear-oblong or linear, forming an acute angle with the costa, SIP rarely subparallel to it; receptacle crossing the areolae. No indusium.

Rhizome more or less creeping. Fronds not articulate to the rhizome, simple and entire; veins immersed, invisible, (so the main ones when present), anastomosing irregularly to form areolae with or without included free veinlets. Bedd., Handb. Ind. Ferns, fig. 228-229. (*)

Paleotropical.

a. Fronds uniform or nearly so.

b. Sori subparallel to the costa.

(1) L. parallela. Sip

b.b. Sori erecto-palent.

c. Fronts rather long-stallicd.

(2) L. grandis. Sip

c.c. Fronds sessile or short-slalked.

a. Costa flatlened abov, prominent benealh.

(3) L. involuta.

d.d. Costa prominenl "bove, flallened benealh.

(*) Diels referred Loxogramme to Polypodium, $\mathbb{S}$ Selliguea, from which it is distinguished by the fronds adherent to the rhizome and the hidden or wanting main veins. 


\section{e. Sori short \\ e.e. Sori long.}

(4) L. lanceolata.

(5) L. Blumeana.

a.a. Fronds distinctly dimorphous, the fertile ones much the narrowest.

+. Fronds small, uniler 3 c.M. long.

*. Fron!s larger, $10-30$ c.M. long.
(6) I. conferta.

(7) L. iridifolia. Si p 329

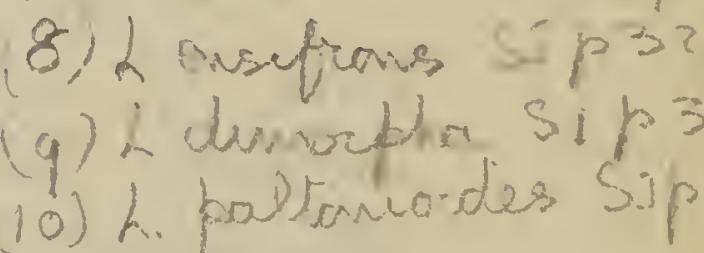

(1) H. Darallella, Copel., Polypod. Philipp., 68; Polypodium parallelum, C. Chr., Ind. Fil.

Rhizome short, creeping, the scales greyish-reddish-hrown, Ianceolate, acuminate. Fronds linear, \pm 1 c.M. long, \pm 6 m.M. hroad, sessile, erect, acuminate, entire, narrowed gradually to the base. Texture coriaceous; surfaces naked; costa distinct beneath; veins immersed. Sori oblong, in 1 row on each side near the costa, subparallel to it.

Luzon.

* (2) L. gmandis, Copel., Philipp. Journ., III, 35; Gymnogramme grandis, Rac., Flor. Btz., I, 72; Polypodium Raciborskii, C. Chr., Ind. Fil.

Rhizome short-creeping, thick, the scales long, lanceolate. Stipes approximate, $10-12$ c.M. long. Fronds 70-90 c.M. long, to 10 c.M. broad, lanceolate, acute, the edge entire, the lower part narrowed gradually into the stipe. Texture coriaceous; costa prominent: main veins hidden, parallel; areolae wilh free veinlets. Sori linear, oblique, reaching nearly to the edge.

Nusa Kembangan (Java).

* (3) L. involuta, Pr., Copel., Polypod. Philipp., 68; Bedd., Ferns S.I., tab. L; Gymnogramme involuta, Hk., Hk. Bk., Syn. Fil., 387; Polypodium. involutum, Mell., Christ, Farnkr. d. Erde, 106; P. scolopendrinum, C. Chr, Ind. Fil.; Antrophyum involulam, Bl., Flor. Jav., II, 87; - var. gigas, Copel, Philipp. Journ., III, 53 .

Rhizome creeping, the scales large, hrown, lanceolate. Fronds scattered, $15-50$ c.M. long, $2-5$ c.M. broad, ligulate-lanceolate, the point acumiuate, the edge entire or somewhat repand, \pm involute, the lower part narrowed very gradually to the base or a short stipe. Texture thick, coriaceous, flaccid: surfaces naked; costa broad, compressed, flattened above, keeled beneath; veins fine, obscure; areolae with few free veinlets. Sori oblique, reaching from the midrib nearly to the margin. 
Var. gigans: Fronds to 65 c.M. long, to 8 c.M. broad, caudate, the margin hardly involute, slightly crisped.

Trop. Asia, China, Melanesia; - var. gigas : Laguna (Philippines).

* (4) L. Ianceolata, Pr., Copel., Polypod. Philipp., 68; Bedd. Ferns S.I., tab. LI; Gymnogramme lanceolata, Hk., Rac., Flor. Btz., I, 71• Antrophyum lanceolatum, Bl., Flor. Jav., II, tab. XXXVI; Polypodium loxogramme, Mett., Farng., I, Polypod., 112; C. Chr., Ind. Fil.

Rhizome slender, wide-creeping, the scales small, dense, brown, linearlanceolate. Fronds $15-30$ c.M. long, $5-20$ m.M. broad, the point acute or acuminate, the edge entire, the lower $1 / 3-1 / 2$ narrowed gradually to the base or a short stipe. Texture coriaceous, flaccid; surfaces naked; costa slightly prominent above, flattened beneath; areolae with few free veinlets. Sori oblique, short, near the costa, falling well short of the margin.

Trop. Asia, Polynesia, Japan, Abessinia, Guinea, Mascarenes, Natal.

* (5) L. Blumeana, Pr., Tent. Pterid., 215; L. avenia \& coriacea, Pr., l. c.; Bedd., Handb. Ind. Ferns, 595 ; Gymnogramme avenia, Bk., Rac., Flor. Btz., I, 72; Antrophyum avenium \& coriaceum, Bl., Flor. Jav., II, tab. XXXVII: Polypodium avenium \& Blumei, Mell., Farng., I, Polypod., 113 \& 114; P. Blumeanum, C. Chr., Ind. Fil.; - var. Forbesii, Rac., l. c., 73.

Rhizome creeping, the scales linear-lanceolate, acuminate, brown. Fronds $\pm 10-60$ c.M. long, $\pm 1-7$ c.M. broad, linear- or spathulate-lanceolate, acute or acuminate, the edge entire, the lower part narrowed gradually to the acutely cuneate base or a short stipe to 2 c.M. long. Texture coriaceous; surfaces naked; colour mostly darker in the smaller forms (L. avenia, Pr.: \pm $10-30$ c.M. long, $\pm 1-2$ c.M. broad), commonly paler in the larger ones (L. coriacea, Pr., = Blumeana typica: $\pm 25-60$ c.M. long, $\pm 21 / 2-7$ c.M. broad); costa prominent above, flattened beneath; areolae fine, small, with several free veinlets. Sori erecto-patent, reaching nearly from the midrib to the edge.

Var. Forlbesii: Like $L$. coriacea, $P r$, but the fronds with the lower half broad, abruptly narrowed at the broadly cuneate or rounded base.

Malaya; Japan; - var. Forbesii: Sumatra (Forbes, Nos. 2234 \& 2262a).

(6) L. Conferta, Copel., Polypod. Philipp., 68; Drymoglossum conferIum, Copel., Perk., Fragm. Philipp., 187; Polypodium Copelandii, C. Chr., Ind. Fil. Rhizome slender, creeping, clothed with small, thin, brown, lanceolate, acuminate scales. Fronds crowded, on stalks $1-7 \mathrm{~m} . M$. long. Sterile fronds 
elliptical, to \pm 2 c.M. long, $\pm 1 \frac{1}{2}$ c.M. broad, naked, entire, cordate, the apex rounded. Texture thick; veins anastomosing; areolae few, without free veinlets. Fertile fronds linear-oblanceolate, $\pm 2 \frac{1}{2}$ c.M. long, $\pm 5^{1} / 2$ m.M. broad, the apex rounded, the base narrowed into the stipe. Sori superficial, medial, afterwards filling up the whole under surface.

\section{Mindanao.}

* (7) L. Iridifolian, Copel., Philipp. Journ., I, Suppl., 149; Gymnogramme iridifolia, Chrisl, Ann. Btz., XV, 170, tab. XVI, fig. 26, a-b; Rac., 'Flor. Btz., I, 73 ; Polypodium iridifolium, Diels, in Engl. \& Prantl, Nat. Pfl. Fam., I, 316; C. Chr., Ind. Fil.

Rhizome slender, creeping, the scales brown, lanceolate. Stipes very short, 0-2 m.M. long, $5-15 \mathrm{~m}$.M. apart. Barren fronds $10-50$ c.M. long, $21 / 2-4$ c.M. broad, lanceolate, entire, the point acuminate, the lower part narrowed gradually to a rather broad, rounded or truncate hase. Texture firm; costa prominent; areolae fine, with free veinlets. Fertile fronds as long as the barren ones or longer, 4-15 m.M. hroad, narrowly lanceolate or nearly linear. Sori linear, close, nearly parallel to the costa.

Java, Celebes, Mindanao.

\section{SYNGRAMMA, J. Smith.}

Sori linear, occypying the veins, (some of them sometimes oblong or round), free or joining, with paraphyses. No indusium.

Rhizome creeping or erect, setaceous, hairy or fibrillose. Stipes not articulate to the rhizome. Fronds naked, simple, rarely pinnate; veins pinnately arranged, free or anastomosing more or less copiously.

Malaya ${ }^{\top}$ and Polynesia.

Arrangement of the sections.

$\$$ 1. AUSTROGRAMME. Veins and sori free. (Not in Malaya).

$\$$ 2. TOXOPTERIS. Veins uniting $1 \times$ at or near the margin. Sori free. Diels, in Engl. \& Pranll, Nat. Pfl.Fam., I, fig. 135, D.

S) 3. CALLOGRAMME. Veins uniling $2-5 \times$ near the margin. Sori free, or joining like the veins. Diels, l.c., lig. 155, E. 
\$ 4. HEMIGRAMMA. Veins anastomosing more or less copiously. Sori free or reticulate. Fronds simple or irresularly incised, dimorphous, the barren ones often forming a rather dense rosette. Main veins present.

$\$$ 5. DICTYOGRAMME. Veins and sori as in $\$ 4$. Fronds simple or divided, uniform, the barren ones not in a dense rosette. No main veins.

\section{S 2. TOXOPTERIS.}

a. Fronds simple, entive, crenate or slighly toothed.

b. Fronds obling, nol more than $4 \times$ as long as broad.

(1) S. valleculata.

b.W. Froids lanceolate, ligulate or linear, more than $4 \times$ long as broad.

c. Fronds rounded at the apex.

(2) S. obtusifolia.

c.c. Fronds not decidedly rounded at the apex.

d. Fronds narrow-linear, under 5 m.M. broad, the apex suddenly acule.

(3) S. Dayi.

a.d. Fronds broader, at least the birren ones more than 5 m.M. broad, the apex \pm acuminale.

e. Fronds entire; barren fronds not much broader than the ferlile ones.

(4) S. Lobbiana.

e.e. Fronds crenale or slighly toothed; barren fronds distinctly broader than the ferite ones. $\quad$ (5) S. borneensis.

a.a. Fronds simple, conspicuously toothed with \pm spreading, sharp or bluntoblong, cartilagineous teeth or spines.

(6) S. cartilagidens.

(1) 9. valleculata, C. Chr., Ind. Fil.; Gymnogramme v'alleculara, Bk., Journ. of Bot., XXVI, 325.

Rhizome woody, short-creeping, clothed with short, stiff, subulate, brown sciles. Stipes glossy, naked, castaneous, 15-25 c.M. long. Fronds oblong, entire, 10-13 c.M. long, 3\%._. c.M. broad at the middle, deltoid or rather rounded at the base, the apex deltoid or obtuse, the margin revolute. Texture rigid, thick; costa castaneous; surfaces naked; veins inmersed, obscure, anastomosing near the margin. Sori immersed, erecto-patent, reaching nearly to the edge.

Borneo. 
66. SYNGRAMMA. $\mathbb{S}$ 2. TOXOPTERIS.

* (2) S. obtusifolia, J. Sm., Diels, in Engl. \& Prantl, Nat. Pfl. Fam., I", 257; Gymnogramme oblusifolia, Hk., Rac., Flor, Btı., I, 70; Hk., Spec. Fil., V, tab. CCIC.

Rhizome creeping, furnished with short, black hairs. Stipes 5-8 8 c.M. long, naked, flexuose. Fronds $15-25$ c.M. long, $1 / 2-11 / 2$ c.M. hroad, ligulate, the apex rounded, the edge entire, the lower part gradually narrowed. Texture \pm coriaceous; surfaces naked; costa prominent; veins distinct or hidden, sim. ple or forked, connected near the edge. Sori medial, often occupying the whole veins.

Java; Sumalra.

(3) \$. Dayi, Bedd., Handb. Ind. Ferns, Suppl., 100; Gymnogramme Dayi, Bedd., Journ. of Bot., XXVI, b̆, tab. CCLXXIX, B, fig. 1-4.

Rhizome creeping, slightly fihrillose. Stipes $2 \frac{1}{2}-4$ c.M. long. Fronds narrow-linear. subentire or obscurely crenate, 10-18 c M. long, \pm 4 in.M. broad, narrowed gradually at the base. Texture coriaceous; veins obscure, simple or forked, the apices running into a transverse, continums or interrupted submarginal vein. Sori lincar, narrow, occupying the veins. - The; young frouds are less coriaceous, with the veins also less hidden.

Malacea.

* (4) S. Lobloiana, J. Sm., Diels, in Engl. \& Prant, Nat. Pfl. Fam. I", 257; Gymnogramme Lobbiana, IIk., Hk. Bk., Syı. Fil., 586; Hk., Spec. Fil., V, tab. CCG; - var. latior.

Rhizome creeping, woody, the scales small, brown, subulate. Stipes whether or not approximale, $5-50$ c.M. long, glossy, dark-coloured. Fronds 12-25 c.M. long, 1-2 c.M. broad, linear-lanceolate, entire, the apex acuminate, the base narrowed or slightly rounded. Texture coriaceous; surfaces naked; veins simple or forked, united by transverse veinlets near the edge. Sori copious.

Var'. Iation: Fronds $2-4$ c.M. broad.

Borneo, Malacca.

* (5) S. Don'meensis, J. Sm., Diels, in Engl. \& Prantl, Nat. Pfl. Fam., 14, 257, fig. 15b, G \& D; Gymnogramme borneensis, Hk., Hk. Bk., Syn. Fil., 386; Hk., Spec. Fil., V, tab. CCCI.

Rhizome creeping, woody, densely clothed with nearly black, fibrillose scules. Stipes nearly wanting or to $\breve{b}$ c.M. long. Fronds $10-45$ c.M. long, 
$1 / 2-21 / 2$ c.M. broad, ligulate, narrowed to both ends, but more gradually to the base, the edge slightly toothed or crenate; barren fronds the broadest. Texture coriaceous; surfaces naked; veins immersed, 1-2 $\times$ forked; connecting veinlets indistinct, submarginal.

Bornen, Celebes, Amboyna; Fiji.

* (6) S. carrilagidens, Diels, Bull. Dép. Agr. I. N., 1908, XVIII, 18; Gymnogramme cartilagidens, Bk., Hk. Bk., Syn. Fil., 586; Ces., Fel. di Bor., tab. II, fig. 5-5a; Neurogramme cartilagidens, Chris/, Farnkr. d. Erde, 65, fig. 156; Acrostichum Borneense, Burck, Ann. Btz., IV, 99; Elaphoglossum borneense, C. Chr. Ind. Fil.

Rhizome short-creeping, densely clothed with small, black or dark-browu hairs or fibres lowards the apex. Stipes approximate, $1 / 2-4$ c.M. long, (the ferlile fronds on the longest stipes in the fully developed plants), fibrillose at the base, the fibrils deciduous. Fronds decidedly dimorphous in the adult plants, but less so in the younger ones; barren fronds $\pm 10-50$ c,II. long, $\pm 2-5$ c.ll. broad, lanceolate or linear-lanceolate, narrowed gradually from the middle towards both ends, the apex acuminate, the edge cartilagineous, decoloured, densely fringed with small, cartilagineous, short-oblong, bluntish, spreading or erecto-patent teeth or serratures in the younger or smaller forms, sharply serrato-dentate throughout or towards the base only in the adult or largest forms, which are not rarely subentire towards the apex. Texture coriaceous; surfaces naked; costa prominent beneath, more or less distinctly canaliculate towards the base on the upper side in the larger and sometimes also in the smaller forms; veins close, fine, simple or forked, connected by the cartilagineous edge or by fine, transversal veinlets near the margin. Fertile fronds longer and narrower than the barren ones, not rarely subsimilar to the latter in the smaller forms, $\pm 15-60$ c.M. long, $1 / 2-11 / 2$ c.M. broad, linear-lanceolate or linear, narrowed very gradually towards both ends in the larger forms. Sori occuping the upper $1 / 2-9 / 10$ of the fertile fronds, reaching from the costa to the cartilagineous margin, at length often confluent. - The description is taken from the specimens gathered by Mr. Teuscher (described by Dr. Burck as Acroslichum Borneense) and Dr. Nieuwenhuis (determined by Dr. Christ). Borneo. 
66. SYNGRAMMA.

\section{\$ 3. CALLOGRAMME.}

†. Fronds simple.

+. Fronds entire, oblong, acuminale.

(7) S. alismifolia.

+.+. Fronds irregularly repand, spathulale-oblong, acule. (8) S. vittaeformis. +. Pronds lernate or quinate.

(9) S. quinata.

* (7) S. alismifolia, J. Sm., Copel., Polypod. Philipp., 69; Lond. Journ. of Bot., IV, 168, tab. VII-VIII, fig. B; Bedd., Ferns Br.I., II, tab. CCXL; Gymnogramme alismaefolia, Hk., Hk. Bk., Syn. Fil., 386 ; Neurngramme alismaefolia, Christ, Farnkr. d Erde, 64; Diplazium alismaefolium, Pr., (oldest name); - var. Wallichii; G. Wallichii, Hk., Hk. Bk., l. c.; Hk., Spec. Fil., V, tab. CCCII; S. Wallichii, Bedd., Ferns Br.I., II, tab. CLIII.

Rhizome creeping. Stipes 10-45 c.M. long, firm, glossy, chestnut-brown, naked, or scaly towards the base. Fronds $12-50$ c.M. long, $5-8$ c.M. broad, oblong, acuminate, entire, cuneate or rounded at the base. Texlure thinly coriaceous; surfaces naked; costa distinct; veins fine, numerous, nearly spreading, uniting $2-3 \times$ near the margin. Sori extending from the midrib to where they join.

Var. Wallichii: Fronds narrower, $2-5$ c.M. broad, the base narrowed, the veins less spreading.

Malaya; - var. Wallichii : Singapore, Borneo.

(8) S. vittaeformis, J. Sm., Copel., Polypod. Philipp., 69; Lond. Journ. of Bot., IV, 168, tab. VII-VIII, fig. A; Gymnogramme villaeformis, Mell. (not $H k$.), Hk. Bk., Syn. Fil, 386 .

Stipes subtufted, 50-45 c.M. long, naked, flexuose, dark-brown. Fronds $20-30$ c.II. long, $31 / 2-7$ c.M. hroad, spathulate-oblong, the edge irregularly repand, the point acute. Texture subcoriaceous; surfaces naked; veins fine, parallel, forming 1--2 rows of distinct areolae near the edge. Sori extending from the midrib to the edge.

Philippines.

* (9) S. quimata, Carr., Diels, in Engl. \& Prantl, Nat. Pfl.Fam., I I", 257; Gymnogramme quinala, Hk., Hk. Bk., Syn. Fil., 387; Hk., Spec. Fil., V, tab. CCXCVII; Neurogramme quinala, Christ, Farnkr. d. Erde, 64; - var. ternata, Christ, Fil. Saras., III, 250. 
Rhizome creeping. Stipes $15-40$ c M. long, pale or brown, glossy, naked. Fronds $15-50$ c.I. long, $10-20$ c.M. broad, quinate. Central pinna the largest, $15-50$ c.M. long, $31 / 2-5$ c.M. broad, oblong-lanceolate, slightly stalked, the point acuminate, the edges entire, the base narrowed gradually; lateral pinnae subsessile, swaller, the lowest deflexed, distinct or originating from the hase of the next higher ones. Texture coriaceous; surfaces naked; veins fine. parallel, uniting near the edge. Sori on all the veins, extending from the midrib to where they join.

Var. termata: Fronds ternate.

Malaya; Salomon Islands; - var. ternata: Celebes, Sumatra.

\section{\$ 4. HEMIGRAMMA.}

* (10) \$. Zollingervi, Diels, in Engl. \& Prantl, Nat. Pfl.Fam., I ${ }^{4}$, 257; Hemionilis Zollingeri, Kurz, Rac., Flor. Btz., I, 64; Chrisl, Farnkr. d. Erde, 60, fig. 147; Hemigramma Zollingeri, Christ, Philipp. Journ., II, 170; H. lalifolia, Copel., Philipp. Journ., II, 406, p.p.; - var. Teysmamii.

Rhizome erect, the scales dense, brown, with the edges fringed or ciliate. fronds dimorphous, simple or irregularly incised. Sterile fronds often in a dense rosette. 8-25 c.M. long, 3-10 c.M. broad, sessile or short-stalked, the broadest part nearer the blunt or short-acuminate apex than the base, the lower part narrowed gradually, the very base rounded or truncale. Texture membranaceo-herhaceous; main veins distinct nearly to the edge; venation \pm as in Aspidium: areolae numerous, fine, with free veinlets. Fertile fronds linear-lanceolate or ligulate, $6-10$ c.ll. long, $5-7 \mathrm{~m} . \mathrm{ll}$. broad, the edge subentire or slightly repand, the stipe 4-13 c.M. long. Sori in 2-3 rows, parallel to the costa, united by short, transversal bars.

Var. Teysmannii: Fronds coriaceous, more or less cordate at the very base.

Malaya; - var. Teysmannii: Amboyna (Teysmann).

\section{S 5. DICTYOGRAMME.}

S. Fronds simple. Sori joining.

*. Fronds narrowed at the base.

(11) S. lanceolata.

*.*. Fronds more or less rounded at the base.

(12) S. Hosei. 


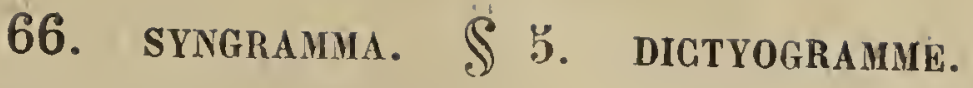

\$.\$. Fronds pinnate, sometimes 2-pinnate at the base.

+. Pinnae short, herbaceous, unequal-sided at the base. Sori free.

(13) S. Boerlageana.

+.+. Pinnae long, rather coriaceous, narrowed gradually at the base. Sori often confluent.

(14) S. pinnata.

(11) S. lanceolata, Diels (not J. Sm.), in Engl. \& Prantl, Nat. Pfl.Fam. I4 2 257; Hemionilis lanceolata, Hk., Hk. Bk., Syn. Fil., 598 ; Hk., $2^{\text {nd }}$ Cent. of Ferns, tab. LV; S. Hookeri, C. Chr., Ind. Fil.

Rhizome short, ascending. Stipes $15-25$ c.M. long, firm, erect, brown, naked, glossy. Fronds 15 -25 c.M. long, $51 \frac{1}{2}-6 \frac{11}{2}$ c.M. broad, ovate or oblong-lanceolate, the point acute, the edge entire or repand, the base narrowed. Texture coriaceous: surfaces naked; midrib distinct; areolae copious, elongate, oblique. Sori copiously reticulate.

New Guinea; Fiji.

(12) S. Tlosei, Diels, in Engl. \& Prantl, Nat. Pfl.Fam., I I, 257; Hemionilis Ilosei, Bk., Journ. of Bot., XXIX, 108.

Rhizome stoul, short-creeping. Stipes naked, glossy, castaneous, 15-30 c M. long. Fronds simple, lanceolate, \pm 50 c.M. long, $31 \frac{1}{2}-5$ c.M. broad at the middle, more or less rounded at the base. Texture subcoriaceous; surfaces naked; veins fine, distinct, erecto-patent, anastomosing in the barren fronds mainly in the outer $1 / 3$, but in the rather narrower fertile fronds, in which the slender sori are confined to a band $\pm 1 / 2$ c.M. broad remote from both midrib and edge, they anastomose copiously.

Borneo.

* (13) S. Boerlageana, v. A. v. R., Bull. Dép. Agr. I. N., 1908, XVIII, 19, tab. III (the paraphyses not quite correct).

Stipes tufted, naked, $\pm 1 \%$-25 c M. long, firm, erect. Fronds pinnate, $\pm 10-15$ c.M. long, triangular, $6-12$ c.ll. hroad. T'erminal pinna $\pm 3-6$ c.M. long, simple, lanceolate or more commonly hastate, $1 \frac{1}{2}-4$ c.M. broad, narrowed gradually towards the bluntish apex, the base broadly cuneate, the lateral lobes spreading, deltoid, blunt; lateral pinnae in 3 - 5 pairs, the lowest the largest, $1 \frac{1}{2}-21 / 2$ c.M. broad, spreading, unequal-sided, the upper base broadly cuneate, truncate or cordate, the lower more narrowly cuneate, the apex gradually narrowed, blunt, the edge slightly irregularly wavy; higher pinnae erecto-

Filices. 
patent, sublanceolate, but distinctly unequal-sided. Texture herbaceous; su faces naked; no main veins; veins distinct, anastomosing irregularly; areolae oblong, oblique, resembling those of Acrostichum. Sori linear, straight, curved or flexuose, irregularly oblique, intermixed with shorter ones, which are roundish or oblong; capsules intermixed with numerous, densely crowded, jointed, linear paraphyses, which have the upper part narrowly ellipsoidal, deciduous.

Amboyna (Boerlage).

* (14) S. pinnata, J. San., Lond. Journ. of Bot., IV, 168, tab. VIIVIII, fig. C; Gymnogramme pinnala, Hk., Hk. Bk., Syn. Fil., 590; Hemionilis elongata, Brack., Wilk.. Expl. Exp., XVI, tab. VIII.

Stipes subtufted, $13-30$ c.M. long, firm, erect, glossy. Fronds 30 c.M. or more long, nearly as broad, pinnate. Pinnae erecto-patent, to 15 -25 c.M. long, $1-21 / 2$ c.M. broad, narrowed gradually to both ends, cuneate at the base, the lower ones stalked, simple or pinnate, the edges entire or nearly so. Texture coriaceous; rachis and surfaces naked; areolae narrow, irregular, usually in 2 rows between the costa and edge. Sori linear or oblong, irregular, often confluent.

East-Malayan Isles; Polynesia, Trop. Australia.

\section{6\%. HEMIONITIS, Linné.}

Sori linear, continuous along the veins, reticulate, without paraphyses. No indusium.

Rhizome short. Stipes not articulate to the rhizome. Fronds simple or lobed in malayan material, the fertile ones on the longest stipes: veins distinct, anastomosing copiously, bearing the sori throughout. Hk. Bk., Syn. Fil., tab. VI, fig. 59, a; Diels, in Engl. \& Prantl, Nat. Pfl.Fam., I ${ }^{4}$, fig. 158, C-D. A small genus, almost confined to the tropics.

+ Barren fronds lanceolate or cordate.

+. Barren fronds lanceolate, repand.

(1) H. gymnopteroided.

+.+. Barren fronds cordate, entire or crenate.

(2) H. arifolia.

+. . Barren fronds palmately 5-lobed.

(3) H. palmata. 
(1) H. Gymnopteroidea, Copel., Polypod. Philipp., 67; Hemigramma latifolia, Copel., Philipp. Journ., II, 406, p. p.; (? Syngramma Zollingeri, Diels); - var. major; Hemigramma Zollingeri, Christ, var. major, Christ, Philipp. Journ., II, 170.

Rhizome short, erect, scaly at the extremity. Fronds clustered, the sterile sessile or subsessile, $7-17$ c.M. long, $21 / 4-5$ c.M. broad, oblanceolate, obtuse or acute, repand and crisped at the edge, broad or contracted at the base. Texture papyraceo-herbaceous; colour dark-green with light patches: surfaces naked except on the usually scaly costa; areolae rather large, with copious free veinlets. Fertile fronds on stipes $5-1$ c.M. long, the fronds כ-10 c.M. long, $2-4$ c.M. broad, the lamina often interlupted. Soriferous veins $1-5$ on each side, \pm parallel to the costa, occasionally anastomosing; entire lower surface soon covered by the sporangia.

War. major: Stipes of barren fronds to 16 c.M. long, scaly. Barren fronds simple or pinnatifid, or pinnate at the base. Segments to 5 on each side. Fertile fronds much contracted, 8 c.M. long; segments to 2 on each side. Texture herbaceo-membranaceous.

Philippines.

* (2) H. arifolia, Moore (not Bedd.), Christ, Farnkr. d. Erde, 60; II. cordata, Hk. \& Grev., Ic. Fil., tab. LXIV; (not Rb.), Rac., Flor. Btz., I, 65; Bedd., Ferns S.I., tab. LIII; H. cordifolia, Rb., Hk., Fil. Exot., tab. XXXV; Asplenium arifolium, Burm., (oldest name).

Rhizome erect, the scales linear-lanceolate. Stipes erect, polished, reddish-brown or black, furnished with spreading hairs. Fronds dimorphous. Barren fronds cordate, $2 \frac{1}{2}-71 / 2$ c.M. long, often nearly as broad, with a deep sinus at the base, the edge entire or crenate, the point blunt, the stipe 4-10 c.M. long. Fertile fronds sagittate, the lobes acute; lateral lobes \pm deflexed, the edges entire, straight or concave; the stipe $20-25$ c.M. long. Texture herbaceous or coriaceous, \pm flaccid; each lobe with a central rib; veins anastomosing copiously. Sori reticulate.

Trop. Asia.

\# (3) T. Dalmanda, K., Hk. Bk., Syn. Fil., 398; Diels, in Engl. \& Prantl, Nat. Pfl. Fam., I"4, fig. 158, C-D.

Rhizome erect. Stipes of barren fronds $5-10$ c.M. long, of the fertile fronds $\mathbf{1 5 - 5 0}$ c.M. long, glossy, dark-chestnut-brown, clothed with soft, yellowish hairs. Fronds $5-15$ c.M. each way, palmatifid with 5 nearly 
67. HEMIONITIS.

equal, deltoid-lanceolate, crenato-lobate segments, which are sometimes sub. entire or lobed $1 / 3$ of the way down, those of the barren fronds blunt, of the fertile more acute. Texture herbaceous; surfaces hairy; central ribs radiate, 1 to each segment.

In cultivation. - Orig. loc.: Trop. America. 
TRIBE IX. GRAMMTIIDEAE. 



\section{MONOGRAMMA, Schleuthr.}

Sori linear, placed on or close to the costa, often protected by $1-2$ lateral outgrowths of leaf-tissue.

Fronds narrow, linear, grass- or rush-like, simple or rarely subdichotomous, not articulate to the creeping rhizome, mostly with no other veins than the costa. Hk. Bk., Syn. Fil., tab. VI, fig. 51; Diels in Engl. \& Prantl., Nat. Pfl.Fam., I ${ }^{4}$, fig. $157, B-G$.

Tropical.

Arrangement of the sections.

$\$$ 1. EUMONOGRAMMA. Fronds more or less approximate; lateral veins wanting.

$\$$ 2. PLEUROGRAMmE. Fronds tufted; lateral veins present.

\section{S 1. EUMONOGRAMMA.}

+. Fronds gradually dilated towards the apex. Sori with 1 raised outgrowth at the side. (if) M emarginarta Sip 335

+. Fronds not gradually dilated towards the apex. Sori flanked by 2 raised (1) M. dareicarpa. Sip 335 outgrowths.

+. Sori once or twice interrupted.

(2) M. trichoidea.

+.+. Sori not interrupted.

(5) M. paradoxa.

(1) M. dareicarpa, Hhi., Hk. Bk., Syn. Fil., 375; Hk., Spec. Fil., V, tab. CCLXXXVIII, A.

Rhizome slender, creeping, the scales minute, narrow, brown. Fronds $1 \frac{1}{2}-21 / 2$ c.M. long, $1-1 \frac{1}{2}$ m.M. broad near the top, subacute, narrowed gradually downwards but without a distinct stipe, the fertile taller and relatively more slender than the barren ones. Sorus along 1 side of the costa, covered by an outgrowth from it reaching nearly to the margin, occupying the higher part of the frond, not more than 6 m.II. long.

Borneo, Philippines, New Guinea. 
* (2) M. trichoidea, J. Sm., Hk. Bk., Syn. Fil., 375.

Rhizome slender. Fronds approximate, thread-like. 7-10 c.M. long, the fertile ones dilated in 2-5 places for a space of $\pm 5-6 \mathrm{~m}$.M., and there bearing the sori with a raised edge on each side.

Philippines, Borneo.

-(3) M. paradoxa, Heda., Handb. Ind. Ferns, 575; M. Junghuhnï, Hk., Rac., Flor. Błz., I, 57; Bedd., Ferns S.I., tab. CGX; Hk., Spec. Fil., V, tab. CGLXXXIX, B; Pleurogramme paradoxa, Fée, (oldest name).

Rhizome slender, the scales narrow, lanceolate, finely acuminate. Fronds densely approximate, grass-like, flaccid, כ- 30 c.M. long, $1 / 2-11 / 2$ m.M. broad. Sori sunk in a furrow with a raised edge on each side, occupying a large portion of the costa or confined to its upper half.

Ceylon to Hawaii and Australia.

\section{\$2. PLEUROGRAMME.}

+. Sori interrupted.

+. +. Sori continuous.

+. Sori medial.

+.+. Sori rather marginal.
(4) M. interrupta:

(5) M. intermedia.

(6) M. Loheriana.

(4) W. interroupta, lerrupla, Christ, Farnkr. d. Erde, ら̌.

Stipes densely tufted, wiry, naked, $\breve{b}-8$ c.M. long. Fronds linear, $21 / 2-4$ c.M. long, \pm 2 m.M. broad. Texture rigidly coriaceous, thick; surfaces naked; veins quite hidden. Sori filling the whole space between the midrib and margin, broken up into a series of pits of unequal length, in which the sporangia are immersed.

New Guinea.

(5) D. intermedia, Copel., Philipp. Journ., I, Suppl., 255.

Rhizome erect, slender. Fronds tufted, 4-6 c.M. long, 3-5 m.M. broad, obtuse, the lower part narrowed gradually towards the base. Texture coriaceous ; surfaces naked; costa narrow, sulcate above; veins hidden. Sori continuous, medial, immersed, the groove opening towards the margin.

Negros (Philippines). 
68. monograma. $\mathbb{2}$ 2. Pleurogramie.

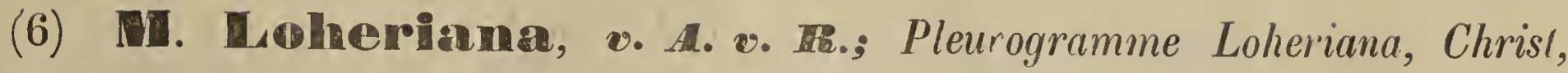
Bull. Herh. Boiss., 2e Série, VI, 1006; (? Vitlaria).

Rhizome short, erect, caespitose. Fronds fasciculate, to 8 c.M. long, to $\pm 21 / 2 \mathrm{~m} . \mathrm{M}$. or more broad, ligulate, often obtuse, narrowed at the base into a short stipe. Texture rigidly corriaceous; surfaces naked; costa slender but prominent; veins hidden. Sori narrow, deeply immersed, protected by a very broad outgrowth of leaf-tissue and therefore (apparently) marginal. - Near l. pusilla, Christ (Vittaria pusilla, Bl).

Luzon, Mindoro.

\section{VITITALEIA, J. Smith.}

Sori long, linear, continuous, commonly sunk in marginal, submarginal or intramarginal, mostly 2-lipped furrows.

Rhizome creeping, rarely erect. Fronds linear, tape- or grass-like, simple or rarely forked, often pendulous, whether or not articulate to the rhizome: veins simple, rarely forked, erecto-patent, often very oblique, free or united by the receptacle, mostly invisible. $\left(^{*}\right)$

Tropical and subtropical.

Arrangement of the sections.

S 1. EUVITTARIA. Sori immersed, \pm marginal, the upper (outer) lip of the furrows not much broader than the lower (immer) one, not rolled over the sorus when young. Hk. Bk., Syn. Fil., tab. VI, fig. 56, a; Diels, in Engl. \& Prantl, Nat. Pfl.Fam., Í4, fig. 157, J-K.

$\$ 2$. TAENIOPSIS. Sori rarely superficial, mostly immersed, submarginal or intramarginal, the lips of the furrows \pm wanting or the outer one much broader than the inner and rolled over the sorus when young, or the sorus protected by the recurved margin of the frond. Hk. Bk., 1. c. fig. 56, b-c; Diels, l. c., fig. 157, L, M \& Q.

\section{$\$ 1$. EUVITTARIA.}

a. Fronds simple, or some of them occasionally forked.

b. Fronds sessile or subsessile, under 1 c.M. broad in most of the specimens.

${ }^{\star}{ }^{*}$ There is no genus whose species are more difficult of determination (Copel.). 
c. Fronds generally $1 / 2-3$ m.M. broad.

+. Costa distinct, fronds under 1 m.M. broad. (1) V. caudiformis. *. Costa indistinct, fronds more than 1 m.M. broad.

*. Fronds small, to 12 c.M. long, $1-1 \frac{1}{2}$ m.M. broad.

(2) V. lloydiifolia.

*.*. Fronds longer, 15-25 c.M. long, 11/2-3 m.M. broad.

(3) V. angustifolia. onit

c.c. Fronds mostly 3-10 m.M. broad.

d. Sori confined to the upper part of the frond.

(4) V. crassifolia.

d.d. Sori long, continuous, not confined to the upper part of the frond.

e. Rhizome scales grey.

(5) V. rigida.

e.e. Rhizome scales blackish.

f. Fronds erect.

f.f. Fronds pendulous.
(6) V. ensiformis.

(7) V. elongata.

b.b. Fronds distinctly stalked, more than 1 c.M. broad in most of the specimens.

*. Barren fronds entire.

$\mathrm{x}$. Rhizome scaly.

(8a) V. zosterifolia.

$\times . \times$. Rhizome nalied, \pm setose at the apex. (8b) V.pachystemma. *.*. Barren fronds crenulato-undulate. Rhizome sparingly setose.

(8c) V. crispomarginata.

a.a. Fronds mostly 2-4-fid, the segments simple or forked again.

* Fronds rather small, sessile or subsessile.

(9a) V. Bensei.

t. . Fronds long, stalked.

(9b) V. Merrillii.

* (1) V. caudiformis, Bt., Enum., 200.

Rhizome creeping, scaly, the scales hair-pointed. Fronds linear-filiform, under 1 m.M. broad, lax, pendulous, elongate, acuminate, revolute. Texture coriaceous; costa visible. Sori marginal.

Java.

* (2) V. Iloydiifolia, Iewc., Flor., Btz., I, 59.

Rhizome short-creeping, the scales dense, short, thin, subentire, brown, narrowed gradually from the base to the fine, acute point. Fronds linear, 1-10 m.M. apart, 3-12 c.M. long, $1-1 \frac{1}{2}$ m.M. broad, acute, narrowed 
gradually towards the base, which is $\pm 1 / 2$ m.M. broad. Texture rigid; costa nearly invisible. Lips of the grooves equal.

Sumatra, Java, Borneo, Celebes.

* (3) V. angustifolia, Bst, Rac., Flor. Btz., I, 60.

Rhizome short-creeping, the scales dense, thin, brown, nearly entire, narrowed gradually from the base to the fine, subulate point. Fronds approximate, linear, acute, $15-25$ c.M. long, $1 \frac{1}{2}-3$ m.M. broad, narrowed gradually towards the base, which is $\pm 1 / 2-1 \frac{1}{2}$ m.M. broad. Texture rigid; costa nearly invisible.

Malacca, Sumatra, Java, Borneo.

* (4) V. Crassifolia, mk., Kew Bull., 1893, 212.

Rhizome short-creeping, woody. Fronds densely approximate, sessile, linear, to 10-12 c.M. long, $\pm \mathbf{5}$ m.M. broad, narrowed gradually at the båse. Texture coriaceous, very thick; surfaces naked. Sori in the upper part of the frond, the upper lip of the groove projecting a little beyond the lower.

\section{Borneo, Banca.}

(5) V. rigida, Kuf, Enum. Fil., 193; Bau. \& Hk., Gen. Fil., tab. LXVIII; V. plantaginea, Hk. \& Grev., Ic. Fil., tab. CLXXXVII.

Rhizome creeping. Fronds close, linear, subfalcate, 25-40 c.M. long, b-8 m.M. broad, the base narrowed, clothed with linear-lanceolate, grey, glossy scales. Texture rigid; costa hardly visible. Sori marginal, continuous, reaching nearly to the apex.

\section{Malaya; Polynesia.}

* (6) V. ensiformis, Sw., Ges. Nat. Fr., II, 134, tab. VII, fig. 1; V. ensifolia, Bl., Enum., 198; V. elongata, Sw., var. ensiformis, Rac., Flor. Btz., I, 59; V. intermedia, Bl., l.c., 199; - var. dilatata.

Rhizome creeping, the scales black, thin, narrowed gradually from the base to the acuminate, hair-pointed apex, the margin serrulate. Fronds sessile, approximate, erect, straight or falcate, $10-30$ c.M. long, $\pm 4-7$ m.M. broad, narrowed gradually towards both ends. Texture rigid; costa whether or not visible; veins immersed. Sori marginal; both lips of the grooves equal or the upper projecting a little beyond the lower.

Var. dilatata: Fronds $\pm 1-1 \frac{1}{2}$ c.M. broad.

Java, Sumatra; Mascarenes. 
* (7) V. elongata, Sw., Christ, Farnkr. d. Erde, 53, fig. 12̆ ; Bedd., Ferns S.I., tab. XXI; V. elongata, Sw., var. genuina, Rac., Flor., Btz., I, 59.

Rhizome creeping; scales dense, black, narrowed gradually from the base to a fine, acuminate point, the edge serrulate. Fronds linear, 20-180 c.M. long, 3-10 m.M. broad, pendulous, the apex bluntish or more commonly acute, the lower part narrowed gradually towards the base. Texture subcoriaceous; costa distinct; veins hidden or indistinct. Sori long; lips of the grooves equal or the upper projecting a little beyond the lower.

Trop. Asia \& Polynesia, New South Wales.

* (8a) V. zosterifolia, illd., Spec., V, 406; V. elongata, Sw., var. zosteraefolia, Rac., Flor., Btz., I, s9, - var. pellucida.

Rhizome woody, wide-creeping; scales blackish, narrowed gradually from the base to the acuminate, hair-pointed apex, the edge serrulate. Stipes scattered, $1-5$ c.M. apart, slender, 5-25 c.M. long. Fronds lanceolate or linear-lanceolate, $1-1 \frac{1}{2}$ c.M. broad, 20-120 c.M. long, narrowed gradually towards both ends, the apex acute, the base decurrent upon the stipe. Texture coriaceous; costa distinct; veins visible but not very distinct. Sori long, reaching nearly the base and apex of the fronds; lips of the grooves equal or the upper projecting beyond the lower.

Var. pellucida: Texture thinner, pellucid; veins conspicuous.

Malaya; Polynesia, Comores, Mascarenes.

\section{(8b) W. pachystemma, Christ, Philipp. Journ., II, 174.}

Rhizome creeping, the extremity crowned with black, crisped setae, the rest naked. Stipes approximate, rufo-stramineous like the costa, \pm 6 c.M. long. Fronds $25-50$ c.ll. long, falcate, linear-lanceolate, acute (not long-acuminate) $\pm 1^{1 / 4}$ c.M. broad. Texture succulent; colour lurid-glaucous; costa flat but distinct. Sori submarginal, constinuous from the base to the apex; indusium (? lips of the groove) narrow, pale-coloured.

Mindanao.

(8c) V. Crispomarginata, Christ, Bull. Herb. Boiss., 2e Série, VI, 1007.

Rhizome slender, creeping, sparingly clothed with thin, short, flaccid, brown setae. Stipes approximate; slender, often filiform, green, 8-10 c.M. long, widening gradually into the base of the frond. Fronds to \pm 25 c.M. long, the fertile ones the longest. Barren fronds linear-lanceolate, to $1 \frac{1}{2}$ c.M. 
broad, long-acuminate, with the margin distinctly crenulato-undulate. Texture flaccid; colour livid-glaucous; costa distinct, white; veins few, very oblique, nearly parallel to the costa. Fertile fronds flat, entire. Sori marginal, the lips of the grooves \pm 1 m.M. broad, whitish.

\section{Luzon.}

* (9a) V. Bemsei, v. A. v. R., Bull. Dép. Agr. I. N., 1908, XVIII, 19 ; XXI, tab. II, fig. 1, a-e.

Rhizome short-creeping, rather climbing, the scales dense, thin, dark-brown, narrowed gradually from the base to a fine, acuminate point, the margin serrulate. Fronds sessile, approximate, few, \pm horizontal, \pm 10 c.N. long, forked near the narrowed base. Segments linear, falcate, \pm decurved, $2-3$ m.M. broad, bluntish or acute, simple or forked again. Texture coriaceous; costae indistinct; veins hidden. Sori long, continuous; lips of the grooves equal.

Java (Preanger Regencies, Capt. H. L. Bense).

(9b). V. Menruillii, Christ, Philipp. Journ., II, 174.

Rhizome horizontally creeping, hardly branched, not caespitose, clothed with erect, black-brown setae. Stipes distant, pendulous, setulose at the base, slender, flexuose, fusco-stramineous, \pm 20 c.M. long. Fronds \pm 60 c.M. or more long, 1-2 c.M. broad, linear, narrowed gradually to the base, simple and acuminate, but the apex often $2-4$-fid, the segments falcate, acute, $\pm 11 / 2$ c.M. long. Texture flaccid; colour pale-green, opaque; costa slender, often inconspicuous. Sori narrow, strictly marginal, with the lips of the grooves pale-coloured.

Mindanao, Mindoro. Luzen, hagreces Sips.3y

\section{S2. TAENIOPSIS.}

1. Fronds clothed with long, whitish, sliff hairs.

1.1. Fronds minutely puberulous.

(10a) V. hirta.

(10b) V. subcoriacea.

1.1.1. Fronds naked.

2. Fronds to 4 m.M. broad.

3. Fronds under 2 m.M. broad, the point acule or acuminate. +. Fronds erect, $10-15$ c.M. long, at best \pm 1 m.M. broad.

(11a) V. parvula. (11b) V. alternans. 
69. vittaria. $\$ 2$. TAENiopsis.

t.+. Fronds pendulous, to 70 c.M. long, $\pm 1-1^{1 / 2}$ m.M. broad.

(12) V. longicoma.

3.3. Fronds 2-4 m.M. broad, the apex blunt or rounded.

4. Rhizome scales dark-brown; midrib lkeeled above.

(15) V. pumila.

1.4. Rhizome scales pale-brown; midrib slightly sulcate above.

5. Veins simple.

(14) V-bitis.mit

5.5. Veins forked.

6. The outer lip of the groove rather thin at the edge.

(15) $¥$. pusilla.

6.6. The outer lip of the groove thick at the edge.

(16) $\forall$-stiterta.

2.2. Fronds mostly 4-10 m.M. broad.

+. Fronds 10-13 c.M. long, submembranaceous.

(17) V. amboinensis.

t.+. Fronds 15-120 c.M. long.

x. Coriaceous. $\left(18 a^{2} a\right)$ V sesenles Sip338 (18a) V. lineata. SIp

$\times \cdot \times \cdot$ Carnoso-herbaceous.

(18b) V. taeniophylla.

2.2.2. Fronds 1-3 c.M. broad in most of the specimens.

+. Costa slout, especially towards the base. Fronds under 50 c.M. long.

(19) V. scolopendrina.

†. . Costa slender, inconspicuous. Fronds 50-60 c.M. long when fully developed.

(20) V. philippinensis. laoylV Copelandici sip

(10a) V. Inirta, Fée, Mém., X, 12, tab. XXXI, fig. 4.

Fronds linear, nearly filiform, bluntish, clothed with long, stiff, whitish, spreading hairs. Sori extra-marginal; sporangia roundish.

Borneo.

(10b) V. subcoriacea, Clevist, Philipp. Journ., II, 175.

Rhizome (probably) short-creeping, clothed like the base of the fronds with slender, black-brown, setiform scales. Fronds tufted, linear, \pm 55 c.M. long, \pm 8 m.M. broad, narrowed gradually into a stipe $3-5$ c.M. long, the apex broadly subacute, the edge broadly reflexed, adpressed. Texture succulent, brittle; colour black-castaneous in the lower part of the frond, ochraceousgreen above; surfaces minutely rugulose and puberulous; costa strong below, 
rather inconspicuous and flattened upwards. Sori continuous from below the middle to the apex, quite covered by the reflexed margin.

Palawan.

(11a) W. Darvula, Bory, Bél., Voy. Bot., II, 35.

Fronds erect, linear, subulate, $10-12 \frac{1}{2}$ c.M. long, \pm 1 m.M. broad. Texture rather rigid.

Java.

(11b) V. alternans, Copel., Philipp. Journ., I, Suppl., 157.

Rhizome slender, creeping, densely clothed with minute, subulate, purpleblack scales. Fronds seriate, whether or not close, sessile, 10-15 c.M. long, at the utmost 1 m.M. broad, $\pm 1 / 2$ m.M. thick, apparently ecostate. Sori intramarginal, in deep rrooves, interrupted, not protected by the margin.

Mindanao. Regras.

* (12) V. Iongiooma, Cherist, Ann. Btz., XX, 129.

Rhizome creeping, the scales black, linear, hair-like, finely acuminate, \pm 5 m.M. long. Fronds numerous, to 70 c.M. long and longer, $1-1 \frac{1}{2}$ m.M. broad, linear, acuminate, the base narrowed. Texture firm; costa prominent, \pm keel-shaped; veins hidden, very oblique. Sori narrow, reaching nearly the apex and base of the fronds, continuous, placed in submarginal grooves; lips of the grooves elevated, the outer produced, rolled over the sorus when young.

Borneo.

V. pumila, Mett., Hk. Bk., Syn. Fil., 517,

Rhizome short, the scales hardly $5 \mathrm{~m}$. M. long, rather rigid, blackish-brown, lanceolate-subulate, serrulate at the base. Fronds linear-spathulate, $51 / 2-5$ c.M. long, \pm 3 m.M. broad, obtuse, falcate or straight, narrowed towards the base, the edge much recurved. Texture coriaceous; costa very prominent beneath, keeled above; veins immersed, oblique, short. Sori hidden by the revolute edge, medial between the midrib and margin.

Borneo.

(14) V. Hobitis, Kalear, Hk. Bk., Syn. Fil., 318.

Rhizome creeping, the scales linear, pale-brown. Fronds sessile, tufted, ligulate-linear, obtuse, $21 / 2-$ b c.M. long, $21 / 2-4$ m.M. broad, narrowed gradually at the base. Texture firm, subcoriaceous; costa distinct beneath from 
the base to the apex, slightly sulcate above; veins subimmersed, oblique, simple, free, the apices not or hardly thickened, hardly produced beyond the receplacle in the fertile region. Sori in rather deep grooves between the thickened costal parenchyma and the margin; the margin \pm thin, nuch produced beyond the costal parenchyma, which is \pm half as broad as the lamina, i. e. the leaf-tissue beyond the soral groove in transversal section \pm .as. in V. pusilla, $B l$., but rather spreading.

Borneo.

* (15) V. prasilHer, \#1., Rac., Flor. Btz., I, 60; Bull. Dép. Agr. I. N., 1908, XXI, 7, tab. II, tig. 2, a-c; V. falcata, Kze, Hk. Bk., Syn. Fil., 595; Taenitis pusilla, Mett., Ann. Mus. Bot. L. B., IV, 172, tab. VII, fig. 11-14; Pleurogramme pusilla, Christ, Pbilipp. Journ., II, 175; - var. minor; V. minör, Fèe, Hk., Spec. Fil., V, 185.

Rhizome ascending, the scales membranaceous, yellow-brown, lanceolate, not acuminate. Fronds multiseriate, $2-12$ c.M. long, $\pm 3-4$ m.M. broad and nearly as thick, simple or occasionally forked, straight or falcate, linearligulate, the apex blunt or rounded, the lower part narrowed gradually to the base. Texture coriaceous, firm; nidrib \pm distinct beneath, but lost in the not abruptly thickened fertile region, slightly sulcate above; veins free, oblique, forked, transversed by the receptacle in the fertile part. Sori confined to the upper $1 / 3-1 / 2$ of the frond, deeply sunk in submarginal grooves, the thickened costal parenchyma nearly as broad as the lamina or produced a little beyond the margin, which is rather thin, i. e. the leaf-tissue beyond the soral groove in transversal section rather narrowly linear with the base \pm as broad as the extremity or the latter narrowed.

War. mindr: Fronds shorter, less than 5 m.M. broad. Borneo, Java, Malacca; Ceylon, Queensland.

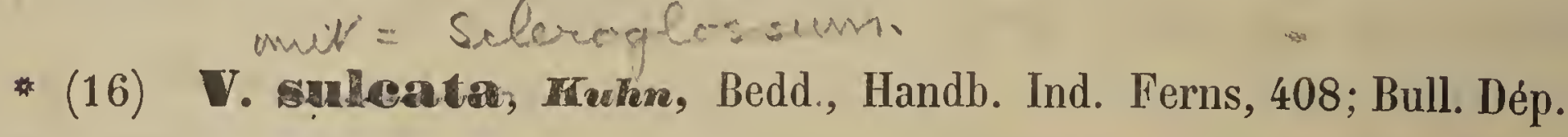
Agr. I. N., 1908, XXI, 7, tab. II, fig. 5, a-c; Taeniopsis falcata, Bedd., Ferns Br.I., II. tab. CLXXV; Taenitis simplicivenia, Ces., Fel. Becc. Polin., 丂 \& 8 .

Rhizome short-creeping, the scales dense, pale-brown, lanceolate. Fronds crowded, ligulate, obtuse, sessile, narrowed towards the base, $5-10$ c.M. long, 3-4 m.M. broad. Texture coriaceous; midrib visible in the lower, barren part of the frond, quite lost in the thickened, fertile region; veins forked or rarely with 2 branches, not reaching the margin. Sori in deep, intramarginal furrows, occupying the upper half of the frond. The margin very thick, much 
produced beyond the costal parenchyma, i.e. the leaf-tissue beyond the soral groove in transversal section broadly rhomboidal with the basal part \pm as broad as the extremity or the latter broader, more or less obliquely truncate. Malaya; Ceylon, Polynesia.

(17) V. amboinensis. Fée, Bedd., Handb. Ind. Ferns, 407; Taeniopsis amboinensis, Bedd., Ferns Br.I., I, tab. CXVII.

Rhizome flexuose, contorted, scaly, the scales rigidly toothed at the margin. Fronds stalked, 10-15 c.M. long, 7-10 m.M. broad, falcate, acuminate, tapering gradually downwards. Texture submembranaceous; surfaces naked; costa slender, disappearing below the apex. Sori submarginal, cuticle of the margin resembling a spurious indusium.

Amboyna, Mindoro; Martaban., hundaraco SIp 338

* (18a) V. lineata, Sm. (not Sw.), Rac., Flor. Btz., I, 60; Taeniopsis lineata, J. Sm., Bedd., Ferns S I., tab. LIV; Pleris lineata, L., (oldest J FHS. name); - var. trichoides, Christ, in Warb., Mons., I, 57.

Rhizome creeping; scales dense, linear-lanceolate, the hase broad, the apex suddenly acuminate into a fine point, the colour blackish-brown. Fronds linear, 15-120 c.M. long, 4-9 m.M. broad, stipitate, narrowed gradually to both ends. Texture coriaceous, costa visible, running from the base to the apex; veins immersed, parallel, oblique. Sori intramarginal, in shallow grooves, protected by the margin of the frond when young.

Var. trichoides: Differs from the type in having the fronds $\pm 1 / 2$ m.M. broad, and the margin so folded over the sorus, that it may scarcely appear. Trop. Asia, Japan; Trop. \& Soulh. Africa; America, from Florida to Soulh. Brasilia; - var. trichoides: Philippines.

$(18 b)$

V. taeniophylla, Copel., Philipp. Journ., I, Suppl., 157.

Rhizome creeping, the scales dense, lanceolate, subentire, brown, at length whitish. Fronds close, $30-55$ c.M. long, $5-7$ m.M. broad, acuminate, narrowed gradually towards the base. Texture carnoso-herbaceous; costa distinct to the apex, prominent beneath: veins few, hidden. Sori dorsal, superficial. Luzon.

* (19) V. scolopendrina, Thw., Rac., Flor. Btz. I, 59; V. scolopendrioides, Metl. (not Thw.), Christ, Ann. Btz., XIX, 59; Taeniopsis scolopendrina, J. Sm., Bedd. Ferns S.I., tab. CGXII; Pteris scolopendrina, Bory, (oldest name). 
Fronds 50-45 c.M. long, $1-5$ c.M. broad, the point acute, the edge entire, the lower part narrowed very gradually to the base. Texture thick: midrib thick, blackish, grooved, sometimes nearly lost upwards; veins oblique, fine, parallel. Sori in broad, continuous, submarginal grooves, with the firm, unaltered edge of the frond at first rolled over it.

Samoa to Ceylon, Br. India, South. Africa.

V. philippinensis, Christ, Bull. Herb. Boiss., 2e Série, VI, 1007.

Rhizome creeping, caespitose, crowned with numerous, long; .slender, flexuose, setaceous scales. Stipes subfasciculate, \pm b c.M. long, widening gradually into the frond. Fronds $\pm 50-60$ c.M. long, $\pm 1 \frac{1}{4}$ c.M. broad, long-acuminate. Texture flaccido-coriaceous; colour light-green, opaque; 'costa slender, inconspicuous; veins very oblique, inconspicuous. Sori narrow, intramarginal, impressed, reaching from the base to the apex of the frond, more or less covered by the \pm recurved, indusium-like margin.

Luzon.

\section{O. TAENITIS, Willdenow.}

Sori long, linear, continuous or interrupted, superficial or more or less immersed, in 1 line on each side, parallel to the costa or the margin; paraphyses linear, the terminal cell large and thickened: spores globose to tetrahedral. No indusium.

Rhizome hairy. Stipes not articulate to the rhizome. Fronds simple or more commonly pinnate; veins anastomosing copiously. Hk. Bk., Syn. Fil., tab. VI, fig. 57; Diels, in Engl. \& Prantl, Nat. Pfl.Fam., I4, fig. 161, C--D.

Tropical Asia \& Fiji.

+. Fronds simple, obluse.

+. . Fronds pinnale; pinnae acule or acuminate.

$$
\begin{aligned}
& \text { +. Pinnae } \pm 1-41 / 2 \text { c.M. broad. } \\
& \text { +.+.Pinnae } \pm 1 / 2-1 \text { c.M. broad. }
\end{aligned}
$$

(1) T. obtusa. (1a) T. druprogloss (1) T. Brootsii

(2) T. blechnoides

(3) T. stenophylla.

(1) T. Olotusa, Hk., Hk. Bk., Syn, Fil., 596 ; Hk., Icon. Pl., X, tab. CMXCIV ; T. blechnordes, Sw., var., C. Chr., Ind. Fil. 
Rhizome creeping. Stipes $5-8$ c.M. long, slender, glossy, naked. Fronds $5{ }_{2}^{\prime}-5$ c.M. long, $1-2$ c.M. broad, undivided, ovate-oblong, the apex blunt, mucronate, the edge entire (sometimes irregularly incised from the effect of injury), the base \pm rounded. Texture subcoriaceous; areolae large, oblique. Sori in a continuous or slightly interrupted line $\pm 5 \mathbf{z}$.II. from the edge, often united at the apex.

Borneo.

* (2) T. blechnoides, Saw., Rac., Flor. Btz., I, 61; Bedd., Ferns Br.I., I, tab. LIV ; Pleris blechnoides, Willd., (oldest name); - var. interrupta, Hk., Spec. Fil., V, 188; T. interrupla, Hk. \& Grev., Ic. Fil, tab. LXIII ; var. latior, Christ Ann. Btz., XX, 128.

Rhizome creeping, the scales capillary, short. Stipes $20-70$ c.M. long, firm, naked, glossy. Fronds simply pinnate, $15-60$ c.M. long, 13 -50 c.M. broad. Pinnae $\pm \mathbf{5}-7$ or more on each side below the terminal one, $15-50$ c.M. long, 1-a c.M. broad, the fertile ones not rarely the narrowest, lanceolate-elongate, the point acuminate, the edge entire or wavy, \pm thickened, the base cuneate; lower pinnae stalked. Texture coriaceous; areolae copious, oblique, without free veinlets. Sori commonly in a continuous line \pm midway between the midrib and edge. -- Fronds of the young plants not rarely simple, similar to the pinnae of the adult fronds, but mostly broader.

Var. interrupta : Pinnae smaller; sori commonly in an interrupted line nearer the edge than the midrib, sometimes submarginal.

Var. Iatior: Pinnae few $( \pm 5-5)$, to $\pm 4 \frac{1}{12}$ c.ll. broad.

Trop. Asia, Fiji; - var interrupta: Singapore, Lingga, Borneo; - var. latior: Borneo, Banca.

* (5) T. stenophylla, Christ, Ann. Btz., XX, 129.

Near T. blechnoides, Sw. Pinnae \pm 8 on each side, \pm 12 c.M. long, \pm $1 / 2-1$ c.M. broad, linear-lanceolate, the fertile ones the narrowest. Costa narrow; veins very fine. Sori submarginal, hardly immersed, continuous or slightly interrupted.

Borneo. Celebes (Sip 342 ) 

TRIBE X. POLYPODIEAE. 


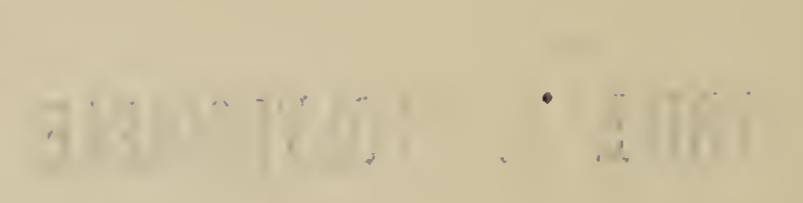




\section{POLY PODIUM, Linné.}

Sori round, oblong or linear, many on each side, superficial or sunk in cavities; the oblong ones often, the linear ones always dorsal, mostly oblique to. the costa and margin; the round and oblong ones dorsal, submarginal or on marginal outgrowths, sometimes immersed in saccate, indusium-like depressions of the margin, rarely covered by the raised edges of the cavities or by long-stalked, peltate scales. No indusium.

Rhizome creeping or erect. Stipes articulate to the rhizome, the articulation not always visible in the smaller species. Fronds simple, pinnalifid or pinnate, rarely more compoundly divided; surfaces naked, scaly or hairy, the hairs not stellate; veins free or anastomosing variously.

A very large genus, inhabiting principally the tropics.

Arrangement of the sections and groups.

\$1. EUPOLYPODIUM (incl. Grammitis). Veins free. Sori superficial, or immersed in dorsal or submarginal pits, but not as in $\mathbb{2}$. Hk. Bk., Syn. Fil., tab. V, fig. 48, a-b; Diels, in Engl. \& Prantl. Nat. Pfl.Fam., I ${ }^{4}$, fig. 162 .

a. Integrvifoliae. Fronds simple, the margin entire, crenate, repand or toothed.

b. Furcatae. Fronds typically forked, the brauches simple or forked again.

c. Pinmatifidae. Fronds lobed or pinnatifid. ( $\left.{ }^{1}\right)$

d. Pinmatae. Fronds \pm pinnate. (')

e. Compositae. Fronds at least 2-pinnatifid.

\$2. PROSAPTIA (incl. Acrosorus). Veins free. Sori terminal on the veins, immersed in \pm marginal, saccate, indusium-like depressions or in adnate, retroflexed portions of the margin. Fronds simple, crenate, lobed to pinnatifid, at best once pinnate. Diels, l. c., fig. 115, C-H (under Davallia). $\left({ }^{2}\right)$

$\left(^{1}\right)$ The limit between $c$. Pinnatifidae and $d$. Pinnatae being not always distinclly marked, it will often be advisable to consult both groups.

$\left({ }^{2}\right)$ Regarding this section see the information in Christ, Farnkr. d. Erde, 305. - Copeland thinks the section would better be treated as 2 distinct genera, Prosaptia \& Acrosorus. Anyhow, the species of this group are no Davalliae. 
3. GONIOPHLEBIUM. Veins forming 1 or more rows of regular areolae \pm as in Nephrodium, each with a simple or rarely forked, included, excurrent free veinlet. Sori terminal on the included veinlets, commonly in the costal areolae only. Hk. Bk., l. c., fig. 48, h; Diels l. c. fig. 163, B \& D.

a. Crypsimus. Fronds simple. (Not in Malaya).

b. Synammia. Fronds pinnatifid. (Not in Malaya).

c. Marginaria. Fronds pinnate; pinnae broadly adnate to the rachis.

d. Sehellolepis (Schellopsis). Fronds pinnate; at least the lower pinnae \pm stalked, or sessile with a cuneate to truncate, not adnate base.

$\$ 4$. PHLEBODIUM. Veins forming more or less regular areolae, each with $1-\tilde{z}$ included, excurrent free veinlets, which bear the sori on their united tips; costal areolae always destitute of free veinlets and sori. Hk. Bk., l. c., fig. 48, g; Diels, l. c., fig. 163, F \& G. (Not in Malaya).

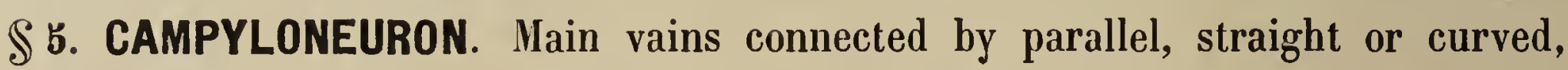
transverse veinlets forming regular, subquadrangular areolae, each with commonly 2 or more included, excurrent free veinlets. Sori subterminal on the free veinlets, 1 to each. Hk. Bk., l. c., fig. 48, j; Diels, l. c., fig. 163, H. (Not in Malaya).

\$6. PLEOPELTIS. Veins anastomosing commonly more or less copiously, forming several to numerous, mostly more or less irregular areolae; included free veinlets (if present) directed towards the midrib or more generally spreading in various direclions, rarely excurrent but then not as in $\mathbb{5}$. Sori round or oblong, very rarely more than $\mathbf{3} X$ as long as broad. Hk. Bk., l. c., fig. 48, m.; Diels, l. c., fig. 164, B \& E. (*)

a. Myrmecophila. Rhizome inflated, \pm cylindrical or tuberous, soon cavernous and inhabited by ants, the scales peltato-orbicular or wanting. Fronds rarely simple, commonly pinnatifid or pinnate.

*. Aspidopodium. Sori not on marginal tooth- or lobe-like outgrowths. Rhizome-scales present. Diels, l. c., fig. 166, D-E.

**. Lecanopteris. Sori on marginal tooth- or lobe-like outgrowths.

Rhizome scales wanting. Diels, l. c., fig. 169.

b. Atactosia. Rhizome not as in $\boldsymbol{a}$. Rhizome scales very rarely roundish or wanting, generally oval, oblong, ovate, lanceolate, linear or subulate. Fronds simple.

(') This section would perhaps better be treated as a distinct genus. 
*. Lepisorus. Main veins indistinct, not rarely wanting.

**. Pleuridium (incl. Microsorium). Main veins distinct nearly or quite to the edge.

c. Chrysopteris. Rhizome and scales as in 6. Fronds lobed, pinnatifid or pinnate.

*. Phymatodes. Fronds stipitate, lobed or pinnatifid.

**. Phymatopsis. Fronds stipitate, pinnate.

***. Drynariopsis. Fronds sessile, lobed, pinnatifid or pinnate. Fertile segments not contracted.

****. Aglaomorpha. Like $¥ * *$ but the sori restricted to the much contracted higher segments.

$\$ 7$. SELLIGUEA. Venation as in $\mathbb{S} 6$. Sori linear or linear-oblong, more than $3 X$ as long as broad, continuous or interrupted, rarely abbreviated or round, more or less oblique to the costa. Fronds simple or pinnate. Hk. Bk., l. c., tab. VI, fig. 52, e-f. (")

Key to the malayan sections and groups.

a. Veins quite free.

b. Sori superficial, or immersed in dorsal or submarginal pits, but not as in b.b.

$\$ 1$. EUPOLYPODIUM.

c. Fronds simple, lobed, pinnatifid or forked.

d. Fronds simple.

d.d. Fronds lobed or pinnatifid.

d.d.d. Fronds $1-2 \times$ forked.
S 1 , a. Integrifoliac.

S 1 , c. Pinmatifialae.

S 1 , b. Fureatae.

c.c. Fronds \pm pinnate or more compoundly divided.

*. Fronds pinnate, the pinnae distinct or slightly confluent at the base.

$\mathbb{1}$, d. Pinnatae.

*.*. Fronds at least 2-pinnatifid.

$\mathbb{S} 1$, e. Compositae.

b.b. Sori immersed in saccate or indusium-like, marginal or submarginal depressions. Fronds simple to deeply pinnatifid. $\$ 2$. PROSAPTIA.

a.a. Veins free, forked, the anterior branch of the veins not rarely reaching to the posterior branch of the next higher vein so as to form a row of regular costular areolae; the posterior veinlet always free towards the margin of the frond. Fronds deeply pinnatifid.

P. Cesatianum, $B /$. a.x.a. Veins anastomosing more or less copiously.

( ${ }^{*}$ This section would perhaps better be treated as a distinct genus. 
1. Veins forming 1 or more rows of regular areolae \pm as in Nephrodium, each with a single, simple or rarely forked, included, excurrent free veinlet. Sori terminal on the free veinlets, often confined to the costal areolae only. Fronds pinnate in malayan material.

\section{$\$$ 3. GONIOPHLEBIUM.}

5. Pinnae broadly adnate to the rachis. $\$ 5$, c. Marginarian.

\$.\$. At least the lower pinnae stalked, or sessile with a cuneate to truncate, not aduate base.

S 3, d. Selnellolepis.

1.1. Veins forming commonly more or less irregular areolae. Included free veinlets wanting or present but then spreading in various directions, rarely directed towards the costa or the margin only, but not \pm as in 1 .

2. Sori linear or linear-oblong, more than $3 \times$ as long as broad, more or less oblique to the costa and margin, continuous or

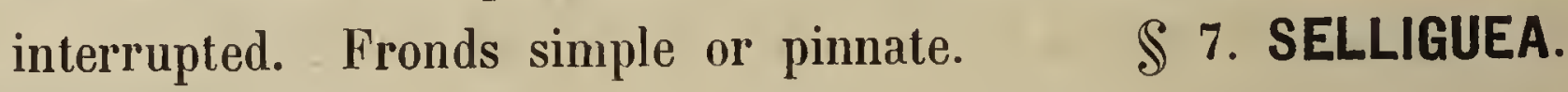

2.2. Sori round or oblong, very rarely more than $3 X$ as long as broad, if much elongated then always parallel to the costa or the margin.

$\$$ 6. PLEOPELTIS.

3. Rhizome scales peltato-orbicular or wanting. Rhizome inflated, \pm cylindrical or tuberous, soon cavernous and inhabited by ants. $\quad \$ 6$, a. Dyrmecopliila. †. Fronds simple, pinnatifid or pinnate. Sori not on marginal outgrowths. Rhizome scales peltato-orbicular.

$S 6 ; \mathrm{a}^{*}$. Aspidopodium.

$+\div$ Fronds pinnatifid or pinnate. Sori on specialized, marginal, tooth- or lobe-like, mostly inflexed outgrowths of the fertile segments. Rhizome scales wanting.

$\int 6, a^{* *}$. Lecanopteris.

3.3. Rhizome scales oval, oblong, ovate, lanceolate, linear or subulate, very rarely wanting or orbicular. Rhizome not as in $\mathbf{3}$, solid.

4. Fronds simple. $\$$, 6 , Atactosia. *. Main veins indistinct, often wanting.

$\$ 6, b^{*}$. Lepisorus.

***. Main veins distinct nearly or quite to the edge.

$\mathbb{S} 6, \mathrm{~b}^{* *}$. Pleuridium.

4.4. Fronds lobed, pinnatifid or pinnate.

S 6, c. Chrysopteris. 
†. Fronds stipitate.

$\times$. Fronds lobed or pinnatifid.

$\mathbb{S} 6, \mathrm{c}^{*}$. Phymatodes.

$\times \cdot \times$. Fronds pinnate. $\quad \mathbb{6} 6, c^{* *}$. Phymatopsis.

†.+. Fronds sessile.

*. Sori not on much contracted fertile segments.

S $6, c^{* * *}$. Drynariopsis.

*.*. Sori restricted to the much contracted higher segments. $\quad \mathbb{6} 6, c^{* * * *}$. Aglaomorpha.

\section{\$1. EUPOLYPODIUM. a. Integrifoliae (').}

a. Sori round, not oblong when young; receptacle round.

b. Fronds small, under $7 \frac{1}{2}$ c.M. long. .

c. Fronds roundish or oblong, nearly as broad as long, naked.

(1) P. flabellivenium.

c.c. Fronds linear or linear-lanceolate, much longer than broad.

d. Fronds naked or sparingly scaly. (2) P. oblanceolatum.

d.a. Fronds hairy.

b.b. Fronds larger, more than $71 / 2$ c.M. long.

(5) P. trichopodum.

(3a) P. sparsifilum SI 344

5. Sori in 1 regular row on each side of the costa.

*. Fronds under 20 c.M. long, naked. (4a) P. oleandroides.

*.*. Fronds longer, hairy.

(4b) P. ornatissimum.

\$.\$. Sori in 1 or more irregular rows, or scattered irregularly.

*. Fronds membranaceous, villose.

(5) P. Friderici et Pauli.

*.*.Fronds coriaceous, rather naked.

(6) P. pleiosoroides.

a.a. Sori oblong, at least when young; receptacle oblong.

1. Stipes and fronds naked ( $\left.{ }^{2}\right)$.

(6a) P. Subupardum S.7p 34

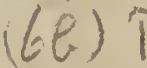

2. Fronds narrow, under 5 m.M. broad.

+. Fronds subterete, rush-like.

(7) P. bisulcatum.

+.+. Fronds flattened, not rush-like.

*. Fronds short, under 10 c.M. long. Sori subimmersed.

(8) P. Maxwellii
Sori subimmersed.

*.*. Fronds longer, more than 10 c.M. long when fully developed. Sori deeply immersed.

$\left.{ }^{(}\right)$See also P. Iudens, $B \%$.

$\left({ }^{2}\right)$ See also P. Koordersii, Christ. 
71. POLYPODIUM. $\$$ 1. EUPOLYPODIUM. a. INTEGRIFOLIAE

×. Rhizome short-creeping.

$\times . \times$. Rhizome erect. (9a) P. locellatum.

(9b) P. paucisorum.

2.2. Fronds 5-15 m.M. broad.

3. Sori medial between the midrib and edge.

(10) P. Stanleyanum.

3.3. Sori nearer the midrib than the edge.

4. Fronds sessile or subsessile ( $\left.{ }^{1}\right)$.

5. Veins simple.

(11) P. diminutum.

5.5. Veins forled.

6. Fronds tufted.

(12) P. malaicum.

6.6. Fronds scattered or approximate.

8. Sori rather close.

(13) P. australe.

ซ.ซ. Sori rather distant.

(14) P. adspersum.

4.4. Fronds decidedly stalked.

s. Fronds short, to \pm 15 c.M. long.

(15) P. subselligueum.

\$.\$. Fronds longer, more than 15 c.M. long.

$\times$. Rhizome scales broad.

(16a) P. fasciatum.

$\times \cdot \times$. Rhizome scales narrow. $(16 b)$ P. subfasciatum.

1.1. Stipes or fronds more or less distinctly hairy, tomentose, furfuraceous or scaly, at least on the midrib or the margin $\left({ }^{2}\right)$.

$\boldsymbol{2}^{\prime}$. Fronds narrow, to $\pm 5 \mathrm{~m} . \mathrm{M}$. broad.

3'. Fronds short, to 5 c.M. long.

1'. Stipes short or wanting. Frords slightly hairy or ciliale.

5'. Fronds minute, under 3 c.M. long.

6'. Under surface slighlly pubescent.

(17) P. vittariifolium.

6.6. Both surfaces covered with brown, scattered hairs.

(18) P. Merrillii.

$\boldsymbol{5}^{\prime} \cdot \boldsymbol{5}^{\prime}$. Fronds somewhat larger, $\pm 31 / 2-5$ c.M. long. when fully developed.

*. Fronds sessile.

(19) P. universe.

*.*. Fronds short-stalked, the stipe scaly.

(20) P. sucklingianum.

1.1. Stipes distinct, 1 c.M. long or longer. Fronds densely hairy.

(21) P. lasiosorum.

( $\left.{ }^{1}\right)$ See also P. subfasciatum, Rst.

$\left({ }^{2}\right)$ See also P. australe, Mett. \& ornatissimum, Rst. 
71. POLYPodium. $\$ 1$ eUPOLYPODIUN. a. INTEGRIFOLIAE.

3'.3'. Fully developed fronds $\pm 5-15$ c.M. long.

+. Sori scattered.

(22) P. pilosiusculum.

+.+. Sori seriate.

*. Sori ultimately confluent.

+. Fronds very narrow, $\pm 2-3$ m.M. broad.

$\times$. Fronds entire, the hairs scattered.

(23) P. Christii.

$\times \cdot \times$. Fronds distantly crenato-dentate, the hairs often placed in stellate clusters.

(24) P. Koordersii.

+.+. Fronds somewhat broader, 4-5 m.M. broad.

(25) P. parasiticum. Sip 344

*.*. Sori rather distant.

+. Sori superficial,

$\times$. Stipes tufted.

$\triangle$. Fronds membranaceous, hairy.

(26) P hirtellum.

$\Delta . \triangle$. Fronds coriaceous, slighily furfuraceous on the midrib.

(27) P. subevenosum.

$\times \cdot \times$. Stipes seriate, approximate.

(28) P. congenerum.

+.+. Sori immersed.

(29) P. caespitosum.

2'.2'. Fully developed fronds 5-10 m.M. broad.

a. Fronds under $121 / 2$ c.M. long.

$\beta$. Hairs of the fronds in stellate clusters.

$\times$. Upper surface hairy. (30a) P. Jagorianum.

$\times \cdot \times$. Upper surface naked. (30b) P. pleurogrammoides.

$\beta . \beta$. Hairs of the fronds not in clusters, scattered.

$\gamma$. Veins simple or once forked.

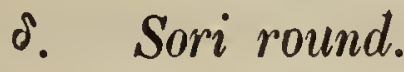

¿. Texture thin, submembranaceous.

(31) P. Reinwardtil.

¿.\&. Texture. firmer, subcoriaceous.

*. Surfaces thinly hairy. (32) P. Hookeri。 *.*. Surfaces densely hairy.

(33) P. mollipilum.

o. Sori oblong.

(34) P. Havilandii: 
71. POLYPodium. $\$ 1$ EUPOLYPODIUM. a. INTEGRIFOLIAE.

$\gamma . \gamma$ : Veins pinnate or $2 \times$ forlied.

+. Stipes very short.

(35) P. knutsfordianum.

+.+. Stipes distinct, to 8 c.M. long or longer.

(56) P. intromissum

a.a. Fully developed fronds more than 121/2 c.M. long.

$\beta^{\prime}$. Slipes scabrous; fronds nearly naked. (57a) P. scabristipes.

$\beta^{\prime} . \beta^{\prime}$. Stipes hairy; fronds naked.

(57b) P. dolichosorum. S $\perp p$

$\beta^{\prime} \beta^{\prime} \beta^{\prime}$. Stipes hairy; fronds hairy, at least on the costa.

$\gamma^{\prime}$. Sori in 1 regular row on each side of the costa.

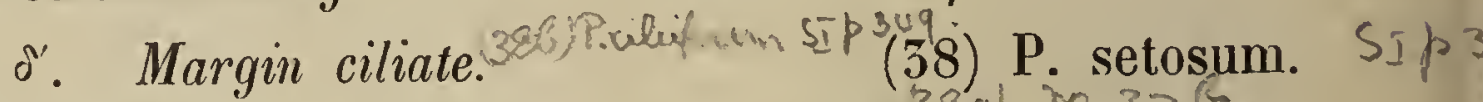

$\delta^{\prime} . \delta^{\prime}$. Margin not ciliate.

(59) P. pubinerve.

$\gamma^{\circ} \cdot \gamma^{\prime}$. Sori in 1-2 irregular rows on each side of the
costa $\left(^{*}\right)$.
(40) P. diplosorum.

$\mathbf{2}^{\prime} \cdot \mathbf{Z}^{\prime} \cdot \mathbf{2}$. Fully developed fronds more than $10 \mathrm{~m}$. M. broad.

p. Sori in 1 row on each side of the costa.

q. Veins simple or once forked.

r. Frondis entire or slightly repand.

s. Fronds \pm sessile or subsessile.

(41) P. padangense.

s.s. Fronds distinctly stalked.

(42) P. obscurum. SI $p$

r.r. Fronds sinuate.

(43) P. Warburgii.

$\boldsymbol{q} \cdot \boldsymbol{q}$. Veins pinnate or $2-3 \times$ forked.

(44) P. setigerum. Si $p$

p.p. Sori in 2-3 rows on each side of the costa.

(45) P. sumatranum.

(4iv) T. Toricellanum sip

(4sb) P subreticilum Sif

(1) P. Nabellivenium, Bk., Hk. Bk., Syn. Fil., 322; Christ, Farnkr. d. Erde, fig. 207; Ces., Fel. di Bor., tab. III, fig 7-7a.

Rhizome wiry, slender, creeping, the scales thin, brown, lanceolate. Stipes $2_{2}^{1} / 2$ _ c.M. long, filiform, naked, black, glossy. Fronds roundish or broadly oblong, $1 / 2-11 / 2$ c.M. long and nearly as broad, the point subacute, the edge thick, cartilagineous, deeply and sharply toothed, or with shallow, rounded lobes or sometimes subentire, the base slightly cordate, broadly rounded or \pm cuneate. Texture coriaceous; surfaces naked; veins subflabellate, once or more times forked, the ultimate forks sometimes uniting before they reach the border. Sori 1-6 to a frond, all in the upper half, not far from the margin.

Borneo.

(*) See also P. setosum, $P r$. 
71. POLYPODIUM. $\$$ 1. EUPOLYPODIUM.' a. 'INTEGRIFOLIAE.

(2) P. oblainceolatum, Bk., Ann. of Bot., VIII, 128.

Stipes short, filiform, naked. Fronds simple, $51 / 2-5$ c.M. long, \pm 5 m.M. broad, oblanceolate, obtuse, crenulate, the base narrowed gradually. Texture membranaceous; surfaces naked or covered with some few brown, subulate scales; veins visible, not close, forked. Sori superficial, subglobose, in 1 row on each side, medial between the midrib and margin.

New Guinea.

(5) P. trichopodum, Muell., Journ. of Bot., XXVIII, 107.

Rhizome short-creeping, the scales dense, small, ovate, brown, imbricate. Stipes slender, approximate, brown, wiry, clothed with inconspicuous, fine, spreading hairs. Fronds simple, linear, obtuse, entire, $21 / 2-5$ c.M. long, $4-5$ m.M. broad, narrowed gradually to the base. Texture thick, moderately firm; surfaces clothed with fine, spreading, brown hairs; veins erecto-patent, forked. Sori round, superficial, costal.

New Guinea.

(4a) P. oleandroides, BR., Ann. of Bot., VIII, 128.

Stipes short, nearly $21 / 2$ c.M. long, the scales dense, subulate, brown, recurved. Fronds lanceolate, 12-15 c.M. long, 10-13 m.M. broad, entire, obtuse, narrowed at the base, the margin ciliate with few, subulate, brown scales. Surfaces naked; veins conspicuous, erecto-patent, forked near the base. Sori semiglobose, superficial, close, in 1 row on each side near the costa.

New Guinea.

(4b) P. ormatissimum, Rst., Fed., Rep., V, 41.

Rhizome slender, caespitose. Stipes densely tufted, slender, 4-6 c.M. long, clothed with soft, spreading, rather long, purple-black hairs. Fronds pendulous, linear-lanceolate, to 60 c.M. long, 1 c.M. broad, acute, entire or slightly undulate, narrowed very gradually towards the base. Texture membranaceous; both surfaces clothed with moderate-long, single or tufted, purpleblack hairs, the upper side covered with many, round, white, peltate, cretaceous scales; costa black, prominent beneath; veins $1-2 \times$ forked, thickened at the apex. Sori terminal, in 1 row on each side near the costa; (receptacle oblong?); sporangia naked.

New Gainea.

(5) P. Friderici et Pauli, Christ, Ann. Btz., 148, tab. XVI, fig. $21, \mathrm{a} \& \mathrm{~b}$. 
Rhizome short, the scales brown. Stipes tufted, rigid, castaneous, \pm ; c.M. long, densely clothed with dark-coloured, spreading hairs. Fronds $1 \breve{b}-20$ c.M. long, $\pm 1 \frac{1}{2}-2$ c.M. broad, lanceolate, the apex and base narrowed, the point bluntish. Texture membranaceous, thin; colour green, paler beneath; midrib prominent; main veins zigzag, pinnate; vein tips thickened; both surfaces villose. Sori terminal on the 5-4 lower veins so as to form several irregular rows on each side of the midrib.

Celebes.

(6) P. pleiosoroides, Copel., Polypod. Philipp., 120.

Rhizome short, creeping. clothed with broad, lanceolate, acuminate, stramineous scales. Stipes slender, 2-4 c.M. long, densely provided with strimineous, spreading hairs. Fronds lanceolate, $10-15$ c.M. long, $1-1 \frac{1}{2}$ c.M. broad, narrowed towards both ends, the margin sinuate especially in the lower part. Texture coriaceous; surfaces naked, but the edges ciliate with a few short hairs; veins free, immersed, hidden, pinnate or to $\pm 4 \times$ forked. Sori round, large, superficial, in $1-3$ irregular rows, or altogether scattered.

Philippines.

(7) P. bisuleatum, Ht., Hk. Bk., Syn. Fil., 521; Grammitis bisulcata, Hk., Icon. PI., X, tab. CMXCVIII.

Rhizome creeping, slender, the scales narrow, brown. Fronds scattered, sessile or short-stalked (stalks under $2^{1 / 2}$ c.M. long), resembling the stipe of a rush, subterete, $15-25$ c.M. long, less than $21 / 2$ m.M. broad and thick, with 5 furrows, of which the 2 lowest are the deepest. Texture corriaceous; surfaces naked; no veins. Sori oblong, vertical, alternate, placed in the deepest furrows.

Borneo.

* (8) P. Maxwellii, Bks, Kew Bull., 1893, 211.

Rhizome short-creeping, the scales dense, erect, lanceolate, membranaceous, pale-brown. Stipes short, naked, approximate. Fronds simple, $21 / 2-61 / 2$ c.II. long, $\pm^{\circ} 31 / 2-4$ m.M. broad, \pm entire, obtuse, narrowed at the base. Texture firm; surfaces naked; veins distant, erecto=patent, forked, not reaching the margin. Sori in 1 row on each side, subdistant, rather close to the costa, subinumersed, oblong.

Borneo. 
71. POLYPODIUM. $\$ 1$. EUPOLYPODIUM. a. INTEGRIFOLIAE.

(9a) P. Iocellatum, His., Journ of Bot., XXVIII, 108.

Rhizome short-creeping, the scales dense, small, ovate-lanceolate, palebrown. Stipes slender, naked, wiry, erect, linear, entire, $12-15$ c.M. long, 4-4 $1 \frac{1}{2}$ m.M. broad at the middle, narrowed gradually to both ends. Texture thick, rigid; surfaces naked; veins hidden. Sori oblong, oblique, immersed in deep pits, forming a long row on each side nearer the midrib than the margin.

New Guinea.

(9b) P. paucisorum, Copel., Philipp. Journ., II, 137, tab. III, B. Rhizome erect, short, scaly. Fronds tufted, sessile, 8-12 c.M. long, 3-4 m.M. broad, sublinear, subacute, entire, narrowed gradually towards the base. Texture subcoriaceous; surfaces naked; veins forked, hidden. Sori in 1 row on each side, medial between the costa and margin, few, distant, deeply immersed, tending slightly towards oblong.

Mindoro.

P. Stanleyamum, Hz., Journ. of Bot., XXVIII, 107.

Stipes naked, $1-1 \frac{1}{2}$ c.M. long. Fronds linear, obtuse, entire, $7-13$ c.M. long, 6-9 m.M. broad, narrowed gradually from the middle to the base. Texture very thick and rigid; surfaces naked; veins quite hidden. Sori globose, superficial, in 1 row on each side medial between the midrib and margin, confined to the upper part of the frond.

New Guinea.

(11)? P. dimimutum, Br., Hk. Bk., Syn. Fil., 507.

Rhizome short-creeping, the scales dense, firm, lanceolate, dark-brown. Fronds subsessile, narrow, ligulate, blunt, 10-15 c.M. long, $5-10$ m.M. broad at the middle, narrowed gradually to the base. Texture rigidly coriaceous, thick; surfaces naked, pale-green; midrib very prominent beneath; veins close, immersed, obscure, simple, reaching the edge, erecto-patent (very oblique). Sori oblong, oblique, placed close to the midrib in the upper $1 / 3$ of the frond.

A plant found in New Guinea differs a little from the Lord-Howe's-Island typical plant in scales, stipes and sori.

(12) P. malaicum, v. A. v. R.; P. sessilifolium, Hk., Hk. Bk., Syn. Fil., 322; Hk., Spec. Fil., IV, 168 (not 251), tab. CCLXXII, A; Bedd., Ferns Br.I., I, tab. CXIX; P. subevenosum, Bk., var., C. Chr., Ind. Fil.; Grammitis sessilifolia, J. Sm., Hist. Fil., 181.

FiLices. 
Fronds sessile, tufted, 7-23 c.M. long, $\mathbf{5}-7$ m.M. broad, narrowed gradually towards the base, the edge entire or slightly undulate, the point narrowed, bluntish. Texture subcoriaceous; surfaces naked; veins oblique, forked, not reaching the margin. Sori oblong, distant, in 1 row on each side near the midrib, occupying the anterior veinlets.

Malaya.

(13) australe, Mett., Hk. Bk., Syn. Fil., 322; Christ, Farnkr. d. Erde, fig. 204; Grammitis australis, R. Br., Prod., 146 ; G. Billardieri, Willd., Kze., Anal., tab. IX, fig. 2 ; P. Billardieri, C. Chr., Ind. Fil.

Rhizome creeping, copiously short-branched, forming a dense mass. Fronds short-stalked or subsessile, $21 / 2-15$ c.M. long, smaller ones spathulate, the larger ligulate, obtuse at the apex, tapering gradually towards the base. Texture coriaceous; stipes and surfaces naked or slightly ciliate, the edge not bordered; veins oblique, often forked. Sori copious, nearly close, in 1 row on each side, nearer the midrib than the edge, \pm parallel to the costa, terminal on the anterior veinlets.

Philippines, New Guinea; Australia, Antarct. America, South. Africa.

(14) P. adspersum, H., Hk., Spec. Fil., IV, 168; Grammitis adspersa, Bl., Flor. Jav., II, 115, tab. XLVIII, fig. 2 ; P. hirtellum, Bl., var., C. Chr., Ind. Fil.

Rhizome creeping or ascending, the scales ovate-oblong, acuminate, entire, ochraceous, membranaceous, deciduous. Fronds sessile or very short-stalked, scattered, linear-lanceolate, $7-13$ c.M. long, 6-8 m.M. broad, bluntish, the edge subrepand, the base narrowed. Texture coriaceous; surfaces naked, but the upper side sparingly covered with blackish dots; costa distinct in the lower, obsolete in the upper half; veins hidden, forked, not reaching the margin. Sori rather distant, oblong or subrotund, near the midrib, terminal on the short, anterior veinlets.

Java, Singapore.

(15) subselliguenm, Bk., Journ. of Bot., XXVIII, 107.

Stipes naked, $3 \frac{1}{2}-5$ c.M. long. Fronds simple, linear, entire, 12-15 c.M. long, 6-7 m.M. broad at the middle, narrowed gradually to both ends. Texture thick; surfaces naked; veins quite hidden. Sori oblong, superficial, 4-7 m.M. long, confined to the middle of the frond, in 1 row on each side, close to the midrib and parallel to it.

New Guinea. 
71. POLYPODIUM. $\mathbb{S} 1$. EUPOLYPODIUM. A. INTEGRIFOLIAE.

- (16a) P. fasciatum, Pr. (not Melt.), Rac., Flor. Btz., I, 88, Grammitis fasciata, Bl., Flor. Jav., II, 117, tab. XLIX, fig. 1.

Rhizome strong, horizontally creeping, clothed with broad, grey or ferrugineous scales. Stipes $1 / 2-1 / 2$ c.M. apart, $21 / 2-10$ c.M. long, rigid, naked, slightly scaly at the base, dark-colored. Fronds to $30-45$ c.M. long, m.M. broad, linear, narrowed gradually towards both ends, the edge entire. Texture coriaceous; surfaces naked; midrib prominent, conspicuous; veins immersed, once $0 \mathrm{l}^{\circ}$ rarely trice forked, with the branches reaching nearly to the edge. Sori oblong (elliptical when young), close to the midrib.

Malaya.

(16b) P. subfasciatum, Iest., Fed., Rep., V, 41.

Rhizome short-creeping, slender, clothed with pale-rufescent, narrow, lanceolate, entire scales. Stipes $0-2$ c.M. long, stramineous, naked. Fronds linearlanceolate, to 25 c.M. long, $12 \mathrm{~m} . \mathrm{M}$. broad, narrowed gradually towards the base, the margin entire, reflexed (towards the base?). Texture coriaceous, thick, the margin thinner; surfaces naked, upper bright-green, lower paler, costa prominent beneath; veins immersed, subdistinct, $1-2 \times$ forked or subpinnate. Sori at the base of the anterior veinlets, in 1 row on each side near the costa, suboblong, confined to the upper part of the frond, subimmersed; capsules setose.

\section{New Guinea.}

(17) P. vittarifolium, C. Chr., Ind. Fil.; P. minimum, $B k$, Journ. of Bot., XVII, 41.

Fronds densely tufted, simple, sessile, ligulate, entire, obtuse, $1-21 / 2$ c.M. long, to $21 / 2$ m.M. broad, narrowed gradually from the middle to the base. Texture subcoriacaous; upper surface naked, lower slightly pubescent; veins simple, erecto-patent, reaching nearly to the margin. Sori round, superficial, close, forming a single row close to the midrib, confined to the upper $1 / 2-2 / 3$ of the frond, in the finest fronds $8-12$ in a row.

Borneo.

P. Mer'rillii, Copel., Polypod. Philipp., 119.

Rhizome short, erect, the scales small, brown. Fronds minute, sessile ol narrowed into a short stipe, linear-oblanceolate, obtuse, entire, to $2 \frac{1}{2}$ c.M. long, under 2 m.M. broad. Texture coriaceous; surfaces clothed with a pubescence of short, straight, red-brown hairs mostly confined to the upper 
side and margin; costa conspicuous; veins simple, immersed. Sori superficial, large, \pm 6 on a frond, near the costa, forming a single wavy line.

Philippines. Aruboina $S: \beta 347$

(19) P. universe, Bh., Ann. of Bot., V, 464.

Fronds sessile, densely tufted, simple, linear, $3 \frac{1}{2}-\mathbf{5}$ c.M. long, $2-4$ m.M. broad above the middle, narrowed gradually towards the base. Texture rigidly coriaceous; surfaces furnished with deciduous, brown hairs; costa distinct; veins hidden. Sori oblong, crowded, in 1 row on each side, confined to the upper part of the frond, filling up the whole space between the midrib and margin.

Penang.

(20) P. sucklingiamum, Bik., Ann. of Bot., VIII, 128.

Stipes short, clothed with subulate, brown, spreading scales. Fronds simple, linear, $5^{1} / 2$-5 c.M. long, $\pm 5 \mathrm{~m} . \mathrm{M}$. broad, obtuse, crenate, the base narrowed. Surfaces naked; the margin minutely ciliate; veins distant, erectopatent, simple. Sori oblong, superficial, oblique, close, in 1 row on each side near the costa.

New Guinea.

* (21) P. Iasiosorum, Fite., Spec. Fil., IV, 166; Bedd., Ferns Br. I., II, tab. CLXXII ; Grammitis pusilla, Bl., var. lasiosora, Bl., Flor. Jav., II, 110, tab. XLVI, fig. 6; P. hirtellum, Bl., var., C. Chr., Ind. Fil.

Rhizome short. 'Stipes tufted, $\pm 1-2$ c.M.' or more long, slender, clothed with spreading, ferrugineous hairs. Fronds spathulate- or ligulate-lanceolate, $2-4$ c.M. long, $21 / 2-5$ m.M. broad, the apex rounded, the edge entire, the base gradually narrowed. Texture membranaceous to subcoriaceous; surfaces densely villose and ciliate with patent, soft, ferrugineous hairs more or less deciduous in age; veins not discernible. Sori round, commonly occupying the upper half of the frond, crowded in 2 lines close to the costa; capsules copiously intermixed with hairs.

Java.

(22) P. pilosiusculum, Pr. (not Hk.), Hk., Spec. Fil., IV, 168; Grammitis pilosiuscula, Bl., Flor. Jav., II, 107, tab. XLVI, fig. 2.

Rhizome creeping, the scales membranaceous, ovate, obtuse, entire, yellowish-fuscous. Stipes $1-21 / 2$ c.M. long, slender, dirty-brown, approximate, 
clothed with setiform hairs. Fronds linear or narrowly lanceolate, \pm 8 c.M. long or shorter, $\pm 7 \frac{1}{2}$ m.M. broad, the apex obtuse, the edge entire or subrepand, the base narrowed. Texture coriaceous; surfaces moderately covered with \pm ferrugineous, setiform hairs. Sori small, scattered, oblong, hardly immersed, $\pm 5-6$ to each frond.

Java.

(23) P. Chuistii, Copel., Polypod. Philipp., 118.

Rhizome short, the scales deciduous, stramineous. Stipes clustered, 015 m.M. long, clothed with brown or reddish, short hairs. Fronds linear, \pm b-8 or rarely to 15 c.M. long, $2-5$ m.M. broad, obtuse or subacute, narrowed very gradually downward, entire, or subentire. Texture subcoriaceous; surfaces bearing scattered, stiff, nearly black hairs; veins immersed, forked. Sori oblong, oblique, superficial, ultimately confluent.

Mindanao.

(24) P. Koondersii, Christ, Ann. Btz., XV, 144, tab. XV, fig. 19, $a-c$.

Fronds tufted, stalked or subsessile, linear, 6-8 c.M. long, 2-3 m.M. broad, slightly and remotely crenato-dentate, rounded at the apex, narrowed at the base. The whole plant furnished and ciliate with black, strigose hairs, which often are placed in stellate groups or clusters; costa conspicuous ; veins simple except a short, basal, soriferous branch. Sori oblong, oblique, approximate, close to the costa, ultimately confluent, confined to the upper part of the frond.

Celebes. - A similar, but quite naked plant was found in Penang.

* (25) P. parasiticum, Mett., Hk. Bk., Syn. Fil., 319; Bedd., Ferns S.I., tab. CLXV; Ann. Btı., XV, tab. XV, fig. 19, d; P. mediale, Bl.., var., C. Chr., Ind. Fil.

Fronds tufted, $5-8$ c.M. long, $4-\breve{b}$ m.M. broad, subsessile or on stalkw to 1 c.M. long, narrowed very gradually below, the edge entire or slightly undulate, the point bluntish. Texture coriaceous; both surfaces when young rather thickly clothed with long, soft hairs; veins immersed, forked. Sori roundish, oblong when young, placed on the anterior branches of the veins, medial between the costa and margin, forming 1 row on each side of the costa, ultimately conflent.

Java, Celebes, Philippines. 
* (26) P. hirtellum, Bt., Rac., Flor. Btz., I, 86; Bedd., Ferns Br. I., II, tab. CCXII ; Grammitis pusilla, Bl. (typica \& var. alpestris), Flor. Jav., II, 109-110, tab., XLVI, fig. 4-5; P. pusillum, Christ, Ann. Btz., XV, 145.

Rhizome short, ascending, the scales broadly lanceolate. Fronds linearlanceolate, densely tufted, $5-15$ c.M. long, $\pm 21 / 2-5$ m.M. broad, narrowed gradually towards both ends, the apex bluntish, the edge entire or slightly repand, the stipe 1-4 c.M. long, slender, brown, provided with soft, spreading, reddish hairs. Texture firm-membranaceous; surfaces hairy like the stipe; veins distinct or more or less hidden, forked near the base, sometimes simple, not reaching the margin, with the branches \pm of the same length. Sori rather distant, in 1 row on each side of the slightly wavy midrib, close to it or nearer the latter than the margin.

Malaya; New Caledonia, South. China.

(27) P. subevenosum, Bk., Hk. Bk., Syn. Fil., 320 ; Bedd., Ferns Br.I., II, tab. CCGXXIII.

Stipes tufted, very short, black, wiry. Fronds ligulate, 7-10 c.M. long, $\pm 2-4 \mathrm{~m} . M$. broad, the apex bluntish, the edge slightly repand, the lower part narrowed gradually. Texture subcoriaceous; midrib black, slightly furfuraceous below; veins simple, short, indistinct. Sori roundish, tending slightly towards oblong, in a long row on each side close to the costa.

Malacca. to Celebes t the Phil ppines Sip 348

* (28) P. congenerum (congener), Pr. (not Hk.), Rac., Flor. Btz., I, 88; P. alatellum, Christ, Fil. Saras., IV, 441; Grammitis congener, Bl., Wlor. Jav., II, 108, tab. XLVI, fig. 5, a-b.

Rhizome creeping, the scales pale-rufous. Stipes approximate, wiry, more or less densely clothed with rigid, short, spreading, red-brown hairs. Fronds linear-lanceolate, $71 / 2-12 \frac{1}{2}$ c.M. long, $21 / 2-5$ m.M. broad, narrowed very gradually towards both ends, the apex bluntish, the edge entire. Texture coriaceous or thinner: upper surface naked or covered with black dots corresponding with the apices of the veinlets, under surface moderately provided with short, blackish-fuscous hairs; veins branched with $2-4$ branches. Sori roundish, elliptical when young, superficial, in 1 row on each side, close to the midrib, placed on the lowest anterior branch of the veins.

Malaya.

* (29) P. caespitosum, Mett., Rac., Flor. Btz., I, 87; Grammitis caespitosa, Bl., Flor. Jav., II, 106, tab. XLVI, fig. 1. 
Rhizome short, scaly. Stipes approximate, 1-2 c.M. long, clothed with numerous, very short hairs. Fronds $\mathbf{5}-\mathbf{1 0}$ c.M. long, to 4 m.M. broad, linear, narrowed towards both ends. Texture coriaceous; surfaces naked; veins once forked. Sori roundish, elliptical when young, deeply immersed, rather distant, \pm medial between the midrib and margin.

Java, Philippines.

(30a) P. Dagoropanum, Mett., Hk. Bk., Syn. Fil., 507.

Rhizome 5-10 c.M. long, clothed with pale-brown chaff. Stipes tufted, short or wanting, at hest 2 c.M. long, densely clothed with reddish hairs. Fronds ligulate, $21 / 2-10$ c.M long, 5 - 8 m.M. broad, entire, obtuse, narrowed gradually towards the base. Texture coriaceous; surfaces clothed (especially near the margin and apex) with firm, usually fascicled, reddish hairs; veins forked, almost invisible. Sori near the midrib, close, oblong, on the anterior fork branch of the veins; capsules setaceous.

Philippines.

(30b) P. pleurogrammmides, rest., Fed., Rep., V, 42.

Rhizome ascending, branched, clothed with ovate-lanceolate, obtuse, slightly adpressed, \pm fuscous, peltate scales, bearing the fronds towards the apex. Stipes scattered or subtufted, nearly $1 / 2$ c.M. long, purple-black, adpressed to the rhizome. Fronds linear-ligulate, \pm s c.M. long, 6-7 m.M. broad, the edge slightly repando-crenate, the base narrowly cuneate. Tecture coriaceous; upper surface naked, lower clothed principally near the margin with purpleblack, deciduous, forked or stellate hairs, the incisions provided with single, simple, thicker, incurved hairs; costa greenish, prominent on both sides, evanishing in the upper $1 / 3$; veins immersed, forked. Sori at the base of the anterior veinlets, immersed, oblique, in I row near the costa; capsules setose, the setae subulate, geminate, black-puiple. - Near P. Jagorianum, Mett.

New Guinea.

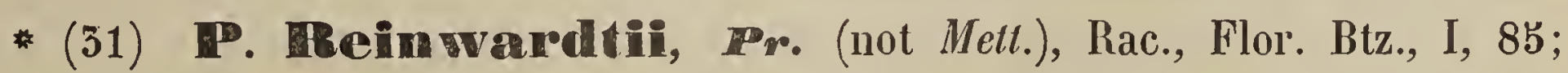
Grammitis Reinwardtii, Bl., Flor. Jav., II, 114, tab. XLVIII, fig. 1.

Rhizome slender, creeping, the scales dense, lanceolate, obtuse. Stipes 2-b c.M. long, blackish-brown, densely clothed with reddish, spreading hairs. Fronds lanceolate or linear-lanceolate, $5-121 / 2$ c.M. long, $5--10$ m.M. broad, narrowed towards both ends, the apex bluntish, the edge entire or crenatorepand. Texture thin, pellucid; surfaces (especially the edge and midrib) 
hairy like the stipe; costa conspicuous, straight; veins erecto-patent, forked at the base, the soriferous branches very short, the sterile ones not reaching the edge. Sori round, elliptical when young, in a long row on each side, close to the midrib.

Java, Philippines.

(32) P. Hookeri, Brock., Hk. Bk., Syn. Fil., 319; P. setigerum, Hk. \& Arn., Beech. Voy., tab. XXI, A.

Stipes tufted, $1 \frac{1}{4}-4$ c.M. long, clothed with soft, spreading hairs. Fronds narrow-lanceolate, 7-10 c.M. long, 5-10 m.M. broad, tapering at both ends, the point acute or bluntish, the edge entire. Texture rather thinly subcoriaceous; surfaces thinly clothed with short, soft hairs; veins simple or forked. Sori round, in a long row on each side, close to the midrib.

Philippines; Polynesia, North. Australia.

P. mollipilum, Ble., Journ. of Bot., XXVIII, 107.

Stipes slender, brown, wiry, $211_{2}-4$ c.M long, clothed with fine, spreading hairs. Fronds simple, linear, entire, $7-10$ c.M. long, 6-7 m.M. broad at the middle, narrowed gradually to both ends. Texture moderately firm and thick; surfaces densely clothed with fine, spreading, brown hairs; veins forked. Sori round, superficial, costal.

New Guinea.

(34) P. Havilandii, IBt., Trans. Linn. Soc., Bot., $2^{\text {nd }}$ Series, IV, 255.

Stipes caespitose, slender, nearly $21 / 2$ c.M. long, clothed with fine, soft, spreading hairs. Fronds simple, lanceolate, $5-8$ c.M. long, $\pm 71 / 2$ m.M. broad at the middle, obscurely crenate, narrowed gradually towards both ends. Texture subcoriaceou; surfaces pubescent; veins obscure, forked. Sori oblong, oblique, subremote, in 1 row on each side close to the costa.

Borneo.

P. knutsfordianum, BHE., Journ. of Bot., XXVIII, 107.

Rhizome short-creeping, the scales dense, small, pale-brown, ovate, imbricate. Stipes very short, densely clothed with spreading, brown hairs. Fronds simple, linear, entire, 7-10 c.M. long, 6-7 m.M. broad, obtuse, narrowed gradually to the base. Texture firm; surfaces clothed with few, spreading. brown hairs; veins distinct, with 2 short anterior branches. Sori round, superficial, in 2 rows near the midrib.

New Guinea. 
71. Polypodum. $\mathbb{S} 1$. EUtolypodium. a. integrifoliae.

(36) P. intromissumn, Chrest, Fil. Saras., IV, 440; Ann. Btz., $\mathrm{XV}$, tab. XV, fig. 20, a-b.

Stipes filiform, 8 c.M. and more long. Fronds 5-8 c.M. long, 7-10 m.M. broad, ovate-lanceolate, apex and base rounded. Texture papyraceous, thin; surfaces clothed like the stipe with reddish-brown, spreading hairs; costa distinct; veins forked and the branches branched again. Sori in 1 row on each side near the midrib, on the lowest veinlets, at length confluent.

Celebes.

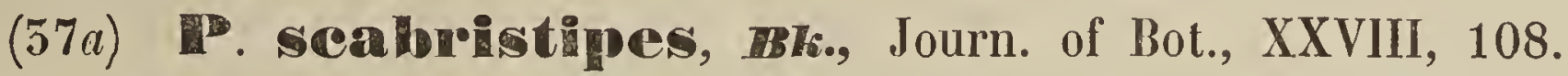

Stipes brown, wiry, scabrous, $5-8$ c.M. long. Fronds simple, linear, entire, $12 \frac{1}{2}-15$ c.M. long, 8-9 m.M. broad at the middle, narrowed towards the base. Texture thick, rigid; surfaces nearly naked; veins forked, erecto-patent. Sori oblong, oblique, rather immersed, in 1 row on each side nearer the midrib than the margin.

New Guinea.

(37b) P. dolichosormm, Copel., Philipp. Journ., I, Suppl., 159, tab. XVI.

Rhizome wide-creeping, clothed with rather large, ovate, fulvous scales. Stipes firm, black-brown, \pm 4 c.M. long, clothed with short, reddish hairs, or naked towards the base. Fronds linear-lanceolate, \pm 15 c.M. long, \pm 1 c.M. broad, narrowed towards both ends, the apex blunt, the edge entire, the base cuneate. Texture coriaceous; surfaces naked, opaque; veins often forked. Sori oblong, oblique, nearer the midrib than te margin, slightly immersed.

\section{Mindanao.}

* (38) P. setosum, (not Bl.), Rac., Flor. Btz., I, 87 p.p.; Grammilis selosa, Bl., Flor. Jav., II, 116, tab. XLVIII, fig. 3; P. diplosorum, Christ, var., C. Chr., Ind. Fil.; - var. calvum, Copel., Philipp. Journ., II, 136.

Rhizome short-creeping, scaly, the scales lanceolate, yellow-brown, Stipes wiry, 2-5 c.M. long, dirty-brown, clothed with spreading, soft, red-brown hairs. Fronds approximate, erect, $12 \frac{1}{2}-40$ c.M. long, $\pm 7-10 \mathrm{~m} . \mathrm{M}$. broad, linear-lanceolate, narrowed gradually towards both ends, the margin and costa on both sides more or less clothed with dark-reddish-brown hairs. Texture \pm coriaceous; veins slightly conspicuous, $2-3 \times$ forked, the soriferous branch short; costa prominent below. Sori round (elliptical when young), approximate, placed in 1 row on each side \pm close to the midrib, someti- 
mes accompanied by a few others placed in an outer row close to the former.

ar. calvam: Upper surface sparingly pilose.

Java, Celebes, Philippines; - var. calvum: Mindoro.

(39) Dubinerve, Christ, Ann. Btz., XV, 146; Grammitis pubinervis, Bl., Flor. Jav., II, 117, tab. XLVIII, fig. 4.

Rhizome suberect, scaly. Stipes approximate, clothed with short, spreading hairs. Fronds linear-lanceolate, $20-25$ c.M. long, \pm 10 m.M. broad, narrowed towards both ends. Texture coriaceous; costa prominent below, hairy; surfaces naked; veins pinnate, conspicuous. Sori oblong, close to the costa, rather distant, occupying the upper $1 / 2-2 / 3$ of the frond.

Java, Celebes. Murdanow. Sipzeq

P. Iiplosorumn, Cherist, Ann. Btz., XV, 146 ; Grammitis hirla, Bl., Flor. Jav., II, 111, tab. XLVII, fig. 1.

Rhizome short, clothed with blackish scales. Stipes tufted, rigid, lightbrown, 5-4 c.M. long, furnished like the costa with short hairs, sometimes only asperous. Fronds ligulate, $\pm 12 \%$ moderately narrowed towards both ends, the edge entire or slightly wavy. Texture coriaceous; surfaces naked or short-hairy; costa blackish and prominent beneath; veins hidden, pinnate on the anterior side; veinlets $5-4$, the lowest forked. Sori superficial, round, elliptical when young, in 1 or 2 irregular rows between the midrib and edge, rather distant, the inner row close to the costa.

Java, Borneo, Celebes. Luzon, Thuidana, hegros, hear Gurinea, SI p 349

P. padingense, Bk., Journ. of Bot., XVIII, 215.

Rhizome short-creeping, the scales dense, imbricate, large, pale-brown, lanceolate, membranaceous. Stipes almost obsolete. Fronds ligulate, entire, \pm 15 c.M. long, $1-1 \frac{1}{2}$ c.M. broad at the middle, narrowed gradually to the base. Texture very thick and coriaceous; surfaces almost naked, but the margin ciliate with few, minute, black hairs; veins forked. Sori round, slightly immersed, placed in 1 row on each side near the thick midrib, a short space from each other, confined to the upper half of the frond.

Sumatra.

(42) P. Doscurum, Mett., Farng., I, Polypod., 38; Grammitis obscura, Bl., Flor. Jav., II, 115, tab. L, fig. 1; P. Reinwardlii, Pr., var., C. Chr., Ind. Fil. 
Rhizome creeping, the scales small, scariose, pale-fuscous, lacerate. Stipes approximate, slender, $1-4$ c.M. long, clothed with short, fine hairs. Fronds 8-15 c.M. or more long, $1-1 \frac{1}{2}$ c.M. broad, linear-lanceolate, the apex obtuse, the edge entire or slightly repand, the lower part narrowed. Texture coriaceous; colour deep-green; the margin and the distinct costa on both sides provided with short, dark-reddish-brown hairs; veins simple or forked, not reaching the margin. Sori suboblong or oval, rather distant, in 1 row on each side near the costa, slightly immersed.

Java.

P. Warburgin, Christ, Warb., Mons., I, 59.

Rhizome short, the scales adpressed, ovate, inconspicuous, scattered. Stipes short, tufted, to \pm 2 c.M. long, clothed with long, black, spreading hairs. Fronds narrow, lanceolate-ligulate, \pm 12 c.M. long, $\pm 1 \%$ c.M. broad, the apex acuminate, the margin sinuate, the base narrowed gradually. Texture chartaceous; costa and margin clothed or ciliate with black hairs; veins conspicuous, prominent, forked. Sori on the lower veinlets, large, oblong, 30-40 on each side, occupying the upper $1 / 2$ of the frond.

Batjan.

* (44) P. setigerum, IBt., Rac., Flor. Btz., I, 86; Hk., Icon. Pl., X, tab. CMXLI; Grammilis fasciculata, Bl., Flor. Jav., II, 11.2, tab. XLVII, fig. 2.

Rhizome short, densely clothed with brownish scales. Stipes tufted or approximate, 5-10 c.M. long, reddish-black, densely clothed with long, soft, spreading, ferrugineous or reddish hairs. Fronds $20-45$ c.M. long, $1-2$ c.M. broad, linear, the point acute, the base narrowed, the edge entire. Texture thick, coriaceous, succous, thin and translucid when dry; both surfaces hairy like the stipe; veins pinnate or $2-3 \times$ forked, the soriferous branches the shortest. Sori round, in 1 row on each side near the midrib, distant.

Singapore, Java, Moluccas, Philippines.

* (45) P. sumatramum, IRk., Bull. Dép. Agr. I. N., 1908, XVIII, 19 ; P. subpleiosorum, Rac., Flor. Btz., I, 89.

Rhizome short, creeping, the scales dense, lanceolate, pale-brown. Stipes approximate, 2-6 c.M. long, wiry, erect, densely clothed with minute, rigid, spreading, brown hairs. Fronds linear-lanceolate, $15-40$ c.M. long, $1 \frac{1}{2}-4$ c.M. broad, narrowed gradually towards both ends, the edge repando-crenate to irregularly undulate with the crenations to $4 \mathrm{~m} . \mathrm{M}$. broad, to $2-3 \mathrm{~m} . \mathrm{M}$. 
71. POLYPODIUM. $\mathbb{S} 1$. EUPOLYPODIUM. a. INTEGRIFOLIAE.

deep. Texture coriaceous; the edges and midrib beneath very sparingly covered with distant, minute, inconspicuous, blackish-brown hairs; veins hidden, pinnate with $1-\mathbf{3}$ veinlets on each side, which are very rarely joining at the apex. Sori round, \pm elliptical when young, nearly superficial (very slightly and indistinctly immersed), in $2-5 \pm$ irregular rows on each side of the midrib. - Beccari's and Raciborski's plants in the Buitenzorg herbarium are quite the same plants.

Java, Sumatra. hav Gurmea (Sip. 349 )

\section{\$ 1. EUPOLYPODIUM. b. Furcatae.}

* (46) P. subdichotomumen, Rece, Bull. Dép. Agr. I. N., 1908, 5 I p s 5 XVIII, 20; XXI, tab. III.

Rhizome short, the scales membranaceous, dense, ferrugineous, narrowed gradually from the base to the apex, the edge entire. Stipes tufted or approximate, short, clothed like the whole frond with long, spreading, red-brown hairs. Fronds $10-15$ c.M. long, once or more times forked, tapering very gradually into the slender stipe. Segments of the fronds linear, $2-5$ m.M. broad, with a gradually narrowed apex. Texture coriaceous; veins hidden, short, forked. Sori in 1 row on each side near the costa, large, alternate, nearly confluent, filling up the whole under surface of the ultimate segments.

Sumatra (Forbes Nos. 2408 \& 2497).

\section{\& 1. EUPOLYPODIUM. c. Pinmatifidae.}

a. Sori solitary on the lobes. The lower edge of the lobes folded over the sori.

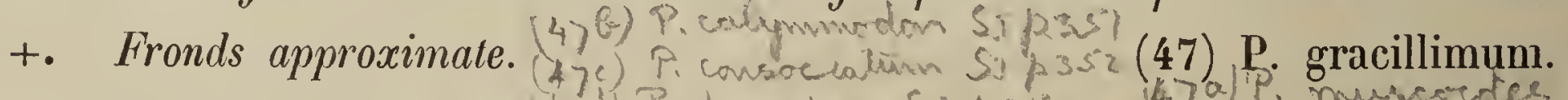

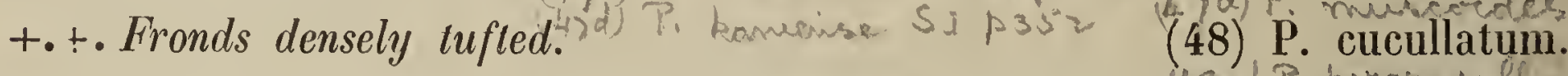
a.a. Sori whether or not solitary. The lower edge of the lobes not folded over the sori $\left(^{+}\right)$.

b. Fronds narrow, to 5 m.M. broad.

+. Fronds rather small, to $21 / 2$ c.M. long or somewhat longer.

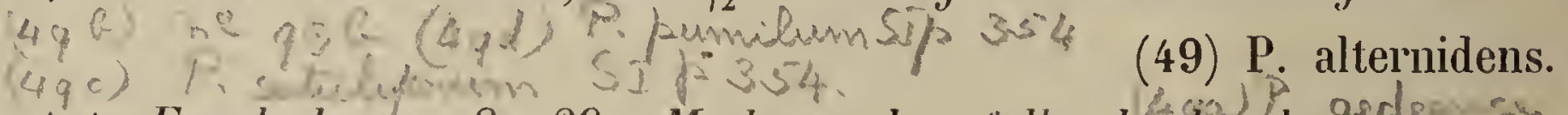
+.+. Fronds longer, 8-30 c.M. long when fully developed.

(50) P. subpinnatifidum.

b.b. Fully developed fronds 5-10 m.M. broad. c. Lobes irregular, entire.

(51) P. Loherianum.

${ }^{*}$ ) See also under P. cucullatum, Nees \& Bl. 
* (50) P. sulopimmatifidum, Bl., Rac., Flor. Btz., I, 91; Grammitis subpinnatifida, Bl., Flor. Jav., II, 118, tab. XLIX, fig. 2.

Rhizome erect, short, clothed with ovate-lanceolate scales. Stipes tufted, slender, 2-4 c.M. long, covered with soft, spreading, red-brown hairs. Fronds linear, 8-50 c.M. long, 5-5 m.M. broad, deeply lobed, the apex and base narrowed. Lobes with the upper edge nearly straight and horizontal, the lower edge oblique and the apex blunt, entire or slightly emarginate, the sinuses \pm roundish. Texture subcoriaceous; both surfaces naked or the midrib hairy beneath; veins forked in the lobes. Sori 1 or rarely 2 to a lobe. Java, Malacca. Reur Geunea., Phelppeice. SIp 354

(51) H. Loheriamum, Cherist, Bull. Herb. Boiss., VI, 197, tab. III, fig. 2, $a-b$.

Rhizome short-creeping, scaly. Stipes $1-3$ c.M. long; brown, naked. Fronds ligulate-lanceolate, \pm 15 c.M. long, $7 \%$ very gradually into the stipe, the edge shallowly lobed (rather conspicuously and deeply toothed), the apex bluntish. Lobes deltoid, irregularly shaped, obtuse, to $5 \mathrm{~m} . \mathrm{M}$. long. Texture coriaceous; surfaces naked; costa and veins inconspicuous; main veins pinnate in the lobes. Sori round or oblong, in 1 row on each side nearer the midrib than the edge, medial on the lower anterior veins, rarely accompanied by a second, submargina. row.

Philippines.

- (52) P. denticulatum, Pr., Rac. Flor. Btz., I, 89 ; Grammitus denticulata, Bl., Flor. Jav., II, 121, tab. L, fig. 4 .

Rhizome short, erect, the scales short, brown, lanceolate. Fronds subsessile or short-stalked, 4-10 c.M. long, 6-8 m.M. broad, deeply pinnatifid. Lobes deltoid-oblong, erecto-patent, \pm falcate, the point acute, the edge with 2 -b often sharp teeth. Texture coriaceous; surfaces naked; veins with $1-2$ branches. Sori $1-3$ to a lobe.

Java.

* (53) P. Bunlbidgei, B7., Journ. of Bot., XVII, 42.

Rhizome suberect, the scales lanceolate or linear, membranaceous, brown, ciliate. Fronds tufted, sessile, lanceolate, deeply pinnatifid, to 50 c.M. long, $21 / 2-51 / 2$ c.M. broad at the middle, cut down to a broad wing to the costa into numerous close, entire, obtuse, spreading or ascending segments $21 / 2-3^{1} / 2$ m.M. broad at the base, the lower segments growing gradually smaller and 
the basal part of the costa bordered only by a moderate-long, entire wing \pm 4-b m.M. broad at the top and narrowed gradually to the base. Texture subcoriaceous; under surface \pm pubescent on the costa, the rest glabrous; veins distant, simple, erecto-patent, reaching nearly to the edge. Sori semiglobose, slightly immersed, commonly in a single row in the wing of the costa, not or hardly prominent on the upper snrface.

Borneo, New Guinea.

(54) P. Iudens, B1s., Ann. of Bot., VIII, 129.

Rhizome short-creeping, the scales dense, broad-lanceolate, pale-brown. Stipes $\pm 5-71 / 2$ c.M. long, clothed with subulate, recurved, brown scales. Fronds lanceolate, 15-20 c.M. long, $2-5$ c.M. broad, the base narrowed, the margin entire or cut nearly $1 / 2$-way down to the costa into irregular lobes. Surfaces naked; veins forked, erecto-patent, immersed, obscure. Sori oblong, superficial, oblique, in 1 row on each side near the costa.

Java.

\section{S 1. EUPOLYPODIUM. d. Pinmatae.}

a. Pinnae contiguous, dilated and often confluent at the base; lower pinnae sometimes distant.

b. Fronds narrow, to $\pm 12^{1 /} / 2$ m.M. broad.

c. Pinnae entire, the sori solitary on the pinnae.

5. Sori terminal on the pinnae.

*. Sori superficial.

(55) P. streptophyllum.

*.*. Sori rather deeply immersed.

$\times$. Sori quite terminal on the pinnae.

(56) P. triangulare. Sip35

$\times \cdot X$. Sori occupying the upper half of the pinnae.

(57) P. subtriangulare.

\$.5. Sori at the base of the pinnae.

+. Fronds small, under 5 c.M. long, under 5 m.M. broad.

(58) P. musgravianum.

+.+. Fronds larger, $\pm 10-13$ c.M. long, $\pm 71 / 2$ m.M.

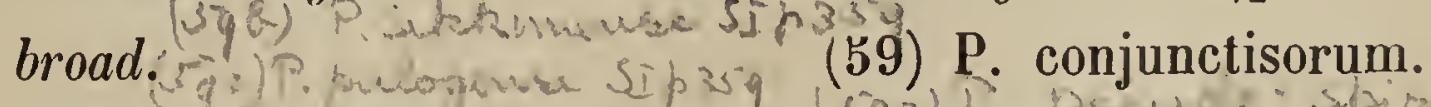

c.c. At least the largest pinnae \pm crenate or repand, or the sori not solitary on the pinnae. 
71. POLypodium. $\$ 1$. eUpolypodium. d. Pinnatae.

d. Stipes naked.

e. Stipes under $1 \frac{1}{2}$ c.M. long; fronds erect.

f. Costae forked.

f.f. Costae pinnate.

e.e. Stipes longer; fronds pendulous.

d.d. Stipes hairy.

c.c.c. Pinnae sharply toothed.

c.c.c.c. Pinnae bluntly toothed.
(60) P. cornigerum.

(61) P. inconspicuum.

(62) P. undosum.

(63) P. minutum. (64a) P. serrato-dentatum

(64b) P. Merritti. SIP

b.b. Fully developed fronds more than $121 / 2$ m.M. broad (*).

1. Texture herbaceous or papyraceous; fronds often pendulous.

+. Surfaces hairy.

*. Pinnae entire or slightly crenate to repand.

×. Pinnae very narrow, \pm 1 m.M. broad.

(65) P. subrepandulum.

$\times \cdot \times$. Pinnnae broader, \pm 2 m.M. broad.

t. Fronds short, to \pm 6 c.M. long. Sori distant.

(66) P. -subminutum onul

+.+. Fronds longer, $6-10$ c.M. long, sori copious, close.

(67) P. laneifolium.

*.*. Pinnae toothed or lobed on 1 or both sides.

$\triangle$. Pinnae incised on the upper side only, the apex entire or slightly toothed. (68) P. subsecundo-dissectum. Sif

$\triangle . \triangle$. Pinnae incised on both sides. (69) P. subfalcatum.

+. Surfaces \pm naked or glabrescent, but, the rachis often hairy.

$\diamond$. Sori superficial or slightly immersed.

+. Rachis naked.

(70a) P. repandulum.

+.+. Rachis hairy.

(70b) P. exfthrotrichum.

$\diamond . \diamond$. Sori deeply immersed. aris

t. Sori round.

×. Pinnae narrow, $\pm 1-2$ m.M. broad.

(71) P. brevifrons. Sip

$\times \cdot \times$. Pinnae broader, $\pm 4-8$ m.M. broad.

(72) P. papillosum.

+.+. Sori oblong.

(73) P. obliquatum.

(74) P. Schenkii.

(*) See also P. inconspicuum, $B l$. 
71. POLYPODIUM. $\mathbb{S} 1$. EUPOLYPODIUM. d. PINNATAE.

1.1. Texture chartaceous to coriaceous; fronds often erect. ( $\left.{ }^{*}\right)$

2. Pinnae \pm hairy or scaly beneath.

a. Fronds to $31 / 2$ c.M. broad.

$\beta$. Pinnae entire.

$\gamma$. Sori immersed.

(75) P. decipiens. SI $p 3$

$\gamma \cdot \%$. Sori superficial or hardly immersed.

ঠ. Stipes hairy.

(76a) P. mollicomum.

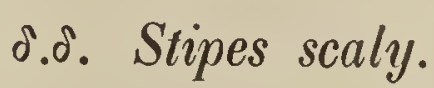
(76b) P. pseudoarticulatum.

\&. Surfaces scaly. (77) P. malaccanum.

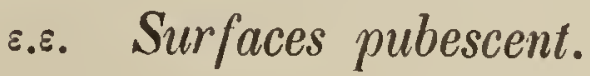

(78) P. brachyphlebium.

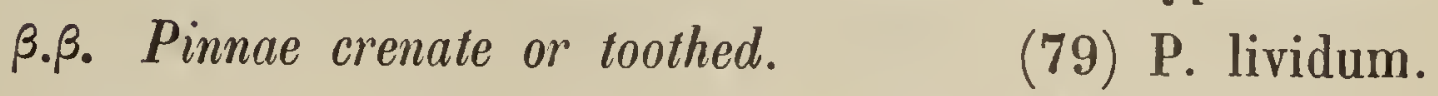
a.a. Fully developed fronds more than $31 / 2$ c.M. broad.

+. Fronds nearly sessile.

(80) P. khasyanum.

+.+. Fronds dislinctly stalked.

(81) P. celebicum.

2.2. Pinnae naked, the rachis often so.

3. Rachis naked.

4. Pinnae entire or slightly crenate.

5. Sori superficial.

6. Sori submarginal.

(82) decrescens.

6.6. Sori not submarginal.

*. Pinnae $\pm 11 / 4-1^{3} / 4$ c.M. long, slightly and irregularly crenate.

(83) P. Cesatianum.

\%. Pinnae $\pm 31 / 2-41 / 2$ C.M. long, entire.

(84) Curtisii.

5.5. Sori \pm immersed.

6'. Sori solitary and terminal on the pinnae.

(85) P. davalliaceum.

6'.6'. Sori otherwise, 3 or more to a pinna.

-. Pinnae sublanceolate, narrowed near the base. (86) P. duriusculum.

\%'.8'. Pinnae not sublanceolate, not narrowed near the base.

(') See also P. obliquatum, $B l$.

Fuiraes. 
71. polypodium. $\$ 1$ eupolypodium. d. pinNatae.

8'. Stipes very short; fronds to 2 c.M. broad.

(87) P. barathrophyllum.

'.8'. Stipes 5-8 c.M. long; fronds $21 / 2-4$ c.M. broad.

(88a) P. blechnoides.

8'.8'.8'. Stipes to 10 c.M. long; fronds more than 5 c.M. broad.

4.1. Pinnae toothed.

(88b) P. multicaudatum.

*. Sori round, confluent.

(89) P. sibarongae.

+. Sori oblong, distant.

(90) P. solidum. Sip 36

3.3. Rachis hairy on 1 or both sides.

p. Sori superficial or hardly immersed.

+. Fronds $\pm 10-15$ c.M. long. Sori slightly immersed.

(91) P. subobliquatum.

+. . Fronds $\pm 20-40$ c.M. long. Sori quite superficial.

p.p. Sori distinctly immersed.

q. Sori submarginal.

$\times$. Stipes winged.

(92) P. nutans.

$\times \cdot \times$. Stipes not winged.

(94) P. stenobasis.

q.q. 'Sori not submarginal.

r. Rims of the cavities elevated.

(95) P. craterisorum. oni

r.r. Rims of the cavities not elevated.

s. Pinnae subentive (96) P. decorum.

s.s. Pinnae crenate or toothed.

(97) P. Lobbianum. S $1 . p_{3}$

a.a. Most of the pinnae distonctly separate at the base.

b'. Sori solitary on the pinnae.

(98) P. clavifer. Sipz

$\boldsymbol{b}^{\prime} . \boldsymbol{b}^{\prime}$. Sori not solitary on the pinnae.

$c^{\prime}$. Fronds rather small, under 15 c.M. long, under $1 \frac{1}{2}$ c.M. broad.

(98a) P. conduplaturans.

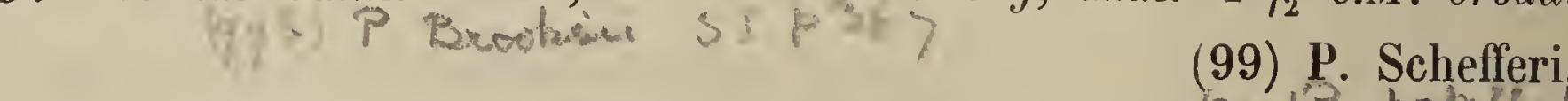

$\boldsymbol{c}^{\prime} \cdot \boldsymbol{c}^{\prime}$. Fronds larger, more than 15 c.M. long, more than $11 /{ }_{2}$ c.M. broad.

$\boldsymbol{d}^{\prime}$. Pinnae entire, crenate or undulate.

$\boldsymbol{e}^{\prime}$. Pinnae entive, blunt. Stipes clothed with reddish hairs.

(100a) P. venulosum. Sip? $B G G$. 


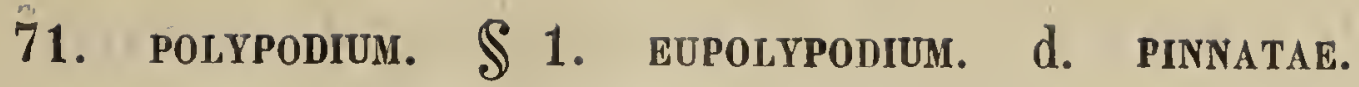

$\boldsymbol{e}^{\prime} \cdot \boldsymbol{e}^{\prime}$. Pinnae undulate, subacute. Stipes clothed with fuscous hairs.

(100b) P. macrum.

d'd'. Pinnae serrate or toothed.

*. Pinnae adnate at the base. (101a) P. halconense.

*.*. Pinnae not adnate at the base. (101b) P. harpophyllum.

* (55) P. streptophyllum, Bk., Journ. of Bot., XVII, 42.

Fronds subsessile, densely tufted, linear, 7-10 c.M. long, \pm 5 m.M. broad, cut down to the rachis into very numerous, ligulate, entire, slightly twisted, adnate, contiguous pinnae $\pm 1 / 2$ m.I. broad, with a single medial vein; lower pinnae gradually reduced. Texture firm; colour green; surfaces naked. Sori solitary and terminal on the pinnae.

Borneo, Singapore.

(56) P. triangulare, Scort., Bedd., Journ. of Bot., XXV, 324, tab. GCLXXVIII, fig. 1.

Rhizome erect, short, scaly. Fronds tufted, subsessile, linear, narrowed at both ends, $15-20$ c.M. long, $\pm 5 \mathbf{~ m . M . ~ b r o a d , ~ c u t ~ d o w n ~ t o ~ t h e ~ r a c h i s ~ i n t o ~}$ distichous, obliquely triangular pinnae; barren pinnae obtuse, the fertile ones acute; upper surface convex, lower flat. Texture coriaceous; surfaces naked, the lower whitish; veins hidden. Sori solitary, terminal, sunk in a deep pit near the apex of the higher pinnae, the edge on both sides of the sorus folded inwards.

Malacca.

* (57) P. subtriangulare, v.A. v. R., Bull. Dép. Agr. I.N., 1908, XVIII, 20.

Fronds tufted, subsessile, linear, narrowed at both ends, $71 / 2-15$ c.M. long, \pm 5 m.M. broad, cut down to the rachis into distichous, oblique, oblong, blunt pinnae $1-1 \frac{1}{2}$ m.M. broad, dilated at the base; upper surface convex, lower flat; edge of the barren pinnae slightly recurved. Texture coriaceous; surfaces naked, but the costa slightly clothed beneath with scattered, reddish, deciduous hairs; veins hidden. Sori confined to the upper half of the frond, solitary and terminal on the segments, deeply sunk in longitudinally oblong cavities, occupying the upper half of the segments, the inner edge of each cavity forming with the much recurved, meeting lateral edges a subcylindrical hollow quite enclosing the sorus when young.

Amboyna (Boerlage). 
(58) P. musgravianum, BR., Journ. of Bot., XXVIII, 108.

Stipes tufted, very slender, nearly nảked, 1-2 $1 / 2$ c.M. long. Fronds linear, $21 / 2-4$ c.M. long, 3-51/2 m.M. broad, cut down to the rachis into ovate, adnate, erecto-patent pinnae. Texture firm; surfaces naked. Sori large, round, superficial, solitary at the base of the pinnae.

New Guinea.

(59) P. Conjunctisorum, Bks., Ann. of Bot., VIII, 129.

Fronds linear, $10-13$ c.M. long, $\pm 7 \frac{1}{2}$ m.M. broad, simply pinnate, narrowed gradually at the base. Pinnae ovate-linear, entire, obtuse, contiguous, dilated at the base. Texture rigidly coriaceous; veins hidden. Sori large, subglobose, superficial, solitary at the base of the pinnae.

New Guinea.

(60) P. connigerum, Bk., Hk. Bk., Syn. Fil., 508.

Fronds tufted, subsessile, erect, ligulate, 7-10 c.M. long, 5-7 m.M. broad, pinnate. Pinnae 20-30-jugate, diminishing in size towards both ends of the frond, almost triangular, subacute, with the upper edge repand. Texture subcoriaceous; surfaces naked; veins 1 to each pinna, forked, falling far short of the apex. Sori large, round, 1 to each pinna, close to the rachis.

Malacca; Ceylon.

* (61) P. inconspicuum, Bt., Rac., Flor. Btz., I, 90 ; P. parvu lum, Bl. (not Bory), Flor. Jav., II, 187, tab. LXXXVII, C.

Rhizome erect or ascending, the scales narrow, lanceolate. Stipes under 1 c.M. long. Fronds commonly subsessile, 5-20 c.M. long, 6-12 (rarely to 30) m.M. broad, linear-lanceolate, narrowed towards both ends, cut down to the rachis into oblong to linear, erecto-patent or subspreading pinnae. Pinnae to $2^{1 / 1}$ m.M. broad, dilated at the base, the largest or longest ones repand or crenate, the point bluntish. Texture herbaceous to subcoriaceous; rachis and both surfaces naked or deciduously hairy; veins simple. Sori 1-6 (rarely to 12) to a pinna, medial or costal.

Sumatra, Java, New Guinea, Philippines.

(62) IP. Indosum, Bk., Journ. of Bot., XXVIII, 108.

Stipes naked, wiry, $21 / 2-4$ c.II. long. Fronds pendulous, lanceolate, simply pinnate, $12-15$ c.M. long, $10-12 \frac{1}{2}$ m.M. broad. Pinnae numerous, adnate, not approximate, subtrapezoidal, 2 - $4 \mathrm{~m}$.M. broad, obtuse, deeply crenate 
71. Polypodum. $\$ 1$ eUpolypodium. d. Pinnatae.

especially on the upper edge. Texture coriaccous: surfaces naked; veins hidden. Sori round, superficial, filling up nearly the whole under surface of the pinnae.

New Guinea.

* (65) P. minutum, Bt., Rac. Flor. Btz., 94; Bl., Flor. Jav., II, 188, tab. LXXXVII, D.

Rhizome erect, the scales very small. Stipes tufted, 4-8 m.M. long, clothed with fine, long, soft, whitish hairs. Fronds 3-8 c.M. long, 5-10 m.M. broad, linear-lanceolate, narrowed towards both ends. Pinnae oblong, $1 / 2-11 / 2$ m.M. broad, to \pm 6 m.M. long, blunt, erecto-patent, slightly decurrent, hardly rrenate, the lower ones reduced. Texture thin-membranaceous, hyaline; surfaces and margin hairy; veins few, simple, short. Sori $1-5$ to a pinna, alternate, \pm costal.

Malaya.

* (64a) P. serrato-dentatum, v. A. v. R., Bull. Dép. Agr. I. N., 1908, XVIII, 20.

Rhizome short-creeping, the scales \pm linear-subulate, pale-brown. Stipes approximate, 1-2 c.M. long, clothed with short, spreading hairs. Fronds linear-lanceolate, $\pm 10-15$ c.M. long, 8-12 m.M. broad. Pinnae triangular, erecto-patent, slightly confluent, 3-4 m.M. broad at the base, the apex acute, the edge strongly recurved and conspicuously serrate-dentate with \pm 4 oblique teeth on each side; higher and lower pinnae diminishing gradually in size, Texture rigidly coriaceous; upper surface dark-coloured, lower paler, naked; rachis black, hairy; veins immersed, 1 to each tooth, forked at the base with a short, anterior branch, the apex of the principal branch black like the costa (when seen towards the light). Sori small, oblong when young, 1 to each tooth, terminal on the short anterior veinlets, subcostal.

? Java (True habilat unknown, Forbes, No. 244).

$(64 b)$

P. Menoitti, Copel., Philipp. Journ., I Suppl., 255.

Rhizome short-creeping, stout, clothed with lanceolate, glanduloso-ciliate, fulvo-ferrugineous scales. Stipes 1-2 c.M. long, clothed like the whole plant with short, scattered, hyaline, subglandulous hairs. Fronds $10-17$ c.M. long, \pm 1 c.I. broad, hardly narrowed at the apex. Segments oblong, often obtuse, decurrent-confluent at the base, the edges obtusely toothed with $1-3$ teeth on each side. Texture firm-herbaceous; veins simple, inconspicuous. Sori 2-5 to a segment, round, superficial, costal, sometimes confluent.

Mindoro. 
* (65) P. subrepandulum, Christ, Ann. Btz., XX, 119.

Rhizome short, erect, scaly. Stipes tufted, short, to 2 c.M. long, clothed with long, spreading, brownish hairs. Fronds $6-10$ c.M. long, $1 \frac{1}{2}-2$ c.M. broad, acuminate, narrowed at the base, pinnate. Pinnae subpatent, decurrent, slightly confluent at the base, $\pm 2 \mathrm{~m}$.M. apart, $\pm 12-25$ on each side, \pm 1 m.M. broad, crenate, rather slightly wavy, the apex subacute. Texture herbaceous, firm; rachis and surfaces short-hairy; costulae pinnate; veins simple. Sori few, 1-2 on each side of the costules, slightly immersed, terminal on the veins.

Borneo.

* (66) P sultminutum, v. A. v. R.; ? P. minutum, Bk. (not Bl.), Hk. Bk., Syn. Fil., 328; ? P. parvulum, Bedd., Ferns S.I., tab. CLXVI.

Rhizome erect, clothed with lanceolate, brown scales. Stipes tufted, 4-8 m.M. long, clothed with spreading, long, soft, pale-ochraceous hairs. Fronds 3-6 c.M. long, lanceolate, acuminate, $1_{12}^{1}-2$ c.M. broad. Pinnae \pm 2 m.M. broad, linear, \pm erecto-patent, bluntish, slightly repando-crenate, subcontiguous, \pm decurrent, the lower ones gradually reduced. Texture papyraceo-herbaceous; surfaces \pm hairy like the stipe; veins simple, short. Sori $2-5$ on each side, distant, alternate, superficial, medial between the midrib and edge.

Java (Forbes).

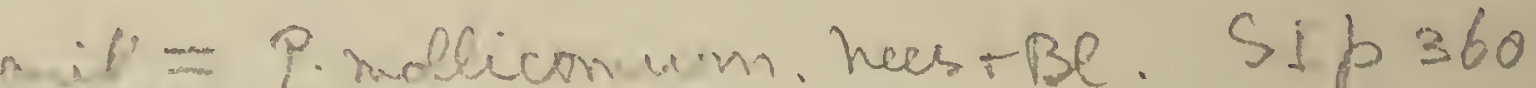

* (67) IP. Iancitolium, v. A. v. T., Bull. Dép. Agr. I. N., 1908, XVIII, 21.

Like P. subminutum, $v$. A. $v . R$. but the hairs shorter, white or palereddish, the fronds $6-10$ c.M. long, the pinnae semetimes nearly horizontal. Sori copious, close, occupying the whole under surface of the pinnae.

Sumatra (Hagen).

(68) P. subsecundo-dlissectum, zoll., Hk. Bk., Syn. Fil., 328; (? P. subfalcatum, $B l$., var. semiintegrum, Copel., Philipp, Journ., II, 158).

Stipes tufted, $1 / 2-1 \frac{1}{2}$ c.M. long. Fronds $10-20$ c.M. long, $2-21 / 2$ c.M. broad, cut down nearly to the rachis into numerous, close, subdimidiate, oblong pinnae, which are quite entire or slightly toothed towards the point on the posterior side, but cut down nearly to the midrib on the anterior side into 4-6 oblong lobes. Texture papyraceo-herbaceous; both surfaces clothed with soft, spreading, yellowish hairs; veins abbreviate. Sori close to the midrib. - Copeland's plant in very small, under 10 c.M. long.

Java,? Mindoro; New Caledonia. 
71. polypodium. $\mathbb{S} 1$. eupolyrodium. d. pinnatae.

- 69) P. subfalcatum, Bt., Rac., Flor., 94; Bl., Flor. Jav., II, 186, tab. LXXXVII, A-B; Bedd., Ferns Br.I., II, tab. CLXXXIX, A.

Rhizome erect, clothed with short, inconspicuous scales Stipes densely tufted, 1-2 c.M. long, more or less clothed with soft, spreading, reddish hairs. Fronds linear-lanceolate, 8 -20́ c.M. long, $1 \frac{11}{2}-21 / 2$ c.M. broad, narrowed towards both ends. Pinnae \pm erecto-patent, contiguous, straight or falcate, slightly decurrent at the base, the edge distinctly, bluntly or sharply toothed, the apex bluntish or acuminate; lower pinnae gradually reduced. Texture papyraceo-herbaceous; surfaces slightly and the rachis more densely hairy like the stipe; veins simple. Sori superficial, $\pm 3-6$ on each side, 1 to each tooth, rather distant.

Malaya; North. India, South. China.

* (70a) D. repandulum, Mett., Hk. Bk., Syn. Fil., 328; P. oblv- J F.MS qualum, Hk., Spec. Fil., IV, 190, p. p.; P subfulcalum, Bl., var. glabrum., Bedd., Ferns Br I., I, tab. LXXVI; II, tab. CLXXXIX, B ; Ctenopteris repandula, Kze, (oldest name).

Stipes tufted, very short, naked. Fronds $10-15$ c.M. long, $21 / 2-4$ c.M. broad, cut down to the rachis throughout into erecto-patent, blunt, repandocrenate pinnae 1-2 m.m. broad. Texture firm-herbaceous; rachis and both surfaces \pm naked; veins simple. Sori distant, slightly immersed, terminal on the veins, filling nearly the whole space between the midrib and edge.

Amboyna, Borneo; Ceylon.

(70b) I. enythmotrichum, Copel., Philipp. Journ., I, Suppl., 160 , tab. XX.

Rhizome short-creeping, clothed with short, subciliate, deciduous, fuscous scales. Stipes approximate, 2-5 c.M. long, densely clothed like the rachis with red-purple hairs. Fronds pendulous, $30-50$ c.M. long, $21 / 2-4$ c.M. lroad. Pinnae very numerous, spreading, $\pm 2 \mathrm{~m}$.M. broad, hardly dilated at the base, entire, obtuse, the lower reduced gradually to mere teeth. Texlure papryaceo-herbaceous; surfaces glabrescent; costae sinuate (flexuose?) lowards the apex; veins simple, erecto-patent. Sori oblong, nearly parallel to the costae, to 10 on each side, subimmersed, the edges of the cavities slightly raised.

Mindanao, Mindoro. 
71. polypodium. $\$ 1$. eupolypodium. d. pinnatae.

(71) P. Drevifroms, Scort., MS.; P. repandulum, Mett., var. malay. anum, Bedd., in Journ. of Bot., XXXI, 226.

Like $\mathrm{P}$. repandulum, Mell., but the sori deeply sunk in cavities with raised margins.

Malacca.

* (72) P. papöllostum, Hit., Rac., Flor. Btz., I, 90; Bl., Flor. Jav., II, 191, tab. LXXXIX, A-B: Hk., Icon. Pl., X, tab. CMXLVI; Christ, Farnkr. d. Erde, fig. 234.

Rhizome horizontally creeping, the scales lanceolate, acute. Stipes scattered, \pm 5-20 c.M. long, erect, slender, rigid, naked. Fronds linear-lanceolate, $20-60$ c.M. long, 4-8 c.M. broad, cut down to the rachis into numerous spreading pinnae. Pinnae linear, blunt, entire or crenate to toothed, 4-8 m.M. broad, dilated at the base, the lowest not reduced. Texture papyraceo-herbaceous, thin; rachis and both surfaces naked; veins conspicuous, forked. Sori in 1 row on each side near the edge, deeply immersed, much prominent on the upper surface so as to form conspicuously elevated, conical or saccate papillae.

Malaya. Luzon.

* (73) P. olbliquatum, Bt., Rac., Flor. Btz., I, 93; Bl., Flor. Jav., II, 181, tab. LXXXV, B; Bedd., Ferns S.I., tab. GLXVII.

Rhizome short, the scales lanceolate, ciliate. Stipes tufted, $21 / 2-71 / 2$ c.M. long, rigid, naked or pilose. Fronds $20-70$ c.M. long, $\pm 21 / 2-6$ c.M. broad, linear-lanceolate, cut down to the rachis into entire or slightly wavy, close, subspreading, bluntish pinnae $21 / 2-4 \mathrm{~m} . \mathrm{M}$. broad, dilated at the base, the lower ones growing shorter, reduced, deltoid, very blunt. Texture herbaceous to subcoriaceous; rachis naked or hispid; surfaces naked; veins simple. Sori elliptical, oblique, $4-6$ on each side of the costae, immersed, somewhat prominent on the upper surface, the edges of the cavities distinctly raised and covering the sori when young.

Malaya; Ceylon, South India.

(74) P. Selnenkiil, Haser., Journ. of Linn. Soc, Bot. XVI, 31 ; (? P. obliquatum, $B l$. .).

Rhizome thick, horizontal, densely clothed with slender, brown scales. Stipes clustered, $5-8$ c.M. long, brown, pubescent, firm, erect. Fronds $15-30$ c.M. long, $3 \frac{1}{2}-5$ c.M. broad, oblong, pinnate, narrowing gradually to both 
71. polypodum. $\mathbb{S} 1$. eupolypodium. d. pinnatae.

ends. Pinnae numerous, $11_{1}^{1 / 2}-21 / 2$ c.M. long, $31 / 2-5$ m.M. broad, linear, obtuse, entire, broadened and nearly confluent at the base, the lowest ones small, triangular. Texture membranaceous; rachis pubescent; surfaces naked; veins simple, free, falling short of the margin. Sori deeply immersed, oblong, 4-8 in a row on each side of the midribs, oblique, nearly covered by the recurved margins of the depressions.

\section{Philippines.}

* (75) P. decipiens, Rett., Rac., Flor. Btz., I, 93; P. cryptosorum, C. Chr., Ind. Fil.

Rhizome short-creeping, densely clothed with lanceolate-subulate, ciliate, black-brown scales. Stipes tufted, short or 1-2 c.M. long, densely furnished with long, spreading, reddish hairs. Fronds linear-lanceolate, 10 - 40 c.M. long, $1^{1 / 1}-2^{1 / 2}$ c.M. broad, narrowed towards both ends, cut down nearly to the costa into linear or lanceolate, nearly close, entire, blunt lobes. Texture coriaceous, rather fleshy; surfaces thinly beset with red-brown hairs, the midrib more densely; veins zigzag throughout or only at the base; veinlets translucent, $5-14$-jugate, simple or the lower forked. Sori submarginal, deeply immersed in elliptical cavities.

Malaya.

* (76a) P. mollicomum, Nees SPl., Rac., Flor. Btz., I, 91 ; Bl., Flor. Jav., II, 184, tab. LXXXVI, B ; - var. fuscatum; P. furcatum Bl., l.c., tab., LXXXVI, G; P. fuscatum, Bl., l.c , 185; C. Chr., Ind. Fil.; Bedd., Ferns Br. I., II, tab. CCCXXIV.

Rhizome erect or suberect, densely clothed with shining, adpressed, lanceolate scales. Stipes tufted, 2-8 c.M. long, densely purveyed with soft, spreading, reddish hairs. Fronds $7-30$ c.M. long, $1^{1 / 4}-3$ c.M. broad, cut down nearly or quite to the rachis throughout into close, entire, blunt pinnae 1-4 m.M. broad, the base often dilated, the lower ones shorter and broader, close. Texture more or less coriaceous; rachis and both surfaces hairy; veins simple, obscure. Sori superficial,' forming a close row on each side of the midribs, at length often filling up nearly the whole under surface.

Var. fuscatum: Lower pinnae distant, narrowed towards the base, the very base mostly much dilated again.

Malaya.

(76b) P. pseudoamticulatum, Copel., Philipp. Journ., I, Suppl., 160 , tab. XVIII. 
Rhizome short-creeping, clothed with narrow, black, ciliate scales. Stipes $2-4$ c.M. long, puberulous. Fronds $10-20$ c.M. long, $1 \frac{1}{2}-3 \frac{1}{2}$ c.M. broad, acuminate or caudate, the rachis black, short-pubescent. Pinnae linear, spreading, often separated by more than their own breadth, the longest \pm 2 m.M. broad, blunt, entire, dilated at the base, the lower reduced, more distant, hardly decurrent. Texture coriaceous; under surface clothed with more or less deciduous, reddish hairs; veins hidden, simple. Sori nearly terminal on the veins, nearly parallel to the costae, hardly immersed, \pm 22 on the longest pinnae.

Luzon.

(77) P. malaccanum, Bh., Ann. of Bot., VIII, 129.

Stipes densely lufted, slender, scaly, $2^{1 / 2}-5$ c.M. long, the scales brown, subulate, spreading, deciduous. Fronds lanceolate, $12-15$ c.M. long, $1 \frac{1}{4}-1 \frac{1}{2}$ c.M. broad. Pinnae multijugate, linear, entire, obtuse, the base dilated, the lower ones smaller. Texture moderately firm; surfaces covered with subulate, brown scales; veins simple, erecto-patent, 6-8-jugate in the central pinnae. Sori round, superficial, in 1 row on each side of the costae.

Malacca.

(78) Dorehyphlebium, HIs., Ann. of Bot., VIII, 129.

Stipes short, slender, tufted, clothed with short, spreading, subulate scales. Fronds lanceolate, \pm 15 c.M. long, $\pm 1 \frac{1}{2}-1^{3} / 4$ c.I. broad, narrowed at the base. Pinnae contiguous, multijugate, linear, obtuse, entire, $\pm 21 / 2 \mathrm{~m}$. M. broad, dilated at the base. Texture moderately firm; surfaces pubescent; veins short, erecto-patent, simple. Sori semiglobose, superficial, in 1 row on each side of the costae.

Sumatra.

(79) IP. Lividum, Mett., Ann. Mus. Bot. L. B., II, 221.

Rhizome short, subascending, the scales membranaceous, ferrugineous, oblong-lanceolate. Stipes short, clothed with short, rigid hairs. Fronds $5-15$ c.M. long, $\pm 11_{4}^{1 /}-1{ }_{1}^{1}$, c.M. broad, lanceolate, narrowed gradually towards both ends, the edge pinnatifid nearly to the costa. Segments numerous, spreading, decurrent, confluent, linear-oblong, the apex narrowed, obtuse, crenate; lowest segments decurrent upon the stipe. Texture thinly coriaceous; colour bluish-olivaceous; under surface hairy like the stipe, the hairs glanduliform; 
71. polypodium. $\$ 1$. eupolypodiun. .d. pinnatale.

veins subimmersed. Sori immersed, medial between the costulae and the margin.

Java.

(80) P. k thasyantwn, He., Hk. Bk., Syn. Fil., 525 ; Hk., Icon. Pl., X, tab. CMXLIX; Bedd., Ferns Br.I., II, lab. CLXXIII.

Stipes tufted, very short, fringed wilh soft hairs. Fronds 30 c.M. or more long, \pm 4 c.M. broad, flaccid, cut down nearly to the costa into linear-oblong, entire or slightly undulate, blunt lobes 5-8 m.M. broad. Texture thick, coliaceous; rachis and both surfaces hairy; veins simple. Sori sunk, in rows of 4-6 on each side of the costulae, elliptico-rotundate.

Malacca; Khasya, Assam.

* (81) P. celelicum, Hü.; Flor. Jav., II, 179, tab. LXXXIV, B.

Rhizome short, woody, reddish-brown, scaly, the scales densely imbricate, membranaceous, scariose, hairy, pale-reddish-brown. Stipes 7-15 c.M. long, or shorter, approximate (tufted, Hk. Bk., Syn. Fil., 550), reddish-brown, clothed with brownish, spreading hairs like the rachis. Fronds commonly nutant, 20-40 c.M. long, 5-8 c.M. broad, lanceolate, narrowed towards both ends. Pinnae close, nearly horizontal, $51 \%$-5 m.M. broad, numerous, entire, bluntish, subconfluent at the base, the lower ones reduced. Texture coriaceous; costae indistinct, slightly hairy beneath like the margin; veins simple. Sori immersed, distant, 8-12 on each side, nearer the edge than the midrib, \pm oblong, the cavities ciliate at the margin, the ciliae covering the sori when young

Malaya.

(82) P. Aecrescens, Christ, Ann. Btz., XIX, 35; Philipp. Journ., I, Suppl., 159, tab. XVII.

Rhizome oblique, short-creeping, clothed with brown, ovate, acute scales. Stipes short, brown like the rachis. Fronds approximate, nearly tufted, 20 c.M. long (incl. the stipe). Pinnae 15-20 on each side, often unequal, 2 c.M. long, 2 m.M. broad, spreading, blunt, not close, connected at the base by a narrow wing; lower pinnae suddenly reduced so as to form an undulate wing to the rachis. Texture papyraceo-coriaceous; surfaces naked, under side \pm glaucous; veins hidden. Sori \pm 9 on a side, round, submarginal.

Celebes, Mindoro, Luzon.

* (85) P. Cesatianumm, 1Bk., Journ. of Bot., XVII, 42; P. papillosum, Ces. (not Bl.), Fel. di Bor., 25. 
Rhizome wide-creeping, woody, the scales dense, brown, small, narrowed gradually from a rounded, peltate base towards the acuminate point. Stipes scattered, brownish, naked, glossy, wiry, slender, \pm 10 c.M. long. Fronds \pm lanceolate, $15-20$ c.M. long, $21 / 2-31 / 2 \quad$ c.M. broad, narrowed towards both ends, or the base nearly as broad as the central part of the frond, the edge cut down nearly to the costa. Pinnae spreading, 3-5 m.M. broad, the apex blunt, the edge slightly, not regularly crenate, the base dilated, the sinuses as broad as the lobes. Texture coriaceous; surfaces naked; costa prominent below; costulae distinct, \pm wavy; veins oblique, forked, free or united near the base by the arched anterior veinlets, which are nearly parallel to the costulae and bear a very short soriferous branch directed towards the edge. Sori round, small, superficial, $\pm 6-8$ on each side, nearer the costulae than the edge, 1 between each pair of veins. - The description is taken from a specimen gathered by Hallier ( No. 3512) and determined by Christ (Ann. Btz., XX, 120).

Borneo.

(84) P. Curtisii, Bris., Journ. of Bot., XIX, 567.

Rhizome wide-creeping, the scales dense, large, lanceolate, brown, membranaceous. Stipes brown, naked, $5-8$ c.M. long. Fronds oblanceolate, $20-25$ c.M. long, 7-9 c.M. broad at the middle, cut down nearly or quite to the rachis. Pinnae close, entire, linear, $21 / 2-4$ c.M. long, $\pm 4-5 \mathrm{~m}$. M. broad above the dilated deltoid base; lower pinnae reduced so as to form a repand wing to the rachis. Texture subcoriaceous; surfaces naked; veins hidden. Sori round, medial, superficial, 6-9 on each side of the costa in the fully developed central pinnae.

Sumatra.

(85) P. davalliacenm, Mrelle \& Bh., Journ. of Bot., XXVIII, 108.

Rhizome short-creeping, the scales small, brown, ovate-lanceolate. Stipes wiry, naked, $2 \frac{1}{2}-5 \quad$ c.M. long. Fronds lanceolate, simply pinnate, 15-20 c.M. long, to $21 / 2$ c.M. broad. Pinnae adnate, lanceolate or oblique-cuneate, $1^{1} / 2-21 / 2$ m.M. broad, entire or obscurely crenate on the upper edge. Texture coriaceous; surfaces naked; veins hidden. Sori solitary, immersed, subterminal on the pinnae, the edges of the latter folded round them.

New Guinea.

(86) P. duriusculum, Christ, Ann. Btz., XV, 151, tab. XVI, fig. 
71. polypodum. $\mathbb{S} 1$. eupolypodium. d. Pinnatae.

Rhizome short. Fronds densely tufted, \pm 10 c.M. long, lanceolate, acuminate. Pinnae erecto-patent, \pm 1 c.M. long, 5-6 m.M. apart, lanceolate, slightly crenate, the base narrowed and more or less decurrent, the apex blunt; upper and lower pinnae reduced. Texture very firm; surfaces naked, darkcoloured; veins hidden. Sori on the broadest part of the pinnae, $3-6$ to a pinna, immersed, confluent.

Celebes.

* (87) P. Warathrophyllum, Bk., Journ. of Bot., XXIX, 107.

Rhizome erect. Stipes tufted, very short. Fronds lanceolate, to \pm 30 c.M. long, $1 \frac{1}{4}$-2 c.M. broad, narrowed gradually towards both ends, cut down to a narrow wing into entire, linear-oblong segments $\pm 2 \mathrm{~m}$.M. broad above the dilated base. Texture thick, flexible; surfaces naked or the margin ciliate; veins hidden. Sori medial, semiglobose, $6-8$ in a row on each side of the costae, sunk in distinct, round cavities, which do not look as papillae on the upper surface of the frond.

Borneo.

(88a) P. Dlechnoides, Hk., Hk. Bk., Syn. Fil., 331; P. contiguum, Brack., Expl. Exp., XVI, tab. II, fig. 1; Grammitis blechnoides, Grev., (oldest name).

Rhizome stout, the scales dense, linear. Stipes $5-8$ c.M. long, rigid, erect, naked. Fronds $20-30$ c.M. long, $21 / 2-4$ c.M. broad, cut down very nearly to the rachis throughout. Fertile pinnae confined to the upper half of the frond, longer and narrower than the barren ones, which are bluntish, $\pm 3-3^{1} / 2$ m.M. broad, growing gradually shorter and broader downwards. Texture coriaceous; rachis and both surfaces naked. Sori oblong, immersed, in rows near the midribs.

Java, Borneo, New Guinea; Queensland, Polynesia.

(88b) P. multicaudatum, Coped., Philipp. Journ., I, Suppl., 160, tab. XIX; P. obliquatum, Copel. (not Bl.), Polypod. Philipp., 122.

Rhizome short-creeping, clothed with rather long, ciliate, fuscous scales. Stipes approximate, to 10 c.M. long, sparingly clothed with reddish-black hairs. Fronds 50-60 c.M. long, often more than 6 c.M. broad, the rachis naked. Pinnae erecto-patent, narrowed gradually from the rather suddenly dilated base towards the caudiform apex, the margin entire; lower pinnae reduced. Texture subcoriaceous; surfaces naked; veins simple, oblique. Sori often restricted to 
71. Polypodum. $\$ 1$ eupolypodum. d. pinnatae.

the central part of the pinnae, 4-1.0 on each side of the costae, reaching nearly from the midrib to the margin, immersed, the margins of the cavities conspicuously crateriform.

Mindanao.

(89) P. sibarongae, Christ, Ann. Btz. XIX, 36.

Rhizome short, oblique, clothed with thin, subulate, brown scales. Stipes short, tufted. Fronds linear-lanceolate, \pm 1 s c.M. long, $\pm 11 / 2$ c.M. broad, acuminate. Pinnae numerous, 30-40 on each side, often opposite, 8 m.M. long, 5 m.M. broad, oblong, lower deltoid, higher toothed, the teeth deep, large, \pm 3 on a side, deltoid, acute. Texture coriaceous; rachis ebeneous, rigid; colour dark; surfaces naked, under side glaucous; veins hidden. Sori medial, large, round, confluent, 1 to each tooth.

Celebes.

P. Solidum, Mett., Hk. Bk., Syn. Fil., 324; Mett., Farng., I, Polypod., tab. I, fig. 1-3; Ctenopteris solida, Kze, (oldest name).

Rhizome stout, creeping, clothed with lanceolate, ferrugineous seales. Stipes $21 / 2$ c.M. long, firm, erect, naked. Fronds 10-20 c.M. long, 2 c.M. broad, cut down nearly to the midrib into close, distinctly toothed, bluntish lobes \pm 5 m.M. broad. Texture coriaceous; both surfaces naked; veins once or more times forked. Sori oblong, subimmersed, $1-4$ on each side, medial between the costulae and the margin.

Java, Philippines.

(91) P. subololiquatum, Cherst, Bull. Herb. Boiss., VI, 197; P. obtusissimum, C. Chr., Ind. Fil.

Rhizome short-creeping, slightly scaly. Stipes approximate, 1-2 c.M. long, brown, clothed like the rachis with short, cinnamon-coloured hairs. Fronds 10-15 c.M. long, \pm 2 c.M. broad, lanceolate-oblong. Pinnae obtuse, alternate, \pm 2 m.M. broad, dilated at the base, remote, reduced towards the ends of the frond. Texture coriaceous; colour rufescent; surfaces naked; veins oblique, simple, inconspicuous. Sori 4--6 on each side, medial, oval, hardly immersed, the margins of the cavities not crateriform.

Luzon.

* (92) P. nutams, BH., Rac., Flor. Btz., I, 92; Bl., Flor. Jav., II 182, tab. LXXXVI, A. 
Rhizome creeping, clothed with dark-brown, narrow, lanceolate, ciliate scales. Stipes 2-8 c.M. long, provided with very short reddish hairs. Fronds lanceolate, $20-40$ c.M. long, $1 \frac{1}{2}-3$ c.M. broad, narrowed towards both ends, the edge cut down to the rachis into entire, blunt pinnae $1-3 \mathrm{~m}$.M. broad. Texture coriaceous; surfaces \pm naked; rachis hairy; veins hidden, simple or forked. Sori round (elliptical when young), in 1 row on each side of the midribs, at length filling up the whole under surface.

Malacca, Sumatra, Java; New Caledonia.

(93) P. Leysii, B1e., Journ. of Bot., XVII, 66.

Rhizome short-creeping, the scales small, dense, dark-brown, lanceolate. Stipes winged nearly or quite down to the base, $2^{1} / 2-5$ c.M. long to where the pinnae begin. Fronds lanceolate, 12̆-25 c.M. long, $21 / 2-3^{1} / 2$ c.M. broad above the middle, narrowed gradually from the middle to the base, cut down to the rachis into very numerous, crowded, adnate, linear, subentire or slightly repand pinnae $2-21 / 2$ m.M. broad. Texture firm; surfaces naked; rachis minutely pubescent beneath; veins simple, erecto-patent, 10-12-jugate in the central pinnae, not reaching the margin. Sori terminal on the veins, globose, submarginal, distinctly immer'sed.

Sulu Islands.

(94) Ftendioasis, Bk., Ann. of Bot., VIII, 130.

Rhizome hardly creeping, the scales lanceolate, brown, membranaceous Stipes nearly naked. Fronds lanceolate, 15-25 c.M. long, 3-4 c.M. broad, narrowed at the base. Pinnae linear, multijugate, $\pm 21 / 2$ m.M. broad, obscurely crenate, dilated and adnate at the base. Texture coriaceous; surfaces naked; rachis greenish, pubescent; veins simple, obscure. Sori in 1 row on each side of the costae, submarginal, deeply immersed.

Sumatra.

(95) P. contevisomum, Marm., Journ. of Linn. Soc., Bot., XVI, 51; (? P. celebicum, Bl.).

Rhizome densely clothed with brown, lanceolate scales. Stipes clustered, 1-4 c.M. long, hirsute with brown hairs, firm, erect. Fronds 20-30 c.M. long, $3 \frac{1}{2}-5$ c.M. broad, oblong or oblong-oblanceolate, tapering gradually to both ends, pinnate. Pinnae numerous, linear, \pm 5 m.M. broad, obtuse, entire, dilated and \pm confluent at the base, passing below into the narrow, lobed wing of the stipe. Texture membranaceous; rachis pubescent; surfaces naked; 
veins simple, not quite reaching the margin. Sori confined to the upper pinnae, immersed, oval, $5-10$ in a row on each side of the midrib, \pm medial between this and the margin, the edge of each cavity forms a projecting ring, but does not cover the sorus.

Philippines.

(96) P. Aecorum, Brack., Hk. Bk., Syn. Fil., 351; Bedd., Ferns S.I., tab. CCXXXVIII, A; P. mutans, J. Sm. (not Bl.), Journ. of Bot., III, 394.

Rhizome short, creeping, densely ferrugineo-squamose. Stipes approximate, $2^{1 / 2}$ c.M. or less long, naked. Fronds $15-30$ c.M. long, $1 \frac{1}{4}-21 / 2$ c.M. broad, linear-lanceolate, narrowed towards both ends, cut down nearly or quite to the rachis into numerous pinnae. Central pinnae longest, rather spreading, linear-oblong, $\pm 21 / 2-3 \mathrm{~m} . M$. broad, blunt, the lower ones gradually becoming blunter, shorter and broader. Texture coriaceous; surfaces naked, or the rachis hispid; costulae and veins indistinct. Sori oblong, $2-8$ on each side, medial between the costulae and the edge, moderately filling up the space between both, apical on the short veins, sunk in hairy cavities.

Malaya; Ceylon, Polynesiu.

(97) D. Lobbianum, Hks., Spec. Fil., IV, 226 (not V, 100), tab. CCLXXVIII, B ; P. pediculatum, Bk., C. Chr., Ind. Fil.; P. inarticulatum, Copel., Philipp. Journ., I, Suppl., 160.

Rhizome short-creeping, stout, densely scaly. Fronds subsessile, 10-15 c.M. long, 2-3 c.M. broad, lanceolate-acuminate. Pinnae numerous, close, $1-1 \frac{1}{2}$ m.M. broad, the edge with distinct, rounded crenations or teeth; lower pinnae gradually reduced. Texture coriaceous; surfaces naked; rachis wiry, ebeneous, sparingly and deciduously hairy; veins simple, indistinct, 1 to each crenation, short. Sori immersed, \pm medial, 1 to each vein.

Borneo, Mindanao.

(98) P. Clavifer, Mk., Hk. Bk., Syn. Fil., 354; P. claviferum, Hk., Becc., Mal., III, 47; Grammitis clavifer, Hk., $2^{\text {nd }}$ Cent. of Ferns, tab. V.

Stipes densely tufted, very short. Fronds $10-30$ c.M. long, $\pm 12^{1 / 2}$ m.M. broad, pinnate throughout. Pinnae dimorphous, distant; barren pinnae linear-subulate or ligulate, fertile ones spathulate, with the lower half narrowly linear, the upper half oblong-elliptical, with recurved sides. Texture coriaceous; rachis ciliate with deciduous hairs; pinnae tipped with $1-3$ erect 
71. Polypodium. $\int 1$. eupolypodium. d. pinnatae.

bristles; veins 1 to each pinna. Sori large, oblong, solitary on the pinnae. placed in the centre of the dilated fertile part.

Bornen, New Guinea.

* (99) P. Sehefferi, v. A. v. R., Bull. Dép. Agr. I. N., 1908, XVIII, 21.

Rhizome short, clothed with dark-brown, entire, lanceolate scales. Stipes \pm tufted, $1 \frac{1}{2}$-5 c.M. long, clothed with very short, spreading, erecto-patent or adpressed gland-like hairs. Fronds linear, narrowed towards both ends, 5-10 c.M. long, $\breve{5}-\mathbf{1 0}$ m.M. broad, pinnate. Pinnae erecto-patent, irregularly rhomboidal-oblong in the narrowest, ovate-oblong in the broadest forms, the higher ones rather confluent, subentire or crenate, the central decurrent, distant, crenate, crenato-dentate or crenato-pinnatifid with few crenations, the lower much reduced, narrow, entire, distant. Texture firm-herbaceous, fragile when dry, pellucid; rachis and surfaces papillose, the papillae clavate, pellucid, yellowish-brown, subadpressed; costae pinnate with $\pm 1-3$ simple veins on each side. Sori round, 1 to each vein, close to the costae, at length often contiguous. - Differs from P. glandulosum, IIk., Spec. Fil., IV, 194, tab. CCLXXVI, $\mathrm{A}$, in having all the pinnae distant, not confluent, and the opposite sori contiguous, costal, though terminal on the short veins.

Java (Scheffer). Sumwita (S T 366$)$

* (100a) P. venulosum, Bt., Rac., Flor. Btz., I, 92 ; Bl., Flor. Jav., II, 180, tab. LXXXV, A.

Rhizome short-creeping, clothed with dark, lanceolate, ciliate scales. Stipes subtufted or to 1 c.M. apart, $2 \frac{1}{2}-12$ c.M. long, densely covered with deciduous or persistent, spreading, reddish hairs. Fronds linear-lanceolate, 30-70 c.M. long, $21 / 2-4$ c.M. broad, narrowed gradually towards both ends, cut down to the rachis throughout into entire, linear, blunt, horizontal, sessile pinnae $2-3 \mathrm{~m}$.M. broad, the base often slightly narrowed. Texture herbaceous to subcoriaceous; rachis villose; surfaces naked or villose; veins parallel, simple. Sori copious, superficial or immersed, round, elliptical when young.

Malaya. huzon.

(100b) P. macrum, Copel., Polypod. Philipp., 121.

Rhizome short, erect, densely clothed with brown scales. Stipes \pm tufted, $1-2 \frac{1}{2}$ c.M. long, blackish-brown, covered with hairs of the same colour. Fronds linear-lanceolate, acute, pinnate, \pm 25 c.M. long, $\pm 21 / 2$ c.M. broad. 
Pinnae narrow, subacute, undulate, subfalcate, decurrent, the higher ones confluent, the lower distant, reduced. Texture subcoriaceous; rachis \pm hairy; surfaces naked or nearly so; veins simple. Sori \pm elliptical, terminal on the veins, medial between the costae and the margin, (oblique?), superficial. Philippines.

(101a) Inalconense, Copel., Philipp. Journ., II, 138, tab. II, B. Rhizome creeping, clothed with grey-fuligineous, lanceolate scales. Stipes approximate, \pm 5 c.M. long, clothed like the rachis with straight, castaneous hairs. Fronds \pm 20 c.M. long, $\pm 4 \frac{1}{2}$ c.M. broad, pinnate, abruptly narrowed at both ends. Pinnae suberecto-patent, straight or curved, $\pm 21 / 2$ c.M. long, $\pm 5^{1} / 2$ m.M. broad, obtuse, decurrent, toothed, only the superior ones confluent, the lower rather remote, abruptly reduced to mere auricles, the teeth reaching $1 / 2-2 / 3$-way down to the costa, distant, spreading. Texture coriaceo-papyraceous; costae and apices of the teeth setiferous; veins simple, hidden. Sori superficial, occupying the bases of the veins, often opposite, and the pairs not rarely confluent.

Mindoro. Mindawad 518367

(101b) Horpophyllum, Zerets., Hk. Bk., Syn. Fil., 511; Christ, Ann. Btz., XV, 150, tab. XVI, fig. 22, a-b.

Rhizome wide-creeping, slender. Stipes slender, fragile, black-brown, rough with short, dark scales, like the rachis, \pm 10 c.M. long, \pm 5 c.M. apart. Fronds, \pm 45 c.M. long, oblong-lanceolate, pinnate. Pinnae ligulateacuminate, falcate, serrate, $3 \frac{1}{2}-5$ c.M. long, $\pm 1-1 \frac{1}{2}$ c.M. broad, subpetiolate; upper base parallel to the rachis, auricled, lower cuneate-truncate. Texture subcoriaceous; surfaces glabrous; veins 2-5-furcate. Sori medial between the edge and midribs. terminal on the lowest anterior veinlets.

Celebes; South. India.

\section{$\$$ 1. Eupolypodium. e. Compositae.}

a. Texture thin, hyaline.

a.d. Texure thick, not hyaline.

b. Stipes naked.

7.3. Slipes hairy.

c. Ruchis naked.

(102) P. gedeantur. $\left(102\right.$ a) bo $88^{\circ}$ (1020) P. Oredicunerellu 5 . (103) P. tamariscinum.

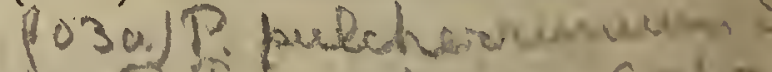
$1030)$ ip ferrforue $s[p=3$ (104) P. bipinnatifidum. 5 I $p^{3}$ 
71. polypodium. ' $\mathbb{S}$ 1. nupolypodum e. compositae.

c.c. Rachis hairy.

d. Pinnae irregularly divided.

d.d. Pinnae regularly pinnatisect.

(105) P. millefolium.

e. Sori occupying the base of the secondary segments.

(106) P. tenuisectum.

e.e. Sori not occupying the base of the secondary segments.

f. Fertile pinnulae linear.

f.f. Fertile pinnulae spathulate.

(107a) P. taxodioides.

(107b) P. Yoderi.

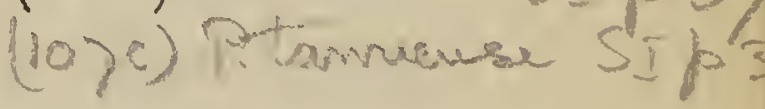

* (102) P. gedeanum, Fac., Flor. Btz., I, 96.

Rhizome erect or suberect, slender. Stipes tufted, 1-2 c.M. long, densely clothed with spreading, yellow-brown hairs. Fronds linear-lanceolate, narrowed towards both ends, to 12-18 c.M. long, 2-3 c.M. broad. Pinnae 5 m.M. apart, decurrent, unequal-sided, subdimidiate, deeply pinnatifid, the upper side with $5-6$, the lower with $1-5$ segments, the lower base cut away and without segments. Segments linear, rounded, entire, separated by narrow spaces between them, 3-4 m.M. long, 1-1 $1 / 2$ m.M. broad. Texture very thin, hyaline; rachis, veins and edges furnished with very soft, white, spreading hairs; veins free, 1 to each segment. Sori sulitary at the base of the ultimate segments.

Java.

(103) P. Tamaniscimum, Mlf., Hk. Bk., Syn. Fil., 538; Diels, in Engl. \& Prantl., Nat. Pfl.Fam., Iㄴ, fig. 162, H-K; Adenophorus Tamarisci, Hk. \& Grev., Ic. Fil., tab. GLXXV; A. bipinnatus, Gaud., Hk. \& Grev., I. c., tab. CLXXIV.

Rhizome stout, creeping, scaly. Stipes $5-8$ c.M. long, naked, wiry, flexuose. Fronds 10-20 c.M. long, $3^{1} \frac{1}{2}-8$ c.M. broad, ovate-lanceolate. Pinnae close, erecto-patent, $1 / 2-1$ c.M. broad, cut down to the rachis into simple or forked, linear or oblong lobes. Texture subcoriaceous; both surfaces naked; veins 1 to each lobe. Sori copious, 1 to each ultimate segment, near the apex.

Malaya; Polynesia.

(104) P. Dipimmatifiotumin, Mle., Journ. of Bot., XXVIII, 109.

Stipes very slender, $5 \frac{1}{2}-5$ c.M. long, clothed with fine, spreading, brown hairs. Fronds lanceolate-oblong, $12-15$ c.M. long, $\pm 2 \frac{1}{2}$ c.M. broad, pendulous, 2-pinnatifid. Pinnae distant, linear, cut down to a narrowly winged 
l'achis into small, oblong $01^{\circ}$ ovate lobes. Texture coriaceous; surfaces naked; veins 1 to each lobe. Sori round, superficial, 1 to each lobe.

New Guinea.

* (105) P. millefolium, Bz.., Rac., Flor. Btz., I, 95 ; Bl., Flor. Jav., II, 190, tab. LXXXVIII, B.

Rhizome short, slender, erect, hidden by the stipes and roots. Stipes tufted, $21 / 2-8$ c.M. long, densely clothed with spreading, ferrugineous or palecoloured hairs, like the rachis. Fronds lanceolate, $\pm 15-20$ c.M. long, \pm ${ }_{2} 1 / 2-31 / 2$ c.M. broad, narrowed towards both ends. Pinnae erecto-patent, \pm stalked, 7-10 m.M. broad, lanceolate, cut down nearly or quite to the rachis into oblong or linear-oblong to spathulate, erecto-patent segments $\pm \mathfrak{5}-10$ m.M. long, 1-3 m.M. broad. Segments blunt, the edge entire, toothed or pinnatifid, the base narrowed, slightly decurrent. Ultimate lobes $\mathbf{1 - 5}$ on each side. Texture subcoriaceous; under surface slightly hairy; veins simple. Sori roundish, terminal on very short veinlets, $\pm 1-\mathbf{3}$ to each pinnula.

Sumatra, Java, Philippines.

* (106) P. temuisectum, Bt., Rac., Flor. Btz., I, 95; Bl., Flor. P.F. Ho Jav., II, 189, tab. LXXXVIII, A; Christ, Farnkr. d. Erde, fig. 243; Hk., 2nj F F HS. Cent. of Ferns, tab. XXI; - var. paucisetosum, Rst., in Fed., Rep., V, 42.

Rhizome short-creeping, densely clothed with lanceolate scales. Stipes approximate, 5-b c.M. long, clothed with soft, spreading, ferrugineous hairs. Fronds linear-lanceolate, narrowed towards both ends, $15-25$ c.M. long, $51 / 2$ 6 c.M. broad. Pinnae close, to 8 m.M. broad, cut down quite to the rachis $01^{\circ}$ a narrow wing into linear, regular, entire, erecto-patent segments 2-3 m.M. apart, 3-4 m.M. long, 1/2-1 m.M. broad. Texture subcoriaceous; rachis erect, straight, pilose; surfaces naked or the veins sparingly hairy beneath; veins simple, hidden, 1 to each lobe. Sori broader than the lobes, 1 to each lobe, at the base.

Var.. paucisetosum: Ultimate segments narrower, provided at the apex with 1 or rarely 2 setae.

Malacca, Java to Samoa and the Philippines; - var. paucisetosum: New Guinea.

(107a) P. taxodioides, HE., Journ. of Bot., XVII, 42.

Rhizome filiform, wide-creeping. Stipes wiry, brown, $21 / 2-4$ c.M. long, clothed like the rachis with fine, spreading, brown hairs. Fronds lanceolate, 
71. polypodum. $\mathbb{1}$ 1. eupolypodum. e. compositae.

regularly 2-pinnate, $15-20$ c.M. long, $4 \frac{1}{2}-51 / 2$ c.M. broad. Pinnae numerous, close, lanceolate, $\pm 6-7 \mathrm{~m} . M$. broad, regularly pectinato-pinnate with narrow, linear, parallel, erecto-patent, 1-nerved pinnulae not more than $1 / 2$ m.M. broad. Texture rather rigid; surfaces naked. Sori confined to a few of the uppermost pinnae, solitary in the centre of the pinnulae.

Borneo.

(107b) P. Yoderi, Copel., Philipp. Journ., I, Suppl., 161.

Rhizome filiform, sparingly clothed with brown, ovate-lanceolate scales. Stipes woody, clothed with reddish-black hairs, or glabrescent towards the base. Fronds $15-25$ c.M. long, lanceolate, the rachis pilose. Pinnae erectopatent, $\pm \quad \mathbf{5}$ m.M. broad, contiguous, the rachis winged. Barren pinnulae narrow, hardly $1 / 4$ m.M. broad at the base, somewhat broader towards the apex, often bearing a single terminal hair: fertile pinnulae spathulate. Sori solitary on the pinnulae, occupying the dilated portion.

Mindoro, Panay.

\section{S2. PROSAPTIA.}

a. Fronds under $1 \frac{1}{2}$ c.M. broad. Sori 1 to each looth or segment. (Acrosorus). b. Fronds toothed, lobed, or pinnatifid nearly or quite to the costa, the teeth or segments deltoid, acute or biuntish, not narrowed at the base.

c. Fronds sharply toothed in the fertile region.

c.c. Fronds bluntly lobed in the fertile region.

(108a) P. Schlechteri.

(108b) P. exaltatum.

(108c) P. tortile.

b.b. Fronds pinnatifid nearly or quite to the costa, the fertile segments subclavate, narrowed at the base.

(109) P. Sarasinorum.

a.a. Fronds more than $1 \frac{1}{2}$ c.M. broad when fully developed. Sori rarely 1, commonly many to each segment. (Euprosaptia).

1. Fronds lobed to $\pm{ }^{2} / 3$-way down to the costa. (110a) P. serraeforme.

(110b) P. polymorphum. SI〉3 >

1.1. Fronds pinnatifid nearly or quile to the costa.

2. Lobes entire, broadly toothed or sinuate.

2.2. Lobes crenate or serrate towards the apex.

(111) P. contiguum. 
3. Base of frond crenate or repand. Sori $18-25$ on the largest lobes.

(112a) P. cryptocarpum, Sip3)?

3.3. Base of frond simuate. Sori \pm 9 on the largest lobes.

(112b) P. Toppingii. Sip 37

(108a) P. Selnechteni, v. A. v. IR.; Prosaptia Schlechteri, Christ, Schum. \& Laut., Flor. deut. Sch.geb., Suppl., 41, tab. I, fig. B, c; Davallia Schlechteri, C. Chr., Ind. Fil.

Rhizome short. Fronds sessile, tufted, numerous, \pm 25 c.M. long, \pm $1 / 2$ c.M. broad, linear-ligulate, acuminate, narrowed at the base, the edge rotundato-crenate in the lower, sharply toothed towards the fertile higher part. Texture coriaceous, rigid; surfaces naked, upper bright-green, lower ochraceous; costa immersed; veins oblique, hidden. Sori solitary on the teeth, oblong, the depressions saccate, ovate, not scariose, consisting of the partially reflexed margin of the lobes.

New Guinea.

* (108b) P. exaltatum, Copel., MS. in Herb. Bog.; Davallia exaltata, Copel., Polypod. Philipp., 52; C. Chr., Ind. Fil.; Acrosorus exaltatus, Copel., Philipp. Journ., I, Suppl., 159, tab. XV.

Rhizome short, ascending, the scales dense, linear, brown. Fronds sessile, crowded, pendulous, $30-50$ c.M. long, $5-9$ m.M. broad, narrowed towards the base, the lower $1 / 3$ part sterile, pinnatifid almost to the costa, the lower segments reduced. Segments unequally triangular, oblique, the apex bluntish. 'Texture coriaceous; surfaces naked, the lower densely covered with irregularly scattered, black or dark-brown dots; veins hidden. Sori solitary, deeply immersed in terminal, saccate, indusium-like depressions, which form much prominent, laterally compressed projections on the upper surface.

Mindanao (Copeland, No. 1478).

(108c) FP. tortile, v. A. v. R.; Acrosorus Merrilli, Copel., Philipp. Journ., II, 136.

Differs from P. exaltatum, Copel., in the fronds being smaller, with narrower sterile segments and more reduced and twisted fertile segments giving the fertile apical part of the frond an appearance of distinctness wanting in P. exaltatum, Copel.

Mindoro. 
(109) P. Sarasinorum, v. A. v. I.; P. Friderici et Paul, Christ, Ann. Btz., XIX, 37 (not XV, 148); Davallia Friderici et Pauli, Christ, I. c., XV, 94, tab. XIV, fig. 10, a-d; C. Chr., Ind. Fil.; Acrosorus friderici et pauli, Copel., Philipp. Journ., I, Suppl., 159.

Rhizome woody, ascending, the scales few, ovate, reddish-brown. Fronds numerous, $15-20$ c.M. long, ligulate, $\pm 6 \mathrm{~m}$.M. broad, narrowed towards the apex, pinnate. Pinnae deltoid, bluntish, $\pm 2 \mathrm{~m}$.M. each way, close, $60-90$ on each side, the lower ones gradually becoming shorter. Texture thick, spongy, but firm-coriaceous when dry; veins inconspicuous, hidden, 1 to each pinna. Sori occupying the upper half of the fronds, 1 to each pinna. Soriferous pinnae slightly narrowed near the base, the upper part subclavate, thickened, with the sori solitary, immersed in \pm deep, marginal, subterminal depressions.

Celebes.

- (110a) P. serractorme, Æ. Sme., Journ. of Bot., III, 594 ; Davallia alala, Bl., Rac., Flor. Btz., I, 132; C. Chr., Ind. Fil.; D. Emersoni, Hk. \& Grev., Ic. Fil., tab. CV; D. serraeformis, Wall. (oldest name); Prosaptia Emersoni, J.M.S. vel Pr., Bedd., Ferns S.I., tab. XX; Pr. serraeformis, Christ, Bull. Herb. Boiss., VI, 145; Pr. alata, Christ, Copel., Philipp. Journ., I, Suppl., 158, tab. XIV, B.

Rhizome short, the scales dense, ciliated. Fronds sessile, tufted or subtufted, linear-lanceolate, $15-30$ c.M. long, 2-5 c.M. broad, narrowed towards Telon kid both ends, cut $\pm 1 / 2-2 / 3$-way down to the costa into numerous, linear-oblong, spreading or suboblique, blunt lobes, except in the lower part, which is often entire, repand or sinuate with short, deltoid lobes. Texture coriaceous; under surface covered with scattered, short, acute glands or hairs. Sori $1-12$ to a lobe, closely placed round the edge, especially near the apex, deeply sunk in submarginal, indusium-like depressions.

Trop. Asia, Samoa.

(110b) P. polymorphmm, v. R. R.; Prosaptia polymorpha, Copel., Philipp. Journ., II, 136.

Differs from P. serraeforme, $J$. Sm. by the broader and less truncate segments and the sori immersed in obtuse teeth. Fronds to \pm 40 c.M. long, 5 c.M. broad, acuminate. Segments oblong, obtuse or subacute, the lower gradually passing into a wavy wing $5-8$ c.M. long, entire at the base and narrowed into a short, slender stipe. Sori $\pm b$ to a segment, not restricted to the apical part.

Mindoro. 
* (111) P. contiguum, J. Sm., Journ. of Bot., III, 394; Davallix contigua, Spr., Rac., Flor. Btz., I, 132; C. Chr.. Ind. Fil.; Prosaptia contigua, Bedd., Ferns S.I., tab. XIX; Trichomanes contiguum, Forst., Prod., 84; - var. monosorum, Copel., in Perk., Fragm. Philipp., 179; - var. pectinatum; $D$. pectinata, Bl. (not Sm.), Enum., 229.

Rhizome short, the scales dense, brown, ciliate. Fronds sessile or on stipes to 7 c.M. long, tufted or subtufted, $\mathbf{1 5 - 5 0}$ c.M. long, 2-5 c.M. broad, linear-lanceolate, narrowed towards both ends, incised nearly or quite to the rachis into linear-oblong, blunt, contiguous or slightly joined segments $\pm 2-4$ m.M. broad, slightly dilated at the base, the edge entire but remotely, shallowly and broadly toothed towards the apex, the lower segments shorter, deltoid. Texture coriaceous; under surface sparingly hairy, especially on the rachis. Sori not numerous, 1 to each tooth, more or less deeply sunk in \pm marginal, indusium-like depressions.

Var. monosorum: Segments narrower, quite entire, $1-1 \frac{1}{2} \mathrm{~m} . M$. broad. Sori solitary and terminal on the segments.

Var pectinatum: Segments undulate. Sori marginal, all round the edge.

Malaya; Polynesia; - var. monosorum: Mindanao, New Guinea - var. pectinatum : Java.

- (112a) P. cryptocarpum, v. A. v. R.; Prosaptia cryptocarpa, Copel., Philipp. Joưrn., I, Suppl., 158, tab. XIV, a \& d.

Rhizome short, rather creeping, clothed with black-brown, lanceolate, acuminate scales. Stipes $1-1 \frac{1}{2}$ c.M. long, minutely pubescent, the base black. Fronds $20-55$ c.M. long, $\mathbf{5}^{1} / 2-5$ c.M. broad, the apex acute to caudate, the edge deeply pinnatifid, the costal wing $\pm 1 / 4-1 \frac{1}{j_{2}}$ c.M. broad, the base gradually narrowed, crenate to repand. Lobes numerous, \pm spreading, 2-3 m.M. broad, obtuse or acute, slightly repand or serrate towards the apex, dilated at the base. Texture coriaceous; upper surface naked, lower provided with scattered, short, red, subulate hairs, especially on the costa; costulae inconspicuous; veins hidden, simple. Sori 18 -25 on the largest lobes, marginal or submarginal.

Mindanao.

(112b) P. 'Toppingii, v. A. v. R.; Prosaptia toppingii, Copel., Philipp. Journ., I, Suppl., 158, tab. XIV, c.

Near P. cryptocarpum, v. A. $v$. $R$. Fronds $20-50$ c.M. long, 5-4 
71. POLYPODIUM. $\$ 2$. PROSAPtia.

c.M. broad, acute, the costal wing $2-3 \mathrm{~m} . \mathrm{M}$. broad, the base sinuate. Lobes triangular-lanceolate, subacute, $\pm \mathbf{5}$ m.M. broad, obtusely'serrate. Sori \pm 9 on the largest lobes, marginal.

Luzon.

\section{\$3. GONIOPHLEBIUM. c. Marginaria.}

(115) P. Prainii, C. Chr., Ind. Fil.; Goniophlebium Prainii, Bedd., Journ. of Bot., XXXI, 226.

Rhizome stout, densely clothed with long, finely acuminate, brown scales, which are very iridescent in the broader part near the peltate base. Stipes 45-60 c.M. long, firm, erect, naked. Fronds deltoid-lanceolate, \pm 30 c.M. long, \pm 25 c.Mr. broad, pinnate. Pinnae numerous, \pm 2 c.M. broad, narrowlanceolate from a broad base, separate, the margin slightly crenate especially towards the apex. Texture somewhat papyraceous; surfaces naked except some minute scales and a few hairs on the rachis below; veins prominent on both sides; areolae in 2 series. Sori in $1-2$ rows on each side of the costae. Malacca.

\section{S 3. GONIOPLEBIUM. d. Sehellolepis.}

1. Pinnae acutely cuneate or gradually narrowed at the base.

5. Sori in 2-3 rows on each side of the costae.

(114) P. Korthalsii.

5.S. Sori in 1 row on each side of the costae.

$x$. Pinnae subentire.

(115a) P. integriore.

$x \cdot x$. Pinnae crenate, serrate or toothed.

$(115 b)$ P. persicifolium. SI $p 3>2$

1.1. Pinnae broadly and abruptly cuneate at the base.

*. Pinnae paucijugale.

(116a) P. Koningsbergeri.

*.*. Pinnae multijugate.

(116b) P. verrucosum

1.1.1. Pinnae cordate, broadly rounded, truncate or the higher adnate at the base (").

2. Surfaces more or less densely hirsute, hairy or tomentose.

a. Veins forming 1 row of areolae on each side of the coslae.

b. Sori scarcely immersed.

(117a) P. molliculum.

b.b. Sori distinctly immersed.

(117b) P. pallens.

a.a. Veins forming 2-3 rows of areolae on each side of the costae.

(118) P. Beddomei.

2.2. Surfaces naked.

(*) See also P. verrucosum, Wall. 
71. polypodium. $\mathbb{S} 5$. GONIOPHebium. d. Schellolepis.

3. Sori súperficial.

4. Sori in 1-2 rows on each side of the costae.

5. Pinnae narrowly triangular.

(119a) P. argutum.

5.5. Pinnae not uniformly narrowed from the base to the apex.

(119b) P. pseudoconnatum.

4.4. Sori in $\mathbf{3}$ rows on each side of the costae.

(1.20) P. lampongense.

3.3. Sori more or less immersed.

+. Terrestrial. Sori subimmersed.

(121a) P. benguetense. +.+. Epiphytical. Sori deeply immersed.

(121b) P. subauriculatum. (121C) P. deneresum S I 3 )

* (114) P. Konthalsii, Mett., Hk. Bk., Syn. Fil., 345; Goniophlebium Korthalsii, Bedd., Handb. Ind. Ferns, Suppl., 91.

Rhizome creeping, clothed with small, linear-lanceolate-subulate, ciliate, reddish-brown scales. Stipes $12-15$ c.M. long, smooth, reddish-brown. Fronds 30-40 c.M. long, to \pm 30 c.M. broad. Pinnae lax, spreading or erecto-patent, $12-15$ c.M. long, $1 \frac{1}{2}-4$ c.M. broad, lancéolate-acuminate, the base cuneate, articulate, the edge slightly crenate. Texture subcoriaceous; rachis and both surfaces naked; areolae in $5-4$ rows. Sori $\pm 2-5$-serial, superficial or hardly immersed.

Java, Sumatra, Malacca.

* (115a) IP. integriore, Copel., Philipp. Journ., II, 159.

Rhizome creeping, woody, clothed with lanceolate-acuminate, castaneofulvous scales or glabrescent, and not calcareous. Stipes naked, 15-25 c.M. long, brown-stramineous. Fronds \pm 50 c.ll. long. Pinnae linear, to \pm 20 c.M. long, to $\pm 1 \frac{1}{2}$ c.M. broad, stalked, the base narrowly acuminate, the edge entire or crenulate, the apex distinctly caudate, hardly serrulate. Texture membranaceous; surfaces naked; areolae in \pm 3 rows on each side. Sori large, slightly immersed. - Nearly related to P. persicifolium, Desv.

Mindoro, Java.

* (115b) P. persicifolium, Desv., Rac., Flor. Btz., I, 115; P.cuspidatum, Bl. (not Don), Flor. Jav., II, 175, tab. LXXXII; P. phlebodioides, Copel., Polypod. Philipp., 123; Philipp. Journ., I, Suppl., 162; Goniophlebium 


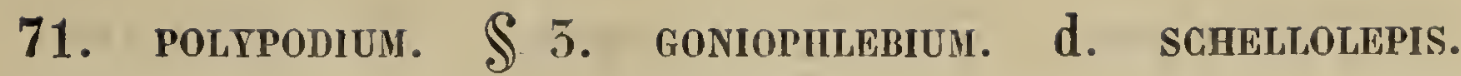

cuspidatum, Pr., Bedd., Ferns Br.I., I, tab. LXXIX; - var. grandidens; P. grandidens, Kze, Bot. Zeit., 1846, 425.

Rhizome creeping, clothed with lanceolate to linear, dark-brown, \pm ciliate scales, not cretaceous. Stipes $15-45$ c.ll. long, firm, naked, stramineous or subebeneous. Fronds 50-500 c.M. long, 20-40 c.M. broad, often subpendulous. Pinnae articulate, distant, short-stalked, $1-31 / 2$ c.M. broad, the apex acuminate or gradually barrowed, the edge crenate, serrate or slightly toothed, the base rather acutely cuneate or gradually narrowed. Texture membranaceous to subcoriaceous; rachis and surfaces naked; areolae in \pm 5 rows on each side. Sori in 1 row on each side, not deeply immersed (often apparently superficial in dried material).

Var. grandidens: Edges deeply toothed.

Sumatra, Java, Celebes, Philippines.

* (116a) IP. Koningsbergeri, v. A. v. Ra., Bull. Dép. Agr. I. N., 1908, XVIII, 21.

Near P. verrucosum, Wall. Rhizome scales indistinctly ciliato-dentate, rather entire. Stipes distant, slender, soon naked, $\pm 10-15$ c.M. long. Fronds small, $15-20$ c.M. long, $\pm 12-15$ c.M. broad. Pinnae paucijugate $( \pm 2-3$ on each side below the terminal one; terminal pinna $\pm 10-12 \frac{1}{2}$ c.M. long, the lateral ones similar, sessile, \pm opposite, articulate, erecto-patent, $7-8$ c.M. long, $\pm 1 \frac{1}{2}$ c.M. broad near the base, narrowed gradually towards the acuminate apex, the margin indistinctly crenate or crenato-serrate, the base broadly, abruptly cuneate. Texture subcoriaceous; surfaces naked except a few scattered, deciduous, fimbriate, minute, lanceolate scales on the costae beneath, \pm hairy in the younger forms; areolae in 5 rows on each side. Sori confined to the costal areolae, slightly immersed, not very prominent on the upper surface; paraphyses yellow, indistinctly incised at the apex. - This species bears the name of Dr. J. C. Koningsherger, Subdirector of the Agricultural Department in Netherlands India.

Java (Preanger Regencies, v. A. v. R.).

* (116b) P. vererucosum, Wall., Hk Bk., Syn. Fil., 344; Hk., Veverrucoses Gard. Ferns, tab. XLI; Goniophlebium verrucosum, J.Sm., Bedd., Ferns Br.I., Pliv der '4' II, tab. CCLVII.

Rhizome firm, creeping, not cretaceous; scales lanceolate-oblong, the base peltate, the edge ciliate, the apex acuminate, erect, subadpressed. Stipes scattered, 30-60 c.M. long, copiously clothed like the rathis with caducous scales, 
at length quite naked, the scales linear-acuminate, subulate, ciliate, recurved or spreading. Fronds subpendulous, $45-120$ c.M. long, $15-50$ c.M. broad. Pinnae numerous, subsessile, articulate to the rachis, erecto-patent or spreading, linear, to 20 c.M. long, $1-4$ c.M. broad, the edges mostly \pm parallel, entire or crenato-dentate, the base obtusely cuneate or nearly rounded, the upper half narrowed gradually to the point, or the apex abruptly narrowed, shortcuspidate; terminal pinna simple, similar to the lateral ones but not rarely very elongated and strap-shaped. Texture papyraceous or subcoriaceous; surfaces naked or villose, often conspicuously hairy in the younger forms; costae whether or not with some few scattered fimbriate scales beneath; areolae in $4-5$ rows on each side of the costae. Sori in 1 row on each side, confined to the costal areolae, immersed in deep cavities, which form very dislinct warts or tubercles on the upper surface; paraphyses dark-brown, oblong and mostly irregularly, pinnately or stellately incised at the apex.

Malaya; Trop. Australia.

(117a) P. molliculum, Copel., Polypod. Phiipp., 124; P. tomentellum, C. Chr., Ind. Fil.

Rhizome wide-creeping, the scales small, subulate, ferrugineous. Stipes \pm 10 c.M. long, suberect, naked or nearly so. Fronds $15-20$ c.M. long, \pm 8 c.M. broad, pinnate. Pinnae narrowly lanceolate, $\pm 6-8$ m.M. broad, acute, serrate or crenate towards the base, short-auriculate, the base \pm truncate, sessile but not adnate. Texture herbaceous; surfaces clothed with a short, soft tomentum; veins free beyond a single row of areolae on each side. Sori scarcely immersed.

Philippines.

* (117b) P. pallens, Bt., Flor. Jav., II, 178, tab. LXXXIV, A; P. subauriculatum, Bl., var., C. Chr., Ind. Fil.

Rhizome creeping, pruinose, clothed with few, thin, linear scales, at length \pm naked. Stipes subremote, 5-15 c.M. long, glabrescent, pale-green, here and there pale-fuscous. Fronds $10-40$ c.M long, 5-10 c.M. broad, oblong, the rachis dirty-stramineous, hirsute, the hairs intermixed with small, adpressed or curved, narrow-lanceolate or subulate, fimbriato-denticulate, black-fuscous, deciduous scales. Pinnae $\pm 10-1$-jugate; terminal pinna \pm pinnatifid at the base, the lateral ones opposite or alternate, sessile, straight or subfalcate, the base broadly rounded to cordato-truncate, the edge crenatoserrulate, the apex bluntish or acute. Texture rather herbaceous to coriaceous; 
71. POLYPodium. $\mathbb{S} 3$. gONIOPHLEBIUM. d. SGHELLOLEPIS.

surfaces more or less densely clothed with \pm deciduous, whitish hairs; veins anastomosing commonly in 1 row of large, costal areolae. Sori in 1 row on each side of the costae, immersed.

Java.

(118) P. Beddomei, Bk., Hk. Bk;, Syn. Fil., 344; Goniophlebium molle, Bedd., Handb. Ind. Ferns, 322; Ferns Br.I., II, tab. CGVI.

Rhizome creeping, densely clothed with reddish-brown, subulate scales. Fronds \pm 45 c.M. long, 17-20.c.M. broad, oblong, acuminate. Pinnae numerous, $1-1 \frac{1}{2}$ c.M. broad, sinuate-crenate, superior base often subauricled; superior pinnae decurrent on the rachis, remainder sessile from a broad base, not adnate, or inferior ones subpetiolate. Texture membranaceous; rachis and both surfaces covered with soft, weak, whitish hairs; veins forming $2-3$ rows of areolae. Sori in 1 row on each side of the costae.

Màlacca;Burmah.

(119a) P. argutum, Wall., Hk. Bk., Syn. Fil., b11; Goniophlebium argutum, J. Sm., Bedd., Ferns Br.I., I, tab. VI.

Rhizome firm, wide-creeping, the scales minute, linear-subulate, darkbrown. Stipes 7-15 c.M. long, naked, castaneo-stramineous. Fronds suberect, lanceolate-oblong, 30-60 c.M. long, 20-30 c.M. broad. Pinnae 1020-jugate, ligulate-acuminate, faintly inciso-crenate, $1 \frac{1}{4}-2$ c.M. broad, many free, distant, uniformly narrowed from the base to the apex, lower subpetiolate, lowest not reduced. Texture membranaceous; surfaces bright-green, naked; areolae 1-serial. Sori 1-serial, nearer the midribs than the edge, superficial. Luzon; North. India.

(119b) Pseudocommatum, Copel., Philipp. Journ., I, Suppl., 161, tah. XXII.

Rhizome woody, cretaceous, densely clothed with deciduous, lanceolate, acuminate, brown scales. Stipes \pm 20 c.M. long or longer, strong, glabres cent. Fronds \pm 50 c.M. long, 30-50 c.M. broad, acuminate, the rachis sordido-paleaceous towards the apex. Pinnae often opposite, sessile. lowest largest, \pm 20 c.M. long, to \pm 2 c.M. broad, cordate at the base, the edge coarsely serrate, the apex acuminate. Texture herbaceous; surfaces nearly naked; veins forming 1 row of large costal areolae and sometimes 1 or more series of smaller areolae outside the costal ones. Sori large, superficial.

Luzon. 
Fronds scattered, pinnate. Pinnae linear-lanceolate, the higher and fertile ones narrower than the barren, subensiform, sessile, cordate, subauriculate at the base. Rachis angular, sparingly paleaceo-villose; veins slender, naked: Sori in 3 rows on each side.

Java.

(121a) P. benguetense, Copel., Philipp. Journ., I, Suppl., 256; P. mengtzeense, Copel. (not Christ), l. c., 161, tab. XXI.

Rhizome creeping, densely clothed with lanceolate, acuminate, black-fulvous scales. Stipes \pm 15 c.M. long, often stramineous and glabrescent like the rachis. Fronds $20-25$ c.ll. long, $12-20$ c.M. broad. Pinnae $\pm 1-2$ c.M. apart, often opposite, sessile, the base subcordate or hastato-dilatate, the edge acutely serrate, the apex acuminate; higher pinnae distinct, not decurrent, nor broadly adnate. Texture membranaceous; surfaces naked; costae prominent; veins forming 1 row of costal areolae and sometimes also a second row of smaller areolae outside the costal ones. Sori subimmersed.

\section{Luzon.}

* (121b) P. Subauroiculatum, Rt., Rac., Flor. Btz., I, 116; Bl., Flor. Jav., II, 177, tab. LXXXIII ; P. Reinwardlii, Kze, Linn., XXIII, 285; Goniophlebium Reinwardiii, de Vr., Ned. Kruidk. Arch., I, 257; G. subauriculatum, Pr., Bedd., Ferns Br.I, I, tab. LXXVIII; - - var. serratifolium; G. serratifolium, Brack., Expl. Exp., XVI, 35.

Rhizome wide-creeping, pruinose, scaly, at length \pm naked, the scales dark-brown, linear-lanceolate or subulate, entire or ciliato-dentate, finely acumi nate, erecto-patent or spreading. Stipes scattered, firm, 15-50 c.M. long, glossy, clothed like the rachis with densely crowded, \pm spreading or recurved, brownish, deciduous, finely acuminate, ciliate scales, afterwards naked. Fronds subpendulous, \pm 50-500 c.M. long, 8-50 c.M. broad, oblong-lanceolate, pinnate. Terminal pinna mostly pinnatifid at the base; lateral pinnae numerous, subspreading, linear-lanceolate, $1 / 2-21 / 2$ c.M. broad, articulate to the rachis, sessile, with \pm their own breadth between them, the base cordate, \pm truncate or rounded, often \pm auricled on one or both sides, the edge entire, slightly crenate or faintly toothed, the apex narrowed \pm gradually, acute or acuminate. Texture herbaceous to subcoriaceous; surfaces naked, the lower covered with scattered, minute, roundish, irregularly ciliate, deciduous, peltate scales when young; rachis at length naked; 
71. POLYPODIUM. $\mathbb{S} 3$. gONIOPHLEBIUM. d. SCHELlolepis.

areolae in $2-5$ rows on each side. Sori in 1 row on each side, distinctly immersed.

Var. senoratifolium: Pinnae coarsely loothed.

Malaya; Samoa, Trop. Australia, New Caledonia.

\section{S. PLEOPELTIS. a. Myrmecophila. * Aspidopodium.}

1. Fronds simple or lobed.

(122) P. sinunsum.

1.1. Fronds deeply pinnatifid or pinnate.

2. Rhizome forming a single, bulbous or wide-spreading crust.

3. Fronds pinnatifid at the base; sori subcostular.

(123) P. lomarioides.

3.3. Fronds pinnate at the base. Sori medial.

(124) P. sarcopus.

2.2. Rhizome forming a row of united, subconvex, oblong or roundish crusts.

(125) P. imbricatum.

* (122) P. simuosum, Walt., Rac, Flor. Btz., I, 103; Hk., Spec. Fil., V, tab. CCLXXXIV; Pleopeltis sinuosa, Bedd., Ferns Br.I., I, tab. VIII.

Rhizome wide-creeping, thick, densely clothed with adpressed, peltate, roundish scales, dark in the centre and pale round the edge. Stipes $1 / 2-5$ c.M. long, firm, naked, arising from large, prominent, conical protuberances. Fronds dimorphous; barren fronds $7-171 / 2$ c.M. long, $2-2 \frac{1}{2}$ c.M. broad, the apex blunt or rounded, the edge entire, narrowed to the base, fertile ones \pm 20-40 c.M. long, 1-2 c.M. broad, narrowed to the base, the edge \pm sinuate. Texture coriaceous; surfaces naked; veins obscure. Sori large, immersed, in 1 row on each side, nearer the edge than the midrib, 1 to each lobe.

Malaya. P.Suam.

- (123) D. Iomanioides, Fae, Hk. Bk., Syn. Fil., 565; Mett., Farng., I, Polypod., tab. II, fig. 18-19; Drynaria lomarioides, J. Sm., Journ. of Bot., III, 397.

Rhizome forming a thick, wide-spreading crust densely clothed with small peltate scales, ferrugineous in the centre, with a broad, scariose border. Stipes arising from conical protuberances, $\breve{b}-10$ c.M. long, firm, erect. Fronds 15-45 c.M. long, 7-15 c.M. broad, the barren ones cut down within 5-7 m.M. of the costa into close, horizontal, oblong, entire, blunt 
lobes \pm 2 c.M. broad; the fertile ones cut nearly to the costa with more numerous lobes 6-20 m.M. broad. Texture coriaceous; surfaces naked; veins immersed, irregular; areolae fine, with free veinlets. Sori immersed, round or oblong, forming 2 close rows near the central ribs of the lobes.

Malaya; Formosa.

(124) P. sarcopus, de Vr. Teysm., Hk. Bk., Syn. Fil., 514; P. myrmecophilum, Chrisi, Fil. Saras., I, 24; III, tab. III, fig. 21-24.

Rhizome inflated, greyish, 6-10 c.M. thick (high), \pm 15 c.M. broad (each way), the scales dense, small, roundish, peltate, black in the centre, with a whitish border. Stipes $10-30$ c.M. long, stramineous, thick, arising from conical protuberances or with the base immersed in the rhizome. Fronds \pm 40 c.M. long, with $30-35$ pinnae on each side. Pinnae entire, 7-9 c.M. long, $\pm 2 \frac{1}{2}$ c.M. broad, the point blunt; higher pinnae close, connected, the lower ones free. Texture moderately coriaceous, rather succulent; veins fine, not very conspicuous; main veins $6-8$ on a side, not quite reaching the margin; areolae irregular, with few free veinlets. Sori in 1 row on each side of the costae, medial, very deeply immersed, forming very prominent papillae on the upper surface of the pinnae, the mouth of the pits surrounded by a distinctly raised border.

Celebes; South. China.

(125) P. imbricatum, Karst., Ann. Btz., XII, 168, tab. XV, fig. 29-30, tab. XIX; P. mirabile, C. Chr., Ind. Fil.

Rhizome climbing, consisting of several to numerous divisions separated by distinct constrictions 4-8 c.M. broad, each internode roundish or oblong, convex, 8-16 c.M. long, 7-13 c.M. broad, \pm 8 m.M. thick in the centre, concave beneath, \pm 2 m.M. thick at the margin, clothed with black, roundish, peltate scales, which are scattered on the upper, but densely crowded on the under side. Fronds $4-9$ to each division, ranged in 2 approximate rows (1 row on each side of the longitudinal axis), 30-50 c.M. long, deeply pinnatifid in the fully developed plant, the stipes placed on conical protuberances. Lobes more or less numerous, erecto-patent. Sori deeply immersed, prominent on the upper surface, in 1 row on each side of the costulae.

Moluccas. 


\section{S 6. PLEOPELTIS. a. Myrmecophilat. **. Lecanopteris.}

a. Soriferous teeth or lobes turned back on the upper surface of the frond.

b. Sori immersed in the outgrowths.

c. Oulgrowths not twisted, the mouth of the cavities facing upwards.

d. Sori oblong, rather distant.

a.d. Sori round, ralher close.

(126) P. lecanopteris.

(127) P. Nieuwenhuisii.

c.c. Outgrowths twisted, the mouth of the cavities facing lowards the apex of the pinna.

(128) P. deparoides.

b.b. Sori superficial on the outgrowths.

*. Outgrowths twisted.

*.*. Outgrowihs not twisted.

(129) P. Macleayi.

(130) P. barisanicum.

a.a. Soriferous teeth or lobes erect or erecto-patent, not lurned back on the upper surface of the frond.

(131) P. naviculare.

* (126) P. lecanopteris, Mett., Ann. Mus. Bot. L. B., II, 224; L. carnora P. carnosum, Christ, Ann. Btz.. XV, 160; P. palelliferum, Burck., Ann. Btz.; TFMS, VIV IV, 96, tab. VII ; Lecanopteris carnosa, Bl., Flor. Jav., II, tab. XCIV, A; Copel., Polypod. Philipp., 133; C. Chr., Ind. Fil.: - var pumilum; L. pumila, Bl., l. c., tab. XCIV, B; Copel., l. c, 154; C. Chr., l. c.

Rhizome thick, naked, yellowish, inflated, forming a semiglobose mass \pm 15 c.M. broad, \pm 9 c.M. high, covered with several conical or semiglobose protuberances and subulate, simple or branched, scaly prickles (probably reduced fronds). Stipes on the protuberances, 7-13 c.M. long, brown, naked, glossy. Fronds dimorphous, pinnatifid nearly or quite to the costa. Segments many to numerous, $21 / 2-5$ c.M. long, $\pm 1-2$ c.M. broad, the sterile ones oblong-lanceolate, blunt, with the margin entire or repand, the fertile ovatelanceolate, acute, with the margin lobed with soriferous projections, the lobes (projections) \pm oblong, oblique, rather distant, obtuse, narrowed at the base, turned back on the upper surface of the frond, with the deeply immersed sori facing upwards. Texture coriaceous; surfaces naked: veins indistinct. Sori rather large, 3-6 m.M. long, \pm oblong, immersed in cavities of the same shape, solitary on and occupying nearly the whole of the lobe-like projections.

Var. pumilum: Segments blunt or bluntish; texture firm but pellucid; veins distinct; sori smaller.

Malaya, especially Celebes.

Filices. 
* (127) Nienwemhuisii, v. A. v. R.; Lecanopteris Nieuwenhuisii, Christ, Ann. Btz., XX, 127, tab. III, fig. 1; C. Chr., Ind. Fil.

Rhizome naked, inflated, thick. Stipes $4-6$ c.M. long, firm, naked, stra mineous like the rachis. Fronds linear-lanceolate, \pm 40 c.M. long, $\pm \mathbf{5} 1 / 2$ c.I. broad, acuminate, narrowed gradually towards the base, the edge deeply pinnatifid nearly to the costa. Lobes \pm 25 on each side below the long terminal one; lower lobes oblong, entire, barren, the central and higher ones fertile, sinuato-lobate, the central ones \pm 3 c.M. long, $\pm 11 / 2-2$ c.M. broad. Soriferous outgrowths rather close, semiorbicular (the apex and sinuses rounded), subspreading, turned back on the upper surface of the frond, with the deeply immersed sori facing upwards. Texture firm, pellucid when dry; surfaces naked; costulae and main veins visible; areolae fine, with free veinlets. Sori large, 1 to each outgrowth, $\pm 5-6$ on each side, deeply immersed so as to form semiglobose, \pm cucullate, mamillary papillae on the upper surface.

Borneo.

* (128) T. Aleparoides, Christ, Farnkr. d. Erde, 116; Davallia deparoides, Ces., Fel. di Bor., 13; Lecanopteris deparoides, Bk., Journ. of Bot., XIX, 366 ; C. Chr., Ind. Fil.; Cyathea deparoides, Ces., l. c., tab. IV.

Rhizome \pm 3 c.M. thick, creeping, tortuous, thinly pubescent, afterwards pulverous, at length naked, tuberculous, yellowish-brown. Stipes stramineous, naked. Fronds erect, to \pm 65 c.M. long. Pinnae to 40-jugate, npposite, linear, obtuse, lnbato-dentate, the lower ones free, $\pm 41 / 2$ c.II. long, the following \pm 5 c.M. or more long, 6-8 m.M. broad, the higher ones growing gradually shorter, connected by a narrow wing. Texture firm; surfaces naked; costae and main veins distinct; areolae with free veinlets. Sori on the lobe-like teeth, deeply immersed, 1 to each tooth, the teeth turned back on the upper surface of the frond, induplicate, twisted, the cavities becoming oblong with the opening facing towards the apex of the pinna so as to form spurious iudusia resembling those of Davallia. - Cesati's drawing does not agree with Teysmann's Karimata, plant (Becc., Mal., II, 244-245), which has the soriferous teeth distinctly inflexed and twisted.

Borneo, Sumatra.

(129) Macleayi, v. v. ve.; Lecanopteris Macleayi, Bk., Becc., Mal., II, 244; C. Chr., Ind. Fil.

Like P. deparoides, Chrisl, but the sori terminal on the teeth, not in cavities. Jara. 
71. POLYPODIUM. $\$ 6$. PLEOPELTIS. $a^{* *}$. LEGANOPTERIS.

(130) P. barisanicum, v. v. R.; Lecanopteris incurvala, Bk., Ann. of Bot., VIII, 123 ; C. Chr., Ind. Fil.

Stipes short, erect, firm, yellow-grey to brownish, naked. Fronds oblonglanceolate, caudate, simply pinnate, $2 \breve{b}-40$ c.M. long. Pinnae multijugate, J-5 c.M. long, confluent at the base or connected by a narrow wing, the barren ones linear-oblong, entire, $1 \frac{1}{2}-2$ c.M. broad, obtuse, the fertile ones narrower, to 1 c.M. broad, lanceolate, deeply crenate (toothed?). Texture membranaceous; under surface glaucescent; areolae hexagonal, copious, with copious free veinlets. Sori solitary and terminal on the teeth, which are induplicate, boat-shaped, and turned back on the upper surface of the frond.

Sumatra.

* (151) D. maviculare, v. A. v. R.; Lecanopteris Curtisii, Bk., Journ. of Bot., XIX, 566 ; Hk., Icon. Pl., XVII, tab. MDCVII; C. Chr., Ind. Fil.

Stipes 5 c.M. long or longer, shining, pale-brown like the rachis. Fronds lanceolate, simply pinnate or deeply pinnatifid, $35-45$ c.M. long, 5-12 c.M. broad. Pinnae $\pm 10-50$ pairs below the terminal one, ligulate, obtuse, narrowed near the base, ${ }^{2} 1 / 2-6$ c.M. long, 6-12 m.M. broad, all fertile except the 2-7 lower pairs, which are rather shorter or \pm reduced. Texture chartaceous; surfaces naked, the lower glaucous; main veins distinct; areolae fine. Sori small, 1 to each tooth; soriferous teeth minute, $\pm 7-8$ on each side of the pinnae, erect or erecto-patent, twisted, not turned back on the upper surface of the frond, each with a laterally compressed, boat-shaped cavity, with the mouth facing towards the apex or margin of the pinna.

Sumalra, Lingga, Borneo, Celebes.

\section{\$ 6. PLEOPELTIS. b. Atactosia. ${ }^{*}$. Lepisorus.}

a. Substance of the fronds thick; all the veins \pm obscure.

b. Sori scallered irregularly.

\$. Fronds roundish or oblong, nearly as broad as long, under 2 c.M. long.

(152) P. holophyllum.

\$.S. Fronds elongate, more than 2 r.M. long.

*. Rhizome wide-creeping or scandent.

×. Fronds narrow, to 2 c.M. broad.

+. Fronds \pm 7-15 c.M. long, distinctly slalked.

(135) P. subsparsum. 
71. POLYPodiun. $\mathbb{S} 6$. PleOpeltis. $b^{*}$. LePisorus.

..++ Fronds $\pm 20-45$ c.M. long, sessile or shorl-slallied.

(154) P. tenuilore.

$\times . \times$. Fronds broader, $\pm 2^{1} l_{2}-5$ c.M. broad when fully developed.

+. Rhizome naked. Sori slightly immersed.

(155) P. sarawakense.

+.+. Rhizome scaly. Sori superficial.

$\triangle$ Rhizome scales brown, lanceolale.

(156) $P$. supèrficiale.

$\Delta . \Delta$. Rhizome scales black, roundish, the margin brown.

(137) P. peltatum.

*.*. Rhizome short-creeping.

×. Fronds short and broad, spathulate, entire.

(138) P. antrophyoides.

$\times \cdot \times$. Fronds moderately long and narrow, lanceolate, crenat()dentate.

(159) P. curtidens.

b.b. Sori in 1 or sometimes 2 rows on each side of the costa.

c. Fronds more or less dimorphous; fertile fronds longer and narrower than the barren ones, sometimes much contracted. (*)

d. Fertile fronds stipitiform, the lamina contracted to a mere midrib.

(140) P. Bakeri.

d.d. Fertile fronds not stipitiform, the lamina distinctly developed.

e. Sori superficial.

f. Fertile fronds entire or slightly crenate.

y. Barren fronds narrow, mostly under 1 c.M. broad, the fertile ones not narrowed in the soriferous part.

h. Barren fronds under 5 c.M. long.

(141) P. Wrayi.

7.h. Barren fronds $\pm 6-10$ c.M. long.

(142) P. Beccarii.

$\boldsymbol{y} \cdot \boldsymbol{y}$. Barren fronds mostly broader, and then often $11 / 2-3$ c.M. broad, the fertile ones narrowed in the soriferous part.

×. Barren fronds more than 2 c.M. long.

(143a) P. accedens.

(i) See also P. neglectum, $\ddot{B}$. 
71. POLYPODIUM. $\mathbb{S} 6$. Pleopeltis. $b^{*}$. Lepisorus.

$$
\times . \times . \text { Barren fronds under } 2 \text { c.M. long. }
$$

(143b) P. damunense.

f.f. Fertile fronds repand or slightly lobed.

*. Repand. Sori on the lobes.

(144) $P$, nummularium.

*.*. Lobed. Sori on the anterior side of the lobes.

(145) P. hammatisorum.

e.e. Sori dislinclly immersed.

+. Fertile fronds lanceolate in the lower, linear in the soriferous upper half.

(146) P. stenopteris.

P. Soronucuns I

*.*. Fertile fronds linear-lanceolate. and longer stalked.

(147) $P$ - soridens.

1. Sori superficial or slightly immersed.

2. Sori in 1 row on each side of the midrib.

3. Fronds small, under 3 c.M. long.

*. Fertile fronds cuneate at the base.

(148) P. neglectum.

*.*. Fertile fronds rounded at the base.

(149) P. pudimentum.

3.3. Fronds larger, 5-30 c.M. long.
4. Sori submarginal.
(150) P. subecostatum.

4.4. Sori distant from the margin.

5. Fronds lanceolate-oblong, rostrate, 5-10 c.M. long. (151) P. rostratum.

5.5. Fronds linear-lanceolate, not rostrate, 10 30 c.M. long.

2.2. Sori in 2 rows on each side of the midrib.

(152) P. lineare.

*. Fronds lanceolate-oblong, under 15 c.M. long, shortstalked.

(155) P. Forbesii. Si $p 3$ ) q

*.*.Fronds linear-lanceolate, more than 15 c.M. long, long-stalked.

(154) P. induratum.

1.1. Sori distinctly immersed.

a. Sori nearer the edge than the midrib.

B. Sori round.

$\beta . \beta$. Sori oblong.

a. . Sori distant from the margin.
(155) P. stenophyllum.

(156a) P. revolutum. (156b) P. productum. 
71. POLyPodium. $\mathbb{S} 6$. Pleopeltis. $\mathrm{b}^{*}$. Lepisorus.

$$
\begin{aligned}
& \times \text { Sori round. } \\
& \times \times \text {. Sori oblong. }
\end{aligned}
$$

(158) P. papuanum.

a.a. Substance of the fronds rather thin; veins distinct. (1)

b'. Sori in 1-2 regular or irregular rows on each side of th midrib.

c'. Fronds dimorphous.

+ Fertile fronds orbicular and barren in the lower, long-linear in the soriferous upper part.

(159) P. Annabellae. SI $p$

+.+. Fertile fronds ligulate, cuneately narrowed at the base.

(160) P. Iycopodioides.

$\boldsymbol{c}^{\prime} \cdot \boldsymbol{c}^{\prime}$. Fronds uniform, the fertile sometimes narrower than the barren.

d'. Fronds ralker small, under 20 c.M. long.

$\boldsymbol{e}^{\prime}$. Areolae with free veinlets.

$\boldsymbol{e}^{\prime} \cdot \boldsymbol{e}^{\prime}$. Areolae without free veinlets.

(161) P. Raapii.

(162) P. zosteriforme.

$\boldsymbol{d}^{\prime} \cdot \boldsymbol{d}^{\prime}$. Fronds larger, \pm 30-60 c.M. long. (163).P. normale.

$\boldsymbol{b}^{\prime} . \boldsymbol{b}^{\prime}$. Sori in several rows on each side, or scaltered irregularly. $\left.{ }^{2}\right)$

1. Sori superficial.

2'. Rhizome scales blackish or dark-brown, not squarrose.

(164a) P. myriocarpum. SI $p$

(164b) P. sablanianum.

$\mathbf{2}^{\prime} \cdot \mathbf{Z}^{\prime}$. Rhizome scales brown, squarrose.

1'.1'. Sori immersed.

(bu 165) $\mathrm{p}$ glossipes.

(166) P. linguaeforme.

(152) P. holopinyllum, Brte., Journ. of Bot., XVII, 45 (not XXVI, 325); (? P. flabellivenium, Bk., C. Chr., Ind. Fil.).

Rhizome wide-creeping, the scales dense, erecto-patent, minute, linearsubulate. Stipes subdistant, brown, polished, slender, naked, $21 / 2-5$ c.M. long. Fronds roundish or oblong, 8-15 m.M. each way, crenulate round the edge except towards the base. Texture rigid; surfaces naked; no distinct midrib; veins flabellate, forming copious irregular areolae without free veinlets. Sori few, round, superficial, scattered irregularly.

Borneo.

P. Subsparsum, Bourn. of Bot., XVIII, 215.

Rhizome slender, wide-climbing, firm, flexuose, thinly clothed with small, adpressed, bright-brown, lanceolate scales. Stipes distant, stiffly erect, naked,

(') See also P. revolutum, C. Chr.

( $\left.{ }^{2}\right)$ See also P. normale, Don. 


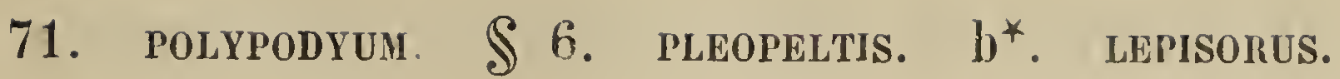

$21 / 2-8$ c.M. long. Fronds linear-lanceolate, entire, $7-1$ b.M. long, $1 / 2-2$ c.M. broad below the middle, narrowed gradually to both ends. Texture rigidly coriaceous; both surfaces naked; veins obscure, the main ones erecto-patent, enclosing copious, small, irregular areolae. Sori superficial, large, round, crowded in the narrowed upper half of the frond, not in regular rows.

Sumatra.

(134) P. tenuilore, Fre, Hk. Bk., Syn. Fil., 354; Mett., Farng., I, Polypod., tab. I, fig. 28; Diblemma samarensis, J. Sm., Bau. \& Hk., Gen. Fil., tab. CIX, B; Drynaria tenuiloris, J. Sm., Journ. of Bot., III, 397.

Rhizome slender, woody, scandent. Fronds $20-45$ c.M. long, $1-1 \frac{1}{2}$ c.M. broad, the apex acuminate, the edge entire, the lower part narrowed very gradually into a short stipe or the base. Texture rigidly coriaceous; surfaces naked; no main veins; areolae fine, hidden, with free veinlets. Sori small, copious, scattered, sometimes confluent especially along the edge.

Philippines.

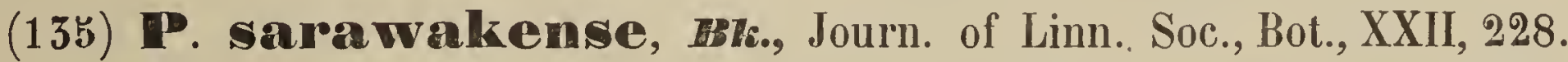

Rhizome slender, wide-creeping, branched, naked. Fronds few, distant, erect, simple, oblong-lanceolate, acuminate, with the base cuneately and gradually narrowed, $10-15$ c.M. long, 5-4 c.M. broad at the middle, on stipes $3^{1 / 2}-8$ c.M. long. Texture subcoriaceous; surfaces naked; veins fine, immersed, hidden; areolae hexagonal. Sori large, irregularly scattered all over the under surface of the frond except the apex, slightly immersed.

Borneo, New Guinea.

* (156). D. superficiale, Bu., Rac., Flor. Btz., I, 108 ; Bl., Flor. Jav., II, 136, tab. LVI, fig. 1; Pleopeltis superficialis, Bedd., Ferns Br.I., I, tab. LXXV; P. normale, Don, var. sumalranum, Bk, Journ. of Bot., XVIIl, 215.

Rhizome wide-creeping, blackish; scales brown, lanceolate, peltate, the base acute, round or cordate, adpressed, the apex recurved or erect. Stipes 丂-15 c.M. long, firm, naked, slightly scaly when young. Fronds linear-lanceolate, $13-40$ c.M. long, $21 / 2-b$ c.M. broad, narrowed gradually towards both ends, the edge entire. Texture coriaceous, commonly weak; surfaces naked; veins hidden or moderately visible; no main veins; areolae fine, with free veinlets. Sori roundish, somelimes slightly irregular, numerous, scattered irregularly.

Malaya; Queensland, Japan, Korea, China, North. India. 
(137) P. peltatum, v. A. v. R.; Pleopeltis peltata, Scort., MS.; Pl. superficialis, Bedd., var. latifrons, Bedd., Journ. of Bot., XXXI, 226.

Near P. superficiale, $B l$. but the scales of the rhizome roundish, \pm adpressed, black with a brown edge. Stipes shorter; fronds shorter and broader.

Malacca.

* (158) P. antroplnyoides, v. A. v. R., Bull. Dép. Agr. I. N., 1908, XVIII, 22.

Rhizome short-creeping, the scales brownish, linear-lanceolate, entire or slightly toothed. Fronds sessile or short-stalked, 8-15 c.M. long, the upper $1 / 2-2 / 3$ ovate-lanceolete, $5-5$ c.M. broad, the apex short-acuminate, the cdge entire, recurved, the base narrowed into the narrow, linear-cuneate, decurrent lower part the frond. Texture coriaceous; surfaces naked; costa prominent in the lower part, becoming gradually finer and indistinct upwards, nearly wanting towards the apex; veins hidden; areolae very irregular, numerous, with copious free veinlets. Sori scattered irregularly, moderately large.

Sumatra (Forbes, No. 3119).

* (139) P. currtidems, Chavist, Ann. Btz., XX, 122.

Rhizome short-creeping, the scales not dense, lanceolate-subulate, firm, brown. Stipes short, to \pm 5 c.M. long, tufted, slender. Fronds \pm 1 b-20 c.M. long, $\pm 1 \frac{1}{2}$ c.M. broad, lanceolate, acute, the edge slightly undulate and broadly crenate with shallow, tooth-like, decumbent crenations, the base narrowed very gradually into the stipe. Texture coriaceous but not very thick; surfaces naked; costa prominent; no distinct main veins; areolae irregular, with few free veinlets. Sori numerous, small, placed in $3-4$ irregular rows in each side, leaving a space from the margin, hardly immersed.

Borneo.

* (140) P. IBakeri, Luerss., Abh. Nat. Ver. Brem., VII, 48, P. torulosum, Bk., Journ. of Bot., XVIII, 21 b (not Journ. of Linn. Soc., Bot., XVI, 204).

Rhizome slender, wide-creeping, densely clothed with linear, acuminate, ciliate, reddish-brown scales. Fronds very dimorphous; sterile fronds on stiffly erect, naked stipes $21 / 2-4$ c.M. long, the lamina simple, oblong or linear-oblong, entire or slightly and broadly crenate, blunt or acute, $21 / 2-7$ c.M. long, $1 \frac{1}{2}-2 \frac{1}{2}$ c.M. broad at or below the middle, the base cuneate. Texture rigidly coriaceous; surfaces naked; veins immersed, obscure; no mains veins; areolae copious, small, irregular, with free veinlets. Fertile fronds on much 


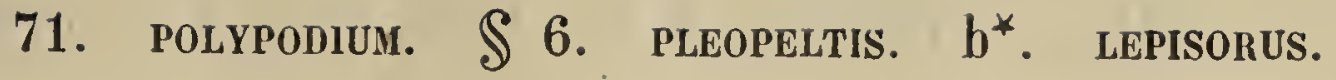

longer stipes (10-15 c.M. long), the lamina 10-15 c.M. long, reduced to a mere midrib, from which the large, round or oblong sori bulge out at intervals on each side.

\section{Sumatrá.}

* (141) P. Wrayi, BE., Journ. of Bot., XXV, 206.

Rhizome slender, wide-creeping, the scales dense, lanceolate, acuminate, membranaceous, ferrugineous, ciliate. Stipes of barren fronds $\pm 1 \frac{1}{2}-4$ c.M. long. Barren fionds oblanceolate, $2 \frac{1}{2}-5$ c.M. long, $6-9 \mathrm{~m}$. M. broad, obtuse. Texture thick, coriaceous; surfaces naked like the stipe; veins reticulate, immersed, obscure. Fertile fronds \pm b-13 c.M. long, 3-5 m.M. broad, linear, obtuse, with a longer stipe. Sori round, superficial, in 1 row on each side of the midrib; receptacle round or oblong.

Malacca, Sumatra. Roweo. SI p $37^{6}$

* (142) P. Beccanii, v. A. \%. R., Bull. Dép. Agr. I. N., 1908, XVIII, 22.

Rhizome creeping, firm, the scales lanceolate-oblong, with the apex acute and the base rounded or acute. Stipes scattered, $1-5$ c.M. long, erect, naked. Sterile fronds $\pm 6-10$ c.M. long, $7-8 \mathrm{~m} . M$. broad, linear-lanceolate, narrowed gradually towards both ends, the apex more or less blunt, the edge indistinctly crenate. Texture coriaceous; surfaces naked; costa prominent beneath; no main veins; areolae hidden, in $\pm 1-2$ rows on each side, with free veinlets. Fertile fronds on the longest stalks, linear-lanceolate, 12-15 c.M. long, 5-7 m.M. broad, narrowed gradually towards both ends. Sori in 1 row on each side, medial or nearer the midrib than the edge, distant, superficial, occupying the upper $1 / 2-2 / 3$ of the frond; receptacle \pm oblong. Baker determined this plant as P. congener, IIk. (Journ. of Bot., XVIII, 215), from which it differs by the quite naked fronds and the anastomosing veins.

Sumatra (Beccari, No. 442).

* (143a) P. arceclems, Bu., Rac, Flor. Btz., I, 103; Pleopeltis accedens, More, Bedd., Ferns Br.I., II, tab. CGXV.

Rhizome slender, wide-creeping, sparingly clothed with narrow, lanceolate, ciliate scales. Stipes none or to 1 c.M. long, $1 \frac{1}{2}-5$ c.M. apart. Fronds dimorphous. Barren fronds oblong to lanceolate, $21 / 2-8$ c.M. long, $11 / 2-3$ c.M. broad, the apex bluntish, the base cuneate or rounded, the edge entire, not thickened. Texture coriaceous; surfaces naked or sparingly covered with scattered, deciduous, stellate scales; no main veins; veins hidden; areolae 
irregular; free veinlets often directed towards the midrib. Fertile fronds narrower and longer than the barren ones, the upper part soriferous, narrowed gradually or linearly. Sori in 1 row on each side of the costa, superficial.

Malaya; Polynesia.

(143b) P. damunense, Rst., Fed., Rep., V, 42.

Rhizome wide-creeping, filiform, sparingly clothed with small, thin, lanceolate, ciliate scales. Fronds subsessile, \pm 1 c.M. apart, dimorphous. Barren fronds roundish-ovate or ovate-lanceolate, $1-1 \frac{1}{2}$ c.M. long, $\pm 3 / 4$ c.M. broad, cuneate at the base. Texture subcoriaceous; surfaces glabrescent; costa prominent on both sides; areolae immersed, in 2 rows between the costa and edge. Fertile fronds narrowly linear or more generally elongate-ovate, narrowed at the apex. Sori round, in 2 rows, occupying the narrowed apex of the fronds, intermixed with peltate scales.

New Guinea.

* (144) P. nummularium, Mett., Hk. Bk., Syn. Fil., 340; Mett., Farng., I, Polypod. tab. I, fig. 44-45; P. pyrolifolium, Goldm., G. Chr., Ind. Fil.; Marginaria nummularia Pr., (oldest name).

Rhizome creeping, slender, clothed with linear-lanceolate, acuminate, ferrugineous, subadpressed scales. Frondș distant, the barren ones mostly shortstalked, suborbicular, oval or ovate, $\pm 1-4$ c.M. long, $\pm 1-2$ c.M. broad when fully developed, the edge entire or shallowly and broadly crenate. Texture coriaceous; surfaces naked; veins immersed, obscure, forming 5-4 rows of areolae on each side, with free veinlets. Fertile fronds linear, 7-10 c.M. long, \pm 3-4 m.M. broad, narrowed gradually towards both ends, on stipes nearly as long as the fronds, the edge repand, the stipes slender, the veins forming 1-2 rows of longitudinally elongated areolae. Sori in 1 row on each side near the costa, 1 to each lobe, superficial, but the position marked on the upper surface of the frond.

Philippines.

\section{mit = nummularia Sip37)}

(145) P. Lammatisorum, Harr., Copel., Polypod. Philipp., 125; (? P. nummularium, Mett.).

Rhizome long, slender, the scales thin, membranaceous, long, lanceolate, light-brown. Stipes scattered, $1 / 2-4$ c.I. long, slender, erect, naked. Sterile fronds elliptical, $1-4$ c.M. long, $1 / 2-21 / 2$ c.M. broad, obtuse, coarsely and shallowly crenate except at the narrowed base. Texture coriaceous: surfaces 
71 POLYPoDium. $\mathbb{S} 6$. Pleopeltis. $\mathrm{b}^{*}$. LEPISORUS.

naked; veins immersed; midrib distinct. Fertile fronds linear, $5-13$ c.M. long, $\pm 5 \mathrm{~m} . \mathrm{M}$. broad, on stipes $21 / 2-8$ c.M. long, with a lobe under each solus. Sori \pm 20 in a row on each side of the midrib, large, giving the frond a knotted appearance.

\section{Philippinnes.}

* (146) P. Stenopteris, Bk., Journ. of Bot., XVII, 45 ; Christ, Ann. Btz., XX, tab. III, fig. 4 .

Rhizome wide-creeping; scales dense, squarrose, brown, the base roundish, peltate, the point long, fine, linear. Stipes nearly none or to 4 c.M. long, the fertile fronds on the longest stipes. Fronds dimorphous. Barren fronds lanceolate-spathulate, $3-5$ c.M. long, $1 / 2-1$ c.M. broad, the apex bluntly rounded, the edge entire, thickened, the base gradually narrowed, \pm cuneate. Texture very rigidly coriaceous; costa conspicuous; veins hidden. Fertile fronds 20-30 c.M. long, the lower half narrowly lanceolate, the edge entire, the base cuneately narrowed, the apex narrowed gradually into the narrow, linear, repand upper half of the frond. Sori immersed, rather distant, confined to the linear upper half of the frond, placed in the projections of the waves, 1 to each lobe, prominent on the upper surface.

Bornèo.

* (147) P. sonidems, Mk., Hk. Bk., Syn. Fil., 555; Hk., Spec. Fil., V, tab. CCLXXXIII, B.

Rhizome wide-creeping; scales squarrose, the base roundish, peltate, the apex long, fine, linear. Stipes $21 / 2-71 / 2$ c.M. long, slender, naked, scattered. Fronds linear-lanceolate, $10-30$ c.M. long, $1 / 2-1 \%$ c.M. broad, narrowed very gradually to both ends, the barren ones with the edge entire or repand; fertile fronds toothed with the teeth distant and rounded, or deeply and very irregularly incised with the lobes spreading, oblong, bluntly rounded, $1-\mathbf{z} 0$ m.M. apart, the sinuses broadly rounded. Texture rigid, coriaceous; surfaces naked; no main veins; areolae fine; free veinlets rare. Sori submarginal, terminal on the lobes, 1 to each tooth or lobe, deeply immersed, forming very distinct papillae on the upper surface.

Borneo.

* (148) P. neglectum, Bi., Flor. Jav., II, 135, tab. LIV, fig. 1.

Rhizome moderately long, creeping, dirty-brown; scales dense, small, lanceolate-subulate, recurved, the younger ones reddish-brown, ereso-ciliate, villo- 
se near the base, the others blackish-brown, adpressed, naked. Fronds subdimorphous, the barren ones on stalks under $8 \mathrm{~m}$.M. long, the fertile on stalks $\pm 2 \frac{1}{2}$ c.M. long. Barren fronds distant, 8-25 m.M. long, 6-15 m.M. broad, obovate, the apex rounded, the edge broadly crenate, slightly reflexed, the base narrowed suddenly. Texture coriaceous; surfaces naked; costa distinct beneath in the lower half. Fertile fronds lanceolate-spathulate, \pm 2 c.M. long, $5-8$ m.M. broad, the apex rounded, the base cuneate. Sori in 1 row on each side, $\pm 5-5$ to a row, occupying the upper $1 / 2-3 / 4$ of the frond.

Java, Luzon.

(149) P. rudimentum, Copel., Polypod. Philipp., 125 ; (P. oodes, Kze, Copel., Philipp. Journ., III, 55).

Rhizome wide-creeping, slender, the scales linear-subulate, brownish. Stipes $1 \frac{1}{2}-2 \frac{1}{2}$ c.M. long, erect, filiform, naked, stramineous. Fronds orbicularovate, the fertile ones rather narrower, 1-2 c.M. long, rounded at both ends, entire or finely serrate. Texture coriaceous; surfaces naked; costa evanishing near the apex; veins obscure, anastomosing irregularly, or sometimes free but hamate. Sori few, subimmersed, round, in 1 row on each side, \pm medial between the costa and margin.

Philippines.

(150) P. subecostatum, Hk., Hk. Bk., Syn. Fil., 353; Ḧk., Spec. Fil., V, tab. CCLXXXIII, A.

Rhizome creeping, the scales brown, fibrillose, squarrose. Fronds sessile, 10-20 c.M. long, $1-1 \frac{1}{2}$ c.M. broad, narrowed gradually to both ends, the edge entire. Texture thick, coriaceous; colour pale-green; surfaces naked; midrib upwards indistinct; no main veins; areolae obscure. Sori in a single submarginal row.

Borneo.

* (151) T. rostratum, Hk., Hk. Bk., Syn. Fil., 353; Hk., Icon. Pl., X, tab. CMLIII; P. subrostratum, C. Chr., Ind. Fil!; Pleopeltis rostrata, Bedd., Ferns Br.I., II, tab. CLIX; - var. trifurcatum, Christ, Bull. Herb. Boiss., $2^{\mathrm{e}}$ Série, I, 449.

Rhizome filiform, wide-creeping, the scales small, fibrillose. Stipes $21 / 2-$ 5 c.M. long, firm, naked. Fronds $\breve{5}-10$ c.M. long, $1-2 \frac{1}{2}$ c.M. broad, narrowed gradually to both ends, the edge entire, the apex rostrate. Texture 
71. POLYPODIUM. $\$ 6$. PleOPELTIS. $\mathrm{b}^{*}$. LEPISORUS.

coriaceous; surfaces naked; no distinct main veins; veins immersed; areolae fine, with free veinlets. Sori large, in single rows not far from the midrib.

Var. trifurcatum: Fronds 2-3-furcate, with acute lobes.

Luzon; North. India, South. China; - var. trifurcatum :- New Guinea.

* (152) P. Iineare, Thb., Hk. Bk., Syn. Fil., 354; P. loriforme, $H k$., Gard. Ferns, tab. XIV; P. contiguum, Wall., List, No. 285; Pleopeltis nuda, Hk., Bau. \& Hk., Gen. Fil., tab. XVIII; Pl. Wightiana, Bedd., Ferns S.I., tab. CLXXX; Pl. linearis, Moore, Bedd., Handb. Ind. Ferns, 346.

Rizome wide-creeping, woody, the scales lanceolate, dull-brown. Stipes varying from \pm none to 5 c.M. long. Fronds $10-30$ c.M. or more long, 1-5 c.M. broad, entire, narrowed gradually to both ends. Texture subcoriaceous; sufaces nearly naked; areolae fine, with copious free veinlets. Sori hardly immersed, large, \pm oblong, in 1 row on each side, medial or nearer the midrib than the edge, distant, covered with copious peltate scales when young.

Malaya; Hawaii, Japan, China, North. India, Ceylon, South. Africa.

* (155) P. Forlbesii, v. A. v. R., Bull. Dép. Agr. I. N., 1908, XVIII, 23.

Rhizome wide-creeping, firm, the scales dense, strongly adpressed, ovate or oblong, rounded or acute at both ends, peltate, brown, with a blackish centre. Stipes distant, 5 c.M. or more apart, $1 \frac{1}{2}-21 / 2$ c.M. long, erect, firm, naked, not very slender (with regard to the rhizome). Fronds broadly lanceolate, $10-12$ c.M. Iong, $21 / 2-4$ c.M. broad below the middle, narrowed gradually to an acuminate apex and base. Texture coriaceous, not thick; surfaces naked; veins fine, irregularly anastomosing; areolae with free veinlets. Sori moderately large, distant, in 2 rows on each side of the midrib, the outer row medial between the midrib and edge, the apex and base of the fronds destitute of sori.

Sumatra (Forbes, No. 2333).

(154) P. induratum, BF., Ann. of Bot., V, 475.

Rhizome slender, wide-creeping. Stipes wiry, naked, 7-10 c.M. long. Fronds simple, linear, $20-25$ c.M. long, $1-1 \frac{1}{2}$ c.M. broad at the middle, narrowed gradually to both ends. Texture rigidly coriaceous; surfaces naked; veins quite hidden. Sori semiglobose, superficial, forming a single lax row 
71. POLYPODIUN. $\$ 6$. PLEOPELTIS. $b^{*}$. LEPISORUS.

on each side of the costa, with a few others forming an outer row at the middle of the frond.

New Guinea.

- (155) P. stenophyllum, Bu., Rac., Flor. Btz., I, 104 ; Bl. Flor. Jav. II, 134, tab. LV, fig. 1, a-b; Pleopeltis stenophylla, Hoone, Bedd., Ferns Br.I, II, tab. CCXXXIV.

Rhizome wide-creeping, the scales dense, lanceolate-subulate, acuminate, entire, brownish. Stipes $1 / 2-5$ c.M. apart, $1-21 / 2$ c.I. or more long, firm, erect. Fronds $8-25$ c.M. long, $5-13$ c.M. broad, narrowed gradually to both ends, the apex varying from acute to rounded, the edge entire. Texture very coriaceous; surfaces naked; no distinct main veins; veins hidden; areolae with few free veinlets. Sori deeply immersed, very prominent on the upper surface, placed in 1 row on each side near the edge. - The form with the bluntly rounded fronds is var. obtusum, Christ (Ann. Btz., XV, 153).

Malaya; Fiji.

* (156a) P. revolutam, C. Chr., Ind. Fil.; P. longifolium, Mett., Rac., Flor. Btz., I, 104; P. contiguum, Hk. (not Wall.), Fil. Exot., tab. XX; Icon. PI., X, tab. CILXXXVII: Pleopeltis longifolia, Bedd., Ferns Br.I., I, tab. VII; Grammitis longifolia, Bl., Enum., 119; Drynaria revoluta, J. Sm., Journ. of Bot., III, 421.

Rhizome creeping, woody, the scales linear-lanceolate, brown or black, not quite spreading. Stipes short, firm. Fronds 50-70 c.M. long, $1-4$ c.M. broad, \pm ligulate, narrowed gradually to both ends, the apex blunt or bluntish, the edge entire, often revolute. Texture coriaceous; under surface naked or slightly furfuraceous; no main veins; areolae fine, hidden, with free veinlets. Sori oblong, 2-5 $X$ as long as broad, immersed, parallel to the edge, confined to the upper $1 / 3-2 / 3$ part of the frond, placed in a line nearly close to the edge; young capsules mixed with small peltate scales. - The young plants have the texture thin, membranaceous to herbaceous, the veins conspicuous. A form found in Celebes has the sori round, large.

Malaya: New Caledonia.

(156b) Productum, Cherist, Philipp. Journ., II, 178.

Rhizome short-creeping, covered with small, scattered, setiform scales. Stipes approximate, \pm 10 c.M. long, stramineous, naked. Fronds linear, \pm 63 c.M. long, $\pm 1-1 \%$ c.M. broad, the apex acutely long-acuminate, the 
base narrowed gradually into the stipe, the edge narrowly revolute. Texture rigidly coriaceous; surfaces naked; colour yellow-greenish; costa prominent, stramineous: veins hidden. Sori oblong, rather large, submarginal, impressed, with a space less than their own length between them, the higher ones protruded beyond the margin.

Mindanao.

(157) P. subgeminatum, Christ, Schum. \& Laut., Flor. deut. Sch.geb., Suppl., 47.

Rhizome wide-creeping, very strong, the scales short, furfuraceous. Fronds subsessile, usually in distant pairs, uniform, entire, $\pm 71 / 2-15$ c.M. long, $1-21 / 2$ c.M. broad, narrowed towards both ends, the point often blunt. Texture coriaceous; surfaces naked; areolae copious, small, with numerous included veinlets. Sori large, in 1 row on each side, medial between the midrib and edge, much immersed.

New Guinea.

(158) P. papuanum, Bti., Becc., Mal., III, 48.

Rhizome wide-creeping. Stipes strong, rigid, naked, erect, $2 \frac{1}{2}-5$ c.M. long. Fronds simple, lanceolate-oblong, \pm 1 b.M. long, $21 / 2-4$ c.M. broad, the base cuneate, the edge entire, the apex acuminate. Texture firm; surfaces naked; veins immersed, obscure. Sori oblong, in 1 row on each side of the midrib, immersed in the substance of the frond.

New Guinea.

(159) P. Anmabellae, Forb., Journ., of Bot., XXVI, 33, tab. CCLXXX ; ? P. cyclobasis, Bk., Kew Bull., 1896, 42.

Rhizome creeping, slender, clothed with scattered, brown, membranaceous, lanceolate, acuminate scales. Fronds sessile, remote, imbricating, simple. Barren fronds suborbicular, entire, cordate at the base. Texture membranaceous; veins anastomosing •irregularly; arreolae large, enclosing smaller ones with few free veinlets; costa disappearing \pm towards the centre of the frond. Fertile fronds similar but the apex suddenly produced into a long, narrow, linear-lanceolate fertile part several times longer but much narrower than the barren part, with the costa distinct quite to the point. Sori \pm oblong, in 1-2 rows on each side of the costa.

New Guinea. 
(160) P. Iycopodioides, \&., Hk. Bk., Syn. Fil., 557; Christ, Farnkr. d. Erde, fig. 280; P. lagopodioides, Desv., Berl. Mag. ; V, 313.

Rhizome wide-creeping, the scales lanceolate-subulate, imbricate, reddish when young, at length ferrugineous or decolored. Stipes none or short, distant. Fronds dimorphous. Barren fronds 5-10 c.M. long, 1-3 c.M. broad, ovate-oblong, the apex commonly bluntly rounded, the base narrowed, the edge entire. Texture coriaceous; surfaces naked or the costa slightly scaly; veins moderately visible, forming on each side a first row of narrow, longitudinal costal areolae, a second row of large transveral areolae with included, free or anastomosing veinlets, which are directed towards the edge, and near the latter 1 or more rows of small areolae with or without free veinlets. Fertile fronds longer and narrower than the barren ones, narrowed gradually below. Sori large, in 1 row on each side, solitary in the largest areolae (those of the $2^{\text {nd }}$ row), on the included veinlets.

Java; Hawaii, Trop. America \& Africa, Mascarenes.

- (161) IP. IRampii, v. A. v. It., Bull. Dép. Agr. I. N., 1908, XVIII, 25, tab. IV, fig. 1, a-b.

Rhizome creeping, the scales linear-lanceolate, deciduous. Stipes scattered, 1-b̆ c.M. long, naked. Fronds lanceolate, $\pm 10-12$ c.M. long, $3 / 4-11 / 2$ c.M. broad at or a little below the middle, the fertile ones the narrowest, narrowed gradually towards both ends, the apex blunt, acute or acuminate, the edge entire. Texture thinly herbaceous or membranaceous; surfaces naked; costa distinct; veins visible, forming $\mathbf{1 - 5}$ rows of irregular areolae on each side of the costa; areolae with free veinlets. Sori distant, partially round, partially oblong and oblique, placed in 1 row on each side nearer the margin than the midrib, sometimes accompanied by some few $(1-5)$ scattered ones. - In swamps and ditches.

Another (submerged) water-ferm, found in Lombok by Dr. Ernst, has the stalks shorter, the fronds a little broader and slightly scaly on the costa beneath, and the sori placed in 1-2 rows nearer the midrib than the edge, whether or not accompanied by a few others placed in a $3^{\text {rd }}$, outer row ( $v$. A. v. R., l. c., tab. IV, fig. 2, a-b).

Batu Islands (Raap, No. 671).

(162) P. zosteriforme, wall., Hk. Bk., Syn. Fil., 357; Mett., Farng., I, Polypod., tab. I, fig. 26-27; Pleopeltis zosteraeformis, Bedd., Ferns Br.I., I, tab. CXXIII. 
71. POLYPodium. $\$ 6$. Pleopeltis. $b^{*}$. Lepisorús.

Rhizome wide-creeping, slender, scaleless. Stipes $1-21 / 2$ c.M. long, slender. Fronds $10-15$ c.M. long, \pm 5 m.M. broad, the apex scarcely acuminate, the edge entire, the base gradually narrowed. Texture herbaceous; colour dark-green; surfaces naked; no main veins; veins distinct; areolae in $2-5$ irregular rows, without free veinlets. Sori distant, round or \pm oblong, in 1 regular or irregular row on each side nearer the midrib than the edge.

Malacca.

(163) P. normale, Don., Hk. Bk., Syn. Fil., 358; Pleopellis normalis, Moore, Bedd., Ferns Br.I., I, tab. X; - var. longifrons; Pol. longifrons, Wall., List, No. 274; Hk. \& Grev., Ic. Fil., tab. LXV.

Rhizome woody, scandent, clothed with deciduous, fibrillose, ovate or lanceolate, almost hair-pointed scales. Stipes approximate, $21 / 2-8$ c.M. long, stramineous or reddish. Fronds linear-lanceolate, 50-60 c.M. long, $21 / 2-5$ c.M. broad, narrowed gradually towards both ends, the point acute, the edge entire or slightly wavy. Texture membranaceous to slightly coriaceous; surfaces naked, or a few scattered, closely adpressed scales present on the stipes and near the base of the costa beneath; no main veins; areolae moderately large, with free veinlets. Sori large, superficial, in 1 regular or more commonly 1-2 irregular, \pm wavy rows on each side of the midrib. - Near P. lineare, Thb., but the capsules not intermixed with peltate scales.

Var. Iongifrons: Sori copious, scattered irregularly.

Trop. Asia, China, Madagascar.

* (164a) P. myriocarpum, Mett., Hk. Bk., Syn. Fil., 558; Mett., Farng., I, Polypod., tab. I, fig. 38; Phymalodes myriocarpa, Pr., Tent. Pterid., tab. VIII, fig. 12.

Rhizome firm, woody, the scales subadpressed, ovate or lanceolate, peltate, blackish, the edge brownish, toothed, erose or slightly fimbriate. Stipes distant, 1-马 c.M. long. Fronds lanceolate, 15-90 c.M. long, $2 \% \frac{1}{2}-10$ c.M. broad, acuminate, entire, narrowed gradually to the base. Texture papyraceoherbaceous; surfaces naked or the under side pubescent; primary veins forming a series of large, costal primary areolae, a second series of stout veins forms smaller but still very conspicuous primary areolae outside the costal ones, both including numerous finer ones resembling those between the second series and the margin, with included free veinlets. Sori copious, scattered irregularly, sometimes confluent.

New Guinea, Amboyna, Borneo, Philippines; Cochin॰China.

Filices, 
(164b) P. sablaniamum, Christ, Philipp. Journ.gin, 177.

Near P. myriocarpum, Mett., but: Rhizome scandent, brown, clothed with stiff, subulate, dark-brown scales. Fronds to \pm 73 c.M. long, to $\pm 5 / 2$ c.M. broad, the apex long-caudate, the margin undulate, the base long-decurrent. Texture membranaceous; colour bright-green; costa light-yellow; venation slender, forming a single row of very large, square primary areolae and another row of very narrow, obscure ones.

Luzon. Bones, Mundano S: p 381 ?

(165) P. Glossipes, Bk., Ann. of Bot., V, 476.

Rhizome wide-creeping, clothed with few, small, squarrose, linear, brown scales. Stipes $3 \frac{1}{2}-4$ c.M. long. Fronds lanceolate-oblong, acute or obtuse, narrowed very gradually at the base, $15-20$ c.M. long, $3 \frac{1}{2}-6 \frac{1}{2}$ c.M. Iroad. 'Texture chartaceous; surfaces naked; venation as in P. myriocarpum, Mot. Sori globose, superficial, scattered all over the frond.

New Guinea; Cambodja.

(166) D. Iimguae forme, Mett., Hk. Bk., Syn. Fil., 558.

Rhizome stout, short-creeping. Fronds sessile, 20-45 c.M. long, 6-8 c.M. broad, tongue-shaped, narrowed from the centre to $3 / 4$ of the way down, and then dilated again to a broadly-rounded base, the edge entire. Texture papyraceous; both surfaces naked; veins very distinctly prominent, the main ones irregular; areolae subquadrangular, with a single, distinctly immersed sorus on free or joined veinlets in the centre of each.

Luzon, East. Malaya; Polynesia, Melanesia.

\section{$\$ 6$. PLEOPELTIS. b. Atactosia. **. Pleuridium.}

a. Sori in 1 row on each side of the midrib, solitary between the mann veins, sometimes confluenl.

b. Sori superficial, round, rarely oblong.

c. Barren fronds distinctly shorter than the fortile ones, and much broader, under 10 c.M. long.

d. Fertile fronds under 6 m.M. broad.

(167) P. costulatum.

a.d. Fertile fronds broader, 7-20 m.M. broad.7 a) Re. de Rechui Si 3

e. Rhizome scales lanceolale, whitish.

(168) P. Hellwigii. 


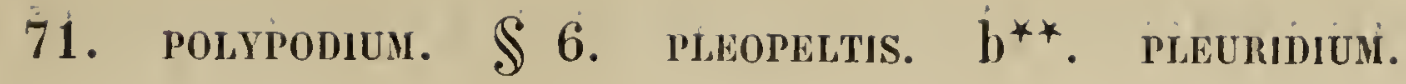

e.e. Rhizome scales fibrillose, ferrugineous.

(169) P. rhynchophyllum.

c.c. Barren fronds hardly shorter than the fertile ones, more than 10 c.M. long. (job) \& ableswila si p $383(170)$ P. Griffithianum.

b.b. Sori \pm immersed, round. (171) P. Whitfordi.

b.h.h. Sori \pm immersed, oblong.

(i)1a) re subcuidi

*. Sori oblique to the costa. 1)ra a Al batas Sip 38 s.

Voonsies sıp366**. Sori parallel to the costa. (172b) P? Valetonianum.

a.a. Sori in 1 row between the main veins, free or confluent. (1)

1. Upper surface of the fronds copiously covered wilh white dots.

(175) P. platyphyllum.

1.1. Upper surface of the fronds without white dots.

2. Texhure membranaceous.

2.2. Texlure ralher coriaceous.

(174) P. campyloneuroides. (1)4a) Pl salligivadis Sip 386

3. Fronds small, under 121/2 c.M. long. Main veins crecto-patent.

(175) P. phlebiscopum.

3.3. Fronds larger, more than $12 \%$ c.M. long.
*. Main veins \pm horizonlal.
(176a) P. hemionitideum.
*.*.Main veins oblique.
(176li) P. Werneri.

a.a.a. Sori in 2 rows belween the main veins, 1 to several in a row.

b'. Texlure membranaceous or herbaceous 10 papyraceous.

*. Slipes distant.

(177) P. Zippelii. Sts S p of

*.*. Stipes approximate. $38 y$

b'.t'.'T'exture charlaceous to coriaceous.

$\boldsymbol{c}^{\prime}$. Upper surface of the fronds covered with white dots.

(179) P. leucophorum.

$\boldsymbol{c}^{\prime} \cdot \boldsymbol{c}^{\prime}$.Upper surface of the fronds without white dots.

d'. Rhizome scales blunt at the apex, pale-ochraceous.

(180) P. Uriquetrum.

$\boldsymbol{d} \cdot \boldsymbol{d}$.Rhizome scales acuminate or aristale at the apex.

$\boldsymbol{e}^{\prime}$. Rhizome scales dark-brown, somelimes white.

f.. Sori 4-8 in a row.

$\boldsymbol{f}^{\prime} \cdot \boldsymbol{f}^{\prime}$. Sori $1-3$ in a row.

(181a) P. rupestre.

(181b) P. Inzonicum.

$\boldsymbol{e}^{\prime} \cdot \boldsymbol{e}^{\prime}$. Rhizome scales pale-coloured, yellowish. (182) P. albulum.

a.a.a.a. Suri scatteręd irregularly, free or sonnelimes confluent.

${ }^{2}$ ) See also $\S 7$, Selliguea.

(') See also P. membranaceum, Don, Zippeli, Bl. \& Ieucophorum, $B k$. 
1. Fronds small, under 15 c.M. long.

*. Rhizome scales fibrillose, yellowish. Sori rather large, superficial.

(183) P. oodes. S.1 $p_{3}$

*.*. Rhizome scales lanceolate, pale-brown. Sori rather small, subim: mersed.

(184) P. dulitense.

1.1'. Fully developed fronds more than 15 c.M. long.

2. Texture membranaceous or herbaceous.

s. Rhizome naked.

*. Fronds short-stalked.

*.*.Fronds long-stalked.

(18丂a) P. suboppositum. Si $p 30$

(185b) P. Scortechinii.

\$.S. Rhizome scaly.

×. Sori irregularly 1-5-serial.

$\times \cdot \times$.Sori numerous.

(186a) P. ovatum. SI $p 3 q$

(186b) P. Zollingerianum.

$\mathbf{2}^{\prime} \cdot \mathbf{2}$. Texture charlaceous to coriaceous.

$\boldsymbol{3}^{\circ}$. Fronds commonly $\pm 2^{1} /{ }_{2}-6^{1} /_{2}$ c.M. broad. ( $\left.{ }^{*}\right)$

1'. Stipes stout, narrowly winged by the gradually decurrent base of the fronds.

1:.4'. Stipes short or wanting, not winged. Fronds \pm blunt at the base.

(188) P. punctatum. Si $p 3 q$ i

$\mathbf{3}^{\prime} \cdot \mathbf{3}^{\prime}$. Fronds commonly broader, $\pm 6{ }_{2}-20$ c.M. broad.

5. Fronds cordate or rounded at the base.

\$.S. Fronds gradually narrowed at the base.

(189) P. musifolium. Si $p 3 q$

*. Rhizome short, thick.

(190a) P. validum.

*.*. Rhizome scandent, slender.

P. mơnstrosum。

* (167) P. costulatum, IBT., Journ. of Bot., XVIII, 215; Acrostichum costulatum, Ces., Fel. Becc. Polin., 5 \& 8; Drymoglossum rigidum, IIk., var. longistipilatum, Christ, MS. in Herb. Bog.

Rhizome wide-creeping, slender, woody; scales erecto-patent, lanceolatesubulate, brownish . or bleached, the base roundish, dilated, peltate. Stipes $2 / 2-15$ c.M. long, those of the fertile fronds the longest, scattered, naked, erect. Fronds dimorphous. Barren fronds ovate or deltoid-oblong, obtuse, 
$21 / 2-7$ c.M. long, $2-4$ c.M. broad, the base broadly cuneate or subtruncate, the edge thickened, broadly and shallowly crenate. Texture rigidly coriaceous; surfaces naked; main veins prominent beneath, distinct and straight nearly to the edge, erecto-patent or the lower spreading; veins quite hidden. Fertile fronds linear, 6--10 c.M. long, 5-5 m.M. broad, narrowed gradually towards both ends; midrib very prominent beneath; edges recurved. Sori \pm contiguous, round or oblong, sometimes confluent, medial, in 1 row on each side parallel to the costa, occupying the space between the midrib and edge.

Sumatra, Borneo, New Guinea.

(168) P. Mellwigii, Diels, Schum. \& Laut., Flor. deut. Sch.geb., 140, tab. III, A-B.

Rhizome wide-creeping, slender, the scales copious, large, whitish, lanceolate, long-acuminate. Stipes $1-4$ c.M. long, the fertile fronds on the longest stipes. Fronds dimorphous. Barren fronds subobovate, $1 \frac{1}{2}-21 / 2$ c.M. long, $\pm 1 \frac{1}{4}-1 \frac{1}{2}$ c.M. broad, the apex blunt, the base cuneate. Texture coriaceous; the margin entire, subrevolute; surfaces naked; costa prominent; main veins erecto-patent, \pm 4 on each side, prominent; areolae hidden. Fertile fronds elongate, $4-5$ c.M. long, $\pm 3 / 4-1$ c.M. broad; main veins $\pm 8-9$ on each side. Sori medial, in 1 row on each side of the costa.

New Guinea.

* (169) P. Phynchophyllum, Hlk., Hk. Bk., Syn. Fil., 359; Hk., Icon. Pl., X, tab. CMLIV; Pleopeltis rhynchophylla, Moore, Bedd., Ferns Br.I., I, tab. IX.

Rhizome firm, wide-creeping, the scales copious, peltate, lanceolate, acuminate, ferrugineous. Stipes $2 \frac{1}{2}-10$ c.ll. long, the fertile fronds on the longest stipes. Fronds dimorphous. Barren fronds ovate, $21 / 2-4$ c:M. long. Texture coriaceous; surfaces naked; main veins distinct to the edge; areolae copious, fine, with free veinlets. Fertile fronds 7-15 c.I. long, 1-2 c.M. broad, narrowed very gradually upwards, the base cuneate, the edge ohscurely toothed or rotundato-crenate. Sori 1 -serial on each side, confined to the upper $1 / 4-$ $1 / 2$ of the frond.

Philippines; North. India.

* (170) P. Crimithianum, Hk., Hk. Bk., Syn. Fil., 359; Hk., Icon. Pl., X, tab. CMLI; Pleopeltis Grifflliana, Moore, Bedd. Ferns. Br.I., II, tab. CLVIII; - var. borneense, Christ, Ann. Btz., XX, 122, 
Rhizome wide-creeping, the scales dense, linear, squarrose, dull-brown. Stipes distant, $7-15$ c.M. long, firm, erect. Fronds $15-26$ c.M. long, $51 / 2-5$ c.M. broad, the point acute or acuminate, the edge repand, the base rounded or rather narrowed and auricled. Texture coriaceous; surfaces naked; main veins very distinct to the edge; areolae fine, hidden, with copious free veinlets. Sori large, in 1 row on each side near the midrib, solitary between the main veins.

Var. borneense: Sori more distant-from the midrib, smaller, more numerous; rhizome scales linear-lanceolate, pale-brown.

South. China, North. India; - var. borneense: Borneo.

(171) P. Whitfordi, Copel., Philipp. Journ., I, Suppl., 2̧6, tab. IV, B.

Rhizome creeping, the scales lanceolate, apiculate, persistent, pale-feriugineous when young. Stipes distant, filiform, $1-4 \frac{1}{2}$ c.M. long, the fertile fronds on the longest stipes. Fronds dimorphous. Barren fronds $1-31 / 2$ c.M. long, the smallest ones orbicular, the largest oblong, obtuse, the margin cartilagineous, broadly and shallowly crenate. Texture coriaceous; surfaces naked; costa black beneath; main veins straight, reaching nearly to the margin; areolae quadrangular, in $\pm \mathbf{5}-4$ rows on each side, with few included, excurrent free veinlets. Fertile fronds $20-60$ c.M. long, 6-9 m.M. broad, the smallest ones entire, obtuse, the largest crenate, acute, cuneate at the base. Sori in 1 row on each side, medial between the costa and margin, subimmersed, prominent on the upper surface, not restricted to the highest part of the frond.

\section{Luzon.}

* (172a) P. Treubii, Christ., Ann. Btz., XX, 121; P. dolichosorum, Chrisl, MS. in Herb. Bog.

Rhizome wide-creeping, slender; scales firm, the base roundish, peltate, the point long, fine, hair-like, spreading, reddish-brown. Stipes slender, firm, 5-9 c.M. long, naked. Fronds subdimorphous. Barren fronds lanceolate-ovate, 5-7 c.M. long, $\pm 1 \frac{1}{1} / 2-2$ c.ll. broad, the apex subacute, the margin entire, the base cuneate. Texture \pm coriaceous; surfaces naked; main veins fine but visible, slightly prominent, oblique; areolae hidden, with free veinlets. Fertile fronds on the longest stipes, narrowly lanceolate, longer and narrower than the barren ones, to 11 c.M. long, to 1 c.M. broad; main veins hidden. Sori in 1 row on each side, to \pm 20 to a row, oblong, medial between the mid- 
71. polypodium. $\$ 6$. Pleopeltis. $b^{* *}$. Pleuridium.

rib and edge, parallel to the main veins, immersed, prominent on the upper surface. - Scarcely different from a small form of P. heterocarpum, Metl. Borneo.

* (172b) P. Valetomianum, v. A. v. R., Bull. Dép. Agr. I. N., 1908, XVIII, 25, tab. V.

Rhizome creeping, stout, green, at length naked, the scales thin-membranaceous, yellowish, lanceolate, acuminate, erect, slightly but distinctly crisped, with the base rounded and peltate. Stipes \pm remote, naked, \pm terete, firm, erect, reddish or brownish-green in fresh material, $\mathbf{5}-\mathbf{1 5}$ c.M. long, the fertile fronds on the longest stipes. Fronds dimorphous. Barren fronds ovate-oblong or sublanceolate, $\pm 9-11$ c.M. long, \pm 4-b c.M. broad below the middle, narrowed towards the blunt or bluntish apex, the edge thickened and shallowly crenate, the crenations broad, 1 to each main vein, straight or more commonly slightly convex, the base rounded or cuneate, slightly decurrent upon the stipe. Texture very coriaceous; surfaces naked; colour bright-green above, paler beneath in fresh material; costa prominent; main veins distinct, erecto-patent, not quite reaching the margin; areolae hidden, with free veinlets. Fertile fronds linear, \pm 15 c.M. long, \pm 1 c.M. broad below the middle, narrowed gradually towards the bluntish apex, the base suddenly cuneate; main veins horizontally spreading, except the lowest pair, which is distinctly erecto-patent. Sori large, medial, solitary between the main veins, oblong, perfeclly parrallel to the costa, the highest ones nearly round, the others gradually becoming longer, the lowest $\pm 4-6 \times$ as long as broad, $\pm 1 / 2$ c.M. long, all deeply immersed so as to form large, conspicuous papillae on the upper-surface of the frond. - The species bears the name of Dr. Th. Valeton, Director of the Buitenzorg Herbarium.

Java (Preanger Regencies, v. A. v. R.).

* (175) Platyphyllum, Sav., Rac., Flor. Btz., I, 104 ; P. crasplents sinervium, Bl., Flor. Jav., II, 14ら, tab, LXI : Pleopellis plalyphylla, Bedd., Handb. Ind. Ferns, Suppl., 94.

Rhizome creeping, \pm woody, the scales dense, lanceolate, subulate-acuminate, dark-brown or blackish. Stipes $2-5$ c.M. apart, 5-15 c.M. long, strong, erect, canaliculate. Fronds 15-50 c.M. long, 4-12 c.M. broad, narrowed to both ends, the point acute, the edge entire. Texture rigid, coriaceous, very thick and firm; both surfaces naked, the upper densely covered with small cretaceous dots; midrib prominent; main veins parallel, very distinct to 
the edge, glossy. Sori immersed, in single rows between the main mains, $2-12$ in a row, confined to the upper $1 / 3-2 / 3$ of the frond or rarely.occupying the whole lamina.

Java, Borneo, Malacca.

P. Campylomeunoides, Bk., Journ. of Linn. Soc., Bot., XXII, 229.

Rhizome slender, wide-creeping, the scales small, lanceolate, adpressed. Stipes erect, naked, 1-4 c.M. long. Fronds simple, 10-15 c.M. long, 1-2 c.M. broad, oblanceolate, obtuse, narrowed gradually from the middle to the base. Texture membranaceous; surfaces naked; main veins fine, parallel, erecto-patent, indistinct; transversal veins forming subquadrangular areolae. Sori in 1 row between the main veins, $3-4$ in a row.

Borneo.

(175) P. phlebiscopum, Bk., Journ. of Linn. Loc., Bot., XV, 110.

Rhizome woody, flexuose, short-creeping, the scales membranaceous, erect, lanceolate, acuminate, pale-brown, $1 / 2$ c.M. long. Stipes $21 / 2-8$ c.M. long, rigid, naked, stramineous, canaliculate. Fronds simple, oblong or ovate-oblong, entire, $3 \frac{1}{2}-8$ c.M. long, $2-31 / 2$ c.M. broad at the middle, blunt or subacute, deltoid at the base. Texture rigidly coriaceous; surfaces naked; main veins erecto-patent, distinct to the edge; areolae fine, immersed. Sori superficial, in single rows between the main veins, $5-4$ in a row, often confluent and then forming an oblong mass $\breve{5}-8$ m.M. broad.

Ternate.

* (176a) P. hemionitideum, Wall.; Hk. Bk., Syn. Fil., 360; Pleopellis hemionitidea, Moore, Bedd., Ferns S.I., tab. GLXXXII.

Rhizome creeping, the scales lanceolate. Stipes $21 / 2-15$ c.M. long, erect, firm, scaly. Fronds $20-45$ c.M. long, 5-8 c.M. broad, narrowed towards both ends, the edge entire. Texture thinly coriaceous; surfaces naked; costa slightly scaly; veins distinctly prominent; main veins not reaching the edge, blackish, \pm horizontal, including lather large areolae; areolae in \pm 4 rows, subquadrangular, with many free veinlets. Sori on the anastomosing veins, moderately large, round or oblong, often confluent, in 1 row belween the main veins, the rows rather irregular.

Malaya; North. India, South. China. 
71. polypodiun. $\mathbb{S} 6$. pieopelitis. $\mathrm{b}^{* *}$. pleuridiun.

(176b) P. Wermeri, Rst., Fed., Rep., V, 45.

Rhizome wide-creeping, whitish-glaucescent, clothed with lanceolate-triangular, acuminate, entire, rufous-brown scales. Stipes slender, \pm 10 c.M. long, 5-10 c.M. apart, stramineous, naked. Barren fronds broadly ovate-lanceolate, \pm 18 c.M. long, \pm 6 c.M. broad near the base, the apex acuminate, the acumen \pm 4 c.M. long, narrow, the edge entire, the base cuneate or subrotund, slightly decurrent; fertile fronds rather similar but narrower, 5-4 c.M. broad. Texture chartaceous; surfaces naked; costa prominent beneath; main veins erecto-patent, nearly straight, prominent on both sides; areolae in 8-9 rows on each side of the costa, with many free veinlets. Sori in 1 row between the main veins, in pairs, subrotund or (principally the lower ones) oblique-oblong or rarely conduplicate, slightly immersed.

New Guinea.

* (177) P. Zippelii, Ixt., Rac., Flor. Btz., I, 105 ; Bl., Flor. Jav., II, 172, tab. LXXX; P. oxyphyllum, Kze., Bot. Zeit., 1848, 116 ; Pleopeltis Zippelii,Bl Moore, Bedd., Handb. Ind. Ferns, 357; - val'. sparsisorum.

Rhizome creeping, dark-coloured, the scales lanceolate, with the base peltate, the margin ciliate or shortly doothed, the point acute. Stipes distant, 1-10 c.M. long, firm, erect, naked. Fronds lanceolate, $25-70$ c M. long, 3-10 c.M. broad, the edge entire or repand, both ends narrowed, the apex acute, the base gradually decurrent upon the stipe. Texture herbaceous but firm; surfaces naked; costa conspicuous, sometimes with a few scales beneath in the lower part; main veins distinct nearly to the edge; areolae large, with included smaller ones, with numerous free veinlets. Sori distant, in 2 rows near the main veins, $2-4-6$ in a row.

Var. sparsisorum : Sori scattered irregularly.

Malacca, Java, Borneo, Philippines; North. India

* (178) T. membramaceum, Don, Hk. Bk., Syı. Fil., 560; Pleopeltis membranacea, Moore, Bedd., Ferns S.I., tab. CLXXVII; — var. grandifolium; P. grandifolium, Wall., List, No. 282.

Rhizome firm, the scales ovate, acuminate, spreading, membranaceous, lurid-green. Stipes $0-12 \frac{1}{2}$ c.M. long, firm, erect, approximate or subtufted. Fronds 30-90 c.M. long, 2-15 c.M. broad, lanceolate, narrowed towards both ends, the base decurrent, the edge entire or more or less sinuate. Texture thinly herbaceous or membranaceous; surfaces naked; main veins distinct; areolae large, distinct, copious, with finer secondary areolae and free 
veinlets. Sori on the anastomosing veins, in 2 rows between the main veins, round or oblong, $\pm 4-8$ in a row.

Var. grandifolionm: Fronds larger. Sori more copious, scattered Irregularly.

Celebes, Philippines; Soulh. China, North. India, Ceylon.

* (179) IP. Ieucophorum, Bk., Journ. of Linn. Soc., Bot., XXII, 229.

Rhizome slender, glaucous, creeping, the scales shining, filiform, brown, nearly spreading, deciduous, to $1 / 2$ c.M. long., Stipes $1-2$ c.M. long, erect. Fronds oblong-lanceolate, acuminate, $\boldsymbol{b}-25$ c.M. long, $2-\mathbf{3}^{1 / 2}$ c.M. broad at the middle, with the margin recurved. Texture coriaceous; upper surface shining, covered with whitish cretaceous dots, many of wich are arranged in a close row placed at or near the margin of the frond; under side thinly villose; main veins fine, straight, erecto-patent; veins anastomosing irregularly. Sori small, superficial, in 2 irregular rows between the main veins or scattered irregularly.

Borneo.

* (180) P. troiquetrum, Br., Rac., Flor. Btz., I, 10马; Bl., Flor. Jav., II, 141, tab. LIX.

Rhizome long, woody, the scales dense, pale, rather large, broad, elliptical or deltoid-ovate, with the base rounded and peltate, the apex bluntish, the edge entire or erose to lacerate, membranaceous, afterwards deciduous. Stipes distant, firm, erect, naked, glossy, $6-20$ c.M. long, the fertile fronds often on the longest stipes. Fronds $10-25$ c.M. long, $5^{1 / 2}-71 / 2$ c.M. broad, varying from ovate-oblong to lanceolate, the apex obtuse to acuminate, the base cuneate or rounded, \pm slightly decurrent upon the stipe, the edge subentire or \pm repand, bounded by a narrow, often recurved margin. Texture very coriaceous; surfaces naked, the upper covered with minute, indistinct, scattered black dots; costa and main veins distinct, prominent and subtriquetrous beneath, the latter distinct to the edge. Fertile fronds like the barren ones or longer and narrower. Sori superficial. in 2 rows between the main veins, $4-8$ in a row.

Malaya; Samoa.

* (181a) P. rupestne, Mt., Rac., Flor. Btz., I, 106; Bl., Flor. Jav., II, 142, tab. LV, fig. 2, tah. LX; P. saxatile, Mell., Farng., I, Polypod., 116; P. 
71. POLYPodium. $\mathbb{S} 6$. Pleopeltis. $b^{* *}$. Pleuridium.

triquetrum, Bl., var., C. Chr., Ind. Fil.; Pleopeltis rupestris, Moore- Bedd., Handb. Ind. Ferns, Suppl., 94; - var. taeniopsis; P. taeniopsis, Christ, Fil. Saras., IV, 443; P. Iriquelrum, Bl., var. taeniopsis, Christ, Ann. Btz., XV, 157, tab. XVI, fig. 24, a-d; - var. leucolepis, Rst., Fed., Rep., V, 43.

Rhizome long, woody; scales dull-brown, rather small, narrow, elongate-lanceolate, rounded or cordate at the base, the edge slightly denticulate, the apex spreading, acuminate, at length deciduous. Stipes scattered, firm, erect, naked, glossy, 5-25 c.M. long. Fronds 10-20 c.M. long, 1-丂 c.M. broad, lanceolate, acuminate, entire or repand, the edge callous, recurved, the base cuneale or rounded. Texture coriaceous; surfaces naked, the upper side covered with minute, indistinct, scattered black dots; costa keeled beneath; main veins distinct. Fertile fronds similar to the barren ones or longer and narrower. Sori superficial, in 2 rows between the main veins, $4-8$ in a row.

Var. taeniopsis: Rhizome scales ferrugineous; stipes distant, solitary or in pairs, \pm 5 c.M. long; fertile fronds linear or linear-lanceolate, 410 II.M. broad, narrowed gradually towards both ends; main veins not very distinct; sori in 1 row on each side, or in 2 irregular rows but then rather marginal.

Var. Ieucolepis: Rhizome scales white, narrower, minutely ciliatodentate; stipes slender; texture chartaceous; areolae more conspicuous.

Malaya; - var. taeniopsis; Celebes; - var. leucolepis: New Guinea.

P. Inronicum, Copel., Philipp. Journ., I, Suppl., 162, tab. XXIII.

Rhizome scandent, clothed with black-brown, lanceolate, long-acuminate, minutely ciliate scales. Stipes 1 -5 c.M. long, stramineous, clothed with deciduous, brown scales. Fronds lanceolate or oblanceolate, 20-50 c.M. long, to 4 c.M. broad, entire, acuminate, the base narrowed gradually into the stipe. Texture subcoriaceous; surfaces naked; main veins distinct nearly to the edge; areolae hidden. Sori large, in 2 rows between the main veins, forming 1-5 rows on each side of the costa, superficial.

Luzon.

(182) P. albulnum, Christ, C. Chr., Ind. Fil.; P. lagopodioides, Christ, Ann. Btz., XIX, 37.

Like P. rupestre, $B l$. but smaller; fronds narrower, the point finer; scales of the rhizome yellowish-white, papyraceous, lanceolate, aristate.

Celebes. 
Rhizome slender, the scales small, fibrillose, yellowish. Stipes distant, slender, naked, $7-10$ c.M. long. Fronds $3^{1 / 2}-6^{1 / 2}$ c.M. long, $2^{1 / 2}-31 / 2$ c.M. broad, ovate, entire, the base rounded, hardly decurrent. Texture coriaceous; both surfaces naked; main veins distinct nearly to the edge; areolae fine, with free veinlets. Sori rather large, few, scattered.

Philippines, Borneo.

(184) P. dulitense, Bk., Kew Bull., 1893, 211.

Rhizome slender, wide-creeping, the scales lanceolate, membranaceous, pale-brown, erecto-patent. Stipes firm, 7-13 c.M. long, naked, stramineous. Fronds ovate, $\mathbf{5}-8$ c.M. long, $2-51 / 2$ c.M. broad, simple, acute or acuminate, crenate in the lower half, the base rounded or deltoid. Texture chartaceous; surfaces naked, glossy; main veins erecto-patent, parallel, distant; areolae hexagonal, with free veinlets. Sori small, globose, subimmersed.

Borneo.

(185a) P. suboppositum, Christ, Bull. Herb. Boiss., $2^{e}$ Série, VI, 995.

Rhizome creeping, naked. Stipes approximate, \pm 3 c.M. long, naked, winged nearly to the base by the gradually decurrent base of the fronds. Fronds lanceolate, acuminate, 35-55 c.M. long, \pm 6 c.M. broad at the middle. Texture herbaceous, flaccid; surfaces naked; colour pale-green; costa distinct; main veins horizontally spreading, flexuose, distinct nearly to the edge; primary areolae hidden, longitudinal, in $4-5$ rows between the midrib and margin, divided into numerous smaller secondary ones, with included free veinlets. Sori irregular, numerous, \pm 25 to each primary areola.

Luzon.

(185b) P. Scortechimii, Bk., Ann. of Bot., V, 477; Pleopeltis Scortechinii, Bedd., Handb. Ind. Ferns, Suppl., 95.

Rhizome woody, wide-creeping, flexuose, calvate. Stipes brown, naked, 35-40 c.M. long. Fronds oblanceolate, acuminate, $40-45$ c.M. long, 7-9 c.M. broad, obscurely repand, narrowed gradually from the middle to the base. Texture membranaceous; surfaces naked; main veins distinct to the edge. Sori minute, superficial, scattered, often confluent.

Malacca. 


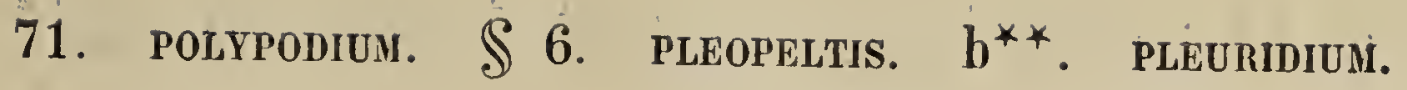

(186a) P. ovatum, Wall., Hk. Bk., Syn. Fil., 359; Hk. \& Grev., Ic. Fil., tab. XLI; P. phyllomanes, Christ, var. ovatum, Christ, Bull. Ac. Int. Bot., 1902, 210, tab. page 213 (right hand figures); C. Chr., Ind. Fil.; Pleopeltis ovata, Moore, Bedd., Ferns, Br.I., II, tab. CLVII.

Rhizome wide-creeping, woody, the scales lanceolate, dull-brown, deciduous. Stipes $10-20$ c.M. long, erect, slightly scaly below. Fronds $\mathbf{1 5 - 3 0}$ c.M. long, $5-8$ c.M. broad, the point acute or acuminate, the edge entire, the base rounded to decurrent. Texture firm-herbaceous; both surfaces naked; main veins distinct; areolae copious, with free veinlets. Sori irregular, $\mathbf{1}-\mathbf{3}$-serial.

Luzon; China, North. India.

* (186b) P. Zollingerianum, Kae, Bot. Zeit., 1846, 422; P. heterocarpum, Bl., Rac., Flor. Btz., I, 107; Bl., Flor. Jav., II, 167, tab. LXXV.

Rhizome creeping, blackish when dry, the scales adpressed, lanceolate, brown, not dense. Stipes 5-20 m.M. apart, 7-40 c.M. long, the unwinged portion often short, \pm scaly below, those of the fertile fronds the longest. Fronds lanceolate, entire, $20-60$ c.M. long, 4-12 c.M. broad, the apex acute, the base gradually or rather suddenly decurrent, so as to form a long, narrow wing to the stipe. Texture thin, herbaceous; surfaces naked; costa conspicuous; main veins distinct to the edge; veins forming copious areolae with free veinlets. Sori scattered irregularly, roundish or elliptical, often confluent.

Malaya.

(187) P. millisortum, Mre. Journ. of Linn. Soc., Bot., XV, 109.

Stipes stout, with a narrow wing extending nearly to the base. Fronds linear-ligulate, $60-75$ c.M. long, $5-61 / 2$ c.M. broad at the middle, narrowed very gradually to both ends. Texture rigidly coriaceous; surfaces naked; main veins zigzag, reaching $3 / 4$ on the way to the edge; veins fine, hidden; areolae copious, minute, with numerous free veinlets. Sori round, superficial, crowded, filling up the upper $1 / 2$ or $2 / 3$ of the frond, distinctly visible on the upper surface.

Kei Islands. hew quava to Pouncera ojp3qo

* (188) D. punctatum, Sav., Christ, Farnkr. d. Erde, 106; $P$. irioides, Poir., Rac., Flor. Btz., I, 106; Bl., Flor. Jav., Il, 169, tab. LXXVII ; Hk., Fil. Exot., tab. IV; Pleopellis irioides, Moore, Bedd., Ferns S.I. tab CLXXVIII: Pl. punctata, Bedd., Handb. Ind. Ferns, 357; Acrostichum punclatum, L., (oldest 
name); - var. mindanense, subirideum \& subdrynariaceum; P. mindanense, subirideum \& subdrynariaceum, Christ, Bull. Herb. Boiss., $2^{\mathrm{e}}$ Série, VI, 994.

Rhizome creeping, stout, the scales deltoid-oblong to ovate-lanceolate, blunt or acute, \pm dark-coloured. Stipes rather approximate, 0-1 c.M. long. Fronds linear-lanceolate, $\pm 30-90$ c.M. long, $21 / 2-6^{1} / 2$ c.M. broad, narrowed gradually towards both ends, the edge entire, narrowly subrevolute, the apex \pm acute or acuminate, sometimes bluntish, the very base bluntish or slightly rounded. Texture subcoriaceous, rather fleshy; surfaces naked; costa prominent on hoth sides; main veins hidden in fresh material, not coloured, fine, slightly prominent when dry, reaching \pm the edge; areolae fine, copious, with free veinlets. Sori small, very abundant, often nearly close, scaltered irregularly, occupying the upper $1 / 3-2 / 3$ of the frond.

Wr. mindanense: Fronds considerably dilated at the base; texture papyraceous; veins prominent; areolae hidden; sori larger.

War. subirideum: Fronds $20-50$ c.M. long, $21 / 2-3$ c.M. broad, the apex often obtuse, the base often dilated; texture fleshy; sori near the apex, larger.

Var. smbdrynariaceum: Like var. mindanense, but the venation. more conspicuous and the hase of the fronds scariose; sori very numerous, small.

Trop. Asia \& Australia, Polynesia, Trop. Africa, Mascarenes; - the varielies in Luzon.

* (189) IP. nusifolium, Bt., Rac. Flor. Btz., I, 107; Bl., Flor. Jav., J FM II, 171, tab. LXXIX; P. Schunannianum, Diels, Schum. \& Laut., Flor. deut. Sch. geb., 159, tab. III, C-D ; Pleopeltis musaefolia, Moore, Bedd., Ferns Br.I., II, tab. CCCXVII.

Rhizome woody, branched, creeping, firm, the scales ovate-lanceolate, rather dark-brown. Fronds sessile, approximate or distant, 30-100 c.M. long, $7 \frac{1}{2}-20$ c.M. broad, linear or ligulate, the apex bluntish or acute, the edge entire, the base rounded or cordate. Texture thinly coriaceous, firm; surfaces naked; costa and main veins distinct; main veins straight, rather darkcoloured in fresh material, connected by transversal, arched veins; included areolae copious, with free veinlets. Sori small, very abundant, sometimes occupying the whole under surface. - P. Schumannianum, Diels from New Guinea seems to be a local derivative of this species, with smaller fronds, which are ovate-oblong, or panduriform with a narrowed part $\pm 1-1 \frac{1}{2}$ c.Mr. broad, and with the base cordate, rounded or cuneate. 


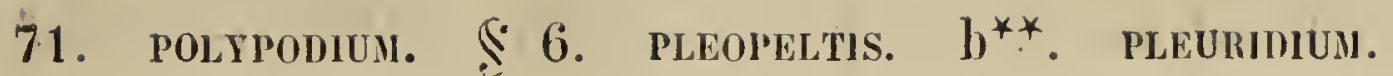

(190a) D. valialum, Copet., Polypod. Philipp., 126.

Rhizome short, thick, the scales ovate, adpressed, obtuse, cordate or peltate. Fronds tufted, nearly sessile, \pm 70 c.M. long, 10 c.M. or more broad, lanceolate, entire, subacute, narrowed gradually to the base, the lower $1 / 3$ part wing-like, the margin entire. Texture carnoso-coriaceous, fragile; surfaces naked; main veins fine, reaching nearly to the margin; Iransversal veins parallel to the costa, forming \pm 7 lows of divided areolat on each side, with free veinlets. Sori numerous, scattered irregularly.

Plilippines.

(1906) P. monstrosum, Coper., Leafl., I, 78 ; - var. leucophlehiunı \& integrius, Copel., l. c.

Rhizome scandent, slender, clothed with dark-grey, lanceolate, acuminate scales, which are peltate at the base. Stipes $1 / 2-1$ c.M. long, naked. Fronds 50-50 c.M. long, 4-7 c.M. or more broad, narrowed gradually towards both ends, acuminate, the edge coarsely crenate or lobed, with the central lobes whether or not much produced. Texture subcoriaceous; surfaces naked; costa prominent, beneatlı acute, above 2 -angular in the upper part; main veins conspicuous, black, reaching nearly the margin; transversal veins \pm 6 , inconspicuous; veinlets hidden. Sori crowded, scattered irregularly.

Var. leucophlebium: Fronds often narrowed and rather entire; veins beneath white.

Var. integrons: Hardly different from var. leucophlebium, the fronds crenato-sinuate.

Luzon, Mindoro.

Species of an indefinile systematical place. Sori unknown.

(191) W. Weinlandii, Christ, Bull. Herb. Bois., 2e Série, I, 448, with figure.

Rhizome long, creeping, the bristles subulate, brown, dense, subadpressed. Stipes distant, 5-6 c.M. long, firm, densely covered like the whole frond wilh simple, white, diaphanous, spreading hairs. Fronds ovate-elongate, $7-10$ c.M. long, \pm 4 c.M. broad, shortly acute or obtuse, the base broadly cuneate, the margin undulate or repand. Texture coriaceous; colour pale-brownish; veins very conspicuous; çosta prominent; main veins oblique, reaching to the margin; areolac subquadrangular, large, 5-4 hetween each pair of main 
veins, with included free veinlets; upper surface covered with numerous, scattered, cretaceous dots. Sori unknown.

New Guinea.

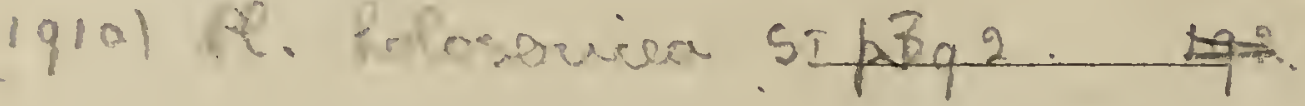

\section{S 6. Pleopeltis. c. Chrysopteris. *. Phymatodes.}

a. Sori superficial.

b. Sori in 1-4 rows on each side of the costulae.

c. Texture herbaceous to papyraceous.

d. Lobes entire or repand.

e. Fronds rather small, under 25 c.M. long.

f. Lateral segments in $\pm 2-4$ pairs.

f.f. Lateral segments in $\pm 8-9$ pairs.

(192) P. paucijugum.

(193) P. sundense.

e.e. Fully developed fronds more than $25 \mathrm{c.M}$. long.

+. Rhizome \pm naked.

$\times$. Stipes not winged.

(194a) P. alatum.

$x \cdot x \cdot$ Stipes winged.

(194b) P. flaccidum.

+. Rhizome scaly. Slipes wingell. (195) P. commutatum.

d.d. Lobes serrulate or toothed.

(196) P. ebenipes.

c.c. Texture chartaceous to coriaceous.

\$. Under surface bluish-glaucous.

(197) P. glaucum.

\$.S. Under surface green, nol glaucous.

t. Sori nearer the costulae than the margin. ( $\left.{ }^{1}\right)$

(198) P. hastatum.

+. Lower sori medial, the higher ones nearer the margin than the costulae.

b.b. Sori scattered irregularly. $\left({ }^{2}\right)$

1. Fronds dimorphous.

(199) P. quinquefidum.

1.1. Fronds uniform.

2. Lower segments much reduced.

(201) P. grandidentatum.

2.2. Lower segments hardly, if at all, reduced.

3. Stipes \pm short-winged. Fronds typically 3-fid, but sometimes simple or $5-f i d .\left({ }^{3}\right)$

(200) P. anomalum.

(roo) Re Kingu sj p 3 yo

(') See also P. rostratum, $H$.

$\left({ }^{2}\right)$ See also P. monstrosum, Copel.

(') See also P. rivulare. Copel. 
71. POLYPODIUM. $\$ 6$. Pleopeltis. $c^{*}$. PHYMATODES.

3.3. Stipes short-winged. Fronds as in 3.3.3.

(202b) P. dolichopterum.

3.3.3. Stipes long-winged. Fronds lypically pinnatifid with 3 or more pairs of lateral segmenls below 'the terminal one.

1. Fronds small or middle-sized, less than 40 c.M. long above the wing of the stipe. Rhizome scales linear or lanceolate.

5. Rhizome scales sparse.

6. Rhizome fleshy. (205a) P. rivulare:

6.6. Rhizome woody. (205l) P. pentaphyllum.

5.ซ๊. Rhizome scales crowded.

1.4. Fully developed fronds large, more than $40 \mathrm{~cm}$. long.

a.a. Sori more or less deeply immersed. ( $\left.{ }^{1}\right)$ (205) P. dilatatum. (2osa) ap. Schuctice

b'. Fronds dimorphous. Barren fronds with the segments lanceslate-oblong, fertile with the segments narrowly linear.

(206) P. incurvatum. SESI ps

$b^{\prime} \cdot b^{\prime}$. Fronds uniform, rarely subdimorphous.

$c^{\prime}$. Fronds \pm as broad as long, the lower lobes deflexed.

$\boldsymbol{c}^{\prime} . \boldsymbol{c}^{\prime}$. Fronds distinclly longer than broad.

(207) P. macrochasmum. Si p $3 q$

d'. Sori shallowly immersed. $\left(^{2}\right)$

*. Fronds under 1 M. long.

*.*. Fronds more Ihan $1 \mathrm{M}$. long.

(208a) P. phymatodes. Si $)=399$
$\left(208 a^{3}\right)$ Pe. tenuinderis si p 39

(208b) P. phanerophlebium.

d'. Sori deeply immersed.

$e^{\prime}$ Laleral segments in $\pm 2-10$ pairs.

$\times$. Under surface pale-violescent. Fronds \pm 15 c.M. long.

(209) P. violascens.

$\times . \times$. Under surface green. Fronds \pm 20-50 c.M. long.

(210) P. nigrescens.

$\boldsymbol{e}^{\prime} \cdot \boldsymbol{e}^{\prime}$.Lateral segments in many or numerous pairs.

f'. Texture thinly papyraceous; segmenls acuminale.

(211) P. Schneideri.
f'. Pexture frm; segments acule id blunt.

(212) P. longissimum.

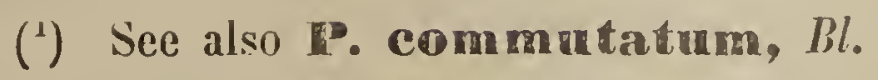

$\left.{ }^{2}\right)$ See also Pongissimam, $\mathrm{Bl}$.

Fiucres. 
* (192) P. paucijugam, v. A. v. R., Bull. Dép. Agr. I. N., 1908, XVIII, 24.

Rhizome slender, creeping, the scales lanceolate. Stipes slender, erect, scaly, 4-10 c.M. long below the winged portion. Fronds $10-20$ c.M. long, with an entire terminal lobe 5-10 c:M. long, $1 / 2-1 \frac{1}{2}$ c.M. broad, and 2-4 similar lobes on each side, which are suberect or erecto-patent, narrowed gradually towards an acute or bluntish point, connected by a costal wing $\mathbf{3}-\mathbf{5}$ m.M. broad, the lowest gradually decurrent upon the stipe. Texture thin but firm; under surface minutely hairy; costa and costulae \pm scaly beneath, prominent like the primary veins, which stop short and unite at $\pm 2 / 3$ of the way to the margin, forming 1 series of large primary areolae on each side, each with commonly 1 sorus in the narrower and mostly 2 sori in the broader segments; secondary areolae in and beyond the primary ones fine, indistinct, with few free veinlets. Sori small, rather oblong.

Borneo (Teuscher).

(195) P. Sundense, C. Cher., Ind. Fil.; P. sumatranum, Bk., Ann. of Bot., VIII, 151 (not Journ. of Bot., XVIII, 214).

Stipes moderately long, naked, stramineous. Fronds lanceolate-oblong, 17-20 c.M. long, 7-10 c.M. broad, deeply pinnatifid, the base hardly narrowed. Segments 8-9-jugate, contiguous, lanceolate, entire, acute, confluent at the base, $11 / 4-11 / 2$ c.M. broad. Texture moderately firm; surfaces naked; areolae hexagonal, copious, with free veinlets. Sori large, semiglobose, superficial, in 1-2 rows on each side of the costulae.

Sumatra.

(194a) aldatum, I1k. Hk. Bk., Syn. Fil., 365; P. Wilkesii, C. Chr., Ind. Fil.; Drynaria alata, Brack., Expl. Exp., XVI, 48, tab. VI, fig. 1.

Rhizome woody, scaleless. Stipes 50-45 c.M. long, firm, erect. Fronds $45-60$ c.M. long or shorter, $25-30$ c.M. or more broad, cut down nearly to the rachis below (within $1 \frac{1}{2}$ c.M. above) into few or numerous $(4-50)$, rather distant or more close, erecto-patent, repand, linear-oblong, acuminate lobes $2 \frac{1}{2} \quad$ c.M. or more broad. Texture papyraceo-herbaceous; hoth surfaces naked; main veins dislinct to the edge; areolae copious, with free veinlets. Sori in rows of $5-4$ near the costulae.

Celebes; Samoa, Fiji.

(194b) IP. Ilaceidunn, Christ, Philipp. Journ., II, 178. 
Rhizome creeping, grey-brown. Stipes slender, stramineous, 6-8 c.M. long, naked, or providerl with blackish setulac downwards, winged nearly or quite to the base. Fronds oval, \pm 40 c.M. long, \pm 18 c.M. broad, deeply pinnatifid. Terminal lobe \pm 18 c.M. long, caudate; lateral lobes $\pm 4-5$ on each side, $\pm 2-5$ c.M. apart, \pm 10 c.M. long, $\pm 1 \frac{1}{2}$ c.M. broad, caudate, connected by a costal wing $\pm 1 \%$ c.M. broad, the sinuses broadly rounded, the lowest lobes decurrent into the wing. Texture flaccido-papyraceous, hyaline; colour pale-green; surfaces naked; costa and costulae distincl, stramineous; main veins slender, curved, indistinct near the edge; arcolae numerous, with included free veinlets. Sori numerous, rather small, roundish, irregularly 2 -5-seriate, not immersed in pits.

\section{Luzon.}

* (195) P. commatatum, TEt., Flor. Jav., II, 165, tab. LXXIII; I'. affinc, Bl., Rac., Flor. Btz., I, 115; Bl., I. c., 160, tab. LXIX.

Rhizome woody, the scales roundish, oblong when young, entire, adpressed, dark-brown, deciduous. Stipes $\pm 20-45$ c.M. long, firm, glossy. Fronds 50-120 c.M. long, $15-50$ c.M. or more broad, cut down into few or several spreading or erecto-patent lobes on each side. Lobes linear, acuminate to caudate, $\pm 1-4$ c.M. broad, connected at the base by a costal wing $1 / 2-2$ c.M. broad, the sinuses rounded; lowest lobes decurrent so as to form a narrow wing to the stipe. Texture papyraceous; surfaces naked; primary veins flexuose, becoming gradually finer towards the margin, uniting several times so as to form \pm 5 series of alternate, \pm hexagonal primary areolae; secondary areolac numerous, fine, indistinct, with copious free veinlets. Sori superficial or immersed, in $2-5$ rows on each side of the central ribs of the laciniae.

Malaya.

- 196) P. ebenipes, M7k., Hk. Bk., Syn. Fil., 365; Pleopellis ebenipes, Bedd., Ferns Br.I., I, tab. CXXXVIII.

Rhizome stout, creeping, the scales large, lanceolate, glossy, \pm black, subcoriaceous, not hair-pointed. Stipes $15-25$ c.M. long, naked, glossy, on short branches of the rhizome. Fronds $15-45$ c.M. long, 20-50 c.M. broad, cut down to a broadly winged costa into 6-20 pairs of segments. Segments $1-3$ c.M. broad, a little serrulate, acuminate, the lowest pair generally deflexed and either a little decurrent on the stipe or scooped out and subcordate at the lower base, sometimes quile spreading as are the other seg- 
ments. Texture firm-papyraceous; surfaces naked; costa puberulous; main veins distinct to the edge; areolae fine, with free veinlets. Sori in single rows near the costulae.

Borneo; Yunnan, North. India.

(197) Tr. glaucumn, Fae, Hk. Bk., Syn. Fil., 365; Mett., Farng., I, Polypod., tab. II, fig. 12-13; P. glauco-pruinatum, C. Chr., Ind. Fil.

Rhizome short, creeping, the scales lanceolate-subulate, dark-brown, rigid. Stipes 7-30 c.M. long, firm, erect, glossy. Fronds oblong, $20-40$ c.M. long, deeply pinnatifid. Lobes $\pm 4-6$ on each side, $7-15^{\circ}$ c.M. long, \pm 1 c.M. broad, erecto-patent, linear, acuminate, the edge entire or distantly crenatoserrulate, the lowest lobes slightly decurrent on the stipe, broad, sterile, a little abbreviate, the higher ones narrow, fertile. Texture coriaceous; under surface glauco-prtinose, upper often covered with calcareous scales; no main veins: areolae hidden. Sori superficial, in 1 row on each side of the costulae.

Philippines.

* (198) T. Hastatume, Thb., Hk. Bk., Syn. Fil., 561; Kze, Farnkr., I, tab. LXXXIII; Pleopeltis oxyloba, Bedd., Ferns S.I., tab: CLXXV; Pl. hastata, Moore, Bedd., Handb. Ind. Ferns, 362 ; - var. trifidum; Pol. trifulum, Don, Hk. Bk., l. c., 565 .

Rhizome firm, short-creeping, the scales linear-lanceolate, squarrose, brownish. Stipes scattered, $5-13$ c.M. long, erect, firm, glossy. Fronds $10-30$ c.M. long, either simple, lanceolate, $1-4$ c.M. broad, or 5-fid with the lateral lobes erecto-patent, similar to the terminal one but smaller, or the fronds pinnatifid with 2-4 pairs of lateral lobes below the terminal one; lobes elongate, 7-15 c.M. long, $1-2 \frac{1}{2}$ c.M. broad, narrowed gradually towards the acute or acuminate point, the margin subentire or slightly crenate to repand; lowest lobes sometimes forked, slightly decurrent on the stipe. Texture thinly coriaceous; surfaces naked, the lower pale-green; main veins distinct, straight, parallel; areolae with free veinlets. Sori round, large, superficial, in 1 row on each side. nearer the costulae than the margin, solitary between the main veins.

War. Inofidum : Larger form, with more than 4 pairs of lateral lobes. Philippines, Malacca; Ceylon, North. India, China, Japan, Formosa.

(199) IP. quimguefidtum, The, Journ. of Bot., XVIII, 216.

Rhizome woody, the scales brown, linear. Stipes distant, naked, erect, 
71. polypodum. $\mathbb{S} 6$. Pleopelpis. $\mathrm{c}^{*}$ phymatodes.

rigid, pale-brown, 12-23 c.M. long. Fronds deltoid, 15-20 c.M. long, 2025 c.M. broad, cut down nearly or quite to the costa. Segments b-7, lanceolate, acuminate, 10-15 c.M. long, 1-2 c.M. broad, the edge obscurely repand. Texture coriaceous; main veins of the segments raised, erecto-patent, distinct and straight to the edge; areolae small, copious, hexagonal. Sori large, round, superficial, solitary between the main veins, the lower medial between the costulae and margin, the higher nearer the margin.

Sumatra.

(200) D. Anornalusen, Cherist, Bull. Herb. Boiss., VI, 201, tab. III, lig. 5, a-d; P. helerolobum, C. Chr., Ind. Fil.

Rhizome creeping, the scales brown, ovate-subulate, crisped, patent. Stipes scattered, 5-4 c.M. long, naked like the whole plant, stramineous. Fronds \pm 20 c.M. long, the base gradually decurrent; sterile fronds to \pm 8 c.M. broad, irregularly pinnatifid $\pm 1 / 2$-way down to the costa into lobes different in size and shape; fertile fronds lanceolatè-ligulate, $\pm 11 / 2$ c.M. broad, the margin irregularly repand. Texture membranaceous; costa distinct; main veins conspicuous; areolae large, principally in \pm 4 rows on each side of the costa, with free veinlets. Sori numerous, irregularly scattered.

Philippines.

(201) P. grandidentatum, FIs., Ann. of Bot., V, 479; P. dilalalum, Wall., var: grandidentalum, Ces., Fel. di Bor., 27.

Stipes 30 c.M. or more long below the wing, the wing $\pm \mathbf{1 5}$ c.M. long to the lowest segment. Fronds oblong, \pm 90 c.M. long, deeply pinnatilid. Segments lanceolate, the central ones $20-25$ c.M. long, $21 / 2-51 / 2$ c.M. broad, sharply toothed, the lower ones much dwarfed. Texture membranaceous; surfaces naked; main veins of the segments erecto-patent, distinct to the edge. Sori copious, minute, scattered.

Borneo.

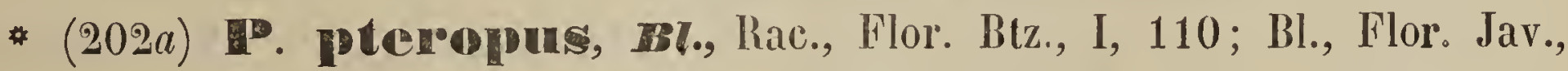
II, 168, tab. LXXVI; P. tridactylum, Wall., Hk. \& Grev., Ic. Nil., tab. CGIX ; Pleopeltis tridactyla, Moore, Bedd., Ferns Br.I., I, Lab. XI; Pl. pteropus, Moore; Bedd., Handb. Ind. Ferns, 359.

Rhizome creeping, the scales lanceolate-subulate, blackish or brownish. Stipes scattered, 5 -20 c.M. long, naked or sparingly scaly. Fronds lanceolate, simple to pinnatifid with a large terminal lohe $10-30$ c.M. long, $21 / 2-5$ c. MI. 
broad and 1-2 smaller ones on each side. Lohes lanceolate, acute or acuminate, the edges entire or irregularly crenate; lowest lobes (or the base of the simple frond) gradually decurrent so as to form a narrow wing to the upper part of the stipe. Texture herbaceous; surfaces naked or the lower \pm scaly on the veins; areolae fine, copious, with free veinlets; main veins not reaching the edge. Sori small, not abundant, scattered irregularly, $1-7$ between the main veins.

Trop. Asia.

(2026) Alp. Adichopter'un, Copel., Philipp Journ., I, Suppl., 162. Rhizome creeping, the extremity clothed with black, lanceolate scales. Stipes seriate, 10-15 c.M. long, stramineous, naked, or sparingly scaly towards the base. Fronds deltoid, pinnatilid. Lobes divaricating, comnected at the base by a costal wing $2-5$ m.M. broad, the lowest lanceolate, 10-12 c.M. long, $1-1 \frac{1}{4}$ c.M. broad, entire or undulate, acuminate, the base decurrent on the stipe so as to form a short wing to 3 c.M. long. Texture membranaceous; surfaces naked; veins laxly reticulate; areolae with few free veinlets. Sori scattered or irregularly seriate, superficial.

Philippines.

(205a) rivulare, Copel., Philipp. Journ., I, Suppl., 163.

Rhizome creeping, green, fleshy, sparingly clothed with black, lanceolate, acuminate scales. Stipes 5-10 c.M. long, glabrescent, stramineous, narrowly winged, the unwinged basal part 1-5 c.M. long. Fronds 10-16 c.M. long, broadly ovate, pinnatifid, the costal wing \pm as broad as the lobes Lobes 1-- 4-jugate, to 7 c.M. long, $1 / 2-1 / 2$ c.M. broad, acute, entire or undulate, the terminal one often longer. Texture membranaceous; surfaces naked; lateral veins inconspicuous, not visible by reflected light. Sori scattered irregularly.

Luzon.

(205b) I. pentapleyllum, Bk., Ann. of Bot., V, 478.

Rhizome wide-creeping, woody, the .scales small, sparse, lanceolate, acuminate. Stipes naked, $\pm 2{ }^{1} / 2$ c.M. long below the wing. Fronds $\pm \mathbf{1 5}-50$ c.M. long, deeply pinnatifid. Lobes distant, linear-lanceolate, $\pm 3 / 4-1$ c.M. broad, the lowest ones decurrent so as to form a mere wing to the stipe \pm 15 c.M. long. Texture membranaceous; surfaces naked; veins fine, copious. Sori minute, scattered.

Philippines. 


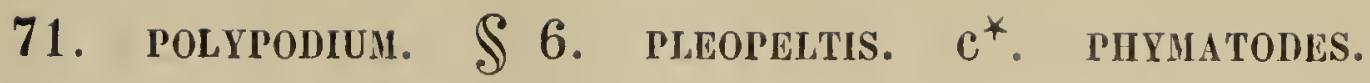

* (204) D. insigne, Bt., Rac., Flor., Btz., I, 113; Bl., Flor. Jav., II, 166, tab. LXXIV; P. Iridaclylon, Mell., (not Wall.), Farng., I, Polypod., 104, tab. I, fig. 39-40; Pleopellis insignis, Bedd., Ferns Br.I., II, tab. CCXIV; Diynaria decurrens, Brack., Expl. Exp., XVI, 48.

Rhizome creeping, the scales narrow, lanceolate-linear, spreading. Stipes scattered or approximate, erect, naked, $\pm 2-5$ c.ll. long below the wing. Fronds $15-50$ c.M. long, $10-20$ c.M. broad, with an entire, lanceolate-acuminate terminal lobe $\breve{b}-10$ c.M. long, $1-1 \frac{1}{2}$ c.M. broad or broader and $2-6$ or more similar ones on each side, which are connected by a costal wing $5-15$ m.M. broad, the lowest lobes decurrent so as to form a narrow wing to the stipe $\pm \mathbf{1 5}-50$ c.M. long. Texture herbaceous, firm; surfaces naked; veins fine; areolae with free veinlets. Sori small, superficial, roundish or irregularly oblong, often confluent, scattered irregularly.

Malacca, Java, Pholippines.

* (205) P. dilatatum, Wall., Hk. Bk., Syn. Fil., 565; P. curynhyllum, C.Chr., Ind. Fil.; Pleopelis dilatala, Bedd., Ferns Br.I, I, tab. CXXII.

Rhizome woody, the scales ovate, large, brown. Stipes up to $50-40$ c.M. long, with a narrow wing reaching down nearly to the base. Fronds 45-90 c.M. long, \pm 30 c.II. or more broad, cut down within $1 / 2-2 \frac{1}{2}$ c.M. of the costa into 8-16 erecto-patent lobes on each side. Lobes \pm 20 c.M. long, $1-4$ c.M. broad, entire, acuminate. Texture membranaceo-papyraceous; surfaces naked; main veins fine, flexuose, not quite reaching the margin; areolae copious, fine, with free veinlets. Sori small, scattered irregularly, often confluent.

Malaya; Ceylon, North. India, South. China, Samoa.

* (206) D. incurvatum, Bt., Rac., Flor. Btz., I, 110; Bl., Flor. Jiv., II, 151, tab. LXV; Pleopeliis incurvala, Moore, Bedd., Ferns Br.I., I, tab. CXXIV.

Rhizome creeping, woody; scales ovate-lanceolate, the base roundish, peltate, adpressed. Stipes distant, hrown, \pm 25 c.M. long. Fronds dimorphous. Barren fronds 15-25 c.M. each way, rarely simple, more generally hastatotrifid or pinnatifid with 2-8 pairs of lateral lobes below the terminal one; lobes approximate, ovate-deltoid or lanceolate-triangular, the edge entire, thickened, the point acute. Texture lirm, coriaceous; surfaces naked; main veins distinct to the edge; veins hidden; areolae with free veinlets. Fertile fronds cut down nearly or quite to the costa into erecto-patent, linear or linear-lanceolate lobes, the lobes $\pm 5-7$ on each side, $1 / 2-1$ c.M. broad, 
distant, decurrent, the lowest sometimes forked. Sori round, or oblong and parallel to the central ribs of the lobes, in 1 row on each side, quite immersed in deep cavities, which form conical, truncate tubercles on the upper surface.

Malaya.

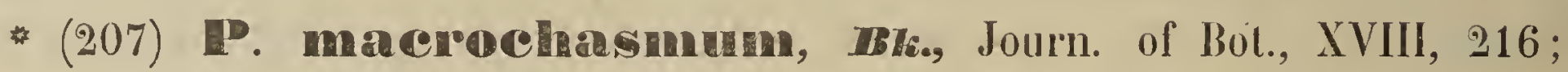
Hk., Icon. Pl., XVII, tab. MDCLXXV; P. lacinialum, Bl., Rac., Flor. Blz., I, 111; Bl., Flor. Jav., II, 149, tab. LXIII; Plempelis laciniala, Bedd., Handb. Ind. Ferns, Suppl., 97.

Rhizome woody, wide-creeping, the scales dense, linear-lanceolate, acuminate, ciliate, squarrose. Stipes distant, 10-50 c.M. long, firm, erect, naked. Fronds deltoid-ovate, $20-50$ c.M. each way, cut down nearly (to a narrow wing) to the costa into $\pm 6-18$ linear-lanceolate, acuminate lobes. Liobes to 25 c.M. long, $1-1 \frac{1}{2}$ c.M. broad, with the edge entire or crenulate to slightly undulate, the lowest ones deflexed. Texture coriaceous; surfaces naked; main veins prominent below, distinct and straight to the edge; areolae with free veinlets. Sori in 1 row on each side of the costulae, nearer the costulae than the edge, immersed, prominent on the upper surface.

Malacca, Sumatra, Java, Borneo, Celebes.

* (208a) P. Pltyrnatodes, I., Rac., Flor. Btz., I, 114; P. Irifidum, C'es. (not Don), Fel. Becc., Polin., ă; Pleopellis Phymalodes, Mráre, Bedd., Ferns S.I. tab. CLXXIII; - var. dimorphum, Christ., Fil. Saras., I, 23.

Rhizome wide-creeping, the scales ovate-lanceolate, acuminate, peltate, adpressed, deciduous. Stipes scatlered, 7-50 c.M. long, firm, erect, naked, glossy. Fronds varying from simple (oblong-lanceolate, 10-20 c.M. long, entire or irregularly crenate or slightly lobed) to deeply pinnatifid (20-90 c.M. long, 15-60 c.M. broad) with 1 to numerous entire, erecto-patent lobes on each side. Lateral lobes lanceolate-oblong to linear, similar to the terminal one, 10-56 c.M. long, 1-4 c.M. broad, the apex acuminate, the hases connected by a costal wing $\pm 1 / 2-1$ c.M. broad, the sinuses \pm rounded. Texture \pm coriaceous; surfaces naked; no distinct.main veins; costal areolae of the fertile fronds large, 1-serial, secundary ones copious, fine, will free veinlets. Sori large, shallowly immersed, round or oblong, placed in 1-2 regular or irregular rows in the smaller forms of the species, or scattered irregularly in the larger.

War. dinnorpolnum: Barren fronds shallowly 5-lobed, the lobes 


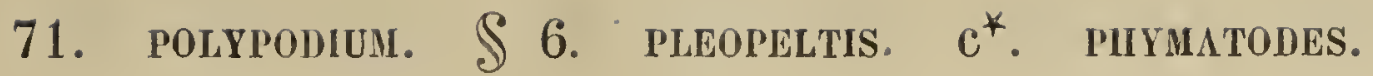

very broad. Fertile fronds with \pm 4 pairs of lobes \pm 12 c.M. long, $\pm \mathbf{3}$ c.M. broad. Sori numerous, copious, scaltered.

Trop. and Subtrop. Asia, Africa \& Australia, Pplynesia; - var. dimorphum: Celebes.

(208b) ID. phaneropln leboum, Copel., Philipp. Journ., I, Suppl., 163, tab. XXIV.

Rhizome scandent, clothed with ovate or orbicular, peltate, entire, imbricate, persistent scales. Stipes naked, $40-80$ c.M. long. Fronds $\pm 1 \frac{1}{2}$ I. long, \pm 60 c.M. broad. Lobés \pm 55 c.II. long, $\pm 4^{1} \frac{1}{2}$ c.M. broad, entire, accuminate, connected at the base by a costal wing $1-1 \frac{1}{2}$ c.M. broad. Texture herbaceous or subcoriaceous; surfaces naked; venation as in P. commutatum, Bk., the primary veins very conspicuous. Sori large, hardly immersed, often in 2 rows on each side of the costulae, 1 in each primary areola.

\section{Mindanao.}

(209) EP. Violascens, Irett., Ann. Mus. Bot. L. B., II, 227.

Rhizome creeping, the scales rufo-ferrugineous, nearly glossy, lanceolateacuminate, hardly ciliate. Stipes $7-8$ c.M. long. Fronds \pm 15 c.M. long, oblong, pinnatisect. Segments approximate, \pm 6 on each side, spreading, lanceolate, acute, the margin callous, serrate; lower segments nearly free, with the base narrowed, adnate, the higher ones adnate or decurrent. Texture coriaceous; under surface pale-violescent; costulae prominent; areolae immersed. Sori in 1 row on each side of the higher costulae, deeply immersed.

Java.

* (210) migrescens, Rut., Rac., Flor. Btz., I, 111; Bl., Flor. Jav., II, 161, tab. LXX; Hk., Fil. Exol., tab. XXII; Pleopellis nigrescens, Garr., Bl Bedd., Handb. Ind. Ferns, 367; Pl. longissima, Bedd., Ferns S.I. tab. CLXXVI. Rhizome stout, creeping, the scales ovate, adpressed, thin, brown. Stipes 20-90 c.Ir. long, firm, erect, pale, glossy. Fronds $50-90$ c.M. long, 20-50 c.M. broad, cut within $1 / 2-21 / 2$ c.M. of the costa into $\pm 2-10$ linear, spreading or erecto-patent, entire, acuminate to caudate lobes on each side to 30 c.M. long, $1 \div 5$ c.M. broad, the sinuses as broad or narrower. Texture thinly coriaceous; surfaces naked; colour often blackish when dry; main veins prominent, flexuose, forming 1 row of large costal areolae; areolae in and 
beyond the costal ones fine; free veinlets abundant. Sori 1 in each costal areola, sunk in deep cavities, very prominent on the upper surface. - The young plants have the fronds simple or 5 -fid.

Malaya; Polynesia, Trop. Australia, Ceylon, South. India.

(211) IP. Selnneiden'i, Christ, Bull. Herb. Boiss., VI, 855.

Rhizome wide-creeping, the scales ovate, acute, pellucid, with the margin toothed, pale-brown. Stipes distant, the base broad, very stout, lirm, \pm 60 c.M. long, terete, naked, brownish in the lower part, the upper part yellowish to purpureous like the costa. Fronds \pm 100 c.M. long, to \pm 18 c.M. broad, linear-lanceolate. Segments \pm 24 on each side, linear-lanceolate, erecto-patent, alternate, the higher ones subopposite, $\pm 11 / 2$ c.II. broad, \pm 2 c.M. apart, \pm 12 c.M. long, acuminate, with the margin entire or undulate, rarely denticulate at the apex, and the bases decurrent, joined so as to form a narrow wing $1 \frac{1}{2}$ c.M. broad, with rounded sinuses: lower lobes moderately obtuse, \pm 8 c.M. long. Texture thinly papyraceous; surfaces naked; costa very prominent; costulae yellowish, very prominent; veins conspicuous, fine, prominent, dark-coloured, spreading, straight, forked; areolae subpentagonal, including smaller areolae with free veinlets. Sori large, roundish, occupying the upper part of the frond, 1-serial on each side of the costulae, nearer the costulae than the margin and commonly close to the former, 12-15 in a row, remote, immersed, forming papillae on the upper surface of the frond.

Sumatra.

* (212) longissimum, Bl., Rac., Flor. Btz., I, 112; Bl., Flor. Jav., II, 159, tab. LXVIII; Pleopellis longissima, Moore, Bedd., Ferns S. Br.I., Suppl., tab. CCCLXXXVIII; - var. batjanense, Christ, in Warb., Mons., I, 62.

Rhizome wide-creeping, the scales ovate or broadly lanceolate, blunt, thin, adpressed. Stipes scattered, $15-120$ c.M. long, firm, glossy, naked. Fronds elongate, $30-120$ c.M. long, $10-50$ c.M. broad, cut down nearly to the costa into numerous erecto-patent lobes. Lobes linear, bluntish or acute, entire or nearly so, 7-20 c.M. long, $1 / 2-2$ c.M. broad, the bases concected by a costal wing $\pm 1-2 \mathrm{~m}$.M. broad, the sinuses rounded. Texture subcoriaceous; surfaces naked; veins forming large, distinct costular areolae and in and beyond these irregular smaller ones with free veinlets; main veins indistinct, not reaching the margin. Sori deeply immersed, round, in single rows on each side near the costulae. 


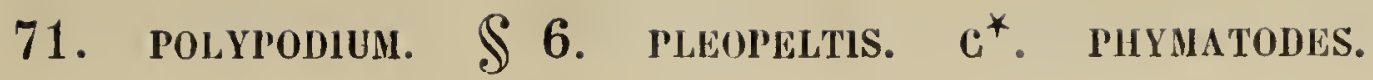

Var. batjanense: Fronds smaller; lobes abbreviate; texture firmer; sori hardly immersed.

Malaya; Polynesia; - var. batjanense: Batjan Island.

\$ 6. PleOPEltis. c. Chrysoptenis. $c^{* *}$. Phymatopsis.

a. Fronds dimorphous.

(213) P. lagunense.

a.c. Fronds uniform.

b. Sori deeply immersed.

*. Pinnae acule.

(214) P. sculpturatum.

*.*. Pinnae obtuse.

(215) P. Sauvinieri.

b.b. Sori superficial or shallowly immersed.

c. Upper surface covered with submarginal or scattered white dots.

d. Pinnae under 1 c.M. broad; veins hidden; surfaces pale-green.

(216) P. subaquatile.

d.d. Pinnae 1-2 c.M. broad or narrower, but then the veins distinct; upper surface bright-green. (217) P. albidosquamatum. SI p Aor

c.c. Upper surface without white dots. (21) a) fe hatheur SIP 401

+. Pinnae dilatato-adnate at the base.

(218) P. Moseleyi.

+. + At least the lowest pinnae narrowed at the base and not ranienvata bi pyorely \pm stalked.

*. Sori superficial.

*.*. Sori slightly immersed.

(219a) P. palmatum. (219b) P. proteus.

(213) IP. Iagunense, christ, Bull. Herb. Boiss., VI, 201, tab. III, fig. $4, a-d$.

Rhizome wide-creeping, the scales dense, ovate, acute at the apex, umbonate lowards the base, adpressed, reddish-brown, leaving behind roundish, prominent cicatrices when they fall. Stipes scattered, naked, firm, $10-15$ c.ll. long. Fronds dimorphous, 15-20 c.M. long, pinnate. Barren fronds with 6-7 pinnae on each side below the pinnatifid apex. Pinnae distant, ovate, \pm 4 c.M. long, \pm 2 c.M. broad, sessile or short-stalked, the base narrowed, the edge crenate or slightly toothed, the apex acute or elongated into a long, serrate, linear cauda. Surfaces naked; costae conspicuous; main veius less distinct, reaching the edge; areolae indistinct. Fertile fronds with the pinnae linear-lanceolate or ligulate, \pm 12 c.M. long, 3-10 m.M. broad, erecto-patent, 
distinctly crenate; costae conspicuous. Sori numerous, in 1 row on each side of the costae, 1 to each crenation, large, immersed, medial.

Philippines.

(214) serilptureatum, Filk., Hk. Bk., Syn. Fil., 514.

Stipes grey, glossy, naked. Fronds oblong, 5:-45 c.M. long, 20-25 c.II. broad. Pinnae 15-25-jugate, erecto-patent, subdistant, adnate, much dilated at the base, narrowed to a point, slightly repand, $1 / 2-1$ c.M. broad at the middle, lowest largest. Texture rigidly subcoriaceous; surfaces naked; veins distinctly raised in the dried plant. Sori in 1 row on each side of the midribs, midway between these and the edge, 20-55 in a row, deeply immersed, the pits without bordered edges, prominent on the upper surface.

Java.

(215) Sarvinierio, Bli., Ann. of Bot., V, 480 .

Stipes naked, stramineous, $10-13$ c.M. long. Fronds lanceolate-oblong, \pm 45 c.M. long, $10-15$ c.M. broad at the middle, narrowed to the base. Pinnae 30-40-jugate, linear, obtuse, $6-7$ in.M. broad, adnate by a dilated base. Texture firm; surfaces naked; veins hidden. Sori in 1 row on each side of the central ribs, medial, sunk in deep pits forming papillae on the upper surface, \pm 20 ir a row in the central pinnae.

Celebes.

* (216) Fo subaquatille, Christ, Ann. Btz., XX, 124.

Rhizome creeping, the scales dense, subulate, hrown, $\pm 5 \mathrm{~m} .11$. long. Stipes \pm 55 c.M. long, glossy, brownish-grey. Fronds \pm 65 c.M. long, \pm 20 c.M. broad. Pinnae \pm 13 on each side, distant, nearly erect, linear-lanceolate, narrowed gradually towards both ends, the terminal one \pm 25 c.M. long, 6-7 m.M. broad, with the edge \pm undulate. Texture flaccid, subcoriaceous; surfaces pale-coloured, glaucous, opaque, naked, the upper covered with small, submarginal or rarely scattered, cretaceous dots; veins irregular, hidden; areolae oblong, with few free veinlets. Sori in 1 row on each side of the costae, $\pm 10-12$ in a row, medial, superficial.

Borneo.

* (217) P. albidosquamatume, Rt., Rac, Flor. Btz., I, 115; B1., Flor. Jav., II, 157, tab. LVII; Hik., Gard. Irerns, tab. XLVII; - var. varians; P. varians, Bl., Melt., Farng., I, Polypod., 108; Bl., l. c., tab. LVIII. 
Rhizome woody, creeping, the scales dense, spreading, filiform-subulate, fine, brown, to 15 m.M. long. Stipes $10-50$ c.M. long, firm, erect, naked, glossy. Fronds sometimes simple, commonly pinnate, to 50-60 c.M. long, 15-40 c M. broad, with several (to 17) \pm distant, linear-lanceolate, sessile or stalked, erecto-patent pinnae on each side, which are 10-25 c.M. long, 1-2 c.M. broad, the apex much acuminate, the edges entire or slightly repand towards the point, the base narrowed. Texlure coriaceous; upper surface covered with small, white, cretaceous dots all over or only near the edge; veins usually indistinct. Sori in a single row on each side between the midrib and edge.

War. Varoians: Pinnae narrower; main veins distinct.

Malaya.

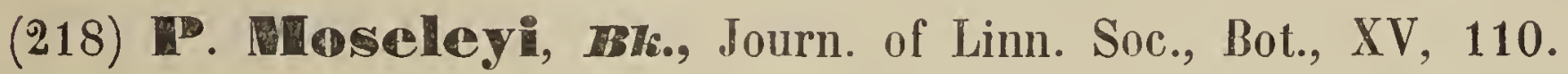

Stipes 15-25 c.M. long, stramineous, naked. Fronds quadrangular or rhomboidal, simply pinnate, $20-40$ c.M. long, 20-30 c.M. broad. Pinnae 4-6-jugate, linear, acuminate, all dilatato-adnate at the base, erecto-patent or subpatulous, $1-2$ c.M. broad, the terminal one like the rest but often larger, the margin horny, irregularly repand. Texture subcoriaceous; surfaces naked; costae and main veins glossy and stramineous; areolae immersed, rather large; free veinlets copious, knobhed. Sori round, slightly immersed, in 1 row on each side nearer the margin than the costa.

Moluccas, New Guinea.

* (219a) IP. Daetmatainm, IBt., Rac., Flor. Btz., I, 114; Bl., Flor. Jav., II, 1丂̆0, tab. LXIV; P. crenulatum, Kze, Mett., Farng., I, Polypod., 110; Pleopellis palmata, Moore, Bedd., Handb. Ind. Ferns, 568; Ferns Br.I., II, tab. CLVI; - var. angustatum; P. angustatum, Bl., Mett., l. c., 108; Bl., 1. c., 14S, tab., LXII; - var. obtusum.

Rhizome stout, creeping; scales dense, conspicuous, linear-lanceolate or lanceolate, thin, pale-brown, the base broad, rounded, peltate, the point acute, the edge obscurely toothed or ciliate. Stipes distant, 7-50 c.M. long, erect, naked, glossy. Fronds 15-45 c.M. long, 15-50 c.M. broad or broader, pinnate. Terminal pinna linear or linear-oblong, entire or slightly repand, crenate or toothed; lateral pinnae similar, 1-10 on each side, erecto-patent, $10-25$ c.M. long, $1 / 2-4$ c.M. broad, lanceolate, acuminate or caudate, narrowed to the base and then dilated again, broadly adnate to the rachis; lower pinnae not rarely \pm stalked, and the barren ones often the broadest. Tex- 
71. Polypodium. $\mathbb{S} 6$. Pleopeltis. $c^{* *}$. Phymatopsis.

ture subcoriaceous; surfaces naked; main veins distinct nearly or quite to the edge: areolae fine, hidden. Sori in 1 row on each side of the costae, \pm medial, superficial. - Young plants with the fronds simple and yet often fructiferous.

Var. angustatum: Pinnae \pm cuneate at the base, the lower ones \pm stalked, the higher sessile, narrowly or hardly adnate to the rachis.

War. Olbtastum: Like var. angustatum, but the pinnae \pm blunt, very thick in texture.

Malaya.

(219b) Drotens, Copel., Philipp. Journ., I, Suppl., 164, tab. XXV. Rhizome creeping, the scales subulate, short-ciliate, with the base peltate, rounded or sometimes hastate. Stipes $1 / 2-17$ c.M. long, naked. Fronds polymorphous, simple, 2-3-fid or pinnate with 1-4 pinnae on each side below the terminal one. Simple fronds $1 / 2$-5 c.M. long, oblong or lanceolate, obtuse at both ends. The $2-3$-fia fronds are intermediate forms between the simple and pinnate ones. Pinnate fronds to 20 c.M. long, nearly as broad. Pinnae lanceolate, acute or acuminate, entire or undulate, sessile, adnate or the lower short-stalked, articulate to the rachis. Texture coriaceous; surfaces naked; main veins distinct nearly to the edge; veins immersed. Sori in 1 row on each side of the costa in the simple fronds and in 1-5 rows on each side in the pinnate forms, slightly immersed.

Luzon.

\section{\$ 6. PLEOPELTIS. c. Chrysopteris.}

*. Sori in 1 row belween the main veins. *.*. Sori scattered irregularly.
(220) P. coronans. (221) P. heracleum.

* (220) T. Coronans, Wall., Mett., Farng.. I, Polypod., 121; Hk., Fil. Exot., tab. XCI; P. conjugalum, Bk. (not Lam.), Hk. Bk., Syn. Fil., 366; Drynaria coronans, J. Sm., Bedd., Ferns Br.I., I, tab. XIII.

Rhizome very thick, the scales dense, long, linear, crisped, brown. Fronds sessile, arranged in a circle, 60-120 c.M. long, the lower part 10-20 c.M. broad, the base dilated, cordate, the edge narrowed, lobed, passing gradually into the upper part of the frond, which is 50-45 c.M. broad and cut down nearly to the costa throughout into entire, erecto-patent segments $21 / 2-4$ c.M. 
hroad, linear, acute or acuminate. Texture rigid; surfaces naked; main veins of the segments distinct to the edge, united by transversing veins forming \pm 6 quadrangular areolae on each side of the costulae. Sori in single rows between the main veins near their anterior sides, sometimes confluent.

Malacca; Norlh. India, Soulh. China, Formosx.

* (221) Leracleuma, Tae, Rac. Flor. Btz., I, 116; Hk., Gard. Ferns, tab. I; Drynaria IIeracleum, Moore, Bedd., Handb. Ind. Ferns, Suppl., 95.

Rhizome stout, fleshy, succulent, creeping, the scales narrow, linear or lancenlate, brown. Fronds sessile, $90-\mathbf{5} 50$ c.M. long, the lower part $7-\mathbf{1 5}$ c.M. broad, moderately sinuato-lobate, rounded or cordate at the base, the upper part much dilated, 50-100 c.M. broad, cut down to a broadly winged costa into linear-lanceolate. entire, acute lohes $5 \%-10$ c.M. broad at the base. Texture coriaceous, firm; surfaces naked; veins distinct, with $6-8$ \pm irregular, quadrangular areolae on each side of the costulae, enclosing smaller ones will free veinlets. Sori small, copious, scaltered irregularly, slighlly immersed, often confluent.

Malaya.

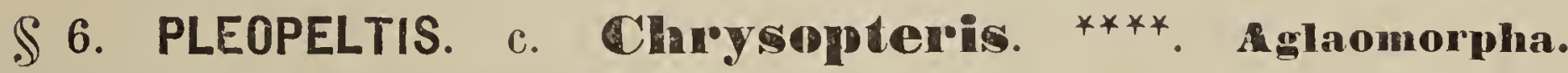

(222) TP. Heyenianume, \#1. (not Scholl), Hk. Bk., Syn. Fil., 366; Diels, in Engl. \& Prantl, Nat. Pfl.Fam., I ${ }^{4}$, fig. 166, A-C; Aglaomorpha Meyeniana, Scholl, Bau. \& Hk., Gen. Fil., tab. XGI.

Rhizome very stout, the scales dense, linear, crisped, bright-ferrugineous, $1-1 \frac{1}{2}$ c.M. long. Fronds $60-100$ c.M. long, the basal part barren, \pm 15 c.M. broad, shallowly lobed, the central part 20-30 c.M. broad, sterile, cut down nearly to the costa into erecto-patent, linear-oblong, blunt, entire lobes $7-15$ c.M. long, 1-3 c.M. broad, the upper part fertile, pinnate, the pinnae 10-20 c.M. long, narrowly linear, sinuous, consisting only of a firm midrib with a row of small, \pm semiorbicular lobes on each side, each with a single sorus. 'Texture coriaceous; surfaces naked; main veins reaching the margin; areolae copious, with free veinlets.

Philippines. 


\section{\$ 7. SELHGUEA. $(*)=$ genum Pleopeltis}

a. Fronds simple.

b. Texture herbaceous to papyraceous; main veins cominonly fine.

1. Rhizome scales blackish.

5. Fronds narrow, 1-31/2 c.M. broad. Sori occupying the wholefrond.

* Areolae regular.

(225a) P. selliguea.

\%. Areolae irregular.

(225b) P. Bolsteri.

\$.\$. Fronds broader, $31 / 2-5$ c.M. broad. Sori confined to the upper $1 / 3-1 / 2$ of the frond.

(224) P. interruptum.

1.1. Rhizome scales brown.

2. Primary areolae \pm regularly subquadrate.

3. Fertile fronds $\pm 1 / 2 \times$ as long as the barren ones.

(225) P. regulare.

3.3. Fertile fronds not or hardly shorter than the barren ones.

佂. Fronds cuspidate, short-stalked, $\pm 20-25$ c.M.

$$
\text { long. } \quad \text { (226) P. Hosei. }
$$

1. Fronds acule, rather long-stalked, $\pm 25-45$ c.M.

$$
\text { long. }
$$

2.2. Primary areolae irregular.
(227) P. macrophyllum.

(228) P. spurium.

b.b. Texture coriaceous or subcoriaceous: main veins mostly prominent.

c. Sori superficial.

d. Lower part of the frond suddenly narrowed into a decurrent base.

(229) P. pedunculatum.

d.d. Lower part of the frond suddenly or gradually narrowed, if suddenly, the base not or hardly decurrent.

e. Barren fronds obtuse, truncate at the base, fertile ones acute at both ends.

(250) P. Elmeri.

e.e. Both barren and fertile fronds \pm acute at both ends.

(251a) P. Feei.

(251b) P. calophlebium.

c.e. Sori immersed.

(252) P. heterocarpum.

w.a. Fronds deeply pinnatifid or pinnate.

* Segments decurrent.

(255) P. ellipticum.

+. Segments not decurrent.

(254) P. Maingayi.

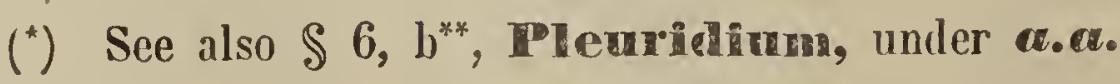


* (223a) P. selliguea, Mett., Christ, Farnkr. d. Erde, 108; Gymnogramme membranacea, Hk., Hk. Bk., Syn. Fil., 588; Selliguea membranacea, Bl., Flor. Jav., II, 126, tab. LII, fig. 2; S. Selliguea, Christ, Bull. Herb. Boiss., $2^{\mathrm{e}}$ Série, VI, 992.

Rhizome woody, creeping, the scales small, linear, nearly black. Stipes 1-20 c.M. long, nearly naked. Fronds $10-30$ c.M. long, $1-51 / 2$ c.M. broad, the point acuminate, the edge entire, the lower part narrowed very gradually. Texture papyraceo-herbaceous; surfaces naked; main veins distinct to the edge, zigzag, very slender; areolae hexagonal. Fertile fronds on the longest stipes. Sori in oblique, single, parallel, often interrupted lines between the main veins.

Malaya; Queensland.

(225b) P. Bolsteri, Copel., Philipp. Journ., I, Suppl., 257, tab. IV, A. Rhizome wide-creeping, stout, clothed with black, aculeate-ovate, deciduous scales. Fronds scattered, sessile or short-stalked, 20-50 c.M. long, 1-2 c.M. broad, narrowed gradually towards both ends. Texture membranaceous; surfaces naked; main veins flexuose, hardly reaching the margin; areolae fine, irregular, with free veinlets. Sori oblong, irregular, or in single rows between the main veins.

Mindanao.

(224) P. interruptum, C. Chr., Ind. Fil.; Gymnogramme acuminata, Bk., Journ. of Bot., XXVI, 326.

Rhizome wide-creeping, the scales minute, linear, black. Stipes remote, slender, naked, 10-15 c.M. long. Fronds simple, oblong-lanceolate, very acuminate, tapering gradually to the base, $15-20$ c.M. long, $\tilde{3}^{1} / 2-5$ c.M. broad at the middle. Texture membranaceous; surfaces naked; main veins fine, parallel, erecto-patent, reaching nearly to the edge; areolae with free veinlets. Sori linear, much interrupted, confined to the upper $1 / 3-1 / 2$ of the frond.

Borneo.

(225) P. regulare, Mett., Ann. Mus. Bot. L. B., II, 225; Gymnogramme regularis, Bk., Hk. Bk., Syn. Fil., 388.

Rhizome creeping, the scales ovate to lanceolate, subferrugineous or darkbrown. Stipes $0-15$ c.M. long. Fronds $15-40$ c.M. long, $4-7$ c.M. broad, the fertile ones the shortest and narrowest, oblong-elongate, narrowed gra-

Filices. 
dually to hoth ends, the edge entire. Texture papyraceous; surfaces naked; main veins parallel; areolae copious, subquadrate, divided into smaller, distinct secondary ones with free veinlets. Sori in single, continuous or interrupted lines between the main veins.

Borneo.

* (226) I. Hosei, C. Chr., Ind. Fil.; Gymnogramme campyloneuroides, Bk., Journ. of Linn. Soc., Bot., XXIV, 261; Selliguea campyloneuroides, Bedd., Handb. Ind. Ferns, Suppl, 101.

Rhizome woody, wide-creeping, the scales small, lanceolate, dark-brown. Stipes scattered, short. Fronds simple, 20-25 c.M. long, 6-9 c.M. broad at the middle, oblong, cuspidate, narrowed very gradually to the base. Texture moderately firm; surfaces naked; main veins very distinct, erecto-patent, produced regularly from the midrib to the margin; transverse veins regularly parallel; areolae with free veinlets. Sori in single, interrupted rows reaching from the midrib to the margin.

Borneo, Malacca.

* (227) P. macrophyllum, Reinev. (not Mell.), Mett., Farng., I, Polypod., 111; Gymnogramme macrophylla, Hk., Hk. Bk., Syn. Fil., 388 ; Sel- J FM liguea macrophylla, Bl., Flor. Jav., II, 127, tab. LIII; Grammitis macrophylla, Bl., Enum., 119.

Rhizome creeping, slender, the scales. lanceolate, brown. Stipes $5--20$ c.M. long. naked, distant. Fronds $25-45$ c.M. long, 5-10 c.M. broad, acute, narrowed to both ends, the edge entire. Texture thin, papyraceous; surfaces naked; main veins distinct, slender, zigzag; areolae subquadrangular, with free veinlets. Fertile fronds often longer stalked than the barren ones. Sori in single, continuous or interrupted, parallel lines between the main veins.

Malaya; South. China.

(228) P. Spurium, Ifett., Ann. Mus. Bot. L. B., II, 226; Gymnogramme spuria, Bk., Hk. Bk., Syn. Fil., 588.

Rhizome creeping, the scales ovate-acuminate, brown. Stipes $\pm 20-25$ c.M. long, reddish-brown, margined upwards. Fronds \pm 50 c.M. long, $\pm 7-8$ c.M broad, ovate-oblong, the base cuneate, the point bluntish, the edge subrepand. Texture papyraceous; surfaces naked; main veins straight, prominent; areolae irregular, large, divided into smaller ones, and those again so- 
metimes subdivided, with free veinlets. Sori in single, interrupted rows between the main veins.

Celebes.

* (229) P. pedumculatum, Ihet., C. Chr., Ind. Fil.; P. Ilamiltonianum, Diels, in Engl. \& Prantl, Nat. Pfl.Fam., I ${ }^{4}$, 316; Gymnogramme Hamiltoniana, Hk., Hk. Bk., Syn. Fil., 589; Selliguea Hamilloniana, Bedd., Ferns Br.I., II, tab. CCXXXIX; Ceterach pedunculata, Hk. \& Grev., Ic. Fil., tab. V.

Rhizome wide-creeping, woody, the scales linear, dull-brown. Fronds dimorphous. Barren fronds $\pm 15-50$ c.M. long, $\pm 6-10$ c.M. broad, elliptical-oblong, entire, acuminate, the lower part suddenly narrowed into a gradually decurrent base, the stipe $5-12$ c.II. long. Texture rather thinly coriaceous; surfaces naked; main veins distinct to the edge; areolae copious, with free veinlets. Fertile fronds $10-20$ c.M. long, $2-4$ c.M. broad, entire or repand, on naked, slender stipes more than 30 c.M. long. Sori in broad, continuous rows, solitary between and parallel to the main veins.

Malacca; North. India, South. China.

(250) Elmen', Copet., Polypod. Philipp., 152; - var. separatum, Christ, Bull. Herb. Boiss., 2 e Série, VI, 992.

Rhizome creeping, firm; scales ovate, acuminate, the base peltate, the margin scariose. Stipes firm, naked, brownish or blackish, 5-6 c.M. long. Sterile fronds deltoid-oblong, \pm 10 c.M. long, 6-8 c.M. broad, obtuse, entire or subsinuate, the base truncate. Texture firmly coriaceous; surfaces naked; main veins parallel, conspicuous, reaching the margin; veins hidden. Fertile fronds \pm 10 c.M. long, \pm 4 c.M. broad, acute, subentire, cuneate at the base, on stipes 15 -20 c.M. long; texture coriaceous. Sori narrow, continuous, reaching the costa and the margin.

Var. separatum: Sori not continous, interrupted, forming 2 rows of round sori on each side of the costa, one costal, the other marginal.

Luzon.

* (251a) P. Feei, Mett., Farng., I, Polypod., 110; Gymnogramme Féei, Hk., Rac., Flor. Btz., I, 74; Selliguea Feei, Bory, Bl., Flor, Jav., II, 123, tab. LI; Bedd., Ferns Br.I., II, tab. CLI; - var. vulcanicum; P. vulcanicum, Bl., Mett., l. c., 111; Bl., 1. c., 144, tab. LVI, fig. 2; - var. caudiforme; 
P. caudiforme, Bl., Mett., I. c., 110 ; Bl., l. c., 146, tab. LIV, fig. 2 ; Selliguea caudiformis, J. Sm., Bedd., Handb. Ind. Ferns, $\mathbf{5 9 0}$.

Rhizome creeping, the scales lanceolate-linear, light-brown. Stipes $21 / 2-40$ c.M. long, firm, erect, naked, more or less glossy, pale or brown, those of the fertile fronds the longest. Fronds subdimorphous, $\mathbf{5}-\mathbf{2 5}$.c.M. long, 2-10 c.M. broad, ovate-oblong, the fertile ones commonly the longest and narrowest, often much the narrowest, acute, entire, narrowed at the base. Texture coriaceous; surfaces naked; main veins distinct; areolae hidden. Sori nol immersed, linear, continuous, solitary between and parallel to the main veins. not reaching either the midrib or the edge, distant or contiguous.

Var. vulcanicum: Stipes of the fertile fronds not always longer than those of the barren ones. Fronds smaller, \pm ovate, bluntish, uniform, or the fertile ones narrower. Sori interrupted so as to form several parallel rows of round, oblong or linear-oblong sori.

Var. caudiforme: Fertile fronds much narrowed, long-acuminate, subcaudate. Sori large, round, solitary between the main veins.

Malaya, Polynesia.

(251b) P. calophlebium, Copel., Philipp. Journ., II, 140, tab. III, A.

Rhizome wide-creeping, clothed with squarrose, broadly lanceolate, fulvoferrugineous scales, which are peltate and castaneous at the base. Stipes erect, naked, 3-10 c.M. long, those of the fertile fronds the longest. Barren fronds ovate, \pm 14 c.M. long, \pm b c.M. broad, long-acuminate, the edge brown, rigid, the base rounded (acute in Copeland's table). Texture coriaceous; surfaces naked; main veins stout, straight, reaching the margin, erecto-patent; veins hidden beneath, visible above. Fertile fronds contracted, linear, \pm 16 c.M. long, \pm 7-11 m.M. broad, broadest near the base, narrowed gradually towards the apex, the base cuneate, the edge entire or crenulate (undulatocrenate in Copeland's drawing). Sori 1-2 between the oblique main veins, the pairs often confluent.

Mindoro.

- 252) D. heterocarpum, Mett., Farng., I, Polypod., 110; Gymnogramme heterocarpa, Hk. (not Bl.), Rac., Flor. Btz., I, 74; Grammitis heterocarpa, Bl., Enum., 118 ; Selliguea heterocarpa, Bl., Flor. Jav., II, 125, tab. LII, fig. 1; - var. interruptum; P. vulcanicum, Christ (not Bl.), Farnkr. d. Erde, 108; - var. abbreviatum; P. caudiforme, Christ (not Bl.), l. c. 
Rhizome creeping, woody, the scales dense, linear-lanceolate, brown. Stipes 4-25 c.M. long, firm, erect, naked, those of the fertile fronds often the longest. Fronds 7-30 c.M. long, $1 \frac{11}{2}-\mathbf{5}$ c.M. broad, the fertile ones not much narrower than the barren, lanceolate, acute or acuminate, the edge entire, the base more or less gradually narrowed. Texture coriaceous; surfaces naked, glossy; main veins distinct; veins hidden. Sori immersed, long, linear, solitary between and parallel to the main veins, continuous or slightly interrupted.

Var. interruptum : Sori distinctly interrupted, forming rows of roundish or oblong sori.

Var. abbreviatum: Fertile fronds much narrowed, subcaudate. Sori roundish or oblong, 1-2 between the main veins.

Malacca, Banca, Java, Celebes.

* (253) P. ellipticum, Th»., Christ, Farnkr. d. Erde., 107; Gymnogramme elliptica, Bk., Hk. Bk., Syn. Fil., 389; G. decurrens, Hk., Spec. Fil., V, 161; Selliguea elliptica, Bedd., Handb. Ind. Ferns, 592; S. decurrens, Pr., Bedd., Ferns Br.I., I, tab. CL; Grammitis decurrens, Wall., Hk. \& Grev, Ic. Fil., tab. VI.

Rhizome woody, creeping, firm, the scales adpressed. Stipes scattered, 30-40 c.M. long, firm, erect, naked, pale. Fronds 50-50 c.M. long, 15-25 c.M. broad, cut down nearly or quite to the rachis into 4-6 linear-oblong or lanceolate, distant, sessile, opposite, acute segments narrowed towards the base, mostly connected by the decurrent, oblique bases, which form a wing to the rachis; longest segments $1-4$ c.M. broad. Texture herbaceous; rachis and surfaces naked; costal areolae large, with smaller, irregular included ones with free veinlets. Sori linear, oblique, nearer the midribs than the edge.

Malacca, Philippines; Formosa, Japan, North. China, North. India, Queensland.

(254) P. Maingayi, Diels, in Engl. \& Prantl, Nat. Pfl.Fam., I', 318; Gymnogramme Maingayi, Bk., Hk. Bk., Syn. Fil., 517; Selliguea Maingayi, Bedd., Handb. Ind. Ferns, 592.

Stipes \pm 45 c.M. long, dull-brown, naked. Fronds deltoid, to $30 \mathrm{c} \mathrm{M}$. long, with \pm 5 oblong-lanceolate pinnae. Largest pinnae \pm 15 c.M. long, $4^{1} /_{2}-5^{1} /_{2}$ c.M. broad, slightly repand, narrowed gradually at base, the lowest pair distant. Texture membranaceous; surfaces naked; main veins distinct to the edge; areolae copious, small, wilh free veinlets. Sori abundant, irregular, punctiform or confluent in lines or curves.

Malacca. 


\section{OYOLOPHIORUS, Desuax.}

Sori round, rarely oblong, and then oblique or sometimes subparallel to the costa. No indusium.

Rhizome creeping. Stipes articulate to the rhizome. Fronds simple, \pm entire in malayan material; surfaces covered with scattered or more or less densely crowded or interlaced stellate hairs, which are fastened by a central point, those of the upper surface often caducous; veins anastomosing, hidden; areolae with free included veinlets. Sori sometimes quite hidden among the tomentum. Hk. Bk., Syn. Fil., tab. V, fig. 48, k-1; Diels, in Engl. \& Prantl, Nat. Pfl. Fam., I ${ }^{4}$, fig. 168. (Niphobolus).

\section{Arrangement of the sections.}

$\mathbb{S}$ 1. NIPHOBOLUS. Venation as in Campyloneuron, i. e. areolae \pm regularly subquadrangular, with 2 or miore included, excurrent, simple or forked free veinlets. Diels, l. c., fig. 163, H.

S2. NIPHOPSIS. Venation as in Pleopeltis, i. e. areolae \pm irregular, the free veinlets spreading in various directions. Diels, l. c., fig. 164, B-E.

\section{$\$ 1$. NIPHOBOLUS.}

a. Tomentum adpressed, often very thin.

b. Fronds dimorphous, the fertile ones mostly narrower and often longer than the barren.

+. Fertile region of the frond with the tomentum as thin as in the harren part.

*. Rhizome scales black. Stellate hairs of the under surface scattered.

(1) C. pachydermus.

*.*. Rhizome scales ferrugineous. Stellate hairs of the under surface crowded.

(2) C. rupestris.

+. Fertile region of the frond with the tomentum thicker and looser than in the barren part.

×. Rhizome scales adpressed. Fertile fronds to 1 c.M. broad.

$\times \cdot \times$. Rhizome scales spreading at the point. Fertile fronds $1 \frac{1}{2}$

(3) C. adnascens. S!p 4

$$
2 \text { c.M. broad. }
$$

(4) G. varius.

b.t. Fronds uniform or nearly so. 
72. GYGLPHORUS. $\$ 1$. NIPHOBOLUS.

c. The stellate hairs of the under surface scattered.

+. Main veins hidden. Sori in 5-6 rows between the midrib and margin.

(5) C. anetioides.

+.+. Main veins distinct. Sori in 10-20 rows between the midrib and margin.

(6) C. sphaerostichus.

c.c. The stellate hairs of the under surface crowded or interlaced, but adpressed.

d. Main veins hidden.

+. Fronds contracted in the fertile region. Sori immersed in the tomentum.

(7) C. macropodus.

+. Fronds hardly contracted in the fertile region. Sori not immersed in the tomentum.

(8) C. acrostichoides. $1 / p 4 / 2$

d.d. Main veins distinct.

e. Fronds small, under 30 c.M. long.

f. Rhizome scales adpressed, obscurely peltate at the base, rather sessile.

(9) C. pannosus.

f.f: Rhizome scales spreading, distinctly peltate at the base.

(10) C. heteractis.

e.e. Fronds larger, $60-90$ c.M. long.

a.a. Tomentum loose, woolly, thick.

(11) C. princeps.

1. Fronds small, under 6 c.M. long. $\left(^{\star}\right)$

$\times$. Barren fronds suburbicular, cordate or rounded at the base, on stipes 1-2 m.M. long.

(12) C. nummularifolius.

$\times \cdot \times$. Barren fronds obovate, cuneate at the base, on stipes \pm 10 m.M. long.

(15) C. obovatus.

1.1. Fronds larger, more than 6 c.M. long when fully developed.

2. Texture thin or weak.

+. Fronds linear, $\pm 1 / 2$ c.M. broad.

(14) C. lanuginosus.

.++ Fronds lanceolate, 2-8 c.M. broad.

(15) C. penangianus.

2.2. Texture thick, firm.

3. Fronds mostly 8-30 c.M. long.

1. Fronds narrow, to \pm 5 m.M. broad. Sori in 1-3 rows on each side of the costa.

(16) C. rasamalae.

1.4. Fully developed fronds \pm 1 c.M. broad, or broader.

5. Sori in 2-4 rows on each side of the costa.

+. Upper surface without depressed dols and minute blackish scales.

(17) C. flocciger.

(') See also under C. Masamalae, C. Chr. 
72. CYGLOPHORUS. $\mathbb{1} 1$. NIPHOBOLUS.

+. Upper surface purveyed with depressed dots, which are covered with minute, deciduous, blackish, calcareous scales. (18) C. porosus.

5.5. Sori in 5-8 rows on each side of the costa.

6. Upper surface purveyed wilh depressed dots and minute, deciduous, blackish, calcareous scales.

(19) C. sticticus.

6.6. Upper surface not purveyed with depressed dots and minule blackish scales.

(20) C. mollis.

3.3. Fully developed fronds more than 30 c.M. long. Sori in $5-8$ rows on each side of the costa.

(21) G. albicans.

(1) C. pachydermus, C. Chr., Ind. Fil.; Polypodium pachydermum, Bk., Journ. of Limn. Soc., Bot., XV, 108.

Rhizome wide-creeping, woody, flexuose, the scales minute, adpressed, lanceolate, black, mixed with a brown powder. Stipes naked, $1-2 \frac{1}{2}$ c.M. long. Fronds dimorphous, the barren ones oblanceolate-oblong, obtuse, $21 / 2$ 5 c.M. long, 1-2 c.M. broad, cuneate at the base, the fertile ones ligulate, 7-10 c.M. long. Texture thick, coriaceous; upper surface naked, lower clothed with a thin tomentum visible by magnifying power, the hairs with a distinct bare space round each; veins immersed. Sori occupying the upper $1 / 2$ or $2 / 3$ of the frond, superficial, $6-8$ in erecto-patent rows between midrib and edge.

Kei Islands, Moluccas.

* (2) C. rupestris, C. Chr., Ind. Fil.; Polypodium rupestre, R. Br., Mett., Farng., I, Polypod., 125; P. confluens, Hk. (not R. Br.), Hk. Bk., Syn. Fil., 549; Niphobolus rupestris, Spr., Gies., Niph., 169; Hk. \& Grev., Ic. Fil., tab. XCIII.

Rhizome wide-creeping, slender, rather filiform, branched, densely clothed with pale-ferrugineous, linear-subulate, hair-pointed scales, peltate at the base. Fronds scattered, dimorphous. Barren fronds short-stalked or subsessile, orbicular, oblong, rhomboidal or spathulate, $\pm 1-2$ c.M. long, $\pm 1 / 2-1$ c M. broad, mostly broadest at or above the middle, the apex rounded, the base cuneate or rounded. Texture very thick; upper surface often soon naked, lower clothed with dense but adpressed, moderately woolly, brownish tomentum; veins quite hidden. Fertile fronds linear or ligulate, 2-15 c.M. long, 
2-5 m.M. broad, the apex blunt or rounded, the lower $1 / 3-1 / 2$ cuneate, narrowed gradually into the short stipe; upper surface soon naked, subinduplicato-canaliculate when dry, lower densely clothed with subadpressed, ferrugineous tomentum. Sori rather large, in 1-2 irregular rows on each side of the costa, immersed, but elevated above the tomentum, occypying the upper $1 / 2-2 / 3$ of the fertile frond, but sometimes covering the whole under surface. - Plants gathered in New Guinea by Dr. Versteeg, which may be a form of this species, have the barren and fertile fronds subsessile, the barren oblong, rounded at the apex, cuneate, rounded or cordate at the base; fertile fronds with the young sori deeply immersed, and the cavities closed by a small, roundish, lid-like, deciduous lateral outgrowth of leaf tissue covered with large, globose tufts of densely crowded, very long-stalked, ferrugineous stellate hairs, the tufts $\pm 2-b$ m.M. each way.

? New Guinea; Australia, New Zealand.

- (3) C. adnascens, Desv., Berl. Mag., V, 300; Polypodium adnascens, Sw., Rac., Flor. Btz., I, 98; P. caudatum, Mett., Farng., I, Polypod., 126; P. carnosum, Mett., l. c., 124; P. Koenigii, Bl., Flor. Jav., II, 50; Niphobolus adnascens, Klf., Hk., Gard. Ferns, tab. XIX; Gies., Niph., 196; N. caudatus, $K l f .$, Bl., l. c., 56, tab. XXII ; N. carnosus, Bl., l. c., 50, tab. XIX, N. elongalus, Bl., l. c., 52, tab. XX; - var. minor, Christ, MS, in Herb. Bog. kch pran hoc',

Rhizome wide-creeping, the scales dense, peltate, dark-coloured, ovate or lanceolate, with the base rounded, the apex blunt; acute or acuminate, the edge ciliate, pale-brown or whitish. Stipes $1-5$ c.M. or more apart, $1 / 2-5$ c.M. long, firm. Fronds dimorphous. Barren fronds oblong, linear or spathulate, 2-12 c.M. long, 1-2 c.M. broad, the apex blunt, the edge entire, the base cuneate or gradually narrowed. 'Texture rigidly coriaceous, thick; costa distinct; veins hidden; upper surface naked or nearly so, lower thinly tomentose, the stellate hairs abundant but not crowded, caducous. Fertile fronds linear, longer than the barren ones, 8-50 c.M. long, 4-10 m.M. broad, with the edges more or less recurved, on stipes $1-8$ c.M. long, the tomentum thicker, woolly (the hairs densely crowded) in the soriferous part of the frond. Sori small, often crateriform, occupying the upper $1 / 1_{2}$ $2 / 3$ of the frond, immersed, hidden in the tomentum when young. - Ferns with the habit of Drymoglossum heterophyllum, C. Chr. in the smaller forms.

Var. minor: Fertile fronds subsessile, \pm 6 c.M. long, $3-6$ m.M. broad in the fertile region.

Trop. Asia, Polynesia; - var. minor: Batu Islands (Raap). 
* (4) C. varius, Gaazd., Freyc., Voy. Ur. Phys., Bot., 564; Polypodium varium, Mell., Rac., Flor. Btz., I, 100 ; Niphobolus varius, Klf., Gies., Niph, 208; Bl., Flor. Jav., II, 54, tab. XXI.

Rhizome wide-creeping, slightly branched, the scales oblong-lanceolate, brown, with the base peltate, the apex acuminate and \pm spreading, the margin ciliate. Stipes scattered, 1-2 c.M. long. Fronds dimorphous. Barren fronds $\pm 8-12$ c.M. long, $2-4$ c.M. broad, lanceolate, obtuse. Texture coriaceous; upper surface naked, lower covered with scattered, adpressed stellate hairs; costa conspicuous; main veins hardly visible. Fertile fronds $\pm 15-25$ c.Mr. long, $1 \frac{1}{2}-2$ c.ll. broad, the soriferous region often narrowed and the under surface densely covered there with deciduous, \pm loose and woolly tomentum Sori \pm immersed in shallow, indistinct cavities, \pm crateriform, closely placed in 6-8 rows between the midrib and edge, occupying the upper part of the frond, hidden in the tomentum when young.

Malaya; Polynesia.

(5) C. anetioides, C. Cler., Ind. Fil.; Niphobohus anetioides, Christ, Ann. Btz., XIX, $\mathbf{3} 8$.

Rhizome wide-creeping, the scales subulate-acuminate, yellow-brown. Stipes distant, $1 / 2-1$ c.M. long. Fronds ovate-oblong to lanceolate, $6-10$ c.M. long, to 2 c.M. broad, obtuse to acuminate, cuneately narrowed at the base, often lobed there with $1-3$ round lobes. Texture papyraceo-coriaceous; upper surface bright-green, the stellate hairs short, whitish; under surface pale, the hairs sparingly scattered; reddish-brown, adpressed; costa ebeneous, conspicuous; main veins hidden, erecto-patent, 8-15 on each side, with $5-6$ rows of longitudinal areolae on each side of the costa. Fertile fronds narrower. Sori not immersed in the tomentum, occupying the upper part of the frond, covering the whole space between the midrib and edge, placed in 2 rows between the main veins, with $5-6$ sori in a row.

Celebes.

(6) C. spaerostichus, C. Chr., Ind. Fil.; Polypodium sphaerostichum, Melt., Hk. Bk., Syn. Fil., 350 ; Niphobolus sphaerostichus, Copel., Polypod. Philipp., 114.

Rhizome woody, wide-creeping, the scales ovate, acuminate, brown, crisped. Stipes $\mathfrak{b}-8$ c.M. long, tirm, erect. Fronds uniform, 10-13 c.M. long, $\pm 2 \frac{1}{2}$ c.I. broad, oblong-lanceolate; acuminate, the base narrowed suddenly. 
72. cyclophorus. $\mathbb{S} 1 . \quad$ NIPHOBOLUS.

Texture coriaceous; under' surface very thinly matted: main veins distinct to the edge. Sori confluent, covering the whole under surface, placed in 10-20 rows between the midrib and edge.

Celebes, Luzon.

(7) C. ma cropodus, C. Cher., Ind. Fil.; Polypodium macropodum, Bk., Journ. of Limn. Soc., Bot., XV, 108.

Rhizome woody, short-creeping, the scales minute, adpressed, deltoid, black, mixed with a brown powder. Phyllopodes 7-10 m.M. long, scaly like the rhizome. Stipes bordered very nearly to the base. Fronds uniform, ligulate, 10-20 c.M. long, $1-2$ c.M. broad, the fertile region contracted, the point acute, the base narrowed very gradually. Texture coriaceous, thick; upper surface naked, lower clothed with thin tomentum; veins hidden. Sori occupying the upper half of the frond, minute, immersed in a pale-brown tomentum, placed-in erecto-patent rows between midiib and edge, and each showing distinctly on the upper surface of the frond, $6-8$ in a row.

Aru Islands.

* (8) C. acrostichoides, Epim., 150 ; Polypodium acrostichoides, Forst., Rac. Flor. Btz., I, 98; Niphobolus acrostichoides, Rich. (not J. Sm.), Copel., Polypod. Philipp., 113; Gies., Niph., 215; Bedd., Ferns Br.I., I, tab. LXXXI ; N. puberulus, Bl., Flor. Jav., II, 57, tab. XXIII ; N. fissus, Bl., I. c., 58, tab. XXIV (abnormal form); - var. gracilis, Copel., Leafl., I, 234.

Rhizome creeping; scales roundish or oblong, rarely acute, peltate, adpressed or subadpressed, dark-coloured, the margin paler or whitish when young, \pm entire. Stipes 5-7 c.M. long, deciduously tomentose with adpressed stellate hairs. Fronds uniform, 20-60 c.M. long, 1-5 c.M. broad, ligulate or linear, the apex bluntish or subacute, the edge entire, the base narrowed gradually. Texture coriaceous; upper surface naked or nearly so, lower tomentose, the stellate hairs greyish or brownish, often white when young, crowded but adpressed; costa conspicuous; veins hidden. Sori small, close, numerous, crateriform, occupying the upper $1 / 3-2 / 3$ of the frond, slightly immersed in shallow cavities, which are not or obscurely prominent on the upper surface, not hidden in the tomentum.

Var. gracilis: Stipes shortel'; fronds hardly 1 c.M. broad, less coriaceous; sori in $3-4$ rows.

Malaya; Ceylon, Polynesia, Queensland.

* (9) C. Dannosus, C. Chr., Ind. Fil.; Polypodium pannosum, Mett., 
Hk. Bk., Syn. Fil., 512: Niphobolus pannosus, Bedd., Gies., Niph., 105; N. lingua, Bedd., Ferns S.I., tab. CCXL.

Rhizome wide-creeping, the scales lanceolate, acuminate, \pm toothed, adpressed, obscurely peltate at the base, rather sessile. Stipes $21 / 2-15$ c.M. long, those of the sterile fronds often the longest. Fronds nearly uniform, $\mathbf{5}-\mathbf{1 5}$ c.M. long, $21 / 2-4$ c.M. broad, narrowed towards both ends. Texture subcoriaceous; upper surface at length naked, lower tomentose, the stellate hairs close, adpressed, palebrown, with long branches; costa and main-veins distinct. Sori densely crowded, $5-6$ in a row between the main veins, ceasing a space from the edge. - Fertile fronds very small in Beddome's drawing.

? Java; Tenasserim, Ceylon, Burmah.

* (10) C. Ineteractis, c. Chr., Ind. Fil.; Polypodium Heteractis, Mett., Linn., XXXVI, 140 ; Niphobolus Heleractis, J. Sm., Gies., Niph., 153 ; N. Lingua, Spr. (not J. Sm.), Copel., Polypod. Philipp., 113, p. p.; Bedd., Ferns S.Br.I., Suppl., tab. CCCLXXXV. (*)

Rhizome wide-creeping, the scales dense, spreading, lanceolate, ferrugineous, with the base peltate, \pm lobed, the edge ciliate towards the apex. Stipes \pm 4-10 c.M. long, firm, erect. Fronds 8-16 c.M. long, $2 \frac{1}{2}-4 \frac{1}{2}$ c.M. broad; ovate or oblong-lanceolate, the apex often cuspidate, the base cuneate or rounded. Texture coriaceous; upper surface at length naked, lower matted with adpressed, ferrugineous tomentum; branches of the stellate hairs mostly short, some of them long, the longer ones interlaced; costa and main veins distinct. Sori large, rather prominent, immersed among the tomentum when young, placed in close, rather irregular rows of $4-6$ between the main veins.

Philippines; North. India.

(11) C. proinceps, C. Chr., Ind. Fil.; Polypodium princeps, Mett., Ann. Mus. Bot. L. B., II, 232; Niphobolus princeps, Gies., Diels, in Engl. \& Prantl, Nat. Pfl.Fam., I4, 325.

Rhizome short; scales lanceolate-subulate, with the base dilated, the margin subentire, the apex divided into 3-4 ciliae. Fronds approximate, subsessile, 60-90 c.M. long, 5-10 c.M. broad, spathulate-lanceolate, short-acuminate, the margin entire, subcallous. Texture coriaceous; upper surface covered with small, cretaceous dots, lower thinly tomentose, the stellate hairs much adpressed, their branches short, or long and interlaced; costa prominent;

(") See Gies., Niph., 157-158. 
main veins very distinct, distant, oblique. Sori numerous, contiguous, occupying the upper $1 / 3-1 / 2$ of the frond or more.

\section{New Guinea.}

* (12) C. nummularifolius, c. Chr., Ind. Fil.; Polypodium nummulariaefolium, Metl., Rac., Flor. Btz., I, 101 ; Acrostichum nummularifolium, Sw., Bl., Flor. Jav., II, 33, tab. XI, fig. 1-2; Niphobolus nummulariaefolius, J. Sm., Gies., Niph., 179 ; Bedd., Ferns Br.I., II, tab. CCCXX ; - var. rufus, v. A. v. R., Bull. Dép. Agr. I. N., 1908, XXI, 8.

Rhizome slender, creeping, the scales roundish and peltate at the base, long, linear, acuminate at the point, \pm ciliate, erect or erecto-patent, white or afterwards brownish or blackish. Fronds dimorphous. Barren fronds on stipes 1-2 m.M. long, placed closely in 2 opposite rows, \pm adpressed to the substratum, suborbicular, $1 / 2-2$ c.M. each way, the base obliquely cordate, truncate or rounded. Texture lleshy; stipe and upper surface covered with scattered, deciduous or persistent stellate hairs, lower side densely clothed with white or brownish tomentum. Fertile fronds oblong, $11 / 2-4$ c.M. long, $\breve{b}-7$ m.M. broad, on stipes $2-20$ m.M. long, scattered, the apex rounded, the hase cuneate. Sori in 3-4 rows on each side, \pm confluent, occupying the whole under surface, immersed among the tomentum.

Var. rufus: Scales of the rhizome bright-reddish-brown, copiously ciliate; tomentum bright-reddish-brown, dense.

Malaya; Norlh. India; - var. rufus: Batu lslands (Raap).

(13) C. obovatus, v. A. v. R.; C. nummularifolius, C. Chr., var., C. Chr., Ind. Fil ; Polypodium obovatum, Mett., Rac., Flor. Btz., I, 101; Acrostichum obovatum, Bl., Flor. Jav., II, 35, tab. XI, fig. 5: Niphobolus obovatus, Kze, Bot. Zeit., 1848, 120.

Very near C. nummularifolius, C. Chr., but the sterile fronds obovate, to $1 \frac{1}{2}$ c.M. long, to $7 \mathrm{~m} . \mathrm{M}$. broad, cuneate at the base, on stipes \pm 1 c.M. long; fertile fronds linear-elliptical, to 5 c.M. long, under $51 / 2 \mathrm{~m} . \mathrm{M}$. broad, on stipes to 3 c.M. long.

Java.

(14) C. Innuginosus, C. Chr., Ind. Fil.; Niphobolus lanuginosus, Gies., Niph., 190.

Rhizome wide-creeping; scales greyish-brown, the base peltate, oblong, the apex long, finely acuminate. Stipes scattered, 2-3 c.M. long. Fronds 
linear, to $\pm \mathbf{3} 0$ c.M. long, $\pm 1 / 2$ c.M. broad, the apex bluntish or acuminate the edge entire, recurved, the base narrowed. Texture weak; stipe and upper surface densely tomentose when young, but at length naked; under surface densely tomentose; midrib prominent beneath, but covered by the tomentum; main veins fine. Sori small, hidden among the tomentum when young. Philippines.

* (15) C. penangianus, C. Chr., Ind. Fil.; Polypodium penangicnum, Hk., Hk. Bk., Syn. Fil., 352; Niphobolus penangianus, Hk., Bedd., Handb. Ind. Ferns, 352; Hk., Icon. Pl., III, tab. CCIII; Bedd., Ferns Br.I., I, tab. CXXI; Bau. \& Hk., Gen. Fil., tab. LXXXIII: Gies., Niph., 97.

Rhizome short-creeping, the scales lanceolate, long-acuminate, brown. Stipes none or short, approximate. Fronds oblong-lanceolate, 20-70 c.M. long, 2-8 c.M. broad, the apex acuminate, the base very gradually narrowed, the edge commonly irregularly undulate and repand. Texture papyraceous or flaccid; upper surface at length naked, lower clothed with fine, silky tomentum; main veins oblique, connected by nearly straight veins forming $10-12$ rows of narrow, longitudinal, subquadrangular areolae between the midrib and edge; areolae with $3-6$ sori in each, the rows close, forming a broad mass confined to the upper half of the frond, not reaching the margin; capsules commonly mixed with stellate hairs.

Java, Sumatra, Malacca; Burmah.

- (16) C. rasamalae, C. Cler., Ind. Fil.; Polypodium Rasamalae, Rac., Flor.. Btz., I, 99; Niphobolus Rasamalae, Gies., Niph., 187.

Rhizome wide-creeping, black, with the scales pale-brown or ferrugineous, ovate or lanceolate, erecto-patent or recurved, finely long-acuminate, the base peltate, rounded. Stipes $1-10$ c.M. apart, $\pm 1-5$ c.M. long, brown, clothed with deciduous tomentum, at length naked. Fronds linear, 8-50 c.M. long, to \pm 5 m.M. broad, the apex bluntish, the edge recurved, the base narrowed gradually into the stipe. Texture coriaceous, thick; upper surface at length naked, lower densely tomentose with short-stalked (long-branched) and longstalked (short-branched) hairs; veins hidden; costa prominent, but covered by the tomentum. Sori roundish, small, close or confluent, in $1-5$ rows between the midrib and edge, 1-serial in the narrowest, 2-5-serial in the broadest forms, immersed in the tomentum when young.

Forma minor: Fronds very short, $2 \frac{1}{2}-5$ c.M. long, short-stalked. Java, Sumatra. 
72. GYGLOPHORUS. $\mathbb{1}$ 1. NIPHOBOLUS.

* (17) C. Iloceiger, Pr., Epim., 151; Polypodium floccigerum, Mett., Rac., Flor. Btz., I, 101; Antrophyum niphoboloides, Kze, Hk., Spec. Fil., V, 174; Niphobolus flocciger, Bl., Copel., Polypod. Philipp., 115 ; Bl., Flor. Jav.. II, 61, tab. XXVI.

Rhizome wide-creeping; scales narrowly lanceolate, ferrugineous, the base adpressed, the apex acuminate, spreading, entire. Stipes $0-5$ c.M. long, those of the fertile fronds often the longest. Fronds $15-50$ c.M. long, $1-21 / 2$ c.M. broad, narrowed gradually towards both ends, the edge entire. Texture coriaceous; upper surface soon naked or nearly so, lower densely covered with cinnamon or yellow-brown, loose tomentum; veins hidden. Sori close, numerous, placed in $2-4$ rows on each side of the costa, immersed in the tomentum, at length confluent. - Too near C. albicans, Pr.

Malaya; North. India.

* (18) C. porosus, Pr., Epim., 150; Polypodium porosum, Wall., Mett., Farng., I, Polypod., 128; P. fissum, Bk., Hk. Bk., Syn. Fil., 551, p.p.; Niphobolus fissus, Bedd. (not Bl.), Copel., Polypod. Philipp., 113, p. p.; Bedd., Handb. Ind. Ferns, 550; N. porosus, Pr., Tent. Pterid., 202; Bedd., Ferns S. I., tab. CLXXXIII; N. Mannii, Gies., Niph., 107.

Rhizome short, creeping, the scales ferrugineous, narrowly lanceolate, long-acuminate, entire, subspreading. Stipes 0 -2 c.M. long below the winged part, subapproximate. Fronds 15 - 55 c.M. long, $1-4$ c.M. broad, lanceolate, linear-lanceolate or subspathulate, bluntish to acuminate, narrowed very gradually towards the base so as to form a wing to the stipe. the edge entire, irregularly wavy or purveyed with short or long, subulate, lobe-like outgrowths. Texture coriaceous; surfaces at first wholly tomentose with ferrugineous or greyish, densely crowded stellate hairs, the upper side at length naked, purveyed with small depressed dots, which are covered with deciduous, blackisi, calcareous scales, the stellate hairs purveyed with an erect central branch at the point of union of the spreading ones; venation quite sunk; areolae with 2 -5 soriferous, excurrent veinlets. Sori rather large, confined to the upper half or occupying the whole under surface of the frond, placed in $2 \div 4 \pm$ irregular rows on each side of the costa, at length scarcely elevated above the tomentum.

Malacca, Philippines; China, North. India.

- (19) C. sticticus, C. Chr., Ind. Fil.; Polypodium sticticum, Mett., Farng., I, Polypod., 128; P. fissum, Bk., Hk. Bk., Syn. Fil., 551, p. p.; Ni- 
phobolus sticticus, Kze, Gies., Niph., 135; N. fissus, Bedd. (not Bl.), Copel., Polypod. Philipp., 115, p. p.

Rhizome creeping; scales rigid, dark-brown, lanceolate, suberect, acuminate, the margin pale and more or less ciliate. Fronds approximate, spathulate, lanceolate or linear-lanceolate, $15-30$ c.M. long, 1-2 c.M. broad, the apex varying from blunt to acuminate, the base narrowed very gradually so as to form a winged stipe \pm 6 c.M. long, the edge entire. Texture coriaceous; veins hidden; upper surface naked or provided with scattered, adpressed, greyish or brownish hairs and small depressed dots, which are covered with deciduous, blackish, calcareous scales; under surface densely tomentose; areolae with $3-4$ soriferous, excurrent veinlets. Sori rather large, confined to the upper half of the frond, placed in $5-8$ rows on each side of the costa, immersed among the tomentum, but at length distinct. - Clearly distinguished from C. porosus, Pr. by the rhizome scales.

Philippines; South. China, Ceylon.

(20) C. mollis, Pr., Epim., 131; Polypodium molle, Mett., Farng., 1, Polypod., 128; Niphobolus mollis, Kze, Bot. Zeit., 1848, 121.

Rhizome creeping, the scales moderately large, membranaceous, reddishbrown, not closely adpressed, narrow, lanceolate, long-acuminate. Stipes \pm $1 \frac{1}{2}$ c.M. long. Fronds $20-30$ c.M. long, 2-21/2 c.M. broad, lanceolate, acuminate, the base narrowed gradually. Texture \pm coriaceous; upper surface covered with dirty-white, the lower with reddish-brown tomentum; costa prominent beneath, at length naked, flexuose; main veins slightly visible. Sori superficial, crowded in the upper part of the frond, not reaching the margin and the apex, placed in $6-8$ rows.

Java, Bali, Timor; Irawaddi River.

* (21) C. albicans, Pr., Epim., 131; Polypodium albicans, Mett., Rac., Flor. Btz., I, 101; Niphobolus.Blumeanus, Kze, Bot. Zeit., 1848, 120; N. albicans, Bl., Flor. Jav., II, 60, tab. XXV; N. glaber, Klf., Bl., I. c., 62, tab. XXVII.

Rhizome wide-creeping, the scales dense, pale-brown or ferrugineous, lanceolate, sometimes crisped, erecto-patent or spreading, peltate and adpressed at the base. Stipes 2-4 c.M. apart, 4-15 c.M. long, covered with white or brown, often deciduous tomentum. Fronds $30-80$ c.M. long, $1-$ b c.M. broad, narrowed towards both ends, the edge entire, \pm recurved. Texture very coriaceous, upper surface at length naked, lower densely clothed with white or brownish tomentum; costa less densely tomentose, like the stipe; 
main veins often distinct to the edge, venation not rarely partially irregular. Sori in $4-6$ close rows between the main veins so as to form $5-8$ rows between the midrib and edge, sunk in the tomentum when young.

Java.

\section{\$2. NIPHOPSIS.}

a. Sori in 1 row on each side of the costa.

7. Fronds small, the barren ones under 3 c.M. long, under $3 / 4$ C.M. broad.

(22) C. Lauterbachii.

b.b. Fronds larger, the barren ones 3-60 c.M. long, $\left.{ }^{3}\right|_{4}-5$ c.M. broad.

c. Rhizome scales ciliate.

(25) C. confluens.

c.c. Rhizome scales entire.

d. Fronds 4-30 c.M. long, 2-5 c.M. broad; rhizome scales decoloured at the apex; sori slightly immersed in shallow pits.

(24a) C. angustatus. SI +413

a.d. Fronds 30-60 c.M. long, 1-2 c.M. broad; rhizome scales pale-brown at the apex; sori superficial. (24b) C. samarensis.

a.a. Sori not in 1 row on each side of the costa, often densely crowded. $\left({ }^{*}\right)$

1. Barren fronds generaliy under 20 c.M. long.

2. Fronds blunt or rounded at the apex.

2.2. Fronds acute to caudate at the apex.

(25) G. abbreviatus.

3. Barren fronds 5-8 c.M. long, on slipes 1-4 c.M. long.

(26) C. Warburgii.

3.3. Barren fronds 11-18 c.M. long, on stipes 7-17 c.M. long.

(27) C. Sarasinorum.

1.1. Fully developed barren fronds more than 20 c.M. long.

a. Barren fronds malled beneath with scaltered stellate hairs.

(28) C. Christii.

๙. $\alpha$. Barren fronds clothed beneath with densely crowded or interlaced stellate hairs.

B. Sori large.

+. Fertile fronds much exceeding the barren ones.

(29) C. distichocarpus. SI p 413 +.+. Fertile fronds not much exceeding the barren, ones.

(30) C. asterosorus.

$\left(^{*}\right)$ See also C. albicans, $P r$.

FuLGES. 
72. GYGLOPHORUS. $\mathbb{2} 2$. NIPHOPSIS.

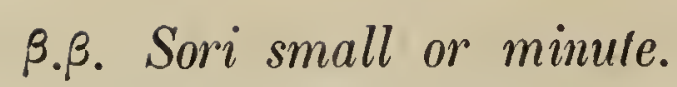

$\%$. Rhizome wide-creeping; fronds dislanl, solitary.

(51) C. argyrolepis.

$\% \%$ Rhizome short-creeping; fronds not solitary, aggregate or approximale.

ס. Stellate hairs without a spine-like central branch; lenf-tissue with palisade cells (*).

\&. Fronds stalked; stipes to 30 c.M. long, subtercle or laterally compressed, not angled, grooved in front.

(32) C. stigmosus.

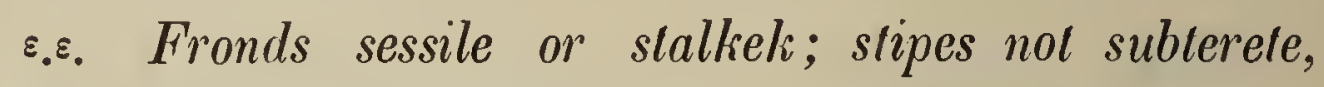
angled, not grooved, flattened in front.

(35) G. Beddomeanus.

$\delta . \delta$. Stellate hairs with a very long, erect, spine-like central branch; leaf-tissue withoul palisade cells.

(54) C. splendens.

* (22) C. Tauterbachii, C. Chr., Ind. Fil.; Niphobolus Lauterbachii, Chrisl, Schum. \& Laut., Flor. deut. Sch.geb., 142; Gies., Niph., 221, fig. 20 .

Rhizome wide-creeping, filiform, the scales subulate, peltate, pale-coloured, thin, scattered. Fronds scattered, dimorphous. Barren fronds spathulate, ovate or lanceolate, $\pm 1 \frac{1}{2}-21 \frac{1}{2}$ c.M. long, \pm 5 m.M. broad, obluse, entire, on stipes $1-2$ c.M. long. Texture rigidly coriaceous; under surface with the stellate hairs small, adpressed, scarcely visible, greyish-green; veins inconspicuous; areolae oblong. Fertile fronds linear-ligulate, 6-8 c.M. long, 2-5 m.M. broad, acute to caudate, sinuato-crenate, on stipes 1-2 c.M. long. Sori submarginal, occupying the crenations, the stalks of the capsules immersed in deep cavities.

New Guinea.

(23) C. confluens, C. Cler., Ind. Fil.; Polypodium confluens, R. Br., Warb., Mons., I, 61 (not Hk. Bk., Syn. Fil., 349); P. glabrum, Mett., Hk. Bk., Syn. Fil., 356; Mett., Farng., I, Polypod., tab. III, fig. 6-8; Niphobolus confluens, Spr., Gies., Niph., 172.

(*) See Gies., Niph., 78-79, fig. 15. 
Rhizome filiform, wide-creeping, branched, the scales lanceolate, acuminate, ciliate, ferrugineous, peltate at the base. Stipes $1 / 2-11 / 2$ c.I. long. Fronds subdimorphous. Sterile fronds lanceolate or oblong, 5-9 c.M. long, 8-12 m.M. broad, the apex blunt. Texture coriaceous; upper surface naked, lower densely clothed with adpressed, subferrugineous stellate hairs, at length not rarely quite naked; veins hidden. Fertile fronds \pm linear-lanceolate or linear, longer than the barren ones. Sori large, not hidden in the tomentum, commonly confined to the apex or the upper $1 / 5-1 / 2$ of the frond, in 1 row on each side, often confluent so as to form a ridge on both sides of the costa. - Near C. angustatus, Desv., but the sori more confluent.

New Guinea; Australia, Norfolk Island, Lord Howe's Island, New Caledonia, New Zealand.

* (24a) C. angustatus, Desw., Berl. Mag., V, 500; Polypodium anguslatum, Sw., Rac., Flor. Btz., I, 100; Niphubolus angustatus, Spr. (not J. Sm.), Copel., Polypod. Philipp., 115; Gies., Niph., 195; Hk., Gard. Ferns, tab. XX ; Bedd., Ferns S.I., tab. CLXXXV; N. sphaerocephalus, Hk. \& Grev., Ic. Fil., tab. XCIV; Pleopeltis angustala, Pr., Bedd., Handb. Ind. Ferns, 551.

Rhizome firm, woody, wide-creeping, branched, the scales with a roundish, peltate, adpressed, brown or black, coriaceous base and a very long, linear, finely acuminate, whitish, decoloured, membranaceous, entire, spreading, deciduous or persistent point. Stipes scattered, 1-10 c.M. long, covered like the upper surface of the frond with fugacious tomentum. Fronds lanceolate, 4-50 c.ll. long, 2-5 c.M. broad, narrowed towards both ends, the apex bluntish, the edge entire. Texture coriaceous: under surface densely clothed with adpressed, white or subferrugineous tomentum: costa conspicuous; main veins hidden, slightly visible when dry. Fertile fronds commonly longer than the barren ones, $\pm 20-50$ c.M. long, $1-2$ c.M. broad in the fertile region, the barren part often broader. Sori large, \pm immersed, round or oblong, oblique or subparallel to the costa, in 1 row on each side, nearer the \pm recurved edge than the midrib, sometimes confluent, slightly prominent on the upper surface, occupying the upper $1 / 6-5 / 6$ of the frond.

Malaya; Polynesin, North. India.

(24b) C. Samarensis, C. Chr., Ind. Fil.; Polypodium samarensc, Mell., Hk. Bk., Syn. Fil., 556; Niphobolus samarensis, Fée, Copel., Polypod. Philipp., 115; Gies., Niph., 191; Gyrosorium samarense, Pr., (oldest name).

Rhizome firm, wide-creeping; scales ovate-lanceolate, entire, the base pel- 
tate, with a fuscous centre, the point long, linear, acuminate, pale-brown (not white), spreading. Stipes firm, erect, $21 / 2-10$ c.M. long. Fronds linearlanceolate, $50-60$ c.M. long, $1-2$ c.M. broad, the soriferous upper part linear, contracted, the base narrowed. Texture coriaceous; upper surface naked or slightly tomentose when young, lower densely coated with dirty-white or greyish-ferrugineous tomentum; veins hidden. Sori large, oblong, placed in 1 row on each side of the midrib, confined to the narrowed upper $1 / 3$ $1 / 2$ of the frond, confluent.

Philippines.

* (25) C. abloreviatus, C. Cher., Ind. Fil.; Polypodium abbreviatum, Mett., Rac., Flor. Btz., I, 98; Niphobolus abbreviatus, Zoll., Gies., Niph., $160 ; N$. Lingua, Spr., p. p. $\left(^{*}\right)$

Rhizome wide-creeping; scales peltate, oblong-lanceolate, acuminate, brown, the margin pale, ciliate, the ciliae fine, crisped, deciduous. Stipes $14-20$ c.M. long, densely covered with adpressed stellate hairs. Fronds dimorphous. Barren fronds roundish or ovate, 7-10 c.M. long, 5-7 c.M. broad, the apex blunt or rounded, the base suddenly narrowed into a short, decurrent wing. Texture coriaceous; upper surface covered with scattered, fugacious, adpressed stellate hairs and often also with white cretaceous dots; under side densely tomentose, the tomentum adpressed; costa and main veins conspicuous; areolae irregular, with few free veinlets. Fertile fronds more elongate, $\pm 1 / 3 X$ as broad as long, narrowed gradually to the stipe and the bluntish apex. Sori densely crowded, at length confluent, occupying the upper $^{2 !}$ of the frond. - The scales at the bases of the stipes are pale, blunt, deciduously ciliate, rather large.

Java, Sumatra.

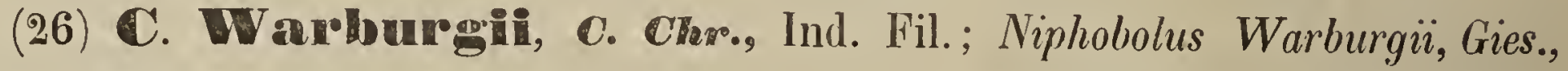
Niph., $165 ;$ N. Lingua, Spr., p. p. $\left(^{*}\right)$

Rhizome wide-creeping, branched; scales peltate and rounded or emarginate at the base, the point long-acuminate, the margin long-ciliate. Stipes 1-4 c.M. long, 1-丂 c.M. apart. Sterile fronds commonly $\breve{b}-8$ c.M. long and $2-5$ c.M. broad, oblong, the apex acuminate, the base subcuneate; fertile fronds longer and broader, on longer stipes. Texture coriaceous; upper surface naked; under side covered with adpressed, whitish or brownish to-

$\left(^{*}\right)$ See Gies, Niph., 157-158. 
72. GYGLOPHORUS, $\$ 2$. NIPHOPSIS.

mentum; costa conspicuous beneath; main veins hidden; areolae irregular, with free veinlets. Sori numerous, densely crowded, occupying the whole or nearly the whole under surface of the frond.

Celebes.

(27) C. Sarasinorum, C. Cher., Ind. Fil.; Niphobolus Sarasinorum, Gies., Niph., 162 ; N. Lingua, Spr., p. p. ${\left({ }^{*}\right)}^{*}$

Rhizome wide-creeping; scales dense, black-brown, adpressed, the younger ones narrow, lanceolate, long-acuminate, with the apex crisped, the margin long-ciliate. Sterile fronds oblong, 11-18 c.M. long, \pm 5 c.M. broad, the apex acuminate to caudate, the base suddenly narrowed and slightly decurrent, the stipe 7-17 c.M. long. Fertile fronds sometimes longer and narrower. Texture coriaceous; upper surface naked, lower covered with lightbrown, adpressed tomentum; costa and main veins distinct; areolae irregular, with free veinlets Sori small, dense, occupying the whole under surface or only the upper half of it.

Celebes. mundravas, Tegros $(5 i p+13)$

* (28) C. Chroistiei, C. Chr., Ind. Fil.; Niphobolus Christii, Gies., Niph., 140; N. Lingua, Spr., p. p. $\left(^{\star}\right)$

Rhizome wide-creeping, the scales lorown, obovate and peltate at the base, narrowed to a long, lanceolate-acuminate, spreading, often capillary, crisped point, the margin pale and slightly ciliated towards the point. Barren fronds ovate or oblong, 10-12 c.M. long, to 5 c.M. broad below the middle, on stipes 5-10 c.M. long, narrowed gradually from the broadest part to a longacuminate point, the base cuneate or rounded; fertile fronds lanceolate, narrowed gradually to both ends, $10-12$ c.M. long, to $2{ }^{1} / 2$ c.M. broad, on stipes \pm 15 c.M. long. 'Texture coriaceous: costa and main veins distinct; upper surface naked, lower covered with scattered, adpressed stellate hairs in the barren, but more woolly in the fertile fronds. Sori large, crowded, at length confluent, occupying the whole under surface.

Borneo.

* (29) C. Iistichocanpas, C. Chr., Ind. Fil.; Polypodium distichocarpum, Metl., Hk. Bk., Syn. Fil., 3̈2 ; Niphobolus distichocarpus, Gies., Diels, in Engl. \& Prantl, Nat.Pfl. Fam., I", 525.

(*) See Gies., Niph., 157-158. 
Rhizome creeping, scaly. Barren fronds linear-oblong, $20-30$ c.M. long, 3-5 c.M. broad, narrowed towards hoth ends, on stipes to $12 \frac{1}{2}$ c.M. long; fertile fronds linear-lanceolate, $35-65$ c.M. long, $2-4$ c.M. broad, on stipes

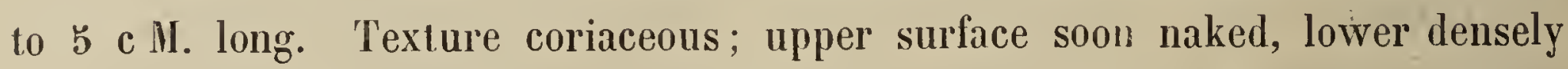
clothed with soft, brown tomentum; costa prominent; main veins slightly prominent; areolae hidden, with the included veinlets simple or forked, free or anastomosing. Sori large, in 2 rows between the main veins, occupying the upper $1 / 4^{--1} / 2$ of the frond, forming $3-6$ rows on each side of the costa in the broader part of the frond; capsules mixed with stellate hairs, especially when young. - Baker and Diels placed this species in Niphobolus, but the specimens from Java (Leg. de, Vriese) and Sumatra (Leg. Korthals) determined by Burck (as P. distichocarpum, Melt.) and a plant sent from Malacca and cultivated in the Buitenzorg gardens have the venation decidedly. irregular.

Java, Sumalia, Malacca.

- (50) C. asterosurus, C. Chr., Ind. Fil.; Polypodium asterosorum, Bk., Journ. of Bot., XVIII, 214.

Rhizome slender, wide-trailing, clothed with large, lanceolate, pale-reddishbrown, membranaceous scales. Stipes scaltered, naked, pale-brown, $\mathbf{5}-8$ c.M. long. Fronds lanceolate, entire, $20-50$ c.M. long, $2-2 \frac{1}{2}$ c.M. broad above the middle, acute, narrowed gradually towards the base. Texture coriaceous; upper surface naked, lower whitish, matted with loose, soft, reddish-brown tomentum; main veins obscure, erecto-patent, enclosing copious minute areolae; free veinlets simple or forked. Sori large, round, superficial, densely pilose, in erecto-patent rows of $5-6$ between the midrib and margin, filling up the whole of the upper part of the frond and mixed with copious soft, brown stellate hairs. - Near C. distichocarpus, C. Chr.

Sumatra.

(31) C. argyrolepis, Christ, Bull. Herb. Boiss., 2e Série, VI, 991. Rhizome wide-creeping, string-shaped, branched, black-purple, densely clothed with subulate, aristate, scariose, squarrose, glistering-white scales. Stipes distant, solitary, \pm :j c.M. long, flattened, slender, white-woolly, soon naked. Fronds linear-lanceolate, $18-40$ c.M. long, $2-21 / 2$ c.M. broad, the apex elongate, acuninate, the edge entire, involute when dried, the base ovate, not or hardly decurrent. Texture carnoso-coriaceous, flaccid; costa distinct; veins rather occult; areolae elongate, irregular, with free veinlets; upper surface 
rather naked, lower densely covered with adpressed, white, minute stellate hairs intermixed with larger, scattered, fulvous ones. Sori occupying the narrowed apical part of the frond, confluent, also covering the costa, forming a dark-brown mass $5-18$ c.M. long.

Luzon, Mindoro.

* (52) C. stigmosus, Desv., Berl. Mag., V, 501; Polypodium shgmosum, Sw., Rac., Flor. Btz., I, 102; Hk. Bk., Syn. Fil. 550, p. p.; Niphobolus venosus, Bl., Flor. Jav., II, 65, tab. XXVIII, fig. 1; N. stigmosus, Moore, Gies., Niph., 113; Bedd., Handb. Ind. Ferns, 328, p. p.

Rhizome short-creeping; scales long, narrow-lanceolate, finely acuminate, the margin entire or with few short teeth, the base not peltate. Stipes always present, not rarely to $20-30$ c.M. long, not angled, subterete or laterally compressed especially in dried material, not angled, tomentose, the upper (inner) side furrowed, not flattened. Fronds lanceolate, $20-60$ c.M. long, 3-7 c.M. broad, the apex acute or acuminate, the base cuneately narrowed. Texture coriaceous; costa and main veins distinct beneath; areolae hidden, in 10-16 rows on each side of the costa; upper surface densely tomentose, afterwards naked, often purveyed with numerous depressed dots, which are commonly covered with deciduous, white, dot-like cretaceous scales; under surface clothed with interlaced, long- and short-branched stellate hairs forming a dense coat. Sori numerous, small, close, placed in irregular rows, hidden among the tomentum when young, occupying the upper $2 / 3-4 / 5$ of the frond.

Malaya; Ceylon, Soulh. India.

* (33) C. Peddomeanus, C. Chr., Ind. Fil.; Polypodium sligmosum, Sw., Hk. Bk., Syn. Fil., 550, p. p.; Niphobolus sligmosus, Moore, Bedd., Handb. Ind. Ferns, 328, p. p.; N. Beddomeanus, Gies., Niph., 101; N. coslatus, Pr., Bedd., Ferns Br.I., I, tab. CXX.

Rhizome short-creeping, scaly at the extremity, the scales dark-brown, narrowed from a broad base into a long, acuminate, hair-like point, the base nut peltate. Stipes $0-18$ c.M. long, deciduously tomentose, not laterally compressed, the upper (inner) side flat, angled, not furrowed, the lower (outer) side convex or angular. Fronds lanceolate, 30-90 c.M. long, 3-7 c.M. broad or broader, the apex acuminate, the lower part narrowed very gradually to the base. Texture coriaceous, rather thin; costa and main veins distinct beneath; areolae hidden, in 8-14 rows on each side of the costa; upper surface covered with long-branched, interlaced stellate hairs, 
afterwards naked, not rarely purveyed with minute depressed dots, which are covered with deciduous, white, dot-like cretaceous scales; under surface tomentose like the upper, but the hairs intermixed with short-branched ones, the tomentum pale-brown, or white when young, forming a close coat. Sori numerous, minute, immersed among the tomentum when young, occupying \pm the upper half of the frond, reaching to $1-5 \mathrm{~m}$.M. or more from the margin, placed in irregular, contiguous rows.

Malaya; South. China, North. India.

(34) C. splendens, C. Chr., Ind. Fil.; Polypodium splendens, Hk., Spec. Fil., V, 52 (not V, 95); P. nilens, Bk., Hk. Bk., Syn. Fil., 555 ; Niphobolus splendens, J. Sm., Gies., Niph., 99.

Rhizome short-creeping, the scales narrowed from a sessile, truncate or rounded, broad base into a subulate point. Fronds approximate, sessile or subsessile, 45-90 c.M. long, 6-10 c.M. broad, broadest in the upper half, narrowed very gradually from there to the base, the edge entire. Texture subcoriaceous; upper surface white-cobwebby, at length naked, often purveyed with white, dot-like cretaceous scales; under surface densely clothed with long- and short-branched, brown stellate hairs, the short-branched ones purveyed with a long, erect, spine-like central branch (Gies., Niph., fig. 8, E); costa and main veins distinct. Sori small, numerous, close, immersed among the tomentum, not reaching the margin. - Among the long- and the shortbranched hairs there are many intermediate forms with both short and long branches, but without central spines.

Philippines.

\section{DIEYNA REA, J. Smeth.,}

Sori round or punctiform, placed 'on the points of union of the anastomosing veins. No indusium.

Rhizome creeping or ascending. Fronds articulate to the rhizome, dimorphous. Barren fronds (cup-leaves) rigid, mostly oakleaf-like, sessile, snon becoming brown, commonly cordate at the base, collecting quantities of humus into which the roots grow; fertile fronds large, stalked, green, pinnatifid or pinnate, the segments mostly articulate; reins anastomosing copiously; primary areolae often quadrangular, secondary with free included veinlets spreading in various directions. Diels, in Engl. \& Prantl, Nat. Pfl.Farm., I I , fig. 171, A.

Trop. Asia, Aústralia, \& Polynesia. 
Arrangement of the sections.

S1. EUDRYNARIA. Cup-leaves rather flat, at best slightly convex. Fertile fronds pinnatifid, or pinnate with the segments contiguous and adnate with a broad base.

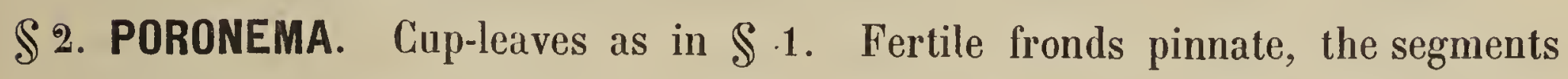
stalked, or sessile with a cuneate or acute base.

$\$ 3$. THAYERIA. Cup-leaves induplicate or convolute.

\section{S 1. EUDRYNARIA.}

a. Sori in 1 row on each side of the costulae (central ribs of the segments).
b. Segments quite entire.
(1) D. pleuridioides.

to.b. Segments crenate or slightly toothed.

(2) D. propinqua.

a.e. Sori not as in a.

1. Sori in 2 rows between the main veins of the segments.

2. Segments connected by a broad wing.

2.2. Segments connected by a narrow wing.

1.1. Sori scattered irregularly.
(5) D. descensa.

(4) D. quercifolia. Sip 4 is

(5) D. sparsisora.

* (1) ID. Pleuridioides, (not J. Sm.), Diels, in Engl. \& Prantl, Nat. Pfi.Fam., I', 530; Polypodium pleuridioides, Mett., Rac., Flor. Btz., I, 117; P. Willdenowii, Bl. (not Bory), Flor. Jav., II, 156, tab. LXVI; var. amboinensis.

Rhizone thick, the scales dense, narrow, linear or lanceolate ciliate. Cupleaves $10-50$ c.M. long, 7-20 c.M. broad, lobed $\pm 1 / 2$-way down, the lobes blunt, linear-ohlong. Fertile fronds $45-100$ c.M. long, 20-40 c.M. broad, with a distinct stipe, the lobes reaching down nearly or quite to the costa, 1-2 c.M. broad, blunt, acute or acuminate, quite entire; lower lobes decarrent upon the stipe. Texture subcoriaceous; surfaces naked; areolae copious, with free veinlets. Sori in 1 row on each side, very near the midribs, more or less immersed.

Var. amboinensis: Cup-leaves shallowly lobed; lobes of fertile fronds \pm 5 c.M. broad, united at the base by a broad wing.

Java; - var. anboinesis: Amboyna (Boerlage).

Surnatio Sa is 415 . 
* (2) D. propinqua, J. Sm., Bedd., Handb. Ind. Ferṇs, 359; Ferns Br.I., II, tab. CLX; Polypodium propinquum, Wall., Hk. Bk., Syn. Fil., 367; P. Willdenowii, Hk. (not Bory), Gard. Ferns, tab. XXXV; Pleopellis Parishii, Bedd., l. c., I, tab. CXXV; - var. sumatrana.

Rhizome stout, creeping, the scales linear-lanceolate, reddish. Cup-leaves 10-25 c.M. long, 7-10 c.M. broad, cut $1 / 2-3 / 4$-way down into bluntish or acute lobes. Fertile fronds $40-90$ c.M. long, often 50 c.M. broad, with a distinct stipe, the lobes 10-13 c.M. long, 1-2 c.M. broad, reaching down nearly or quite to the costa, crenate, slightly toothed or undulato-crenate; lowest lobes decurrent. Texture subcoriaceous; surfaces naked; areolae copious, with free veinlets. Sori in a single row on feach side, near the midribs. Very near D. pleuridioides, J. Sm.

Var. sumatrana: Sori very large, nearly medial.

Java; Norlh. India, South. China, Fernando Poo; - var sumatrana: Sumatra (Leg. . . . . . . ?).

(3) D. Alescensa, Copel., Philipp. Journ., III, 36.

Near D. quercifolia, J. Sm. Rhizome 5-10 c.M. thick, the apex mammiform, the scales peltate, aristate, caducous. Cup-leaves $5--10$ c.M. long, dry, hard, ovate, slightly crenato-lobate, brown, or grey beneath, the base cordate with the basal lobes overlapping. Stipes of fertile fronds winged, the wing consisting of the lower, reduced lobes. Fertile fronds $40-60$ c.M. long, deeply lobed or pinnatifid. Lobes to $10-20$ c.M. long, $\pm 1 \frac{1}{4}-21 / 2$ c.M. broad, acuminate, crenate, slightly narrowed at the base, connected by a wing \pm 4 c.M. broad. Texture papyraceous; surfaces naked.

Luzon.

- (4) D. quercifolia, J. Sm., Bedd., Handb. Ind. Ferns, 541; Diels, in Engl. \& Prantl, Nat Pfl.Fam., I', fig. 171, A ; Bedd., Ferns S.I., tab. CLXXXVII; Polypodium quercifolium, L., Rac., Flor. Btz., I, 118.

Rhizome stout, ascending, densely clothed with narrow, linear-subulate, eroso-ciliate scales, which. are narrowed gradually and rather regularly from the rounded, peltate base to the point. Cup-leaves $71 / 2-30$ c.M. long, $5-15$ c.M. broad, rigid, bluntly lobed often $1 / 2$-way down. Fertile fronds $60-150$ c.M. long, 30-40 c.M. broad, deeply pimnatifid nearly to the costa, on stipes to 30 c.M. long. Lohes entire, erecto-patent, linear-lanceolate, blunt, acute or acuminate, $1-4$ c.Ir. broad, the lowest not rarely short, often suddenly decurrent so as to form a wing reaching not rarely to the base of the stipe. 
73. DRYNARIa. $\$ 1$. EUdRYNaRia.

Texture rigidly coriaceous; surfaces naked; main veins (of the lobes) distinct \pm to the edge; primary areolae \pm quadrangular, in $4-6$ rows, enclosing copious finer secondery oues with few included free veinlets. Sori rather large, in 2 rows between the main veins.

Trop. Asia \& Australia, South. China, Fiji.

* (5) D. spareisora, Moore, C. Chr., Ind. Fil.; D. Linnaei, Bedd., Handb. Ind. Ferıs, 543; Ferns Br.I., II, tab. CCCXV; Polypodium Linnei (Linnaei), Bory, Rac., Flor. Btz., I, 118; P. sparsismum, Desv., (oldest name).

Rhizome stout, the scales ovale, short, adpressed, black or brown, peltate, eroso-ciliate, with a suddenly narrowed, long, linear-subulate, often recurved, fugacious apex. Cup-leaves bluntly lobed, \pm similar to those of D. quercifulia, J. Sm. Fertile fronds $4 \breve{b}-90$ c.M. long, $15-35$ c.M. broad, stipitate, cut down nearly to the costa into erecto-patent, lanceolate to linear, entire lobes; lower lobes decurrent so as to form a shorter or longel wing to the stipe. Texture rigidly coriaceous; surfaces naked; main veins distinct to the edge; areolae large, \pm quadrangular, divided into numerous finer ones. Sori small, scattered irregularly.

Malaya; Ceylon, Trop. Australia, Fiji.

\section{\$ 2. PORONEMA.}

* (6) D. rigidula, Bead., Handb. Ind. Ferns, 544; Ferns Br.I., II, tab. CCCXIV; Polypodium rigidulum, Sw., Rac., Flor. Btz., I, 117; P. diversifolium, R. Br., Hk., Gard. Ferns, tab. V; P. Gaudichaudii, Bory, Bl., Flor. Jav., II, 158, tab. LXVII.

Rhizome stout, creeping, the scales linear-lanceolate, narrow, ciliate, erectopatent, brown, with the base adpressed. Cup-leaves sessile, $15-30$ c.M. long, 7-10 c.M. broad, the base sinuate, the edge deeply incised towards the costa into blunt, oblong or linear lohes. Fertile fronds 60-120 c.M. long, 15-45 c.M. broad, pinnate, long-stalked, the stipe and rachis grey or brown, densely clothed with a greyish tomentum consisting of deciduous, copiously ciliate, peltate scales, at length naked, the stipe purveyed with 2 opposite rows of few distant, large glands (rudimentary pinnae). Pinnae to $2 \frac{1}{2}$ c.M. or more apart, 4-10 m.M. broad, stalked or sessile, with a cuneate base, articulate to the rachis, the edge entire, crenate or toothed, the apex acuminate. Texture subcoriaceous; surfaces naked; main veins indistinct, rather wanting; 
areolae copious; free veinlets few. Sori immersed, in 1 row \pm medial between the midribs and the edge.

Trop. Asia, Australia \& Polynesia.

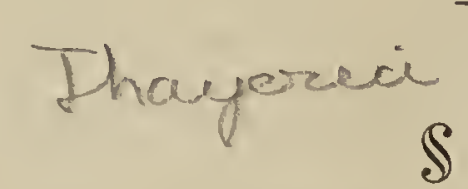

*. Cup-leaves ${ }^{*}$ deeply lobed or pinnatifid.

$\$$ 5. THAYERIA

*.*.Cup-leaves slightly undulale, subentire.

(7) D. nectarifera.

(8) D. cornucopia.

(9) D. involuta.

\section{Thergerua}

(7) nectaniferen, Hiels, in Engl. \& Prantl, Nat. Pfl.Fam., I ${ }^{4}$, 330 ; Polypodium neclariferum, Bk., Becc., Mal., II, 247, tab. LXV; Thayeria nectarifera, Copel., Philipp. Journ., I, Suppl., 166.

Rhizome stout, woody, tortuose, scaly towards the extremity, the scales adpressed, orbicular, peltate. Cup-leaves ovate, pinnatifid, induplicate, the lobes oblong, obtuse. Fertile fronds stipitate, oblong-lanceolate, 45-60 c.M. long, simply pinnate. Pinnae numerous, the lower ones adnate, lanceolate, covered beneath with copious dot-like glands; upper pinnae narrowed or contracted, linear, torulose, soriferous, \pm similar to those of Polypodium Meyenianum, Hk.

New Guinea,? Luzon.

Dhayerecia

(8) D. connumeopian, v. v. Th., Bull. Dép. Agr. I. N., 1908, XXI, 8; Thayeria cormucopia, Copel., Philipp. Journ., I, Suppl., 165, tab. XXVIII.

Rhizome wide-creeping, scandent, often descendent, clothed with small, lanceolate, subpeltate, acuminate, adpressed scales. Cup-leaves to 50 c.M. long, cornet-shaped, i. e. with the large basal lobes convolute and overlapping so as to form an oblique, humus-collecting cup placed on a horizontal branch of the rhizome 1-6 c.M. long, which passes through the sinus between the lobes and ends in the base of the cornet; lower part scariose, brown, upper green, deeply pinnatifid, the segments deciduous. - Fertile fronds unknown.

Mindanao.

* (9) D. involuta, v. A. v. R., Bull. Dép. Agr. I. N., 1908, XXI. 8 , tab. IV.

Rhizome long, woody, ascending or climbing, flexuose, densely scaly; scales suberose, the base fuscous, broadly ovate, peltate, the margin paler, scariose, 
the apex narrowed suddenly into a long, linear-subulate, recurved, deciduous point. Cup-leaves distant, 6-10 c.M. long, induplicate or convolute, scariosocoriaceous, with the outer side subopaque, the inner glossy, the base cordate, the apex rounded, the side edges slightly undulate and overlapping so as to form rather short, closed, subtubular organs quite enclosing distant, rooting portions of the rhizome, not solitary on lateral branches of the rhizome. Fertile fronds distant, similar to those of D. quercifolia, J. Sm., but often much smaller. Sori placed in 2 rows of $4-7$ between the main veins of the lobes. Borneo (Teysmann, Nos. 8577 \& 8590; Teuscher). Lava. Si p 4 is

\section{\% 4. DREYOSTA OHYUUM, J. Smith.}

Sori oblong or subquadrangular, close, confined to the contracted upper pinnae, in 1 row on each side of the midribs. No indusium.

Rhizome stout, creeping. Fronds sessile, articulate to the rhizome, pinnate or subpinnate; lower pinnae broad, barren; veins anastomosing copiously; areolae with free included veinlets. Diels, in Engl. \& Prantl, Nat. Pfl. Fam., I ${ }^{4}$, fig. 170, A-C.

Malaya.

* D. Splendens, Æ. Sm., Journ. of Bot., III, 399; Bau. \& Hk., Gen. Fil, tab. XCV; Diels, in Engl. \& Prantl, Nat. Pfl.Fam., I* fig. 170, A-G; Polypodium splendens, IIk., Hk. Bk., Syn. Fil., 567; Hk., Spec. Fil., V, 95 (not V, 52); Drynaria splendens, Bedd., Ferns Br.I., II, tab CCGXVI; - var. pilosum; Dryosı. pilosum, J. Sm., Kze, Farnki., I, 139, tab. LXI.

Rhizome stout, creeping, the scales linear-lanceolate, grey or brown. Fronds \pm sessile, $60-90$ c.M. long, $20-50$ c.M. or more broad, the lowest part brown, rigid, narrow, \pm 4 c.M. broad, forming a shallowly lobed wing, the central part sterile, cut down nearly or quite to the costa into 4-8 suberecto-patent, linear-oblong, acute or acuminate lobes or pinnae $10-$ 20 c.M. long, $21 / 2$ - c.M. broad, dilated at the base; highest part fertile, pinnate, the pinnae distant, ligulate, $10-20$ c.M. long, \pm 1 c.M. broad. Texture firmly herbaceous; surfaces naked; main veins distinct; areolae copious, with few free veinlets. Sori oblong or subquadrangular, in 1 row on each side of the costae; filling up the whole under surface of the fertile pinnae except the costa and the main veins. 
Var. pilosum: Upper surface of the fertile pinnae covered with brown, hairy, elliptical patches corresponding with the receptacles of the sori. Capsules crowned with \pm 6 bristles.

Malaya; - var. pilosum: Philippines.

\section{DRYMOGLOSSUM, Prest.}

Sori long, linear, 1 on each side, parallel to the costa, continuous or interrupted. No indusium.

Rhizome creeping. Stipes articulate to the rhizome. Fronds dimorphous, simple, entire; veins anastomosing. Hk. Bk., Syn. Fil., tab. VI, fig. 58; Diels, in Engl. \& Prantl, Nat. Pfl.Fam., I', fig. 160.

Tropical and extra-tropical.

S. Rhizome scales lanceolate, rhomboidal or otate, toolhed, fimbriate or laciniate.

+. Sori nearer the midrib than the edge.

+. Sori nearer the edge than the midrib, often submarginal? $D$. follase

(1) D. carnosum.

(2) D. heterophyllum.

5.5. Rhizome scales subulate, entire.

×. Barren fronds under 4 c.M. long; fertile fronds long-stalked.

(3) D. rigidum.

$\times \cdot \times$. Barren fronds \pm 8 c.M. long: ferile fronds not long-stalked.

(4) D. novo-guineae.

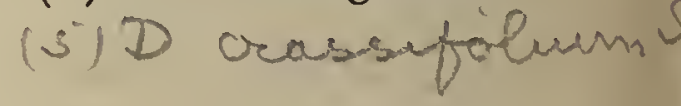

* (1) D. carnosum, J. Sm. (not Hk.), Hk. Bk, Syn. Fil., 397 (excl. var.); Bau. \& Hk., Gen. Fil., tab. LXXVIII, A; Bedd., Ferns Br.I., I, tab. LV; Diels, in Engl. \& Prantl, Nat. Pfl.Fam., I ${ }^{4}$, fig. 160; Nothochlaena carnosa, Wall., (oldest name).

Rhizome creeping, long, filiform, clothed with peltate, lanceolate, toothed scales. Barren fronds $5-6$ c.II. long, on stipes $1-2^{1 / 2}$ c.M. long, lanceolate-oblong, rather obtuse or subaculc. Texture coriaceous, thick and fleshy; areolae with free veinlets. Fertile fronds linear-spathulate, $\pm \mathbf{5}-8$ c.ll. long, $\pm 6 \mathrm{~m}$.II. hroad, suhacute, narrowed at the base, on stipes $3-4 \frac{1}{2}$ c.ll. long. Sori linear, continuous, forming a line nearer the midrib than the 
edge, soon filling up nearly the whole under surface of the frond, covered by numerous stalked peltate scales when young.

Amboyna, Philippines; Formosa, North. India.

* (2) D. heterophyllum, C. Cher., Ind. Fil.; D. piloselloides, Pr., Rac., Flor. Btz., I, 61; Bedd., Ferns S.I., tab. LV; Hk., Gard. Ferns, tab. XLVI; D. carnosum, Rac. (not Hir.), I. c., 62; Niphobolus nummularifolius, Bedd., l. c., tab. CLXXXVI; Acrostichum heteroplyllum, L., (oldest name).

Rhiżome wide-creeping, slender, the scales dense, roundish, oblong or laciniate. Fronds dimorphous. Barren fronds roundish or oblong, subsessile or short-stalked, $1-5$ c.ll. long, 1-2 c.M. broad, the apex rounded, the edge entire, the base more or less obliquely truncate or cuneate. Texture coriaceous or lleshy; surfaces covered with scattered, deciduous stellate hairs, especially when young; veins immersed; areolae with free veinlets. Fertile fronds $5-10$ c.M. long or longer, $3-8 \mathrm{~m}$.M. broad, on stipes to 2 c.M. long. Sori in a broad, submarginal line, not rarely filling the whole under surface of the fertile fronds in the narrowest forms; capsules mixed a few stellate, pedicellate hairs.

Trop. Asia.

- (3) D. Pigidum, Hk., Hk. Bk., Syn. Fil., 398; Hk., Icon. Pl., X, tab. CMXCivi.

Rhizome firm, wide-creeping, the scales dense, lanceolate-subulate, brownish. Fronds dimorphous, the barren ones $1 \frac{1}{2}-31 / 2$ c.M. long, oblong, the apex rounded, the base \pm cuneate, the edge entire, thickened, on firm stipes to $\pm 2{ }^{1} / 2$ c.M. long; fertile fronds $10-15$ c.M. long, nearly semiterete, $\pm \mathbf{5}$ m.M. broad, narrowed into a stipe $\pm 10-15$ c.M. long. Texture very thick and rigid; surfaces naked; main veins hidden; areolae without free veinlets. Sori sunk in a deep groove between the midrib and edge.

Borneo.

(4) D. novo-guineae, Christ, Schum. \& Laut., Flor. deut. Sch. geb., 157.

Rhizome wide-creeping, the scales at first white, afterwards reddishbrown, subulate, dense, subadpressed. Sterile fronds scattered, on stipes $\tilde{3}-4$ c.M. long, naked, ovate-elongate, \pm 8 c.M. long, $\pm \mathbf{5}$ c.II. broad, the apex acute, the base narrowed, the margin entire, cartilagineous. Texture thick, rigidly coriaceous; costa conspicuous; veins inconspicuous near the margin; 
areolae hidden. Ferile fronds longer, \pm 10 c.M. long, linear-ligulate, obtuse, $\pm 5 \mathrm{~m} . M$. broad, on stipes \pm 4 c.M. long; costa conspicuous. Sori linear, parallel to the costa and covering the margin.

New Guinea.

\section{CHRISTOPTERIS, Copeland.}

Sori long, linear, close to the costa, 1 on each side, finally covering the whole under surface of the contracted fertile fronds. No indusium.

Rhizome creeping. Stipes articulate to the rhizome. Fronds dimorphous. Barren fronds sagittate, fertile 3-partite with narrow segments; veins anastomosing; areolae with included free veinlets.

Philippines.

C. Sagitta, Copel., 'Polypod. Philipp., 111; Philipp. Journ., I, Suppl. 157, tab. XIII ; Polypodium Sagitla, Chrisl, Bull. Herb. Boiss., VI, 199.

Rhizome creeping or scandent, the younger part densely clothed with spreading, cinnamon-coloured, filiform scales $\pm 8 \mathrm{~m}$.M. long, which are deciduous, leaving older parts sparsely covered with ferrugineous scales \pm 4 m.M. long. Stipes fuscous or ebeneous, of sterile fronds \pm 10 c.M., of fertile \pm 20 c.M. long, naked. Barren fronds $15-20$ c.M. long and broad, deltoid, the point acuminate, with a triangular sinus 2 c.M. high and wide where the stipe is attached, with a broad, shallow sinus between the apex and each lateral point. Texture coriaceous; surfaces naked; the $\mathbf{3}$ main ribs conspicuous, the main veins strictly parallel, subevident. Fertile fronds cleft to within \pm 1 c.M. of the base into 5 narrowly linear, somewhat spreading, obtuse segments 8-20 c.M. long, \pm 5 m.M. broad.

Philippines. 
TRIBE XI. ACROSTICHEAE.

Fittcës. 



\section{PLATYCERIUM, Desvax.}

Sori indefinite, forming large patches on the under surface of the frond, occupying the ultimate segments or the lower sinuses, or placed on transversally or longitudinally oblong, stalked segments near the base of the frond.

Rhizome commonly short-creeping. Fronds dimorphous, articulate into a depression of the rhizome. Barren fronds (basal fronds) roundish-reniform in general outline, closely applied to the substratum, at least at the base, collecting quantities of detritus into which the roots grow, the outer edge entire or more or less deeply lobed; fertile fronds standing out from the substratum, forked or more generally dichotomously branched with stag-horn-like divisions; surfaces often clothed with more or less deciduous stellate hairs; principal veins dichotomous, secondary ones anastomosing; areolae with included free veinlets. Diels, in Engl. \& Prantl, Nat. Pfl.Fam., I ${ }^{4}$, fig. 177. (*)

Paleotropical, and in temperate Australia.

\section{Arrangement of the sections.}

$\$ 1$. EUPLATYCERIUM. Sori on the ultimate segments or in the lower sinuses of the fertile fronds, but then not as in $\mathbb{2} 2$.

$\$ 2$. SCUTIGERA. Sori placed on specialized, stalked, oblong or broadly reniform segments springing from the lower part of the frond, in the lowest sinus.

\section{S 1. EUPLATYCERIUM.}

a. Sori 1 to each fertile frond, occupying the primary disk (i. e. the cuneate base of the frond), placed against the upper edge.

(1) P. grande.

a.a. Sori 2 to each fertile frond, occupying the secondary disks (i. e. the cuneate base of the primary fork branches), placed against the upper cdge.

*. Fronds forked, both fork branches dichotomously branched. (2) P. Wallichii. *.*. Fronds forked, the outer lranch of each, frond simple, broadly cuneatoflabellate, 2-cornate, the inner dichotomously branched.

(5) P. Wilhelminae Reginae.

u.a.a. Sori several to each fertile frond, occupying the ultimate segments.

${ }^{*}$ ) Mostly beautiful plants, whose extraordinary appearance has made them universally beloved in cultivation. 
b. Fertile fronds shorter than the barren ones, with the ultimate segments cuneate, dilated towards the apex.

(4) P. Wandae.

b.b. Fertile fronds longer than the barren ones, with the ultimate segments not cuneate, but rounded, blunt or narrowed at the apex.

c. Soriferous segments involute, the sori thickened with a dense tomentum giving them a corky appearance.

(5) P. sumbawense.

c.c. Soriferous segments not involute, the sori not thickened, not corky.

d. Barren fronds 1, fertile 3, pendulous.

(6) P. Willinckii.

d.d. Barren fronds 2 or more, fertile 4-7, erect or nutant, but not decidedly pendulous.

(7) P. bifurcatum.

(1) P. grande, J. Sm., Rac., Flor. Btz., I, כ̌6, p. p.; Hk., Fil. Exot., tab. LXXXVI; Nich., Dict. d'Hort., IV, fig. 210; Bedd., Ferns Br.I., II, tab. CCCXXVI; Acrostichum grande, A. Cunn., MS.; Alcicornium grande, Und., Bull. Torr. Cl., XXXII, 594.

Basal fronds roundish, $40-90$ c.M. each way, convex, deeply incised, the lobes simple or once or more times forked. Fertile fronds in pairs, 100-200 c.M. long, dichotomously branched, the basal part (disk) broadly cuneate, the ultimate segments broad, linear, loriform, bluntly rounded. Texture thinly coriaceous; surfaces naked. Sori only 1 to each frond, occupying the disk only, placed against the upper edge between the 2 primary fork branches.

Malaya; Trop. Australia.

(2) P. Wallichii, Irk., Hk. Bk., Syn. Fil., 425; Hk., Fil. Exot., tab. XCVII; Bedd., Ferns Br.I., I, tab. CVIII; Alcicornium Wallichii, Und., Bull. Torr. Cl., XXXII, 596.

Near P. grande, J. Sm., but the fertile fronds shorter, 30-70 c.M. long. Texture thick; under surface covered with a thin, yellowish or reddish tomentum. Sori 2 to each frond, occupying the secondary disks, i. e. the cuneate base of the primary fork branches, placed angaist the upper edge, which is much produced in the sinus.

Malacca.

* (3) P. Wilhelminae Reginae, v. A. v. R., Bull. Dép. Agr. I. N., 1908, XVIII, 24, tab. VI-VII; Alcicornium Wilhelminae Reginae, v. A. v. R., l. c., 25 .

Basal fronds 2 or more, large, to \pm 100 c.M. each way, convex, the 
upper edge deeply lobed, the lobes linear, elongate, erect, simple or $1-2 \times$ forked, the base rounded, obliquely cordate, the outer edge sinuate, with the lobes gradually passing into the higher, linear ones. Fertile fronds in pairs, to 200 c.M. long, divided into 2 unequally developed halfs. The inner halfs (i. e. the 2 contiguous halfs) of the fronds pendulous, dichotomously branched, the segments cuneate, widening gradually from the base to the next higher branching; ultimate segments lanceolate or triangular-elongate, narrowed towards the apex. The outer halfs of the fronds spreading horizontally in opposite directions, simple, large, to 75 c.M. broad, broadly flabellato-cuneate, the outer edge slightly rounded and flanked by 2 blunt, falcate, incurved horns, the horns horizontal or pendulous. Texture flaccido-coriaceous, firm when dry; surfaces clothed with numerous, scattered but not crowded, stellate hairs. Sori large, 2 to each frond, occupying the secondary disks, i.e. one placed in the lowest sinus of the dichotomously divided half of each frond and the other on the simple half, between the horns, the latter much the largest, to \pm 45 c.M. broad, to \pm 20 c.M. deep; capsules copiously intermixed with stellate hairs. - The description of this splendid and interesting fern is taken from a spicimen cultivated in the Buitenzorg gardens and probably gathered in one of the malayan islands. Raciborski referred it to P. grande, J. Sm., which has the segments loriform, naked, and the sori solitary, i. e. 1 sorus to each frond, occupying the primary disk. - This species in dedicated to Her Majesty WilmeLmina, Queen of the Netherlands.

\section{? Malayan.}

(4) P. Wandae, Rac., Bull. Ac. Crac., 1902, 58.

Basal fronds 150-200 c.M. long, 100 c.M. or more broad, the upper edge deeply incised, the base deeply cordate, the lobes furnished with numerous excrescenses, which are very thin, \pm 6 c.M. long, several times dichotomously forked and hiding the apex of the scaly rhizome. Fertile fronds penduluus, $2 \times$ forked, smaller than the barren ones, to 120 c.M. long; ultimate segments. cuneate, $20-40$ c.M. broad at the apex, which is not truncate but repand or incised. Sori covering the under surface of the terminal segments.

New Guinea.

* (5) P. sumbawense, Christ., Warb., Mons., I, 64; Alcicornium sumbawense, Und., Bull. Torr. Cl., XXXII, 596.

Basal fronds roundish-reniform, $15-50$ c.M. each way, laciniate, the laciniae deeply forked; texture scariose, fragile, spongy; surfaces \pm glossy; 
colour ochraceous-fulvous. Fertile fronds 2-ă, narrowed gradually towards the base, to 65 c.M. long, repeatedly dichotomous, pale-coloured, flocculent, the tomentum adpressed; ultimate segments rather numerous ( $\pm 16-20)$ to each frond, lanceolate, ligulate or elongate-triangular, to 7 c.I. long, narrow, subobtuse, rostrate, involute. Sori occupying the whole under surface of the ultimate segments, densely covered with a thick, whitish tomentum when young, but less so at full maturity. - A plant gathered in Timor by Teysmann, very probably a form of this species, has the fertile fronds very coriaceous and rigid, $45-75$ c.M. long, with the ultimate segments not rostrate, the sori often reaching from the apex of the ultimate segments to considerably. below the highest sinuses.

Sumbawa, Timor.

(6) Willinckii, Moore, Nich., Dict. d' Hort, IV, 175; Gard. Chron., N. S., III, fig, 56 ; Alcicornium Willinckii, Und., Bull. Torr. Cl., XXXII, 596.

Basal fronds single, erect, suborbicular and lobed. Fertile fronds triple, elongate, pendulous; each frond narrowly cuneate, dichotomously forked, the lobes narrow, ensiform. Sori on the under surface of the ultimate lobes.

Java.

* (7) P. Ioifurecatum, C. Cher., Ind. Fil.; P. alcicorne, Desv., Rac., Flor. Btz., I, 57 ; Diels, in Engl. \& Prantl, Nat. Pfl.Fam., I ${ }^{4}$, fig. 177, A; Nich., Dict. d' Hort., IV, fig. 209; Alcicornium bifurcalum, Und., Bull. Torr. Cl., XXXII, 594; Acrostichum bifurcatum, Cav., (oldest name).

Rhizome thick, creeping, densely scaly, bearing the fronds in more or less distant groups. Basal fronds 2 or more, roundish or cordate, imbricate, convex, entire, sinuate or lobed, $10-20$ c.I. each way, afterwards brown, the lobes spreading or erect. Fertile fronds mostly 4-7, clustered, the stipes thick, to $\pm b$ c.M. long or longer, \pm erect, the fronds 40-90 c.M. long, cuneate at the base, $2-3 \times$ dichotomously branched, with about $4-8$ ultimate lobes, which are ligulate, flat, 10-20 c.M. long, 2-5 c.M. broad, with the apex blunt or bluntish. Texture thick; colour pale-green; young fronds covered with a thin, whitish or pale-reddish, \pm fugacious, adpressed tomentum; areolae \pm hexagonal, with few free veiniets. Sori occupying \pm the upper $3 / 4$ of the ultimate lobes.

Much cultivated. - Orig. loc.: Australia, New Caledonia, Lởd Howe's Island. 


\section{\$2. SCUTIGERA.}

* (8) D. Corominuium, Desv., Prod., 215; P. biforme, Bl., Rac., Flor. Btz., I, 57 ; Bl., Flor. Jav., II, 44, Lab. XVIII ; Bedd., Ferns Br., I, tab. CIX; II, tab. CCXXIV; Alcicornium coronarium, Und., Bull. Torr. Cl., XXXII, 594; Osmunda coronaria, Kön., (oldest name); - var. cucullatum, v. A. v. R., Bull. Dép. Agr. I. N., 1908, XVIII, 2 ๖.

Basal fronds roundish, thick, at length yellow-brown, the upper edge often deeply lobed. Fertile fronds single, double or clustered, to $100-450$ c.M. long, stalked, pendulous, repeatedly dichotomous; ultimate lobes ligulate, 2-5 c.M. broad. Texture coriaceous; surfaces not rarely clothed with more or less numerous stellate hairs. Sori placed on a broadly reniform or transversally oblong, mostly convex, sometimes half-cupshaped, stalked segment $10-20$ c.M. broad, springing from the lower part of the fertile fronds, in the lowest sinus, 1 to each frond.

Var concullatumn: Ultimate lobes of fertile fronds dilated towards the obliquely rotundato-truncate and slightly emarginate apex. Soriferous segment longitudinally oblong, subcucullate, rather slipper-shaped, the edge broadly recurved.

Malaya; Siam, Burmah; - var cucullatum: Lingga Islands (Teysmann).

\section{ELAPHOGIOSSUM, schott.}

Sori indefinite; sporangia densely covering the under surface of the fertile fronds.

Rhizome mostly creeping. Fronds simple, articulate or subarticulate to the rhizome, uniform or nearly so, rarely exceedingly different in shape; veins free or united. by a submarginal veinlet or a marginal, cartilagineous or decoloured strand. Hk. Bk., Syn. Fil., tab. VII, fig. 60, a-b; Diels, in Engl. \& Prantl, Nat. Pfl.Fam., I ${ }^{4}$, fig. $175 \& 174$, A, E \& H.

Pantropical, but more especially neotropical.

Arrangement of the sections.

S1. ACONIOPTERIS. Fronds bordered by a submarginal vein or marginal, diaphanous, decoloured, cartilagineous or thickened line or strand.

2. EU-ELAPHOGLOSSUM. Fronds not bordered as in $\$ 1$. 


\section{\$ 1. ACONIOPTERIS. $\left(^{*}\right)$}

a. Veins united by a submarginal veinlet.

(1) E. gorgoneum.

a.a. Veins united by a marginal, thickened, carlilagineous, decoloured or diaphanous line or strand.

b. Rhizome scales blackish, jagged or fimbriate.

(2) E. conforme.

b.b. Rhizome scales yellowish.

(3) E. angulatum.

b.b.b. Rhizome scales brown.

c. Fronds bluntly rounded at the apex.

*. Veins rather hidden.

(4a) E. decurrens.

*.*. Veins rather visible.

(4b) E. luzonicum.

c.c. Fronds not bluntly rounded at the apex.

d. Fronds naked or very sparingly scaly, the scales minute, orbicular.

e. Stipes short with regard to the fronds.

(5) E. Beccarianum.

e.e. Stipes long with regard to the fronds.

(6) E. callifolium.

d.d. Fronds minutely scaly, especially beneath, the scales lanceolatesubulate or stellate-fimbriate.

(7) E. laurifolium.

(1) E. gorgoneum, Brack., Expl. Exp., XVI, 74; Acrostichum gorgoneum, Klf., Hk. Bk., Syn. Fil., 416; ? A. pellucido-marginatum, Christ, Fil. Saras., III, 255.

Rhizome short-creeping, firm, the scales brown. Stipes approximate, firm, erect, $21 / 2-5$ c.M. long, passing gradually into the barren fronds, which are $15-40$ c.M. long, $5-8$ c.M. broad, the point acute, the lower $2 / 3$ narrowed very gradually, the edge entire. Texture subcoriaceous; surfaces naked; veins united by a straight, submarginal veinlet. Fertile fronds narrower, on stipes 15 c.M. or more long.

Malaya; Polynesia.

- (2) E. conforme, Schott (not Moore), Christ, Farnkr. d. Erde, 33; Diels, in Engl. \& Prantl, Nat. Pfl.Fam., I4, fig. 173; Bedd., Ferns S.I., tab. CXCVIII; Acrostichum conforme, Sw., Hk. Bk., Syn. Fil., 401; A. marginatum, Wall., List., No. 17; Vittaria acrostichoides, Hk. \& Grev., Ic. Fil., tab. CLXXXVI.

(') See also E. hirtum, C. Chr. 
Rhizome creeping, woody, the scales blackish, ovate, jagged or fimbriate, not hair-pointed. Stipes firm, approximate, erect, $5-8$ c.M. long, blackish at the base, generally clothed with scattered, pale, sheathing scales. Sterile fronds $5-30$ c.M. long, $2-5$ c.M. broad, lanceolate, narrowed towards both ends, the point acute or acuminate, the edge entire, decoloured or cartilagineous, slightly revolute in age. Fertile fronds the longest and narrowest, longer stalked. Texture coriaceous; both surfaces covered with a few deciduous scales when young, those on the midrib beneath the largest; veins hidden, generally once forked.

\section{Pantropical.}

* (3) E. angulatum, Moore, G. Chr., Ind. Fil.; Acrostichum angulatum, Bl., Rac., Flor. Btz., I, 47; Bl., Flor. Jav., II, 25, tab. VI.

Rhizome creeping, the scales yellowish, lanceolate, thinly membranaceous. Stipes firm, erect, stramineous, naked or slightly scaly, 1-3 c.M. apart, 5 -20 c.M. long, those of the fertile fronds the longest. Fronds ellipticallanceolate, 8-40 c.M. long, $2-4$ c.M. broad, the fertile ones the smallest, narrowed towards both ends, the apex acute, the margin entire, with a narrow, decoloured line. Texture coriaceous; surfaces naked or slightly scaly on the midrib beneath; veins subparallel, simple or forked.

Java.

* (4a) E. decurrens, Moore, C. Chr., Ind. Fil.; Acrostichum decurrens, Desv., Rac., Flor. Btz., I, 47; Bl., Flor. Jav., II, 32, tab. X; A. obtusifolium, Spr. (not Brack.), Hk., Spec. Fil., V, 204; - var. Cumingii; E. Cumingii, Moore, Copel., Polypod. Philipp., 137; A. Cumingii, Hée, Hk. Bk., Syn. Fil., 407.

Rhizome creeping, the scales dense, long, linear-lanceolate, brown. Stipes $21 / 2-15$ c.M. long, those of the fertile fronds the longest. Barren fronds 15-40 c.M. long, 4-8 c.M. broad, the apex bluntly rounded, the margin cartilagineous or \pm pellucid, the lower part narrowed gradually into the stipe. Texture coriaceous; surfaces naked or the under side sparingly and minutely scaly, the edge more or less fringed with minute, ovate-lanceolate, acuminate, thin, brown scales; veins immersed, nearly hidden. Fertile fronds often small and narrow.

Var. Cumingii: Stipes longer; barren fronds 3-4 c.M. broad, fertile ones narrower; upper surface scaly like the lower.

Sumatra, Java, Moluccas, Philippines; - var. Cumingii: Philippines. 
(4b) A. Iuzonicum, Copel., Leafl., I, 255.

Rhizome strong, densely scaly. Stipes approximate, slender, 16 - 00 c.M. long, scaly, the scales different, the largest ones narrowly ovate Barren fronds obtuse, 20-25 c.M. long, 4-31/2 c.M. broad, cuneate at the base, the margin bounded by a cartilagineous strand and ciliate with an intramarginal row of deciduous, subciliate scales. Texture subcoriaceous; surfaces glabrescent; veins rather visible, at length conspicuous. Fertile fronds smaller, on longer stipes. - Near E. decurrens, Moore.

Luzon.

(5) E. Becearianum, C. Chr., Ind. Fil.; Acrostichum Beccarianum, Bk., Becc., Mal., III, 27; A. Norrisii, Ces. (not Hk.), Fel. di Bor., 51.

Rhizome short-creeping, densely clothed with small, lanceolate, brown scales. Barren fronds oblong-lanceolate, firm, naked, to $30-40$ c.M. long, to \pm 4 c.M. broad, narrowed gradually into a short stipe, the edge entire, thick; veins inconspicuous, erecto-patent, not closely placed. Fertile fronds often much smaller, on stipes to \pm 15 c.M. long.

Borneo.

* 6) E. Callifolium, Moore, C. Chr., Ind. Fil.; Acrostichum callaefolium, Bl., Rac., Flor. Btz., I, 47; Bl., Flor. Jav., II, 22, tab. IV.

Rhizome thick, creeping, the scales narrow, lanceolate, brown, dense. Stipes $\pm 15-50$ c.M. long, firm, erect, naked or slightly scaly. Barren fronds 10-80 c.M. long, 3-10 c.M. broad, fertile ones shorter and narrower than the barren, elliptical-lanceolate, narrowed towards both ends or rounded at the base, the edge with a narrow, decoloured line. Texture membranaceous to coriaceous; surfaces naked or slightly scaly, the scales microscopical, roundish; veins fine, indistinct, simple or forked.

Java, Mindanao.

* (7) C. Iaunofolium, I., tab. CG; E. latifolium, Bedd., Handb. Ind. Ferns, 416; Acrostichum laurifolium, Thouars, Flor. Trist. d'Ac., 31; A. commutatum, Mett., Ann. Mus. Bot. L. B., IV, 292; A. conforme, Bl. (not $S w$. ), Flor. Jav., II, 23, tab. V.

Rhizome creeping, woody, densely clothed with lanceolate, acuminate, brown scales. Stipes erect, firm, subangular, $3 \frac{1}{2}-7 \frac{1}{2}$ c.M. long, those of the fertile fronds the longest, covered with scattered, small, deciduous scales, and purveyed with an elevated, decurrent margin on each side. Sterile fronds 
7-15 c.M. long, $1 \frac{1}{2}-4$ c.M. broad, oblong-lanceolate, narrowed towards both ends, but more gradually into the stipe, the point acute, the margin entire or slightly repand, thickened, diaphanous. Texture rigid; both surfaces (especially the lower) clothed with scattered, minute, deciduous, brownish, lanceolatesubulate or stellate-fimbriate scales; veins fine, hardly visible, often forked. Fertile fronds narrower, thinner, subrepand.

Luzon, Celebes, Java; Ceylon, South. India, Mascarenes, Tristan d'Acunha.

\section{S 2. EU-ELAPHOGLOSSUM.}

1. Under surface of the fronds naked or nearly so.

2. Fronds small, under 10 c.M. long.

(8) E. microphyllum.

2.2. Fully developed fronds larger, more than 10 c.M. Pong. botansicum, Rsk.

3. Stipes of barren fronds wanling or very short, under 3 c.M. long.

(9) E. melanosticticum.

3.3. Stipes of barren fronds distincl, 7-15 c.M. long. (10) E. Lessonii. 1.1. Under surface of the fronds rather densely tomentose or scaly.

a. Barren fronds suddenly narrowed at the base. Under surface scaly.

(11) E. miniatum.

a.c. Barren fronds gradually narrowed at the base.

b. Barren fronds clothed beneath with stellate hairs.

(12) E. petiolatum.

b.b. Barren fronds clolhed beneath with ciliate or fimbriate scales.

c. Barren fronds densely scaly above.

c.c. Barren fronds sparingly scaly above.
(13) E. hirtum.

(14) E. Copelandi.

* (8) E. microphyllum, v. A. v. R., Bull. Dép. Agr. I. N., 1908, XVIII, 25.

Rhizome slender, creeping, blackish, the scales linear-lanceolate, brown, entire. Stipes distant, $1 / 2-4$ c.M. apart, slender, $1-21 / 2$ c.M. long. Sterile fronds lanceolate, entire, $5-6$ c.M. long, $1 \frac{1}{1} 2-2$ c.M. broad, shortly acuminate but the point bluntish, the base narrowed gradually into the stipe. Texture herbaceous, firm; surfaces naked; veins not close, simple or once or more times forked, not quite reaching the unaltered margin. Fertile fronds shorter, narrower, the edge subentire, the base narrowed more suddenly and 
then tapering very gradually into the stipe so as to form a very narrow wing to the upper part of the stipe, which is $\pm 7-8$ c.M. long.

Java (Ploem).

(9) E. melanosticticum, Moore, C. Chr., Ind. Fil.; Acrostichum melanosticticum (melanoslycton), Bl., Flor. Jav., II, 26, tab. VII; A. Norrisii, Hk., Hk. Bk., Syn. Fil., 401; E. Norrisii, Bedd., Handb. Ind. Ferns, 418.

Rhizome creeping, stout, woody, the scales ovate-lanceolate, long-acuminate, suberose, brownish, dense. Stipes wanting or very short, to $2 \frac{1}{2}$ c.M. long, approximate. Barren fronds $30-45$ c.M. long, 2-4 c.M. broad, broadest $\pm 1 / 3$ on the way to the base, blunt or acute, narrowed gradually from the broadest part towards both ends. Texture coriaceous; surfaces naked or nearly so; veins immersed, indistinct. Fertile fronds much narrower than the barren ones.

Java, Penang.

(10) E. Lessonii, C. Chr., Ind. Fil.; Acrostichum Lessonii, Mett., Linn., XXXVI, 60.

Rhizome thick, the scales dense, brownish, oblong-lanceolate, with the edge slightly ciliate. Stipes approximate, 7-15 c.M. long, compressed. Sterile fronds $\pm 37^{1 / 2}$ c.M. long, \pm 4 c.M. broad, linear-spathulate, obtuse, narrowed gradually into the stipe. Texture coriaceous; upper surface naked or nearly so, lower hardly covered with punctiform, fugacious scales; veins immersed, repeatedly forked, erecto-patent. Fertile fronds linear-lanceolate, \pm 20 c.M. long, \pm 2 c.M. broad, narrowed gradually towards both ends, on stipes \pm 2 c.M. long; costa prominent.

Sumatra; Vanikoro.

(11) E. minintum, ChrisI, Mon. Elaph., 72, fig. 30; Acrostichum miniatum, Chrisl, Ann. Btz., XV, 175; Fil. Saras., III, 254, tah. III, fig. 25-27.

Barren fronds \pm 25 c.M. long, \pm 3 c.M. broad, finely acuminate, suddenly narrowed into the stipe. Texture very thick; veins hidden; upper surface naked, light-green, scaly on the costa; under side covered with regularly scattered, branched, reddish-brown scales, those of the margin peltate, ciliate, densely crowded. Fertile fronds longer, narrowly linear, on longer stipes; upper surface densely covered with cinnamon-coloured, round, stellate hairs.

Celebes. 
78. ELAPHOGLOSSUM. $\$ 2$. EU-ELAPHOGLOSSUM.

* (12) E. petiolatum., Urb., C. Chr., Ind. Fil.; E. viscosum, Scholt, Christ, Farnkr.d. Erde, 39; Bedd., Ferns S.I., tab CXCVI; Acrostichum viscosum, Sw., Rac., Flor. Btz., I, 46; Hk. \& Grev., Ic. Fil., tab. LXI; A. petiolatum, Sw., (oldest name).

Rhizome woody, short-creeping, the scales dense, linear-lanceolate, darkbrown. Stipes approximate, 7-15 c.M. long, firm, erect, covered with small scales and stellate hairs. Barren fronds 15-30 c.M. long, 1-21/2 c.M. broad, the apex acute or acuminate, the lower part narrowed gradually. Texture thinly coriaceous; under surface covered with stellate hairs, upper naked or hairy too; midrib conspicuous; veins visible, fine. Fertile fronds narrower and longer stalked.

Trop. Asia, Africa, America.

* (15) E. hirtum, C. Chr., Ind. Fil.; E. squamosum, J. Sm., Ghrist; Farnkr., d. Erde, 56, fig. 83 ; Bedd., Ferns S.I., tab. CXCVII ; Acrostichum squamosum, Sm., Hk. Bk., Syn. Fil., 411; A. paleaceum, Hk. \& Grev., Ic. Fil., tab. CCXXXV;A. hirtum, Sw., (oldest name).

Rhizome woody, short-creeping, the scales ovate to lanceolate, ciliate, blackish-brown. Stipes tufted or approximate, $21 / 2-10$ c.M. long, densely clothed with lanceolate, ciliate, pale, brown and blackish scales. Fronds $\mathbf{1 5 - 3 0}$ c.M. long, $2-3^{1 / 2}$ c.M. broad, elongate-ligulate, acute or short-acuminate at the point, the base narrowed gradually. Texture thick but flaccid; surfaces densely covered with ovate-lanceolate, ciliate, brown scales, the scales on the midrib are longer and those on the under surface intermixed with polished, blackish-brown ones; midrib conspicuous; veins hidden. Fertile fronds narrower and longer stalked than the barren ones, the edge more or less membranaceous.

Sumatra; Ceylon, South. India, East. Africa, Madeira, Azores, Trop. America, Hawaii.

E. Copelandi, Christ, Philipp. Journ., II, 176.

Rhizome creeping, woody, sparingly clothed with black-brown, subulate setulae. Stipes approximate, to 35 c.M. long, with the fertile fronds on the longest stipes, rufo-stramineous, clothed with black, fimbriato-lacerate squamulae, the base black-brown, provided with scattered, brown, lanceolate scales. Barren fronds linear-lanceolate, to $\pm 421 / 2$ c.M. long, $\pm 21 / 2$ c.M. broad, narrowed towards the acute apex and base, not decurrent on the stipe. Texture firm-charlaceous; colour dark-brown; upper surface sparingly scaly, lower 
densely so, the scales peltate, copiously ciliate to fimbriate, partially smaller and decoloured, partially larger and cinnamon-coloured; costa prominent, rufous, rather sparingly scaly; veins hidden, horizontal. Fertile fronds linear, to $\pm \mathbf{3}$ c.M. long, \pm 1 c.M. broad; upper surface densely scaly, lower densely soriferous.

Mindanao.

\section{STENOCHLAENA, J. Smith.}

Sori indefinite; sporangia densely crowded over the under surface of the much contracted or narrowed, \pm linear pinnae of the fertile fronds.

Rhizome woody, high-scandent, often reaching the tops of the highest trees. Fronds pinnate, dimorphous or polymorphous, whether or not articulate to the rhizome, the abnormal barren fronds, when present, variously and often finely divided, the fertile fronds Lomaria-like; veins free, simple or forked, those of the fertile pinnae sometimes slightly anastomosing, but always united at the base by a more or less distinct or spurious, \pm costal, transversing vein, those of the barren pinnae sometimes so. Hk. Bk., Syn. Fil., tab. VII, fig. 60, f-g; Diels, in Engl. \& Prantl, Nat. Pfl.Fam., I, fig. 153. (*) Pantropical.

Arrangement of the sections.

$\$$ 1. LOMARIOPSIS. Barren fronds uniform; abnormal fronds wanting. 2. TERATOPHYLLUM. Barren fronds dimorphous; abnormal fronds present.

\section{\$1. LOMARIOPSIS.}

a. Barren pinnae not arliculate to the rachis, cordate at the base.

(1) S. laurifolia.

a.a. Barren pinnae articulate to the rachis.

b. Barren pinnae unequal-sided at the base; upper base rather truncate, lower \pm cuneate.

(2) S. arthropteroides.

$\left({ }^{*}\right)$ The fertile pinnae have the edges not rarely recurved, \pm modified and indusium. like, and then it is rather difficult to distinguish the species from Lomaria, except when the rhizome is shown. 
79. STENOCHLAENA. $\$ 1$. LOMARIOPSIS.

7.h. Barren pinnae equal-suded at the base.

c. Lateral pinnae few, 1-3 on each side.

(5) S. Smithii.

c.c. Lateral pinnae more numerous, \pm 6 or more on each side.

a. Rhizome naked or nearly so; barren pinnae with a small gland at or near the base on the upper edge.

(4) S. palustris.

a.d. Rhizome rather copiously scaly; barren pinnae without a gland at the base.

e. Barren pinnae with the edges not cartilagineous.

(๖) S. sorbifolia.

e.c. Barren pinnae with the edges cartilagineous.

(6) S. subtrifoliata.

(1) S. Iaurifolia, Pr. (not Diels), Copel., Polypod. Philipp., 88; Acrostichum laurifolium, Hk., Hk. Bk., Syn. Fil., 412.

Stipes firm, erect, naked. Fronds 60-90 c.M. long, 30-45 c.M. broad. Barren pinnae $15-25$ c.M. long, 51/2-41/2 c.M. broad, sessile, not articulate to the rachis, narrowed gradually from the cordate base to the apex, the edge sharply but finely toothed, without a gland. Texture coriaceous; rachis and both surfaces naked. Fertile pinnae as long as the barren ones, $1 / 2-11 / 2$ c.M. broad.

Philippines and Celebes to Polynesia.

(2) S. anthropten'oides, Christ, Bull. Herb. Boiss., 20 Série, VI, 998.

Rhizome wide-excurrent, rugulose, not aculeate, brown, clothed with scattered, adpressed, black, furfuraceous scales. Stipes scattered, fulvo-stramineous, to $\breve{~ c . M . ~ l o n g . ~ F r o n d s ~} \pm 2$ bै c.M. long, \pm 15 c.M. broad, broadly ovate, hardly narrowed at the base, the rachis slender, minutely winged. Pinnae lanceolate, $\pm 8-10$ on each side, spreading, stalked, articulate on distinct, black, calliform protuberances of the rachis, \pm 9 c.M. long, \pm 2 c.M. broad in the fully developed plants, the upper base auriculate-truncate, the lower cuneate, the edge crenato-serrate. Texture thinly herbaceous; colour bright-green; veins forked, more than 1 m.M. apart, clothed beneatl with scattered, black, furfuraceous scales, as is the rachis. Fertile fronds with the pinnae linear, very distant, acuminate, rounded or nearly cordate at the base. 
* (3) S. Smithii, v. A. v. R.,; S. Raciborskii, C. Chr., Ind. Fil.; Acrostichum Smithii, Rac., Bull. Ac. Crac., 1902, 59.

Rhizome wide-creeping (scandent), densely clothed with lanceolate, acuminate, fimbriate scales. Stipes 8-10 c.M. long, green, slightly canaliculate, scaly especially near the base. Fronds pinnate, 50-45 c.M. long, 30-56 c.M. broad. Pinnae $1-3$ on each side below the terminal one, alternate, articulate, distant, linear-lanceolate, $13-20$ c.M. long, $2-3$ c.M. broad, the base narrowed, the margin entire or indistinctly crenate; terminal pinna 25-50 c.M. long, often inequilateral. Texture rigid, fragile; surfaces smooth, naked; reins parallel, spreading or suberecto-patent, simple or often once forked. Fertile pinnae linear, $2^{1} / 2-5$ m.M. broad, thinly herbaceous.

Moluccas, Aru Islands.

- (4) S. palustris, Bedd. (not Mett.), Copel., Polypod. Philipp., "88; Diels, in Engl. \& Prantl, Nat. Pfl.Fam., I I, fig. 135, G-D; S. scandens, J.Sm., Bedd., Ferns S.I., tab. CGI; Acrostichum scandens, Hk. (not J. Sm.), Rac., Flor. Btz., I, 54; Lomariopsis palusiris, Kuhn (not Mett.), Christ, Farnkr. d. Erde, 41; Polypodium palustre, Burm., (oldest name); - var. juglandifolia; S. juglandifolia, Pr., Copel., l. c.

Rhizome woody, wide-scandent, naked or sparingly covered with roundish or ovate, adpressed scales. Stipes 7-20 c.M. long, firm, erect; naked. Fronds 30-200 c.M. long, 20-50 c.M. broad, pinnate. Pinnae articulate, numerous, lanceolate, $2-4$ c.M. broad, acuminate, pungently serrate towards the apex, the base cuneately rounded, with a small pulvinate gland on the upper side, which is often black in dried material. Texture firm; surfaces naked; veins simple or forked, united at the base by a costal line or costal arches, otherwise free, but not rarely irregularly and slightly anastomosing in the fertile pinnae. Fertile fronds with the pinnae linear, 2-5 m.M. broad, the edge mostly covering the sori when young.

Var. juglandifolia: Fertile pinnae leafy at the base; stipes muricate.

Trop. Asia, Australia \& Polynesia; - var. juglandifolia: Philippines.

* (5) S. sorbifolia, J. Sm., Copel., Polypod. Philipp., 88; Diels, in Engl. \& Prantl, Nat. Pfl.Fam., I ${ }^{4}$, fig. 133, A-B; Acrostichum sorhifolium, L., Hk. Bk., Syn. Fil., 412; Lomariopsis sorbifolia, Fée, Christ, Farnkr. d. Erde, 59; Bedd., Ferns Br.I., II, tab. CXCII; - var. spectabilis; A. spectabile, Rac., Flor. Btz., I, כ̌4; Lomaria spectabilis, Kze, Bot. Zeit., 1848, 144. 
Rhizome high-climbing, thick, wooly, often angled by the decurrent bases of the stipes, clothed with lanceolate-subulate, often ciliate, brownish scales. Stipes firm, slightly scaly, $10-30$ c.M. long. Fronds 30-100 c.I. long, 20-60 c.M. broad, pinnate, the rachis often narrowly winged towards the apex. Pinnae distant, articulate, $\pm 6-50$ on each side, sublanceolate, 2-5 c.M. broad, acute, acuminate or subcaudate, entire, crenate, serrate or dentate, the base \pm cuneately narrowed. Texture firm; surfaces naked; colour blackish-green when dry; veins parallel, distinct quite to the margin, simple or forked. Fertile fronds with the pinnae smaller and narrower, \pm 5-9 m.M. broad.

Var. spectabilis: Fertile pinnae as long as the barren ones, linear, 2-5 m.M. broad.

Pantropical; - var. spectabilis: Malaya.

PSain.

(6) S. subtrifoliata, Copel., Philipp. Journ., I, Suppl., 152.

Rhizome scandent, angular, densely clothed with rather long, lanceolate or ovate, fuscous scales. Stipes 10-20 c.M. long, firm, densely scaly at the base, subglabrescent towards the frond. Fronds of the fully developed plants pinnate, 45-70 c.I. long, ovate. Pinnae articulate to the rachis, the lower stalked, \pm 25 c.M. long, $21 / 2-5$ c.M. broad, acute or caudate, the edge entire, cartilagineous; higher pinnae sessile, often oblique. Texture coriaceous; surfaces naked. Fertile pinnae \pm 1 c.M. broad.

Mindanao.

Indefinite species.

-(7)? S. dubia, v. A. v. R., Bull. Dép. Agr. I. N., 1908, XVIII, 26.

Rhizome scandent, woody, stout, densely scaly like the base of the stipes, blackish-brown, the older parts rough and rather naked. Stipes $\pm \mathbf{5 5}$ c.M. long, dark-purple-brown, densely scaly at the base, densely tomentose in front like the rachises, provided with 2 rows of elliptical, flattened, depressed, paler coloured glands resembling scars of fallen pinnae, the scales long, linear-subulate, brown, leaving the stipes asperous when they fall, the tomentum dark-reddish-brown. Fronds 2-pinnate, the rachis dark-purple-brown. Pinnae erecto-patent, not articulate to the rachis. Pinnulae numerous, rather spreading, articulate to the secondary rachises, ovate-oblong, acuminate, \pm 3 c.M. long, $\pm 1 / 2$ c.M. broad near te base, the base rounded or broadly Filices. 
cuneate, slightly unequal-sided, the edge shallowly crenate but more deeply towards the apex. Texture coriaceous; surfaces naked, upper dark-coloured, lower paler; costae prominent on both sides, with the upper side tomentose towards the base; veins prominent beneath, the higher ones simple or forked, the lower $2 \times$ furcate or subpinnate, all united at the base by a prominent costal line. Fertile fronds not seen. - The description is taken from a specimen determined as Lomariopsis sorbifolia, Fée.

Amboyna (Teysmann).

\section{\$2. TERATOPHYLLUM.}

* (8) S. aculeata, Kae, Bot. Zeit., 1848, 142; S. gracilis, Kze, 1. c.; Acrostichum aculeatum \& gracile, Rac., Flor. Btz., I, 55; Teralophyllum aculeatum, Mell., Ann. Mus. Bot. L. B., IV, 296; Olfersia aculeala \& gracilis, Bl., Flor. Jav., Suppl., tab. XCV_XCVI; Davallia achilleaefolia, Wall., Christ, Farnkr. d. Erde, fig. 96, i; Hk., Spec. Fil., I, tab. LVI, D; Lomaria aculeata \& gracilis, Bl., (oldest names); - - var. inermis, Mett., l. c., 297; Ann. Btz., XII, tab. XIV-XV, fig. 25-28; Bedd., Ferns Br.I., II, tab. CGIX.

Rhizome firm, wide-climbing, prickly, varying from slender to $5 \mathrm{~m} . \mathrm{M}$. thick. Fronds scattered, the barren ones dimorphous. Normal barren fronds stalked, 40-100 c.M. long, pinnate. Pinnae articulate, acute or acuminate, entire, cuneate or rounded at the base, to 11 c.M. long, to $21 / 2$ c.M. broad. Texture firm and green (thin and reddish-purplish in S. gracilis, Kze); rachis and costae often minutely scaly; surfaces naked. Abnormal barren fronds variously divided, with very small, entire, crenate or incised, roundish, oblong or linear ultimate segments, much smaller than the normal fronds and adpressed to the substratum; texture membranaceous. Fertile fronds pinnate, the pinnae narrowly linear. - The formis of this species are often considered as forms of S. sorbifolia, J. Sm. or palustris, Bedd.

Var. iner'mis : Rhizome unarmed.

Trop. Asia.

\section{O. POLYBOTRYA, Humb. Hompt.}

Sori at first terminal on the veins, but soon occupying \pm the whole under surface of the much contracted fertile segments. 
Rhizome erect or creeping, but not high-scandent. Fronds not articulate to the rhizome, at least simply pinnate, dimorphous, the fertile ones not Lomaria-like; veins free in malayan material.

Pantropical.

Arrangement of the seclions.

$\$ 1$ EGENOLFIA. Veins free; leaflets with a tooth or seta in the sinuses of the crenations or lobes. Rhizome short-creeping. Hk. Bk., Syn. Fil., tab. VII, fig. 60, h-j; Diels, in Engl. \& Prantl, Nat. Pfl. Fam., I ${ }^{4}$, fig. 102.

S2. PSOMIOCARPA. Veins free; leaflets without a tooth or seta in the sinuses. Rhizome erect or slightly tuberous. Diels, l. c., fig. 105, B.

S3. EUPOLYBOTRYA. Veins free; leaflets without a tooth or seta in the sinuses. Rhizome, wide-creeping, scaly. Hk. Bk., l. c., fig. 60, c-e; Diels, l. c., fig. 104. (Malayan?).

$\$$ 4. ARTHROBOTRYA. Like $\mathbb{S}$, but the rhizome naked; leaflets articulate to the rachis.

\$5. OLFERSIA. Vein tips united by an intramarginal transversing vein. Hk. Bk., l. c., fig. 60, m-0. Diels, l. c., fig. 103, E. (Not in Malaya).

S6. SOROMANES. Veins anastomosing \pm as in Nephrodium, but less regularly. Hk. Bk., l. c., fig. 60, l--s; Diels, l. c., fig, 105, C. (Not in Malaya).

Key to the species $\left(^{*}\right)$.

a. Pinnae nol arliculate to the rachis.

b. Leaflets with a loolh or sela in the sinuses of the crenalions or lobes.

(1) P. appendiculata.

b.b. Leaflets wilhout a loolh or sela in the simuses.

c. Fronds 2-pinnatifid.

d. Pinnae deciduously scaly at the margin.

d.d. Pinnae nol scaly al the margin.

c.c. Fronds 2-3-pinnate.

a.a. Pinnae arliculate to the rachis.
(4) P. stenosemioides.

(2) P. Nieuwenhuisii.

(3) P. apiifolia.

(5) P. articulata.

(*) 'The rhizome of one of the species being unknown to me, I don't follow the arrangement of the sections in this key. 


\section{\$ 1. EGENOLFIA.}

* (1) P. appendiculata, J. Sm. (not Bedd.), Christ, Farnkr. d. Erde, 45; Diels, in Engl. \& Prantl, Nat. Pfl.Fam., I', fig. 102; Bedd., Ferns S.I., tab. CXCIV; P. marginata, Bl., Enum., 100; Acrostichum appendiculatum, Willd., Rac., Flor. Btz., I, 52; - var. Hamiltoniana, Bedd., Handb. Ind. Ferns, 426; Ferns Br.I., I, tab. CXI (the 3 lower figures); P. Hamilconiana, Pr., Tent. Pterid., 251; A. Hamiltonianum, Wall., List, No. 29.

Rhizome firm, woody, short-creeping, the scales brown, lanceolate. Stipes approximate, 7-15 c.M. long, erect, slightly scaly like the rachis, the scales linear. Barren fronds simply pinnate, ovate-lanceolate, sometimes rooting at the apex, $15-50$ c.M. long, 6--20 c.M. broad. Pinnae short-stalked, \pm approximate, $1 / 2-2$ c.M. broad, the sides parallel, the apex blunt, the edges varying from slightly crenate to cut $1 / 2$-way down to the midrib into oblong, blunt lobes, with a seta or bristle-like tooth in the sinuses, the base unequalsided, the upper base subtruncate, auricled, the lower truncate or cuneate. Texture herbaceous, firm; surfaces naked; veins visible, pinnate. Fertile fronds on the longest stipes, pinnate; pinnae oblong or linear-oblong, much shorter and narrower than the barren ones.

Var. Hamiltomiama: Fertile pinnae contracted. Sori in beadlike clusters without any connecting leafy membrane.

Trop. Asia; - var. Hamiltoniana: Malacca; Chittagong, Assam.

\section{PSOMIOCARPA.}

* (2) P. Nienwenhmisii (Nieuwenhuisenii), Rac., Bull. Ac. Crac., 1902, 57; Acrostichum Nieuwenhuisii, Rac., MS. in Herb. Bog.

Rhizome erect, scaly at the extremity, the scales yellowish-brown, spreading, lanceolate. Stipes $5-40$ c.M. long, clothed towards the base with many scattered, spreading or deflexed, lanceolate-acuminate, brownish scales, the rest glossy, minutely pubescent or short-fibrillose and blackish-purplish, as is the rachis. Fronds lanceolate-oblong, acuminate, 10-30 c.M. long, 7-15 c.M. broad near the base, the apex pinnatifid, the rest pinnate. Pinnae linearoblong, acuminate, pinnatifid, to $21 / 2$ c.M. broad, broadest in the upper half, slightly narrowed towards the base, the lowest a little abbreviate and deflexed. Lobes oblong, erecto-patent, rather close, rounded at the apex, the longest 6-10 m.M. long, 5-5 m.M. broad, the lowest spreading and not rarely a little elongated. Texture firm-herbaceous; surfaces naked; costae fibrillose 
above; veins 5-7-jugate, simple. Fertile fronds as long or shorter, narrower, often on the longest stipes; pinnae contracted, with shorter and narrower, more distant, spreading lobes; lowest pinnae not deflexed, except when casually barren.

\section{Borneo.}

(5) I. aprifolia, J. Sm. (not Hk.), Copel., Polypod. Philipp., 40; Diels, in Engl. \& Prantl, Nat. Pfl.Fam., I*, fig. 103, B; Kze, Farnkr., I, tab. LXII ; Acrostichum apiifolium, Hk., Hk. Bk., Syn. Fil., 413.

Rhizome stout, woody, erect. Stipes of barren fronds $\breve{b}-8$ c.M. long, erect, densely fibrillose-tomentose. Barren fronds 10-15 c.M. each way, deltoid, 5-pinnate. Pinnae close, only the lowest pair with pinnate pinnulae; ultimate divisions oblong-romboidal, $1 / 2-1$ c.M. long, the base equally cuneate, the outer edge slightly toothed. Texture herbaceous; rachises tomentose. Fertile fronds on slender, rather naked stipes 1 b-20 c.M. long, panicled, with a few distant, slender, simple or compound, beaded branches.

Philippines.

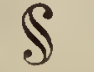

(4) P. Stemosemioides, Copel., Polyopod. Philipp., 40: Acrostichum slenosemioides, Bk., Journ. of Linn. Soc., Bot., XXII, 230.

Stipes of barren fronds to $\pm \mathbf{5 0}$ c.M. long, castaneous, covered with a few lanceolate scales towards the base. Fronds oblong-lanceolate, 50-45 c.M. long, 16-20 c.M. broad, 2-pinnatifid. Pinnae sessile, multijugate, lanceolate, pinnatifid, the lower ones to 12 c.M. long, $21 / 2-31 / 2$ c.M. broad, the margin beset with a few hyaline, deciduous scales. Segments oblong, obtuse, 4-6 m.M. broad. Texture submembranaceous; surfaces naked; main veins pinnate in the segments; veins 6-8-jugate, the lower ones forked, the higher simple. Fertile fronds similar, but the pinnae smaller, less dense, the stipes \pm 60 c.M. long.

Borneo, Philippines.

\section{\$4. ARTHROBOTRYA.}

(5) P. anticulata, J. Sm., Copel., Polypod. Philipp., 40; Christ, Farnkr. d. Erde, fig. 101; Acroslichum arliculalum, Hk., Hk. Bk., Syn. Fil., 415; Lomagramma arliculala, Copel., Philipp. Journ., III, 52. 
80. polybotrya, $\$$. 4. ARTHRobotrya.

Rhizome woody, wide-creeping, naked. Stipes firm, erect, slightly scaly, \pm 50 c.M. long. Barren fronds 50-80 c.M. long, 20-50 c.M. broad, oblongovate. Pinnae numerous, articulate to the rachis, stalked, rather distant, spreading, lanceolate, pinnate. Pinnulae rhomboidal, articulate, unequal-sided, the lower base narrow-cuneate, the upper more broadly cuneate and often \pm auricled, the edge deeply toothed. Texture herbaceous; costae and veins conspicuous, scaly. Fertile fronds with the pinnulae contracted, blunt, often sessile.

Timor, Celebes and the Philippines across Melanesia

\section{STENOSEMIA, Presi.}

Sori indefinite, densely covering the dorsal or both surfaces of the much contracted linear segments of the fertile fronds.

Rhizome short. Stipes not articulate to the rhizome. Fronds dimorphous, 3-5-angular in general outline, the basiscopical side of the lower segments strongly developed; veins anastomosing \pm as in Pleocnemia, i. e. forming 1-2 rows of areolae against the costae and costulae. Hk. Bk., Syn. Fil., tab. VII, fig. 60, $\mathrm{t}-\mathrm{u}$; Diels, in Engl. \& Prantl, Nat. Pfl.Fam., I $\mathrm{I}^{4}$, fig. $105, \mathrm{~A}-\mathrm{B}$.

Malayan and Polynesian.

5. Barren fronds ternale, $\pm 20-30$ c.M. long.

(1) S. aurita.

\$.\$. Barren fronds pinnate.

*. Barren fronds \pm 30 c.M. long.

(2) S. pinnala.

*.*. Barien fronds $45-90$ c.M. long.

(3) S. Teysinanniana.

* (1) S. aurita, Pr., Copel., Polypod. Philipp., 41; Pr., Tent. Pterid., tab. X, fig. 24; Diels, in Engl. \& Prantl, Nat. Pfl.Fam., I ${ }^{4}$, fig. 105, A-B; Acrostichum aurilum, Sw., Rac., Flor. Btz., I, 52; Polybotrya aurila, Bl, Hk., Fil. Exot., tab. LXXXI ; Gymnopleris aurila, Keys., Christ. Farnkr. d. Erde, fig. 124; - var. minor, Christ, Fil. Saras., III, 252.

Rhizome short-creeping or erect, firm, the scales blackish, lanceolate. Sterile fronds ternate, $20-30$ c.M. cach way, the central segment deeply pinnatifid with oblong, blunt or acute, straight or subfalcate, entire or crenate 
lobes. Lateral segments unequal-sided, the upper side cut $\pm 1 / 2$-way down into erecto-patent lobes, the lower lobes shorter than the medial ones, the lower side broader than the upper, deeply pinnatifid into entire, toothed or lobed lobes, the lowest of which are much elongated, pinnatifid, falcate. Texture herbaceous; surfaces naked. Fertile fronds of the same shape, but all the divisions linear, $1-1 \frac{1}{2}$ m.M. broad. - Stipes to 45 c.M. long.

Var. mimor: Dimensions $1 / 3$ smaller than those of the type.

Malaya; Salomon Isles; - var. minor: Celebes.

(2) S. pinmata, Copel., Philipp. Journ., I, Suppl., 146.

Rhizome stout, erect. Stipes tufted, black-fuscous, or yellowish towards the frond, clothed with a few distant, deciduous scales, $25-40$ c.M. long, the fertile fronds on the longest stipes. Barren fronds deltoid-ovate, \pm 30 c.M. long, \pm 20 c.M. broad, pinnate, the rachis densely short-hairy. Lowest pinnae stalked, subfalcate, ovate, acuminate, pinnalifid to $\frac{2}{3}$. on the way to the costa, with the lobes on the lower side produced, those near the base shorter, the edges serrate, the sinuses provided with minute setae; next following pinnae sessile, higher adnate, highest connected. Texture membranaceous; surfaces nearly naked. Fertile fronds \pm 10 c.M. long, 2-pinnate.

Mindanao.

V. edentula SI p432

* (3) S. Teysmanniana, Diels (not Bk.), in Engl. \& Prantl, Nat. Pfl. Fam., I' ${ }^{4}$ 198; Acrostichum Teysmannianum, Bk., Becc., Mal., III, 56.

Stipes castaneous like the rachis, naked, \pm 45 c.M. long. Sterile fronds oblong-rhomboidal, 45-90 c.M. long, 50-60 c.M. broad, pinnate. Pinnae erecto-patent, the lower ones short-stalked, acuminate, $51 / 2-6$ c.M. broad, deeply pinnatifid nearly to the costa into numerous linear-oblong, bluntish, entire or inciso-crenate to toothed lobes $5-8 \mathrm{~m}$.M. broad, the lower lobes shorter. Texture herbaceous, firm; surfaces naked, or the costae and costulae clothed with numerous short, gland-like hairs. Fertile fronds similar, but smaller and narrower; ultimate divisions linear, \pm 2 m.M. broad, united by a very narrow costal wing.

Sumba Island.

\section{HYMEIVOLEPIS, Kaulfuss.}

Sporangia densely covering the under side of the much contracted, linear or spoon-shaped apex of simple fronds, often protected by the recurved edge when young. 
Rhizome \pm creeping. Stipes articulate to the rhizome. Sterile part of the fronds lanceolate; veins anastomosing copiously; areolae with free included veinlets. Diels, in Engl. \& Prantl, Nat. Pfl.Fam., I ${ }^{4}$, lig. 161, l'-H; Hk. Bk., Syn. Fil., tab. VIII, fig. 60, cc-ee.

\$. Fertile region linear.

†. Fronds stalked.

*. Fronds cartilagineous.

(1) H. rigidissima.

*.*.Fronds \pm coriaceous, sometimes membranaceous.

(2) H. spicata. Si pu

(3) H. callifolia.

t.+. Fronds sessile.

(4) H. brachystachys.

\$.S. Ferile region spoon-shaped.

(b) H. platyrhynchos. SIp 4

(1) H. rigidlissima, Christ, Bull. Herb. Boiss., $2^{\circ}$ Série, VI, 990.

Rhizome firm, black, crowned with minute, brown, strigillose scales. Stipes seriate, short. Fronds $1-2$, linear-lanceolate, $8-16$ c.M. long, $2-8$ m.M. broad, the base narrowed, the sporangia occupying the upper $1 / 3-1 / 2$ of the frond. Texture cartilagineous, indurate; colour blackish-ferrugineous; costa distinct; veins hidden. Sori fulvo-testaceous.

Luzon, Mindoro. hew Gurisa (S 1 p 432)

* (2) H. spicata, Pr., Christ, Farnkr. d. Erde, 129, fig. 561; Hk., Fil. Exot., tab. LXXVIII; Bedd., Ferns S.I., tab. XLVI; H. revoluta, Bl., Enum., 201; Acrostichum spicalum, L.f. (not L.), Rac., Flor. Btz., I, 51; A. platyrhynchos, Ces. (not Hk.), Fel. Becc. Polin., 5; - var. latifrons, Bedd., Journ. of Bot., XXVI, 6; - var. tenella; Acrostichum revolutum, Zoll., var. Ienellum, Zoll., MS. in Herb. Bog.

Rhizome creeping, the scales short, ovate-lanceolate, short-acuminate. Stipes 1-7 c.M. long, firm, often dark-coloured like the costa. Fronds $15-45$ c.M. long, 1-3 c.M. broad, linear-lanceolate, the lower part narrowed very gradually, the edge entire, or slightly and irregularly undulate, the upper part more or less suddenly narrowed into a linear, contracted apex $1-15$ c.M. long, 2-4 m.M. broad, with the unaltered edge much recurved, quite enclosing the sori when young. Texture rigid, chartaceous; surfaces naked; costa distinct; veins hidden; areolae with free veinlets. Sori broadly linear, occupying the linear apex of the frond; capsules intermixed with peltate scales. 
Var. Iatifrons: Fronds to 75 c.M. long, $6-7$ c.M. broad; fertile part $15-20$ c.M. long.

Var. tenella: Fronds linear, $20-50$ c.II. long, $\pm 1 / 2$ c.Il. broad, broadest $\pm 1 / 3-1 / 6$ from the base, narrowed gradually towards both ends. Texture membranaceous.

Trop. Asia, Australia, Polynesia, Madagascar, Mascaren Islands; - var. latifrons: Malacca; - var. tenella: . . . . . . ? (Zollinger).

* (3) H. Callifolia, Christ, Ann. Btz, $\mathrm{XX}, 128$.

Stipes \pm 7 c.ll. long, thick, brown, canaliculate. Fronds $40-60$ c.ll. long, $\pm \mathbf{5}-\mathbf{5} 1 / 2$ cll. broad, lanceolate, acuminate, the base narrowed, the soriferous apex \pm 25 c.M. long, $\pm 5 \mathrm{~m}$.M. broad, with the margin recurved. Texture coriaceous; surfaces opaque, naked; costa prominent; veins fine, oblique, flexuose; primary areolae broad, divided into smaller ones with included free veinlets. - Perhaps identical with H. spicata, Pr., var. latifrons.

Borneo.

* (4) H. Juachystachys, J. Sm., Diels, in Engl. \& Prantl, Nat. Pfl.Fam., Í ${ }^{4}, 30$; H. spicala, Pr., var. brachystachys, Hk., Gard. Ferus, tah. III; Acrostichum brachystachyum, Rac., Flor Btz, I, 51; A. spicatum, L.f., var. brachystachys, Hk., Spec. Fil., V, 280; A. validinervis, Rac.; MS. in Herb. Bog.

Much resembling H. spicata, Pr., but the scales of the rhizome with a very long, linear-subulate, finely acuminate apex. Fronds sessile, less rigid, the costa often green or pale-coloured.

Malaya.

(5) II. Datyr-hynchos, Kae., Christ, Farnkr. d. Erde, 129; Hk., Icon. Pl., X, tab. III; Acrostichum plalyrhynchios, IIk., Hk. Bk., Syn. Pil., 424; Gymnopteris platyrhynchos, J. Sm., (oldest name).

Stipes rather tufted, short. Fronds $30-40$ c.Il. longg, $\pm 21 / 2$ c.ll. broad, the lower part narrowed gradually, the edge entire, the soriferous apex spoonshaped. Texture very coriaceous; surfaces naked; areolae fine, hidden, with copious free veinlets. Sori in a subterminal patch $2 \frac{1}{2}-5$ c.M. long, \pm 1 c.II. broad, not reaching to the edge.

Celebes, Phlippines. 


\section{ACROSTICHUM, Linné.}

Sori indefinite, densely covering the under surface of the higher pinnae of simply pinnate fronds.

Rhizome stout, erect. Stipes not articulate to the rhizome. Fronds commonly large; pinnae not articulate, uniform or nearly so, the fertile ones rarely much contracted; veins anastomosing copiously and moderately regular; areolae obliquely elongato-subhexagonal, without free veinlets. Diels, in Engl. \& Prantl, Nat. Pfl.Fam., I' ${ }^{4}$, fig. 174, F \& J. (*)

Pantropical, mostly in brackish marshes.

$$
\operatorname{Sip} 433
$$

* A. aureum, L., Rac., Flor. Btz., I, 50; Bedd., Ferns S.I., tab. CGIV ; A. inacquale, Willd., Bl., Flor. Jav., II, 40, tab. XVI; A. speciosum, Willd., B1., l. c., 42, tab. XVII ; Chrysodium aureum, Melt., Christ, Farnkr. d. Erde, 47; - var. attenuatum, v. A. v. R., Bull. Dép. Agr. I. N., 1908, XXI, 9; ( ? A. praestantissimum, Bory, Hk. Bk., Syn. Fil., 45j; Ch. praestantissimum, Mell., Christ, 1. c.).

Caudex erect, woody, scaly. Stipes tufted, 50-60 c.M. long, strong, erect, naked, glossy, pale-brown when dried. Fronds 60-300 c.M. long, 50-60 c.M. broad. Pinnae numerous, distant, erecto-patent, stalked, $\pm 15-$ 45 c.M. long, 1-9 c.M. broad, ligulate-oblong or lanceolate, both sides often parallel, entire; barren pinnae with the base \pm truncate or cuneate, the apex blunt (A. inaequale, Willd. = aureum typicum), acute or acuminate (A. speciosum, Willd.), if blunt sometimes retuse with a mucro; upper pinnae fertile, similar to the barren ones but mostly smaller and blunt. Texture firm, often rigidly coriaceous; surfaces naked; costae prominent and veins often so; areolae small, copious, moderately regular, without free veinlets. Sori filling up the space between the costae and margin. - The young plants have the fronds simple or ternate, sterile.

Var. attenuatum: Fertile pinnae much contracted, narrow-linear. Both barren and fertile segments resembling those of Leptochilus Raapii, $v$. $A . v$. R., but longer and narrowed gradually towards both ends.

Pantropical; - var. attenuatum: Karimon Djawa Islands (Koorders).

(*) The genus Acrostichum formerly included all ferns with the sporangia covering the fruiting surface, without evident diflerentiation of sori (Copel.). 


\section{PHOTINOPTERIS, J. Smith.}

Sporangia crowded over the under surface of the much contracted, linear, highest segments of the pinnatipartite or pinnate fronds.

Rhizome creeping. Fronds articulate to the rhizome, deeply pinnatifid or pinnate: segments dimorphous, the barren ones lanceolate, articulate to the rachis, free and stalked or adnate and joined; veins anastomosing copiously; areolae with included free veinlets. Diels, in Engl. \& Prantl, Nat. Pfl. Fam., I ${ }^{4}$, fig. 170, D-F.

Malayan.

\$. Fronds deeply pinnatifid in the lower, barren part. \$.\$. Fronds pinnate in the lower, barren part.
(1) Ph. drynarioides.

* (1) Ph. Irymanoides, Hedd., Handb. Ind. Ferns, 442; Ferns Br.I., II, tab. CGGXXV; Acrostichum drynarioides, IIk., Hk. Bk., Syn. Fil., 425 ; Polypodium drynarioides, Christ, Farnkr. d. Erde, 117; Dryostachyum drynarioides, Kuhn, Ann. Mus. Bot. L. B., IV, 296 ; C. Chr., Ind. Fil.

Fronds subsessile, to 90 c.M. long, deeply pinnatifid below with numerous close, entire, lanceolate, acuminate, sterile lobes. Lobes 10 - 20 c.M. long, $21 / 2-4 \%$ c.M. broad, connected by a narrow wing, articulate though adnate to the costa (rachis), the lower ones passing down gradually into a mere, undulate wing to the costa, which is continued to its very base; above the sterile lobes numerous distant, linear pinnae sometimes 50 c.M. long, $\pm 2 \frac{1}{2}$ m.M. broad. Texture very coriaceous; surfaces naked; main veins prominent, with transverse veins; areolae copious, small, with free veinlets.

Malaya; Salomon Islands.

* (2) Ph. speciosa, mi. (not J. Sm.), Copel., Polypod. Philipp., 154; Diels, in Engl. \& Prantl., Nat. Pll.Fam., I4, fig. 170, D-F; Ph. rigida, Bedd., Ferns Br.I., II, tab. CCXI; Polypodium speciosum, Christ, Farnkr. d. Erde, 121, fig. 346; Acrostichum rigidum, Wall., Rac., Flor. Btz., I, 50 ; Lomaria speciosa, Bl., (oldest name); - var. simplex; Ph. simplex, J.Sm., Journ. of Bot., III, 405 .

Rhizome woody, creeping, whitish, the scales brown, subulate, mixed with hairs. Stipes short or long, naked, provided with 2 opposite rows of 
few distant glands or auricles. Fronds ovate-lanceolate, $60-90$ c.M. long, 20-50 c.I. broad. Pinnae numerous, the lower ones sterile, stalked, jointed at the base, alternate, rather distant, $7-15$ c.M. long, $3^{1 / 2}-8$ c.M. broad, ovate, acuminate, the stalks provided at the base with a stipule- or auriclelike outgrowth. Upper pinnae fertile, distant, $10-15$ c.M. long, $5-3^{1} 1 / 2$ m.II. broad, short-stalked. Texture very coriaceous, rigid, thick; colour light-green; rachis naked; upper surface covered with scattered, deciduous, white-cretaceous dots, lower with rather long hairs, soon naked; main veins connected by raised transverse veins; areolae copious, with free veinlets.

Var. simplex : Fertile pinnae reduced to 1 , the terminal one. Malaya.

\section{CHEIROPLEURIA, Prest.}

Sori indefinite, covering the whole under surface of the much contracted, nearly linear fertile fronds.

Rhizome creeping. Fronds scattered, not articulate to the rhizome, dimorphous. Barren fronds simple or more generally 2 -fid, the lobes sometimes 2-fid again; main ribs 2 or more in each lobe, uniting towards the apices of the segments; veins anastomosing copiously. Diels, in Engl. \& Prantl, Nat. Pfl.Fam., I ${ }^{4}$, fig. 175 .

Australasia.

\section{Sip 433}

* Ch. Dicuspis, Pr., Christ, Farnkr. d. Erde, 128, fig. 360; Diels, in Engl. \& Prantl, Nat. Pfl.Fam., I" , fig. 175 ; Acroslichum bicuspe, Ilk., Rac., Flor. Btz., I, 48; Gymnopteris Vesperlilio, Hk., Lond. Journ. of Bot., V, tab. VII-VIII; Polypodium bicuspe, Bl., Flor. Jav., II, 173, tab. LXXVIII, B ; var. integrifolia, Hk. Bk., Syn. Fil., 421.

Rhizome woody, creeping or subscandent, densely clothed with silky, yellow hairs. Stipes of barren fronds \pm 30 c.M. long, firm, naked. Barren fronds \pm 20 c.M. long, 10 c.M. or more broad, the base cuneate, rounded or subcordate, the upper part consisting of 2 elongate-deltoid, divaricate, acute or acuminate lobes \pm half as long as the whole frond, sometimes 2-fid again. Texture coriaceous; surfaces naked; main ribs $\pm 4-8$, springing from the base of the frond, uniting lowards the apices of the lobes; areolae copious. Fertile fronds $15-25$ c.M. long, $1-1 \frac{1}{2}$ c.M. broad, linear- 
lanceolate, simple, narrowed towards both ends, with \pm 3 prominent ribs, on stipes 45 c.M. or more long.

Var. integrifolia: Barren fronds ovate-acuminate, simple.

Sumalra, Java, Borneo, New Guinea, Philippines; Formosa, Liu-Kiu.

\section{6a. LEPTOCHILUS, Iantfuss.}

Sporangia densely crowded over the under surface of the contracted fertile fronds or pinnae of fertile fronds. Paraphyses mostly small or wanting. Spores generally bilateral or ellipsoidal, often purveyed with more or less deciduous, elevate; reticulate, entire, plicate or fimbriate membranes.

Rhizome generally creeping. Stipes not articulate to the rhizome. Fronds dimorphous, simple or pinnate; veins anastomosing copiously, \pm as in Aspidium, very rarely as in Nephrodium; areolae generally with included free veinlets.

Pantropical.

Arrangement of the sections.

S1. POECILOPTERIS (Gymnopteris). Main veins distinct nearly or quite to the edge. Hk. Bk., Syn. Fil., tab. VII, fig. 60, v-x, aa-bb; Diels, in Engl. \& Prantl, Nat. Pfl.Fam., I ${ }^{4}$, fig. 106-107.

$\$ 2$. CHRYSODIUM. Main veins wanting or indistinct. Fronds simple or ternate, the segments not articulate to the rachis. Hk. Bk., l. c., fig. $60, \mathrm{Y}-\mathrm{z}$.

\$5. LOMAGRAMMA. Like $\$ 2$, but the fronds pinnate, the segments articulate to the rachis. ( $\left.{ }^{*}\right)$

\section{$\$$ 1. POECILOPTERIS}

a. Barren fronds typically simple and entire, but some of them somelimes ternale or quinale.

\$. Veins anastomosing in costal arches only, the rest free.

(1) I. oligodictyus

\$.\$. Veins anastomosing copiously.

(*) This section would perhaps better be treated as a distinct genus 
*. Barren fronds $1-1 \frac{1}{2}$ c.M. broad. Areolae wilhout free veinlets.

(2) L. Linnaeanus.

*.*.Barren fronds 4-10 c.M. broad. Areolae with free venlels.

(3) L. decurrens.

a.a. Barren fronds typically 3-fid, but somelimes simple or pinnate. ${ }^{2}$, ovaltus

$x$. Segments of the fertile fronds lanceolate-oblong, rather short.

(4) L. trifidus.

$x . \times$. Segments of the fertile fronds narrouly linear, rather long.

(5) L. tatifolius.

a.a.a.Barren fronds lypically 3-foliate or pinnate, but some of them sometimes simple, or very rarely 2-pinnate in No. $10 a$.

b. Fronds pedatisect.

(6) L. Hollrungii.

b.b. Barren fronds with 1-6 pairs of lateral pinnae.

c. Fronds small, under $121 / 2$ c.M. long.

+. Lateral pinnae 1-jugale.

(7) L. zeylanicus.

+.+. Laleral pinnae 2-6-jugale.

(8) L. inconstans:

c.c. Fully developed fronds larger, more than $121 / 2$ c.M. long.

d. Lateral pinnae truncale at the base, the edge troadly crenate and finely toothed.

(9) L. prolifer.

d.d. Lateral pinnae cuneale or rounded at the base, the edge entire, repand, toothed or sinuate.

e. Fronds scaltered.

(10a) L. heteroclitus.

e.e. Fronds approximate.

(11) $\mathrm{T}$. diversifolius.

6.b.b. Barren fionds as a rule copiously pinnate.

1. Fronds 1030 c.M. long.

\$. Pinnae entire or crenale.

*. Pinnae entire, acuminale, narrowed at the base.

(12) L. Preslianus.

*.*.Pinnae crenule, acule, truncate at the base.

(13) L. exsculptus.

\$.\$. Pinnae lobed.

(14) L. celebicus.

1.1. Fully developed fronds mosily 30-70 c.M. long.

2. Pinnae herbaceous or subcharlaceous, under 4 c.M. broad.

3. Rachis narrowly winged. Pinnae under 8 c.M. long.

(15) L. virens. + SI

(*) I don 't know whether this species is well-classified here. 
86a. LEPTOGHILUS. $\$ 1$. POEGILOPTERIS.

3.3. Rachis not winged. Pinnae $\pm 9-15$ c.M. long in the barren fronds.

4. Pinnae whether or not lobed, the lobes without produced anterior teeth.

(16a) L. cuspidatus.

1.4. Pinnae subpinnatifid, the lobes toothed, with the lower anterior teeth produced. (16b) L. Naumanni.

2.2. Pinnae subcoriaceous, more than 4 c.M. broad in the fully developed barren fronds.

$\times$. Pinnae $31 / 2-5$ c.M. broad.

(17) L. Zollingeri.

$\times \cdot \times . P$ innae 5-8 c.M. broad, tinged with red.

(18) L. scalpturatus.

(1) L. oligodictyus, C. Chr., Ind. Fil.; Acrostichum oligodictyon, Bk., Journ. of Linn. Soc., Bot., XXIV, 261.

Rhizome short-creeping. Stipes $5-8$ c.M. long, naked, pale-brown. Fronds lanceolate, $20-25$ c.M. long, $1-2$ c.M. broad at the middle, rarrowed gradually to both ends. Texture rather rigid; both surfaces naked; veining of Nephrodium, paucijugate, only the lowest veins anastomosing. Fertile fronds linear, $\breve{5}-8 \mathrm{~m}$.M. broad, on stipes $15-20$ c.M. long.

\section{Borneo.}

* (2) L. Linmaeanus, Fée, C.Chr., Ind. Fil.; L. heteroclitus, $C$. Chr., var. Linnaeanus, Christ, Philipp. Journ., II, 160; Acrostichum Linnaeanum, Hk., Hk. Bk., Syn. Fil., 417; Hk., 2 ${ }^{\text {nd }}$ Cent. of Ferns, tab. XXVI; Gymnopleris Linnaeana, Christ, Copel., Polypod. Philipp., 41.

Rhizome creeping, scaly. Stipes more or less distant, $1 / 2-3$ c.M. apart, erect, slender, 5-15 c.M. long, scaly \pm throughout or at the base only. Barren tronds 10-25 c.M. long, $1-1 \frac{1}{2}$ c.M. broad, linear-lanceolate, entire or repand, narrowed rather gradually towards both ends, simple or sometimes with a terminal pinna similar to the simple fronds and below this $1-2$ pairs of mostly very small, sessile or stalked, oblong or linear-lanceolate lateral segments to $\pm 12 \frac{1}{2}$ c.M. long, to $\pm 1 / 2$ c.M. broad. Texture herbaceous to papyraceous; surfaces naked; main veins distinct nearly to the edge, more or less zigzag; areolae copious; no free veinlets. Fertile fronds simple or sometimes pinnate, similar to the barren ones but shorter and narrower, sometimes linear, on stipes $10-20$ c.M. long.

Malaya, Annam. 
* (3) L. Iecurrens, Bt., Enum., 206; Acrostichum variabile, Hk., Hk. Bk., Syn. Fil., 417 (excl. var.); A. variabile, Hk., var. decurrens, Rac., Flor. Btz., I, 49; Gymnopteris lariabulis, Bedd, Handb. Ind. Ferns, 429; Ferns Br.I., II, tab. CCLXXII; G. decurrens, Moore (not Hk.), Hk., Gard. Ferns, tah. VI ; - var. rasamalae, Rac., l. c., 50.

Rhizome wide-creeping, the scales linear-lanceolate. Stipes $1 / 2-2$ c.M. apart, $0-10$ c.M. long. Sterile fronds ovate-oblong or spathulate, 15-45 c.M. long, 4-10 c.M. broad, acute or acuminate, the edge entire, the base cuneate or rounded, decurrent on the stipe. Texture papyraceous or herbaceous; surfaces naked; midrib prominent; main veins distinct, straight or zigzag, reaching nearly to the edge; areolae with free veinlets. Fertile fronds linear or linear-lanceolate, $15-50$ c.M. long, $2-7 \mathrm{~m}$. M. broad, on stipes to 50 c.M. long.

$$
\text { onit = L. diveranfolus (undiv.) SI. } 1.434
$$

Var. rasamalae: Barren fronds 40-80 c.M. long, the apex acuminate; fertile fronds lanceolate, to $\mathbf{3}$ c.M. broad, long-stalked.

Trop: Asia; -- var. rasamalae: Java.

* (4) L. trifidus, v. A. v. R., Bull. Dép. Agr. I. N., 1908, XVIII, 26.

Rhizome creeping. Stipes approximate, $\pm 10-20$ c.M. long, those of the fertile fronds the longest, densely clorhed with lanceolate-subulate, short, crisped, brown scales, at length less scaly. Fronds simple, lanceolate or more commonly 5 -fid with the lateral lobes similar to the central one but shorter. Simple fronds \pm 25 c.M. long, \pm 7 c.M. broad, the apex rather suddenly acuminate, the edge irregularly wavy, the base suddenly narrowed and then short-decurrent. Central lobe of the $\mathbf{3}$-fid fronds similar to the simple fronds, but joined at the base with the lateral segments, which have the lower base suddenly short-decurrent upon the stipe. Texture herbaceous; surfaces naked; costae \pm scaly beneath, but more distinctly towards the base; main veins conspicuous, nearly straight to the edge, united by strongly arching transversing veins forming $\pm 6-7$ distinct primary areolae on each side of the costae, divided into finer secondary ones with free veinlets. Fertile fronds quite similar to the barren ones but much smaller, the central lobe $\pm s$ c.M. long, \pm 2 c.M. broad, the lateral lobes smaller. - The description is taken from specimens cultivated in the Buitenzorg gardens an probably gatheral in one of the malayan islands. Near L. Harlandii, C. Chr. (= Gymnofteris decurrens, IIk., Fil. Exot., tab. XCIV).

? Malayan. 


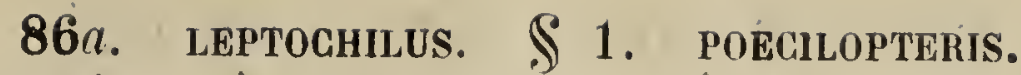

(5) C. Iatifotius, c. Chr., Ind. Fil.; Acrostichum taccaefolium, Hk., Hk. Bk., Syn. Fil., 418 ; Gymnopteris lalifolia, Pr., Tent. Pterid., 244; G. taccrefolia, J. Sm., Copel., Polypod. Philipp, 42; G. trilobata, J. Sm., Hk., Icon. Pl., X, tab. CMVII; G. subquinquefida, Pr., Epim., 131; Hemigramma lalifolia, Copel., Philipp. Journ., II, 406; III, 51, tab. I; Polybotrya lalifolia, Meyen, (oldest name).

Rhizome short, stout, creeping, the scales copious, dark-reddish-brown linear. Stipes of barren fronds $21 / 2-10$ c.Mr. long, those of fertile fronds about 50 c.M. long, both clothed below with narrow, spreading scales. Barren fronds to 50 c.M. long or longer, typically 5 -fid, sometimes simple and b-8 c.M. broad or pinnate, sometimes rooting at the apex, the pinnate fronds to 60 c.M. long. Pinnae acute, entire, lanceolate, rachis winged in the more complex forms and the lowest pimnae forked. Texture papyraceous; surfaces naked; main veins distinct nearly to the edge, with regular transverse veinlets and copious areolae with included free veinlets. Fertile fronds typically 5 -fid, the central segment \pm 15 c.M. long, the lateral ones \pm 10 c.M. long, both 5-4 m.M. broad, exceptionally simple or pinnate. - Exceedingly variable. Copeland includes this under Ilemigramma latifiola (Syngramma Zollingeri, Diels; probably he is correct in this, and I am inclined to helieve that Hemigramma (Syngramma $\$$ ) would better be treated as a distinct genus.

Philippines.

(6) L. Hollrumgii, C. Chr., Ind. Fil.; Acrostichum Hollrungii, Bk., Ann. of Bot., V, 495; Gymnopteris Hollrungii, Kuhn, Schum. \& Hollr., Flor. Kais. Wilhl., 8.

Rhizome erect, densely clothed with ferrugineous, long-acuminate, bristlelike scales. Stipes scaly at the base, $40-50$ c.M. long, canaliculate. Sterile fronds $25-50$ c.M. long, $55-40$ c.M. broad, with the base pedatisecl, the higher part pinnatifid; lobes lanceolate, $25-30$ c.M. long, 5-4 c.M. hroad, entire, acuminate. Texture subcoriaceous, surfaces naked. Fertile fronds $25-50$ c.M. long, 50-40 c.M. broad, pinnatifid, on stipes 60-65 c.M. long; lobes $15-20$ c.M. long, linear, entire or slightly sinuato-repand.

New Guinea.

* (7) L. zeylamicus, C. Cher., Ind. Fil.; Acrostichum quercifolium, Relz, Hk. Bk., Syn. Fil., 418; Gymnopteris quercifolia, Bernh., Hk., Fil. Exol., tab. LXXX; Hk., Icon. Pl., X, lab. CHV; Bedd., Ferns S.I., tab. XLVII; Ophioglossum zeylanicum, Houtt., (oldest name).

Fucrs. 
Rhizome stout, creeping, scaly. Stipes of barren fronds $21 / 2-5$ c.M. long, clothed with soft, brownish or reddish, spreading hairs. Barren fronds oblong, 7-10 c.M. long, 5 $1 / 2-6$ c.M. broad, with an ovate or oblong, large, blunt, bluntly lobed terminal pinna, the lobes sometimes reaching to $1 / 4$-way down to the costa. Below this usually a single pair of small, sessile, roundish or ovate, spreading, auricled segments, blunt at the apex, \pm truncate or subcordate at the hase. T'exture thinly herbaceous; main veins distinct to the edge; veins hairy beneath; areolae copious, with free veinlets. Fertile fronds ternate, on slender stipes $15-25$ c.M. long, naked except at the base; terminal segment linear, $2 \frac{1}{2}-5$ c.M. long, $\pm 2 \frac{1}{2}$ m.M. broad, entire; lateral segments erecto-patent, similar but shorter.

Trop. Asia.

$$
\text { onit }=L \text {. heteroclitios. SI } 1.434 \text {. }
$$

(8) C. inconstans, C. Chr., Ind. Fil.; Gymnopleris inconslans, Copel., Polypod. Philipp., 45; L. heleroclitus, C. Chr., var. inconslans, Christ Philipp. Journ., II, 160.

Rhizome wide-creeping, scaly. Sterile fronds rarely simple, often pinnate, 4-8 c.M. or sometimes more long, linear, lanceolate, oblanceolate or ovate, on stipes $1-3$ c.M. long, the stipes slender, scaly or naked; terminal pinna commonly very long, narrow, proliferous; lateral pinnae 2-6-jugate, erectopatent, commonly obovate, rarely orbicular or lanceolate, obtuse, entire or rarely serrate, \pm decurrent; veins inconspicuous; areolae few, with free veinlets. Fertile fronds linear, on stipes 5-10 c.M. long, pinnate, the stipes erect, filiform, naked above, the pinnae 2-4-jugate, distant, the lowest sometimes stalked, orbicular or oblong, entire, 1-4 m.M. long; free veinlets few or none.

Luzon.

(9) Dr. prolifer, C. Chr., Ind. Fil.; Polybotrya prolifera, Bory, Bél., Voy. Bot., II, 18; Poecilopteris prolifera, Pr., Epim., 172.

Stipes naked, subtrigonal, twisted, $\pm 17 \frac{1}{2}$ c.M. long. Fronds dimorphous. Barren fronds pinnate with $\pm 5^{\prime}$ pinnae on each side below the often proliferous terminal one, $\pm 22 \frac{1}{2}$ c.M. long. Pinnae alternate, $7-10$ c.M. long, $\pm 21 / 2$ c.I. broad, acuminate, ovate-oblong, short-stalked, truncate at the base, the edge broadly and bluntly crenate, the crenations finely toothed. Colour pale-green; veins whitish and very conspicuous beneath. Fertile fronds with the pinnae linear, pale-reddish, slightly twisted.

New Guinea; Br. India. 
86a. LEPTOGHLUS. $\$ 1$. POEGILOPTERIS.

* (10a) H. heteroclitus, C. Cher., Ind. Fil.; Acrostichum flagelliferum, Wall., Rac., Flor. Btz., I, 56 ; Hk. \& Grev., Ic. Fil., tab. XXIII; Bl., Flor. Jav., II, 37, tab. XIII; Gymnopteris flagellifera, Bedd., Handb. Ind. Ferns, 433; Poecilopteris flagellifera, J. Sm., Bedd., Ferns Br.I., I, tab. CXII; Acrosichum heteroclilum, Pr., (oldest name); - var. curybasis, Christ, Philipp. Journ., II, 159 ; - var. Foxworthyi, Christ, l.c., 160.

lhizome creeping, firm, the scales brown, lanceolate. Stipes scattered, $15-25$ c.M. long, often scaly. Fronds $15-43$ c.M. long, simple or more commonly with an entire, toothed or repand, often long-acuminate and rooting terminal pinna and $1-6$ pairs of stalked, lanceolate, similar but not longacuminate lateral ones; terminal pinna to 40 c.M. long, lateral ones 7-15 c.M. long, $2-5$ c.M. broad. Texture herbaceous; surfaces naked; main veins distinct to the edge; areolae copious, with or without free veinlets. Fertile fronds similar, but the pinnae smaller and narrower, sometimes partially covered with meniscioid sori. - Variable.

Var. eurybasis: Differs from the type by its aberrant fronds being in part 2-pinnate, deltoid at the enlarged base, posteriorly deeply incised. Even the fertile fronds are sometimes 2-pinnate at the base.

Var. Foxworthyi: Fronds reduced; lateral pinnae 2, reduced, orbicular or oblong, hardly $1 / 2$ c.M. long; terminal pinna linear or oblong, linear-lanceolate when fertile, with 2 ovate lateral lobes.

Trop. \& Subtrop. Asia; Melanesia; - var. eurybasis: Mindanao; - var. Foxworthyi: Luzon.

(10b) L. Stolonifer, Christ, Bull. Herb. Boiss., 2e Série, VI, 1004.

Rhizome stoloniferous, the stolones bearing rows of simple fronds similar to the pimnae of the normal barren fronds, decurrent at the base, on stipes \pm 6 c.M. long. Stipes of barren fronds stramineous, 20-25 c.M. long, more or less densely clothed with black, subulate or setiform scales. Barren fronds deltoid-ovate, \pm 40 c.M. long, \pm 30 c.M. broad, pinnate. Terminal pinna largest, \pm 25 c.M. long, $\pm 4 \%$ c.ll. hroad, oblong, acute, repando-lobate, decurrent at the narrowed base, the lohes irregular; short, obtuse; lateral pinnae distant, alternate, $\pm 2-5$ on each side, erecto-patent, \pm 20 c.M. long, 2-4 c.M. broad, subsessile, the base rather unequal-sided, sometimes subauriculate on the lower side, the edge repando-lobate or undulato-crenate, the apex acute, the lobes \pm 10 on each side, short; lowest pinnae hardly reduced. T'exture herbaceous; costae distinct; main veins distinct when seen towards the light, straight from the costa to the edge; areolae with free 
86a. LEPTOCHILUS. $\$ 1$. POECILOPTERIS.

veinlets. Fertile fronds $\pm 1 / 2 \times$ as long as the barren ones, on stipes \pm 14 c.M. long; pinnae $\mathbf{5}-\mathbf{7}$, much contracted, linear-lanceolate, $\pm \mathbf{5}$ c.M. long, 7-10 m.M. broad, subacute, the base subcordate.

Luzon.

- (11) L. diversifolius, C. Chr., Ind. Fil.; Acrostichum diversifolium, Bl., Rac., Flor. Btz., I, 48; Bl., Flor. Jav., II, 36, tab. XIl; Poecilopleris diversifolia, Pr., Tent. Pterid., 242.

Rhizome woody, creeping, the scales lanceolate. Fronds approximate; barren fronds $\pm \quad 50-70$ c.M. long, long-stalked, simple or more commonly witl a terminal segment to 40 c.M. long, to $12 \frac{1}{2}$ c.M. broad, ovate-lanceolate, acuminate, entire or repando-sinuate and below this $1-5$ pairs of lateral segments similar to the terminal one, but shorter and narrower, to 20 c.M. long, to 7 c.M. broad, stalked. Texture herbaceous; surfaces naked; areolae with few free veinlets. Fertile fronds with $1-2$ pairs of short-stalked, ovatelanceolate lateral pinnae to 10 c.I. long, to $1 \frac{1 / 4}{4}$ c.M. broad and a longer terminal one.

Malaya.

(12) L. Preslianus, C. Chr., Ind. Fil.; Acrostichum Preslianum, Hk., Hk. Bk., Syn. Fil., 420; Poecilopteris Presliana, Moore, Bedd., Ferns Br.I., II, tab. CCLXIX; Gymnopleris Presliana, J.Sm., Bedd., Handb. Ind, Ferns, 459; Heteroneuron Preslianum, Fée, (oldest name).

Rhizome stout, creeping, the scales narrowed, lanceolate. Stipes 10-25 c.M. long, more or less scaly like the rachis and the stalks of the pinnae. Fronds $15-50$ c.M. long, pinnate with \pm numerous erecto-patent, remote pinnae. Lower pinnae stalked, $\breve{-10}$ c.M. long, $1-1 \frac{1}{2}$ c.M. broad, lanceolate, acuminate, the base narrowed, the edge entire. Texture membranaceous or subcoriaceous; rachis \pm winged, especially towards the apex; surfaces naked; venation as in Nephrodium. Fertile fronds generally longer stalked; pinnae much narrowed, lanceolate, $2-5$ c.l. long, $5-7$ m.M. broad.

Philippines; Soulh. India, Madagascar. Sungapore.

(15) L. exsculptus (exculptus), c. Cler., Ind. Fil.; Acrostichum exsculptum, Bk., Journ. of Bot., XXVI, 326.

Rhizome creeping. Stipes of barren fronds slender, naked, \pm 15 c.M. long. Barren fronds lanceolate, pinnate, $20-50$ c.M. long, 5-7 c.M. broad. Pinnae multijugate, sessile, lanceolate, acute, crenate, truncate at the base, ${ }_{2}^{1} 1_{2}-51 / 2$ c.M. long, 8-9 m.M. broad; the lower ones not reduced. T'exture 
rigid; surfaces naked; veins anastomosing as in Nephrodium; main veins distinct to the edge; veins 3 -jugate. Fertile fronds \pm 50 c.M. long, $\pm 51 / 2$ c.M. broad, on longer stipes; pinnae sessile, remote, 4-5 m.M. broad.

Borneo.

(14) T. celebicus, C. Chr., Ind. Fil.; Acrostichum celebicum, Bk., Kew Bull., 1901, 145.

Stipes densely tufted, slender, naked, 7-15 c.M. long or longer, those of the fertile fronds the longest. Fronds oblong-lanceolate, the barren ones 12-15 c.M. long, $5-8$ c.M. broad, pinnate. Pinnae sessile, lanceolate, $1 \frac{1}{5}-1 \frac{1}{2}$ c.M. broad at the base, those of the fertile fronds narrower, slightly pinnatifid, the lobes obtuse, the base truncate, auricled on the upper side. Rachis slender, pubescent; under surface obscurely pubescent; main veins pinnate; veins 5-4-jugate, anastomosing at the apex.

Celebes.

* (15) L. virens, C. Chr., Ind. Fil.; Acrostichum virens, Wall., Hk. Bk., Syn. Fil., 420, p. p.; Hk. \& Grev., Ic. Fil., tab. CGXXI; Gymnopteris virens, Keys., Pol. Gyath. Bung., 35; G. contaminans, Bedd., Handb. Ind. Ferns, 435; Poecilopteris repanda, Bedd., Ferns S.I. tab. CCII; P. semicordata, Moore, Bedd., Ferns Br.I., II, tab. CGLXX.

Rhizome thick, short-creeping. Stipes scaly, 10-20 c.M. long. Fronds 30-60 c.M. long, pinnate; rachis \pm scaly, more or less winged. Pinnae 11-30 on each side, sessile or short-stalked, lanceolate, to 8 c.M. long, to $21 / 2$ c.M. broad, the point acute, the edge entire, crenate or more or less deeply lobed or repand, with the lobes crenate or toothed; terminal pinna often \pm elongated and proliferous. Texture rather herbaceous; costae prominent; main veins distinct to $\pm 2 / 3$ of the way to the margin; areolae broad, irregular, in 3-4 rows, the costal ones without free veinlets, the others generally with several free or irregularly joining included veinlets. Fertile fronds with the pinnae much contracted.

Malacca, Celebes, Philippines; Burmah, South. India, Ceylon.

* (16a) L. cuspidatus, C. Chr., Ind. Fil.; Acrostichum repandum, Bl., Rac., Flor. Btz., I, 55; Bl., Flor. Jav., II, 39, tab. XIV-XV; Gymnopteris repanda, Christ, Farnkr.d. Erde, 50; Poecilopteris repanda, Pr., Epim., 172; Nephrodium cuspidatum, Pr., (oldest name); - var. Quoyanus; A. Quoyanum, Gaud., Freyc., Voy. Ur. Phys., Bot., 506, tab. III. 
Rhizome creeping, the scales, short, lanceolate. Stipes of barren fronds 15 -50 c.M. or more long, naked or slightly scaly. Barren fronds $30-70$ c.M. long, $20-30$ c.M. broad, sometimes elongated, with about $10-20$ pinnae on each side; lower pinnae $10-15$ c.M. long, 2-3 c.M. broad, short-stalked, the edge cut into entire, crenate or serrate, blunt lobes reaching to $1 / 3$ of the way down, sometimes with a seta in the sinuses. Texture herbaceous; rachis and both surfaces naked, or the rachis scaly; main veins distinct; areolie copious, without free veinlets. Pinnae of fertile fronds $5-10$ c.M. long, 5-7 m.M. broad, stalked, entire or more or less deeply repand.

Var. Duoyanus: Barren pimnae lobed $1 / 2$-way down or more to the costa, the lobes toothed.

Trop. Asia, Australia, Polynesia, Seychelles; - var. Quoyanus: Philippines, Moluccas, New Guinea.

L. Naumanni, C. Cher., Ind. Fil.; Heteronevrm Naumanni, Kuhn, Forschr. Gaz., IV, Farne, b, tah. I; Gymnopteris Naumanni, Diels, Schum. \& Laut., Flor. deut., Sch.geb., 117.

Rhizome creeping, elongate, clothed like the base of the stipes with lanceolate, obtuse, ferrugineous scales. Fronds distichous, pinnate, pinnatifid towards the often proliferous apex. Stipes of barren fronds 18-24 c.M. long, stramineous, deeply sulcate, sparingly scaly. Fronds $25-47$ c.M. long, 14-22 c.M. broad; oblong, acuminate. Lower pinnae stalked, $9-13$ c.M. long, \pm .2 c.II. broad, lanceolate-acuminate, subpinnatifid; the apex sharply serrate, the base cuneate; higher pinnae sessile, highest confluent. Lobes oblong, toothed, the lower anterior teeth produced. Texture subchartaceous; surfaces naked; colour greenish-opaque; costulae prominent; areolae distinct, lax, appendiculate. Fertile fronds 50-55 c.M. long, 18-20 c.M. broad, ovate-lanceolate, acuminate, on stipes to \pm 42 c.M. long; lower segments sulpetiolate, higher ones sessile, the longest $10-15$ c.M. long, \pm 1 c.M. broad, lobato-pinnatifid, acuminate; lobes ovate or elongate, entire; areolae in 1 row on each side of the costulae.

New Guinea; New Hannover.

(17) L. Zollingener, Fée, Gen., 55; Acrostichum subrepandum, IIk., y Hk. Bk., Syn. Fil., 419; Gyminopteris subrepanda, Hosm., Copel., Polypod. Philipp., 45; Poccilopleris subrepanda, Pr., Bedd., Ferns Br.I., II, tab. CCGXXXIX; Acrostichum Zollingeri, Kze, (oldest name).

Rhizome woody, wide-creeping. Stipes of barren fronds stout, erect, 
nearly naked. Barren fronds varying from simple, \pm 50 c.M. long, $\pm \mathbf{5} 1 / 2$ c.M. broad, to copiously pinnate, 60 c.M. long, 50 c.M. hroad, with several linear-oblong, entire or subrepand pinnae on each side, which are sometimes 15-25 c.M. long, \pm b c.M. broad. Texture subcoriaceous; rachis and surfaces naked; main veins distinct nearly to the edge, with copious free veinlets in the areolae. Fertile fronds similar, but smaller.

\section{Malaya; Fiji.}

(18) L. scailpturatus, C. Chr., Ind. Fil.; Acrostichum costatum, Wall., Hk., Spec. Fil., V, 262; Gymnopteris costuta, Bedd., Copel., Polypod. Philipp., 44; Poecilopteris costata, Moore, Ind., 8; Heteronevron scalpturatum, Fié, (oldest name).

Rhizome creeping, bearing subulate scales. Stipes 45 c.M. or less long. Fronds 60 c.M. or more long. Pinnae up to 55 c.M. long and 8 c.M. broad, stalked, acuminate, entire, crenate or sinuate. Texture subcoriaceous; surfaces naked; main veins prominent, close; areolae and excurrent included veinlets copious. Pinnae of fertile fronds smaller and more coriaceous.

Philippines; North. India, Burmah. halacea.

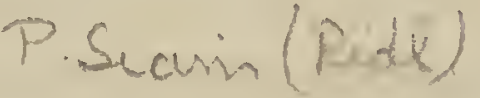

\section{\$2. CHRYSODIUM.}

a. Fertile fronds simple, as are the barren ones.

b. Barren fronds small, under $7 \frac{1}{2}$ c.M. long.

*. Fertile fronds obtuse.

(19a) L. minor.

*.*. Fertile fronds acuminate.

(19b) L. rizalianus.

b.b. Barren fronds larger, more than $7 \frac{1}{2}$ C.M. long when fully developed. c. Barren fronds rounded at the base. (20) L. antrophyoides. c.c. Barren fronds subacute or gradually narrowed at the base.

d. Barren fronds 10-15 c.M. long, to \pm 1 c.M. broad. *. Rhizome shorl.

(21a) L. hydrophyllus. *.*. Rhizome long.

(21b) L. modestus.

d.d. Barren fronds $15-45$ c.M. long, 1-5 c.M. broad.

e. Rhizome creeping.

e.e. Rhizome scandent.
(22) L. lanceolatus.

(25) L. axillaris. (24) L. Raapii.

a.c. Fertile fronds ternate, barren ones simple or ternate. 
* (19a) L. mimor, Fée, C. Chr.. Ind. Fil.; Acrostichum minus, Melt., Hk. Bk., Syn. Fil., 420; Gymnopteris minor, Hk. (not Bedd.), Copel., Polypod. Philipp., 42: Hk., $2^{\text {nd }}$ Cent. of Ferns, tab. LXXVIII (the description, not the figure, which is Asplenium); G. minus, Bedd., Handb. Ind. Ferns, 430; Ferns Br.I., I, tab. CXVI.

Rhizome wide-creeping, firm, scaly towards the apex, the scales lanceolate. Stipes remote, slender, those of the barren fronds $21 / 2-b$ c.M. long. Sterile fronds $5^{1} / 2-5$ c.M. long, $\pm 1 \frac{1}{2}-21 / 2$ c.M. broad, ovate-oblong, the point bluntish, the edge quite entire, the base tapering gradually into the stipe. Texture membranaceous or herbaceous; surfaces naked; costa distinct; areolae with free reinlets, bounded by a \pm wavy intramarginal line. Fertile fronds $3 \frac{1}{2}-\breve{b}$ c.M. long, $\pm 5 \mathrm{~m} . \mathrm{M}$. broad, linear-lanceolate, obtuse, on stipes $7 \frac{1}{2}-10$ c.M. long.

Philippines, Malacca; North. India.

(19b) L. rigalianuis, Chmist, Bull. Herb. Boiss., 2e Série, VI, 1004 ; L. normalis, Copel., Philipp. Journ., III, 31, p. p.

Rhizome short-creeping, slender, crowned with flaccid, brown, subulate scales. Fronds scattered or approximate. Barren fronds rather sessile, spathulate, cuneate-oblong, $\pm 4^{1} / 2$ c.M. long, \pm 1 c.M. broad, obtuse, the base narrowed. Texture herbaceous; costa distinct: areolae hidden, in 1 or rarely 2-3 rows on each side, with free included veinlets. Fertile fronds linear, \pm 6 c.M. long, $\pm 1 \frac{1}{2}$ c.M. broad, acuminate, on stipes \pm 6 c.M. long.

Luzon.

(20) L. antroplnyoides, C. Chr., Ind. Fil.; Acrostichum anliophyoides, Bk., Journ. of Linn. Soc., Bol., XXII, 231.

Rhizome short-creeping. Fronds sessile, oblanceolate, 1弓-20 c.M. long, $2-2 \frac{1}{2}$ c.M. broad, the point acute, the base rounded. Texture subcoriaceous; surfaces naked; veins obscure, immersed; areolae small. Fertile fronds linear, rigid, 20-25 c.M. long, 5-5 m.M. broad, bearing the sori in the upper half, the lower half narrowed to a naked wing to the costa.

Borneo.

(21a) I. Inydrophyllus, Copel., Philipp. Jourı., I, Suppl., 146.

Rhizome short-creeping, clothed at the extremity with short, fuscous scales. Stipes $1-7$ c.M. long, those of the fertile fronds the longest. Barren fronds linear-lanceolate, acute at the apex, subacute at the base, 1 c.M. 
broad, \pm 10 c.M. long and entire, rarely 20 c.M. long and undulate. Texture fleshy, papyraceous when dry; surfaces \pm naked; veins hidden, inconspicuous; areolae with few free veinlets. Fertile fronds linear, \pm 7 c.ll. long, $\pm \mathbf{3}$ m.M. broad, obtuse, narrowed gradually into the stipe.

Mindanao.

(21b) L. modestus, C. Chr., Ind. Fil.; Acrostichum modestum, Blk., Journ. of Linn. Soc., Bot., XXII, 231.

Rhizome slender, wide-creeping, the scales small, lanceolate. Stipes distant, slender, $\breve{b-8}$ c.M. long. Fronds simple, $10-15$ c.M. long, b̆-9 m.M. broad at the middle, tapering gradually to the base and acuminate apex, the margin entire, the surfaces naked. Areolae hexagonal. Fertile fronds 5-8 c.M. long, $4-4^{1}{ }_{2}$ m.M. broad.

\section{Borneo.}

* (22) L. Innceolatus, Fée, C. Chr., Ind. Fil.; Acrostichum lanccolatum, Hk., Hk. Bk., Syn. Fil., 420; Gymnopteris lanceolala, Bedd. (not Hk.), Copel., Polypod. Philipp., 42; G. Feei, Moore, Bedd., Ferns S.I., tab. XLVIII; G. variabilis, Bedd., var. lanceolata, Bedd., Handb. Ind. Ferns, 429; - var. normalis, Hk., Spec. Fil., V, 276; G. normale, J. Sm., Journ. of Bot., III, 405 ; L. normalis, Copel., Philipp. Journ., III, 51, p. p.

Rhizome woody, creeping. Stipes of barren fronds $21 / 2-15$ c.M. long. Barren fronds 1 b- 30 c.M. long, $1-5$ c.M. broad, the point blunt or acute, the edge entire, the lower part narrowed very gradually. Texture herbaceous; surfaces naked; main veins short or indistinct; areolae copious, with free veinlets. Fertile fronds $1 \mathfrak{b}-50$ c.M. long, $3-7$ m.M. broad, the stipes as long.

Var. normalis : Barren fronds sessile.

Trop: Asia.

* (23) L. axillanis, Kıf., Enum., 147, lab. I, fig. 10; Acrostichum axillare, Cav., Hk. Bk., Syn. Fil., 420; A. variabile, Hk., var. axillare, Rac., Flor. Btz., I, 49; Gymnopleris variabilis, Bedd., var. axillaris, Bedd., Handb. Ind. Ferns, 430 ; G. axillaris, Pr., Copel., Polypod. Philipp., 42 ; Bedd., Ferns Br.I., II, tab. CCLXXI.

Rhizome wide-scandent, slender, much branched. Barren fronds $2-7$ c.II. apart, 1丂-4弓 c.M. long, 1-4 c.M. broad, the point bluntish or nearly so, the edge entire, the lower half tapering gradually to the base or a short 
or rather long stipe. Texture papyraceous; surfaces naked; areolae copious, with abundant free veinlets. Fertile fronds $15-50$ c.M. long, $21 / 2-71 / 2 \mathrm{~m} . \mathrm{M}$. broad, flexuose, on stipes $21 / 2-15$ c M. long.

Trop. Asia.

* (24) L. IEanpiii, v. A. v. R., Bull. Dép Agr. I. N., 1908, XVIII, 27, tab. VIII.

Rhizome erect, clothed with densely crowded, erect, linear-lanceolate scales with a dark-brown longitudinal axis and a pale-brown margin. Stipes densely tufted, $15-50$ c M. long, naked, firm, erect, those of the fertile fronds the longest. Fronds dimorphous. Barren fronds simple or some of them ternate, the simple ones ovate-elongate, \pm entire, $12-20$ c.M. long, 3-4 c.M. broad, broadest near the \pm rounded or broadly cuneate base, narrowed gradually towards the short-acuminate point, the ternate ones with the segments similar to the simple fronds, but smaller. Texture flaccido-coriaceous; surfaces naked; veins prominent, reticulate as in Acrostichum aureum, $L$. Fertile fronds ternate, the segments stalked, linear, \pm 4-6 c M. long, \pm 5 m.M. broad, acute. Sori occupying the whole under surface except the midribs and edges.

Batu lslands (Raap).

\section{3. LOMAGRAMMA.}

*. Texlure membranaceous. Pinnae serrate.

(25) L. lomarioides. *.*. Texlure subcoriaceons. Pinnae entire or abscurely crenate.

(26) L. perakensis.

* (25) D. Iomarioides, BB., Enum., 206; Acrostichum Blumeanum, Hk., Rac., Flor. Btz., I, ร̌, p. p.; A. lomarioides, Christ, Ann. Btz., XV, 179; Lomagramme lomarioides, J. Sin., Bedd., Handb. Ind. Ferns, Suppl., 106 ; Gymnopteris lomarioides, Christ, Bull. Herb. Boiss., 2e Série, I, 456; - var. pteroides; Lom. pteroides, J. Sm., Journ. of Bot., III, 402; Bau. \& Hk., Gen. Fil., tah. XCVIII ; - var. subcoriacea, Copel., Philipp. Journ., III, 52.

Rhizome wide-scandent, the scales lanceolate. Stipes $15-50$ c.M. long, deciduously scaly. Barren fronds 50-100 c.M. long. Pinnae numerous, sessile, articulate, rather falcate, $6-20$ c.M. long, $1 \frac{1}{2}-21 / 2$ c.M. broad, the base 
truncate, rounded or broadly cuneate, the upper base not rarely broader than the lower, the edge serrate or toothed, but more prominently lowards the apex, the apex acuminate. Texture thinly membranaceous, transparent, pellucid-dotted; rachis and costae \pm scaly beneath, the former more or less winged, especially towards the apex; veins reticulate; areolae without free veinlets. Fertile pinnae $\pm 6 \mathrm{~m}$.M. broad, normally soriferous throughout beneath, sometimes partially contracted and soriferous.

Var. pteroides: Sori confined to the margin of the fertile pinnac.

Var. subcoriacea: Texture subcoriaceous, reddish when dry; veins very conspicuous beneath.

Malaya; Assam, Polynesia; - var. pteroides: Celebes, Philippines; - var. subcoriacea: Mindanao.

(26) A. perakensis, C. Chr., Ind. Fil.; Acrostichum Bhmeamun, Hk., Rac., Flor. Btz., I, 55, p. p.; Lomagramme pernkensis, Bedll., Handb. Ind. Eerns, Suppl., 107.

Like L. lomarioides, Bl., but the texture subcoriaceous, the pimnae entire or obscurely crenate, the veins less conspicuous, the rachis not winged. Fertile pinnae $1-4$ m.M. broad.

Java, Malacca.

\section{6\%. PLATYTAENIA, Kukn.}

Like Leptochilus, but the paraphyses with a large terminal cell and the spores globoso-tetrahedral.

Fronds pinnate, with the vegetative characters of Taenitis by the appearance of Leptochilus.

Nalayan and Polynesian.

P. Requiniana, Kurhe, Copel., Polypod. Philipp., 111; Acrostichum Requinianum, Gaud., Hk., Spec. Fil., V, 269; Freyc., Voy. Ur. Phys., Bot., 504, tab. IV.

Rhizome shor', hairy. Stipes approximate, 20-30 c.M. long. Barren fronds ternate or pinnate. Pinuae linear-lanceolate, $12-18$ c.ll. long, \pm 5-4 c.II. broad, narrowed gradually towards the apex, the base narrowerl. Venation \pm as in Acrostichum aureum, $L$. Fertile fronds pinnate; pinnae 
linear, short-stalked, 10-20 c.M. long, $\pm 5 \mathrm{~m}$.M. broad, acute, the base narrowed. Sori filling up the whole under surface of the fertile pinnae, except the costa.

Singapore, Philippines, Moluccas, New Guinea; West. Polynesia. 
FAMILY VII. PARKERIACEAE. 



\section{PARTERIA CEAE.}

Sporangia dorsal, not gathered in sori, scattered irregularly on the few longitudinal veins of the fertile fronds. Indusium wanting, but the margin of the fertile fronds broadly recurved, hardly changed in texture, the edges meeting against the midribs, quite enclosing the capsules when young. Ring vertical, broad, incomplete, short or interrupted by the very short, nearly wanting stalk of the capsule, wanting in the american form. Stomium transversal.

Rhizome short, erect. Fronds divided, rather dimorphous; veins anastomosing, but more copiously in the barren than in the fertile fronds.

Pantropical; in quiet, shallow waters, or even dry ground in humid regions or during the rains.

No. 87. Ceratopteris.

\section{CERATOPTERIS, Brongmiart.}

Characters of the family.

* C. Thalictroidles, Brong., Rac., Flor. Btz., I, 165; Hk. Bk., Syn. Fil., tab. III, fig. 32; Diels, in Engl. \& Prantl, Nat. Pfl. Fam., I ${ }^{4}$, fig. 178-179; Bau. \& Hk., Gen. Fil., tab. XII; Bedd., Ferns S.I., tab. LXXV; Parkeria pleridioides, Hk., Exot. Flor., II, tab. CXLVII; Hk. \& Grev., Ic. Fil., tab. XCVII; Acrosichum thalictroides, L., (oldest name).

Rhizome erect. Stipes tufted, thick, succulent, filled with large air-cells, naked, 5-20 c.M. long. Barren fronds floating or erect, 2-3-pinnatisect with linear or lanceolate ultimate segments $1-7$ c.M. long; fronds of the young plants simple or slightly incised. Texture flaccid, succulent; surfaces naked; veins anastomosing copiously and irregularly. Fertile fronds with the segments narrow-linear, pod-like, the veins few, distantly anastomosing, running down the frond longitudinally. - Parkeria pteridioides, II/. is the american form with exannulate capsules.

Pantropical. 

FAMILY VIII. OSMUNDACEAE. 



\section{OSMUUNDACEAE.}

Sori dorsal (on the under surface of normal segments) or lateral (on the margin of much contracted fertile segments). Sporangia with a very short, incomplete, horizontal ring often consisting of a small group of thickened cells only. Stomium vertical.

Caudex thick, rarely arborescent. Stipes dilated at the hase, not articulate to the caudex. Fronds large, at least simply pinnate, covered with a tomentum of long. wonlly hairs when young, at length naked; veins free.

Generally inhabiting temperate climates.

\section{Key to the genera.}

* Fertile segments much contracted, articulate to the rachis. Sori globose, placed in opposite, marginal clusters. Texture of the fronds herbaceous or coriaceous.

No. 88. Dsmundat.

$\div \div$. Fertile segments not contracted, not articulate to the rachis. Sori \pm flat, dorsal. Texture of the fronds membranaceous. No. 89. Leptopteris.

\section{OSMIUIDA, tinné.}

Sori subglobose, placed in opposite, marginal, thyrsoid clusters No indusium.

Fronds large, at least simply pinnate, herbaceous or coriaceous; leaflets dimorphous, articulate to the rachis, the fertile ones much contracted; veins free. Hk. Bk., Syn. Fil., tah. VIII, fig. 62 ; Diels, in Engl. \& Prantl, Nat. Pfl.Fam., I', fig. 205.

Pantropical, and extra-tropical in the northern hemisphere.

\section{Arrangement of the sections.}

S1. PLENASIUM. Pinnae at best lobed.

2. OSMUNDASTRUM. Pinnae deeply pimnatifid. (Not in Malaya).

\$3. EU-OSMUNDA. Pinnae pinnate. (Not in Malaya). 


\section{S 1. PLENASIUM.}

- (1) D. javanica, zt., Rac., Flor. Btz., I, 丂̆; Bedd. Ferns S.I., tab. LXXVII; O. Banksiaefolia, Kuhn, Ann. Mus. Bot. L. B., IV, 299; O. Presliana, J. Sm., Diels, in Engl. \& Prantl, Nat. Pll.Fam., I I, fig. 205, A; 0. bromeliaefolia, Copel., Philipp. Journ., II, 147.

Caudex stout, erect, $30-50$ c.M. high, $10-20$ c.M. or more thick. Stipes $\mathbf{1 5 - 3 0}$ c.M. long, erect, firm, naked. Fronds to $\mathbf{3}$ M. long, 30-60 c.M. broad, simply pinnate, the lower or central pinnae fertile. Barren pinnae erecto-patent, $2-21 / 2$ c.M. broad, lanceolate, the point acute, the edge entire, crenate, serrulate or toothed, the base cuneate. Texture coriaceous; rachis and surfaces naked; veins distinct, pinnate, subspreading (erecto-patent in 0. Banksiaefolia, Kuhn).

Trop. Asia, Japan, Kamschatka.

(2) D. blechnoides, Zoll., Syst. Verz., 49.

Very near 0 . javanica, $B l$, , but broader and thicker. - A dubious species. Java.

\section{LEPTOPTERIS, Presi.}

Sori roundish-oblong, dorsal, occupying the lower part of the veins.

Fronds at least 2-pinnate, thinly membranaceous ( \pm as in Hymenophyllum); pinnae not articulate to the rachis, the fertile ones not contracted; veins free. Diels, in Engl. \& Prantl, Nat. Pfl.Fam., I4, fig. 204, B-C.

Almost confined to the south temperate zone.

*. Fronds 2-pinnate. Pinnulae deeply toothed.

(1) L. Wilkesiana. *.*. Fronds 3-pinnatifid. Tertiary segments entire.

(2) L. alpina.

(1) L. Wilkesiana, Christ, Farnkr. d. Erde, 334; Todea Wilkesiana, Brack., Wilk., Expl. Exp., XVI, tab. XLIII; T. Fraseri, Hk. \& Grev., var. Willesiana, Hk. Bk., Syn. Fil., 427.

Caudex erect, arborescent, to 2-5 M. high. Stipes $15-25$ c.M. long, firm, naked. Fronds 1-2 M. long, 50-80 c.M. broad, ovate, 2-pinnate. Pin- 
nae close, lanceolate, $21 / 2-3$. c.M. broad, connected by a narrow wing, the lower ones not much shorter, deflexed. Pinnulae linear-oblong, $\pm \mathrm{b}$ m.M. broad, the edge sharply and deeply toothed. Texture thin; rachises villose. New Guinea; Polynesia.

(2) C. alpina, C. Cher., Ind. Fil.; Todea alpina, Bk., Kew Bull., 1899, 121.

Stipes short, naked. Fronds oblong-lanceolate, $45-60$ c.l. long, 20-2b c.M. broad at the middle, narrowed gradually towards the base. Pinnae lanceolate, sessile, $\pm 21 / 2$ c.M. hroad, the rachis narrowly winged; lower pinnae deflexed. Pinnulae lanceolate, sessile, erecto-pateut, deeply pinnatifid. Ultimate segments linear, entire, 1-nerved. Texture membranaceous; rachis and surfaces naked. Sori few, scattered irregularly.

New Guinea. 

FAMILY IX. MARATTIACEAE. 



\section{MARATTIACEAE.}

Sori on the under surface of normal fronds, round or oblong, consisting of $\pm 6-24$ free or connected capsules placed in a whorl or in 2 close rows; indusium wanting or minute, consisting of 2 opposite, flat, entire, or deeply fimbriate, inconspicuous, inferior scales, adpressed to the parenchyma; annulus wanting; sporangia opening by a slit down the inner side or by a pore at the apex.

Rhizome erect or creeping. Stipes with 2 large, stout stipules. Fronds either large and pinnately divided or small and simple or digitate; leaffets often articulate; veins free or anastomosing.

Tropical, and extra-tropical in the southern hemisphere.

\section{Key to the genera.}

a. Sporangia 2-serial, contiguous but not concrete. Fronds large, pinnately divided; veins free.

No. 90. ngiopteris.

a.a. Sporangia concrete, joined in 2-valved or circular synangia.

b. Synangia 2-valved. Fronds large, pinnately divided; veins free.

No. 91. Manattian.

b.b. Synangia circular. Fronds small, simple, ternate or quinate; veins anastomosing.

No. 92. Christensenia.

\section{1). ANGIOPTERIS, Hoffimann.}

Capsules sessile, not concrete, closely placed in 2 contiguous rows, $2-10$ in a row, forming roundish or oblong, submarginal sori, opening by a slit down the inner side. Indusium minute, squamiform or deeply fimbriate.

Caudex short, thick, often semiglobose. Stipes flanked by 2 large, firm stipulae at the base. Fronds large, 1-3-pinnate; veins free, simple or forked, not rarely accompanied by intermediate spurious veins (recurrent veinlets) running from the margin in the direction of the costa. Hk. Bk., Syn. Fil., tab. IX, fig. 69; Diels, in Engl. \& Prantl, Nat. Pil.Fam., I', fig. 258, A \& 239, A-B. 
*. Fronds simply pinnale.

(1) A. Smithii.

t.+. Fronds 2-3-pinnale.

*. Pinnulae pectinato-serrate, the teeth cartilagineous. (2) A. cartilagidens.

*.*. Pinnulae entire, crenate, serrate or toothed, the teelh not cartilagineous.

(3) A. evecta.p 83 of forms

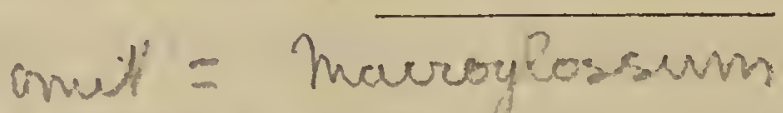

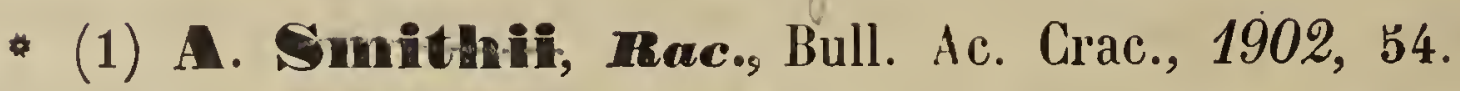

Caudex very short, \pm 10 c.M. thick. Fronds large, $\pm 11 / 2-21 / 2$ M. high (incl. the stipe), simply pinnate. Pinnae $5-10$ or more on each side, shortstalked, articulate, ovate-oblong, $20-40$ c.M. long; 5-10 c.M. broad in the lower half, the base obliquely or unequally rounded or subcordate, the edge entire, the upper half narrowed gradually to the acuminate apex. Texture flaccido-coriaceous; upper surface naked, dark-green, lower pale-green, minutely and sparingly scaly, nearly naked; costae prominent on both sides; veins numerous, generally forked, upcurved, rather spreading at the base, oblique towards the apex; recurrent veinlets wanting. Sori close, subwarginal, the largest consisting of $\pm 20-30$ capsules.

? Malayan.

(2) A. Cantilagidens, Christ, Bull. Herb. Boiss., VI, 207; $A$. carlilaginea, Christ, l. c., tab. IV, fig. 8, a-d.

Like A. evecta, Hoffm., but the fronds larger, to 5 M. long; rachis dark-purple, covered with oblong, subulate, spinuloso-ciliate scales, the ciliae geminate. Pinnulae close, sessile or short-stalked, linear-lanceolate, 10 c.M. or more long, \pm 1 c.M. broad, the margin pectinato-serrate with the teeth oblique or spreading, $1 / 2-1 \mathrm{~m}$.M. long, the apex acuminate, the base equally rounded or cuneate on both sides or the upper base truncate. Texture very coriaceous, the teeth cartilagineous; surfaces naked; costae and veins covered beneath with small, rough, bullate scales; veins very numerous, conspicuous, spreading, with spurious veins. Sori not contiguous, small.

Luzon.

* (5) A. evectu, Hoffm., Rac., lilor. Btz., I, 1; Bedd., Ferns S.I., tab. LXXVIII; Hk., Fil. Exot., tab. LXXV; Polypodium evectum, Forst., (oldest name).

Caudex erect, semiglobose, to \pm 50 c.M. thick. Stipes long, articulate at the base, flanked by 2 large, persistent, leathery stipulae. Fronds large, 
to $4 \frac{1}{2}$ M. long, 2-4-pinnate. Pinnae to $1 \mathrm{M}$. long, spreading, the lowest the largest. Leallets $10-40$ c.M. long, $1-4$ c.I. broad, linear-lanceolate or linear, sessile or short-stalked, acute, acuminate or cuspidate, the edge entire, crenate, serrate or toothed, often conspicuously serrato-dentate towards the apex, the hase cuneate, rounded or truncate, articulate. Texture more or less coriaceous, rarely thin; surfaces often naked; veins parallel, simple or forked, whether or not pellucid; recurrent veinlets mostly present. Sori in 1 row on each side, near the margin, consisting of $\pm \delta-18$ capsules. - A very variable plant with numerous forms:

Trop. Asia \& Africa, Tahiti.

\section{MARATTIA, Swart:}

Capsules sessile, concrete in oblong sori consisting of 2 opposite, hoatshaped, $\pm \breve{a}$-15-celled synangia, opening by slits down the inner side, \pm medial or subterminal on the lateral veins, rarely occupying the central ribs. Indusium wanting or present, but then minute, inconspicuous, fimbriate, often persistent.

Fronds large, 2-3-pinnate, stipitate, the stipes provided with 2 distinct stipulae at the base; veins free, simple or forked; recurrent veinlets wanting. Hk. Bk., Syn. Fil., tab. IX, fig. 70; Diels in Engl. \& Prantl, Nat. Pfl.Fam., $\mathrm{I}^{4}$, fig. 239, C \& 259, E-F.

Tropical, and subtropical in the southern hemisphere.

Arrangement of the sections.

$\$ 1$. EUMARATTIA. Sori occupying the lateral veins of the ultimate segments. Indusium present.

\$2. GYMNOTHECA. Sori as in $\$ 1$. Indusium wanting.

a. Eugymmothecen. Sori sessile.

b. Eupodium. Sori stalked. (Not in Malaya).

$\$$ 5. MESOCARPUS (Mesosorus). Sori occupying the central ribs of the ultimate segments.

\section{$\$$ 1. EUMARATTIA. See $S+p 447$}

a. Rachis densely scaly.

a.a. Rachis not densely scaly.
(1) M. vestita.

(1a) M. squancosa Sip 4 . 
b. Ultimate pinnulae often aculely cuneate at the buse.

*. Stipes Iuberculate; main rachis \pm asperulous.

*.*. Stipes not tuberculate, main rachis smooth or nearly ${ }_{\text {so. }}$

(3) M. silvatica.

(2) M. sambucina. $\operatorname{sip}$ Sip Sil

b.b. Ultimate pinnulae mostly abruptly cuneate, truncate or rounded at the base.

c. Texlure rather thin, membranacems or herbaceous.

+. Veins nearly always simple. Texture herbaceous.

(4) M. pellucida. $5 I P 4$

+.+.Veins partially simple, partially forlsed. Texture memlranaceous.

c.c. Texlure ralher thick, charlaceous or coriaceous.

(5) M. fraxinea. SI $\mathrm{P}^{2}$ (5a) M. paloofata SI 56. M caudatá Sip

d. Veins beneath naked. Synangia $\pm 8-10$-celled. (6) II. termalea. SI pe

d.d. Veins beneath deciduously dilaceralo-paleaceous. Syndngia \pm SI pu 15:celled.

(7) M. Smithii. (4a) M. Ie ysmarin va

(1) M. vestita, Christ, Philipp. Journ., II, 18 .

Large. Stipes thick, reddish-brown, opaque, densely pustulous and cluthed with ovate, flaccid scales, which are intermixed with narrower and smaller paleae, the main rachis rufo-fuscous below, ochraceo-rufous above, densely clothed like the lateral rachises with brown, lanceolate scales and fibrils. Pinnae oblong, \pm 70 c.M. long, \pm 30 c.M. broad, petiolate, narrowed at the base, the apex acuminate. Pinnulae petiolate, \pm 10 c.M. apart, 20 c.M. or more long, \pm 15 c.M. broad, narrowed at the base. Tertiary segments $\pm 21 / 2$ c.M. apart, in several pairs below the terminal one, lanceolate, \pm 9 c.M. long, $\pm 1 \%$ c.M. broad, alternate, articulate, acuminate, cuneate at the base, toothed with open, spreading teeth, the lowest very short-stalked. Texture thinly but firmly chartaceous; upper surface dark-green, lower paler, opaque; veins conspicuous, simple, remote. Sori minute, remote; synangia \pm b-celled. Mindanao.

* (2) D. sambucina, tht., Rac., Flor. Btz., I, 2; de Vr., Mon. Maratt., 6; Christ, Philipp. Journ., II, 184; M. sambucifolia, Christ (not Bl.), Ann. Btz., XIX, 43.

Stipes to \pm b0 c.M. long, tuberculate or asperous, the rachis naked, asperulous. Fronds $2-5$-pinnate, \pm 60-120 c.M. long, the ultimate rachises narrowly winged. Leaflets lanceolate, the higher ones longer than the lower, 
the central ones to \pm 5 c.M. long, to $\pm 3 / 4-1 \frac{1}{2}$ c.M. broad, with the apex acuminate, the edge serrate, the base cuneate. Texture membranaceous to subcoriaceous; surfaces naked; veins simple, pellucid. Sori distant from the margin; synangia $\pm \check{b}$-8-celled.

Malaya.

* (3) M. silvatica, $\boldsymbol{B}$., de Vr., Mon. Maratt., 6, tab. III, fig. 25; Christ, Phillipp. Journ., II, 184.

Stipes naked. Fronds large, 3-pinnate. Ultimate leaflets opposite or alternate, to \pm 10 c.M. long, to $\pm 1 \frac{1}{3}$ c.M. broad, the higher ones larger than the lower, linear-lanceolate, acute, serrate, the base cuneate. Texture firm-chartaceous; surfaces naked, upper dark-green, lower paler, minutely albopunctulate; ultimate rachises narrowly winged, rather marginate; veins simple, rather spreading. Sori intramarginal, or nearly medial on the veins; synangia \pm 12 -15-celled.

Java, Luzon, New Guinea.

* (4) M. pellucida, Pr., de Vr., Mon. Maratt., 6; Christ, Philipp. Journ., II, 184.

Fronds 2-pinnate. Leaflets linear-oblong, subabruptly acuminate, serrate, the base cuneate; highest leaflets the largest, to $\pm 12^{1 / 2}$ c.M. long, to \pm $11 / 2$ c.M. broad. Texture herbaceous; surfaces naked, upper rather darkgreen, lower paler; costae and veins beneath naked or nearly so; veins mostly simple, very rarely forked, straight, subspreading, pellucid. Sori rather remote from the margin, sometimes nearly medial on the veins; synangia \pm 6-8-celled.

Philippines; New Caledonia.

* (5) M. fraximea, Sm., Hk. Bk., Syn. Fil., 440; Bedd., Ferns S.I., tab, LXXIX; M. calliodus, de Vr., Mon. Maratt., 6, tab. III, fig. 20.

Stipes 20-60 c.M. long, smooth, deciduously scaly and swollen in the lower part. Fronds rather large, 2-5-pinnate. Highest leaflets largest, elongatelanceolate, $\pm 10-15$ c.M. long, $\pm 1 \frac{1}{2}-2$ c.M. broad, acuminate, the edge serrate, the base broadly and obliquely cuneate or slightly rounded. Texture membranaceous; surfaces naked; costae rather naked, or slightly scaly at the very base; veins simple or forked, \pm pellucid. Sori somewhat remote from margin; synangia $\pm 6-12$-celled.

Trop. Asia, Australia \& Africa. 
* (6) M. ternatea, de Vr., Mon. Maratt., 4, tab. III, fig. 16; Christ, Philipp. Journ., II, 18 s.

Fronds 5-pinnate. Ultimate leaflets $\pm 12-20$ c.M. long, $\pm 2-2 \frac{1}{2}$ c.M. broad, linear-lanceolate, acuminate or acute, the edge serrate, the base ovate-cuneate, broadest on the upper side, the petiole squamulose. Texture coriaceous; surfaces naked, upp lark-green, lower paler; rachis \pm ochraceous; costae and veins fuscous (ochraceous after Christ); veins simple, nearly horizontal, pellucid. Sori not close, somewhat remote from the margin; synangia \pm 15-celled. - A plant found in Ternate by Mr. Teysmani and determined as M. ternatea, de Vr. has the lcaflets not dark-coloured above, the rachis, costae and veins ochraceous, the costae and veins beneath sparingly provided with very minute squanulae, the veins hardly pellucid.

Luzon, Moluccas; ? New Caledonia.

(7) Snnithii, Mett., Verh. Zool. Bot. Ges., XIX, 584.

Fronds 2-pinnate. Pinnae oblong, the base slightly narrowed. Pinnulae spreading, to \pm 15 c.M. Jong, $10 \pm 2 \frac{1}{2}$ c.M. broad, linear-oblong, acuminate, the lower base rounded, the upper rotundato-truncate, the cdge slightly serrate, but more distinctly at the acuminate apex. Texture coriaceous, opaque; rachis smooth, soon naked; costae and veins covered beneath with lanceolate, ferrugineous, lacerato-fimbriate, caducous scales; veins commonly simple, rather spreading, subapproximate. Sori distant from the margin, subapproximate; synangia oblong, 8-10-celled.

New. Guinea; Polynesia.

\section{S 2. GYMNOTHECA. a. Eugynandihecan.}

(sa) M. aldata, Sme, Hk. Bk., Syn. Fil., 442; Christ, Farnkr. d. Erde, fig. 1128.

Stipes 50-60 c.M. long, deciduously scaly. Fronds $90-120$ c.M. long, 2-5-pinnate at the base, the ultimate rachises distinctly winged. Lower pinnae largest. Leaflets $1-21 / 2$ c.M. long, $1 / 2-1$ c.M. broad, oblong, blunt or acute, the base cuneate, the edge crenate, serrate or toothed. Texture herbaceous; under surface more or less chaffy. Sori copious, submarginal, 1-2 m.M. long. - A plant found in Celebes is probably a form of this species.

? Celebes; Trop. America. 


\section{$\$$ 5. MESOCARPUS.}

(9) M. Werneri, Rst., Fed., Rep., V, 44.

Rhizome and stipes unkwown. Fronds large, \pm 2 M. long, 3-pinnate. Pinnae petiolate, elongate-oblong, to 70 c.M. or more long, \pm 25 c.M. broad, broadest at the centre, the rachis adherent to the main one. canaliculate above, brown, clothed with few scattered, minute, narrowly lanceolate scales. Pinnulae short-stalked, suberecto-patent, articulate to the secondary rachises, deciduous, linear, the central ones the longest, \pm 14 c.M. long, $\pm 11 / 2$ c.M. broad, the apex abruptly acuminate, the terminal pinnulae somewhat longer than the highest ones, the internodations of the rachises winged between the the pinnulae, the wings nearly $1 / 2 \mathrm{~m}$.M. broad at the centre, narrowed towards both ends. Tertiary divisions sessile, articulate at the base, deciduous, elongateoblong, subfalcate, $\pm 71 / 2$ m.M. long, \pm 3 m.M. broad, short-acuminate, serrato-dentate at the margin, cuneate at the base, the terminal ones caudiform. Texture coriaceous; surfaces naked, upper surface lucent (opaque when dry), darker in colour than the lower; midribs of the ultimate segments (leaflets) prominent above; veins simple, terminating in the teeth, sterile. Sori 1 to each leaflet, occupying the upper part of the midrib: synangia $\pm 9-11$ celled; indusium wanting.

New Guinea.

\section{CHRISTENISEIVIA, Maxon.}

Capsules sessile, concrete in raised, circular, \pm 10-20-celled synangia, which are concave at the top so as to form nearly cupuliform or ring-shaped masses, opening by slits down the inner side or by apical pores.

Rhizome creeping. Stipes scaltered or approximate, with 2 fleshy stipulac. Fronds simple, or digitate and $\overline{5}$-- -foliate: veins anastomosing. Hk. Bk., Syn. Fil., tab. IX, fig. 72; Diels, in Engl. \& Prantl, Nat. Pfl.Fam., I ${ }^{4}$, fig. 258, D \& 259, G-H. (Kaulfussia).

Australasia.

*. Fronds simple, or 3-partile with adnate lateral segments. Synangia in 2 rows belween the main veins.

(1) C. Cumingiana. *.*. Fronds 3-5-foliale, with the lateral segments \pm stalked. Synangia scallered irregularly.

(2) C. aesculifolia. 
(1) Cumingiana, Christ, Philipp. Journ., II, 186.

Rhizome thick, short, fleshy. Stipes approximate, or subfasciculate in the younger plants, to 14 c.M. long, rufo-stramineous and furfuraceous, as are the costae and main veins. Fronds either simple, ovate, subcordate at the base, 8-15 c.M. long, 3-5 c.M. broad, repand or coarsely toothed, shortly acute at the apex, or 3-partite with the central segment broadly ovate, \pm 11 c.M. long, $\pm \mathbf{b}$ c.M. broad, acute at the point, repando-lobate at the edge, narrowly cuneate at the base and the lateral segments adnate, very unequal-sided, cordate on the produced lower, narrowly cuneate on the upper side, \pm 9 c.I. long, \pm 3 c.I. broad. Texture succulent; under surface whitish, provided with numerous roundish pores; main veins distinct, horizontal. Synangia in 2 rows between the main veins, \pm 4 in a row.

Mindanao.

* (2) C. aesculifolia, Max., C. Chr., Ind. Fil.; Kaulfussia aesculifolia, Bl., Rac., Flor. Btz., I, 2; Hk, \& Grev., Ic. Fil., tab. CGXXIX; K. assamica, Griff., Bau. \& Hk., Gen. Fil., tab. LIX, A: Bedd., Ferns Br.I., II, tab. GLXXXV.

Rhizome creeping. Stipes succulent; 20-45 c.M. long, auricled at the hase with 2 fleshy stipulae. Fronds digitate, ternate or quinate. Central segment the largest, ovate-lanceolate, narrowed to both ends, with the edge entire, crenate or slightly toothed, 15 - 40 c.M. long, 7-12 c.M. broad; lateral segments similar but smaller, falcate, unequal-sided. Texture fleshy-herbaceous; surfaces naked, but the lower side dotted over with copious stomata-like pores; main veins conspicuous, pinnate; veins anastomosing; areolae copious, immersed, with free veinlets. Synangia copious, scattered irregularly.

Malaya; Assam. 
FAMILY X. OPHIOGLOSSACEAE.

Filices. 



\section{OPHIOGI OSSACEAE.}

Sori on much contracted, spicate or paniculate fertile segments opposite to and springing from the base, the centre or the margin of the normal barren segments. Capsules \pm globose, opening across the apex or by a slit down the side; ring wanting.

Rhizome erect, rarely creeping, sometimes tuberous. Stipes not articulate to the rhizome. Barren segment of the fronds simple or variously divided; veins free or anastomosing.

Tropical and extra-tropical.

Key to the genera.

1. Fertile segment spicate.

2. Capsules sessile or immersed, placed in 2 opposite rows. Barren segment mostly simple; veins anastomosing.

No. 93. Dphioglossum.

2.2. Capsules placed in numerous small, crested clusters spreading in all directions. Barren segment divided; veins free.

№. 94. Helmintostachys.

1.1. Fertile segment paniculate; capsules placed in 2 rows on the branches of the panicle, on the side directed towards the mostly divided barren segment; veins free.

No. 95. Botrychium.

\section{OPHIOGLOSSUM, Linné.}

Capsules sessile or immersed, arranged in 2 opposite rows so as to form a long-stalked, close spike (fertile segment).

Mostly sinall and erect, rarely long and pendulous plants. Rhizome short, with 1 -2 or rarely 3-4 or more naked, stalked fronds; each frond with a barren and 1 or rarely more fertile segments; fertile segments simple or sometimes double or triple, opposite to the barren one, arising from its base, centre or margin; barren segment mostly simple, rarely divided; veins reticulate; costa mostly indistinct.

Tropical and extra-tropical. 
Arrangement of the sections.

$\$ 1$ EU-OPHIOGLOSSUM. Fertile spike single, mostly simple, rarely $2-3$ partite, arising from the base of the barren segment, which is sometimes wanting or rudimentary. Rhizome naked, hypogeous. Hk. Bk., Syn. Fil., tab. IX, fig. 73; Diels, in Engl. \& Prantl, Nat. Pfl.Fam., 14, fig. 259, A \& $\mathrm{C}$.

\$2. OPHIODERMA. Fertile spike as in $\mathbb{S} 1$, but arising from the centre of the barren segment. Rhizome papillose, epiphytical. Diels, l. c., fig. 265, A.

\$5. CHEIROGLOSSA. Fertile spikes many or numerous, springing from the base and margin of the barren segment. Rhizome long-hairy, epiphytical. Diels, l. c., fig. 265, B-G. (Not in Malaya).

\section{$\$$ 1. EU-OPHIOGLOSSUM.}

a. Barren segment wanting or rudimentary.

a.a. Barren segment distinctly developed.

(1) 0 . simplex.

b. Barren segment linear or linear-lanceolate, more than $5 \times$ as long as broad. $\times$. Fronds $\pm 4 \frac{1}{2}$ c.M. high, the barren segment 1-11/2 c.M. long, 1-2 m.M. broad.

(2) 0. gramineum. $\mathrm{x} \cdot \mathrm{x}$. Fronds 7-20 c.M. high, the barren segment $\pm 1 \frac{1}{2}-8$ c.M. long, 2-6 m.M. broad.

(3) 0. inconspicuum. Sip

b.b. Barren segment lanceolate or oblong, less than $5 \times$ as long as broad.

c. Barren segment cuneate at the base.

d. Barren segment small, mostly $1 / 4-1$ c.M. long.

\$. Barren segment roundish, nearly as broad as long.

(4) 0 . pumilum.

\$.\$. Barren segment elongate, $\pm 1 / 2 \times$ as broad as long.

(5) 0. macrorrhizum.

d.d. Barren segment larger, mostly 1-5 c.M. long.

e. Barren segment placed quite at the base of the whole frond.

(6)" 0 . fibrosum.

e.e. Barren segment placed above the base of the frond.

f. Veins indistinct.

+. The whole plant 5-10 c.M. high, with the barren segment \pm ovate, broadest at or below the middle.

(7) 0. parvifolium. 
95. ophioglosstim. $\$$ 1. EU-OPHIOGLOSSUM.

+.+. The whole plant \pm 15 c.M. high, with the barren segment obovale, broadest above the middle.

(8) 0. obovatum.

f.f. Veins distincl.

g. Barren segment membranaceous.

(9) 0. timorense.

g.g. Barren segment flaccid or subcarnose.

(10) 0 . pedunculosum.

c.c. Barren segment cordate, subtruncate or rounded at the base.

+. Barren segment with the margin minulely crenulate, i. e. bordered by a row of cellules, which have the outer wall convex $\left(^{*}\right)$.

(10) 0 . pedunculosum.

.++ Barren segment with the margin quite continuous, $i$. $e$. bordered by a row of cellules, which have the outer wall straight $\left(^{*}\right)$.

(11) 0 . reticulatum.

(1) D. simplex, Ridl., Ann. of Bot., XVIII, 205, tab. XV; XXII, 327.

Rhizome short, tuberous. Fronds solitary or in pairs, 10-15 c.M. high, flattened, 3-5 $1 / 2$ m.M. broad, the sterile segment absent or rudimentary and represented by a more or less pronounced outgrowth at a short distance below the fertile region, with a slightly increased width of the petiole below that point. Fertile spike $\pm 21 / 2$ c.M. long.

Sumatra.

(2) D. gramineum, Willd., Prantl, 0phiogl., 311, tab. VII, fig. 4. Rhizome cylindrical, slightly tuberous. Fronds commonly in pairs, \pm $41 / 2$ c.M. high; sterile segment linear or linear-lanceolate, $1-1 \frac{1}{2} \quad$ c.M. long, 1-2 m.M. broad, sessile, placed below the middle, the apex acute. Texture rigid; primary veins 5 , the central one stouter, straight, the lateral parallel, reticulate; areolae elongate, rarely with free veinlets. Fertile spike under 1 c.M. long, the peduncle $1-2 \times$ as long as the barren segment.

New Guinea; Br. India, West. Africa.

(*) Only visible in fresh or boiled material, by high $( \pm 100 \times)$ magnifying po. wer. 
* (3) D. inconspicuum, ש. A. v. R., Bull. Dép. Agr. I. N., 1908, XXI, 9; 0. moluccanum, Schl., forma inconspicua, Rac., Nat. T'ydschr. Ned. Ind., LIX, 237, tab. II, fig. 5; - var. majus, v. A. v. R., l. c.

Rhizome \pm cylindrical. Fronds $1-2$, sometimes more, 7-10 c.M. high, the barren segment sessile, elongate-lanceolate, $\pm 1 \frac{1}{2}-3$ c.M. long, $2-31 / 2$ m.M. broad, acute at both ends, placed mostly below the middle. Texture \pm fleshy, often thin when dry; areolae longitudinally elongated. Fertile spike $\pm 1-2$ c.M. long, the peduncle $\pm 11_{2}-2 \times$ as long as the barren segment.

War. majus: Like the type but all the dimensions $\pm 2 \times$ as large, and the fronds more numerous, even to 12-15, tufted.

Java, New Guinea; - var. majus: New Guinea (Versteeg).

(4) D. Pumilum, - A. v. T.; 0. moluccanum, Schl., forma pumila, Rac., Nat. Tydschr. Ned. Ind., LIX, 237, tab. II, fig. 2-5 ; ? Ann. Btz., XXI, tab. XIX, fig. 1 茫.

Rhizome short. Whole plant $1-5$ c.M. high. Barren segment roundish or rotundo-ovate, \pm sessile, placed near the base of the plant, 3-10 m.M. long, nearly as broad. Fertile spike $2-6 \mathrm{~m} . \mathrm{M}$. long, with the peduncle to $31 / 2$ c.M. long.

Java.

(5) Ma crorohiraum, Kae, Prantl, Ophiogl., 322, tab. VIII, fig. 22 ; Kze, Farnkr., I, tab. XXIX, fig. 1, a-e.

Rhizome short, thick. Whole plant under 5 c.M. high. Sterile segment placed at or below the middle, lanceolate or oblong, 5-10 m.M. long, 2-3 m.M. broad, the apex blunt or acute, not apiculate, the base cuneate, decurrent on the petiole. Texture thin; principal veins 3 , fine, the central one stouter; areolae indistinct. Fertile spike \pm as long as the sterile segment; peduncle slender, 1-2 c.M. long.

? Philippines; South. Brasilia, Argentine Republic.

(6) D. Pilonosum, Schum., Prantl, Ophiogl., 525, tab. VIII, lig. 26; 0. brevipes, Bedd., Ferns S.I., tab. LXXII.

Rhizome thick, bulbous. Fronds 1-7. Stipes very short, with the sterile segment \pm close to the base, oblong or lanceolate, $4-7$ c.M. long, $11 / 4-2$ c.M. broad, sometimes smaller $( \pm 21 / 2$ c.M. long and \pm 1 c.M. broad), the apex obtuse or acute, the base cuneate. Texture thick, subcarnuse; veins 
indistinct (except when dry), the midrib a little stouter. Fertile spike 4-5 c.lI. long, on a peduncle $10-12^{1 / 2}$ 'c.M. long.

Sumalra; Br. India, Trop. Africa.

* 7) D. parvifolinm, Grev. Ho Ho., Bot. Misc., III, 218; Bedd., Ferns S.I., tab. LXXI; O. mudicaule, L.f., Hk. Bk., Syıl. Fil., 44b; Kze, Farnkr., I, tab. XXIX, fig. $\tilde{5}$, b.

Rhizome slightly tuberous. Whole plant $\pm b-10$ c.M. high. Barren segment ovate or oblong, $\pm 1 \frac{1}{4}-4$ c.M. long, $\pm 1 / 2-1 \frac{1}{2}$ c.M. broad, sessile or subsessile, placed considerably below the middle of the whole plant, narrowed towards both ends. Texture thin; no evident costa; veins indistinct. Fertile spike $1-1 \frac{1}{2}$ c.M. long, the peduncle often $3-5$ c.M. long or even longer. - Besides the fertile fronds there are often some shorter ones without fertile segments.

Malaya; Japan, South. India, West. A frica, Trop. \& Subtrop. Americ.

(8) D. obovatum, Miq., Ann. Mus. Bot. L. B., IV, 93,

The whole plant \pm 15 c.M. high. Sterile segment oblong-obovate, rarely broadly obovate, placed considerably below the middle, $\pm 3 \frac{1}{2}$ c.ll. long, \pm $1 \frac{1}{4}-13 / 4$ c.M. broad, with a haft $\pm 1 \frac{1}{2}$ c.M. long, the apex rounded or obtuse, the base broadly cuneate. Texture coriaceous; veins nearly hidden. Fertile spike $\pm 21 / 2$ c.M. long, on a slender peduncle \pm 10 c.M. long.

Timor.

(9) 1). timorense, Miq., Ann. Mus. Bot. L. B., IV, 93.

The whole plant mostly $6-10$ c.M. high. Sterile segment often placed considerably below the middle, ovate, $2-3 \frac{1}{2}$ c.M. long, the apex obtuse or subacute, the base broadly cuneate, narrowed into a short and broad haft. Texture membranaceous; veins distinct, densely reticulate. Fertile spike $1-21 / 2$ c.M. long, on a slender peduncle $21 / 2-5$ c.M. long.

\section{Timor.}

* (10) D. pediunculosum, Desv., Prantl, Ophiogl., 328, tab. VIII, fig. 33-34; O. moluccanum, Schl., Rac., Flor. Btz., I, 4; Nat. Tydschr. Ned. Ind., LIX, 236, tab. II, fig. 1; Ann. Btz., XXI, tab. XIX, fig. 155; 0. petiolaıum, H/., Exot. Flor., I, tab. LVI; - var. lanceolatum; O. moluccamum, Schl., forma lanceolata, Rac., l. c. 257 , tab. II, fig. 4.

Rhizome cylindrical. Fronds 1-2, rarely 5 -4, the whole plant \pm 
93. ophioglossum. $\mathbb{S} 1$. EU-OPHIOGLOSSUN.

6-25 c.M. high. Barren segment placed (often considerably) below the middle, ovate, lanceolate, oval or rarely subrhomboidal, $\pm 1 \frac{1 / 2}{1 / 2}$ c.M. long, \pm 1-4 c.M. broad, sessile or with a haft, the broadest part below the middle, the base broadly cuneate, rounded or subtruncate, rarely \pm cordate, the apex obtuse or subacute, whether or not apiculate, the marginal cells with the outer wall convex. Texture flaccid or subcarnose, thin when dry; veins distinct: costa flexuose, somewhat stouter near the base, often indistinct towards the apex. Fertile spike with the peduncle to $\pm 3 \times$ longer than the barren segment.

Var. Ianceolatum: Whole plant 10-18 c.M. high. Barren segment lanceolate, 3-4 c.M. long, to 1 c.M. broad, placed a little below the middle, acute at both ends; marginal cells.....?; peduncle $\pm \mathbf{3}-\mathbf{5}$ c.M. long.

Trop. Asia, Australi, New Zealand, New Caledonia, Japan; - var. lanceolatum: Java.

* (11) D. reticulatums, $\boldsymbol{x}$. , Hk. Bk., Syn. Fil., 446; Prantl, 0phiogl., 330, tab. VIII, fig. 52 ; Bedd., Ferns S.I., tab. LXX; Hk. \& Gręv., Ic. Fil., tab. XX ; Christ, Farnkr. d. Erde, fig. 1157.

Rhizome not tuberous. Fronds $1-2$, the whole plant $10-30$ c.M. high. Barren segment placed at or sometimes considerably below the middle, 2-8 c.M. long, $1 \frac{1}{2}-7$ c.M. broad, with a haft, oblong, rarely reniform, the apex obtuse, often rounded, rarely subacute, often apiculate, the base cordate, rarely subtruncate, the margin quite continuous, i. e. the marginal cells with the outer wall straight. Texture mostly thin, rarely rigid; veins distinct, the midrib somewhat stouter near the base, flexuose, becoming finer towards the apex. Fertile spike $\pm 2^{1} / 2-4$ c.M. long, on a slender peduncle often $3 \times$ as long as the barren segment.

Pantropical.

\section{S 2. OPHIODERMA.}

†. Fronds erect, 10-20 c.M. long.

+.+. Fronds pendulous, 30-150 c.M. long.

(12) 0 . intermedium $\ln e$ e h (15) 0 . pendulum.

* (12) D. intermedium, Hk., Hk. Bk., Syn. Fil., 446; Hk., Icon Pl., X, tab. GMXCV. 
Fronds erect, 10-20 c.Mr. long, the flattened stipe passing gradually into the lealy part, which is \pm 1 c.M. broad not far from the apex. Texture fleshy; veins indistinct. Fertile spike $3-4$ c.M. long, on a peduncle $3-4$ c.M. $\operatorname{long}$.

Java, Borneo, Mindoro, New Guinea.

* (15) D. pendulium, L., Rac., Flor. Btz, I, 3; Prantl, Ophiogl., 351; Hk. \& Grex., Ic. Fil., tab. XIX; Bedd., Ferns S.I., tab. CCLXIX; Hk., Gard. Ferns, tab. XXXIII.

Fronds $1-5$, pendulous, $30-150$ c.M. long, the short, terete stipe passing gradually into the leafy part, which is $2 \frac{1}{2}-71 / 2$ c.M. broad, simple, forked or dichotomous. 'Texture fleshy or coriaceous; veins indistinct. Fertile spike $5-20$ c.M. long, on a peduncle shorter than itself.

Trop. Asia, Australia \& Polynesia.

\section{HILMINTOSTACHIYS, Kauliuss.}

Capsules in crested clusters spreading in all directions, forming a long, loose spike (fertile segment).

Rhizome thick, creeping. Fronds scaltered, erect. Each frond with a barren and a fertile segment, placed on the same stipe; the fertile segment simple or rarely double or triple, opposite to the barren one and arising from its base; barren segment digitate or pinnatipartite; veins free; costae distinct. Hk. Bk., Syn. Fil., tab. IX, fig. 74; Diels, in Engl. \& Prantl, Nat. Pfl.Fam. I ${ }^{4}$, fig. 260, $\mathrm{F}$.

Tropical Asia and Australia.

* Nor. zeylamica, Mk., Rac., Flor. Btz., I, 4; Hk., Gard. Ferns, tab. XXVIII ; Bedd., Ferus S.I., tab. LXIX; Hk., @2nd Cent. of Ferns, tab. XCIV; II. dulcis, Klf., Enum., 28, tab. I, fig 1; Osmunda zeylanica, L., (oldest name).

Stipes erect, $15-30$ c.M. long. Barren segment digitate with commonly 5 primary divisions. Primary divisions stalked and forked or pinnate. Ultimate segments $7-15$ c.M. long, 2-4 c.M. broad, lanceolate, acute or acuminate, the edge entire or slightly toothed, the base \pm cuneate. Fertile spike 7-20 c.M. long, on a peduncle of about the same length.

Trop. Asia \& Australia, New Caledonia. 


\section{BOTIRYCHIUM, Swant:}

Capsules sessile, placed in 2 rows on the inner face of spikes, which form a more or less compound panicle (fertile segment).

Mostly small, erect plants. Rhizome short, erect. Each frond with a barren and a fertile segment placed on the same stipe, the fertile segment arising from the base or the centre of the barren one, which is once or more times pinnatisect; veins free. Hk. Bk., Syn. Fil., Lab. IX, fig. 75; Diels, in Engl. \& Prantl, Nat. Pfl.Fam., I' ${ }^{4}$, fig. 259, B.

Ferns inhabiting different zones and climates.

Arrangement of the sections.

$\$ 1$. EUBOTRYCHIUM. Fronds always naked. (Not in Malaya).

S2. PHYLLOTRICHIUM. Fronds hairy, at least when young.

\section{\$2. PHYLLOTRICHIUM.}

+. Fertile segment arising from the base of the barren one. (1) B. daucifolium. $+\div$. Fertile segment arising from the centre of the barren one.

(2) B. lanuginosum.

* (1) BB. daucifolium, Wall., Rac., Flor. Btz., I, 4; Hk. \& Grev., Ic. Fil., tab. CLXI; B. subcarnosmm, Wall., Bedd., Ferns S.I., tab. LXVIII.

Stipes stout, $15-50$ c.M. long. Barren segment 15-50 c.M. long, \pm as broad, deltoid, 3-pinnatifid to 5 -pinnate, on a petiole $2 \frac{1}{2}-15$ c.M. long. Lowest pinnae largest. Ultimate segments $1 / 2-1$ c.M. broad, finely toothed. Texture herbaceous; surfaces at length naked. Panicle 5-10 c.M. long, rather loose, long-stalked, arising from the base of the barren segment.

Philippines, Java; Ceylon, North. India.

(2) LB. Lanuginosum, Wall., Christ, Farnkr. d. Erde, 366; $B$. virginianum, Sm. (virginicum, Willd.), var lanuginosum, Bedd., Handb. Ind. Ferns, 471; Ferns S.I. tab LXVII; - var. nanum, Christ, Philipp. Journ., II, 187. Stipes $7 \frac{1}{2}-45$ c.M. long. Barren segment $10-40$ c.M. each way, deltoid, 
95. Botrichiun. . 2. phyllothichum.

5-4-pinnatifid. Lower pinnae much the largest. Pinnulae ovate-oblong, variously lobed and decompound. Texture subcarnose; main and partial rachises more or less hairy; surfaces slightly hairy or at length naked. Fertile peduncle arising from the centre of the barren segment, which the panicle not or scarcely overtops.

Var. nanum is the form with the smaller fronds

Br. India, Ceylon; - var nanum: also in Luzon.

gewar sip 455 . 

APPENDIX. 



\section{APPENDIX.}

This appendix principally treats with the ferns discovered after January Ist 1907, besides the additions which could not be inserted in the first part of the work, when in the press.

The numbers within brackets indicate the sequence in the keys of the handbook, but only approximately for the new or supplementary species (marked $a, b, c, \& c$.$) .$

Buitenzorg, September 1908.

v. A. v. R.

\section{CYATHEA, Smith.}

* (1) C. moluceana, R. Ir.; C. Brunonis, Wall. - Insert: Bedd., Ferns Br.I., I, tab. LXXXVII.

(2) C. philippinensis, Bk., Christ, Bull. Herb. Boiss., $2^{\mathrm{e}}$ Série, VI, 1009.

Trunk 1-2 M. high, slender. Stipes unarmed, angular, rufo-stramineous, \pm 10 c.M. long, densely clothed with narrow, subulate, aristate scales provided with a black-brown central line. Fronds 2-pinnate, \pm 65 c.M. long, \pm 25 c.M. broad, ovate, acuminate, narrowed towards the base; rachises scaly like the stipe, but the scales adpressed, shorter and the main rachis clothed on the upper side with short, grey pubesence. Pinnae close, \pm 15 on each side, broadly oblong; central pinnae largest, \pm 15 c.M. long, \pm 6 c.M. broad, sessile, acuminate. Pinnulae \pm 16 on each side, lanceolate, close, sessile, $\pm 2 \frac{1}{2}$ c.M. long, \pm 1 c.M. broad, cut to $1 / 3$-way down (or rarely nearly) to the costa. Lobes triangular, acute, \pm 6 on each side, obtuse, entire, \pm 3 m.M. each way, the lowest posterior one adnate, the lowest anterior overlapping the rachis. Texture coriaceous; surfaces naked, upper black-green, lower paler; main veins pinnate in the lobes; veins \pm 3 on a side, distinct, simple. Sori $2-3$ to a lobe; indusium persistent, coriaceous, brown, at length breaking up into irregular pieces. - This 
description does not agree with Baker's original diagnosis taken from a cultivated specimen.

Luzon.

* (5) C. alteruans, r. - Insert as a synonym: Polypodium alternans, Wall., (oldest name).

* (12) C. cyclodomta, v. A. v. F. - Insèrt: Bull. Dép. Agr. I. N., 1908, XVIII, 1.

(15a) C. rufopannosa, Chreist, Philipp. Journ., II, 180.

Stipes thick, \pm ๖5 c.M. long, castaneous, provided at the base with numerous short, pungent verrucae and long, lanceolate, acuminate, falcate, rigid, squarrose, very lucid, castaneous scales and clothed like the rachises with a dense, furfuraceous, fibrillose, brick-red tomentum. Fronds 5-pinnatifid, broadly ovate, to 150 c.M. long, \pm 60 c.M. broad, rather narrowed towards the base, the rachis verrucose. Pinnae remote, \pm 15 on each side below the pinnatifid apex, central longest, \pm 57 c.M. long, \pm 11 c.M. broad, acuminate, somewhat narrowed at the base, lowest deflexed, \pm 22 c.M. long. Pinnulae \pm 50 on each side, approximate, $\pm 5^{1} / 2$ c.M. long, $\pm 1 \frac{1}{2}$ c.M. broad, lanceolate, subacute, cut down to the costa. Segments pectinate, \pm 20 on each side, ligulate, bluntish, crenulate, \pm 5 m.M. long, \pm 2 m.M. broad. Texture herbaceous; surfaces sparingly setulose; costae densely covered beneath with rufous, lanceolate and bullato-umbonate scales; costulae pinnate in the segments; veins forked. Sori small, few, occupying the lower veins; indusium reddish-brown, breaking down irregularly.

Mindanao.

(15a) C. Perruginest, Christ, Philipp. Journ., II, 181.

Stipes not very thick, and like the rachis somewhat glossy, angular, cas taneous, floccose-paleaceous. Fronds 5-pinnatifid. Pinnae \pm 26 c.M. long, \pm $11 \frac{1}{2}$ c.M. broad, stalked, ovate-acuminate, the rachis floccose-paleaceous with rufous, crisped scales. Pinnae \pm 15 on each side below the lobed apex, \pm 2 c.M. apart, lanceolate, acute, sessile, \pm 6 c.M. long, \pm 11 m.M. broad, cut down to a narrowly winged costa, the lowest somewhat reduced. Lobes \pm 14 on each side, close, ovate, falcate, subacute, \pm 5 m.M. long, \pm 5 m.M. broad, minutely crenulate. Texture herbaceous; colour pale-green, opaque; surfaces nearly naked; costae puberulous above, clothed beneath with grey: 
iufous, ovate, acute, adpressed scales: veins \pm 6 on each side of the costulae, often forked. Sori small, $\pm 4-5$ on each side, confluent; indusium fugacious, hardly conspicuous.

Palawan.

- (16) C. Rollingeriama, Mett.

Sori on the lower veins, $1-4$ on each side of the costulae, the lowest close to the costae.

(18a) C. adendehlamys, Christ, Bull. Herb. Boiss., 2e Série, VI, 1008.

Fronds above 1 M. long and 60 c.M. broad, ovate, the rachis rufo- or fulvo-stramineous, pubescent. Pinnae alternate, distant, subpetiolate, articulate to the main rachis, hardly narrowed at the base, to 40 c.M. long, \pm 15 c.M. broad, caudate-acuminate. Pinnulae in $\pm 2:$ pairs, close, \pm 7 c.M. long, $\pm 1 \frac{1}{2}$ c.M. broad, pinnatifid to the costa, the apex shortly, abruptly acuminate. Segments close, falcate, pectinate, \pm 17 on each side, oblong, obtuse or subacute. Texture coriaceous; upper surface black-green, lower paler, but not glaucous: costae and costulae rufo-pubescent on both sides; veins 10-12 on each side, distinct, black, simple, lower forked. Sori \pm $\breve{5}-6$ on each side, near the costulae; indusium persistent, rigid, green, covered densely with pale, sessile glands, opening down by a slit.

Luzon.

* (19) C. orientalis, Moore. - Insert as a synonym: Disphenia orientalis, Kze, (oldest name), p. p.

* (19a) C. caudata, Copel., Philipp. Journ., I, Suppl., 144; Alsophila caudata, J. Sm., Hk. Bk., Syn. Fil., 42; v. A. v. R., Mal. Ferns, 37 ; Hk., Spec. Fil., I, tab. XX, B.

Indusium present, membranaceous, evanishing completely.

(19b) C. Chnoistii, Copel., Philipp. Journ., I, Suppl., 144.

Stipes sparingly aculeate with short prickles, minutely and deciduously tomentose, the base clothed with rigid, dirty-brown, setaceous scales. Fronds $1 \frac{1}{2}-2$ M. long, 5-pinnatifid, the rachis subasperous below, fuscous and shortpubescent above. Pinnae \pm horizontally spreading, the central ones the largest, \pm 50 c.M. long, $\pm 12-14$ c.M. broad, acuminate, th elower diminished,

Filices. 
deflexed. Pinnulae $\pm 1 \frac{1}{2}$ c.M. broad, serrato-caudate, cut down nearly to the costa into linear-oblong, remote, denticulate, often obtuse segments. Texture thinly coriaceous; upper surface blackish-green, lower paler, minutely scaly on the veins. Sori costular; indusium fragile.

Luzon, Mindanao.

* (20) C. rumensis, v. A. v. R. - Insert: Bull. Dép. Agr. I. N., 1908, XVIII, 1.

(21a) C. Werneri, Rst., Fed., Rep., V, 34.

Fronds 3-pinnatifid, the rachis livid-fuscous, unarmed, strigose above, clothed beneath with linear-lanceolate, ferrugineous, copiously and irregularly dilacerate, spinuloso-ciliate scales. Pinnae to 40 c.M. long or longer, to 20 c.M. broad, short-stalked, the petiole articulate to the main rachis, the rachis hirsute and scaly like the main one. Pinnulae $12-15$ on each side, sessile, linear, narrowly aruminate, deeply pinnatifid, to 10 c M. long, \pm 2 c.M. broad, slightly narrowed at the base, the terminal one lobed, serrate at the apex. Lobes broadly linear, obtuse, entire, subfalcate, remote. Texture chartaceous; surfaces livid-green, glossy, nearly naked; costae and costulae scaly like the rachises, the scales copiously intermixed with white, acuminate, bullate squamulae; veins 4 on each side of the costulae, forked, conspicuous, brown. Sori \pm medial between the costulae and the margin, $\pm 7-8$ to each lobe, distant, large, fuscous; indusium globose, pale-fuscous, membranaceous, at length irregularly lacerate, persistent.

New Guineà.

* (28) C. spinulosa, Wall. - Insert: Bedd., Ferns S.I., tab. LVII.

(29a) C. negrosiana, Christ. Philipp. Journ., II, 181.

Stipes rather thick, $15-20$ c.M. long, the base black, densely clothed with subulate-setaceous, flexuose, lucent, black-brown scales, the rest rufocastaneous and rough with minute verrucae, as is the rachis. Fronds $\mathbf{3}$-pinnate, to 1 M. or more long, \pm 25 c.M. broad, ovate, acuminate, narrowed gradually towards the base. Pinnae distant, $\pm 10-15$ on each side, erecto-patent, medial largest, sessile, \pm 55 c.M. long, \pm 14 c.M. broad, caudato-acuminate, not narrowed at the base. Pinnulae subremote, $\pm 1 \frac{1}{2}$ c.M. apart, sessile, \pm 20 on each side, cut down to the costa (rachis). Tertiary segments ap- 
proximate, falcato-lanceolate, subacute, \pm 7 m.M. long, $\pm 21 / 2$ m.M. broad, obtusely crenulate. Texture herbaceous; colour black-green, opaque; costae and costulae densely scaly with reddish-brown, inflated scales; veins forked at the base, $8-10$ on each side. Sori small, $5-5$ on each side, costular; indusium green-brown, soon breaking down irregularly.

Negros.

(51a) C. Loheri, Cherist, Bull. Herb. Boiss., 2e Série, VI, 1007; var. tonglonensis, Christ, Philipp. Journ., II, 180.

Fronds above 1 M. long, pinnate \pm to the base of the stipe. Stipes stout, terete, castaneous, scabrous with minute pustules, clothed densely like the rachises and costae with adpressed, lanceolate, white-scariose, fimbriate scales intermixed with a short, rufous tomentum and small, umbilicate, bullate, rufous scales with a black centre and placed on the pustules. Fronds ovate-oblong, \pm 40 c.M. broad, narrowed conspicuously towards the base. Pinnae alternate, short-acuminate, central ones \pm 50 c.M. long, \pm 12 c.M. broad, \pm 10 c.M. apart, the lowest hardly 6 c.M. long. Pinnulae imbricate, \pm 22 on each side below the incised apex, \pm 7 c.M. long, $\pm 1 \frac{1}{4}$ c.M. broad, subfalcate, sessile, acuminate, cut down \pm to the costa. Segments pectinate, falcate, \pm 20 on each side, linear-lanceolate, entire or slightly crenulate, subacute, \pm 5 m.M. long, $\pm 21 / 2$ m.M. broad. Texture subcoriaceous; upper surface black-green, lower paler; costulae rufo-puberulous above, scabrous beneath with small, umbilicate, bullate scales at the base; veins inconspicuous, \pm 8 on each side. Sori confluent, at length occupying the whole under surface of the fertile segments; indusium globose, lucid, thin, fulvous, soon opening.

Var. tonglonensis: Stipes rugose and cicatrose, scaly, the scales subulate-setaceous, spreading, flexuose, black-brown, flaccid, verrucose at the base. Costae densely scaly with brown, bullate scales. Segments smaller, densely pectinate.

Luzon.

(31b) C. Callosa, Christ, Bull. Herb. Boiss., 2e Série, VI, 1008.

Large. Stipes unknown. Main rachis stout, pale-yellow-brown, covered with numerous minute verrucae and provided with some long, black, scattered setae. Pinnae \pm 60 c.M. long, \pm 20 c.M. broad, nearly sessile, hardly narrowed at the base, calloso-articulate to the main rachis. Pimnulae close, numerous, sessile, \pm 11 c.M. long, $\pm 2{ }^{1 / 2}$ c.M. broad, oblong, acuminate, 
caudate, incised to the costa (rachis?), the lowest segments distinct, narrowed at the base, the others pectinate, close, \pm 20 , falcate, broadly linear, bluntish, \pm 1 c.M. long, \pm 4 m.M. broad, crenato-serrulate. Texture coriaceous; upper surface black-green, lower very pale, but not glaucous; secondary and terliary rachises sparingly clothed with brown, furfuraceous, scattered scales; costulae rufous, densely rufo-puberulous on the upper side; veins black, distincl, 2-5-furcate, \pm 11 on each side. Sori \pm 4 on a side, cnstular; indusium pale-green, long-persistent.

Luzon.

* (53) C. celcbican, v. A. v. R. - Insert. Bull. Dép. Agr. I. N., 1908, XVIII, 2.

(54) C. troipinnata, Copet., Philipp. Journ., I, Suppl., 251.

Stipes \pm 60 c.M. long, black-purple, prickly, densely fulvo-tomentose like the rachis, the base hidden among the long, linear, whitish-stramineous scales of the trunc, the prickles scattered, acute. Fronds $\pm 2 \mathrm{M}$. long, $\pm 1 \frac{1}{2}$ M. broad, 5-pinnate. Central pinnae largest, \pm 80 c.M. long, $\pm 221 / 2$ c.M. broad, abruptly acute. Pinnulae $2-21 / 2$ c.M. broad, abruptly acuminate. Tertiary segments sessile, \pm 3 m.M. broad, the base cordate, the edge serrulate, the apex subacute, the higher ones adnate at the base. Texture herbaceous; surfaces naked, but the under side scaly on the costae and some times on the veins. Sori costal, $\pm \vec{b}$ on each side, occupying the central veins; indusium whitish-stramineous, thin, soon breaking down into persistent, sericeous fragments. - Near C. arachnoidea, Hk. and celehica, v. A. v. R.; the latter has the tertiary segments pinnate at the base.

Luzon, Mindoro.

\section{HEMITEELIA, R. Brovn.}

(2) H. conpensis, R. Br. - Insert as a synonym: Polypodium capense, L.f., (oldest name).

* (4) MI. Sumatrama, v. A. v. Re. - Insert: Bull. Dép. Agr. I. N., 1908, XVIII, 2. 


\section{ALSOPHILA, H. Hrown.}

* (2) A. Gabra, Ho. - Insert as a synonym: Gymnosphaera glabra, Bl., (oldest name).

* (5) A. Squamulata, Hle. - Insert as a synonym: Gymnosphaera squamulula, Bl., (oldest name).

(11a) A. caldeonan, Chreist, Philipp. Journ., II, 182; - var. con gesta, Christ, l. c.; A. lepifera, J. Sm., var. congesta, Christ, in Bull. Herl. Boiss, VI, 157.

Stipes unarmed, but covered with minute tubercles, clothed at the base with a dense mass of long, scariose, pale, lucent, silvery scales, which are broadly ovale at the hase, subulate, caudate, aristate at the apex, the point reddish. Fronds large, j-pinnatisect, the rachis rufo-ochraceous, opaque, provided with crowded, verrucose tubercles and scattered, furfuraceous scales. Pinnae \pm 75 c.M. long, \pm 25 c.M. broad, petiolate, caudato-acuminate. Pinnulae close, $\pm 20-50$ on each side below the pinnatifid apex, nearty sessile, lanceolate, acuminate, \pm 15 c.M. long, $\pm 2^{1}{ }_{2}$ c.M. broad, cut down to the costa, the highest broadly adnate, the lowest not reduced. Tertiary segments ligulate, falcate, bluntish or subacute, \pm 55 on each side, \pm $11 \mathrm{m.M.}$. long, $\pm 5 \mathrm{~m}$.M. broad, subentire, close, pectinate, the lowest free, distant, tolerably narrowed. Texture flaccid, herbaceous; upper surface darkcoloured, naked, lower paler, scaly on the costae and costulae with a row of white, lucent, ovate, ciliate, adpressed scales; veins \pm 12 on each side, fine, 2 or more times forked. Sori $8-10$ on each side, medial, not confluent.

Van. Congesta: Differs from the type in having the ultimate segment shorter, narrower, more falcate and more strongly serrate. The pinnulae do not exceed 8 c.M. in length. - In general appearance different from the type, but with the same essential characters.

\section{Luzon.}

- (19) A. Iatebrosa, Wcall. - Insert as a variety: - var. major, Christ, Philipp. Journ., II, 183.

A plant found in Mindoro and which is probably this species has the base of the stipes densely clothed: $a$, with long, brown hairs; $b$, with lanceolate, membraneous, almost white scales to 5 c.M. long, with a narrow, black base; $c$, with paleae intermediate in form. - It seems incredible that these 
should have escaped description if this is the real A. latebrosa, Wall. (Copel., Philipp. Journ., II, 145). •

Wan. majon: Main rachis fulvo-stramineous, naked or clothed with minute, furfuraceous scales. Pinnae \pm 28 on each side, \pm b̆ c.M. long, \pm 18 c.M. broad, oblong, acuminate, nearly sessile. Pinnulae close, horizontal, sessile, oblong, \pm 2 c.M. broad, caudate, cut down to the slender, black costa. Segments imbricate, oblong, straight, \pm 20 on each side, $\pm 21 / 2$ m.M. broad, obtusely rounded, crenulate. Texture thinly herbaceous; costulae clothed with roundish, peltate, yellow, umbilicate scales; veins 2-3-furcate. - Mindanao.

* (20) A. Saparuensis, v. A. v. R. - Insert: Bull. Dép. Agr. I. N., 1908, XVIII, 2.

(25) Ar. ornatat, Scott. - var. sikkimensis, Bedd, Journ. of Bot., XXXI, 22 $\dot{b} ; A$. sikkimensis, Clarke \& Bk., Journ. of Linn. Soc., Bot., XXIV, 409 .

Var. sikkimensis: Not spinose. Fronds 3 -pinnatifid, $1 \frac{3}{4}-3 \mathrm{M}$. long, the rachis densely clothed with adpressed, brown-castaneous, linearligulate scales. Pinnae 45-60 c.M. long, \pm 1 c.M. broad, oblong, the sides parallel. Pinnulae \pm 10 c.M. long, $\pm 21 / 2$ c.M. broad. Tertiary segments narrowly oblong, crenate or sometimes slightly incised. Texture thin; rachises ferrugineo-bullate, not short-hairy; veins 2-fid, sometimes 3-fid. Sori 4-10 to a segment, placed in 2 straight rows. - The Malacea fern agrees with the Sikkim plant, except that the stipe and main rachis are more prominently muricate.

Malacca; Sikkim.

* (27) atlauca, o. Sma.; A. contaminans, Wall. - Insert: Bedd., Ferns Br.I., I, tab. LXXXV.

(27a) Clementis, Copel., Philipp. Journ., I, Suppl., 143.

Stipes fuscous in the lower part, furnished with rather long, acute, dense, nearly black scales, the base clothed with linear, whitish-fulvous scales, the upper part stramineous like the main rachis. Fronds $1-1 \frac{1}{2}$ M. long, ovate, 5-pinnatifid; rachis naked, prickly, the prickles rather short. Cientral pinnae $30-40$ c.M. long, the rachis asperous. Pinnulae $6-7$ c.ll. long, \pm $1 \frac{1}{2}$ c.M. broad, cut down nearly to the costa into entire, subfalcate lobes. 
Texture coriaceous; surfaces naked, upper blackish-tgreen, lower subglaucous. Sori nude (no spurious indusium ?).

Mindanao.

- (32) A. tomentosa, Hik. - Insert as a synonym: Guoophora 10menlosa, Bl., (oldest name), and as a variety: - var. novo-guineensis.

Var. movo-guinecensis: Spines of the rachis longer; laciniae broader, the secondary ones densely scaly beneath. - New Guinea.

* (34) A. Iunidat, Hz. - Insert as a synonym: Cnoophora lurida, Bl., (oldest name).

(54a) A. melandrhachis, Copel., Philipp. Journ., II, 146.

Stipes \pm 60 c.M. long, black, the lower part beautifully brown-dotted, the base clothed with long, lanceolate, rigid, castaneous, pale-margined scales, the rest asperulous, clothed like the main rachis with narrow, crinite, fulvous scales. Fronds to $\pm 1 \frac{1}{2}$. M. long, broadest below the middle, 5-pinnate. Pinnae \pm 12 on each side, the largest \pm 50 c.M. long, \pm 15 c.M. broad, nearly horizontal, stalked, acuminate, the rachis scaly above, black and glabrescent beneath. Pinnulae distinct, $\pm \mathbf{3 0}$ on each side, short-stalked, \pm 7 c.M. long, \pm 1 c.M. broad, the apex acuminate, serrate, the lower part pinnate, the rachis clothed beneath with 2 different kinds of scales, densely short-hairy above. Tertiary divisions obovate, obtuse, adnate, minutely crenato-serrate. Texture thinly coriaceous; upper surface nearly black, naked, lower black-olivaceous, clothed on the costae with ciliate, bullate scales; veins simple, the lower barren ones sometimes forked. Sori costal, filling up the whole under side of the contracted fertile segments.

Mindoro.

\section{DICKSONIA, béritien.}

* (1) D. Blumei, Moore. - Also in the Philippines.

(2) D. Copelandi, Christ, Philipp. Journ., II, 183.

Stipes rufo-stramineous, rather glossy, hairy when young, the base densely clothed with fine, reddish-brown, moderately long hairs. Fronds large. Pinnae deltoid, acuminate, petiolate, \pm 45 c.M. long, \pm 24 c.Ml. broad, produ- 
ced on the upper side at the hase. Pinnulae \pm 20 on each side, close, lower and central deltoid, lowest \pm 15 c.M. long, \pm 12 c.Ir. broad, stalked, acuminate. Tertiary segments deltoid-oblong, acuminate, \pm 12 on each side, the lowest \pm 6 c.II. long, \pm 5 c.II. broad, petiolate, rather unequal-sided. Quaternary segments oblong, acute, the lowest free, $\pm 11 / 2$ c.M. long, \pm 8 m.M. broad, rather unequal-sided, the margin serrate, the teeth triangular, acute, mucronate. Texture coriaceous; upper surface naked, rather glossy, lower hairy on the veins; colour ochraceous-green; veins forked or pinnate in the ultimate segments, rather obscure. Sori numerous, terminal on the teeth, surpassed by the mucrones, 1 to each tooth, occupying especially the anterior side; indusium coriaceous, globose, irregularly 2-valved.

Luzon.

(3) Gorallis, Ist., Fed., Rep., V, 34.

Fronds large, 4-pimnate. Pinnae subsessile, to nearly 1 M. long, 30 c.II. brond, linear-oblong, the apex acuminate, serrate, the rachis sulcate above. Pinnulae subsessile, linear-lanceolate, acuminate, suberecto-patent or subfalcate, the central ones the longest, to 16 c.M. long, $4 \frac{1}{2}$ c.M. broad, the lower not much smaller, the higher gradually reduced. Tertiary divisions shortstalked or sessile, the higher ones sessile with a broad base, the lower and central linear, obtuse, to 2 c.M. long or a little longer, nearly $3 / 4$ c.M. broad, pinnate towards the base, pinnatifid towards the apex. Ultimate segments short-oblong, narrowed at the base, the lower ones short-stalked, the central sessile, both sterile and fertile deeply toothed with $2-3$ teeth on each side. Texture coriaceous; surfaces nearly naked, upper blackishgreen, glossy, lower paler; primary rachis unkwown, secondary and tertiary ones short-ferrugineo-tomentose above (the tomentum more or less intermixed with longer, rubro-fuscous hairs), the under side deciduously tomentose, glossy, black, verruculose; central ribs of the ultimate segments subpellucid, with 2- 3 veins on each side. Sori subglobose, 1 to each ultimate segment, terminal on the lowest anterior vein; indusium 2-valved, the valves similar, subentire.

New Guinea.

\section{CIBO'TIUM, Kaulfuss.}

* C. Darometa, J. Smo.; Polypodium Barometz, L., (oldest name). 
'This species, as construed on page 48, includes several forms: it is not very difficult to recognize the following.

a. Fertile pinnulne rather broad, $13 / 4-21 / 2$ c.M. broad.

Forma typica ( $r$. Karanetz, J. Sm., Christ, I'hilipp. Journ., II, 117): Ultimate segments lanceolate-falcate, acute, subentire or crenato-serrate. Rachis and costae deciduously floccoso-araneous. Sori $1-2$ or somelimes 5 or 4 on each side of the costulae, occupying the lower part of the segments, the lowest at a very short distance from the costae, suboblique, but subparallel to the edge, small, not prominent beyond the teeth, $\pm 1 \mathrm{~m} . \mathrm{M}$. broad; valves of the indusium unequal, the outer one semiglobose, the inner narrower, oblong, yellow-brown, not pruinose. - Trop. Asia.

Var. assamicum (C. Assamicum, Hk., Spec. Fil., I, 85, tab. XXIX, B ; Christ, I. c.; C. glaucum J. Sm., Bedd., Ferns Br.I., I, Lab. LXXXIII): Ultimate segments lanceolate-oblong, acute, subfalcate, distinctly serrale-dentate. Rachis nearly naked; costae and costulae sparingly, deciduously floccosoaraneous. Sori $5-6$ on each side in the fully developed fronds, occupying more than the lower half of the segments, prominent beyond the teeth, the lowest remote from the costae, $1-1 \frac{1}{2}$ m.M. broad; valves of the indusium unequal, as in the type, brown, not pruinose. - Assam, Tonkin.

a.a. Ferlile pinnulae rather narrow, $3 / 4-11 / 2$ cM. broact.

b. Costae and coslulae \pm naked or bristly.

Van. Spmatranum (C. Sumatranum, Christ, l. c., 118): Ultimate segments ligulate-oblong, bluntish or acute, crenate-denticulate. Rachis, costae and costulae neaked or nearly so. Sori 2 or rarely 5 on each side, occupying the lower part of the segments, the lowest remote from the costae, small, $1 / 2-1$ m.M. broad; valves of the indusium nearly equal, rufo-fulvous, not pruiliose. - Sumatra.

Var. Setostum, v. A. v. R., Bull. Dép. Agr. I. N., 1908, XVIII, 5 : Like var. sumatranum, but the rachis, costae and costulae densely provided with pale-brown or yellowish bristles spreading in various directions and leaving the rachis subasperous when they fall. Sori 1 or rarely 2 on each side, occupying the base of the segments, remote from the costae; indusium fulvous, not pruinose. - Malayan?

b.b. Costae and costulae pubescent or furfuraceous.

Var. Cumingii (C. Cumingii, Kze, Christ, l.c.): Ultimate segments triangular-ovate, acute, decumbent, minutely subserrulate-crenate. Costae and costulae densely pubescent (furfuriceous?, the hail's whitish or rufous. Sori 1 on each side, occupying the base of the segments, adpressed to the costae, 
rather large, $1 \frac{1}{2}-2 \mathrm{~m} . \mathrm{M}$. broad, often very oblique and then nearly parallel to the costae; valves of the indusium nearly equal, pale-brown, often pruinose. - A specimen received from Luzon (Leg. A. D. E. Elmer) has the costae and costulae densely but deciduously furfuraceous, the tomentum adpressed, pale-coloured, intermixed with some firm, spreading, pale, rather long, bristlelike hairs. - Philippines.

Var. Iampongense, v. A. v. R., l.c.: Like var. Cumingii, but the ultimate segments falcate, bluntly crenato-serrate. Costae and costulae copiously (not densely), but deciduously furfuraceous, the tementum loose, pale-brown, intermixed with long, firm, straight or crisped, bristle-like, dark-brown hairs Sori rather close to the costae, less oblique; indusium brown, not pruinose. - Sumalra (Lampong Districts, Teysmann!

\section{GLEICHENIA, Smith.}

\section{\$2. EUGLEICHENIA.}

* (1) C. Circinata, Sw.; G. semivestila, Lab. - Insert: Bedd., Ferns Br.I., II, tab. CLXXVII.

(2a) C. dicarpa, R. Wr., Hk. Bk., Syn. Fil., 12; Hk., Spec. Fil., I, tab. I, C;-Fil. Exot., tab. XL.

Lobes of pinnulae (leaflets) round, subhemispherical, very fornicate. Capsules about 2, concealed within the almost slipper-shaped leaflets and mixed with ferrugineous, paleaceous hairs, which often extend to the rachis. Very near G. vulcanica, $B l$., and approaching it in some specimens, but larger and the leaflets more close.

Mindoro, Palawan; Australia, Tasmania, New Caledonia.

\section{S 5. MERTENSIA.}

(4) G. glauca, IIk., as construed on page 58, includes 2 distinct forms: G. glauci, IIIk. \& gigantea, Wall.

- (4a) C. glanca, Mt., Spec. Nil., I, 4, tah. III, B; G. longissima, Bl., Rac., Flor. Btz., I, 10, p.p.; Polypodium glaucum, Thb., (oldest name): Lobes obtuse, crenulate or serrulate at the apex, very glaucous heneath; costae flatte ${ }^{-}$ ned, not marginate above. 
(4b) Ci. gigigantea, Wall., Hk., I.c., כ̆, tah. III, A ; G. longissima, Bl., Rac., l.c., p.p.; G. excelsa, J. Sm., Hk., l.c, 5, tab. IV, B: Lohes ohtuse, entire, slightly glaucous beneath, provided at the base above with an elevated crest forming a margin on each side of the channelled costa.

* (6) T. Wanownegii, Christ. - Also in Luzon.

* (7) C. Limearis, clarke, var. normalis.

An irregularly developed form of this shows a frond with some of the internodations geniculate midway between the accessory branches and the next higher forkings aud provided there with 2 simply pinnatifid segments, the segment placed on the outer side provided with an axillary bud at the base on the upper side, and not rarely elongate and growing out to a 3-partite or normally developed forked branch often again geniculate at the middle and provided there with 2 nearly opposite pinnatifid segments. Ultimate lobes irregular, varying from $1 / 2-4$ c.M. long.

Billilon (Vorderman), Banca (Teysmann, Berkhout), Penang (Hunger).

* 7) C. linearis, Chartie, var. rigida. - Insert as synonynns: ? G. crassifolia, Copel., Philipp. Journ., I, Suppl., 257 (G. rigida, J.Sm., Journ. of Bot., III, 420; Mertensia crassifolia, Pr., Epim., 23, tab. XIII).

(7) A. Iinearis, clarke. - Insert as varieties: - var. tenera, Bl., Enum., 249; - var. stipulosa, Christ, Bull. Herb. Boiss ; $2^{e}$ Série, VI, 1010.

Vare tenera: Texture membranaceous.

Var. stiprilosa; Axillary stipulae of all the forkings very long, \pm 20 c.M. long, \pm 4 c.M. broad, developed like the terminal branches, which are shorter, \pm 14 c.M. long, \pm 3 c.M. broad. - Luzon.

40

(7a) C. Laevissima, Clerist, Bull. Ac. Int. Bot., 1902, 268.

Fronds to $1 \mathrm{M}$. liigh, repeatedly dichotomous, the higher axes intel'upted, lerminating in a globose coma (tuft) of ovate, acute, ivory-white, squarrose, entire scales. Ultimate fork branches \pm 45 c.M. long, \pm 20 c.M. broad, ovate, narrowed towards both ends, 2-pinnate, the apex caudate. Pinnulae \pm 25 on each side, sessile, the central ones the longest, to 12 c.M. long, the lowest shorter, \pm 6 c.M. long, $1 / 2 \rightarrow 2$ c.M. broad, caudate. Ultimate segments leaflets), linear-subulate, falcate, pectinate, $\pm \mathbf{3 6}$ on each side, to \pm 1 c.M.long, 
the hase $\pm 1 \frac{1}{2}$ m.M. broad, slightly decurrent, adnate, the margin reflexed. Texture firm; surfaces naked, upper light-green, lower somewhat bluish; ribs distinct, stramineous; veins numerous, forked at the hase. Sori medial between the ribs and the margin, few, punctiform; capsules whitish.

Luzon; China.

* (8) C. Iaevigata, H. - Insert as a synonym: Merlensia laevigala, Willd., (oldest name).

(9a) C. con ndida, Rst., Fed., Rep., V, 33.

Stipes subterete, black-brown, or yellow-brown upwards. Fronds large, \pm 2 M. long, repeatedly dichotomous, rigid. Lowest internodations $2-5$ c.M. long, firm, more or less yellow-brown, naked or clothed with lanceolate, acuminate, brownish scales, not leafy. Secondary and tertiary internodations shorter, of the same colour, deeply pinnatifid, with the lowe'st segments (lobes) often reduced or wanting; the axillary buds scaly, proliferous. Ultimate branches oblong-lanceolate, acuminate, to 25 c.M. long, $\pm 21 / 2$ c.ll. broad, straight or curved, deeply pinnatifid; lobes suberecto-patent, the largest 10 $1 \frac{1}{2}$ c.M. long, $51 / 2$ m.M. broad, linear-oblong, acute, the edge slightly revolute, serrulate. Texture subcoriaceous; surfaces naked, upper dark-green, lower' white or glaucous; costae sparingly scaly; veins pellucid, forked. Sori \pm medial or nearer the margin; sporangia 2-5, yellow.

New Guinea.

(13a) A. Ioheri, Christ, Bull. Herb. Boiss., 2e Série, VI, 1009.

Between G. hispida, Mell. \& vestita, Bl. Rachises cinnamon-coloured, densely clothed with flaccid, lanceolate and subulate, fimbriato-ciliate, rufous, spreading scales. Ultimate segments triangular-lanceolate, contiguous, $\pm 11 / 4$ c.M. long, $\pm 3 \mathrm{~m}$. .M. broad at the base, the edge often reflexed, entire, the apex rather acute; texture subcoriaceous; upper surface black-green, lower bright-green, scaly on the midribs.

Luzon.

* (16) T. amboinensis, v. A. v. R. - Insert: Bull. Dép. Agr. I. N., 1908, XVIII, 3. 


\section{HYMENOPHYLLUM, Smith.}

\section{. 1 . EUHYMENOPHYLLUM.}

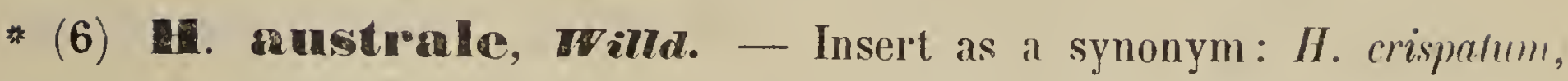
Wall., Bedd., Ferns S.I., tah. CCVII; Hk. \& Grev., Ic. Fil., tab. LXXVII.

* 7) Alemissum, Sow. - Insert as a synonym: Trichomanes demissum, Forst., (oldest name).

(8) H. subdemissum, Chrisl. - Omit this as a species. Christ considers it now as a form of $H$. pycnocarpum, $V$. D. B., which he separates from $\mathbf{H}$. Blumeanum, Spr.

* (14) TI. Bliumeanum, Spr.; H. pycnocarpum, V. D. B.; I. subdemissum, Christ, Bull. Herb. Boiss., VI, 140 ; Philipp. Journ., II, 155.

H. pycnocarpum, V. D. B.: Smooth. Fronds ovate, 5-pinnatifid, the rachis winged. Sori terminal, paniculate, the valves acutely triangular.

(22a) 置. Inalconense, Copel., Philipp. Journ., II, 144.

Rhizome filiform, creeping, hirsute, at length naked. Stipes filiform, $2-\tilde{3}$ c.M. long, glabrescent, winged narrowly towards the frond. Fronds 4-9 c M. long, $1 \frac{1}{2}-2$ c.M. broad, 2 -pinnatifid, with the secondary segments simple or sometimes forked, the edges entire, the rachis winged throughout. Upper surface naked, lower covered with red-brown hairs on the rachis, costae and veins and the bases of the indusia. Sori sessile, hardly sunk $1 / 2$-way down, terminal on the lowest, anterior secondary segments.

Mindoro.

\section{\$ 2. LEPTOCIONIUM.}

* (27) 11. Kunzii, Prantl. - I found in the Buitenzorg Herbarium about 3-4 plants quite similar to those gathered by the Ladies von Grävenitz and Stein; they were labeled with the names of other species. The wings of the secondary rachises are whether or not denticulate.

(29) II. tunbridgense, Sme - Insert as a synonym: Trichomanes tunbridgense, $L$., (oldest name). 
(29a) H. Campanulatum, Christ, Philipp. Journ , II, 155.

Densely caespitose. Rhizome slender, but firm, branched. Stipes $\pm 11 / 2$ c.M. long, slender, black and hispid with rigid hairs, as is the rachis. Fronds \pm 4 c.M. long, \pm 1 c.M. broad, oblong, narrowed at both ends. Pinnae \pm 6 on each side, arcúate-reflexed, \pm 1 c.M. long, flabellatipartite with $4-5$ linear lobes hardly 1 m.M. hroad and sparingly aristate-serrate. Texture rather rigid; colour fuscous. Sori few, placed near the base of the costae, stalked; indusium campanulate, the valves ovate, entire. - General habit of H. tunbridgense, $S m$.

Negros.

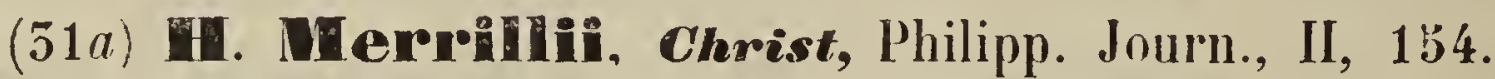

Rhizome creeping, filiform, caespitose, sparingly clothed with short, reddish-hrown hairs, as are the stipes. Stipes filiform, \pm 5 c.M. long. Fronds orate, \pm 6 c.M. long, \pm 5 c.M. broad, acuminate, narrowed at the base, the rachis sparingly hairy, not winged. Pinnae close, \pm 8 on each side, cuneateovate, higher acute, sessile, not adnate, lower stalked, \pm 6 m.M. broad, deeply pinnatifid. Secondary segments cuneate, obtuse, $\pm \mathbf{5}$ on each side, deeply incised. Lobes lanceolate, flat. \pm 2 m.M. broad, serrulate-dentate. Texture rather rigid; colour black-brown. Sori $\pm \tilde{3}-\mathbf{- 4}$ on each side, solitary on the pinnae, occupying the lowest anterior laciniae; indusium ovate, the apex 2valved, the valves serrulate; receplacle much exserted.

Luzon.

* (34) M. maltifidum, Sw. - Insert as a synonym: Trichomanes mullifilum, Forst., (oldest name).

(35) YI. serrulatum, C. Chr. - Insert as a synonym: Didymoglossum serrulalum, Pr., (oldest name).

A form gathered in Johor State (Malacca), which may be a narrow intermediate belween this species and $H$. nultifidum, Sw. has the fronds $5-8$ c.M. long, $1 \frac{1}{2}-2$ c M: broad, the main rachis flexuose, sparingly piloso-paleaceous below, winged above, the wing entire. Pinnae erecto-patent, pinnatifid, the segments linear, simple or forked, the ultimate lobes $2-5 \mathrm{~m} . \mathrm{M}$. long, under $1 \mathrm{~m}$. M. broad, serrate, the serratures rather distant. Indusium elliptical, whether or not exserted.

* (42) H. aculeatum, Rac. - Insert as a synonym: Trichomanes aculealum, J. Sm., (oldest name). 
9. TRICHOMANES, Linné.

\section{\& 2. EUTRICHOMANES.}

* (9) '. mitidulum, $\boldsymbol{V}$. D. BB. - Also found in Luzon and Mindoro.

- (15) Tr. diflisum, $\boldsymbol{B t}$. - Also found in Luzon and Mindanao.

(22a) T. Werneri, Rst., Fed., Rep., V, 35.

Rhizome wide-creeping, filiform, short-tomentose. Stipes slender, $\pm \mathbf{5}$ m.M. long, winged nearly to the hase. Fronds ovate, to 3 c.M. long, 2 c.M. broad. Pinnae to T-jugate, the central ones the longest, $\pm 12 \mathrm{~m} . \mathrm{M}$. long, כ̆ m.M. broad, lanceolale-rhomboidal, the lower \pm smaller. Lower secondary segments pinnatifid, higher forked or simple, the laciniae linear, $4 / 1,-5 / 10$ m.M. broad, simple or the lowest forked, emarginate at the apex, the margin bounded by a diaphanous line. Texture thin; rachises narrowly winged: veins slender. Sori immersed; indusium infundibuliform, the mouth dilated, undulate; receptacle $12--15 \times$ longer than the indusium $(21 / 2-5$ c.M. long).

New Guinea.

(59) T. maximum, $B l$. is construed as including 2 distinct forms: T. maximum, $B l$. \& millefolium, $\mathrm{Pr}$.

- (39a) T. maximum, Bt., Enum., 228; Rac., Flor. Btz., I, 29 ; V. D. B., Hym. Jav., 2b, tab. XVIII.

Stipes not winged, or winged towards the frond only. Ultimate lobes recurved towards the apex. Indusium winged quite to the mouth.

* (59b) T. millefolium, Pr., Hym., 16, 43 ; V. D. B., Hym. Jav., 27, tab. XX; T. anceps, Hk., var. $\beta$, Hk., Spec. Fil; I, tab. XL, C, fig. 3.

Stipes winged \pm throughout. Ultimate lobes flat, straight. . Indusium stalked, or winged at the base only.

(41) T. javanicum, Bl. is construed as including 2 distinct forms: T. javanicum, Bl. \& rhomboideum, J. Sm.

* (41a) T. javanicum, Bt., Enum., 224; Hk. \& Grev., Ic. Fil., 
tab. CCXL; Rac., Flor. Btz., I, 27, p. p.; Cephalomanes javanicum, Pr., V. ID. B., Hym. Jav., 30, tab. XXII; C. Zollingeri, V. D. B., I. c., 51, tab. XXIII: - var: intercalatum, Christ, Philipp. Journ., II, 156.

Pinnae irregularly toothed, the teeth on the anterior side blunt, those on the posterior side acute or subsetiform, but rather short. Indusium erect, with the mouth slightly contracted or slightly dilated.

Var. intercenlatum : Pinnae often dissected, the lower side toothed, the teeth elongate, aristate, conspicuous. Sori numerous, \pm 12 to a pinna, placed on the anterior side, the apex and the upper part of the posterior side, all conspicuously exserted; indusium clavato-campanulate, the mouth not dilated. - Luzon.

- (41b) T. Mhomboideum, J. Sm., Journ. of Bot., III, 417; T. javanicum, Bl., Rac., l. c., p. p.; Cephalomanes rhomboideum, V. D. B., l. c., 35, tab. XXIV.

Like T. javanicum, $B l$, but the tceth on the posterior side very long, setiform, often curved. Indusium reflexed, the mouth distinctly dilated.

* (42a) T. sumatranum, v. A. v. R., Bull. Dép. Agr. I. N., 1908, XVIII, 4 .

Near T. javanicum, Bl. and aspolenioides, $P r$. Pinnae growing gradually shorter towards the apex of the frond, the lower rather suberect, lobed on the upper side, the lobes loothed at the apex like the apex of the pinnae, the $1-\overline{3}$ lower lobes \pm elongate and auriculiform, free in the lowest pinnae and then not rarely short-stalked; higher pinnae erect, undivided, toothed, the uppermost contracted to mere, narrowly marginate petioles to the sori. Sori confined to the higher part of the frond, terminal on the pinnae, those on the not contracted pinnae sessile; indusium narrowly winged, the limb erect, truncate, upcurved at the sides, provided with 2 short, lateral, tooth-like, erect processes consisting of the slightly produced ends of the wings; receptacle exserted.

Sumatra (Burck). Banco.

(47a) T. Chr.istii, Copel., Philipp. Journ., I, Suppl., 251.

Rhizome wide-creeping. Stipes slender, \pm 1 c.M. long; sparingly pubescent with a few short hairs. Fronds $5-8$ c.M. long, $21 / 2-51 / 2$ c.M. broad, acute, 5-pinnatifid, the main rachis narrowly winged in the upper part. Pinnae oblong, obtuse, the lowest reduced. Ultimate segments linear, entire. 
Indusium infundibuliform-campanulate, narrowly winged, the limb suberect, sub-2-labiate; receptacle included.

\section{Mindoro.}

* (48a) Tr. Nerroillii, Copel., Philipp. Journ., I, Suppl., 144, tal. I; - var. borneense.

Rhizome erect, strong. Stipes tufted, 10-15 c.M. long, clothed with short, rigid, reddish-black hairs. Fronds $15-20$ c.M. long, acute, 2-pinnate, the rachis terete, pilose. Pinnae \pm spreading, $5-51 / 2$ c.M. long, obtuse; higher pinnae \pm erecto-patent. Lowest acroscopical pinnulae largest, \pm 9 m.M. long, \pm כ m.M. broad, deeply incised, the segments setiform. Texture coriaceous; colour blackish-green; surfaces naked. Sori deflexed, 2-angular, placed above the axils of the acroscopical segments of the pinnae; indusium with the mouth slightly dilated. - General aspect of T. javanicum, $B l$.

Var. Don'meense: Fronds smaller. Pinnulae somewhat shorter and narrower. Sori not deflexed, narrowly 2-marginate; receptacle not conspicuously exserted.

Palawan; - var. borneense: Borneo (Teuscher).

* (49a) T. setaceum, T. D. B., Ned. Kruidk. Arch., V', 176; T. cupressoides, Desv., vair., C. Chr., Ind. Fil.

Rhizome short, ascending. Stipes approximate, subtufted, 10-18 c.M. long, clothed with-deciduous, fuscous hairs, at length quite naked. Fronds $15-20$ c.M. long, densely paleaceo-hirsute. Pinnae \pm spreading, the lower ones often deflexed, the higher erecto-patent, oblong or lanceolate-oblong. Pinnulae erecto-patent, subcontiguous, lanceolate, deeply incised, the segments setiform, long. Texture firm; surfaces naked; colour olive-green. Sori in the axils of the lower anterior segments of the pinnae, \pm deflexed, emerged; indusium not conspicuously marginate, cylindric-infundibuliform, the mouth not dilated; receptacle exserted.

Singapore, Banca, Borneo.

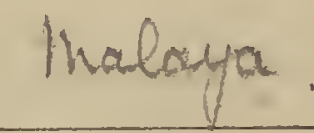

\section{LYGODXUM, Swarta.}

\section{\$1. EULYGODIUM.}

* (2) M. Teysmamuii, v. A. v. B. - Insert: Bull. Dép. Agr. I. N., 1908 , XVIII, 丂.

Filices. 
(2a) Dasilumicum, Christ, Philipp. Journ., 11, 179.

Main rachıs slender, ochraceous. Primary petioles \pm 3 c.M. long, narrowly winged. Pinnulae stalked, 5-4-lobate, the stalk $\pm 1 / 2$ c.M. long, winged, the central part undivided; lobes pedately arranged, \pm 9 c.M. long, $\pm 6 \mathrm{~m}$. M. broad, patent, thinly marginate, the basal ones deflexed. Texture coriaceous; costulae slender, distinct, rufo-stramineous; veins prominent, oblique, 2-5-furcate, close. Fertile segments suddenly contracted at or below the middle to a wing $\pm 1 \mathrm{~m} . M$. broad. Soriferous spikes close, peclinate, $\pm 21 / 2$ m.M. long.

Basilan.

* (j) L. Circinatum, Sav. - Insert as a synonym: Ophioglossum circinalum, Burm., (oldest name). - After var. monstruosum \& cristatum, insert: v. A. v. R., Bull. Dép. Agr. I. N., 1908, XVIII, 5.

Var. Cristatum: Marginal strand very indistinct, apparently wanting. By its crested spores this approximates the examined specimens of $\mathrm{L}$. trifurcatum. $B / i$, but the fertile spikes are closely pectinate, not in groups.

* (b) 1. trifurcestum, BB. - The specimens gathered in New Guinca by Prof. Dr. Treub and those cultivated in the Buitenzorg gardens have the laciniae narrower than in the typical form, the fertile spikes partially in groups of $1-5$, and the spores verrucose and crested.

- (7) L. Scandens, Sw. - Insert as a synonym: Ophioglossum scandens, L., (oldest name).

- (10) D. Hexuosum, Sw. - Insert as a synonym: Ophioglossum flexuosuin, L., (oldest name).

- (11) H. japonicum, Sw. -- Insert as a synonym: Ophioglossum japonicum, Thb., (oldest name).

(11a) L. Mearonsii, Copel., Philipp. Journ., III, 57.

Near L. flexuosum \& japonicum, Sw. Primary petioles $\breve{5}-\mathbf{9}$ m.M. long. Barren pinnae \pm 15 c.M. long, $12-18$ c.M. broad. Pinnulae $2-5$ on each side, pinnate, on stalks more than 1 c.M. long. Leaflets in 1 pair below the terminal ones; lateral leaflets stalked, כ̆-fid with obtuse lobes; terminal ones larger, lanceolate; edges obscurely crenate, the crenations denticulate. Texture 
APPENDIX. 10. LYGODIUM.

Lerbaceous; surfaces naked. Fertile pinnae smaller, the leaflets entire, ovate. Spikes short, oblong.

Batan 1sland.

\section{\$2. HYDROGLOSSUM.}

(12) L. Matthevi, Copel., Philipp. Journ., III, 36.

Fronds high-scandent. Pinnae more than 50 c.M. long. Pinnulae stalked, 1-2 on each side below the terminal one, not or hardly articulate at the base, the stalks $1 \frac{1}{2}-21 / 2$ c.M. long; terminal pinnulae deeply palmatifid with \pm 6 spreading segments $20-30$ c.M. long, 5-4 c.M. broad, the lateral ones 2-5-furcate with the segments \pm 20 c.M. long; edges serrulate. Texture herbaceous; surfaces naked, or the veins pubescent at the base on the under side; veins anastomosing. - Fertile fronds unknown.

Philippines.

(15) ע. Merrolli, Copel., Philipp. Journ., II, 146, tab. IV.

Near L. Matthewi, Copel., but the terminal pinnulae forked. Fertile fronds with the spikes not very numerous, not close (conf. Copeland's drawing).

Mindoro.

\section{SCHITLEA, Smith.}

* (3) S. dichotoma, Sm. - Insert as a synonym: Acrosichum dichotomum, L., (oldest name).

* (4) S. digizata, Sw. - Insert as a synonym: Acrostichum digitatum, L., (oldest name),

\section{DIPLAZIOPSIS, christensen.}

Indusium sausage-shaped, quite enclosing the sorus when young, rupturing irregularly when the spores mature, apparently fastened all round the receptacle, i.e., the indusium is fixed by its very broad base to the posterior side of the vein, with the free edge strongly involute and closely adpressed to the anterior side of the vein. - Rac., Ueber die Farngattung Altantodin, Wall., Bull. Ac. Crac., 1905, 546-549; Bot. Centralbl., 1906, I, 261. 


\section{DENISTAAEDTA}

(5) D. erythrorachis, Diels. - Also in the Philippine Islands.

(6a) D. dennstacdtioides, Copel., Philipp. Journ., II, 126; Microlepia dennstaediioides, Copel., I. c., I, Suppl., 148, tab. IV; - var. arthrotricha, Copel., l. c., III, 34.

Rhizome creeping, naked or nearly so. Stipes 13 -20 c.Mr. long, brown, naked. Fronds 40-60 c.M. long, 20-30 c.M. broad, 4-pinnatifid. Pinnae lanceolate, acute, the lower smaller, the rachis narrowly winged. Pinnulae ovate-lanceolate, obtuse. Ultimate segments obovate, entire or toothed. Texture herhaceous; surfaces naked. Sori small, marginal or submarginal.

Var. ardhetrolehan: Fronds larger; rachis and upper surface clothed with short, articulate hairs.

Mindanao, Luzon.

(6h) D. Merroilli, Copel., Philipp. Journ., II, 126; (? Microlepia).

Rhizome thick, creeping. Stipes erect, firm, \pm 60 c.M. long and like the main rachis castaneous, slightly puberulous, rather glabrescent. Fronds 100-120 c.M. long, \pm 50 c.M. broad, 4-pinnatifid. Largest pinnae $\pm \mathbf{5 0}$ c.M. long, \pm 11 c.M. broad, acuminate, with the rachis puberulous below; lower pinnae reduced. Pinnulae lanceolate-deltoid, distinctly acuminate. Terliary segments lanceolate-deltoid, obtuse, decurrent, subpetiolate, the lowest acroscopical ones the largest, to 2 c.M. long, \pm 1 c.M. broad, cut down on each side to a winged costa into \pm 4 subremote, obtuse or truncate, entire or obscurely serrate lobes. Texture herbaceous; surfaces naked, the lower paler than the upper. Sori \pm marginal, in the sinuses, the margin of the lobe forming with the true indusium an imperfect cup to the sorus.

Mindoro.

(7) D. sammensis, Moore. - Insert as a synonym: Silolobium samoense, Brack., Expl. Exp., XVI, tab. XXXVIII, fig. 1.

(7a) D. Williamsi, Copel., Philipp. Journ., I, Suppl., 148; Christ, l. c., II, 168 .

Stipes tufted, \pm 2 M. long, rufous-yellowish, densely clothed like the rachis with fulvous, strigose hairs, at length rather naked. Fronds \pm 2 M. long, 4-pinnatifid. Pinnae sessile, \pm 90 c.M. long ( \pm 120 c.M. long after 
Copel.), to 50-35 c.M. broad, oblong, acuminate, hardly narrowed at the base. Pinnulae \pm 35 on each side, petiolate, oblong, acuminate, lowest distant, \pm 16 c.M. long, $4-7$ c.M. broad, broadest at the base, upper base truncate, lower cuneate; higher pinnulae approximate. Tertiary divisions close, rather imbricate, decurrent, \pm 25 on each side, lowest anterior largest, \pm 2 c.M. long, $\pm 1 / 2$ c.I. broad, deeply pinnatifid. Lobes oblong, obtuse, crenate on the upper side, $\pm 1 / 2$ c.M. long, $\pm 1 / 4$ c.M. broad. Texture rigidly coriaceous; colour grey-green; costae and veins clothed with short, adpressed, rufous hairs. Sori in the sinuses, 1 or rarely more on each lobe, marginal.

\section{Mindanao.}

(76) D. Wooveni, Cherist, Philipp. Journ., 11, 169.

Rhizome creeping. Stipes $1 \frac{1}{2}-2$ M. long. Fronds \pm 2 M. long, subdeltoid, 4-pinnatifid, the rachises pubescent with short, strigose, rufous hairs. Pinnae \pm 60 c.M. long, \pm 18 c.M. broad, short-stalked, hardly narrowed at the base, acuminate. Pinnulae alternate, approximate, petiolulate, \pm 55 on each side, \pm 9 c.M. long, $\pm \mathbf{3}$ c.M. broad, the upper base produced, the rachis not winged. Tertiary segments \pm 18 on each side, close, subimbricate, obtusely ovate, \pm 1 c.M. long, $\pm 1 / 2$ c.M. broad, cut down to the costa, unequal-sided, upper base produced, truncate, lower cuneate. Ultimate segments $\mathbf{3}-4$ on each side, cuneate-oblong, obtuse, $\pm 5 \mathrm{~m}$.M. long, $\pm 21 / 2$ m.M. broad, crenato-lobate in the fertile, elongate and more acutely toothed in the barren fronds. Texture thinly herbaceous; colour dark-green; surfaces pilose with whitish, tortuous hairs; veins pinnate and forked in the ultimate segments. Sori roundish, 1 (or rarely more) on each ultimate segment, placed on the short, obtuse, basal teeth; indusium thin, membranaceous, grey, soon evanished.

\section{Midanao.}

* (10) D. cumeata, Moore. - Insert as a synonym: Sitolobium cunealum, J. Sm., (oldest name).

- (12) D. Inceida, Berme. - Insert as a synonym: Trichomanes flaccidum, Forst., (oldest name).

(13a) D. Elmeri, Copel., Leafl., I, 235.

Rhizome creeping, black, aculeate. Stipes to 25 c.M. apart, probably 
to 2 M. long, aculeate. Fronds to $3 \mathrm{M}$. long, $\pm 1-1 \frac{1}{2}$ M. broad, 5-pinnate, the main rachis short-aculeate, castaneous. Pinnae opposite, apparently articulate to the main rachis, broadly lanceolate, $20-25$ c.M. broad, acuminate, the rachis aculeate towards the base. Pinnulae sessile, pseudo-articulate, the lower ones opposite, the higher alternate, acuminate, the rachis slightly pubescent. Leaflets sessile, obtuse, auriculate, to $1 \frac{1}{2}$ c.M. long, to $7 \mathrm{~m}$.M. broad, the edge cut more than $1 / 2$-way down to the costa. Texture subcoriaceous; costae slightly pubescent beneath, the rest naked. Sori to 7 on a leaflet, at the tops of the sinuses, inflexed.

Luzon.

* (14) D. sumattana, v. A. v. Te. - Insert: Bull. Dép. Agr. I. N., 1908, XVIII, 6.

\section{OLEANDRA, Cavanilles.}

* (1) Cuspidata, - A form gathered in New Guinea has the rhizome scales subulate and much deflexed at the apex, the fronds \pm 25-50 c.M. long, $\pm 4-5$ c.M. broad, the surfaces hairy on the veins, the indusia fugacious. - This may be Copeland's 0. colubrina, Copel., var. membranacea.

* (3) D. colvibrima, Copel., var. brachypus. - Copeland distinguishes 2 forms (Philipp. Journ., III, 52-33):

Var. nitida (? var. brachypus): Fronds to 40 c.M. long, \pm 2 c.M. broad, coriaceous, soon naked, glossy.

Var. membranacea (? 0. cuspidata, Bk). Fronds \pm 20 c.M. long, \pm $21 / 2$ c.M. broad, narrowly caudate, pubescent, ciliate, membranaceous. Sori small, in an irregular row \pm medial between the costa and margin.

(4a) (1). Werneri, Rst., Fed., Rep., V, 40.

Rhizome long, scandent, subcompressed, branched, scaly; scales dense, lanceolate, deciduously acuminate at both ends, at length ovate, adpressed, peltate, the centre black, the margin rufo-ferrugineous, fimbriate; branches 3-10 c.M. or more apart, simple or branched again, slightly scaly, the ultimate ones to $1 / 2-5$ c.M. long, hearing the fronds. Stipes $\pm 2-4$ c.M. long, articulate \pm at the base. Fronds dimorphous. Barren fronds elongate- 
lanceolate, to 25 c.M. long, to 5 c.M. hroad, narrowed towards both ends, the base cuneate, the edge entire, the point long.cuspidale. Texture papyraceous; surfaces naked, \pm glossy; costa prominent on both sides, sparingly scaly; veins $\pm 1-2 \times$ forked. Fertile fronds linear, to 50 c.M. long, $1 \frac{1}{2}-2$ m.M. broad (!). Sori rather distant, large, transversal (not oblique), often protruded beyond the margin of the frond; indusium reniform.

New Guinea.

* (5) D. musifolia, Pr. - Insert as a synonym: Aspidium musifolium, $B l .$, (oldest name).

\section{NHPHIROLTPIS, Schot.}

\section{\$ $1 . \quad$ LINDSAYOPSIS.}

* (5a) N. davalliae, v. A. v. R., Bull. Dép. Agr. I. N., 1908, XXI, 2. Rhizone short, stoloniferous, densely clothed with bright-brown, subulate scales. Stipes \pm 15 c.M. long, approximate, grey-brown and deciduously furfuraceous like the rachis, the tomentum consisting of fuscous, crisped, fibril-like scales. Fronds $\pm \check{0} 0$ c.M. long, narrowed towards the apex. Pinnae numerous, rather distant, horizontally spreading, falcate, short-stalked, lower sterile, lowest more or less reduced but not auricle-like, oblong, higher fertile, central largest, \pm 4 c.M. long, $5-6$ m.M. broad at the rotundatotruncate base, narrowed towards the apex, the margin entire or shallowly crenate in the lower part, more deeply crenate, dentate or dentato-lobate towards the apex, the crenations or teeth oblique, bluntish, the fertile ones truncate. 'Texture coriaceous; surfaces naked; veins 2-5-furcate. Sori roundish, solitary and terminal on the crenations or teeth, rarely solitary on the veins, mostly uniting the apices of the fork branches of the veins, slightly immersed and prominent on the upper surface; indusium brown, semiorbicular, attached at the rounded base and sides, free at the truncate apex, opening outwardly.

New Guinea.

\section{\$ 2. EUNEPHROLEPIS.}

-(5) N. Hoceigeran, Moore. -- Inserl as a synonym: Aspidium floccigerum, $B l .$, oldest name. 
* (8) N. hirsutula, Pr. - Insert as a synonym: Polypodium hirsululum, Forst., (oldest name).

(9a) N. glabra, Copel., Philipp. Journ., I, Suppl. 146.

Near N. cordifolia, Pr. Fronds 7-15 c.I. long, rarely longer, lanceolate, the rachis winged like the stipe, naked or nearly so. Pinnae hardly deciduous, the fertile ones crenato-serrate. Texture herbaceous; veins distinct. -- This species is notable for its exposure to extremes of moisture. Instead of resisting desiccation, as do all the other species, this one yields readily and endures it, without losing its pinnae, and promptly recovers (Copel.).

Luzon.

* (15) N. exailtata, Schott. - Insert as a synonym: Polypodium exaltatum, L., (oldest name).

\section{CYCLOPELTIS, ग. Smith.}

* (1) C. semicordata, J. Sm. - Insert as a synonym: Polypodium semicordatum, Sw., (oldest name).

* (2) C. Presliana, Berli. - Insert as a synonym: Lastruea l'resliana, J. Sm., (oldest name). - After var. biauriculata, inserl: v. A. v. R., Bull. Dép. Agr. I. N., 1908, XVIII, 6.

\section{POLYSTICHUM, Toth.}

* (1) P. auriculatumn, - Insert: Bedd., Ferns S.I., lab. CXX; and after var. nervosum, insert: $P$. dellodon, Diels, var. nervosum, Christ, Philipp. Journ., II, 157.

(1a) P. Copelandi, Christ, Philipp. Journ., II, 157.

Rhizome caespitose. Stipes fasciculate, slender, $\pm 21 / 2$ c.ll. long, sparingly clothed with subulate, black scales, as is the rachis. Fronds linearlanceolate, simply pinnate, not narrowed at the base, to 20 c.M. long and 2 c.M. broad, acuminate. Pinnae densely imbricate, \pm 50 on each side, rhomboidal, \pm 1 c.M. long, $\pm 1 / 2$ c.M. broad at the base, the apex subacute, the edges parallel; upper base acutely auriculate, truncate, lower cuneate; lower side entire, upper minutely toothed, the teeth not aristate. Texture herba- 
ceous; surfaces naked; colour yellow-green, opaque; veins forked. Sori \pm 6 on a pinna, placed in 1 row on the anterior side of the costae, distant from the margin, impressed; indusium minute, fugacious.

Luzon.

(1b) P. oliqumum, Moore, C. Chr., Ind. Fil.; I'. caespitosum, Schotl., Bedd., Ferns Br.I., I, tab. XXXIII; P. auriculalum, Pr., var. caespitosum, Bedd., Handb. Ind. Ferns, 204; Aspidium auriculaum, Sw., var. obliquum, Hk. Bk., Syn. Fil., 493; A. obliquım, Don, (oldest name); - var. luzonicun, Christ, Philipp. Journ., II, 157.

Rhizome short, thick, the scales ferrugineous, ovate, often ciliate. Stipes tufted, slender, 丂丂-20 c.M. long, stramineous as well as the rachis. Fronds 10-25 c.M. long or longer, oblong- or linear-lanceolate, rather acute, simply pinnate. Pinnae rather distant, horizontal, rhomboidal-oblong, $1 \frac{1}{2}-3 \frac{1}{2}$ c.M. long, obtuse or acute, sharply but scarcely mucronato-serrate; upper base truncate and obtusely auricled, lower cuneate. Texture chartaceo-membranaceous; surfaces naked; veins forked, lowest anterior pinnate in the auricle. Sori in 1 row on each side of the costae, medial or nearer the edge than the costae; indusium peltate, ciliate or toothed, at length deciduous.

Van'. Inzonicumn: Pinnae imbricate, acutely auricled, the edge nearly entire, the teeth very faint, scarcely visible but nevertheless aristate. Texture herbaceous; veins hidden.

North. India; - var. luzonicum: Luzon.

(2a) P. nudum, Copel., Philipp. Journ., I, Suppl., 145.

Rhizome ascending, clothed with long, linear, brown scales. Stipes close, 40-50 c.M. long, clothed towards the base with long, brown, often ovate scales and towards the frond with paler, often smaller, crinite ones. Fronds \pm 70 c.M. long, \pm 50 c.M. broad, the rachis clothed with brown, crinite scales. Pinnae close, horizontally spreading, $15-18$ c.M. long, $\pm 2 \frac{1}{2}$ c.M. broad, the lowest somewhat shorter. Pinnulac oblong, acute, inciso-serrate, the teeth aculeate, the auricle nearly free, not imbricating. Texture herbaceous; upper surface naked, lower pale-coloured, provided with whilish scales on the veins. Sori naked.

Mindanao.

* (3) P. aculentum, schott. - Insert as a synonym: Polypodium aculealum, L., (oldest name). 
(4a) IP. Wlepha ristegium, Copel., Philipp. Journ., I, Suppl., 14 b.

Stipes close, 25-40 c.M. long, clothed with rather long, polymorphous scales. Fronds to \pm 40 c.M. long, to \pm 25 c.M. broad, the rachis densely clothed with narrow, pale-fulvous, silky hairs and scales. Lower pinnae deflexed, hardly shorter than the following which are \pm horizontally spreading, \pm 15 c.M. long, $2-2^{1} / 2$ c.M. broad, acuminate, pinnate. Lowest acroscopical pinnulae cut down nearly to the costa, the others not or hardly incised, broadly auriculate, obscurely toothed, the teeth often provided with short setae, the auricle imbricating. Texture papyraceous; upper surface nearly naked, lower clothed with fulvous, stellate hairs. Indusium whitish, silky, ciliate.

Luzon.

(6) P. Iobatum, Pr. - Insert as a synonym: Polypodium lobalum, Huds., (oldest name).

(8) P. Dlatypus, Diels. - Insert as synonyms: Aspidium platypus, Kze, Bot. Zeil., 1848, 262; Lastraea platypus, Moore, Bedd., Ferns Br.I., II, tab. CCXXVIII.

* (10) P. aristatum, Pr. - Insert as a synonym: Polypodium aristanum, Forst., (oldest name). - Omit: var. Hamiltonii, it being not malayan.

\section{PLEOCNEMIA, Prest.}

(1) P. heterophylla, v. A. v. R. - Insert as a synonym: Ilaplodictyum heterophyllum, Pr., (oldest name).

* (4) P. Heuneama, Pr. - Insert: Tec:laria leuzeana, Copel., Philipp. Journ., II, 417; Polypodium Leuzeanum, Gaud., (oldest name); - var. angilogensis; Aspidium Angilogense, Christ, Bull. Herb. Boiss., $2^{\mathrm{e}}$ Série, VI, 1003.

Var. angilogensis: Very large, the adult plant very probably arborescent. Main rachis fulvo-castaneous, naked or furfuraccous, sublucid. Pinnae petiolate, \pm 60 c.II. long, \pm 18 c.ll. broad, acuminate. Pinnulac horizontally spreading,,$\pm \mathbf{3 5}$ on each side, short-stalked, $\pm \mathbf{3}$ c.ll. broad, oblong, acule, deeply pinnatifid. Lobes pectinate, \pm 20 on each side, broadly 
linear, subacute, 5 m.M. broad, separate, the sinuses rounded, the higher lobes close, the edges lobato-crenate, the teeth obtuse, \pm 8 on each side, \pm 1 m.M. each way. Costae and veins subfurfuraceous or naked. Sori near the costulae, in the forkings of the veins, $6-8$ on a side. - See Copeland's information, 1. c. - Luzon.

* (5) P. cigantea, Pr. - Omit as synonyms: P. Trimeni, Bedd. and Sagenia giyantea, Moore. - P. Trimeni, Bedd. is a distinct species and Sagenia gigantea, Moore its synonym.

(7) P. Bakeri, v. A. v. R. - Omit this name, it should be P. Trimeni, Bedd.

- (7) P. Trimeni, Bedd., Handb. Ind. Ferns, 223; Nephrodium giganteum, Bk., Hk. Bk,, Syn. Fil., 503; Sagenia gigantea, Bedd., Ferns S.I., tab. LXXX; Aspidium giganteum, Copel. (not Bl.), Polypod.Philipp., 38; (Bl., C. Chr., Ind. Fil., p.p.).

Stipes tufted, 50-60 c.M. long, grey or brown; basal scales linear. Fronds 50-90 c.M. long, deltoid or deltoid-lanceolate, pinnatifid at the apex, below pinnate with $\pm 5-6$ lateral pinnae on each side, which are more or less stalked and all pinnatifid more than $1 / 2$-way down to the costa. Lowest pinnae largest, pinnate at or towards the base, with the lower (lowest) basiscopical pinnulae prolonged and deeply pinnatifid. Ultimate lobes bluntish, slightly crenate or nearly entire. Texture rather thin, both surfaces naked; costae and veins \pm rusly above, less so or rather naked beneath; veins forming 1-2 rows of areolac near the midribs, the rest free, no included free veinlets. Sori in 1 row on each side of the costulae; indusium subcordate, reniform. - A from found in Sumatra by Dr. Burck has the rhizome erect, densely clothed with long, linear-subulate, fuscous scales, the stipes and rachises sparingly fibrilloso-paleaceous, the ultimate lobes blunt to subacute, entire to broadly toothed.

? Philippines, Sumatra; Ceylon, South. India.

* (8) P. devexa, v. A. v. R.; P. membranacea, Bedd., Handb. Ind. Ferns, 225; Aspidium memiranaceum, Hk., Hk. Bk., Syn. Fil., 259; A. devexum, Kze, Bot. Zeit., 1848, 259 ; C. Chr., Ind. Fil.; Tectaria devexa, Copel., Philipp. Journ., II, 415; - var. minor; A. giganteum, Bl., var. minor, Hk., Spec. Fil., IV. 50; Sagenia giganlea, Bedd., var. minor, Bedd., Ferns S.I., tab CGXLIII. Stipes tufted, 20-50 c.M. long, nearly naked, with a few spreading, li- 
near scales below. Fronds $55-60$ c.M. long, deltoid, acuminate, pinnatifid at the apex. Lateral pinnae $\pm 4-7$ on each side, the lowest much the largest, subdeltoid, long-stalked, pinnate, with the lower pinnulae on the lower side prolonged and again pinnate at the base, the tertiary segments being stalked and deeply pinnatifid; higher pinnae gradually less compound. Ultimate lobes entire or crenulate to toothed. Texture thin, herhaceous or membranaceous; upper surface somewhat hairy towards the margins, lower slightly puberulous; costae and veins rusty or puberulous; veins anastomosing principally in costal arches, but not rarely also as in Aspidium. Sori copious, commonly submarginal and terminal on free veinlets; indusium orbicular or reniform.

Var. minor: A small and leśs divided form, divided \pm as in $\mathbf{P}$. 'T'rimeni, Bedd., or with the tertiary leaflets not deeply pinnatifid. - A plant. gathered in Borneo and cultivated in the Buitenzorg gardens, which may be a form of this, has the fronds inconspicuously glanduloso-pilose beneath and the costae and veins \pm naked.

Malaya; Formosa, Soulh. China, Ceylon.

(9) D. profereoides, v. A. v. Ir.; Aspidium profereoides, Christ, l'hilipp. Journ., II, 158; Teclariu ambigun, Copel., l. c. 415, p.p.

Stipes $\pm 40-75$ c.M. long, castaneous, sulcate and sparingly scaly and bristly like the rachis, the scales brown, subulate. Fronds dimorphous, the fertile ones on the longest stipes. Barren fronds more than 50 c.M. long, 52 c.M. bruad, deltoid-oblong, pinnate. Pinnae distant, horizontally spreading, \pm 15 on each side below the acuminate, inciso-lobate apex, sessile, broadly lanceolate, \pm 18 c.M. long, $\pm 3 \frac{1}{2}$ c.M. broad, acute, cut $1 / 2$-way down or more to the costa, the lowest not reduced, not forked. Lobes \pm 18 on each side, subentire, ovate-obtuse, $\pm 1 \%$ c.M. long, \pm 1 c.M. broad, separated by narrow, obtuse sinuses, the lowest a little larger. 'Texture flaccido-herbaceous; colour dark-green, opaque; costae furfuraceo-puberulous above; main veins not prominent, pinnate in the lobes; veins forming 1 row of narrow costal areolae, $1-5$ rows of areolae near the costulae and 3-4 areolae between the costal ones and the sinuses. Fertile fronds contracted, \pm 50 c.M. long, the pinnae distant, \pm 10 c.M. long, $\pm 2 \%$ c.M. broad, deeply incised, the lobes linear-lanceolate, falcate, \pm 4 m.M. broad. Sori round; indusium flaccid, soon corrugate, probably reniform.

Mindanao. 


\section{\$1. LASTRAEA.}

* (9) Teuscheri, v. A. v. R., - Insert: Bull. Dép. Agr. I. N., 1908, XVIII, 6.

(10) D. pectimata, v. A. v. R. - Insert as a variety: - var. Webbiana: Nephrodium Webbianum, IIk., Spec. Fil., IV, 85; D. orientalis, C. Chr., var. Webbiana, Christ, Philipp. Journ., II, 207.

Var. Webloiama: Differs from the type in having the fronds quite naked, without calcareous dots on the upper surface, and the lobes more horizontal and more angular. - Mindanao, Amboyna, New Guinea; Fiji.

(11) D. ligulata, o. Ktze. - Insert as synonyms: D. immersa, $O$. Ktze, var. ligulata, Christ, Philipp. Journ, II, 208; Lastraea ligulata, J. Sm., (oldest name).

* (15) D. mttenug 1a, O. Htze. - Insert as a synonym: Lastraea attemuala, J. Sm., (oldest name).

- (18) D. viscoosa, D. Ktze, Christ, Philipp. Journ., II, 211.

Detailed description. - Rhizome thick, erect, blackish, provided with many old stipes. Stipes densely tulted, 12-20 c.M. long, firm, erect, densely tomentose like the rachis with ochraceous-grey hairs and clothed with ovate, black-brown scales. Fronds 20-55 c.II. long, 8-15 c.M. broad, oblong, acuminate. Pinnae spreading, 20-23 on each side, $1-1 \frac{1}{2}$ c.M. broad, shortacuminate, sessile, cut down nearly to the costa into oblong, obtuse, subcreate segments separated by acute sinuses; lower pinnae rather distant, somewhat shorter, deflexed. Texture somewhat fleshy: costae, costulae and especially the under surface densely pubescent with white, rigid hairs (glands?); veins \pm 6 on eacl side, simple. Sori medial; indusium persistent, lorown, coriaceous.

* (25) D. Peekeli, v. M. v. R. - Insert: Bull. Dép. Agr. I. N., 1908, XVIII, 7.

* (24/1) D. diversifolia, v. A. v. R. -- Insert: Bull. Dép. Agr. I. N., 1908, XVIII, 7. 
(25) D. patens, O. Htze. - Insert as a synomyn; Polypodium pulens, Sw., (oldest name).

(26) D. exigua, o. It:e. - Insert as a synonym : Lastraea exigua, J. Sm., (oldest name).

(27a) D. Foxii, Christ, Philipp. Journ., II, 208; Nephrodium Foxii, Copel., MS.

Rhizome short, creeping or ascending. Stipes close, 5-10 c.M. long, stramineous, naked. Fronds lanceolate, 20-30 c.M. long, 6-9 c.M. broad, narrowed at both ends. Pinnae lanceolate, acuminate, ascending, the lowest remote, minute. Lower pinnulae $\pm 8 \mathrm{~m} . \mathrm{M}$. long, $1-1^{1} \frac{1}{2}$ m.M. broad, acute, obscurely toothed, adnate, the others confluent, the higher tapering gradually into a subseriate tail. Texture membranaceous; upper surface naked, lower sparingly pubescent, the hairs whitish, short; veins \pm 5 on each side. Sori medial; indusium naked, subpersistent. - Fronds sometimes reaching a size $4 \times$ as large as indicated above.

Luzon, Mindanao.

* 54) D. flix mas, Schott. - Insert as a synonym: Polypodium Filix mas, L., (oldest name). — Insert as a variety: - var. marginata; Nephrodium Filix-Mas, Rich., var. marginala, Clarke, Trans. Linn. Soc., Bot., $2^{\text {nd }}$ Series, I, 521, tab. LXXI; Aspidium marginalum, Wall, List, No. 591 (not 566); ? Lastraea Filix-Mas, Pr., var. elongata, Bedd., Handb. Ind. Ferns, 250; ? L. elongata, Pr., Bedd., Ferns S.I. tab. CXII; ? Nephrodium elongalum, Hl. \& Grev., Ic. Fil., tab. CCXXXIV; D. marginata, Christ, Philipp. Journ., II, 212.

Var. maregimata : Fronds large, oblong or ovate-lanceolate, not narrowed at the base; lowest pinnae falcate, often 2-5-pinnate; main and partial rachises nearly naked; tertiary segments oblong, obtuse, serrate or pinnatifid sometimes nearly to the costa. - Luzon; Centr. China, North. India.

var. parallelogramma: - Also found in Luzon.

(34a) D. Ineleopteroides, Christ, Philipp. Journ., II, 212.

Rhizome short, thick. Stipes fasciculate, $\pm 6-17$ c.M. long, those of the barren fronds the shortest, brown at the base, rufo-stramineous, clothed with diaphanous, subulate, pale-brown scales, those of the fertile fronds the longest, fibrillose. Fronds dimorphous, the barren ones deltoid, \pm 16 c.M. 
long, nearly as broad, pinnate, the apex lobed. Pinnae \pm 10 , approximate, lowest largest, petiolulate, \pm 8 c.M. long, $\pm 3^{1} / 2$ c.I. broad, oblong, obtuse, deeply pinnatifid, higher coarsely lobed. Lobes 8-10, ovate-rhomboidal, obtuse, lowest largest, \pm 2 c.M. long, \pm 1 c.M. broad, coarsely and irregularly crenato-serrulate. Texture subcoriaceous; colour pale-green, opaque; rachis and surfaces naked; veins pinnate and forked in the lobes. Fertile fronds \pm 10 c.M. long, \pm 7 c.M. broad, pinnate; pinnae \pm 8 on each side, distant, the segments rhomboidal, obtuse, equal, subentire, \pm 1 c.M. long, \pm $1 / 2$ c.M. broad. Sori submarginal, close, \pm 4 on each side in the lobes; indusium pale, bullate, subpersistent.

Luzon.

- (55) D. syrmatica, o. Ktze. - Insert as a variaty: var. petiolosa, Christ, Philipp. Journ., II, 210.

Var. petiolosa: Pinnae long-stalked, \pm 16 c.M. long, $\pm 5^{1 / 1} / 2$ c.M. broad, on stalks 1 c.M. or more long. Sori medial, minute: indusium grey. - Luzon, Mindanao.

(55a) D. Metteniana, Hier., Christ, Philipp. Journ., II, 210.

Near D. syrmalica, 0 . Klze, but the pinnae cut to $1 / 2$-way down to the costa, to 4 c.M. broad or broader, the lowest pinnae 2-pinnatitid, conspicuously produced on the lower side, with the lowest posterior segment deflexed and deeply lobed. Lobes serrato-crenate, subacute. Texture thinly membranaceous; veins 2-5-furcate. Sori medial, minute; indusium rudimentary.

Luzon, Mindanao, Celebes.

(56) D. erythrosora, O. Ktac. - Insert as a synonym: Aspidium erythrosorum, Eat., (oldest name).

* (40) D. Ilaccida, O. Ktae. - Insert as a synonym: Lastraca Maccida, Moore, Bedd., Ferns S.I., tab. CGL.

* (44) D. sparsa, o. Kt*e. - Insert as a synonym: Polypodium sparsum, Ham., (oldest name).

(44a) D. rinalensis, Christ, Bull. Herl. Boiss., 2e Série, VI, 1001; ? Philipp. Journ., II, 216.

Rhizome short. Stipes lufted, to \pm 40 c.M. long, slender, stramineous, 
rigid, clothed with short, grey pubescence and long, black hairs. Fronds elongate-deltoid, \pm 50 c.M. long, \pm 20 c.M. broad at the base, 2-pinnatifid. Terminal pinna incised, the lobes obtuse, subentire. Lateral pinnae $\pm 7-8$ on each side, oblong, bluntish, lobed nearly to the costa at the base, the lowest ones elongate-deltoid, with the lowest lobes on the lower side produced and deeply lobed. Texture herbaceous, flaccid; under surface paler than the upper; costae and costulae distinct, hlack, the latter pinnate and forked in the lobes, flexuose. Sori several on each lobe, terminal on the veins; indusium grey, flaccid, fugacious. - Near D. sparsa, O. Klze.

Luzon, Mindanao.

\# (4ら) D. Raciborskii, v. A. v. R. - This species has a distinct sagenioid habit, with the veins sometimes pleocnemioid, forming here and there a single costal or costular areola.

* (46) D. recedens, o. Ktze. - Insert as a synonym: Polypodium recedens, J. Sm., (oldest name).

- (51) D. intermedia, o. Htze. - Insert as variẹties: - var. Mannii, Christ, Philipp. Journ., II, 215 ; Nephrodium Mannii, Hope, Journ. of Bot., XXVIII, 145; - var. microloba, Christ, l. c.

Var. Irannii : Fronds resemhling D. filix mas, Scholl, much elongated, oblong, 2-pinnatifid; pinnae regularly lobed, lobes simple, only the lowest pinnae 2-pinnatifid, produced on the posterior side.

Var. microloban: Stipe and rachis purpureous, densely clothed with red-black, spreading hairs; lower pinnae $1 \frac{1}{2}-2$ c.M. long, $1 / 2$ c.M. broad; lobes close, \pm 6 on each side, 2-4 m.M. hroad.

Mindanao.

(56a) ID. balabacensis, Christ, Philipp. Journ., II, 215.

Stipes \pm 55 c.M. long, angular, naked like the whole plant, rufo-stramineous or castaneous, as are rachises. Fronds 5-pinnate, deltoid, $\pm \mathbf{5 0}$ c.M. long, as broad or broader, 3-partite at the base. Pinnae $\pm 8-10$ below the pinnatifid apex, distant, the lowest \pm 14 c.M. apart, \pm 50 c.M. or more long, \pm 25 c.M. broad at the base, deltoid, on stalks \pm 5 c.M. long, the lowest posterior pinnulae $\pm 15^{1 / 2}$ c.M. long, \pm 7 c.M. broad, the tertiary segments ovate-oblong, $4-5$ c.M. long, \pm 2 c.M. broad, obtusely inciso-lobate: higher pinnae sessile, oblong, acuminate, cut down to the costa in the 
lowest part, lobed towards the apex, the lobes decurrent, oblong, subacute, \pm 8 m.M. broad, with the sinuses acute, toothed, the teeth decumbent. Texture coriaceous; colour yellowish-green, rather glossy; veins pinnate and 2-3-furcate in the lobes. Sori numerous, minute, medial or submarginal; indusium black, carnoso-coriaceous, soon convolute, persistent.

Balabac, Palawan, Sibuyan.

(58a) D. dubia, Copel., Leafl., I, 255.

Rhizome ascending, clothed with lancèolate, castaneous scales. Stipes approximate, 10 -20 c.M. long, red-castaneous, clothed towards the frond (like the rachis) with minute hairs and small, distant scales. Fronds lanceolate-deltoid, to 50 c.M. long, to 20 c.M. broad, acuminate, 4-pinnatifid. Pinnae opposite or the higher ones alternate, the lower deltoid, to 12 c.M. long, to 10 c.M. broad. Ultimate divisions lanceolate, cut down nearly to the costa into obtuse, broadly oblanceolate segments. Texture membranaceous; surfaces nearly naked; veins simple. Sori terminal; indusium athyrioid, sometimes nephrodioid with a broad or nearly closed sinus, rarely asplenioid. - Judging by the sori this fern would be an Athyrium, but the frond's form and the colour and texture of the indusium mark it as a relative of Dryopteris rhodolepis, C. Chr. (Copel.).

Luzon. hegros (\$1 p 168)

* (59) D. setigeran, O. Kt:e. - Insert as synonyms: Lastraea flaccida, Bedd., Ferns S.I., tab. IC; Cheilanthes setigera, Bl., (oldest name). My var. pallida seems to be the common form or even the type itself: Omit its synonyms, which are synonyms of Phegopteris ornata, Fée.

* (61a) D. Hadeori, v. A. v. R., Bull. Dép. Agr. I. N., 1908, XVIII, 8; - var. aspera, v. A. v. R., l. c., XXI, 5; Polypodium asperum, Zipp., MS. in Herb. Bog.

Stipes and rachises pale-brown, the upper side pubescent with a line of fine, not very short, pale-coloured hairs, the rest provided throughout with numerous squarrose, deciduons, narrow, linear-subulate, pale-brown, finely and deciduously ciliate scales leaving the stipes and rachises rough by their persistent hases. Fronds like those of $\mathrm{D}$. setigera, 0 . Ktze, but the primary and secondary segments looser. Texture firm-herbaceous when dry; tertiary rachises narrowly winged, pubescent above and scaly beneath, as are the costae; upper surface nearly naked, lower hairy on the costulae and veins with whitish

Fitices. 
hairs; costulae (main veins) pinnate in the ultimate lobes. Sori numerous, minute, in rows near the costae (central ribs of the tertiary segments), 1-2 on each lobe; indusium minute, membranaceous, whitish, soon hidden among the capsules, visible by $\pm 50 \times$ magnifying power. - Mr. C. A. Backer found this plant in the new vegetation of the small volcanic island Krakatau, which was totally destroyed by an eruption in 1885 . It may be a hybrid between D. setigera, O. Kize and multiseta, C. Chr. or Phegopteris ornata, Fée. It differs: $a$, from D. setigera in having the stipes and rachises provided with deciduous, subulate scales with persistent, rough bases; $b$, from D. multiseta in having a line of hairs on the upper side of stipes and rachises; $c$, from Phegopteris ornata in having the fronds much smaller, with the rachises not winged and the sori minutely indusiate.

Wa耳. aspera: Differs from Mr. Backer's plant in having the rachises not beset with deciduous, flat, subulate scales, but with \pm persistent, subulate, subterete bristles of the same colour, the pinnulae horizontally spreading. the tertiary segments rather small, with the edges much recurved when dry. Indusium somewhat larger, visible by $\pm 15 \times$ magnifying power, but also hidden among the capsulus. Rhizome creeping. - Perhaps a distinct species. Kralkatau; - var. aspera: Java (Preanger Regencies, Zippelius No. 268).

\section{\$2. NEPHRODIUM.}

* (65) D. Dterdoides, O. Mtze. - Insert as a synonym: Polypodium pteroides, Retz, (oldest name).

(66a) D. mindamaensis, Christ, Philipp. Journ., II., 194.

Rhizome creeping or very oblique. Stipes distant, \pm 30 c.M. long, plumbeo-rufous, short-puberulous like the whole plant, the base clothed with brown, opaque, ovate, acuminate scales. Fronds \pm 70 c.M. long, \pm 40 c.M. broad, ovate-acuminate, caudate, not or hardly narrowed at the base. Pinnae \pm 28 on each side below the incised apex, spreading, tolerably approximate, sessile, not narrowed at the base, $\pm 2 \frac{1}{2}$ c.M. broad, caudate-acuminate, the edge cut to $1 / 2$-way down to the costa. Lobes $\pm 45-50$ on each side, close, pectinate, subfalcate, obtuse but mucronulate, nearly without sinuses between them, $\pm 3 / 4$ c.M. long, $\pm 1 / 2$ c.M. broad. Texture herbaceous; colour brightgreen, opaque; veins stramineous and densely white-puberulous, as are the costae, $\pm 10-12$ on each side, simple, $1-2$ lower anastomosing. Sori $5-8$ on each side; indusium flaccid, grey, ciliate.

Mindanao. 
APPENDIX. 22. DRYOPTERIS.

(69) D. procurrens, o. Ktze. - Also found in Luzon and Mindanao

* (72) D. invisa, o. Ktze. - Insert as a synonym: Polypodium invisum, Forst., (oldest name).

* 74) D. Cucullata, Christ, - Insert as a variety: - var. mucronata, Christ, Philipp. Journ., II, 195; Nephrodium mucronalum, J.Sm., Journ. of Bot., III, 412.

Var. mueromata. Pinnae 2 c.M. or more broad, the lower ones narrowed towards the base, the points of insertion of the pinnae callous; veins \pm 12 on each side of the main veins, 6 lower anastomosing. - Intermediate between the type and D. callosa, C. Chr. - Luzon, Mindanao.

(78) D. hirsuta, o. Htze; Nephrodium hirsutum, J. Sm. - Insert: Bedd., Ferns Br.I., tab. XLVI.

* (81) D. Glandulosa, o. Ktze; Nephrodium glandulosum, Moore. - Insert: Bedd., Ferns Br.I., I, tab. CXXXII.

* (85) D. urophylla, C. Chr. - Insert as a variety: var. pustulosa, Christ, Philipp. Journ., II, 203.

Var. pustulosa: Surfaces hispid, rough-pustulous. - Luzon.

* (91) D. callosa, C. Chr. - Insert as a synonym: Aspidium callosum, Bl., (oldest name).

(93) D. Hrachyodus, o. Ktze; Nephrodium brachyodon, Hk. Insert: Bedd., Ferns S.Br.I., Suppl., tab. CCCLXXIX; Polypodium brachyodus, $K z e$, (oldest name).

Veins all free or the lowest anastomosing and with sometimes an excurrent veinlet; a single vein generally rises from the costa between each pair of lobes and runs to the margin.

* (94) D. ferox, o. Ht:e. - Insert as a variety: - var. calvescens, Christ, Philipp. Journ., II, 195.

Var. calvescens: Axillar setae and pustules nearly evanished. Mindanao. 
(95) D. Wolneriana, C. Chr. - This species, with all the appearances of Lastraea, has the basal veins not always joined. Christ considers it now as a Lastraea.

* (97) D. piloso-spuamata, v. A. v. Re. - Insert: Bull. Dép. Agr. I. N., 1908, XXI, 4.

(99) D. caudiculata, v. A. v. R., as construed on page 225 , includes 2 distinct forms: D. basilaris, C. Chr. and caudiculata, $v . A . v . R$.

(99a) D. basilaris, C. Chr., Ind. Fil.; Christ, in Philipp. Journ., II, 196; Nephrodium basilare, Pr., Epim, 258; N. philippinense, Bk., Copel., Polypod. Philipp., 51.

Detailed description. - Rhizome oblique, suberect. Stipes $\pm 4-5$, subtufted, naked, rufo-stramineous, to \pm 45 c.M. long, provided on each side with 8-10 rudimentary, distant, obtuse auricles, the base clothed with long, lanceolate-subulate, hair-pointed, brown scales. Fronds ovate-acuminate, 60 c.M. long or longer. Pinnae alternate, erecto-patent, numerous, sessile or short-stalked, \pm 14 c.M. long or longer, $1-1 \frac{1}{2}$ c.M. broad, cut to $1 / 3$-way down to the costa, the base truncate on the upper, semicordate on the lower side, the apex caudate-acuminate; terminal pinna often very elongated. Lohes decumbent, \pm 5 m.M. long, subobtuse. Texture subcoriaceous; surfaces naked like the rachis; colour brownish-green; costae distinct, pale; veins $\pm \mathbf{b}-8$ on each side, only the lowest anastomosing. Sori minute, medial, $\pm \mathfrak{b}$ on each side of the costulae; indusium grey, persistent. - Philippines.

(99b) D. caudieulata, v. A. v. IR.; D. microloncha, Chrisl, Philipp. Journ., II, 202; Nephrodium caudiculatum, J. Sm. (not Pr.), Journ. of Bot., III, 411.

Near D. basilaris, C. Chr. Rhizome thick, oblique, black-brown. Stipes tufted, 2-5 c.M. long, rufo-stramineous, whether or not clothed with some scattered, brown scales. Fronds oblong, 16-24 c.M. long, 4-6 c.M. broad, caudate. Pinnae \pm 12 on each side, \pm 5 c.M. long, $\pm 1 / 2$ c.M. broad, sessile, the base nearly hastate or auriculate on both sides, the anterior auricle the largest, the edge cut hardly $1 / 2$-way down to the costa into truncate lobes; lower pinnae gradually reduced into mere, obtuse auricles $\breve{5}-\mathbf{5} \mathrm{m}$.M. each way. Surfaces naked; rachis stramineous, sparingly furfuraceous; main veins sparingly pinnate in the lobes, the lowest veins anastomosing irregularly. Sori 
numerous, in 5 irregular rows; indusium black-brown, orbicular, persistent. - Philippines.

(99c) D. Inzonica, Cherist, Philipp. Journ., II, 196; - var. puberula \& polyotis, Christ, l. c., 197.

Like D. basilaris, C. Chr., but distinguished by the following characters: Stipes slender, flavido-stramineous, naked, or minutely scaly at the base. Pinnae more distant, much elongated to an almost filiform apex, opposite, horizontal, dilated (substipulate) at the base on both sides; 1-2 lowest pairs of pinnae reduced to mere auricles. Lobes blunt, often truncate and denticulate. Texture thin, diaphanous; colour pale-emerald-green; veins often 5 on each side. Indusium thin, caducous.

Var. puberula: Rachis, costae and veins puberulous.

Var. polyotis: Pinnae \pm 16 m.Mr. broad at the base, short-acuminate; lower pinnae reduced to mere auricles; auricles \pm 20 on each side, reaching to the base of the stipe.

Luzon.

* (102) D. parasitica, O. Ktze. - Insert as a variety: - var. lalcatula, Christ, Philipp. Journ., II, 197.

Var. falcatula: Lower pinnae opposite, refracted, stipulate at the base on the anterior side; lobes deeply incised, falcate. - Mindanao.

(111a) D. todayensis, Clerist, Philipp. Journ., II, 195.

Rhizome suberect, black-brown, nearly naked. Stipes thick, firm, greybrown, \pm 40 c.M. long, naked or sparingly covered with lanceolate, brown scales. Fronds 70 c.M. or more long, \pm 20 c.Mr. broad, oblong, acuminate, the rachis grey-brown, puberulous. Pinnae numerous, $40-55$ on each side, close, \pm 11 c.II. long, $\pm 11 \mathrm{~m}$.II. broad, the apex caudato-acuminate, the base subcallous, cuneato-truncate, nearly unequal-sided, the margin cut to $1 / 2$-way down to the costa, the lobes close, \pm 45 on each side, lanceolate, \pm 2 m.M. broad, acute, strongly falcate; lower pimnae rudimentary, suddenly reduced into 8-10 short auricles. Texture herbaceous, flaccid; colour black-green; upper surface puberulous, lower clothed with adpressed hairs on the costae and costulae; veins $7-8$ on each side, the lowest anastomosing, the next following terminating in the acute sinuses. Sori minute, medial; indusium small, brown, puberulous.

Mindanao, Negros. 
(111b) D. Bordenii, Christ, Philipp. Journ., II, 204.

Rhizome oblique, thick, sparingly clothed with minute, crisped, lanceolate, pale-brown scales. Stipes subfasciculate, firm, to 30 c.M. long, often shorter, yellowish or brownish, puberulous. Fronds ovate, 25-35 c.M. long above the auricles, 15-20 c.M. broad, pinnate, the apex pinnatifid, acuminate. Pinnae lanceolate, \pm 15 on each side; horizontal, sessile, \pm 10 c.Mr. long, $\pm 1 \frac{1}{2}$ c.M. broad, the base truncate, the edge cut to $1 / 2$-way down to the costa, the apex acuminate; higher pinnae adnate, close, lower not-reduced ones sharply deflexed, cuneate at the base; lower pinnae suddenly reduced into \pm 10 small, triangular, subacute auricles or minute lobes or glands occupying the stipe to the base. Secondary segments oblique, subfalcate, close, pectinate, \pm 3 m.M. long, $\pm 2^{1 / 2}$ m.M. broad, entire, obtuse. Texture herbaceous; colour dark-green; rachis and surfaces shortly pubescent; veins not very distinct, $\pm \mathbf{7}$ on each side, only the lowest anastomosing. Sori medial, small; indusium small, dark-grey, soon evanished.

Luzon, Palawan.

* (112) D. Truncata, O. Htze. - Insert as a synonym: Polypodium truncatum, Poir., (oldest name).

23. MESOCHLAENA, R. Hrown.

* (1) M. polyearpa, Bedd. - Insert as a synonym: Dryopteris polycarpa, Christ, Philipp. Journ., II, 202.

* (2) M. Iarutensis, v. A. v. R., var. borneensis. - Insert: Bull. Dép. Agr. I. N., 1908, XVIII, 8.

\section{ASPIDIUM, Swartr.}

\section{S 1. TECTARIA.}

(4) A. Calcareum, Pr. - Insert as a synonym: Sagenia calcarea, J. Sm., (oldest name).

* (5) A. angulatum, J. Sm. - Insert as a synonym: Polypodium angulatum, Willd., (oldest name). 
APPENDIX. 25. ASPIDIUM.

* (8) A. termatense, v. A. v. R. - Insert: Bull. Dép. Agr. I. N., 1908, XVIII, 9; Teclaria temalensis, v. A. v. R., l. c.

\section{S2. SAGENIA.}

* (12) vastum, $\boldsymbol{\pi} \boldsymbol{t}$. - Insert as a synonym : - Nephrodium vasıum, Bk., Hk. Bk., Syn. Fil., 296.

* (15) A. Sulbcaudatum, v. A. v. He - Insert: Bull. Dép. Agr. I. N., 1908, XVIII, 9; Tectaria subcaudala, v. A. v. R., l. c.

* (20) A. semaibipinnatum, Walt. - Insert as a synonym: Sagenia semibipinnata, Moore, Bedd., Ferns Br.I., I, tab. CXXXVIl.

* (25) A. subtuiplinylium, HT. - Insert as a synonym: Polypodium sublriphyllum, Hk. \& Arn., (oldest name).

* (31) A. varoiolosum, Wall. - Insert: Bedd., Ferns S.Br.I., Suppl., tab. CGCLXV.

* (35) A. Iatifolioum, J. Sm. - Insert as a synonym: Polypodium latifolium, Forst., (oldest name).

* (59) A. siifolidum, Mett. - Inser't as a synonym: Polypodium siifolium, Willd., (oldest name).

\section{ODONTOSOLEA, Prest.}

\section{\$ 1. EU-ODONTOSORIA.}

* (4) D. Iindsayae, v. A. v. R., Bull. Dép. Agr. I. N., 1908, XXI, 4.

Stipes and rachises pale-brownish-stramineous, naked. Fronds 4-5-pinnate. Ultimate leaflets cuneate, sessile, simple or $2-5$-fid, $3 / 4-11 / 4$ c.M. long, $2-5$ m.M. broad at the apex, the incised ones the broadest, the apices rather horizontally or \pm obliquely truncate. Texture subcoriaceous or firm-herbaceous; surfaces naked; veins flabellate, dichotomous. Sori narrow, terminal on the ultimate segments (leaflets or lobes), occupying the 'whole breadth, uniting the apices of 2 or more veinlets. - In habit this resembles 0. chinensis, J. Sm., but in the Lindsaya-like sori it approximates 0 . retusa, J. Sm. New Guinea. 


\section{LINDSA Y A, Dryander.}

\section{\$ 1. ODONTOLOMA.}

* (1) L. repens, Bedd. - Insert as synonyms: Davallia Boryana, Pr., Hk. \& Grev., Ic. Fil., Lab. CXLIII; Dicksonia repens, Bory, (oldest name).

\section{\2. EULINDSAYA.}

* (2) L. gracillis, Bt. - Insert as a synonym: L. Lobbiana, Hk., Bedd., Ferns Br.I., I, lab. XXVIII.

* (18a) L. cultrata, Sav. - Insert: Hk. \& Grev., Ic. Fil., tah. CXLIV; Adiantum cultratum, Willd., (oldest name).

* (20) L. scandens, His. - Insert: Bedd., Ferns Br.I., II, tab. CGXCVIII.

\section{SCHIZOLOMA, Gandichund.}

\$2. EUSCHIZOLOMA.

(9) S. Guerinianum, Gand. - Insert: Bedd., Ferns Br.I., II, tab. CGCXL.

* (11) S. coriaceum, v. A. v. R. - Insert: Bull. Dép. Aggr. I. N., 1908, XVIII, 10.

\section{HUM A TA, Cavanilles.}

\section{$\$ 1$. EUHUMATA.}

* (3) H. Craimardiana, J. Sme. - Insert as a synonym: Nephrodium Gaimardianum, Gaud., Freyc., Voy. Ur. Phys., Bot., Lab. XII, fig. 1.

* (5) H. parvula, Wall. - Insert as a synonym: Acrophorus par vulus, Moore, Bedd., Ferns Br.I., I, tab. XGVII. 
34. DAVALLIA, Smith.

\section{S2. COLPOSORIA.}

* (5) D. Groflithiama, Hz. - Insert: Bedd., Ferus Br.I., I, Lab. CVI.

(17) D. trielnománmoides, Bt. - Insert. Bedd., Ferns Br.I., II, tab. GLXXVIII.

\section{MICROLERIA, Prest.}

(2) N. Inaroginalis, Bedd. - Insert as synonyms: M. urophylla, Moore, Bedd., Ferns Br.I., I, tab. CIII ; Polypodium marginale, Thb., (oldest name).

* (6) MI. Spelumcac, Moore. - Insert as a synonym: Polypodium Speluncae, L., (oldest name).

(6a) B. sablanemsis, Chreist, Philipp. Journ., II, 168.

Fronds large, 5-pinnate, the rachis opaque, fulvo-stramineous, shorlly and finely puberulous. Pinnae 55 c.M. and more long, \pm 9 c.M. broad, hardly narrowed at the base, short-stalked, elongate-caudate. Pinnulae approximate, pectinate, numerous ( \pm 40 or more pair), horizontal, nearly sessile, acuminate, produced at the base on the upper side. Tertiary segments \pm 20 on each side, close or approximate, separated by narrow sinuses, unequal-sided, the lowest free, adpressed to the rachis; upper base truncate, lower cuneate; upper side crenate, lower subentire; lobules $\pm \mathbf{3}$, minute. Texture herbaceous; colour dark-green; upper surface smooth, lower pilose on the costae and veins; veins distinct, 2-3-furcate in the lobules. Sori minute, $2-3$ on the anterior side, in the sinuses of the lobules; indusium inconspicuous, thin. - Very near M. speluncae, Moore.

Luzon.

* (10) DI. stroigosa, P*. - Insert as a synonym. Trichomanes slrigosum, Thl., (oldest niume). 
37. ADIANTTUM, Linné.

\section{$\mathbb{S}$ 1. EU-ADIANTUM.}

* (15) A. Mettenii, Kouthe. - Also found in Timor (Forbes, No. $3755)$.

* (15a) A. aculeolatum, v. A. ש. R. - Insert: Bull. Dép. Agr. I. N., 1908, XVIII, 10.

* (21) suborbiculare, v. A. v. R. - Insert: Bull. Dép. Agr. I. N., 1908, XVIII, 11.

\section{HYPOLEPIS.}

* (3) H. tenuifolia, Bernhe. - Insert as a synonym: Lonchitis tenuifolia, Forst., (oldest name).

\section{PLA GIOGYRIA, Mettemius.}

(1a) Palcata, Copel., Philipp. Journ., II, 155, tab. I, B.

Rhizome erect, thick. Stipes tufted, naked, without basal tubercles, 724 c.M. long, the fertile fronds on the longest stipes. Barren fronds \pm 20 c.M. long, 6-7 c.M. broad, short-acuminate, cul down nearly or quite to the costa. Pinnae approximate, $\pm \mathrm{g}$ m.M. broad, acute, straight or subfalcate, sharply serrate, or entire towards the not or hardly dilated, adnate base; lowest pinnae much deflexed, somewhat abbreviate. Texture submembranaceous; surfaces naked; colour black-green; veins conspicuous, mostly simple. Fertile fronds $15-24$ c.M. long, $21 / 2-4$ c.M. broad, acuminate, pinnate; pinnae rather distant, falcato-arcuate, $2-3$ c.M. long, \pm 2 m.M. broad.

Mindoro.

(5) P. Christii, Copet. - Also in Mindoro.

(7) Tuberculata, Copel. - Insert as a variety:- var. latipinna, Copel., Philipp. Journ., II, 135.

Var. Iatopinna: Fertile pinnae broader, 3-4 m.M. broad. - Mindoro. 
11. PELIAAEA, Rink.

\section{\$ 2. PTERIDELLA.}

* (4) E. tiomonemsìs, v. A. v. R. - Insert: Bull. Dép. Agr. I. N., 1908, XVIII, 11.

\section{5a. PTIFIRIS, Lineé.}

\section{$\$ 1$. EUPTERIS.}

* (3) Pt. orientalis, v. A. v. Ir. - Insert: Bull. Dép. Agr. I. N., 1908, XVIII, 12.

* (6) Ft. Trevbii, v. A. v. R. - Insert: Bull. Dép. Agr. I. N., 1908, XVIII, 12.

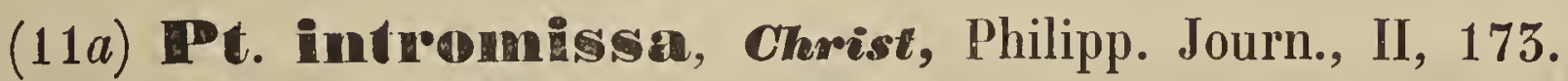

Rhizome short. Stipes fasciculate, slender, rufo- or fusco-stramineous, opaque. Fronds \pm 30 c.M. long, as broad, pinnate, the apex ternate. Pinnae opposite, medial simple, decurrent, longest \pm 20 c.M. long, linear-lanceolate or linear and caudate, lowest 2-3-partite, decurrent, edges acutely serrate when barren; barren pinnae or segments $\pm 1 \%$ c.M. broad, fertile \pm 6 m.M. broad. Texture thinly papyraceous; colour dark-green, opaque, subglaucous; veins slender, not very distinct, oblique, simple or forked. Sori and indusia narrow. - Very near Pt. cretica, $L$.

Luzon, Mindanao; China.

* (20) Pt. Danhousiac, HI. - Insert: Bedd., Ferns Br.I., II, tab. CXCI.

* (22a) FDt. Crevillesemse, Walt., var. oruata. -- Insert: v. A. v. R., Bull. Dép. Agl'. I. N., 1908, XXI, 丂.

* (25) Pt. Iong gipoinnala, Wall., var. sumatrana. - Insert: v. A. v. R., Bull. Dép. Agr. I. N., 1908, XXI, 5. 


\section{LOMA RIA, Willdenow.}

* (1) L. Patersoni, Spr., var. elongata; L. elongala, Bl. - Insert: Bedd., Ferns S.I., tab. XXVIII-XXVIII, A.

(4) L. areolaris, IIarr. - Omit this, it being referred to Stenochlaena further on.

\section{DTPLAZIUM, Swarta.}

\section{$\$$ 1. EUDIPLAZIUM.}

* (2b) D. zeylanicum, Moore. - Insert: Bedd. Ferns S.I., tab. CGXXVIII.

* (7) D. silvaticum, Sw. - $\Lambda$ form found in Java (Depok, v. A. v. R.) has the sori on the pinnae small and irregular.

(30) D. Prescottianum, Moone. - Insert: Bedd., Ferns Br.I., II, tab. CCXLIII ; D. silvaticum, Sw., var. Prescoltianum, Bedd., Handb. Ind. Ferns, 178.

* (42a) D. umbrosum, Bedd., Handb. Ind. Ferns, 188; Asplenium umbrosum, J. Sm., Rac., Flor. Btz. I, 228; Athyrium umbrosum, Pr., Christ, Farnkr. d. Erde, 225; G. Chr., Ind. Fil.; A. australe, Bedd, Ferns S.I., tah. (CLVIII; Polypodium umbrosum, Ait., (oldest name).

Caudex erect, to 25 c.M. high, densely covered with the bases of fallen stipes, roots and brown, lanceolate scales. Stipes 30-80 c.M. long, firm, scaly at the base. Fronds often $90-160$ c.M. long, 60-120 c.M. broad, ovate-lanceolate to deltoid. Pinnae ovate- to deltoid-lanceolate, 7-20 c.M. broad. Pinnulae close, pimnatifid at the apex, cut down nearly or quite to the costa into unequal-sided, elliptico-rhomboidal segments $5-15 \mathrm{~m}$.M. long, 2-5 m.M. broad. Segments sessile, the apex rounded, the edge toothed to deeply inciso-crenate, the base narrowed or broad and decurrent. Texture herbaceous; surfaces naked; central rilss of the segments pinnate; veins simple or forked. Sori copious, oblong, the lower often double; indusium inflated, entire. - Variable.

Trop. Asia \& Australia, New Zealand, Africa. 
* (45c) D. Drevisorum, J. Sm., Journ. of Bot., III, 408, Asplenium basilare, Moore, Rac., Flor. Btz., I, 229; A. woodwardioides, Bk., Hk. Bk., Syn. Fil., 229; Athyrium woodwardinides, Christ., Fil. Saras., III, 253;A. silvaticum, Milde, Bot. Zeit., 1866, 576; C. Chr., Ind. Fil.; Allantodia sylvatica, Bl., Enum., 175.

Rhizome erect. Stipes firm, erect, naked, dark-brown, to \pm 70 c.M. or more long. Fronds lanceolate-triangular, 60-100 c.M. long, 50-60 c.M. broad. Lower pinnae largest, to 50 c.M long, $7 \frac{1}{2}-10$ c.M. broad, pinnate. Pinnulae subpetiolate, $1-2$ c.M. broad, narrowed towards the apex, cut \pm $2 / 3$-way down or more to the costa into \pm close, linear-oblong, blunt, toothed, subfalcate segments to \pm 1 c.M. long, to $\pm 1 / 2$ c.M. broad. Texture herbaceous; rachis and surfaces naked; main veins pinnate in the lobes; veins simple or forked, $\pm 4-5$ on a side. Sori short-oblong, close to the costulae, the lower ones often double, close to the costae, not reaching more than $1 /{ }_{2}$ way the edge; indusium ciliate or eroso-firmbriate. - Resembles in habit D. polypodioides, $B l$. The javan form has the dimensions not rarely $2 X$ as large.

Java, Cetebes, Philippines.

(4⿹̆c) D. muricatum, v. A. v. T.; Asplenium muricalum, Mell., Ann. Mus. Bot. L. B., II, 259; Athyrium umbrosum, Pr. var., C. Chr., Ind. Fil.

Stipes nodulous or aculeate. Fronds \pm 60 c.M. long, deltoid, \pm 5-pinnatisect. Lowest pinnae distinctly stalked, \pm 20 c.M. long, oblong, acuminate. Pinnulae to \pm 5 c.M. long, $\% / 4$ c.M. hroad, short-stalked, oblong, narrowed towards the blunt apex, the base truncate, not rarely oblique. Lobes oblong, obtuse; upper edge slightly toothed, lower subpinnatifid. Texture firm-membranaceous; colour opaque-green; upper surface naked, lower sparingly scaly; veins forked. Sori near the costulae; indusium curved, pale. membranaceous, entire. - Near D. umbrosum, Bedd.

Java.

\section{S2. ANISOGONIUM.}

* (55) D. proliferum, Thomars; Callipteris prolifera, Bory. Insert: Bedd., Ferns Br.I, I, tab. LXX.

Pinnae often proliferous in the axils. 
54. ATHYRIUM, Roth.

* (1i) A. pusillum, v. A. v. R. - Insert: Bull. Dép. Agr. I. N., 1908, XXI, 5, tab. I, a-c.

(15) A. umbrosum, Pr. - Omit this, it being referred to Diplazium.

(16) A. silvaticum, Milde. - Omit this, it being referred to Diplazium brevisorum, J. Sm.

\section{ASPLENIUM, Linné.}

S 1. THAMNOPTERIS.

* (ac) - niofus, L. - Insert as synonyms: A. Phillitidis, Don, Prod. Flor. Nep., 7; Thamnopleris Phyllitidis, Pr., Bedd., Ferns S.I., tab. CXXIII.

\section{S 3. EU-ASPLENIUM.}

* (57) maciophyllum, Sav., var. minus. - Insert: (? A. integerrimum, Wall., Hk. \& Grev., Ic. Fil., tab. CXXXVI).

* (69) A. pracemorsum, Sw. - Insert as a synonym: A. cunealum, IIk. \& Grev., Ic. Fil., tab. CLXXXIX.

\section{0a. PHEGOPTERIS, Fée.}

\section{S 5. MENISCIUM.}

* (41) Ph. Uriphylla, Mett.; Meniscium triphyllum, Sw. - Insert: Hk. \& Grev., Ic. Fil.; tab. GXX.

\section{CEROPTERIS, Lin.}

* (1) C. tartarea, Link. - Insert as a synonym: Neurogramme tarlareum, Diels, in Engl. \& Prantl, Nat. Pfl.Fam., I ${ }^{4}, 264$. 
66. STIVGIR AMIMA, J. Smith.

$\$ 4$. Hemigramma. - Omit this as a section, it being a distinct genus.

(10) S. Zollingeri, Diels. - Omit this, it is Hemigramma Zollingeri, Christ.

\section{HEMTONITIS, Limé.}

(1) H. gymnopteroidea, Copel. - Omit this, it is Hemigramma Zollingeri, Christ.

\section{8 a. HEMTGIRA MMA, Christ}

Sori linear, running along the veins, in $\pm 2-3$ longitudinal rows on each side of the costa, approximate or contiguous, united by transversal bars, at length not rarely confluent, sometimes acrostichoid. Paraphyses? No indusium.

Rhizome oblique or erect. Fronds dimorphous, not articulate to the rhizome, simple or irregularly incised or divided. Barren fronds sessile or stalked, clustered, if sessile or subsessile then not rarely in a dense rosette; venation as in Aspidium; main veins distinct; areolae irregular, with free veinlets. Fertile fronds long-stalked, contracted. $\left(^{*}\right)$

Malaya.

* H. Zollingeni, Chorist, Philipp. Journ., II, 170; H. latifolia, Copel., Philipp. Journ., II, 406, p.p.; Syngramma Zollingeri, Diels, in Engl. \& Prantl. Nat. Pfl.Fam., I ${ }^{4}, 257$; C. Chr., Ind. Fil.; Hemionitis Zollingeri, Kurz, Rac., Flor. Btz., I, 64; Christ, Farnkr. d. Erde, fig. 147; H. gymnopteroidea, Copel., Polypod. Philipp., 67; - var. major, Christ, Philipp. Journ., l.c.

Rhizome erect or oblique, the scales dense, brown, often crisped, lanceolate or subulate, entire or variously fringed. Fronds dimorphous, simple or irregularly divided. Barren fronds sessile or stalked, clustered or placed in a

$\left(^{*}\right)$ Differs from Syngramma and Hemionitis by the aspidioid venation, the distinct main veins and the areolac provided with included free veinlets. Its natural place is near Leptochilus, from which genus it is hardly distinguishable in the forms with confluent sori. The sporangia are densely intermixed with paraphysiform corpuscles, probably the persistent stalks of fallen sporangia. 
dense rosette, 7-25 c.M. long, 5-10 c.M. broad, oblanceolate, acute or obtuse, the edge entire or repand to irregularly undulate or incised, the lower part broad or contracted, the base cordate (var. Teysmannii), rounded or acute. Texture varying from membranaceous to subcoriaceous; surfaces naked; costa sometimes scaly like the rather short stipe; main veins distinct, not reaching the edge: areolae copious, irregular, with few or many free veinlets. Fertile fronds linear-lanceolate or ligulate, $5-15$ ciM. long, 5-12 m.M. broad, narrowed gradually to the apex and a stipe 3-15 c.M. long, the edge subentire, irregularly repand or interrupted. - Exceedingly variable. A form gathered in Borneo by Dr. Hallier (no. 1822), determined by Dr. Christ has the sori decidedly acrostichoid.

Var. major: Stipes of barren fronds to 16 c.M. long, scaly, the scales subulato-setiform, black. Barren fronds varying from simple to pinnate; pinnae $\pm \mathbf{3}$ on each side, connected by a narrow wing. Fertile fronds contracted; pinnae \pm 2 on each side, \pm z c.M. long, \pm 5 m.M. broad. Texture herbaceomembranaceous, nearly diaphanous. - Leptochilus latifolius, C. Chr. is distinguishable from this by its firmer texture, not diaphanous, its colour, black when dry, its often proliferous fronds.

Malaya; - var. major: Luzon, Mindanao.

\section{ซ1. POLYPODIUM, Limné.}

\section{\$ 1 . EUPOLYPODIUM.}

(60) P. cornigerum, T7\%. - Insert: Redd., Ferns S.Br.I., Suppl., tab. CCGLXXXI.

\section{S2. PROSAPTIA.}

* (111) D. contiguum, J. Sm.; Davallia conligua, Spr. - Insert: Hk. \& Grev., Ic. Fil., tab. CXLI.

\section{\$6. PLEOPELTIS.}

* (198) W. Lastadum, Thb. - Insert as a synonym: Pleopeltis malacodon, Bedd., Ferns S.Br.I., Suppl., Lah. CCCLXXXVII (not Handb. Ind. Ferns, 563). 


\section{STIENOCHILA ENA, J. Smith.}

\section{$\$$ 1. LOMARIOPSIS.}

(4a) S. aredanois, Copel., Philipp. Journ., II, 406; Lomaria areolaris, Harr., Journ. of Linn. Soc., Bot., XVI, 28; Blechnum areolare, Copel., Polypod. Philipp., 90.

Rhizome long, slender, naked, twisted. Stipes of barren fronds $\pm \mathbf{1 5}$ c.M. long, naked. Barren fronds ovate, 10-15 c.M. long, 7-10 c.M. broad, pinnate. Pinnae 7-9, lateral nearly sessile, terminal stalked, linear-lanceolate, $\breve{5}-8$ c.M. long, $1-2$ c.M. broad, acute, finely serrate, truncate or rounded at the base. Texture coriaceous; surfaces naked; costae and veins slightly chaffy beneath; veins free, simple or forked, united at the base by a series of arches \pm close to the midribs, thus forming on each side a row of long, narrow costal areolae. Fertile fronds on stipes \pm 30 c.M. long, the pinnae narrowly linear, $3^{1} / 2-5$ c.M. long, rather distant. Sori protected by the specialized, recurved, indusium-like margin when young. - Near S. palustris, Bedd. I saw a plant, probably a form of this, which had the pinnae with 2 glands at the base, 1 on the upper and 1 on the lower edge.

Philippines.

\section{ANGIOPTEREIS, Mofmann.}

(3) A. evecta, Hoffm. - This variable species is construed as including several forms (considered by de Vriese as distinct species) united by intermediates which are difficult of determination $\left(^{*}\right)$.

a. Recurrent veinlets present, reaching at least $1 / 2$-way down to the costa.

b. Pinnae rather thick, chartaceous to coriaceous.

A.sulfurfuracea ${ }^{5.4 \%}$ Largest pinnulae $\pm 171 / 2$ m.M. or more broad. StosI 60

c.c. Largest pinnulae $\pm 9-171 / 2$ m.M. broad.

d. Pinnulae pruinose beneath.

d.d. Pinnulae not pruinose beneath. (3a) A. evecta. is $p 44$
(3b) A. Miqueliana. S $p 44$ s. $3 G^{*} A$. Subintgarrma sip4 (3c) A. pruinosa. s: p 442

(*) Determining these forms one should bear in mind that: $a$, the complete fronds are very large; $b$, the collectors commonly gather only some pinnae of a frond; $c$, the gathered pinnae often are those having not the largest pinnulae; $d$, the limit between opaque (impellucid) and pellucid veins or veinlets is not well-marked and it is often uncertain whether a transparent vein or veinlet should be regarded as an opaque or pellucid one; and $e$, the cuncate or rounded bases of the pinnulae are not rarely imperfectly cuneate or rounded, i. e. nften \pm intermediate between both.

Fulices. 
APPENDIX. 90. ANGIOPTERIS.

e. Veins beneath pale, opaque.

(3d) A. crassifolia. $5 i p 4$

e.e. Veins beneath black or fuscous.

f. Pinnulae \pm cordate at the base on both sides.

(3e) A. javanica. SI P 44

f.f. Pinnulae not cordate at the base, upper base \pm cuneate, lower \pm rounded.

(3f) A. Hartingeana. S $5 p 4$

$(5 g)$ A. angustifolia. SIp 44

c.c.c. Largest pinnulae under 9 m.M. broad.

(3h) A. angustata. SI P4h

(3i) A. caudata. Si $p 4$ L

W.6. Texture rather thin, membranaceous to papyraceous.

1. Pinnulae while-waxy beneath.

(3j) A. hypoleuca. Sip 4

1.1. Pinnulae not white-waxy beneath.

2. Largest pinnulae less than 14 c.M. long.

3. Pinnulae \pm equal-sided at the base. (5/k) A. approximata. SIp 44

3.3. Pinnulae distinctly unequal-sided at the base.

1. Upper base narrower than the lower.

(3l) A. aphanosorus. SI $p 44$

4. Upper base broader than the lower.

(3m) A. cuspidata. S5p4

(3n) A. Teysmanniana. SI $p 4$

2.2. Largest pinnulae more than 14 c.M. long.

+. Pinnulae al least 20 c.M. long.

(כo) A. Willinckii. SI p 4

+.+. Pinnulae at best 20 c.M. lony.

+. Veins beneath pale or indistinct.

*. Veins oblique.

(3p) A. Presliana. $55 p_{4}$

*.*. Veins rather subhorizontal.

(3q) A. pallescens.

(3r) A. similis. Si p 4 i

(3s) A. D’Urvilleana.

t.+. Veins beneath fuscous or dark-coloured, distinct.

(3t) A. microsporangia. Si $p 44$

(3u) A. ankolana. SI $p 41$

a.a. Recurrent veinlets wanting or very shorl, often hardly visible.

b'. Texture thin, rather membranaceous or herbaceous.

c'. Veins pellucid.

(5v) A. amboinensis. $S y+44$

$\boldsymbol{c}^{\prime} \cdot \boldsymbol{c}^{\prime}$. Veins not pellucid.

(5w) A. muricata. Sip 4

$(3 x)$ A. crassipes. Sipl

$\boldsymbol{b}^{\prime} \boldsymbol{b}^{\prime}$. Texture firm, rather chartaceous or coriaceous.

(3z) A. uncinata. Si p 
(3a) A. evecta, Hoffm., de Vr., Mon. Maratt., 16, tab. III-IV, fig. 10.

Pinnulae subpellucid, subpetiolulate, lanceolate-elongate, straight or falcate, acuminate, the base unequally subrotundate or subtruncate, rarely subcuneate; largest pinnulae $\pm 17^{1 / 2}$ c.M. long, to $\pm 21 / 4$ c.M. broad at the centre; upper surface dark-green, lower paler; costa beneath black-brown; veins subhorizontal at the base, \pm oblique towards the apex, pale; recurrent veinlets subpellucid; sori subcontiguous, intramarginal, consisting of $\pm 10-13$ capsules; indusium membranaceous, fimbriate. - (? Trop. Asia \& Africa), Tahiti.

(3b) A. Miqueliana, de $\boldsymbol{V} \boldsymbol{x} .$, l. c., 26.

Pinnulae petiolate, lanceolate, short-acuminate, the base nearly equally cordate or truncate on both sides or rounded on the upper side; lower and central pinnulae $\pm \$ 17$ c.M. long, \pm 2 c.M. broad; colour pale-green; costa and veins beneath sometimes sparingly furfuraceous or piloso-paleaceous; veins pale, opaque (? subtransparent); recurrent veinlets pellucid; sori contiguous, remote from the margin, consisting of 8-10 (after Miquel 4-5) capsules, encircled by a whorl of hairs. - Java.

(3c) A. pruinosa, Hze, Bot. Zeit., 1846, 417; de Vr., l. c., 26.

Pinnulae short-stalked, lanceolate-oblong, hardly linear, narrowly acuminate, the base unequally subcordate, the upper sometimes subcuneate; lowest pinnulae $\pm 14 \frac{1}{4}$ c.M. long, $\pm 11 / 3$ c.M. broad; upper surface opaque-olivaceous in dried material, lower white-pruinose; veins black-fuscous; recurrent veinlets whether or not pellucid; sori intramarginal, consisting of $\pm 8-17$ capsules. - Java, Philippines, New Guinea.

(3d) A. crassifolia, de $V$ r., l. c., 17.

Pinnulae subpetiolate, linear-lanceolate, straight or falcate, long-acuminate, the base \pm cuneate on the upper, \pm rotundato-cuneate on the lower side; largest pinnulae \pm 14 c.M. long, $\pm 1 \frac{1}{2}$ c.M. broad; colour pale, yellowish or yellow-green; costa and veins sometimes minutely paleaceous, rather pale; veins often oblique; recurrent veinlets reaching \pm the costa, opaque, as are the veins; sori close or subcontiguous, intramarginal, consisting of $\pm 8-10$ capsules; indusium thick. - Java, Sumatra.

(3e) Javaniea, Pr., Tent. Pterid., Suppl., 20;A. Dregeana, de Vr., l, c., 17, tab. III-IV, fig. 8 .

Pinnulae petiolulate, linear or linear-oblong, acuminate, the base unequally 
cordate or truncate; largest pinnulae $\pm 15-17^{1 / 2}$ c.M long, $\pm 1 \frac{1}{4}-1 \frac{1}{1} 3$ c.M. broad; under surface paler in colour than the upper; costa clothed towards the base beneath with scattered, chaffy, hair-like or filiform, caducous scales; veins close, subhorizontal, generally blackish or fuscous, pellucid; recurrent veinlets often very pellucid; sori intramarginal, rather close, consisting of $\pm 6-12$, mostly 9 capsules. - Java, Sumatra.

\section{(3f) A. Hartingeana, de Vr., l. c., 25.}

Pinnulae petiolulate, linear-lanceolate, acuminate; upper base \pm cuneate, lower \pm rounded; largest pinnulae \pm 15 c.M. long, \pm 1 c.M. broad; colour black-green above; costa and veins black; recurrent veinlets pellucid; sori slightly remote from the margin, contiguous, consisting of 10--18 capsules. - Java.

(3g) A. angustifolia, Pr., l. c., 21; de Vr, l. c. 18.

Pinnulae subsessile. narrowly linear, long-acuminate; upper base \pm cuneate, lower \pm rounded; largest pinnulae \pm 15 c.M. long, $\pm 11 / 4$ c.M. broad; colour above deep-green, beneath pale-green; costa rather deciduously, sparingly and minutely setaceo-paleaceous beneath; veins close, slender, nearly horizontal, fuscous beneath, subtransparent; recurrent veinlets long, pellucid or opaque; sori often contiguous, remote from the margin, consisting of \pm b-12 capsules. - Luzon, Mindanao, New Guinea.

(3h) A. angustata, Miq., de Vr., l. c., 26.

Pinnulae short-stalked, linear, acute, the base slightly cordate, subinequilateral; central pinnulae 10-12 c.M. long, \pm 6-9 m.M. broad; under surface pale; costa beneath fuscous; veins opaque; sori contiguous, \pm marginal, consisting of $\pm 6-8$ capsules. - Java.

(3i) A. caudata, de Vr., 1. c., 20.

Pinnulae approximate, stalked, linear, caudato-acuminate, the base unequally subcordate, the lower base the broadest; largest pinnulae $\pm 16 \frac{1}{2}$ c.M. long, \pm 5-8 m.M. broad; upper surface dark-green, lower fuscous, rather woolly on the costa and in the lower part; veins beneath fuscous, opaque, rather horizontal; recurrent veinlets long, reaching \pm the costa; sori contiguous, subremote from the margin; consisting of $\pm 9-18$ capsules. - Philippines; Bismarck Islands.

(jj) A. hypoleuca, de $\boldsymbol{r}$., l.c., 21. 
Pinnulae subsessile, lanceolate-oblong, \pm falcate, long-acuminate; upper base oblique, cuneate, lower broader, cuneate or rounded; largest pinnulae to \pm 16 c.I. long, to $\pm 41 / 2$ c.I. broad at the centre; upper surface yellow green, lower white-waxy; veins oblique, pellucid; recurrent veinlets not reaching the costa, pellucid. - Java. purvulae serrate (SI).

(3k) A. approximata, de $\boldsymbol{V} r$., l. c., 25;

Pinnulae short-stalked, linear-lanceolate, straight, the base \pm equilateral, rounded or subcordate; largest pinnulae $\pm 13^{1} / 2$ c.M. long, $\pm 1 \frac{3}{3} / 4$ c.M. broad at the centre; costa fuscous; veins opaque, subhorizontal; recurrent veinlets reaching nearly to the costa, indistinct, partially pellucid; sori contiguous, distant from the margin, consisting of $\pm 9-10$ capsules. - Sumalra. Rumulare crevate in the laven, serrate in the upp. pearl. S I.

(3l) A. mphanosorus, de Vro, l. c., 19.

Pinnulae petiolate, lanceolate, subfalcate, rather straight, the base oblique on the upper, broadly cuneate to subtruncate on the lower side; largest pin. nulae \pm 11 c.M. long, $\pm 11 / 2$ c.M. broad; texture pellucid; surfaces very minutely tomentose; costa castaneous; veins subfuscous; recurrent veinlets pellucid; sori minute, distant from the margin, consisting of $\pm 10-12$ capsules. - Sumatra.

(3m) A. cuspidata, de Wr., I. c., 18, tab. III-IV, fig. 7.

Pinnulae petiolulate, linear, long-cuspidate; upper base rounded, lower cuneate; largest pinnulae \pm 12 c.M. long, \pm 1 c.M. broad; upper surface dark-green, lower paler; costa beneath woolly-tomentose, fuscous; veins fuscous, opaque; recurrent veinlets pellucid; Sori small, consisting of $\pm 7-9$ minute capsules. - Java.

(5n) A. Teysmanniana, de Vr., l. c., 24, tab. I-II.

Pinnulae petiolate, subulate-lanceolate, straight or curved, acute; upper base broadly cuneate or rounded, lower narrower; largest pinnulat \pm 11 c.M. long, $\pm 13 / 4$ c.M. broad at the base; upper surface dark-green, lower paler, opaque; costa finely fusco-paleaceous beneath; veins distinct, pellucid like the recurrent veinlets; sori distant or approximate, remote from the margin, consisting of $\pm 9-13$ capsules. - Java.

(3o) A. Willinckii, Miq., de Vr., l. c., 21.

Pinnulae petiolulate, elongate, very acuminate, the base rounded or sub- 
truncate, subinequilateral; barren pinnulae $20-25$ c.M. long, $\pm \mathbf{5}$ c.M. broad, fertile $15-20$ c.M. long, $\pm 2 \frac{1}{2}$ c.M. broad; upper surface dark-green, lower pale-green; costa and veins fuscous; veins and recurrent veinlets \pm oblique, pellucid; sori distant from the margin, consisting of $\pm 6-9$ capsules. Java.

(3p) A. Presliana, de Vr., l. c., 20.

Pinnulae nodoso-petiolate, lanceolate, acute or long-acuminate, the base cuneate on the upper, rounded on the lower side; pinnulae $\pm 171 / 2$ c.M. long; upper surface dark-green, lower pale, subglaucous, opaque; veins oblique, pellucid. - Java.

(3q) A pallescens, de $\mathbf{V}$ r., l. c., 25.

Pinnulae petiolate, lanceolate, long-acuminate, the base unequally subtruncate or rotundato-cuneate; largest pinnulae not rarely coriaceous, $\pm 17^{3} / 4$ c.M. long, $\pm 11^{3 / 4}$ c.M. broad; under surface pale-green, sparingly black-scaly; veins pale, suboblique at the base, oblique towards the apex; recurrent veinlets opaque; sori subremote from the margin, hardly contiguous, consisting of \pm 5-8 capsules. - Java, Sumatra.

(3r) A. similis, Pr., de Vr., l. c., 17.

Pinnulae pellucid, petiolulate, straight or falcate, long-acuminate, the base unequally rounded; upper base shorter and broader, lower longer and narrower; largest pinnulae $\pm 18 \frac{1}{2}$ c.M. long, \pm 2 c.M. broad; upper surface green, lower paler; veins and veinlets suboblique or horizontal, subpellucid; recurrent veinlets opaque; sori distant from the margin, not contiguous, consisting of \pm 8-9 capsules. - Java, Mindanao, New Guinea.

(3s) A. D'Urvilleama, de Vro, l. c., 17, tab. III-IV, fig. 11.

Pinnulae subpellucid, petiolulate, linear, acuminate; the base unequally rounded, broadest on the lower side; upper surface black-green when dry, lower pale-green, fuscous or blackish near the costa; costa fuscous; veins nearly horizontal; recurrent veinlets reaching hardly more than $1 / 2$-way down to the costa; sori intramarginal, subcontiguous, consisting of $\pm 8-10$ capsules. - Philippines; Tahiti.

(3i) A. microsporangia, de $\boldsymbol{W}$ r., l. c., 18.

Pinnulae subpellucid, petiolulate, linear-lanceolate, long-acuminate, the base 
unequally subcuneate to subtruncate, broadest on the lower side; largest pinnulae \pm 15 c.M. long, $\pm 13 / 4$ c.M. broad; colour fuscous when dry; costa beneath fuscous; veins black or fuscous, sometimes opaque like the recurrent veinlets; sori intramarginal, consisting of $\pm 8-10$ minute capsules. - Java, Sumatra.

(3u) A. ankolana (angkolana) de Wro, l. c., 19, tab. III-IV, fig. 9.

Pinnulae petiolulate, linear-lanceolate, long-acuminate, \pm equal- or unequalsided at the base, the largest \pm 17 c.M. long, $\pm 1{ }^{3} / 4$ c.M. broad; costa fuscous or castaneous, sparingly paleaceous beneath; veins fuscous, close, pellucid ; recurrent veinlets long, fuscous, pellucid; sori consisting of $\pm 10-12$ capsules. - Java, Sumatra, ? New Guinea.

(3v) A. amboinensis, de $\boldsymbol{V}$ r., l. c., 32.

Pinnulae petiolate, lanceolate, straight, suddenly acuminate, the base sub. equilateral, subtruncate or subrotundate; largest pinnulae $\pm \mathbf{1 5}$ c.I. long, \pm 2 c.M. broad, subpellucid; costa beneath fuscous; veins fuscous, pellucid, \pm horizontal; sori intramarginal, hardly contiguous, consisting of $\pm 10-20$ capsules. - Amboyna. Punulioe obturel terithed, apese obtural serrate norecurent venilets.

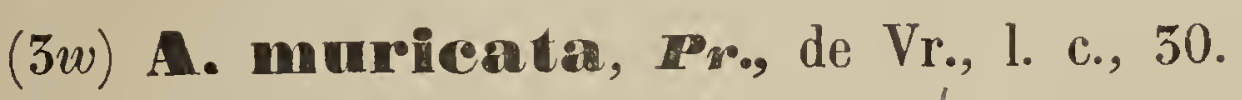

Pinnulae subsessile, pellucid, lanceolate, narrowly acuminate; upper basis broadly cuneate, lower narrowly rounded; largest pinnulae \pm 11 c.M. long, $\pm 21 / 2$ c.ll. broad; costa black-fuscous; veins oblique, blackish; recurrent veinlets present, short; sori hardly contiguous, distant from the margin, consisting of $\pm 10-12$ capsules. - Borneo.

Runclie cremete, serrate al the opese, recurrend ventets vers shor/, (3x)A. crassippes, Wall., de Vr., 1. c., 27; Diels, in Engl. \& Prantl, Nat. Pff.Fam., I ${ }^{4}$, fig. 238, A.

Pinnulae pellucid, subpetiolate, linear-lanceolate, or lanceolate-oblong, the base unequally cuneate or rounded; largest pinnulae $\pm 16^{1 / 2}$ c.M. long or longer, \pm 3 c.M. broad or broader; colour pale- or yellow-green; veins suboblique, opaque, fuscous beneath; sori contiguous, near the edge, consisting of $\pm 10-20$ capsules; indusium fimbriato-laciniate. - Sumatra, Malacca; North. India, Burmah, South. China.

(3z) A. uncinata, de $V \boldsymbol{r}$. , l. c., 29, tab. III, fig. 6.

Pinnulae petiolate, lanceolate-oblung, the apex acuminate, rather conspicu- 
APPENDIX. 90. ANGIOPTERIS.

ously upcurved, the base unequally cuneate, broadest on the upper side: largest pinnulae \pm 11 c.M. long, $\pm 2-21 / 2$ c.M. broad; under surface minutely punctulate; costa fuscous beneath; veins pellucid; sori contiguous, distant from the edge, consisting of $\pm 9-10$ capsules. - Amboyna; New Caledonia. 
INDEX. 



\section{IN DEX.}

A.

Abrodictyum

83

Cumingii, Pr. 99

Aconiopteris 711

Acrophorus 295

affinis, Moore 293

immersus, Moore 293

nodosus, $P r$. 295 parvulus, Moore 824

pulcher, Moore 292 slipellatus, Moore 295

Acropterygium

Acrosorus 567 exaltatus, Copel. 614 friderici \& pauli, Copel. ... 61 b Merrilli, Copel. ......... 614

Acrosticheae 122

Acrostichum 730

aculeatum, Rac. 722

angulatum, $B l$. 713

antrophyoides, Bk. 744 apiifolium, $1 \mathrm{k} k$. 725 appendiculatum, Willd..... 724 articulatum, $I / k . \ldots \ldots \ldots .725$ aureum, L. ......... 730 auritum, $S w . \ldots \ldots \ldots \ldots .726$ axillare, Cav........ 745 Beccarianum, Bk....... 714 bicuspe, Hk. ......... 732 bifurcalum, Cav.......... 710 Blumeanum, Hk.... 746, 747
Acrostichum.

borncense Burck........ $\mathbf{5 4 0}$

brachystachyum, Rac. ..... 729

callaefolium, Bl. ....... 714

calomelanos, L.......... 528

celebicum, Bk............ 741

commutatum, Mell. . .... 714

conforme, Bl. ......... 714

conforme, Sw. ........ 712

costatum, Wall. ....... 743

costulatum, Ces. ........ 644

Cumingii, Fée .......... 715

decurrens, Desv. ....... 715

dicholomum, L. ........ 805

digitatum, $L . \ldots \ldots \ldots \ldots .803$

diversifolium, $B l . \ldots \ldots \ldots .740$

drynarioides, Hk...... 731

exsculptum, Bk. ....... 740

flagelliferum, Wail.......759

gracile, Rac. .......... 722

grande, A. Cunn. ........ 708

gorgoneum, lilf. . .......712

IIamillonianum, Wall..... 724

heteroclitum, Pr. ....... 739

helerophyllum, L. ...... 703

hirlum, Sw. ........ 717

Hollrungii, Bk. ........ 757

inaequale, Willd. ....... 750

Ianceolatum, $\mathrm{H} / \mathrm{k} . \ldots \ldots \ldots .745$

laurifolium, Hk. ....... 719

laurifolium, Thouars ..... 714

Lessonii, Mett.......... 716 
Acrostichum

Linnaeanum, $I / k$.

lomarioides, Christ

marginatum, 'Wall.

melanosticticum, Bl.

melanosticton, $B l$.

miniatum, Christ

minus, Mett.

modeslum, Bk.

743

Nieuwenhuisii, Rac.

724

Norrisii, Ces.

714

Norrisii, Hk. 716

nummularifolium, $B l$. 685

obovatum, Bl. 685

obtusifolium, Spr. 715

oligodictyon, $\boldsymbol{B} k$.

755

paleaceum, Hk. \& Grev.

pellucido-marginatum, Christ.

peliolatum, Sw......... 717

platyrhynchos, Ces. ....... 728

platyrhynchos, Hk....... 729

praestantissimum, Bory .... 750

Preslianum, Hk. ....... 740

punctatum, L.......... 655

quercifolium, Retz ...... 757

Quoyanum, Gaud. ........ 741

repandum, Bl. ......... 741

Requinianum, Gaud. ...... 747

revolutum, Zoll. var. tenellum 728

rigidum, Wall, ........ 751

scandens, Hk. ......... 720

Smithii, Rac. ......... 720

sorbifolium, L. ........ 720

speciosum, Willd........ 750

spectabile, Rac......... 720

spicatum, L.f. ......... 728

var. brachystachys ..... 729

squamosum, $S w$.

\section{Acrostichum}

stenosemioides, $\mathrm{Bl}$. 725

subrepandum, H/k. 742 taccaefolium, Hk........ 757 tartareum, Cav......... 528 Teysmannianum, Bk. .... 727 Ihalictroides, L......... 751 validinervis, Rac. ...... 729 variabile, Hk. ........ 756

var. axillare ........ 745

var. decurrens ....... 756

virens, Wall. ......... 741

viscosum, Sw. ......... 717

Zollingeri, Kze ........ 742

Actinostachys .......... 115

Adenophorus

bipinnatus, Gaud. ........ 611

Tamarisci, Hk. \& Grev.... 611

Adiantellum ........... 519

Adiantum ......... 519, 826

aculeolatum, v. A. v. R. 527, 826

aethiopicum, L. ..... 550, 551

affine, Hk. ........ 325

alatum, Copel. ......... 526

amoenum, Hk. \&.Grev. .... 554

capillus veneris, L. ..... 553

cardiochlaena, Kze ...... 528

caudatum, L. ......... 524

var. $\beta \ldots \ldots \ldots \ldots \ldots . .524$

var. ciliatum ......... 524

celebicum, Christ. ....... 551

ciliatum, $B l . \ldots \ldots \ldots \ldots .524$

concinnum, H. B. K. ... 552

cultratum, Willd........ 824

cuneatum, L. \& F. .... 332

denticulatum, Burm....... 301

diaphanum, $B l . \ldots \ldots \ldots . \mathbf{3 2 3}$

decorum, Moore. ........ 552 
Adiantum

flabellulatum, $L . \ldots \ldots \ldots . \quad 354$

formosum, R. Br. ..... 328

gomphophyllum, Bk. ... . 522

hispidulum, $S w . \ldots \ldots \ldots .555$

Hosei, Bk. ........ 325

lanceum, L. .......... 275

Lobbianum, Hk. ...... 327

lunulatum, Burm. ..... 525

var. Meltenii ....... 526

lunulatum, Hoult. ....... 170

macrophyllum, Sw. ..... 521

Mettenii, Kuhn ..... 526, 826

mindanaoense, Copel. . . 527, 528

neoguineense, Moore . .... 550

nobile, Fisch. ....... 530

opacum, Copcl......... 550

orbiculalum, Lam ...... 270

Parishii, Hk. ........ 520

pendactylon, L. \& F. .... 525

peruvianum, $K l$. ... 321, 326

philippense, L. ........ 525

platyphyllum, Sw. ... 521, 526

polyphyllum, Willd. ..... 528

pleroides, L. ......... 545

pulchellum, $B l \cdot \ldots \ldots \ldots .527$

repens, L.f. .......... 288

rhizophorum, $S w . \ldots \ldots .524$

Seemanni, Hk. ........ 521

Spencerianum, Copel. .... 525

stenochlamys, $B k$. ...... 554

suborbiculare, v.A.v.R. 531, 826

tenerum, $S w . \ldots \ldots \ldots . \quad 550$

tinctum, Moore ........ 552

trapeziforme, L. ....... 525

Wagneri, Melt. ........ 532

Zollingeri, Melt. ....... 525

Aglaomorpha ......... 569
Aglaomorpha

Meyeniana, Scholl ........671

Alcicornium

bifurcalum, Und. ....... 710

coronarium, Und. ....... 711

grande, Und. ......... 708

sumbawense, Und........ 709

Wallichii, Und. ........ 708

Wilhelminae Reginae,

v.A.v.R. . 708

Willinckii, Und........ 710

Aleuritopteris .......... 557

Allantodia .............. 140

Brunoniana, Wall....... 140

javanica, Trev. ........ 140

nitidula, $K z e \ldots \ldots \ldots \ldots \quad 454$

Solenopteris, hze ....... 435

sylvalica, Bl. ........ 829

Allosurus

Zippelii, Miq....... 545

Alsophila ......... 29, 789

alternans, IIk. ......... 17

batjanensis, Christ ...... 40

Brunoniana, Bedd. ....... 41

Burbidgei, Bli....... 55

calocoma, Christ ....... 789

caudala, J. Sm. ........ 785

celebica, Mell. ........ 42

Christii, v. A. v. R. .... 42

Clementis, Copel. ....... 790

commutata, Mell........ 54

comosa, Christ........ 42

comosa, Wall. ........ 55

contaminans, Wall..... 41, 790

crenulala, Mell......... 27

crinita, Hk. ......... 40

cyclodonta, Christ ....... 19

dimorpha, Christ ....... 56 
Alsophila

dubia, Bedd.

extensa, Spr.

fuliginosa, Christ

gigantea, Wall.

glabra, $H /$.

32, 789

glauca, J. Sm.

41, 790

Haenkei, Pr.

intermedia, Mett.

Junghuhniana, Kze

Kingi, Clarke

latebrosa, Wall.

58, 789

lepidoclada, Christ

lepifera, J. Sm.

var. congesta 789

lunulala, R. Br.

lurida, $H k$.

44, 791

Margarethae, Schroet.

33

melanopus, Hassk.

melanorhachis, Copel.

mindanensis, Christ ...... 44

modesta, $B k$. ....... 57

obscura, Scort. ........ : $\mathbf{3 4}$

ornata, Scott ......... 790

polyphlebia, $B k \ldots \ldots \ldots .45$

ramispina, $H k . \ldots \ldots \ldots \ldots \quad 34$

Ridleyi, Bk. ........ 32

sangirensis, Christ ....... 57

saparuensis, v. A. v. R. . 58, 790

scaberula, Christ........ $\mathbf{3 5}$

sikkimensis, Clarke \& B/. . . 790

squamulnta, Bedd. ...... 54

squamulata, IIk. . .... 55, 789

Ienuisecta, Bl. ......... 257

Teysmanniana, Rac. ..... 51

tomentosa, $H k$. ... 59, 45, 791

trichodesma, Scort. . . . . . $\mathbf{5}$ b

tristis, Bl.

44,257
Alsophila

truncata, Brack. ........ 42

vexans, Ces. ......... 52

Wallacei, Mett......... 36

Warburgii, Christ ........ 204

xantholepis, Christ ....... 44

Amphicosmia ........... 27

aliernans, Moore ........ 17

riparia, Gardn. ........ 27

Angiopteris $\ldots \ldots \ldots \ldots 761,85 \tilde{3}$

amboinensis, de Vr. ..... 859

anglkolana, de Vr....... 839

angustata, Miq. ....... 856

angustifolia, $\operatorname{Pr} . \ldots \ldots \ldots .85$

ankolana, de Vr. ....... 859

aphanosorus, de Vr. .... 857

approximata, de Vr. .... 857

cartilagidens, Christ ...... 762

cartilaginea, Christ ...... $\mathbf{7 6 2}$

caudata, de $V r . \ldots \ldots \ldots .836$

crassifolia, de Vr. ...... 855

crassipes, Wall. ....... 839

cuspidata, de $V r . \ldots \ldots .857$

Dregeana, de Vr. ...... 855

D' Urvilleana, de Vr. ..... 838

evecta, Hoffm. ... 762, 855, 855

Hartingeana, de $V r . \ldots .836$

hypoleuca, de $V r . \ldots \ldots \ldots 856$

javanica, $\operatorname{Pr} . \ldots \ldots \ldots \ldots .835$

microsporangia, de Vr. ... 858

Miqueliana, de $V r . \ldots \ldots .855$

muricata, Pr. ........ 839

pallescens, de $V r . \ldots \ldots .858$

Presliana, $d e \mathbf{V r} . \ldots \ldots \ldots \mathbf{8 5 8}$

pruinosa, Kze ........ 835

similis, Pr. .......... 858

Smithii, Rac. ......... 762

Teysmanniana, de $V r . \ldots .857$ 
Angiopteris

uncinata, de $V r$.

Willinckii, de $\mathrm{Vr}$.

Anchistea 390

Anisogonium 595

alismaefolium, Chris! 425 cordifolium, Bedd. 422 elegans, $\mathrm{Pr}$. 425

esculentum, $\operatorname{Pr} . \ldots \ldots \ldots . . .425$

lineolatum, Bedd....... 425

Smithianum, Bedd....... 425

Antigramme ........... 477

Antrophyum ........... 529

avenium, $B l . \ldots \ldots \ldots \ldots .558$

Boryanum, Bl........ 555

Brookei, Hk........ 554

callifolium, $B l . \ldots \ldots .551,555$

var. alalum ....... 555

Clementis, Christ ....... 551

coriaceum, Bl......... 558

coriaceum, Wall. ...... 554

costatum, v. A. v. R. ... 552

Cumingii, Fée ....... 555

elongatum, Fée ....... 555

falcatum, $B l . \ldots \ldots \ldots \ldots .555$

Grevillei, Balf. ........ 555

immersum, Mett. ...... 551

involutum, $B l . \ldots \ldots \ldots .557$

lanceolatum, $B l . \ldots \ldots \ldots .558$

latifolium, $B l . \ldots \ldots \ldots \ldots .555$

marginale, $B l . \ldots \ldots \ldots \ldots$ 551

niphoboloides, Kze ...... 687

obtusum, $B l . \ldots \ldots \ldots \ldots \ldots$ 551

ovatum, v. A. v. R. ... 554

parvulum, $B l . \ldots \ldots \ldots \ldots \quad 552$

var. elongatum ...... 555

plantagineum, $K l f . \ldots \ldots .555$

pumilum, Klf.
Antrophyum

reticulalum, Bedd. ..... 555, 554

reticulatum, $K l f . \ldots \ldots \ldots \quad 555$

semicostatum, $B l \ldots \ldots$ 552, 555

spathulatum, v. A. v. R... 556

strictum, Mett........ 552

subfalcatum, Brack. ..... 554

Arcypteris ............

Arthrobotrya ........... 725

Arthropteris ............ 154

glabra, Copel. .......... 155

obliterata, J. Sm. ....... 15丂

ramosa, Mett......... 155

Aspidieae ............. 121

Aspidium .......... 255, 822

aborlivum, Bl. ........ 218

var. $B \& C \ldots \ldots 218$

aculeatum, Schott ....... 166

var. obtusum ........ 167

acutum, Schk......... 162

adiantoides, $B l . \ldots \ldots \ldots .262$

adnatum, Bl. ......... 191

alatellum, Christ ........ 210

alatum, Wall.......... 241

amabile, $B l . \ldots \ldots \ldots \ldots .168$

amabile, Rac.......... 167

ambiguum, Diels ......... 521

andaiense, C. Chr. ...... 514

Angilogense, Christ ....... 810

angulatum, Christ ....... 245

angulatum, IIk........ 255

angulatum, J. Sm. ... 256, 822

Arbuscula, Willd. ....... 218

aridum, Don .......... 212

arislatum, $S w . \ldots \ldots \ldots . . . . . .69$

var. coniifolium ...... 169

var. Sarasinorum .... 169

atratum, Wall.......... 180 
Aspidium

altenuatum, Kze 184

auriculatum, Sw.

var. obliquum ....... 809

Barberi, C. Chr. ....... 515

batjanense, Christ ....... 166

Beccarianum, Bk....... 258

Beccarianum, Diels ....... 515

Beddomei, Prantl ........ 191

Bencilianum, Gaud....... 225

biarislatum, Bl. ........ 167

biserinlum, Christ ........ 251

biserratum, Sw. ....... 162

Bolsieri, Copel. ......... $\$ 19$

Boryanum, Willd. ....... 201

brachiatum, Zoll. \& Mor. .. 252

brachyodus, Gris. ........ 220

Brongniarlii, Diels ........ 515

Bryanti, Copel. ......... 514

calcaratum, $B l . \ldots \ldots \ldots, 185$

calcareum, $P r . \ldots \ldots$ 256, 822

callosum, Bl. .......... 819

canescens, Christ ......... 208

forma acrostichoides ... 505

forma gymnogrammoides 507

forma nephrodiiformis .. 251

carvifolium, Kze ....... 169

caryolideum, Wall........ 255

Cesatianum, C. Chr...... 238

chaerophyllaefolium, Zipp. . . 194

cicutarium, Chirist ........ 248

cicutarium, $S w . \ldots \ldots \ldots .249$

coadunatum, Wall. ..... 248

coniifolium, Wall. ...... 169

comioncuron, Fée. ........ 210

Copelandii, C. Chr........ 246

costale, Bl. .......... 455

crassifolium, Bl. ....... 182

\section{Aspidium}

crenatum, Kuhn ........ 202

cucullalum, Bl. ........ 215

curvifolium, Kze ........ 169

cyatheoides, Klf. ........ 216

Dayi, Bedd. .......... 188

decurrens, Pr. ........ 247

densum, Zipp.......... 167

deversum, Kze ........ 189

devexum, Kze .......... 811

diaphanum, Zoll. \& Mor. ... 165

difforme, Bl. .......... 520

discrelum, Don ......... 167

dissectum, Christ ....... 196

dissectum, Metı. ....... 212

echinatum, Metı. ........ 182

edulentum, Kze ......... 194

erythrosorum, Eal. ...... 815

Everettii, C. Chr........ 241

excellens, $B l . \ldots \ldots \ldots \ldots .171$

exiguum, Kze ........ 190

extensum, Bl. ......... 210

falcatum, $S w . \ldots \ldots \ldots \ldots .253$

Fauriei, Christ

var. elatius ....... 429

ferox, $B l . \ldots \ldots \ldots \ldots \ldots, 221$

ferrugineum, Diels ....... 516

Filix-mas, Sw. ........ 192

var. fibrillosum ...... 192

var. megaphyllum .... 204

flaccidum, Bl. ........ 195

Roccigerum, Bl......... 807

giganteum, Bl. ....... 811

var. minor ....... 811

giganteum, Copel. ........ 811

glanduligerum, Kze ...... 186

glandulosum, $B l . \ldots \ldots \ldots .215$

goggilodus, Schk. ......... 212 


\section{Aspidium}

gongylodes, Schk.

gracilescens, Bl.

grammitoides, Christ

grande, J. Sm.

grandifolium, Mell.

grandifolium, $\mathrm{Pr}$.

Haenkei, $\operatorname{Pr}$

IIallieri, Christ

helerocarpon, $B l$.

heterodon, Copel.

helerophyllum, II/s.

hirsutum, $\mathrm{Kz} e$

hirtipes, $B l$.

hispidulum, Dec.

228

Hookeri, Bl.

Hookeri, Wall.

IIosei, C. Chr.

hymenophylloides, Bl.

294

immersum, Bl.

188

immersum, Hl.

intermedium, Bl.

199

intermedium, Christ

202

invisum, Chrisl

irriguum, J. Sm.

245

irregulare, C. Chr.

520

Keckii, Luerss.

Kehdingianum, Luerss.

Kingii, Hance

165

Koordersii, Christ

Kuhnii, C. Chr.

Künstleri, Bedd.

labrusca, Christ

laeve, $K z e$

lamoense, Copel.

latebrosum, $K z e$

latifolium, J. Sm. .... 249, 825

latipinna, Hance
Aspidium

Leuzeanum, $K z e \ldots \ldots \ldots, 172$

ligulatum, $K z e \ldots \ldots \ldots . . .184$

lineatum, Bl. .......... 209

lobalum, Sw........... 167

Lobbii, Hk. ........... 244

Loherianum, Christ ....... 221

longipes, $B l . . . \ldots \ldots \ldots . .211$

Luerssenii, Christ . . ...... 190

macrocarpon, $B l . \ldots \ldots \ldots .451$

macrodon, Keys. ........ 516

malayense, Christ ........ 249

mamillosum, C. Chr. ..... 247

marginatum, Wall. ....... 814

megalocarpum, C. Chr..... 172

megaphyllum, Christ ...... 204

megaphyllum, Mett. ...... 218

melanocaulon, $B l . \ldots \ldots \ldots 245$

melanorachis, C. Chr. ..... 250

membranaceum, Hk. ..... 811

membranifolium, Kze .... 175

menisciicarpon, Mett....... 251

menyanthidis, $\operatorname{Pr} . \ldots \ldots .244$

moluccense, Bl. ......... 166

Motleyanum, Christ ...... 182

moulmeinense, Christ ...... 217

mucronifolium, Bl. ...... 166

multicaudatum, Wall. .... 250

multilineatum, Christ ... 215, 217

musifolium, Bl........ 807

nebulosum, C. Chr....... 246

nephrodioides, IIk. ...... 251

nigripes, $B l . \ldots \ldots \ldots \ldots .455$

nudum, Diels ......... 250

obliquum, Don ......... 809

obtusilobum, Prantl ....... 205

oblusum, Kze ......... 166

ochtodes, Kze ......... 21

Filices. 


\section{Aspidium}

oligophyllum, Rst. 257

ornatum, Christ

otaria, Kze ........ . 210

pachyphyllum, Kze ... 259, 252

paleaceum, Rac. ........ 191

palmatum, Mett. ....... 247

parallelogrammum, Kze ... 192

parasiticum, $S w . \ldots \ldots \ldots .224$

patens, $S w . \ldots \ldots \ldots \ldots .189$

pectinatum, Christ ....... 185

pennigerum, $B l . \ldots \ldots \ldots .218$

pentaphyllum, v. A. v. R. . $\quad 519$

perakense, Bedd. ........ 226

persoriferum, Copel...... 251

phaeosigma, Ces. ........ 181

platanifolium, Mett...... 255

platyphyllum, Pr....... 258

plalypus, Kze ......... 810

polycarpum, Bl. ....... 252

polymorphum, Wall. .. 259, 245

Preslianum, Mett. ........ 164

procurrens, Mett. . ....... 211

profereoides, Christ .... . 812

productum, Klf. ....... 250

psilopodum, C. Chr. ..... 245

pteroides, Sw. ......... 209

pteropodum, Diels ....... 242

pteropus, Kze ......... 247

pulvinuliferum, Rac...... 200

purpurascens, Bl. ....... 201

repandum, Willd....... 258

Riedleanum, Gaud. ....... 250

rufescens, Bl. ......... 495

sagenioides Mett. ........ 191

sagenioides, Rac. ....... 197

sagittaefolium, Bl....... 222

saxicola, Bl. ......... 515
Aspidium

semibipinnatum, Wall. . 244, 825 semicordatum, $S w . \ldots \ldots .163$ setigerum, Kuhn ...... 202 siifolium, Mett. .....251, 825 var. pachyphyllum . . 252 simplicifolium, $H l . \ldots \ldots$ s.... singaporianum, Wall. .... 255 sparsum, Spr. ........ 197 splendens, Christ ........ 195 stenophyllum, Diels ...... 247 stipellatum, Bl. ........ 227 subcaudatum, v. A. v: R. . 242 subdecurrens, C. Chr. ..... \$14 subdigitatum, $B l . \ldots \ldots \ldots$ 485 subtriphyllum, Hk. . 246, 248, 825 sumatranum, C. Chr. ..... 518 syrmaticum, Willd. ...'. 195 tenuisectum, $B l . \ldots \ldots \ldots .257$ ternatense, v. A. v. R. . 258, 825 ternatum, Diels ........ 242 Teysmannianum, Ilk. ..... 251 tricuspe, Bedd. ........ 255 triste, $B l . \ldots \ldots \ldots \ldots \ldots .257$ truncatum, Gaud. ....... 227 unitum, Mett. ........ 212 unitum, Sieb. .......... 215 urophyllum, Christ. ...... 216 variolosum, Wall. ... 248, 825 varium, $S w . \ldots \ldots \ldots \ldots 168$ vastum, $B l$. 241, 247, Б18, 825 var. heterosorum. .. . . 518 vestitum, Sw. ......... 167 vile, Kze ........... 199 vitis, C. Chr. ........ vulcanicum, Bl. ....... 166 Wallichii, Hk. ........ 155 Warburgii, Kuhn \& Christ . 180 
Aspidium

Warburgii, var. debile ..... 501

Weinlandii, Christ ....... 244

Whitfordi, Copel. ...... 519

Wigmanii, Rac. ....... 192

Zippelianum, C. Chr..... 516

Zollingerianum, Bedd. . 248, 252

Aspidopodium ......... 568

Aspidotis ........... 555

Asplenidictyum ......... 457

Asplenieae ............ 122

Asplenium . . . . . . . 456, 850

acrostichoides, Sw. ...... 451

acuminalum, Wall. ...... 409

acutiusculum, $B l . \ldots . .463$

adiantoides, C. Chr. . 465, 464,

465

aequibasale, Bk........ 404

affine, $S w . \ldots \ldots \ldots \ldots .472$

alismaefolium, $H k . \ldots \ldots .423$

alternifolium, Metl. ..... 405

amboinense, Willd....... 441

amoenum, $\operatorname{Pr} . \ldots \ldots \ldots \ldots \quad 466$

anisodontum, $\operatorname{Pr} . \ldots \ldots \ldots 463$

amplissimum, Bk. ...... 419

apoense, Copel. ........ 444

approximatum, $B l . \ldots \ldots .462$

arayatense, Christ ...... 460

asperum, Hk. ........ 420

arifolium, Burm. ....... 547

australasicum, Hk...... 459

Bakeri, C. Chr. ....... 475

bantamense, Bk. ...... 405

barisanicum, Bk ....... 404

basilare, Moore ........ 829

batuense, $v$. A. v. R. ... 445

Beccarianum, Ces. ...... 473

Belangeri, Bory ........ 457
Asplenium

Belangeri, Kze ........ 474

biseriale, Bl. ........ 405

brachypodum, Bk. ..... 413

Brackenridgei, Bk...... 415

borneense, Hk. ...... 457

bulbiferum, Forst. ....... 471

bullatum, Wall. ........ 471

camarinum, $B k . \ldots \ldots \ldots, 402$

canaliculatum, $B l . \ldots \ldots .465$

caudatum, Bedd. ....... 464

caudatum, Forst. .... 460, 469

var. horridum ....... 468

ceramicum, Miq. ...... 421

Cesatianum, $B k . \ldots \ldots \ldots \quad 465$

cheilosorum, Kze ....... 466

chlorophyllum, Bk. ..... 401

comosum, Christ ....... 446

colubrinum, Christ ...... 458

concolor, Hk......... 442

confertum, Bk. ........ 404

confluens, $K z e \ldots \ldots \ldots \ldots \quad 428$

contiguum, Bedd. ....... 460

contiguum, Klf. ....... 461

cordifolium, Mett. ...... 422

crenato-serratum, $B l . \ldots . .407$

crinicaule, Hance ....... 463

crinitum, Bk......... 414

cultratum, Hk. ........ 407

cuneatum, Hk. \& Grev. ... 850

cuneatum, Lam. ....... 470

curtisorum, Christ ...... 459

cyatheifolium, Rich. ...... 416

cymbifolium, Christ. ..... 440

decorum, $K z e \ldots \ldots \ldots \ldots \quad 474$

decussatum, Sw. ........ 424

deltoideum, Pr. ........ 418

densum, Brack. ....... 452 
Asplenium

denticulatum, $B l$.

dichotomum, $I I /$ 474

dimidiatum, $S w$.

diversifolium, $B l$.

454

forma concolor ...... 442

forma indivisa ...... 442

Doreyi, Kze ........ 458

echinosporum, Rac. ...... 445

Elmeri, Christ ......... 469

elongatum, $S w . \ldots \ldots \ldots .458$

epiphyticum, Copel. ..... 441

erectum, $B l . \ldots \ldots \ldots \ldots .487$

erectum, Bory ......... 458

esculentum, Pr. ........ 425

exiguum, Bedd........ 455

falcatum, Bedd........ 465

falcatum, Lam. ........ 464

fejeense, Brack. ....... 441

filipes, Copel. ......... 467

Filix Femina, Bernh. var. . 454

Fińlaysonianum, Wall. ... 476

Forbesii, Bk. ........ 422

fraxinifolium, Wall. ..... 408

fuliginosum, $H k_{0} \ldots \ldots \ldots \quad 456$

furcatum, Thb. ....... 470

Gardneri, Bk. ........ 464

gedeanum, Rac. ....... 429

glochidiatum, Rac. ... 444, 445

grammitoides, Hk....... 410

griseum, Copel. ......... 459

gymnogrammoides, $K l$. ... 454

Hagenii, v. A. v. R. . . . 468

Hancei, $B k . \ldots \ldots \ldots \ldots \quad 463$

heterocarpum, Wall. .... 466

heterodon, Mett. ....... 456

heteropter on, Mett....... 425

hirtum, Klf. ......... 462

\section{Asplenium}

horizontale, $B / k \ldots \ldots \ldots \ldots \quad 456$

horridum, Klf. .... 461, 468

Huttoni, Bk. . ........ 421

impressum, Christ ....... 464

insigne, Copel. ........ 459

insititium, Brack. ....... 461

integerrimum, Wall. ..... 850

integrifolium, Mell. ..... 422

japonicum, Thb. ....... 408

javanicum, $B l \ldots \ldots \ldots .140$

Labillardieri, Kze. ...... 454

laciniatum; Don. ....... 468

laserpiiiifolium, Bedd. .... 471

laserpitiifolium, Lam. .... 472

lasiopteris, Mett. ....... 411

latifolium, Don ........ 416

Lauterbachii, Christ ...... 475

laxivenum, Copel. ........ 461

lepturus, J. Sm. ........ 461

tineolatum, Melt. ...... 42.5

Linza, Ces. .......... 479

Lobbianum, Hk. ....... 408

Loherianum, Ghrist ...... 452

lomariaceum, Christ ....... 401

longissimum, $B l \ldots \ldots \ldots .457$

lugubre, Hk......... 456

lunulatum, $S w . \ldots \ldots \ldots .458$

macrocarpum, $B l . \ldots \ldots \ldots \quad 451$

inacrophyllum, $S w . \ldots 464,463$, 466,850

Mactierii, Bedd. ........ 443

manilense, Spr. ........ 417

Meyenianum, Mett....... 418

Meyenianum, Pr. ...... 459

microxiphion, $B /$. ...... 442

militare, Copel. ......... 462

minus, $B l . \ldots \ldots \ldots \ldots .451$ 
Asplenium

monotis, Christ...
multijugum, Wall
multilineatum, Hl.
muricatum, Mett. .
musacfolium, Mett.

myriophyllum, Muell. 459

natunae, $B F$. $47 \%$

nidus, $L$ 459,850

var. pachyphyllım 459 var. Simonsianum 458

nigrescens, $B l$. 461

nigripes, $B l$. 455

nitidulum, Moore 454

nitidum, $S w$. 471

normale, Don 455

normale .1/ett. 451

novo-guineense, $R s t$. 476

obscurum, $B l$. 467

obtusilobum, IIk....... 474

oceanicum, C. Chr. 474

oxyphyllum, H/s. 455

pachyphyllum, Kze 459

paradoxum, $B l$. 465 pallidum, $B l$. 405 pellucidum, Lam... 454, 459, 462 persicifolium, J. Sm. .... 460 Pelersenii, Kze ........ 411 Phyllitidis, Don ...... 459, 850 plicatum, Zipp......... 459 polypodioid.s, Melt. . . 419, 420 porphyrorachis, Ble..... 4.01 porrectum, Wall. ....... 407 praemorsum, $S w . \ldots .470,850$ Prescoltianum, Wall. ..... 415 prionurus, J. Sm. ...... 459 proliferum, Lam. ....... 424 pusillum, Bl.
Asplenium

remotum, Moore ....... 45 bै reseclum, Sm. ......... 466 salignum, $B l . \ldots \ldots \ldots \ldots 454$ salignum, IIk. ......... 454

Sancti-Christophori, Christ .. 465 Sarasinorum, Copel. ...... 452 scandens, J. Sm. ....... 475 Schoggersii, v. A. v. R. .. 460 . scolopendrioides, J.Sm. . 444, 446 scolopendrioides, Muell. ..... 442 scolopendropsis, Muell. .... 477 Scortechinii, Bedr........ 445

Selenopteris, Mett. ....... 455

serraeforme. Melt. ....... 467

serrulatum, Pr.......... 417

setisectum, $B l . \ldots \ldots \ldots \ldots \quad 472$

shepherdioides, Bl. ...... 408

Simonsianum, II/....... 458

simplex, $B l . \ldots \ldots \ldots \ldots .442$

simplex, Melt. ......... 459

Smulhianum, Bk. ....... 424

sorzogonense, $\operatorname{Pr} . \ldots \ldots \ldots .412$

var. majus ... ..... 414

spathulatum, $B k . \ldots \ldots .442$

spathulinum, J. Sm.... . 472

speciosum, Mett. ....... 415

spinulosum, Mett. .... 424, 425

squamulatum, $B l . \ldots . . .445$

Stantoni, Copel......... 452

Steerei, Harr. .......... 459

stereophyllum, Kze .... 469

subaquatile, Ces. ....... 455

subavenium, H/....... 455

subnormale, Copel. ....... 451

subserralum, Bl. ....... 400

sulserratum, Ces. ....... 480

sulcatum, Metı......... 472 
Asplenium

sumatranum, II/...... 455

suindense, $B l . \ldots \ldots \ldots \ldots .444$

sylvaticum, $\operatorname{Pr} \ldots \ldots \ldots \ldots \quad 402$

taeniosum, Kze ........ 442

tenerum, Forst. ....... 458

var. Belangeri ...... 474

tenuifolium, Don ....... 469

thelypteroides, Mchx ..... 451

tomentosum, Hlk........ 414

tomentosum, Mett. ........ 411

Toppingianum, Copel. ..... 428

Toppingii, Copel. ........ 429

trichomanes, $L \ldots \ldots \ldots \ldots$. 452

truncatilobum, Fée ..... . 460

umbrosum, J. Sm. ...... 828

unilaterale, Lam. ... 466, 467

vacillans, Kze ......... 405

vestitum, Hk. ....... 417

vittaeforme, Cav. ....... 444

vulcanicum, $B l . \ldots \ldots \ldots .456$

Warburgianum, Christ .... 467

Werneri, Rst. . . . . . . 445

Wightianum, Ces. ....... 463

Wightianum, Wall. ...... 456

woodwardioides, Bk..... 829

xiphophyllum, Bk. .... 406

zamiaefolium, Pr....... 464

zamiaefolium, Willd..... 462

zamioides, Hk. ....... 465

zeylanicum, Ces......... 401

zeylanicum, Hk. ....... 400

Atactosia .............. 568

Athyrium ......... 426, 830

acrostichoides, Diels ...... 451

allantodioides, Bedd. ..... 431

anisopteron, Christ ....... 429

anisopterum, Christ
Athyrium

aristulatum, Copel. ...... 452

australe, Bedd. ........ 828

benguetense, Christ ...... $\mathbf{4 5 0}$

Copelandi, Christ ....... 430

drepanopteron, Moore ..... $4 \mathbf{4 3 3}$

drepanopterum, R. Br. ... 435

gedeanum, Christ. ...... 429

gymnogrammoides, Bedd. . $4 \mathbf{4 5 4}$

hyalostegium, Copel...... 451

Loheri, Christ ........ $\mathbf{4 5 2}$

macrocarpum, Bedd...... 451

nanum, Christ ......... 428

nigripes, Bedd. ........ $4 \mathbf{4 3 5}$

nigripes, Moore ....... 455

nitidulum, Milde ....... $\mathbf{4 3 4}$

oxyphyllum, Moore ...... 435

pectinalum, Bedd........ $\mathbf{4 5 0}$

philippinense, Christ ..... . 432

pusillum, v. A. v. R. . 428, 850

Sarasinorum, Christ ..... 432

selenopteris, Moore...... $\mathbf{4 3 3}$

silvaticum, Milde ....... 829

solenopteris, Moore ...... 433

thelypteroides, Desv. ...... 431

Toppingianum, Copel. .... 428

umbrosum, Pr. ....... 828

var. muricatum ..... 829

woodwardioides, Christ .... 829

Austrogramme ........ . 539

\section{B.}

\section{Balantium}

Blumei, Kze ......... 47

Bipinnatifidae (Pteris) . . . . 552

Blechneae ............. 122

Blechnum ........... 585 
Blechnum

areolare, Copel.

Blumei, Moore ......... 587

capense, Schl. ........ 581

cartilagineum, $S w . \ldots \ldots . \quad 386$

colubrinum, Blanco ....... 152

egenolfioides, C. Chr. ..... 580

egregium, Copel....... 388

elongatum, Gaud. . .... .. 386

Finlaysonianum, Wall. .... 387

Fraseri, Luerss. . . . . . . . 582

lanceola, $S w . \ldots \ldots \ldots \ldots .586$

nitidum, $\operatorname{Pr} . \ldots \ldots \ldots \ldots \ldots$

var. contracta ...... 586

orientale, L. . ....... 587

Patersoni, Mett. ....... 579

var. majus ...... 579

punctulanum, Sw....... 580

radicans, L. .......... 391

serrulatum, Rich. ..... 588

stenoplerum, Hance ....... 541

striatum, R. Br. ...... 588

Treubii, v. A. v. R. .... 586

vestitum, Kuhn ........ 581

vulcanicum, Kuhn ....... 579

Botrychium ........... 778

daucifolium, Wall. ..... 778

lanuginosum, Wall. ..... 778

subcarnosum, Wall. ...... 778

virginianum, $S w$.

var. lamuginosum .....

778

virginicum, Willd.

var. lanuginosum

\section{C.}

\section{Callipteris}

alismaefolia, J. Sm.

cordifolia, Copel.

\section{Callipter's}

eleyans, J. Sm.

esculenta, J.Sin....... 425

pariens, Copel. ......... 424

prolifera, Bory ...... 424, 829

Simithiana, Bedd........ 425

sylvatica, Bory ........ 402

Callogramme .......... 559

Callymodon cucullatus, Pr. ... 589

Campyloneuron ......... 568

Campteria ............ 552

anamallayensis, Bedd. ..... 571

biaurila, IIk. ........ 571

helerophlebia, Moore ...... 372

Junghuhnii, Reinw. . . . . 574

Kleiniana, Pr. ........ 571

Wallichiana, Moore ...... 572

Camptosorus ........... 477

Cardiomanes ........... 85

Cephalomanes ........... 84

asplenioides, Pr........ 101

auriculatum, $V . D . B . \ldots .96$

javanicum, V. D. B. .... 800

rhomboideum, V. D. B. ... 800

Zollingeri, V. D. B. .... 800

Ceratopteris .......... 751

thalictroides, Brong. ..... 751

Ceropteris ........ 527, 850

calomelanos, Und....... 528

chrysosora, v. A. v. R. . . 529

tartarea, Link . . . . . 528, 850

Ceterach

pedunculata, Hk. \& Grev. . 675

Cheilanthes ........... 556

alpina, $B l . \ldots \ldots \ldots \ldots \ldots$

argentea, Kze ....... 557

var. chrysophylla .... 538

Belangeri, C. Chr. ...... 559 


\section{Cheilanthes}

Boltoni, Copel. ........ 557

chrysophylla, Hk. ...... 558

distans, Mett. ......... 484

farinosa. $K l f . \ldots \ldots \ldots \ldots \ldots 558$

fragilis, Hk........ 340

gigantea, Ces. ......... 494

hirsula, Mett . ...... 485

hirta, Sw. .......... 540

hispidula, Kze........ 559

multifida, $S w . \ldots \ldots \ldots \ldots \quad \mathbf{3 5} 9$

pallida, Bl. ......... 556

parviloba, Sw. ........ 540

pteroides, $S_{u} \ldots \ldots \ldots \ldots \ldots \quad 345$

resinifera, $B l \ldots \ldots \ldots \ldots, 142$

rufa, $D_{0 n} \ldots \ldots \ldots \ldots \ldots . \mathbf{5 5} 8$

setigera, $B l . \ldots \ldots \ldots \ldots .817$

tenuifolia, Sw ....... 559

varians, $H k . \ldots \ldots \ldots \ldots .559$

Cheiroglossa ........... 772

Cheiropleuria ......... 752

bicuspis. $P_{r}, \ldots \ldots \ldots \ldots .752$

Christensenia .......... 767

aesculifolia, Max. ...... 768

Cumingiana, Christ ..... 768

Christopteris ........... 704

sagitta, Copel......... 704

Chrysodium .......... 755

aureum, Mett......... 750

praestantissimum, Mett. ... 750

Chrysopteris ........... 569

Cibotium ........ 47, 792

Assamicum, Hk. ....... 795

Baranetz, J. Sm. ....... 795

barometz, J.Sm. .... 48, 792

Cumingii, Kze ......... 795

sumatranum, Christ... . . 793

Gincinalis ........... 484
Colposoria . . . . . . . . . 296

Compositae (Polypodium) ... 567

Compositae (Pteris) ....... 552

Coniogramme .......... 527

fraxinea, Diels ........ 527

Craspedoneuron

album, V. D. B. ....... 95

Braunii, V. D. B. ...... 95

pallidum, V. D. B. ...... 95

Crepidomanes

humile, V. D. B. ....... 94

Crypsinus . . . . . . . . . 568

Cryptogramme

aurata, Prantl ........ 550

japonica, Prantl ........ 551

Ctenopteris

repandula, Kze ....... 599

solida, Kze ......... 606

Cuneatae (Adiantum) ... . . . 519

Cyathea .......... 15, 785

adenochlamys, Christ..... 785

alternans, $\operatorname{Pr}_{r} \ldots \ldots \ldots$ 17, 784

aneitensis, $I I / . \ldots \ldots \ldots \ldots 16$

arachnoidea, $H k . \ldots \ldots \ldots .26$

arborea, $S m$.

var. pallida ......... 21

assimilis, $I I k . . \ldots \ldots \ldots .20$

Beccariana, Ces......... 20

Brunonis, Wall. ....... 15 783

callosa, Christ ......... 787

capensis, Sm.......... 27

caudata, Copel.......... 785

celebica, Bl. ........ 42

celebica, $v . A . v . R$. . 26, 788

Christii, Copel. ......... 785

crenulata, $B l . \ldots \ldots \ldots \ldots .21$

cyclodonta, $v . A . v . R . \quad$ 19, 784

deparoides, Ces.......... 626 
Cyathea

dulitensis, $B /$.

excelsa, Kze

ferruginea, Christ

784

fusca, $B /$.

Havilandii, $B /$.

hymenodes, Mell.

inquimans, Chrisı

integra, J. Sm.

javanica, $B l$.

Korthalsii, Meti.

leucophä̈s, IIassk.

leucotricha, Chist

Lobbiana, IIl.

Loheri, Christ

Macgregorii, Muell.

moluccana, $R$. $B r$.

15,785

Huelleri, $B k$.

negrosiana, Christ 786

oinops, Hassli.

orientalis, Moore

peliolala, J. Sm.

philippinensis, $B /$. .... 16, 785

polypoda, Bk. ........ 18

rufopannosa, Christ ...... 784

l'unensis, v. A. v. li. . . 22, 786

saccata, Christ ......... 19

sarawakensis, $11 / . \ldots \ldots .17$

schizochlanys, Bk...... 25

sinops, Pac........... 25

spinulosa, Wull. ..... 25, 786

strigosa, Christ ......... 24

suluensis, Bk. ....... 18

sumatrana, $B / . \ldots \ldots \ldots . .25$

tripinnata, Copel. ....... 788

Werneri, Rsl. ........ 786

Zollingeriana, Mell. .... 20,785

Cyatheaceae
Cyatheae ............. 9

Cyclopeltis ......... 163, 808

Presliana, J. Sm. .... 164, 808

semicordata, J. Sm. ... 165, 808

Cyclophorus .......... 678

abbreviatus, $C$. Chr. .... 692

acrostichoides, $\mathrm{Pr} . \ldots . .685$

adnascens, Desv. ....... 681

albicans, $\operatorname{Pr} . \ldots \ldots .687,688$

angustatus, Desv........ 691

anetioides, C. Chr..... . 682

argyrolepis, Christ ....... 694

asterosorus, C. Chr. ..... 694

Beddomeanus, C. Chr..... 695

Christii, C. Chr. ........ 695

confluens, C. Chr. ...... 690

distichocarpus, C. Chr. . 695, 694

flocciger, Pr. ......... 687

heteractis, $C$. Chr....... 684

lanuginosus, $C . C h r . \ldots .685$

Lauterbachii, C. Ch. .... 690

macropodus, C. Chr. ..... 685

mollis, Pr. .......... 688

nummularifolius, C. Chr. . 685

var. obovatus ....... 685

obovatus, v.A.v.R. .... 685

pachydermus, C. Chr... 680

pannosus, C. Chr...... . 685

penangianus, C. Chr..... 686

porosus, Pr. ......687, 689

princeps, C. Chr....... 684

rasamalae, C. Chr....... 686

rupestris, C. Chr. ...... 680)

samarensis, $C$. Chr...... 691

Sarasinorum, C. Chr. .... 695

sphaerostichus, C. Chr. ... 682

splendens, C. Chr...... 696

stictiçus, C. Chr....... 687 
Cyclophorus

stigmosus, Desv. $69:$

varius, Gaud. 682

Warburgii, C. Chr.

Cyclosorus 175

Cyrtomium 255

caryolideum, $P$ r. 255

falcatum, $\mathrm{Pr}$.

235

lystodium

282

sorbifolium, d. Sin.

282

Ciystopteris

tenuisecta, Mell.

tristis, Metl.

44,257

\section{D.}

Darea 457

Davallia 296, 825

achilleaefolia, Wall...... 722 affinis, Hk......... 295 alpina, $B l . \ldots \ldots \ldots \ldots \ldots .290$

amboynensis, $I I /$. 515 angustata, Wall. 286 asperrima, Ces. 282

Beccariana, Ces ......... 501

Belangeri, Bory .......... 291

biflora, Klf. .......... 259

bipinnatifida, Bk. ...... 290

bipinnatifida, $B l . \ldots \ldots \ldots 291$

Blumeana, Ces.......... 265

Blumeana, IIk. ......... 265

borneensis, J. Sm. ........ 198

Boryana, Pr. .......... 824

botrychioides, Bk. ....... 290

brevipes, Copel. ........ 506

bullata, Wall. ........ 505

caudata, Cav.......... 505

celebica, Christ. ........ 145

chaerophylla, Ces. ....... 291
Davallia

chaerophylla, Wall...... 292 cicutarioides, Bk. ....... 292 ciliata. IIk. ........... 299 contigua, Spr. ......616, 852 corniculata, Ces......... 501 corniculata, Moore ....... 502 Cumingii, Hk. ......... 289 decipiens, Ces. ........ 259 decurrens, $H \% . \ldots \ldots \ldots .502$ delicatula, Christ ....... 262 Denhami, IIk. ......... 516 denticulata, Metl. .... 501, 502 var. elata ........ $\quad 502$ deparoides, Ces......... 626 dissecta, Moore ........ 506 divaricata, $B l . \ldots \ldots \ldots 505,506$ elata, Spr. .......... 302 elegans, Hedw. ........ 305 elegans, $S w . \ldots \ldots \ldots \ldots \ldots 501$ var. pulchra ....... 502 embolostegia, Copel. ...... 50弓 Emersoni, Hk. \& Grev. .... 615 epiphylla, $B l . \ldots \ldots \ldots \ldots .502$ exallata, Copel. ......... 614 falcinella, Pr.......... 292 fejeensis, Hk. ....... 507 fijiensis, H/. ...... 304, 507 flaccida, R. Br. ....... \$10 flagellifera, Will........ 515 Friderici et Pauli, Christ ... 615 fructuosa, Christ ........ 504 Gaimardiana, $\operatorname{Pr} . \ldots . . . .286$ gracilis, Bl. ........ 515 Griffithiana, $H /$. . . . 500, 825 hemiptera, Bory ........ 261 hirsuta, v. A. v. R. .. 294, 299 hirta, Klf. ......... 515 
Davallia

Hosei, Bk.

hymenophylloides, $B /$.

264

hymenophylloides, Kuhn.

295

immersa, Wall.

inaequalis, Kze

var. minôr

282

intermarginalis, $B l$.

287

intramarginalis, Ces.

515

Kingii, Bk.

294

Korthalsii, Kuhn

500

Kunzeana, Hk 274

Kurzii, Clarke 512

lanceolata, Bk.

475

Lapeyrousï, Hk. 264

lepida, Pr. 289

Lindleyi, $I 1 k$. 505

Lobbiana, Moore 500

lonchitidea, Wall. 511

longipinnula, Ces. 514

longula, Kze 289

Lorrainii, Hance ......... 505

Luzonica, III. 515

manilensis, Goldm. 509 marginalis, $B /$. 509

moluccana, Bl. ........ 282

moluccana, Rb. ........ 515

Mooreana, Masters ....... 501

nephrodioides, Bk....... 295

nodosa, Hk. ......... 295

Novae Guineae, Rst. ...... 285

oligophlebia, Bk....... 514

ornata, Wall. ........ 505

pallida, Mett. ........ 501

parallela, Wall. ........ 287

parvula, Wall. ........ 287

pectinata, Bl. ....... 616

pectinata, Sm.......... 288
Davallia

peduta, Sm. ......... 288

pentaphylla, Bl. ....... 297

philippincnsis, Ilart. ..... \$11

pinnata, Cav. ........ 514

pinnalifida, Bk. ....... 288

platyphylla, Don ........ 511

polyantha, Hk. ....... 505

polypodioides, Don

var. hispida ...... 515

var. pubescens ...... \$10

var. rhomboidea ...... 515

var. subglabra ...... 510

proxima, $B l . \ldots \ldots \ldots \ldots .512$

pulchella, Hk......... 262

pulchra, Don .......... 292

pusilla, Mett.......... 289

pyxidata, Cav. ......... 505

repens, Desv........... 261

retusa, Cav. .......... 259

rhomboidea, Wall. ...... $\mathbf{5 1 3}$

Sarasinorum, Christ ...... 509

Schlechteri, C. Chr. ..... 614

serraeformis, Wall...... 615

sessilifolia, Bl. ........ 287

solida, $S w . \ldots \ldots \ldots \ldots$ 505, 506

var. fijiensis ...... 507

Speluncae, Bk. ...... 146, 510

var. exserta ....... 511

var. trichosticha ..... $\mathbf{3 1 0}$

stenoloba, $B k \ldots \ldots \ldots \ldots \ldots, 501$

stenomera, Kze ....... 504

strigosa, (Sw.) Kze ..... 512

var. rhomboidea ..... 515

tenuifolia, Sw. ........ 259

trapeziformis, Rb. ...... 315

trichomanoides, $B l$... 504, 825

trichosticha, IIl. ....... 510 
I)a vallia

triphylla, $1 / k$. 297

triquelra, Bik. 263

Irislis, Rac.

Veitchii, $B /$. 506

vestila, Bl. 291

villosa, Wall. 509

viscidula, Metl. 294

Wagneriana, Copel. 504

Davallieac 121

Davallodes 297 grammatosorum, Copel. . 299, 500 gymnocarpum, Copel. . . 299, 500 hirsutum, Copel. ...... 299, 500 Dennstaedtia 140,804 ampla, Bedd. 142 cuneata, Moore 144,805 deltoidea, Moore 145 dennstaedtioides, Copel. .... 804 Elmeri, Copel. .......... 805 erychrorachis, Dicls ... 142, 804 flaccida, Bernh. ...... 145, 80 : glabrata, C. Clir. ........ 145 gomphophylla, C. Chr. .... 146 Hooveri, Christ ......... 805 javanica, Christ ......... 145 Kingi, Bedd. .......... 145 Merrilli, Copel. ........... 804 moluccana, Moore ..... 146, 147 remota, Diels 144 resinifer'a, Melt. 142 rhombifolia, C. Chr. 141 samoensis, Moore .... 145, 804 scabra, Moore .......... 145 scandens, Moore ..... 146, 147 Smithii, Moore .......... 145 sumatrana, v. A. v. R. . 146, 806 Williamsi, Copel. ........ 804
Diacalpe ............. 159

aspidioides, $B l . \ldots \ldots \ldots \ldots 159$

pseudo-caenopteris, Kze .... 159

\section{Diblemma}

samarensis, J. Sm. ....... 651

Dicksonia .........4 47, 791

ampla, Bedd.......... 142

Barometz, Link ......... 48

Blumei, Moore ....... 47, 791

chrysotricha, Moore ...... 47

Copelandi, Christ ........ 791

cuneata, Hk........... 144

delicata, Muell. ......... 145

delloidea, H/.......... 145

erythrorachis, Chrisl ...... 142

flaccida, Sw. ......... 145

glabrata, Ces.......... 145

gomphophylla, Bk. ...... 146

grandis, Rst. .......... 792

javanica, Bl. ......... 145

Kingi, Bedd. ......... 145

moluccana, Bl. ......... 146

nephrolepioides, Christ ..... 156

remota, Christ.......... 144

repens, Bory .......... 824

rhombifolia, Bk. ....... 141

samoensis, Bk........ 145

scabra, Wall. ......... 145

scandens, Bl. ......... 146

Smithii, Hk. ......... 145

sorbifolia, Sm.......... 282

Zippeliana, Kze ........ 146

Dicksonieae ........... . 9

Dicranopteris .......... 56

dolosa, Copel. ......... 62

Dictyogramme .......... 540

Dictyopteris .......... 511

ambigua, v. A. v. R. ... 521 
Dictyopteris

andaiensis, $v, A . v . R . \ldots .514$

Barberi, Bedd.......... ร15

Beccariana, v. A. v. R. .. 515

Bolsteri, v. A. v. R. ....

Bryanti, v. A. v. li. ..... 514

difformis, Moore....... 520

ferruginea, $v, A . v . R$. . . 516

Hancockii, v. A. v. R. ... 518

heterosora, Bedd. ...... ๖1s

irregularis, $\operatorname{Pr} . \ldots \ldots \ldots \ldots$

labrusca, $v . A . v . R \ldots 517$

lamoensis, $v . A . v . R . \ldots .517$

macrodonta, $\operatorname{Pr} . \ldots \ldots \ldots \quad \mathbf{5} 16$

pentaphylla, v. A. v. R. ... 519

pelrophya, Moore ....... 515

polycarpa, Bedd........ 820

pteroides, $\operatorname{Pr} . \ldots \ldots \ldots \ldots$..... 15

saxicola, v. A. v. R. ..... ๖ 15

subdecurrens, $v$. A. v. K. . 514

vitis, v. A. v. R. .....

Whitfordi, v. A. v. R. ... 519

Didymochlaena .......... 170

lunulata, Desv......... 170

polycarpa, Bk........ 252

simuosa, Desv. ........ 170

truncalula, J. Sm. ...... 170

\section{Didymoglossum}

capillaum, V. D. B.

Filicula, Desv.

lale-alalum, V. L. B. ..... 95

laxum, V. D. B. ....... 94

serrulalum, $\mathrm{Pr}$.

Digrammaria

ambigua, Pr.

robusla, Fée

Diplaziopsis

159,805

javanica, C. Chr.
Diplazium

395,828

accedens, $B l$.

424

acrotis, Christ

405

acuminatum, $\mid B l$. 409

acuminalum, $P$

402

aequibasale, C. Chr.

404

alismacfolium, Pr.

345

alismifolium, $v . A . v . R$.

425

allernifolium, $B l$.

405

amplissimum, Diels

419

angustatum, Amann

425

asperum, Bl.

atratum, Chris

418

bantamense, $\mathrm{Bl}$.

405

barisanicum, C. Chr.

404

biseriale, C. Chr.

405

Bolsteri, Copel.

415

brachypodum, Copel.

415

brachysoroides, Copel.

412

Brackenridgei, Diels

415

hrevisorum, J. Sm

bulbiferum, Brack.

415

Burchardi, Rst.

411

camarinum, Copel.

402

ceramicum, C. Chr.

Ceylanicum, Chrisl 400

chlorophyllum, Bedd.

401

Christii, C. Chr......... 409

confertum. C. Chr. ...... 404

cordifolium, $B l$.

422

crenato-serratum, Moore ... 407

crinitum, C. Chr....... 414

cultratum, $\operatorname{Pr} . \ldots \ldots \ldots .407$

Cumingii, C. Chr. ...... 423

cyatheifolium, $P_{r} . \ldots \ldots .416$

davaoense, Copel. ....... 416

decussalum, Bedd....... 408

decussalum, Christ....... 424 


\section{Diplazium}

deltoideum, $\boldsymbol{P r} . \ldots \ldots \ldots \ldots 418$

dilatatum, $B l . \ldots \ldots \ldots \ldots .416$

dolichosolum, Copel. ..... 417

eheneum, J. Sm. ....... 420

clegans, Hk. ....... 425

esculentum, $S w . \ldots \ldots \ldots \quad 425$

Forbesii, C. Chr. ....... 422

fraxineum, Don ....... 527

fraxinifolium, Bedd. ..... 405

fraxinifolium, $\operatorname{Pr}_{2} \ldots \ldots \ldots \quad 425$

fructuosum, Copel. ...... 420

grammitoides, $\operatorname{Pr}$. . 409, 410, 415

Hosei, Christ .......... 407

Huttoni, C. Chr....... 421

inconspicuum, Christ ......401

japonicum, Bedd. ....... 408

larutense, Bedd. ........ 406

Lasiopteris, Kze ...... 411

latifolium, Moore ....... 416

linélalum, $B l . \ldots \ldots \ldots .425$

Lobbianum, Moore ....... 408

manilense, $C$. Chr...... 417

maximum, C. Chr. ...... 416

Merrilli, Copel. ......... 400

Meyenianum, $\operatorname{Pr} . \ldots \ldots \ldots 418$

muricatum, v.A.v. R. .. 829

oligosorum, Copel. ....... 419

palauanense, Copel. ...... 406

pallidum, Moore ........ 405

pariens, C. Chr. ....... 424

Petersenii, Christ ....... 411

petiolare, $\operatorname{Pr} . \ldots \ldots \ldots \ldots .409$

polypodioides, Bedd. ...... 420

polypodioides, $B l$. . 419, 420, $4 \mathbf{3} 6$

porphyrorachis, Diels ..... 401

porreclum, Pr. ........ 407

Prescottianum, Moore . 415, 828

\section{Diplazium}

prionophyllum, $K z e \ldots \ldots \quad 420$

proliferum, Thouars ... 424, 829

shepherdioides, C. Chr. ... 408 silvaticum, $S w . \ldots \ldots 402,828$

var. Prescoltianum..... 828

Smithianum, Diels ....... 425

sorzogonense, $\operatorname{Pr}_{r} \ldots . .412,415$

speciosum, $B l . \ldots \ldots \ldots$ 4 415

spinulosum, $B l . \ldots \ldots \ldots \quad 425$

subserratum, Moore ....... 400

tabacinum, Copel. ....... 404

tomentosum, $B l$. ....... 414

umbrosum, Bedd. ....... 828

vacillans, $C$. Chr. ..... 405

vestitum, $\operatorname{Pr} . \ldots \ldots \ldots \ldots 417$

Weinlandii, Christ ...... 402

Whitfordi, Copel. ....... 415

Williamsi, Copel. ....... 409

Woodii, Copel. ......... 410

xiphophyllum, C. Chr. .... 406

zeylanicum, Moore .... 400, 828

Diplopterygium ........ 57

Dipteris ........... 521

bifurcala, Christ........ 522

conjugata, Reinw....... 525

Dipteris, Christ ........ 525

IIorsfieldii, Bedd. ....... 525

Lobbiana, Moore ......... 522

Nieuwenhuisii, Christ ..... 522

quinquefurcata, Christ .... 525

Disphenia

orientalis, $K z e \ldots \ldots \ldots \ldots \quad \mathbf{7 8 5}$

Doodia ............... 589

dives, $K z \boldsymbol{z} \ldots \ldots \ldots \ldots$ 589, 590

media, R. Br. ........ 590

Doryopteridastrum . . . . . . 546

Doryopteris ........... 546 


\section{Doryopteris}

concolor, Kuhn 347

ludens, $J$. Sm.

547

Drymoglossum

702

carnosum, J. Sin. ...... 702

carnosum, Rac. ........ 705

confertum, Copel. ....... 558

heterophyllum, C. Chr. . 681, 705 novo-guineae, Christ ..... 705 piloselloilles, $\mathrm{Pr} . \ldots \ldots \ldots .705$ rigidum, IIk. ....... 705 var. longistipitatum .... 644

Drynaria . . . . . . . . . 696

alata, Brack. ......... 658

cornucopia, v. A. v. R. .. 700

coronans, J.Sm........ 670

decurrens, Brack. ....... 665

descensa, Copel. ......... 698

Heracleum, Moore ........ 671

involuta, v. A. v. R. ..... 700

Linnaei, Bedd. .......... 699

lomarioides, J. Sm....... 625

nectarifera, Diels ....... 700

pleuridioides. Pr. ... 6 697, 698

propinqua, J. Sm. ...... 698

quercifolia, J.Sm. . 698, 699, 701

revoluta, J. Sm. ........ 658

rigidula, Bedd. ......... 699

sparsisora, Moore ........ 699

splendens, Bedd. ........ 701

tenuiloris, J. Sm. ....... 651

Drynariopsis . . . . . . . . . . 569

Dryopteris .......... 174, 815

abortiva, 0.Ktze ....... 217

aciculata, C. Chr. ...... 200

acromanes, Christ ........ 50 马

adenophora, C. Chr. ...... 214

adnata, v. A. v. R. ...... 191

\section{Dryopteris}

africana, C. Chr. ....... 498

alatella, C. Chr......... 210

amboinensis, $0 . K t z e \ldots . .219$

aortisora, C. Cir........ b01

appendiculata, C. Chr. .... 215

arbuscula, O. Ktze ...... 218

arfaliana, C. Chr. ...... 502

arida, $0 . K t z e \ldots \ldots \ldots \ldots .212$

asperula, C. Chr. ...... 495

attenuata, $0 . K ı z e .184,185,815$

Backeri, v. A. v. R. .... 817

Bakeri, Copel. ......... 208

balabacensis, Christ ...... 816

basilaris, C. Chr. ...... 820

Beccariana, C. Chr...... 185

Beddomei， 0. Ktze ....... 191

Benoitiana, v. A. v. R. ... 225

Blumei, v. A. v. R. ..... 231

Bordenii, Christ ......... 822

borneensis, 0 . Ktze ...... 198

Boryana, C. Chr. ........ 201

brachyodus, O. Ktze ... 220, 819

brevipinna, C. Chr. ..... \10

brunneo-villosa, C. Chr. ... 494

calcarata, 0. Ktze .... 185, 228

callosa, C. Chr.......220, 819

cana, O. Ktze ......... 489

canescens, C. Chr. . 251, 503, 丂07

var. Bakeri ......... 208

var. heterophylla .... 171

var. simplicifolia ..... . 500

caudiculata, v. A. v. R. . . 225

ceramica, v. A. v. R. .... 506

Cesatiana, C. Chr. ...... 509

chaerophyllifolia, C. Chr. .. 194

chamaeolaria, Christ...... 50马 


\section{Dryopteris}

cochleata, C. Chr. ........ 195

conterminoides, C. Chr. ... 190

Copelundi, Christ ........ 492

crassifolia, O. K/ze f... 182

Creaghii, C. Chr. ........ 185

crenata, O. Klze ........ 202

crinipes, O. Klze . . . . . 229

cucullata, Christ . 212, 215, 819

cuspidala, Christ ........ 511

cyatheoides, O. Kıze ..... 216

Dayi, C. Chr. .......... 188

debilis, C. Chr. ....... 501

didymosora, C. Chr. ..... 225

dissecta, O. Kıze ....... 196

diversifolia, v. A. v. R. . 189, 813

diversiloba, Christ . ......

dubia, Copel. .......... 817

echinata, 0. Kize ....... 182

edulenta, 0 Kize ........ 194

eminens, C. Chr. ........ 214

erubescens, C. Chr. ...... 489

erythrosora, O. Klze _. 195, 815

exigua, O. K/ze ..... 190, 814

extensa, $0 . \quad K l z c \ldots \ldots .210$

ferox, O. Ktze ..... 221, 819

filix mas, Scholl . 181, 192, 814 var. adnata ........ 191

firmula, C. Chr.......... 501

llaccida, O. K/ze . 195, 198, 815

Foxii, Christ .......... 814

glandulosa， O. Klze . . 215, 819

glaucostipes, C. Chr...... 226

gongylodes, $0 . \quad K i z e \ldots . .212$

gracilescens, 0. Klze .... 186

grammitoides, C. Chr. .... 181

gramulosa, C. Chr. ......

gymnopoda, C. Chr...... 182

\section{Dryopteris}

Haenkeana, O. Klze ...... 214

Hallieri, C. Chr. ........ 184

Hasseltii, C. Chr. ........ 494

heleopteroides, Christ ..... 814

heterocarpa, 0 . $K t z$ e $\ldots . .228$

hirsuta, O. Ktze .... 214, 819

hirtipes, $0 . K / \approx e \ldots \ldots .180$

hispidula, $0 . K / z e \ldots \ldots .228$

holophylla, C. Chr. ..... 500

IIosei, C. Chr. ......... \$

immersa, O. Ktze ...... 188

var. ligulata ....... 813

imponens, C. Chr. ....... 506

indica, $v$. A. v. R. ..... 224

intermedia, O. Ktze . . 199, 816

invisa, O. Kize ..... 212, 819

Keraudreniana, C. Chr. ... 496

Kingii, C. Chr. ....... 497

Koordersii, C. Chr. ...... 181

labuanensis, C. Chr. ...... 500

laevis, C. Chr. ......... 220

larutensis, C. Chr. ....... 252

laserpitiifolia, C. Chr. .... 494

latebrosa, C. Chr. ...... 221

latipinna, $0 . K t z e \ldots \ldots .217$

ligulata, $0 . K l z e \ldots \ldots$ 184, 815

lineata, C. Chr. ....... 209

Loheriana, C. Chr. ... 221, 820

longipes, 0 . Ktze. ...... 211

loxoscaphoides, C. Chr. .... 495

Luerssenii, C. Chr. ...... 190

luzonica, Christ ........ 821

marginata, Christ ........ 814

megaphylla, C. Chr. .. 218, 219

Merrillii, Christ ....... 50马

Metteniana, IIier. ....... 815

microchlamys, v. A. v. R. . 226 
Dryopteris

microloncha, Christ ...... 820

Milletlii, C. Chr. ......... 198

mindanaensis, Christ ..... 818

monodonta, C. Chr. ...... 187

Molleyana, C. Chr....... 182

moulmeinensis, C. Chr. ... 217

multilineata, O. Kize ..... 219

multiseta; C. Chr. ....... 205

nephrodioides, O. Klze.... 251

obscura, O. Klze ....... 492

obtusiloba, O. Kıze ....... 205

ochtodes, C. Chr......... 215

oosora, C. Chr. ........ 250

opaca, C. Chr. ........ 498

orbicularis, C. Chr. ...... 251

orientalis, C. Chr. ...... 183

var. Webbiana ...... 815

irnala, C. Chr.......... 495

otaria, O. Klzt ......... 209

oxyodus, C. Chr. ....... 491

padangensis, C. Chr...... 198

papuana, C. Chr. ....... 196

parasitica, O. K/ze . 211, 217, 224,

250,821

var. amboinensis ..... 219

var. lalipinna ...... 217

patens, O. Ktze ...... 189, 814

pectinata, v. A. v. R. . 185,815

Peekeli, v. A. v. R. . . 188, 815

penangiana, C. Chr. ..... 229

pennigera, C. Chr. ...... 504

perakensis, C. Chr. ..... 226

peranemiformis, C. Chr.

var. obtusiloba ....... 205

phaeostigma, C. Chr...... 181

phegopteroidea, C. Chr.... 195

philippina, C. Chr. ...... 190

FILICES.

\section{Dryopteris}

pilosiuscula, C. Chr. ... 185, 215 piloso-squamata, $v . A \quad v \cdot R$. 222 820

polycarpa, Christ ....... 822

polytricha v. A. v. R. . .. 187

Preslii, O. Ktze ........ 194

procurrens, O. Klze ... 211, 819

producta, C. Chr. ...... 250

prolifera, C. Chr........ 504

pseudoreptans, C. Chr. ... 225

pteroides, U. K/ze .... 209, 818

pulvinulifera, O. Klze .... 200

punctala, C. Chr. ..... 555, 495

purpurascens, v. A. v. R. .. 201

quadriaurita, Christ ...... 489

Raciborskii, v. A. v. R. . 197, 816

Ramosii, Christ ......... 502

recedens, O. Kize .... 198, 816

rhodolepis, C. Chr. . 199, 202, 817

var. sawarakensis ..... 200

Riedleana, $v . A . v . R . \ldots .250$

rizalensis, Christ ....... 81 g

rubid.), C. Chr ......... ถ02

rufescens, C. Chr. ........ 495

sageninides, O. Ktze ..... 191

var. olscura ....... 492

sagittifolia, 0. Klze ...... 222

sakayensis, C. Chr. ...... 224

sulirifolin, C. Chr. ...... 511

sawarakensis, v. A. v. R. .. 200

setigera, 0. Ktze . . 57, 202, 817

selosa, C. Chr. ......... 492

setosa, O. Klze ......... 198

simillima, C. Chr. ....... 225

simplicifolia, Christ ...... 500

singalanensis, C. Chr. .... 192

Smillii, v. A. v. R. ..... 490 
Dryopteris

sparsa, 0. Kıze . . 197, 200, 202, 815,816

var. purpurascens ........ 201

Spenceri, Chris! ......... 508

splendens, O. Kıze. ...... 195

squamaeslipes, C. Chr. .... 490

stegnogramme, C. Chr. .... ๖08

stenobasis, C. Chr. ....... 184

stipellata, 0. Ktze ...... 227

subarborea, C. Chr...... 204

subconnexa, C. Chr. ..... 496

subobscura, C. Chr. ...... 491

sumatrana, $v$. A. v. R. ... 227

syrmatica, O. Kıze ... 195, 815

Teuscheri, v. A. v. R. . 185, 815

todayensis, Christ ...... 821

trichopoda, C. Chr....... 187

triphylla, C. Chr. ,...... 509

truncata, O. Kt: .... 227, 822

Iuberculala, C. Chr. ..... 491

Inita, 0. Ktze ........ 215

urophylla, C. Chr. . 216, 511, 819

var. cuspidata ....... bै 11

vilis, 0. Ktze ......... 199

viscosa, $0 . K t z e \ldots \ldots .186,813$

vulcanica, C. Chr........ 185

Warburgii, C. Chr. ...... 180

Wigmanii, C. Chr. ...... 192

xiphioides, Christ ....... 501

zeylanica, v. A. v. R. .... 20.

Dryostachyum ........... 701

drynarioudes, Kuhn ....... 751

pilosum, J. Sm. ........ 701

splendens, J. Sm. ....... 701

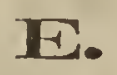

Hgenolia
Elaphoglossuni ......... 711

angulatum, Moore ....... 715

Beccarianum, C. Chr.... 714

borneense, C. Chr. ...... 542

callifolium, Moore ....... 714

conforme, Schott ....... 712

Copelandi, Christ ....... 717

Cumingii, Moore ........ 715

decurrens, Moore .... 715, 714

gorgoneum, Brack....... 712

hirtum, C. Chr........ 717

latifolium, Bedd........ 714

laurifolium, Moore ....... 714

Lessonii, C. Chr. ....... 716

luzonicum, Copel........ 714

melanosticticum, Moore .... 716

microphyllum, v. A. v. R. . 715

miniatum, Christ ....... 716

Norrisii, Bedd.......... 716

petiolatum, Urb........ 717

squamosum, J. Sm. ...... 717

viscosum, Schott ........ 717

Eu-adiantum ........... $\$ 19$

Eu-aspidium .......... 254

Eu-asplenium .......... 457

Eublechnum .......... 585

Eubotrychium ......... 778

Eucheilanthes .......... 557

Eudavallia ............. 297

Eudiplazium .......... 595

Eudoryopteris .......... 546

Eudrynaria ............ 697

Eu-elaphoglossum ......... 711

Eugleichenia $\ldots \ldots \ldots \ldots \ldots$ ๖6

Eugymnotheca .......... 765

Euhemitelia .......... 27

Euhumata ............ 284

Euhymenophyllum ........ 66 
Euhypolepis .......... . 555

Eulindsaya ............ 260

Eulygodium ........... 109

Eumonogramma .......... 551

Eunephrolepis .......... $1: 36$

Eunotholaena ........... 485

Eu-odontosoriáa ......... 258

Eu-ophioglossum ......... 772

Eu-osmunda .......... $75:$

Euphegopteris ........... 486

Euplatycerium ......... 707

Eupodium ............ 765

Eupolybotrya .......... 725

Eupolypodium ......... 567

Eupteris ............ 552

Eusaccoloma .......... 282

Euschizaea ........... 115

Euschizoloma .......... 276

Euscolopendrium ......... 477

Eutrichomanes ........... 85

Euvittaria ............. รั5ว

Euwoodwardia ......... 590

\section{F.}

Féea

Furcalae (Polypodium) ..... 567

\section{G.}

Gleichenia .......... 55, 794 amboinensis, v.A.v.R. .62, 796 arachnoidea, Melt. ...... ๖8

bifurcala, $B l . \ldots \ldots \ldots \ldots \quad$ 59 candida, Rst. .......... 796 circinata, $S w . . \ldots \ldots$ b6, 794 crassifolia, Copel. ....... 795 dicarpa, R. Br. ........ 794 var. a minn ๖6
Gleichenia

dichotoma, H/......... 59

dolosa, C. Chr......... 62

excelsa, J.Sm......... 795

ferruginea. $B l . \ldots \ldots \ldots \ldots . \quad 59$

flabellata, R. Br. ....... 60

flagellaris, Spr. ....... 59

gigantea, Wall. ........ 795

glauca, $/ / \hbar . \ldots \ldots \ldots$ 58, 794 var. arachnoidea ..... 58

Hallieri, Chrst ......... 61

IIermanni, R. Br. ..... 59

hecistophylla, A. Cunn. .... 56

hirta, $B l . \ldots \ldots \ldots \ldots \ldots$

hispida, Nell .......61, 796

Koordersii, Christ ........ 60

laevigata, HK. . . . . . ร9, 769

laevissima, Christ ....... 795

linearis, Clarlie ...... 59, 795

Loheri, Christ .......... 796

longissima, $B l . \ldots$. 58, 794, 795 var. arachnoiles ..... 58

var. rigida ........

microphylla, R. Br. .....

Norrisii, Melt. ........ 58

oceanica, Kuhn ....... 60

rigida, J. Sm, ......... 79.

semivestita, Lab. ....... 56, 794

vestita, $B l . \ldots \ldots \ldots \ldots 61,796$

vulcanica, $B^{\prime} . \ldots \ldots \ldots \ldots$

Warburgii, Christ ..... 58, 79:5

Gleicheniaceae ..........

Gnoophripa

glauca, Bl.......... 41

lurida, B/.......... 791

tomentosa, $B l . \ldots \ldots \ldots \ldots \quad 791$

Goniophlebium .......... 568

arigutum, J. Sm........ 621 
Goniophlebium

cuspidatum, $\mathrm{Pr}$. 619

Korlhalsii, Bedd. 618

molle, Bedil.

Prainii, Bedd.

Reinwardtii, de $\mathrm{Vr}$.

622

serralifolium, Brock

$6 \geq 2$

subauriculatum, Pr.

verrucosum, J. Sm.

619

Goniopteris

486

lineata, Bedd.

217

multilineata, Bedd.

217

penangiana, Bedd.

229

rubid:, J. Sm.

丂02

Gonocormus ........... 85

diffusus, V. D. B. ...... 90

minutus, V. D. B. ...... 90

palmalus, V. D. B. ..... 90

Teysmanni, V.D.B. .... 91

Grammitideae ........... 122

Grammitis ............. 567

adspersa, Bl.

578

australis, R. Br. ...... 578

blechnoides, Grev. ....... 605

Billardieri, Willd. ....... 578

bisulcata, Hk. ........ 576

clavifer, Hk. ......... 608

congener, $B l . \ldots \ldots \ldots \ldots$ 582

cucullata, Bl. ......... 589

decurrens, Wall......... 677

denticulata, $B l . \ldots \ldots \ldots \ldots, \$ 590$

fasciata, Bl. ........ 579

fasciculata, Bl. ........ 587

heterocarpa, Bl. ........ 676

lirta, $B l . \ldots \ldots \ldots \ldots \ldots \quad 586$

longifolia, $B l . \ldots \ldots \ldots \ldots 658$

macrophylla, Bl........ 674

ubscura, $B l . \ldots \ldots \ldots \ldots \ldots . \$ 886$

\section{Grammitis}

pilosiuscula, Bl. ....... 580

pubinervis, B/......... 586

pusilla, Bl.

var. alpestris ....... 582

var. lasiosora ....... 580

Reinvv $\operatorname{rdtii}, B l . \ldots \ldots \ldots . \quad 585$

sessilifolia, J. Sm. ....... 577

setosa, Bl. ......... Б85

subpinnalifida, $B l . \ldots \ldots \ldots \quad 590$

Totta, Pr........... 497

Gymuogramme

acuminata, Bk. ....... 675

alismaefolia, Hk........ 543

ambigua, IIk. ......... 521

appendiculata, Bl........ 215

aspidioides, Hk. ....... 508

avenia, Bk. ......... 538

Boerlageana, Chrisı ...... 528

borneensis, Hk. ........ 541

calomelanos, Klf. ....... 528

var. chrysophylla .... $\quad \mathbf{5 2 8}$

campyloneuroides, Bk. .... 674

canescens, Bl. ........ 507

cartilagidens, Bl........ 542

chrysophylla, Klf. ...... 528

chrysosora，Bi. ........ 529

Dayi, Bedd.......... 541

decurrens, Hk. ........ 677

edulis, Ces.......... 425

elliptica, Bk. ....... 677

Féei, $11 k . \ldots \ldots \ldots \ldots .675$

fraxinea, Bedd. ........ 527

grandis, Rac.......... 557

IIamiltoniana, IIk. . . . . . 675

heterocarpa, IIk. ...... 676

iridifolia, Christ : ...... 559

involuta, H/. ......... 557 
Gymnogramme

javanica, Bl.

lanceolata, H/. ........ 558

Lobbiana, H/......... 541

Lowii, IIK. \& Grev. . . . . 497

macrophylla, IIk. ...... 674

Maingayi, Bk. ........ 677

membranacea, IIk...... 675

whusata, Bl. .......... 498

obtusifolia, Hk. ....... 541

ochracea, Pr. .........

opaca, Spr........... 498

pinnata, H/. ........ 546

pteridiformis, Ces. ...... 484

quinata, $H k . \ldots \ldots \ldots \ldots 545$

regularis, Bk. ........ 675

serrulata, $B l . \ldots \ldots \ldots \ldots .527$

spuria, Bk. ......... 674

Stegnogramme, Bl. ...... ら08

Lartarea, Desv. ......... 528

var. ochracea ...... 528

Totta, Schl. ......... 497

valleculata, Bk. ....... 540

vitlaeformis, Mett. ..... 545

Wallichii, Hk. ....... 545

Gymnogrammeae ......... 122

Gymmopteris ........... 755

aurila, Keys. ........ 726

axillaris, $\operatorname{Pr} . \ldots \ldots \ldots \ldots .745$

contaminans, Bedrl. ....... 741

costata, Bedd......... 745

decurrens, Hk........ 756

decurrens, Moore ....... 756

Feci, Moore ......... 745

Alagellifera, Bedd........ 759

Hollrungii, Kuhn ....... 757

inconstans, Copel. ....... 758

lanceolata, Bedd........ 745
Gymnopteris

lalifolia, Pr.......... 757

Limnaeana, Chisit ........ 755

lomarioules, Christ ........ 740

minor, IIk. .......... 744

minus, Bedd........... 744

Naumanni, Diels ....... 742

normale, J. Sm. ....... 745

platyrhynchos, d. Sm. .... T299

Presliana, J. Sin. ........ 740

quercifolia, Bernh........ 757

repanda, Christ ........ 741

subquinquefida, Pr. ..... 757

subrepanda, J. Sm. ...... 742

laccacfolia, J. Sm. ....... 757

Irilobata, J. Sin........ 737

variabilis, Bedd. ........ 756

var. axillaris ...... 745

var. lanceolata ...... 74 b̆

Vespertilio, Hk. ....... 752

virens, Keys. ......... 741

Gymnosphaera

ylalma, Bl. ......... 789

squamulala, Bl. ....... 789

squamulata, J. Sim. ...... 55

Gymmotheca ........... 765

Gyrosorium

samarense, $\mathrm{Pr}$.

\section{1.}

Habroduclyon ........... 85

Cumingii, V. I). B. ...... 99

Helmintostachys ......... 777

dulcis, Kl. ......... 777

zeylanica, Hk........ 777

Ilemidictyum .......... 457

Finlaysonianum, Moore .... 476 
Henigramma . . . . . . . . . 851

lalifolia, Copel. ...... 757, 851

Zollingeri, Diels ........ 851

Hemionitis ........ 546,851

arifolia, Hoore ........ 547

cordula, IIV. \& Greu. .... 547

cordifolia, Rlı.........

coriacer, Don ......... 554

elongata, Brack........ 546

esculenta, Relz......... 428

gymmopteroidea, Copel. .... 851

Hosei, Bli. ......... 545

immersa, Bory.........

lanceolala, IIk......... ๖̌

opaca, Don........... 498

palmata, $L . \ldots \ldots \ldots \ldots \ldots$ อ̆ 47

plantaginea, Cav. ....... \$5

prolifera, Retz......... 504

reticulata, Forst. ....... 555

Zollingeri, Kurz ....... 851

Hemíphlebium ........ 83

Hemipteris .......... 575

Werneri, Rist. ....... 576

Hemitelia ......... 27, 788

allernans, Hk. ....... 17

capensis, R. Br. .....27, 788

crenulata, Mell........ 27

Junghuhniana, Meı. ..... 28

latebrosa, Mell. ......... 58

sumatrana, v. A. v. R. . 28, 788

truncala, Christ ......... 42

Ileteronevron

Naumanni, Kuhn ...... 742

Preslianum, Fíc ........ 740

scalpluratum, Fice ...... 745

Heleropterygium ........ 57

Hewardia ............. 519

Histiopleris . . . . . . . . 549
Histiopteris

incisa, . Sm. ......... 349

montana, Copel. ....... 54 9

Holopterygium ......... 57

Humata .......... 284, 824

alpina, Moore ... 289, 290, 291

angustata, .. Sm........ 286

botrychioides, Rracli. .... 290

cicutarioides, Diels ....... 292

Cumingii, Brack. ......... 289

falcinclla, Copel......... 292

Gaimardiana, J. Sm. ... 286, 824

heterophylla, Desv. ...... 286

var. angustata ...... 286

Hosei, v. A. r. R. ...... 295

hymenophylloides, Copel. ... 295

immersa, Mell. ........ 292

intermeda, C. Chr. ...... 288

Kingii, Diels .......... 294

lepida, Moore .......... 289

neoguineensis, $C$ : Chr. ... 290

nephrodioides, $v . A . v . R$. 295

parallela, Brack........ 286

parvula, Melt. ....... 287, 824

peclinata, Desv......... 288

pedata, J. Sm. .......... 288

pinnatifida, Bedd........ 288

polypodioides, Brack. ..... 287

pulchra, Diels ........ உ92

pusilla, Carr. ........... 289

repens, Diels . 288, 289; 290, 29 J

var. alpina ........ 290

sessilifolia, Mett........ 287

vestita, Moore .......... 291

viscidula, v. A. v. R. .... 294

Hydroglossum . . . . . . . . . 109

Hymenolepis ............ 727

brachystachys, J. Sm. .... 729 
Hymenolepis

callifolia, Christ ........ 729

platyrhynchos, Kze ..... 729

revoluta, Bl. ......... 728

rigidissima, Christ ....... 7 르 8

spicala, $P r . \ldots \ldots \ldots 728,729$

var. brachystachys. . . . 729

Hymenophyllaceae

65

Hymenophyllum

63, 797

aculealum, Bedd.

81,82

aculeatum, Ric....81, 82, 798

affine, Rac.

78

atrovirens, Colen

australe, Willd.

69,797

badium, Hk. \& Grev. .... 70

bismarckianum, Christ .... 82

blandum, Rac. ........ 78

Blumeanum, Spr. .... 71, 797

borneeuse, $H k . \ldots \ldots \ldots$. 74

brachyglossum, A. Br.... 82

campanulatum, Christ .... 798

crispatum, Wall. ........ 797

demissum, $S w . \ldots \ldots 69,797$

denticulatum, $S w . \ldots .81,82$

dilatatum, $B l . \ldots \ldots \ldots$. 75

dilatatum, $S w . \ldots \ldots 66,72$

discosum, Christ ........ 67

edulentum, C. Chr. ...... 76

crosum, Bl. ......... 69

eximium, Kze ........ 68

fimbrialum, J. Sm. ...... 69

flabellatum, $L a b, \ldots \ldots \ldots .68$

formosum, Brack. ....... 72

fraternum, Harr. ....... 80

fuscum, $V . D . B . \ldots \ldots \ldots \quad 75$

halconense, Copel. ....... 797

holochilum, C. Chr. ..... 78

Junghuhnii, V. D. B. . . . 75
Hymenophyllum

integrum, $V$. IJ. B...... 71

javanicum, Spr. ....... 69

var. badium ....... 70

klabulense, Christ ........ 79

Kurzii, Pranll ...... 77, 797

Lobbii, Moore ......... 77

Nerrillii, Christ ........ 798

micranlhum, V. D. B. ... 69

modestum, V. D. B. .... 68

multifidum, Sw. .... 79, 798

Neesii, IIk.......... 81

nilens, R. Br. ........ 68

obtusum, Hk. \& Arn..... 74

ooides, Muell. \& Bk..... 67

pachydermicum, Ces...... 75

paniculiflorum, $P r$....... 70

pedicularifolium, Ces..... 74

physocarpum, Christ ..... 80

polyanthos, Sw.......... 71

vai. dentahum ...... 79

praetervisum, Christ ..... 79

produclum, Kze ........ $6 \mathrm{G}$

pycnocarpum, I. I. B. . 71, 797

rarum, R. kr........ 72

Reinwardtii, V. D. l'..... 80

ringens, Christ .......... 70

sabinifolium, $B k \ldots \ldots \ldots$. 81

salakense, Ruc. ........ 71

semibivalve, IIk. \& Grev. .. 72

serrulatum, C. Chr....99 798

Smilhii, Hk........ 78,79

Steerei, C. Chr. ......... 80

subdemissum, Christ ...... 797

subflabellatum, Ces. ...... 76

lısmanicum, V. D. B. ... 69

thuidium, Harr. ........ 71

Treubii, Rac. ......... 72 
Iymenophyllum

tunbridgense, Sm. .... 78, 797

violaceum, Meyen ....... 79

Zollingerianum, Kze ..... 73

IIypodematium

phegoplernideum, Kuhn .... 195

Hypolepis .......... 554, 826

alpina, $I I k . \ldots \ldots \ldots \ldots .555$

pallida, IIl. ........ 556

punclala, Bedd. ........ 555

munctata, Mell......... $49: 3$

resinifera, IIl......... 142

rugulosa, J. Sm......... 495

tenuifolia, Bernh..... 556, 826

\section{I.}

Integrifoliae (Polypodium) . . . 567

Isoloma . . . . . . . . . . 276

lanuginosum, J. Sm...... 157

\section{IE.}

Kaulfussia

aesculifolin, Bl.

768

assamica, Grifl.

768

\section{L.}

Lacostea

Lastl'aea

amabilis. Moore

arislala, Moore

allenuala, J. Sim.

815

Blumei, Moore

202

borneensis, II/s.

198

Boryana, Moore

201

calcarala, Hoore

185

var. sericea

186

cochleala, Moore

coniifolia, Moore
Lastraea

crassifolia, Moore ....... 182

crenala, Bedd.......... 202

Dayi, Bedd. .......... 188

dissecla, Carr. ......... 196

divisa, Moore ........... 201

clongata, Pr........... 814

eriocarpa, Pr. ......... 202

exigua, J. Sm......... 814

falciloba, IIk. ........ 18:j

Filix-mas, Pr. ......... 192

var. elonga'a ....... 814

flaccida, Beld. ......... 817

flaccida, Moore ......... 815

/uscipes, Moore .......... 191

gracilescens, Berld. ........ 191

gracilescens Monre ........ 186

hirlipes, Moore .......... 180

immersa, Hoore ......... 188

ligulala, J. Sim. ........ 815

melanopus, Bedd. ........ 191

membranifolia, Bedd. ...... 196

nephrodioides, Beild. ...... 182

oblusiloba, Berld. ........ 205

orlontoloma. Mnore ........ 192

padungensis, Bedd. ....... 198

plalypus, Moore ......... 810

Prestima. J. Sm. ........ 808

pulvinulifera, Bedd. ...... 200

reccidens, J. Sm. ......... 198

sericea, $S$ coll ........... 186

singalanensis, Berdı....... 192

sparsa, Moore .......... 197

speclabilis, J. Sm........ 195

splendens, Bedd. ......... 195

syrmalica, Moore ......... 195

tenericaulis, Moore ....... 202

unidenlala, Bedd. ........ 187 


\section{Lastraea}

viscosa, J. Sm.

186

Lecanopleris . . . . . . . . . . 弓6 68

carnosa, Bl. 625

Curlisii, Bk. 627

deparvides, Blk. 626

incurvata, lik. 627

Macleayi, Blc.

Nieuwenhuisii, Christ

626

pumila, Bl.

625

Lepisorus

569

Leptochilus

755

antrophyoides, C. Ch\%... 744

axillaris, $K l / . \ldots \ldots \ldots .74$. 74

celebicus, C. Chr. ...... 741

cuspidalus, C. Chr...... 741

lecurrens, Bl. ....... 756

diversifolius, C. Chr...... 740

exculpıs, C. Chr. ....... 740

exsculptus, C. Chr. ..... 740

Harlandii, C. Chr....... 756

heteroclitus, C. Chr. ..... 759

var. inconstans ....... 758

var. Linnaeanus ..... 755

Hollrungii, C. Chr. ...... 757

hydrophyllus, Copel....... 744

inconstans, C. Chr. ...... 758

latifolius, C. Chr. ...... 757

lanceolatus, fíe ....... T4.

Limnaeanus, Féc ........ 755

lomarioides, $B l$. .... 746,747

minor, Fée .......... 744

modestus, C. Ch........ T45

Naumanni, C. Chr. ...... 742

normalis, Copel. ...... 744, 745

oligodictyus, C. Chr...... 755

perakensis, C. Chr....... 747

Preslianus, C. Chr. ...... 740
Leptochilus

prolifer, C. Chr. ....... 758

Raapii, v. A. v. R. ..... 746

rizalianus, Christ ....... 744

scalpturatus, C.Chr..... 745

stolonifer, Christ ....... 759

trifidus, $r . A . v . R . \ldots . .756$

virens, $C . C h r . . . \ldots \ldots \ldots 741$

zeylanicus, C. Chr. ..... 757

Zollingeri, Fée ........ 742

Leptocionium .......... 66

acanlhoides, V. II. B. ..... 81

aculeatum, V. I). R. .... 82

affine, V. II R. ......... 78

Braunii, V. D. B....... 82

denliculalım, V. I). R. .... 81

edulenlum, V. I). B. ..... 76

holochilum, V. D B $\ldots . .78$

Neesii, V. D. B. ....... 81

violaceum, V. D. B. ..... 79

Leplogramma $(e) \ldots \ldots \ldots \ldots .486$

opaca, Bedd. .......... 498

Tılla, ..Sm. ......... 497

Leptolepia . . . . . . . . . . 285

novae guineae, $v . A . v . R . .285$

Leptomanes ........... 84

Leptopteris .......... 756

alpina, C. Chr......... 757

Wilkesiana, Christ ....... 757

Leucostegia ........... 284

hirsula, d.Sm......... 299

hymenophylloides, BI. ..... 294

immersa, Pr........... 295

pulchra, J. Sm. ........ 292

Lindsaya . . . . . . . . 260, 824

aculıfolia, Desv: ....... 157

adianloides, I. Sm........ 268

adiantoides, Kuhn ...... 262 
INDEX.

Lindsaya

ambigens, Ces.

apiculala, Kze

apoensis, Copel

azurea, Christ

275

blanda, Mett.

262

Blumeana, kuhn 263

borneensis, H/s.

capillacea, Christ ........

264

caudata. $1 / \%$.

chinensis, Mell.

concinna, J. Sm.

262,267

Copelandi, C. Chr. 267

cordala, Gaud. 279

crassipes, Rst. 269

crispa, $B k$. 268

cultrata, Sw. 269,824

cuneifolia, $P r$. 259

cyathicola, Copel. 263

davallioides, $B l$. 274,275 decomposita, Willd. 274,275 delicatula, Christ 262 divergens, Hk. \& Grev. 278 ensifolia, Sw. 280

falcata, Dry. 268 flabellulata, Dry. 270

gomphophylla, $B k$. 270 gracilis, Bl. $261,267,824$ gracillima, Copel. 267

Gueriniana, Gaud. 280)

Havicei, Copel. $\because 65$ heterophylla, Dry. 281

Hosei, C. Chr. 280

humilis, Kuhn 268

hymenophylloides, $B l$. 264 impressa, Christ 272 indurata, Bk. ........ 277 Jamesonioides, Bk. 276
Lindsaya

lancea, Bedd. 275

lanuginosa, $\mathrm{Hk}$. 157

Lapeyrousii, Bk. ....... 264

Leprieurii, Hk. ......... 268

lobala, Poir. ........... 274

Lobbiana, Hk. ....... 267, 824

Loheriana, Christ ........ 267

longissima, Christ ...... 272

Merrilli, Copel. ......... 264

montana, Copel. ........ 267

natunae, $B k . \ldots \ldots \ldots .272$

nitens, $B l . \ldots \ldots \ldots \ldots .274$

oblongifolia, Reınw. ...... 269

orbiculata, Melt. .. 267, 270, 281

ovata; J. Sm. ......... 277

pectinata, Bl. . 261, 264, 269, 270

pellaeiformis, Christ ...... 278

polymorpha, Wall....... 270

propinqua, Hk. ........ 274

pulchella, Metı........ 262

recurvata, Wall. ......... 274

repens, Bedd. ...... 261, 824

repens, Kze ....... 296, 270

retusa, Melt .......... 259

rigida, J. Sm. ......... 271

Sarasinorum, Clorist ...... 273

scandens, Hk. .....2270, 824

striata, Bl. .......... 270

tenera, Dry. ........... 270

tenuifolia, $B l . \ldots \ldots \ldots \ldots .265$

tenuifolia, Mett. ........ 259

trapeziformis, Dry. ... 268, 273

tricrenata, Bk. ....... 271

trilobata, Bk. ........ 280

triquetra, Bk. ......... 265

Wallerae, Hk........ 278 
Lindsaya

Werneri, Rst.......... 274

Lindsayopsis ......... 156

Litobrochia .......... 552

aurila, $P r . \ldots \ldots \ldots \ldots$. 549

incisa, Pr. .......... 549

ludens, Bedd. ......... 547

marginata, $P r . \ldots \ldots \ldots .575$

microdiclyon, Fée ....... 574

pedata, Bedd. ........ 547

tripartita, Pr. ........ 575

Lomagramma $(e) \ldots \ldots \ldots \ldots \quad 755$

articulata, Copel. ........ 725

lomarioides, J. Sm. ...... 746

perakensis, Bedd. ........ 747

pteroides, J. Sin. ........ 746

Lomaria . . . . . . . . . 578, 828

aculeata, $B l . \ldots \ldots \ldots \ldots .722$

adiata, Bl. .......... 542

areolaris, Harr. ......... 855

articulata, Muell. ........ 545

auriculata, Bl. ....... 587

capensis, Willd. ........ 581

concinna, Bk.......... 541

egenolfioides, $B l . \ldots \ldots \ldots . \quad .80$

elongata, Bl. ...... 579, 828

var. Cumingiana ..... 579

euphlebia, Kze ........ 545

Fraseri, A. Cunn. ....... 581

glauca, Bl. ......... 542

gracilis, Bl.......... 722

Patersoni, Spr. ..... 579, 828

procera, Spr. .......... 581

punctulata, Kze....... 580

pycnophylla, Kze ....... 545

speciosa, Bl. .......... 751

spectabilis, Kze ........ 720

stenoptera, Bk. ........ 541
Lomaria

vestita, $B l . \ldots \ldots \ldots \ldots . \quad 581$

vulcanica, Bl. ........ 579

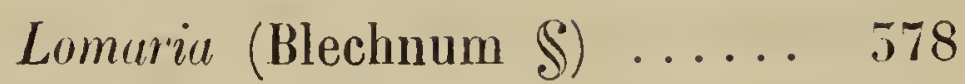

Lomariopsis ............. 718

palustris, Kuhn ........ 720

surbifolia Fée .......... 720

Lonchitis

tenuifoliu, Horst. ....... 826

Lophidium ........... 11 b

Lorinseria . . . . . . . . . . 590

Loxogramme ..........

avenia, $\operatorname{Pr} . \ldots \ldots \ldots \ldots .558$

Blumeana, $P r . \ldots \ldots \ldots \ldots \quad 558$

conferta, Copel. ........ 558

coriacea, $\mathrm{Pr} . \ldots \ldots \ldots \ldots$. 558

grandis, Copel. ......... 857

involuta, $P r . \ldots \ldots \ldots \ldots$. 557

iridifolia, Copel. ....... $\$ 559$

lanceolata, $\mathbf{P r} . \ldots \ldots \ldots \ldots \quad 558$

parallela, Copel. ....... 557

Loxoscaphe ........... 457

Luerssenia ............. 255

Kehdingiana, Kuln ..... 255

Lygodium .......... 109, 801

altum, v. A. v. R. ..... 114

basilanicum, Christ ..... 802

circinatum, $S w . \ldots 111,112,802$ var. Irifurcatum ..... 112

dichotomum, $S w . \ldots .111,112$

digitatum, $P r . \ldots \ldots \ldots .112$

flexuosum, $S w . \ldots 111,114,802$ var. alta .......... 114

japonicum, $S w . \ldots \ldots$ 114, 802

Matthewi, Copel. ....... 805

Mearnsii, Copcl. ........ 802

Merrilli, Copel. ......... 805

microphyllum, R. Br..... 113 
Lygodium

pinnalifidum, Pranll

pinnalifidum, Sw.

$11 \bar{\jmath}, 114$

polystachyum, Wall.

115

salicifolium, $\mathrm{Pr}$.

scandens, $S u$

$11 \overline{5}, 802$

semihastatum, Desv. ..... 111

Teysmannii, v. A.v. R. . 11!, 801 trifurcalum, $B k . \ldots \ldots 112,802$

\section{M.}

Marallia 765

alata, $S m$. 766

callioidus, de $V r$. 765

fraxinea, $S m$. 765

pellucida, $P r$ 765

sambucifolia, Christ 764

sambucina, $B l$. 764

silvatica, $B l$. 765

Smithii, Mell 766

ternatea, de $V r . \ldots \ldots \ldots .766$

vestita, Chírist 764

Werneri, Rst. 767

Marattiaceae 761

Marginaria 568

nummularia, Pr. 654

Matonia

pectinata, R. Br. 51

sarmentosa, Bl........

Matoniaceae ........... ら 1

Meniscium ........... 486

Beccarianum, Ces. ....... ๖09 cuspidatum, Bl........ 511

Ilosei, Bk. ........ 510 proliferum, Sw. ...... 504, 510 salicifolium, Bk. ....... 510 stenophyllum, B/........ 510 Iriphyllum, Sw. ...... 509, 850
Mertensia $\ldots \ldots \ldots \ldots \ldots \ldots$ crassifolia, Pr......... 795 laevigata, Willı........ 796 Mesocarpus ............ 763 Mesochlaena ......... 251, 822 javanica, R. Br........ 252 larutensis, v. A. v. R. . 2.72, 822 polycarpa, Bedd. . 185, 252, 822 rar. microchlamys .... 226

Mesosorus .............. 765

Microgonium

bimarginatum, V. D. B. ... 86 Motleyi, V. D. B. ....... 85 sublimbatum, V. D. B. ... 86 Microlepia ......... 507, 825 ciliata, Copel. .......... 299 dennstaedtioides, Copel. ..... 804 exserta, Mett. ........ 511 firmula, C. Chr......... 508 hirsuta, Pr. .......... 299 hirta, $\operatorname{Pr} . \ldots \ldots \ldots \ldots \ldots .515$ Kurzii, Bedd.......... 512 manilensis, $\operatorname{Pr} . \ldots \ldots \ldots \ldots .509$ marginalis, Bedd. .... 509, 825 marginata, C. Chr. ..... 509 moluccana, Bedd. ....... 285 philippinensis, Copel. ..... 511 pinnata, J. Sm. ........ 515 var. gracilis........ 515 var. Luzonica ...... 515 platyphylla, J. Sm. .... 511, 512 polypodioides, Bedd...... 515 proxima, $\operatorname{Pr} . \ldots \ldots \ldots \ldots .512$ rhomboidea, Pr........ $\mathbf{3 1 5}$ sablanensis, Christ....... 825 scaberula, Mett. ........ 509 scabra, J. Sm.'......... 509 speluncae, Moore . 510, 515, 825 
Microlepia

strigosa, $\operatorname{Pr}$. ... 512, 515,825

trapeziformis, Kuhn ..... 515

trichosticha, J. Sm...... 510

urophylla, Moore ....... 825

Monachosorum .......... 485

subdigitatum, Kuhn ..... 485

Monogramma .......... 5ร 1

dareicarpa, $H / \ldots . \ldots \ldots \ldots$ 弓̆

intermedia, Copel. ...... 552

interrupta, $B k . \ldots \ldots \ldots, 552$

Junghuhnï, Hk. . . . . . 552

Loheriana, v. A. v. R. ... 555

paradoxa, Bedd. ....... 552

trichoidea, J. Sm. .......

Myrmecophila

\section{N.}

Neottopteris

4.56

Nephrodium

175

abortivum, J. Sm.

217

abruptum, Bedd.

abruptum, J. Sm.

227

aciculatum, Bk.

200

acrostichoides, J. Sm.

505

alatellum, Christ

210

albo-punctatum, Desv.

183

amboinense, $\mathrm{Pr}$.

219

angustifolium, $\mathrm{Pr}$.

228

aortisorum, Copel.

501

appendiculatum, Rac.

Arbuscula, Desv. 218

aridum, J. Sm. 212

aristatum, Hk. 209

asperulum, Copel.

495

allenuatum, Fée ....... 184

auriculatum, Diels ....... 490

Bulieri, Harr.

Nephroduum.

basilare, Pr. ......... 820

Beccarianum, Ces........ 185

Beddomei, Bk. ......... 191

Benoilianum, Pr........ 225

Blumei, Hk. .......... 202

Blumei, J. Sm.......... 251

Boryanum, Bk........ 201

borneense, Hk. ......... 198

brachyodon, Hk. ..... 220, 819

calcaratum, Hk. ....... 186

callosum,Keys......... 220

canescens, Christ ...... 251, 507

caudiculatum, J. Sm. ..... 820

conjugatum, T. \& B. .... 196

costatum, Bedd......... 229

crassifolium, Hk........ 182

Creaghii, Bk.......... 185

crenatum, $B k . \ldots \ldots \ldots \ldots .202$

crinipes, Hk. ........ 229

cucullatum, Bk....... 215

cuspidatiom, Pr. ......... 741

cyatheoides, Pr......... 216

Dayi, Bedd. .......... 188

debile, Bk........... 223

debile, Diels............ 501

decurrens, Bk.......... 247

didymosorum, Par....... 225

dissectum, Desv. ........ 196

dissitifolium, Bk. ...... 196

diversilobum, Pr....... 503

divisum, Hk. ......... 201

echinatum, Bk. ........ 182

edulentum, B/......... 194

elongatum, Hk. \& Grev..... 814

eminens, Bl.......... 214

erubescens, Diels ........ 489

erylhrosorum, II/....... 195 
Nephrodium

eusorum, Bedd.

excellens, II/.

exiguum, $H /$.

cxtensum, Moure ........

var. minor

Everettii, Bk.

falcilobum, $\boldsymbol{H} k$.

Fauriei, Christ

var. elatius

ferox, Moore

Filix-mas, Rich.

var. marginata

814

flaccidum, IIk.

195

Foxii, Copel.

814

Gaimardianum, Gaud.

824

giganteum, $B /$.

$17 \overline{3}, 811$

glandulosum, J. Sin. ..... 209

glandulosum, Moore ... 215, 819

glaucosiipes, Bedd.

226

gongylodes, Schott

gracilescens, Hk.

186

gramimitoides, Copel.

181

grande, $B k$.

granulosum, J. Sm.

505

gymnopodum, B/.

182

Haenkeanum, Pr.

214

heterocarpon, Moore ...... 228

heterophyllum, IIk. ..... 171

hirsutum, J. Sm. ..... 214, 819

hirtipes, IIk. ........ 180

hirtum, Copel. ........ 492

hispidulum, Bk......... 228

Hosei, Bk. .......... 247

immersum, $H / . \ldots \ldots \ldots . .188$

intermedium, Bk....... 202

invisum, Carr........... 212

irriguum, Bk. ........ 245
Nephrodium

javanicum, IIk. ...... 232

Keckii, Bk. ......... 248

Keraudrenianum, Diels ..... 496

Labrusca, Rac.......... 517

larutense, Bedd. ........ 232

latifolium, Bk........ 249

latipinna, Hk. ......... 217

Leuseanum, Hk. ...... 172

ligulatum, Hk........ 184

lineatum, Bedd. ........ 216

lineatum, $P r . \ldots \ldots \ldots \ldots .209$

Lobbii, Bk. .......... 244

longipes, Moore .......... 211

Loherianum, Copel. ....... 221

Luerssenii, Harr. ........ 190

Mannii, Hope ......... 816

megaphyllum, Bk....... 204

melanocaulon, Bk...... 245

melanopus, Hk. ........ 191

melanorachis, Bk. ....... 250

membranifolium, Pr..... 173

Menyanthidis, Bli. ....... 244

microchlamys, Bk. ..... 226

molle, R. Br........... 224

var. amboinense ..... 219

var. major ........ 227

Motleyanum, II/k....... 182

moulmeinense; Bedd. ..... 217

mucronalum, J. Sm. ..... 819

mulicaudatum, Clarke ..... 25้0

multijugum, Bl. ...... 215

multilineatum, Bedd...... 219

mullilinealum, $\operatorname{Pr} . . . . . .214$

multisetum, Bli........ 203

nelulosum, Bk. ........ 246

nudum, $\quad$ kk. .......... 250

obliteratum, R. Br. ..... 155 
Nephrodium

obscurum, Diels ........ 492

obscurum, Moore ....... 212

obrusatum, Diels ........ 498

obtusilobum, Bk. ....... 205

ochtodes, Hk......... 215

odoratum, Bli........ 202

oligodictyon, Bk. ..... 172

oosorum, Bk. ¿....... 250

ornatum, Christ........ 495

Otaria, Bk. ......... 209

oxyodon (oxyilon), Copel.... 491

pachyphyllum, Bk. ...... 2 ๖े 2

parasilicum, Desv....... 224

patens, Desv. ......... 189

pectinatum, IIier. ....... 185

pennigerum, Bedd. ....... 224

pennigerum, Moore .... 217, 218

pennigerum, Pr. ....... 504

perakense, Bk........ 226

philippinense, Bk. ...... 820

pilosiusculum, Zipp. ...... 21 马

platypus, Hk. ......... 168

polymorphum, Bk....... 245

polytrichum, Bk. ...... 187

polyırichum, Schrad. ..... 189

Preslii, Bk. .......... 194

procurrens, Bk. ........ 211

proliferum, Keys........

prolificum, Diels ........ 195

propinquum, R. Br. ..... 212

pteroides, J. Sm. ........ 209

pteropodum, Bk........ 242

pulvinuliferum, Bk....... 200

punctatum, Diels ........ 495

punclatum, Par. ........ 210

purpurascens, Hk........ 201

recedens, Hk. .......... 198
Nephrodium

rhodolepis, Clarke ....... 202

Riedlianum, Moore ....... 230

rulidum, Copel. ........ 502

rufescens, Diels ......... 495

rugulosum, Copel........ 495

sagenioides, Bk. ......... 191

sagittaefolium, Moore ..... 222

saliayense, Zeill. ........ 224

salicifolium, Diels ........ ら11

sarawakense, Bk. ....... 200

semibipinnatum, Bk. ..... 244

setigerum, Bk. ....... 202

setosum, Bk. ......... 198

siifolium, $B k . \ldots \ldots \ldots \ldots .251$

simplicifolium, J. Sm. .... 500

simulans, Bk. ....... 190, 223

singalanense, Bk. ....... 192

singaporianum, Bk. ...... 25 b

sparsum, Don ......... 197

spectabile, $H k . \ldots \ldots \ldots \ldots .195$

Spenceri, Copel. ........ 508

splendens, Hk........ 195

Stegnogramme, Diels ..... 508,

stenophyllum, Bk. ...... 247

stipellatum, Moore...... 227

subdigitatum, Bk. ....... 245

subdimorphum, Christ ..... 251

subtriphyllum, Bk. ..... 246

syrmaticum, Desv. ....... 195

teclum, Bedd. ........ 225

tenericaule, IIlk. ..... 202, 495

Itrminans, J. Sm. ...... 209

ternatum, Bk. ........ 242

Tolta, Diels ........... 498

triphyllum, Diels ........ 509

truncatum, Pr. ................ 227

luberculatum, Ces......... 491 


\section{Nephrodium}

unitum, Bory

unitum, R. Br......... 212

urophyllum, Keys. .... 216, :11

variolosum, Bk......... 248

vastum, Bk. ......... 825

vile, Bk. . . . . . . . . 199

viscosum, Bk. ........ 186

Vilis, Rac. .......... $\$ 16$

vulcanicum, Bk. ....... 185

Webbianum, Hk..... 185, 815

Wightii, Clarke ........ 245

Wigmanii, Rac. ....... 192

Zollingerianum, Bk. ..... 255

Nephrolepis ......... 1马̆5, 807

acuta, $\operatorname{Pr} . \ldots \ldots \ldots \ldots \ldots, 162$

var. rufescens ...... 160

acutifolia, Christ ........ 157

acuminata, Kuhn ....... 159

acuminata, Pr. ........ 162

barbata, Copel. ......... 161

biserrata, Schott ........ 162

celebica, Zoll. ......... 160

cordifolia, $\operatorname{Pr} . \ldots \ldots \ldots \ldots \quad 160$

var. Laulerbachii ..... 160

davalliae, v. A. v. R. ... 807

davalloides, $K z e \ldots \ldots \ldots . . .159$

dicksonioides, Christ ...... 156

Duffi, Moore ........... 159

exaltata, Schotl ..... 161, 808

floccigera, Moore ..... 159, 807

glabra, Copel .......... 808

hirsutula, Pr. ...... 160, 808

Lauterbachii, Christ ...... 160

lindsayae, Christ ........ 157

obliterata, J. Sm. ........ 155

punclulala, Pr......... 162

radicans, Kuhn ........ 161
Nephrolepis

ramosa, Moore ......... 155

rufescens, Wawr' ....... 160

tuberosa, Pr. .......... 160

volubilis. J. Sm. ........ 161

Neurogramme ........... 528

alismaefolia, Christ ....... 545

calomelanos, Diels ....... 528

cartilagidens, Christ ...... 542

fraxinea, Christ ......... 527

quinala, Christ ......... 543

tartareum, Diels ........ 850

Niphobolus ............ 678

abbreviatus, Zoll......... 692

acrostichoides, Rich....... 685

adnascens, Klf. ........ 681

albicans, $B l . \ldots \ldots \ldots \ldots .688$

anetioides, Chist ........ 682

angustalus, Pr.......... 691

Beddomeanus, Gies........ 695

Blumeanus, Kze ........ 688

carnosus, $B l \ldots \ldots \ldots \ldots \ldots 681$

caudatus, Kl........... 681

Christii, Gies. .......... 695

confluens, spr. ........ 690

costatus, $\operatorname{Pr} \ldots \ldots \ldots \ldots \ldots 695$

distichocarpus, Gies. ...... 695

elongatus, Bl: ........ 681

fissus, Bedd. ....... 687, 688

fissus, $B l . \ldots \ldots \ldots \ldots \ldots 685$

flocciger, Bl.......... 687

glaber, Klf. ......... 688

Heleraclis, J. Sm......... 684

lanuginosus, Gies....... 685

Lauterbachii, Christ ...... 690

lingua, Bedı. .......... 684

Lingua, Spr. . . . 684, 692, 695

Mannii, Gies. ......... 687 


\section{Niphobolus}

mollis, Kze ......... 688

nummulariaefolius, J. Sm. . 685

nummularifolius, Bedd. ... 705

obovatus, Kzer......... 685

pannosus, Bedd.......... 684

penangianus, Hk........ 686

porosus, Pr. ......... 687

princeps, Gies. .......... 684

puberulus, $B l . \ldots \ldots \ldots .685$

Rasamalae, Gies......... 686

rupestris, Spr. ......... 680

samarensis, Fẻe ......... 691

Sarasinorum, Gies. ....... 693

sphaerocephalus, Hk. \& Grev. 691

sphaerostichus, Copel. ..... 682

splendens, J. Sm. ....... 696

sticticus, Kze ........... 688

stigmosus, Moore ......... 695

varius, Klf. ......... 682

venosus, Bl........... 695

Warburgii, Gies. ....... 692

Niphopsis ............. 678

Notho $(c h)$ laena .......... 483

carnosa, Wall. ........ 702

densa, J. Sm. ......... 483

distans, R. Br........ 484

hirsuta, Desv. ........ 483

pteridiformis, Bk. ..... 484

\section{O.}

Odontoloma

260

Boryanum, J. Sm. ...... 261

Odontosoria ......... 258, 825

biflora, C. Chr. ....... 259

chinensis, J. Sm. .... 259, 823

lindsayae, v. A. v. R. ... 825

Filices.
Odontosoria

retusa, J. Sm. ...... 259, 823

Oleandra ......... 151, 806

ciliata, $K l . \ldots \ldots \ldots \ldots \quad 152$

colubrina, Copel. ...... 152, 806

var. membranacea .... 806

var. nitida ........ 806

Cumingii, J. Sm. ....... 153

cuspidata, Bk...... 153, 806

hirtella, Miq......... 152

mollis, Pr. ......... 152

musifolia, Pr. ...... 153, 807

neriifolia, Pr. ...... 152, 153

neriiformis, Bedd........ 155

neriiformis, Cav. ...... 152

var. brachypus ...... 152

ornata, Christ ......... 154

pilosa, Hk. .......... 152

Sibaldii, Grev........... 155

tricholepis, Kze ....... 154

Wallichii, $\operatorname{Pr} . \ldots \ldots \ldots \ldots$ 1 $15 \tilde{z}$

Werneri, Rst. ......... 806

Whitmeei, Bk......... 154

Olfersia ............ $\mathbf{7 2 5}$

aculeata, Bl. ........ 722

gracilis, Bl.......... 722

Oligosoriae (Adiantum) .... $\quad 319$

Onychium ............. $\mathbf{5 5 0}$

auratum, Klf. ........ 550

japonicum, Kze ....... 551

lucidum, Spr. ......... 551

siliculosum, C. Chr...... 550

tenue, Christ ..........

Ophioderma ........... 772

Ophioglossaceae ......... 771

Ophioglossum .......... 771

acuminatum, Houtt...... 159

brevipes, Bedd. ........ 774 


\section{Ophioglossum}

circinalum, Burm.

802

fibrosum, Schum.

774

Mexusum, L......... 802

gramineum, Willd.

inconspicuum, $v . A . v . R$.

775

intermedium, $H$ \%.

776

japonicum, Thh.

802

macrorrhizum, Kze

774

moluccanum, Schl.

7.75

forma inconspicua 774

forma lanceolala .....

775

forma pumila

774

nudicaule, L.f. 773

obovatum, Miq. 775

parvifolium, Grev. \& Hk. . 775

pelolatum, Hk. 775

pedunculosum, Desv.

775

pendulum, $L$.

777

pumilum, v. A. v. R. ... 774

reticulatum, $L . \ldots \ldots \ldots \ldots \quad 776$

scandens, L. ......... 802

simplex, Ridl.

775

timorense, Miq.

775

Zeylanicum, Hoult.

757

Osmunda

755

Banksiaefolia, Kuhn

756

blechnoides, Zoll.

756

bromeliaefolia, Copel.

756

capensis, L. .......... 381

coronaria, Kön......... 711

javanica, $B l . \ldots \ldots \ldots \ldots .756$

Presliana, J. Sm........ 756

zeylanica, L........... 777

Osmundaceae .......... 755

Osmundastrum ......... 755

Oxygonium

ulismacfolium, I. Sm.

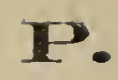

Paesin (Pteris \$) ........ 577

Paesia ............... 576

radula, $C . C h r . \ldots \ldots \ldots .576$

rugulosa, Kuhn ........ 577

Parasaccoloma .......... 282

Parkeria

pleridioides, H/....... 751

Parkeriaceae ........... 751

Partitae (Pteris) ........ 552

Palania .............. 140

Pedatae (Adiantum) ....... 519

Pellaea ............ 544, 827

concolor, B/. ........ 547

Doniana, Hk. ........ 346

falcata, Fée ......... 545

geranicuefolia, Fée ....... 547

ludens, Prantl......... 547

pteroides, Prantl ....... 545

timorensis, v.A. v. R. . 546, 827

Zippelii, Bk.......... 345

Phegopterideae................. 122

Phegopleris ........ 486, 850

acromanes, $v$. A. v. R. ... 505

aortisora, v. A. v. R. .... 501

appendiculatn, v. A. v. R. . 489

arfakiana, v. A. v. R. ... 502

asperula, $v . A . v . R . \ldots .495$

auriculata, J. Sm. ...... 490

barbata, Mett......... 221

Barberi, Mett. ......... ร15

borneensis, v. A. v.R. ... 500

Beccariana, v. A. v. R. ... 509

Biongniarlii, Melt......... 515

canescens, Mell........ 507

ceramica, v. A. v. R. .... 506

chamacotaria, v. A. v. R. .. 505 
Phegopteris

cheilanthoides, v. A. v. R. . 494

Copelandi, v. A. v. R. ... 492

cuspidata, Mell........ 511

debilis, Hell......... 501

difformis, Melt......... Б20

distans, Mell. ......... 496

diversiloba, v. A. v. R. ... 505

erubescens, J. Sm. ..... 489

ferruginea, Melı........ \$16

firmula, v. A. v. R. .... 501

granulosa, v. A. v. R. ... 505

Hasseltii, Melt. ........ 494

hirta, Christ ......... 492

holophylla, v. A. v. R. ... ๖ّ00

Hosei, v. A. v.R. ..... 510

imponens, v. A. v. R. ... 506

irregularis, Mell....... 520

Keraudreniana, Mann ..... 496

Kingi, Bedd.......... 497

laserpitiifolia, Bedd. ...... 494

loxoscaphoides, v.A.v.R.. 493

luxurians, Meıl........ 504

macrodonla, Mell. ....... 516

Merrillii, v. A. v. R. .... 505

nervosa, Fée .......... 165

obscura, Fée ......... 492

obtusata, Christ ........ 498

opaca, Mell. ......... 498

ornata, Fée .......... 494

oxyodus, v. A. v. R. .... 491

pennigera, $v$. A. v. R. ... 504

pelrophya, Mell. ........ ๖ 15

philippinensis, Mell., var.1. . 521

prolifera, Kuhn ...... 504, 510

punctata, Mell. ..... 555 , 495

quadriaurita, v. A. v. R. . 489

Ramosii, v. A. U.R..... 502

\section{Phegopteris}

rubida, v. A. v. R. .... b02

rufescens, Mell. ....... 495

salicifolia, Mell. ....... 511

simplicifolia, v. A. v. R. ... 500

Smithii, v. A. v. R. .... 490

Spenceri, v.A.v.R. .... 508

stegnogramme, Mell. ..... 508

stenophylla, v. A. v. R. .. 510

subdigilala, Bedd....... 485

subconnexa, Christ ....... 496

subdecurrens, Luerss. ...... 514

subobscura, Chrisl ....... 491

totta, Mell. .......... 498

triphylla, Mell. ..... 509, 850

tuberculata, $v$. A. v. R. ... 491

xiphioides, ".A. v. R A. 501

Phlebodium ........... 568

Photinopteris .......... 751

drynarioides, Bedd. ...... 751

simplex, J. Sm. ........ 751

speciosa, $B l . \ldots \ldots \ldots \ldots .751$

Phyllitis ............ 476

intermedia, $v$. A. v. R. .. 478

mambare, v. A. v. R. ... 479

schizocarpa, v. A. v. R. ... 479

scolopendropsis, v. A. v. R. 477

478

Phyllotrichium ......... 778

Phymatodes ........... 569

myriocarpa, Pr........ 641

Phymatopsis ........... 569

Physapteris .......... 536

Pinnatae (Polypodium) ..... 567

Pinnatae (Pteris) . . ..... 552

Pinnatifidae (Polypodium) .... 567

Pinnatifidac (Pteris) ...... 352

Plagiogyria ........ 540, 826 


\section{Plagiogyria}

adnata, Bedd.

Christii, Copel. ..... 542, 826 euphlebia, Mett. ...... 545

falcata, Copel. ........ 826

glauca, Mett. ........ 542

pycnophylla, Mett...... 343

stenoptera, Diels ....... 341

tuberculata, Copel. ... 543, 826

Platycerium .......... 707

alcicorne, Desv. ........ 710

biforme, Bl. .......... 711

bifurcatum, C. Chr. .... 710

coronarium, Desv....... 711

grande, J. Sm. ..... 708, 709

sumbawense, Christ ...... 709

Wallichii, Hk. ....... 708

Wandae, Rac. ......... 709

Wilhelminae Reginae,

$$
\text { v. A. v. R. } 708
$$

Willinckii, Moore ...... 710

Platyloma ............. 344

falcatum, J. Sm. ...... $\mathbf{7 4 5}$

Platytaenia ........... 747

Requiniana, Kuhn ...... 747

Platyzoma ............

Plenasium ............. 755

Pleocnemia ......... 170, 810

aristata, Bedd. ........ 210

devexa, v. A. v. R. ..... 811

excellens, $v . A . v . R . \ldots .171$

gigantea, $\operatorname{Pr} . \ldots \ldots \ldots 175,811$

heterophylla, v. A. v. R. 171, 810

Leuzeana, Pr. ...... 172, 810

megalocarpa, Bedd. ..... 172

membranacea, Bedd. ...... 811

membranifolia, Bedd...... 173

profereoides, v. A. v. R. .. 812
Pleocnemia

Trimeni, Bedd. ........ 811

Pleopeltis ............ $\quad 568$

accedens, Moore ....... 632

angustata, Pr. ....... 691

dilatata, Bedd. ........ 663

ebenipes, Bedd. ......... 659

Griffithiana, Moore ...... 645

hastata, Moore ........ 660

hemionitidea, Moore ...... 648

incurvata, Moore ........ 663

insignis, Bedd. ........ 663

irioides, Moore ......... 655

laciniata, Bedd. ........ 664

linearis, Moore ........ 637

longifolia, Bedd. ........ 638

longissima, Bedd. ....... 665

longissima, Moore ....... 666

malacodon, Bedd. ....... 852

membranacea, Moore ...... 649

musaefolia, Moore ....... 654

nigrescens, Carr. ....... 665

normalis, Moore ........ 641

nuda, $H k . \ldots \ldots \ldots \ldots .657$

ovata, Moore .......... 655

oxyloba, Bedd. ......... 660

palmata, Moore ......... 669

Parishii, Bedd. ........ 698

peltata, Scort. ........ 632

Phymatodes, Moore ...... 664

platyphylla, Bedd....... 647

pteropus, Moore ......... 661

punctata, Bedd. ........ 655

rhynchophylla, Moore .... 645

rostrata, Bedd. ........ $\mathbf{6 5 6}$

rupestris, Moore ........ 651

Scortechinii, Bedd....... 652

sinuosa, Bedd. ......... 625 


\section{Pleopelis}

stenophylla, Moore...... 638

superficialis, Bedd. ....... 631

var. latifrons ...... 632

tridactyla, Moore ....... 661

Wightiana, Bedd........ 637

Zippelii, Moore ........ 649

zosteraeformis, Bedd. ..... 640

Pleuridium ........... 569

Pleurogramme ......... ร̌

interrupta, Christ ........ 552

Loheriana, Christ ....... 555

paradoxa, Fée .......... ร็ 2

pusilla, Christ ....... ๖ร3, 560

Poecilopteris ........... 755

costata, Moore ........ 745

diversifolia, Pr. ....... 740

flagellifera, J. Sm. ...... 759

Presliana, Moore ....... 740

prolifera, Pr......... 758

repanda, Bedd......... 741

repanda, Pr. .......... 741

semicordata, Moore ...... 741

subrepanda, Pr......... 742

Polybotrya ........... 722

apiifolia, J. Sm. ...... 725

appendiculata, J. Sm. . 505, 724

articulata, J. Sm. ...... 725

aurita, $B l . \ldots \ldots \ldots \ldots .726$

Hamiltoniana, $\operatorname{Pr} . . . . . .724$

lalifoli, Meyei ........ 757

marginala, Bl. ........ 724

Nieuwenhuis(en)ii, Rac. ... 724

prolifera, Bory ......... 738

stenosemioides, Copel. ..... 725

Polypodiaceae ............ 121

Polypodieae ............ 122

Polypodium ......... 568, 832
Polypodium

abbreviatum, Mett. ...... 692

accedens, $B l . \ldots \ldots \ldots .655$

acrostichoides, Forst. ..... 683

aculeatum, L. ......... 809

adnascens, Sw. ......... 681

adspersum, $B l . \ldots \ldots \ldots .578$

affine, $B l . \ldots \ldots \ldots \ldots \ldots \quad 659$

alatellum, Christ ...... ร82

alatum, $H k . \ldots \ldots \ldots \ldots .658$

albicans, Mett. ........ 688

albidosquamatum, $B l . \ldots .668$

albulum, Christ ........ 651

alternans, Wall. ........ 784

alternidens, Ces. ........ 589

andaiense, Bk.......... §14

angulatum, Willd....... 822

angustatum, Bl......... 669

angustatum, Sw........ 691

Annabellae, Forb. ....... 639

anomalum, Christ ....... 661

antrophyoides, v. A. v. R. . 632

aortisorum, Harr. ....... 501

appendiculatum, Wall..... 489

var. squamaestipes .... 490

arfakianum, Bk........ 502

argutum, Wall. ........ 621

aristatum, Forst........ 810

asperulum, J. Sm. ...... 495

asperum, Zipp. ....... 817

asterosorum, Bk. ....... 694

auriculatum, Wall. ...... 490

australe, Mett. ........ 578

avenium, Mett........

Bakeri, Luerss. . . . . . . 632

barathrophyllum, $B /$. .... 605

barbatum, $I I k . \ldots . . . .221$

Barberi, Hk......... ร 15 
Polypodium

barisanicum, v. A. v. R. . 627

Barometz, L. ......... 792

Beccarianum, Ces....... ๖ั15

Beccarii, v. A. v. R. .... 635

Beddomei, Bk........ 621

benguetense, Copel. ...... 622

bicuspe, $B l . \ldots \ldots \ldots \ldots .752$

bifurcatum, $B / \ldots \ldots \ldots \ldots$

Billardieri, r. Chr. ..... 578

bipinnatifidum, $B /$. ...... 611

bisulcatum, Hk. ..... 576

blechnoides, $I I / . \ldots \ldots \ldots 605$

Blumeanum, C. ('/r. ..... 558

Blumei, Mell. ......... 558

Bolsteri, Copel. ........ 675

bomeense, IIk........ 500

brachyodus, Kze ....... 819

hrachypblebium, B/. ... 602

brevifrous, Scort........ 600

Brongniartii, Bory ...... 513

Burbidgei, Bl......... 590

caespitosum, Met!. ...... 582

calophlebium, Copel. ..... 676

campyloneuroides, $B l$.... 648

canescens, Bl......... 507

capense, L.f. .......... 788

carnosum, Christ ....... 625

carnosum, Mell......... 681

caudalum, Mell. ........ 681

caudiforme, Bl. ....... 676

caudiforme, Christ ....... 676

celebicum, Bl. ..... 605, 607

Cesatianum, Bk. ...... 605

cheilanthoides, Bli...... 494

Christii, Copel. ......... 581

clavifer $(u m), H k . . . . . .608$

commutatum, $B l . \ldots \ldots \ldots 659$
Polypodium

confluens, Hk. ....... 680

confluens, R. Br....... 690

congener, Pr. ........ 582

congenerum, $P r . \ldots \ldots \ldots$. 582

conjugalum, Bk. ...... 670

conjunctisorums, Bli..... 596

contiguum, Bracli....... 605

contiguum, Hk. ....... 658

contiguum, J. Sm. ...6616,852

conliguum, Wall. ....... 637

Copelandi, C. Chr. ....... 558

cordifolium, L. ........ 160

cornigerum, B/..... 596, 852

coronans, Wall. ....... 670

costulatum, Bl........ 644

craterisorum, /larr. ...... 607

crenatum, fiorsk. ...... 202

crenulatum, Kze ........ 669

cryptocarpum, v. A. v. R. . 616

cryptosorum, C. Ch...... 601

cucullatum, Nees \& Bl. ... 589

Cumingianum, IIk....... 516

curtidens, Christ ....... 652

Curtisii, Bk........... 604

cuspidatum, Bl. ........ 618

cyclobasis, Bli........ 659

damunense, Rsı........ 634

davalliaceum, Mucll. \& Bli.. 604

davalloides, Mell........ 48 ğ

debile, B/............ '501

decipiens, Mett. ........ 601

decorum, Brack........ 608

decrescens, Christ ......6 603

denticulatum, Pr. ......

deparoides, Christ ...... 626

difforme, $B l . \ldots \ldots \ldots \ldots$. 520

dilatatum, Wall........ 663 
Polypodium

dilatalum, var. yrandidentalum . 661

diminutum, B/....... $\$ 77$

diplosorum, Christ ...... 586

var. setosum ....... 585

Dipleris, Bl. ........ 525

distans, Don .......... 496

distichocarpum, Melt...... 695

diversifolium, Sw. ........ 699

dolichosorum, Christ ...... 646

dolichosorum, Copel. ...... 585

dolichopterum, Copel. .... 662

drepanopteron, Kze ...... 455

drynarioides, Christ ...... 751

dulitense, $B k . \ldots \ldots \ldots .632$

duriusculum, Christ ...... 604

ebenipes, Hk. ....... 659

ellipticum, Thb....... 677

Elmeri, Copel. .......... 675

erubescens, Wall. ........ 489

erythrotrichum, Copel. .... 599

euryphyllum, C. Chr. .... 665

exaltatum, Copel. ....... 614

exaltalum, L. ........ 808

extensum, Forst........ 45

evectum, Forst. ........ 762

fasciatum, $P r . \ldots \ldots \ldots . \quad 579$

Feei, Melt. ......... 675

ferrugineum, B/. ...... $\$ 16$

Filix Mas, L. ........ 814

firmulum, $B / . \ldots \ldots \ldots \ldots$ b01

fissum, Bk......... 687

flabellivenium, B/.... 574, 650

floccigerum, Mell. ...... 687

Forbesii, v. A. v. R. ... 657

Friderici et Prauli, Christ .. 575

Friderici el Pauli, Christ . 615

furcalum (fuscatum), Bl. .. 601
Polypodium

Gaudichaudii, Bory ...... 699

gedeanum, Rac......... 611

glabrum, Mell. ........ 690

glandulosum, IIk........ 609

glauco-pruinatum, C. Chr. . 660

glaucum, Kze ......... 660

glaucum, Thb......... 794

glossipes, Bk. ......... 642

gracillimum, Copel. ..... 589

grandidens, Kze ....... 619

grandidendatum, $B k \ldots \ldots .661$

grandifolium, Wall. ...... 649

granulosum, Pr. ....... 505

Griffithianum, $\| 1 / \ldots \ldots \ldots 645$

halconense, Copel. ...... 610

Ilamillonianum, Diels ..... 675

hammatisorum, Ilarr. .... 634

Hancockii, Bk. ......... 518

harpophyllum, Zenk...... 610

IIassellii, Bl. .......... 494

hastatum, Thb. ....660, 832

Havilandii, Bk......... 584

Hellwigii, Jiels ......... 645

hemiontideum, Wall .....6 648

heracleum, Kze ....... 671

IIeteractis, Mett. ........ 684

helerocarpum, Bl. ...... 655

heterocarpum, Mett. . 647, 676

helerolobum, C. Chr. ..... 661

helerosorum, Bk. ........ 518

hirsululum, forst. ...... 808

hirtellum, Bl. ....... 582

var. adspersum ...... 578

var. lasiosorum ....... 580

hirlum, $\operatorname{Pr} . \ldots \ldots \ldots \ldots .492$

holophyllum, B/. ....... 500

holophyllum, Bk...... 630 
Polypodium

Hookeri, Brack. ........ క84

Horsfieldii, R. Br. ......

Hosei, C. Chr. ........ 674

imbricalum, Karsl. ...... 624

imponens, Ces. ......... 506

inarticulalum, Copel. ...... 608

inconspicuum, $B l . \ldots \ldots . .596$

incurvalum, $B l . \ldots \ldots \ldots .665$

induratum, $B /$. ....... 657

insigne, $B l . \ldots \ldots \ldots \ldots \ldots 665$

integrius, Copel. ........ 618

interruptum, C. Chr..... 673

intromissum, Christ ...... ร85

invisum, Forst. ........ 819

involutum, Mett. ....... 537

iridifolium, Diels ....... 559

irioides, Poir. .......... 653

irregulare, $\operatorname{Pr} . \ldots \ldots \ldots \ldots$

Jagorianum, Melt. ...... 585

Keraudrenianum, Gaud. .... 496

khasyanum, Hk....... 605

knutsfordianum, $B l . \ldots \ldots$ ๖84

Koeningii, Bl. ......... 681

Koningsbergeri, v. A. v. R. . 619

Koordersii, Christ ....... 581

Korthalsii, Mett........ 618

Lıbrusca, Hk. ........ Б17

lacinialum, $B l . \ldots \ldots \ldots \ldots 664$

lagopodioides, Christ ... 640, 65ّ1

lagunense, Christ ........ 667

lampongense, Zoll. ....... 622

lancifolium, v. A.v. R. .. 598

laserpitiifolium, Scort. .... 494

lasiosorum, Hk....... 580

lalifolium, Forst. ....... 823

lecanopteris, Mett....... 625

leucophorum, $B k . \ldots . \ldots .650$
Polypodium

Leuzeanum, Gaud. ....... 810

Leysii, Bk. .......... 607

lineare, Burm......... 59

lineare, Thb. ......657, 641

linealum, Colebr......... 229

linguaeforme, Mell. ...... 642

Linn(a)ei, Bory ......... 699

lividum, Mett. ......... 602

lobatum, Huds. ........ 810

Lobbianum, IIk. ........ 522

Lobbianum, Hk........ 608

locellatum, $B k . \ldots \ldots \ldots \ldots .577$

Loherianum, Christ ...... 590

lomarioides, $K z e \ldots \ldots \ldots \quad 625$

longifolium, Mett. ....... 658

longifrons, Wall. ........ 641

loriforme, Hk. ........ 637

longissimum, $B l . \ldots \ldots \ldots 666$

loxogramme, Mett. ...... 538

loxoscaphoides, Bk....... 493

ludens, $B k . \ldots \ldots \ldots \ldots \ldots . .591$

luzonicum, Copel ........ 651

lycopodioides, L. ....... 640

Macleayi, v. A. v. R. .... 626

macrochasmum, $B k$. $\ldots \ldots 664$

macrodon, Reinw....... 516

macrophyllum, Bl. ..... 674

macropodum, Bk. ...... 685

macrum, Copel. ........ 609

Maingayi, Diels ......... 677

malaccanum, Bk. ....... 602

malaicum, v. A. v. R. ... 577

marginale, $T h b . \ldots \ldots \ldots .825$

Maxwellii, Bk. ........ 576

mediale, $B /$.

var. parasilicum ..... 581

megalocarpum, Hk. ..... 172 


\section{Polypodium}

membranaceum, Don..... 649

mengtzeense, Copel.'...... 622

Merrillii, Copel. ......... 579

Merritti, Copel. ......... 597

Meyenianum, Hk. ... 671, 700

millefolium, $B l . \ldots \ldots \ldots 612$

millisorum, $B k . \ldots \ldots \ldots .655$

mindanaense, Christ ...... 654

minimum, Bk. .......

mimutum, Bk. ........ 598

minutum, Bl. ....... 597

mirabile, C. Chr. ....... 624

molle, Mett. ......... 688

mollicomum, Nees \& Bl. . 601

molliculum, Copel. ...... 620

mollipilum, Bk....... 584

monstrosum, Copel. ...... 655

Moseleyi, Bk. ........ 669

multicaudatum, Copel. .... 605

mullilineatum, Wall...... 217

musgravianum, $B k$..... 596

musifolium, $B l$....... 654

myriocarpum, Mett...... 641

myrmecophilum, Christ .... 624

naviculare, $v . A . v . R . \ldots .627$

nectariferum, Bk. ...... 700

neglectum, $B l . \ldots \ldots \ldots .65$

Nieuwenhuisii, v. A. v. R. . 626 nigrescens, $B l$....... 665

nitens, $B /$. ......... 696

normale, Don ......... 641

var. sumatranum ..... 651

mummulariaefolium, Melt. ... 685

nummularium, Mett. .... 654

nutans, $B l . \ldots \ldots \ldots \ldots .606$

nutans, J. Sm. ........ 608

sbovatum, Mett......... 685
Polypodium

oblanceolatum, $B k . \ldots \ldots .575$

obliquatum, $B l$....... 600

obliquatum, Copel. ....... 605

obliqualum, H/........ 599

obscurum, IIl. ......... 492

obscurum, Mett. ....... 586

oblusifolium, C. Chr. ..... 606

oleandroides, $B k . \ldots \ldots \ldots \quad 575$

oodes, Kze ....... 636, 652

ornatissimum, Rst....... 575

ornatum, Wall.......... 494

ovatum, Wall. ........ 653

oxyodon, Bk. ......... 491

oxyphyllum, Kze ........ 649

pachydermum, Bk...... 680

padangense, $B k$. ....... 586

pallens, $B l . \ldots \ldots \ldots \ldots .620$

palmatum, $B l . \ldots \ldots \ldots .669$

paludosum, Bl. ........ 496

palustre, Burm......... 720

pannosum, Mett. ....... 683

papillosum, Bl. ........ 600

papillosum, Ces......... 605

papuanum, Bk........ 639

parallelum, C. Chr. ..... 557

parasiticum, L......... 224

parasiticum, Mett. ...... 581

parvulum, Bedd........ 598

parvulum, Bl. ........ 596

patelliferum, Burck ...... 625

patens, Sw. .......... 814

paucijugum, v. A. v. R. . . 658

paucisorum, Copel. ...... 577

pectinatum, Forsli....... 185

pediculatum, Bk....... 608

pedunculatum, Mett..... 675

peltatum, v. A. v. R. .... 632 
Polypodium

penangianum, IIl. .... 229, 686 pennigerum, Forst....... 504 pentaphyllum, B/...... 662 persicifolium, Desv. ...... 618 petrophyum, Bl. ....... ๖े phanerophlebium, Copel. ... 665 phlebiscopum, Bl....... 648 phlebodioiles, Copel. ...... 618 phyllomanes, Christ. var. ovalum 635 phymatodes, L. ....... 664 pilosiusculum, Pr. ...... כ้ 80 platyphyllum, Sw. ...... 647 pleiosoroides, Copel. ..... 576 pleuridioides, Metı. ...... 697 pleurogrammoides, Rst. ... 585 polycarpum, Bk........ ว้20 polymorphum, v. A. v. R. . 615 porosum, Wall. ....... 687

Prainii, C. Chr. ........ 617 princeps, Melt......... 684 productum, Christ ....... 638 proliferum, $R b . \ldots \ldots \ldots \ldots \quad 504$ propinquum, Wall........ 698 proteus, Copel. ......... 670 pseudoarticulatum, Copel. .. 601 pseudoconnatum, Copei. ... 621 pteroides, $\operatorname{Pr} . \ldots \ldots \ldots \ldots .5 \mathbf{5 1 3}$ pteropus, $B l . \ldots \ldots \ldots \ldots 661$ pubinerve, Christ ........ ๖ 86 punctatum, $S w . \ldots \ldots \ldots .655$ punclalum, Thb........ 495 pusıllum, Christ ........ pyrolifolium, Goldm...... 654 quercifolium, L. ........ 698 quinquefidum, $B l . \ldots . \ldots 660$ quinquefurcalum, $B k$..... 523
Polypodium

Raapii, v. A.v.R. ..... 640 Raciborskii, C. Chr. ...... 557 radicans, Burm. ........ 161 Rasamalae, Rac. ....... 686 recedens, J. Sm. ........ 816 regulare, Metl. ........ 675 Reinwardlii, Kze ...... 622 Reinwardtii, Pr. ....... 585 var. obscurum ...... 586

repandulum, Mett. ....... 599 var. malayanum ..... 600 revolutum, C. Chr...... 658 rhynchophyllum, $H l_{i} . \ldots .645$ rigidulum, $S w . \ldots \ldots \ldots . .699$ rivulare, Copel. ........ 662 rostratum, $H / . \ldots \ldots \ldots .656$ rubidum, Hk........ rudimentum, Copel. ...... 636 rufescens, Bl. ....... 495 rugulosum, Lab. ........ 495 rupestre, $B l$.......6 650,651 rupestre, R. Br. ....... 680 sablanianum, Christ ...... 642 sagilla; Christ .......... 704 sımarense; Mell. ........ 691 Sarasinorum, v. A. v. R. .. 615 sarawakense, Bk. ...... 631 sarcopus, de Vr. \& Teysm. . 624 Sauvinieri, $B k . \ldots \ldots \ldots .668$ saxatile, Melı........ 650 scabristipes, $B k . \ldots \ldots \ldots \quad 585$ Schefferi, v. A. v. R. .... 609 Schenkii, Harr. ......... 600 Schlechteri, $v . A . v . R . \ldots 614$ Schneideri, Christ ...... 666 Schumannianum, Diels ..... 654 scolopendrinum, C. Chr.... 557 
Polypodium

Scortechinii, $B /$.

242,652

sculpturatum, $B /$

668

selliguea, Metl.

scmicordatum, Sw........ S08

serraelorme, J. Sm. ..... 615

serrato-dentatum, $v$. A. v. R. 597

sessilifolium, H/........ 577

setigerum, $B l . \ldots \ldots \ldots \ldots$ 587

seligerum, Hl. \& Arn. ... 584

setosum, $\operatorname{Pr} . \ldots \ldots \ldots \ldots$ 585

sibarongae, Christ ...... 606

siifolium, Willd........ 825

simplicifolium, IIl....... ら00

sinuosum, Wall....... 625

solidum, Mell........ 606

soridens, Hk. ........ 655

sparsisorum, Desv. ...... 699

sparsum, Ham. ....... 815

speciosum, Christ ....... 751

Speluncae, L. ......... 825

sphacrostichum, Mett. ..... 682

splendens, Hk. ...... 696, 701

spurium, Mett........ 674

Stanleyanum, Bli....... 577

stenobasis, Bk....... 607

stenophyllum, $B l$....... 658

stenopteris, Bl....... 655

sticticum, Melt. ........ 687

stigmosum, $S w . \ldots \ldots \ldots .695$

streptophyllum, Bk. .... 595

subaquatile, Christ ....... 668

subarboreum, Bl........ 204

subauriculatum, Bl...... 622

var. pallens ........ 620

subdichotomum, Rac. .... 588

subdigitalum, Bl........ 485

subdrynariaceum, Christ.... 654
Polypodium

subecostatum, IIk...... 636

subevenosum, $B l i \ldots \ldots$ 582

var. sessilifolia ..... \$77

sublalcatum, Bl........

var. glabrum ....... 599

var. semiintegrum ....

subfasciatum, list. ...... 579

subgeminatum, Christ .... 65?

subirideum, Christ ....... 654

subminutum, v. A. v. R. . 598

subohliquatum, Christ .... 606

suboppositum, Christ ..... 632

subpinnatifidum, $B l . \ldots \ldots g$. .

subpleiosorum, Kac....... 587

subrepandulum, Christ .... \$ \$98

subrostratum, C. Chr..... 656

subsecundo-dissectum, Zoll. . 598

subselligueum, Bk......

subserratum, H/k....... 401

subsparsum, Bk....... 650

subtriangulare, v. A. v. R. . 595

subtriphyllum, Hl. \& Arn. . 825

sucklingianum, Bl...... 580

sumatranum, $B k . \ldots \ldots \ldots \quad 587$

sumatranum, Bk....... 658

sundense, C. Chir. ...... 658

superficiale, Bl. .... 651, 652

taeniopsis, Christ ........ 651

tamariscinum, Kl/....... 611

taxodioides, Bl........ 612

tenuilore, $K z e \ldots \ldots \ldots \ldots .651$

tenuisectum, $B l . . . \ldots \ldots .612$

tomentellum, C. Chr. ..... 620

Toppingii, v. A. v. I. .... 616

tortile, v. A. v. K. ..... 614

torulosum, Bl. ....... 652

lollum, Willd. ........ 497 
Polypodium

Treubii, Christ 646

triangulare, Scort. ....... ร95

trichopodum, Muell. ..... 575

tridactylon, Metı....... 665

tridactylum, Wall. ....... 661

trifidum, Ces.......... 664

trifidum, Don.......... 660

triquetrum, $B l . \ldots \ldots \ldots 6$

var. rupestre ....... 651

var. Iaeniopsis ....... 651

truncatum, Poir. ........ 822

tuberculatum, Bk....... 491

umbrosum, Ait. ..... 455, 828

undosum, $B k . \ldots \ldots \ldots \ldots .596$

universe, $B l . \ldots \ldots \ldots \ldots .580$

urophyllum, Wall....... 216

Valetonianum, v.A.v.R. . 647

validum, Copel. ........ 655

varians, $B l . \ldots \ldots \ldots \ldots \ldots 668$

varium, Mett. ........ 682

venulosum, $B l . \ldots \ldots \ldots .609$

verrucosum, Wall. ..... 619

violascens, Mett. ....... 665

viltariifolium, $C$. Chr. ... 579

vulcanicum, $B l . \ldots \ldots \ldots .675$

vulcanicum, Christ ...... 676

Warburgii, Christ ....... 587

Weinlandii, Chrisı ...... 655

Werneri, Rst. ......... 649

Whitfordi, Copel. ....... 646

Wilkesii, C. Chr........ 658

Willdenowii, $B l . \ldots \ldots \ldots .697$

Willdenowii, IIK........ 698

Wrayi, Bl........... 655

Yoderi, Copel. .......... 612

Zippelii, Bl. ........ 649

Zullingerianum, Kze ..... 655
Polypodium

zosteriforme, Wall. ...... 640

Polysoriae (Adiantum) ...... $\quad \mathbf{5 1 9}$

Polystichum ......... 164, 808

aculeatum, Schott.... 166, 167

168,809

var. biaristatum ..... 167

amabile, $J . S m . \ldots \ldots \ldots . . . .168$

aristatum, $\operatorname{Pr} . \ldots \ldots$ 169, 810

var. platypus ........ 168

auriculatum, $\operatorname{Pr} . \ldots \ldots$ 165, 808

var. caespilosum ..... 809

Benoitianum, Gaud......... 225

biaristatum, Moore ....... 167

blepharistegium, Copel. .... 810

caespitosum, Schott ...... 809

carvifolium, C. Chr...... 169

coniifolium, Pr......... 169

Copelandi, Christ ....... 808

deltodon, Diels

var. nervosum ....... 808

diaphanum, Moore ....... 165

discretum, Diels ........ 167

falcatim, Diels ......... 255

horizontale, Copel. ........ 166

lobatum, $\operatorname{Pr} . \ldots \ldots \ldots 167,810$

nudum, Copel. ......... 809

obliquum, Moore ....... 809

obtusum, J. Sm. ........ 166

platypus, Diels ...... 168, 810

Preslianum, Moore ....... 164

Riedleanum, Gaud. ....... 250

semicordatum, Moore ...... 165

varium, $\operatorname{Pr} . \ldots \ldots \ldots \ldots . . \ldots 8$

vestitum, $\operatorname{Pr} . \ldots \ldots \ldots \ldots . . \ldots 167$

Poronema ............ 697

Prosaptia ............. 567

alata, Christ ......... 615 


\section{Prosaptia}

contigua, Bedd.

616

- cryptocarpa, Copel.

616

Emersoni, Pr.........615

polymorpha, Copel....... 615

serraeformis, Christ...... 615

Schlechteri, Christ ...... 614

toppingii, Copel. ....... 616

Protogleichenia .......... 56

Psomiocarpa ........... 725

Pterideae ............. 121

Pteridella ............. 544

Pteridium ........... 577

aquilinum, Kuhn ...... 577

Pteris ............ 551, 827

amoena, $B l . \ldots \ldots \ldots \ldots .567$

aquilina, L.......... 577

argentea, Gmel. ........ 557

argyraea, Moore ........ 566

asperula, J. Sm. ....... 566

aurita, $B l . \ldots \ldots \ldots \ldots \ldots \quad 549$

Beccariana, C. Chr...... 564

biaurita, L. .... 571, 572, 574

var. quadriaurila .... 565

var. reducta ....... 555

blechnoides, Willd. ...... 565

Blumeana, Ag. ........ 366

var. asperula ...... 566

var. pluricaudata ..... 564

caesia, Copel. ......... 567

chrysocarpa, Hk. \& Grev... 550

chrysosperma, Hk. \& Grev. . 5 ว̆0

concinna, Bk. ........ 564

concolor, L. \& F. ..... 547

crenata, Sw.......... 560

cretica, L. .......... 558

var. heteromorpha .... 562

var. melanocaulon ..... 558

\section{Pteris}

cretica, var. stenophylla .... 557

Dalhousiae, IIk..... 565, 827

Dalhousiae, Rac........ 554

decussata, J. Sm........ 568

dimidiata, Willd....... 562

dispar, Kze ......... 562

distans, J. Sm. ....... 562

divaricatissima, $B k . \ldots \ldots, 577$

diversifolia, $\mathbf{S} w . \ldots \ldots \ldots \mathbf{5 5 5}$

ensiformis, Burm...... 560

esculenta, Forst......... 577

excelsa, Gaud......... 568

falcata, R. Br. ....... 545

farinosa, Forsk. ....... 558

finisterrae, Rst....... 575

furcans, $B k . \ldots \ldots \ldots \ldots \ldots$

geminata, Wall........ 571

geraniaefolia, Raddi..... 547

Grevilleana, Wall. ... 564, 567,

827

Griffithiana, Hl...... 564

heteromorpha, Fée ..... 562

heterophlebia, Kze ..... 572

hirsuta, Poir. ........ 485

inaequalis, $B k . \ldots \ldots \ldots .562$

incisa, Thb......... 349

Indica, Christ ........ 557

intromissa, Christ ...... 827

Junghuhnii, Bk. ...... 574

Kleiniana, Christ ........ 371

laevigata, Zipp. ........ 554

lanuginosa, Spr. ....... 577

ligulata, Gaud. ........ 570

lineata, $L . \ldots \ldots \ldots \ldots \ldots .561$

longifolia, L. ...... 555, 556

longipes, Don ......... 569

longipinnula, Ces........ 564 
Pteris

longipinnula, Wall. .. 565, 827 ludens, Wall. ......... 547

marginata, Bory ....... 575

maxima, Bk. ....... 571

melanocaulon, Fic:...... 558

mertensioides, Willd. .... 573

microdictyon, $I K$. ...... 574

Milneana, $B / . . \ldots \ldots \ldots \ldots 574$

mixta, Christ ........ 370

moluccana, $B l$....... 557

multifida, Poir......... 561

nemoralis, Willd. ...... 566

normalis, Don ........ 566

var. $B \ldots \ldots \ldots \ldots .566$

opaca, J. Sm......... 556

orientalis, $v$. A. v. K. . 555, 827

papuana, Ces. ........ 558

parviloba, Christ ....... 567

palens, Hk.........

pellucens, Ag. ....... 569

pellucida, $\operatorname{Pr} . \ldots \ldots \ldots \ldots .557$

var. stenophylla ..... .557

philippinensis, Fée ...... 570

platysora, $B /$. . ....... 556

pluricaudata, Copel. ..... 564

quadriaurita, Retz .... 565, 567

$571,574,489$

var. biaurita ....... 571

var. digitata ...... 564

var. Lauterbachii ..... 570

var. longipinnula ... . 565

radicans, Christ ........ 569

Radula, Bls.......... 577

rangiferina, $\operatorname{Pr} . \ldots \ldots \ldots .5$

reducta, Bk.......... $5 \sqcup 5$

rugulosa, Lah. ......... 577

scolopendrina, Bory ......
Pteris

semipinnata, L. .... 362, 567

var. dispar ....... 562

siliculosa, Desv. ........ 550

serrulata, L.f. . . . ..... 561

stenophylla, Wall....... 557

sumatrana, Bk....... 561

torricelliana, Christ ..... 565

trachyphylla, Kze ..... 566

Treacheriana, Bl........ 558

Treubii, v. A. v. R. . 5 56, 827

tripartita, Siw........ 575

var. Junghuhnii ..... 574

var. Milneana ....... 574

umbraculifera, Mett...... 565

varians, Wall. ........ 559

venulosa, $B l . \ldots \ldots \ldots \ldots \ldots .557$

venusta, $K \approx e \ldots \ldots \ldots \ldots \ldots \quad 557$

Vespertilionis, Lab. ...... 549

Victoriae, hort. ........ 560

Walkeri, Bk......... 568

Wallichiana, Ag....... 572

Warburgii, Christ ....... 575

Whilfordi, Copel. ....... 566

Zollingeri, Metı. ....... 569

\section{IE.}

Reniformiae (Adiantum) ... 519

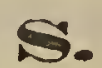

Saccoloma ............. 281

moluccanum, Mett....... 282

sorbifolium, Christ ...... 282

Sadleria $\ldots \ldots \ldots \ldots \ldots \ldots \quad 588$

cyatheoides, Klf. ...... 588

Sagenia ............. 254

alata, Bedd........... 241

calcarea, I. Sm......... 282 


\section{Sagenia}

coadunata, J.Sm.

decurrens, Iloulst.

ferruginea, Christ

516

giganten, Bedd.

var. minor

Griffithii, Bedel.

Labrusca, Chist

Lobbii, Christ

mamillosn, Moore

melanocaulon, Moore ...... 245

pachyphylla, Moore ....... 252

palmata, Christ .......... 257

polymorpha, Christ ,...... 245

pteropoda, Christ ......... 242

repanda, Moore ......... 238

rufipubis, Christ ........ 516

semibipinnata, Moore ...... 825

subdigitata, Christ ....... 245

subtriphylla, Bedd. ....... 246

vasta, Moore .......... 241

Vitis, Christ ......... 516

Salpichlaena .......... 583

Schafineria ........... 477

Schellolepis (Schellopsis) ....

Schiziea ........... 113, 805

dichotoma, Sm. ..... 116, 803

digitata. $S w, \ldots \ldots \ldots 116,805$

fistulosi, $L a b . \ldots \ldots \ldots \ldots \quad 116$

var. malaccana ...... 116

Forsteri, Spr. ......... 116

malaccana, Bk........ 116

Schizaeareae ........... 109

Schizocaena

Brunomis, J. Sm. ........ 15

Schizoloma .......... 275, 824

angustum, Copel........ 277

cordatum, Gaud. ........ 279
Schizoloma

coriaceum, v. A. v. R. . 280, 824

davallioides, Moore ....... 274

divergens, Kuhn ....... 278

ensifolium, \&. Sim. ..... . 280

fuligineum, Copel ........ 277

Guerinianum, Gaud. ... 288, 824

var. ovatum ......... 277

heterophyllum, J. Sm. ... 281

induratum, C.Chr...... 277

jamesonioides, Copel. ..... 276

lobala, Bedd.......... 274

ovatum, Copel.......... 277

pellaeiforme, C. Chr...... 278

recurvatum, Moore ....... 274

trilobatum, v. A. v. R. ... 280

Walkerae, Kuhn ....... 278

Schizostege ........... 548

calocarpa, Copel. ....... 548

pachysora, Copel. ....... 548

Scolopendrium ......... 477

longifolium, Pr. ....... 480

mambara, Bail......... 478

pinnalum, J. Sm. ....... 480

schizocarpum, Copel ...... 479

Scutigera ............ 707

Scyphularia ............ 296

Selliguea ............ . $\quad 569$

campyloneuroides, Rech. .... 674

caudiformis, J. Sm. ...... 676

decurrens, Pr.......... 677

rlliptica, Bedd. ........ 677

Feei, Bory ........... 675

Hamilloniana, Bedi....... 675

heterocarpa, Bl. ....... 676

Mainyayi, Bedd. ....... 677

macrophylla, Bl........ 674

membranacea, Bl....... 673 


\section{Selliguea}

Selliguea, Christ ........

Sitolobium

cuneatum, J.Sm........ 805

samoensé, Brack......... 804

Soromanes ........... 723

Sphaerostephanos

csplenioides, J. Sm. ......

Stegania

Patersoni, R. Br. ...... 579

Stegnogramme ......... 486

aspidioides, Bl. ...... 508

Stenochlaena ........ 718, 855

aculeata, $K z e \ldots \ldots \ldots \ldots 722$

areolaris, Copel........ 855

arthropteroides, Christ .... 719

dubia, v. A. v. R. ...... 721

gracilis, Kze ........ 722

juglandifolia, Pr. ...... 720

laurifolia, $\operatorname{Pr} . \ldots . . . \ldots .719$

palustris, Bedd...... 720, 722

Raciborskii, C. Chr...... 720

scandens, J. Sm........ 720

Smithii, v. A. v. R. ..... 720

sorbifolia, J. Sm. .... 720, 722

var. dimorphophylla ... 480

subtrifoliata, Copel. ...... 721

Stenoloma ............. 258

chinensis, Bedd........ 259

Stenosemia ........... 726

aurila, J. Sm. ......... ร21

aurita, $\operatorname{Pr}_{2} \ldots \ldots \ldots \ldots \ldots . \ldots 26$

pinnata, Copel......... 727

Teysmanniana, Diels ..... 727

Synammia ............ 568

Synaphlebium ........... 260

recurvatum, J. Sm. ...... 274

Syngramma $(e) \ldots \ldots \ldots$ 559, 851

\section{Syngramma $(e)$}

alismifolia, $J . S m . \ldots \ldots \ldots \quad 543$

Boerlageana, v. A. v. R. .. 545

borneensis, J. Sm....... 541

cartilagidens, Diels ...... 542

Dayi, Bedı.......... 541

fraxinea, Bedd......... 527

Hookeri, C. Chr. ....... 545

Hosei, Diels ......... 545

lanceolata, Diels ........ 545

Lobbiana, J. Sm. ........ 541

obtusifolia, J. Sm....... 541

pinnata, $J . S m . \ldots \ldots \ldots \ldots \quad 546$

quinata, Carr.......... 545

valleculata, C. Chr...... 540

vittaeformis, J. Sm...... 545

Wallichii, Bedd........ 545

Zollingeri, Diels ....... 851

\section{T.}

Taeniopsis ...........

amboinensis, Bedd. ...... 561

falcata, Bedd.......... 560

lineata, J. Sm......... 561

scolopendrina, J. Sm...... 561

Taenitis ............. 562

blechnoides, $S w . \ldots \ldots \ldots \ldots 55$

var. obtusa ........ 562

interrupta, Hk. \& Grev. .... 563

obtusa, Hk......... 562

pusilla, Mett......... 560

simplicivenia, Ces........ 560

stenophylla, Christ ...... 563

Tapeinidium .......... 315

amboinense, C. Chr. .... 515

Denhami, C. Chr. ...... 516

gracile, $v . A . v . R . \ldots \ldots .315$

oligophlebium, C. Chr. ... 514 
Tapeinidium

pinnatum, C. Chr. 514 var. gracile. 315

Tectaria 234 ambigua, Copel. 521,812 Barberi, Copel. 515

Bryanti, Copel. 514, 519 calcarea, Copel. 256

Christii, Copel. 249 crenata, Cav. $238,251,252$ decurrens, Copel. 246, 247 devexa, Copel. 810 grandifolia, Copel. 249 irregularis, Copel. ..... 519, 520 var. Brongniartii ..... 513 var. macrodon ....... $\quad 516$ irrigua, Copel. .......245, 518 Labrusca, Copel. ........ 517 latifolia, Copel. ......... 249 leuzeana, Copel......... 810 malayensis, Copel. ........ 249 melanocaulon, Copel. ... 245, 249 Menyanthidis, Copel. ...... 244 pentaphylla, v. A. v. R. . . 519 polymorpha, Copel. ......243 siifolia, Copel. ...... 249, 251 subcaudata, v. A. v. R. ... 825 subtriphylla, Copel. ...... 246 iernatensis, v. A. v. R. ... 825 vasta, Copel. .......... 241

Teratophyllum .......... 718

acuieatum, Mett. ....... 722

Thamnopteris ........... 456

Nidus, Pr. ......... 459

Phyllitidis, Pr........ 850

Simonsiana, Moore ...... 458

stipitata, Pr. ......... 445

Thayeria ............ 697

Filices.

\section{Thayeria}

cornucopia, Copel........ 700

nectarifera, Copel. ........ 700

Todea

alpina, $B k . \ldots \ldots \ldots \ldots .757$

Fraseri, Hk. \& Grev...... 756

Wilkesiana, Brack....... $\mathbf{7 5 6}$

Toxopteris ........... $\quad 559$

Trichomanes ........ 82, 799

aculeatum, J. Sm......... 798

adiantoides, L. ......... 464

anceps, Hk., var. B. ..... 799

aphlebioides, Christ ...... 102

apiifolium, $P r . \ldots \ldots \ldots .104$

asplenioides, $\operatorname{Pr} . \ldots \ldots \ldots .101$

Aswijkii (Asnykii), Rac. ... 88

auriculatum, $B l . \ldots \ldots \ldots .96$

Bauerianum, Endl....... 104

Beccarianum, Ces. ...... 86

bilabiatum, Nees \& $\mathrm{Bl}$. ... 94

var. bilingue ....... 102

bilingue, $H k . \ldots \ldots \ldots \ldots .102$

bimarginatum, V. D.,B. . . 86 bipunctatum, Poir....... 95

var. capillatum ...... 95

var. nana-subflabellata . 95

brevipes, Bk. .......94, 102

capillatum, Taschn...... 95

cellulosum, Hk. ....... 10马

chinense, L. . .......... 259

Christii, Copel. ......... 800

contigunm, Forst. ....... 616

corticola, Bedd. ......... 89

Cumingii, C. Chr. ....... 99

cupressoides, Desv. ...... 105

var. setaceum ....... 801

demissum, Forst. ....... 797

denticulatum, Bk. ...... 79 


\section{Trichomanes}

dichotomum, $K z e \ldots . . .96$ diffusum, Bl. ...... 90, 799 digitatum, $S w . \ldots \ldots \ldots . \quad 89$

var. palmalifidum .... 90

dissectum, J. Sm. ...... 96

ericoides, Hedw. ........ 10马

Filicula, Bedd. ........ 98

Filicula, Bory ....... 94, 9:

filiculoides, Christ ....... 95

Rabellatum, V. D. B. .... 89

flaccidum, Forst. ....... 80 o

foeniculaceum, Bory ...... 105

gemmatum, J. Sm. ...... 10马

giganteum, Bory ........ 105

glauco-fuscum, Hk....... 95

gracile, $V$. D. B. ..... 98

Henzaiense, Bedd. ....... S马̈

hispidulum, Mett........ 97

Hosei, Bk. .......... 98

humile, Forst. . . . . . . 94

ignobile, Ces. ........ 97

japonicum, Thb. ........ 551

javanicum, $B l$. . 100, 799, 800

var. asplenioides ..... 101

Kur $\approx i$, Bedd. ......... 89

Lauterbachii, Christ ...... 97

longiselum, Bory ........ 105

maximum, $B l . \ldots \ldots$. 99, 799

meifolium, Bl. ........ 104

meifolium, Bory ......... 105

melanorhizon, H/...... 102

Merrilli, Copel. ......... 801

microchilum, Bk...... 95

millcfolium, Pr. ....... 799

minutum; $B l . \ldots \ldots \ldots .90$

Motleyi, V. D. B. ..... 85, 86

ral'. pamosum ....... 86

\section{Trichomanes}

millifidum, Forst. ...... 798

muscoides, Bk. ........ 86

nanum, $V$. D. B. ...... 89

neilgherrense, Bedd. ..... 86

nitidulum, V. D. B. . . 88, 799

Nymani, Christ ........ 94

obscurum, Bl. ........ 105

omphalodes, C. Chr....... 85

pallidum, $B l . \ldots \ldots \ldots \ldots .95$

palmatifidum, K. Müll. ... 90

pannosum, Ces, ........ 86

parviflorum, Poir. ....... 105

parvulum, Poir. ....... 88

peltatum, $B k \ldots \ldots \ldots \ldots . \quad 85$

pluma, Hk. .......... 106

polyanthos, Hk......... 104

proliferum, $B l . \ldots . \ldots 999,91$

pyxídiferum, $L . \ldots \ldots \ldots .98$

racemulosum, V. D. B. ... 102

radicans, Sw.......... 99

rhomboideun, J. Sm..... 800

rigidum, Sw. ....... 102, 105

rupicolum, Rac......... 89

saxatile, Moore .......... 105

saxifragoides, $P r \ldots \ldots \ldots \quad 88$

serrulatum, $B k, \ldots \ldots \ldots .95$

setaceum, V. D. B. ..... 801

Smithii, Hk. ......... 99

speciosum, Willd. ....... 99

strigosum, Thb. ....... 825

sublimbatum, K. Müll. ... 86

sumatranum, v. A. v. R. . 800

tenuifolium, Burm. ...... 559

tenuissimum, Christ ....... 102

Teysmanni, V. D. B. ..... 91

trichophyllum, Moore ..... 106

unbridgense, Sin. ....... 797 
Trichomanes

vestitum, $B / \varepsilon$.

Warburgii, Christ.

Werneri, Rst 799

Trichomanopsis ......... 84

Triphlebia ............ 479

dimorphophylla, Bk. .... 480

linza, Bk. ......... 479

longifolia, Bk........ 480

pinnata, $B /$.

\section{V.}

Vittar'ia 555 acrostichoides, IIk. \& Grev. . 712 alternans, Copel. ......... ร̌59 amboinensis, Fée ....... 561 angustifolia, $B l . \ldots \ldots \ldots . \quad 555$

Bensei, v. A. v. R. ..... 557 caudiformis, $B l . \ldots \ldots \ldots .554$ crassifolia, Bk. ....... 555 debilis, Kuhn ........ 559 divergens, $R b . \ldots \ldots \ldots \ldots .278$ elongata, $S w . \ldots \ldots \ldots \ldots .556$ var. ensisformis ...... Б55 var. genuina ....... 556 var. zosterifolia ...... 556 ensifolia, $B l$. 555 ensiformis, $S w . \ldots \ldots \ldots .55$ falcata, $K z e \ldots \ldots \ldots \ldots . \mathbf{5 6 0}$ hirta, Fée .......... 558 intermedia, $B l . \ldots \ldots \ldots \ldots$ ๖. lineala, Sm. ๖61

Vittaria

lloydiifolia, Rac........ 554

longicoma, Christ ....... 559

Merrillii, Christ ........ 557

minor, Fée ......... 560

pachystemma, Christ ..... 556

parvula, Bory ......... 559

philippinensis, Christ .... 562

plantaginea, Hk. \& Grev.... 555

pumila, Mett. ......... 559

pusilla, $B l . \ldots \ldots \ldots \ldots 553,560$

rigida, $K l f . \ldots \ldots \ldots \ldots \ldots .55$

scolopendrina, Thw...... 561

scolopendrioides, Melt. ..... 561

subcoriacea, Christ ....... §58

sulcata, Kuhn ......... 560

taeniophylla, Copel. ...... 561

zosterifolia, Willd........

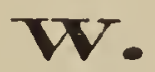

Wibelia ............. 514

amboynensis, Cuhn...... 515

Denhami, Kuhn ........ 516

gracilis, Christ ........ 515

oligophlebia, Christ ....... 314

pinnata, Fée .......... 515

Woodsieae ............. 121

Woodwardia ........... $\quad 390$

auriculala, Bl. ........ 591

prolifera, Hk. \& Arn. ..... 391

radicans, $S m . \ldots \ldots \ldots \ldots .591$ 



\section{ADDITIONS, MODIFICATIONS \\ AND \\ CORRECTIONS.}

This list principally contains additions and modifications that could not be inserted in the Appendix; most of them may be cut out and pasted on the places indicated.

Typographical and grammatical errors of no importance with regard to the purpose of the work are not considered.

$$
\text { (P. = Page; l. = line; fr. b. = from bottom). }
$$

P. XXXI, 1. 1-7 should be modified as follows:

GENUS 66. SYNGRAMMA. Veins mostly uniting $1-5 \times$ at or near the margin, sometimes anastomosing copiously, but then distinctly visible like the costa; areolae without free included veinlets. No main veins. Sori with paraphyses.

GENUS 67. HEMIONITIS. Veins anastomosing copiously, distinctly visible like the costa; areolae without free included veinlets. No main veins. Sori without paraphyses.

CENUS 67a. HEMIGRAMMA. Differs from genera 66 and 67 by the distinct main veins, and the areolae provided with free veinlets.

P. XXXVI, 1. 4 should be modified as follows:

86a Leptochilus (Gymnopteris), 67a Hemigramma. 

P. 5, 1. 2 fr. b.; cuncale, should be: clavate,

P. 14, l. 14 fr. b.; rupturing irregularly. should be:

rupluring irregularly or breaking down hy a sli.

1. 5-1 fr. b. should be modified as follows:

5. Veins $\pm 4-5$ on cach side of the costulae. (21) G. Havilandii.

P. 15, 1. 1--2 should be modified as follows:

\$.S. I'eins $\pm 7-10$ on each side of the cosulae.

l. 5-4 fr. b.; brunonis, should be: Brunonis,

P. 17, l. 4; (not Hi.), Christ, Farnkr. d. Erde, 527; should le: Bedd., Handl). Ind. Ferns, Suppl., 2;

P. 21, l. 5; serrate should be: or serrate

l. 7 fr. b. (et passim); lower $1-3$ veins should be: $1-5$ lower veins P. $25,1.4$; to $1 \frac{1}{2}$ c.M. should be: to 2 c.ll.

l. 2 fr. b.; soon deciduous should be: caducous.

P. 27, 1. 7 fr. b.; near the base. should be: occupying the lower veins.

P. 28, l. 2 fr. b.; fimbriated should be: ferrugineous, limbriate

P. 32, 1. 11-12; not divaricating. should be: whether or not divaricating.

l. 15; Omit: (not $H k$.),

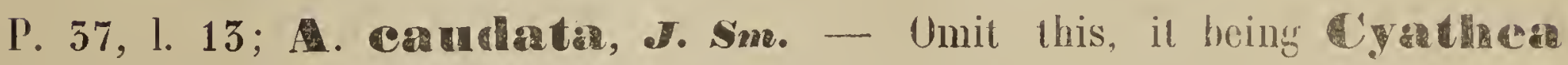
caudata, Copel. - See the Appendix.

l. 16 fr. b. (et passim); semicoriaceous should be: subcoriaceous

P. 39, 1. 10; broadly ovate should be: broadly oval,

1. $14 \& 5 \mathrm{fr}$. b.; var congesta. - Omit this, it being a variety of $\mathrm{Al}$ sophila calocoma, Christ. - See the $\Lambda_{\text {ppendix. }}$

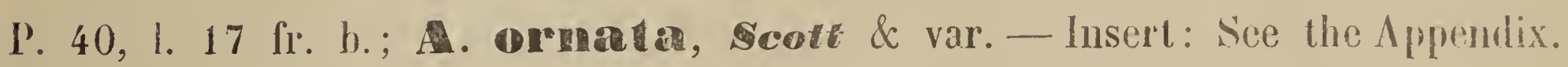

P. 41, l. 4 fr. b.; less glaucous shouid be: under surface less glaucous.

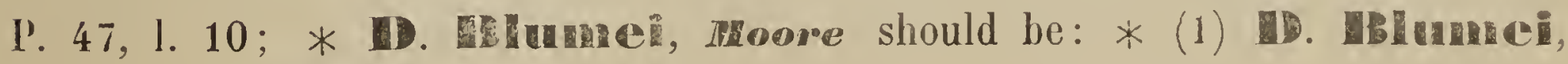
IFoore.

P. 48, I. У; C. Wanomedz, J. Saa. - Inserl: See the Appendix.

P. ๖ъ, 1. 13; Omit the comma after: sporangia

l. 11 fr. b.; after recognized by, insert: a distinct articulation or

P. $58,1.10$; C. glauca, His. - Insert: See the Appendix.

1. 7, fr. b.; bifurcate should be: $\pm 2 \times$ furcate 

P. 59, 1. 16; after long, insert: entire or emarginate at the apex.

P. 65, 1. 11; for: climates-read: zones.

P. 67 , l. 1 ; P. 68 , 1. 17 ; P. 69 , l. 16 fr. b.; for: obovate-read: ovate

P. 70, 1. 5; - sublemissum, Christ. - Insert: See the Appendix.

l. 5 fr. b.; ohovate should be: ovate,

P. 71, l. 8 fr. b.; II. Blumeanum, Spr. - Insert: See the Appendix.

P. 71, l. $3 \& 17$ fr. b.; P. 72, l. 4 ; P. 73 , l. $5 \& 10$, \& 7 fr. b.; P. 74,1 . $1 \& 7$; P. 77, l. 17 fr. b.; P. 78, l. $7 \& 13$ fr. b.; P. 80, l. 12 fr. b.; P. 93, l. 12 fr. b.; P. 94, l. 16 ; P. 95, l. 7 ; P. 96, l. 15 fr. b.; P. 104, l. 1; P. 143, l. 8; for: obovate - read: ovate

P. 75, 1. 15-10 fr. b. should be modified as follows:

*. Indusium without crest-like ridges at the base.

(29) H. tunbridgense.

*.*.Indusium with some (1 or more) indistinct, hardly elevated, longitudinal, crest-like ridges at the base.

(30) H. holochilum.

P. 76, I. 13; on the back. should be: on the back throughout.

1. 17-18 should be modified as'follows:

1.1.1. Indusium provided with irregularly spinoso-fimbriate appendages on the back at the base.

l. 15 fr. b.; after down, insert: valves retuso-denticulate.

l. 13 fr. b.; after down, insert: valves sharply toothed.

l. 11-10 fr. b. should be modified as follows:

1.1.1.1. Indusium provided with rather close, longitudinal crests on the back at the base.

(44) H. brachyglossum.

P. $78,1.14$; climates should be: zones

l. 15-12 fr. b.; surrounded by a row of longitudinal crests, should $b e$ : provided with -some (1 or more) indistinct, hardly elevated, longitudinal, crest-like ridges,

P, 81, 1. 13; on te back, should be: on the back throughout,

P. 82, 1. 4-5 should be modified as follows:

of the way down, the base provided with deeply and irregularly spinoso-fimbriate appendages, the valves slightly retuso-denticulate towards the apex. 

P. 82, I. 6 fr. b.; for: surrounded by a row of - read: provided with

P. 84, 1. 1, \& 8 fr. b.; ovate should be: oblong,

P. 91, l. 11 fr. b.; for: appearantly - read: apparently

P. $93,1.10$ (et passim); for: $2^{\mathrm{d}}-\mathrm{read}: 2^{\text {nd }}$

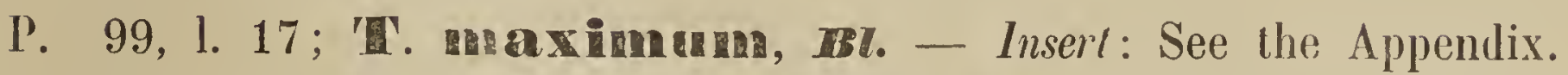

P. 100, 1. 15 fr. b.; 'T javanicuar, BBt. - Insert: See the Appendix.

P. 109, l. 4 fr. b.; Omit: (Not in Nalaya). - See the Appendix.

P. 121, l. $16 \mathrm{fr}$. b.; fastened all round the receptacle, should be: fastened all round the receptacle, but apparently so in Diplaziopsis,

P. 122, 1. 15; for: not articulate \&ce. - read: rarely articulate to the rhizome.

P. 123, 1. 4-6 should be modified as follows:

2. Indusium cupuliform, globose or sausage-shaped, fastened beneath the sorus on all sides, but apparently so in genus $\mathrm{N}^{\circ} .15$, open at the top or bursting down irregularly.

S 1 . Wodlsieac.

P. $126-127$.

2. DAVALLIEAE. - Modify the key. to the genera:

1. Sori solitary and terminal on the veins; indusium attached by a very narrow base to the apex of the vein only, otherwise free, the outer edge lacerato-lobate.

No. 516 . 其e ptolepia.

1.1. Sori solitary and dorsal or terminal on the veins, or uniting the apices of 2 or more veins; indusium attached by a broad base or by the hase and sides to the vein and the parenchyma, the outer edge rather entire.

2. Fronds divided; leaflets dimidiate, i: e. the half on the lower side of the midrib cut away.

No. 29. Mindsa ya.

2.2. Fronds simple or divided, if divided the leaflets not dimidiate.

3. Stipes articulate to the rhizome; rhizome scaly. Sori roundish or oblong, solitary on the vein tips.

1. Indusium fastened by a broad base, the sides and outer edge free.

No. 52. 娄umata.

1.1. Indusium fastened by the base and sides, the outer edge free.

No. 54 . Davallia.

3.3. Stipes not articulate to the rhizome; rhizome hairy, scaly or fibrillose.

a. Sori occupying the broad apex of the \pm cuneate ultimate segments.

No. 28. Mdiontasgeriat.

a.a. Sori not as in a. Ultimate segments not \pm cuneate. 

b. Sori uniting the tips of 2 or more veins or veinlets.

*. Fronds pinnate, pinnae articulate to the rachis.

(No. 17. Nepllerolepis, $\mathbb{S}$ Lindsayopsis).

*.*. Fronds simple or divided, if divided the leaflets not articulate to the rachis.

No. 50. Se. Hi⿱

W.H. Sori dorsal or terminal, solitary on the veins or veinlets, sometimes confluent in pairs.

c. Sori dorsal, or terminal on very short, rather inconspicuous lateral veinlets.

$x$. Indusium attached at the base, often cucullate, at length reflexed.

No. 27. Cystopteris.

$x \cdot x$. Indusium attached at the base and sides, half-cupshaped, never reflexed.

(No. 55. Aspleneiusm, $\mathbb{S}$ Loxoscaphe).

c.c. Sori always terminal on the veins or rather long veinlets.

d. Sori placed in conspicuously cucullate marginal outgrowths, which are closed by the \pm flattened, transversally oblong indusia.

No. 31a. Saccolonata (sorbifolium). $\boldsymbol{d}, \boldsymbol{d}$. Sori not as in $\boldsymbol{d}$.

e. Rhizome erect. Stipes tufted.

+. Indusium cuneate, open at the outer edge.

No. 31a. Saccollona

+... Indusium roundish, attached by a broad base, otherwise free.

No. 33. A rerophorus.

e.e. Rhizome creeping. Stipes remote or approximate.

f. Segments rhombuidal or linear-triangular, unequal-sided at the base. Receptacle distinct.

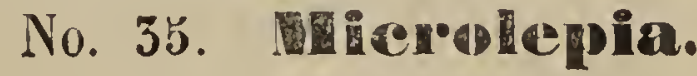



f.f: Segments oblong or linear, not or hardly unequal-sided at the base. Receptacle indistinct.

No. 56. Tapeinidium.

P. 128 , l. 14 ; bearing $\pm 3-6$ should be: bearing generally $\pm 2-12$

l. 11 fr. b.; No. 42 . should be: No. $42 a$.

1. 10-9 fr. b. should be modified as follows:

3.3. Sori roundish, on terminal, $T$-shaped expansions of the veins or veinlets, or uniting the apices of the branches of forked veins.

No. 42b. Sehizostege.

3.3.3. Sori linear or linear-oblong, the receptacle uniting the vein tips, sometimes running the veins transversally.

a. \&c.

P. 129, 1. 16; No. 45. should be: No. 45a.

1. 19-17 fr. b. should be modified as follows:

*. Stipes black. Fronds simple or divided, if divided the segments adnate, connected at the base. $\$$ Eudoryopleris. No. 42a. Daryoptenis,

*.*. Stipes not black. Fronds divided, at least the primary segments not connected, not adnate at the base.

$x$. Sori occupying both anterior and posterior edges of the ultimiate $\mathrm{seg}$ ments. No. $45 a$. Hicris. $x \cdot x$. Sori occupying only the posterior edge of the ultimate segments, the anterior side destitute of sori.

No. $45 b$. Tremipteris.

P. 152, 1. 11; Syngramme should be: Syngrannma,

1. 8-4 fr. b. should be modified as follows:

3.3. Fronds thinner; veins distinctly visible when seen towards the light. Sori free or reticulate, running along the veins. 

4. Main veins present. Areolae with free included veinlets.

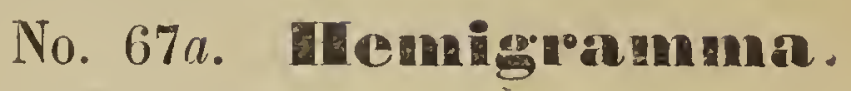

1.4. Main veins wanting. Areolae without free veinlets.

5. Sori with paraphyses.

No. 66. Symgramana, $\mathbb{S}$ Diclyogramme. 5.5. Sori without paraphyses, No. 67. Memionitis.

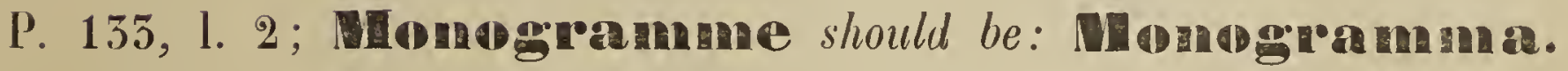 \\ P. 134, 1. 3-9 should be modified as follows:}

\$. Sori more or less oblique to the costa and margin, many on each side of the costa. No. 71. Folypodium, $\mathbb{S}$ Selliguea.

\$.\$. Sori parallel to the costa or margin, 1 on each side of the costa.

*. Sori in marginal or submarginal, 2-lipped grooves. Grass-like plants.

(No. 69. Vittaria).

-*.*. Sori not in marginal or submarginal grooves. No grass-like plants.

+. Fertile fronds simple, as are the barren ones.

No. 75. Drymoglossum.

+.... Fertile fronds 3-partite, barren sagittate.

No. 76 . Christopteris.

P. $139,1.4$ fr. b.; 13. DIPLAZIOPSTS, Christensen. - Inserl: See the Appendix.

P. 141, 1. 11; for: creeping. - read: creeping or erect, but not arborescent.

1. 10 fr. b.; for: Stipes ebeneous, muricale. - read: Stipes ebeneous or castaneous, muricate or aculeolate.

P. 152, l. 15 fr. b; P. 155, l. 1; obovate - should be: lanceolate,

l. $17 \mathrm{fr}$. b.; after var. brachypus, insert: See the Appendix.

P. 155, 1. 7; scaly should be: sparingly scaly.

l. 14 ; after scaly, insert: not rarely glabrous in age.

P. 157 , l. 11 ; lanuginosa, Hk., should be:

- lanuginosa, H/. (not Wall.),

P. 160, l. 10 fr. b.; cordifolia, should be: cordifolia,

P. 162. 1. 12 ; G. Chr., Ind. Fil.; should be: Gen. Fil., tab. III.;

l. 9 fr. b.; on should be: or on

P. 164, l. 9 fr. b.; scaly or fibrillose. should be:

scaly, fibrillose or hairy.

FiLICES. 

P. 164, 1. 7 fr. b.; rather coriaceous. should be: papyracens to coriaceous.

1. 3 fr. b.: ferrugineous. should be: ferrugineous or fulvous.

P. 163, 1. 2; scaly or fibrillose. should be: scaly, fibrillose or hairy.

P. 166, I. 4 ; for: 165 - read: 165 ;

1. 7 ; for: 926 - read: 996 ;

P. 168, I. 4 fir. b.; for: 19 - read: 18 ;

P. 171, I. 18-19 should be modified as follows:

d. Surfaces naked.

(7) P. Trimeni.

d.d. Upper surface \pm hairy lowarls the margin, lower shigthly puberulous.

(8) P. devexa.

l. 14 fr. b.; Mell., should be: Hk. (not Metl.),

P. 175, 1. 6;

l. 17 fr. b.; for: Farns, 235 - read: Ferns, 225 ,

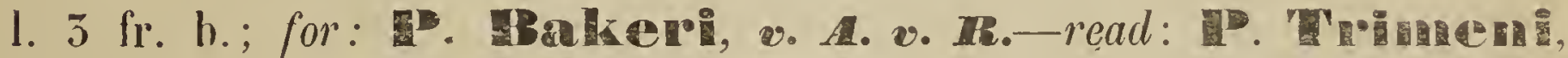
Bedd., Handb. Ind. Ferns, 225. - See the Appendix.

P. 174, l. 12; devexa, v. W. ש. I. - See the Appendix.

P. 180, l. 10 fr. b.; C. Chr., should be: O. Htae, C. Chr.,

P. 186, 1. 3 ; Scholt, should be: Scott,

P. 188, l. 14 fr. b.; P. 189, l. 14; obovate should be: ovate

P. 197, l. 16 fr. b.; for: 178 - read: 179 .

P. 199, l. $10 \& 8$ fr. b.; obovate should be: ovate

P. 202, 1. 7 ; for: XCX - read: XCV;

l. 3 fr. b.; for: tab. CGLXIX - read: 142 (not tab. CCLXIX);

l. 2 " ".; after var. pallida, - inserl: See the Appendix.

P. $205,1.15$ fr. b.; for: pinnae - read: ones

P. 209, 1. 2 fr. b.; P. 210, l. 1; for: otaria - read: Otaria,

P. 210, 1. 10 fr. b.; for: Bedd., - read: Par., Bedd.,

P. 215 , l. $16 \mathrm{fr}$. b.; for: caute - read: acute,

P 214, l. 16 fr. b. ; reduced pinnae. should be: reduced lower pinnac

P. 223, 1. 6; Cadiculata, v. A. v. Th. - Insert: See the Appendix.

P. 228, 1. 6; 2-5 should be: 2-5

P. 230, l. 11 fr. b.; for: Nephrodium - read: Aspidium

P. 252, l. 3; for: 84 - read: 94 ;

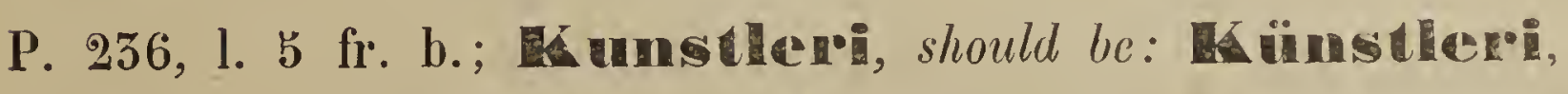

P. 241，1. 16; for: Everettii, \& Everetti, - read: Everettii, \& Everettii, 

P. 244, l. 14; For: 49 - read: 59,

P. 251, l. 14 fr. b.; Meli., should be: Mett. (not Bl.),

P. 252, l: 11 fr. b.; impressum should be: immersum,

P. 255, l. 8 ; for: 206 - read: 106.

P. 257, l. $15 \mathrm{fr}$. b.; tristis should be: triste,

P. 259, 1. 5; Burck, should be: Mell.,

P. 260, 1. 14 ; for $:$ tendence - read: tendency

P. 262, l. 18 fr. b.; for: 79 - read: 97,

P. 267 , l. 5 fr. b.; for: 148 - read: 149

P. 268, 1. 15; for: 298 - read: 208,

P. 269, l. 9 fr. b.; for: Syn. Fil. - read: Syn. Fil., 106;

P. 270, 1. 11; flebellulata should be: flabellulala,

1. 14 ; for: I, tab. LXIII - read: I, 211, tab. LXIII, A ;

l. 15 ; for: Ferns S.I., tab. XXIV; L. tenera, Dry., 1. c., tab. X; — read: 1. c.; L. tenera, Dry., I. c., tab. X; Bedd., Ferns S.I., tab XXIV;

P. 274, l. 9; for: S. recurvata, Bedd. - read: S. recurvalum, Moore, Bedd.,

P. 281, 1. 12; for: 148 - read: 149

P. 282, 1. 7, \& 2 fr. b.; for: inequalis - read: inaequalis,

l. 3 fr. b.; for: Diels, etc. - read: Christ, Farnkr. d. Erde, 310;

P. 285, 1: 3 \& 9; for: higher ones - rearl: following.

P. 286, 1. 5; for: J. Sme, Copel., - read: \$. Sme. (not Wall.), Copel.,

P. 287, 1. 2; for: intramarginalis, Bl., - read: intermarginalis, Moore (not Bl.),

1. 15 ; for: $($ not $S m$.$) - read: ($ not J.Sm.),

l. 4 fr. b. ; CXXXVII should be: CXXXVIII,

P. 288, 1. 4 fr. b.; pedela should be: pedata,

l. 5 fr. b.; L., should be: L.f.,

P. 289, l. 15 fr. b.; XVL should be: XLV,

P. 300, 1. 8; for: IRett., - read: Huhne,

P. 307, 1. 12; for: (fejensis) - read: (fejeensis),

P. $\ddot{3} 09$, l. 5 fr. b.; Hk. should he: Goldm. (not Hk.),

l. $16 \mathrm{fr}$. h.; XXVI should be: XXXVI,

P. 311, l. 16; for Copel., - read: Copel. (not Harr.),

P. 512, 1. 8 \& 18 fr. b.; Davalia should be: Davallia

P. 315, 1. 4 fr. b.; Chistensere. should be: Christenser.

P. 515, 1. 1; for: 7 \& 8 - read: 5 \& 7 ;

1. 18; for: Christ, - read: Christ (not Bl.),

l. 5 \& $5 \mathrm{fr}$. b.; amboinensis should be: amboynesis, 

P. 319, 1. 3 fr. b.; for: With view on - read: In view of

P. 323, l. 16; for: Hk., - read: Hk. (not Willd.),

P. 356, l. 1 \& 4 fr. b.; for: 116 - read: 146

P. 345, l. 2 ; for: Burm. - read: R. Br.,

P. 347, 1. 4; for: 146 - read: 151 ;

P. 359, l. 14 fr. b.; for: spinulose serrale - read: spinulose or serrate

P. 367, 1. 8; for: in and size - read: in size and

P. 380, 1. 17 fr. b.; L. areolaris, Marr. - 0mit this. See the Appendix.

P. 381, 1. 1 fr. b.; Cunne. should be: A. Cunn.,

P. 412, 1. 12; major should be: majus,

l. 17 fr. b.; major should be: majus:

P. 435 , 1. 15; A. umbrosum, Pr. - Omit this. See the Appendix.

l. $4 \mathrm{fr}$. b.; A. silvaticum, Milde. - 0 mit this. See the Appendix.

P. 450, 1. 2 fr. b; for: group - read: group a.a.

l. 1 fr. b.; for: Fors - read: Forst.

P. $510,1.8$; for: sumbensi - read: sumbensis,

P. 555, 1. 13 ; A. semicostatum should be: A. semicostatum,

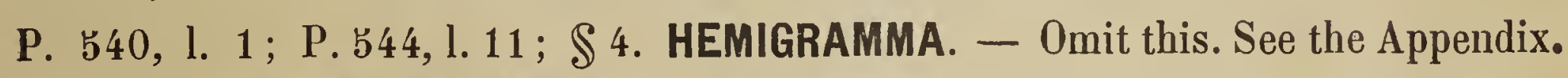

P. 544, 1. 12; Zollingeri, Diels. - Omit this. See the Appendix.

P. 547, 1. 1 ; H. gymmoptendidea, Copel. - Omit this. See the Appendix.

P. 551, l. $\mathbf{5}$; for: wit - read: with

P. 570, 1. 12; for: 1 . - read: 1 .

P. 575, 1. $2 \& 1$ fr. b. should be modified as follows:

(b) P. Friderici et Pauli, Christ, Ann. Btz., XV, 148, tab. XVI, fig. 21, a \& b (not XIX, 37).

P. 585, l. 5 fr. b.; for: $2-5 \times$ forked - read: 2-3-furcate,

P. 598, 1. 2 fr. b.; for: in - read: is

P. $617,1.14 \mathrm{fr}$. b.; fir integriore. - read: integrius.

l. 11-10 fr. b. should be modified as follows:

*. Sori slighlly immersed; paraphyses yellow-brown.

(116a) P. Koningsbergeri. *.*. Sori deeply immersed; paraphyses black-brown. (116b) P. verrucosum. P. 618 , 1. 12 fr. b.; for: integriore, - read: integrolus, 

P. $619,1.19$; one should be: one).

1. 8-7 fr. b. should be modified as follows:

the Agricultural Department in Netherlands India. The description is taken from 5-4 years old plants, and I am inclined to suppose that the adult plants have the fronds large and more copiously pinnate.

Java (Preanger Regencies, v. A. v. R.).

P. 622, l. 9 fr. h.; for: $8-30$ - read: 850

1. 7 fr. b. ; for: $1 / 2-21 / 2-$ read: $1 / 2-5$

P. 625 , 1. 17 ; for: var. pumilum; - read: var. pumilum;

P. 677, 1. 14; decurrens, Hk. - should be: decurrens, IIk.,

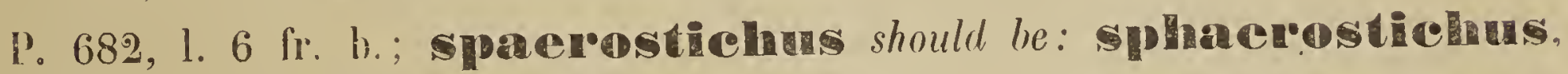

P. 684, 1. 15; Mett., should be: Melt.,

P. $688,1.9$ fr. b.; Kze, should be: Kze,

P. $778,1.11$ fr. b.; for: subcarnosmm, — read: subcarnosum,

P. 824, 1. 2 fr. b.; all. should be: Irett.

P. $848,1.10$; devexum, Kze should be: devexum, Kze

\section{LIBRARY}





